\title{
DE GAROEDA EN DE OOIEVAAR
}

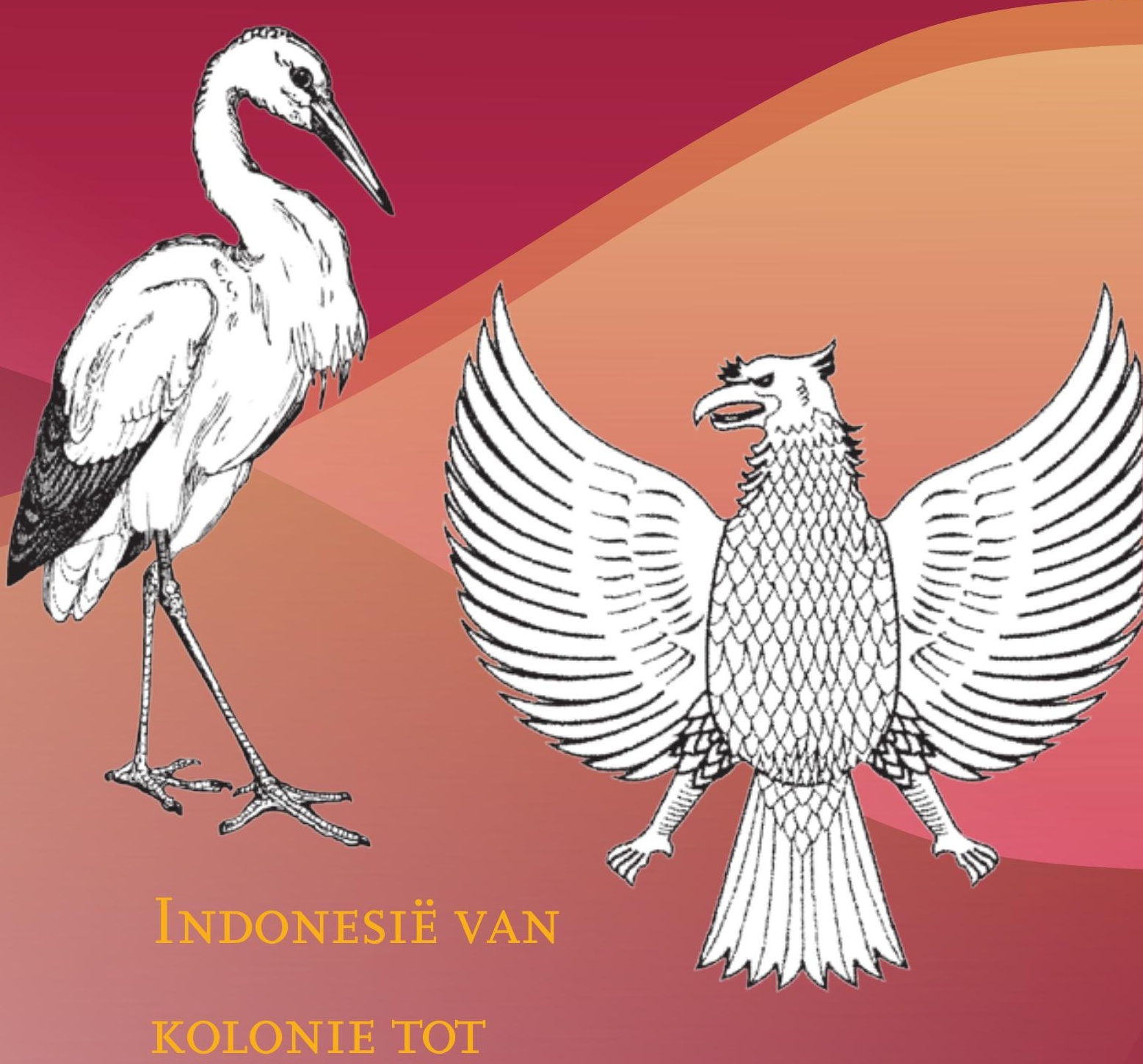

NATIONALE STAAT

HeRman BuRgers 
DE GAROEDA EN DE OOIEVAAR 



\section{E R H A N D E L I N G E N}

VAN HET KONINKLIJK INSTITUUT

VOOR TAAL-, LAND- EN VOLKENKUNDE

\section{6}

\section{HERMAN BURGERS}

\section{DE GAROEDA EN DE OOIEVAAR}

\section{Indonesië van kolonie tot nationale staat}

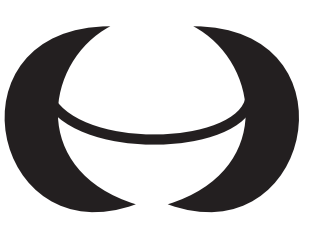

KITLV Uitgeverij

Leiden

2011 
Uitgegeven door:

KITLV Uitgeverij

Koninklijk Instituut voor Taal-, Land- en Volkenkunde

(Royal Netherlands Institute of Southeast Asian and Caribbean Studies)

Postbus 9515

2300 RA Leiden

website: www.kitlv.nl

e-mail: kitlvpress@kitlv.nl

KITLV is een instituut van de Koninklijke Nederlandse Akademie van Wetenschappen (KNAW)

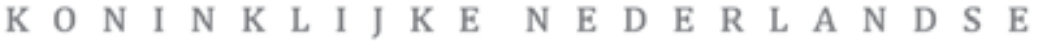

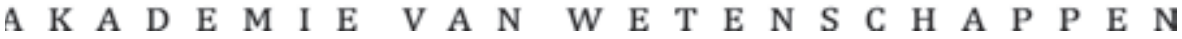

Omslag: Creja ontwerpen, Leiderdorp.

ISBN 9789067183475

(C) 2012 Koninklijk Instituut voor Taal-, Land- en Volkenkunde

Tweede, gewijzigde editie

Standaardformulering, p.iv van KITLV Open Access boekpublicaties, edited volumes/ coll of essays:vermelding CC-licentie.

Deze vervangt de 'klassieke' copyrightvermelding.

Vastgesteld 3 februari 2011.

KITLV Press applies the Creative Commons Attribution-NonCommercial-NoDerivs 3.0 Unported License (http://creativecommons.org/licenses/by-nc-nd/3.0/) to selected books, published in or after January 2011.

Authors retain ownership of the copyright for their articles, but they permit anyone unrestricted use and distribution within the terms of this license. 


\section{Inhoud}

Lijst van geografische kaarten

xiii

Lijst van in facsimile afgedrukte titelpagina's

xiv

Overzicht van het fotokatern

Voorwoord

xvi

I Indonesië voor de komst van de Nederlanders

Inleiding en overzicht 1

De Indonesische archipel 2

De bevolking van de archipel 3

Cultuur en samenleving in het begin van onze jaartelling 4

De Hindoe-Indonesische culturen 5

Hindoe-Indonesische vorstendommen op Sumatra en Java 7

De komst van de islam 9

Nieuwe moslimstaten in Malakka en Indonesië 10

De Molukken en de specerijenteelt 13

Portugese machtsuitbreiding in Azië 14

De Portugezen in Indonesië 16

Aantekeningen bij hoofdstuk I 18

II Indonesië en de Verenigde Oost-Indische Compagnie

Inleiding en overzicht 19

De geboorte van de Nederlandse staat 20

De eerste Nederlandse tochten naar Azië 21

Oprichting van de Verenigde Oost-Indische Compagnie 25

Einde van de Portugese heerschappij in de Molukken; vestiging van de VOC op Ambon 26

Britse concurrentie 28

Nederlaag van de Britten; stichting van Batavia 31

De doelstellingen van de VOC 33

Ontvolking van de Banda-eilanden 35

Onderwerping van de Molukken 37

Machtsuitbreiding in India en op Ceylon, Sumatra en Celebes 39

Verwerving van de oppermacht op Java 41

Het handelsrijk van de VOC 43

Het bestuursstelsel van de VOC 47 
Indonesië als studieterrein en thuisland voor Compagniesdienaren 50 Invoering van de koffieteelt op Java 52

Chinees verzet en Chinezenmoord 53

Ondergang van Mataram 54

Ontstaan van de Djojobojo-legende 56

Achteruitgang van de VOC 57

Einde van de VOC 59

Aantekeningen bij hoofdstuk II 62

III Indonesie en het Nederlandse koloniale bestuur

Inleiding en overzicht 67

Geschiedenis van de kolonie Nederlands-Indië tot het begin van

de twintigste eeuw 69

Begin van de koloniale verhouding 69

Java onder Daendels 71

Brits intermezzo 72

Herinrichting van het Nederlandse koloniale bestel 74

Het Binnenlands Bestuur 76

Verzet tegen de terugkeer van het Nederlandse gezag 78

Het Nederlands-Britse verdrag van $1824 \quad 80$

De Java-oorlog 80

Cultuurstelsel en batig slot 84

Koloniale machtsuitbreiding buiten Java voor $1870 \quad 87$

Nederlandse kritiek op het koloniaal beleid 91

Einde van Cultuurstelsel en batig slot 96

Eerste fase van de Atjeh-oorlog 97

Opmars van de westerse ondernemingen 100

Slavernij, dwangarbeid, koeliecontracten en de poenale sanctie 103

Wetenschappelijke aandacht voor Indonesië 104

Christelijke zending en missie 108

De bloeitijd van het imperialisme 109

Groeiende betekenis van Indonesië voor het Nederlandse zelfbewustzijn 113

Ethische politiek 114

Voortzetting en beëindiging van de Atjeh-oorlog 117

De Korte Verklaring 121

Afronding van het koloniale rijk 122

Enige kenmerken van het koloniale bestel 129

De voornaamste bevolkingsgroepen in de kolonie 129

Het koloniale rechtsbestel 132

De exorbitante rechten 134

Drukpersreglement, haatzaai-artikelen en muilkorfcirculaire 136

Decentralisatie en democratisering 137

Het recht van vereniging en vergadering 139

Het koloniale taalbeleid 140

Het koloniale onderwijsbestel 142

Aantekeningen bij hoofstuk III 147 
Inleiding en overzicht 151

Ontluiking van de Indonesische drang naar mondigheid 154

Buitenlandse stimulansen voor het Indonesische zelfbewustzijn 157

Boedi Oetomo en andere organisaties op etnische grondslag 158

Vakverenigingen 160

De Indische Partij en het Comité Boemi Poetra 160

De Sarekat Islam 163

Sneevliet en de Indische Sociaal-Democratische Vereeniging 165

De Politieke Inlichtingen Dienst 167

De Indië Weerbaar-campagne 168

Instelling van de Volksraad 170

Uitzicht op geleidelijke dekolonisatie 171

Studenten in Nederland; de Indische Vereeniging en het Indonesisch Verbond van Studeerenden 174

Verharding van het Nederlands koloniaal beleid 177

Het Indo-Europeesch Verbond 180

De Nationaal-Indische Partij 181

De non-coöperatiepolitiek 182

De wilde scholen 184

Machtsstrijd tussen de Sarekat Islam en de marxisten 186

Hervorming van het Nederlands-Indische staatsbestel 189

De Ondernemersraad voor Nederlandsch-Indië en de Utrechtse indologenopleiding 192

Studenten in Nederland; de Perhimpoenan Indonesia 193

De studieclubs van Soetomo en Soekarno 197

Mislukte communistische opstand 198

Boven-Digoel 202

De vertrouwenspolitiek van De Graeff 203

De eerste nationalistische massabeweging: Soekarno's PNI 204

Het Indonesisch Jeugdcongres van 1928206

De 'Inlandse meerderheid' in de Volksraad 207

De Vaderlandsche Club 209

Rijkseenheid 210

De Stuw-groep 211

Het proces-Soekarno 212

Hergroeperingen binnen de Indonesische nationale beweging 216

Verzet tegen de wilde-scholenordonnantie 220

Muiterij op 'De Zeven Provinciën' 221

Onderdrukking van de Indonesische vrijheidsbeweging 224

Einde van de non-coöperatiepolitiek 228

India, Birma en de Filippijnen op weg naar dekolonisatie 232

De petitie-Soetardjo 234

Het eenheidsfront Gapi en de campagne 'Indonesië parlementair' 239

De maatschappelijke positie van de Indonesiërs omstreeks 1940243

Nederland in oorlog met Duitsland 244

De defensiecapaciteit van Nederlands-Indië 247

Bevriezing van het koloniale bestel 249 
Laatste confrontaties tussen de nationale beweging en het koloniale gezag 253

Nederland in oorlog met Japan 257

Verwijdering van niet-Indonesische geïnterneerden uit Nederlands-Indië 259

Verloop van de oorlog tot maart 1942261

De Nederlandse capitulatie 263

Aantekeningen bij hoofdstuk IV 267

$\mathrm{V} \quad$ Indonesië onder Japanse bezetting

Inleiding en overzicht 275

Afronding van het Japanse offensief 276

Inheemse reacties op de Japanse verovering van Indonesië 279

Enige kenmerken van het Japanse beleid tegenover Indonesië 281

De beginfase van de Japanse bezetting 284

De inrichting van het bezettingsbestuur 286

De Tiga A Beweging 289

Japan in het defensief 291

De Japanse behandeling van de krijgsgevangenen 292

Internering van de Nederlandse burgers 293

Terugkeer van Soekarno naar Java 297

De 7-december-rede van koningin Wilhelmina 299

De Poetera-beweging 304

Mobilisatie van de jeugd 306

Verruiming van Indonesische medezeggenschap 308

De hulpsoldaten, de hulppolitie en het vrijwilligerskorps Peta 311

De Masjoemi 313

De Djawa Hokokai 315

Het Tonarigumi-stelsel 316

Economische ontreddering 317

De romusha's 319

Van Mook en de NICA 321

De NEFIS 323

De Japanse toezegging van onafhankelijkheid 325

De Barisan Pelopor 327

De Hizboellah 328

Anti-Japanse activiteiten 328

Eerste stappen ter inlossing van de Japanse toezegging 330

Radicalisering van de nationalistische jongeren 332

Nederlandse voorbereidingen voor de terugkeer naar Indië 335

Problemen tussen Nederland en zijn bondgenoten 339

De Indonesische onderzoekscommissie voor de onafhankelijkheid 341

Laatste stappen ter inlossing van de Japanse toezegging 343

Ontvoering van Soekarno en Hatta door militante jongeren 345

De opstelling van de onafhankelijkheidsproclamatie 348

Aantekeningen bij hoofdstuk V 350 
VI Het conflict tussen Nederland en de Republiek Indonesië- Eerste fase

Indonesië onder tijdelijk Brits gezag

Inleiding en overzicht 355

De geboorte van de Republiek Indonesië 358

Japanse reacties op de onafhankelijkheidsverklaring 360

De Nederlandse opstelling tegenover de onafhankelijkheidsverklaring 361

De Nederlandse houding tegenover Indonesië aan de vooravond van de Tweede Wereldoorlog 362

De Nederlandse houding tegenover Indonesië tijdens de Duitse bezetting 365

De Nederlandse houding tegenover Indonesië na de bevrijding van Nederland 368

Tijdelijke plaatsing van Indonesië onder Brits militair gezag 370

Andere onafhankelijkheidsbewegingen binnen het Britse gezagsgebied 372

Geleidelijke consolidering van het Republikeinse gezag op Java 374

Verspreide steun voor de Republiek buiten Java 377

De Nederlandse krijgssgevangenen en geïnterneerden 379

Tegenstellingen tussen de Republikeinse leiders en de militante jongeren 381

Terugkeer van Tan Malaka in de Indonesische politiek 383

Brits-Nederlands vlootbezoek aan Batavia 384

Anti-Nederlandse schepenboycot in Australië 387

Britse neiging tot de facto erkenning van de Republiek 388

Verwerping van de Republiek door de Nederlandse regering 391

Eerste geallieerde troepenlandingen in Indonesië na de Japanse capitulatie 395

Terugkeer van Van Mook in Batavia 398

De gewelddadige fase van de Indonesische revolutie 399

Oprichting van het Republikeinse leger 404

Britse druk tot overleg tussen Nederland en de Republiek 405

Eerste ontmoeting van Van Mook met Soekarno 407

Strijd in Midden-Java 411

Strijd in Soerabaja 413

Nederlands besluit tot uitzending van een grote troepenmacht naar Indonesië 418

Hervorming van het staatsbestel van de Republiek 421

Aantreden van het kabinet-Sjahrir 426

Benoeming van Soedirman tot Republikeins opperbevelhebber 428

Eerste overleg tussen Van Mook en Sjahrir 428

Van Mook's keuze voor federalisering van Indonesië 431

Overleg van Van Mook in Den Haag en Londen 433

Samenwerking van de regering-Sjahrir met de Britse bezettingsmacht 435

Verplaatsing van de hoofdzetel van de Republiek naar Jogjakarta 436 
Benoeming van Spoor tot Nederlands opperbevelhebber in Indonesië 437

Formele Nederlandse erkenning van het Indonesisch zelfbeschikkingsrecht 438

Eerste bemoeienis van de Verenigde Naties met de kwestieIndonesië 440

Toenemende verdeeldheid in Nederland over het beleid tegenover de Republiek 441

Toenemende verdeeldheid in de Republiek over het beleid tegenover Nederland; aantreden van het tweede kabinet-Sjahrir 443

Aankomst op Java van de eerste brigades oorlogsvrijwilligers uit Nederland 447

Voorlopig akkoord tussen Van Mook en Sjahrir 449

De conferentie op de Hoge Veluwe 452

Terugkeer van het Nederlandse gezag in de archipel buiten Java en Sumatra 456

Nieuw overleg tussen Sjahrir en Van Mook 458

Poging tot staatsgreep in de Republiek 461

Aantreden van het Nederlandse kabinet-Beel 463

De conferentie van Malino 466

Verheviging van de strijd op Java 468

Instelling van de Nederlandse commissie-generaal 471

Britse aandrang tot hervatting van het overleg met de Republiek 474

Eerste uitzending van Nederlandse dienstplichtigen naar Indonesië 475

Aantreden van het derde kabinet-Sjahrir 477

Het eerste bestand tussen Nederland en de Republiek 478

Het overleg in Linggadjati 481

Tekst van het ontwerp-akkoord van Linggadjati 484

Einde van het tijdelijke Britse gezag over Indonesië 488 Aantekeningen bij hoofdstuk VI 489

VII Het conflict tussen Nederland en de Republiek Indonesië - Tweede fase Nederlandse pogingen tot beslechting van het conflict op basis van militaire macht

Inleiding en overzicht 503

Aankleding van Linggadjati 507

Nederlands verzet tegen Linggadjati 509

Indonesisch verzet tegen Linggadjati 510

Oprichting van de deelstaat Oost-Indonesië 512

Nederlandse terreur in Zuid-Celebes 514

Nederlandse marineblokkade van de Republiek 519

Ondertekening van het akkoord van Linggadjati 520

Dekolonisatie in andere delen van Azië 524

Invloed van de koloniale troika en de Indische Nederlanders op het Nederlandse beleid 527

Nederlands-Indonesisch overleg over de uitvoering van Linggadjati 531 
Verdeeldheid in Nederland over het gebruik van geweld tegen de Republiek 536

Ultimatieve voorstellen van Nederland aan de Republiek 538

Vaste Nederlandse denkpatronen in Batavia 543

De aanloop naar het Nederlandse offensief; aantreden van het kabinet-Amir Sjarifoeddin 547

Het eerste Nederlandse offensief (de eerste 'Politionele Actie') 552

De reactie van de Verenigde Naties op het Nederlandse offensief 555

Uitbreiding van het Nederlandse bestuur op Java en Sumatra 558

De VN-Commissie van Goede Diensten en het Renville-akkoord 560

Tekst van het politieke deel van het Renville-akkoord 567

Val van het kabinet-Amir Sjarifoeddin; aantreden van het kabinet-Hatta 569

Verscherping van de tegenstellingen binnen de Indonesische vrijheidsbeweging 571

Voortzetting van het Nederlandse federaliseringsbeleid 573

Verder overleg na het Renville-akkoord 576

Wijziging van de Nederlandse grondwet 581

De Bijeenkomst voor Federaal Overleg (BFO) 583

Aantreden van het Nederlandse kabinet-Drees 584

Voortgezette aanwezigheid van de Nederlandse strijdmacht in Indonesië 586

Anti-Republikeinse maatregelen in Batavia 590

Amerikaanse bemiddelingspoging 592

De Madioenopstand 594

De aanloop naar het tweede Nederlandse offensief 597

Het tweede Nederlandse offensief (de tweede 'Politionele Actie') 603

De reactie van de Verenigde Naties op het tweede Nederlandse offensief 605

De reactie van de federalisten op het tweede Nederlandse offensief 608

Aantekeningen bij hoofdstuk VII 610

VIII Het conflict tussen Nederland en de Republiek Indonesië-Derde fase

Onvolledige politieke oplossing

Inleiding en overzicht 621

De militaire situatie na het tweede Nederlandse offensief 625

De politieke situatie na het tweede Nederlandse offensief 628

Nederlands aanbod tot vervroegde overdracht van de soevereiniteit 630

Het akkoord tussen Roem en Van Roijen 636

Terugkeer van Soekarno en Hatta in Jogjakarta 641

Akkoord tussen de Republiek en de federalisten 643

Het derde bestand tussen Nederland en de Republiek 647

De Rondetafelconferentie in Den Haag 653

Het externe zelfbeschikkingsrecht voor Indonesische minderheden 656 
De kwestie Nieuw-Guinea 660

De tekst van het Charter van Soevereiniteitsoverdracht 666

De soevereiniteitsoverdrachten 668

Terugblik 674

Aantekeningen bij hoofdstuk VIII 676

IX Het conflict tussen Nederland en de Republiek Indonesië-Laatste fase

Het geschil over Nieuw-Guinea

Inleiding en overzicht 685

De politieke situatie na de soevereiniteitsoverdracht 689

De APRA-affaire 691

Ontmanteling van de federale staatsstructuur 693

Mislukte muiterij in Makassar 695

Uitroeping van de Republiek der Zuid-Molukken 697

Opheffing van het KNIL 699

Herstel van de Indonesische eenheidsstaat 700

Herovering van Ambon 703

Impasse over Nieuw-Guinea 705

Overbrenging van Ambonese ex-KNIL-militairen naar

Nederland 708

Mislukking van de Indonesisch-Nederlandse Unie 709

De eerste jaren parlementaire democratie in Indonesië 714

Verscherping van het geschil over Nieuw-Guinea 719

Anti-Nederlandse processen in Djakarta 724

De eerste Indonesische parlementsverkiezingen en het laatste parlementaire kabinet 729

Volledige breuk van Indonesië met Nederland 733

Ondergang van de democratie in Indonesië 737

Militaire confrontatie over Nieuw-Guinea 742

Ontdooiing van het Nederlandse standpunt over Nieuw-Guinea 745

Beëindiging van het conflict en overdracht van Nieuw-Guinea 749 Aantekeningen bij hoofstuk IX 755

Lijst van afkortingen

Bibliografie

Register van personen

Register van zaken

Fotokatern tussen pp. 392 en 393 


\section{Lijst van geografische kaarten}

Kaart 1. Zuid-Azië voor de komst van de Nederlanders

xxiv

Kaart 2. Prekoloniaal Java

Kaart 3. De Molukken $\quad 12$

Kaart 4. Java in de zeventiende en de achttiende eeuw 30

Kaart 5. Het handelsrijk van de VOC 44

Kaart 6. Eind 1799 door de VOC beheerste gebieden in Indonesië $\quad 60$

Kaart 7. Sumatra 88

Kaart 8. De kolonie Nederlands-Indië anno $1930 \quad$ 126-7

Kaart 9. Java 1942-1946 346

Kaart 10. Nederlandse offensieven op Java in 1947 en $1948 \quad 502$

Kaart 11. Territoriale indeling van de Republiek der

Verenigde Staten van Indonesië eind 1949 


\section{Lijst van in facsimile afgedrukte titelpagina's}

Itinerario (1595-96) door J.H. van Linschoten

Spraeck ende woord-boeck in de Maleysche ende Madagaskarsche talen

(1603) door F. de Houtman

D'Amboinsche Rariteitkamer (1705) door G.E. Rumphius

Oud en Nieuw Oost-Indiën (1724-26) door F. Valentyn 63

Max Havelaar (1860) door Multatuli 94

Java (1849-53) door F. Junghuhn $\quad 106$

Door duisternis tot licht (1911) door Kartini 156

Als ik eens Nederlander was (1913) door Soewardi Soerjaningrat $\quad 162$

Indonesië vrij! (1928) door M. Hatta 196

Naar de 'Republiek-Indonesia' (1925) door Tan Malaka 200

Indonesië klaagt aan! (1930) door Soekarno 214

Buiten het gareel (1940) door Soewarsih Djojopoespito 226

Daar wèrd wat groots verricht (1941) door W.H. van Helsdingen 300

Onze strijd (1945) door Sjahrir $\quad 424$

De Indonesische tragedie (1949) door J. de Kadt 632 


\section{Overzicht van het fotokatern}

Het katern bevat een reeks foto's uit verschillende fasen van de Indonesische nationale beweging. Achtereenvolgens betreft dit:

- de STOVIA; de Indische Partij

- Tjokroaminoto, Agoes Salim, Soetomo en Tan Malaka

- de Perhimpoenan Indonesia

- het proces tegen Soekarno; Sjahrir in Boven-Digoel

- Thamrin, Ratoelangie en Soetardjo

- Soekarno en Hatta tijdens de Japanse bezetting

- de onafhankelijkheidsproclamatie

- de proclamatieceremonie; het eerste Republikeinse kabinet

- de betoging op het Ikada-terrein; leuzen in Djakarta

- de eerste bespreking tussen Sjahrir en Van Mook; Soedirman in Batavia

- het akkoord van Linggadjati

- Spoor, Beel en Jonkman; Nederlandse soldaten op patrouille

- bezoek BFO-delegatie aan Soekarno op Bangka; overleg tussen Roem en Van Roijen

- terugkeer van Soedirman in Jogja; de Inter-Indonesische conferentie

- de Rondetafelconferentie; de Nederlandse soevereiniteitsoverdracht

- aantreden van president Soekarno in het paleis in Djakarta 


\section{Voorwoord}

Dit boek beschrijft de wordingsgeschiedenis van de staat Indonesië. Het grootste deel ervan behandelt dan ook de verschillende stadia van Indonesië's dekolonisatie in de twintigste eeuw, namelijk de ontwikkeling van de Indonesische vrijheidsbeweging onder het koloniale bestel, de gebeurtenissen tijdens de Tweede Wereldoorlog, het conflict van de Republiek Indonesië met Nederland in 1945-1949 en de nasleep daarvan tot de beëindiging van het geschil over Nieuw-Guinea in 1963. Tussen deze verschillende stadia bestaat een nauwe samenhang; het hele proces heeft zich binnen het tijdsbestek van een mensenleven afgespeeld. De continuïteit ervan weerspiegelt zich onder meer in de levens van Soekarno, Hatta en vele andere dramatis personae zoals Soewardi Soerjaningrat, Agoes Salim, Ratoelangie, Jonkman en Van Mook. De beschrijving van dit dekolonisatieproces beslaat de hoofdstukken IV tot en met IX van dit boek.

Omdat de Indonesische nationale beweging zich verzette tegen de Nederlandse overheersing, kan men haar pas goed begrijpen als men weet hoe die overheersing tot stand gekomen was en wat die inhield. Daarom wordt de beschrijving van de dekolonisatie in dit boek voorafgegaan door de hoofdstukken II en III, die handelen over de Verenigde Oost-Indische Compagnie en over het Nederlandse koloniale bewind. Tegelijk moet men in het oog houden dat de Indonesische geschiedenis veel ouder is dan die van de Nederlandse aanwezigheid in de archipel. Het boek opent daarom met een korte blik op die vroegere geschiedenis, hoofdstuk I. Dit is ook van belang omdat men binnen de nationale beweging graag naar die oude geschiedenis placht te verwijzen, bijvoorbeeld naar de grootheid van de vroegere rijken Sriwidjaja en Modjopahit. Ook het rood-wit als nationaal symbool is aan Modjopahit ontleend.

Wat de totstandkoming van de Nederlandse overheersing betreft, hielden de meeste Nederlanders er voor de Tweede Wereldoorlog een simpele voorstelling op na: zij dachten dat heel 'Indië' al in de zeventiende eeuw onder de macht van Nederland was gekomen. Een soortgelijke misvatting leefde bij 
veel Indonesische nationalisten, die dan ook plachten te spreken over 'driehonderd jaar' of zelfs 'driehonderdvijftig jaar' Nederlandse onderdrukking. In werkelijkheid heeft de stapsgewijze uitbreiding van de Nederlandse macht binnen de archipel zich over drie eeuwen uitgestrekt. De hoofdstukken II en III behandelen stelselmatig wanneer bepaalde Indonesische gebieden onder Nederlandse heerschappij gekomen zijn en hoe dat in zijn werk is gegaan. De in die eeuwen tegen de Nederlanders gevoerde strijd krijgt daarin ruime aandacht (waarbij ook enige strijders ter sprake komen naar wie in het huidige Indonesië straten en pleinen genoemd zijn). Daarnaast gaan deze hoofdstukken herhaaldelijk in op het rechtskarakter van die heerschappij.

In het algemeen krijgen juridische kwesties in dit boek meer aandacht dan in andere geschiedwerken over Indonesië. Zo gaat het tweede deel van hoofdstuk III ook uitvoerig op het koloniale rechtsbestel in. Men kan de Indonesische nationale beweging niet voldoende begrijpen als men niet op de hoogte is van zulke zaken als de 'exorbitante rechten', de 'haatzaai-artikelen' en de door Nederland wettelijk vastgelegde discriminatie van de inheemse bevolking van de kolonie. Een ander punt waarop dit boek meer inhoudt dan vergelijkbare geschiedwerken is het koloniale taalbeleid. Daar is een afzonderlijke paragraaf aan gewijd, evenals aan het koloniale onderwijsbestel. Verder ben ik uitdrukkelijk ingegaan op de wetenschappelijke aandacht die van Europese kant zowel in de VOC-tijd als in de koloniale tijd aan Indonesië geschonken is. Daarentegen krijgen economische kwesties in dit boek slechts beperkte aandacht.

Hoofdstuk IV over de Indonesische nationale beweging valt te beschouwen als het centrale bestanddeel van het boek. Ook de geschiedenis van het Nederlandse koloniale bewind in de twintigste eeuw passeert in dit hoofdstuk de revue, tot aan de capitulatie van Nederlands-Indië voor Japan in begin 1942. Vervolgens behandelt hoofdstuk V het tijdvak van de Japanse bezetting, waarin de grondslag werd gelegd voor de naoorlogse dekolonisatie. Dat hoofdstuk eindigt met de opstelling van de Indonesische onafhankelijkheidsverklaring.

In de hoofdstukken VI, VII en VIII volgt dan een kroniek van het daarna ontbrande conflict tussen de Republiek Indonesië en Nederland, vanaf de stichting van de Republiek in augustus 1945 tot de overdracht van de Nederlandse soevereiniteit in december 1949. Die kroniek beslaat bijna de helft van het boek. Ik heb die ruimte nodig gehad om te beschrijven en te verduidelijken wat ik voor een goed begrip van de gang van zaken nodig vond. Daar was veel bij dat in de bestaande literatuur niet of nauwelijks ter sprake gekomen is.

Voor een goed begrip is het in de eerste plaats van belang te weten, dat het Nederlandse gezag in Indonesië van augustus 1945 tot eind november 1946 aan het Britse gezag ondergeschikt geweest is op grond van een tussen 
de beide regeringen gesloten overeenkomst. Dit tijdvak wordt behandeld in hoofdstuk VI. Dat in november 1946 een politiek akkoord tussen Nederland en de Republiek Indonesië tot stand kwam (het akkoord van Linggadjati) valt alleen te begrijpen uit de vaste wens van de Britse regering om nog voor de beëindiging van het Britse gezag een akkoord te bewerkstelligen tussen de twee partijen bij het dekolonisatieconflict.

Intussen had de Nederlandse regering op Java en Sumatra een grote strijdmacht opgebouwd die voor een belangrijk deel bemand werd door uit Nederland aangevoerde vrijwillige en dienstplichtige militairen. Het onder Britse druk tot stand gekomen akkoord van Linggadjati kon niet verhinderen dat de Nederlandse regering daarna tweemaal een grootscheeps offensief tegen de Republiek lanceerde, de eerste maal in juli 1947, toen die strijdmacht inzetbaar geworden was, en de tweede maal in december 1948, toen het tijdstip naderde dat Nederland die overzeese strijdmacht niet langer kon handhaven. Beide malen omschreef de regering het offensief verhullend als een 'politionele actie'. Hoofdstuk VII behandelt het tijdvak van december 1946 tot begin 1949, waarin Nederland probeerde op basis van zijn militaire macht een beperkte dekolonisatie van Indonesië tot stand te brengen onder blijvende Nederlandse regie. Een belangrijk onderdeel van het Nederlandse beleid was daarbij de vorming van een reeks Indonesische deelstaten als tegenwicht tegen de Republiek.

Het Nederlandse offensief van december 1948 begon spectaculair met de verovering van de Republikeinse hoofdstad en de gevangenneming van prominente Republikeinen, onder wie president Soekarno en vice-president Hatta. Niettemin was dit offensief zowel militair als politiek een misgreep. Het leidde er onder meer toe dat de meeste door Nederland gecreëerde deelstaten zich niet tegenover maar naast de Republiek opstelden. Hoofdstuk VIII behandelt het jaar 1949, waarin het Nederlandse Indonesiëbeleid noodgedwongen een grote ommezwaai maakte. Uiteindelijk kwam op een Rondetafelconferentie in Den Haag een veelomvattend akkoord tot stand, op grond waarvan Nederland op 27 december 1949 zijn soevereiniteit over Indonesië overdroeg. Daarna kon Soekarno als officieel erkend president van het onafhankelijke Indonesië zijn intrek nemen in het vroegere paleis van de Nederlandse gouverneur-generaal.

Het liefste zou ik het boek hiermee hebben willen eindigen, maar ik kwam er niet onderuit ook nog het trieste vervolg te behandelen, waarin de verstandhouding tussen Indonesië en Nederland volledig verstoord werd. Dat was vooral maar niet uitsluitend een gevolg van de Nederlandse weigering om Nieuw-Guinea aan Indonesië over te dragen. Dit trieste vervolg heeft bijna driemaal zo lang geduurd als het dekolonisatieconflict van 1945-1949. Het wordt behandeld in hoofdstuk IX, dat loopt van januari 1950 tot de officiële vestiging van het Indonesische gezag over Nieuw-Guinea in mei 1963. 
Graag wil ik toelichten wat mij tot het schrijven van dit boek gebracht heeft. Ik ben in 1926 in Delft geboren en behoor dus nog tot de Nederlanders die als kind leerden dat 'Indië' en Nederland bij elkaar hoorden en voor wie plaatsnamen als Medan en Makassar even vertrouwd klonken als Deventer en Dordrecht. Niettemin ontdekte ik al in mijn jeugd dat de band tussen Nederland en Indië niet onaanvechtbaar was en dat er Indonesiërs waren die zich tegen het koloniale bestel verzetten.

Toen in september 1945 in Nederland bekend werd dat Indonesische nationalisten een onafhankelijke Republiek hadden uitgeroepen, studeerde ik in Amsterdam. Het bericht verraste mij, maar verbaasde mij toch minder dan het gros van mijn landgenoten. Enkele maanden later las ik Indonesische overpeinzingen van Sjahrazad, een boek dat diepe indruk op mij maakte. Ik vond het bijzonder hoopgevend te vernemen dat de auteur niemand anders was dan de zojuist aangetreden Republikeinse premier Sjahrir. Voor de studenten waarmee ik omging sprak het vanzelf dat Indonesië recht op onafhankelijkheid had, evenzeer als het voor ons vanzelf sprak dat tussen Indonesië en Nederland een bijzondere band zou blijven bestaan. Dat Nederland in juli 1947 de zogenaamde politionele actie tegen de Republiek begon stelde mij en mijn vrienden diep teleur.

Eind 1947 werd ik opgeroepen voor militaire dienst. Ik werkte eerst bij een krijgsraad in Nederland en vervolgens van oktober 1948 tot mei 1950 bij de krijgsraad voor de Koninklijke Landmacht in Batavia/Djakarta. Met intense belangstelling volgde ik daar van dag tot dag de politieke ontwikkelingen. Die ontwikkelingen voltrokken zich in hoog tempo: het vertrek van Van Mook als landvoogd en het aantreden van Beel als Hoge Vertegenwoordiger van de Kroon - het overleg van Nederlandse ministers met vice-president Hatta de tweede 'politionele actie' en de gevangenneming van de Republikeinse leiders - het ingrijpen van de Veiligheidsraad van de Verenigde Naties de omzwaai van de deelstaatvertegenwoordigers - het overleg tussen Van Roijen en Roem - de dood van generaal Spoor - het aftreden van Beel - de terugkeer van Soekarno en de zijnen in de Republikeinse hoofdstad - de bestandsovereenkomst en de amnestie - de Rondetafelconferentie in Den Haag - de Nederlandse soevereiniteits- en bestuursoverdracht - de intocht van Soekarno in Djakarta - de couppoging in Bandung - de snelle onttakeling van de federale staatsstructuur - en tenslotte de muiterij in Makassar.

Intussen had ik in Batavia ruime gelegenheid om mij breder te oriënteren. $\mathrm{Al}$ in het begin van mijn verblijf daar las ik Geschiedenis van den Indischen archipel door B.H.M. Vlekke, waaruit ik leerde dat die geschiedenis veel ingewikkelder was dan het simplistische beeld dat ik van school meegekregen had. Verder had ik veel profijt van de centrale bibliotheek van het Bataviaasch 
Genootschap, waar ik dichtbij woonde. Daar leende ik ook vooroorlogse boeken over de nationalistische beweging en de communistische beweging in Indonesië. Wat de recente geschiedenis betreft las ik al in 1949 The birth of Indonesia door David Wehl en Indonesië, Nederland en de wereld door Van Mook. Ik leerde de Indonesische taal en abonneerde mij op een Indonesische krant. Ook raakte ik bevriend met een staflid van het Bataviaasch Genootschap die officier in het Republikeinse leger was geweest en wiens oom Sjafroeddin Prawiranegara de Republikeinse noodregering had geleid na de gevangenneming van Soekarno en Hatta in december 1948. (Dat Nederlandse onderofficieren in 1949 zonder problemen met Indonesische Republikeinen konden omgaan is tekenend voor de ontspannen sfeer in het Batavia van die dagen.)

Mijn kijk op het conflict tussen Nederland en de Republiek werd in 1949 sterk beïnvloed door de wetenschap, dat Indië lang voor de Tweede Wereldoorlog al een omvangrijke nationale beweging had gekend die naar Indonesische onafhankelijkheid streefde, iets wat aan de meeste Nederlandse militairen onbekend was. Niet alleen van Hatta en Soekarno maar ook van allerlei andere figuren die in de kranten genoemd werden, zoals Agoes Salim, Dewantoro, Ratoelangie, Sartono, Soekiman, Sjahrir en Yamin, wist ik dat ze een rol in die vooroorlogse beweging hadden gespeeld. Ik zag het conflict dan ook steeds als een deel van een ontwikkeling die al voor 1914 begonnen was.

$\mathrm{Na}$ terugkeer in Nederland en voltooiing van mijn rechtenstudie trad ik in 1953 in dienst van het Ministerie van Buitenlandse Zaken, waar ik tot 1987 ben blijven werken. In mijn werk had ik niet met Indonesië te maken, maar ik behield mijn belangstelling voor dat land en voor het stuk geschiedenis dat ik van 1945 tot 1950 meebeleefd had. Jarenlang bestonden daarover maar twee serieuze geschiedwerken, beide daterend uit 1952, namelijk Nationalism and revolution in Indonesia van de Amerikaan George McTurnan Kahin en De Indonesische quaestie van de Nederlander C. Smit. In de loop der jaren kreeg ik steeds meer behoefte aan een nieuw geschiedwerk over de dekolonisatie van Indonesië, waarin de Nederlandse aspecten beter tot hun recht zouden komen dan in het boek van Kahin en de Indonesische beter dan in het boek van Smit. Bovendien kwamen zowel over de Indonesische nationale beweging als over het conflict tussen Nederland en de Republiek steeds meer gegevens beschikbaar, eerst vooral door buitenlandse studies en later ook door Nederlandse studies en bronnenpublicaties.

Tegen de tijd dat ik het Ministerie van Buitenlandse Zaken verliet ging ik mij afvragen of ik niet moest proberen zelf het geschiedwerk samen te stellen dat mij voor ogen stond. Daarbij hechtte ik er in de eerste plaats belang aan dat zo'n werk de geschiedenis van de vooroorlogse vrijheidsbeweging, van de Japanse bezetting en van het conflict tussen Nederland en de Republiek als één doorlopend verhaal zou weergeven. In de tweede plaats zou zo'n werk gebruik moeten maken van de omvangrijke literatuur en documentatie die 
sinds de jaren vijftig over deze onderwerpen verschenen was. Verder zou zo'n boek ook moeten verduidelijken, hoe de Indonesische archipel in het verleden onder de macht van Nederland gekomen was en wat het koloniale bestel inhield waar de vrijheidsbeweging zich tegen keerde.

Intussen was diezelfde geschiedenis nu ook door L. de Jong behandeld in de delen 11a, 11b, 11c en 12 van zijn grote werk Het Koninkrijk der Nederlanden in de Tweede Wereldoorlog, maar dat was voor mij geen reden om van mijn plan af te zien. Ten eerste nam die geschiedenis bij De Jong ruim drieduizend pagina's in beslag, afgewisseld met andere onderwerpen en verdeeld over zes boeken, terwijl ik eerder dacht aan een tekst van ongeveer zeshonderd pagina's. Ten tweede waren daarin sommige zaken zeer gedetailleerd beschreven die ik alleen maar zou willen aanstippen, terwijl soms andere zaken die mij van wezenlijk belang leken daarin niet of nauwelijks aan de orde kwamen. Ten derde zou het boek dat mij voor ogen stond zich op een ander lezerspubliek moeten richten dan het publiek waar het werk van L. de Jong voor bedoeld was. Het zou bestemd zijn voor lezers in de eenentwintigste eeuw, voor wie de bijzondere band tussen Indonesië en Nederland al tot een ver verleden zou behoren.

In het midden van de jaren negentig kreeg ik tijd om aan het beoogde geschiedverhaal te beginnen. Omdat het onderwerp zowel Indonesië als Nederland aanging terwijl ook in derde landen zoals Amerika en Australië veel belangstelling voor dit stuk geschiedenis getoond was, probeerde ik mijn verhaal zo te schrijven dat het zowel voor Nederlanders als voor Indonesiërs en andere buitenlanders bevattelijk zou zijn. Tegelijk ging ik wel op enkele stukjes vaderlandse geschiedenis in die voor het dekolonisatiedrama relevant waren, zoals de geboorte van de Nederlandse staat (evenals de Republiek Indonesië voortgekomen uit een opstand tegen vreemde overheersing) en de Belgische onafhankelijkheidsproclamatie van 1830. Ik hoopte dat het boek ook in Indonesische en Engelse vertaling zou kunnen verschijnen.

Het verzamelen van de nodige gegevens voor dit boek heeft veel tijd gekost. De relevante literatuur en documentatie is zeer omvangrijk. De aantekeningen bij de hoofdstukken van dit boek bevatten verwijzingen naar een groot deel van de door mij geraadpleegde bronnen. Mijn belangrijkste bron was de meer dan vijftienduizend pagina's tellende publicatie van Nederlandse interne documenten, getiteld Officiële bescheiden betreffende de Nederlands-Indonesische betrekkingen 1945-1950. Overigens heb ik ook bijna tweeduizend afleveringen van dagbladen uit die periode doorgenomen. Het merendeel van de boeken die voor mijn studie van waarde zijn gebleken dateert van na 1950. Het zou te ver voeren hiervan op deze plaats een overzicht te geven, maar ik wil toch een uitzondering maken voor drie Nederlandse werken waar ik bijzonder profijt van heb gehad: allereerst het hierboven al genoemde geschiedwerk van L. de Jong uit 1984-1988, dan het in 1988 verschenen Diplomatie of strijd van J.J.P. de Jong en tenslotte Afscheid van Indië uit 2000 van H.W. van den Doel. 
Wie in ongeveer zeshonderd pagina's zowel de kolonisatie als de dekolonisatie van Indonesië wil beschrijven moet zich strenge beperkingen opleggen: om alles te behandelen dat hij voor een goed begrip van de historische ontwikkeling essentieel acht moet hij helaas veel weglaten dat boeiend en relevant is. Mijn werk aan dit boek bestond dan ook voor een belangrijk deel uit selecteren, samenvatten en snoeien. Veel personen heb ik ondanks hun interessante rol niet met name vermeld. Twee belangrijke bevolkingsgroepen, de Indo-Europeanen en de Chinezen, komen slechts hier en daar ter sprake. Niettemin is de omvang van het boek toch aanzienlijk groter geworden dan $\mathrm{ik}$ beoogd had. Ik heb het dus niet kunnen laten erg veel zaken als 'voor een goed begrip essentieel' te beschouwen. Twee overwegingen droegen daartoe bij. Ten eerste vond ik het nodig sommige zaken te behandelen omdat die in de meeste literatuur naar mijn mening verkeerd worden voorgesteld. Ten tweede vond ik het nodig aan sommige zaken aandacht te geven omdat die in de bestaande literatuur nergens behandeld worden. In het bijzonder de hoofdstukken VI, VII en VIII zijn daardoor omvangrijker geworden dan ik had verwacht.

Wie een veelomvattende historische ontwikkeling beknopt wil weergeven kan zekere vereenvoudigingen van de gang van zaken moeilijk vermijden. Een voorbeeld van zo'n vereenvoudiging is het toekennen van motieven aan collectiviteiten, zoals landen, volkeren en regeringen. Dit valt toe te lichten aan de hand van het beleid van Nederland tegenover de Republiek Indonesië in de jaren 1945-1949. Eigenlijk is het bepalende lidwoord 'het' hier namelijk niet op zijn plaats. De term 'beleid' veronderstelt immers duidelijke doelstellingen, een bepaalde visie en daarop gebaseerde plannen en instructies. Wat Nederland betreft was daarvan geen sprake. Steeds bestonden er binnen de regering grote meningsverschillen over het in Indonesië te voeren beleid, en nog scherpere verschillen leefden binnen de politieke achterbannen waarvan de regering afhankelijk was. Dit maakte het soms onmogelijk om besluiten te nemen. Bovendien hinkten sommige belangrijke beleidsmakers zelf op verschillende gedachten. Verder veranderden de meningen voortdurend in het licht van de gebeurtenissen. Het feitelijke beleid was dan ook meer dan eens het resultaat van handelen buiten het kader van de officiële instructies. Niettemin heb ook ik soms geschreven over uitgangspunten en oogmerken van 'het' Nederlandse beleid, hoewel dat in feite een versimpeling was.

Overigens moet een geschiedschrijver niet alleen voorzichtig zijn met het toekennen van motieven aan collectiviteiten, maar ook met het weergeven van motieven van individuen. Men mag niet zonder meer afgaan op de redenen die de individuen zelf aanvoeren, ook al menen zij het oprecht. Mensen weten niet altijd waarom ze handelen zoals ze handelen, en dat geldt ook voor 
politiek handelen. Besluiten komen soms tot stand onder de drang van uiterlijke omstandigheden of van innerlijke sentimenten zonder dat de besluitnemers zich daar voldoende van bewust zijn. Naar mijn mening gold het eerste bijvoorbeeld voor de Nederlandse besluiten tot het lanceren van offensieven tegen de Republiek in 1947 en 1948 en gold het tweede voor het Nederlandse Nieuw-Guinea-beleid in het tijdvak 1950-1961.

\section{IV}

Tenslotte moet ik nog uitleggen waarom ik in de titel van dit boek, naast de garoeda als welbekend symbool voor Indonesië, de ooievaar als symbool voor Nederland heb opgevoerd.

De ooievaar behoort tot de grootste vogels van Nederland; hij is al vanouds een markante figuur in het Nederlandse rivieren- en polderlandschap en speelt bovendien een mythische rol in het volksgeloof. Daarbij siert hij al eeuwenlang het stadswapen van Den Haag. Hoewel de ooievaar geen officieel symbool van Nederland is, staat hij dus wel symbool voor Den Haag. Dat is relevant in het kader van de in dit boek behandelde geschiedenis, omdat tijdens de hele periode dat Indonesisch grondgebied onder Nederlands koloniaal gezag stond de Nederlandse bemoeienis met dat gebied van Den Haag uit is bedisseld. Dat gold ook tijdens het dekolonisatieproces dat het hoofdonderwerp van dit boek vormt. Overigens was Den Haag al in de negentiende eeuw de plaats waar Nederlanders die uit Indonesië terugkeerden zich het liefste vestigden en is het ook nu nog de meest 'Indische' stad van Nederland.

Er zijn nog twee aanvullende redenen waarom ik de ooievaar graag in de titel van dit boek wilde opvoeren. Ten eerste past zijn uiterlijke verschijning met zijn hoge poten en lange snavel wel bij dat stijve en pedante dat de Nederlanders in hun houding tegenover Indonesië vaak gekenmerkt heeft. Ten tweede maken ooievaars lange reizen en overwinteren ze graag op het zuidelijk halfrond; dat past wel bij de Nederlandse koloniale traditie die niet had kunnen ontstaan zonder de bereidheid van Nederlanders om ook aan de andere kant van de aardbol te leven en te werken. 


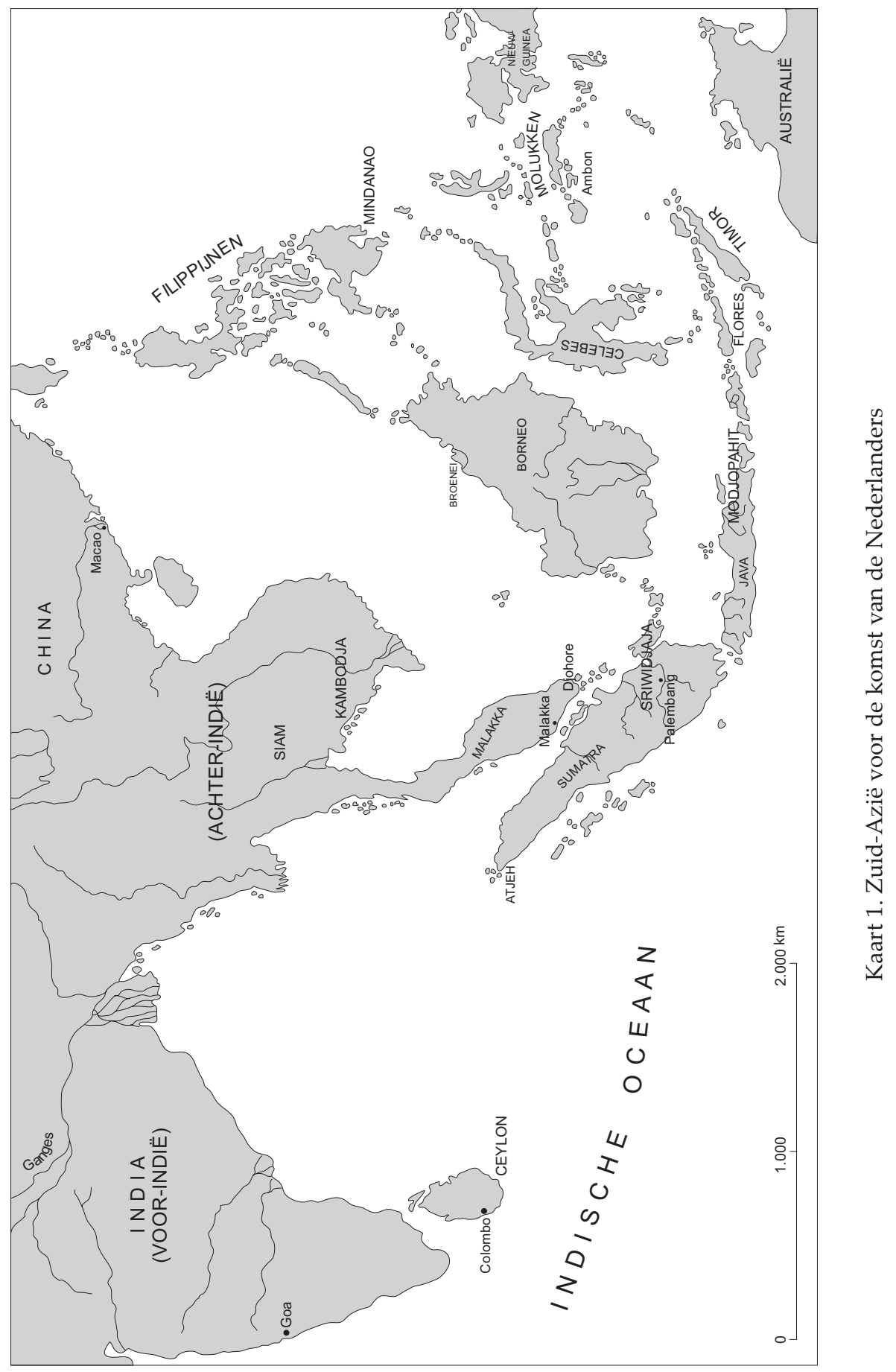




\section{HOOFDSTUK I}

\section{Indonesië voor de komst van de Nederlanders}

\section{Inleiding en overzicht}

Drie-en-een-halve eeuw is de geschiedenis van Indonesië nauw verbonden geweest met die van Nederland, maar dat betekent niet dat de Indonesische archipel daarvoor een gebied zonder geschiedenis was. Toen de eerste Nederlandse schepen tegen het eind van de zestiende eeuw in die archipel kwamen, had het merendeel van de bevolking al een bewogen en kleurrijk verleden achter zich.

$\mathrm{Al}$ in het eerste millennium van onze jaartelling ontstonden in Indonesië talrijke feodale staten en staatjes. Op religieus en cultureel terrein werden Sumatra en Java toen sterk beïnvloed door India; onder meer verbreidden zich hier het hindoeïsme en het boeddhisme. Sommige vorstendommen bereikten in deze tijd een hoog peil van ontwikkeling; daarvan getuigt onder meer de Boroboedoer, een uit de negende eeuw stammend boeddhistisch heiligdom op Java. Hindoe-Indonesische staten hebben tot in de vijftiende eeuw bestaan. Twee ervan verwierven enige tijd een overheersende positie waarin zij grote delen van Indonesië en Malakka in hun macht hadden. Dit waren het ZuidSumatraanse rijk Sriwidjaja in de dertiende eeuw en het Oost-Javaanse rijk Modjopahit in de veertiende eeuw. De meeste vorstendommen leidden overigens een wisselvallig bestaan als gevolg van interne en externe conflicten; herhaaldelijk kwamen nieuwe staten op en verdwenen andere van het toneel.

In veel Indonesische staten en staatjes vormde de landbouw de basis van de economie, maar er waren er ook waar zeevaart en handel een belangrijke inkomstenbron vormden. In de loop van de eeuwen ontwikkelde zich een levendig handelsverkeer, zowel binnen de archipel als met andere delen van Azië, zoals China, India en Perzië. Er kwam zelfs enige uitvoer van Indonesische producten naar Europa op gang. Dit betrof voornamelijk de specerijen peper, kruidnagelen en muskaatnoten, waarvoor men in Europa hoge prijzen betaalde. Ze werden over zee naar Arabische havens vervoerd en vandaar over land naar havens aan de Middellandse Zee gebracht. 
Een nieuw hoofdstuk van de Indonesische geschiedenis brak aan met de komst van de islam. Tussen het einde van de dertiende en het begin van de zeventiende eeuw werd de meerderheid van de bevolking hiertoe bekeerd. Dit gebeurde in de eerste plaats in de kustgebieden; pas later drong de islam tot de binnenlanden door. De vorsten van de nieuwe moslimstaten lieten zich meestal 'sultan' noemen. Tegen het eind van de zestiende eeuw was bijna heel Java geïslamiseerd en was een deel van de hindoeïstische elite naar Bali uitgeweken. De heerschappij over Java berustte nu grotendeels bij twee nieuwe vorstendommen, het sultanaat Bantam in het westen en het sultanaat Mataram in het midden en oosten. Ook elders in de archipel ontstonden enige machtige moslimstaten.

Intussen veranderde de situatie in de zestiende eeuw ingrijpend door het optreden van een Europees volk, de Portugezen. Voor het eerst schiepen zij een zeeroute tussen Europa en Azië om Afrika heen. Zij veroverden verschillende steunpunten aan de Aziatische kust. In de Indonesische archipel openden zij handelsbetrekkingen met havens op Sumatra en Java. Eén van de motieven voor de Portugese expansie was de wens de lucratieve specerijenhandel aan zich te trekken. Omdat kruidnagelen en muskaatnoten uitsluitend uit de Molukken kwamen, richtte Portugal ook daar enige steunpunten op; onder meer bouwde het een fort op het eiland Ambon. Bovendien bekeerden de Portugezen op verschillende plaatsen de bevolking tot het katholieke geloof.

Toen op het eind van de zestiende eeuw ook de Nederlanders in de Indonesische archipel kwamen, troffen zij daar geen statische situatie aan; zowel op politiek als op godsdienstig gebied was er veel in beweging.

\section{De Indonesische archipel}

Het woord Indonesië betekent letterlijk 'Indische eilandengroep'. Pas in de twintigste eeuw is Indonesië een staatkundig begrip geworden. Spreekt men van Indonesië met betrekking tot het vroegere verleden, dan hanteert men een aardrijkskundig begrip, waarvan de begrenzing niet hoeft samen te vallen met die van de hedendaagse Indonesische staat. Men zou er de hele archipel onder kunnen verstaan die tussen het vasteland van Azië en Australië gelegen is, van de Filippijnen in het noorden tot Timor in het zuiden en van Sumatra in het westen tot en met Nieuw-Guinea (Irian) in het oosten. Maar om historische redenen is het gebruikelijk de Filippijnen en de oostelijke helft van Nieuw-Guinea niet tot Indonesië te rekenen. Dat spraakgebruik zal in dit boek worden gevolgd.

Ook met deze inperking is Indonesië een gebied van reusachtige afmetingen. De afstand tussen de westpunt van Sumatra en het midden van NieuwGuinea is groter dan die tussen Ierland en de Oeral; de lengte van Sumatra 
overtreft de afstand van Amsterdam tot Rome. De Indonesische archipel omvat duizenden eilanden, waaronder enkele zeer grote: Sumatra, Java, Borneo (Kalimantan) en Celebes (Sulawesi), terwijl het op één na grootste eiland ter wereld, Nieuw-Guinea, de overgang vormt naar de eilandgebieden van de Stille Oceaan.

De ligging van Indonesië aan weerszijden van de evenaar zorgt voor hoge temperaturen. De regenval is in de meeste gebieden overvloedig. Het land telt honderden vulkanen, waaronder ruim tachtig die nog actief zijn. Deze drie factoren dragen bij tot de meestal hoge vruchtbaarheid van de bodem.

Indonesië is niet altijd een eilandgebied geweest. Het grootste deel van het grondgebied, waaronder dat van de huidige eilanden Sumatra, Java en Borneo, vormde vroeger één geheel met het vasteland van Azië. De huidige archipel ontstond ruim tienduizend jaar geleden, toen na de laatste IJstijd de zeespiegel meer dan honderd meter steeg.

\section{De bevolking van de archipel}

Al sinds de dageraad van de mensheid hebben mensen geleefd binnen het grondgebied van het huidige Indonesië, want op Java zijn skeletresten van menselijke wezens gevonden die honderdduizenden jaren oud moeten zijn. Talrijker zijn de vondsten van schedelfragmenten en stenen werktuigen van enkele tienduizenden jaren geleden. Het is onzeker of zich in Indonesië nu nog afstammelingen bevinden van die prehistorische bewoners uit de tijd dat het gebied nog deel uitmaakte van het Aziatische vasteland.

De overgrote meerderheid van de huidige bevolking stamt af van volkeren die in de laatste millennia voor het begin van onze jaartelling uit Achter-Indië en Zuid-China naar de archipel zijn getrokken. Uit de onderling verwante talen van deze volkeren zijn de meeste hedendaagse Indonesische talen voortgekomen, zoals het Atjehs, het Balinees, het Bataks, het Javaans, het Madoerees, het Maleis en het Soendanees. Alleen de Papoea's in Nieuw-Guinea en bewoners van enige naburige eilanden spreken talen die niet tot deze groep behoren.

Hierbij moet worden aangetekend dat het woord 'Maleis' in twee verschillende betekenissen gebruikt wordt. Men pleegt namelijk alle talen van de hier bedoelde groep (waartoe bovendien nog aanverwante talen behoren die elders worden gesproken, onder meer op het schiereiland Malakka en op de Filippijnen) wel samenvattend aan te duiden als 'Maleise talen'. In dezelfde ruime zin spreekt men eveneens van 'Maleise volkeren'; daar worden dus ook verschillende niet-Indonesische volkeren onder verstaan, terwijl anderzijds de Papoea's er niet toe worden gerekend. Ter voorkoming van verwarring zal deze ruime toepassing van de term 'Maleis' in dit boek worden vermeden. De term zal hier verder alleen in engere zin worden gebruikt ter aanduiding 
van één bepaalde taal, afkomstig uit het zuiden van Malakka en een deel van Sumatra. Doordat handelaren uit dit gebied zich over de kuststreken van de hele archipel verspreidden werd deze taal, vaak in sterk versimpelde vorm, een wijdverbreid communicatiemiddel tussen personen uit verschillende taalgemeenschappen. In de twintigste eeuw is het authentieke Maleis doelbewust uitgebouwd tot de moderne eenheidstaal van Indonesië, de 'Bahasa Indonesia'.

Een verduidelijking is ook gewenst met betrekking tot de woorden 'Javaan' en 'Javaans'. Het Javaans is de taal van de talrijkste Indonesische bevolkingsgroep, maar het is niet de enige taal van de bevolking van Java. Javaans wordt gesproken in Midden-Java, in bijna heel Oost-Java en in enige delen van West-Java, waaronder Noord-Bantam. In het grootste deel van West-Java wordt Soendanees gesproken, in Djakarta en omstreken een vorm van Maleis en in een klein deel van Oost-Java Madoerees. In dit boek wordt de term 'Javanen' niet gebruikt voor alle bewoners van Java, maar alleen voor hen wier moedertaal het Javaans is. Overigens heeft men vroeger, voordat het woord 'Indonesiër' in zwang kwam, de term 'Javaan' ook wel gebruikt voor iedere inheemse inwoner van de kolonie Nederlands-Indië, in dezelfde geest als alle Nederlanders soms als Hollanders worden betiteld.

De migratie uit het Aziatische vasteland naar Indonesië vond duizenden jaren geleden plaats in verschillende golven, waarbij later binnengetrokken volkeren dikwijls de afstammelingen van vroegere immigranten verdrongen naar afgelegen gebieden. De laatste grote immigratiegolf voltrok zich enkele eeuwen voor het begin van onze jaartelling. De volkeren die zich in die periode in de archipel vestigden waren hoger ontwikkeld dan hun voorgangers. $\mathrm{Zij}$ brachten onder meer de bewerking van brons en ijzer mee en de verbouw van rijst in sawahs (onder water staande terrassen die met dijkjes worden omsloten).

Anders dan in Europa heeft zich in het gebied van Indonesië na het begin van onze jaartelling geen grootschalige volksverhuizing meer voorgedaan. Wel heeft het land in de loop der eeuwen op beperkte schaal migranten van elders opgenomen, voornamelijk uit India, China en Europa. Van hun afstammelingen vormen de Chinezen verreweg de grootste groep, maar ook die maken nog geen drie procent van de Indonesische bevolking uit.

\section{Cultuur en samenleving in het begin van onze jaartelling}

$\mathrm{Al}$ eeuwen lang bezitten grote delen van Indonesië, in tal van variaties, een cultuur met een eigen karakter. De aanzet tot dit eigen Indonesische cultuurpatroon moet zijn gegeven door de volkeren die enkele eeuwen voor het begin van onze jaartelling de archipel binnentrokken en vooral op Sumatra en Java 
een overheersende positie veroverden. Aan de hand van archeologische vondsten en andere gegevens kan men zich een beeld vormen van de cultuur en de samenleving van deze Indonesische volkeren in de eerste eeuwen van onze jaartelling. De bevolking beschikte over vaardigheden op het punt van landbouw, metaalbewerking, weefkunst en het maken van sieraden, maar gebruikte nog geen schrifttekens. De religieuze denkbeelden waren animistisch: men beschouwde niet alleen mensen en dieren maar ook planten, voorwerpen en natuurverschijnselen als bezield of als dragers van magische krachten. Allerlei rituelen dienden voor het gunstig stemmen van de vele geesten en goden waarmee men de wereld bevolkt achtte, zoals de geesten van de voorouders en de godin van de rijst. De basiseenheid van de samenleving was de dorpsgemeenschap. Werkzaamheden werden door de dorpsgenoten veelal gezamenlijk of in onderling hulpbetoon verricht. In het bijzonder de natte rijstbouw eiste een behoorlijke graad van maatschappelijke organisatie. Productie vond niet voor de verkoop plaats, maar voor het voorzien in de eigen behoeften van de dorpsbevolking én in de behoeften van hoger geplaatsten. Dit laatste was niet onbelangrijk, want de dorpsgemeenschappen maakten meestal deel uit van grotere verbanden onder plaatselijke landheren en vorsten, aan wie men een gedeelte van de oogst moest afdragen en voor wie men herendiensten moest verrichten.

In de loop van het eerste millennium van onze jaartelling ontstonden in Indonesië talrijke feodale staten en staatjes. In vele daarvan vormde de landbouw de basis van de economie; uit de agrarische opbrengsten werden ook de vorst, zijn hofhouding, zijn krijgsmacht en de lagere gezagsdragers onderhouden. In sommige staten, onder andere in de binnenlanden van Java, moest de landbouwende bevolking daartoe drievijfde van de oogst afstaan. Naast deze overwegend agrarische staten ontstonden aan de kusten ook staten met een overwegend maritiem karakter. Zeevaart en handel vormden hier een belangrijke inkomstenbron. In deze staten hield ook de adel zich actief met het drijven van handel bezig, in tegenstelling tot de adel in de agrarische staten. In de loop van de eeuwen ontwikkelde zich een levendig handelsverkeer, zowel binnen de archipel zelf als met andere delen van Azië, zoals China, India en Perzië.

\section{De Hindoe-Indonesische culturen}

In de tijd waarin het Indonesische cultuurpatroon zich begon te vormen waren China en India de belangrijkste nabij gelegen beschavingscentra, beide beschikkend over een eeuwenoude cultuur en een eigen schriftstelsel. Hoewel deze beide landen handelscontacten met de Indonesische archipel hadden was hun culturele invloed zeer ongelijk: van de Chinese cultuur werd in 
Indonesië bijzonder weinig overgenomen en van de Indiase cultuur bijzonder veel. Dat gold in de eerste plaats voor de twee grote uit India afkomstige religieuze stelsels, het hindoeïsme en het boeddhisme. Het gold eveneens voor de daarmee verbonden bouwkunst, beeldende kunst, legenden en maatschappelijke opvattingen. Zo ontstonden de Hindoe-Indonesische culturen die ruim duizend jaar op Sumatra en Java hebben bestaan en nu nog voortbestaan op Bali en Lombok.

Het hindoeïsme bereikte de archipel in de derde of vierde eeuw van onze jaartelling; verering van de god Sjiwa werd op den duur de dominerende variant daarvan. Het boeddhisme kwam enige eeuwen later naar Indonesië, in een tijd toen het in India zelf al op de terugtocht was maar wel was begonnen aan zijn opmars in Achter-Indië en China. Het naast elkaar bestaan van deze beide religies leidde in Indonesië niet tot grote conflicten; bovendien verbreidde het boeddhisme zich er in een versie die veel elementen uit het hindoeïsme overnam. Sommige vorsten gaven zowel aan hindoeïstische als aan boeddhistische priesters een officiële aanstelling en er werden zelfs heiligdommen gebouwd waarvan het ene deel aan Sjiwa en het andere deel aan Boeddha gewijd was. Er deden zich evenmin ernstige botsingen voor met de eerder door de bevolking gehuldigde religieuze denkbeelden en gebruiken, die trouwens op zichzelf niet met de Indiase religies strijdig waren. De nieuwe religies traden dan ook niet in de plaats van de animistische tradities maar vormden veeleer een overkapping daarvan. Verscheidene van die oude denkbeelden en gebruiken zijn overigens in Indonesië duurzamer gebleken dan het hindoeïsme en het boeddhisme en zijn ook na de overgang van de bevolking tot de islam blijven bestaan, deels zelfs tot op de huidige dag.

De Hindoe-Indonesische culturen hebben een groot aantal bouwkundige monumenten achtergelaten. Zo zijn op het Diëng-plateau in het bergland van Midden-Java de resten te vinden van een sjiwaïtisch tempelcomplex uit de achtste eeuw. Ruim vijfentwintig kilometer ten noordwesten van Jogjakarta ligt de Boroboedoer, een boeddhistisch heiligdom uit de negende eeuw in de vorm van een met beeldhouwwerk overdekte vierkante heuvel. Beroemd zijn ook de hindoeïstische tempels uit de tiende eeuw in Prambanan, ten oosten van Jogjakarta. In de loop der eeuwen verwijderde de Hindoe-Indonesische beeldende kunst zich geleidelijk van haar Indiase voorbeelden en kreeg zij een meer eigen karakter, bij voorbeeld door het invoegen van komische figuren tussen de Indiase helden.

De belangrijkste erfenis van de Hindoe-Indonesische culturen is te vinden in de volksverhalen die in het wajangspel worden uitgebeeld, want die zijn nog steeds grotendeels gebaseerd op de Indiase heldendichten. Sommige van de daarin optredende goden, ridders en andere figuren, zoals de mythische vogel Garoeda, hebben daardoor een plaats gekregen in de voorstellingswereld van een belangrijk deel van de Indonesische bevolking. 
De maatschappelijke opvattingen uit India die in de Hindoe-Indonesische culturen werden overgenomen, hingen nauw samen met het hindoeïstische kastenstelsel. Deze opvattingen droegen bij tot een streng hiërarchische inrichting van de samenleving, tot een grote rechtsongelijkheid tussen de verschillende bevolkingsgroepen en tot verabsolutering van de macht van de vorsten, die op één lijn met de goden werden gesteld. Uit die tijd stamt ook het wijdverbreid gebruik, dat de vorst zich niet zelf met het dagelijkse bestuurswerk bezighoudt maar dit delegeert aan een rijksbestuurder, de patih.

\section{Hindoe-Indonesische vorstendommen op Sumatra en Java}

Het eerste grote Hindoe-Indonesische rijk was Sriwidjaja, waarvan de hoofdstad nabij het huidige Palembang lag. Ontstaan in de zevende eeuw, breidde het in de volgende eeuwen zijn macht uit over grote delen van Sumatra, het schiereiland Malakka en andere eilanden en kustgebieden. Het ontleende zijn positie aan handel en scheepvaart en de beheersing van belangrijke zeestraten. Tegelijk was de hoofdstad een invloedrijk boeddhistisch centrum, met een universiteit die ook door pelgrims uit India en China bezocht werd. Geen enkele Indonesische staat is zo lang in stand gebleven als dit maritieme rijk. Ondanks een reeks conflicten met Javaanse vorstendommen en met Cambodja bereikte het in de dertiende eeuw het toppunt van zijn macht. Na een mislukte poging tot verovering van Ceylon (Sri Lanka) raakte Sriwidjaja in verval en in 1377 werd het veroverd door het Javaanse rijk Modjopahit. De prominente rol die Sriwidjaja eens speelde heeft een belangrijk taalkundig gevolg gehad: daarmee werd de grondslag gelegd voor de verbreiding van het Maleis als algemene verkeerstaal.

Terwijl het rijk Sriwidjaja zich eeuwenlang kon handhaven, leidden de Hindoe-Indonesische vorstendommen op Java een wisselvallig bestaan ten gevolge van zowel interne als externe conflicten. Die interne conflicten werden niet veroorzaakt door verzet van de lagere tegen de hogere bevolkingsgroepen, maar door onenigheid binnen de regerende bovenlaag zelf in de vorm van hofintriges en opvolgingstwisten. Ook extern waren de vorstendommen weinig stabiel door hun talrijke onderlinge oorlogen; grenzen werden veelvuldig gewijzigd en herhaaldelijk kwamen nieuwe staten op en verdwenen andere van het toneel.

Midden-Java verloor in de tiende eeuw zijn leidende rol. De boeddhistische dynastie die de Boroboedoer had laten bouwen was inmiddels verdreven door een sjiwaïtisch koningshuis dat zijn zetel naar Oost-Java overbracht. Tegen het eind van de eeuw viel dit rijk uiteen. In de elfde eeuw wist de uit Bali afkomstige koning Erlangga heel Oost-Java onder zijn bestuur te verenigen en opnieuw tot bloei te brengen, maar ook zijn rijk bleef niet lang bestaan. In 


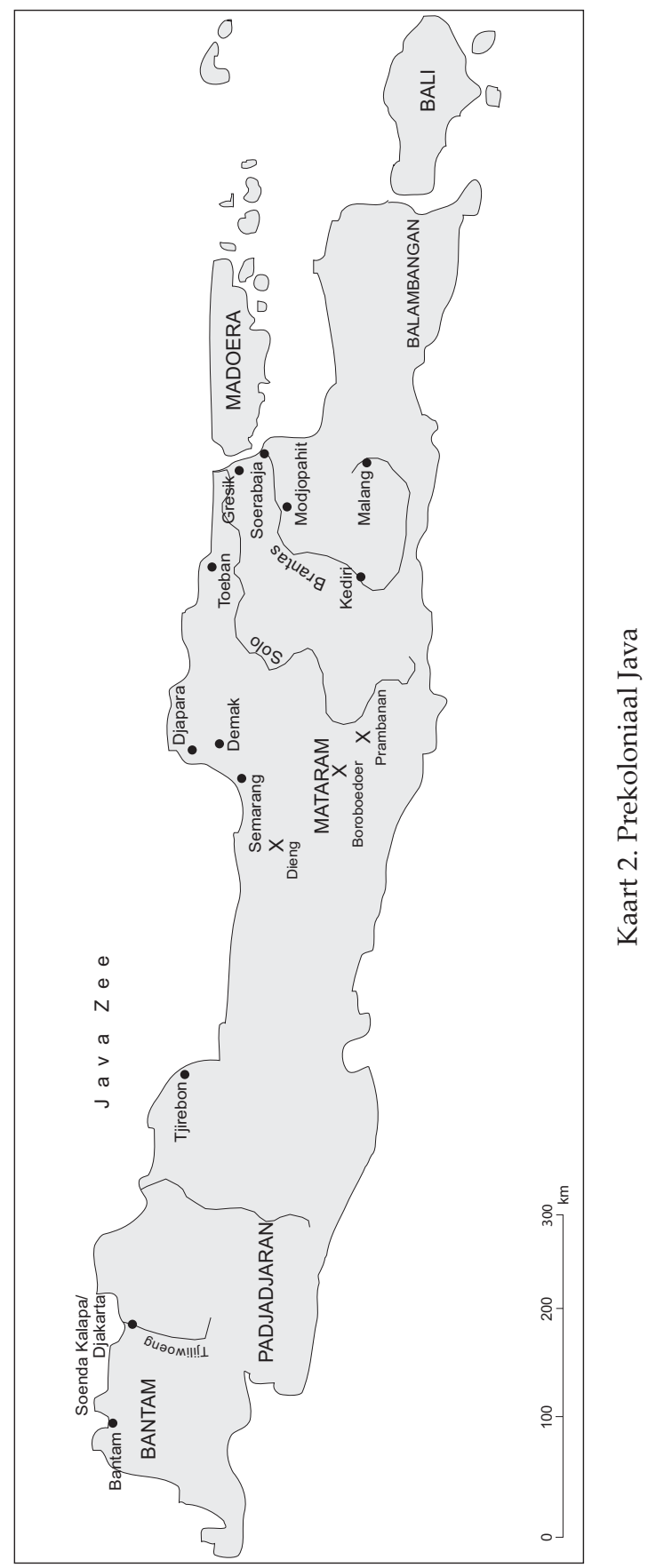


de twaalfde eeuw berustte de hegemonie bij het Oost-Javaanse rijk Kediri, dat zich tot een maritieme macht ontwikkelde die ook Bali en delen van Borneo en Celebes beheerste. De bekendste koning van Kediri is Djojobojo, die onder meer een Javaanse bewerking heeft laten maken van het Indiase heldendicht Mahabharata. In de dertiende eeuw ging de macht van Kediri over op het rijk Singasari, dat gesticht was door de rebel Ken Angrok. Dit rijk, waarvan de hoofdstad ten noorden van het huidige Malang lag, verwierf de oppermacht over een groot deel van Java en over delen van Sumatra, Malakka, Borneo en de Molukken, maar ging binnen een eeuw ten onder aan een conflict met China.

De zoon van de laatste koning van Singasari stichtte een nieuw rijk en vestigde zijn hoofdstad in Modjopahit, een dorp aan de rivier de Brantas, ongeveer vijftig $\mathrm{km}$ ten zuidwesten van Soerabaja. Dit rijk, dat van 1294 tot omstreeks 1520 heeft bestaan, kreeg gedurende enige tijd bijna heel Indonesië en Malakka onder zijn macht. Die machtsuitbreiding was vooral te danken aan Gadjah Mada, die van 1331 tot 1364 als rijksbestuurder optrad onder koning Hajam Woeroek. Gadjah Mada was niet alleen een groot krijgsman maar ook een bekwaam organisator van het binnenlands bestuur. Tijdens zijn bewind kwam het rijk Modjopahit tot grote bloei en groeide de hoofdstad uit tot een stad van honderdduizend inwoners. Maar ook dit rijk heeft zich niet kunnen handhaven; in de vijftiende eeuw brokkelde zijn macht snel af.

Van de geschiedenis van West-Java in de Hindoe-Indonesische tijd is weinig bekend. De daar opgekomen Soendanese vorstendommen wisten meestal hun onafhankelijkheid tegenover de Midden- en Oost-Javaanse heersers te bewaren. Wel vestigden Javanen zich in enkele West-Javaanse gebieden, in het bijzonder het gebied van Bantam. In de veertiende eeuw ontstond het Soendanese rijk Padjadjaran. Het had zijn hoofdstad aan de rivier de Tjiliwoeng nabij de plaats van het huidige Bogor en bezat een haven, Soenda Kalapa, aan de mond van die rivier. De bekendste vorst van Padjadjaran is de legendarische koning Siliwangi.

\section{De komst van de islam}

Tussen het eind van de dertiende en het begin van de zeventiende eeuw ging het merendeel van de Indonesische bevolking tot de islam over. Deze godsdienst werd in hoofdzaak door Perzische en Indiase handelaren naar Indonesië overgebracht. De eerste gebieden die het nieuwe geloof omhelsden lagen aan de kust van Noord-Sumatra; één daarvan was Atjeh. In de vijftiende eeuw kreeg de islam vaste voet in verschillende handelsplaatsen op het schiereiland Malakka, in Zuid-Sumatra, op de noordkust van Java en in de Molukken. Maleise handelaren hadden een belangrijk aandeel in deze verbreiding van 
het nieuwe geloof, die dikwijls de grote scheepvaartroutes volgde. De hindoeistische priesters boden blijkbaar weinig tegenspel aan de bekeringsijver van de moslims. Dat de islam alle mensen in beginsel gelijkwaardig noemde zal bovendien voor de meerderheid van de bevolking een aantrekkelijk contrast betekend hebben met de kastenleer van het hindoeïsme.

Het nieuwe geloof vond in de eerste plaats aanhang in kustgebieden en jonge staten die zich af wilden zetten tegen de traditionele hindoeïstische machtscentra. Pas later drong de islam in de binnenlanden door. De vorsten die het nieuwe geloof aanvaard hadden, maakten aanspraak op de titel 'sultan' in plaats van 'radja' of 'maharadja'.

Tegen het eind van de zestiende eeuw was heel Java geïslamiseerd, met uitzondering van enkele ontoegankelijke berggebieden en van de uiterste oosthoek waar het hindoeïstische staatje Balambangan zich nog twee eeuwen handhaafde. Vluchtend voor de moslim-overheersing was een deel van de hindoeïstische adel en geestelijkheid intussen naar Bali uitgeweken. Daar bleef het hindoeïsme (tezamen met een vorm van boeddhisme) tot op de huidige dag in stand, terwijl het bovendien in de achttiende eeuw nog vandaar naar West-Lombok geëxporteerd is.

In de rest van de archipel gingen alle volkeren die het hindoeïsme of het boeddhisme hadden aangehangen tot de islam over. Hetzelfde gold voor een deel van de volkeren die deze religies nooit hadden aanvaard. Enkele van deze volkeren, waaronder de Bataks rondom het Toba-meer in Sumatra, de Dajaks in het binnenland van Borneo en de Toradja's in Midden-Celebes, lieten zich echter ook niet tot de islam bekeren.

\section{Nieuwe moslimstaten in Malakka en Indonesië}

De ondergang van het rijk Sriwidjaja op het eind van de veertiende eeuw maakte de weg vrij voor de opkomst van een nieuw rijk met als centrum de stad Malakka, gelegen aan de westkust van het schiereiland waaraan later dezelfde naam is gegeven, ongeveer tweehonderd kilometer van het huidige Singapore. Omstreeks 1400 was dit oord weinig meer dan een vissershaven en was de plaatselijke heerser een vazal van Siam (Thailand). Hij wist zich aan de Siamese heerschappij te onttrekken door zich onder de bescherming van China te stellen. Met deze rugdekking nam de haven van Malakka al spoedig de rol van Palembang als handelscentrum over. Intussen was de koning tot de islam overgegaan; zijn opvolgers voerden dan ook de titel van sultan.

In het midden van de vijftiende eeuw breidde het sultanaat zijn grondgebied uit over delen van het schiereiland en van Sumatra. Het versloeg Siam te land en ter zee. Tegelijk profiteerde het van het verval van Modjopahit, dat zijn betekenis als maritieme macht had verloren. Aldus werd het sultanaat 
Malakka in de tweede helft van de eeuw de sterkste maritieme mogendheid van Zuidoost-Azië en werd zijn hoofdstad het belangrijkste handelscentrum van dat gebied. Van China was het niet langer afhankelijk. De handelaren uit het sultanaat waren in de hele Indonesische archipel actief. Het feit dat het rijk Malakka een moslimstaat was, stimuleerde de verbreiding van de islam in de archipel. Tegelijk versterkte zijn leidende rol in het handelsverkeer daar de positie van het Maleis als verkeerstaal voor algemeen gebruik.

Ook binnen de Indonesische archipel zelf voltrokken zich veel politieke veranderingen in het tijdvak van de verbreiding van de islam.

In het noorden van Sumatra werd de havenstad Atjeh (het huidige Banda Aceh) het centrum van een sultanaat dat in de zestiende eeuw zijn macht uitbreidde over een deel van de oostkust en van de westkust van het eiland. Het sultanaat Atjeh, dat nauwe banden met het Turkse rijk onderhield, ging een belangrijke rol spelen in het westwaartse handelsverkeer van Indonesië.

Aan de noordkust van Java maakten de havensteden die tot de islam bekeerd waren zich los van de hindoeïstische staten in het binnenland. Eén daarvan was Bantam (nu Banten) in West-Java. Het gebied van Bantam, waar veel Javanen woonden, ging over tot de islam en scheidde zich af van het Soendanese Padjadjaran. In 1527 veroverde het Soenda Kalapa en gaf het daaraan een nieuwe naam: Djajakarta of kortweg Djakarta. Het rijk Padjadjaran kon zich niet lang meer handhaven. Bantam werd een sultanaat dat zijn gezag uitbreidde over een deel van West-Java en de zuidelijke punt van Sumatra. De havenstad Bantam ontwikkelde zich tot een belangrijk handelscentrum; de haven van Djakarta ging in betekenis achteruit.

Intussen was omstreeks 1500 in Demak, vijfentwintig kilometer ten oosten van Semarang, een nieuwe moslimstaat gesticht die in korte tijd grote delen van Java aan zich onderwierp. Na een halve eeuw viel dit sultanaat Demak weer uiteen. Dertig jaar later ondernam de bestuurder van het MiddenJavaanse district Mataram een volgende poging tot het scheppen van een groot Javaans rijk, met duurzamer resultaat. In de overlevering is hij blijven voortleven als Senopati (de Legeraanvoerder). Zijn schepping, het rijk Mataram, heeft van 1582 tot 1755 bestaan. Toen Senopati in 1601 overleed, had hij het grootste deel van het Javaanse binnenland al onder zijn macht gebracht. Zijn opvolgers veroverden in de volgende decennia de noordelijke kustdistricten en Madoera, waarna Mataram nog slechts grensde aan Bantam in het westen en Balambangan in het oosten. De naam van dit rijk was gelijk aan die van een legendarisch Midden-Javaans vorstendom uit de tiende eeuw. Ook in mentaliteit leek het nieuwe Mataram terug te keren naar oude tijden. Het was een naar binnen gekeerd agrarisch rijk dat despotisch werd bestuurd. Heel anders dan de heersers over de Noord-Javaanse havensteden Bantam, Tjirebon, Djapara, Toeban, Gresik en Soerabaja stelden de vorsten van Mataram geen belang in handel en scheepvaart. 


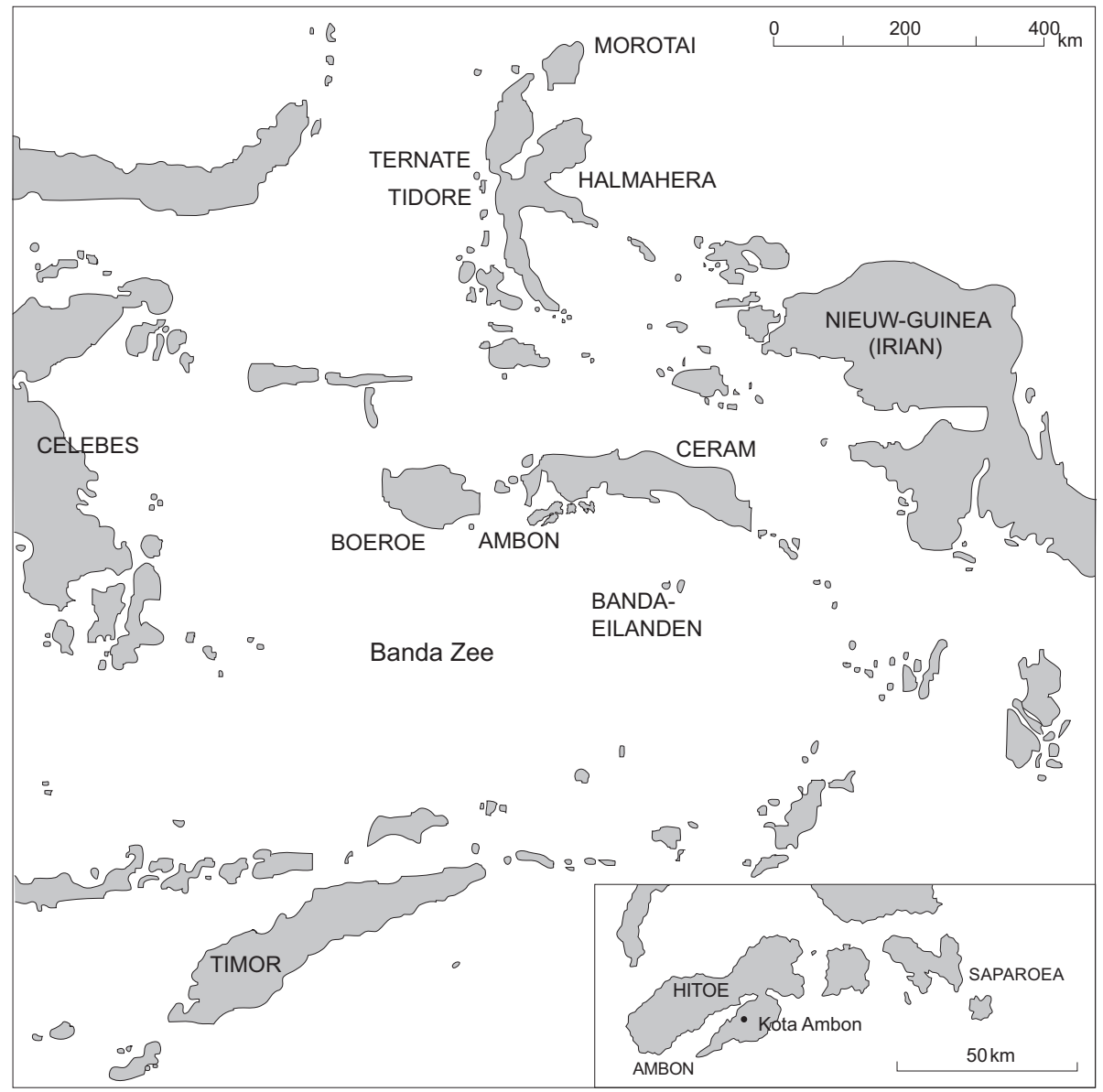

Kaart 3. De Molukken 


\section{De Molukken en de specerijenteelt}

In de vijftiende eeuw kreeg de islam vanuit Java ook vaste voet in verschillende handelsplaatsen in de Molukken, het eilandgebied tussen Celebes en Nieuw-Guinea. Dat er met dit tamelijk afgelegen gebied een levendig handelsverkeer bestond, kwam door zijn betekenis voor de specerijenproductie. Aziatische specerijen waren al eeuwenlang een zeer gewild artikel, niet alleen in Azië zelf maar ook in Europa waar er bijzonder hoge prijzen voor betaald werden. Verschillende van die specerijen werden slechts in beperkte gebieden geproduceerd. Kaneel kwam in hoofdzaak uit Ceylon, peper uit Sumatra, kruidnagelen en muskaatnoot uitsluitend uit de Molukken.

De Molukken bestaan uit enkele middelgrote en tientallen kleine eilanden. Die eilanden vormen twee groepen, een noordelijke en een zuidelijke. Al in de vijftiende eeuw berustte in beide groepen de hegemonie niet bij de grote maar bij één of twee kleine eilanden.

In de Noord-Molukken was het grootste eiland, Halmahera, aanvankelijk ook het machtigste. Dit veranderde echter nadat delen van de bevolking waren uitgeweken naar de voor de westkust gelegen vulkaaneilandjes Ternate en Tidore. Deze eilandjes zijn ongeveer vijftien kilometer lang en liggen slechts enkele kilometers van elkaar. De twee ministaatjes legden zich niet alleen op handel toe, maar ook op de opbouw van een maritiem rijk. In voortdurende onderlinge wedijver breidden ze in de loop van de vijftiende en zestiende eeuw hun macht uit tot ver buiten de Molukken. Beide gingen ze tot de islam over, maar Ternate was fanatieker in zijn geloofsijver dan Tidore. Op het eind van de zestiende eeuw heerste het sultanaat Ternate niet alleen over een deel van Halmahera en over talrijke noordelijk, westelijk en zuidelijk daarvan gelegen eilanden, maar ook over het zuiden van het Filippijnse eiland Mindanao en delen van Celebes en Flores. Het sultanaat Tidore beheerste de rest van Halmahera, de oostelijk daarvan gelegen eilanden en de westelijke kustgebieden van Nieuw-Guinea.

In de Zuid-Molukken werden de twee grootste eilanden, Boeroe en Ceram, in betekenis overvleugeld door het veel kleinere Ambon, ongeveer vijftig kilometer lang. Een diep insnijdende baai verdeelt dit eiland in een noordelijk en een zuidelijk deel, die slechts door een smalle landengte worden verbonden. Al voor de opkomst van Ternate en Tidore vormde deze baai een veel bezochte handelshaven. De hoofdplaats lag destijds op Hitoe, het noordelijke deel van Ambon. Als gevolg van het handelsverkeer vestigden zich daar ook Javanen en Maleiers en werd in de haven veel Maleis gesproken. De islam vond in de eerste plaats aanhang onder deze immigranten en vervolgens onder de andere bewoners van Hitoe. De bevolking ten zuiden van de baai handhaafde haar traditionele geloof. Terwijl Ambon zelf niet op veroveringen uit was, wist het wel vrij lang zijn zelfstandigheid tegenover Ternate en Tidore te bewaren. Op 
het eind van de zestiende eeuw werd het onderhorig aan Ternate.

In de Zuid-Molukken werd het bestuur over het algemeen niet door vorsten uitgeoefend, maar door colleges van vooraanstaande personen. Buiten Ambon was het bekendste deel van de Zuid-Molukken destijds een groepje zeer kleine eilanden, de Banda-eilanden. De Bandanezen hielden zich zowel met de productie van muskaatnoot bezig als met scheepvaart tussen de Molukken en Java. Zij waren zeer op hun onafhankelijkheid gesteld en waren in het begin van de zestiende eeuw nog niet geïslamiseerd.

\section{Portugese machtsuitbreiding in Azië}

De eerste Europeanen van wie bekend is dat zij in Indonesië geweest zijn, waren Italianen. In 1292 verbleef Marco Polo, destijds in dienst van de Chinese keizer, enige maanden in Noord-Sumatra tijdens een dienstreis naar Perzië; in 1321 bracht de katholieke missionaris Odorico de Pordenone een bezoek aan Modjopahit. Maar de eersten die op grote schaal naar Indonesië kwamen waren Portugezen.

Portugal begon in de vifftiende eeuw aan een grootse onderneming: het scheppen van een zeeroute om Afrika heen naar 'Indië', in die tijd een verzamelnaam voor alle Aziatische landen en eilanden tussen Arabië en Perzië enerzijds en China en Japan anderzijds. Deze onderneming had zowel een commercieel als een politiek-religieus motief.

De handel tussen 'Indië' en Europa had van oudsher via het MiddenOosten plaatsgevonden. Portugal wilde deze handel aan zich trekken. Daarbij ging het vooral om de specerijenhandel. De hoge prijzen die men in Europa voor Aziatische specerijen betaalde kwamen in hoofdzaak de tussenhandel ten goede. Die specerijen werden in 'Indië' geproduceerd, vandaar naar Arabische havens gebracht en vervolgens over land naar Egypte en Syrië vervoerd, waar ze werden opgekocht door handelaren uit Genua en Venetië. Zou Portugal die specerijen rechtstreeks uit de productielanden kunnen halen, dan zou het grote rijkdommen kunnen vergaren.

Tegelijk ging het Portugal om de bestrijding van de islam en de verbreiding van het christendom. Portugezen en Spanjaarden voerden destijds oorlog tegen de Moren, de moslims die zich zeven eeuwen eerder op het Iberisch schiereiland gevestigd hadden. Maar de Portugezen wilden meer dan alleen de verdrijving van de Moren uit het schiereiland (die tenslotte in 1492 een feit werd): zij wilden een totale overwinning op de moslims. Daarom was in Portugal het plan opgekomen hen in Noord-Afrika en het Midden-Oosten in de rug aan te vallen. Alleen al door het scheepvaartverkeer tussen het MiddenOosten en 'Indië' te verbreken zou de moslimwereld grote schade kunnen worden toegebracht. 
Twee misvattingen droegen ertoe bij dat de Portugezen zich aan deze grootse onderneming waagden: ze dachten dat in 'Indië' veel christenen woonden en ze stelden zich Afrika veel kleiner voor dan het in werkelijkheid is. In een reeks expedities verkenden Portugese schepen de Afrikaanse westkust, maar het duurde tot 1487 eer ze eindelijk de zuidpunt van Afrika bereikten.

Vervolgens lukte het in mei 1498 aan vier schepen onder Vasco da Gama om van de oostkust van Afrika over te steken naar de westkust van India. $\mathrm{Na}$ allerlei conflicten met plaatselijke autoriteiten en handelaren keerde Da Gama in september 1499 in Lissabon terug. Hierna voltrok de Portugese expansie zich in hoog tempo. Al in het voorjaar van 1500 vertrok een nieuwe Portugese vloot naar Azië, gevolgd door verdere vloten in de jaren daarna. Op de westkust van India werden in 1502 de eerste Portugese handelskantoren geopend en werd in 1503 het eerste Portugese fort gebouwd. In 1504 stelde de koning van Portugal een onderkoning voor Indië aan.

Zowel in Afrika als in India profiteerden de Portugezen ervan dat ze meestal te maken hadden met afzonderlijke staatjes die in onderlinge conflicten verwikkeld waren en waarvan sommige bereid waren als steunpunt voor Portugal te dienen. Vanuit deze steunpunten ontplooiden de Portugezen hun militaire macht in het hele gebied tussen de Hoorn van Afrika en het eiland Ceylon, vertoonden zich in de Rode Zee en de Perzische Golf, verwoestten een reeks Afrikaanse, Arabische en Indiase kuststeden en plunderden zoveel mogelijk handelsschepen op de scheepvaartroutes. Intussen vernamen zij dat de herkomstgebieden van de kostbaarste specerijen ver ten oosten van India lagen en dat op de route daarheen Malakka de voornaamste haven was.

Alfonso d'Albuquerque, onderkoning van 1509 tot 1515, was ervan overtuigd dat Portugal in Azië eigen grondgebied als machtsbasis nodig had. In 1507 had hij al Hormoez veroverd, dat de toegang tot de Perzische Golf beheerste. In 1510 maakte hij zich meester van Goa, een grote havenstad aan de westkust van India die ten prooi was aan interne politieke twisten. Dit werd de voornaamste Portugese basis in Azië. Een jaar later sloeg hij zijn volgende slag. Met negentien schepen voer hij naar Malakka. Na harde strijd werd de stad veroverd. Weliswaar probeerde de sultan van Demak de Portugezen te verdrijven met een Javaanse vloot van honderd schepen onder prins Pati Oenoes, maar deze vloot bleek niet opgewassen tegen de Portugese kanonnen. De verslagen sultan van Malakka kon zich overigens met zijn strijdkrachten terugtrekken en stichtte later een nieuw rijk in Djohore op de zuidpunt van het schiereiland.

In de decennia na de verovering van Goa en Malakka veroverde Portugal nog verscheidene steden aan de kusten van India en Ceylon. 


\section{De Portugezen in Indonesië}

Met de verovering van Malakka bezat Portugal een sterk bruggehoofd in Zuidoost-Azië en beheerste het de belangrijkste scheepvaartroute tussen Sumatra en het vasteland. Intussen bleef het belang stellen in rechtstreekse toegang tot de specerijeneilanden. Nog voor het eind van 1511 zond Albuquerque drie Portugese schepen van Malakka door naar de Molukken. Deze schepen deden in 1512 achtereenvolgens Java, Ambon en Banda aan. Slechts één keerde naar Malakka terug, met een lading muskaatnoot en kruidnagelen. De twee andere schepen leden schipbreuk, maar een deel van de bemanning wist Ambon te bereiken en ging vervolgens naar Ternate op uitnodiging van de sultan.

In de jaren hierna kwamen de Portugezen regelmatig in de Molukken om handel te drijven, maar ze bezaten er nog geen vast steunpunt. Zowel Ternate als Tidore bood zich hiervoor aan. De Portugezen kozen Ternate en begonnen daar in 1522 met de bouw van een machtig fort dat over een eigen toegang tot de zee beschikte en de zetel werd van een Portugese gouverneur. Bovendien vestigden ze in 1525 een handelspost op Ambon.

Het bezit van een eigen basis in de Molukken was ook dringend gewenst in verband met een conflict tussen Portugal en Spanje. In 1494 hadden de beide landen een verdrag gesloten over hun gebiedsaanspraken in de nietchristelijke wereld, waarbij ze de aarde onder elkaar in twee helften verdeeld hadden volgens een meridiaan 370 zeemijlen ten westen van Kaap Verde. In de zestiende eeuw was het lange tijd onzeker hoe de Aziatische landen lagen ten opzichte van die demarcatielijn. Fernando de Magelhaes, een Portugees die met Portugal had gebroken en die stelde dat de Molukken aan de Spaanse kant van de lijn lagen, liet zich in 1519 door Spanje met vijf schepen daarheen sturen. Varend langs de zuidpunt van het Amerikaanse continent en door de Stille Oceaan kwam deze vloot na anderhalf jaar in de Filippijnen terecht, waar Magelhaes omkwam in een gevecht met eilandbewoners. Het restant van de expeditie bereikte in 1521 met twee schepen de Molukken en werd daar hartelijk ontvangen door de sultan van Tidore. In de volgende decennia kwamen de Spanjaarden herhaaldelijk wederom in de Molukken en vestigden ze zich enkele jaren op Tidore en Halmahera. Bovendien vestigden zij zich in het midden van de eeuw definitief in de Filippijnen. Ten oosten van de Molukken ontdekten ze een groot land dat hen deed denken aan Guinea op de westkust van Afrika; daarom noemden zij het Nieuw-Guinea. De demarcatielijn van 1494 liep overigens in werkelijkheid door dit Nieuw-Guinea, ver ten oosten van de Filippijnen en de Molukken.

Intussen was ook de Portugese positie in Malakka niet onbedreigd. De haven had zijn functie als handelscentrum weliswaar grotendeels kunnen behouden, maar de moslimregeerders op Java wilden er jarenlang geen 
betrekkingen mee onderhouden. Op het schiereiland zelf had Portugal te maken met de voortdurende vijandschap van het sultanaat Djohore. Verder mengde ook Atjeh zich in de 'heilige oorlog' tegen de Portugese vijanden van de islam. Het verdreef de Portugezen uit hun vestigingen op de noordkust van Sumatra en belegerde meer dan eens de stad Malakka zelf.

Bij de verbreiding van het christendom boekten de Portugezen geen onverdeeld succes. Het was een streep door hun rekening dat ze op veel plaatsen in Azië en in het bijzonder in Indonesië vooral volkeren aantroffen die juist tot de islam bekeerd waren. Weliswaar veranderden de Portugezen Goa en Malakka in katholieke steden, maar in de Molukken moesten ze hun geloofsijver intomen om de samenwerking met het sultanaat Ternate niet in gevaar te brengen. Het missiewerk vond dan ook grotendeels buiten Ternate plaats, kreeg weinig steun van de Portugese autoriteiten en behaalde voornamelijk resultaat bij mensen die nog niet tot de islam waren overgegaan. Aldus ontstonden katholieke gemeenschappen onder meer op Halmahera en het zuidelijk deel van Ambon en later ook op Flores en Timor.

In de tweede helft van de zestiende eeuw kon Portugal zijn positie op handelsgebied in Zuidoost-Azië iets verbeteren. Het sloot een verdrag met het sultanaat Broenei, toen een machtig rijk in Noord-Borneo. Portugese handelaren mochten zich vestigen in Makassar op Celebes. Portugese schepen werden nu eindelijk toegelaten tot de havens van Atjeh en Bantam. Buiten de Indonesische archipel was Portugals voornaamste succes dat het in 1557 de Chinese havenstad Macao kon pachten.

Daarentegen verloor Portugal zijn basis op Ternate nadat de gouverneur in 1570 de sultan had laten vermoorden. De bevolking keerde zich massaal tegen de Portugezen, die nog een paar jaar stand konden houden in hun fort maar uiteindelijk moesten capituleren. Het Portugese gezag trok zich terug op ZuidAmbon en bouwde daar een nieuw sterk fort. Veel katholieke Ambonezen vestigden zich daar dichtbij. Overigens kreeg Portugal in 1578 ook toestemming van Tidore, de aartsrivaal van Ternate, om een klein fort te bouwen.

Een belangrijke politieke verandering was dat Portugal zelf in 1580 onder gezag van de Spaanse koning kwam te staan. De plaats die Portugal destijds in Azië innam beantwoordde niet aan de grote plannen waarmee het er gekomen was. Noch in politiek noch in godsdienstig opzicht had het daar de bestaande situatie ingrijpend veranderd. Het vervulde er voornamelijk de rol van een hinderlijke handelsconcurrent, maar was er nooit in geslaagd een effectief monopolie op de specerijenhandel te verwerven. Het beschikte weliswaar met Hormoez, Goa, Colombo, Malakka en Macao over enige belangrijke handelshavens, maar het had geen echte koloniën gesticht. Bovendien had Malakka als handelscentrum aan betekenis ingeboet; het was op dit punt overvleugeld door Bantam. Het elan waarmee Portugal zijn expansie in Azië was begonnen had op het eind van de zestiende eeuw plaats gemaakt voor corruptie en sleur. 


\section{Aantekeningen bij hoofdstuk I}

\section{Literatuuroverzicht}

De literatuur over de geschiedenis van Indonesië is zeer omvangrijk. Een groot deel ervan werd door Nederlanders geschreven. Een belangrijk (nog uit de tijd van het Nederlandse bewind daterend) algemeen overzicht is het vijfdelige werk Geschiedenis van Nederlandsch-Indie, in 1938-1940 uitgegeven onder redactie van F.W. Stapel. Anders dan de titel doet vermoeden gaan de eerste twee delen van dit werk in hoofdzaak over de geschiedenis van het gebied vóór de komst van de Nederlanders. Stapel had in 1930 al een beknopt overzicht onder dezelfde titel gepubliceerd. In 1947 liet B.H.M. Vlekke een uitvoeriger en meer analyserend geschiedwerk het licht zien, getiteld Geschiedenis van den Indischen archipel; dit werk bevat ook veel gedetailleerde verwijzingen naar andere literatuur. Twee jaar later verscheen een vergelijkbaar boek met een meer verhalend karakter, Geschiedenis van Indonesië van de hand van H.J. de Graaf.

Het ligt voor de hand dat deze werken van Nederlandse historici de Indonesische geschiedenis sinds het eind van de zestiende eeuw vooral uit Nederlandse gezichtshoek behandelden. Nadat Indonesië onafhankelijk geworden was bleven in Nederland tal van geschiedkundige publicaties over dit land verschijnen, maar streefden veel auteurs ernaar een eenzijdig neerlandocentrische aanpak te vermijden.

In Indonesië zelf is sinds de verwerving van de onafhankelijkheid vrij veel over de eigen geschiedenis gepubliceerd. De belangrijkste algemene publicatie hierover is een werk in zes delen, Sejarah nasional Indonesia (Nationale geschiedenis van Indonesië), in 1975-1977 verschenen onder redactie van Sartono Kartodirdjo et al. Zie Klooster 1985 voor een overzicht van de Indonesische geschiedbeoefening in het tijdvak 1900-1980.

Buiten Indonesië bestaat niet alleen in Nederland belangstelling voor de Indonesische geschiedenis, maar ook in andere landen zoals Australië en Amerika. Zo publiceerde de Australiër M.C. Ricklefs in 1981 A history of modern Indonesia since c. 1300.

In het laatste decennium van de twintigste eeuw zagen twee omvangrijke en rijk geillustreerde werken het licht die allerlei facetten van land en volk van Indonesië, waaronder de geschiedenis, behandelen. In Nederland verscheen in 1994-1996 in tweeënvijftig afleveringen Weerzien met Indië, onder redactie van onder meer Martin Bossenbroek. In dit voor het Nederlandse publiek bestemde werk wordt de geschiedenis vooral uit Nederlands gezichtspunt belicht. Bijna tegelijkertijd, namelijk in 1996-1998, verscheen in Jakarta en Singapore in vijftien delen Indonesian heritage, een werk waaraan talrijke Indonesische en buitenlandse auteurs (onder wie ook Nederlanders) hebben bijgedragen. Het werk bevat onder meer een deel 'Ancient history' onder redactie van John Miksic en een deel 'Early modern history' onder redactie van Anthony Reid. Van deze twee delen, die vooral de Indonesische rol belichten, is in 1998 een Nederlandse vertaling gepubliceerd onder de titel Geschiedenis van Indonesië: Land, volk en cultuur.

Een andere belangrijke bron van informatie over Indonesië, ook voor historische en biografische gegevens, is de Ensiklopedi Nasional Indonesia, van 1988 tot 1991 verschenen in achttien delen.

Bij dit hoofdstuk volgen verder geen speficieke bronverwijzingen. De inhoud is in hoofdzaak gebaseerd op de hierboven genoemde publicaties van De Graaf, Stapel en Vlekke. 


\section{HOOFDSTUK II \\ Indonesië en \\ de Verenigde Oost-Indische Compagnie}

\section{Inleiding en overzicht}

De bijzondere betrekkingen tussen Indonesië en Nederland hebben hun ontstaan te danken gehad aan de wens van Nederlandse kooplieden op het eind van de zestiende eeuw om de lucratieve specerijenhandel aan zich te trekken. Zij wilden de specerijen die toen nog alleen door Portugal werden aangevoerd voortaan zelf in de productiegebieden aanschaffen en stuurden daartoe tientallen bewapende schepen om Afrika heen naar Zuidoost-Azië. In 1602 voegden zij hun ondernemingen samen tot één nieuwe maatschappij, de 'Verenigde Oost-Indische Compagnie' (VOC). De Nederlandse republiek, die zelf pas kort voordien tot stand gekomen was, machtigde deze Compagnie tot het uitoefenen van overheidsfuncties.

De VOC maakte al snel een eind aan Portugal's heerschappij in de Molukken, onder meer door verovering van het Portugese fort op Ambon. Later verdreef zij de Portugezen ook uit Malakka, Ceylon en een deel van India. Zij opende een groot aantal handelsposten binnen en buiten de Indonesische archipel. Zij verwoestte de havenstad Djakarta op Java en stichtte daar een eigen hoofdkwartier, Batavia, dat uitgroeide tot het belangrijkste handelscentrum van Zuidoost-Azië.

Ter verkrijging van zo veel mogelijk winst uit de specerijenhandel spande de VOC zich in om alle concurrentie uit te schakelen. Daarbij keerde zij zich niet alleen tegen haar Europese rivalen, maar gebruikte zij ook geweld om de inheemse bevolking te dwingen uitsluitend aan haar te leveren. Overigens hield de Compagnie zich met veel meer dan alleen specerijenhandel bezig. Zij ging ook een grote rol spelen in het handelsverkeer tussen de Aziatische landen onderling. Haar keten van handelsposten strekte zich uit van Arabië tot Japan. Naar Europa exporteerde zij vooral specerijen en textiel en later ook koffie en thee. Zij beschikte in Azië over een strak georganiseerd ambtenarenapparaat onder leiding van een gouverneur-generaal.

De VOC was geen staat, maar trad wel op als een staat. Zij oefende bestuur 
en rechtspraak uit, nam krijgsvolk in dienst, liet forten bouwen en sloot verdragen met Aziatische vorsten. Hoewel zij was opgericht om handel te drijven en niet om land te veroveren, kwam toch in de loop van de zeventiende en achttiende eeuw steeds meer Aziatisch grondgebied onder haar heerschappij. Dit was niet alleen het gevolg van oorlog met handelsrivalen maar ook van conflicten tussen Aziaten onderling. Vooral binnen de Indonesische archipel werd de VOC omringd door staten die elkaars vijanden waren of zelf door interne twisten werden verscheurd; dit stelde haar in staat hier een overheersende positie te verwerven. $\mathrm{Al}$ in de zeventiende eeuw werd zowel Mataram als Bantam daardoor aan haar onderhorig. Omdat steeds meer gebied onder heerschappij van de VOC kwam te staan, moest een deel van haar ambtenaren zich meer met bestuur dan met handel bezighouden. Daar kwam bij dat de Compagnie ook een actieve rol ging spelen in de productie van sommige handelsgoederen, zoals koffie. Aldus werd de VOC behalve een maritieme macht ook een territoriale macht; tegelijk werd zij naast een handelsonderneming ook een landbouwonderneming.

De VOC heeft bijna twee eeuwen bestaan. Op het eind van de achttiende eeuw had zij het oppergezag over heel Java en de Molukken en bezat zij verscheidene steunpunten in de rest van de archipel, maar als handelsonderneming maakte zij het slecht. Haar organisatie leed onder verstarring en corruptie. Van Groot-Brittannië en Frankrijk ondervond zij sterke concurrentie. Haar uitgaven waren sterk gestegen, haar inkomsten daalden, zij raakte in de schuld en vroeg de Nederlandse overheid om financiële steun. Uiteindelijk besloot deze de VOC met ingang van het jaar 1800 op te heffen. Al haar bezittingen en schulden gingen toen over op de Nederlandse staat.

\section{De geboorte van de Nederlandse staat}

De ontdekkingsreizen van Portugezen en Spanjaarden in verre werelddelen en de daar door hen verworven rijkdommen prikkelden andere zeevarende Europese volkeren tot navolging. In de loop van de zestiende eeuw waagden eerst Fransen, vervolgens Britten en tenslotte ook Nederlanders zich aan soortgelijke ondernemingen. Dat Nederlanders hier pas laat in de eeuw aan begonnen kwam niet door gebrek aan maritieme ervaring. De als 'Nederlanden' bekend staande gewesten (waarvan het grondgebied ruwweg overeenkwam met dat van het huidige Nederland en België en een stuk van Noord-Frankrijk) beheersten al in het begin van de eeuw het leeuwendeel van het handelsverkeer over zee in een gebied dat zich uitstrekte van Scandinavië en de Oostzeelanden tot Portugal en Spanje. Gezamenlijk beschikten ze over de grootste handelsvloot van West-Europa. Anders echter dan Frankrijk en Engeland waren de Nederlanden geen zelfstandige staat maar een groep 
afzonderlijke gewesten, die pas in de eerste helft van de zestiende eeuw volledig onder één gezag kwamen te staan. Door vererving werd dit het gezag van de koning van Spanje. In 1568 begon prins Willem van Oranje, bijgenaamd 'Willem de Zwijger', een gewapende opstand tegen het Spaanse bestuur, die een tachtigjarige oorlog tegen vreemde overheersing inluidde.

Het verloop van de strijd leidde tot een splitsing van het gebied, doordat het Spaanse gezag zich wel in de zuidelijke gewesten wist te handhaven of te herstellen maar uiteindelijk niet in de noordelijke. Deze laatste gewesten gingen sinds 1588 verder als een onafhankelijke republiek, de 'Verenigde Nederlanden'. In deze nieuwe staat, die van 1594 af uit zeven provincies bestond, had men een voorkeur voor collegiaal bestuur. Elke provincie werd bestuurd door een college, de 'Staten', en de Republiek als geheel werd eveneens door een college bestuurd, de 'Staten-Generaal'. Wel beschikten de provincies meestal over een aan de Staten ondergeschikte gouverneur, de 'stadhouder'. Bovendien werd de Republiek in de praktijk gedomineerd door Holland, de grootste en rijkste provincie, en volgden de Staten-Generaal in de eerste decennia meestal de leiding van Johan van Oldenbarnevelt, voorzitter van de delegatie van Holland.

\section{De eerste Nederlandse tochten naar Azië}

Het verloop van de opstand tegen Spanje leidde er ook toe, dat Antwerpen zijn toegang tot zee verloor, dat Amsterdam nu het belangrijkste handelscentrum werd en dat ervaren en kapitaalkrachtige handelaren uit de zuidelijke gewesten zich in de provincies Holland en Zeeland vestigden. Daar stimuleerden zij onder meer de ontluikende belangstelling voor het openen van eigen handelswegen naar Azië.

Deze belangstelling gold in de eerste plaats de specerijenhandel. De Aziatische specerijen die de Portugezen in Lissabon aanvoerden werden al jarenlang grotendeels door Nederlandse kooplieden verder verhandeld. De Nederlandse handel zou natuurlijk veel meer kunnen verdienen als men die specerijen rechtstreeks uit Azië zou invoeren. Daar kwam bij dat, sinds Portugal zelf onder gezag van de Spaanse koning was komen te staan, de Portugese havens herhaaldelijk gesloten werden voor schepen uit de opstandige Nederlandse gewesten.

In de jonge Republiek werd stelselmatig kennis vergaard over Azië en de scheepvaartroutes daarheen. Belangrijke bijdragen daartoe leverde Jan Huyghen van Linschoten, een Hollander die vijf jaar in Goa gewerkt had en in 1592 in Nederland terugkeerde. Hij bezat niet alleen een schat van gegevens over de Aziatische landen, maar kende ook de zwakheden van de Portugese positie in Azië en in het bijzonder in de Indonesische archipel. Een 


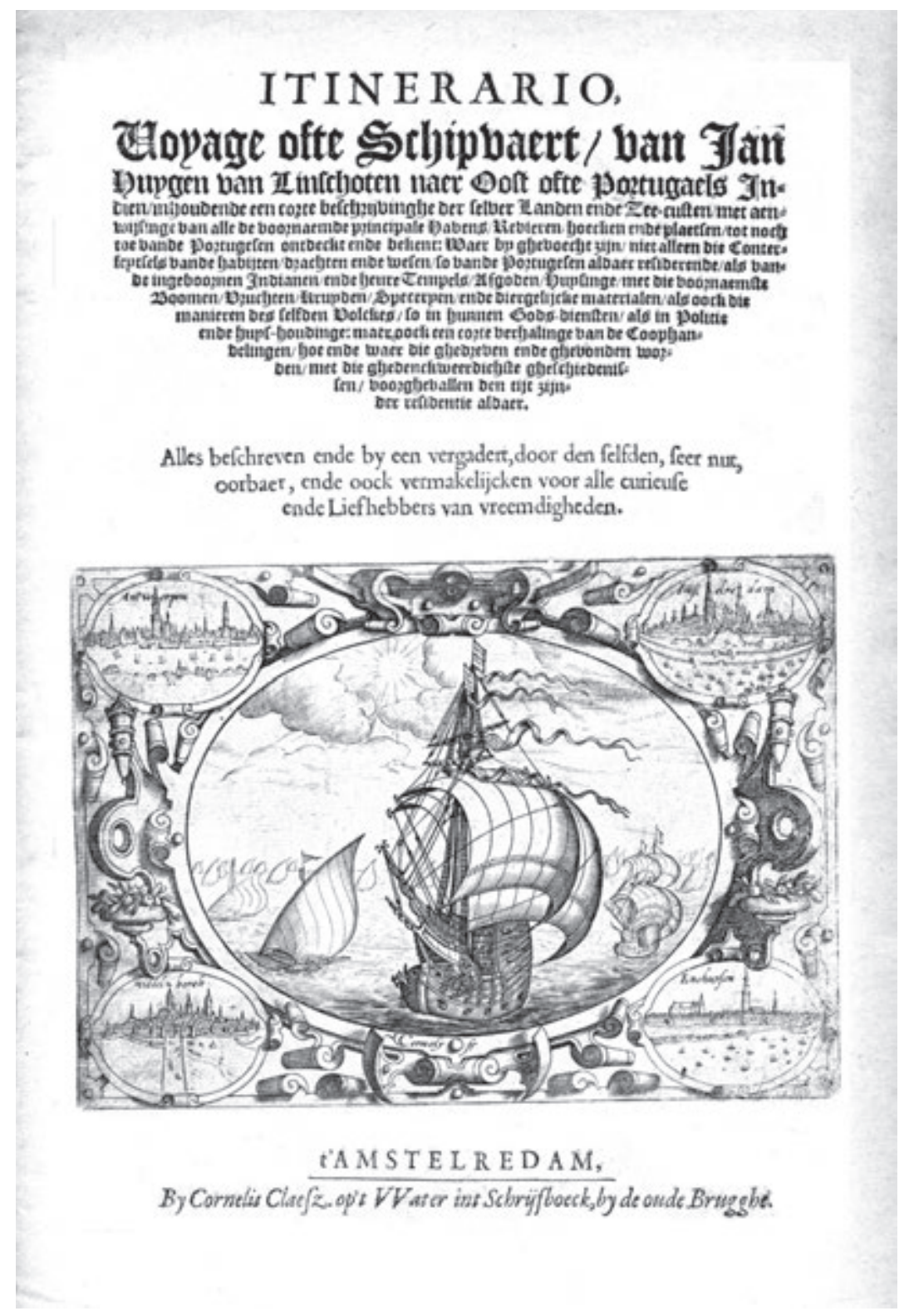

Het in 1595-96 in druk verschenen Itinerario bevatte in negenennegentig hoofdstukken een schat van gegevens over Azië, verzameld door Jan Huygen van Linschoten (1563-1611), een Nederlander die grote reizen had gemaakt en onder meer vijf jaar had gewoond in Goa, de voornaamste Portugese vestiging in India. 
en ander legde hij neer in zijn boek Itinerario, voyage ofte schipvaert naer Oost ofte Portugaels Indien.

Van Linschoten behoorde overigens tot degenen die aanvankelijk geloofden dat de kortste weg van Nederland naar 'Indië' om het noorden van Europa en Azië liep. Men had geen vermoeden van de uitgestrektheid van Siberië en dacht dat de Aziatische kust voorbij Noord-Rusland meteen naar China afboog. Van Linschoten nam zelf in 1594 en 1595 deel aan expedities die vruchteloos probeerden deze 'noordoostelijke doorvaart' te vinden. Een derde expeditie, in 1596 vertrokken onder leiding van Willem Barentsz en Jacob van Heemskerk, liep uit op een onvrijwillige overwintering op Nova Zembla. Daarna gaf men deze pogingen op.

De route naar 'Indië' om Afrika heen bleek toch de beste te zijn. Ten tijde van de overwintering op Nova Zembla had de eerste Nederlandse expeditie langs deze 'zuidoostelijke doorvaart' haar bestemming al bereikt. Die expeditie was georganiseerd door enige Amsterdamse kooplieden die daartoe een maatschappij hadden opgericht, de Compagnie van Verre. Zij rustten een vloot van vier schepen uit die in april 1595 vertrok, met 249 opvarenden onder leiding van Cornelis de Houtman. Omdat de Portugezen de Straat van Malakka beheersten zou men via Straat Soenda naar Java en de Molukken gaan. Het werd een rampzalige tocht.

De heenreis duurde ruim een half jaar langer dan verwacht en kostte het leven aan de helft van de schepelingen, vooral ten gevolge van scheurbuik. Pas eind juni 1596 kwam de vloot aan op de rede van Bantam; daar werd zij begroet door Portugese handelaren die in Bantam waren om peper in te kopen. De vloot bleef enige maanden op de rede liggen in afwachting van de nieuwe peperoogst. De Bantamse bestuurders ontvingen De Houtman welwillend. Hij voerde onderhandelingen met hen (in het Portugees), sloot een Nederlands-Bantams vriendschapsverdrag en sprak af dat zijn schepen bij voorrang bevoorraad zouden worden. Maar in september ontstond hierover hooglopende ruzie. De Houtman dreigde de stad te laten beschieten; de Bantammers namen hem en zijn gevolg daarop gevangen. De bemanning van de schepen loste inderdaad kanonschoten op de stad, sloeg een aanval van Bantamse oorlogsscheepjes af en maakte zich meester van de lading van enkele Portugese boten, maar moest uiteindelijk een hoog losgeld betalen om De Houtman en de zijnen vrij te krijgen.

Hierna vertrok de Nederlandse vloot oostwaarts. Zij deed de haven van Djakarta aan, maar werd verder tot geen enkele Javaanse haven meer toegelaten. Bij Soerabaja verloor men twaalf man door een aanval van zeerovers; bij Madoera doodde men uit paniek de plaatselijke vorst die ter begroeting kwam aanvaren. Pas op Bali kregen de Nederlanders een warm onthaal. Hier bleven zij enige tijd om zich op de terugreis voor te bereiden; van het voorgenomen bezoek aan de Molukken zagen zij af. In augustus 1597 keerde het 
restant van de expeditie, nog maar 89 man, met drie schepen in Nederland terug. Twee bemanningsleden waren op Bali gedeserteerd; zij waren de eerste Nederlanders die zich in Indonesië vestigden.

Het fiasco van deze eerste tocht ontmoedigde de Nederlandse kooplieden allerminst. In verschillende Hollandse en Zeeuwse steden richtten zij compagnieën op voor de handel met $\mathrm{Azië.} \mathrm{Al}$ in 1598 vertrokken vijf nieuwe eskaders met in totaal tweeëntwintig schepen daarheen. De belangrijkste vloot werd weer uitgezonden door de Amsterdamse Compagnie van Verre en bestond uit acht schepen onder leiding van Jacob van Neck. In zeven maanden voer deze vloot naar Bantam. Daar bleek men de Nederlanders weer gunstig gezind te zijn; dit was het averechtse gevolg van een strafexpeditie die de Portugezen kort daarvoor tegen Bantam hadden ondernomen. Van Neck kon hier goede zaken doen; nadat de helft van zijn vloot vol geladen was, keerde hij daarmee naar Nederland terug. De andere vier schepen voeren door naar de Molukken. Ook hier werden de Nederlanders hartelijk verwelkomd omdat ze als bondgenoten tegen de Portugezen werden gezien. Ze bezochten Ambon, Banda en Ternate, deden grote aankopen van specerijen en richtten enkele handelsposten in. Binnen twee jaar na vertrek waren alle acht schepen weer in Nederland terug. De Amsterdamse compagnie boekte $400 \%$ winst.

Van de andere in 1598 ondernomen expedities had slechts één een matig succes en liepen drie uit op een mislukking. Eén van die drie was een Zeeuwse expeditie onder leiding van Cornelis de Houtman naar Atjeh, destijds na Bantam het belangrijkste Indonesische handelscentrum. Pas na vijftien maanden kwamen de Zeeuwse schepen daar aan. De sultan ontving de Nederlanders eerst vriendelijk maar keerde zich later tegen hen. Cornelis de Houtman vond de dood bij een aanval op zijn schepen; zijn broer Frederik werd gevangen genomen. De schepen konden ontkomen en naar Zeeland terugkeren, maar Frederik de Houtman bleef twee jaar in Atjeh gevangen. Hij schreef daar het eerste Maleis-Nederlandse woordenboek.

Twee van de in 1598 ondernomen expedities probeerden Azië te bereiken via de 'zuidwestelijke doorvaart', dat wil zeggen langs de zuidpunt van het Amerikaanse continent. Daartoe behoorde een Rotterdamse vloot van vijf schepen, waarvan er slechts één terugkeerde maar dit was niet verder dan Zuid-Amerika gekomen. Een ander schip van deze vloot, genaamd de 'Liefde', strandde in 1600 voor de kust van Japan; het daarop volgende verblijf van de bemanning in dat land vormde het begin van de Nederlands-Japanse betrekkingen. De tweede westwaartse expeditie werd ondernomen door een Amsterdamse vloot van vier schepen onder Olivier van Noort. Ook hiervan keerde er maar één terug, met Van Noort. Zijn schip had Indonesië bereikt en was via de zuidpunt van Afrika naar Nederland gevaren; dit was de eerste Nederlandse reis om de wereld.

Het ongelukkige verloop van sommige van de eerste Nederlandse tochten 
naar Azië heeft zich later niet meer in vergelijkbare mate herhaald. In 1599 vertrokken er drie eskaders naar Indië, in 1600 twee en in 1601 weer drie. In totaal namen hier negenendertig schepen aan deel; ze keerden allemaal behouden terug. $\mathrm{Al}$ in deze periode vertrokken er uit Nederland meer schepen naar Azië dan uit Portugal. Die Nederlandse schepen bezochten niet alleen Indonesië maar ook Ceylon, Thailand, Indochina en de Filippijnen.

Op Java en de Molukken hadden de Nederlanders over het algemeen een goede verstandhouding met de Indonesiërs met wie ze te maken kregen. Een Zeeuwse expeditie slaagde er in 1601 in ook het conflict met Atjeh bij te leggen. De sultan, die graag militaire hulp van Nederland tegen de Portugezen wilde hebben, liet Frederik de Houtman vrij en zond met de Zeeuwse retourvloot een gezantschap mee. De Atjehse gezanten verbleven ruim een jaar in Nederland; zij waren de eerste Indonesiërs die dit land bezochten. De bejaarde leider van het gezantschap stierf daar en werd in Middelburg begraven.

\section{Oprichting van de Verenigde Oost-Indische Compagnie}

Hoewel de Nederlandse tochten naar Azië particuliere ondernemingen waren, hielden ook de Nederlandse overheden zich er van begin af aan mee bezig, onder meer wegens de oorlog met Spanje. De Staten van de betrokken provincies stelden geschut en munitie beschikbaar en voorzagen de leiders van de expedities van instructies. Ook prins Maurits, zoon van Willem de Zwijger en stadhouder in vijf provincies, instrueerde de vertrekkende vloten en gaf brieven mee voor Aziatische staatshoofden; in Indonesië werd hij door de Nederlandse kooplieden vaak als monarch voorgesteld. De Staten-Generaal bemoeiden zich zowel met de militaire en politieke als met de economische aspecten van de vaart op Azië. $\mathrm{Al}$ in 1598 deden zij een dringend beroep op de verschillende Hollandse en Zeeuwse compagnieën om elkaar niet tegen te werken. Maar ook zonder opzettelijke tegenwerking was het onvermijdelijk dat de concurrentie tussen de compagnieën de handelswinst niet ten goede kwam. De in Indonesië te betalen inkoopprijzen en havenrechten vlogen met sprongen omhoog; de verkoopprijzen op de Europese markt zakten flink onder de prijzen die de Portugezen plachten te rekenen. Bovendien bemoeilijkte het gescheiden opereren van de Nederlandse compagnieën het bieden van doeltreffende tegenweer tegen de toenemende Portugees-Spaanse inspanningen om met militair geweld de Portugese positie in de Indonesische archipel te herstellen.

Johan van Oldenbarnevelt vond dat men zo niet door kon gaan. Met hulp van prins Maurits overreedde hij alle compagnieën (inmiddels gevestigd in Amsterdam, Delft, Enkhuizen, Hoorn, Middelburg en Rotterdam) om samen te gaan in één nieuwe maatschappij. Aldus kwam op 20 maart 1602 de 
'Generale Vereenichde Geoctroyeerde Oost-Indische Compagnie' tot stand, beter bekend onder de naam 'Verenigde Oost-Indische Compagnie' (VOC). Met 'Oost-Indië' bedoelde men destijds het hele gebied tussen Arabië en Perzië enerzijds en China en Japan anderzijds, terwijl de term 'West-Indië' op Amerika betrekking had.

Deze VOC was een hoogst merkwaardige instelling: een particuliere maatschappij op aandelen die niettemin gerechtigd was belangrijke overheidsfuncties uit te oefenen. De Staten-Generaal verleenden haar een uitgebreid octrooi. Daarin kreeg de VOC in de eerste plaats het alleenrecht om handel te drijven in het deel van de wereld gelegen ten oosten van Kaap de Goede Hoop en ten westen van Straat Magelhaes. Tegelijk kreeg zij het recht om daar namens de Staten-Generaal verdragen te sluiten met plaatselijke autoriteiten, om forten en versterkingen te bouwen, om krijgsvolk in dienst te nemen en om bestuur en rechtspraak uit te oefenen. Het aan de VOC verleende handelsmonopolie bond de Nederlandse onderdanen, maar kon natuurlijk geen anderen binden, noch in Europa noch in Azië. Het octrooi werd in eerste aanleg verleend voor een periode van 21 jaar; het is daarna telkens voor bepaalde tijdvakken verlengd, tot aan het einde van de achttiende eeuw.

Aan het hoofd van de VOC stond een college van zeventien bestuurders, gewoonlijk de Heren Zeventien genoemd. Pas in 1609 werd ook voorzien in een hieraan ondergeschikt centraal bewind in Azië, bestaande uit een gouverneur-generaal en enige andere belangrijke Compagniesdienaren, die tezamen de Raad van Indië vormden. Dit bewind werd niet in de eerste plaats ingesteld om gebied te besturen, maar om leiding te geven aan handelsactiviteiten. Het oppergezag berustte bij de gouverneur-generaal, maar in overeenstemming met de toen in Nederland heersende afkeer van eenhoofdig bestuur mocht hij de meeste van zijn bevoegdheden alleen met instemming van de meerderheid van de Raad uitoefenen. De eerste gouverneur-generaal was Pieter Both.

Einde van de Portugese heerschappij in de Molukken; vestiging van de VOC op Ambon

Op het eind van de zestiende eeuw lag op Zuid-Ambon de voornaamste Portugese basis ten oosten van Malakka. In maart 1599 werd het eiland voor het eerst door Nederlandse schepen bezocht, behorende tot de vloot van Jacob van Neck. Hun ondercommandant was Jacob van Heemskerk, die twee jaar eerder nog op Nova Zembla overwinterde. De bevolking van Hitoe, het noordelijk deel van Ambon, hoopte op Nederlandse hulp om de Portugezen te verjagen, maar de Nederlanders waren alleen gekomen om handel te drijven.

Een jaar later arriveerde een ander Nederlands eskader, onder Steven van der Hagen die wel bereid was militaire hulp te verlenen. Daarop kwam in 1600 
een formeel bondgenootschap tussen Nederland en Ambon tot stand, maar het lukte Van der Hagen niet het sterke Portugese fort te veroveren.

Portugal besloot nu tot drastische actie om een eind te maken aan de Nederlandse opmars in de Indonesische archipel. Daartoe vertrok eind 1601 een vloot van dertig oorlogsschepen uit Malakka. Eerst blokkeerden de Portugezen de haven van Bantam, maar zij hieven deze blokkade op nadat ze waren aangevallen door een juist uit Nederland aankomend eskader van vijf schepen, dat enkele Portugese schepen tot zinken bracht. Deze overwinning voor de kust van Bantam kwam het Nederlandse prestige op Java zeer ten goede. De Portugezen voeren nu door naar Ambon, waar zij in Hitoe grote verwoestingen aanrichtten als straf voor het bondgenootschap met Nederland. Vervolgens probeerden zij Ternate te onderwerpen, maar daarvoor bleken zij niet sterk genoeg. Zwaar gehavend keerde de vloot naar Malakka terug.

Door deze mislukte expeditie werd de Portugese positie in de Molukken zowel militair als politiek ernstig verzwakt. Eind 1604 zonden de leiders van Hitoe een dringend hulpverzoek aan Van der Hagen die wederom met een vloot uit Nederland in Bantam was aangekomen, nu onder de vlag van de VOC. Van der Hagen voer daarop naar Ambon voor een nieuwe poging om het Portugese fort te veroveren. Ditmaal capituleerde het fort terstond. De Nederlanders namen het in bezit en doopten het Victoria. Korte tijd later veroverden zij ook de Portugese vesting op Tidore. Dit betekende het einde van de Portugese heerschappij in de Molukken.

Het eiland Ambon werd in februari 1605 in feite de eerste Nederlandse kolonie overzee. De VOC beschouwde het van Portugal overgenomen ZuidAmbon als eigen grondgebied krachtens het 'recht van verovering'. Bovendien sloten de hoofden van Hitoe na de Portugese capitulatie een nieuw verdrag met de VOC, waarin ze eeuwige trouw aan Nederland en de Compagnie beloofden. In hetzelfde verdrag verplichtten ze zich zonder Nederlands verlof geen kruidnagelen aan anderen dan Nederlanders te leveren. Terwijl het verdrag van 1600 nog op basis van gelijkheid gesloten was, werd Hitoe door het 'Eeuwig Verbond' van 1605 in feite een vazal van Nederland.

Door een en ander kwam de VOC op Ambon in een nieuwe positie te verkeren. In alle andere plaatsen waar zij vestigingen had, zoals Bantam, Djakarta en Ternate, was zij ondergeschikt aan het plaatselijk gezag; op Ambon was zij baas in eigen huis.

De Compagnie vestigde haar hoofdkwartier in het fort Victoria. Frederik de Houtman, die met Van der Hagen meegekomen was, werd gouverneur van Ambon. In de dorpen nabij het fort woonden destijds ongeveer zestienduizend katholieke Ambonezen, die nu vrijwel allen tot het protestantisme overgingen. Voor hen vertaalde De Houtman verschillende christelijke teksten in het Maleis. Doordat de VOC haar basis aan de zuidzijde van de baai vestigde, verschoof daarheen het politieke en commerciële zwaartepunt van 
Ambon. Uit de VOC-basis ontstond de huidige hoofdplaats van het eiland, Kota Ambon.

De Compagnie maakte op Ambon al spoedig gebruik van haar bevoegdheid om krijgsvolk in dienst te nemen. Zowel christelijke als islamitische Ambonezen wierf zij als soldaten aan.

\section{Britse concurrentie}

In de tweede helft van de zestiende eeuw was de Indonesische archipel enige malen door Britse zeevaarders bezocht, maar die hadden daar toen nog geen handelsbetrekkingen aangeknoopt. Pas nadat de Nederlandse tochten waren begonnen, begaven ook Britse kooplieden zich in de handel met 'Indië'. Eind 1600 verenigden zij zich daartoe in een Company of Merchants of London Trading to the East Indies beter bekend onder de naam East India Company (EIC). Deze compagnie kreeg monopolierechten van de Britse kroon, maar viel verder meer te vergelijken met de Amsterdamse Compagnie van Verre. Zij beschikte niet over publiekrechtelijke bevoegdheden zoals in 1602 aan de VOC werden verleend (zulke bevoegdheden verkreeg zij pas tegen het eind van de zeventiende eeuw, onder uitdrukkelijke verwijzing naar het Nederlandse voorbeeld). Haar kapitaal was oorspronkelijk slechts een achtste van dat van de VOC.

Hoewel de EIC veel minder schepen inzette dan de VOC, wist zij al spoedig in Indonesië verscheidene handelsposten in te richten, vrijwel steeds op plaatsen waar de VOC zulke posten al bezat. Dit Britse optreden wekte veel ergernis bij de Nederlanders. Dezen vonden dat de Britten kosteloos profiteerden van de strijd die zij zelf tegen de Portugezen hadden gevoerd. Nog erger was dat de Britse concurrentie precies die handelsvoordelen teniet dreigde te doen waarvoor de VOC als monopoliemaatschappij in het leven was geroepen. Juist dit laatste leidde soms tot gewapende conflicten met de Britten, onder andere op de Banda-eilanden.

De koning van Groot-Brittannië protesteerde keer op keer bij de StatenGeneraal tegen de inbreuken van de VOC op de Britse vrijheid van handel. In 1613 en 1615 vonden hierover Brits-Nederlandse besprekingen plaats, waarbij Hugo de Groot de opstelling van de VOC verdedigde. De Nederlanders bleven onverminderd vasthouden aan hun monopolieposities in de Molukken. Tenslotte zond de Britse regering in 1618 een vloot naar Azië om kracht bij te zetten aan haar aanspraken op vrijheid van handel in de Indonesische archipel. 


\title{
Spraeckende woord-boeck, Jnoe ftalleplebe ende ftladagatlkat=

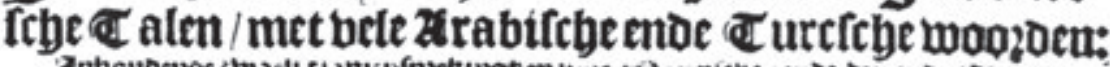

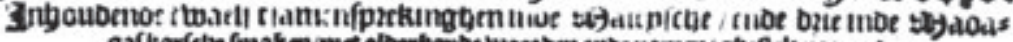

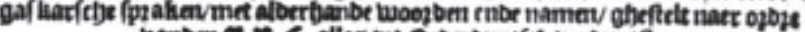

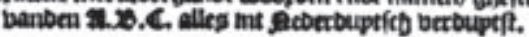

\section{Rocb jijn biet bpgbeboecht be Declinatien ban bele bafte Stetcen/ fachoe ontrent ben zupo-pool : booz befen tijot nopt obotien.}

\section{Sonderling nut voor de ghene die de Landen van Ooft-Indien befoecken :ende niet mia vermakelick voor alle curieafis Lief-hebbers van vreemdiclicydt. Alles gheflelde, gheobferveert, ende befchreren doot}

Frederick de Howemen vas Gowde.

\author{
कx

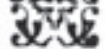 \\ T'AMSTELREDAM, \\ 3p 3. \\ moen grooten bpod. 9 . bje. mbe 33 3. \\ Afet Previlegie vale acbet leren.
}

Dit eerste Nederlandse woorden- en leerboek van de Maleise taal werd in 1603 gepubliceerd door Frederik de Houtman (1571-1627), die had deelgenomen aan de eerste Nederlandse reizen naar Indonesië, maar daar van 1599 tot 1601 gevangen was gehouden door de sultan van Atjeh en toen de taal grondig had bestudeerd. 


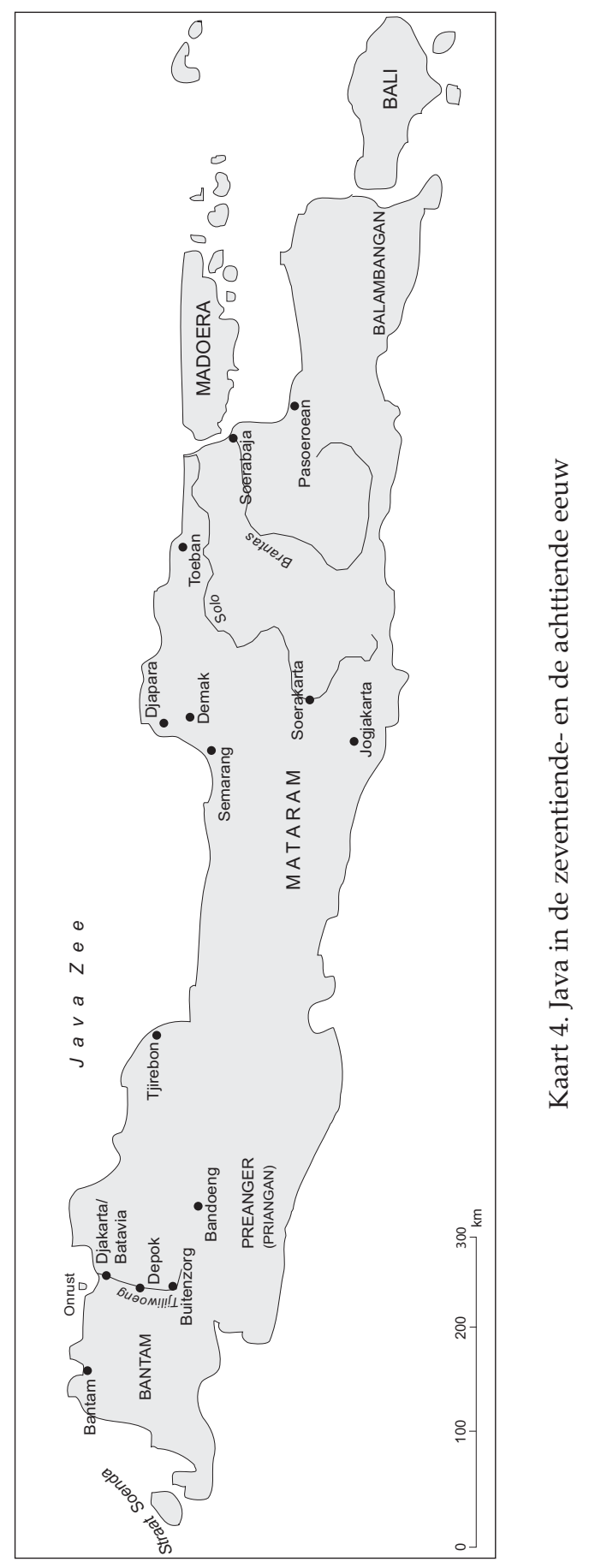




\section{Nederlaag van de Britten; stichting van Batavia}

Al binnen tien jaar na de oprichting van de Verenigde Oost-Indische Compagnie ging haar arbeidsveld veel meer omvatten dan alleen de Molukken. Niet alleen beschikte zij al over verscheidene vestigingen op Java en Sumatra, maar ook had zij tussen 1605 en 1610 al vier handelsposten aan de kust van India ingericht. Bovendien opende zij in 1609 een post in Japan. De Heren Zeventien vonden het daarom wenselijk binnen dit arbeidsveld een centraal steunpunt in te richten, dat zij aanduidden als 'rendez-vous'. Zij wilden de in Azië verworven handelswaren daar centraal laten opslaan en vandaar naar Nederland laten verschepen. Ook zou de gouverneur-generaal daar zijn kantoor moeten hebben. Het ging dus in feite om de hoofdzetel van de Compagnie in Azië.

Het VOC-bestuur vond Ambon te ver oostelijk gelegen om als centraal rendez-vous te dienen en zocht daarom naar een plaats in de nabijheid van Straat Soenda. Hoewel Bantam hier het dichtst bij lag, wilde de VOC haar hoofdzetel daar niet vestigen omdat zij dan geheel van de sultan en zijn regering afhankelijk zou zijn. Daarom ging haar voorkeur uit naar het kleinere Djakarta, dat wel aan Bantam onderhorig was maar aan de rand van het Bantamse gebied lag op de westelijke oever van de Tjiliwoeng. De eerste drie gouverneurs-generaal kwamen niet aan de oprichting van een nieuw hoofdkwartier toe en verbleven meestal in de Molukken. Wel werd het commerciële hoofdkantoor van de VOC in Bantam gevestigd en werd de centrale boekhouding uit Ambon daarheen overgebracht. Pas de vierde gouverneur-generaal, Jan Pieterszoon Coen, stichtte het beoogde definitieve hoofdkwartier.

Coen was in 1613 op 26-jarige leeftijd aangesteld als directeur van de VOCkantoren in Bantam en Djakarta. De plaatselijke bestuurder van Djakarta had de Compagnie toegestaan daar op de oostelijke oever een handelspost met pakhuizen in te richten onder de strikte voorwaarde dat er geen fort zou worden gebouwd. In strijd hiermee liet Coen de pakhuizen in het geheim toch versterken. In $1618 \mathrm{kreeg}$ hij bericht van de Heren Zeventien dat hij tot gouverneur-generaal benoemd was met ingang van de dag waarop zijn voorganger, Laurens Reael, hem in die functie zou beëdigen. Vooreerst had hij echter geen gelegenheid om voor zijn beëdiging naar Ambon te gaan. Hij had een conflict met de regering van Bantam, terwijl tegelijkertijd de Britse houding steeds dreigender werd. Coen nam zijn intrek in de VOC-post in Djakarta en liet het complex nu openlijk tot een fort versterken. De bestuurder van Djakarta protesteerde hiertegen en verbood de bevolking voor de Nederlanders te werken. Inmiddels hadden de Britten een handelspost gevestigd aan de westkant van de Tjiliwoeng tegenover de VOC-post. Coen, die een aanval van de Britse vloot verwachtte, liet eind december de Britse post verwoesten, nadat daar geschut was opgesteld dat op het Nederlandse complex gericht was. Daarop begonnen de Djakartanen met Britse hulp een belegering 
van het Nederlandse fort. Enkele dagen later naderde een Britse vloot van elf schepen. De Nederlanders beschikten bij Djakarta slechts over zeven schepen en weinig munitie; hun hoofdmacht lag in de Molukken. Na enige gevechten met de Britse vloot besloot Coen op 3 januari 1619 met zijn schepen naar de Molukken uit te wijken. Hij droeg de bezetting van het fort op zich zo lang mogelijk te verdedigen.

Voortdurende onderlinge onenigheid tussen de Djakartanen, de Britten en de Bantammers werd de redding van het belegerde fort. Na een maand van onderhandelen besloten de Nederlanders zich over te geven aan hun belegeraars, maar op de dag dat de overgave zou plaatsvinden kwam de regering van Bantam tussenbeide. Zij zette de bestuurder van Djakarta af en eiste dat het fort aan haar zou worden overgegeven. De Britten vertrokken en de Bantammers namen zowel de belegering als de onderhandelingen over.

Deze toestand duurde nog voort toen Coen, inmiddels als gouverneurgeneraal geïnstalleerd, op 28 mei met een vloot van zeventien schepen uit de Molukken aankwam. Nadat het krijgsvolk aan land was gebracht viel Coen op 30 mei met duizend man Djakarta aan, dat hier volstrekt niet op voorbereid was. De Bantamse krijgslieden sloegen op de vlucht. De verovering van de plaats kostte de Nederlanders één dag en één dode. De bevolking van Djakarta en omstreken werd volledig verdreven; het stadje werd in zijn geheel verbrand en gesloopt.

Hierna voer Coen naar Bantam en eiste vrijlating van het inmiddels gevangen genomen VOC-personeel. De Bantamse regering liet de Nederlanders vrij maar verbood de Compagnie verder nog in Bantam handel te drijven. Coen antwoordde hierop met een blokkade van de haven van Bantam. Vervolgens gingen eskaders van de Nederlandse vloot jacht maken op de Britse schepen, waarvan zij er in enkele maanden zeven uitschakelden. De andere Britse schepen trokken zich terug naar India. Zo verloor Groot-Brittannië de strijd om de oppermacht ter zee in de Indonesische archipel.

De verovering van Djakarta stelde de VOC in staat haar centrale hoofdkwartier op eigen grondgebied te vestigen. Coen claimde zelfs dat de territoriale soevereiniteitsrechten van de Compagnie zich uitstrekten tot de zuidkust van Java. Hij liet als hoofdkwartier een nieuwe en grotere versterking bouwen. Ten zuiden en ten westen daarvan verrees een nieuwe stad, met kanalen en bruggen in Nederlandse trant. Op aanwijzing van het Nederlandse VOCbestuur ging de stad Batavia heten, naar een toen in de mode zijnde Latijnse naam voor Nederland.

De blokkade van Bantam, die tot 1628 is voortgezet, stelde Batavia in staat nu zelf het belangrijkste handelscentrum van de archipel te worden. Daar kwam bij dat sultan Agoeng van Mataram in diezelfde periode een eind maakte aan het bestaan van alle andere Noord-Javaanse handelsstaatjes. Deze Mataramse veroveringen werden in 1625 afgerond door de val van Soerabaja. 
De stad Batavia kreeg een gevarieerde bevolking. De grootste groep naast de Nederlanders werd gevormd door de Chinezen, van wie zich in 1620 al achthonderd in de stad gevestigd hadden. Daarnaast waren er onder meer Maleise handelaren, Ambonese en Japanse huursoldaten en Balinese slaven, maar lange tijd vrijwel geen Javanen of Soendanezen. De algemene omgangstaal in de stad was niet het Nederlands maar het Portugees, dat later werd verdrongen door het Maleis.

Omdat de oorspronkelijke bevolking in de wijde omtrek verdreven was, werd Batavia aan de landzijde omringd door een verwilderd niemandsland, waar hoge Compagniesdienaren soms gingen jagen op tijgers en neushoorns.

Coen ging in 1623 naar Nederland, maar keerde vier jaar later terug voor een tweede termijn als gouverneur-generaal. Sultan Agoeng van Mataram probeerde in 1628 en opnieuw in 1629 Batavia te veroveren, maar ondanks inzet van een enorme troepenmacht was hij beide keren gedwongen het beleg op te breken. Hierna is de stad niet meer aangevallen. Coen stierf in 1629 tijdens het tweede Mataramse beleg.

\section{De doelstellingen van de VOC}

De Portugezen en de Spanjaarden waren de wereld ingetrokken 'om te veroveren en te bekeren', ook al wilden ze tegelijkertijd rijkdommen verwerven. De pioniers van de Spaanse kolonisatie heten dan ook de 'conquistadores'. Daarentegen was de VOC een organisatie van kooplieden. Tegenover de onder haar gezag komende Aziatische gebieden gedroeg zij zich daarom anders dan Portugal en Spanje tegenover hun koloniën. Zij stelde weinig belang in migratie van Nederlandse onderdanen naar die gebieden en zij spande zich niet in om daar de Nederlandse taal ingang te doen vinden bij de inheemse bevolking noch om die bevolking tot het christendom te bekeren. Alleen op Ambon en later op Ceylon sloot haar bestuur nauwer aan bij het Portugese model, vooral onder invloed van de inheemse christenen die onder het vorige bewind de status van Portugese onderdanen hadden genoten. Verder kregen de Bandaeilanden een geheel afwijkende behandeling.

Het handelsbeleid van de VOC berustte op drie beginselen: goedkoop inkopen, duur verkopen en concurrentie tegengaan. Het haar door de StatenGeneraal verleende handelsmonopolie beschermde haar tegen Nederlandse concurrentie. Buitenlandse concurrentie probeerde zij in de eerste plaats te weren door ook van Aziatische gezagsdragers en leveranciers monopolies te verkrijgen, vooral in de vorm van exclusieve inkooprechten. Daarnaast was zij bereid geweld te gebruiken, hetzij om Europese concurrenten te verdrijven hetzij om Aziaten te dwingen de monopoliecontracten na te leven.

Binnen de VOC vond in de eerste decennia veel discussie plaats over het te 
voeren beleid. Jan Pieterszoon Coen had daar vastomlijnde denkbeelden over die hij in tal van geschriften aan de Heren Zeventien voorlegde. Hem stond de schepping voor ogen van een groot Aziatisch handelsrijk. De Nederlanders, die zich al als de vrachtvaarders van Europa beschouwden, zouden ook de vrachtvaarders van Azië moeten worden. Van Perzië tot Japan zouden zij een overheersende positie dienen in te nemen in het overzeese handelsverkeer tussen de Aziatische landen onderling. Daarmee zouden zij grote winsten kunnen maken omdat, zo betoogde Coen, die landen de Europese landen in bevolking, in verbruik van goederen en in industrie overtroffen. Uit de met die handel te behalen winsten zou men niet alleen de apparaatskosten van de VOC kunnen betalen maar ook de aankoop van de naar Europa uit te voeren specerijen.

Om dit handelsrijk te scheppen en te handhaven achtte Coen sterke militaire middelen nodig. $\mathrm{Al}$ in 1613 pleitte hij voor verovering van Macao en Manila om de Portugezen en Spanjaarden van de Chinese kust en uit de Filippijnen te verdrijven. Telkens weer drong hij aan op versterking van de Nederlandse vloot in de Aziatische wateren. Aan Nederlandse soldaten had hij minder behoefte. Zijns inziens zou de VOC het grootste deel van haar krijgsvolk in Azië zelf kunnen aanwerven. In het bijzonder dacht hij aan het recruteren van Japanse huursoldaten.

Coen pleitte niet voor het verwerven van omvangrijke territoriale bezittingen. Het zou voor de VOC voldoende zijn hier en daar over steunpunten in de vorm van eigen grondgebied te beschikken. In die gebieden zouden Nederlanders zich als kolonisten moeten vestigen. Aan deze kolonisten wilde Coen een deel van de Aziatische handel overlaten, onder toezicht van de Compagnie. Ook zouden zij de specerijenproductie moeten overnemen, met de hulp van slaven naar het voorbeeld van de slavenarbeid op de plantages in Amerika. Ter versterking van de kolonisten in de Nederlandse steunpunten wilde Coen arbeidskrachten goedschiks of kwaadschiks aanvoeren uit China, Achter-Indië en Madagaskar. De eigen bevolking van Indonesië speelde in Coen's plannen nauwelijks een rol.

Uiteindelijk heeft het VOC-bestuur de denkbeelden van Coen maar ten dele gevolgd. Voor offensieve operaties in de door hem bepleite omvang voelde het weinig. De mislukking van een door Coen in 1622 ondernomen poging om Macao te veroveren vormde ook geen aanmoediging om op deze lijn door te gaan. Evenmin is er veel terecht gekomen van Coen's plannen voor de vestiging van Nederlandse kolonisten. Het VOC-bestuur was trouwens volstrekt niet bereid om aan particuliere Nederlandse burgers toe te staan in Azië handel te drijven.

Daarentegen onderschreef de VOC het belang van een zo groot mogelijk aandeel in de handel tussen de Aziatische landen onderling. Zoals uit Coen's betoog al blijkt, zag men de Aziatische landen destijds niet als achterlijk maar 
als ontwikkeld, ook al waren de Europeanen maritiem en militair superieur gebleken. Het ontwikkelingspeil van die landen bracht ook mee dat de import van specerijen, zijde, porselein en andere kostbaarheden uit Azië niet voldoende kon worden bekostigd door de export van Europese goederen, aangezien Europa nauwelijks goederen te bieden had die aantrekkelijk waren voor de Aziatische markt. Daarom betaalden de Europese kooplieden de Aziatische goederen vooral met zilver, dat toen in Azië een hogere ruilwaarde had dan in Europa.

Terwijl de VOC de Aziatische handel nodig had om haar eigen kosten te dekken, verwachtte zij haar winsten in de eerste plaats van de specerijenimport in Europa. Daarbij wilde zij, in elk geval wat de Molukse specerijen betrof, een volstrekt monopolie hebben om de prijzen in Europa hoog te kunnen houden. De discussies binnen de VOC betroffen vooral de vraag hoe men zich van zulk een monopolie zou moeten verzekeren. De voorstanders van de zachte lijn (onder wie Laurens Reael en ook Steven van der Hagen, die in 1617 gouverneur van Ambon werd) wilden dit monopolie langs vrijwillige weg bewerkstelligen op basis van een goede verstandhouding met de inheemse bevolking. De voorstanders van de harde lijn, zoals Coen, vonden gebruik van geweld onmisbaar om het monopolie te handhaven; daarbij zou men onder meer een eind moeten maken aan het inheemse scheepvaart- en handelsverkeer.

Hoewel de VOC-leiding soms kritiek had op het brute optreden van Coen, koos zij in feite voor de harde lijn. Een consequentie daarvan was dat zij zich niet alleen met de handel maar ook met de productie van de specerijen ging bemoeien. Overigens ging zij daarbij niet over tot het door Coen bepleite stelsel van productie in eigen beheer met volledige uitschakeling van de inheemse productie, behalve op de Banda-eilanden waar Coen dit beleid al ten uitvoer had gebracht.

\section{Ontvolking van de Banda-eilanden}

Muskaatbomen leveren twee specerijen op die destijds in Europa bijzonder gezocht waren: muskaatnoot en foelie. Deze bomen groeiden vroeger uitsluitend in de Zuid-Molukken, voornamelijk op de kleine bergachtige Bandaeilanden. In de zestiende eeuw probeerden de Portugezen vergeefs zich hier een monopoliepositie te verschaffen. In 1599 werd de eilandengroep bezocht door Nederlandse schepen onder Jacob van Heemskerk, die er een handelspost vestigde. Vervolgens verwierf de VOC in de eerste jaren van haar bestaan op verschillende Banda-eilanden exclusieve rechten op de levering van muskaatnoot.

De zo goed begonnen verstandhouding tussen Nederlanders en Bandanezen verslechterde al spoedig. De eersten stonden op hun exclusieve rechten, maar 
de laatsten bleven aan andere afnemers leveren. In 1609 stuurde de VOC een expeditie naar de Banda-eilanden om haar monopolie af te dwingen. Daartoe wilde zij er forten vestigen, in de eerste plaats op Neira, het eiland met de voornaamste ankerplaats. De bevolking was daar tegen en doodde de Nederlandse commandant en zijn gevolg. De Nederlanders moordden uit wraak enige dorpen uit, namen Neira in bezit en bouwden er het fort Nassau.

Enige jaren later vestigde ook de East India Company een handelspost op de Banda-eilanden. De VOC bleef in conflicten gewikkeld, zowel met de Bandanezen als met de Britten, over haar monopolie-aanspraken. Zij placht de te leveren specerijen van te voren te betalen en was bijzonder gegriefd wanneer die vervolgens toch aan anderen verkocht werden. De Heren Zeventien adviseerden, de voornaamste Bandanezen 'uit te roeien' als straf voor hun voortdurende contractbreuk, maar gouverneur-generaal Laurens Reael was daartoe niet bereid.

Coen, die als jong VOC-ambtenaar al had deelgenomen aan de expeditie van 1609, voer als gouverneur-generaal in 1621 met een grote strijdmacht naar de Banda-eilanden. De Bandanezen boden onderhandelingen aan, maar Coen wees die af. Hij wilde de door het VOC-bestuur aangegeven definitieve oplossing van het Banda-probleem doorvoeren, namelijk de eilanden volledig veroveren en van een nieuwe bevolking voorzien. De verovering nam maanden in beslag wegens hardnekkig verzet van de Bandanezen. Coen liet hun kustdorpen en vaartuigen in brand steken om vluchten te beletten. Van de ruim vijftienduizend eilandbewoners overleefden nog geen duizend het Nederlandse optreden. Velen sneuvelden in de strijd. Ruim veertig vooraanstaande personen werden van verraad beschuldigd, gemarteld en door Japanse soldaten geëxecuteerd. Van de bevolking die zich in de bergen verschanst had, werd een deel door de VOC-soldaten gedood en stierf de rest de hongerdood. Een paar honderd anderen slaagden er in naar het eiland Ceram te vluchten. De ongeveer zevenhonderdenvijftig Bandanezen die zich hadden overgegeven werden weggevoerd naar Batavia; een vijfde deel daarvan overleefde het transport niet.

De VOC beschouwde de Banda-eilanden voortaan als eigen grondgebied krachtens het recht van verovering. Naar het vrijwel geheel ontvolkte gebied bracht zij nieuwe bewoners over van zeer uiteenlopende herkomst, voornamelijk gewezen dienaren en soldaten van de Compagnie. Die kregen slaven tot hun beschikking, die de Compagnie onder meer op Bali gekocht had en waarmee zij voortaan de muskaatbomen moesten verzorgen. De aldus gewonnen specerijen mochten alleen aan de VOC worden geleverd. Alle muskaatbomen die buiten de Banda-eilanden groeiden, voornamelijk op Ambon, werden door de VOC uitgeroeid.

Toen Coen's optreden tegen de Bandanezen in Nederland bekend werd wekte dit veel kritiek, waarbij zowel politieke als morele argumenten wer- 
den aangevoerd. Sommigen noemden het onverstandig om de Nederlandse positie in Azië in hoofdzaak te baseren op het aanstichten van vrees. Anderen merkten op dat de Bandanezen voor hun vrijheid gevochten hadden zoals de Nederlanders tegen de Spanjaarden.

\section{Onderwerping van de Molukken}

Kruidnagelbomen groeiden oorspronkelijk alleen in de Noord-Molukken, maar werden in de loop van de zestiende eeuw ook in de Zuid-Molukken aangeplant. Het heeft de VOC ruim een halve eeuw gekost om zich volledig van het kruidnagelmonopolie te verzekeren. Daartoe moest zij de oppermacht over de Molukse bevolking verwerven en bovendien haar Europese concurrenten uitschakelen: de Portugezen, de Spanjaarden en de Britten.

De macht van Portugal in de Molukken werd al in 1605 gebroken, toen het zijn steunpunten op Ambon en Tidore verloor; handel bedreef het daarna nog alleen vanuit Makassar. In plaats van Portugal verwierf Spanje nu een machtspositie in het gebied. Het trok in 1606 uit de Filippijnen de Molukken binnen en dwong Ternate en Tidore om Spaanse forten op hun grondgebied te dulden. Maar wat voor de Nederlanders in militair opzicht een tegenslag was bleek hun in politiek opzicht winst op te leveren. De vijandschap met Spanje bracht de sultan van Ternate al in 1607 ertoe een verdrag met Nederland te sluiten waarin hij de Republiek als zijn beschermer erkende. Bovendien mocht de VOC ook een fort op Ternate bouwen (het fort Oranje) en kreeg zij een exclusief recht op de aankoop van kruidnagelen.

De Britten werden in 1619 uit de Indonesische archipel verdreven, maar keerden er een jaar later op bescheiden schaal weer terug, nadat de twee moedercompagnieën in Europa een verdrag van vrede en samenwerking hadden gesloten. Zo opende de EIC handelsposten onder meer in Batavia en op Ambon. Aan haar samenwerking met de VOC kwam echter al in 1623 een eind na een incident dat in de Britse geschiedschrijving is blijven voortleven als de 'Amboyna massacre'. Een tiental Britten op Ambon werd verdacht van een complot tegen de VOC, gemarteld en vervolgens veroordeeld en terechtgesteld. De EIC trok zich daarop grotendeels uit Indonesie terug. De VOC verbood alle buitenlandse scheepvaart in de Molukse wateren.

De voornaamste strijd om het kruidnagelmonopolie heeft de VOC met de bevolking van de Molukken zelf gevoerd. Dat Indonesische vorsten en besturen aan de Compagnie monopolierechten verleenden was op zichzelf niet iets nieuws. Ook voor de komst van de Nederlanders waren zulke rechten vaak verleend, onder meer aan de Portugezen, maar ze waren zelden strikt toegepast. Het nieuwe van de VOC was dat zij de haar verleende monopolies streng naar de letter uitlegde en dat zij bereid was geweld te gebruiken om 
ze te handhaven. Door voorschotten te verlenen maakte zij haar leveranciers tot schuldenaren. Tegelijkertijd stelde zij eenzijdig lage inkoopprijzen voor de specerijen vast. De bevolking leed nadeel van het verbod om specerijen aan anderen te verkopen, niet alleen omdat die bereid waren meer te betalen dan de VOC maar ook omdat de Molukkers de verkoop binnen de Indonesische archipel nodig hadden ten behoeve van hun eigen invoer, vooral die van rijst. Weliswaar nam de VOC op zich om zelf voor de invoer van rijst en andere benodigdheden te zorgen, maar daarvoor rekende zij hogere prijzen dan die op de vrije markt.

Intussen was de VOC niet in staat om met haar zeemacht een eind te maken aan de inheemse kruidnageluitvoer uit de Molukken. Weliswaar verbood zij de bevolking om buiten de Molukse wateren te varen, maar zij kon in dit uitgestrekte gebied nu eenmaal niet met enkele tientallen grote schepen al het verkeer van honderden kleine bootjes controleren. Daarom greep zij naar een ander middel: vernietiging van de kruidnagelbomen op alle eilanden die niet direct onder haar toezicht stonden, een bijzonder effectief middel omdat deze bomen pas na twaalf jaar vrucht beginnen te dragen. Men begon hiermee in 1625 door het verbranden van vijfendertigduizend kruidnagelbomen op het eiland Ceram.

Het Nederlandse optreden tastte de bevolking van de Molukken aan in haar twee voornaamste middelen van bestaan: de specerijenteelt en de vrije scheepvaart. Dit leidde tot een reeks opstanden die met korte onderbrekingen van 1635 tot 1656 hebben geduurd en waarbij van beide kanten wreed is opgetreden. De eerste opstanden braken uit op Ambon en werden langdurig in de Zuid--Molukse berggebieden voortgezet. De grootste opstand begon in 1650 gelijktijdig op Ambon en Ternate en breidde zich over het hele gebied van de Molukken uit. Pas na zes jaar slaagde de VOC er in deze opstand volledig te onderdrukken.

Als reactie op de Ambonse opstanden beëindigde de VOC de formele onderhorigheid van Hitoe aan Ternate en bracht zij heel Ambon onder haar rechtstreeks bestuur. De kruidnagelteelt werd beperkt tot dit eiland en drie nabij gelegen eilandjes. Daarmee verminderde de VOC de kruidnagelproductie tot een kwart van de vroegere omvang. De sultans van Ternate en Tidore kregen een jaargeld als compensatie voor de afschaffing van de kruidnagelteelt in hun gebieden. Ter handhaving van het VOC-monopolie werden jaarlijkse controle-expedities uitgevoerd, de hongi-tochten. De gouverneur van Ambon maakte dan, begeleid door een vloot van inheemse schepen, een tocht langs alle eilanden, waarbij ontdekte clandestiene vruchtbomen werden omgehakt en de bij inbreuken op het monopolie betrokken bevolking werd gestraft, onder meer door het platbranden van dorpen. Door dit alles verviel het eens zo bloeiende gebied van de Molukken tot armoede en apathie, terwille van de handelswinsten van de VOC. 
De liquidatie van de specerijenteelt buiten de door de VOC daarvoor aangewezen gebieden was voor de Spanjaarden aanleiding de Molukken te verlaten; in 1663 trokken zij zich terug uit Ternate en Tidore.

In 1680 kwam Ternate nog eenmaal in verzet. Nadat dit verzet was gebroken veranderde de VOC de formele status van het sultanaat: in plaats van een bondgenoot werd het nu een leen van de Compagnie.

\section{Machtsuitbreiding in India en op Ceylon, Sumatra en Celebes}

Hoewel de Heren Zeventien uit waren op het scheppen van een handelsrijk en niet op het veroveren van land, kwam in de zeventiende eeuw toch steeds meer Aziatisch grondgebied onder de directe of indirecte heerschappij van de Compagnie. Aldus werd de VOC behalve een maritieme macht ook een territoriale macht. In het algemeen waren de VOC-bestuurders in Azië meer tot machtuitbreiding geneigd dan die in Nederland. Zulke machtsuitbreiding kon zowel het resultaat zijn van oorlogen tussen de VOC en haar handelsrivalen als van bemoeienis door de VOC met conflicten tussen Aziaten onderling.

In het bijzonder in de Indonesische archipel bevond de Compagnie zich te midden van staten die elkaars vijanden waren of die zelf door interne twisten werden verscheurd, meestal over opvolgingskwesties. Het kwam herhaaldelijk voor dat één van de partijen bij zulk een conflict steun bij haar zocht. Wanneer de bestuurders in Batavia daar op ingingen, plachten zij bij voorkeur steun te geven aan de zwakste partij. Voor de verleende steun vroegen zij tegenprestaties die zowel op commercieel als op politiek terrein konden liggen. Aldus belandden heel wat Aziatische regeerders in een positie van afhankelijkheid van de Compagnie.

Tussen 1637 en 1663 schakelde de VOC haar oudste rivaal, Portugal, bijna geheel uit. Met hulp van het sultanaat Djohore lukte het haar in 1641 eindelijk Malakka te veroveren. Zij legde een militaire bezetting in deze stad, maar verwaarloosde de handelshaven, want aan een concurrent van Batavia had zij geen behoefte. Enkele jaren daarvoor had de Compagnie zich al meester gemaakt van een deel van de Portugese vestingen op Ceylon. Zij was daartoe aangemoedigd door de koning van Kandy in het binnenland van het eiland. $\mathrm{Na}$ een tienjarige wapenstilstand tussen Nederland en Portugal, dat intussen weer onafhankelijk van Spanje was geworden, hervatte de Republiek in 1652 de oorlog. Op aandrang van de Staten-Generaal viel de VOC opnieuw de Portugese posities in Azië aan. In 1658 verdreef zij de Portugezen volledig uit Ceylon, waardoor zij alle kuststeden in handen kreeg. Voortaan zetelde in Colombo een gouverneur van de VOC, terwijl de koning van Kandy het binnenland bleef regeren. De Compagnie bezat nu het monopolie op de handel in kaneel, dat alleen op dit eiland gewonnen werd. In dezelfde periode ver- 
overde de VOC bovendien alle Portugese vestingen aan de oostkust van India en verschillende van die aan de westkust.

Intussen vergrootte de VOC ook haar invloed op Sumatra. Daar had Atjeh in de eerste decennia van de zeventiende eeuw het toppunt van zijn macht bereikt onder het bewind van sultan Iskandar Moeda. Zijn gezag strekte zich toen aan de westkant van Sumatra uit tot voorbij het kustgebied van Minangkabau, aan de oostkant tot alle kustgebieden tegenover het schiereiland Malakka en ten noorden van Sumatra tot enige delen van dit schiereiland zelf. Atjeh beheerste daardoor een groot deel van de handel in peper en in tin. Maar de vele door Iskandar Moeda gevoerde oorlogen hadden het land zelf uitgeput en zijn vloot verzwakt. Na de verovering van de stad Malakka zette de VOC, die de peper- en tinhandel naar zich toe wilde trekken, Atjeh steeds meer onder druk. De positie van de Compagnie werd versterkt doordat de vorstendommen Palembang en Djambi zich met haar verbonden en haar monopolierechten gaven. De conflicten met Atjeh leidden de VOC tot enige havenblokkades en tenslotte tot een militaire expeditie, waarmee zij het sultanaat in 1659 tot een vernederend vredesverdrag dwong. Onder meer moest Atjeh voortaan aan de Compagnie het leeuwendeel van de tinhandel overlaten. Enkele jaren later maakten vier vorstendommen aan de westkust zich van Atjeh los en stelden zij zich onder bescherming van de VOC. Deze vestigde in 1667 in Padang haar hoofdkantoor voor Sumatra's westkust, terwijl zij zich bovendien enige invloed in het bergland boven Padang verschafte door een verdrag met de vorst van Minangkabau.

Een gevaarlijker rivaal van de VOC dan Atjeh was Gowa. In Zuid-Celebes woonden twee volken voor wie de scheepvaart een belangrijk middel van bestaan was: de Makassaren en de Boeginezen. De belangrijkste Makassaarse staat was Gowa in het zuidwesten met de havenstad Makassar; de belangrijkste Boeginese staat was Boni in het oosten. Beide staten gingen pas bij het begin van de zeventiende eeuw tot de islam over. Kort daarna werd Gowa een sultanaat en ontwikkelde het zich tot een groot zeerijk; het veroverde niet alleen Boni maar ook andere delen van Celebes en een aantal van de omliggende eilanden. Makassaarse kooplieden namen de rol van de Javaanse handelaren over toen de meeste Javaanse havensteden in verval raakten na te zijn veroverd door Mataram. Daardoor werd Makassar onder het bewind van sultan Hasanoedin de belangrijkste havenstad in de oostelijke helft van de Indonesische archipel. Het werd in het bijzonder het centrum van de handel in Molukse specerijen buiten de VOC om, een handel die de Compagnie als smokkel beschouwde. De Portugezen maakten Makassar tot hun voornaamste handelsbasis in Indonesië; ook Britse en Deense kooplieden vestigden zich daar.

Gowa en de VOC koersten af op een frontale botsing. Al in het midden van de eeuw voerden ze een paar keer oorlog, maar de Compagnie was toen nog 
niet aan een echte confrontatie toe, omdat zij haar soldaten nodig had voor het onderdrukken van de opstanden in de Molukken en voor het bestrijden van de Portugezen in India en op Ceylon. Enige jaren later, toen de VOC haar handen weer vrij had, bood een verbannen vorst van Boni, Aroeng Palaka, zich als bondgenoot aan. Daarop begon de VOC in 1666 een grootscheepse oorlog tegen de Makassaren. De leiding berustte bij Cornelis Speelman, die ook beschikte over Ambonese en Ternataanse hulptroepen en samenwerkte met de Boeginese krijgers onder Aroeng Palaka. Het duurde tot 1669 voordat sultan Hasanoedin definitief verslagen was. De VOC bracht Gowa daarop tot kleine omvang terug. Van de vroeger door dit sultanaat veroverde gebieden in en buiten Celebes werden sommige aan Ternate toegewezen als beloning voor de bewezen diensten; de andere werden vazalstaten van de Compagnie, met inbegrip van Boni, dat overigens wel een voorkeursbehandeling kreeg. Veel Makassaren verlieten Gowa en bleven de Nederlanders elders bestrijden, hetzij als zeerovers hetzij als krijgers in dienst van vijanden van de Compagnie. De VOC maakte de stad Makassar tot eigen grondgebied en ontmantelde er de talrijke zware versterkingen, behalve het fort Oedjoeng Pandang, dat werd omgedoopt tot fort Rotterdam. Zij liet in Makassar geen andere Europeanen meer toe dan haar eigen dienaren. Het VOC-monopolie van de Molukse specerijen was voortaan onaantastbaar.

Intussen had de VOC al voor de verovering van Makassar een steunpunt verworven in de noordoosthoek van Celebes, namelijk in Menado waar zij het fort Amsterdam had gebouwd. Zij had zich hier in 1658 gevestigd op verzoek van de plaatselijke bevolking, die Nederlandse bescherming zocht tegen de Ternatanen en de Spanjaarden.

\section{Verwerving van de oppermacht op Java}

Terwijl de VOC nu oppermachtig was in de oostelijke helft van de Indonesische archipel, lag haar hoofdstad Batavia nog steeds ingeklemd tussen het sultanaat Bantam en het rijk Mataram. In 1628, toen Mataram zich tegen Batavia keerde, had de Compagnie snel vrede met Bantam gesloten en de blokkade opgeheven, maar die vrede bleek niet duurzaam. Met Mataram bleef de oorlogstoestand bestaan zolang sultan Agoeng leefde; pas na diens dood in 1645 sloot zijn zoon vrede met de VOC.

De regeerders van Mataram grepen terug op het Javaanse verleden. Zij vervingen de titel van sultan door de titel 'soesoehoenan', tooiden zich niet meer met Arabische maar met Javaanse namen en droegen een kroon van gouddraad die afkomstig heette te zijn van Modjopahit. Ook onderdrukten zij de activiteiten van islamitische geestelijke leiders. De VOC behandelde Mataram met respect. $\mathrm{Al}$ in 1614 en volgende jaren hadden gezanten van de Compagnie 
het hof van sultan Agoeng bezocht. Zijn residentie, de kraton, lag ten zuiden van het huidige Jogjakarta. Na de vrede met zijn opvolger zond de VOC weer jaarlijks een gezantschap naar het Mataramse hof.

Het grote rijk Mataram was echter een reus op lemen voeten. Het was door Senopati en sultan Agoeng met geweld bijeengebracht, maar de door hen onderworpen vorstenhuizen schikten zich niet gemakkelijk in hun lot. In 1676 brak een opstand uit onder leiding van de Madoerese prins Troenodjojo, die met hulp van Makassaarse krijgers een deel van Oost-Java veroverde. De meeste kustgewesten liepen naar hem over. Zowel de soesoehoenan als de opstandige prins vroeg nu hulp aan de VOC. De Compagnie besloot de soesoehoenan te steunen en zond een expeditie onder Speelman, die Troenodjojo uit Soerabaja verdreef. Maar de rebel was niet verslagen; integendeel, enkele maanden later veroverde hij de kraton van de soesoehoenan. Deze laatste stierf op de vlucht; hij werd opgevolgd door zijn oudste zoon, die in 1677 een verdrag met Speelman sloot waarin hij grote concessies deed in ruil voor terugkeer op de troon. Onder meer beloofde hij aan de VOC de kosten van haar militaire bijstand te vergoeden en gaf hij haar de stad Semarang als onderpand voor zijn schuld. Ook stond hij het gebied tussen Batavia en het gewest Tjirebon aan de VOC af en verleende hij haar handelsmonopolies.

Om de nieuwe soesoehoenan op de troon van Mataram te plaatsen trok de Compagnie in 1678 met een grote strijdmacht het binnenland van Java in. Ook Aroeng Palaka met zijn Boeginezen nam daaraan weer deel. Na zware strijd werd Troenodjojo eindelijk verslagen. De Nederlandse legeraanvoerder gaf de gouden kroon van Modjopahit, die Troenodjojo uit de kraton had meegenomen, aan de soesoehoenan. Een jaar later werd de rebel zelf gevangen genomen en door de soesoehoenan gedood. Deze laatste vestigde zich in 1680 in een nieuwe kraton, Kartasoera. Daarnaast kwam een Nederlandse vesting met een VOC-detachement als 'lijfwacht' voor de vorst. Mataram was een vazalstaat van de VOC geworden.

De betrekkingen tussen de VOC en het sultanaat Bantam waren wisselvallig. De in 1628 gesloten vrede werd verschillende malen door oorlogen onderbroken. Niettemin wist Bantam zich goed te herstellen van de door de blokkade geleden schade en na het midden van de eeuw kwam het zelfs tot grote bloei onder het bewind van sultan Ageng. Het dreef handel met Arabië, Perzië, India, China en de Filippijnen en verleende gastvrijheid aan Britse, Deense en Franse kooplieden. Bantam werd niet alleen een concurrent van de VOC maar ook een militaire bedreiging, vooral toen het van het verval van Mataram gebruik maakte om zich meester te maken van Priangan ('de Preanger', het Soendanese bergland ten zuiden en zuidoosten van Batavia). Maar wederom werd een intern Indonesisch conflict de redding van de VOC. In 1680 werd sultan Ageng afgezet door een zoon, die later in de daarop gevolgde burgeroorlog de steun van de Compagnie inriep. Speelman, intus- 
sen gouverneur-generaal geworden, stelde daarvoor zware voorwaarden, die door de jonge sultan werden aanvaard. De troepen van de VOC versloegen daarop diens tegenstanders, waarbij ze diep het binnenland introkken en voor het eerst over land de zuidkust van Java bereikten. In 1683 gaf sultan Ageng zich over; hij eindigde zijn leven als gevangene in Batavia.

Ook het sultanaat Bantam werd nu een vazalstaat van de VOC. Omdat het gewest Tjirebon in diezelfde tijd eveneens haar opperheerschappij erkende, was voortaan heel West-Java onderhorig aan de Compagnie. De VOC bracht het dun bevolkte gebied van Priangan onder haar eigen bestuur. Een verder gevolg van de onderschikking van Bantam aan de Compagnie was, dat nu ook het aan Bantam onderhorige Lampong-gebied in het zuiden van Sumatra (een belangrijk produktiegebied van peper) onder VOC-heerschappij kwam. Als havenstad speelde Bantam geen grote rol meer. Alle niet tot de Compagnie behorende Europeanen moesten de stad verlaten. De Britten vestigden zich daarop in Benkoelen aan de westkust van Sumatra.

Bij het overlijden van Jan Pieterszoon Coen in 1629 waren Atjeh, Bantam, Mataram, Gowa en Ternate de vijf machtigste rijken van Indonesië. Toen Cornelis Speelman in 1684 stierf had Atjeh zijn macht verloren en waren de vier andere rijken onderhorig aan de VOC geworden.

\section{Het handelsrijk van de VOC}

Tegen het einde van de zeventiende eeuw was de Verenigde Oost-Indische Compagnie de grootste Europese macht in Azië. Portugal had daar alleen nog enige vestigingen aan de westkust van India, in Macao en op Timor (Hormoez had het al in het begin van de eeuw verloren). De Spaanse aanwezigheid beperkte zich tot de Filippijnen. De Britse EIC had haar vestigingen voornamelijk in India en Perzië. Zij beschikte sinds kort ook over publiekrechtelijke bevoegdheden naar het voorbeeld van de VOC en was vastbesloten daar gebruik van te maken; voorlopig echter lag zij nog ver achter bij de Nederlandse Compagnie. Intussen was op initiatief van de Franse regering ook een Franse Indië-maatschappij opgericht, maar deze bezat pas enkele vestigingen in India. Franse en Britse pogingen om vaste voet op Ceylon te krijgen waren door de strijdkrachten van de VOC verijdeld. Het Aziatische handelsrijk onder Nederlandse leiding was een feit geworden. De Compagnie bezat nu meer dan honderd handelsposten en andere vestigingen. Vele daarvan waren door forten versterkt.

Het meest westelijk lag de Kaapkolonie, in 1652 aan de zuidpunt van Afrika gesticht als pleisterplaats waar de VOC-schepen verse groente en vlees konden inslaan en reparaties ondergaan. Het was het enige gebied waar de Compagnie doelbewust een volksplanting stichtte. Zij hielp Nederlanders 


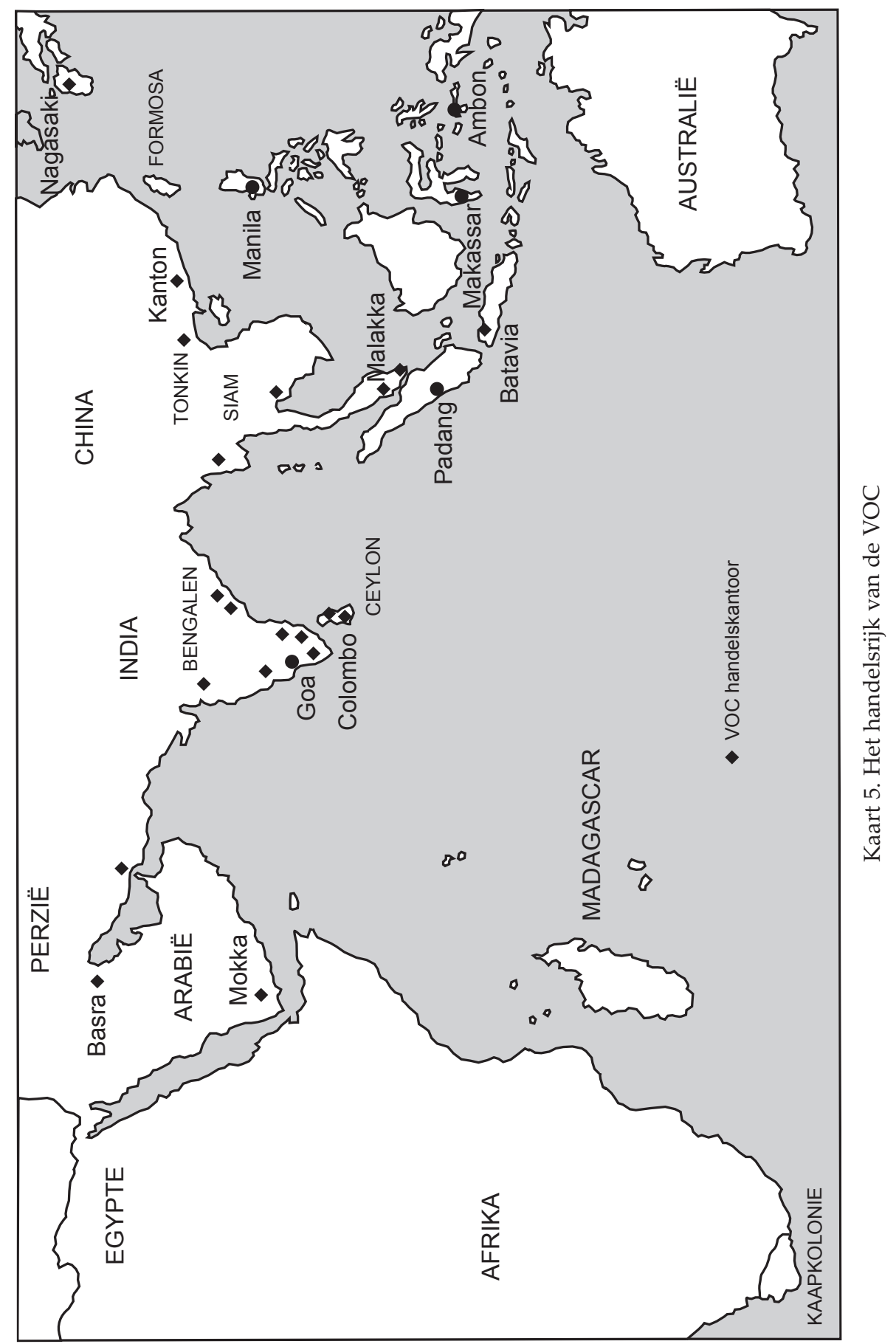


maar ook protestantse Duitsers en Fransen om zich daar als boeren te vestigen; Britten waren hiervan uitgesloten.

De meest westelijke plaatsen in Azië zelf waar de Compagnie ooit vestigingen bezat waren Mokka aan de Rode Zee en Basra aan de Perzische Golf. Daarnaast waren er ruim twintig VOC-posten langs de kusten van Perzië en India en ook verscheidene in het Perzische en Indiase binnenland. Op Ceylon beheerste de VOC Colombo en alle andere kuststeden. Wat Achter-Indië betreft, had zij handelsposten in Siam (Thailand) en Tonkin en aan de westkust en de oostkust van het schiereiland Malakka. Ten zuiden en zuidoosten daarvan beheerste zij een groot deel van de Indonesische archipel.

Daarentegen bezat de VOC lange tijd geen vestigingen in China. Zij had het daar verbruid door pogingen om zich met geweld toegang tot de Chinese markt te verschaffen. Weliswaar had zij zich in 1624 op Formosa (Taiwan) gevestigd, maar daar was zij in 1662 uit verdreven door Chinese tegenstanders van de Mantsjoe-dynastie; twintig jaar later had China zelf Formosa in bezit genomen. Overigens voerde de Compagnie wel degelijk handel met China, maar het transport tussen dat land en Batavia gebeurde meestal met Chinese schepen.

Terwijl de VOC in China geen posten mocht hebben, was haar verstandhouding met Japan uitgesproken goed. Al in 1609 had zij daar een handelskantoor kunnen openen. In de eerste decennia daarna nam zij veel Japanse huursoldaten in dienst. Toen de Japanse regering in 1636 besloot het land voor Europeanen te sluiten, mocht alleen de VOC daar een handelspost handhaven. Deze meest oostelijke VOC-post, gevestigd op het eilandje Desjima in de haven van Nagasaki, was meer dan twee eeuwen de enige verbinding van Japan met de westerse wereld.

De Compagnie had een groot aandeel verworven in de handel tussen de Aziatische landen. Met haar schepen zorgde zij voor de uitwisseling van bijvoorbeeld koffie uit Arabië, goud en edelstenen uit Perzië, katoenen weefsels, indigo, salpeter en opium uit India, kaneel en olifanten uit Ceylon, tin van het schiereiland Malakka, peper uit Sumatra, rijst en suiker uit Java, kruidnagelen, muskaatnoot en foelie uit de Molukken, zijde, porselein en thee uit China en zilver, koper en lakwerk uit Japan. De VOC-invoer uit Europa omvatte slechts een beperkt warenpakket, waaronder spiegelglas en wollen stoffen, en bestond verder voornamelijk uit zilveren munten. De uit Nederland komende schepen waren dan ook gedeeltelijk met ballast geladen, onder meer met bakstenen. De uitvoer van de Compagnie naar Europa bestond merendeels uit specerijen en textiel.

Bijna alle voor Europa bestemde waren werden eerst naar Batavia gebracht en daar opgeslagen in de centrale pakhuizen van de Compagnie, in afwachting van het transport met de retourvloten, die twee maal per jaar naar Nederland vertrokken. Voor het onderhoud van haar schepen beschikte de Compagnie 
over grote scheepswerven op het voor de kust gelegen eilandje Onrust. De VOC-schepen deden meestal een maand of zeven over de reis naar Nederland en acht of negen maanden over de reis van Nederland naar Batavia, maar volbrachten die reizen soms ook binnen een half jaar.

In het handelsbeleid van de VOC nam de verkrijging van monopolies een grote plaats in. Het ging daarbij zowel om exclusieve inkooprechten als om exclusieve verkooprechten. Toen bijvoorbeeld in 1677 de soesoehoenan van Mataram hulp vroeg om op zijn troon terug te keren, bedong de Compagnie daarvoor onder meer een exclusief recht op de invoer van katoenen weefsels en opium in zijn rijk. De verkoop van opium was één van de belangrijkste inkomstenbronnen van de VOC; zij heeft het gebruik daarvan dan ook sterk bevorderd.

De Compagnie werkte niet alleen met exclusieve inkooprechten, maar legde aan sommige gebieden ook verplichtingen tot levering op, hetzij tegen door haar vastgestelde prijzen hetzij als een soort van belastingen. Zulke gedwongen leveranties vormden een steeds belangrijker grondslag voor haar verwerving van handelswaren. Overigens beschikte zij over monopolies en leverdwang voornamelijk in Indonesië en op Ceylon. Daarbuiten, zoals in India, moest zij haar waren meestal op de vrije markt inkopen.

De kracht van de VOC kwam voor een deel voort uit haar strakke organisatie en haar unieke beschikking over kennis. Zij kon de prijzen en de kwaliteiten van waren op ver van elkaar gelegen markten vergelijken. Al haar posten moesten geregeld gedetailleerde rapporten aan het hoofdkwartier in Batavia opzenden, die daar werden verwerkt in de centrale boekhouding. Ook aardrijkskundige en zeevaartkundige gegevens werden door de Compagnie centraal verwerkt en bewaard. Op basis hiervan kregen haar scheepskapiteins kaarten uitgereikt die ze na afloop van hun reis weer moesten inleveren. Het hogere personeel werd binnen het handelsrijk veelvuldig overgeplaatst van de ene post naar de andere. Van de gouverneurs-generaal bijvoorbeeld zijn er vier in hun eerdere loopbaan hoofd geweest van het kantoor in Japan, vier gouverneur van Ceylon en vier gouverneur van de vestigingen aan India's oostkust.

De VOC was destijds de grootste particuliere onderneming ter wereld. Tegen het eind van de zeventiende eeuw had zij in Azië ongeveer 25.000 personen in dienst (van wie meer dan de helft militairen). Ruim 4000 hiervan behoorden tot het hoofdkwartier in Batavia. In en rondom de stad woonden toen ongeveer 70.000 mensen. Daarvan waren er een 6000 van Europese afkomst. Veel talrijker waren de Chinezen; verder waren er onder meer Portugees-sprekende immigranten uit Malakka en India naast Balinezen, Boeginezen, Javanen, Makassaren, Maleiers en Molukkers. De bevolking bestond voor meer dan de helft uit slaven. In de begintijd was Batavia een stad zonder achterland geweest, die over zee werd bevoorraad. Naderhand werd 
in de omtrek wel enige landbouw bedreven, maar pas in de laatste decennia van de eeuw, toen Bantam geen bedreiging meer vormde, begon men op grotere schaal het omliggende land in gebruik te nemen.

\section{Het bestuursstelsel van de VOC}

De Compagnie was een particuliere onderneming waaraan het recht verleend was overheidsfuncties uit te oefenen. Zij was geen staat, maar trad overzee wel op als een staat. Haar centraal bestuur overzee, bestaande uit de gouverneurgeneraal en de Raad van Indië, werd dan ook in de officiële instructies van de VOC aangeduid als de 'Hoge Regering'. Naast de gouverneur-generaal zelf telde de Raad aanvankelijk vier, maar uiteindelijk negen leden; de individuele leden werden eveneens Raad van Indië genoemd.

Het optreden van de VOC als een de facto staat hield onder meer in dat zij meende het recht te hebben over bepaalde gebieden het oppergezag uit te oefenen. Wat de grondslag van dat recht betreft volgde zij geen vaste lijn. In sommige gevallen gaf zij te kennen op te treden namens de Staten-Generaal, zodat de soevereiniteit over die gebieden eigenlijk bij Nederland zou berusten, terwijl zij in andere gevallen zichzelf als de soeverein presenteerde. In feite had het door de Staten-Generaal verleende octrooi de VOC niet uitdrukkelijk gemachtigd tot het verwerven van soevereiniteit over grondgebied, noch voor Nederland noch voor zichzelf. Niettemin achtte de Compagnie zich hiertoe bevoegd sinds het Portugese fort op Ambon zich in 1605 aan haar had overgegeven. De Staten-Generaal aanvaardden dat de VOC deze ruime uitleg aan haar mandaat gaf, maar verdiepten zich niet in de soevereiniteitskwestie. Zij namen zelfs geen kennis van de verdragen over de verwerving van grondgebied die de VOC met Aziatische vorsten sloot. Gelet op deze passieve houding van de Staten-Generaal zullen alle gebieden waarover de Compagnie het oppergezag uitoefende hier verder worden aangeduid als 'eigen grondgebied' van de VOC.

Wat betreft de uitoefening van overheidsfuncties door of namens de Hoge Regering in Batavia kan men verschillende categorieën van gebieden onderscheiden. Daarbij is het in de eerste plaats relevant of de VOC een gebied wel of niet als eigen grondgebied beschouwde. Ging het om eigen grondgebied, dan is het vervolgens van belang of de VOC dit gebied wel of niet onder haar rechtstreeks bestuur plaatste.

Aldus vallen als eerste categorie de gebieden te onderscheiden die de VOC als eigen grondgebied beschouwde en rechtstreeks bestuurde. Dit waren in hoofdzaak gebieden waarover de VOC meende het oppergezag te bezitten krachtens het recht van 'verovering in een rechtvaardige oorlog' (uiteraard vond de VOC alle door haar gepleegde oorlogshandelingen rechtvaardig). Bij 
het einde van de zeventiende eeuw was dit nog steeds een zeer beperkte categorie. Binnen Indonesië was het grootste van deze gebieden het deel van WestJava tussen de gewesten Bantam en Tjirebon; de VOC strekte daarbij haar soevereiniteitsaanspraken uit van Batavia tot Priangan en de zuidkust. Verder behoorden tot deze categorie alleen Ambon, de Banda-eilanden en de stad Makassar. Buiten Indonesië omvatte deze categorie de stad Malakka, de op Portugal veroverde steden in India en op Ceylon en tenslotte de Kaapkolonie. In de achttiende eeuw werd het rechtstreeks bestuurde gebied op Java sterk uitgebreid.

Een tweede categorie wordt gevormd door de gebieden die de VOC wel als eigen grondgebied beschouwde maar niet zelf bestuurde. In de regel waren dit gebieden die door inheemse vorsten aan de VOC waren overgedragen maar vervolgens door de VOC weer aan die vorsten 'in leen' waren gegeven. Het oppergezag berustte dan bij de VOC, maar deze liet het bestuur aan de vorsten over. Deze zwakkere vorm van soevereiniteit werd meestal 'suzereiniteit' genoemd. De gebieden placht men aan te duiden als 'leenroerige rijken'. Bij het einde van de zeventiende eeuw was het sultanaat Ternate het belangrijkste gebied uit deze categorie; in de achttiende eeuw kwamen ook Bantam, Mataram, Madoera en Tidore er onder te vallen.

In de derde plaats waren er gebieden die formeel soeverein waren gebleven, maar in feite door verdragen en andere regelingen ondergeschikt waren geworden aan de Compagnie. Dit waren bijvoorbeeld verdragen waarin 'eeuwige trouw' aan de VOC was beloofd of permanente bescherming van de VOC was aanvaard. Soms werd in zulke verdragen de fictie gehandhaafd van een bondgenootschap op voet van gelijkheid. Tot deze derde categorie behoorden aan het einde van de zeventiende eeuw verscheidene gebieden op Celebes, Java en Sumatra en ook het koninkrijk Kandy op Ceylon. Men duidde zulke gebieden aan als 'bondgenootschappelijke rijken'. Hun eigen speelruimte verschilde van geval tot geval; meestal waren het niet meer dan vazalstaten. Overigens was het onderscheid tussen leenroerige en bondgenootschappelijke rijken in de praktijk niet altijd duidelijk. De bepalingen van de door de VOC gesloten verdragen leenden zich soms voor verschillende uitleg; bovendien werden die verdragen altijd in meer dan één taal opgesteld en kwam het voor dat de Nederlandse tekst afweek van de anderstalige tekst.

Naast deze drie categorieën kan men als vierde categorie de plaatsen onderscheiden waar de VOC wel handelsposten bezat, maar zelf volledig ondergeschikt was aan de autoriteiten van het land. Dit gold onder meer voor de VOC-posten in Perzië, in het Indiase rijk van de Groot-Mogols en in Japan.

Over deze vier categorieën van gebieden had de Compagnie één hiërarchisch netwerk van ambtenaren uitgespreid. De top daarvan werd gevormd door de Hoge Regering in Batavia. Onmiddellijk daaronder ressorteerden de 
gouverneurs. Een stap lager in de hiërarchie stonden de plaatselijke vertegenwoordigers die als 'residenten' werden betiteld. In eerste aanleg was dit ambtelijk apparaat niet gevormd om gebied te besturen maar om handel te drijven, maar langzamerhand nam het bestuurswerk een steeds belangrijker plaats in. Niettemin bleven sommige VOC-ambtenaren, zelfs op het niveau van de gouverneurs en residenten, zich in hoofdzaak met commerciële en diplomatieke activiteiten bezighouden, bijvoorbeeld aan India's oostkust.

Het feit dat een gebied onder rechtstreeks bestuur van de Compagnie stond betekende overigens niet dat de hele bevolking rechtstreeks door VOCambtenaren bestuurd werd, zelfs niet in Batavia. Al in de begintijd was daar het dagelijks bewind over de Chinese bevolkingsgroep toevertrouwd aan een eigen 'kapitein der Chinezen', benoemd door de gouverneur-generaal. Later breidde men dit systeem ook uit tot andere etnische groepen in Batavia. Toen de VOC in het begin van de achttiende eeuw heel Priangan onder haar gezag bracht, liet zij de daar bestaande bestuursstructuur grotendeels intact. Daarbij profiteerde zij ervan dat hier, evenals in veel andere delen van Indonesië, een erfelijke ambtsadel bestond zonder vaste regels voor de opvolging. De Compagnie benoemde nu zelf uit deze adellijke families in de verschillende gewesten de hoogste inheemse bestuurders, door haar 'regenten' genoemd. Onder de regenten ressorteerden inheemse districts- en dorpshoofden. Dit inheemse bestuursnet stond onder oppertoezicht van de Compagnie. Wat de rechtspraak betreft, bepaalde de Hoge Regering dat alle strafzaken en burgerlijke zaken van de bevolking van Priangan berecht zouden worden door de regenten en de inheemse rechters op basis van het inheemse recht. De ambtenaren van de VOC zouden er alleen op moeten toezien dat onpartijdig recht gesproken werd. Ook in andere 'rechtstreeks bestuurde' gebieden handhaafde de Compagnie tot op zekere hoogte de inheemse rechts- en bestuursstelsels.

Omgekeerd maakte, in de gebieden die de VOC niet zelf bestuurde, het onderscheid tussen de tweede en de derde categorie (de leenroerige en de bondgenootschappelijke rijken) in de praktijk niet veel verschil. In beide gevallen berustte het bestuur bij de vorsten en andere inheemse gezagsdragers (eveneens vaak als 'regenten' aangeduid), maar in beide gevallen bevonden zich hoge VOC-ambtenaren (gouverneurs of residenten) in of nabij het gebied die controleerden of men zich wel hield aan de verplichtingen tegenover de Compagnie. Bovendien had de Compagnie er gewoonlijk eigen forten en garnizoenen. Ook in gebieden waarover de VOC niet soeverein was gedroeg zij zich soms als heer en meester, bijvoorbeeld binnen het sultanaat Ternate, waar zij al lang voordat dit gebied een 'leen' werd naar eigen goeddunken vruchtbomen vernielde en dorpen verbrandde.

Verder achtte de VOC zich ook bevoegd strafmaatregelen tegen politieke tegenstanders te nemen die ze buiten haar eigen grondgebied gevangen had genomen. Een veel toegepaste maatregel was interne verbanning; de bal- 
lingsoorden waren gewoonlijk gebieden van de eerste categorie. Zo heeft de VOC op Ceylon en in de Kaapkolonie een aanzienlijk aantal Indonesiërs geïnterneerd; in Zuid-Afrika is daar een aparte islamitische gemeenschap uit ontstaan.

\section{Indonesië als studieterrein en thuisland voor Compagniesdienaren}

Dienaren van de VOC deden soms nog andere dingen dan varen, handeldrijven, besturen en oorlog voeren. Sommigen publiceerden reisverhalen over hun eigen belevenissen, anderen schreven over de geschiedenis van de Compagnie. Deze geschriften bevatten natuurlijk allerlei gegevens over de vreemde landen en volkeren waarmee men in aanraking kwam, maar betroffen toch in de eerste plaats wat Nederlanders hadden beleefd en gedaan. Verschillende Compagniesdienaren ondernamen echter ook studies die zich rechtstreeks op die vreemde landen en volkeren richtten.

Hiertoe behoorde in de eerste plaats de studie van het Maleis en andere Aziatische talen, in het voetspoor van Frederik de Houtman die daar al voor de oprichting van de VOC mee begonnen was. De grootste talenkenner in VOC-dienst was Herbert de Jager, die van 1662 tot 1692 afwisselend in Batavia, Perzië en India gewerkt heeft. Hij kende Arabisch, Perzisch, Sanskriet, Tamil, Malgassisch, Maleis en Javaans en hield zich ook met vergelijkende taalkunde bezig. In de tweede plaats maakten verscheidene VOC-dienaren nauwkeurige beschrijvingen van de bevolking en de geografie van bepaalde gebieden. Enkelen verdiepten zich ook in de eigen geschiedenis van die gebieden voor de komst van de Nederlanders. Verdere voorwerpen van studie waren de godsdiensten, waaronder het hindoeïsme, en de inheemse rechtsstelsels, zoals de adat, het oude gewoonterecht. Tal van Compagniesdienaren waren gefascineerd door de tropische natuur. Meerderen van hen hielden zich met plantkunde bezig; één liet een twaalfdelige flora van India's westkust samenstellen die eeuwenlang als standaardwerk heeft gegolden.

De VOC nam zelf meermalen het initiatief voor geografische ontdekkingsreizen, zoals die in 1642 van Abel Tasman die heel Australië omzeilde, waarbij hij onder meer het eiland ontdekte dat later Tasmanië genoemd is en de eilandengroep die de naam Nieuw-Zeeland gekregen heeft.

De beroemdste geleerde onder de VOC-ambtenaren was de Duitser Georgius Rumphius, die in 1655 in Ambon geplaatst werd en daar tot zijn dood in 1702 is gebleven. Hij schreef veelomvattende boeken, onder meer over de geschiedenis van Ambon en over de plantenwereld, de schaal- en schelpdieren en de mineralen van de Molukken. Hij deed dit werk naast zijn bestuurstaken en werkte onvermoeibaar door hoewel hij blind werd en nog door andere rampen getroffen werd. De VOC-leiding in Batavia liet hem de 


\section{D'AMBOINSCHE RARITEITKAMER,}

Behelzende cene BESCHR Y VINGE van allerhande zoo weeke als harde

\section{SCHA A L VIS S C HEN,}

te weeten raare

KRABBEN, KREEFTEN, en diergelyke Zeedieren, als mede allerbande

\section{HOORNTJES en SCHULPEN,}

die men in d Amboinfche Zee vindt:

Dar beneven zommige

MINER AALEN, GESTEENTEN,

en foorten van AARDE, die in d Amboinfche, en zom-

mige omleggende Eilanden gevonden worden.

$V$ erdeels in drie Bocken,

En met nodige PRINTVER BEELDINGEN, alle nar 't leven getekent, roorzien,

Befchreven door

GEORGIUS EVERHARDUS RUMPHIUS,

van Hanaur, Koopman en Rad in Amboina, miesgaders Lid in d' Aradrwie Carie/wam Natare, in 't Daitkhe Roomfche Ryk opgerechs, onder den nam van

PLINIUS INDICU \&

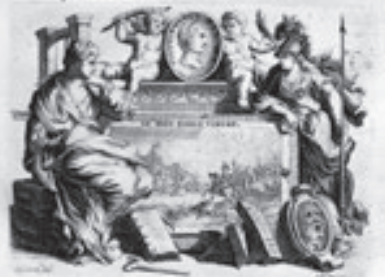

T A M S T E R D A $M$,

Gedrukt by F R A N C O I S H A L M A, Bockverkoper in Konftantijn den Grooten,

I 705 .

De in 1705 in druk verschenen Amboinsche Rariteitkamer, een rijk geïllustreerde beschrijving van in de Molukken aangetroffen schaaldieren, schelpen en mineralen, was het laatste grote werk van de VOC-dienaar Georg Rumphius (1628-1702), die onder meer ook over de flora en de geschiedenis van Ambon heeft geschreven. 
vrijheid om dit werk te verrichten en zorgde soms voor assistentie.

Niet alleen toonden verschillende Compagniesdienaren door hun studies dat zij belang stelden in het land waar zij hun dienst verrichtten, maar ook bleken velen zich er thuis te voelen. Al sinds de begintijd keerden veel lagere Europese dienaren na hun diensttijd niet naar Europa terug, omdat zij inmiddels een inheemse levensgezellin gevonden hadden en omdat zij niet rijk genoeg waren om zich in hun vaderland een nieuw bestaan op te bouwen. Maar sinds de laatste decennia van de zeventiende eeuw bleven ook steeds meer hogere ambtenaren in Azië wonen, hoewel zij het zich financieel zeer wel konden veroorloven om hun leven in Europa voort te zetten. Dit gold onder andere voor verscheidene hoge VOC-functionarissen die landgoederen stichtten in de omgeving van Batavia en daar een grote staat voerden, naar het voorbeeld van de inheemse adel. Ook zeven gouverneurs-generaal gaven er de voorkeur aan in Indonesië te sterven nadat zij het ambt hadden neergelegd. Tegelijk nam onder de hoge Compagniesdienaren het aantal toe van hen die zelf niet in Europa maar in VOC-gebied geboren waren. Hiertoe behoorden ook vier gouverneurs-generaal (geboren in Ambon, Batavia, Ceylon en de Kaapkolonie). In het bijzonder Indonesië werd door velen beschouwd als het land waar men thuis was.

De eerste gouverneur-generaal die welbewust in Indonesië bleef wonen was Joannes Camphuys. Hij had zijn ambt vervuld van 1684 tot 1691 en bezat een kring van vrienden die een humaan beleid jegens de inheemse bevolking voorstonden. Ook de geleerden De Jager en Rumphius behoorden tot die kring, evenals Cornelis Chasteleyn, die onder meer een ethisch manifest schreef tegen de koopmanspolitiek van de VOC. Deze Chasteleyn stichtte drie landgoederen bij de hoofdstad. Eén daarvan was Weltevreden, waar later een nieuw deel van Batavia naar genoemd is; een ander was Depok, dat Chasteleyn bij zijn dood naliet aan zijn tot het christendom bekeerde slaven, waarna het tot in de twintigste eeuw als christengemeenschap is blijven bestaan. De vooruitstrevende denkbeelden van Camphuys en de zijnen hebben echter nauwelijks invloed gehad op het VOC-beleid in de achttiende eeuw.

Invoering van de koffieteelt op Java

Lange tijd bracht het gebied van Batavia zelf geen handelswaren voort. In de tweede helft van de zeventiende eeuw kwam hierin verandering toen Chinese ondernemers in de omstreken van de stad suikerrietplantages stichtten. De VOC zette de daar gewonnen suiker meestal in Azië af, omdat in Europa toen de rietsuiker uit West-Indië goedkoper was. Tegen het eind van de eeuw breidde deze Chinese suikerindustrie zich sterk uit. 
Intussen begon in diezelfde tijd het koffiedrinken in Europa populair te worden en de Compagnie maakte goede winsten met de koffie die zij daar uit Arabië importeerde. Dit bracht enige leidende VOC-functionarissen op de gedachte te onderzoeken of koffie ook op Java geteeld zou kunnen worden. Hun gedachte had tot gevolg dat de VOC behalve een handelsonderneming ook een landbouwonderneming werd. Het in de eerste decennia van de achttiende eeuw ondernomen experiment had zoveel succes, dat Java al spoedig meer koffie voortbracht dan Arabië en dat de verkoop van koffie in het laatste kwart van de eeuw de voornaamste inkomstenbron van de VOC werd.

De Compagnie ondernam de koffieproductie niet zelf, maar verstrekte zaden en plantgoed aan de regenten in West-Java opdat zij hun onderdanen koffie zouden laten verbouwen. In het bergland van Priangan (de Preanger) bleek dit grote oogsten op te leveren. De Compagnie kocht de koffie van de regenten tegen een door haarzelf vastgestelde prijs en liet het aan hen over hoe zij de door hun boeren verrichte arbeid wilden vergoeden. De regenten verleenden vrijwillig hun medewerking aan de koffieteelt, maar de bevolking toonde hier na enige tijd weinig animo meer voor. Daarom ging de Compagnie over tot een minder vrijblijvend systeem. Zij kondigde een monopolie op koffie af en voerde een leveringsplicht in, zich baserend op haar soevereiniteit over het gebied. Evenals daar vroeger verplichtingen gegolden hadden tot de afdracht van rijst en dergelijke aan de soesoehoenan, werden de regenten voortaan verplicht koffie aan de VOC te leveren. Eerst bepaalde de Compagnie alleen de te leveren hoeveelheden, later stelde zij jaarlijks ook de aanplant van een bepaald aantal koffiebomen verplicht. Aan elke regent werd een VOC-controleur toegevoegd, de koffiesergeant, om te helpen bij het toezicht op de productie.

Dit regiem van gedwongen aanplant en levering werd later het Preangerstelsel genoemd. De regenten hadden groot persoonlijk belang bij het stelsel omdat de Compagnie niet aan de boeren maar aan hen voor de koffie betaalde. Zij vergrootten bovendien hun eigen afhankelijkheid van de Compagnie door voorschotten op die betalingen op te nemen; na enige tijd overtroffen hun schulden de waarde van de jaarlijkse koffieoogst.

\section{Chinees verzet en Chinezenmoord}

Chinezen speelden in Batavia een belangrijke rol als tussenhandelaren, winkeliers en ambachtslieden en werden door de VOC van begin af aan met voorkomendheid behandeld. $\mathrm{Zij}$ woonden evenals de Europeanen verspreid door de stad en niet in een afzonderlijke wijk buiten de stadswallen zoals de andere Aziatische bevolkingsgroepen. In het laatste deel van de zeventiende eeuw vestigden zich ook veel Chinezen in de omstreken, waar zij onder meer 
werkten in de landbouw en de suikerindustrie. Hun aantal overtrof na enige tijd dat van de Chinezen in Batavia en nam decennia lang verder toe door immigratie uit het Chinese moederland. Voor veel van deze immigranten was er echter geen emplooi, onder andere omdat de VOC de suikerproductie drastisch inperkte om de prijs hoog te houden. Intussen was ook de Nederlandse gemeenschap er niet goed aan toe. De bloeitijd van de VOC was voorbij, de welvaart ging achteruit en Batavia werd sinds 1732 geteisterd door een reeks epidemieën die veel slachtoffers eiste.

De werkloos rondzwervende Chinezen, die soms de omstreken van Batavia onveilig maakten, verontrustten de Hoge Regering steeds meer. Nadat verschillende pogingen tot beperking van de Chinese immigratie waren mislukt, besloot zij eind juli 1740 alle Chinezen zonder middelen van bestaan op te pakken. Men zou hen dan naar Ceylon of Zuid-Afrika kunnen deporteren. Onder de Chinezen verspreidde zich het gerucht dat men van plan was hen in zee te verdrinken. Een beperkt aantal Chinezen werd inderdaad opgepakt, velen vluchtten het binnenland in om zich aan deportatie te onttrekken, sommigen vormden gewapende strijdgroepen. Begin oktober vonden dicht bij Batavia enige gevechten plaats tussen zulke strijdgroepen en VOC-detachementen. $\mathrm{Na}$ een Chinese aanval op één van de stadspoorten brak op 9 oktober paniek uit onder de Nederlandse bevolking van Batavia, wat leidde tot een anti-Chinese pogrom. De ruim vierduizend Chinese inwoners van de stad werden in enkele dagen volledig uitgeroeid, hun bezittingen geplunderd, hun huizen verbrand. De Hoge Regering ondernam niets om deze moordpartij tegen te gaan.

Gedurende de maanden hierna werden nog eens duizenden Chinezen gedood bij militaire acties tegen de in West-Java rondzwervende groepen. De resterende strijdgroepen weken naar Midden-Java uit. Intussen nam de Hoge Regering wel verschillende maatregelen om het vertrouwen van de buiten Batavia verblijvende 'reguliere' Chinezen terug te winnen. Chinezen mochten echter voortaan niet meer in de binnenstad wonen. Zij kregen als woonoord een terrein buiten de stadswal toegewezen, waar later de wijk Glodok uit is ontstaan.

\section{Ondergang van Mataram}

Nadat het rijk Mataram door het verdrag van 1677 afhankelijk van de VOC was geworden, bleef het nog driekwart eeuw bestaan. Het werd in die tijd veelvuldig geteisterd door oorlogsgeweld. Dat kwam zowel door conflicten over de troonopvolging als door opstanden binnen het rijk, die zich ook tegen de VOC keerden.

In Mataram bestond geen vaste regel voor de opvolging van de vorst; zowel zoons als broers kwamen daarvoor in aanmerking. Vrijwel steeds wanneer een soesoehoenan overleed, maakten verschillende leden van zijn familie 
aanspraak op de troon. Driemaal leidde dit tot een langdurige opvolgingsoorlog. Telkens steunde de VOC met haar strijdkrachten één van de rivalen en telkens liet zij zich voor die steun belonen met nieuwe concessies. Zo werden na de eerste opvolgingsoorlog in het begin van de achttiende eeuw alle districten van Mataram verplicht tot regelmatige leveranties aan de Compagnie. Bovendien werd Semarang toen definitief aan de VOC afgestaan; deze vestigde daar haar hoofdkwartier voor Midden- en Oost-Java en bouwde er een sterke vesting.

Veel Mataramse gezagsdragers ergerden zich aan de bevoogding van hun land door de VOC. Zij gaven daarom soms steun aan opstandige bewegingen die weliswaar het gezag van de soesoehoenan aantastten maar toch in de eerste plaats een bedreiging voor de Compagnie vormden. De eerste van die bewegingen werd geleid door Soeropati, een Balinees die officier in het VOC-leger geweest was. In 1686 overviel hij het Nederlandse garnizoen in Kartasoera; daarna trok hij met zijn aanhangers naar het Oost-Javaanse gebied van Pasoeroean, waar hij zich twintig jaar wist te handhaven. De tweede opstand begon in 1717 en richtte zich onder meer tegen de VOC-post in Soerabaja, die bijna een jaar lang werd belegerd. Nadat de VOC de belegeraars daar eindelijk had verslagen, overleed de soesoehoenan en brak een nieuwe opvolgingsoorlog uit. De Soerabajase rebellie ging op in deze oorlog, die vier jaar duurde.

De derde en voor de VOC gevaarlijkste rebellie brak in 1741 uit, als gevolg van het Nederlandse optreden tegen de Chinezen in en rondom Batavia. De naar Midden-Java uitgeweken Chinese strijdgroepen keerden zich samen met Javaanse strijders tegen de posten van de Compagnie. Zij slaagden er bijna in de VOC-vesting in Semarang te veroveren; pas tegen het eind van het jaar kon de Compagnie het beleg van de vesting doorbreken. Wat als Chinees verzet was begonnen werd intussen steeds meer een Javaanse opstand. In Kartasoera werd het VOC-garnizoen overmeesterd en het Nederlandse fort afgebroken. Een jaar later verdreven de rebellen ook de soesoehoenan uit Kartasoera en riepen zij een tegen-soesoehoenan uit. De VOC kon de rebellie uiteindelijk bedwingen dank zij de hulp van een Madoerese vorst. De door haar op zijn troon teruggebrachte soesoehoenan verplaatste zijn kraton naar een nieuwe residentie, Soerakarta aan de rivier de Solo. In 1743 sloot hij een verdrag met de VOC waarbij hij haar onder meer de hele noordkust van Midden- en Oost-Java afstond. De rijksbestuurders van Mataram moesten voortaan in Semarang een eed van trouw aan de Compagnie afleggen. Naast de nieuwe kraton bouwde de VOC een sterke vesting waarin een Nederlandse resident kwam te zetelen. Semarang werd de zetel van een gouverneur.

In 1749 stond de soesoehoenan op zijn sterfbed zijn hele rijk af aan de Compagnie en liet hij de beslissing over zijn opvolging aan haar over. Mataram werd daardoor in feite een leen van de VOC. Een deel van de Mataramse adel 
erkende deze daad niet als rechtsgeldig en riep in Jogjakarta de broer van de soesoehoenan tot zijn opvolger uit. Hierna begon een jarenlange opvolgingsoorlog tussen de zoon van de overledene, die door de VOC als opvolger werd aangewezen, en de in Jogjakarta ingehuldigde broer. De laatste had veel meer aanhang onder de Javaanse bevolking; de legers van de eerste en van de Compagnie bleken niet in staat hem een beslissende nederlaag toe te brengen. Overigens ontwikkelde de strijd zich tot een driehoeksoorlog, omdat nog een derde familielid aanspraak op de troon maakte. Tenslotte waren alle partijen zo verzwakt dat de VOC in 1755 een eind aan de strijd kon maken door een politieke oplossing. Er werden twee even grote vorstendommen gevormd: Soerakarta (ook wel Solo genoemd) onder de door de VOC aangewezen soesoehoenan en Jogjakarta onder zijn oom, die de titel van sultan kreeg. Bovendien werden ook enige gebieden toegewezen aan de derde pretendent, met de titel van 'mangkoenegara' en met zetel in Soerakarta. Deze deling betekende het eind van het rijk Mataram. In het vervolg moesten de soesoehoenan, de sultan en de mangkoenegara zelf trouw aan de Compagnie zweren. Ook Jogjakarta kreeg nu een VOC-resident en een VOC-garnizoen.

\section{Ontstaan van de Djojobojo-legende}

De Javaanse samenleving werd door de opvolgingsoorlogen ernstig ontwricht ten gevolge van de oorlogsmethodiek van de troonpretendenten. Meestal probeerden zij overwicht te krijgen door massale legers op de been te brengen. De recrutering daarvan beroofde de landbouw van het merendeel van haar arbeidskrachten. Bovendien richtte de oorlogvoering zich in sterke mate op vernietiging van de bestaansmiddelen van de tegenpartij. Grote delen van de bevolking werden getroffen door hongersnood. Sommige gebieden in OostJava werden door deze oorlogen geheel ontvolkt; later vestigden zich daar immigranten uit Madoera.

In het tijdvak van de ondergang van het rijk Mataram begonnen voorspellingen de ronde te doen die de Javaanse bevolking enige troost boden in haar ellende. Volgens de legende zouden die voorspellingen gedaan zijn door koning Djojobojo, de vorst van Kediri uit de twaalfde eeuw die het heldendicht Mahabharata voor de Javanen toegankelijk gemaakt had. Hij zou een toekomst geprofeteerd hebben waarin het volk door rampspoed zou worden getroffen, de vorsten verderfelijke bevelen zouden geven en het land in de macht zou komen van een zeevarend volk van overzee. Maar na verdere rampen en verwikkelingen zou er tenslotte redding komen in de persoon van een 'rechtvaardige vorst', een ratoe adil, die de vijanden zou verdrijven en een rijk van vrede en voorspoed zou vestigen. Deze aan Djojobojo toegeschreven profetie vertoont verwantschap zowel met islamitische heilsverwachtingen als 
met hindoeïstische voorstellingen over een afwisseling van slechte en goede tijden. De profetie werd in allerlei varianten doorgegeven; de kern ervan was steeds de verwachting van de verlossende ratoe adil, een verwachting die nog eeuwen lang zou voortleven.

\section{Achteruitgang van de VOC}

De VOC werd in de achttiende eeuw weliswaar steeds sterker als territoriale macht op Java, maar als handelsonderneming ging zij in diezelfde tijd achteruit omdat de verhouding tussen haar inkomsten en uitgaven zich ongunstig ontwikkelde.

De uitgaven van de VOC stegen in de achttiende eeuw onder meer als gevolg van haar talrijke militaire operaties. Dat waren in de eerste plaats de hierboven al vermelde operaties in Midden- en Oost-Java; daarnaast bood de VOC het hoofd aan grote opstanden in Bantam en op Ceylon en voerde zij jarenlang strijd tot onderwerping van het eiland Madoera en van het deel van Java ten oosten van Pasoeroean ('Java's Oosthoek').

De kostenstijging van de VOC weerspiegelde bovendien de groei van haar personeelsbestand in Azië, van ongeveer vijfentwintigduizend man burgerlijk en militair personeel in 1700 naar ongeveer vijfendertigduizend in 1750 . Deze groei had enerzijds zakelijke gronden, omdat de Compagnie zich steeds intensiever met bestuurswerk ging bezighouden, maar was anderzijds ook te wijten aan voortschrijdende bureaucratisering. Overigens was de salariëring van het Compagniespersoneel uitzonderlijk laag en bestond er geen recht op pensioen. De meeste Compagniesdienaren probeerden er dan ook wat bij te verdienen, bijvoorbeeld door zelf in monopoliewaren zoals opium te handelen. De hoogste VOC-functionarissen vergaarden dikwijls enorme persoonlijke rijkdommen, ten koste van de inheemse bevolking én ten koste van de Compagnie.

Evenals vroeger bij de Portugezen had nu bij de Nederlanders in Azië het oorspronkelijk elan plaats gemaakt voor corruptie en sleur. De boekhouding volgde nog steeds het systeem dat in het begin van de vorige eeuw was opgezet, de zeevaartkundige kennis werd niet vernieuwd, de bewapening van de schepen was verouderd, vestingwerken werden slecht onderhouden.

De wantoestanden bij de Compagnie in Azië verontrustten het VOCbestuur in Nederland zozeer, dat het in 1731 de gouverneur-generaal en enige andere hoge Compagniesdienaren ontsloeg en naar Nederland liet komen. Deze bijna wanhopige poging om orde op zaken te stellen kon het tij echter niet keren. Van de gouverneurs-generaal uit de achttiende eeuw heeft maar één geprobeerd de sleur te doorbreken. Dit was Gustaaf van Imhoff, die in 1743 benoemd werd en die de Heren Zeventien al eerder voorstellen gedaan 
had om het verval tegen te gaan. Hij voerde in Batavia allerlei vernieuwingen in, bevorderde de uitgave van een krant (die prompt door het Nederlandse VOC-bestuur verboden werd), reisde door het land en bezocht de soesoehoenan in zijn kraton. Terwijl hij in 1740 als lid van de Raad van Indië het ongelukkige initiatief genomen had tot deportatie van de werkloze Chinezen, spande hij zich nu in om de positie van de Chinezen te verbeteren. Ten zuiden van Batavia liet hij aan de voet van de bergen het landhuis 'Buitenzorg' bouwen. Na zijn dood in 1750 was dit vrijwel het enige dat van zijn vernieuwingen in stand bleef.

Ook de belangstelling voor wetenschappelijk onderzoek ging in de achttiende eeuw achteruit, maar het eind van de eeuw bracht hier een kentering. In 1778 werd het Bataviaasch Genootschap van Kunsten en Letteren opgericht, dat zich onder meer ten doel stelde de studie van de geschiedenis en de gebruiken van de inheemse volkeren te bevorderen.

De achteruitgang van de Compagnie als handelsonderneming had verschillende facetten. In de eerste plaats waren de opbrengsten van de Aziatische handel al sinds het eind van de zeventiende eeuw niet meer voldoende om de apparaatskosten van de VOC in Azië volledig te dekken. Niet alleen stegen die kosten, maar ook ging de rentabiliteit van deze handel zelf achteruit. Verarming van de bevolking op Java bijvoorbeeld bemoeilijkte daar de afzet van Indiase textiel. Het Aziatisch handelsrijk van de Compagnie werd kleiner. Zij sloot haar kantoren in Arabië, Perzië, Siam en Tonkin. Het kantoor in Japan bleef gehandhaafd, maar werd een verliespost. In India verloor de VOC in de achttiende eeuw haar dominerende positie, toen enige belangrijke delen van dat land in de macht kwamen van de Britse en de Franse compagnie, die overigens ook elkaar bestreden. Daar stond tegenover dat de VOC nu eindelijk toestemming kreeg om op China te varen; in 1749 kon zij daar in Kanton een eigen handelspost openen.

Intussen ontleende de VOC haar inkomen in Azië niet alleen aan de Aziatische handel. Omdat zij zich op Java tot een territoriale macht ontwikkelde, werden hier ook andere inkomstenbronnen belangrijk, zoals belastingen en tolheffingen. Bovendien genoot zij onzichtbare inkomsten doordat zij veelvuldig gebruik maakte van 'herendiensten', onbetaalde arbeid van de inheemse bevolking, onder meer voor de aanleg van versterkingen en wegen. De inning van belastingen werd vaak aan Chinezen verpacht. Ook verhuurde de Compagnie soms in de kustgebieden, naar het voorbeeld van de Javaanse regenten, hele dorpen aan Chinese ondernemers, waarbij de bevolking dan verplicht was voor die huurders herendiensten te verrichten. Maar ondanks deze uitbreiding van de inkomstenbronnen van de VOC konden haar ontvangsten in Azië de uitgaven niet bijhouden.

Gedurende de achttiende eeuw bleef de VOC grote hoeveelheden Aziatische waren in Europa importeren, naast specerijen en textiel nu vooral koffie en 
thee. De opbrengst van de verkopen in Europa diende ten dele om de tekorten op de Aziatische begroting te dekken. Maar terwijl de hoeveelheden groot bleven, werden de winstmarges bij verkoop steeds kleiner. Men kon bijvoorbeeld de prijs van kruidnagelen en muskaatnoten niet meer kunstmatig hoog houden, omdat die nu ook in Britse en Franse gebieden geproduceerd werden. Herhaaldelijk eindigde een bedrijfsjaar met verlies voor de VOC als geheel. Het bestuur hield dit geheim om het vertrouwen van de aandeelhouders niet te verliezen. Het ging door met het uitkeren van forse dividenden; eerst sprak het daartoe de reserves aan en vervolgens sloot het zelfs leningen.

De Staten-Generaal maakten zich zorgen over de VOC en gaven daar van tijd tot tijd blijk van wanneer verlenging van het octrooi aan de orde kwam. Om meer greep op de gang van zaken te krijgen benoemden ze in 1749 prins Willem IV, sinds kort stadhouder van alle provincies, tot opperbewindhebber van de VOC. Hij kreeg onder meer het recht belangrijke benoemingen te doen op voordracht van de Heren Zeventien.

\section{Einde van de VOC}

Omstreeks 1780 had de VOC in Indonesië vrijwel geen bedreigingen uit de archipel zelf meer te duchten. $\mathrm{Zij}$ had intussen ook een eind gemaakt aan het hindoeïstische rijkje Balambangan in Java's Oosthoek, zodat Java en Madoera nu volledig aan haar macht onderworpen waren. De inheemse vorsten en regenten waren ingeschakeld bij het bestuur over de bevolking en bij de levering van de door de Compagnie verlangde producten en hadden persoonlijk belang bij handhaving van die rol. Aldus was de VOC in staat met een paar duizend Nederlanders een volk van miljoenen te overheersen. De bevolking van Oost-Java begon weer te groeien nu zij niet meer door oorlogvoering geteisterd werd. Ook de bevolking van Priangan nam toe, ondanks de druk van de gedwongen koffieteelt. Met de eilanden ten oosten van Java bemoeide de VOC zich nauwelijks. Bali en Lombok waren geheel onafhankelijk; op WestTimor had de VOC een steunpunt; op Flores en Oost-Timor bevonden zich nog Portugese vestigingen. In de Molukken was de Compagnie oppermachtig; nog steeds ondernam zij daar de jaarlijkse hongi-tochten. Op Celebes had zij twee steunpunten, Makassar en Menado; verder had zij verdragsbanden met een aantal vorstendommen op het eiland. Op Borneo stelden de sultanaten Bandjermasin in het zuiden en Pontianak in het westen zich juist in deze tijd onder gezag van de VOC. Op Sumatra bezat de Compagnie het Lamponggebied aan de zuidpunt en het gebied van Padang aan de westkust, terwijl zij een vestiging had in het sultanaat Palembang aan de oostkust en ook de aan Palembang onderhorige eilanden Bangka en Biliton beheerste. Het sultanaat Atjeh was intussen als gevolg van een reeks opstanden en opvolgingsoorlogen 


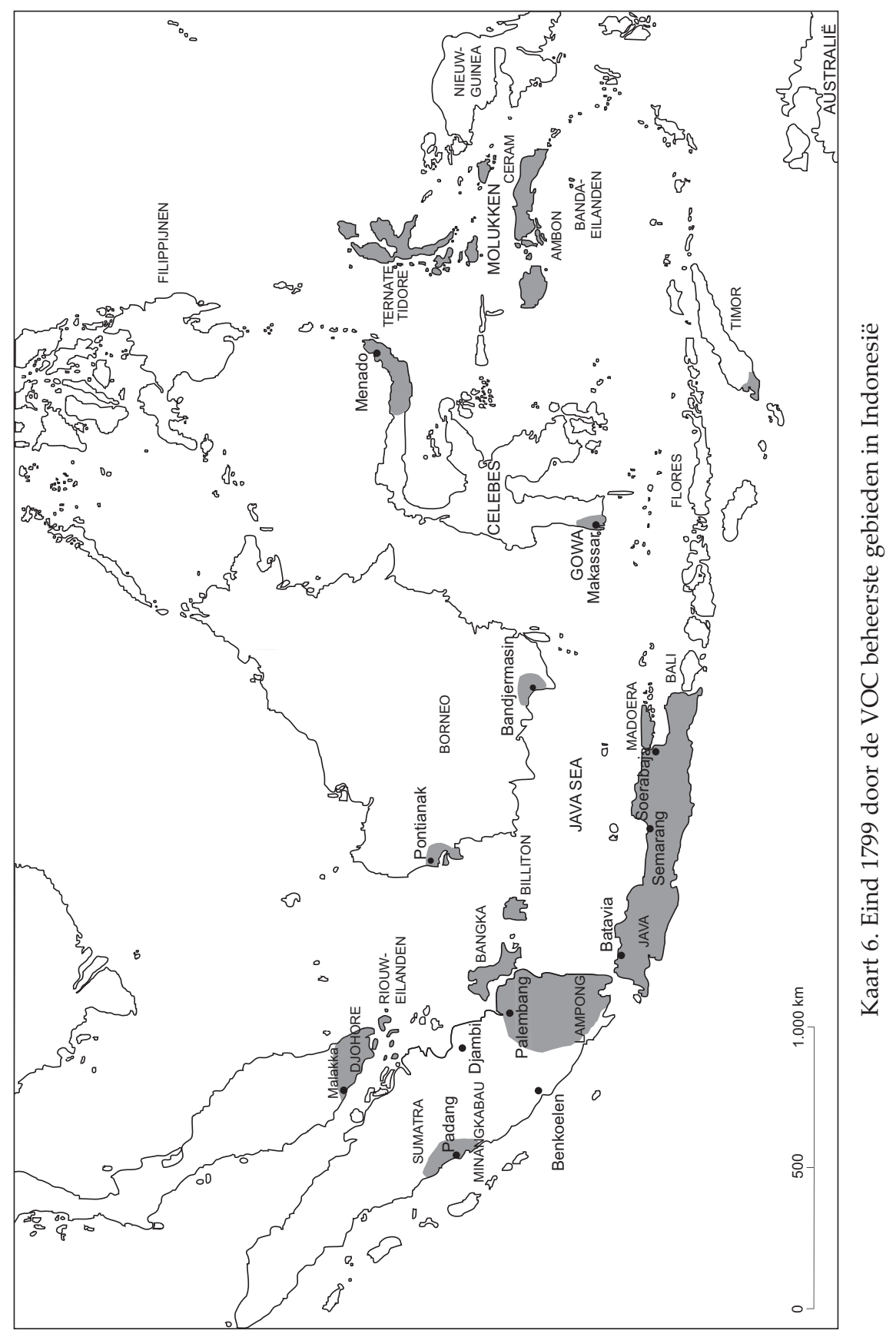


uiteengevallen, al bleef de sultan in naam aan het hoofd staan.

Het enige Indonesische volk waarmee de VOC in deze tijd nog gewapende conflicten had was dat van de Boeginezen; niet in hun stamland Zuid-Celebes maar in het westen van de archipel. Zij beheersten onder meer de Riouweilanden en bedreigden de stad Malakka; in West-Borneo hadden zij een avonturier van Arabische afkomst geholpen bij de stichting van het sultanaat Pontianak; in Zuid-Borneo vielen zij Bandjermasin aan.

Inmiddels waren de Britten in India oppermachtig geworden door een definitieve overwinning op de Fransen. De VOC-posities in India en op Ceylon konden alleen nog gehandhaafd blijven voorzover ze door de EIC werden geduld. Bij een conflict in Bengalen was al gebleken dat de bewapende koopvaardijschepen van de VOC niet opgewassen waren tegen de Britse oorlogsschepen.

Aanvankelijk ontzag Groot-Brittannië de VOC, omdat het Nederland als een bondgenoot tegen Frankrijk beschouwde. In 1780 verklaarde het echter de oorlog aan de Republiek teneinde haar te beletten de voormalige Britse koloniën in Noord-Amerika te steunen die zich in 1776 onafhankelijk verklaard hadden. In Azië bezette de EIC nu enkele posten van de VOC, waaronder Padang. Ernstiger was dat zij het scheepvaartverkeer tussen Batavia en Nederland blokkeerde. In 1783 kwam er een wapenstilstand; in 1784 werd vrede gesloten. De VOC moest haar belangrijkste steunpunt in India opgeven, maar kreeg Padang terug; verder moest zij de Britten vrije vaart toestaan in de Indonesische archipel.

Deze Brits-Nederlandse oorlog gaf de Compagnie een klap waarvan zij zich niet meer hersteld heeft. Terwijl ze haar schuldenlast in de voorafgaande jaren juist had kunnen verkleinen, miste zij door de Britse blokkade drie jaar lang haar handelsinkomsten. Zij staakte nu de betaling van dividend en vroeg financiële steun aan de Staten-Generaal. Bovendien kreeg zij als gevolg van de oorlog een forse nieuwe schuld aan de Nederlandse staat. In 1783 had de Republiek namelijk een eskader van de Nederlandse marine naar Azië gestuurd, dat daar te laat aankwam voor de strijd tegen de Britten maar wel meehielp om de Boeginezen uit de Riouw-archipel te verdrijven. De Republiek bracht de kosten van dit eskader aan de Compagnie in rekening.

De Staten-Generaal vonden verdere financiële steun aan de VOC alleen verantwoord als ingrijpende veranderingen zouden worden doorgevoerd. Over de inhoud van die veranderingen kon men het echter niet eens worden als gevolg van de toen in de Republiek heersende politieke verdeeldheid. Tenslotte benoemde het VOC-bestuur zelf een commissie-generaal om het handels- en bestuurssysteem te reorganiseren. De voorzitter van die commissie, S.C. Nederburgh, nam in 1793 in Batavia het heft in handen en hield alle echte vernieuwing krachtdadig tegen. 
Externe factoren droegen ertoe bij dat toch over het lot van de Compagnie beslist werd. Enige jaren na de Franse Revolutie van 1789 raakte GrootBrittannië in oorlog met het revolutionaire Frankrijk. Onder invloed van de stadhouder prins Willem V sloot de Republiek zich daarbij aan. Maar in 1795 trok een Frans leger Nederland binnen, samen met een contingent Nederlandse revolutionairen, het Bataafs Legioen onder commando van Herman Willem Daendels. Willem V week naar Engeland uit en er kwam nu een eind aan de Republiek der Verenigde Nederlanden. Haar opvolgster, de Bataafse Republiek (de eerste Nederlandse eenheidsstaat), wilde de VOC niet langer als zelfstandige onderneming handhaven. Al in maart 1796 nam een door de regering ingesteld comité het bestuur van de Compagnie over. Vervolgens verlengde men het octrooi van de VOC nog één keer, tot eind 1799, en besloot men dat al haar activa en passiva zouden overgaan op de Nederlandse staat. Het personeel van de VOC overzee, onder wie de gouverneur-generaal, kwam in staatsdienst; de commissie-generaal werd ontbonden. Voorlopig zouden de Aziatische bezittingen nog worden beheerd volgens de inhoud van het laatste octrooi, totdat dit zou zijn vervangen door een nieuw 'Charter'.

Overigens was de feitelijke situatie overzee intussen ingrijpend gewijzigd. Omdat de Bataafse Republiek een Franse vazalstaat was, verkeerde zij van begin af aan in oorlog met Groot-Brittannië. Vanuit Engeland had Willem V als opperbewindhebber van de VOC aan al haar vestigingen opdracht gegeven zich tijdelijk onder Britse bescherming te stellen. In 1795 en 1796 werden de meeste VOC-vestigingen buiten Java door de EIC bezet. Op 31 december 1799 beschikte de VOC behalve over Java nog alleen over haar steunpunten in Palembang, Bandjermasin, Madoera, Makassar, Ternate en West-Timor en over haar handelskantoren in China en Japan.

Ondanks alle verdeeldheid in de laatste decennia van de achttiende eeuw over de vraag wat er met de VOC zou moeten gebeuren, is nooit gesproken over de mogelijkheid om de Nederlandse presentie in Azië eenvoudig op te geven. De overtuiging dat de Aziatische bezittingen onmisbaar voor de Nederlandse welvaart waren bleek onwrikbaar, ook al was de Compagnie in feite failliet. Haar schulden ten tijde van haar opheffing bedroegen 134 miljoen gulden.

\section{Aantekeningen bij hoofdstuk II}

\section{Literatuuroverzicht}

Van de literatuur over de geschiedenis van Indonesië gaat een groot deel over de koloniale tijd, het tijdvak van ruim drie eeuwen waarin Nederlanders zich in de Indonesische archipel vestigden en die bijna volledig onder hun macht brachten. Uiteraard wordt dit tijdvak behandeld in de al bij het vorige hoofdstuk vermelde 


\section{$\mathrm{O} U \mathrm{D}$ en $\mathrm{N}$ I E U W \\ OOST-INDIËN}

VER V A T T E N D E

Een Naukeurige en Uitvoerige Verbandelinge vin

NEDERLANDS MOGENTHEYD

\section{G E W E $S$ T E N,}

B E N E V E N S

Eenewydluftige Befchryvinge der MOLUCCOS, AMBOINA, BANDA, TIMOR, en SOLOK, JAVA, en alle de Eylanden onder dezelve Landbeftieringen behoorende; het Nederlands Comptoir op SURATTE, en de LEVENS DER GROOTE MOGOLS;

\section{$A L S$ OOK}

Een Keurlyke Verhandeling van 't wezentlykifte, dat men behoort te weten van CHOROMANDEL, PEGU, ARRACAN, BENGALE, MOCHA, PERSIEN, MALACCA, SUMATRA, CEYLON, MALABAR, CELEBES Of MACASSAR, CHINA, JAPAN, TAYOUAN OF FORMOSA, TONKIN, CAMBODIA, SIAM, BORNEO, BALI, KAAP DER GÓEDE HOOP' en va MAURITIUS.

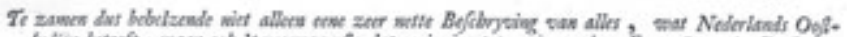

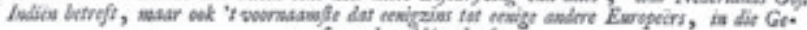
weflow, betribling bef/.

Met meer dan thien honderd en ryftig Prentverbeeldingen verrykt.

Alles zeer nankeurig, in oprigt van de Lasden, Steden, Sterkten, Zoden der Volken, Booenes, Gewaftchen, Lasd-en Zec-dieren, met alle het Wereldlyke en Kerkelyke, van d'Oudfte tyden af tot nu toe aldar voorgevallen, befchrevea, en met veele zeer pette dar toe vercyichte Kurten opgeheldert

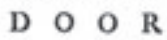

\section{FRA NÇOIS VALEN T Y N,}

Onlangs Bedicwaer des Gaddebkes Woords in Asmorisa, BANDa, eñ. I N V Y F D E E L E N.

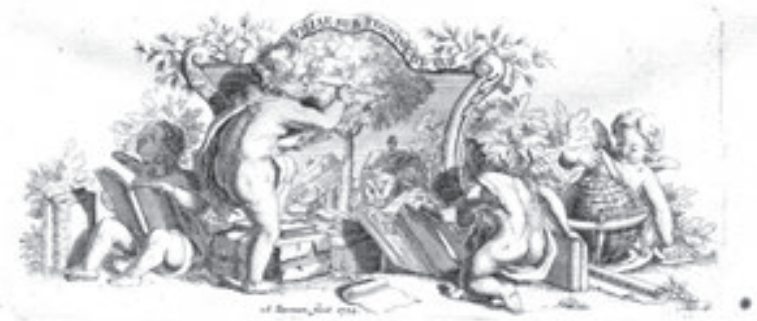

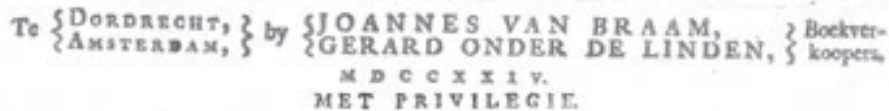

François Valentyn (1666-1727), die de VOC vele jaren als predikant had gediend, schreef na terugkeer in Nederland het standaardwerk Oud en Nieuw Oost-Indiën waarin hij alle vestigingen van de VOC behandelde. Het werk verscheen in 1724-26 in vijf delen met meer dan duizend afbeeldingen en kaarten. 
algemene werken, zoals de in 1938-1940 in vijf delen gepubliceerde Geschiedenis van Nederlandsch-Indië onder redactie van F.W. Stapel. Over het koloniale tijdvak was in 1925-1926 een meer specifiek overzicht in drie delen verschenen van de hand van H.T. Colenbrander: Koloniale geschiedenis. Dit werk bestreek enerzijds veel meer omdat het ook de koloniën van andere landen behandelde en ook de Nederlandse koloniën in Afrika en Amerika, anderzijds veel minder omdat het de koloniale geschiedenis van Indonesië beknopter en de prekoloniale geschiedenis in het geheel niet weergaf.

De koloniale geschiedenis van Indonesië valt ruwweg in twee periodes uiteen: die van de zeventiende en de achttiende eeuw, waarin de Verenigde Oost-Indische Compagnie zich in de Indonesische archipel vestigde, en die van de negentiende en een deel van de twintigste eeuw, waarin deze archipel grotendeels een kolonie van de Nederlandse staat vormde. De eerste periode is het onderwerp van dit hoofdstuk. Deze periode is al vroeg het voorwerp van belangrijke bronnenpublicaties geweest. Onder redactie van J.K.J. de Jonge begon in 1862 een publicatie van archiefstukken onder de titel De opkomst van het Nederlandsch gezag in Oost-Indië. Voortgezet onder redactie van M.L. van Deventer werd dit uiteindelijk een serie van tien delen die het tijdvak 1595-1811 bestreken. Vervolgens begon in 1907 onder redactie van J.R. Heeres een publicatie van in Azië gesloten verdragen onder de titel Corpus diplomaticum Neerlando-Indicum. Voortgezet onder redactie van F.W. Stapel werden dit uiteindelijk zes delen die het tijdvak 1596-1799 bestreken. Daarnaast bestaan er nog verscheidene andere seriepublicaties van documenten uit de archieven van de VOC.

De eerste geschiedwerken over de VOC zijn al tijdens het VOC-tijdperk geschreven. De belangrijkste hiervan zijn Beschryvinge van de Oostindische Compagnie door Pieter van Dam (zeven delen, voltooid in 1701) en Oud en nieuw Oost-Indiën door François Valentyn (vijf delen, gepubliceerd in 1724-1726).

Ook nadat Indonesië onafhankelijk geworden was, bleven Nederlandse en andere historici zich met de koloniale geschiedenis bezighouden. Zo verscheen in 1965 The Dutch seaborne empire van de Britse historicus C.R. Boxer. In 1982 publiceerde F.S. Gaastra De geschiedenis van de VOC (later in een uitgebreide versie herdrukt). Van de hand van J. van Goor verscheen in 1994 De Nederlandse koloniën; Geschiedenis van de Nederlandse expansie 1600-1975. In 1998 zag een nog ambitieuzer werk het licht: De waaier van het fortuin; Van handelscompagnie tot koloniaal imperium; De Nederlanders in Azië en de Indonesische archipel 1595-1950 door J.J.P. de Jong. De genoemde werken van Gaastra en J.J.P. de Jong gaan ook uitvoerig in op de economische aspecten (die in dit boek slechts summier aan de orde komen). In 2002 werd in Nederland herdacht dat vier eeuwen eerder de VOC opgericht was. Dit leidde ook tot verschillende publicaties, waaronder de bundel De Verenigde Oost-Indische Compagnie tussen oorlog en diplomatie onder redactie van Gerrit Knaap en Ger Teitler.

Evenals het vorige hoofdstuk is ook dit hoofdstuk in hoofdzaak gebaseerd op de daar al genoemde werken van De Graaf, Stapel en Vlekke. Hieronder volgen enige aanvullende opmerkingen en verwijzingen bij sommige paragrafen.

Oprichting van de Verenigde Oost-Indische Compagnie

Voor het door de Staten-Generaal aan de VOC gegeven octrooi zie Valentyn 2002, I:186-91. Artikel xxxv van dit octrooi bevat de machtiging tot uitoefening van overheidsfuncties. 
Nederlaag van de Britten; stichting van Batavia

Zoals blijkt uit Mijer 1848:14-5 heeft het VOC-bestuur al in 1609 opdracht gegeven aan gouverneur-generaal Both om te proberen in Djakarta een centraal rendez-vous te stichten dat geheel onder gezag van de Compagnie zou staan.

Over de herkomst en de betekenis van de naam Batavia bestaat veel verwarring. Zo vindt men in de literatuur soms dat die naam van Coen afkomstig was en soms dat de naam door een commandant van het VOC-fort bij Djakarta bedacht was. In werkelijkheid voerde die commandant slechts een besluit van het VOC-bestuur uit, terwijl Coen het hiermee oneens was en jarenlang weigerde de naam Batavia te gebruiken. Verder menen sommigen dat die naam naar het gewest Holland verwees.

De naam Batavia verwees echter naar een destijds in de Republiek gangbare vergelijking van de Nederlandse opstand tegen Spanje met een opstand uit het jaar 69 van de Bataven (een Germaanse stam die toen in de Rijndelta woonde) tegen de Romeinen. De naam doelde dan ook op het hele gebied van de Republiek (zie De Haan 1922, I:10-1).

Het besluit van de VOC over de naam van haar in Azië te stichten hoofdzetel dateerde al van 1617. De Heren Zeventien hadden in oktober van dat jaar tijdens een vergadering in Middelburg besloten dat het centrale rendez-vous Batavia zou moeten heten (zie De Jonge 1862-1909, IV:cxxxvii, noot 2).

Tijdens de belegering van het VOC-fort bij Djakarta gaf de leiding van het fort (in afwezigheid van Coen) uitvoering hieraan door dit fort op 12 maart 1619 de naam Batavia te geven. Tegelijk gaf zij aan de vier versterkte hoeken ervan de volgende namen: West-Vriesland, Geldria, Zeelandia en Hollandia (zie Valentyn 2002: deel IV, boek zes 'Batavia's grondvesting').

Dat de naam Batavia naar niets meer of minder dan Nederland zelf verwees, lijkt volledig in het vergeetboek te zijn geraakt. Mij is behalve Vlekke (1947:151) geen enkel sinds 1945 verschenen werk bekend dat hiervan rept.

De doelstellingen van de VOC

Vergelijk J.J.P. de Jong 1998:49-52.

Ontvolking van de Banda-eilanden

Vergelijk Van der Chijs 1886. Zie voor de destijds in Nederland geuite kritiek ook Vlekke 1947:153-5 en Vanvugt 1996:30-2.

Onderwerping van de Molukken

Zie Verwijnen 1902, Rumphius 1910 en Knaap 1987:25-34.

Het handelsrijk van de VOC

Vergelijk J.J.P. de Jong 1998:87-92. Over de opiumhandel zie Vanvugt 1985:53-99.

Het bestuursstelsel van de VOC

Zie 'Contracten met zelfbesturende landschappen' in Encyclopaedie 1917:525-6, Kleintjes 1903:1-9, Van Kan 1942 en Somers 2001.

Indonesie als studieterrein en thuisland voor Compagniesdienaren

Vergelijk J.J.P. de Jong 1998:109-10, 118-20.

Over Rumphius zie Ballintijn 1944 en Buijze 2006. 
Invoering van de koffieteelt op Java

Zie Vlekke 1947:221-9 en J.J.P. de Jong 1998:107-14.

Chinees verzet en Chinezenmoord

Zie J.Th. Vermeulen 1938; vergelijk Remmelink 1994:125-7, 134-7. Zie over de positie van de Chinezen Blussé 1986, over de epidemieën in Batavia Van der Brug 1994.

Ondergang van Mataram

Vergelijk Remmelink 1994:137-204 en Nagtegaal 1996.

Ontstaan van de Djojobojo-legende

Zie Wiselius 1872:204-5.

Achteruitgang van de VOC

Zie onder meer Van der Brug 1994 en Dillo 1992. Over het Bataviaasch Genootschap zie Groot 2007.

Einde van de VOC

Zie ook Schutte 1974 en Steur 1984. 


\section{HOOFDSTUK III \\ Indonesië en het Nederlandse koloniale bestuur}

\section{Inleiding en overzicht}

De Nederlandse staat trad in 1800 in de plaats van de Verenigde OostIndische Compagnie en verwierf daarmee de heerschappij over een koloniaal rijk. Twaalf jaar later bestond die heerschappij alleen nog in theorie, want Nederland was bij Frankrijk ingelijfd en al het vroegere grondgebied van de VOC was onder Brits bestuur gekomen. Na het herstel van de Nederlandse onafhankelijkheid gaf Groot-Brittannië dit grondgebied niet volledig terug, maar behield het de vroegere VOC-vestigingen in Zuid-Afrika, India, Ceylon en Malakka. Voortaan bezat Nederland in Azië uitsluitend gebieden in de Indonesische archipel (in hoofdzaak Java, de Molukken en steunpunten op Sumatra, Borneo en Celebes). Intussen was Nederland geen republiek meer; in 1815 werd het een koninkrijk. Tot het midden van de negentiende eeuw berustte de bepaling van het koloniaal beleid uitsluitend bij de koning. Pas daarna kreeg het Nederlandse parlement zeggenschap over dit beleid.

$\mathrm{Na}$ het vertrek van de Britten begon Nederland met de herinrichting van het koloniale bestel. Voortbouwend op het stelsel van de VOC schiep het een bestuursorganisatie (het Binnenlands Bestuur) die het mogelijk maakte met een klein aantal Nederlandse ambtenaren over miljoenen Indonesiërs te heersen. Door de overname van de VOC waren die Indonesiërs nu onderdanen geworden waarvoor de Nederlandse staat verantwoordelijkheid droeg. Lange tijd echter was het de voornaamste zorg van het koloniaal beleid, hoe men de kolonie renderend kon maken ten bate van het Nederlandse 'moederland'. De uitgaven van de koloniale overheid in Indië bedroegen namelijk jarenlang meer dan de inkomsten. Wat Java betreft hoopte men aanvankelijk een positief rendement te verkrijgen door een belasting op het grondgebruik (de 'landrente'). In 1830 begon men met de invoering van een nieuw systeem, waarbij de inheemse boeren verplicht werden op een deel van hun grond bepaalde exportproducten te verbouwen en die aan de koloniale overheid te leveren (het Cultuurstelsel). Dit maakte het mogelijk jaarlijks een saldo (het 
'batig slot') van de koloniale begroting naar de Nederlandse schatkist over te boeken.

Omstreeks 1870 begon een nieuwe fase in de ontwikkeling van de kolonie. De overheid trok zich uit de landbouwproductie terug; de exploitatie van de op export gerichte landbouw en mijnbouw kwam in handen van westerse ondernemingen. Nederlands-Indië ontwikkelde zich tot de grootste leverancier van tropische producten op de wereldmarkt. De export leverde het moederland aanzienlijke rendementen, maar die vonden hun weerslag nu niet meer in saldo's op de staatsbegroting maar in winstcijfers van particuliere ondernemingen.

In de loop van de negentiende eeuw groeide onder het Nederlandse publiek de overtuiging, dat de hele Indische archipel aan Nederland toekwam (behalve enkele stukken onder Brits of Portugees gezag). Het duurde echter nog tot het begin van de twintigste eeuw voordat dit gebied geheel onder Nederlandse heerschappij was gebracht. In een aantal gevallen maakte Nederland daarbij gebruik van militair geweld. Ook kwam het koloniale leger veelvuldig in actie om een eind te maken aan opstanden tegen het Nederlandse gezag.

In het begin van de twintigste eeuw begon men van Nederlandse kant meer aandacht te geven aan Nederland's verantwoordelijkheid voor de inheemse bevolking van de kolonie. 'Ethische politiek' werd nu een term voor koloniaal beleid dat geacht werd het belang van die bevolking te dienen. Ook breidde men het koloniale staatsbestel uit met enige vertegenwoordigende lichamen. Nog steeds echter werd het koloniaal beleid uiteindelijk in Nederland bepaald. Nederlands-Indië was en bleef een autocratisch bestuurd land, waarin de inheemse bevolking in tal van opzichten gediscrimineerd werd en waarin veel van de in Nederland geldende rechtswaarborgen ontbraken.

Dit hoofdstuk betreft Indonesië en het koloniale bestuur, maar is daarin niet volledig. Wat de politieke gebeurtenissen betreft, ligt de nadruk op die van de negentiende eeuw. Het gaat daarbij vooral om de ontwikkeling van het koloniaal beleid en om de uitbreiding van de Nederlandse heerschappij over de Indonesische archipel. Het overzicht hiervan is vervat in het eerste deel van dit hoofdstuk. Vervolgens worden in het tweede deel enige kenmerken van het koloniale bestel besproken met betrekking tot het hele tijdvak waarin de kolonie bestond. Daarentegen zullen de voornaamste politieke gebeurtenissen uit de twintigste eeuw, tot aan de verovering van Java door Japan, niet in dit maar in het volgende hoofdstuk worden behandeld wegens hun nauwe samenhang met de ontwikkeling van de Indonesische nationale beweging. 
Eerste deel: Geschiedenis van de kolonie Nederlands-Indië tot het begin van de twintigste eeuw

\section{Begin van de koloniale verhouding}

Als opvolger van de Verenigde Oost-Indische Compagnie verwierf de Nederlandse staat op 1 januari 1800 een groot koloniaal rijk. Daarbij nam Nederland niet alleen de soevereiniteit over die de VOC over een aantal gebieden had uitgeoefend, maar trad het ook in de rechten die voortvloeiden uit door de VOC gesloten verdragen waardoor tal van andere gebieden aan haar onderhorig waren geworden.

De overname van de VOC door de staat maakte een eind aan de anomalie dat overheidsfuncties als bestuur en rechtspraak overzee werden uitgeoefend door een particuliere onderneming. Aan de andere kant leek deze overname een nieuwe anomalie mee te brengen, namelijk dat de staat zou moeten gaan optreden als handels-, productie- en scheepvaartonderneming. Een verdere consequentie van de overname was, dat de staat verantwoordelijkheid ging dragen voor de inheemse inwoners van de Aziatische bezittingen, want die waren nu onderdanen geworden. Voor 1800 hadden enkele voormannen van de Bataafse Republiek bepleit op die onderdanen de beginselen van de Franse Revolutie 'vrijheid, gelijkheid en broederschap' toe te passen, onder meer door de slavernij af te schaffen. Maar de discussie hierover had toen al tot de slotsom geleid, dat er voorlopig overzee geen sprake zou kunnen zijn van vrijheid en gelijkheid voor de inheemse bevolking, noch van afschaffing van de slavernij. Ook de Franse Republiek was hier in de Franse overzeese gebiedsdelen voor teruggeschrokken.

Overigens was in 1800 alleen een beperkt deel van het vroegere VOCgebied nog in Nederlandse handen, maar in 1802 sloot Groot-Brittannië vrede met Frankrijk en met de Bataafse Republiek en verbond het zich tot overdracht aan Nederland van alle door de Britten bezette voormalige VOC-gebieden behalve Ceylon. Ook konden Nederlandse schepen nu weer naar Java vertrekken. De Nederlandse vrachtschepen waren toen nog nauwelijks sneller dan in het begin van de zeventiende eeuw, maar daarnaast kwamen in deze tijd ook snellere schepen in gebruik, die de afstand tussen Nederland en Indonesië in ongeveer vier maanden konden afleggen.

Eind 1802 droeg de regering een kleine commissie op om een nieuw stelsel voor de Aziatische bezittingen te ontwerpen 'in dier voege, dat aan dezelve de hoogst mogelijke trap van welvaart, aan den koophandel dezer Republiek het meeste nut, en aan 's Lands financiën het meeste voordeel worde aangebracht'. Eén van de leden was de inmiddels uit Batavia teruggekeerde Nederburgh. Een ander lid was Dirk van Hogendorp, die de VOC in Bengalen 
en op Java gediend had, daar met Nederburgh in conflict was geraakt en zelfs door hem gevangen was gezet. Van Hogendorp verwachtte alle heil van het vrije spel der economische krachten en pleitte daarom voor afschaffing van monopolies, van gedwongen leveranties en van herendiensten en voor toekenning van individueel grondbezit aan de inheemse boeren, die dan als vrije ondernemers de meest winstgevende producten op de markt zouden kunnen brengen. Het wegvallen van de overheidsinkomsten uit gedwongen leveranties wilde hij compenseren door een belasting op het grondgebruik, zoals in Bengalen bestond. Van Hogendorp kreeg geen steun voor deze voorstellen en verliet de commissie.

De commissie bracht in 1803 een uitvoerig rapport uit, vergezeld van ontwerpen voor een 'Charter voor de Aziatische bezittingen' en andere regelingen. Belangrijke elementen van het VOC-stelsel werden in deze voorstellen gehandhaafd, zoals de monopolies voor koffie, opium en specerijen, de herendiensten en de gedwongen leveranties. Anderzijds stelde de commissie ook ingrijpende vernieuwingen voor. In het bijzonder zouden de staatsorganen zich moeten beperken tot bestuur, rechtspraak en defensie en zou de handel moeten worden overgedragen aan een nieuw op te richten Aziatische Compagnie. De commissie schonk aandacht aan verbetering van het lot van de inheemse bevolking, maar merkte terloops ook op dat zij tot grondregel van haar werk had aangenomen 'dat (in een zin, die alle ongerechtigheid uitsluit) de Coloniën bestaan voor het Moederland, en niet het Moederland voor de Coloniën'.

De regering nam het Charter grotendeels over, maar kon het voorlopig niet in de Aziatische bezittingen invoeren. In 1803 was de oorlog met GrootBrittannië namelijk opnieuw uitgebroken. De Britten hervatten de bezetting van de teruggegeven gebieden (met uitzondering van de Molukken) en blokkeerden wederom het verkeer tussen Nederland en Indonesië. Het Nederlandse bestuur in Batavia was weer op zichzelf aangewezen.

Dat bestuur bestond nog steeds uit een gouverneur-generaal en een Raad van Indië, maar was sinds 1800 een orgaan van de Nederlandse staat geworden. Het centrale bestuur van de kolonie werd in de negentiende eeuw soms aangeduid als 'hoge regering', soms als 'Indische regering' en soms als 'gouvernement'. In dit boek zal in de regel de laatste term worden gebruikt, ten einde dat centrale koloniale bestuur te onderscheiden enerzijds van de 'hoge regering' uit de VOC-tijd en anderzijds van de Nederlandse regering in Den Haag, bij wie het opperbestuur over de kolonie berustte. 


\section{Java onder Daendels}

In 1806 liet de Franse keizer Napoleon de Bataafse Republiek vervangen door een monarchie, het Koninkrijk Holland, met zijn broer Lodewijk als koning. In de grondwet werd bepaald dat het bestuur van de koloniën uitsluitend aan de koning toekwam. Napoleon vond het nodig Java in staat van verdediging te brengen om het uit handen van de Britten te houden. Daarom benoemde zijn broer de voormalige legercommandant Daendels tot gouverneur-generaal. Incognito reizend wegens de Britse blokkade wist deze op 1 januari 1808 Java te bereiken.

Zijn gebrek aan kennis van het land verhinderde Daendels niet daar een dictatoriaal bewind uit te oefenen. Gebruik makend van volmachten die koning Lodewijk hem verleend had, veranderde hij de Raad van Indië van een besturend orgaan in een adviesorgaan. Hij breidde de krijgsmacht uit van vierduizend tot twintigduizend man (van wie ruim negentig procent Indonesiërs) en liet forten en kustbatterijen bouwen. Eveneens ter verbetering van de defensie liet hij van Straat Soenda tot Java's Oosthoek in één jaar een duizend kilometer lange verbindingsweg aanleggen, de Grote Postweg.

Daendels besloot bovendien, voortbouwend op de voorstellen van 1803, ingrijpende veranderingen aan te brengen in het van de VOC overgenomen bestuursstelsel. De Nederlandse ambtenaren werden meer ondergeschikt gemaakt aan het centrale gezag en onder strenge controle gesteld. Hun salarissen werden verhoogd, maar alle bijverdiensten werden verboden. Ook de inheemse regenten kregen nu de status van ambtenaar; zij ontvingen voortaan salaris van het gouvernement, maar hun bevoegdheden werden beperkt. Verder verplaatste Daendels de zetel van het gouvernement van de oude benedenstad van Batavia naar de hoger gelegen omgeving van het landgoed Weltevreden. Aan de westkant daarvan liet hij een exercitieterrein aanleggen met een oppervlakte van bijna een vierkante kilometer.

Terwijl veel van Daendels' maatregelen van blijvende waarde waren, maakte hij zich zowel bij Indonesiërs als bij Europeanen gehaat. Zijn bewind drukte zwaar op de inheemse bevolking. De geforceerde aanleg van de Postweg met onbetaalde herendiensten kostte veel mensenlevens. Hetzelfde gold voor zijn mislukte poging een marinebasis aan te leggen aan Straat Soenda. Dit laatste leidde tot verzet in Bantam, waarop Daendels daar de kraton liet bestormen en de sultan afzette. Ook raakte hij in conflict met de Midden-Javaanse vorsten. Met een grote troepenmacht trok hij naar Jogjakarta, waar hij de sultan tot afstand dwong ten gunste van diens zoon, en vervolgens naar Soerakarta, waar hij de soesoehoenan een vernederend verdrag oplegde. Daendels' maatregelen joegen de overheidsuitgaven op. Om aan geld te komen voor de gouvernementskas legde hij de Nederlanders heffingen op en liet hij stukken grond, waaronder hele landstreken, aan particulieren verkopen. 
In 1810 werd Nederland bij Frankrijk ingelijfd. Napoleon benoemde een nieuwe gouverneur-generaal; Daendels vertrok in juni 1811 naar Europa.

\section{Brits intermezzo}

De Britse East India Company (EIC) was, anders dan de VOC, niet door de staat overgenomen, maar wel op het eind van de achttiende eeuw zodanig onder staatstoezicht gesteld dat zij eigenlijk een semi-overheidsbedrijf vormde. Toen Napoleon in 1810 Nederland bij Frankrijk inlijfde, vond de Britse regering dat de EIC het eiland Java moest uitschakelen als potentiële Franse bedreiging voor de Britse positie in Azië. De Molukken waren intussen al in Britse handen overgegaan.

De EIC stond overzee onder bewind van een gouverneur-generaal met zetel in Calcutta. Bij de voorbereiding van de expeditie tegen Java schakelde deze een jonge functionaris in, Thomas Stamford Raffles, die goed Maleis kende en veel contacten in de archipel had. Raffles probeerde onder meer de sultan van Palembang en de Javaanse vorsten over te halen de kant van de Britten te kiezen.

De EIC zond een troepenmacht van twaalfduizend man naar Java, die in augustus 1811 aan land ging. De door Daendels beoogde versterking van de defensie bleek een mislukking. Zijn opvolger moest na zes weken capituleren, onder meer omdat de inheemse militairen hem te weinig steunden. Raffles werd aangesteld als luitenant-gouverneur van de voormalige Nederlandse koloniën in de archipel, met uitzondering van de Molukken en Sumatra's westkust.

Raffles meende een veel beter bestuurder te zijn dan zijn Nederlandse voorgangers, vooral voor de inheemse bevolking. In feite echter lagen veel van zijn maatregelen op het gebied van rechtspraak en bestuur in het verlengde van die van Daendels. Ook liet hij evenals deze op grote schaal grond aan particulieren verkopen.

Verder trad hij tegen de inheemse vorsten niet minder radicaal op dan Daendels. Omdat de sultan van Palembang de Nederlanders in zijn gebied had laten doden en zich vervolgens onafhankelijk had verklaard, stuurde Raffles daar een strafexpeditie heen en benoemde hij een nieuwe sultan. De gewesten Bantam en Tjirebon plaatste hij onder rechtstreeks bestuur, zodat nu op Java alleen de Midden-Javaanse vorstenlanden nog buiten het rechtstreeks bestuurde gebied vielen. Evenals Daendels trok hij met een troepenmacht naar Jogjakarta en Soerakarta om deze landen in het gareel te brengen. Daarbij liet hij de kraton van de sultan plunderen, verkleinde hij het grondgebied van de vorstenlanden en wees hij een stuk van het sultanaat toe aan een nieuwe vorst met de titel van pakoe alam en met zetel in Jogjakarta. Ook in andere gebie- 
den werd verzet tegen het Britse gezag met harde hand gebroken. Alleen op Zuid-Celebes konden de Britten een guerrilla van de Boeginezen niet de baas worden.

Raffles' belangrijkste vernieuwing was de invoering van een belasting op het grondgebruik, die in de plaats moest komen van de gedwongen leveranties en de herendiensten. Ter rechtvaardiging van het nieuwe stelsel werd uitgegaan van de theorie dat alle grond op Java in eigendom aan de vorsten had toebehoord. Daarom zou de grond in de rechtstreeks bestuurde gebieden nu eigendom van het gouvernement zijn en zou dit pacht mogen heffen van de bebouwers van het land. Naar het Engelse woord voor pacht werd de nieuwe heffing 'landrente' genoemd. Deze bedroeg, afhankelijk van de vruchtbaarheid van de grond, een kwart tot de helft van de opbrengst, af te dragen in geld of rijst. Eind 1813 begon de invoering van het nieuwe stelsel. De aanslagen werden per dorp vastgesteld, hoewel die eigenlijk aan de individuele landbouwers opgelegd hadden moeten worden. In het grootste deel van Java behoorde de bouwgrond trouwens niet aan individuen toe maar aan de dorpsgemeenschap. Verder werd het stelsel niet ingevoerd in de productiegebieden van koffie en teakhout; daar bleven de bestaande plant- en leverplichten gehandhaafd. Van de beoogde totale afschaffing van de herendiensten moest worden afgezien.

Raffles was duidelijker dan Daendels door de ideeën van de Verlichting beïnvloed. Dank zij hem werd foltering afgeschaft als middel van strafrechtelijk onderzoek en werd slavenhandel in de hele archipel verboden. Bovendien probeerde hij de slavernij zelf tegen te gaan (ook de Nederlanders op Java beschikten toen nog algemeen over slaven als huishoudelijk personeel). Verder keerde hij zich tegen het gebruik van opium. Hij stimuleerde het wetenschappelijk onderzoek en werd zelf voorzitter van het Bataviaasch Genootschap van Kunsten en Letteren. Hij leerde Javaans en verwierf een uitgebreide kennis over land en volk van Java, op basis waarvan hij later een groot werk publiceerde, History of Java.

Na de val van Napoleon besloot Groot-Brittannië de Nederlandse koloniën terug te geven, met uitzondering van de Kaapkolonie, Ceylon en Negapatnam (de belangrijkste Nederlandse vestiging in India). Medio 1814 sloot het hierover een verdrag met Nederland. Raffles, voor wie dit een grote teleurstelling was, werd begin 1816 teruggeroepen. Voor de East India Company was de bezetting van Java een schadepost; zij heeft er meer geld aan moeten uitgeven dan zij daar verdiend heeft. 


\section{Herinrichting van het Nederlandse koloniale bestel}

Toen Nederland tegen het eind van 1813 weer onafhankelijk geworden was, wilde men daar de federale Republiek van voor 1795 niet meer terug, maar koos men voor een eenheidsstaat onder een erfelijke monarch. Tegelijk hechtten Groot-Brittannië en andere Europese mogendheden waarde aan het scheppen van een sterke staat ten noorden van Frankrijk. Daarom werden de zuidelijke Nederlanden, die sinds de zestiende eeuw achtereenvolgens onder Spaans, Oostenrijks en Frans bestuur gestaan hadden, in 1815 met de noordelijke gewesten verenigd. Zo ontstond het Koninkrijk der Nederlanden, onder koning Willem I, zoon van de vroegere stadhouder prins Willem V. Het parlement van deze staat ging Staten-Generaal heten, maar was een heel ander orgaan dan het gelijknamige college dat vroeger de Republiek bestuurde.

Evenals de grondwet van 1806 bepaalde de grondwet van het nieuwe koninkrijk, dat de koning bij uitsluiting het opperbestuur over de koloniën had. Hij was daarover geen verantwoording aan de Staten-Generaal verschuldigd. Het Brits-Nederlandse verdrag van 1814 liet hem eveneens de vrije hand in de koloniën, maar verplichtte hem wel tot bestrijding van de slavenhandel.

Eind 1815 zond de koning een commissie-generaal van drie leden naar Batavia om de Aziatische koloniën van de East India Company over te nemen en het nieuwe Nederlandse bestuur te organiseren. Eén van de leden was de nieuw-benoemde gouverneur-generaal Van der Capellen. De commissiegeneraal werd vergezeld door een aantal ambtenaren en door 1800 militairen. Verder kreeg zij een voorlopig regeringsreglement mee, grotendeels ontleend aan het ontwerp-Charter van 1803. Zij was gemachtigd namens de koning de definitieve tekst vast te stellen.

Pas in augustus 1816, ruim drie maanden na aankomst van de commissiegeneraal, droegen de Britten het bestuur over Java aan haar over. In andere gebieden traineerden zij de bestuursoverdracht nog langer: de Molukken werden in 1817 overgedragen, de voormalige VOC-vestigingen in India en op Malakka in 1818 en die aan Sumatra's westkust in 1819. Biliton werd niet teruggegeven.

De commissie-generaal nam de organisatie van het nieuwe koloniale bestel voortvarend ter hand. In de voorgaande jaren hadden Daendels en Raffles weliswaar besloten tot ingrijpende veranderingen in het bestuurlijke en het economische stelsel, maar met de uitvoering van die veranderingen was pas een eerste begin gemaakt. De commissie-generaal handhaafde in grote lijn de door hen ondernomen nieuwe inrichting van het bestuur op regionaal niveau, maar breidde het Nederlandse ambtenarenkorps uit (zie hierover verder de volgende paragraaf). Wat het gouvernement betreft, kreeg de Raad van Indië weer een medebesturende rol, maar de gouverneur-generaal zou onder bepaalde voorwaarden van de mening van de meerderheid mogen afwijken. 
De commissie-generaal stelde een onderzoek in naar de werking van het landrentestelsel en besloot met dit stelsel door te gaan, maar bepaalde verbeteringen in de uitvoering aan te brengen. Zij handhaafde de van de VOC stammende monopolies en plant- en leverplichten voor koffie en specerijen, maar wilde onderzocht zien of die voor de specerijen niet konden worden opgeheven. Zij maakte een eind aan de door de VOC ingestelde beperkingen op de vrijheid van scheepvaart en van handel, behalve in de Molukken. Alle ingezetenen zouden vrijheid van bedrijf genieten. Verder maakte de commissie-generaal onder meer plannen voor verbetering van het onderwijs. Daarbij dacht zij niet alleen aan Nederlands onderwijs voor kinderen van Europese afkomst. Zij wilde dat het gouvernement ook inheemsen tot de Nederlandse scholen zou toelaten en dat het anderzijds onder de Europeanen de kennis van inheemse talen zoals Javaans en Maleis zou bevorderen.

Eind 1818 stelde de commissie-generaal de definitieve tekst van het regeringsreglement vast. Daarna nam Van der Capellen het bewind over en keerden de twee andere commissieleden naar Nederland terug. Om te onderstrepen dat Java nu een deel van het Koninkrijk der Nederlanden vormde, werd het door Daendels in Batavia aangelegde exercitieterrein Koningsplein gedoopt.

Van der Capellen moest niet alleen het beleid uitvoeren dat de commissiegeneraal had uitgestippeld, maar zag zich ook geplaatst voor twee belangrijke kwesties waarover zij geen beslissing genomen had. Eén daarvan betrof de uitgifte van grond (door verkoop of verpachting) aan Europese en Chinese particulieren voor de vestiging van landbouwondernemingen, waarbij de op die grond wonende boeren dan voor deze ondernemingen zouden moeten werken. Van der Capellen keerde zich hiertegen met het argument, dat zulke gronduitgifte kon leiden tot uitbuiting en onderdrukking van de inheemse bevolking door de niet-inheemse ondernemers. Wat de al bestaande particuliere landerijen betreft, maakte hij in West-Java de exploitatie onmogelijk van een aantal door Raffles uitgegeven gronden. Intussen hadden leden van de vorstenhuizen en de adel in de Midden-Javaanse vorstenlanden al talrijke gronden aan Europese ondernemers verpacht. In 1823 annuleerde Van der Capellen daar alle langdurige verpachtingen. Hiermee dupeerde hij niet alleen de Europese ondernemers maar ook de Javaanse verpachters, die de vooruit betaalde pachtsommen nu terug moesten betalen.

De tweede kwestie betrof het specerijenmonopolie, waarover de commissiegeneraal een onderzoek gevraagd had, onder meer naar aanleiding van gewapend verzet in de Zuid-Molukken tegen de terugkeer van het Nederlandse gezag (zie p. 79). Een door Van der Capellen ingestelde ambtelijke commissie adviseerde hem dit monopoliestelsel af te schaffen, maar daar achtte hij zich niet toe bevoegd. In 1824 bracht hij zelf een bezoek aan het gebied, waarbij hij zich geschokt toonde over de ellende die het door de VOC opgelegde regime hier had aangericht. In een dramatische proclamatie aan de volkeren van de 
Zuid-Molukken verklaarde hij onder meer, dat de beruchte hongi-tochten en de daarmee gepaard gaande vernielingen tot het verleden zouden behoren. Men was voortaan vrij om kruidnagelen en muskaatnoten te verbouwen, maar nog steeds mocht men die alleen aan het gouvernement verkopen. Van der Capellen stelde koning Willem I weliswaar afschaffing van het monopoliestelsel voor, maar zijn voorstel werd niet aanvaard. In feite is het kruidnagelmonopolie tot 1864 gehandhaafd en het muskaatnootmonopolie tot 1873 .

Overigens was de koning teleurgesteld in het beleid van Van der Capellen, omdat de uitgaven van het gouvernement de inkomsten bleven overtreffen. Hij verving hem in 1826 door een nieuwe bestuurder, wiens voornaamste opdracht was op de gouvernementsuitgaven te bezuinigen.

Het door de commissie-generaal gemodelleerde nieuwe koloniale bestel verschilde van het VOC-stelsel onder meer hierin, dat bestuur en handel nu in beginsel gescheiden waren. Toch bleef het gouvernement nog optreden als productieonderneming (wegens de handhaving van de verplichte koffieverbouw) en als handelsonderneming (door de verkoop van monopolieproducten op de vrije markt). Anderzijds hield het gouvernement zich niet bezig met koopvaardij. De export uit Indonesië gebeurde nog jarenlang in hoofdzaak door Britse en Amerikaanse handelsondernemingen. Nederlandse kooplieden konden deze concurrentie nauwelijks aan. De Nederlandse scheepvaart op Azië had van 1795 tot 1815 vrijwel stil gelegen; zowel schepen als maritieme ervaring waren verloren gegaan. Koning Willem I kwam tot de overtuiging dat concentratie van kapitaal nodig was om Nederland weer een overheersende positie te geven in de handel en de scheepvaart op de eigen koloniën. Hiertoe stichtte hij in 1824 een geprivilegieerde onderneming, de Nederlandsche Handel-Maatschappij.

\section{Het Binnenlands Bestuur}

De door Daendels en Raffles begonnen en door de commissie-generaal voltooide nieuwe inrichting van het bestuur is tot het eind van het koloniale tijdperk blijven bestaan. Dit stelsel beoogde de inheemse bevolking zoveel mogelijk door inheemse ambtenaren te laten besturen, die zelf onder toezicht van Nederlandse ambtenaren stonden. Daarom werd het bestuur op regionaal en lager niveau uitgeoefend door twee korpsen van ambtenaren, een 'Europees' korps en een 'Inlands' korps, waarbij het eerste als een netwerk over het tweede heen lag. Tezamen vormden deze twee korpsen het Binnenlands Bestuur. (Overigens plachten velen alleen het Europese korps als Binnenlands Bestuur aan te duiden en het Inlandse korps dan als Inlands Bestuur daarvan te onderscheiden, maar deze terminologie zal in dit boek worden vermeden.)

In zijn uiteindelijke vorm omvatte het Europese korps gouverneurs, resi- 
denten, assistent-residenten, controleurs en adspirant-controleurs. Het ambtsgebied van een resident heette 'residentie'. De meeste residenten stonden niet onder gouverneurs maar waren rechtstreeks ondergeschikt aan het centrale gouvernement. Het Inlandse korps bestond uit regenten, districtshoofden en onderdistrictshoofden. Op Java was aan iedere regent een patih toegevoegd als uitvoerder en plaatsvervanger. Al deze inheemse ambtenaren werden door het gouvernement benoemd uit leden van de traditionele ambtsadel. Het laagste inheemse bestuursniveau bestond uit de dorpshoofden; in de regel werden zij door de bevolking gekozen, maar moest hun verkiezing door de resident worden bekrachtigd. Verder beschikte zowel het Europese als het Inlandse korps over diverse soorten administratieve ambtenaren.

De Nederlandse bestuursambtenaren werden regelmatig overgeplaatst; de inheemse bestuurders dienden meestal hun hele loopbaan binnen één gebied. In de regel viel het ambtsgebied van een assistent-resident samen met dat van een regent en kwam het ambtsgebied van een controleur overeen met dat van een districtshoofd. Doordat het Europese korps zich als een netwerk over het Inlandse korps uitstrekte, kon de koloniale overheid met een betrekkelijk klein aantal Nederlandse ambtenaren binnen de inheemse maatschappij gezag uitoefenen tot op het dorpsniveau. Op de meeste standplaatsen had het Europese korps maar één ambtenaar. Deze Nederlandse ambtenaren moesten zich als 'oudere broers' gedragen tegenover hun inheemse tegenspelers. In feite moesten zij er op toezien dat de inheemse gezagsdragers de wensen van het gouvernement vervulden op het punt van bijvoorbeeld de landrente en de verplichte leveranties.

De regenten vormden het hoogste inheemse bestuursniveau. Onder Daendels en Raffles was hun status beknot, maar na 1830 werd hun traditionele positie grotendeels hersteld. Zo kwam in het regeringsreglement te staan, dat men als opvolger van een regent zoveel mogelijk een zoon of andere nabestaande zou benoemen. De regenten waren dus wel ambtenaren, maar bekleedden in feite een erfelijk ambt. Hun gezag bij de inheemse bevolking ging terug op de voor-koloniale tijd, toen zij nog uit eigen hoofde heer en meester waren. De Nederlandse ambtenaren hadden daarom ook tot taak de bevolking tegen willekeur van de regenten te beschermen.

Het hier geschetste stelsel gold alleen voor het rechtstreeks bestuurde gebied. In de gebieden met zelfbestuur, zoals de Javaanse vorstenlanden, functioneerden wel residenten en assistent-residenten, maar vond op lokaal niveau geen Nederlands toezicht plaats.

Naast dit stelsel voor het regionaal en plaatselijk bestuur beschikte het gouvernement uiteraard over een centraal ambtelijk apparaat, waaronder de Algemene Secretarie en andere algemene departementen en diensten. Het grootste deel van dit centrale apparaat was in Batavia gevestigd, evenals de Raad van Indië. Daarentegen had de gouverneur-generaal sinds 1836 zijn zetel 
in Buitenzorg, al beschikte hij ook over een ambtswoning in Batavia (in 1879 werd dit een paleis aan de noordkant van het Koningsplein). Formeel stond de Raad van Indië onder voorzitterschap van de gouverneur-generaal, maar in de regel werkte de Raad zelfstandig onder leiding van de vice-president. Bij afwezigheid van de gouverneur-generaal berustte de dagelijkse leiding van het gouvernement eveneens bij deze vice-president.

Het Europees BB groeide in de loop van de negentiende eeuw van ongeveer honderd man tot ruim vierhonderd. Het gouvernement verlangde van de Europese bestuursambtenaren, dat zij zich niet in het Nederlands maar in inheemse talen onderhielden met de inheemse bestuurders en de inheemse bevolking. In 1843 stichtte de regering een in Nederland gevestigde opleiding voor de Indische bestuursdienst, waarin de studie van het Javaans en Maleis dan ook een belangrijke plaats innam. Bezit van het aan deze opleiding verbonden diploma werd een vereiste voor de bestuursfuncties binnen het Europees BB. In Indië geboren Europeanen konden zonder dit diploma alleen nog administratieve functies vervullen. Vooral de Nederlanders van gemengde Europees-Aziatische afstamming ('Indische Nederlanders') ervoeren dit als discriminatie. Pas in 1867 kwam er ook in Batavia een opleiding voor de bestuursdienst.

\section{Verzet tegen de terugkeer van het Nederlandse gezag}

Hoewel de snelle Britse verovering van Java in 1811 het Nederlandse prestige had geschonden, stuitte de terugkeer van het Nederlandse gezag daar op weinig moeilijkheden. Voor de bevolking betekende die terugkeer trouwens geen dramatische verandering, omdat het binnenlands bestuur ook onder het Britse bewind overwegend door Nederlandse ambtenaren uitgeoefend was. Daarentegen leidde de terugkeer van het Nederlandse gezag in sommige gebieden buiten Java tot ernstige moeilijkheden.

Eén van die gebieden was dat van de Zuid-Molukken, waar de bevolking onder het Britse bewind aanzienlijk beter was gevaren dan onder het Nederlandse. De Britten hadden het specerijenmonopolie weliswaar niet afgeschaft, maar ze hadden geen strenge controlemaatregelen toegepast, zoals de hongi-tochten. Voor de specerijen was redelijk betaald en de haven van Ambon was opgebloeid. Verder hadden de Britten op Ambon een inheems hulpkorps van vierhonderd militairen gevormd. Toen zij de Molukken in maart 1817 aan Nederland overdroegen, werd dit korps ontbonden omdat het gouvernement het niet wilde overnemen. Veel oud-leden van het korps vreesden door de Nederlanders naar Java gedeporteerd te zullen worden en weken daarom uit naar het nabij gelegen eiland Saparoea.

Onder leiding van één van hen, de ex-sergeant-majoor Thomas Matoelesia, 
bijgenaamd Pattimoera, een protestantse Ambonees, begon in mei 1817 een algemene opstand op dit eiland. De opstandelingen doodden daarbij de resident en vrijwel de hele Nederlandse bezetting. Een uit Ambon uitgezonden detachement van ruim tweehonderd man, dat de opstand moest onderdrukken, werd vernietigend verslagen. Het verzet breidde zich uit naar andere delen van de Zuid-Molukken, waaronder Noord-Ambon. Pas in november slaagde een uit Java gearriveerde krijgsmacht er in met steun van hulptroepen uit Ternate en Tidore aan de opstand een eind te maken. Pattimoera en andere verzetsleiders werden terechtgesteld.

Een ander probleemgebied was Zuid-Celebes, dat zich nooit volledig aan de Britten onderworpen had. Hier werd het Nederlandse gezag principieel aangevochten door de vorsten van Boni en enige andere staatjes. Zij betoogden dat hun voorgangers in de zeventiende eeuw met de VOC slechts commerciële verdragen hadden gesloten en dat het gouvernement daar geen politieke rechten aan kon ontlenen. Nederlandse pogingen om deze staatjes met geweld tot een andere houding te bewegen stuitten op aanzienlijke tegenstand. In 1825 zond het gouvernement een krachtige strijdmacht naar Zuid-Celebes, die er met veel moeite in slaagde de hoofdstad van Boni in te nemen, maar de vorstin en haar regering niet kon onderwerpen aangezien die gevlucht waren.

Ook in het sultanaat Palembang leidde de terugkeer van de Nederlanders tot verzet. De Nederlandse bezetting moest in 1819 worden teruggetrokken, nadat zij door het leger van de sultan was aangevallen. Het aan Palembang onderhorige Bangka kwam eveneens in opstand. Een uit Batavia gestuurd eskader brak het verzet op Bangka, maar slaagde er niet in Palembang te bereiken. Pas in 1821 kon een grote Nederlandse strijdmacht na hevige gevechten de stad innemen. Nadat enige jaren later nieuwe opstanden waren uitgebroken, schafte het gouvernement het sultanaat af en lijfde het Palembang in als rechtstreeks bestuurd gebied.

Op West-Borneo werd het Nederlandse gezag niet aangetast door de inheemse vorsten maar door de vele Chinezen die zich daar gevestigd hadden om goud te ontginnen. Zij waren georganiseerd in enige kongsi, praktisch autonome verenigingen, en weigerden aan het gouvernement belasting te betalen en een Nederlands monopolie op zout en opium te erkennen. Het gouvernement zond er tussen 1819 en 1825 verscheidene militaire expedities heen, zonder duurzaam resultaat.

Tenslotte raakte het gouvernement in deze zelfde periode betrokken bij een conflict in West-Sumatra, maar dat kwam in eerste aanleg niet voort uit verzet tegen het Nederlandse gezag. Dit was de Padri-oorlog in Minangkabau, die zich zestien jaar zou voortslepen. 
Het Nederlands-Britse verdrag van 1824

In 1818 keerde Raffles naar Indonesië terug, waar hij voor de East India Company luitenant-gouverneur werd van Benkoelen. Van hier uit beijverde hij zich onvermoeibaar om Nederland dwars te zitten. Hij nam het standpunt in dat het Brits-Nederlandse verdrag van 1814 geen betrekking op Sumatra had, hield de overdracht van Padang tegen, probeerde de Nederlanders uit Palembang te verdrijven en bezette de zuidpunt van Sumatra om daar een grote Britse haven aan te leggen. Het Nederlandse gouvernement protesteerde telkens bij de Britse gouverneur-generaal in Calcutta en werd telkens in het gelijk gesteld.

Daarop wist Raffles in 1819 voor de EIC het eilandje Singapore te verwerven, gelegen voor de zuidpunt van het schiereiland Malakka. Ook dit was in strijd met het verdrag van 1814, want Singapore maakte deel uit van het aan Nederland onderhorige sultanaat Djohore. Raffles stichtte hier een vrijhaven, die hij binnen enkele jaren tot grote bloei bracht, onder meer door persoonlijk Indiase en Chinese handelaren over te halen zich er te vestigen.

De Britse regering wilde Singapore graag behouden, maar dit botste met de Nederlandse rechten op het eiland. Zij verschilde verder met de Nederlandse regering van mening over Biliton en enige andere kwesties. In 1824 losten de beide regeringen hun geschilpunten op in een veelomvattend akkoord. Nederland deed afstand van zijn bezittingen in India en op het schiereiland Malakka, met inbegrip van zijn aanspraken op Singapore. Groot-Brittanië deed afstand van Benkoelen, waar de EIC zich al in de zeventiende eeuw had gevestigd, en van alle verdere aanspraken op Sumatra en de daarbij behorende eilanden, zoals Biliton, en op alle andere eilanden in de archipel zuidelijk van Singapore. In dit verband gaf Groot-Brittannië ook de exclusieve rechten op die de EIC dank zij Raffles in Atjeh had verworven.

Door het verdrag van 1824 veranderde de betekenis van de benamingen Nederlands-Oost-Indië en Nederlands-Indië. Voortaan hadden die alleen nog betrekking op de Indonesische archipel en niet meer op andere Aziatische gebieden.

Intussen liet het verdrag Nederland in deze archipel niet volledig vrij. Wat Atjeh betreft moest Nederland toezeggen, dat het enerzijds de onafhankelijkheid van deze staat zou eerbiedigen en anderzijds ervoor zou zorgen dat de veiligheid van scheepvaart en handel niet door Atjeh zou worden aangetast.

\section{De Java-oorlog}

In 1825 brak in de Midden-Javaanse vorstenlanden een anti-Nederlandse opstand uit onder leiding van prins Diponegoro. Het kostte het gouvernement 
bijna vijf jaar om aan de opstand een eind te maken. Deze strijd staat bekend als de Java-oorlog.

De vorstenlanden behoorden tot de vruchtbaarste en dichtst bevolkte delen van Java, maar in de tijd van het bewind van Van der Capellen bestond hier veel onvrede. Er was treurnis over de verloren gegane glorie van het rijk Mataram, wrok over de vernederingen die van de VOC waren ondervonden en verbittering over het brute optreden van Daendels en Raffles. De landbouwende bevolking verarmde omdat zij de vorstenhuizen en de adelstand, die in omvang niet achteruitgingen, moest onderhouden uit de opbrengsten van een grondgebied dat door het Britse en het Nederlandse bestuur verkleind was, terwijl zij bovendien aan Chinese tolgaarders belastingen moest afdragen ten behoeve van het Nederlands-Indische gouvernement. Daarnaast werden de vorsten en de adel zelf financieel gedupeerd, toen Van der Capellen in 1823 hun pachtcontracten met Europese ondernemers annuleerde (zie p. 75).

Diponegoro, geboren in 1785, was de oudste zoon van een sultan van Jogjakarta die door Daendels op de troon was geholpen maar tijdens het bewind van Raffles was overleden. Het Britse bestuur had toen als opvolger een jongere zoon aangewezen, wiens moeder van hogere rang dan de moeder van Diponegoro was. Diponegoro zelf was een strenge moslim die een afkeer had van de weeldezucht aan het Jogjase hof en zich geregeld in de bergen terugtrok om in eenzaamheid te mediteren en ascese te bedrijven. Soms kreeg hij daarbij visioenen over een heilige opdracht om aan de goddeloosheid een eind te maken. Maar toen zijn halfbroer, de sultan, in 1822 overleed, werd Diponegoro opnieuw voor de opvolging gepasseerd: het Nederlandse gouvernement wees niet hem maar het tweejarig zoontje van de overleden sultan als opvolger aan.

In de jaren daarna werd Diponegoro bovendien gegriefd door onhebbelijk optreden van Nederlandse bestuursambtenaren. Hij kwam echter pas openlijk in verzet toen het gouvernement in 1825 zonder overleg met hem besloot een weg aan te leggen die over zijn landgoed zou lopen. Hij verzamelde krijgers om zich heen. In juli ondernam het Nederlands bestuur een poging om hem te arresteren, maar dit liep uit op een bloedig gevecht. Nu riep hij het volk van de vorstenlanden op tot opstand. Vrijwel de hele Jogjase bevolking gaf aan zijn oproep gehoor, waarbij de volkswoede zich allereerst tegen de Chinese tolgaarders keerde. Ook het grootste deel van de prinsen en de adel schaarde zich achter hem. Diponegoro trok door het land en kreeg steeds meer aanhang. In de stad Jogjakarta konden alleen het Nederlandse fort en de kraton zich tegen de opstandelingen handhaven. De opstand breidde zich uit naar Soerakarta en naar delen van Midden- en Oost-Java buiten de vorstenlanden. Ook Semarang werd bedreigd.

Diponegoro's volgelingen riepen hem tot sultan uit. Hij vestigde zich in de oude kraton van Mataram ten zuiden van de stad Jogja. Velen zagen in hem de 
ratoe adil, de in de Djojobojo-legende voorspelde verlosser (zie pp. 56-7). Eén van zijn vurigste aanhangers, de godsdienstleraar Kiai Modjo, proclameerde een heilige oorlog tegen de ongelovigen.

Het koloniale leger telde in 1825 ongeveer 14.000 man, maar beschikte slechts over enkele garnizoenen in de vorstenlanden. Het grootste deel van het leger bevond zich in West-Sumatra en Zuid-Celebes; deze troepen werden haastig teruggehaald. Pas in september kreeg het leger de stad Jogja weer in handen. Tegen het eind van 1825 beheerste het weliswaar de steden, maar was een groot deel van het Midden-Javaanse land in de macht van de opstandelingen.

De organisatie van deze opstandelingen tot een echte strijdmacht was vooral het werk van de jeugdige prins Prawira Dirdjo, bijgenaamd Sentot. Hij vormde een aantal gedisciplineerde en geuniformeerde eenheden, gedeeltelijk met vuurwapens bewapend en ondersteund door cavalerie en artillerie. Naast deze reguliere eenheden opereerden talrijke ongeregelde benden, bewapend met krissen en bamboesperen. Sentot toonde zich bovendien een knap strateeg. De opstandelingen gingen over tot een guerrilla-oorlog, waarbij zij de koloniale strijdkrachten voortdurend bestookten maar open confrontaties ontweken.

Het Nederlandse leger werd versterkt met Madoerese, Menadonese en Molukse hulptroepen, terwijl ook de soesoehoenan en de mangkoenegara in Soerakarta zich met hun troepen achter het gouvernement schaarden. Het koloniale leger veroverde in 1826 de oude kraton van Mataram, maar slaagde er niet in Diponegoro gevangen te nemen. Omdat het onmogelijk bleek de opstandelingen met een geconcentreerde aanval te verslaan, vormde men een aantal mobiele colonnes die zelfstandig konden opereren; zij moesten proberen Diponegoro te vinden en uit te schakelen. De Nederlandse legercommandant, generaal H.M. de Kock, vestigde zich in Magelang om de acties te leiden. Maar waar de colonnes verschenen, verdwenen Diponegoro's soldaten door op te gaan in de plaatselijke bevolking; zodra de colonnes verder trokken, namen deze strijders de wapens weer op.

In Den Haag bleef men geloven in de mogelijkheid om met een grote strijdmacht in één slag een eind aan de opstand te maken. Daarom stelde de regering een 'Expeditionnaire afdeeling infanterie voor de Oost-Indiën' samen. Deze uit 3.100 vrijwilligers bestaande strijdmacht zonder enige tropenervaring kwam medio 1827 op Java aan. Binnen twee jaar zouden er ruim tweeduizend sterven, grotendeels door ziekte en uitputting.

Intussen was De Kock tot een nieuw systeem overgegaan om de opstand in te dammen. In gebied waar het leger de overhand kreeg liet hij benteng aanleggen, eenvoudige houten versterkingen waarin een kleine bezetting gelegerd werd die voortdurend in de omtrek patrouilleerde. De benteng werden door wegen met elkaar verbonden, waarover de mobiele colonnes zich konden 
verplaatsen. Dit netwerk van benteng breidde hij gestadig uit, van bijna veertig in 1827 tot meer dan honderd in 1829. Het op bezuinigingen toegespitste gouvernement in Batavia vond De Kock's aanpak duur en omslachtig, maar het benteng-stelsel bleek te werken. De greep van Diponegoro op de bevolking werd ingeperkt, zijn aanhang begon te verlopen.

Eind 1828 bood Diponegoro onderhandelingen aan, maar deze stuitten af op zijn eis om de sultanstitel te behouden en te worden erkend als beschermer van de islam op heel Java. In het voorjaar van 1829 nam het koloniale leger Kiai Modjo met vijfhonderd volgelingen gevangen. In het najaar liep Sentot met een deel van zijn troepen naar het gouvernement over. Diponegoro werd met zijn aanhangers teruggedrongen tot een klein gebied ten westen van Jogja, waar hij voortdurend op de vlucht was voor het koloniale leger.

In februari 1830 vroeg Diponegoro om een gesprek met generaal De Kock. Nadat deze hem een vrijgeleide had toegezegd, begaf hij zich met een groot gevolg naar Magelang, waar de besprekingen zouden plaatsvinden en waar hij zijn intrek nam in een huis dat het gouvernement hem ter beschikking stelde. In de onderhandelingen, die op zijn verzoek waren uitgesteld tot eind maart, na afloop van de islamitische vasten, handhaafde hij zijn verlangen te worden erkend als sultan en als beschermer van de islam op Java. Hierop liet De Kock, met schending van het toegezegde vrijgeleide, Diponegoro gevangen nemen.

Dit was het einde van de Java-oorlog. Aan de kant van het gouvernement waren hierin vijftienduizend militairen omgekomen, zowel in de strijd als door ziekte; bijna de helft hiervan waren Indonesiërs. Het geschatte aantal slachtoffers aan de kant van de opstandelingen en de door de strijd getroffen bevolking lag ver boven de honderdduizend.

Diponegoro werd verbannen en stierf in 1855 in het fort Rotterdam te Makassar. Het gouvernement nam weer een flink deel van het grondgebied van Jogjakarta af en annexeerde ook een gelijk deel van het grondgebied van Soerakarta, opdat deze twee vorstenlanden even groot zouden blijven. $\mathrm{Na}$ deze amputaties behielden de vorstenlanden nog maar een kwart van hun onderdanen. Toen de soesoehoenan hier niet mee instemde (tenslotte had hij niet met de opstand meegedaan maar juist geholpen deze te bestrijden), verbande het gouvernement hem naar Ambon.

Al tijdens de opstand had het gouvernement een eind gemaakt aan de gehate tolheffingen en aan het verbod op verpachting van grond aan Europese ondernemers. Dit laatste leidde ertoe dat de westerse ondernemingslandbouw zich in de vorstenlanden eerder heeft kunnen ontplooien dan in de rest van Java. 


\section{Cultuurstelsel en batig slot}

Geheel tegen de verwachtingen leverde het bezit van een koloniaal rijk in Azië de Nederlandse staat decennia-lang geen geldelijk voordeel op. Van 1808 af overschreden de uitgaven in Indië de inkomsten. Van der Capellen's opvolger ondernam rigoureuze bezuinigingen, maar intussen bracht de Javaoorlog ruim twintig miljoen gulden extra kosten mee. Nederland moest grote leningen sluiten om de tekorten op de Indische begroting aan te vullen. Het werd dan ook een nijpend probleem, hoe men de inkomsten van het Indische gouvernement zou kunnen verhogen.

Het gouvernement verkreeg zijn inkomsten deels uit belastingen, waarvan de landrente de belangrijkste was, en deels uit de opbrengst van monopolieproducten als specerijen, koffie, zout en opium. Daarbij werd de inning van belastingen dikwijls aan Chinezen verpacht, evenals de verkoop van opium en zout. Algemeen achtte men verhoging van de gouvernementsinkomsten afhankelijk van uitbreiding van de verbouw op Java van winstgevende exportproducten zoals koffie, suiker en indigo. Men verwachtte echter niet dat de bevolking uit zichzelf tot de verbouw van zulke producten zou overgaan. Daarom zou men volgens sommigen de exportlandbouw in hoofdzaak aan Europese ondernemingen moeten toevertrouwen.

Koning Willem I legde deze kwestie voor aan Johannes van den Bosch, die hij in 1829 tot gouverneur-generaal benoemde. Deze wist de koning echter te winnen voor een heel ander systeem ter vergroting van de exportlandbouw: de inheemse boeren zouden ertoe moeten worden gebracht hier een vijfde deel van hun grond voor te gebruiken en de daarop geteelde producten aan het gouvernement te leveren. Dit systeem sloot aan bij de door de VOC ingevoerde plant- en leverplichten en in het bijzonder bij het Preanger-stelsel.

Van den Bosch kwam in januari 1830 in Indië aan, met een geheime opdracht van de koning om de exportproductie van Java op te voeren tot een bedrag gelijk aan vijf gulden per hoofd van de bevolking. Vier jaar lang wijdde hij zich aan de uitwerking en invoering van zijn systeem. Het gold niet voor de vorstenlanden maar alleen voor de rechtstreeks bestuurde gebieden. Evenals bij de invoering van de landrente ging men ervan uit, dat de grond in deze gebieden eigendom van het gouvernement was. In streken die daarvoor geschikt waren moest de bevolking van de dorpen een deel van die grond bebouwen met door het gouvernement voorgeschreven exportgewassen. Daarvoor kreeg zij een vergoeding, het plantloon, die verrekend kon worden met de landrente.

Omdat in die tijd de woorden 'culture' en 'cultuur' in zwang waren voor de verbouw van gewassen, is dit systeem van gedwongen productie bekend geworden als het Cultuurstelsel. Meer dan de helft van de bevolking van de 
rechtstreeks bestuurde gebieden werd bij de gouvernementscultures ingeschakeld.

De bestuursambtenaren, zowel de Europese als de inheemse, moesten nauwlettend toezicht op de verplichte cultures uitoefenen. Omdat ze daar uit zichzelf weinig voor voelden, keerde het gouvernement premies aan hen uit in verhouding tot de opbrengsten, de 'cultuurprocenten'. Die cultuurprocenten konden voor sommige ambtenaren oplopen tot een bedrag dat hun salaris overtrof. Bovendien versterkte Van den Bosch de positie van de regenten (het hoogste inheemse bestuursniveau) door hun ambt in feite erfelijk te maken.

Het Cultuurstelsel kende ook een rol toe aan particuliere ondernemingen. Voorzover de geoogste producten, zoals suiker, indigo, thee en tabak, een nadere bewerking nodig hadden voordat ze uitgevoerd konden worden, moesten de boeren die ter verwerking afleveren aan fabrieken die werden opgericht door Europese en Chinese ondernemers met voorschotten van het gouvernement. De ondernemers leverden de bewerkte producten door aan het gouvernement, maar mochten soms een deel ervan zelf verkopen. Deze fabrikanten, waaronder veel familieleden en vrienden van hoge bestuursambtenaren, behaalden vaak reusachtige winsten.

De afzet van de producten van het Cultuurstelsel was in handen van de Nederlandsche Handel-Maatschappij, die het monopolie gekregen had om de producten voor rekening van het gouvernement naar Nederland te vervoeren en daar te verkopen, meestal in openbare veilingen in Amsterdam.

Van den Bosch keerde in 1834 naar Nederland terug en werd in NederlandsIndië opgevolgd door zijn naaste medewerker, J.C. Baud. Terstond na zijn terugkeer in Nederland werd hij minister van koloniën. Baud, die een overtuigd voorstander van het Cultuurstelsel was, volgde hem in 1840 ook in dit ambt op en bleef minister van koloniën tot 1848 .

Het duurde enige jaren voordat het stelsel op gang kwam, maar toen leidde het inderdaad tot een sterke stijging van de gouvernementsinkomsten. Die stijging was niet alleen te danken aan de verkoop van exportproducten, maar ook aan voortdurende verhogingen van de landrente, die immers aan de hand van de opbrengst van de grond werd vastgesteld. Aldus kon men gedurende ruim veertig jaar jaarlijks een 'batig slot' van de Indische begroting naar de Nederlandse begroting overboeken.

Voor de Nederlandse schatkist waren deze overboekingen een uitkomst, want de staat had grote schulden, die juist in die tijd nog toenamen in verband met de afscheiding van België. In het zuidelijk deel van het Koninkrijk der Nederlanden brak namelijk in augustus 1830 een opstand uit. De Nederlandse troepen konden zich er niet handhaven en in november 1830 proclameerde een Nationaal Congres van de zuidelijke bevolking de onafhankelijkheid van België. Dit conflict leidde tot overleg tussen Frankrijk, Groot-Brittannië, 
Oostenrijk, Pruisen en Rusland, die in 1831 besloten onder bepaalde voorwaarden in te stemmen met de scheiding van Nederland en België. Maar koning Willem I weigerde acht jaar lang deze voorwaarden te aanvaarden en hield al die tijd het leger op voet van oorlog. Pas in 1839 werd de scheiding definitief geregeld. Het jaar daarop deed Willem I afstand van de troon.

Minister Baud noemde het Cultuurstelsel eens 'het eenige stelsel waardoor Java blijven kan de kurk waarop Nederland drijft'. De jaarlijkse overboekingen van het batig slot van de Indische begroting zijn tot 1877 voortgezet. Over het gehele tijdvak 1831-1877 bedroegen de Indische baten 823 miljoen gulden. In sommige jaren maakten ze bijna een derde van de Nederlandse begroting uit. Een deel van deze gelden is besteed voor het aflossen van de schulden van de VOC en de leningen die Nederland ten bate van de Indische begroting had gesloten. Het grootste deel, 650 miljoen gulden, is gebruikt voor de aflossing van zuiver Nederlandse staatsschulden, zoals die uit hoofde van het conflict met België, en voor andere Nederlandse bestedingen, zoals de aanleg van spoorwegen en havenwerken en subsidiëring van de industrie. Tezelfdertijd beperkte de regering de gouvernementsuitgaven in Indië tot een minimum. Daardoor kwam bijvoorbeeld van de onderwijsplannen van de commissiegeneraal uit 1818 vrijwel niets terecht en werd de uitvoering van openbare werken verwaarloosd voorzover die niet met onbetaalde herendiensten verricht konden worden.

Het Cultuurstelsel bevoordeelde niet alleen de Nederlandse schatkist. Het leidde ook tot grote winsten voor de Nederlandsche Handel-Maatschappij, die aanvankelijk een noodlijdend bestaan had geleden. Verder werd Amsterdam weer een wereldmarkt voor tropische producten en groeide de Nederlandse handelsvloot uit tot één van de grootste ter wereld.

Op Java leidde het Cultuurstelsel onder meer tot aanzienlijke uitbreiding van het landbouwareaal, tot aanleg van wegen en irrigatiewerken en tot verrijking van ambtenaren en fabrikanten. Voor de dorpsbewoners waren de gevolgen van het stelsel minder gunstig. Hun inkomen nam weinig toe, terwijl hun werklast aanzienlijk verzwaard werd. Het toegekende plantloon bedroeg weliswaar over het geheel genomen meer dan de geïnde landrente, maar deze marge werd stelselmatig klein gehouden door de landrente te verhogen. Bovendien werd soms een deel van het plantloon verduisterd door ambtenaren of hoofden. Mislukte de oogst door overstromingen of droogte, dan bestond geen recht op plantloon, terwijl de landrente wel verschuldigd bleef. Verder werd steeds de beste landbouwgrond van een dorp voor de gouvernementscultures aangewezen. Vaak bedroeg de aangewezen grond aanzienlijk meer dan een vijfde van het areaal. De toekenning van 'cultuurprocenten' lokte de bestuursambtenaren uit tot machtsmisbruik.

Wat de werklast betreft, was Van den Bosch ervan uitgegaan dat de gouvernementscultures niet meer dan 66 dagen arbeid per jaar zouden vergen, een 
vijfde van de gebruikelijke arbeidstijd. Maar in de praktijk kostten die cultures de boeren meer tijd en moeite dan de rijstbouw. Verder werd de dorpsbevolking ook ingeschakeld voor het vervoer van de producten en voor de arbeid in de verwerkingsfabrieken, terwijl zij bovendien veelvuldig voor herendiensten werd ingezet. Het kwam dan ook voor dat dorpsbewoners in één jaar meer dan tweehonderd dagen voor het gouvernement moesten werken. In sommige gebieden braken zelfs hongersnoden uit, doordat de bevolking te weinig tijd en bouwgrond overhield voor haar eigen voedselproductie en niet over middelen beschikte om die van elders aan te vullen.

Omdat in het begin veel boeren wegtrokken uit de districten waar de dwangcultures het verst waren doorgevoerd, hanteerde het gouvernement een streng passenstelsel. Het was de bevolking verboden het eigen district zonder pas te verlaten; deed men dit toch, dan stelde men zich bloot aan lijfstraf en gevangenisstraf.

\section{Koloniale machtsuitbreiding buiten Java vóór 1870}

De delen van de Indonesische archipel waarover Nederland in 1830 gezag uitoefende, waren vrijwel dezelfde als die het in 1800 van de VOC had overgenomen. De voornaamste veranderingen hadden zich in Sumatra voorgedaan: de Britten hadden het gebied van Benkoelen overgedragen en het gouvernement had het gebied van Palembang ingelijfd. Het grootste deel van Sumatra, Borneo en Celebes viel echter niet onder Nederlands gezag, evenals Bali en verschillende eilanden ten oosten daarvan. Nog verder oostelijk maakte het gouvernement sinds kort aanspraak op een deel van Nieuw-Guinea, maar feitelijk gezag oefende het daar niet uit.

De houding van de Nederlandse regering tegenover machtsuitbreiding was tweeslachtig. Zij had haar handen al vol aan de gebieden onder haar gezag en richtte zich vooral op Java, dat zij met het Cultuurstelsel tot ontwikkeling wilde brengen. In de overige gebieden, de 'buitengewesten', volstond zij meestal met handhaving van de bestaande toestand. Omdat die gewesten Nederland toen meer kostten dan opbrachten, waren veel Nederlanders beducht voor gebiedsuitbreiding. Sinds Van den Bosch hadden de bestuursambtenaren strikte opdracht ervoor te waken dat het gouvernement niet verwikkeld raakte in oorlogen tegen Indonesische vorsten of volkeren. Maar Van den Bosch wilde op langere termijn wel degelijk de hele archipel onder de macht van Nederland brengen en koning Willem I had hem gemachtigd in ieder geval heel Sumatra ten zuiden van Atjeh te onderwerpen.

Daartoe zou men in de eerste plaats een eind moeten maken aan de burgeroorlog in Minangkabau, het bergland bij Padang. Hier voerden de traditionele stamhoofden al jaren lang strijd tegen een fanatieke moslimbeweging, de 


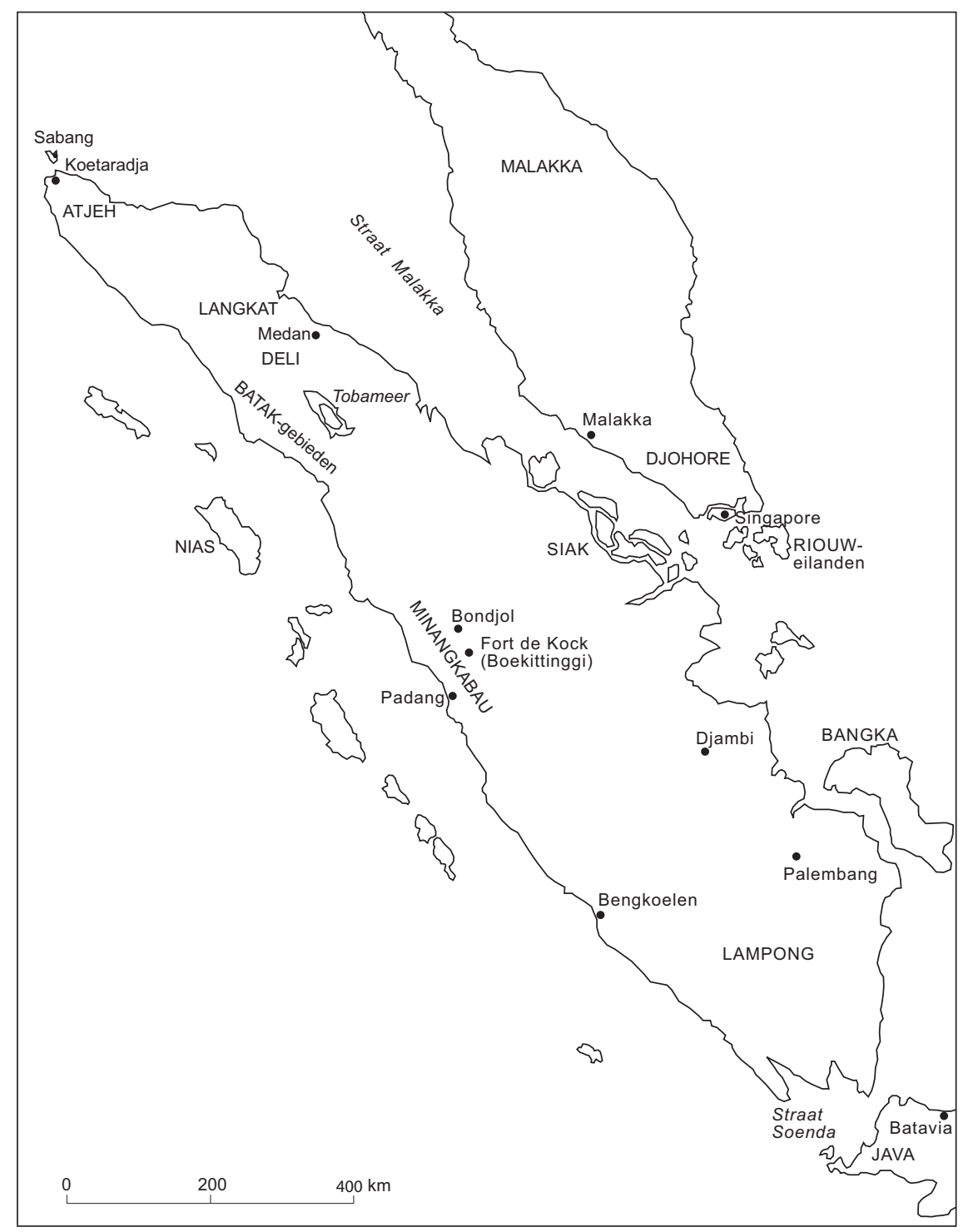

Kaart 7. Sumatra 
Padri. Deze beweging wilde een eind maken aan alle Minangkabause zeden en gebruiken die van de orthodoxe voorschriften van de islam afweken, zoals het matriarchaat. $\mathrm{Zij}$ had een heilige oorlog uitgeroepen en een groot deel van het land in haar macht gekregen. In 1821 hadden de Minangkabause hoofden een overeenkomst met het gouvernement gesloten, waarin zij de soevereiniteit over hun land aanboden in ruil voor verdrijving van de Padri. Daarop had het gouvernement een kleine strijdmacht naar het gebied gestuurd, maar ondanks aanzienlijke steun van inheemse hulptroepen was deze er nog niet in geslaagd de Padri te verslaan toen ze in 1825 teruggehaald werd wegens het uitbreken van de Java-oorlog.

In 1831 hervatte het gouvernement de strijd tegen de Padri. Het werd een zware en langdurige oorlog in moeilijk bergterrein. Het koloniale leger bestond ten dele uit Ambonezen, Boeginezen en Madoerezen en beschikte zelfs enige tijd over een Javaans contingent onder Sentot, de vroegere rechterhand van Diponegoro. Minangkabause hulptroepen vormden tweederde van de totale strijdmacht, die uiteindelijk vijftienduizend man telde. De Padri maakten hun hoofdkwartier, het bergdorp Bondjol, tot een bijna onneembare vesting. Hun leider was de imam (moslimvoorganger) Peto Sarif, bijgenaamd Imam Bondjol. Ook het gouvernement bouwde vestingen; de bekendste daarvan was het op een steile top gelegen Fort de Kock. Na vier jaar kon men de Padri terugdringen tot hun hoofdkwartier. Pas in 1837 viel Bondjol en kwam aan de Padri-oorlog een einde. Imam Bondjol werd verbannen naar Menado. Heel Minangkabau kwam onder Nederlands bestuur, tezamen met de ten noorden daarvan gelegen kustgebieden tot aan de grens met Atjeh. Intussen had het gouvernement ook aan de oostkust van Sumatra zijn positie versterkt door de vestiging van enige civiele en militaire posten.

Het moeizame verloop van de Padri-oorlog versterkte de huiver in Nederland voor expansionistische avonturen. De regering wilde zich onthouden van verdere gezagsuitbreiding in de buitengewesten en in het bijzonder van iedere uitbreiding van rechtstreeks bestuur, omdat de inzet van meer soldaten en meer ambtenaren het batig slot zou aantasten. In 1841 besloot minister Baud zelfs tot ontruiming van een aantal posten aan de kust van Sumatra. In de praktijk kon de regering dit onthoudingsbeleid echter niet handhaven, al hield zij er in theorie nog decennia lang aan vast.

Eén van de bezwaren tegen een strikt onthoudingsbeleid was, dat dit ruimte liet voor bemoeienis van anderen met de Indonesische archipel. De vrees hiervoor werd versterkt door het optreden van een Britse avonturier, James Brooke, in Noord-Borneo. Deze had daar grote invloed gekregen in het sultanaat Broenei, had zich in 1841 laten uitroepen tot vorst van Serawak en had ook enig grondgebied voor het Britse Rijk verworven. Nederland protesteerde hiertegen in Londen, maar de Britse regering achtte het verdrag van 1824 niet geschonden omdat deze delen van Borneo noordelijker dan Singapore lagen. 
Minister Baud maakte zich er nu ongerust over dat de Nederlandse soevereiniteit over veel gebieden in de buitengewesten moeilijk viel aan te tonen. Daarom liet hij een inventaris maken van alle overeenkomsten die men van Nederlandse kant sinds de zeventiende eeuw met inheemse gezagsdragers in Azië had gesloten. Ook gaf hij een geheime opdracht aan het gouvernement om waar mogelijk daden te verrichten die de Nederlandse soevereiniteitsaanspraken zouden kunnen ondersteunen. Als voorbeelden van zulke daden noemde hij 'natuurkundige nasporingen, administratieve maatregelen, het dempen van kleine onlusten en het regelen van ontstane geschillen'. Enige jaren later benoemde de regering gouverneurs voor Borneo en Celebes om de Nederlandse aanspraken daarop te onderstrepen. Tenslotte gaf zij een algemene opdracht aan het gouvernement om te proberen bevriende Indonesische staatjes te bewegen tot aanvaarding van het Nederlandse oppergezag.

Het eerste gebied waar dit hardere beleid werd toegepast was het eiland Bali, dat verschillende vorstendommen omvatte die in 1841 het Nederlandse oppergezag aanvaard hadden. Kort daarna verzeilde het gouvernement hier in allerlei conflicten, onder meer wegens strandroof (plundering van gestrande schepen). In 1846, 1848 en 1849 zond het er militaire expedities heen; bij de derde zette het een strijdmacht van 4600 man in, die de tegenstand van de Balinezen tenslotte wist te breken. Later rezen er nieuwe conflicten, die tot verdere Nederlandse operaties leidden.

In 1850 en 1853 zond het gouvernement militaire expedities naar WestBorneo, waar de sultan van Pontianak het Nederlandse oppergezag erkende, maar de Chinese kongsi zich nog steeds onafhankelijk gedroegen. De strijd speelde zich grotendeels af langs de rivieren in het oerwoud. Een Nederlandse legermacht van tweeduizend man, versterkt met Dajakse hulptroepen, slaagde er tenslotte in de kongsi uit te schakelen.

Nog zwaarder was de oorlog die Nederland van 1859 tot 1863 in ZuidBorneo voerde. In het sultanaat Bandjermasin, dat eveneens het Nederlandse oppergezag aanvaard had, werd sinds het midden van de eeuw steenkool gewonnen (van groot belang voor de stoomscheepvaart). Om de Nederlandse mijnconcessies veilig te stellen greep het gouvernement in de troonopvolging in, maar dit leidde in 1858 tot een opstand waarbij een groot aantal Europeanen vermoord werd. Nederland reageerde hierop door het sultanaat op te heffen en het gebied in te lijven. De hele bevolking keerde zich nu tegen het gouvernement. Pas na vier jaar strijd kon het koloniale leger, wederom met Dajakse hulp, het gebied onderwerpen.

In diezelfde periode bond het gouvernement opnieuw de strijd aan met Boni in Zuid-Celebes, waar het zich in 1825 uit had moeten terugtrekken wegens de Java-oorlog. In dit staatje regeerde nu een vorstin die haar schepen opdroeg de Nederlandse vlag ondersteboven te voeren. Twee militaire expe- 
dities werden er tegen ondernomen. In 1860 lukte het heel Boni te bezetten en de vorstin te vervangen door een pro-Nederlandse prins. Een deel van het grondgebied werd bij het gouvernementsgebied ingelijfd.

Ook op verschillende andere plaatsen breidde het gouvernement zijn machtsgebied uit, onder meer in Midden-Sumatra, waarbij verzet van de bevolking door militaire expedities werd gebroken. Uiteraard diende het koloniale leger niet alleen voor uitbreiding maar ook voor handhaving van de Nederlandse macht. Tientallen malen werd het in de archipel ingezet om opstanden tegen het koloniale gezag te onderdrukken. Zulke opstanden kwamen bijvoorbeeld herhaaldelijk voor in het gebied van Palembang, in het Lampong-gebied en op het eiland Ceram.

De grootste Nederlandse gebiedsuitbreiding vond plaats in 1858 als onverwacht gevolg van het optreden van een Britse avonturier die met een Boeginees privélegertje een greep naar de macht had gedaan in Siak, een sultanaat aan Sumatra's oostkust ten noorden van Djambi. De sultan van Siak vluchtte naar Riouw, vroeg het gouvernement om hulp en stelde zijn rijk, waarvan de onderhorigheden zich tot aan Atjeh uitstrekten, onder het Nederlandse oppergezag. Het belang van deze gebiedsuitbreiding, die Nederland weinig inspanning had gekost, werd niet onmiddellijk beseft. Later zou het noordelijk deel van dit gebied (met de sultanaten Deli en Langkat) het meest winstgevende gewest van de kolonie worden.

\section{Nederlandse kritiek op het koloniaal beleid}

Over het bestuur van de Nederlandse koloniën was de koning tot 1848 geen verantwoording verschuldigd aan de Staten-Generaal; hij bepaalde het beleid zelfstandig, bijgestaan door ministers en ambtenaren. De gouverneurs-generaal bestuurden Nederlands-Indië volstrekt autocratisch volgens de aanwijzingen uit Den Haag. De Raad van Indië had sinds Van den Bosch geen bestuursbevoegdheden meer. De vrijheid van meningsuiting was in de kolonie zeer beperkt en het publiceren van kritiek op het gouvernement was uitgesloten. In Nederland was zulke kritiek wel mogelijk. Zo verschenen daar pamfletten tegen de maatregelen van Van den Bosch, die immers niet te rijmen vielen met de beginselen van het vroegere beleid. Maar het parlement kon hier niet over meepraten.

In 1848 kwam hier verandering in door een wijziging van de Nederlandse grondwet, waardoor de Staten-Generaal een zekere zeggenschap over het beleid in de koloniën kregen. De reglementen op dat beleid zouden voortaan door wetten moeten worden vastgesteld, dus in overleg en in overeenstemming met het parlement. Ook andere onderwerpen zouden bij wet kunnen worden geregeld en de koning zou jaarlijks verslag aan het parlement moeten 
uitbrengen over het beheer van de koloniën en de toestand waarin die zich bevonden.

In diezelfde periode werd de verbinding tussen Nederland en Indonesië verbeterd door de totstandkoming van een zee-land-zeeroute via de landengte van Suez. Voor postverkeer nam deze route maar zes weken in beslag; ook reizigers gingen er gebruik van maken. Eén van de gevolgen van de betere verbinding was, dat in Nederland actuele berichten over hongersnood op Java verschenen, die scherp afstaken tegen de verzekeringen van de regering dat de bevolking het goed maakte.

De belangrijkste criticus van het koloniaal beleid in het parlement werd W.R. van Hoëvell, die twaalf jaar lang predikant in Batavia was geweest. Daar had hij onder meer het Bataviaasch Genootschap van Kunsten en Letteren nieuw leven ingeblazen en het Tijdschrift voor Nederlandsch-Indië opgericht. Het gouvernement wantrouwde hem om zijn liberale opvattingen en gaf hem in 1848 een berisping, nadat hij geprotesteerd had tegen de achterstelling van Indische Nederlanders en gepleit had voor vrijheid van drukpers. Hierop keerde Van Hoëvell naar Nederland terug. Van 1849 tot 1862 was hij lid van de Tweede Kamer, waar hij onverdroten streed tegen misstanden in de koloniën.

Sommigen achtten de invoering van democratische vrijheden in de koloniën gevaarlijk voor een doelmatig koloniaal bestuur. Oud-minister Baud schreef in 1849: 'Wij hebben niets met de Javanen gemeen. Taal, kleur, godsdienst, zeden, afkomst, geschiedkundige herinneringen, alles is verschillend tusschen Nederlanders en Javaan. Wij zijn de overheerschers, zij de overheerschten! Die heterogeniteit sluit eene kiem van ontbinding of scheiding in zich. Zij zal eenmaal plaats hebben; door wijsheid en voorzigtigheid kan dat tijdstip vertraagd worden; door stelselzucht en roekeloosheid zal het worden vervroegd.'

Baud werd in 1850 zelf lid van de Tweede Kamer. Tegelijk hielp hij de regering bij het ontwerpen van een wet ter vervanging van het tot dan toe slechts op koninklijke besluiten berustende regeringsreglement voor NederlandsIndië. In 1851 diende de regering het wetsontwerp bij de Tweede Kamer in. In haar toelichting stelde zij onder meer, dat het beleid er op gericht moest zijn dat 'behoudens de welvaart der inheemsche bevolking, dat wingewest aan Nederland zal blijven verschaffen de stoffelijke voordeelen, die het doel waren der verovering'. Onder invloed van Van Hoëvell nam de Kamer afstand van deze formulering. Het overleg tussen regering en parlement over de wet strekte zich over drie jaar uit. Het nieuwe Regeeringsreglement, dat uiteindelijk in 1854 tot stand kwam, veranderde echter weinig aan de bestaande toestand. Weliswaar kreeg de Raad van Indië weer enige bevoegdheden terug, maar de wet gaf de bevolking van de kolonie, zowel de Indonesiërs als de Europeanen en de Chinezen, geen enkele vorm van invloed op het bestuur. 
Tijdens de debatten had Van Hoëvell de regering onder meer verweten, dat de Nederlandse machtsuitoefening in Indonesië gebaseerd was op het ontzien van de positie van de Inlandse hoofden en dat die hoofden daarom de boerenbevolking op Java straffeloos konden onderdrukken, uitbuiten en bestelen. Wat Van Hoëvell en zijn medestanders over koloniale misstanden onthulden, zowel in als buiten het parlement, bereikte het brede publiek in Nederland echter nauwelijks.

Heel anders ging het toen dezelfde boodschap gebracht werd door Eduard Douwes Dekker, die zeventien jaar lang ambtenaar in Indonesië geweest was, op Sumatra, Java, Celebes en Ambon gediend had en in 1856 ontslag genomen had, omdat hij meende dat zijn superieuren een West-Javaanse regent die zich aan machtsmisbruik schuldig maakte de hand boven het hoofd hielden. Na terugkeer in Europa verwerkte hij zijn ervaringen in de roman Max Havelaar, of de koffij-veilingen der Nederlandsche Handel-Maatschappij, die hij in 1860 publiceerde onder het pseudoniem Multatuli. Dit zowel met passie als met sarcasme geschreven boek maakte een diepe indruk. Veel Nederlandse lezers konden zich voor het eerst in het lot van gewone Indonesiërs inleven, vooral door de in het boek opgenomen vertelling 'Saïdjah en Adinda'. Multatuli's hoofdthema was de tolerantie van het koloniale regime voor door Inlandse hoofden gepleegd onrecht, maar hij roerde ook een andere basis van de Nederlandse machtuitoefening aan: het optreden van het koloniale leger. Aan het slot van de genoemde vertelling voegt Saïdjah zich bij opstandelingen in het Lampong-gebied om zijn bruid Adinda te zoeken. In een dorp 'dat pas veroverd was door het nederlandsche leger, en dus in brand stond', treft hij haar lijk aan, naakt en mishandeld, waarna hij zelf de dood vindt door zich te storten in de bajonetten van de soldaten die de nog levende opstandelingen het vuur in drijven.

In Multatuli's tijd was de term Indonesië nog niet in zwang. Zelf lanceerde hij een andere naam voor de Indische archipel: Insulinde. Hij duidde de Nederlandse koning, Willem III, in zijn boek aan als 'keizer van 't prachtig ryk van Insulinde dat zich daar slingert om den evenaar, als een gordel van smaragd' en besloot het boek met een rechtstreekse vraag aan deze vorst, namelijk 'of 't Uw keizerlyke wil is [...] dat daarginds Uw meer dan dertig millioenen onderdanen worden mishandeld en uitgezogen in UWEN naam?'

Na de verschijning van Max Havelaar publiceerde Multatuli nog veelvuldig over Indonesië. Hij betoogde dat Nederland zijn heerschappij daar niet zou kunnen handhaven als het doorging de bevolking te onderdrukken om er grof geld aan te verdienen. Hij was dan ook ingenomen met een gedicht van zijn vriend S.E.W. Roorda van Eysinga, getiteld 'De laatste dag der Hollanders op Java'. Hij liet dit gedicht, ook aangeduid als 'de vloekzang van Sentot', opnemen in latere drukken van Max Havelaar, met de opmerking dat het toekomstige geschiedschrijvers aangenaam zou zijn te kunnen bewijzen 'dat het niet 


\section{MAX HAVELAAR,}

OY DE.

\section{KOFFIJ-VEILINGEN}

DER

\section{NEDERLANDSCHE HANDEL-MAATSCHAPPIJ,}

DOOR

M ULTATULI.

E E $\mathbf{R}$ T D E E L.

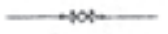

AMSTERDAM,

J. DE RUYTER.

Eduard Douwes Dekker (1820-1887), die bestuursambtenaar in Nederlands-Indië was geweest, wekte in 1860 sensatie met zijn onder de schuilnaam Multatuli gepubliceerde roman Max Havelaar, waarin hij Nederland verantwoordelijk verklaarde voor de knechting en uitbuiting van dertig miljoen onderdanen in Indië. 
aan waarschuwingen ontbroken heeft'. Overigens wilde Multatuli niet ingedeeld worden bij één van de partijen in de destijds in Nederland woedende richtingenstrijd over het koloniaal beleid.

Die strijd richtte zich zowel op het Cultuurstelsel als op de batig-slotpolitiek, maar dit betekende niet dat wie tegen het eene was vanzelfsprekend ook tegen het andere was. De meeste liberalen waren tegen het Cultuurstelsel omdat het inging tegen hun opvatting dat goederenproductie geen staatstaak is. Door dit stelsel was de staat immers op Java gaan optreden als een reusachtige productieonderneming, die weinig ruimte liet voor particuliere ondernemers. Deze liberalen wilden dat het gouvernement zich uit de exportlandbouw zou terugtrekken en die aan Europese ondernemingen zou overlaten. $\mathrm{Zij}$ betoogden bovendien dat het volume van de exportproductie daardoor geweldig zou toenemen. Uitvoerig belichtten zij de verspilling en verarming die men aan het Cultuurstelsel moest wijten. In hun kritiek stelden zij voorop, dat dit stelsel op gedwongen arbeid berustte; daarom duidden zij hun alternatief aan als 'vrije arbeid'. Intussen waren veel liberalen niet principieel tegen de batig-slot-politiek. Zij deelden de destijds overheersende opvatting, dat Europese landen het recht hadden zich uit hun overzeese koloniën te verrijken. Dit kwam overeen met het al in de Bataafse Republiek gehuldigde uitgangspunt, dat koloniën er zijn voor het moederland en niet omgekeerd, en met het spraakgebruik de koloniën als 'wingewesten' te betitelen.

Daarentegen vonden de tegenstanders van de batig-slot-politiek het immoreel dat Nederland zich ten koste van Nederlands-Indië verrijkte. Velen van hen waren ook principieel tegen het Cultuurstelsel als dwangsysteem. Sommigen echter hadden er geen bezwaar tegen als het Cultuurstelsel (gezuiverd van misbruiken en uitwassen) voorlopig nog zou blijven bestaan, mits de baten daarvan geheel aan Indië zelf ten goede zouden komen in plaats van aan Nederland. 'Vrije arbeid' was in hun ogen een misleidende leuze. De liberalen beoogden immers geen werkelijke vrijheid van arbeidskeuze voor de dorpsbewoners, maar vrijheid voor Nederlandse ondernemers om van die arbeid gebruik te maken. Zulk een politiek was evenzeer gericht op exploitatie van de kolonie ten bate van het moederland als het Cultuurstelsel. Alleen zou die exploitatie minder zichtbaar zijn, wanneer ze haar weerslag niet meer zou vinden in de Indische baten op de staatsbegroting maar in de winstcijfers van particuliere ondernemingen.

Bij de discussies over het koloniaal beleid kwam maar zelden de vraag aan de orde of Nederland altijd over Indonesië moest blijven heersen. Slechts enkelen verklaarden, dat de koloniale heerschappij er uiteindelijk op gericht behoorde te zijn dat de koloniën zelfstandige staten zouden kunnen worden. Multatuli hoopte dat Indonesië pas onafhankelijk zou worden wanneer er grotere eensgezindheid onder de bevolking gegroeid zou zijn, omdat de archipel anders verscheurd zou worden door interne conflicten. Hij schreef in dat 
verband: 'Insulinde is 'n prachtig paard, waarop 'n dief zit. Dat men dien dief er afwerpt, is best. Maar men moet het niet doen voor men 't beest aan den teugel heeft, daar 't anders de wildernis inloopt en, onbestuurd, van de rotsen te pletter valt.'

\section{Einde van Cultuurstelsel en batig slot}

In de jaren vijftig en zestig van de negentiende eeuw leverde het Cultuurstelsel grote financiële baten op, onder meer dank zij hoge koffie- en suikerprijzen op de wereldmarkt. Niettemin begon al in deze tijd de geleidelijke afbraak van het stelsel, onder druk van de groeiende kritiek daarop in Nederland. Het Regeeringsreglement van 1854 ging ervan uit, dat het gouvernement zich op de duur uit de exportlandbouw zou terugtrekken. Een tiental jaren later hief de regering de minder lonende gouvernementscultures op, waaronder die van tabak en indigo. In 1866 schafte zij de cultuurprocenten voor Europese bestuursambtenaren af. Het passenstelsel voor de inheemse bevolking werd verzacht. Ook kwam er een eind aan de specerijenmonopolies in de Molukken. $\mathrm{Nu}$ resteerden nog de twee meest rendabele gouvernementscultures: die van koffie en suiker.

De drijvende kracht achter de afbraak van het Cultuurstelsel was de wens om Java open te stellen voor Nederlandse particuliere ondernemingen. De discussie daarover concentreerde zich op de vraag, of zulke ondernemingen het recht zouden moeten krijgen landbouwgrond van de inheemse bevolking te kopen. In de Tweede Kamer werd betoogd, dat dit tot ernstige ontwrichting van de inheemse samenleving zou leiden. Men loste de kwestie in 1870 op door te bepalen, dat inheemsen hun bouwgrond alleen zouden mogen verkopen aan inheemsen; aan niet-inheemse personen en ondernemingen zouden zij zulke grond alleen mogen verhuren, voor ten hoogste vijfentwintig jaar. Verder zou het gouvernement woeste gronden voor een periode van ten hoogste vijfenzeventig jaar aan niet-inheemse personen en ondernemingen in erfpacht kunnen geven. Deze regelingen golden overigens alleen voor rechtstreeks bestuurde gebieden en niet voor de Javaanse vorstenlanden.

Eveneens in 1870 bepaalde men, dat de suikercultures van het gouvernement in twintig jaar geleidelijk zouden worden beëindigd. Na 1890 bleef alleen de verplichte koffiecultuur volgens het Preanger-stelsel nog over; deze is blijven voortbestaan tot 1915 .

Het Nederlandse parlement nam in dit tijdvak nog verschillende andere wettelijke maatregelen met betrekking tot Nederlands-Indië. Het beëindigde de beperkingen op de buitenlandse scheepvaart en handel in de Molukken. Het hief met ingang van 1860 de slavernij in Indië op. Tenslotte verschafte het zich grotere zeggenschap over het koloniaal beleid door te bepalen dat het 
voortaan zelf de begroting van Nederlands-Indië zou vaststellen.

De batig-slot-politiek werd niet bij wet opgeheven maar verdween vanzelf, doordat de inkomsten van het gouvernement sinds het midden van de jaren zeventig achterbleven bij de uitgaven. De inkomsten verminderden door de inperking van de gouvernementscultures. De uitgaven stegen in de eerste plaats doordat de Nederlandse regering niet langer vasthield aan het rigoureuze bezuinigingsbeleid dat sinds 1826 aan de kolonie opgelegd was: sinds het midden van de jaren zestig mocht het gouvernement meer geld besteden voor zaken als onderwijs en openbare werken. De uitgaven stegen in de tweede plaats door de Atjeh-oorlog.

\section{Eerste fase van de Atjeh-oorlog}

In 1870 was Atjeh het belangrijkste land in de archipel dat niet onder Nederlands oppergezag stond. Dit land bestond uit het eigenlijke sultanaat Atjeh en een aantal daarbij aansluitende gebieden die aan de sultan onderhorig waren. Het werd dan ook dikwijls aangeduid als 'Atjeh en onderhorigheden'. Het besloeg een gebied anderhalf keer zo groot als Nederland en had een bevolking van ruim een half miljoen. De eigenlijke Atjehers woonden in tot vestingen versterkte dorpen in het noorden van dat gebied, aan de kust en in de vallei van de Atjeh-rivier. Zowel de islam als het gebruik van wapens speelde een grote rol in hun leven.

Nederland had zich in 1824 tegenover Groot-Brittannië verplicht de onafhankelijkheid van het sultanaat te eerbiedigen maar ook ervoor te zorgen dat de veiligheid van scheepvaart en handel niet door dit land werd aangetast. Van die tweede verplichting had het zich niet kunnen kwijten. Evenals de kustbevolking van sommige andere Indonesische gebieden hield die van Atjeh zich van tijd tot tijd bezig met zeeroof en strandroof; niet alleen Nederlandse maar ook Britse en Amerikaanse schepen hadden daarvan te lijden. Nederland had de Atjehse autoriteiten er nooit toe kunnen brengen daadwerkelijk aan die praktijken een eind te maken. Het besefte destijds niet, dat Atjeh geen krachtig geregeerd rijk meer was zoals in de zeventiende eeuw, maar nu bestond uit een aantal zelfstandige gewesten, die veelvuldig met elkaar oorlog voerden en alleen zuiver formeel het oppergezag van de sultan erkenden. De sultan had geen werkelijke macht buiten de onmiddellijke omgeving van zijn residentie, een paar kilometers landinwaarts gelegen aan de Atjeh-rivier.

In 1857 sloot Nederland een verdrag van handel, vrede en vriendschap met Atjeh, maar de verhouding bleef gespannen. Nu Noord-Borneo in de Britse invloedssfeer geraakt was, vreesde men in Den Haag dat ook Atjeh zich onder de macht van een andere mogendheid dan Nederland zou scharen. De spanning steeg nog als gevolg van het akkoord van 1858 met Siak. Niet alleen had 
Nederland nu het oppergezag verworven over bijna heel Sumatra ten zuiden van Atjeh (met uitzondering van een aantal bergstreken), maar bovendien rekende de sultan van Siak enige gebieden tot zijn rijk waar ook Atjeh aanspraak op maakte.

De onaantastbaarheid van Atjeh werd voor Nederland een acuut probleem, nadat in 1869 het Suezkanaal geopend was. De belangrijkste scheepvaartroute van Indonesië naar Europa liep voortaan niet meer door Straat Soenda maar door Straat Malakka en langs Atjeh. De Nederlandse regering wilde het sultanaat daarom onder haar macht brengen en zocht naar een mogelijkheid zich van haar verplichting uit 1824 te bevrijden. Dit lukte in 1871 door een akkoord met de Britse regering, waarbij Nederland zijn laatste kolonie op de West-Afrikaanse Goudkust (het huidige Ghana) aan Groot-Brittannië afstond in ruil voor de vrije hand in heel Sumatra.

Eind 1872 opende de regering besprekingen met Atjeh, in de hoop dit zonder geweld ertoe te bewegen het Nederlandse oppergezag te aanvaarden, evenals Siak had gedaan. Intussen waren de Atjehers niet geneigd zich aan Nederland te onderwerpen, maar bereidden ze zich al enige tijd op oorlog voor. Ze wierpen versterkingen op en zochten steun bij andere landen. Toen geruchten over dit laatste het gouvernement in Batavia bereikten, meende dit dat men geen tijd meer mocht verliezen. In grote haast zond het een expeditieleger van drieduizend man naar de monding van de Atjeh-rivier.

Op 26 maart 1873 verklaarde Nederland het sultanaat de oorlog wegens 'schending van het verdrag van 1857'. Op 8 april gingen de Nederlandse troepen aan land, waar ze onmiddellijk fel werden aangevallen. Hun opdracht was de kraton van de sultan te veroveren, maar zij kenden de plaats daarvan niet. Wel veroverden en verwoestten ze een grote moskee, die ze eerst voor de kraton hadden aangezien, maar daarbij sneuvelde hun commandant. De Nederlandse troepen konden zich niet handhaven en scheepten zich op 25 april weer in.

Na deze smadelijke nederlaag stuurde Nederland in december een nieuw expeditieleger, ruim achtduizend man sterk. Opnieuw stuitten de troepen op felle tegenstand. Na een langdurig artilleriebombardement slaagden ze er in de kraton te bezetten, maar die bleek inmiddels te zijn verlaten. De gevluchte sultan, een jongen van vijftien jaar, stierf enkele dagen later aan cholera. Nederland meende de oorlog te hebben gewonnen. Het lijfde Atjeh bij Nederlands-Indië in op grond van het 'recht van overwinning' en stelde er een gouverneur over aan. Op het tijdstip van deze annexatie, 31 januari 1874, had Nederland nog niet één duizendste deel van het Atjehse grondgebied veroverd. Als bestuurscentrum zou men een nieuwe stad bouwen, Koetaradja, op de plaats van de verwoeste kraton. De hoofdmacht van het expeditieleger keerde naar Java terug; een bezettingsmacht van ruim drieduizend man bleef achter. 
Nederland vierde de 'overwinning' op Atjeh uitbundig, maar dit bleek voorbarig te zijn. Slechts enkele gewesten aan de kust legden zich bij het Nederlandse gezag neer. De andere gewesten zetten de strijd voort en wezen een driejarig familielid van de gestorven sultan als zijn opvolger aan. Moslimvoorgangers riepen de strijd uit tot een heilige oorlog tegen de ongelovigen. Onafgebroken bestookten de Atjehse strijders de Nederlanders, die aanvankelijk slechts een enclave van ongeveer dertig vierkante kilometer rondom Koetaradja beheersten. Pas eind 1875 veroverde Nederland enige daarbuiten gelegen gewesten, maar een paar jaar later moest het die gedeeltelijk weer prijsgeven. Intussen veranderde het gouvernement de enclave in een modern stukje Nederlands-Indië, met nieuwe straten en huizen, een ziekenhuis, een postkantoor en een trambaan naar de haven.

Hoewel langs de kust van de Atjehse onderhorigheden verscheidene vorsten zich bereid verklaarden het Nederlandse oppergezag te aanvaarden, duurde het verzet in het eigenlijke Atjeh voort. In 1879 ondernam Nederland een grote actie om dit verzet te breken, nadat het de troepensterkte had opgevoerd tot elfduizend man. Generaal K. van der Heijden, een Indische Nederlander, wist binnen een half jaar de hele Atjeh-vallei te onderwerpen. In oktober legde hij in Koetaradja de eerste steen voor een nieuwe grote moskee, die het gouvernement als teken van verzoening liet bouwen. Nederland dacht opnieuw dat de oorlog voorbij was en trok een deel van de troepen uit Atjeh terug.

Wederom was dit voorbarig. Weliswaar hadden verscheidene Atjehse leiders zich nu in het Nederlandse bestuur geschikt, maar na een paar jaar namen andere leiders de guerrillastrijd weer op en heroverden ze sommige van de door Van der Heijden onderworpen gebieden. Dit plaatste de Nederlandse regering voor een moeilijk dilemma. Enerzijds beschikte ze niet over genoeg troepen om het hele gebied te beheersen, maar anderzijds wilde ze Atjeh niet abandonneren. Zo kwam zij tot een nieuwe militaire formule: de geconcentreerde linie. Van 1885 af verschanste het Nederlandse garnizoen zich in een gebied van ruim vijftig vierkante kilometer rondom Koetaradja achter een linie, bestaande uit zestien versterkingen, door tramsporen met elkaar en met de stad verbonden en voorzien van telefoon. Vrijwel al het verdere Atjehse grondgebied gaf men voorlopig prijs. De regering vestigde haar hoop nu meer op politieke dan op militaire middelen om het Nederlandse gezag in Atjeh aanvaard te krijgen.

In de loop van deze eerste fase van de Atjeh-oorlog had het koloniale leger een dertigduizend Atjehers gedood en ruim vierhonderd dorpen verbrand. De oorlog had het gouvernement tot dan toe honderdvijftig miljoen gulden gekost. 
Opmars van de westerse ondernemingen

Omstreeks 1870 begon zich een reeks veranderingen te voltrekken die Nederlands-Indië een ander karakter gaven dat de kolonie tot het eind toe heeft behouden. Het belangrijkste kenmerk van dit nieuwe karakter was de overheersende positie van op export gerichte particuliere westerse ondernemingen.

Het begin van de nieuwe tijd ging vergezeld van belangrijke verbeteringen in de verkeersverbindingen. In 1870 kreeg Batavia via Singapore een telegraafverbinding met Europa. Het in 1869 geopende Suez-kanaal verkleinde de duur van de zeereis tussen Indonesië en Nederland van vier maanden tot minder dan anderhalve maand. In de loop van de jaren zeventig werden twee Nederlandse rederijen opgericht die het leeuwendeel van het scheepvaartverkeer langs deze route gingen verzorgen, de Stoomvaart Maatschappij Nederland en de Rotterdamsche Lloyd. Later stichtten deze twee ondernemingen gezamenlijk een rederij voor het verkeer binnen de archipel, de Koninklijke Paketvaart Maatschappij (KPM). Intussen was in 1877 ten oosten van Batavia een nieuwe haven voor oceaanschepen aangelegd in Tandjong Priok. In 1873 opende een particuliere spoorwegonderneming de eerste spoorlijn, tussen Semarang en Jogjakarta. Daarna werden andere lijnen aangelegd, zowel door het gouvernement als door particuliere maatschappijen, zodat Java tegen het eind van de eeuw over een samenhangend net van spoor- en tramlijnen beschikte. Semarang bleef het belangrijkste spoorwegcentrum; daar verscheen ook het in Midden-Java veel gelezen dagblad De Locomotief. Op Sumatra kwamen er spoorlijnen in Minangkabau, in het gebied van Palembang en in Deli. Op het eind van de eeuw werd op een eiland ten noorden van Atjeh de haven van Sabang ingericht als bunkerplaats voor de stoomscheepvaart.

Terwijl Nederlandse particuliere ondernemingen voor 1870 slechts een beperkte rol in de exportlandbouw speelden, werd Java nu binnen enkele decennia met honderden van zulke ondernemingen bezaaid. De vrees van de Nederlandse conservatieven, dat de Indonesische bevolking na afschaffing van het systeem van gedwongen arbeid weinig bereid tot loonarbeid zou zijn, bleek ongegrond. Integendeel, het aanbod van arbeid was zo groot dat de ondernemers de lonen (en daarmee hun productiekosten) zeer laag konden houden. De liberale voorspelling, dat het volume van de exportproductie geweldig zou toenemen, kwam uit. Indonesië ontwikkelde zich tot de grootste leverancier van tropische producten op de wereldmarkt.

Dank zij de nieuwe ondernemingen produceerde Java in 1885 al twee maal zoveel suiker als in 1870, terwijl suiker toch onder het Cultuurstelsel het belangrijkste exportartikel was geweest. Verschillende cultures waar het gouvernement jaren lang mee had geëxperimenteerd, kwamen juist nu tot grote bloei. Eén daarvan was de theecultuur, die van even veel belang werd 
als de koffiecultuur. Een andere was de verbouw van tabak, die niet alleen in de Javaanse vorstenlanden toenam maar bovendien een geweldige vlucht nam in Deli op Sumatra. Vooral dank zij het succes van de Delise tabak vormde de waarde van de Indonesische tabaksuitvoer in 1890 al het tienvoud van de waarde in 1870. In het midden van de eeuw had het gouvernement de kinaplant uit Zuid-Amerika ingevoerd. Ook de kinacultuur maakte na 1870 een spectaculaire groei door, zodat Indonesië op de duur negen tiende van de wereldproductie van kinine leverde. Verder leverde het driekwart van de wereldproductie van kapok. In de twintigste eeuw werd rubber het belangrijkste Indonesische exportartikel; de voornaamste rubberplantages lagen in Sumatra en Borneo.

De exportlandbouw was overigens niet uitsluitend een zaak van nietinheemse ondernemingen. De productie van copra, peper en kruidnagelen was vrijwel geheel in handen van de inheemse bevolking, die van koffie en rubber gedeeltelijk. De verbouw van rijst en andere voedingsgewassen was eveneens een zaak van de bevolking. De rijstproductie steeg aanzienlijk, maar kon de bevolkingstoename uiteindelijk niet bijhouden. Dit leidde op het eind van de eeuw hier en daar tot voedselschaarste, onder meer in het gebied van Semarang. De inheemse bevolking van Java groeide van 16 miljoen in 1870 tot 28 miljoen in 1900. De bevolking van heel Nederlands-Indië bedroeg in 1900 bijna 40 miljoen.

Naast de exportlandbouw leverde ook de winning van delfstoffen grote baten op. Het gouvernement exploiteerde al lange tijd tinmijnen op Bangka; een particuliere onderneming begon in de tweede helft van de negentiende eeuw de winning van tin op Biliton. De tinproductie nam na 1870 sterk toe en maakte uiteindelijk een vijfde van de wereldproductie uit. Tegen het eind van de negentiende eeuw kwam de winning van aardolie op gang, vooral op Sumatra en Borneo. Aardolie werd uiteindelijk het op één na belangrijkste exportartikel van Nederlands-Indië. De eveneens voornamelijk op Sumatra en Borneo gewonnen steenkolen waren niet voor export bestemd maar voor verbruik binnen de archipel.

Behalve Nederlandse ondernemingen namen ook buitenlandse deel aan de exportproductie van Indonesische landbouwgewassen en delfstoffen. Het Chinese aandeel in deze productie verminderde. De meeste ondernemingen waren niet zelfstandig maar behoorden toe aan grote maatschappijen. De Nederlandsche Handel-Maatschappij, wier positie nu niet meer berustte op het vervoer en de verkoop van gouvernementsproducten, ontwikkelde zich tot een bankonderneming die vooral aan landbouwondernemingen krediet verstrekte.

Van de winsten uit de export van Indonesië vloeide het grootste deel toe aan aandeelhouders in Nederland en in het buitenland en stroomde een kleiner deel terug naar Indonesië door herinvesteringen in de betrok- 
ken bedrijven. De door Indonesië geproduceerde rijkdommen verrijkten het gouvernement echter nauwelijks, omdat dit er slechts weinig belasting over hief. Het gouvernement bleef daarom kampen met begrotingstekorten en had omstreeks de eeuwwisseling een schuldenlast van honderd miljoen gulden.

De groei van de particuliere ondernemingen bracht ook een verandering in de samenstelling van de Europese bevolking teweeg. In 1870 waren er in Nederlands-Indië ruim tienduizend Nederlanders en andere westerlingen, naast een dertigduizend Europeanen van gemengde afstamming, de 'IndoEuropeanen'. Viervijfde hiervan was in dienst van het gouvernement of van het koloniale leger. In 1900 was het aantal westerlingen verdubbeld, maar nu vormden de particulieren er de grootste groep van. Daartoe behoorde het leidende personeel van de plantages (de 'planters') zowel als employés van mijnbedrijven, transportbedrijven, handelskantoren en banken, naast advocaten en journalisten. Intussen vormde ook het gouvernementspersoneel een veelzijdiger gezelschap dan vroeger: naast bestuursambtenaren en militairen omvatte het bijvoorbeeld ingenieurs en docenten. Een toenemend deel van de in Indonesië werkende Nederlanders was in Nederland zelf opgegroeid. Velen van hen stonden vreemd tegenover het autocratische bestuursstelsel van Nederlands-Indië. Politieke vergaderingen en verenigingen waren daar verboden en de drukpers stond formeel onder censuur. Niettemin was een Nederlands-Indische pers ontstaan die niet meer terugschrok voor kritiek op het gouvernement.

Terwijl de Europese bevolking groeide, kwam een steeds groter deel ervan in de steden te wonen. Bandoeng, dat eerst in deze tijd belangrijk begon te worden (vooral dank zij de thee- en de kinacultuur), ontwikkelde zich na 1900 tot de stad met het grootste percentage Europese inwoners.

Nergens voltrokken de economische en maatschappelijke veranderingen zich zo snel als in Noordoost-Sumatra, dat pas in 1858 door het verdrag met Siak onder Nederlands oppergezag was gekomen. Omstreeks 1865 begon de sultan van Deli op grote schaal woeste gronden beschikbaar te stellen voor de verbouw van tabak. Verzet van de bevolking hiertegen werd door het koloniale leger onderdrukt. De tabakscultuur groeide explosief; later kwam daar ook de verbouw van koffie, thee en rubber bij en werden in naburig gebied rijke aardoliebronnen aangeboord. De exploitatie was niet alleen in handen van Nederlandse maar ook van onder meer Amerikaanse, Britse en Duitse ondernemingen. De arbeid werd in hoofdzaak verricht door Chinese en Javaanse contractarbeiders. Er werden herhaaldelijk dividenden uitgekeerd van meer dan $100 \%$. Tegen het eind van de eeuw was oerwoudgebied ter grootte van enige Nederlandse provincies in plantages veranderd. De oorspronkelijke bevolking was een minderheid in eigen land geworden. De sultansfamilie had een groot vermogen verworven. Een bescheiden dorp was uitgegroeid tot de hoofdstad Medan, die door een spoorlijn en een telefoonnet met het achter- 
land verbonden was. De ontwikkeling van Noordoost-Sumatra was zo stormachtig verlopen, dat het gouvernement er in de eerste decennia nog nauwelijks over een bestuursapparaat beschikte. De planters waren toen grotendeels zelf als bestuurders opgetreden. $\mathrm{Zij}$ waren het ook geweest die gezorgd hadden voor de komst van een spoorweg en een telefoondienst.

\section{Slavernij, dwangarbeid, koeliecontracten en de poenale sanctie}

Anders dan in Suriname bestond in Nederlands-Indië geen slavenarbeid in de plantages, maar werkten de slaven hier meestal als huispersoneel. In de tijd van Raffles waren er nog ongeveer dertigduizend. Toen de slavernij in Indië met ingang van 1860 werd opgeheven (vooral dank zij Van Hoëvell), was hun aantal gedaald tot minder dan tienduizend. In de Britse koloniën was de slavernij al in 1833 afgeschaft en in de Franse koloniën in 1848.

Intussen bleef tot 1918 een praktijk bestaan die formeel geen slavernij was, maar er soms weinig van verschilde, namelijk dwangarbeid door strafgevangenen bij militaire operaties, bij wegenaanleg en in tin- en kolenmijnen. Omdat ze aan kettingen gebonden waren, werden deze dwangarbeiders 'kettingberen' genoemd. Hun voeding en huisvesting was meestal slecht, hun werk was zwaar en gevaarlijk en ze stonden vaak aan mishandeling bloot. De sterfte onder hen was zeer hoog. In de Atjeh-oorlog stierf in sommige jaren de helft van de dwangarbeiders en men schat dat ongeveer vijfentwintigduizend dwangarbeiders hun tewerkstelling in de Atjeh-oorlog niet overleefd hebben.

Nederlands-Indië kende nog een andere categorie personen die in een zo rechteloze positie konden belanden dat ze praktisch een slavenbestaan leidden. Dit waren de contractkoelies die werden aangeworven om buiten hun eigen woongebied in mijnen of plantages te werken. Bij hun aanwerving kregen ze een voorschot. Hadden ze aan het eind van de contracttermijn nog een schuld aan de werkgever, dan werd hun dienstverband automatisch verlengd. Velen kwamen aldus in een vorm van schuldslavernij terecht. Zij werden vaak zeer slecht behandeld; ook onder hen was de sterfte hoog.

Vooral Noordoost-Sumatra werd hierom berucht. Voor het aanleggen en bewerken van de tabaksplantages waren zeer veel arbeiders nodig. De in het gebied wonende Bataks en Maleiers waren gering in aantal en voelden meestal weinig voor loonarbeid omdat ze voldoende in hun eigen behoeften konden voorzien. De ondernemingen wierven daarom elders contractkoelies aan, eerst Chinezen en later vooral Javanen, die dikwijls genadeloos werden afgebeuld. Omdat het gouvernement hier in de beginperiode nog niet over een bestuursapparaat beschikte, matigden de planters zich de bevoegdheid aan om zelf straffen aan de koelies op te leggen, zoals geseling en opsluiting. Niettemin stelden zij ook prijs op overheidsdwang ter handhaving van 
de arbeidsdiscipline. Op hun aandrang stelde het gouvernement in 1880 een koelie-ordonnantie voor Noordoost-Sumatra vast die voorzag in 'poenale sanctie', dat wil zeggen publiekrechtelijke bestraffing van contractarbeiders voor inbreuken op hun privaatrechtelijke verplichtingen, zoals desertie, dienstweigering en 'verregaande luiheid'. De straffen, tot een maximum van drie maanden dwangarbeid, werden door de bestuursambtenaren opgelegd op aangifte van de ondernemingen. Later breidde het gouvernement het systeem van de poenale sanctie nog uit tot verscheidene andere gebieden waar met contractkoelies gewerkt werd, zoals Biliton.

De poenale sanctie was van begin af aan omstreden. Voor de planters lag het voornaamste nut van de inschakeling van de overheid daarin, dat het weglopen van koelies effectief werd tegengegaan, zodat de ondernemingen konden blijven beschikken over een overvloed van goedkope arbeidskrachten. Intussen gingen veel planters door met eigenrichting in de vorm van fysieke bestraffing. Geruchten hierover en ook over buitensporige wreedheden drongen van tijd tot tijd tot de buitenwereld door. In 1903 stelde het gouvernement een onderzoek in Noordoost-Sumatra in, dat aantoonde dat de koelie-ordonnantie geen eind had gemaakt aan de wantoestanden op de plantages. Integendeel, de bevindingen van de rapporteur waren zo schokkend dat de minister van koloniën weigerde het parlement inzage in het rapport te geven. De regering nam sindsdien verschillende stappen tot verbetering van de positie van de contractarbeiders, maar handhaafde de poenale sanctie. Tot stapsgewijze afschaffing van dit systeem ging zij pas over nadat het Amerikaanse Congres in 1929 een wet had aangenomen die de invoer verbood van met dwangarbeid of arbeid onder poenale sanctie geproduceerde goederen. Destijds vielen in Indië nog ruim vierhonderdduizend contractarbeiders onder het systeem. Eind 1941 schafte het gouvernement tenslotte de poenale sanctie volledig af.

\section{Wetenschappelijke aandacht voor Indonesië}

Het tijdperk van het koloniaal bestuur gaf een zeer sterke groei te zien van op Indonesië gericht wetenschappelijk onderzoek. Naast Nederlanders droegen ook Britten en Duitsers daartoe bij. Dienaren van de East India Company publiceerden in de eerste decennia van de negentiende eeuw verschillende studies over volkeren en talen van de archipel of delen daarvan. De bekendste daarvan is de in 1817 verschenen History of Java van Thomas Raffles. Als luitenant-gouverneur van Java was Raffles de eerste landvoogd na Joannes Camphuys met een duidelijke wetenschappelijke belangstelling, zowel voor de cultuur als de natuur.

Toen Nederland na het Britse tussenbewind zijn bezittingen in Indonesië 
weer terugkreeg, wilde men de wetenschappelijke bestudering ervan stelselmatig aanpakken. Eerst werd dit één van de taken van C.G.C. Reinwardt, een Amsterdamse hoogleraar van Duitse afkomst die tot 1822 op Java als directeur van landbouw, kunsten en wetenschappen diende en onder meer de Plantentuin in Buitenzorg (Bogor) stichtte. In 1820 droeg de regering het exploratiewerk op aan een team van jonge wetenschapslieden, de Natuurkundige Commissie in Indië. De leden van deze commissie, die dertig jaar bestaan heeft, bereisden en beschreven de archipel en legden wetenschappelijke verzamelingen aan. Intussen groeide de natuurwetenschappelijke belangstelling ook buiten het gouvernementele kader, zoals blijkt uit de oprichting in 1850 van een Natuurkundige Vereeniging in Nederlandsch-Indië.

De beroemdste natuuronderzoeker van Indonesië in de negentiende eeuw was de Duitser F. W. Junghuhn, die er van 1835 tot 1848 vele tochten ondernam. Hoewel hij enige malen lid was van de Natuurkundige Commissie, werkte hij meestal zelfstandig. Hij publiceerde talrijke bevindingen op het gebied van botanie, zoölogie, geologie en etnografie, maar werd vooral bekend door zijn meeslepende natuurbeschrijvingen, wijsgerige bespiegelingen en romantische tekeningen. Zijn hoofdwerk is het uit vier delen bestaande Java: deszelfs gedaante, bekleeding en inwendige structuur (1849-1854). Na een verblijf van enige jaren in Nederland leidde Junghuhn in de laatste periode van zijn leven de kinacultuur op Java.

Bijna even beroemd als Junghuhn werd de Britse natuuronderzoeker A.R. Wallace, die samen met Darwin aan de wieg van de evolutietheorie heeft gestaan. Wallace reisde van 1854 tot 1862 in de Indonesische archipel en bestudeerde onder meer de verschillen tussen de fauna van Borneo en die van Celebes. Teruggekeerd publiceerde hij The Malay Archipelago, the land of the orang-utan and the bird of paradise (1869).

Terwijl men destijds gewoonlijk van de Maleise of de Indische archipel sprak, introduceerde de Britse etnoloog J.R. Logan in 1850 in een tijdschriftartikel de nieuwe naam 'Indonesië', naar het voorbeeld van Melanesië en Polynesië. Later kreeg deze benaming meer bekendheid door het in 1884-94 in vijf delen verschenen boek Indonesien oder die Inseln des malayischen Archipels van de Berlijnse hoogleraar A. Bastian.

Het geologische exploratiewerk van de Natuurkundige Commissie en van Junghuhn werd voortgezet door de in 1852 ingestelde Dienst van het Mijnwezen. Ook in niet-gouvernementeel verband vond zowel natuurwetenschappelijk als volkenkundig onderzoek plaats, in het bijzonder tijdens een reeks expedities georganiseerd door het Koninklijk Nederlandsch Aardrijkskundig Genootschap. Dit genootschap was in 1873 opgericht door de Leidse hoogleraar P.J. Veth, die over een universele kennis omtrent Indonesië beschikte en er vele boeken voor het grote publiek over schreef maar het zelf nooit bezocht.

$\mathrm{Na}$ het Britse tussenbewind over Indonesië had de Nederlandse regering 


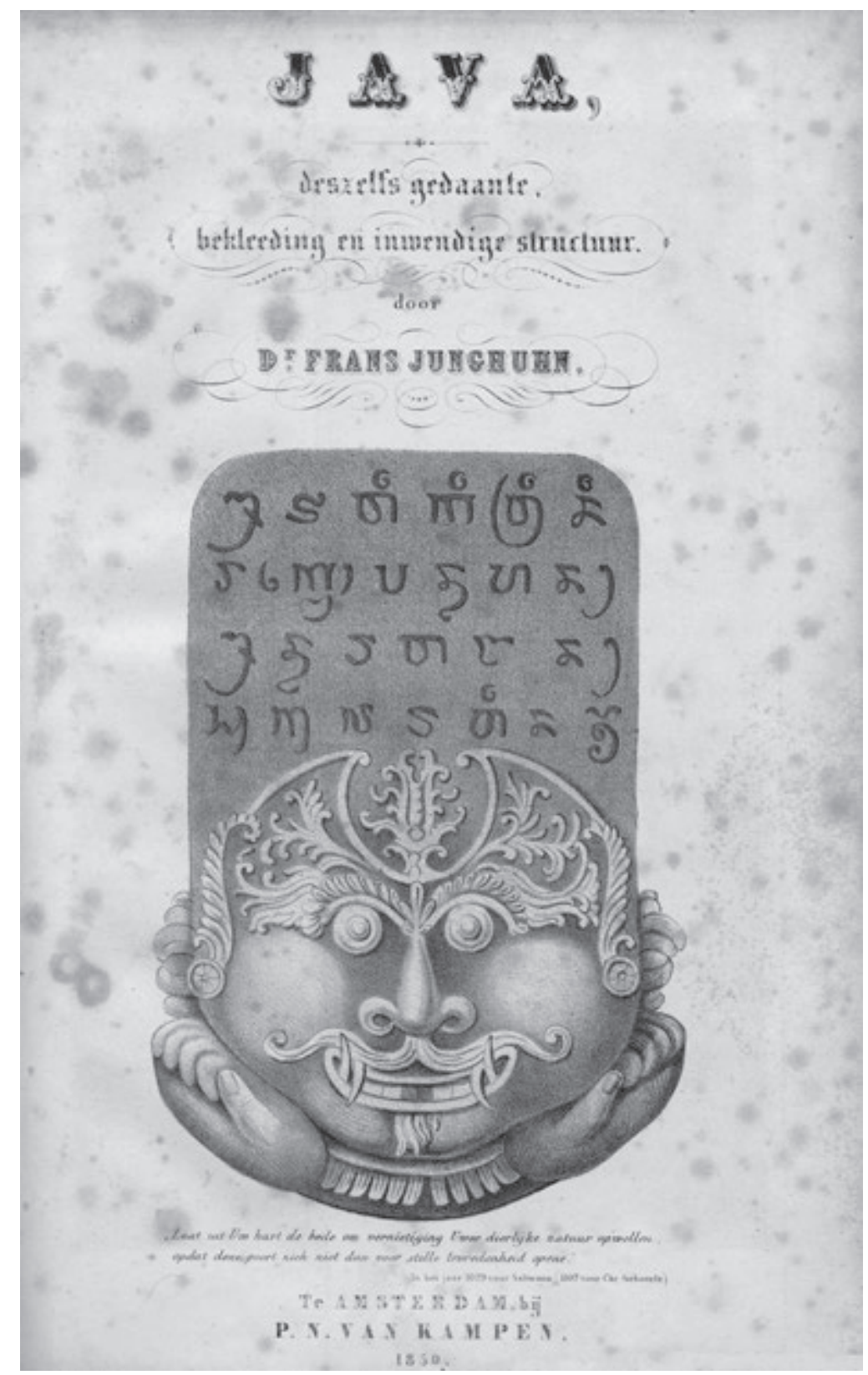

Het in 1849-53 in vier delen verschenen Java was het hoofdwerk van Franz Junghuhn (1809-1864), de beroemdste natuuronderzoeker in dienst van het NederlandsIndische gouvernement, die onder meer alle vulkanen van Java heeft bezocht, beschreven en afgebeeld. 
zich in de eerste plaats op natuurwetenschappelijk onderzoek gericht; pas later ging zij ook taal- en volkenkundige studies bevorderen. Die studies kregen een krachtige stimulans toen minister Baud in 1843 de speciale opleiding voor de Indische bestuursdienst oprichtte. Oorspronkelijk was deze opleiding in Delft gevestigd; in 1864 kwam er een parallelle opleiding in Leiden en in 1901 werd de Delftse opleiding opgeheven. Men ging deze studierichting als 'indologie' aanduiden; zij die haar volgden of gevolgd hadden noemden zich 'indologen'. De Leidse universiteit ontwikkelde zich tot het belangrijkste centrum voor de wetenschappelijke bestudering van Indonesië. Daarnaast droeg het Koninklijk Instituut voor de Taal-, Land- en Volkenkunde van Nederlandsch-Indië veel bij tot de opbouw van kennis over de Indonesische culturen. Dit Instituut werd in 1851 opgericht (op initiatief van oud-minister Baud) en huisde eerst in Delft en daarna in Den Haag. Verder heeft ook het van 1814 daterende Nederlandsch Bijbel Genootschap de bestudering van de Indonesische talen bevorderd.

De meest gezaghebbende taalgeleerde werd J.H.C. Kern, hoogleraar Sanskriet en Javaans in Leiden. Kern en andere taalkundigen verdiepten zich ook in de oude Indonesische literatuur. Omdat die grotendeels uit historische kronieken bestaat, voerden deze studies vanzelf naar bestudering van de oude geschiedenis van de Indonesische volkeren. Tevens nam de belangstelling toe voor inscripties en monumenten uit het Hindoe-Indonesische tijdperk. In 1885 werd in Jogjakarta een Archaeologische Vereeniging opgericht. In 1901 stelde het gouvernement een Oudheidkundige Dienst in; in 1911 werd de Boroboedoer gerestaureerd. Een veel verder weg liggend verleden was het studie-object van E. Dubois, die in Indonesië naar bewijzen zocht voor de evolutietheorie van Darwin en Wallace. In 1891 vond hij in Oost-Java skeletresten van een prehistorische 'aapmens'.

Dank zij de ambtenarenopleiding kregen ook de godsdiensten van Indonesië wetenschappelijke aandacht. Een beroemd islam-kenner was C. Snouck Hurgronje, die in 1885 een half jaar incognito in Mekka doorbracht, later gouvernementsadviseur voor inlandse en arabische zaken werd en vervolgens hoogleraar in Leiden. Anderen bestudeerden de godsdiensten van niet tot de islam bekeerde volkeren, zoals de Toradja's in Midden-Celebes. Wat de geïslamiseerde volkeren betreft, werden de verschillen tussen het islamitische recht en het oudere gewoonterecht, de adat, een belangrijk voorwerp van studie. De voornaamste kenner van het adatrecht was de Leidse hoogleraar C. van Vollenhoven.

Aldus ging in de loop van de negentiende eeuw een groot aantal Nederlanders zich bezighouden met op Indonesië gericht wetenschappelijk onderzoek. Er verscheen een wassende stroom van publicaties, meestal in de Nederlandse taal, op terreinen als hierboven genoemd en op terreinen als tropische geneeskunde, diepzeebiologie, paleontologie, vulkanologie, kunstnij- 
verheid, musicologie en koloniale geschiedenis. Tegelijkertijd breidden zich in Nederlandse musea de collecties uit van uit Indonesië afkomstige kunstvoorwerpen en etnografica. De grootste collectie bevond zich in het Rijksmuseum voor Volkenkunde in Leiden.

In de kolonie zelf bleef het uit de achttiende eeuw daterende Bataviaasch Genootschap van Kunsten en Letteren het centrale instituut voor de wetenschappelijke bestudering van Indonesië. Het gaf een Tijdschrift voor Indische Taal-, Land-en Volkenkunde uit en opende een museum aan het Koningsplein in Batavia met onder meer een rijke verzameling etnografische en oudheidkundige voorwerpen en bovendien de grootste bibliotheek van Nederlands-Indië.

\section{Christelijke zending en missie}

De Verenigde Oost-Indische Compagnie had zich niet ingespannen om de christelijke godsdienst te verbreiden onder de Aziatische volkeren waarmee zij in aanraking kwam. Integendeel, zij verbood christelijk zendingswerk in de islamitische gebieden, omdat zij daarvan onrust onder de bevolking verwachtte. Alleen op sommige plaatsen waar zij een door de Portugezen tot het katholicisme bekeerde bevolking aantrof, zoals op Ambon en Ceylon, zorgde zij voor predikanten en kerken ten behoeve van de inheemsen die tot het protestantisme overgingen. Voor het overige dienden de predikanten in het VOCgebied alleen voor de geestelijke verzorging van de Europese protestanten. Alle predikanten stonden in dienst van de Compagnie.

Toen de Nederlandse staat in de plaats van de VOC trad, bleef het gouvernement de predikanten bezoldigen en onder toezicht houden. Op dezelfde voet liet het nu ook katholieke priesters toe ten behoeve van de geestelijke verzorging van katholieke Europeanen. Evenals de VOC bleef ook het gouvernement lange tijd huiverig voor christelijk bekeringswerk onder de Indonesische bevolking, maar het moest deze houding geleidelijk herzien onder druk uit de Nederlandse samenleving.

$\mathrm{Al}$ tegen het eind van de achttiende eeuw was binnen het Europese protestantisme een beweging op gang gekomen voor actieve verbreiding van het geloof in de niet-christelijke wereld. In Nederland leidde dit onder meer tot de oprichting van het Nederlandsch Zendeling-Genootschap in 1797, het Nederlandsch Bijbelgenootschap in 1814 en tientallen andere protestantse zendingsverenigingen omstreeks het midden van de negentiende eeuw. De onder de Nederlandse protestanten opgebloeide zendingsijver bracht de regering ertoe Nederlands-Indië meer voor de zending open te stellen. Naast Nederlandse zendingsverenigingen werden ook enkele buitenlandse toegelaten, zoals de Rheinische Missionsgesellschaft. Alle zendelingen en priesters hadden echter een vergunning van het gouvernement nodig om in een 
bepaald gebied te mogen werken. Het gouvernement gaf zulke vergunningen in hoofdzaak af voor niet-islamitische gebieden in de buitengewesten. Pas in de tweede helft van de eeuw liet het enig zendingswerk op Java toe, maar niet in het streng islamitische Bantam. Evenzo bleven Bali, Lombok en grote delen van Sumatra voor de zending gesloten.

In het begin van de twintigste eeuw ontstond ook onder Nederlandse katholieken een sterke beweging voor verbreiding van het geloof in verre landen, in deze kring niet 'zending' maar 'missie' genoemd. Deze missiebeweging richtte zich zowel op Indonesië als op andere gebieden, zoals Afrika. Het NederlandsIndisch gouvernement dirigeerde de katholieke missionarissen weer voornamelijk naar buitengewesten en zorgde er daarbij voor, dat binnen eenzelfde gebied niet gelijktijdig protestantse en katholieke bekeringsarbeid plaatsvond. Dit gold onder meer voor de Dajaks op Borneo en de Papoea's op NieuwGuinea. Zowel de zending als de missie ondersteunde haar bekeringsactiviteiten met sociale activiteiten zoals onderwijs, ziekenzorg en kinderopvang.

Aldus ontstonden in de negentiende en twintigste eeuw binnen de Indonesische bevolking verscheidene nieuwe christengemeenschappen naast de van vroeger eeuwen daterende protestantse gemeenschap in de ZuidMolukken en die van de katholieken op Flores en Timor. Het eerste gebied waar dit zich voordeed was de Minahasa, de noordoostelijke punt van Celebes. Naar de hoofdstad Menado duidt men de bevolking van dit gebied meestal als 'Menadonezen' aan. Een groot deel van de Menadonezen werd tot het protestantisme bekeerd, terwijl de rest later merendeels tot het katholicisme overging. Het tweede gebied waar het christendom grote aanhang vond was dat van de Bataks op Sumatra, waar de Rheinische Mission in 1862 haar werk begon. Hier ontstond uiteindelijk de grootste protestantse gemeenschap van Indonesië. De komst van de zending ging hier aan de vestiging van het Nederlandse bestuur vooraf; hetzelfde gold voor verschillende andere gebieden, waaronder dat van de Toradja's in Midden-Celebes. De katholieke missie werkte niet alleen in de buitengewesten maar verwierf ook aanhang op Midden-Java, waar zij al omstreeks 1900 was toegelaten. Dit werd het enige gebied in Indonesië waar tijdens het Nederlandse bestuur een aanzienlijk aantal moslims tot het christendom overging.

\section{De bloeitijd van het imperialisme}

De in de vijftiende eeuw begonnen westerse expansie in de niet-Europese wereld bereikte haar hoogtepunt in de loop van de negentiende eeuw. Zeven Europese landen verdeelden bijna het hele grondgebied van Afrika onder elkaar. Alle eilanden in de Stille Oceaan werden Europees of Amerikaans bezit. Ook in Azië rukten de koloniale mogendheden op. Rusland, dat al 
heel Siberië beheerste, breidde zijn gebied naar het zuiden uit en bouwde bovendien een marinebasis aan de Japanse Zee. Groot-Brittannië werd oppermachtig in India na de onderdrukking van een grote opstand die was voortgekomen uit een muiterij van inheemse militairen in dienst van de East India Company. De Britse regering hief de EIC in 1858 op en maakte India tot een kolonie van het Britse rijk; de gouverneur-generaal kreeg de titel van onderkoning en koningin Victoria werd keizerin van India. Intussen breidde Groot-Brittannië zijn macht ook in oostelijke richting uit. Het voerde oorlog met Burma en lijfde dat land tenslotte als een provincie bij India in. Al in 1842 had het China gedwongen tot afstand van Hongkong, terwijl het omstreeks diezelfde tijd greep op Noord-Borneo kreeg. Later breidde het zijn gezag uit over de Maleise vorstendommen op het schiereiland Malakka. Ook Frankrijk vergrootte zijn koloniaal bezit in Azië. Tussen 1859 en 1893 veroverde het alle delen van Indochina, waarna in Zuid-Azië alleen Siam (Thailand) nog als onafhankelijk land overbleef. Intussen kwamen Duitsland en Italië als nieuwe koloniale mogendheden op. Duitsland nam in 1884 bezit van een deel van noordoostelijk Nieuw-Guinea, waarna Groot-Brittannië een deel van zuidoostelijk Nieuw-Guinea onder zijn gezag stelde.

Het oplevende imperialisme beïnvloedde de Nederlandse houding tegenover Indonesië. In de ogen van velen leek het nu een historische wet, dat de blanke volkeren de rest van de wereld zouden overheersen. In dit kader gingen de Nederlanders het vanzelfsprekend vinden, dat de Indonesische archipel aan Nederland toekwam. Strikt genomen strekte de Nederlandse soevereiniteit zich daar alleen uit over de rechtstreeks bestuurde gebieden en de 'leenroerige rijken', nu gewoonlijk aangeduid als 'zelfbestuursgebieden' (zie p. 48). De rest van de archipel, met inbegrip van de 'bondgenootschappelijke rijken', maakte formeel geen deel van Nederlands-Indië uit. Die 'bondgenootschappelijke rijken', ook wel 'protectoraatslanden' genoemd, waren immers vazalstaatjes die de Nederlandse soevereiniteit niet uitdrukkelijk aanvaard hadden. In de tweede helft van de eeuw raakten deze onderscheidingen in het vergeetboek. Ook de 'bondgenootschappelijke rijken' beschouwde men nu als tot de kolonie behorende zelfbestuursgebieden. Meestal ging men nog verder en zag men als grenzen van de kolonie alleen nog de grenzen met die gebieden die aan andere kolonisatoren toebehoorden, zoals Noord-Borneo en Oost-Timor. Zo werd Nederlands-Indië nu weergegeven in de atlassen, zo stond het op de wandkaarten in de schoollokalen.

Ook het gouvernement in Batavia wilde de volkenrechtelijke situatie aldus opvatten en legde dit in 1890 aan de minister van koloniën voor. Deze antwoordde dat verscheidene gebieden in de archipel, onder meer op Sumatra en op Celebes, nog steeds geen deel uitmaakten van Nederlands-Indië, maar dat 'de natuur der zaken' meebracht dat Nederland zijn gezag naar die gebieden zou uitbreiden zodra de tijd daartoe gekomen was en dat de Nederlandse 
positie in de archipel aangerand zou worden als een andere mogendheid haar gezag daar zou willen doen gelden.

Overigens meende Nederland al op veel gebieden in de archipel recht te kunnen doen gelden op grond van territoriale aanspraken van vorstendommen die zich aan het Nederlandse oppergezag onderworpen hadden. Meermalen maakten die echter aanspraak op gebied dat niet binnen hun machtsbereik viel. Zo pretendeerden sommige vorstendommen aan de kusten van Sumatra, Borneo en Celebes te heersen over in het binnenland wonende Bataks, Dajaks en Toradja's, zonder dat zij daarover werkelijk gezag uitoefenden. Een kras voorbeeld van een territoriale aanspraak die voornamelijk op grootspraak berustte was die van het sultanaat Tidore op de kustgebieden van westelijk Nieuw-Guinea. Op grond hiervan nam het gouvernement in 1828 formeel bezit van de gehele westelijke helft van Nieuw-Guinea, een gebied ruim elf maal zo groot als Nederland. Gedurende het grootste deel van de negentiende eeuw bestond de inbezitname van Nieuw-Guinea uit niet meer dan de plaatsing van Nederlandse wapenborden hier en daar langs de kust.

Atjeh was een geval apart. Tot 1873 vormde het onbetwist een soevereine staat. Daarom liet Nederland toen nog een formele oorlogsverklaring voorafgaan aan zijn inval in deze staat. Vervolgens proclameerde Nederland in 1874 het Atjehse grondgebied (waarvan het nog geen duizendste deel bezet had) tot deel van Nederlands-Indië. Met deze eenzijdige daad veranderde het niet alleen buitenland in binnenland maar ook verdedigers in aanvallers en omgekeerd. Het beschouwde de Atjehers die zich tegen de inval te weer stelden voortaan als opstandelingen tegen het Nederlandse gezag, terwijl omgekeerd de koloniale strijdkrachten die het gebied waren binnengetrokken als verdedigers van dat gezag golden.

Maar ook de term 'opstandelingen' raakte op de achtergrond, want Nederland benaderde de Atjeh-oorlog meer met morele begrippen dan met politieke. Het onderscheidde gewoonlijk twee soorten Atjehers: 'kwaadwillende' en 'goedwillende'. Kwaadwillende Atjehers waren in feite degenen die probeerden hun land tegen de Nederlandse invallers te verdedigen; goedwillende waren zij die met die invallers wilden samenwerken. Militaire operaties tot onderdrukking van het verzet werden dan ook steevast als 'strafexpedities' of 'tuchtigingen' aangeduid, verzetsgroepen heetten 'benden' en verzetsleiders 'bendeleiders'. Ook in de rest van de archipel behandelde Nederland conflicten met de inheemse bevolking bij voorkeur in termen van misdaadbestrijding. Orang djahat (slecht mens, boef) was een vaste aanduiding voor ieder die om politieke redenen verzet pleegde.

Hoe weinig Nederland twijfelde aan zijn moreel en volkenrechtelijk gelijk inzake Atjeh wordt geïllustreerd door het feit, dat de regering zich in 1877 tijdens de Turks-Russische oorlog gerechtigd achtte een nota tot de regering van Turkije te richten waarin de Turken werd verweten, dat zij zich in die oorlog 
aan onmenselijke handelingen schuldig maakten.

De meer imperialistische geest van Nederland bleek ook uit reacties op het optreden van het koloniale leger. De mislukking van de eerste expeditie tegen Atjeh in 1873 veroorzaakte grote opschudding onder het Nederlandse publiek. De kritiek van sommigen op deze onderneming werd overstemd door een golf van patriotisme. Gespannen volgde men daarna de tweede expeditie, die de smet op het Nederlandse blazoen moest uitwissen. Toen het bericht binnenkwam dat de kraton van Atjeh veroverd was, ging in Nederland de vlag uit en trokken mensenmenigten zingend door de straten. Ook in de volgende decennia bleef het oorlogsnieuws uit Indonesië de nationale gevoelens beroeren. Frustratie over tegenslagen wakkerde daarbij het patriotistische vuur niet minder aan dan trots over successen. De martiale stemming bereikte hoogtepunten in 1894 en 1896, in reactie op de tegenslagen die men betitelde als 'het verraad van Lombok' (zie p. 124) en 'het verraad van Teukoe Oemar' (zie p. 118). Beide gebeurtenissen ervoer men in Nederland als een nationale ramp. Zowel hier als in Indonesië gaven Nederlanders ongekende blijken van offervaardigheid maar ook van wraakzucht en moordlust. De militairen van het koloniale leger werden als helden vereerd. Beroepsofficieren leverden actieve bijdragen aan de nationalistische agitatie. Deze agitatie was ongewoon voor het Nederlandse volk, dat geen militaristische traditie kende, maar niet ongewoon in vergelijking met het chauvinisme dat zich in datzelfde tijdsgewricht in Duitsland, Frankrijk en Groot-Brittannië manifesteerde.

Het martiale nationalisme leefde veel sterker onder het protestantse dan onder het katholieke volksdeel (dat drie eeuwen lang was achtergesteld en zich juist nu begon te emanciperen) en ging bovendien hand in hand met een stijgende verheerlijking van het koningshuis, het Huis van Oranje. Koning Willem III, die weinig belang in koloniale zaken gesteld had, was in 1890 gestorven en opgevolgd door zijn in 1880 geboren dochter Wilhelmina; tot haar achttiende verjaardag nam haar moeder haar functie waar. De beide koninginnen toonden zich intens betrokken bij het koloniale leger. De nationalistische ideologie, die uitdrukking vond in de leus 'Voor God, Nederland en Oranje', maakte de jeugdige Wilhelmina tot haar centrale symbool.

Het groeiende nationalisme vond zijn weerslag in de politiek. In 1873 hadden sommige politici en persorganen scherpe kritiek geleverd op de oorlog tegen Atjeh, maar de meesten stelden hun opstelling later bij. Een treffend voorbeeld daarvan biedt Abraham Kuyper, de leider van de in die periode opgekomen Anti-Revolutionaire Partij, de eerste nationale protestants-christelijke partij. In 1875 noemde hij de oorlogsverklaring aan Atjeh nog een onrechtvaardige daad. In 1890 pleitte hij nog voor afstand van heel Borneo aan Groot-Brittannië en van heel Nieuw-Guinea aan Duitsland. Maar in 1896 sprak hij van een 'heilig besef' van de Nederlandse roeping om het koloniale bezit 'af te ronden' en om ook aan Atjeh de zegeningen van veiligheid en orde te brengen. 


\section{Groeiende betekenis van Indonesië voor het Nederlandse zelfbewustzijn}

Terwijl men in Nederland in het midden van de negentiende eeuw slechts in beperkte kring belangstelling voor Indonesië had, was die belangstelling tegen het einde van de eeuw sterk toegenomen. Dit kwam niet alleen door de commoties over Lombok en Atjeh maar onder meer ook door Multatuli, door de zendingsverenigingen, door de vlottere verbindingen, door de opmars van de particuliere ondernemingen en door het snel groeiende aantal in Indonesië werkende Nederlanders. In Nederland was nu een nationaal zelfbewustzijn ontstaan waarin het koloniale bezit een fundamentele plaats innam. Hierbij ging het om veel meer dan alleen het directe belang van de koloniën voor de Nederlandse economie.

Deze betekenis van het koloniale bezit en vooral het bezit van Indonesië voor het nationale zelfbewustzijn betrof in de eerste plaats de internationale politieke en economische status van Nederland. Het land bevond zich op dit punt in een andere positie dan bijvoorbeeld Frankrijk en Groot-Brittannië, die nu eenmaal grote mogendheden waren, ook zonder hun koloniën. Nederland was daarentegen een klein land dat geen actieve rol in de Europese politiek speelde, maar dank zij zijn overzeese imperium de derde plaats op de ranglijst van de koloniale mogendheden bezette en een vooraanstaande positie in de wereldeconomie innam.

De psychologische betekenis van Indonesië voor Nederland was bovendien veel groter dan die van bijvoorbeeld India voor Groot-Brittannië of Indochina voor Frankrijk, omdat deze mogendheden nog vele andere gebieden in verschillende delen van de wereld beheersten, terwijl het Nederlandse imperium naast Indonesië alleen Suriname en de Nederlandse Antillen omvatte. Die betekenis was ook groter omdat de Nederlandse dominantie in Indonesië al ruim een eeuw langer bestond dan de Britse in India en twee eeuwen langer dan de Franse in Indochina.

Het belang van Indonesië voor het Nederlandse zelfbewustzijn hield verder verband met de manier waarop men in Nederland tegen de eigen historie aankeek. In het midden van de zeventiende eeuw had het land op een toppunt van kracht en creativiteit gestaan, maar anderhalve eeuw later was het tot armoede en onbeduidendheid vervallen. Dat leidde in de negentiende eeuw tot gevoelens van minderwaardigheid tegenover het verleden. Aan het eind van die eeuw kreeg Nederland juist door zijn ontplooiing in Indonesië een hogere dunk van zichzelf. Men meende daar weer 'iets groots te verrichten', omdat men met slechts enkele tienduizenden Nederlanders de leiding had over een bevolking van bijna veertig miljoen, die men inschakelde in de wereldeconomie en binnenleidde in de moderne beschaving.

De trots op de Nederlandse prestaties ging gewoonlijk vergezeld van een superioriteitsgevoel tegenover de Indonesische bevolking. Veel Nederlanders 
zagen iedere fabriek, ieder ziekenhuis, iedere spoorbrug in Indonesië als een bewijs van eigen kunnen en eigen onmisbaarheid. Zij vergaten daarbij, dat Nederland zelf de inheemse bevolking stelselmatig uit alle leidende functies weerde, zodat deze geen gelegenheid kreeg haar capaciteiten te tonen. Alleen op het terrein van het bestuur werden Indonesiërs tot hogere functies toegelaten, maar ook daar was hun rol meestal beperkt tot de uitvoering van beleid dat door Nederlanders bepaald werd.

Ook los van superioriteitsgevoelens en los van de mogelijkheid door Indonesië rijk te worden, had dat land voor veel Nederlanders een bijzondere waarde. Omdat aan de inheemse bevolking de toegang tot leidende functies ontzegd werd, vonden individuele Nederlanders daar veel ruimere mogelijkheden dan in eigen land. Jonge mannen kregen als bestuursambtenaar, als militair, als planter of als ingenieur vaak verantwoordelijkheden te dragen die zij in Nederland nooit, of alleen tegen het eind van hun loopbaan, zouden bereiken. Maar ook velen die in Nederland bleven voelden de band met Indonesië als een verruiming van hun horizon. Dat land had immers de afmetingen van een werelddeel, het herbergde een bonte verscheidenheid van culturen, het had gebergten en vulkanen en een fascinerende tropische fauna en flora. Het bezit van Indonesië leek daarom aan Nederland een allure te geven die dit kleine, vlakke land uit zichzelf niet bezat.

Zoals al eerder aangegeven, verschafte Indonesië ook een extra dimensie aan de Nederlandse wetenschap. Zowel dank zij het wetenschappelijk onderzoek als dank zij de activiteiten van het gouvernement en de particuliere ondernemingen beschikte men in Nederland over zeer veel kennis omtrent Indonesië, maar die kennis was over tal van instellingen en plaatsen verspreid. Daarom werd in 1910 het Koloniaal Instituut opgericht als centraal instituut voor wetenschap, onderwijs, handel en industrie met betrekking tot de Nederlandse koloniën. Het instituut kreeg een imposant gebouw in Amsterdam, dat in 1926 door koningin Wilhelmina werd geopend en dat een stenen uitdrukking vormde van de overtuiging dat het Nederlandse koloniale rijk nog lang in stand zou blijven.

\section{Ethische politiek}

In de loop van de negentiende eeuw hadden verschillende critici van het koloniaal beleid, zoals Van Hoëvell en Multatuli, het immoreel genoemd om de belangen van de inheemse bevolking op te offeren aan de welvaart van Nederland, maar pas tegen het eind van de eeuw werd dit in ruimere kring erkend. De oude formule, dat de koloniën er zijn voor het moederland maar dat het moederland er niet is voor de koloniën, klonk velen nu te cynisch. Profijt trekken van het bezit van koloniën leek alleen te verantwoorden als de 
koloniën er ook zelf baat bij zouden hebben. Soortgelijke gedachten leefden eveneens in andere kolonie-bezittende landen. Juist nu men het als een historische wet beschouwde, dat de blanke volkeren de rest van de wereld zouden overheersen, zochten velen de rechtvaardiging daarvan in een roeping om aan de niet-blanke volkeren de zegeningen van de westerse beschaving te brengen. In Frankrijk sprak men in dat verband van een 'mission civilisatrice', in Groot-Brittannië soms van 'the white man's burden'.

Het beginsel dat het koloniaal beleid zich bovenal zou moeten richten op het belang van de gekoloniseerde bevolking, vond in Nederland onder meer aanhang onder veel deelnemers aan de opleiding voor de Indische bestuursdienst. Het vond ook meer en meer ingang in de uitspraken van politici. De Anti-Revolutionaire Partij verklaarde in 1879 in haar beginselprogram, 'dat de baatzuchtige neiging van onze staatkunde, om de koloniën voor de kas van den Staat of van den particulier te exploiteren, dient plaats te maken voor een staatkunde van zedelijke verplichting'. Abraham Kuyper lichtte daarbij toe, dat zulk een staatkunde een 'stelsel van voogdij' inhield en tegenover de gekoloniseerde bevolking de verplichting meebracht om haar op te voeden, om haar bezit te haren bate verstandig te beheren, en om haar 'in de toekomst, zoo God dit wil, het innemen van een zelfstandiger positie mogelijk te maken'.

De Nederlandse socialisten keerden zich van begin af aan tegen de uitbuiting van de Indonesische bevolking en tegen het gebruik van geweld tot uitbreiding van de Nederlandse macht. Zij vergeleken de strijd van de Atjehers met die van de Nederlanders tegen de Spanjaarden en die van de ZuidAfrikaanse Boeren tegen de Britten; zij werden daarom door Nederlandse nationalisten voor landverraders uitgemaakt. Hun invloed op het beleid viel aanvankelijk te verwaarlozen, maar nam toe door H.H. van Kol, die in 1897 tot parlementslid voor de Sociaal-Democratische Arbeiders Partij (SDAP) werd gekozen, nadat hij veertien jaar in Indonesië als ingenieur in dienst van het gouvernement gewerkt had. Hij vertegenwoordigde de SDAP twaalf jaar in de Tweede Kamer en daarna nog eens twaalf jaar in de Eerste Kamer. In zijn persoon had het parlement voor het eerst sinds Van Hoëvell weer een deskundig, principieel en welsprekend criticus van het koloniaal beleid, ook al waren er in de loop der jaren wel meer parlementsleden met deskundigheid inzake Indonesië geweest. Van Kol vond vaak de Anti-Revolutionairen tegenover zich bij zijn strijd tegen wantoestanden zoals mishandeling van contractkoelies en wreed optreden van het koloniale leger, maar in zijn omschrijving van de algemene doelstellingen van het koloniaal beleid hanteerde hij vrijwel dezelfde begrippen als Kuyper in 1879 gedaan had.

Een andere bekende criticus was C.Th. van Deventer, die eveneens een tijd lang in Indonesië gewerkt had, onder meer als advocaat in Semarang. Na terugkeer in Nederland publiceerde hij in 1899 in het tijdschrift De Gids een lang artikel onder de titel 'Een eereschuld'. Hij zette uiteen hoe het Nederlands- 
Indische gouvernement uit geldgebrek allerlei noodzakelijke uitgaven voor bijvoorbeeld onderwijs en openbare werken achterwege moest laten. Ook vermeldde hij dat een kwart van het inkomen van de inheemse bevolking van Java aan belastingen opging, zodat de inheemse gezinnen van ongeveer tachtig gulden per jaar moesten rondkomen. De armlastigheid van het gouvernement zag hij vooral als een gevolg van de batig-slot-politiek, waardoor tussen 1831 en 1877 in totaal 823 miljoen gulden naar de Nederlandse schatkist overgemaakt was. Hij steunde daarom een voorstel van Van Kol om aan Nederlands-Indië in ieder geval dat deel van de koloniale baten terug te geven dat was ontvangen sinds het Nederlandse parlement met ingang van 1867 zelf de begroting van Nederlands-Indië vaststelde. Dit betrof een bedrag van 187 miljoen gulden; hij berekende dat Nederland dit zonder grote problemen zou kunnen opbrengen. Van Deventer kreeg veel waardering voor zijn artikel, maar regering en parlement namen zijn voorstel niet over, afgezien van een eenmalige kwijtschelding van 40 miljoen gulden van de Nederlands-Indische schuld in 1905. In datzelfde jaar werd Van Deventer parlementslid voor een links-liberale partij, de Vrijzinnig Democratische Bond. Zowel in de Tweede als later in de Eerste Kamer bleef hij zich onder meer inzetten voor verhoging van de welvaart en uitbreiding van het onderwijs voor de inheemse bevolking van Indonesië.

Van Deventer had de term 'ereschuld' overgenomen van zijn vriend P. Brooshooft, hoofdredacteur van het Semarangse dagblad De Locomotief, die al jarenlang pleitte voor ingrijpende wijzigingen in het koloniaal beleid, zoals verlaging van de landrente en afschaffing van de herendiensten, het zoutmonopolie en de opiumpacht. In 1901 publiceerde Brooshooft een samenvatting van zijn ideeën in een brochure getiteld De ethische koers in de koloniale politiek.

Eveneens in 1901 kwam in Nederland een nieuw kabinet tot stand, geleid door Abraham Kuyper. De troonrede bevatte dat jaar een passage over Nederlands-Indië waarin onder meer gezegd werd, dat Nederland verplicht was 'geheel het regeringsbeleid te doordringen van het besef dat Nederland tegenover de bevolking dezer gewesten een zedelijke roeping heeft te vervullen'.

'Ethische politiek' werd in de eerste decennia van de twintigste eeuw een veel gebruikte term voor koloniaal beleid dat geacht werd het belang van de inheemse bevolking ten goede te komen. Welke inhoud men aan die term gaf, hing ervan af hoe men dat belang zag. Voor de één betekende het in de eerste plaats vrij baan voor de christelijke zending, voor een ander vooral versterking van de economische positie van de inheemsen, voor een derde meer toegang van inheemsen tot het onderwijs en voor een vierde een grotere inheemse rol in het bestuur. Een ander verschil was, dat sommigen het in het belang van de inheemsen achtten om zo snel mogelijk de westerse cultuur en beschaving over te nemen, terwijl anderen juist meenden dat het eigen karakter van de inheemse culturen zo veel mogelijk behouden moest blijven. 
Verder plakte men het etiket 'ethische politiek' op allerlei maatregelen die evenzeer of zelfs in de eerste plaats de belangen dienden van de Europese ingezetenen, de westerse ondernemingen en het koloniale bestuur. Dat gold bijvoorbeeld voor de aanleg van wegen en irrigatiewerken en voor de bestrijding van besmettelijke ziekten, maar eveneens voor het onderwijs aan inheemsen, daar de koloniale samenleving in de twintigste eeuw niet meer kon functioneren zonder inheems personeel met enige kennis van lezen, schrijven, rekenen en de Nederlandse taal. De begrippen 'voogdij' en 'ethische politiek' kregen daardoor ook de functie van een legitimatie van de voortgaande koloniale overheersing. Weliswaar hield het begrip 'voogdij' eigenlijk in dat die overheersing een tijdelijk karakter had, maar deze gedachte leefde bij de Nederlanders rond de eeuwwisseling niet sterk. Ook Van Kol meende toen dat beëindiging van het Nederlands bestuur voorlopig alleen schadelijk voor de inheemse bevolking zou zijn. Men sprak wel over bevordering van de zelfstandigheid van Indië als een doel op langere termijn, maar ook dan leek behoud van een band met Nederland vanzelfsprekend.

\section{Voortzetting en beëindiging van de Atjeh-oorlog}

Sinds 1885 verschanste Nederland zich in Atjeh achter de geconcentreerde linie rondom Koetaradja, terwijl het verder in de Atjehse onderhorigheden nog enkele kustplaatsen bezet hield. Wat de rest van Atjeh betreft, moest de Nederlandse marine alle invoer en uitvoer blokkeren. De geconcentreerde linie werd veelvuldig aangevallen en de marineblokkade lukte niet helemaal, maar toch leek de Nederlandse positie vooruit te gaan. De twee voornaamste leiders van het Atjehse verzet overleden. Ook deed de traditionele onderlinge verdeeldheid van de Atjehers zich weer gelden. Sommige plaatselijke machthebbers zochten Nederlandse steun tegen hun rivalen. Het gouvernement gebruikte geld en geschenken om Atjehse hoofden naar zich over te halen. Hoewel Nederland het sultanaat had afgeschaft en de inmiddels volwassen geworden sultan dus niet erkende, probeerde het toch een akkoord met hem te sluiten tot herstel van het sultanaat onder Nederlands gezag. In 1893 liep een bekende guerrillaleider, Teukoe Oemar, naar het Nederlandse kamp over. Nederland hoopte nu de overhand te kunnen krijgen door Atjehers met Atjehers te bestrijden. Men gaf Teukoe Oemar de eretitel 'groot oorlogsleider' en het bevel over tweeduizend man, waaronder een eigen keurkorps, betaald en van moderne wapens voorzien door het gouvernement. Daarmee beheerste hij voortaan de gewesten rondom Koetaradja.

Dit beleid ondervond kritiek, onder meer van de gouvernementsadviseur Snouck Hurgronje, die al in 1892 een uitvoerig rapport over de Atjehse samenleving had uitgebracht. Hij was tegen de defensieve formule van de gecon- 
centreerde linie, tegen onderhandelingen met de sultan en tegen een strategie gebaseerd op het gebruik van Atjehse hulptroepen. Naar zijn mening kon men de Atjeh-oorlog alleen winnen door het koloniale leger offensief in te zetten. J.B. van Heutsz, een officier die al driemaal in Atjeh had gediend, verkondigde in diverse publicaties een soortgelijke zienswijze.

In 1896 wilde het Nederlandse bestuur Teukoe Oemar inschakelen voor een veldtocht ten zuidoosten van Koetaradja. Om hem hiertoe over te halen stelde het hem een grote hoeveelheid wapens en munitie ter beschikking. Maar plotseling schaarde Teukoe Oemar zich nu weer aan de kant van het Atjehse verzet. Bijna alle andere Atjehse leiders die Nederland gesteund hadden volgden zijn voorbeeld. Dit betekende een dramatische omslag in de militaire en politieke situatie. De Nederlandse macht in Atjeh leek weer teruggebracht tot de positie die zij twintig jaar eerder innam. Men vreesde zelfs een grote aanval op de Nederlandse enclave.

Het gouvernement in Batavia stuurde onmiddellijk troepen naar Koetaradja. Dank zij de schepen van de KPM was het garnizoen binnen twee weken al versterkt met tweeduizend man. Ook Van Heutsz behoorde tot de naar Atjeh gedirigeerde officieren. In felle gevechten slaagde men er in, de Nederlandse positie in de enclave te consolideren. Teukoe Oemar week met zijn strijders uit naar de bergen. De Nederlandse strijdmacht bereikte een sterkte van negenduizend man, voor drievijfde bestaande uit Indonesiërs zoals Javanen, Molukkers en Menadonezen.

Tegen het eind van het jaar begon het koloniale leger een groot offensief in de Atjeh-vallei. Daarbij ging het anders te werk dan bij vroegere veldtochten. Het behield zijn greep op elk stuk veroverd gebied door onophoudelijk patrouilleren met kleine zelfstandige eenheden. Deze eenheden, in hoofdzaak bestaande uit Indonesische soldaten onder een Europese onderofficier, blonken uit in contraguerrilla-oorlogvoering. Eind 1897 was het leger heer en meester in de vallei, maar die was intussen grotendeels verwoest en ontvolkt. Dorpen waren platgebrand, oogsten waren vernield, tienduizenden bewoners waren weggetrokken, deels naar de kustgewesten, deels naar het schiereiland Malakka. Snouck Hurgronje was ontsteld over de door het leger aangerichte vernielingen; hij had hard optreden tegen het verzet juist willen combineren met een milde behandeling van de burgerbevolking.

Overigens had de verovering van de Atjeh-vallei niet tot uitschakeling van de verzetsleiders geleid: die waren naar andere delen van Atjeh uitgeweken. De regering concludeerde nu, dat men ook de Atjehse onderhorigheden militair zou moeten onderwerpen. Men vertrouwde deze taak toe aan Van Heutsz, die in 1898 tot gouverneur van Atjeh werd benoemd en al spoedig tot generaal werd bevorderd. De troepensterkte werd tijdelijk opgevoerd tot bijna elfduizend man, maar na anderhalf jaar teruggebracht tot zesduizend man, zoals in de tijd van de geconcentreerde linie. Hoewel Van Heutsz vroeger had gezegd 
dat Nederland de Atjeh-oorlog in één jaar zou kunnen winnen, gebruikte hij vijf jaar voor de onderwerping van de Atjehse onderhorigheden langs de noordoostkust en de westkust. Dit gebeurde in een reeks veldtochten die hij grotendeels persoonlijk leidde en waarbij Snouck Hurgronje hem meermalen vergezelde. Hij liet de verzetsleiders onafgebroken achtervolgen en wist de meesten van hen uit te schakelen. Teukoe Oemar sneuvelde in 1899; een deel van diens aanhang zette de strijd voort onder leiding van zijn weduwe Tjoet Nja Din, maar moest zich steeds dieper in de bergen terugtrekken. In 1903 onderwierp de sultan zich; het gouvernement gaf hem een maandelijkse toelage en stond hem toe zich als ambteloos burger in Koetaradja te vestigen. Vier jaar later werd hij alsnog verbannen.

De verzetsstrijders kregen in dit tijdvak minder steun van de bevolking, omdat deze nu beter werd behandeld dan tijdens de strijd in de Atjeh-vallei. De koloniale militairen onthielden zich in de regel van het verbranden van dorpen en oogsten. Niettemin wekte hun optreden soms kritiek in eigen kring. In 1903 klaagde een Nederlandse kapitein bij de legercommandant (de opperbevelhebber van het koloniale leger) over een reeks kwalijke praktijken, zoals het zonder waarschuwing doorschieten van woningen, het doden van ongewapende vluchtelingen, het afmaken van krijgsgevangenen en het pijnigen en uithongeren van gevangenen om inlichtingen los te krijgen. Hij verwees daarbij ook naar wat hij van andere officieren in Atjeh gehoord had. Bevriende Nederlandse politici zonden een anonieme kopie van deze beschuldigingen aan de minister van koloniën, die daarop om een onderzoek vroeg. Van Heutsz gaf hieraan gevolg door zijn officieren opdracht te geven tot een geheim onderzoek en daarbij alvast te laten weten, dat hij zelf weinig geloof aan de beschuldigingen hechtte, dat hij geen verhalen van horen zeggen zou accepteren, dat men feiten en namen zou moeten noemen voorzover er werkelijk ongeoorloofde daden gepleegd waren, dat de schuldigen dan streng gestraft zouden worden, en tenslotte dat de officieren onder elkaar of in gezelschap niet 'allerlei praatjes' moesten vertellen waarvan lasteraars misbruik maakten om de goede naam van het leger te besmetten. Het op deze voet opgezette onderzoek leverde niets op.

Enkele delen van de Atjehse onderhorigheden had Van Heutsz in de periode 1898-1903 nog niet kunnen onderwerpen, namelijk de hooggelegen valleien diep in het binnenland, waarvan de schaarse bevolking het Atjehse verzet placht te steunen. In het voorjaar van 1904 zond hij hier een strafexpeditie heen onder leiding van overste G.C.E. van Daalen. De bergbewoners vielen het leger niet aan, maar verschansten zich in hun versterkte dorpen. Van Daalen liet vrijwel alle bewoners van elf dorpen massaal afmaken, bijna drieduizend mannen, vrouwen en kinderen, samen ruim een kwart van de bergbevolking. Hierbij vielen aan Nederlandse kant zesentwintig doden.

Midden 1904 ging Van Heutsz voor korte tijd naar Nederland, waar hij 
feestelijk werd ingehaald als de overwinnaar van Atjeh. Spoedig daarna volgde zijn benoeming tot gouverneur-generaal. Later in het jaar wekten berichten over Van Daalen's strafexpeditie enige opschudding in het Nederlandse parlement. Een katholieke afgevaardigde, zelf zoon van een generaal uit het koloniale leger, sprak van 'een moordgeschiedenis' en 'beulenwerk', maar de regering hield Van Heutsz en Van Daalen de hand boven het hoofd.

Als gouverneur-generaal benoemde Van Heutsz vervolgens Van Daalen tot zijn opvolger als gouverneur van Atjeh. Deze maakte zich zowel bij Atjehers als Nederlanders onbemind. In het parlement werd zijn optreden onder meer aangevallen door een liberale afgevaardigde die zelf kapitein in Atjeh geweest was. Een andere Atjeh-officier nam in 1907 ontslag uit de dienst en publiceerde in een Nederlandse krant onder pseudoniem een lange reeks artikelen onder de titel 'Hoe beschaafd Nederland in de twintigste eeuw vrede en orde schept op Atjeh'. Hij beschuldigde het leger van het bedrijven van terreur en gaf daarvan gruwelijke bijzonderheden. Het door deze publicatie veroorzaakte schandaal leidde er onder meer toe, dat Van Heutsz wijzigingen gelastte in het Atjeh-beleid en dat Van Daalen ontslag nam. Overigens zuiverde een door de legercommandant ingesteld onderzoek Van Daalen bijna geheel van de beschuldigingen in de pers. Hij kon zijn militaire loopbaan dan ook voortzetten en werd uiteindelijk zelf legercommandant.

De Atjeh-oorlog had geen duidelijk slot. Tijdens het gouverneurschap van Van Heutsz (1898-1904) was er een eind gekomen aan het grote verzet, maar de guerrilla van verspreide groepen ging nog lang door. Tjoet Nja Din werd in 1905 gevangen genomen; de laatste actieve verzetsgroep werd in 1914 uitgeschakeld.

De gouverneurs die Van Daalen opvolgden voerden een meer op verzoening gericht beleid. Het burgerlijk bestuur kreeg een belangrijker rol. Het eigenlijke Atjeh stond onder rechtstreeks bestuur, de onderhorigheden behielden zelfbestuur. Vooral aan de noordoostkust trad enig economisch herstel in. Al onder Van Heutsz was door dat gebied een trambaan aangelegd die aansloot op het spoorwegnet van Deli. De voor 1873 welvarende Atjeh-vallei kwam echter onder het koloniale bestuur de tijdens de oorlog geleden schade nooit meer te boven.

In het tijdvak 1873-1914 zijn in Atjeh aan Nederlandse kant 2009 militairen gesneuveld of aan hun verwondingen bezweken, terwijl er 10.500 aan ziekten overleden zijn. Aan Atjehse kant lag het aantal dodelijke slachtoffers vermoedelijk boven de 70.000. Met inbegrip van de 25.000 omgekomen dwangarbeiders heeft de Atjeh-oorlog dus ruim honderdduizend mensenlevens gekost. 


\section{De Korte Verklaring}

De Verenigde Oost-Indische Compagnie placht de aan haar onderhorige gebieden, voor zover zij die niet rechtstreeks bestuurde, te onderscheiden in 'leenroerige rijken' en 'bondgenootschappelijke rijken' (zie p. 48). Alleen de eerste hadden haar oppergezag formeel aanvaard en behoorden daarom tot haar grondgebied, de tweede hadden dat niet. Nadat de Nederlandse staat in de plaats van de VOC was getreden, raakte dit onderscheid geleidelijk in het vergeetboek (zie p. 110). Nederland ging de gebieden uit beide categorieën als delen van de kolonie beschouwen en duidde ze allemaal als zelfbestuursgebieden aan.

Tot in de tweede helft van de negentiende eeuw werd de verhouding van deze gebieden tot de Nederlandse staat bij beide categorieën geregeld door overeenkomsten, deels nog daterend van de VOC. Omstreeks 1870 ging Nederland ertoe over, nieuwe regelingen voor gebieden met zelfbestuur niet meer te gieten in de vorm van tweezijdige overeenkomsten, maar van eenzijdige verklaringen, af te leggen door de gezagsdragers van die gebieden. Het paste deze nieuwe vorm onder meer toe in de eerste fase van de Atjeh-oorlog. Verscheidene Atjehse hoofden die het Nederlandse oppergezag aanvaardden dienden toen een verklaring van achttien artikelen te ondertekenen, waarin hun verplichtingen nauwkeurig werden uitgespeld.

Van Heutsz en Snouck Hurgronje vonden deze verklaringen veel te uitvoerig. Hun hoofdbezwaar was dat telkens met de hoofden overleg zou moeten plaatsvinden over de ondertekening van nieuwe verklaringen, wanneer het gouvernement het nuttig zou vinden de regeling aan nieuwe omstandigheden aan te passen. Zij stelden daarom voor over te gaan op een systeem van zeer korte verklaringen, die weinig meer zouden inhouden dan een onvoorwaardelijke aanvaarding van het Nederlandse oppergezag. Na uitvoerig overleg tussen Batavia en Den Haag stemde de regering in 1900 hiermee in. Zij stelde het volgende uniforme model voor de Korte Verklaring vast:

Ik ondergeteekende ..., bestuurder van het landschap ..., verklaar:

ten eerste:

dat het landschap ... een gedeelte uitmaakt van Nederlandsch-Indië en derhalve staat onder de heerschappij van Nederland; dat ik mitsdien steeds getrouw zal zijn aan Hare Majesteit de Koningin der Nederlanden en aan Zijne Excellentie den Gouverneur-Generaal als Hoogstderzelver vertegenwoordiger, uit wiens handen ik het bestuur over het landschap ... aanvaard;

ten tweede:

dat ik mij in geenerlei staatkundige aanrakingen zal stellen met vreemde mogendheden, zullende de vijanden van Nederland ook mijne vijanden, de vrienden van Nederland ook mijne vrienden zijn; ten derde: 
dat ik zal nakomen en handhaven alle regelingen, die met betrekking tot het landschap ... door of namens de Koningin der Nederlanden dan wel den Gouverneur-Generaal van Nederlandsch-Indië of diens vertegenwoordiger zijn of zullen worden vastgesteld of toepasselijk verklaard en dat ik in het algemeen alle bevelen zal opvolgen, die mij door of namens den Gouverneur-Generaal of diens vertegenwoordiger zijn of zullen worden gegeven.

Bij deze verklaring hoorde nog een door de gouverneur-generaal te ondertekenen 'akte van bevestiging' die als volgt luidde:

Deze verklaring is goedgekeurd en bekrachtigd op den ..., zijnde daarmede tevens ... erkend en bevestigd als bestuurder van het landschap ...

De formulering van de Korte Verklaring was zo kortaf dat sommigen meenden, dat de daarin genoemde gebieden onder rechtstreeks bestuur kwamen te staan. De formule was echter wel degelijk bestemd voor zelfbestuursgebieden. Snouck Hurgronje had deze formule in hoofdzaak voor nieuwe gevallen bedoeld, maar het gouvernement liet in de eerste decennia van de twintigste eeuw bijna alle zelfbestuurders (enige honderden) de Korte Verklaring ondertekenen, meestal op een voorgedrukt formulier. Slechts voor een klein aantal gebieden, voornamelijk in Midden-Java en Oost-Sumatra, bleef de verhouding voorlopig nog op een overeenkomst berusten. Voor alle andere trad de Korte Verklaring in de plaats van de bestaande overeenkomsten, ook met gebieden zoals Ternate waarvoor al sinds eeuwen een regeling in verdragsvorm gold. De figuur van de 'bondgenootschappelijke rijken' behoorde nu definitief tot het verleden.

\section{Afronding van het koloniale rijk}

In 1873 waren er naast Atjeh nog verscheidene andere gebieden in de Indonesische archipel die het Nederlandse oppergezag niet aanvaard hadden. In de daarop volgende veertig jaar bracht Nederland al die gebieden, voorzover ze niet aan andere kolonisatoren toebehoorden, goedschiks of kwaadschiks onder zijn gezag. Als gevolg daarvan omvatte Nederlands-Indië in 1913 inderdaad het hele grondgebied dat al decennia lang onder die naam op de schoolkaarten werd weergegeven. Wanneer Indonesische gebieden ertoe gebracht werden het Nederlandse oppergezag te aanvaarden, sprak men gewoonlijk niet van 'aanvaarding' maar van 'erkenning', wat strookte met de populaire zienswijze dat dit gezag er al eerder rechtsgeldig was. Had Nederland daarbij geweld gebruikt, dan sprak men bij voorkeur niet van 'verovering' van een gebied of 'onderwerping' van een bevolking, maar van 'pacificatie' (tot vrede brengen).

Eén van de redenen voor deze 'afronding' van Nederlands-Indië was de 
bezorgdheid dat andere kolonisatoren zich over de nog niet door Nederland onderworpen gebieden zouden ontfermen. De Britse expansie in NoordBorneo liet zien dat dit geen denkbeeldig risico was. De Nederlandse bezorgdheid nam toe toen in de tweede helft van de negentiende eeuw de internationale competitie om koloniaal bezit steeds heviger vormen aannam. Die bezorgdheid leidde onder meer tot de overhaaste oorlogsverklaring aan Atjeh. De Nederlandse regering voelde zich vervolgens onbehagelijk toen de Congo-conferentie van Berlijn in 1885 besloot dat aanspraken op koloniaal bezit binnen Afrika gebaseerd moesten zijn op 'effective occupation': toepassing van hetzelfde criterium op Indonesië zou sommige Nederlandse aanspraken ondergraven. Op het eind van de negentiende eeuw betraden bovendien twee niet-Europese mogendheden het koloniale toneel in Azië. Japan dwong China in 1895 tot afstand van Formosa (Taiwan) en de Verenigde Staten namen na een oorlog met Spanje in 1898 de Filippijnen over.

Ook de opkomst van de ethische politiek vormde een aansporing tot afronding van het koloniale bezit. Ervan uitgaande dat Nederland verantwoordelijk was voor het welzijn van de inheemse bevolking van de Indonesische archipel, zag men het niet alleen als een historisch recht maar ook als een morele plicht om de hele bevolking onder Nederlands bestuur te brengen. Alleen zo zou men een eind kunnen maken aan de voortdurende onderlinge oorlogen en de nog veel voorkomende gebruiken van koppensnellerij en kannibalisme, alleen zo zou men de tot het christendom bekeerden tegen vervolging kunnen beschermen en alleen zo zou men de economische ontwikkeling van de bevolking ter hand kunnen nemen. Tegelijkertijd voelde men zich meer dan vroeger verantwoordelijk voor de interne toestanden in de zelfbestuursgebieden. Wrede onderdrukking en uitbuiting van onderdanen door vorsten en adel kwamen daar herhaaldelijk voor en sommige zelfbestuurders maakten geen haast met het uitroeien van verboden praktijken als slavernij, slavenhandel en weduwenverbranding. Nederland kon dan ook (evenals andere koloniale mogendheden in dat tijdsgewricht) herhaaldelijk humanitaire argumenten aanvoeren voor zijn koloniale machtsuitbreiding.

De afronding van het koloniale gebied vereiste natuurlijk ook overeenstemming over de grenzen met andere koloniën. Met Portugal kwam al in 1854 een akkoord tot stand over de grens tussen het Nederlandse en het Portugese deel van Timor, waarbij Portugal bovendien afstand deed van zijn aanspraken op Flores. De grens tussen het Nederlandse en het Britse deel van Borneo werd in 1891 geregeld, de grens op Nieuw-Guinea in 1895.

Bij de voltooiing van de Nederlandse beheersing van de archipel speelde het koloniale leger een beslissende rol, ook al waren niet alle uitbreidingen van de Nederlandse macht het resultaat van wapengeweld. Tot 1875 telde dit leger minder dan 30.000 man; daarna werd het groter tot het in 1898 een sterkte bereikte van bijna 44.000 man, de grootste omvang die het ooit gehad 
heeft voor de Tweede Wereldoorlog. Later nam de sterkte weer af, hoewel het leger juist toen Van Heutsz gouverneur-generaal was (1904-1909) stelselmatig voor de afronding van het koloniale rijk werd ingezet.

In feite begonnen de militaire operaties voor dit doel al in 1873. Afgezien van de Atjeh-oorlog zelf betrof de meest spectaculaire episode de onderwerping van Lombok. Daar heerste een uit Bali afkomstige hindoeïstische minderheid sinds de achttiende eeuw over de islamitische Sasaks, die de overgrote meerderheid van de bevolking uitmaakten. Het regerende Balinese vorstenhuis had in 1843 het Nederlandse oppergezag aanvaard en onderhield goede betrekkingen met het gouvernement. In 1891 kwamen de Sasaks tegen dit vorstenhuis in opstand, wat leidde tot een slepende burgeroorlog waarin de Sasaks meermalen om Nederlandse steun vroegen. In 1894 besloot het gouvernement in te grijpen met een militaire expeditie. In juli ging een troepenmacht van 2400 man aan land aan de westkant van het eiland, waar de voornaamste Balinese plaatsen lagen. De Balinezen verzetten zich niet en de expeditiemacht vestigde zich in enkele kampementen, onder meer aan de kust en tegenover de kraton. De Nederlanders waren opgelucht over dit snelle succes. Er volgden nu driehoeksonderhandelingen tussen het gouvernement, het vorstenhuis en de Sasaks over een definitieve regeling. Het gouvernement wilde vérgaand aan de wensen van de Sasaks tegemoetkomen. Daarop pleegde een deel van de Balinezen eind augustus een nachtelijke overval op het kampement tegenover de kraton. De Nederlandse bezetting slaagde er slechts met moeite in zich naar de kust terug te trekken. Het koloniale leger verloor ruim honderd doden en enkele honderden gewonden, het grootste verlies dat het ooit in één keer had geleden.

In Nederland en Nederlands-Indië was men bijzonder geschokt door deze overval, die bekend werd als het 'verraad van Lombok'. De commandant wilde de expeditie staken, maar het gouvernement droeg hem op te blijven en stuurde hem tweeduizend man versterkingen. Het leger bereidde de onderwerping van de Lombokse Balinezen nu zorgvuldig voor; het veroverde en verwoestte stelselmatig eerst een aantal dorpen, daarna de hoofdplaatsen en tenslotte in november de kraton. De vorst gaf zich over, maar de meesten van zijn familieleden verkozen de ceremoniële Balinese poepoetan, een collectieve zelfmoord waarbij zij in feestkleding op de Nederlandse geweren en bajonetten inliepen. Het leger maakte in de kraton een onvoorstelbare hoeveelheid goud, zilver, kostbaarheden en kunstschatten buit. Het gouvernement plaatste Lombok onder rechtstreeks bestuur. Van de Balinezen had het daar geen last meer, maar wel kreeg het in de volgende jaren herhaaldelijk zelf conflicten met de Sasaks, wat tot nieuw optreden van het koloniale leger leidde.

Het debacle op Lombok en de daarop gevolgde revanche maakten in Nederland de geesten rijp voor actief militair optreden tot vestiging van het Nederlandse gezag in heel de archipel. Intussen was het gouvernement hier 
al lange tijd mee bezig op Sumatra, waar het niet alleen in de Atjeh-oorlog gewikkeld was, maar zich ook richtte op de andere nog niet onderworpen delen van het eiland. De belangrijkste daarvan waren de niet-islamitische Batakgebieden in het binnenland ten zuidoosten van Atjeh. Daar was de Rheinische Mission in 1862 met zendingswerk begonnen, maar later werden de zendelingen en hun bekeerlingen bedreigd door aanhangers van de traditionele Batakse religie, geleid door een priestervorst. Het gouvernement ondernam hiertegen van 1879 tot 1895 een reeks militaire expedities, waarbij het geleidelijk het hele Batakse gebied onder rechtstreeks bestuur bracht. De laatste priestervorst sneuvelde in 1907.

In 1903 en 1905 onderwierp het koloniale leger ten oosten en ten zuiden van Minangkabau de laatste onafhankelijke gebieden op Sumatra, waaronder de Kerintji-vallei. Pas nu stond het hele eiland onder Nederlandse soevereiniteit. Dit betekende overigens niet dat het Nederlands gezag daar nu overal stevig gevestigd was. Zo waren bijvoorbeeld velen in Djambi dit gezag steeds vijandig gezind gebleven. In 1858 had het koloniale leger hier al een grote opstand onderdrukt. Van 1901 tot 1904 ondernam het nieuwe operaties om het verzet de kop in te drukken. In aansluiting daarop stelde het gouvernement Djambi in 1906 onder rechtstreeks bestuur.

In dezelfde periode ontstonden er conflicten met de sultan van de Riouwarchipel, die er toe leidden dat het gouvernement deze sultan in 1911 afzette en zijn gebied onder rechtstreeks bestuur nam.

Op Borneo bracht het gouvernement pas in de twintigste eeuw al de uitgestrekte maar dun bevolkte binnenlanden onder Nederlands bestuur. Over het algemeen leverde dit geen conflicten op met de daar wonende Dajak-stammen, die in het Nederlandse bestuur vaak een bescherming zagen tegen de Maleise kustbevolking. Daarentegen kwamen in het gebied van Bandjermasin in ZuidBorneo de aanhangers van de afgezette sultansfamilie opnieuw in verzet. Het koloniale leger ondervond hier tussen 1902 en 1905 krachtige tegenstand voordat het er in slaagde de sultanspartij uit te schakelen.

Op Celebes oefende het gouvernement omstreeks 1900 alleen in het noorden van het eiland en bij Makassar in het zuiden daadwerkelijk gezag uit. De verschillende vorstendommen in Zuid-Celebes zoals Boni en Gowa stonden weliswaar formeel onder Nederlandse soevereiniteit, maar stelden zich sinds enige tijd weer vijandig op. Het midden van Celebes was nog geheel onafhankelijk; wel werkten hier Nederlandse zendelingen onder de Toradjabevolking. Het oosten van het eiland behoorde tot het zelfbestuursgebied van Ternate. In 1905 zond het gouvernement een legermacht van drieduizend man naar Zuid-Celebes, die Boni en de andere weerspannige sultanaten in korte tijd tot capitulatie dwong. De verslagen vorsten weken met hun aanhang uit naar het noorden van dit gebied, waar ze door legerpatrouilles achtervolgd werden. Vervolgens voer de expeditionaire macht naar Midden-Celebes, waar 


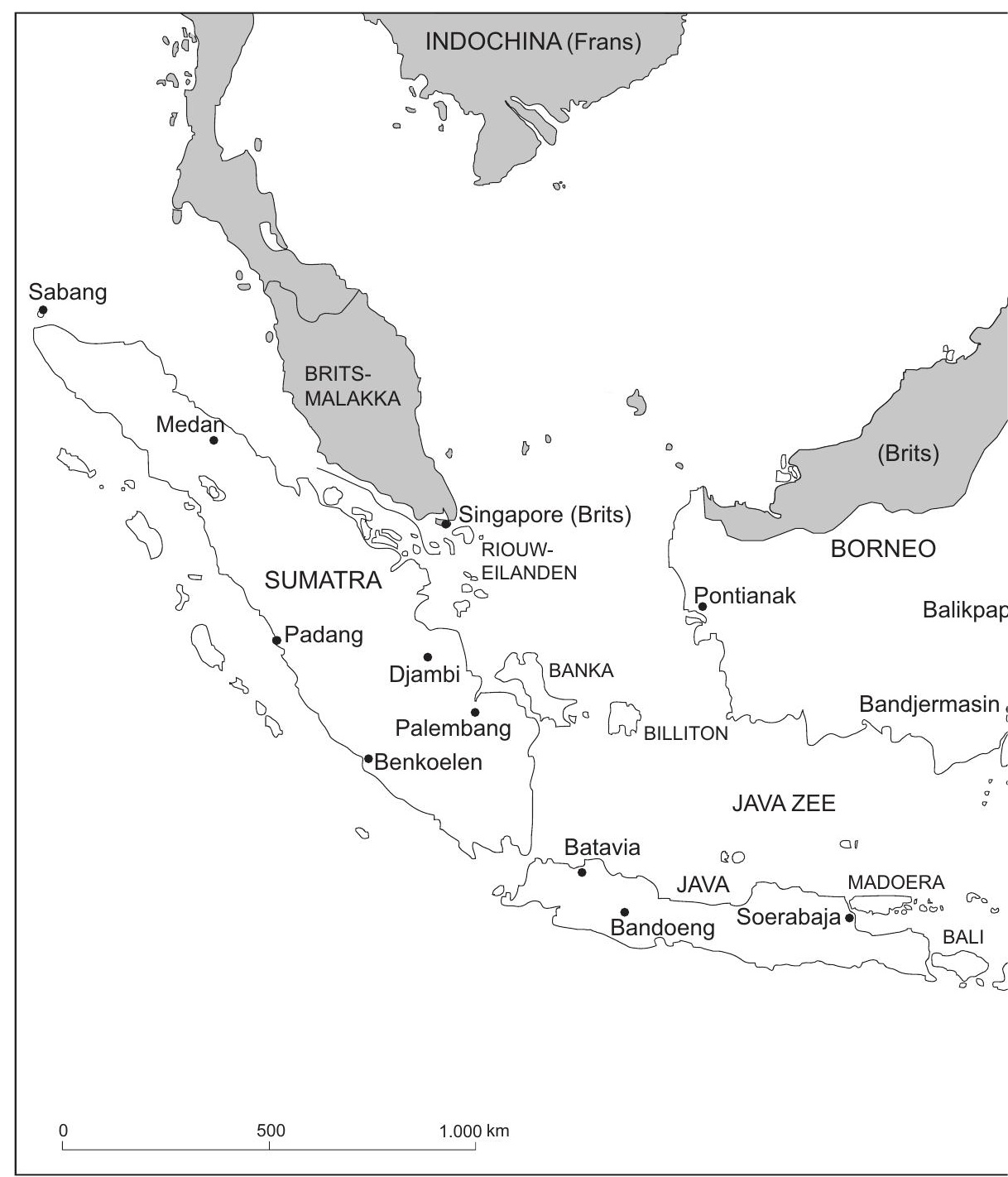

Kaart 8. De kolonie Nederlands-Indië anno 1930 
zij zowel de kustbevolking als de Toradja's met harde hand onder Nederlands gezag bracht. In 1906 nam het gouvernement bovendien het bestuur over Oost-Celebes van Ternate over. Overigens bleef het verzet zowel in ZuidCelebes als in Midden-Celebes nog jarenlang doorgaan; het leger ondernam hier nog verscheidene strafexpedities.

De afronding van het koloniale rijk richtte zich ook op verschillende grote eilanden in het oosten van de archipel. Nadat een in 1890 naar Flores gezonden expeditie door verzet van de bevolking mislukt was, bracht een nieuwe expeditie in 1907 en 1908 dit eiland op gewelddadige wijze definitief onder Nederlands gezag. Ook besteedde het leger in 1908 een jaar om de bevolking van Soembawa te onderwerpen. Bijzonder veel moeite kostte de onderwerping van het binnenland van Ceram; hier voerde het koloniale leger van 1904 tot 1912 een reeks acties uit, waarbij men onder meer een deel van de bevolking onder dwang in nieuwe nederzettingen aan de kust huisvestte.

Bali, dat in 1849 door het koloniale leger onderworpen was, bleef in de negentiende eeuw een bron van onenigheid. In 1882 bracht het gouvernement Noord-Bali onder rechtstreeks bestuur; de vorstendommen in de rest van het eiland behielden zelfbestuur. In het begin van de twintigste eeuw raakte het gouvernement in ernstig conflict met vier van deze vorstendommen. In 1906 brak een legermacht van vierduizend man hun tegenstand, hetgeen leidde tot poepoetan van twee van de vorstenhuizen, waarbij ruim zeshonderd Balinezen zich lieten doden. Eén van de andere vorsten kwam in 1908 opnieuw in verzet, maar moest bukken voor het koloniale leger, waarna ook hij met de zijnen tot een poepoetan overging. In de volgende jaren bracht het gouvernement heel Bali onder rechtstreeks bestuur.

Tegen het eind van de negentiende eeuw was de discrepantie tussen de Nederlandse territoriale pretenties en de feitelijke situatie nergens groter dan op Nieuw-Guinea. In 1895, toen Nederland en Groot-Brittannië een akkoord over de begrenzing van hun aanspraken sloten, verbleven er wel Nederlandse zendelingen in West-Nieuw-Guinea maar was het Nederlandse bestuur er nog steeds niet gevestigd. Pas eind 1897 stemde het Nederlandse parlement in met het inrichten van een bestuursorganisatie voor het gebied. In de volgende jaren richtte het gouvernement er drie bestuursposten in, waarvan één in Merauke, nabij het Britse deel van het eiland. Voortaan waren Sabang ten noorden van Sumatra en Merauke op Nieuw-Guinea de twee verst van elkaar verwijderde bestuursposten van Nederlands-Indië. Hemelsbreed lagen ze ruim vijfduizend kilometer uiteen. 
Tweede deel: Enige kenmerken van het koloniale bestel

\section{De voornaamste bevolkingsgroepen in de kolonie}

Het koloniale karakter van Nederlands-Indië betekende dat een uit het Westen afkomstige minderheid heerste over de al sinds onheuglijke tijden in de archipel wonende inheemse volkeren. Het machtsverschil tussen overheersers en overheersten viel daarom grotendeels samen met het rasverschil tussen blank en bruin. Naast deze twee hoofdgroepen kende de kolonie nog enige andere naar ras of etnische herkomst onderscheiden bevolkingsgroepen. Dit betrof enerzijds een groep van gemengde inheems-westerse afstamming, de IndoEuropeanen. Anderzijds betrof dit de Chinezen en de Arabieren, twee bevolkingsgroepen die weliswaar al eeuwenlang in de archipel gevestigd waren maar niettemin van de autochtone inheemse bevolking verschilden door hun oriëntatie op een stamland buiten de archipel.

De totale bevolking van Nederlands-Indië groeide tussen 1900 en 1940 van bijna veertig miljoen tot ruim zeventig miljoen. In vergelijking daarmee was de blanke bevolking zeer klein, maar zij nam sneller in omvang toe, van ruim twintigduizend tot bijna negentigduizend, dank zij de voortgaande vestiging van nieuwkomers uit Europa. Zowel van de nieuwkomers als van de in de kolonie zelf geboren westerlingen was Nederland het belangrijkste stamland, maar niet het enige. Onder meer hadden zich in de negentiende eeuw ook veel Duitsers in Nederlands-Indië gevestigd. De meeste buiten de kolonie zelf geboren westerlingen waren van plan na een Indische loopbaan naar hun stamland terug te keren. Men onderscheidde hen als 'trekkers' van die blanken die van plan waren ook hun levensavond in de kolonie door te brengen, de 'blijvers'.

De blanke minderheid bezette het leeuwendeel van de leidende functies in het bestuur, het leger en de ondernemingen. Over het algemeen lag haar levensstandaard ver boven die van het gros van de bevolking. De veranderingen die na 1870 binnen de westerse gemeenschap optraden zetten zich in de twintigste eeuw versneld voort. In het verleden waren de westerlingen 'verindischt', doordat ze verschillende elementen van de inheemse levensstijl overnamen. Westerse mannen leefden vaak samen met inheemse vrouwen. Westerse vrouwen droegen binnenshuis meestal de inheemse sarong en kebaja. In de kolonie geboren westerse kinderen leerden al vroeg Maleis, vaak zelfs als eerste taal. In de twintigste eeuw ging de blanke bevolking daarentegen 'vernederlandsen'. Dat kwam onder andere door het toenemende aantal van hen die in Nederland zelf opgegroeid waren. Ook waren nu veel meer blanke mannen met blanke vrouwen gehuwd. De band met Nederland werd bovendien versterkt door snellere post- en verkeersverbindingen. Verder 
woonde een steeds groter deel van de blanke bevolking in aparte villawijken in de steden, wat het haar gemakkelijker maakte haar sociale omgang tot de eigen kring te beperken. Aldus verwijdde zich in de twintigste eeuw de psychologische afstand tussen de westerse en de Indonesische bevolking van Nederlands-Indië.

Eén element van de levensstijl die de westerlingen zich vroeger eigen hadden gemaakt bleef intussen strikt gehandhaafd: naar het voorbeeld van de inheemse aristocratie onthielden zij zich van lichamelijke arbeid (een westerling behoorde bijvoorbeeld geen koffers te dragen).

De Indo-Europese bevolkingsgroep, die de blanke bovenlaag in omvang aanzienlijk overtrof, was een product van de koloniale historie. Al sinds de tijd van de VOC waren uit de omgang van Europese mannen met inheemse vrouwen kinderen van gemengde afkomst geboren. Een groot deel daarvan was opgegaan in de inheemse bevolking, maar een ander deel was formeel met de Europeanen gelijkgesteld. Dat gold in de eerste plaats voor kinderen uit wettige huwelijken en voor onwettige kinderen die door hun vaders erkend waren (en voor de afstammelingen daarvan). In de tweede plaats rekende men lange tijd ook alle christenen van gemengde afkomst tot de Europeanen. Ondanks hun formele gelijkstelling werden de leden van deze groepen echter door de meeste blanken niet als gelijkwaardig beschouwd. Uit deze tweeslachtige positie was de Indo-Europese bevolkingsgroep ontstaan. Zij groeide tussen 1900 en 1940 van ongeveer tachtig- tot een tweehonderdduizend.

Hoewel deze groep enige rijke plantersfamilies en een aantal hoge militairen en ambtenaren telde, waren de meeste Indo-Europeanen weinig bemiddeld. Zij gingen voornamelijk met elkaar om, ontwikkelden een eigen levensstijl en spraken vaak een mengelmoes van Maleis en Nederlands. Zij deden vooral kantoorwerk, bij voorkeur bij de overheid; ook traden velen tot het leger of de politie toe. Er bestond overigens geen scherpe grens tussen deze bevolkingsgroep en de blanke bovenlaag en onderlinge huwelijken waren niet ongewoon. Niettemin leidde de 'vernederlandsing' van die bovenlaag ertoe, dat de IndoEuropeanen zich steeds meer buitengesloten en achtergesteld voelden.

De Chinese bevolkingsgroep omvatte zowel arme plantage- en mijnarbeiders als rijke zakenlieden en groeide van nog geen zeshonderdduizend in 1900 tot meer dan twee miljoen in 1940. Vooral op Java vervulden de Chinezen een sleutelrol in de koloniale economie. Zij beheersten het grootste deel van de detailhandel, het ambachtswezen en de kredietverlening aan de inheemse bevolking. Ook bezaten zij landbouw-, productie- en transportondernemingen. Al sinds de VOC-tijd had het Nederlandse bestuur de economische rol van de Chinezen begunstigd, onder meer door hen in te schakelen bij de inning van belastingen en de exploitatie van monopolies. De Chinese bevolkingsgroep vervulde aldus een bufferfunctie tussen de koloniale overheersers en de inheemse overheersten. Tegelijkertijd beperkte het bestuur deze groep 
in haar vrijheid van vestiging en van beweging: de Chinezen moesten in bepaalde wijken wonen en hadden passen nodig om door het land te reizen. Het passenstelsel verviel in 1915 en het wijkenstelsel in 1918.

De Arabische bevolkingsgroep telde in 1900 ongeveer dertigduizend leden, waartoe overigens ook moslim-families werden gerekend die uit India stamden. Deze Arabieren en Indiërs speelden als handelaren en geldschieters een soortgelijke rol als de Chinezen, maar stonden als islamieten dichter bij de inheemse bevolking.

Tegenover deze verschillende minderheidsgroepen stond de autochtone inheemse meerderheid, die tussen 1900 en 1940 van ongeveer 38 miljoen groeide tot bijna 68 miljoen. Het grootste deel ervan was bijzonder arm. De meesten werkten in de landbouw, als kleine boeren of als plantage-arbeiders. Anderen werkten als fabrieks- of als mijnarbeiders, als huispersoneel of in ondergeschikte posities bij de overheid of in het leger. Betrekkelijk weinig inheemsen traden op als handelaren of ondernemers; in de buitengewesten kwam dit meer voor dan op Java. Het grotendeels ontbreken van een inheemse middenstand betekende een markant verschil tussen de sociale structuur van Nederlands-Indië en die van Brits-Indië: daar speelden inheemse Indiërs zelf de rol die in Nederlands-Indië door Chinezen vervuld werd.

Er was echter één terrein waar juist inheemsen vooraanstaande posities bekleedden en ruime inkomsten genoten: het bestuur over de inheemse bevolking. In de zelfbestuursgebieden betrof dit de door het gouvernement erkende sultans, radja's en andere feodale hoofden; in de rechtstreeks bestuurde gebieden betrof het de eveneens uit de feodale aristocratie afkomstige regenten en andere leden van het Inlands BB. Al deze bestuurders genoten weinig beleidsvrijheid bij de uitoefening van hun functies en waren in feite werktuigen van de koloniale overheersers. Voor de zelfbestuurders bleek dit nog eens overduidelijk uit de tekst van de Korte Verklaringen die de meesten van hen moesten ondertekenen. Wat de leden van het Inlands BB betreft: zij waren ambtenaren, benoemd en betaald door het gouvernement.

Dat Indonesiërs en vooral Javanen strenge vormen in acht plachten te nemen om hiërarchische verhoudingen te markeren, werkte aanstekelijk op sommige leden van het Europees BB. Ook zij voerden in de loop van de negentiende eeuw verschillende rituelen in om hun superieure positie te onderstrepen. Zo moest een Inlands districtshoofd vaak op de vloer plaats nemen tegenover de op een stoel zittende Europese controleur. Gouverneur-generaal Van Heutsz, zelf niet uit het bestuursapparaat maar uit het militaire apparaat afkomstig, probeerde deze praktijken terug te dringen.

Van Heutsz en Snouck Hurgronje waren ook geporteerd voor het opnemen van inheemsen in het Europees BB zelf. Destijds was de toegang daartoe formeel niet tot Europeanen beperkt. Maar toen Van Heutsz de Javaanse prins Koesoemo Joedo, die in Nederland het daarvoor vereiste examen had 
afgelegd, inderdaad bij het Europees BB aanstelde, maakte de regering daar bezwaar tegen. (Koesoemo Joedo ging toen over naar het Volkscredietwezen en vervolgens naar het Inlands BB; hij eindigde zijn loopbaan in 1934 als lid van de Raad van Indië.) De regering besloot nu het Europees BB ook formeel voor inheemsen te sluiten. Bovendien maakte zij een eind aan de in 1867 geopende bestuursopleiding in Batavia, zodat men voortaan alleen nog in Nederland voor het Europees BB opgeleid kon worden. De Nederlandse regering voerde in dit opzicht een diametraal ander beleid dan de Britse regering, die in de twintigste eeuw steeds meer inheemse Indiërs aanstelde bij de Indian Civil Service, het Brits-Indische pendant van het BB.

\section{Het koloniale rechtsbestel}

Het gouvernement kon Nederlands-Indië autocratisch besturen, maar uiteindelijk werd het koloniaal beleid niet in Indië maar in Nederland bepaald. Het Nederlandse parlement had de grondslagen van het koloniale bestel in 1854 neergelegd in het Regeeringsreglement (in 1925 vervangen door een nieuwe wet op de staatsinrichting van Nederlands-Indië). Het parlement toetste het regeringsbeleid met betrekking tot de kolonie en stelde ook jaarlijks de Indische begroting vast. Het was dus onder meer verantwoordelijk voor het feit, dat het Indische gouvernement steeds over te weinig geld beschikte, ook al behaalden particuliere ondernemingen in de kolonie grote winsten. De Nederlandse regering benoemde in Indië zowel de gouverneur-generaal als een reeks andere hoge ambtsdragers, zoals de leden van de Raad van Indië en de legercommandant. De regering trad verder onder meer als wetgever voor Nederlands-Indië op en kondigde hele wetboeken af in de vorm van Koninklijke Besluiten. Alleen voorzover Indische zaken niet door Nederlandse wetten of Koninklijke Besluiten waren geregeld, was het gouvernement tot eigen wetgeving bevoegd, en wel in de vorm van ordonnanties en verordeningen van de gouverneur-generaal.

De ondergeschikte positie van de kolonie kwam ook daarin tot uiting, dat het grootste deel van haar bevolking niet de Nederlandse nationaliteit toebedeeld kreeg. De Nederlandse wetgeving beperkte het Nederlanderschap tot personen van Nederlandse afstamming. Voor het overige werden personen die in de kolonie geboren waren weliswaar niet als vreemdeling beschouwd, maar kregen ze de juridische status van 'Nederlands onderdaan' zonder de status van Nederlander.

Belangrijker dan het onderscheid naar staatsburgerschap tussen Nederlanders, onderdanen en vreemdelingen was het onderscheid naar 'landaard', dat wil zeggen naar ras en etnische herkomst. Het Regeeringsreglement van 1854 verdeelde de bevolking van de kolonie in twee categorieën: 
'Europeanen' en 'Inlanders'. Later werd nog een derde categorie onderscheiden, de 'Vreemde Oosterlingen', waar Chinezen en Arabieren onder vielen. Tot de 'Europeanen' behoorden enerzijds de Nederlanders en de andere westerlingen (met inbegrip van Amerikanen en Australiërs) en anderzijds de Indo-Europeanen. Daarnaast kon het gouvernement in bijzondere gevallen individuele Inlanders of Vreemde Oosterlingen op hun verzoek tot de categorie van de Europeanen toelaten ('Staatsblad-Europeanen'). Bovendien wist Japan in 1899 van Nederland te bereiken, dat alle Japanners in NederlandsIndië de status van Europeaan kregen, en gaf Nederland die status later ook aan de Egyptenaren, de Filippino's, de Siamezen (Thailanders) en de Turken.

Het onderscheid tussen Europeanen en Inlanders doortrok het hele koloniale bestel. Wat de rechtspraak betreft, kwamen zaken tegen Europeanen over het algemeen voor andere rechterlijke organen dan zaken tegen Inlanders. In sommige delen van de kolonie werden overtredingen van Inlanders tot het eind toe berecht door Nederlandse bestuursambtenaren. Bovendien moesten alle strafvonnissen van Inlandse rechters ter goedkeuring aan Nederlandse bestuursambtenaren worden voorgelegd.

Wat het strafrecht betreft, bestonden er lange tijd afzonderlijke wetboeken voor Europeanen en voor Inlanders. De verschillen betroffen in hoofdzaak de straffen (die zich overigens gunstig onderscheidden van de martelingen en verminkingen die dikwijls in inheems strafrecht werden voorzien). Zo konden Inlanders niet tot langdurige gevangenisstraf veroordeeld worden, maar wel tot dwangarbeid, al of niet 'in de ketting'. Tot 1866 kon hun straf ook bestaan uit geseling met rotanstengels; daarna bleef de rotanstraf gehandhaafd als disciplinaire straf voor Inlandse gevangenen. De doodstraf kon zowel aan Europeanen als aan Inlanders worden opgelegd; hetzelfde gold voor geldboetes. Anderzijds bestonden er belangrijke verschillen in het strafprocesrecht. Op het gebied van onder meer huiszoeking, voorarrest en bewijsvoering genoten Europese verdachten waarborgen die niet golden voor Inlandse verdachten.

Terwijl de ongelijkheid op het gebied van het strafprocesrecht tot het eind van het koloniale tijdperk is blijven bestaan, verving men de afzonderlijke strafwetboeken voor de twee categorieën in 1918 door één uniform strafwetboek voor alle landaarden. Ook Inlanders konden voortaan tot langdurige gevangenisstraf veroordeeld worden. Overigens was het gevangenisregime voor Inlandse gevangenen in de regel strenger dan dat voor Europese gevangenen. Verder was dwangarbeid weliswaar formeel afgeschaft, maar bleef het mogelijk aan Inlanders arbeid buiten de strafinrichting op te dragen en bleef ook de disciplinaire rotanstraf bestaan. Wel zette het gouvernement in 1931 een verdere stap in de richting van gelijke behandeling door de opening van een moderne gevangenis (te Soekamiskin bij Bandoeng) voor 'ontwikkelde gevangenen van alle landaarden'.

Het onderscheid naar landaard speelde ook een rol op tal van andere ter- 
reinen dan de rechtsbedeling. Zo verdienden Inlandse werknemers een lager loon dan Europeanen voor hetzelfde werk, zowel bij het gouvernement als bij de ondernemingen.

Het koloniale bestel bracht niet alleen rechtsongelijkheid tussen Inlanders en Europeanen mee, maar ook ingrijpende verschillen tussen enerzijds de voor allen in Nederlands-Indië geldende regels en anderzijds het in Nederland zelf geldende rechtsregime. Zo bleef in de kolonie de doodstraf bestaan, ook al werd deze in Nederland afgeschaft. Kinderarbeid werd in Nederland verboden, maar in de kolonie bleef het gouvernement er zelf gebruik van maken. Nederland kende een strikte scheiding tussen de rechterlijke en de uitvoerende macht, maar in de kolonie kwam een dergelijke scheiding pas geleidelijk en nooit volledig tot stand.

In Nederland overheerste altijd de mening, dat de daar geldende grondrechten zich niet zo maar leenden voor toepassing in de koloniale maatschappij. Terwijl de Nederlandse Grondwet het recht tot vereniging en vergadering erkende, bevatte het Regeeringsreglement voor Nederlands-Indië tot in de twintigste eeuw een verbod van politieke vergaderingen en verenigingen. Evenzo stond de pers in Nederlands-Indië tot in de twintigste eeuw onder preventief toezicht, terwijl Nederland vrijheid van drukpers kende. Het meest omstreden verschil tussen de rechtsbescherming in Nederland en die in Nederlands-Indië was gelegen in de hierna te bespreken 'exorbitante rechten'.

\section{De exorbitante rechten}

$\mathrm{Al}$ sinds de tijd van de VOC paste het centrale bestuur in Batavia nu en dan tegen individuele personen de maatregel van verbanning toe, hetzij door toewijzing van een bepaald ballingsoord binnen zijn machtsgebied, hetzij door terugzending naar Nederland. Het eerste trof voornamelijk Aziaten, het tweede trof alleen Europeanen. Het Regeeringsreglement van 1854 regelde de bevoegdheden van het gouvernement op dit gebied als volgt.

Aan buiten Nederlands-Indië geboren personen die 'gevaarlijk werden geacht voor de openbare rust en orde' kon de gouverneur-generaal het verblijf in de kolonie ontzeggen. Ook kon hij aan buiten Nederlands-Indië geboren personen 'in het belang van de openbare rust en orde' het verblijf in bepaalde delen van de kolonie ontzeggen.

Aan binnen Nederlands-Indië geboren personen kon de gouverneur-generaal 'in het belang van de openbare rust en orde' een bepaalde plaats van verblijf in de kolonie aanwijzen of het verblijf in bepaalde delen van de kolonie ontzeggen.

Voordat de gouverneur-generaal zijn besluit nam, moest de betrokken 
persoon worden gehoord. De gouverneur-generaal had voor zijn besluit de instemming van de Raad van Indië nodig. Hij kon de betrokken persoon in afwachting van diens verwijdering in hechtenis laten nemen.

Alleen als het verblijf in de kolonie werd ontzegd aan een buiten NederlandsIndië geboren Nederlander, moest het besluit met redenen worden omkleed. In alle andere gevallen behoefde het besluit niet gemotiveerd te worden.

Wanneer het besluit niet een Inlander betrof, moest de gouverneur-generaal het met de bijbehorende stukken aan de Nederlandse regering toezenden. Wanneer het besluit een Nederlander betrof, moest de regering het aan het Nederlandse parlement meedelen.

De naam 'exorbitante rechten' voor deze uitzonderlijke bevoegdheden dateerde al van de behandeling van het Regeeringsreglement in het parlement. Ontzegging van het verblijf in de kolonie duidde men aan als 'uitzetting', 'externe verbanning' of 'externering'; aanwijzing van een bepaalde verblijfplaats binnen de kolonie noemde men 'interne verbanning' of 'internering'. De maatregelen werden als regel voor onbepaalde tijd genomen, zodat de banneling niet wist of hij nog terug zou kunnen keren en, zo ja, wanneer. Toepassing van de exorbitante rechten was een bestuurlijke maatregel en geen straf. Men kon er niet tegen in beroep gaan, want de in het strafrecht voorziene rechtsmiddelen golden hier niet. Het 'horen' van hen die voor verbanning bestemd waren, bestond vaak uit het voorleggen van een lijst vragen waar zij met 'ja' of 'nee' op moesten antwoorden.

Het aantal toepassingen bedroeg van 1855 tot 1910 meer dan duizend en ook daarna maakte het gouvernement veelvuldig van deze rechten gebruik. In verreweg de meeste gevallen betrof het internering van Indonesiërs, voornamelijk op beschuldiging van gezagsondermijning, opstand of voorbereiding van opstand. In enkele gevallen betrof het uitwijzing van Nederlanders (bijvoorbeeld Roorda van Eysinga, de auteur van 'De laatste dag der Hollanders op Java').

Hoewel het gouvernement degenen tegen wie de maatregelen gericht waren bijna altijd van strafbare feiten verdacht, besloot het meestal zulke personen niet voor de rechter te brengen, hetzij wegens de lange duur en de ongewisse uitkomst van een strafproces, hetzij wegens gebrek aan wettig bewijsmateriaal. In meer dan honderd gevallen echter interneerde het gouvernement onwelgevallige personen nadat de rechter hen in een strafproces had vrijgesproken.

De exorbitante rechten waren van begin af aan omstreden. De voorstanders betoogden, dat Nederland voor de gezagshandhaving in het uitgestrekte Nederlands-Indië slechts over een zeer kleine land- en zeemacht beschikte en dat het daarom van belang was bloedvergieten te kunnen voorkomen door preventieve uitschakeling van mogelijk verzet. Bij de behandeling van het Regeeringsreglement noemde de regering deze buitengewone bevoegdheden 
een 'levensbeginsel' van de koloniale rechtsorde. Aan de andere kant werden in het Nederlandse parlement herhaaldelijk voorstellen ingediend tot afschaffing van de exorbitante rechten. Deze voorstellen zijn telkens met een grote stemmenmeerderheid verworpen.

\section{Drukpersreglement, haatzaai-artikelen en muilkorfcirculaire}

Tot het begin van de twintigste eeuw beschikte de overheid in NederlandsIndië op grond van het Drukpersreglement over ruime bevoegdheden om 'tot verzekering der openbare orde' in te grijpen in de vrijheid van drukpers. Drukkers en uitgevers moesten van ieder drukwerk vóór de uitgifte exemplaren toezenden aan het bestuur; van kranten en tijdschriften moesten zij uiterlijk twee uur voor de verschijning exemplaren bij het bestuur inleveren. Voor het plakken van aanplakbiljetten was een vergunning nodig. Persdelicten waar straf op stond waren onder meer: aanranding van de eerbied voor wetten en verordeningen, smaad en hoon jegens openbare ambtenaren, en opwekking van haat en verachting tussen bevolkingsgroepen. Wanneer een strafvervolging werd ingesteld wegens verdenking van een persdelict, was het bestuur bevoegd de daarbij betrokken drukkerijen en winkels meteen te sluiten. Los van een strafvervolging had de gouverneur-generaal, naar het model van de exorbitante rechten, de bevoegdheid 'in het belang van de openbare rust en orde' drukkerijen te sluiten en mensen te verbieden het beroep van drukker, uitgever of boekhandelaar uit te oefenen.

In het algemeen maakten de bestuurders slechts spaarzaam gebruik van hun bevoegdheden om in de drukpersvrijheid in te grijpen. In 1906 schafte de regering het preventieve toezicht af. Ook de bevoegdheden van het bestuur tot het opleggen van beroepsverboden en het sluiten van bedrijven kwamen te vervallen. De strafbepalingen bleven gehandhaafd.

In de volgende jaren werd in Nederlands-Indië steeds vrijmoediger kritiek geleverd op het koloniale bestel. Het gouvernement klaagde nu bij de regering, dat het onvoldoende middelen had om in te grijpen tegen misbruik van de vrijheid van meningsuiting. De regering was niet bereid om het bestuur op dit terrein nieuwe bevoegdheden te geven, maar wel om de mogelijkheden van strafrechtelijke vervolging uit te breiden. Dit leidde in 1914 tot de invoering van nieuwe strafbepalingen, die forse vrijheidsstraffen stelden op het door woorden, tekens of vertoningen of op andere wijze opwekken of bevorderen van gevoelens van vijandschap, haat of minachting tegen de Nederlandse regering of het Nederlands-Indische gouvernement, dan wel tussen verschillende bevolkingsgroepen.

Deze eerste 'haatzaai-artikelen', zoals men ze al spoedig noemde, maakten in 1918 plaats voor een uitgebreide en aangescherpte versie. Daarin werd in de 
eerste plaats het in het openbaar uiting geven aan gevoelens van vijandschap, haat of minachting tegen de regering of het gouvernement, dan wel tegen een of meer bevolkingsgroepen, bedreigd met gevangenisstraf tot een maximum van zeven jaar, respectievelijk vier jaar. In de tweede plaats werd het verspreiden of openlijk ten toon stellen van geschriften of afbeeldingen waarin zulke gevoelens tot uiting kwamen, met het oogmerk om aan de inhoud ruchtbaarheid te geven of de ruchtbaarheid daarvan te vermeerderen, bedreigd met gevangenisstraf tot een maximum van vier-en-een-half jaar respectievelijk twee-en-een-half jaar.

In 1926 kwamen er nog twee haatzaai-artikelen bij. Gevangenisstraf tot een maximum van zes jaar werd daarin gesteld op het zich opzettelijk uiten in woord, geschrift of afbeelding waarin, zij het ook zijdelings, voorwaardelijk of in bedekte termen, verstoring der openbare orde of omverwerping dan wel aanranding van het in Nederland of in Nederlands-Indië gevestigd gezag werd aangeprezen of waarin daarvoor stemming werd gemaakt. Gevangenisstraf tot een maximum van vijf jaar werd gesteld op het verspreiden of openlijk ten toon stellen van zulk een geschrift of afbeelding, met het oogmerk om aan de inhoud ruchtbaarheid te geven of de ruchtbaarheid daarvan te vermeerderen.

In 1931 ging de regering nog een stap verder door aan het bestuur toch een bevoegdheid te verlenen tot ingrijpen in de drukpersvrijheid zonder tussenkomst van de rechterlijke macht. De gouverneur-generaal kreeg nu onder bepaalde voorwaarden het recht om 'tot verzekering van de openbare orde' aan een krant of tijdschrift voor korte tijd een verschijningsverbod op te leggen.

Naast deze algemene regelingen golden nog bijzondere regels voor personen in gouvernementsdienst. Een circulaire van de gouverneur-generaal uit 1919 bedreigde hen met ontslag, als zij door openbare uitingen in woord of geschrift meewerkten aan ondermijning van het gevestigde gezag. Deze regel had een aanzienlijke reikwijdte, daar veel ontwikkelde en politiek bewuste onderdanen, zowel Europeanen als Indonesiërs, inderdaad in dienst van het gouvernement stonden. De circulaire kwam bekend te staan als de 'muilkorfcirculaire'. In 1924 werkte een nieuwe circulaire de regel nader uit door te stellen, dat alle gouvernementsdienaren zich moesten onthouden van daadwerkelijke deelname, hetzij in het openbaar hetzij in het verborgene, aan propaganda die tot ontwrichting van het overheidsgezag leidde.

\section{Decentralisatie en democratisering}

Naar gelang in Nederlands-Indië sinds 1870 steeds meer Nederlanders kwamen te werken die niet in dienst van het gouvernement stonden, groeide bij hen de onvrede over hun volstrekte gemis aan zeggenschap over het in de 
kolonie uitgeoefende bestuur. Een ander punt van kritiek was het centralistische karakter van dit bestuur, waarbij ook kwesties van plaatselijk of regionaal belang vaak ter beslissing moesten worden voorgelegd aan de centrale organen in Batavia en Buitenzorg. In 1903 kwam het Nederlands parlement enigszins aan deze bezwaren tegemoet met een wijziging van het Regeeringsreglement, die een bestuursdecentralisatie mogelijk maakte door het instellen van raden op regionaal en plaatselijk niveau met eigen taken en bevoegdheden.

In de daarop volgende decennia stelde het gouvernement ruim vijftig gemeenteraden en regionale raden in. Leden daarvan waren uitsluitend Nederlandse onderdanen, namelijk Nederlanders, Inlanders en 'uitheemse onderdanen' (hieronder vielen zowel Chinezen en Arabieren als Europese onderdanen van niet-Nederlandse afkomst). Het gouvernement bepaalde voor iedere raad de zetelverdeling tussen deze drie bevolkingsgroepen. Alle gemeenteraden kregen een Nederlandse meerderheid. Aanvankelijk hadden alle raden als voorzitter een lid van het Europees BB of een door de gouverneur-generaal benoemde burgemeester. In de jaren twintig kwamen er ook raden met voorzitters uit het Inlands $\mathrm{BB}$, namelijk de door regenten voorgezeten regentschapsraden.

De eerste raden bestonden geheel uit benoemde leden (voornamelijk ambtenaren), maar in 1908 werd kiesrecht ingevoerd voor een deel van de raadszetels. Tot 1917 kwam dit kiesrecht alleen aan Nederlanders toe, daarna ook aan andere onderdanen. Het kiesrecht werd alleen verleend aan hen die een bepaald minimum-jaarinkomen hadden en Nederlands konden lezen en schrijven. De laatste voorwaarde werd in 1926 verruimd tot het kunnen lezen en schrijven van hetzij Nederlands hetzij een inheemse taal. Verder gold sinds 1926, dat de kiezers alleen raadsleden uit hun eigen bevolkingsgroep mochten kiezen.

De bevoegdheden van de raden waren zo beperkt, dat ze nauwelijks leidden tot een minder autocratisch bestuur door de centrale overheid. De overheidsbemoeienis nam in deze tijd juist verder toe, omdat het gouvernement steeds meer taken op zich nam, bijvoorbeeld op het gebied van onderwijs, landbouwvoorlichting, arbeidsinspectie, volksgezondheid, kredietverlening en de productie en levering van opium. Die taakuitbreiding bracht vaak de instelling van nieuwe ambtelijke diensten mee (zoals de Pandhuisdienst en de Opiumregie). Het traditionele arbeidsveld van het BB werd daardoor steeds verder ingeperkt.

Ondanks de geringe bevoegdheden van de raden betekende de decentralisatie toch een zekere stimulans voor het politieke leven in de kolonie, vooral onder de Nederlanders. Het kiesrecht werkte de vorming van politieke groeperingen in de hand. De gemeenteraden bleken een leerschool voor politici en bestuurders, wat het gouvernement bijvoorbeeld in staat stelde burgemeesters te benoemen die niet uit het BB maar uit het raadswerk afkomstig waren. Maar 
als stap in de richting van democratisering had de decentralisatie minder betekenis dan de later gevolgde instelling van de Volksraad (zie pp. 170-1).

\section{Het recht van vereniging en vergadering}

Evenals in Nederland kon een vereniging in Nederlands-Indië niet als rechtspersoon optreden als ze niet officieel door het bestuur erkend was. Die erkenning gebeurde door goedkeuring van de statuten of reglementen door de gouverneur-generaal.

Anders echter dan in Nederland bevatte het Regeeringsreglement van 1854 een artikel dat niet alleen verenigingen en vergaderingen die de openbare orde bedreigden verbood maar ook alle politieke verenigingen en vergaderingen. Toen men het reglement in 1903 wijzigde om de instelling van plaatselijke en regionale raden mogelijk te maken, hief men het laatstgenoemde verbod op voor verenigingen en vergaderingen die uitsluitend bedoeld waren om personen aan te bevelen voor het lidmaatschap van deze raden. Sindsdien drongen Nederlandse parlementsleden herhaaldelijk aan op algehele afschaffing van dit verbod. Ook regering en gouvernement neigden ertoe er niet langer aan vast te houden; men paste het dan ook nauwelijks meer toe. Maar omdat men het er lange tijd niet over eens kon worden, wat daarvoor in de plaats moest komen, duurde het nog tot 1919 voordat de formele verbodsbepaling kwam te vervallen.

Het Regeeringsreglement bepaalde sindsdien: 'Het recht der ingezetenen tot vereniging en vergadering wordt erkend. De uitoefening van dat recht wordt in het belang der openbare orde bij ordonnantie geregeld en beperkt.' De tegelijkertijd van kracht geworden ordonnantie hield onder meer het volgende in. Voor de oprichting van verenigingen was geen machtiging van de overheid nodig, maar het Hooggerechtshof van Nederlands-Indië kon een vereniging verbieden wegens 'strijd met de openbare orde'. Wat vergaderingen betreft, was altijd een vergunning van het bestuur nodig voor vergaderingen in de open lucht. De politie had vrije toegang tot alle vergaderingen waarbij het publiek werd toegelaten. De politie kon onmiddellijk een eind aan een vergadering maken bij verstoring van 'de openbare orde'.

In 1923 en daarna werd deze ordonnantie herhaaldelijk verscherpt. Zo mocht men voortaan geen openbare politieke vergaderingen houden zonder die van te voren bij het bestuur te hebben aangemeld. Personen beneden de leeftijd van achttien jaar mochten geen politieke vergaderingen bijwonen en geen lid van politieke verenigingen zijn. De gouverneur-generaal kon 'in het belang van de openbare orde' aan bepaalde verenigingen verdergaande beperkingen opleggen, die onder meer inhielden dat ze voor alle openbare vergaderingen vergunning moesten vragen. Zeer ingrijpende inbreuken op 
het recht van vereniging en vergadering werden in 1935 ingevoerd. De politie kreeg nu ook vrije toegang tot besloten politieke vergaderingen en de gouverneur-generaal kon voortaan zelf verenigingen verbieden.

Naast deze algemene regelingen kwamen er in de jaren twintig en dertig nog enige bijzondere beperkingen voor personen in overheidsdienst. In 1926 kregen zij een verbod om lid te zijn van de Partai Komoenis Indonesia (PKI) en andere communistische organisaties. In 1933 werd het aan de gouvernementsdienaren op straffe van ontslag verboden om lid te zijn van, of medewerking of steun te verlenen aan, verenigingen die een actie voerden die schadelijk was te achten voor de discipline of de goede geest onder het gouvernementspersoneel of die zich actief of passief tegen het wettig gezag richtte. Op deze grond werd hun het lidmaatschap verboden van een aantal uitdrukkelijk genoemde nationalistische en islamitische organisaties.

\section{Het koloniale taalbeleid}

Terwijl de Portugezen, de Spanjaarden, de Britten en de Fransen hun eigen taal in hun koloniën invoerden als verkeerstaal voor alle bevolkingsgroepen, heeft de Nederlandse taal zich in Indonesië nooit eenzelfde positie verworven. De Nederlandse overheersers spanden zich hier ook zelden voor in.

Toen de Nederlanders omstreeks 1600 in de Indonesische archipel kwamen, troffen zij daar al twee algemeen verbreide verkeerstalen aan: het Maleis en het Portugees. Het viel hun niet moeilijk zich eveneens van die talen te bedienen. Al in de zestiende eeuw waren Nederlanders veel meer dan Britten, Fransen en Spanjaarden gewend aan het gebruik van vreemde talen. Bovendien waren zij, anders dan de Portugezen, niet naar Azië gekomen om te veroveren en te bekeren, maar uitsluitend om handel te drijven.

Ook nadat de VOC zich op Ambon en in het gebied van Batavia 'eigen grondgebied' had verschaft, bleef de rol van de Nederlandse taal beperkt. De eerste gouverneurs van Ambon probeerden daar wel het Nederlands in te voeren, maar na enkele decennia gaf men deze pogingen op en schakelde men over op Maleis als kerk- en onderwijstaal. Het uiteindelijke resultaat was, dat het Maleis op Ambon de oorspronkelijk daar gesproken Molukse taal volledig verdrong.

Evenals op Ambon vormden de Nederlanders in Batavia slechts een kleine minderheid. De Aziatische meerderheid van de bevolking stamde uit zeer verschillende taalgebieden, waaronder ook voormalige Portugese vestigingen zoals Malakka. Tegelijk werden Javanen en Soendanezen lange tijd uit de stad geweerd. Een en ander bevorderde de positie van het Maleis en het Portugees in het verkeer tussen de bevolkingsgroepen. Intussen hingen in Batavia niet alleen de Europeanen maar ook veel Aziaten het christelijke geloof aan. De 
VOC probeerde herhaaldelijk de Nederlandse taal tenminste ingang te doen vinden bij alle protestants-christelijke inwoners, maar zij slaagde daarin niet. In de loop van de zeventiende eeuw ontwikkelde een vereenvoudigde vorm van Portugees zich zelfs tot de huiselijke omgangstaal van een aanzienlijk deel van de Bataviase bevolking, zowel de christelijke als de niet-christelijke. Later nam een vereenvoudigd Maleis die rol over.

Terwijl men in het VOC-tijdperk wel enige pogingen ondernam om Indonesische christenen met de Nederlandse taal vertrouwd te maken, probeerde men dit nooit onder de niet-christelijke Indonesiërs. Zowel om machtspolitieke als om commerciële redenen gaf men er de voorkeur aan, dat de VOC in haar eigen organisatie over een taal beschikte die voor haar Aziatische tegenspelers een gesloten boek bleef.

In het koloniale tijdperk zette men deze lijn voort. Een consequentie hiervan was, dat de Europese bestuursambtenaren zich bij de uitoefening van hun taken van Indonesische talen moesten bedienen en dat men die talen in Nederland intensief bestudeerde. Daarentegen kwam binnen de inheemse bestuursaristocratie steeds sterker de wens naar voren om toegang tot de Nederlandse taal te krijgen. In 1864 besloot de regering in beginsel hieraan tegemoet te komen. Dit gewijzigde beleid stuitte op veel verzet bij Europese BB-ambtenaren. Zij meenden dat Indonesiërs die Nederlands met Nederlanders zouden mogen spreken zich gelijkwaardig aan Nederlanders zouden achten en daardoor hoogmoedig zouden worden. Het gouvernement wees de Europese bestuursambtenaren er herhaaldelijk op, dat zij de Inlandse hoofden en ambtenaren moesten aanmoedigen in het gebruik van de Nederlandse taal, maar tot aan de Tweede Wereldoorlog weigerden sommige bestuursambtenaren Nederlands te spreken met hun Indonesische collega's.

De door veel Europeanen gehuldigde mening, dat Indonesiërs 'hun plaats niet meer zouden weten' als ze Nederlands kenden, leidde tot in de twintigste eeuw er ook toe dat inheemse bedienden kans liepen te worden ontslagen wanneer zij Nederlands bleken te verstaan.

Overigens werd het al tegen het eind van de negentiende eeuw duidelijk dat de moderne koloniale samenleving niet meer kon functioneren zonder Indonesisch personeel met kennis van de Nederlandse taal. Daarvoor bestonden niet alleen praktische maar ook financiële redenen: het was veel goedkoper om middelbare functies, bijvoorbeeld bij de gezondheidszorg en bij de spoorwegen, door Indonesiërs te laten verrichten dan daarvoor personeel uit Europa aan te trekken. De traditionele tegenzin in koloniale kringen tegen het gebruik van Nederlands door Indonesiërs bleef echter remmend werken.

Voorstanders van de ethische politiek zagen daarentegen actieve verbreiding van het Nederlands onder de inheemse bevolking juist als deel van de aflossing van de 'ereschuld'. Tegelijk werd die verbreiding steeds sterker ook 
van Indonesische kant bepleit en bevorderd. Voor Indonesiërs (en ook voor Indonesische Chinezen) was kennis van de Nederlandse taal niet alleen van waarde om vooruit te komen in de koloniale maatschappij, maar ook om toegang te krijgen tot de westerse wetenschap en de westerse cultuur. Op het eind van de negentiende eeuw waren enige Javaanse aristocraten hiervan al zo doordrongen, dat zij ervoor zorgden dat hun kinderen volledig met die taal vertrouwd raakten. In de twintigste eeuw verbreidde de kennis van het Nederlands zich in hoog tempo ook in andere inheemse kringen dan de aristocratie. Westers opgeleide Indonesiërs spraken steeds vaker Nederlands onder elkaar en in een aantal Indonesische gezinnen werd het Nederlands zelfs de huiselijke omgangstaal. Terwijl in 1900 waarschijnlijk nog geen zesduizend Indonesiërs en Indonesische Chinezen Nederlands kenden, waren dit er in 1940 bijna een miljoen, 1,5\% van de niet-Europese bevolking.

Onder de voorstanders van de 'ethische politiek' had men niet alleen oog voor het belang van het Nederlands als toegangspoort tot westerse kennis en cultuur, maar ook voor de waarde van de Indonesische talen zelf voor de ontwikkeling van de Indonesische bevolking. Dit leidde ertoe dat het gouvernement die ontwikkeling krachtig ging steunen door middel van de in 1908 ingestelde Commissie voor de Volkslectuur en het in 1917 opgerichte Kantoor voor de Volkslectuur, met als Indonesische naam Balai Poestaka (Boekenhuis). Balai Poestaka zorgde voor de uitgave van proza, poëzie en populair-wetenschappelijke lectuur in inheemse talen, zoals Maleis, Javaans en Soendanees. Veel van deze uitgaven verschenen in grote oplagen tegen matige prijzen. Voor een deel betrof dit werk uit Indonesische bron, waaronder zowel moderne romans als oude hofkronieken, voor een ander deel betrof het vertaalde werken uit de wereldliteratuur.

$\mathrm{Al}$ sinds de negentiende eeuw had het gouvernement bijgedragen tot de verbreiding van het Maleis in de archipel, doordat het die taal in veel gebieden als bestuurstaal hanteerde, het onderwijs erin bevorderde en een gestandaardiseerde spelling ervan invoerde. De overwegend uit Indonesiërs bestaande redactie van Balai Poestaka speelde een belangrijke rol bij de verdere ontwikkeling van het Maleis tot een algemeen bruikbare moderne taal.

\section{Het koloniale onderwijsbestel}

De indeling van de bevolking van Nederlands-Indië naar landaard lag in het koloniale tijdperk ten grondslag aan zowel het lager als het middelbaar onderwijs: er waren scholen bestemd voor Europeanen en scholen bestemd voor inheemsen. Dit betekende overigens geen strikte segregatie. In beginsel konden ook inheemse leerlingen tot Europese scholen worden toegelaten, al golden hiervoor beperkende voorwaarden. Verder bezochten Europese leer- 
lingen soms scholen die in de eerste plaats voor inheemsen bestemd waren.

De meeste scholen voor inheemsen gebruikten een inheemse taal als voertaal. Op een deel van de voor inheemsen bestemde scholen werd echter het Nederlands als voertaal gebruikt en was het onderwijs op Nederlandse leest geschoeid. Deze scholen rekende men (samen met de Europese scholen) tot het 'onderwijs op westerse grondslag'.

Naast de door het gouvernement en door plaatselijke overheden gestichte onderwijsinstellingen bestonden in de kolonie ook particuliere scholen, die dikwijls subsidie kregen van het gouvernement. Onder meer waren er in de buitengewesten talrijke zendings- en missiescholen.

In de eerste helft van de negentiende eeuw zorgde het gouvernement vrijwel alleen voor basisonderwijs aan Europese kinderen. De kwaliteit was niet hoog; welgestelde Europese ouders namen huisleraren in dienst of stuurden hun kinderen naar scholen in Nederland. Daarnaast subsidieerde het gouvernement het christelijke onderwijs voor inheemse kinderen op Ambon en in de Minahasa. Voor het overige bestond het onderwijs binnen de inheemse samenleving voornamelijk uit islamitisch godsdienstonderricht, zowel op plaatselijke koranscholen als op internaten (pesantren).

In de tweede helft van de eeuw ging het peil van het onderwijs op de Europese scholen flink omhoog. Het werd 'concordant' gemaakt met het onderwijs in Nederland, wat betekende dat leerlingen die naar Nederland gingen hun studie zonder meer op Nederlandse scholen konden voortzetten. Europese en Indo-Europese kinderen kregen basisonderwijs op de Europeesche Lagere School (ELS). In de twintigste eeuw bestonden hier een paar honderd van. Daarnaast was er in sommige grote steden ook Europees middelbaar onderwijs, meestal op een Hoogere Burger School (HBS). De eerste Europese middelbare school was de in 1860 in Batavia geopende Koning-Willem-IIISchool. Behalve een HBS-afdeling had deze van 1867 tot 1913 ook een daarbij aansluitende opleiding voor het Europees BB. Naast dit middelbaar onderwijs bestonden er aparte beroepsopleidingen voor Europese onderwijzers.

De Nederlandse regering en het Nederlands-Indische gouvernement vonden onderwijs op universitair niveau lange tijd voor Nederlands-Indië niet nodig: wie hoger onderwijs wilde volgen, kon naar Nederland gaan. Het gouvernement verliet dit standpunt, toen de theeplanter K.A.R. Bosscha met enige andere ondernemers een initiatief nam tot stichting van hoger technisch onderwijs in Nederlands-Indië. Dit leidde in 1920 tot de opening van een Technische Hoogeschool in Bandoeng. Daarna kwam er in Batavia in 1924 een Rechtshoogeschool en in 1927 een Geneeskundige Hoogeschool. In 1940 en 1941 volgden een Literaire Faculteit in Batavia en een Landbouwhoogeschool in Buitenzorg. Voor de toelating tot het hoger onderwijs golden geen beperkingen naar landaard.

De drie voorgaande alinea's hadden in hoofdzaak betrekking op het onder- 
wijs aan Europeanen. Hierna volgt een meer uitvoerig historisch overzicht van het onderwijs aan inheemsen.

De bemoeienis van het gouvernement met het onderwijs voor niet-christelijke inheemsen begon in het midden van de negentiende eeuw met de stichting van Inlandsche Lagere Scholen (ILS) voor kinderen van de inheemse bestuurselite. Tegen het eind van de eeuw besloot men het basisonderwijs tot andere kringen van de inheemse bevolking uit te breiden. Men voerde nu twee categorieën in: eerste-klassescholen, voor kinderen van vooraanstaande inheemsen naar ambt, afkomst, gegoedheid of opleiding, en tweedeklassescholen, voor kinderen van minder prominente inheemsen. Daarnaast bestond enig voortgezet onderwijs voor inheemsen in de vorm van beroepsopleidingen.

Er kwamen tientallen eerste-klassescholen en honderdtallen tweede-klasscholen, maar het gouvernement had geen geld om dit schoolsysteem uit te breiden tot volksonderwijs op grote schaal. Gouverneur-generaal Van Heutsz besloot het probleem op te lossen door de invoering van een eenvoudiger vorm van volksonderwijs, de Dessa- of Volksscholen. Daarbij moesten in eerste aanleg de plaatselijke overheden voorzien in de inrichting van leslokalen en de betaling van leerkrachten; later gaf het gouvernement hier alsnog subsidie voor. Binnen enkele jaren kwamen er duizenden van deze schooltjes. De tweede-klassescholen werden daarna geleidelijk opgeheven. Ten behoeve van het onderwijs op inheemse grondslag gaf het gouvernement schoolboeken uit in tientallen inheemse talen.

Het bestaan van verschillende vormen van inheems openbaar onderwijs liet onverlet, dat al sinds het midden van de negentiende eeuw tal van kinderen van aanzienlijke inheemsen tot de ELS waren toegelaten (waarvoor een vrij hoog schoolgeld betaald moest worden). Naarmate het aantal aanvragen toenam, verzwaarde het gouvernement de toelatingsvoorwaarden, totdat het tenslotte als eis stelde dat het inheemse kind bij zijn toelating al Nederlands moest verstaan en niet ouder dan zeven jaar mocht zijn. Niettemin bezochten meer en meer inheemse kinderen de ELS, zowel uit de bovenlaag als uit de middenlaag van de samenleving. Hun aandeel onder de scholieren steeg tot meer dan tien procent. Ook gingen steeds meer inheemse kinderen naar de HBS. De meeste blanke scholieren gedroegen zich redelijk sportief tegenover hun gekleurde klasgenoten, maar veel Europese ouders klaagden dat het peil van het onderwijs gevaar liep door de toeloop van inheemse leerlingen.

De groeiende drang naar westers onderwijs onder de inheemse bevolking bracht het gouvernement niet alleen tot een strengere selectie van inheemse gegadigden voor de ELS, maar ook tot de schepping van aparte westerse scholen voor niet-Europeanen. In 1914 werd de eerste-klasseschool omgezet in de Hollandsch-Inlandsche School (HIS), een lagere school met Nederlands als voertaal en met een leerplan naar Nederlands model, onder toevoeging van 
Maleis en de taal van de streek. Voor Chinese kinderen was er de HollandschChineesche School (HCS). Het schoolgeld voor deze scholen kwam overeen met dat voor de ELS. Het aantal HIS- en HCS-scholen steeg na 1920 boven dat van de ELS-scholen.

Eveneens in 1914 werd een nieuwe vorm van voortgezet westers onderwijs ingevoerd, het Meer Uitgebreid Lager Onderwijs (MULO). De MULO-scholen stonden open voor alle landaarden, maar waren in de eerste plaats voor inheemse kinderen bedoeld. In 1919 stichtte het gouvernement ook een middelbare westerse school voor inheemsen, de Algemeene Middelbare School (AMS), als bovenbouw op de MULO. Het leerplan stemde grotendeels met dat van de HBS overeen, maar schonk meer aandacht aan de talen en culturen van Indonesië. Er kwamen in de volgende decennia tientallen MULO-scholen, terwijl het aantal AMS-scholen dat van de HBS-scholen naderde.

De behoefte in inheemse kring aan westers onderwijs was zo groot, dat de invoering van HIS, MULO en AMS niet leidde tot een scherpe daling van het percentage inheemse scholieren aan ELS en HBS. Omgekeerd kreeg de AMS ook vrij veel Europese leerlingen, al vormden de inheemse leerlingen steeds de meerderheid.

Dat in 1919 voorzien werd in algemeen middelbaar onderwijs voor inheemsen, neemt niet weg dat het gouvernement al veel eerder verschillende vormen van voortgezette scholing voor inheemsen had ingevoerd. In het midden van de negentiende eeuw waren, tegelijk met de stichting van de ILS, ook driejarige Kweekscholen voor Inlandsche Onderwijzers opgericht. Enige decennia later stichtte het gouvernement vierjarige 'Hoofdenscholen', om zonen van Inlandse hoofden en andere aanzienlijken voor te bereiden op bestuursfuncties bij het Inlands BB. Het onderricht geschiedde gedeeltelijk in het Nederlands. In 1900 werd het Nederlands volledig als voertaal ingevoerd, de leerstof met een aantal juridische vakken uitgebreid en de cursusduur tot vijf jaar verlengd. In de nieuwe opzet heetten deze scholen voortaan Opleidingsschool voor Inlandsche Ambtenaren (OSVIA).

In het midden van de negentiende eeuw had het gouvernement ook een medische opleiding voor inheemsen gesticht. Deze in Batavia gevestigde opleiding werd bekend als de Dokter-Djawa-school. Het leerprogramma bevatte oorspronkelijk alleen een éénjarige opleiding tot vaccinateur, maar werd steeds verder uitgebreid en verlengd. In 1875 werd de cursusduur op vijf jaar gebracht en werd Nederlands als voertaal ingevoerd. De school kreeg weinig leerlingen uit de Javaanse aristocratie, omdat in die kringen vaak werd neergekeken op het artsenberoep en alleen waarde werd gehecht aan bestuurlijke en ambtelijke functies. Het gouvernement nam daarom maatregelen om voldoende leerlingen voor deze opleiding te recruteren, onder meer door kinderen die door hun ouders hiervoor bestemd waren kostenloos tot de ELS toe te laten. In 1902 werd de cursusduur op zeven jaar gebracht en kreeg de school 
de naam School tot Opleiding van Inlandsche Artsen (STOVIA). De hier opgeleide artsen waren bevoegd tot het behandelen van inheemse patiënten. Later vormde de STOVIA de basis van de Medische Hogeschool.

De twintigste eeuw zag de komst van nog verscheidene andere beroepsopleidingen die vooral voor niet-Europeanen bedoeld waren, zoals ambachtsscholen, landbouwscholen, handelsscholen, een rechtsschool, een veeartsenschool, een tandartsenschool en een tweede artsenschool.

Hoger onderwijs is in het koloniale tijdvak door ruim duizend inheemse en Chinese Indonesiërs gevolgd, grotendeels aan Nederlandse universiteiten en hogescholen. Alleen zeer rijke niet-Europese ouders konden de studie van hun kinderen in Europa zelf bekostigen, maar het gouvernement verstrekte studiebeurzen aan begaafde studenten.

Het Nederlands-Indisch onderwijs op westerse grondslag was van hoge kwaliteit, maar voor inheemse scholieren bijzonder moeilijk als gevolg van zijn geheel Nederlandse opzet. Meer dan de helft van hen maakte de school niet af, ook omdat dit onderwijs voor de ouders vaak kostbaar was. Niet alleen moesten zij schoolgeld betalen, maar meestal moesten zij hun kinderen ook tegen betaling in een kosthuis of pleeggezin onderbrengen als zij zelf niet in de plaats woonden waar de school gevestigd was. De grootste tekortkoming van dit onderwijsbestel was echter het nagenoeg ontbreken van onderricht in de Nederlandse taal als vreemde taal, dus met een inheemse taal als voertaal.

Onderwijs voor de inheemse bevolking van Nederlands-Indië was een belangrijk programmapunt van de ethische politiek. Bij een vergelijking van de onderwijsmogelijkheden in de kolonie voor inheemsen met die voor Europeanen moet men in het oog houden, dat de Europeanen met inbegrip van de Indo-Europeanen minder dan een half procent van de bevolking uitmaakten. Gelet op hun aantal genoten zij een ruim onderwijsaanbod. Het onderwijsaanbod voor inheemsen, zowel op inheemse als op westerse grondslag, bleef daar ver bij achter. Werkelijk algemeen volksonderwijs kwam nooit tot stand. Op het eind van het koloniale tijdvak waren er ongeveer achttienduizend volksscholen, maar daarmee werd slechts een derde van de bevolking bereikt. Vergelijking met het onderwijsaanbod voor inheemsen in andere Aziatische koloniën valt niet onverdeeld gunstig uit. In Brits-Indië was al in de negentiende eeuw op ruime schaal westers hoger onderwijs ingevoerd. De Filippijnen hadden zelfs al sinds 1645 een universiteit; nadat ze onder Amerikaans bestuur gekomen waren, kwam daar in 1908 nog een moderne universiteit bij. Het analfabetisme werd in de Filippijnen verder teruggedrongen dan in Nederlands-Indië.

Sinds het eind van de negentiende eeuw breidde het Nederlands-Indisch gouvernement het onderwijs voor inheemsen stelselmatig uit, naar gelang de moderne koloniale maatschappij meer behoefte kreeg aan geschoold inheems personeel. Tegelijkertijd zag men er voortdurend op toe, dat dit onderwijs 
de strikt zakelijke behoefte niet te boven ging. Men toonde zich bezorgd, dat een snelle toename van westerse vorming ontwrichtend zou werken op de inheemse samenleving. Het gouvernementele aanbod aan westers onderwijs bleef dan ook steeds achter bij de inheemse vraag. In het tijdvak 1930-1940 werd dit aanbod ver overtroffen door het onderwijsaanbod van de zogenaamde 'wilde scholen', dat wil zeggen niet-gouvernementele scholen die onderricht gaven in een meer of minder uitgesproken antikoloniale geest (zie p. 184-6).

\section{Aantekeningen bij hoofdstuk III}

\section{Literatuuroverzicht}

Zeer veel historische literatuur over Indonesië heeft betrekking op het in 1800 begonnen tijdvak waarin de archipel grotendeels een kolonie van de Nederlandse staat was. Gewoonlijk zijn dit boeken en artikelen over bijzondere onderwerpen of bepaalde episodes, zoals het Cultuurstelsel en de Atjeh-oorlog. Een globaal overzicht over de geschiedenis van het hele tijdvak (of tenminste tot het begin van de twintigste eeuw) is te vinden in de algemene werken die hierboven al genoemd zijn in de literatuur bij hoofdstuk I, maar die bestrijken ook de geschiedenis vóór 1800. Een recent geschiedwerk dat wel specifiek dit tijdvak behandelt is Het rijk van Insulinde; Opkomst en ondergang van een Nederlandse kolonie (1996) van H.W. van den Doel, een werk dat ook waardevol is door zijn talrijke verwijzingen naar recente studies.

De historische literatuur met betrekking tot dit tijdvak is overigens niet alleen het product van historici. Eén van de meest boeiende studies over de uitbreiding van het Nederlandse gezag in de negentiende eeuw is oorspronkelijk geschreven als een intern ambtelijk stuk, namelijk Politiek beleid en bestuurszorg in de buitenbezittingen; Historische inleiding (1834-1898). De auteur van deze in 1907 verschenen studie was $\mathrm{H}$. Colijn, destijds adviseur van de gouverneur-generaal (maar later premier van Nederland).

Een andere belangrijke bron van informatie over de kolonie is de negen-delige Encyclopaedie van Nederlandsch-Indië, tussen 1917 en 1939 verschenen. Bovendien verscheen in 1934 een meer beknopte Geillustreerde encyclopaedie van Nederlandsch-Indië onder redactie van G.F.E. Gonggryp.

Hieronder volgen enige specifieke literatuurverwijzingen bij bepaalde paragrafen van dit hoofdstuk.

\section{Begin van de koloniale verhouding}

Voor het rapport van de staatscommissie uit 1803 zie Mijer 1848:117-327. Voor het citaat over de betekenis van de koloniën voor het moederland zie Mijer 1848:141. Vergelijk Fasseur 1995:30-3. Over Dirk van Hogendorp zie Van 't Veer 1958:16-47.

Java onder Daendels

Vergelijk Van den Doel 1996:14-7. 
Brits intermezzo

Vergelijk Van den Doel 1996:18-21.

Herinrichting van het Nederlandse koloniale bestel

Vergelijk Oranje 1936, Platteel 1936, Van den Doel 1996:21-30 en J.J.P. de Jong 1998:17480. Voor het Regeeringsreglement van 1818 zie Mijer 1848:397-426. Voor de proclamatie aan de volkeren van de Zuid-Molukken zie Indisch Staatsblad 1824:384.

Het Binnenlands Bestuur

Zie Van den Doel 1994. Over de opleiding van de Nederlandse bestuursambtenaren zie Fasseur 1993.

Verzet tegen de terugkeer van het Nederlandse gezag

Over de opstand op Saparoea zie Van Kaam 1977:11-37, De Moor 1995a:587-90 en Van den Doel 1996:25-6.

De Java-oorlog

Zie De Moor 1995a:590-8, Van den Doel 1996:39-48 en Carey 2007.

Cultuurstelsel en batig slot

Zie Fasseur 1975 en Van den Doel 1996:48-57 en 91-8.

Koloniale machtsuitbreiding buiten Java voor 1870

Vergelijk Van den Doel 1996:61-74 en De Moor 1995a:598-602 (over de Padri-oorlog) en 602-6 (over de strijd op Bali en Borneo). Over het onthoudingsbeleid zie Colijn 1907:189 en Fasseur 1995:47-73. De algemene opdracht om bevriende Indonesische staatjes te bewegen tot aanvaarding van het Nederlandse oppergezag werd neergelegd in artikel 44 van een niet-openbare 'Instructie voor den Gouverneur-Generaal' van 5 juni 1855. Het resultaat van de op last van Baud ondernomen inventarisatie van verdragen en dergelijke is tussen 1907 en 1955 gepubliceerd als Corpus diplomaticum NeerlandoIndicum onder redactie van J.R. Heeres en F.W. Stapel.

Nederlandse kritiek op het koloniaal beleid

Vergelijk Van den Doel 1996:98-106. Over Van Hoëvell zie Van 't Veer 1958:10144. Voor het citaat van Baud uit 1849 zie Kuitenbrouwer 2001:15. Het nieuwe Regeeringsreglement werd gepubliceerd in Staatsblad 1854, no. 129. Voor het Multatulicitaat over 'een prachtig paard' zie Kok 1903:94.

Einde van Cultuurstelsel en batig slot

Vergelijk Reinsma 1955, Janny de Jong 1989 en Van den Doel 1996:107-10.

Eerste fase van de Atjeh-oorlog

Zie Van 't Veer 1969:9-185 en De Moor 1995b:832-42.

Slavernij, dwangarbeid, koeliecontracten en de poenale sanctie

Over de situatie in Oost-Sumatra zie Breman 1987; vergelijk Van den Doel 1996:115-24.

Over de poenale sanctie zie ook Taselaar 1998:261-300. 
Wetenschappelijke aandacht voor Indonesie

Zie Maier en Teeuw 1976, Bossenbroek 1994, 1995b en Van den Doel 1996:74-80. Over het KITLV zie Kuitenbrouwer 2001. Over het Bataviaasch Genootschap zie Groot 2007.

Christelijke zending en missie

Zie Bossenbroek 1995a:807-25 en Van den Doel 1996:81-9.

De bloeitijd van het imperialisme

Over de juridische status van de niet door Nederland rechtstreeks bestuurde gebieden in de Indische archipel zie Kleintjes 1903:48-79 en Encyclopaedie I(1917):526. Over het standpunt van de Nederlandse regering in 1890 dat sommige van die gebieden niet als delen van Nederlands-Indië beschouwd konden worden zie Colijn 1907:167-8. Over de opkomst van het Nederlandse imperialisme zie Kuitenbrouwer 1985 en Bossenbroek 1995c, 1996.

Groeiende betekenis van Indonesië voor het Nederlandse zelfbewustzijn

Over het Koloniaal Instituut zie Taselaar 1998:165-209.

Ethische politiek

Zie Locher-Scholten 1981:11-117 en 176-201 en Van den Doel 1996:153-74.

Voortzetting en beëindiging van de Atjeh-oorlog

Zie Van 't Veer 1969:186-292, De Moor 1995b:842-9, Van den Doel 1996:131-7, 142-3 en Wekker 1907.

De Korte Verklaring

Zie Somer 1934.

Afronding van het koloniale rijk

Vergelijk Van Goor 1986 en Van den Doel 1996:125-7, 138-45. Voor een beschouwing over de grondslagen en het rechtskarakter van de Nederlandse soevereiniteit over Indonesië zie Burgers 1998.

De voornaamste bevolkingsgroepen in de kolonie

Over de niet-toelating van inheemsen tot het Europese korps van het BB zie Fasseur 1993:379-85.

Het koloniale rechtsbestel

Van de in het koloniale Nederlands-Indië geldende wetgeving zijn de belangrijkste delen te vinden in Engelbrecht 1939. Zie over het koloniale rechtsbestel ook Fasseur 1995:139-89.

De exorbitante rechten

Zie Jongmans 1921. Deze rechten waren vastgelegd in de artikelen 45 tot en met 48 van het Regeeringsreglement van 1854 en vervolgens in de artikelen 35 tot en met 38 van de Indische Staatsregeling van 1925. 
Drukpersreglement, haatzaai-artikelen en muilkorfcirculaire Zie Fasseur 1995:181-3, Maters 1998 en De Meij 2004:12-4. De in 1918 ingevoerde 'haatzaai-artikelen' waren de artikelen 154 tot en met 157 van het Wetboek van strafrecht voor Nederlandsch-Indië. De in 1926 toegevoegde 'haatzaai-artikelen' waren de artikelen 153 bis en 153 ter.

Het recht van vereniging en vergadering

Het verbod op politieke verenigingen en vergaderingen was vervat in artikel 111 van het Regeeringsreglement van 1854. Zie ook De Meij 2004:14-6.

Het koloniale taalbeleid

Zie Groeneboer 1993.

Het koloniale onderwijsbestel

Vergelijk Brugmans 1938, Poeze 1982:xvii-xxv en Lelyveld 1992. 


\section{HOOFDSTUK IV}

\section{De Indonesische nationale beweging}

\section{Inleiding en overzicht}

De Nederlandse machthebbers in de Indonesische archipel hebben zowel ten tijde van de VOC als tijdens het koloniale bestuur talrijke conflicten met de inheemse bevolking gehad, maar ruim drie eeuwen lang waren dat altijd conflicten met afzonderlijke inheemse volken of rijken en niet met een al die volken omspannende Indonesische natie. Pas in het derde decennium van de twintigste eeuw ontstond in Nederlands-Indië een krachtige beweging die de hele inheemse bevolking van de kolonie als één natie zag en daarvoor onafhankelijkheid verlangde. Weliswaar hadden al in het begin van die eeuw verschillende emancipatiebewegingen het daglicht gezien, maar die hadden nog geen nationalistische grondslag.

De eerste emancipatiebewegingen richtten zich op bepaalde etnische groepen, zoals de Javanen, de Chinezen of de Indo-Europeanen. De bekendste daarvan was de in 1908 opgerichte Javaanse bond Boedi Oetomo. Naast zulke organisaties op etnische basis kwamen vakverenigingen tot stand, eerst alleen van Europese werknemers maar al spoedig ook van inheemse werknemers. Een derde grondslag voor aaneensluiting was de godsdienst: er werd een moslim-bond gevormd, de Sarekat Islam, die binnen enkele jaren uitgroeide tot de eerste Indonesische massabeweging. De etnische grondslag van Boedi Oetomo en de religieuze grondslag van de Sarekat Islam weerhielden deze bonden er overigens niet van ook politieke wensen naar te voren brengen, zoals die van inheemse medezeggenschap in het koloniale bestuur. Bovendien trad al in 1912 een echte politieke partij op, die zich zelfs uitdrukkelijk voor onafhankelijkheid uitsprak. Maar deze partij (wier aanhang vooral uit IndoEuropeanen bestond) werd door het gouvernement als onwettig beschouwd en bleef maar kort bestaan.

De meeste emancipatiebewegingen ontstonden binnen niet-Nederlandse bevolkingsgroepen. Niettemin leefde destijds ook onder Nederlandse ingezetenen enig verlangen naar meer mondigheid, omdat zij binnen het koloniale bestel geen enkele zeggenschap over het bestuur hadden. Dit bracht regering en parlement van Nederland ertoe in de kolonie een vertegenwoordigend 
lichaam in het leven te roepen, de Volksraad. Hierin kregen ook Indonesiërs zitting, naast een meerderheid van Nederlanders. De Volksraad werd in 1918 geïnstalleerd en al in datzelfde jaar leverden sommige Indonesische leden scherpe kritiek op het koloniale bestel en drongen zij aan op de vorming van een uit en door het volk gekozen parlement en de instelling van een daaraan verantwoordelijke regering.

In het begin van de eeuw stonden vrij veel Nederlanders welwillend tegenover de inheemse emancipatiebewegingen, maar die welwillendheid nam sterk af toen zulke bewegingen een politieke rol gingen spelen. Bovendien vond aan Indonesische kant een radicalisering plaats, onder meer onder invloed van marxistische actievoerders. Na 1920 verhardde zich ook het officiële koloniale beleid. Het gouvernement legde de politieke activiteiten van de Indonesiërs sterk aan banden. De Sarekat Islam, die al een deel van zijn massaaanhang verloren had, werd in diezelfde periode verzwakt door een machtsstrijd met de marxisten, die zich nu organiseerden als communistische partij. Een deel van de aanhang van deze partij kwam echter eind 1926 in opstand tegen het koloniale gezag, waarop dit gezag rigoureuze maatregelen nam die de communisten als politieke factor uitschakelden.

Intussen hadden enige Indonesische studenten die in Nederland studeerden een nieuwe politieke lijn uitgezet. Zij wensten nationale onafhankelijkheid voor Indonesië, waarbij zij alle inheemse ingezetenen van Nederlands-Indië als één Indonesische natie beschouwden. Ter bereiking van die onafhankelijkheid zou men zich moeten onthouden van samenwerking met de koloniale overheersers. Dit beginsel van 'non-coöperatie' hield op zijn minst in, dat Indonesiërs geen zitting zouden moeten nemen in door de overheersers ingestelde vertegenwoordigende lichamen zoals de Volksraad. De student Hatta was de voornaamste leider van deze groep, die ook het politieke denken in de kolonie zelf beïnvloedde.

Terwijl de Sarekat Islam hier sterk aan invloed had ingeboet en de communistische partij van het politieke toneel was verdwenen, kwam nu in Indonesie een nieuwe beweging op die zich zonder etnische of godsdienstige beperkingen tot de hele inheemse bevolking richtte. Gangmaker van deze eerste Indonesische massabeweging op zuiver nationalistische grondslag was de in 1927 opgerichte Partai Nasional Indonesia. Haar leider, Soekarno, toonde zich een begaafd volksmenner. De partij stelde zich nationale onafhankelijkheid ten doel en onderschreef het non-coöperatiebeginsel. Niettemin was zij bereid tot samenwerking met Indonesische groeperingen die het non-coöperatiebeginsel niet onderschreven. Onder meer Boedi Oetomo en de Sarekat Islam schaarden zich nu ook uitdrukkelijk achter de doelstelling van nationale onafhankelijkheid.

Regering en parlement van Nederland zetten in deze tijd nog enkele stappen tot wijziging van het koloniale bestel. Onder meer bepaalden ze dat 
de Volksraad voor de helft uit inheemse leden zou bestaan; omdat de Raad daarnaast ook enkele vertegenwoordigers van de Chinese en de Arabische bevolkingsgroep telde, zouden de Nederlandse leden er voortaan geen meerderheid meer vormen. Deze afschaffing van de Nederlandse meerderheid in de Volksraad wekte een storm van protest onder de Nederlandse ingezetenen van de kolonie.

De jaren dertig gaven in Nederlands-Indië een voortschrijdende polarisering van het politieke toneel te zien. Terwijl het Indonesisch nationalisme zich gestadig verbreidde, hielden de meeste Nederlanders hardnekkig vast aan het behoud van hun overheersende positie. Soekarno werd eind 1929 gearresteerd en bracht twee jaar in gevangenschap door. Zijn partij hield op te bestaan en binnen de nationale beweging ontstond interne verdeeldheid. Hatta keerde uit Nederland terug, maar stelde zich als een rivaal van Soekarno op. In 1933 en 1934 trad het koloniale gouvernement scherp op tegen de non-coöperatieve vleugel van de nationale beweging. Onder meer verbande het een aantal van haar voormannen, onder wie Soekarno en Hatta, naar afgelegen plaatsen binnen de kolonie. Het stond Indonesiërs niet langer toe voor nationale onafhankelijkheid te pleiten, behalve binnen de Volksraad waar vrijheid van spreken gold. Het zwaartepunt van de nationale beweging verschoof nu naar de coöperatieve vleugel. Haar belangrijkste vertegenwoordiger was Thamrin, leider van de Indonesische nationalisten in de Volksraad.

In deze zelfde periode deed Groot-Brittannië stappen in de richting van autonomie voor India, terwijl Amerika aan de Filippijnen zelfs volledige onafhankelijkheid toezegde. Daarentegen stelde Nederland zich steeds negatiever op tegenover de Indonesische verlangens naar meer zeggenschap. Het stootte daarmee ook invloedrijke Indonesiërs af die prijs stelden op behoud van een staatkundige band met Nederland. Enigen van hen gingen in 1939 met de voorstanders van nationale onafhankelijkheid samenwerken in een brede beweging die aandrong op de invoering van een parlementair stelsel in Indonesië, zoals al in 1918 in de Volksraad bepleit was.

Kort daarna werd Nederland door Duitsland bezet en week de Nederlandse regering naar Londen uit. Dit leidde aan Nederlandse kant niet tot meer begrip voor de Indonesische bezwaren tegen de koloniale verhouding. Het Nederlands-Indische gouvernement vond dat men in die verhouding geen enkele wijziging mocht aanbrengen zo lang Nederland niet bevrijd was. De kloof tussen de Nederlandse overheersers en de politiek bewuste Indonesiërs was dan ook wijder dan ooit, toen Japan in de eerste maanden van 1942 Nederlands-Indië veroverde. 


\section{Ontluiken van de Indonesische drang naar mondigheid}

Een nationale beweging die de hele inheemse bevolking van de kolonie als één natie beschouwde ontstond in Nederlands-Indië betrekkelijk laat in vergelijking met sommige andere koloniën. Gedeeltelijk kan dit worden toegeschreven aan het door de Nederlanders gevoerde taal- en onderwijsbeleid. Tot ver in de negentiende eeuw kenden de meeste Indonesiërs geen Nederlands of Engels; dit gold ook voor de meerderheid van de weinigen die konden lezen. Een belangrijke toegangspoort tot kennis van de wereld buiten de eigen landstreek bleef daardoor voor hen gesloten. Toen die poort eenmaal openging, voltrok de nationale bewustwording zich in hoog tempo.

Deze bewustwording kwam omstreeks 1900 op gang, toen steeds meer inheemsen onderwijs (en vooral ook westers onderwijs) gingen volgen. Zij begonnen de hele kolonie, waarvan de kaart de klaslokalen sierde, als hun eigen land te zien. Bij de aardrijkskundeles ontdekten zij dat het stamland van hun koloniale overheersers maar klein was, zowel in vergelijking met andere Europese landen als in vergelijking met Nederlands-Indië. Bij de geschiedenisles vernamen zij, dat dit land zijn onafhankelijkheid te danken had aan een opstand en een langdurige oorlog tegen vreemde overheersing. Op de middelbare scholen leerden zij bovendien over de Franse Revolutie en de Amerikaanse Onafhankelijkheidsoorlog en over de ideeën van vrijheid en gelijkheid die daarbij waren verkondigd. Terwijl honderden Indonesiërs aldus in Nederlands-Indië kennis maakten met westerse opvattingen, waren er ook al enkelen die in Nederland studeerden en daar de westerse invloed nog veel intensiever ondergingen.

Nationale bewustwording werd bovendien bevorderd door wat Indonesiërs nu dank zij westers onderwijs en onderzoek te weten kwamen over de geschiedenis van de Indonesische archipel voor de komst van de Europese kolonisatoren. Het bleek hun dat sommige inheemse culturen daar toen een hoog niveau bereikt hadden, waarvan onder meer een monumentaal kunstwerk als de Boroboedoer getuigde, en dat daar machtige rijken bestaan hadden zoals het Sumatraanse Sriwidjaja en het Javaanse Modjopahit.

In deze zelfde tijd werd de horizon van veel Indonesiërs verruimd door het verschijnen van diverse periodieken in het Maleis en andere inheemse talen. Het belangrijkste daarvan was Bintang Hindia (Ster van Indië), een veertiendaags tijdschrift dat in Amsterdam gedrukt werd en in Indië tienduizenden abonnees had. Het verscheen van 1902 tot 1907 en werd grotendeels geredigeerd door de Sumatraanse arts Abdoel Rivai, die in die tijd in Europa verbleef.

Eén van de facetten van het westers onderwijs was, dat de leerlingen in de eerste plaats beoordeeld werden op grond van hun kundigheden en prestaties. Dit contrasteerde met sommige Indonesische culturen waarin men men- 
sen in de eerste plaats beoordeelde op grond van hun afkomst en hun functie, en vooral met de Javaanse cultuur die een extreme nadruk op rang- en standsverschillen legde. Maar de door Indonesiërs in het westers onderwijs ervaren behandeling op basis van gelijkheid contrasteerde ook met de ongelijkheid van behandeling die hun verder in de kolonie ten deel viel. Die bestond niet alleen uit de wettelijke verschillen in rechtspositie tussen Inlanders en Europeanen, maar ook uit allerlei andere vormen van discriminatie en vernedering. Veel blanken maakten geen geheim van hun overtuiging dat de inheemse bevolking tot een inferieur ras behoorde. De inlander, zo zeiden zij, was dom, lui, onvolwassen en onbetrouwbaar. In hun mond werd het woord 'inlander' een uitdrukking van minachting.

Het westers middelbaar, beroeps- en hoger onderwijs was door zijn geheel Nederlandse opzet bijzonder zwaar voor inheemse scholieren en de meesten maakten hun studie dan ook niet af. Tegelijkertijd betekende dit, dat zij die hun opleiding wel voltooiden tot de meest intelligente en meest energieke Indonesiërs behoorden. $\mathrm{Zij}$ vormden in de koloniale samenleving het begin van een nieuwe elite tegenover de traditionele elite van de inheemse aristocratie. Hun opleiding bevorderde zowel hun zelfvertrouwen als hun verlangen om zich actief voor meer mondigheid in te zetten. Dit emancipatiestreven leidde in eerste aanleg tot de oprichting van moderne organisaties, onder meer op basis van etniciteit, beroep of religie. Een nationale politieke beweging liet niet lang meer op zich wachten.

De Indonesische nationale bewustwording werd ook gestimuleerd door de uitgesproken nationalistische gezindheid die in ditzelfde tijdsgewricht onder de Nederlanders heerste. Ook inheemse kinderen leerden het lied dat destijds het Nederlandse volkslied was en begon met de woorden 'Wien Neêrlands bloed in d'aders vloeit, van vreemde smetten vrij'. In 1913 werd de honderdste verjaardag van het herstel van de Nederlandse onafhankelijkheid ook in Nederlands-Indië uitbundig gevierd.

Dit betekent niet dat Indonesiërs alleen chauvinistische en racistische Europeanen ontmoetten. Vooral van de in steeds grotere aantallen uit Nederland overkomende vakmensen was een deel geheel vrij van zulke sentimenten. Daartoe behoorden verscheidene leraren bij het middelbaar onderwijs, die dan ook bijdroegen tot een opvoeding in liberale geest van hun Indonesische leerlingen. Hetzelfde gold voor sommige Nederlandse kostgezinnen van inheemse scholieren. Ook waren er hoge ambtenaren die zich met hart en ziel voor de emancipatie van de bevolking inspanden en persoonlijke contacten met ontwikkelde Indonesiërs onderhielden, zoals J.H. Abendanon, van 1900 tot 1905 directeur van onderwijs, eredienst en nijverheid, en G.A.J. Hazeu, van 1906 tot 1920 adviseur en regeringscommissaris voor inlandse en arabische zaken.

Hoe persoonlijk zulke contacten konden zijn, blijkt uit brieven die een 


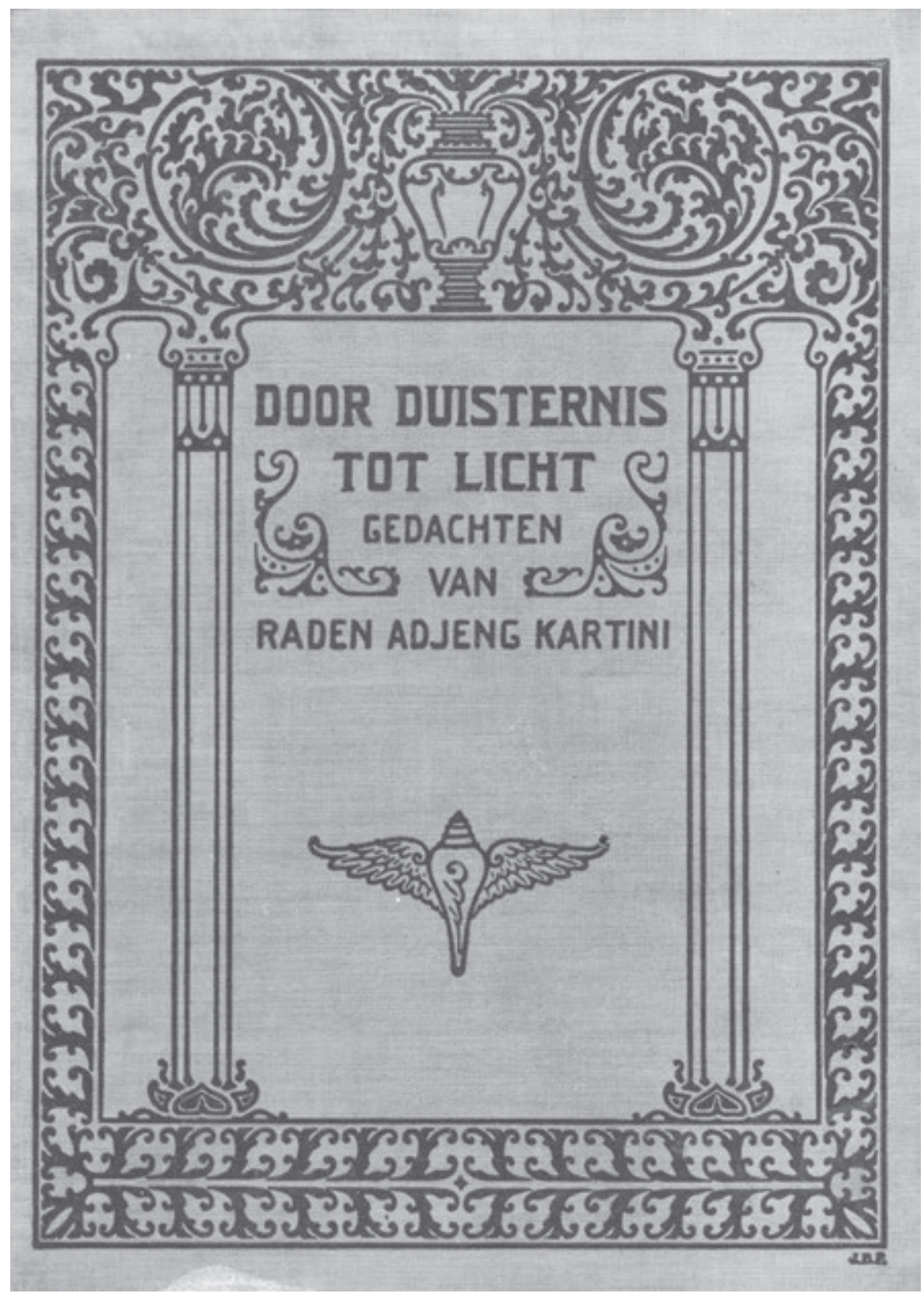

De Javaanse regentsdochter Kartini (1879-1904) schreef aan Nederlandse kennissen een groot aantal brieven, die in 1911 onder de titel Door duisternis tot licht in Nederland zijn gepubliceerd, waardoor men daar voor het eerst rechtstreeks kennis kon nemen van de gedachten en gevoelens van een inheemse ingezetene van Indonesië. 
Javaanse adellijke jongedame, Kartini, tussen 1899 en 1904 schreef aan een aantal Europese vriendinnen en vrienden. Kartini, die slechts vijfentwintig jaar oud is geworden, merkte op dat Nederland en de inheemse adel van de koloniale situatie profiteerden ten koste van het inheemse volk. Zij achtte onderwijs en opvoeding essentieel om die situatie te verbeteren en stelde daarbij al haar hoop op Nederlandse hulp. In 1911 publiceerde Abendanon in Nederland een aantal van haar brieven onder de titel Door duisternis tot licht. Dit boek, dat veel lezers vond, liet voor het eerst een breed Nederlands publiek rechtstreeks kennis nemen van de gedachten en gevoelens van een inheemse ingezetene van Indonesië.

Gouverneur-generaal Van Heutsz werd eind 1909 opgevolgd door A.W.F. Idenburg, een voormalig minister van koloniën. Idenburg was een overtuigd aanhanger van de 'ethische politiek' (zie pp. 114-7) en stond in beginsel positief tegenover de inheemse drang naar mondigheid.

\section{Buitenlandse stimulansen voor het Indonesische zelfbewustzijn}

De Indonesische emancipatiedrang werd ook bevorderd door ontwikkelingen in het buitenland. Vooral India oefende een voorbeeldwerking uit. Al spoedig na de opheffing van de East India Company in 1858 hadden enige inheemse Indiërs zitting gekregen in een wetgevende raad van de Britse onderkoning. In 1885 kwam door een bundeling van inheemse organisaties het Indian National Congress tot stand; twintig jaar later was dit uitgegroeid tot een nationale oppositiebeweging die vroeg om Indiaas zelfbestuur (swaraj). Intussen was deze beweging in overwegende mate een hindoe-organisatie geworden; de moslims, die een kwart van de bevolking vormden, begonnen zich zorgen te maken over hun toekomst in een door de hindoemeerderheid beheerst autonoom India en stichtten daarom een eigen massa-organisatie, de Muslim League. Het Indonesische zelfbewustzijn werd ook gestimuleerd door de in de negentiende eeuw sterk toegenomen westerse waardering voor de klassieke hindoekunst en -literatuur, waar de Indonesische cultuur veel banden mee had. Het Indiase prestige op cultureel gebied bleek verder uit de Nobelprijs die in 1913 werd toegekend aan de Indiase dichter Rabindranath Tagore.

Een andere inspiratiebron was Japan. Sinds 1868 voltrok zich daar het wonder dat het Japanse volk, na ruim twee eeuwen isolement, binnen enkele decennia leerde moderne westerse wetenschap en techniek toe te passen. Indonesische intellectuelen putten hieruit de hoop dat ook hun volk zich veel sneller zou kunnen ontwikkelen dan de Nederlanders mogelijk achtten. Het vernieuwde Japan ontpopte zich bovendien als een militaire macht van de eerste rang. Door een overwinning op China verkreeg het onder meer de heerschappij over Formosa (Taiwan). In 1905 versloeg het Rusland in Azië 
zowel op zee als op het vasteland. Dit maakte grote indruk op de inheemse bevolking van Indonesië en andere Aziatische koloniën. Voor het eerst sinds de vijftiende eeuw had een niet-westers volk een grote Europese mogendheid verslagen.

Nog op een andere manier beïnvloedde de opkomst van Japan de politieke situatie in Nederlands-Indië. Toen Nederland daar in 1899 aan de Japanners de juridische status van Europeanen toekende, lokte dit protest uit van de Chinese bevolking. De Nederlands-Indische Chinezen vormden nu een verbond om zich tegen hun achterstelling te verzetten en begonnen ook andere activiteiten ter versterking van hun positie, zoals de oprichting van eigen scholen. Die activiteiten prikkelden op hun beurt inheemse Indonesiërs tot navolging.

Intussen voltrokken zich ingrijpende veranderingen in de Filippijnen. Sinds de zeventiende eeuw had Spanje deze kolonie van Mexico uit bestuurd, totdat dit zich in 1821 van Spanje losmaakte. De Filippijnse elite, grotendeels van gemengd Spaans-Filippijnse afstamming, oriënteerde zich ook daarna meer op Latijns-Amerika dan op Azië. Al voor 1900 ontstond een Filippijnse onafhankelijkheidsbeweging, onder leiding van de dichter José Rizal. Hij werd in 1896 door de Spanjaarden terechtgesteld na het uitbreken van een opstand tegen het koloniale bewind. Een jaar eerder was ook Cuba tegen Spanje in opstand gekomen. In 1898 greep de Amerikaanse regering in beide conflicten in. De Filippijnse opstandelingen proclameerden nu een onafhankelijke republiek. Amerika dwong Spanje tot afstand van de Filippijnen, maar weigerde de republiek te erkennen. Er volgde een bijna drie jaar durende guerrilla-oorlog, die naar schatting meer slachtoffers gekost heeft dan de hele Atjeh-oorlog. Amerika wilde echter geen koloniale mogendheid zijn en ging de Filippijnen daarom voorbereiden op democratisch zelfbestuur. Het zette een grootscheeps onderwijsprogramma op. Al in 1907 kregen de Filippijnen een gekozen volksvertegenwoordiging. De uit de onafhankelijkheidsbeweging voortgekomen nationalistische partij veroverde daarin de meeste zetels. Enige jaren later begon men de Amerikaanse functionarissen zo veel mogelijk door Filippino's te vervangen.

\section{Boedi Oetomo en andere organisaties op etnische grondslag}

Leerlingen en oud-leerlingen van de artsenopleiding in Batavia (zie p. 145-6) vormden de voorhoede van de nieuwe Indonesische elite. Voorafgaand aan hun specifieke medische opleiding kregen zij een algemene vorming van hoger niveau dan die op de Kweekscholen en de Hoofdenscholen. Zij kwamen uit verschillende delen van de kolonie en behoorden meestal niet tot de hoge adel. De artsenschool STOVIA was een internaat, wat niet alleen het onderlinge contact tussen de studenten ten goede kwam maar ook contacten bevor- 
derde met Europeanen in Batavia die zich daarvoor open stelden. Daartoe behoorden de leraar Javaans D. van Hinloopen Labberton, voorman van de theosofische beweging, en de journalist E.F.E. Douwes Dekker, een achterneef van Multatuli.

Hoewel de oud-leerling Abdoel Rivai in Bintang Hindia gepleit had voor een bond van moderne inheemsen uit de hele archipel, kreeg de eerste inheemse organisatie naar westers model een meer beperkte opzet. Dit was Boedi Oetomo (Nobel Streven), een Javaanse bond ter bevordering van onderwijs en ontwikkeling. Boedi Oetomo werd op 20 mei 1908 opgericht door STOVIA-studenten samen met leerlingen van opleidingsscholen elders op Java, op initiatief van de twintigjarige student Soetomo. Ter herinnering hieraan geldt de datum van 20 mei in het huidige Indonesië als Dag van het Nationale Ontwaken.

Binnen enkele maanden telde Boedi Oetomo meer dan duizend leden, van wie studenten nu een minderheid vormden. Leden van de traditionele bestuurselite namen de leiding over en de bondszetel werd verplaatst naar Jogjakarta. De nieuwe leiding richtte de doelstellingen van de bond vrijwel alleen op zaken van onderwijs en cultuur en beperkte het lidmaatschap tot Javanen, Soendanezen en Madoerezen. Dit was een teleurstelling voor sommige jongere leden die een veel ruimere opzet beoogd hadden. Hiertoe behoorden onder meer de journalist Soewardi Soerjaningrat, die enige jaren aan de STOVIA gestudeerd had, en de arts Tjipto Mangoenkoesoemo. Tjipto had van de bond een politieke organisatie willen maken ten behoeve van de hele bevolking van Nederlands-Indië. Ook Soetomo was teleurgesteld, omdat de meeste bondsleden vooral het elite-onderwijs wilden bevorderen, terwijl hij evenals Tjipto juist het volksonderwijs voorrang wilde geven.

Het gouvernement was blij met de gematigde koers die Boedi Oetomo gekozen had en gaf de bond in 1909 officiële erkenning. Het ledental steeg tot tienduizend, maar daalde in de volgende jaren tot onder de vierduizend. De meeste leden waren ambtenaren of militairen. Ondanks zijn Javaanse opzet gebruikte de bond naast het Nederlands niet het Javaans als voertaal maar het Maleis. Van 1914 af begaf Boedi Oetomo zich ook in politieke activiteiten; van tijd tot tijd nam de bond daarbij radicale standpunten in.

Naast Boedi Oetomo kwamen verscheidene andere inheemse organisaties op etnische grondslag tot stand. Zo werd op Java al in 1908 een bond van Ambonese militairen opgericht, enkele jaren later gevolgd door een Menadonese vereniging. In 1914 vormden Soendanezen de organisatie Pasoendan, in 1917 werd een Sumatranen Bond opgericht en in 1920 een Madoerezenbond. In 1923 zag ook een organisatie voor de inheemse bevolking van Batavia het licht, de Kaoem Betawi. Bovendien ontstond er een reeks jongerenorganisaties op etnische grondslag, deels dank zij initiatieven van Javaanse, Sumatraanse, Menadonese en Ambonese STOVIA-studenten. 


\section{Vakverenigingen}

Tussen 1897 en 1907 richtten Europeanen in Nederlands-Indië de eerste vakverenigingen op. Dit waren onder meer bonden voor onderwijzers en voor personeel van de Staatsspoorwegen, van de posterijen, van landbouwondernemingen en van handelsondernemingen. De meeste van deze bonden hadden alleen Europese leden. Voorzover zij ook niet-Europeanen toelieten bleef de leiding toch in Europese handen.

Daarentegen was de in 1908 opgerichte Vereeniging van Spoor- en Tramwegpersoneel (VSTP) van begin af aan gemengd van opzet. Van 1914 af vormden de Indonesische leden er de meerderheid. In datzelfde jaar werden drie Indonesiërs in het hoofdbestuur opgenomen en werd ook een Maleis orgaan uitgegeven. In 1918 telde deze bond zesduizend leden, van wie Europeanen nog geen tiende deel uitmaakten. De VSTP had haar hoofdkantoor in Semarang.

Tussen 1911 en 1917 kwam een reeks exclusief Indonesische vakverenigingen tot stand. Eerst betrof dit vooral werknemers in intellectuele en administratieve beroepen, zoals journalisten, onderwijzers en personeel van de douane, de opiumregie, de pandhuisdienst en de openbare werken. Daarna volgden bonden van arbeiders en boeren. De belangrijkste daarvan was de in 1917 opgerichte Personeel Fabrieks Bond, die zijn aanhang voornamelijk in de suikerindustrie had.

Eind 1919 werd de eerste Indonesische vakbondsfederatie gevormd, waar al spoedig tweeëntwintig bonden met tezamen 72.000 leden aan deelnamen.

De toenemende vakbondsactiviteit droeg bij tot het ontstaan van talrijke werkstakingen, die in een aantal gevallen leidden tot loonsverhogingen en betere arbeidsvoorwaarden. In 1920 verklaarde het gouvernement dat het stakingen om uitsluitend economische redenen niet zou verhinderen, maar streng zou optreden tegen stakingen met politieke motieven. In 1923 werd de stakingsvrijheid aanzienlijk ingeperkt door de invoering van een nieuwe strafbepaling, die gevangenisstraf tot een maximum van vijf jaar stelde op het teweegbrengen van stakingen die zouden kunnen leiden tot verstoring van de openbare orde of ontwrichting van het economisch leven.

\section{De Indische Partij en het Comité Boemi Poetra}

E.F.E. Douwes Dekker, die een Javaanse grootmoeder had, stond in nauw contact met de oprichters van Boedi Oetomo maar was zelf vooral actief in organisaties van Indo-Europeanen. Hij had veel belangstelling voor de Filippijnse vrijheidsstrijd, waarin personen van Aziatisch-Europese afstamming een leidende rol speelden. Na een verblijf in Europa in 1909-1910 vestigde hij zich in 
Bandoeng en gaf daar een tijdschrift en een dagblad uit. In woord en geschrift sprak hij zich uit voor een vrij Indië als eigen vaderland voor allen die er thuishoorden, inlanders, vreemde oosterlingen en Europeanen: 'Indië voor de Indiërs!'

In september 1912 stichtte Douwes Dekker de Indische Partij, waarvoor hij tijdens een propagandareis door Java verscheidene plaatselijke afdelingen wist op te zetten. De leiding deelde hij met Tjipto Mangoenkoesoemo en Soewardi Soerjaningrat. De partij wilde volgens haar statuten alle Indiërs opwekken tot patriottisme en samenwerking op basis van staatkundige gelijkstelling om hun Indisch vaderland tot bloei te brengen en voor te bereiden voor een onafhankelijk volksbestaan. Zij keerde zich tegen rassendiscriminatie en rechtsongelijkheid en ijverde voor uitbreiding van het onderwijs en voor meer invloed op het landsbestuur. De partij telde al spoedig een zevenduizend leden, voor het merendeel Indo-Europeanen, en organiseerde manifestaties met vaandels en muziek.

De Indische Partij was de eerste echte politieke partij in de kolonie en de eerste organisatie die zich openlijk op nationale onafhankelijkheid richtte. Zij was op dat punt radicaler dan het Indian National Congress, dat nog tot 1920 uitsluitend naar zelfbestuur binnen het Britse Rijk streefde. Douwes Dekker noemde zichzelf en zijn medestanders 'nationalisten'.

De partij vroeg het gouvernement om officiële erkenning. Het gouvernement wees dit verzoek af met de motivering, dat de partij als politieke vereniging die de openbare orde bedreigde uit hoofde van het Regeringsreglement verboden was. Volgens gouverneur-generaal Idenburg betekende de doelstelling van de Indische Partij het voorbereiden van Indië voor het doorknippen van de band met Nederland en kon het Nederlands gezag zulk een doel nooit als wettig erkennen. Ook nadat de partij haar doelstelling anders geformuleerd had handhaafde Idenburg zijn afwijzing, maar hij toonde zich in maart 1913 wel bereid zijn standpunt in een uitvoerig gesprek met Douwes Dekker toe te lichten. Het bestuur ontbond daarop de partij, maar riep de leden op om over te stappen naar een al bestaande vereniging van Indo-Europeanen, Insulinde. Onder de vlag van deze vereniging werden de partij-activiteiten voortgezet. Douwes Dekker ging voor korte tijd naar Nederland om daar actie te voeren tegen de onderdrukking van de Indische Partij.

In diezelfde tijd werd in Nederlands-Indië geld ingezameld, ook bij de inheemse bevolking, voor het eeuwfeest van de Nederlandse onafhankelijkheid. Uit protest hiertegen vormde Tjipto het Inlandsch Comité tot Herdenking van Neêrlands Honderdjarige Vrijheid, naar de Maleise naam meestal aangeduid als het Comité Boemi Poetra (boemi poetra betekent inheems). Het comité vroeg om afschaffing van het verbod op politieke partijen en om instelling van een Indisch parlement. Het gaf ook een brochure uit van de hand van Soewardi onder de titel Als ik eens Nederlander was,... . Hij schreef hierin onder 


\title{
SOERAT EDERAN No. 1.
}

\section{DJIKA SAJA NEDERLANDER,...}

OLEH

\author{
R. M. SOEWARDI SOERJANINGRAT.
}

DI KELOEARKAN OLEH

Comité Boemipoetra goena merajakan Pesta Seratoes Tahoen Keradjaän Belanda. DI BANDOENG.

\section{VLUGSCHRIFT No. 1. ALS II EENS NEDERLAMDER WAS,...}

DOOR

R. M. SOEWARDI SOERJANINGRAT.

UITGAVE VAN HET

Inlandsch Comité tot Herdenking van

Neêrlands Honderdjarige Vrijheid.

\section{GEVESTIGD TE BANDOENG.}

Druk vas de Berare Bondoengache Publikatie Mastschappij.

Toen in 1913 in Nederlands-Indië ook onder Indonesiërs geld werd ingezameld voor het eeuwfeest van de Nederlandse onafhankelijkheid, publiceerde Soewardi Soerjaningrat (1889-1959) deze brochure waarin hij verklaarde dat hij, als hij Nederlander was, dit feest niet zou willen vieren in een door Nederland overheerst land. 
meer: 'Als ik Nederlander was, zou ik [...] niet willen, dat de inboorlingen dezer landen aan die herdenking mee deden [...]. Neen, voorwaar, als ik Nederlander was, ik zou nimmer zulk jubileum willen vieren hier in een door ons overheerst land. Eérst dat geknechte volk zijn vrijheid geven, dan pas onze eigen vrijheid herdenken.'

Naar aanleiding van deze brochure en enige andere publicaties arresteerde het gouvernement op basis van de exorbitante rechten (zie pp. 134-6) Soewardi en Tjipto en, na diens terugkeer, Douwes Dekker. Gesteld voor de keus tussen verbanning naar een uithoek van de archipel of vertrek uit NederlandsIndië, kozen alle drie dit laatste. Hun gedwongen vertrek uit de kolonie werd op initiatief van de Sociaal-Democratische Arbeiderspartij (SDAP) uitvoerig besproken in het Nederlandse parlement. Tjipto, die nog in 1912 een ridderorde had gekregen wegens zijn inzet voor de pestbestrijding, mocht binnen een jaar weer naar Java terugkeren. De verbanning van Soewardi werd in 1917 opgeheven, die van Douwes Dekker in 1918.

\section{De Sarekat Islam}

Dat het gouvernement de leiders van de Indische Partij uit Java verwijderde, gebeurde onder meer uit vrees voor hun mogelijke invloed op een andere beweging die in die tijd opkwam. Dit was de Sarekat Islam (SI, Islam-Bond), een organisatie voor samenwerking tussen moslims, die in 1912 was voortgekomen uit een al bestaande islamitische handelsbond op initatief van een batikhandelaar in Solo. De leiding kwam al spoedig in handen van een bondslid in Soerabaja, Oemar Said Tjokroaminoto. Hij behoorde tot een regentenfamilie en had gestudeerd op een OSVIA (ambtenarenschool, zie p. 145), maar wilde geen loopbaan bij de overheid en werkte onder meer als journalist.

Tjokroaminoto toonde zich een geboren organisator en volksmenner, die zijn toehoorders zelfvertrouwen en strijdbaarheid wist in te boezemen. Zijn optreden leidde tot de vorming van een groot aantal afdelingen van de nieuwe bond. Moslimvoorgangers in de dorpen werkten aan deze snelle uitbreiding mee. Begin 1913 had de SI al honderdduizend leden, ruim een jaar later waren het er meer dan driehonderdduizend. De eerste congressen van de bond, in 1913 in Soerabaja en Solo in de open lucht gehouden, trokken vele duizenden deelnemers. De stormachtige groei van de organisatie bewees, dat emancipatieverlangens niet alleen bij een handvol ontwikkelde inheemsen leefden maar ook onder brede lagen van de inheemse bevolking. Dat die zich juist op grondslag van de islam verenigden, kwam vooral omdat het onderscheid tussen de koloniale overheersers en de overheersten voor een groot deel van de bevolking samenviel met dat tussen christenen en moslims.

Uiteraard werden de bestuursfuncties vooral door ontwikkelden ver- 
vuld. Zo was Soewardi Soerjaningrat begin 1913 voorzitter van de afdeling Bandoeng van de SI. Vice-voorzitter van die afdeling was de journalist Abdoel Moeis. Deze was afkomstig uit Minangkabau, had enige jaren aan de STOVIA gestudeerd en was daarna assistent van Abendanon geweest. Moeis was in 1913 bovendien lid van het Comité Boemi Poetra. In 1916 werd hij vice-voorzitter van het centrale SI-bestuur.

De Sarekat Islam was de eerste Indonesische massabeweging. De beweging bleef bovendien niet tot Java beperkt, maar kreeg ook grote aanhang daarbuiten, vooral op Sumatra en Borneo. Op haar hoogtepunt in 1916 had zij ongeveer een half miljoen leden. De SI was echter geen strak geleide organisatie, maar eerder een losse verzameling plaatselijke bonden, die veel verschillen in opvattingen en in optreden aan de dag legden. Sommige begaven zich in antiChinese agitatie, andere richtten scholen en coöperaties op en legden klachten uit de bevolking voor aan het Binnenlands Bestuur.

Een deel van de aanhang beschouwde de Sarekat Islam als een instrument voor lotsverbetering binnen het bestaande koloniale bestel. Een aanzienlijk deel van de Javaanse leden bleek echter veel verder reikende verwachtingen te hebben: zij zagen in Tjokroaminoto de lang verwachte ratoe adil, die een eind zou maken aan onrecht en vreemde overheersing (zie pp. 56-7). De leiding van de SI was zich ervan bewust dat een confrontatiekoers tegenover het koloniale gezag het gevaar meebracht door het gouvernement te worden uitgeschakeld, zoals met de leiders van de Indische Partij gebeurde. Tjokroaminoto verklaarde in zijn openbare uitspraken, dat de SI niet op revolutie uit was maar graag met het gouvernement wilde samenwerken.

Ook het moslimkarakter van de SI had niet voor allen dezelfde betekenis. Voor sommigen betekende het vooral dat men zich verenigde tegenover de Nederlanders en de Chinezen; voor anderen was bevordering van de islam wel degelijk een belangrijke doelstelling. De islamitische grondslag van de SI had overigens tot gevolg dat verscheidene Arabische handelaren de bond financieel ondersteunden.

De SI had al in september 1912 officiële erkenning aangevraagd. Gouverneur-generaal Idenburg, die in de geest van de ethische politiek de inheemse emancipatie positief tegemoet wilde treden, zag zich hierdoor voor een dilemma geplaatst. Hij besprak de kwestie in maart 1913 met de leiding van de SI. Uiteindelijk wees hij de aanvraag af, maar verklaarde hij zich niettemin bereid erkenning van plaatselijke en regionale SI-bonden te overwegen. Inderdaad kregen daarna ruim vijftig van die bonden rechtspersoonlijkheid. In 1915 sloten ze zich aan bij een nieuwe koepelorganisatie, Centraal Sarekat Islam, met zetel in Soerabaja. Een jaar later werd deze organisatie toch door het gouvernement erkend. Idenburg's welwillende opstelling wekte overigens grote verontwaardiging bij veel Nederlanders; zij vonden van begin af aan dat de Sarekat Islam verboden moest worden. 
De alsnog erkende nationale Sarekat Islam hield in 1916 in Bandoeng een nieuw congres. De bond had intussen als één van zijn symbolen een roodwitte vlag ingevoerd omdat, naar men zei, dit eens de kleuren van Modjopahit geweest waren. Tjokroaminoto beklemtoonde op het congres de noodzaak van inheemse medezeggenschap in het koloniale bestuur, maar gaf opnieuw blijk van een coöperatieve houding tegenover het gouvernement.

Na 1916 nam de Sarekat Islam geleidelijk een meer militante houding tegenover het koloniale gezag aan, deels door de toenemende invloed van een marxistische stroming binnen en buiten de bond.

\section{Sneevliet en de Indische Sociaal-Democratische Vereeniging}

Het ontstaan van een marxistische stroming in de Indonesische politiek was grotendeels het werk van Henk Sneevliet, een socialistische activist die in maart 1913 in Nederlands-Indië kwam. In Europa was toen binnen de socialistische beweging al jaren een richtingenstrijd aan de gang tussen de reformistische rechtervleugel, die de maatschappij in hoofdzaak langs parlementaire weg wilde hervormen, en de radicale linkervleugel, die in massa-actie en eventueel revolutionaire actie het belangrijkste middel zag om een nieuwe maatschappij tot stand te brengen. Sneevliet was in Nederland bezoldigd voorzitter geweest van de vakbond voor spoor- en tramwegpersoneel, maar had die positie verloren als gevolg van zijn radicale opstelling. Daarna was hij naar Indië vertrokken, waar hij korte tijd journalist was in Soerabaja en vervolgens secretaris werd van de Handelsvereeniging in Semarang.

Sneevliet had zijn politieke belangstelling niet verloren. Al in de eerste maanden van zijn verblijf sprak hij zowel met Tjokroaminoto als met Douwes Dekker. Zelf vond hij noch de islam noch de Indische natie een juiste grondslag voor de strijd tegen het kolonialisme, omdat hij dit bovenal als een verschijningsvorm van het kapitalistische stelsel zag. In zijn visie moest men het kolonialisme bestrijden in het kader van de internationale klassenstrijd tegen alle vormen van kapitalisme. Sneevliet onderhield van begin af aan goede contacten met Indonesiërs en wist zijn politieke visie op verscheidenen van hen over te brengen. Ook verwierf hij een behoorlijke kennis van het Maleis en het Javaans. Ter bevordering van zijn politieke doeleinden maakte hij graag gebruik van bestaande organisaties.

De eerste organisatie die zich daartoe leende was de in Semarang zetelende Vereeniging van Spoor- en Tramwegpersoneel, die veel waarde aan zijn oordeel hechtte op grond van zijn vroegere functie. Sneevliet kwam in de redactie van het bondsorgaan. Onder zijn invloed werd de VSTP steeds militanter en nam haar inheemse aanhang sterk toe.

Een tweede mogelijkheid bood de Indische Sociaal-Democratische Vereeni- 
ging (ISDV) die in mei 1914 op initiatief van Sneevliet werd opgericht door dertig Nederlandse socialisten. In de eerstvolgende jaren kreeg deze vereniging er nog ruim honderd leden bij kreeg, onder wie ook enige Indonesiërs. Onder de oprichters vormden de radicalen een kleine minderheid, maar Sneevliet zat wel in het bestuur. Anderhalf jaar later richtte hij een nauw met de ISDV verbonden tijdschrift op. Geleidelijk wisten de radicalen hun invloed in de vereniging te versterken.

In de derde plaats werkte Sneevliet samen met de vereniging Insulinde, die het nationalistische streven van de Indische Partij voortzette en haar hoofdzetel in Semarang had. Tjipto Mangoenkoesoemo kwam na zijn terugkeer uit ballingschap in de leiding daarvan, maar de aanhang bestond nog steeds voornamelijk uit Indo-Europeanen.

Om de Indonesische massa's zelf te bereiken was het van belang invloed te krijgen binnen de Sarekat Islam. Dit gebeurde in hoofdzaak door de Javaanse spoorwegbeambte Semaoen, Sneevliet's meest begaafde discipel, die al op jeugdige leeftijd in de VSTP, de SI en de ISDV actief was. Semaoen werd in 1917 voorzitter van de afdeling Semarang van de SI en spande zich vervolgens in om de hele SI in marxistische zin te beïnvloeden. In de volgende jaren werd hij bovendien lid van de gemeenteraad van Semarang en voorzitter van de VSTP.

Sneevliet richtte in 1915 een actiecomité tegen de haatzaai-artikelen op (zie p. 136-7), waaraan onder meer de Inlandsche Journalisten Bond, de VSTP, de ISDV en Insulinde deelnamen. In 1916 trad hij uit de Nederlandse SDAP en werd hij lid van de Nederlandse Sociaal-Democratische Partij (SDP). Deze partij, die op het punt van koloniaal beleid de leuze 'Indië los van Holland' uitdroeg, doopte zich twee jaar later om tot Communistische Partij.

In maart 1917 reageerde Sneevliet geestdriftig op de Russische revolutie die het tsarenregime ten val had gebracht. In een dagbladartikel stelde hij die revolutie ten voorbeeld aan het volk van Java. Dit leidde tot een strafvervolging en tot zijn ontslag als secretaris van de Handelsvereeniging. Het strafproces vond in november plaats. Sneevliet klaagde het kolonialisme aan in een drie dagen durende verdedigingsrede en kreeg uiteindelijk ontslag van rechtsvervolging. Intussen hadden de reformistische leden van de ISDV hun lidmaatschap opgezegd en een Nederlands-Indische afdeling van de SDAP gesticht, die zich later Indische Sociaal-Democratische Partij (ISDP) noemde. De ISDV werd nu voorgoed een radicaal-marxistisch bolwerk.

Een jaar later spoorde Sneevliet de inheemse militairen van leger en vloot tot dienstweigering aan. Voor het gouvernement was nu de maat vol; het wees hem uit op grond van de exorbitante rechten. Eind 1918 moest Sneevliet de kolonie verlaten. Later verwijderde het gouvernement nog andere Nederlandse radicalen uit Indonesië, waardoor de leiding van de ISDV meer en meer bij Indonesiërs kwam te berusten. In 1920 veranderde de vereniging haar naam in 
Perserikatan Kommunist di India (PKI, Communistische Vereniging in Indië). Voorzitter hiervan werd Semaoen; vice-voorzitter werd Darsono, een andere leerling van Sneevliet.

\section{De Politieke Inlichtingen Dienst}

In 1916 richtte het gouvernement een Politieke Inlichtingendienst (PID) op, voornamelijk om toezicht uit te oefenen op binnenlandse politieke bewegingen. Na drie jaar hief men deze dienst weer op, maar zijn feitelijke werkzaamheden werden al spoedig in andere organisatorische kaders hervat en op de duur zelfs aanzienlijk uitgebreid. Dit werk gebeurde gedeeltelijk op centraal niveau, gedeeltelijk op regionaal en plaatselijk niveau, bijvoorbeeld door speciale afdelingen van de stedelijke politie. Hoewel er sinds 1919 geen centraal orgaan met de naam PID meer bestond, bleef men deze naam algemeen gebruiken voor alle delen van het politieapparaat die zich met toezicht op politieke activiteiten bezighielden. Dit spraakgebruik beantwoordde in zo verre aan de feitelijke situatie, dat het toezicht dat deze verschillende organen uitoefenden inderdaad van een centraal punt uit geleid werd. Daarom zal dit spraakgebruik ook hier gevolgd worden.

Op landelijk en plaatselijk niveau controleerden de PID-organen het doen en laten van alle politieke personen en groeperingen die naar hun mening een bedreiging voor het gevestigd gezag konden opleveren. Daarbij maakten deze organen gebruik van open bronnen en van in het geheim verkregen informatie. $\mathrm{Zij}$ volgden de pers, zowel om inlichtingen te verzamelen als om eventuele persdelicten te signaleren. $\mathrm{Zij}$ waakten tegen de invoer van politiek ongewenst drukwerk uit het buitenland. Zij controleerden of het onderwijs op particuliere scholen geen politieke propaganda bevatte. Zij adviseerden het plaatselijk bestuur bij beslissingen over het toestaan van politieke vergaderingen. Ook namen zij deel aan huiszoekingen, arrestaties en verhoren.

De centrale PID-organen verwerkten de van alle kanten binnenkomende informatie. Zij lichtten de top van het gouvernement voor over de lopende politieke ontwikkelingen. Ook leverden zij gegevens ten behoeve van concrete beslissingen, bijvoorbeeld over strafvervolgingen en verbanningen.

Het voor het publiek meest zichtbare deel van het PID-werk was de uitoefening van toezicht bij openbare vergaderingen. Radicale en nationalistische sprekers werden vaak onderbroken door de altijd aanwezige PID-agenten, die dan tegen bepaalde termen bezwaar maakten. Herhaaldelijk werden vergaderingen door zulke agenten voortijdig ontbonden.

De PID beschikte over een uitgebreid netwerk van informanten. Daartoe behoorden ook personen die zelf actief waren binnen de door de PID gewantrouwde organisaties en soms zelfs in de leiding daarvan. 


\section{De Indië Weerbaar-campagne}

Al sinds het begin van de twintigste eeuw verschilden Nederlandse deskundigen van mening over de vraag hoe men Nederlands-Indië kon verdedigen tegen een van buiten komende aanval (waarbij vooral aan Japan werd gedacht). Het koloniale leger, bestaande uit ongeveer tienduizend Europese en ongeveer vijfentwintigduizend inheemse beroepsmilitairen en vrijwilligers, was noch uitgerust noch opgeleid voor oorlogvoering tegen een modern bewapende buitenlandse vijand. Als dit leger met de externe verdediging van de kolonie werd belast, zou het in ieder geval sterk moeten worden uitgebreid. Die uitbreiding zou onvermijdelijk leiden tot een groter inheems aandeel in de troepenmacht, omdat het Nederlandse volk te klein was om zelf de benodigde mankracht te leveren en bovendien Europese militairen aanzienlijk duurder waren dan inheemse. Om de kosten te beperken zou het verder nuttig zijn, naast de werving van vrijwilligers ook dienstplicht voor inheemsen in te voeren.

Tegen zo'n uitbreiding van de koloniale landmacht bestonden behalve financiële ook politieke bezwaren. Het kon riskant zijn om een overheerste bevolking de beschikking te geven over een grote militaire macht. Zo had de Indian Mutiny van 1857 bijna een eind gemaakt aan de Britse heerschappij in India. Het risico zou nog groter worden als die macht zich in handen van dienstplichtigen zou bevinden, wier loyaliteit jegens de koloniale overheersers vermoedelijk zou onderdoen voor die van vrijwilligers. Aan de andere kant meenden sommige aanhangers van de ethische politiek, dat invoering van inheemse dienstplicht juist blijk zou geven van Nederlands vertrouwen en daardoor de band met de inheemse bevolking zou versterken.

Tegenover de pleitbezorgers van een sterkere landmacht stonden de voorstanders van een sterkere zeemacht. Aangezien het om een archipel ging, zou een externe aanval alleen over zee kunnen plaatsvinden. Daarom was het beter zulk een aanval al op zee af te slaan, maar daartoe zou men over een veel sterkere marine moeten beschikken. Japan had zelf in 1905 het belang van een sterke marine gedemonstreerd door zijn overwinning op de Russische vloot. De Nederlandse regering koos in 1913 weloverwogen voor een maritieme verdedigingsstrategie: de marine zou moeten zorgen voor de externe verdediging van de archipel, terwijl handhaving van de interne rust en orde de hoofdtaak van het koloniale leger zou blijven. In dat verband zou dit leger eerder in aanmerking komen voor inkrimping dan voor uitbreiding, in het bijzonder nu de afronding van het koloniale rijk voltooid was.

Na het uitbreken van de Wereldoorlog in 1914 mobiliseerde Nederland in drie dagen een landmacht van ruim tweehonderdduizend man. Voorstanders van uitbreiding van het koloniale leger brachten nu in Nederlands-Indië een discussie over de externe verdediging op gang, waarbij sommigen in het bijzonder pleitten voor versterking van het leger met een uit inheemse dienst- 
plichtigen te vormen Inlandse militie. Voor dit denkbeeld, dat gesteund werd door gouvernementsambtenaren en oud-gouverneur-generaal Van Heutsz, werd ook geprobeerd Indonesische steun te verkrijgen. De discussie groeide daardoor uit tot een verhitte controverse, waar zowel Indonesiërs als Nederlanders aan deelnamen en die tot het eind van de oorlog is voortgezet. In beide bevolkingsgroepen waren de meningen zeer verdeeld. Weliswaar voelden veel Nederlanders wel voor de invoering van een Inlandse militie, maar de ISDV was daar fel tegen, evenals de vereniging Insulinde. De leiding van Boedi Oetomo wilde het militie-idee steunen, maar moest haar steun op wens van de leden afhankelijk stellen van politieke concessies. Voor het eerst ging Boedi Oetomo nu een politieke rol spelen. Bij de Sarekat Islam keerden verscheidene afdelingen, waaronder die van Semarang en Batavia, zich tegen een Inlandse militie. Daarentegen zag Abdoel Moeis het militieplan als een nuttige hefboom voor politieke veranderingen. Met moeite lukte het hem het centrale SI-bestuur hierin mee te krijgen.

De voorstanders organiseerden in 1916 een grote campagne onder de leuze 'Indië Weerbaar'. De leiding berustte bij een Comité Indië Weerbaar, dat besloot een deputatie naar Nederland te sturen om een motie aan te bieden aan koningin en regering. De motie, die werd aangenomen op door Indië Weerbaar belegde massabijeenkomsten, sprak in algemene termen over de noodzaak van betere weerbaarheid en ging niet op de kwestie van een Inlandse militie in, wegens de bezwaren binnen de Sarekat Islam. Bovendien kreeg de campagne ook steun van voorstanders van een sterkere marine. Van Hinloopen Labberton leidde de deputatie, die verder bestond uit een IndoEuropese legerofficier en vijf vertegenwoordigers van Indonesische organisaties. De SI gaf haar vertegenwoordiger, Abdoel Moeis, een uitvoerige politieke instructie mee. De deputatie arriveerde in maart 1917 in Nederland, waar zij enige maanden bleef en met veel égards behandeld werd. $\mathrm{Zij}$ werd ontvangen door koningin Wilhelmina en had ontmoetingen met ministers en parlementsleden. Individuele leden van de deputatie gaven interviews en hielden spreekbeurten. Daarbij spraken de vertegenwoordigers van Boedi Oetomo en Sarekat Islam zich uit voor de instelling van een echt Indisch parlement met wetgevende macht; alleen zulk een parlement zou mogen besluiten tot de invoering van een Inlandse militie. Moeis verklaarde verder dat de SI zich wilde voorbereiden op een zelfstandig Indië.

De deputatie had slechts weinig invloed op de in Nederland heersende opvattingen. Regering en parlement bleven de externe verdediging van Nederlands-Indië als een marinetaak zien. Wel voerde de regering daar in 1917 dienstplicht voor Nederlanders in en kwam zij in 1918 met plannen voor een Inlandse militie van honderdduizend man, maar deze plannen werden enkele jaren later weer ingetrokken. Ook waren regering en parlement niet bereid wetgevende macht te geven aan een Nederlands-Indische volksvertegenwoordiging. 


\section{Instelling van de Volksraad}

Eind 1916, enige maanden voordat de deputatie van Indië Weerbaar in Nederland kwam, had het Nederlandse parlement een wet aangenomen tot instelling van een nieuw orgaan voor Nederlands-Indië, de Volksraad. Hierin zouden representatief geachte inwoners van de kolonie in het openbaar kunnen meepraten over wetgeving en beleid. Aan deze wet waren jarenlange discussies voorafgegaan, die hun oorsprong vonden in de al voor 1900 opgekomen onvrede onder de in Indonesië werkende Nederlanders over hun volledig gemis aan zeggenschap over het bestuur. Hoewel de nadien in het kader van de decentralisatie ingestelde plaatselijke en regionale raden deze onvrede ten dele hadden kunnen wegnemen, was besloten ook een vertegenwoordigend lichaam voor de hele kolonie in het leven te roepen. Naast Nederlanders zouden ook andere Nederlandse onderdanen (Indonesiërs, Chinezen en Arabieren) daar zitting in kunnen hebben.

Volgens de wet van 1916 kreeg deze Volksraad alleen adviserende bevoegdheden en ook zijn representativiteit was beperkt. Een aanzienlijk deel van de leden zou van bovenaf worden benoemd; de overige leden zouden worden gekozen door de leden van de plaatselijke en regionale raden. De zetelverdeling tussen de verschillende bevolkingsgroepen werd van te voren vastgelegd. De regering besloot dat de Raad uit 39 personen zou bestaan, onder wie 15 Indonesiërs. De regering zou zelf de voorzitter benoemen; van de gewone leden zou de helft worden gekozen en zou de andere helft door de gouverneur-generaal worden benoemd. Deze zou zijn benoemingen ná de verkiezing moeten doen, zodat hij de verkiezingsuitslag nog kon corrigeren als die te weinig recht had gedaan aan bepaalde politieke stromingen, maatschappelijke belangen of delen van de archipel.

De aldus door Nederland vastgestelde opzet van de Volksraad stelde veel politiek bewuste Indonesiërs teleur. Boedi Oetomo, de Sarekat Islam en enige andere verenigingen publiceerden medio 1917 een gezamenlijk politiek program, waarin zij verklaarden te streven naar een 'parlementaire regeringsvorm in nationale geest' en naar gelijkheid en uniformiteit van recht. Niettemin waren ze bereid aan de Volksraad mee te werken. Ten eerste betekende die in elk geval een grote stap vooruit ten opzichte van het bestaande volstrekt autocratische bestel. Ten tweede had de regering zelf verklaard te verwachten dat de Volksraad in de toekomst wetgevende bevoegdheid zou kunnen krijgen. Bovendien was er vertrouwen in de in 1916 aangetreden gouverneur-generaal J.P. van Limburg Stirum, die de benoemingen zou moeten verrichten. Hij was diplomaat van beroep en had geen Indische achtergrond, maar was evenals zijn voorganger Idenburg een overtuigd voorstander van de ethische politiek.

Tot de gekozen leden van de eerste Volksraad behoorden onder meer 
de Indonesiërs Abdoel Rivai, Abdoel Moeis en Koesoemo Joedo en de Nederlanders Bosscha en Van Hinloopen Labberton. Daarnaast benoemde Van Limburg Stirum onder meer Tjokroaminoto, Tjipto Mangoenkoesoemo en de voorzitter van de Indische Sociaal-Democratische Partij, ir. Ch.G. Cramer. Hij installeerde de Raad op 18 mei 1918. Tot zijn teleurstelling had koningin Wilhelmina het niet nodig gevonden een boodschap tot dit nieuwe orgaan te richten.

De leden van de Volksraad werden voor een tijdvak van drie jaar gekozen of benoemd. De Raad kwam tweemaal per jaar een paar maanden bijeen en vergaderde in beginsel in het openbaar. Hoge ambtenaren traden in de vergaderingen op als gemachtigden van het gouvernement om het beleid toe te lichten en te verdedigen. De leden konden niet strafrechtelijk vervolgd worden voor wat zij in de Raad zeiden of schriftelijk aan de Raad voorlegden.

Hoewel de Volksraad tot 1927 uitsluitend een adviesorgaan was, was hij juist in de eerste jaren het toneel van openhartige discussies en scherpe kritiek. Het gouvernement was onder meer verplicht de Raad te raadplegen over de begroting. Dit gaf de Raadsleden op zichzelf al gelegenheid om het hele beleid en allerlei facetten daarvan te bespreken. In de tweede plaats vroeg zowel de Nederlandse regering als het Nederlands-Indische gouvernement de mening van de Volksraad over verschillende voornemens tot wetgeving. Zo wijdde de Raad in 1918 en 1919 uitvoerige besprekingen aan het plan van de regering voor een Inlandse militie. Verder nam de Raad tientallen moties aan en behandelde hij honderden uit de bevolking binnengekomen klachten en verzoekschriften. Ook stelden de leden tal van schriftelijke vragen, die dan samen met de antwoorden gepubliceerd werden.

De Volksraad werd in 1921 uitgebreid tot 49 leden, onder wie 20 Indonesiërs, waarbij de gewone leden wederom voor de helft werden gekozen en voor de helft werden benoemd.

In 1927 kreeg de Volksraad bevoegdheden die verder gingen dan adviesverlening. Tegelijk werd het aantal leden uitgebreid tot 61 en de zittingsduur tot vier jaar, terwijl bovendien het kiesstelsel verandering onderging.

\section{Uitzicht op geleidelijke dekolonisatie}

In de jaren waarin de Volksraad voor Nederlands-Indië werd voorbereid, maakten de Filippijnen aanzienlijk méér voortgang in de richting van dekolonisatie. Al sinds 1907 beschikten ze over een gekozen volksvertegenwoordiging. In 1914 kregen Filippino's de meerderheid in het kabinet van de gouverneur. In 1916 gingen de Verenigde Staten een grote stap verder met de Philippine Autonomy Act. Deze wet gaf de Filippijnen een volledig parlement, bestaande uit een Assemblee en een Senaat, te kiezen op basis van algemeen 
kiesrecht voor allen die Engels, Spaans of een Filippijnse taal konden lezen en schrijven. Nog belangrijker was de preambule van de wet, die verklaarde dat de Verenigde Staten de onafhankelijkheid van de Filippijnen zouden erkennen zodra daar een stabiele regering gevestigd kon worden.

De Britse regering ging ten aanzien van India minder ver. Niettemin gaf zij de inheemse bevolking na 1907 ook daar meer medezeggenschap. Een Indiër werd opgenomen in de uitvoerende raad van de onderkoning (te vergelijken met de Raad van Indië). Daarnaast kreeg de inheemse bevolking meer zetels in de centrale wetgevende raad en in de provinciale en plaatselijke raden. Voormannen van de Congrespartij spraken nu in de wetgevende raad mee over de begroting. Wat de toekomst betreft deed de Britse regering in augustus 1917 toezeggingen waaruit viel af te leiden, dat India eens als deel van het Britse Rijk een zichzelf besturend gebied zou kunnen worden, waarvan de regering verantwoordelijk zou zijn aan een eigen parlement.

Kort daarna ging de Nederlandse regering ten aanzien van NederlandsIndië een eind in dezelfde richting. In maart 1918 verklaarde zij zich ten doel te stellen 'Indië's hulpbronnen zooveel mogelijk door Indische volkskracht te ontsluiten, de bevolking geschikt te maken tot het behartigen van eigen belangen en het bestuur van eigen land en daarmede de grondslag te leggen voor een volledig zelfbestuur'. Onder politiek bewuste Indonesiërs nam de ontevredenheid over het koloniaal bestel niettemin toe. In de eerste zitting van de Volksraad in mei-juli 1918 leverden de Indonesische leden zulke felle kritiek dat veel Nederlanders er diep door geschokt werden. Een eind september bijeengekomen congres van de Sarekat Islam getuigde eveneens van ontstemming en ongeduld. Op voorstel van Tjokroaminoto sprak het congres zich onder meer uit voor spoedige invoering van volledig zelfbestuur, kiesrecht voor alle mannen die schrijven konden en evenredige vertegenwoordiging van alle bevolkingsgroepen in de Volksraad (wat dus een overweldigende Indonesische meerderheid zou meebrengen). Hetzelfde congres koos de marxist Semaoen in het hoofdbestuur.

Op 11 november $1918 \mathrm{kwam}$ er een eind aan de Wereldoorlog. De politieke spanning in Nederlands-Indië steeg door berichten over revoluties in verschillende delen van de wereld. In de weer bijeengekomen Volksraad deelde ir. Cramer nu mee, dat de Raadsleden van de ISDP, de Sarekat Islam, Boedi Oetomo en Insulinde een gezamenlijk urgentieprogram van hervormingen zouden opstellen. Zij noemden hun samenwerkingsverband de Radicale Concentratie en streefden naar de vorming van een uit en door het volk gekozen parlement en de instelling van een aan dat parlement verantwoordelijke regering.

In deze situatie vond gouverneur-generaal Van Limburg Stirum het nodig onverwijld uitzicht op fundamentele veranderingen te bieden om de spanning te verminderen. Hij liet zijn woordvoerder in de Volksraad daarom op 18 
november en 2 december verklaringen voorlezen, waarin onder meer sprake was van een door de jongste wereldgebeurtenissen voorgeschreven nieuwe koers en van een in de toekomst noodzakelijke aanzienlijke uitbreiding van de bevoegdheden van de Volksraad, die dan daadwerkelijke medezeggenschap in en controle op het bestuur zou moeten krijgen. Verder kondigde hij de instelling van een commissie aan die een advies zou moeten opstellen over herziening van de staatsinrichting van Nederlands-Indië.

Deze verklaringen van gouverneur-generaal Van Limburg Stirum zijn bekend komen te staan als de 'november-beloften'. Noch de tekst van zijn verklaringen noch zijn plan voor een herzieningscommissie had hij van te voren aan de Nederlandse regering voorgelegd.

De enige weken later ingestelde commissie telde zesentwintig leden, onder wie acht Indonesiërs, en werd geleid door prof.dr. J.H. Carpentier Alting, president van het Hooggerechtshof. Hoewel de meningen onder de leden sterk uiteenliepen, kon de commissie medio 1920 een veelomvattend rapport uitbrengen met voorstellen waar een meerderheid mee instemde.

De commissie stelde onder meer voor ieder wettelijke onderscheid naar ras en landaard af te schaffen. Indonesiërs zouden toegang moeten krijgen tot alle functies in het Binnenlands Bestuur. De Volksraad zou moeten worden vervangen door een vertegenwoordigend lichaam van minstens honderd leden, onder wie tachtig gekozen leden. Deze volksvertegenwoordigers zouden niet via getrapte verkiezingen maar rechtstreeks gekozen moeten worden, met kiesrecht voor alle onderdanen met een bepaald minimum-inkomen die konden lezen en schrijven. De regering zou bestaan uit de gouverneur-generaal plus de Raad van Indië en zou in beginsel de wetgevende macht samen met de volksvertegenwoordiging uitoefenen. De commissie wilde het bestaande Regeringsreglement vervangen door een geheel nieuwe wet en legde daartoe een ontwerp voor. $\mathrm{Zij}$ stelde ook een verandering voor van de staatsrechtelijke verhouding tussen Nederlands-Indië en Nederland en ontwierp daartoe wijzigingen van de Nederlandse grondwet. Onder meer wilde zij de naam 'Nederlands-Indië' veranderd zien in 'Indië', om aan te geven dat dit Rijksdeel niet aan Nederland ondergeschikt was.

Intussen had het Britse parlement eind 1919 een nieuwe Government of India Act aangenomen, die ter uitvoering van de toezeggingen van 1917 de invloed van de inheemse bevolking op het bestuur aanzienlijk vergrootte. Het ledental van de centrale wetgevende raad en van de provinciale raden werd uitgebreid; de meerderheid van die leden zou voortaan niet meer worden benoemd maar gekozen, op basis van kiesrecht voor allen die aan bepaalde criteria van ontwikkeling en welstand voldeden. Het bestuur over de provincies zou gedeeltelijk worden uitgeoefend door Indiase ministers, die verantwoording verschuldigd zouden zijn aan de provinciale raden. Drie Indiërs werden opgenomen in de uitvoerende raad van de onderkoning. 
De Nederlandse regering diende in 1921 bij het parlement enige ontwerpwijzigingen van de grondwet in, die gedeeltelijk aan de voorstellen van de commissie-Carpentier Alting ontleend waren. In de toelichting op haar grondwetsvoorstellen schreef de regering onder meer, dat 'zoowel wetgeving als bestuur ten aanzien van de inwendige aangelegenheden zooveel mogelijk moeten worden gelegd in handen van in Indië zelf zetelende lichamen en overheden en dat aan de aldaar gevestigde bevolking een zoo groot mogelijke invloed op en aandeel in de samenstelling dier lichamen moet worden toegekend'. Zij handhaafde overigens de naam 'Nederlands-Indië'. Daarentegen besloot de Tweede Kamer op aandrang van de Volksraad het woord 'kolonie' uit de grondwet te verwijderen. In 1922 werd de gewijzigde grondwet van kracht. Terwijl artikel 1 vroeger luidde: 'Het Koninkrijk der Nederlanden omvat het grondgebied in Europa, benevens de koloniën en bezittingen in andere werelddeelen', kwam het nu te luiden: 'Het Koninkrijk der Nederlanden omvat het grondgebied van Nederland, NederlandschIndië, Suriname en Curaçao'. Van nog meer belang was een geheel nieuw artikel, dat bepaalde dat de regeling van de inwendige aangelegenheden van Nederlands-Indië in beginsel werd overgelaten aan aldaar gevestigde organen, terwijl in die gevallen waarin de Nederlandse wetgever onderwerpen betreffende dat gebied zou regelen, het vertegenwoordigend lichaam van het gebied gehoord zou moeten worden.

Uit de grondwetswijziging van 1922 leidden sommige Indonesiërs af, dat Nederland serieus bereid was aan de koloniale verhouding een eind te maken.

Studenten in Nederland; de Indische Vereeniging en het Indonesisch Verbond van Studeerenden

Sinds het eind van de negentiende eeuw kwamen Indonesiërs op beperkte schaal naar Nederland om te studeren aan universiteiten en andere onderwijsinstellingen. In 1900 waren het pas enkelen, maar hun aantal nam toe tot bijna veertig in 1910, ongeveer zeventig in 1920 en een maximum van honderdvijftig in 1930. In gelijksoortige omvang studeerden ook Chinezen uit Indonesië in Nederland. De Indonesische studerenden richtten in 1908 de Indische Vereeniging (IV) op, met Abendanon als erelid. De Chinese studenten hadden een eigen vereniging, de Chung Hwa Hui.

In de beginjaren hield de IV zich nauwelijks met politiek bezig. Eén van haar voorzitters in die tijd was Hoesein Djajadiningrat, een regentenzoon uit Bantam die op aansporing van Snouck Hurgronje in Leiden oosterse talen studeerde en daarna als eerste Indonesiër aan een Nederlandse universiteit promoveerde. Van 1911 tot 1914 berustte het voorzitterschap bij een andere 
aristocraat, Noto Soeroto, die meende dat de emancipatie van Indonesië nog een langdurig samengaan met Nederland vereiste. Hij beijverde zich om het Nederlandse volk bekend te maken met de Javaanse cultuur, schreef gedichten in het Nederlands, werd opgenomen in de Nederlandse kring van schrijvers en kunstenaars en bleef tot 1932 in Nederland.

Na 1912 nam de politieke bewustwording onder de Indonesische studenten sterk toe, ten dele onder invloed van de ontwikkelingen in hun geboorteland. Zo schreef G.S.S.J. Ratoelangie, een christen uit de Minahasa, een brochure over de Sarekat Islam, waarin hij zowel het Nederlandse bestuur als de inheemse adel scherp bekritiseerde. Eind 1914 werd hij voorzitter van de IV. De meest gezaghebbende figuur onder de Indonesiërs in Nederland was in deze periode de vroegere voorman van de Indische Partij, Soewardi Soerjaningrat. Hij was eind 1913 als balling aangekomen en volgde een Nederlandse onderwijzersopleiding. Nadat zijn verbanning was opgeheven, bleef hij nog tot 1919 in Nederland, omdat de regering lange tijd weigerde zijn terugreis te betalen. Soewardi was een principieel voorstander van onafhankelijkheid voor Indonesië, al hoopte hij evenals Ratoelangie dat de scheiding met Nederland zich in vriendschap zou voltrekken. Hij werd lid van de SDAP en probeerde vergeefs deze partij tot het standpunt 'Indië los van Holland' te bekeren. Hij keerde zich tegen de Indië Weerbaar-campagne en pleitte voor de instelling van een Indisch parlement met wetgevende macht. Hij publiceerde veel en redigeerde onder meer het door de IV uitgegeven maandblad Hindia Poetra (Zonen van Indië).

Intussen leidde de politieke bewustwording tot enig onbehagen over het woord Indië ter aanduiding van de Indische archipel. Men gebruikte de naam Indië immers ook voor delen van het Aziatische vasteland, zoals Voor-Indië en Achter-Indië, terwijl de nadere aanduiding Nederlands-Indië onverbrekelijk met de koloniale overheersing verbonden was. Er bestond daarom behoefte aan een andere naam, die ook na het eind van die overheersing in stand zou kunnen blijven. Bovendien waren er problemen met het woord Indiër. Behalve dat dit ook voor de inheemse bevolking van Voor-Indië gebruikt werd, deed zich hier nog een andere complicatie voor. Ter vermijding van de officiële term Inlanders, die een beledigende klank gekregen had, hadden de oprichters van de Indische Vereniging de inheemse bevolking van Nederlands-Indië als Indiërs betiteld. Maar daarna waren de Indische Partij en de Vereniging Insulinde dezelfde benaming uitdrukkelijk gaan gebruiken voor de hele bevolking, met inbegrip van Chinezen, Indo-Europeanen en blanken. Ook op dit punt rees dus behoefte aan een ander woord. Onder Nederlanders die de woorden Nederlands-Indië en Inlanders wilden vermijden bestond nog steeds de gewoonte om van Java en Javanen te spreken, ook als zij de hele archipel en alle inheemsen bedoelden. Voor niet van Java afkomstige inheemsen was dit geen aantrekkelijk woordgebruik. Daarom ging de voorkeur nu uit naar de 
termen Indonesië en Indonesiërs, die in de taalwetenschap en de volkenkunde al jarenlang in zwang waren.

De eerste organisatie die deze nieuwe terminologie in haar naam gebruikte, droeg overigens in overwegende mate een Nederlands stempel. Dit was het Indonesisch Verbond van Studeerenden (IVS), een eind 1917 gevormd samenwerkingsverband van verenigingen van personen die zich voorbereidden op een werkkring in Indonesië. Het initiatief was uitgegaan van de Leidse Indologen Vereeniging onder leiding van H.J. van Mook. Nederlandse verenigingen van onder meer toekomstige bestuursambtenaren, legerofficieren, planters en zendelingen sloten zich bij dit verbond aan, tezamen met de Indische Vereeniging en Chung Hwa Hui. De eerste voorzitter van het IVS werd J.A. Jonkman, een jurist die zelf nog niet in Indonesië geweest was maar zich voorbereidde op een loopbaan bij de rechterlijke macht aldaar. Hij meende in die tijd, dat de Nederlandse 'voogdij' over de kolonie ten einde liep en dat de ethische politiek plaats zou moeten maken voor een 'Indonesischnationale' politiek. Van Mook, die wel in Indonesië geboren en opgegroeid was, werd secretaris-penningmeester. Ook hij stelde zich in op de komst van een zelfstandig Indonesië, dat op voet van gelijkheid plaats zou bieden aan inheemsen, Chinezen en Nederlanders. Hij vond het echter nog te vroeg voor een Indisch parlement. In plaats daarvan pleitte hij voor een geleidelijke ontwikkeling door de instelling van democratische organen op plaatselijk en vervolgens regionaal niveau.

Het IVS organiseerde in de jaren 1918-1922 een zestal congressen en verschillende andere bijeenkomsten. Hindia Poetra verscheen in deze periode als orgaan van het Verbond. Het oogmerk van de oprichters om de verschillende groepen nader tot elkaar te brengen werd onvoldoende bereikt. De politieke opvattingen van de Nederlandse en de Indonesische studenten liepen steeds verder uiteen en de congressen leidden dan ook herhaaldelijk tot verbale botsingen.

Intussen vertrok een deel van hen die in de IV en het IVS een rol gespeeld hadden, onder wie Soewardi, Ratoelangie, Van Mook en Jonkman, in 19181919 naar Indonesië. Omgekeerd kwamen in Nederland nu Indonesiërs studeren die al jaren van politieke beroering hadden meegemaakt. Onder hen was ook de arts Soetomo, eens de initiatiefnemer van Boedi Oetomo, die nu naar Nederland kwam voor een vervolgopleiding. In 1921 was hij voorzitter van de IV. Het jaar daarop veranderde de vereniging haar naam in Indonesische Vereeniging. In 1923 trok zij zich terug uit het IVS; kort daarna hield het Verbond op te bestaan. 


\section{Verharding van het Nederlands koloniaal beleid}

De in 1918 door Van Limburg Stirum afgelegde 'november-beloften' wekten een storm van verontwaardiging, zowel in Nederland als onder de Nederlanders in Indonesië. De voorzitter van de Tweede Kamer, D. Fock, die van 1905 tot 1908 minister van koloniën geweest was, bestempelde ze als 'onbegrijpelijke uitlatingen' en 'verwarring stichtende fantasieën'. Toch lagen die verklaringen in het verlengde van de lijn die de regering enige jaren eerder had uitgezet. De nu gerezen verontwaardiging getuigde er dan ook van, dat de Nederlandse houding tegenover de ontvoogding van Indonesië aan het veranderen was.

In 1908, toen Boedi Oetomo werd opgericht, stonden veel vooraanstaande Nederlanders welwillend tegenover het Indonesische emancipatiestreven. $\mathrm{Zij}$ dachten dat die emancipatie generaties zou vergen en dat de geëmancipeerde Indonesiërs de Nederlandse leiding nog lange tijd zouden aanvaarden. Maar in de sindsdien verstreken tien jaar was veel gebeurd dat vrijwel geen Nederlander verwacht had. Uit het emancipatiestreven was een nationale politieke beweging voortgekomen, die volgens haar eigen innerlijke logica op nationale onafhankelijkheid afkoerste.

Dit laatste ging de meeste Nederlanders (ook Van Limburg Stirum zelf) veel te ver. Velen vonden het daarom hoognodig deze gevaarlijke trend af te remmen. $\mathrm{Zij}$ verweten het gouvernement onder Van Limburg Stirum dat het de trend niet afremde maar juist aanmoedigde, niet alleen door de 'novemberbeloften' maar ook meer algemeen door een te meegaande houding tegenover organisaties als de Sarekat Islam. Een groot deel van de Nederlandse pers in Indonesië trok fel van leer tegen de ethische koers, die men graag als 'huilerig' of 'ziekelijk' betitelde. De aanvallen richtten zich ook op de gouverneurgeneraal persoonlijk en nog meer op diens adviseur Hazeu, die bij uitstek als representant van die koers beschouwd werd. Onder druk van deze campagne nam Hazeu eind 1919 ontslag; met hem vertrok de laatste hoge gouvernementsambtenaar die goede persoonlijke betrekkingen met leiders van de Indonesische beweging onderhield.

De overgrote meerderheid van het Nederlandse volk kon zich een door Indonesiërs bestuurd onafhankelijk Indonesië eenvoudig niet voorstellen. Men aanvaardde in Nederland het kolonialisme als een historisch gegeven en was er trots op dat men zelf tot de koloniale overheersers behoorde. Die overheerserspositie gaf de meeste Nederlanders ook geen gewetensproblemen. Het een halve eeuw eerder nog levendige besef, dat men Indonesië ten eigen bate exploiteerde, was naar de achtergrond gedrongen door het omstreeks de eeuwwisseling in zwang gekomen ethische woordgebruik. De meeste Nederlanders waren er inmiddels van overtuigd, dat het Nederlandse bewind de Indonesische bevolking tot zegen strekte en dat verbreking van de band tussen Nederland en Indië zowel de Nederlanders als de Indonesiërs zou schaden. 
De houding van de blanke Nederlanders in Indonesië zelf werd bovendien beïnvloed door enige aspecten die in Nederland geen rol speelden. Ten eerste was hun eigen maatschappelijke positie in het geding, omdat zij het aan de koloniale verhouding te danken hadden dat ze tot de bevoorrechte bovenlaag behoorden. Ten tweede was hun veiligheid in het geding, omdat zij in de kolonie weinig meer dan een duizendste van de bevolking vormden (en samen met de Indische Nederlanders nog geen half percent). Leger en politie waren voldoende in staat om plaatselijke relletjes en opstanden te onderdrukken, maar de opkomst van een Indonesische massabeweging riep het schrikbeeld op van grootschalig anti-Nederlands verzet.

Tegen deze achtergrond rees in 1918 en daarna de roep om een krachtiger beleid tegenover de Indonesische nationale beweging. Als richtsnoeren voor zo'n beleid werden vooral de volgende punten naar voren gebracht.

Strikte gezagshandhaving was van essentieel belang. Het gouvernement zou geen enkele toegeeflijkheid of wankelmoedigheid aan de dag mogen leggen tegenover hen die zich tegen het Nederlandse gezag keerden, maar zou de beschikbare machtsmiddelen zonder aarzeling moeten gebruiken om duidelijk te maken dat het geen aantasting van dat gezag zou dulden.

Tegelijk was het van belang de banden aan te halen met de inheemse aristocratie en de feodale vorsten, waar het Nederlandse gezag van oudsher op gesteund had. Zij waren de natuurlijke bondgenoten van Nederland, omdat ook hun positie bedreigd werd door de opkomst van de nieuwe elite die de motor van de nationale beweging vormde.

Verder diende men ervan uit te gaan dat er geen Indonesische natie bestond. Drie eeuwen geleden hadden de Nederlanders in de archipel allerlei volkeren aangetroffen, die niet alleen van taal en cultuur verschilden maar ook voortdurend in onderlinge conflicten gewikkeld waren. De sindsdien binnen de kolonie tot stand gekomen eenheid was uitsluitend een product van het Nederlandse bestuur. In de huidige fase moest men juist nadruk leggen op de onderlinge verscheidenheid van de bevolking.

De invloedrijkste pleitbezorger van zulk een beleid was H. Colijn, een man die Abraham Kuyper na 1920 zou opvolgen als leider van de AntiRevolutionaire Partij (ARP). Colijn had als officier van het koloniale leger aan de strijd op Lombok en in Atjeh deelgenomen en was daarna zowel in Atjeh als in Batavia één van de naaste medewerkers van Van Heutsz geweest. Na terugkeer in Nederland werd hij afwisselend lid van het parlement en van de regering, onder meer als minister van oorlog en minister van financiën en in de jaren 1925-1926 en 1933-1939 als minister-president. Bovendien was hij van 1913 tot 1922 directeur van de Bataafsche Petroleum Maatschappij (BPM). Colijn betoogde al in 1918, dat de staatkundige ontwikkeling van NederlandsIndië niet in de richting van een eenheidsstaat moest worden geleid maar in die van een federalistische staat. Die staat zou een aantal eilanden en eilan- 
dengroepen met een aanzienlijke mate van zelfbestuur moeten omvatten, terwijl het centrale federale gezag nog lange tijd in Nederlandse handen zou blijven. In dat verband vond hij de instelling van de Volksraad een ernstige misgreep; hij zou die in de toekomst vervangen willen zien door een federale raad, bestaande uit vertegenwoordigers van de deelstaten. Colijn ontleende zijn denkbeelden gedeeltelijk aan de Britse regering, die begin 1918 plannen ontvouwd had voor een federalisering van India.

Een andere gezaghebbende criticus van de ethische koers was de liberaal M.W.F. Treub, die in de Wereldoorlog minister van financiën geweest was en in 1921 voorzitter werd van de Ondernemersraad voor Nederlandsch-Indië (zie p. 192). Ook hij propageerde een federalistische staatsinrichting. Hetzelfde gold voor F.C. Gerretson, een uitgesproken voorstander van de harde lijn in Nederlands-Indië. Gerretson had onder Colijn als staffunctionaris bij de BPM gewerkt, maar behoorde tot een andere protestants-christelijke partij, de Christelijk-Historische Unie.

Colijn, Treub en Gerretson publiceerden hun denkbeelden in verschillende brochures en artikelen en hadden aanzienlijke invloed binnen de regeringspartijen. In 1920 werd Colijn gepolst voor de post van gouverneur-generaal. Hij weigerde, onder meer omdat de regering niet wilde toezeggen de Volksraad tot een bescheidener positie terug te zullen brengen. Tot opvolger van Van Limburg Stirum benoemde de regering daarop oud-minister Fock, de man die hem in het parlement wegens de 'november-beloften' scherp bekritiseerd had.

De nieuwe gouverneur-generaal trad in 1921 aan en werd door de meeste Nederlanders in Indonesië met vreugde verwelkomd. Hij probeerde geen vertrouwen te winnen onder de leiders van de Indonesische beweging. De regering had hem in het bijzonder belast met het saneren van een toen bestaand tekort op de gouvernementsbegroting. Daartoe voerde hij een rigoureus bezuinigingsbeleid, onder meer door inkrimping van onderwijs en gezondheidszorg, terwijl tegelijkertijd de belastingdruk op de inheemse bevolking sterk werd opgevoerd. Van de kant van Nederland viel geen financiële hulp te verwachten, want ook daar was men bezig met een bezuinigingsoperatie.

Onder het bewind van Fock legde het gouvernement de politieke activiteiten van Indonesiërs steeds verder aan banden. Het verscherpte de voorschriften voor vergaderingen en verenigingen en breidde het politietoezicht uit. Tenslotte werden in 1926 zware strafbepalingen ingevoerd onder meer tegen uitingen waarin 'stemming wordt gemaakt' (ook zijdelings, voorwaardelijk of in bedekte termen) voor verstoring van de openbare orde of aanranding van het gezag (zie p. 137).

Er braken in deze jaren verscheidene stakingen uit. Wanneer dit overheidspersoneel betrof, wist het gouvernement er meestal snel een eind aan te maken, onder meer door de stakers terstond te ontslaan en, wanneer ze in dienstwoningen woonden, uit hun huis te zetten. Maar ook tegen stakingen bij 
particuliere ondernemingen trad het gouvernement soms hard op, vooral na de invoering in 1923 van een strafbepaling tegen het teweegbrengen van stakingen die konden leiden tot verstoring van de openbare orde of ontwrichting van het economisch leven.

De verandering van het politieke klimaat betrof niet alleen het optreden van de overheid. Terwijl in de Volksraad van 1918 de conservatieve leden een minderheid vormden, kregen ze bij de verkiezingen van 1921 een ruime meerderheid. De achtergrond hiervan was dat de conservatief gezinde Nederlanders in Indonesië in de jaren 1908-1918 nauwelijks hadden deelgenomen aan de verkiezingen voor plaatselijke en regionale raden, waardoor de hervormingsgezinde Nederlanders toen niet alleen onder de leden van die lichamen sterk vertegenwoordigd waren geraakt, maar ook in de door deze raadsleden in 1918 gekozen Volksraad. De sindsdien opgekomen agitatie tegen de ethische koers had de politieke belangstelling van de conservatieve Nederlanders aanzienlijk vergroot.

Wat de leiders van de Indonesische beweging betreft, keerden Abdoel Moeis, Tjipto Mangoenkoesoemo en Tjokroaminoto in 1921 niet in de Volksraad terug. Wel werd een andere voorman van de Sarekat Islam, Agoes Salim, nu tot lid benoemd.

\section{Het Indo-Europeesch Verbond}

In de jaren 1912 en 1913 dachten sommige Indo-Europeanen, dat hun bevolkingsgroep een leidende rol zou kunnen spelen wanneer Indonesië onafhankelijk zou worden en de blanke Europeanen het land zouden verlaten. Tot degenen die zo dachten behoorden E.F.E. Douwes Dekker en een deel van zijn aanhang in de Indische Partij. De stormachtige ontwikkeling van de Indonesische emancipatiebeweging in de daarop volgende jaren maakte niet alleen een eind aan deze gedachte, maar gaf ook voedsel aan een omgekeerde verwachting. Velen vreesden dat de Indo-Europese bevolkingsgroep in een door de Indonesiërs zelf geleide onafhankelijke staat een onderdrukte minderheid zou worden. Zo gezien hadden de Indo-Europeanen belang bij handhaving van het koloniale bestel. Intussen ondervonden zij ook in dit bestel al achterstelling op velerlei gebied, terwijl hun positie verder onder druk kwam te staan door de snelle toename van westers opgeleide Indonesiërs, die onder meer met hen concurreerden op de arbeidsmarkt voor administratief werk. Een en ander wekte onder de Indo-Europeanen de wens, hun krachten te bundelen om hun positie te verbeteren en zich tegen de Indonesische emancipatiebeweging af te zetten.

Tegen deze achtergrond kwam in 1919 een nieuwe organisatie tot stand, het Indo-Europeesch Verbond (IEV). Het verbond wilde de intellectuele en 
economische ontwikkeling van de Indo-Europeanen bevorderen, stelling nemen tegen iedere bedreiging van hun belangen en zich verzetten tegen aantasting van het Nederlandse gezag in Nederlands-Indië. Het hield zich onder meer bezig met het oprichten van scholen en met pogingen tot het vormen van een Indo-Europese boerenstand. Ten behoeve van dit laatste stichtte het enige landbouwkolonies op Java en Sumatra.

Hoewel het IEV zich als een niet-politieke belangenorganisatie had aangediend, ging het toch een politieke rol spelen. Met ingang van 1924 stelde het eigen kandidaten voor de plaatselijke raden en de Volksraad. In de Volksraad kreeg het eerst vier, later zes en uiteindelijk acht vertegenwoordigers; dezen steunden waar mogelijk het gouvernement tegen de oppositie. Het IEV telde in de jaren dertig ongeveer twaalfduizend leden en was daarmee de grootste partijgroepering onder de Europese bevolking van de kolonie.

\section{De Nationaal-Indische Partij}

Zoals op p. 163 vermeld hadden de drie leiders van de voormalige Indische Partij in 1913 Nederlands-Indië moeten verlaten en waren de activiteiten van de partij voortgezet onder de vlag van de vereniging Insulinde, die van oorsprong een organisatie van Indo-Europeanen was. Tjipto Mangoenkoesoemo mocht in 1914 terugkeren en woonde daarna enige tijd in Semarang, waar Insulinde haar hoofdzetel had. Hij was ook lid van de ISDV en ontwikkelde zich daarin tot een tegenstander van Sneevliet. In 1918 werd hij tot lid van de Volksraad benoemd. In datzelfde jaar kreeg Douwes Dekker toestemming tot terugkeer, maar een groot deel van zijn vroegere aanhang had zich intussen van Insulinde afgekeerd. De meeste Indo-Europeanen wilden nu de band met Nederland niet losser maken maar juist versterken; enige tijd later leidde dit tot de oprichting van het in de vorige paragraaf besproken Indo-Europeesch Verbond.

In 1919 zette Douwes Dekker met een kleine groep volgelingen Insulinde om in een nieuwe partij, waarvan de statuten in aangescherpte vorm aan de vroegere Indische Partij ontleend waren en het einddoel omschreven als 'volkomen onafhankelijkheid van Indië'. De partij kreeg als Nederlandse naam Nationaal-Indische Partij (NIP) en als Maleise naam Sarekat Hindia (SH). Voorzitter werd eerst Soewardi Soerjaningrat, die nu eveneens was teruggekeerd, en later Tjipto Mangoenkoesoemo. Deze nieuwe partij bleek echter ook onder Indonesiërs niet populair te worden. De verhoudingen tussen de bevolkingsgroepen waren al zo gepolariseerd dat de multiraciale grondslag van de partij velen afstootte. Bovendien voelden veel revolutionair gezinden zich meer aangetrokken tot de PKI. Het gouvernement gaf de partij weinig gelegenheid zich te ontplooien en hield haar aanvraag om erkenning jarenlang aan. Soewardi werd al in 1919 enige tijd vastgehouden. Douwes Dekker zat 
van januari 1920 af ruim een jaar in voorlopige hechtenis. Aan Tjipto werd het verblijf in Semarang en een groot deel van de rest van Java verboden. Soewardi en Douwes Dekker trokken zich geleidelijk uit hun partijpolitieke activiteiten terug en gingen zich bezighouden met onderwijshervorming (zie p. 185). De NIP/SH viel ten prooi aan interne conflicten en hief zichzelf begin 1923 op. Omstreeks dezelfde tijd wees het gouvernement de aanvraag om erkenning af.

\section{De non-coöperatiepolitiek}

Hoewel de vroegere leiders van de Indische Partij geen succes hadden met hun nieuwe partij, de NIP/SH, oefenden zij een blijvende invloed op de Indonesische nationale beweging uit door hun pleidooien voor een nieuwe strategie, de 'non-coöperatie'. Zij ontleenden deze strategie aan de nationale beweging van India.

De in 1917 door de Britse regering gedane toezeggingen over stappen in de richting van autonomie konden niet verhinderen, dat de spanningen tussen de bevolking van India en het koloniale bestuur in de volgende jaren sterk toenamen. Het bestuur voerde nieuwe repressieve wetten in. Een protestbeweging daartegen werd georganiseerd door Mohandas K. Gandhi, die al een reputatie had als ontwerper en toepasser van methodes van geweldloos verzet. Tijdens een langdurig verblijf in Zuid-Afrika had hij geslaagde campagnes gevoerd tegen de achterstelling van de daar wonende Indiërs. Na zijn terugkeer in 1915 had Tagore hem de eretitel Mahatma (Grote Ziel) gegeven.

In april 1919 vond een rampzalig incident plaats in de Indiase stad Amritsar. Enige dagen nadat daar drie Britse burgers in een volksoproer gedood waren, liet een Britse generaal zonder waarschuwing op een ongewapende menigte schieten, met als gevolg honderden doden en ruim duizend gewonden. Het bloedbad van Amritsar verbitterde veel nationalisten zozeer, dat zij geen waardering konden opbrengen voor de hervormingen die het Britse parlement in datzelfde jaar neerlegde in de Government of India Act. Ook bracht het Gandhi ertoe, de leiding van de Indiase nationale beweging op zich te nemen en een nieuwe strategie te lanceren voor de verovering van Indiaas zelfbestuur. Hij betoogde dat men niet tegelijkertijd met het koloniale bestuur kon samenwerken en zich ertegen verzetten. Daarom moesten de Indiërs die samenwerking op allerlei terreinen verbreken, zich terugtrekken uit vertegenwoordigende en rechterlijke organen, niet deelnemen aan verkiezingen, geen onderwijs op gouvernementsscholen volgen en geen uit Groot-Brittannië ingevoerde waren kopen. In 1920 schaarde zowel een grote moslimbeweging als het Indian Congress zich achter de non-co-operation strategie.

In de loop van 1921 werden de tegenstellingen tussen de Indiase nationa- 
listen en het koloniale bestuur steeds scherper. Het Congress riep de Indiase militairen op tot desertie en de Indiase ambtenaren tot het verlaten van de overheidsdienst. Tienduizenden Indiërs werden opgepakt wegens passief of actief verzet. Gandhi had voorspeld dat de non-coöperatiecampagne in één jaar tot zelfbestuur voor India zou leiden, maar toen deze voorspelling niet uitkwam begon de campagne te verlopen. Gandhi tartte het koloniale bestuur door te verkondigen, dat de campagne een opstandige beweging was die ten doel had dit bestuur ten val te brengen. Tenslotte werd hij in maart 1922 gearresteerd en tot zes jaar gevangenisstraf veroordeeld. De non-coöperatiebeweging hield geen stand. In 1923 besloot het Congress alsnog in te stemmen met deelname aan de nieuwe verkiezingen. In 1924 werd Gandhi vervroegd vrijgelaten; hij trok zich daarna enige jaren uit de politiek terug.

Vooral dank zij Soewardi en Tjipto maakte de non-coöperatiegedachte van 1921 af school in Indonesië, waar het verzet tegen de Indië Weerbaarcampagne al velen hiervoor ontvankelijk had gemaakt. De keuze tussen coöperatie en non-coöperatie is de Indonesische nationale beweging sindsdien tot aan de onafhankelijkheid blijven bezighouden. Politici presenteerden zich als coöperatoren of non-coöperatoren en er kwamen coöperatieve partijen naast non-coöperatieve partijen. Zelfs het meestal zo gezagsgetrouwe Boedi Oetomo onderschreef korte tijd de non-coöperatiegedachte. Overigens was de Indonesische non-coöperatiebeweging geen slaafse navolging van de Indiase en hadden Indonesische nationalisten soms kritiek op de uitwerking die men in India aan de non-coöperatiegedachte gegeven had. Ook onderling verschilden deze nationalisten herhaaldelijk van mening over de consequenties van die gedachte. Volgens de meesten bracht non-coöperatie in ieder geval mee dat men geen dienst nam bij de koloniale overheid, maar anderen vonden het al voldoende dat men niet meedeed aan de Volksraad. De door Gandhi voorgestane boycot van gouvernementele onderwijsinstellingen vond in Indonesië geen enkele steun.

In het begin werd non-coöperatie in Indonesië vooral bepleit als een uiting van protest tegen het asociale beleid van het bewind-Fock en de schending van de november-beloften. Al spoedig ging men non-coöperatie als een moreel beginsel zien ('geen samenwerking met de overheersers!'). Later kreeg de zienswijze de overhand, dat het niet om een beginsel maar om een strijdmethode ging. In die zienswijze was het telkens een tactische en niet een morele kwestie, of men onder de gegeven omstandigheden langs de weg van coöperatie dan wel van non-coöperatie de beste kansen had om het einde van de koloniale overheersing naderbij te brengen. Hieruit volgde dat ook de keus voor coöperatie een tactische keus was en niet betekende dat men partij koos voor de overheersers. Na 1930 versmalde het onderscheid tussen coöperatie en non-coöperatie zich tot de vraag, of men wel of niet bereid was zitting te nemen in de Volksraad en andere vertegenwoordigende lichamen. 
De wilde scholen

Niet alleen het gouvernementele maar ook het niet-gouvernementele onderwijs onderging in de twintigste eeuw een grote uitbreiding. Bevordering van onderwijs was een belangrijke doelstelling van vrijwel iedere emancipatiebeweging in Indonesië. Dit gold ook voor andere bevolkingsgroepen dan de Indonesiërs zelf: in het begin van de eeuw waren het de Chinezen die de eerste moderne niet-gouvernementele scholen oprichtten en twee decennia later hield ook het Indo-Europeesch Verbond zich met het stichten van scholen bezig. De belangrijkste uitbreidingen van het niet-gouvernementele onderwijs werden echter door en voor de Indonesische bevolkingsgroep tot stand gebracht.

Bij Boedi Oetomo en de Sarekat Islam was de oprichting van scholen een nevenactiviteit. De eerste organisatie die er een hoofdactiviteit van maakte was de Moehammadiah, een beweging die zich inzette voor hervorming van de islam in moderne zin. Evenals de Sarekat Islam was deze vereniging in 1912 opgericht, maar zij bewoog zich buiten de politiek. Tot 1921 werkte zij alleen in het sultanaat Jogjakarta; daarna breidde ze zich uit over de hele archipel. Naar het voorbeeld van de christelijke zending en missie combineerde de Moehammadiah de verbreiding van haar religieuze boodschap met de oprichting van ziekenhuizen en weeshuizen en vooral van scholen. Behalve godsdienstscholen richtte zij ook gewone scholen op. In 1940 waren dit er zevenhonderd, deels met onderwijs op inheemse grondslag en deels met onderwijs op westerse grondslag; voor een aantal van de laatste scholen kreeg zij subsidie van het gouvernement.

Naast de Moehammadiah-scholen, die geen politieke inslag hadden, kwamen er in de jaren twintig en dertig talloze niet-gouvernementele scholen die onderricht gaven in een meer of minder uitgesproken antikoloniale geest. Zulke scholen noemde men 'wilde scholen'.

De pionier op dit gebied was de Minangkabauer Ibrahim Tan Malaka. Hij was in zijn jeugd door een Nederlandse docent naar Nederland meegenomen, waar hij een onderwijzersopleiding gevolgd had en met het communisme kennis gemaakt had. Eind 1919 keerde hij naar Indonesië terug. Medio 1921 opende hij een eigen school in Semarang onder auspiciën van de daar door marxisten geleide afdeling van de Sarekat Islam. Tan Malaka gaf er onderricht op westerse grondslag volgens een door hemzelf bedacht systeem en leerde zijn scholieren ook het socialistische strijdlied 'De Internationale'. De toeloop tot deze school was aanzienlijk; binnen een jaar kwamen nog meer van zulke rode scholen tot stand en in 1925 waren er enige tientallen. Door het optreden van het gouvernement konden deze scholen zich echter niet handhaven. Een duurzamer bestaan viel ten deel aan nieuwe scholen die gesticht werden door twee leiders van de voormalige Indische Partij, Douwes Dekker en Soewardi Soerjaningrat. 
In 1921 besloot Soewardi, die evenals Tan Malaka een Nederlandse onderwijzersopleiding gevolgd had, zich verder te wijden aan de opbouw van een nationaal onderwijsstelsel. Geïnspireerd door de ideeën van Rabindranath Tagore wilde hij het zuiver intellectuele en materialistische westerse onderricht niet nabootsen, maar westerse kennis op een harmonische wijze combineren met de Javaanse cultuur en andere Aziatische cultuurelementen. Om duidelijk te maken dat hij een nieuw leven begon, nam Soewardi een nieuwe naam aan: Ki Hadjar Dewantoro (Leraar-Boodschapper van de Goden). Zijn scholen noemde hij Taman Siswa (Leerlingentuin). In 1922 werd in Jogja de eerste Taman Siswa-school geopend; in 1940 waren het er tweehonderdvijftig. De voertaal van dit onderwijs was de streektaal, de ideologische grondslag was nationalistisch maar niet islamitisch. Het gouvernement zag de Taman Siswa-scholen eerst vooral als kweekbedden van antikoloniaal sentiment; later kreeg het meer waardering voor hun kwaliteit. Dewantoro stond oorspronkelijk op een strikt non-coöperatiestandpunt, maar toonde zich in de jaren dertig alsnog bereid om subsidie van het gouvernement te aanvaarden.

Douwes Dekker begaf zich in 1922 eveneens in het onderwijs. Hij stichtte in Bandoeng een eigen onderwijsorganisatie, met uiteindelijk vijf lagere scholen en vier beroepsopleidingen. Hij noemde zijn organisatie het Ksatrian Instituut, naar een benaming van edele ridders in de Javaanse mythologie. Hoewel er in het begin klachten kwamen over het anti-Nederlandse karakter van zijn lessen geschiedenis en aardrijkskunde, gaf het gouvernement later toch gedurende een aantal jaren subsidie aan zijn instituut. Ook hij nam een nieuwe naam aan, Setiaboedi (Trouw van Inborst).

De toeloop tot deze en allerlei andere wilde scholen was groot, omdat de gouvernementsscholen nooit konden voldoen aan de stijgende vraag naar westers onderwijs. Niet alleen hield de uitbreiding van het gouvernementsonderwijs geen gelijke tred met de toename van de Indonesische bevolking, maar de bezuinigingen onder het bewind van gouverneur-generaal Fock leidden zelfs tot sluiting van scholen en ontslag van docenten. Kinderen die geen plaats hadden kunnen krijgen op de HIS stroomden in grote getale naar de wilde scholen. Het gouvernement subsidieerde deze scholen gewoonlijk niet. De docenten in dit particuliere onderwijs waren voor een deel geschoolde leerkrachten die geen plaats op een gouvernementsschool gekregen hadden of daar waren ontslagen, dan wel daar niet wilden werken omdat ze zich op noncoöperatief standpunt stelden. Een ander deel van die docenten bezat geen onderwijsopleiding. Dit waren vaak jonge Indonesiërs die wel westers onderwijs gevolgd hadden, maar vervolgens geen daaraan beantwoordende betrekking hadden kunnen krijgen en nu zelf onderwijs gingen geven om in hun onderhoud te voorzien. In het bijzonder bestond er onder de bevolking een bijna onuitputtelijke behoefte aan onderricht in het lezen en schrijven van de Nederlandse taal. Tegen het eind van de jaren dertig telde het wilde onderwijs 
meer dan tweemaal zoveel leerlingen als het gouvernementele onderwijs.

De antikoloniale inslag van de meeste wilde scholen was een bron van zorg voor het gouvernement. In 1923 vaardigde het een ordonnantie uit die ieder die particulier onderwijs wilde geven verplichtte om het bestuur daar van te voren over in te lichten en om controlerende ambtenaren bij de lessen toe te laten. Het gewestelijk bestuur kreeg de bevoegdheid om in het belang van de openbare orde aan een docent het geven van zulk onderwijs te verbieden.

Het koloniale bestuur had overigens ook zorgen over de docenten aan de gouvernementsscholen, zowel de Europese als de Inlandse. In een circulaire van 1924 bedreigde het hen met ontslag als zij geen matiging in acht zouden nemen in hun optreden, niet alleen binnen de school maar ook daarbuiten bij politieke propaganda, vakbondsacties en soortgelijke activiteiten.

\section{Machtsstrijd tussen de Sarekat Islam en de marxisten}

De marxist Sneevliet en zijn volgelingen wilden het Nederlandse kolonialisme bestrijden in het kader van de internationale klassenstrijd tegen alle vormen van kapitalisme. Massa-actie zou daarbij het belangrijkste strijdmiddel moeten vormen. Omdat hun eigen organisatie, de Indische Sociaal-Democratische Vereeniging (ISDV), maar een paar honderd leden telde, probeerden zij greep te krijgen op de enige toen bestaande Indonesische massa-organisatie, de Sarekat Islam.

Sneevliet's discipel Semaoen werd in 1917 voorzitter van de twintigduizend leden tellende afdeling Semarang van de SI en kon daardoor gaan optreden als leider van een linkse oppositie binnen de nationale SI. Onder meer viel hij Abdoel Moeis scherp aan wegens diens steun aan de Indië Weerbaar-campagne. Een jaar later werd de door Moeis aangevoerde rechtervleugel van de SI versterkt, toen Agoes Salim in de leiding van de SI kwam. De Minangkabauer Salim was een Staatsblad-Europeaan (zie p. 133), die vijf jaar op het Nederlands consultaat in Djeddah had gewerkt, lid was geweest van de commissie-Carpentier Alting en vertrouwen genoot bij het gouvernement. Binnen de SI beklemtoonde hij vooral de islamitische grondslag van de organisatie. Tjokroaminoto zelf hechtte aan ideologische kwesties minder belang dan aan het bijeenhouden van zijn organisatie. Met zijn steun kregen Semaoen en Darsono belangrijke functies in de nationale SI. Ook maakte de SI een gebaar in socialistische richting door het 'zondige kapitalisme' te veroordelen, maar Tjokroaminoto legde uit dat men hiermee alleen uitheems kapitalisme bedoelde.

De politieke opstelling van de Sarekat Islam werd geleidelijk radicaler. Op het congres van 1917 overheerste nog de hoop dat aan de koloniale verhouding langs evolutionaire weg een eind zou kunnen komen; de partij stemde 
dan ook in met de aanwijzing van SI-kandidaten voor de Volksraad. In 1918 was die hoop aanzienlijk verminderd. Het SI-congres eiste nu op korte termijn stappen in de richting van volledig zelfbestuur. Het volgend jaar kwam de SI in ernstige moeilijkheden omdat SI-leden verdacht werden van betrokkenheid bij enige gewapende incidenten op Celebes en Java. Er bleek bovendien in West-Java naast de officiële SI-organisatie een geheime revolutionair gezinde 'Afdeling B' te bestaan. Een deel van de gematigde leden keerde zich van de SI af. De aanhang van de organisatie liep trouwens al sinds 1916 terug, vooral in de dorpen, waar veel traditionele hoofden zich inspanden om de SI-invloed terug te dringen. De radicalisering van de SI leidde verder tot het verlies van de financiële steun van een aantal Arabische handelaren.

$\mathrm{Nu}$ de positie van de SI onder de boeren zwak geworden was, probeerde zij haar positie onder de arbeiders te versterken. Prominente SI-leden namen leidende functies in de vakbeweging op zich en de SI bevorderde de oprichting van een overkoepelende vakcentrale. Eind 1919 kwam deze centrale tot stand, met Semaoen als voorzitter. Tientallen vakbonden sloten zich erbij aan, maar de centrale viel al spoedig ten prooi aan interne conflicten, onder meer over de vraag of men staking ook als middel voor politieke doeleinden moest gebruiken. $\mathrm{Na}$ anderhalf jaar liep dit uit op een scheuring, waarbij Semaoen zich afscheidde en een eigen vakcentrale stichtte.

Intussen waren de in de ISDV verenigde marxisten zich communisten gaan noemen, hadden zij hun vereniging omgedoopt tot Perserikatan Kommunist di India (PKI) en hadden zij Semaoen tot voorzitter gekozen. Ook had de PKI zich aangesloten bij de in Moskou gevestigde internationale organisatie van communistische partijen, de Komintern. Om greep te krijgen op de massaaanhang van de SI richtte de PKI zich niet alleen op het verwerven van invloed aan de top, maar ook aan de basis. Dit werd vergemakkelijkt doordat de SI geen strak geleide organisatie was maar een soort federatie van plaatselijke bonden. In een aantal van die bonden kregen de communisten de leiding in handen; dit werden 'rode' SI-bonden.

Binnen de centrale leiding van de SI verzetten vooral Abdoel Moeis en Agoes Salim zich tegen de communistische pogingen om de organisatie over te nemen. Als bewijs dat de communisten tegen de islam waren, konden zij wijzen op een uitdrukkelijke veroordeling van het pan-islamisme door de Komintern. Tjokroaminoto probeerde nog een tijd lang met de communisten samen te werken, maar werd niettemin fel door hen aangevallen. Tenslotte kwam aan deze samenwerking een eind op het nationale SI-congres van oktober 1921, enige maanden na de scheuring in de vakcentrale. Tjokroaminoto ontbrak op dit congres, omdat hij in de zomer gearresteerd was op verdenking van meineed in de Afdeling B-affaire. Salim voerde tegen de communistische propaganda aan, dat de profeet Mohammed de beginselen van het historisch materialisme al twaalf eeuwen vóór Marx verkondigd had. Met grote meer- 
derheid besloot het congres op voorstel van Moeis en Salim met de communisten te breken door SI-leden te verbieden ook lid van een andere partij te zijn. Naar aanleiding hiervan maakte een tiental rode SI-bonden zich los van de centrale SI-organisatie.

Kort na het congres vertrok Semaoen voor enige maanden naar Rusland. Omdat ook Darsono zich in die tijd in Europa bevond, werd Tan Malaka nu voorzitter van de PKI. Hij had zich ontwikkeld tot de belangrijkste ideoloog van de partij. Als PKI-voorzitter streefde Tan Malaka naar een verzoening met de SI, maar zijn voorzitterschap was van korte duur. Begin 1922 brak een staking uit onder het Indonesische personeel van de gouvernementspandhuisdienst. Het gouvernement toonde zich onverzoenlijk en ontsloeg alle stakers. Zowel de SI als de PKI en verscheidene vakbonden namen het voor de stakers op, waarbij Tan Malaka tenslotte tot een algemene solidariteitsstaking opriep. Niettemin verliep de staking binnen enkele weken. Op grond van de exorbitante rechten besloot het gouvernement nu Tan Malaka op Timor te interneren, maar op zijn verzoek stond het hem toe, in plaats daarvan Indonesië te verlaten. Tan Malaka ging naar Nederland, waar de communistische partij hem kandidaat stelde bij de parlementsverkiezingen, en verbleef vervolgens in Moskou, totdat de Komintern hem eind 1923 als agent voor Zuidoost-Azië naar China stuurde.

Tjokroaminoto kwam medio 1922 weer vrij. Ook hij zag nu in dat de PKI zich van zijn organisatie meester wilde maken. De intussen uit Rusland teruggekeerde Semaoen probeerde vergeefs de samenwerking met de SI te herstellen. Het SI-congres van februari 1923 bevestigde de uitsluiting van de communisten definitief. Hierop besloot de PKI de strijd met de SI hard tegen hard te voeren en overal waar SI-bonden waren eigen bonden op te richten met de naam Sarekat Rakjat (SR, Volksbond). Inderdaad kwamen zulke bonden van de grond, hoewel niet alle rode SI-bonden bereid waren zich tot SR-bonden om te vormen, omdat zij zich dan geheel aan de PKI-leiding moesten onderwerpen.

Semaoen kon overigens niet lang leiding geven aan de nieuwe PKIstrategie. In mei 1923 werd hij gearresteerd. De Vereeniging van Spoor- en Tramwegpersoneel (VSTP), waarvan hij voorzitter was, reageerde daarop met een algemene spoorwegstaking. Het gouvernement maakte met harde hand een eind aan deze staking en verbande Semaoen op basis van de exorbitante rechten uit Indonesië, waarna hij zich eerst in Nederland en later in de Sovjetunie vestigde. De leiding van de PKI ging nu over op Darsono, die begin 1923 was teruggekeerd na ruim anderhalf jaar in Moskou en Berlijn bij de Komintern te hebben gewerkt.

Dank zij de rode SI-bonden en de SR-bonden nam de communistische aanhang sterk toe. Een groot deel van die aanhang wist overigens weinig van de communistische leer en liet zich ook leiden door islamitische denkpatro- 
nen en Javaanse heilsverwachtingen. Wat deze bonden vooral kenmerkte, was hun revolutionaire gezindheid. Intussen riep hun optreden reacties op in de vorm van de oprichting van anti-communistische bonden. Deze noemden zich Sarekat Hidjau (Groene Bond), omdat groen als kleur van de islam geldt. Het kwam herhaaldelijk tot gewelddadigheden tussen rode en groene bonden. De PKI slaagde er niet in haar aanhang tot een gedisciplineerde organisatie om te smeden. Overigens veranderde zij in 1924 haar naam in Partai Komunis Indonesia.

Hoewel de communistische strategie niet op verovering van de Sarekat Islam uitliep, droeg ze er wel toe bij deze ernstig te verzwakken. Daarbij bleek uit de vorming van de rode SI-bonden, dat de SI-organisatie juist door haar losse structuur kwetsbaar was. Aan de andere kant had haar moslimgrondslag door het conflict met de PKI een veel sterkere nadruk gekregen. In de jaren 1923-1927 voerde de SI een algehele reorganisatie door, waarbij de federale structuur plaats maakte voor die van een strak geleide partij. De afgeslankte nieuwe organisatie ging Partai Sarekat Islam heten en richtte zich in hoofdzaak op religieuze en sociale activiteiten. Abdoel Moeis trok zich grotendeels uit de politiek terug.

\section{Hervorming van het Nederlands-Indische staatsbestel}

De Nederlandse regering hield zich in de jaren twintig herhaaldelijk bezig met hervormingen van het bestuursstelsel van Nederlands-Indië. Eén van die hervormingen betrof het overhevelen van taken van het Europese korps naar het Inlandse korps van het Binnenlands Bestuur. Al voor 1920 was het gouvernement in sommige gebieden op Java begonnen de adspirant-controleurs en controleurs uit het binnenland terug te trekken en het door hen uitgeoefende toezicht over te dragen aan de inheemse districtshoofden. De taakverdeling tussen de beide korpsen werd nu verder herzien, terwijl de omvang van het Europese korps werd verkleind. Het bestuur van alle regentschappen op Java kwam grotendeels te berusten bij de inheemse regenten en de door hen voorgezeten regentschapsraden, terwijl de Nederlandse assistent-residenten in hoofdzaak een adviserende rol kregen. Aldus verlichtte men niet alleen de taak van het Europees BB, maar versterkte men ook de positie van de inheemse ambtsaristocratie.

In de tweede plaats hervormde de regering het bestuursstelsel ten behoeve van een verdere decentralisatie. Ondanks de in de eerste decennia van de eeuw uitgevoerde decentralisatie werden nog steeds alle gewichtige beslissingen in Batavia of Buitenzorg genomen. Om hierin verlichting te brengen werd de mogelijkheid geschapen, tussen het gouvernement en de residenten een nieuwe bestuurslaag in te voegen. Zo kwamen er op Java drie provincies, 
onder gouverneurs die werden bijgestaan door provinciale raden. De nieuwe bestuurseenheden kregen echter geen belangrijke autonome bevoegdheden, zoals de Britse regering in deze tijd wél verleende aan de provincies van India.

Terwijl de regering weinig gehoor gaf aan de pleidooien van rechtse politici voor een federale staatsinrichting van Nederlands-Indië, hechtte zij evenmin veel betekenis aan het door linkse politici toegejuichte rapport van de commissie-Carpentier Alting (zie pp. 173). Wel had zij naar aanleiding van dat rapport enige voorstellen tot grondwetswijziging ingediend. De hierop in 1922 van kracht geworden nieuwe grondwetsbepalingen hadden onder meer voorgeschreven dat de staatsinrichting van Nederlands-Indië door de wet zou worden vastgesteld. Pas nu bleek echter dat de regering van plan was daarbij de voorstellen van de commissie grotendeels te negeren.

Deze houding van de regering wekte verontwaardigde reacties. In Indonesië leidde dit tot samenwerking van organisaties als Boedi Oetomo en Sarekat Islam met hervormingsgezinde Nederlanders in een gelijksoortig verband als al in 1918 in de Volksraad had bestaan. Dit samenwerkingsverband werd daarom wel 'de tweede Radicale Concentratie' genoemd. Daarbij richtte men een Comité voor de Autonomie van Indië op, dat ijverde voor invoering van de door de commissie-Carpentier Alting voorgestelde hervormingen. Het Comité wilde een delegatie naar Nederland sturen onder leiding van Achmad Djajadiningrat, regent van Serang (Bantam) en sinds 1918 lid van de Volksraad, maar dank zij de ambtenarenstatus van de regenten wist het gouvernement dit te verijdelen. In Nederland werd de regering fel aangevallen door de hoogleraren van de Leidse indologenopleiding. Naast beroemdheden als Van Vollenhoven en Snouck Hurgronje behoorden daartoe nu onder meer ook Carpentier Alting zelf en Hazeu.

Terwijl deze protesten uit Indonesië en Nederland zich richtten tegen de onwil van de regering om grote stappen in de richting van Indisch zelfbestuur te zetten, werd de regering ook aangevallen door rechtse politici die vonden dat zij in die richting al veel te ver ging. M.W.F. Treub schreef in een brochure dat Indië binnen een mensenleeftijd van Nederland zou worden losgescheurd als de regeringsvoorstellen wet zouden worden. Daar kwam nog bij, dat de standpunten over het koloniaal beleid zich verhardden door een controverse over versterking van de marine. De regering had een ontwerp-vlootwet ingediend, die voorzag in de bouw van nieuwe oorlogsschepen voor de externe verdediging van Nederlands-Indië. Dit wetsontwerp was zeer omstreden, omdat het grote uitgaven meebracht terwijl de regering tegelijkertijd ingrijpende bezuinigingsmaatregelen wilde nemen. Het partijblad van de ARP ondersteunde het vlootplan als volgt: 'We moeten Indië houden! Omdat we den band aan de historie voelen! Omdat we eerbied willen betonen aan het bloeitijdperk onzer volkshistorie! Omdat onze welvaart in zoo sterke mate 
van Indië afhankelijk is. [...] We moeten Indië houden!' Uiteindelijk werd het wetsontwerp met 49 tegen 50 stemmen verworpen. De verwerping van de vlootwet maakte partijen als de ARP nog minder bereid om op het punt van het Nederlands-Indische staatsbestel aan de oppositie tegemoet te komen.

In 1925 aanvaardde het parlement de vernieuwde wet op de staatsinrichting van Nederlands-Indië, met tegenstemmen van de vrijzinnig-democraten en de sociaal-democraten. In plaats van als Regeeringsreglement zou deze wet voortaan worden aangeduid als Indische Staatsregeling. Wat de inhoud betreft was een nieuwe naam overigens niet nodig geweest, omdat de oude wet al zo vaak was bijgesteld.

De voornaamste nieuwe elementen in de wet hadden betrekking op de Volksraad, die nu medewetgevende bevoegdheid kreeg. Voor alle ordonnanties (de Nederlands-Indische vorm van wetten) moest de gouverneur-generaal overeenstemming met de Raad zien te krijgen; de Raad mocht de ontwerpen wijzigen en mocht ook zelf ontwerp-ordonnanties voorstellen. Konden de gouverneur-generaal en de Raad het over een ontwerp-ordonnantie niet eens worden, dan besliste uiteindelijk de Nederlandse regering. De ontwerp-begroting moest eveneens in overeenstemming met de Volksraad worden opgesteld; de uiteindelijke vaststelling gebeurde dan bij Nederlandse wet. Verder moest de Nederlandse regering advies van de Volksraad vragen over alle ontwerpen van wetgeving die uitsluitend of in belangrijke mate op Nederlands-Indië betrekking hadden.

De nieuwe wet bracht de zittingsduur van de Volksraad op vier jaar en het ledental op 61, van wie 38 gekozen en 23 benoemd. Het kiesrecht voor de verkiesbare leden bleef berusten bij de leden van de plaatselijke en regionale raden, maar voortaan volgens een raciaal gesplitst systeem: Indonesiërs, Nederlanders en 'uitheemse onderdanen' (voornamelijk Chinezen en Arabieren) mochten alleen nog maar stemmen over kandidaten uit hun eigen categorie. Bovendien gold voor de verkiezing van de Indonesische leden een verdeling van de archipel in twaalf kieskringen, zodat bijvoorbeeld de kiezers op Celebes alleen kandidaten uit Celebes konden kiezen. Een en ander zou een verdere verschuiving in conservatieve richting meebrengen, omdat hervormingsgezinde Nederlanders geen zetel meer konden krijgen door Indonesische stemmen en omdat nationaal bekende Indonesische politici niet meer verkozen konden worden met stemmen buiten hun kieskring. Overigens bestonden de plaatselijke en regionale raden voor een groot deel uit leden die zelf niet gekozen maar benoemd waren, met als gevolg dat de gekozen leden van de Volksraad werden gekozen door kiezers van wie bijna de helft door het gouvernement benoemd was.

$\mathrm{Nu}$ de Volksraad medewetgevende bevoegdheid kreeg, voerde de wet een nieuwe werkwijze in omdat de Raad het grootste deel van het jaar niet in zitting bijeen was. In de toekomst zouden de meeste bevoegheden van de 
Raad tussen de zittingen kunnen worden uitgeoefend door een College van Gedelegeerden, bestaande uit de voorzitter van de Raad en twintig door de Raad op basis van evenredige vertegenwoordiging uit zijn midden gekozen leden.

Wat de samenstelling van de Volksraad betreft, had het voorstel van de regering voorzien in 30 Indonesische en 25 à 27 Nederlandse leden, naast de leden uit andere groepen en de voorzitter. De rechtse meerderheid in de Tweede Kamer veranderde deze verhouding: volgens de nieuwe wet zou de Volksraad 25 Indonesische en 30 à 32 Nederlandse leden tellen.

\section{De Ondernemersraad voor Nederlandsch-Indie en de Utrechtse indologenopleiding}

Indonesië was voor de daar werkende westerse ondernemingen in de eerste plaats een land van goedkope grondstoffen en zeer goedkope arbeidskrachten. Die ondernemingen hadden dan ook rechtstreeks belang bij het beleid van de overheid, onder meer bij zo licht mogelijke fiscale lasten en medewerking bij het tegengaan van werkweigering (zoals door de poenale sanctie). Al sinds de negentiende eeuw organiseerden verschillende groepen ondernemingen zich in grote verbanden voor de gemeenschappelijke behartiging van hun belangen. Ook beheersten zij een deel van de Nederlandstalige pers in de kolonie. Als overkoepelende organisaties vormden zij in de twintigste eeuw de Indische Ondernemersbond in Batavia en de Ondernemersraad voor Nederlandsch-Indië in Den Haag.

Uit het gezichtspunt van de ondernemersbelangen hield de opkomende Indonesische beweging een ernstige bedreiging in. M.W.F. Treub, die in 1921 voorzitter van de Ondernemersraad werd, leverde daarom zware kritiek op de ethische koers in het koloniaal beleid. Daarmee kwam hij lijnrecht tegenover de hoogleraren van de Leidse indologenopleiding te staan, die juist in deze jaren die koers met vuur verdedigden, onder meer in verband met het debat over de herziening van de Nederlands-Indische staatsinrichting. Snouck Hurgronje duidde het koloniale bewind in 1923 zelfs aan als 'een verderfelijk stelsel, dat dagelijks ten hemel schreiend onrecht baart'. Ook beschuldigde hij de Nederlanders van hypocrisie, omdat ze graag blijk gaven van machteloze verontwaardiging over onrecht dat in andere landen plaatsvond terwijl ze geen aandacht schonken aan het onrecht in Nederlands-Indië, waar ze niet machteloos tegenover stonden maar zelf verantwoordelijk voor waren.

De Leidse hoogleraren werden om hun kritische uitspraken zwaar aangevallen, onder andere door F.C. Gerretson. Treub vond dat ze de toekomstige bestuursambtenaren geen begrip bijbrachten voor de goede gevolgen van de westerse investeringen voor de ontwikkeling van Indonesië. In 1924 lanceerde hij een plan voor het stichten van een concurrerende indologenopleiding aan 
de universiteit in Utrecht. Vooral de grote suiker- en handelsondernemingen en de Bataafsche Petroleum Maatschappij brachten daarvoor de nodige gelden bijeen. Colijn, die destijds minister van financiën was, steunde het plan binnen de regering. In oktober 1925 werd de Utrechtse indologiefaculteit geopend; veertien bijzondere hoogleraren waren er aan verbonden. Gerretson kreeg een leerstoel voor de geschiedenis en de vergelijkende volkenkunde van Nederlands-Indië. Hij was de spil en de ziel van de opleiding, die door haar tegenstanders de 'oliefaculteit' werd genoemd.

\section{Studenten in Nederland; de Perhimpoenan Indonesia}

De vereniging van Indonesische studenten in Nederland, die sinds 1922 Indonesische Vereeniging heette, kreeg in deze jaren een volledig politiek karakter. Met ingang van 1924 noemde zij haar blad Indonesia Merdeka (wat zowel 'Vrij Indonesië' als 'Indonesië vrij' betekent). In datzelfde jaar gaf zij ter gelegenheid van haar vijftienjarig bestaan een gedenkboek uit, verlucht met een roodwitte vlag en een portret van Diponegoro, waarin zij zich in onverzoenlijke termen tegen het Nederlandse kolonialisme keerde. In 1925 besloot zij de Maleise versie van haar naam, Perhimpoenan Indonesia (PI), voortaan als officiële naam te gebruiken.

In verschillende artikelen en beginselverklaringen zette de vereniging haar politieke lijn uiteen. Zij duidde het einddoel aan als nationale onafhankelijkheid, zowel in politieke als in economische zin. Het laatste hield in dat Indonesië niet meer zou worden uitgebuit door uitheems kapitaal. Het onafhankelijke Indonesië zou een democratische, aan het volk zelf verantwoordelijke regering moeten krijgen. De vereniging zag massa-actie als het middel om de onafhankelijkheid te bereiken. Zij riep op tot hechte aaneensluiting van alle Indonesiërs, met terzijdestelling van onderlinge groepsverschillen. Ook verkondigde zij dat men moest steunen op eigen kracht en kundigheid, niet op de hulp van anderen. De vereniging sprak zich met nadruk uit voor de non-coöperatiepolitiek. Zij betoogde dat de belangentegenstelling tussen de overheerser en de overheerste het essentiële element is van iedere koloniale verhouding. Men zou de neiging van de overheerser naar verdoezeling en maskering van dit element moeten beantwoorden met verscherping en accentuering van alle tegenstellingen.

De Indonesische Vereeniging/Perhimpoenan Indonesia was de eerste politieke organisatie van Indonesiërs op zuiver nationalistische grondslag. Dat zulk een organisatie juist in Nederland van de grond kwam, hing samen met het feit dat de Indonesische studenten hier maar een kleine groep vormden, dat zich onder hen zowel moslims als christenen bevonden en dat zij niet alleen uit Java maar ook uit andere delen van de archipel afkomstig waren. 
Voor hun vertrek hadden deze studenten al in Indonesië de opkomst van de emancipatiebeweging meegemaakt. In Nederland werd hun politieke bewustwording bevorderd door het contrast van de situatie in hun geboorteland met de bijna onbegrensde politieke vrijheid in hun land van verblijf en het daar ontbreken van een maatschappelijke tweedeling op basis van ras. Ook werden zij beïnvloed door de successen die verscheidene Europese vrijheidsbewegingen na de Wereldoorlog behaald hadden, waardoor landen als Finland, Polen, Tsjechoslowakije en Ierland onafhankelijk waren geworden.

Hoewel de Perhimpoenan Indonesia maar een kleine vereniging was, heeft zij de politieke ontwikkeling in Indonesië zelf aanzienlijk beïnvloed, onder meer omdat veel van haar vooraanstaande leden daar na terugkeer een leidende rol in de nationale beweging gingen spelen. De invloedrijkste figuur binnen de vereniging was Mohammad Hatta. Hij was geboren in 1902, behoorde tot een Minangkabause familie van handelaren en moslimvoorgangers en was actief geweest in de Jong-Sumatranen Bond. Van 1922 tot 1932 studeerde hij economie in Rotterdam; gedurende die tien jaar wijdde hij een groot deel van zijn tijd aan politiek werk. Het initiatief tot de radicalisering van de vereniging was niet van hemzelf uitgegaan, maar hij stond er volledig achter. In $1923 \mathrm{kwam}$ hij in het bestuur, in 1926 werd hij voorzitter. Tijdens zijn studiejaren leerde hij niet alleen Nederland kennen, maar reisde hij ook veel in andere Europese landen.

Eén van Hatta's doelstellingen was te bevorderen dat in Indonesië zelf een nationalistische partij tot stand zou komen. Hij meende dat zo'n partij zich in de eerste plaats zou moeten richten op de vorming van geschoold kader en pas daarna op het organiseren van de volksmassa's. Een massale aanwas die bijna even snel weer verdween als ze gekomen was, zoals die van de Sarekat Islam, leek hem niet doelmatig.

De vereniging in Nederland werd zelf meer en meer een strak geleide politieke strijdgroep. Al in 1924 royeerde zij haar vroegere voorman Noto Soeroto, nadat deze in een artikel positieve opmerkingen had gemaakt over de in dat jaar overleden Van Heutsz. Daarna royeerde de vereniging nog herhaaldelijk leden die zich niet aan haar politieke lijn hielden. Voortaan hadden de leden toestemming van het bestuur nodig als zij in woord of geschrift in het openbaar wilden optreden. Een aantal Indonesische studenten wendde zich van de PI af, omdat deze politisering hun niet aanstond. Bovendien begon de Nederlandse overheid zich tegen de vereniging te keren, onder meer door beursstudenten te bedreigen met intrekking van hun beurs als zij in de PI actief bleven.

De door de PI ingeslagen koers bracht met zich mee, dat haar politieke contacten met Nederlandse groeperingen zich in hoofdzaak richtten op de socialistische en de communistische beweging, want alleen de hiertoe behorende partijen erkenden een Indonesisch recht op onafhankelijkheid. Daarbij ver- 
klaarde de grootste van die partijen, de SDAP, zich echter tegen onmiddellijke verlening van onafhankelijkheid, in tegenstelling tot de communisten, die de leuze 'Indië los van Holland nu!' hanteerden. Verder oefenden de verbannen PKI-leiders Tan Malaka en Semaoen tijdens hun verblijf in Nederland invloed uit binnen de kring van de PI.

Hatta onderschreef in grote lijnen de marxistische analyse van het moderne kolonialisme als een uitvloeisel van het kapitalistische stelsel. Hij sloot zich niet bij de communistische beweging aan (onder meer omdat het daar dominerende atheïsme hem als overtuigd moslim tegenstond), maar was wel bereid ermee samen te werken. In februari 1927 nam de PI deel aan de oprichting van een internationale Liga tegen Imperialisme en Koloniale Onderdrukking, die haar ontstaan dankte aan een initiatief van de Komintern. Hatta werd lid van het Liga-bestuur, samen met onder meer de Indiase politicus Jawaharlal Nehru.

De samenwerking van de PI met de communistische beweging sterkte sommige Nederlandse autoriteiten in hun overtuiging dat de PI een revolutionaire organisatie geworden was. In juli 1927 verrichtte de politie huiszoekingen bij een aantal PI-leden; twee maanden later arresteerde zij Hatta en drie andere PI-leiders. Ondanks de verkoelde verhouding tussen de PI en de SDAP zorgde deze partij voor hun verdediging door een advocaat die parlementslid voor de SDAP was. In maart 1928 sprak de Haagse rechtbank de vier verdachten vrij. De arrestatie en berechting van deze studentenleiders kregen zowel in Nederland als in Indonesië veel publiciteit en vergrootten het prestige van de PI. Hatta publiceerde de verdedigingsrede die hij voor de rechtszitting had opgesteld als een ruim tachtig pagina's tellende brochure onder de titel Indonesie vrij!

$\mathrm{Na}$ zijn invrijheidstelling wijdde Hatta zich meer aan de voortzetting van zijn studie dan aan de PI, al bleef hij nog actief in de internationale Liga tegen Imperialisme en Koloniale Onderdrukking. De oude garde van de PI was intussen naar Indonesië teruggekeerd; verscheidene nieuwe leiders stonden sterk onder communistische invloed. Binnen de vereniging vond Hatta wel een geestverwant in de zeven jaar jongere Minangkabauer Sjahrir (met zijn Minangkabause titel meestal Soetan Sjahrir genoemd), die in 1929 in Nederland rechten kwam studeren. Hatta en Sjahrir konden echter niet beletten dat de leiding van de PI zich volledig op Moskou ging oriënteren, met het gevolg dat zij eind 1931 zelf uit de vereniging geroyeerd werden. Sjahrir keerde kort daarna naar Indonesië terug. In augustus 1932 keerde ook Hatta terug, nadat hij zijn doctoraalexamen economie had afgelegd.

De Perhimpoenan Indonesia had in de jaren dertig minder invloed dan in het verleden. De meeste Indonesische studenten in Nederland gaven er de voorkeur aan zich in ander verband te organiseren. Bovendien nam het aantal in Nederland studerenden af, omdat er meer hoger onderwijs in Indonesië zelf gegeven werd, terwijl het gouvernement geen beurzen voor studie in 


\section{INDONESIË VRIJ!}

ONUITGESPROKEN, AAN DE RECHTBANK

OVERGELEGDE, REDE, TER VERDEDIGING

VAN DE „PERHIMPOENAN INDONESIA"

NAAR AANLEIDING VAN HET PROCES

TEGEN DE INDONESISCHE STUDENTEN

DOOR

\section{MOHAMMAD HATTA}

MET EEN VOORWOORD VAN

EDO FIM MEN

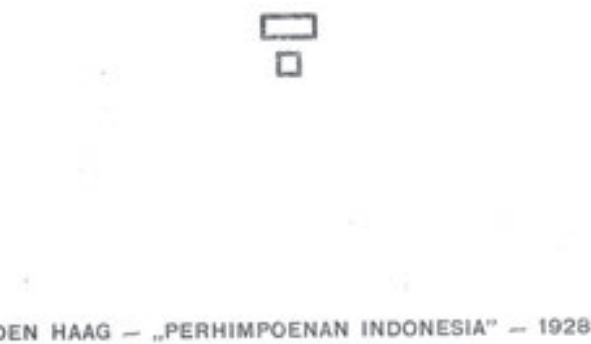

Hatta (1902-1980) stond in 1928 in Den Haag terecht en legde toen aan de rechtbank een in gevangenschap geschreven pleitrede over met een principiële uiteenzetting van het doel en streven van de door hem geleide vereniging Perhimpoenan Indonesia. $\mathrm{Na}$ zijn vrijspraak is die rede als een brochure van 80 pagina's gepubliceerd. 
Nederland meer toekende, nu veel vroegere beursstudenten daar tegenstanders van het koloniale bestuur geworden waren.

\section{De studieclubs van Soetomo en Soekarno}

De Indonesische emancipatiebeweging was omstreeks 1924 ernstig verbrokkeld. Er was een eind gekomen aan de samenwerking tussen Indonesische en Nederlandse groeperingen die in 1922 onder meer geleid had tot het Comité voor Autonomie voor Indië. Het streven van Douwes Dekker en de zijnen naar een nationalistische organisatie op multiraciale grondslag was mislukt. De PKI en de Sarekat Islam hadden zich de laatste jaren vooral beziggehouden met het bestrijden van elkaar. Het gouvernement liet weinig ruimte meer voor politieke activiteiten.

In deze situatie nam Soetomo, die in 1908 aan de wieg van Boedi Oetomo had gestaan en later in Nederland voorzitter van de Indonesische studentenvereniging was geweest, het initiatief tot een nieuwe organisatievorm. In Soerabaja, waar hij docent op de artsenschool was, richtte hij in juli 1924 de Indonesische Studieclub op, bedoeld voor het bestuderen van politieke en sociale kwesties ten behoeve van de vorming van leiders en de voorlichting van de bevolking. Naar dit voorbeeld kwamen ook in andere steden op Java studieclubs tot stand. De belangrijkste daarvan was de eind 1925 opgerichte Algemeene Studieclub in Bandoeng. Terwijl de leiding van deze clubs grotendeels bij oud-leden van de Perhimpoenan Indonesia berustte, kreeg de Bandoengse studieclub als eerste secretaris een man die nog nooit buiten Java geweest was, de student Soekarno.

Soekarno was op 6 juni 1901 geboren als zoon van een Javaan en een Balinese. Zijn moeder kwam uit een hindoeïstische familie en was pas na haar huwelijk tot de islam overgegaan. Zijn vader, een onderwijzer, was geen orthodoxe moslim maar behoorde tot de theosofische beweging. Nadat Soekarno een ILS had doorlopen en nog een jaar op een ELS had gezeten, bezocht hij van 1916 tot 1921 de HBS in Soerabaja. Omdat zijn ouders daar toen niet woonden, werd hij ondergebracht in een kosthuis dat werd gedreven door de vrouw van Tjokroaminoto. Dit kosthuis was ook een trefpunt voor Indonesische nationalisten, zodat Soekarno in deze jaren niet alleen Tjokroaminoto maar ook andere belangrijke politici leerde kennen. Hij ging dikwijls mee wanneer Tjokroaminoto bijeenkomsten toesprak. Zelf was hij in die tijd lid van de met Boedi Oetomo gelieerde vereniging Jong Java en nam hij deel aan een beweging voor afschaffing van het kastenstelsel in de Javaanse taal. Hij wilde na zijn eindexamen in Nederland gaan studeren, maar zijn moeder maakte daar bezwaar tegen. Daarom schreef hij zich in 1921 in aan de één jaar eerder geopende Technische Hogeschool in Bandoeng. Intussen was de echtgenote 
van Tjokroaminoto overleden en was Soekarno met diens dochter getrouwd. Toen Tjokroaminoto zelf in 1921 gearresteerd werd, keerde Soekarno naar Soerabaja terug om de zorg voor diens gezin op zich te nemen; pas een jaar later, na Tjokroaminoto's vrijlating, kon hij zijn studie in Bandoeng opvatten.

In zijn HBS-jaren had Soekarno niet alleen de Javaanse en de islamitische stroming van de nationale beweging leren kennen maar ook de marxistische, die in die tijd binnen de Sarekat Islam veel aanhang kreeg. In Bandoeng kwam hij in nauwere aanraking met de nationalistische stroming, van wie enkele pioniers daar toen woonden: Abdoel Rivai (die voor de Sumatranenbond in de Volksraad zat), Douwes Dekker en Tjipto Mangoenkoesoemo. Soekarno had veel waardering voor Douwes Dekker en gaf enige tijd les op diens Ksatrian Instituut, maar Tjipto werd nu zijn voornaamste mentor. Soekarno's nationalistische oriëntatie leidde tot een zekere verwijdering met Tjokroaminoto, die zich onder invloed van Agoes Salim steeds meer op de internationale panislamistische beweging richtte; bovendien scheidde Soekarno van diens dochter. Tjipto bekeerde hem tot de non-coöperatiepolitiek. Toen Soekarno in mei 1926 zijn ingenieurstitel behaalde, wilde hij dan ook geen overheidsbetrekking aannemen en begon hij een particulier ingenieursbureau.

De Studieclubs in Soerabaja en Bandoeng verschilden van karakter. De Soerabajase studieclub gaf veel aandacht aan sociale problemen, bevorderde de stichting van scholen, vakbonden en een kredietbank en behandelde de non-coöperatiepolitiek als een tactische kwestie. De Bandoengse studieclub was vooral gericht op politieke actie, in nauwe aansluiting bij de opvattingen van de Perhimpoenan Indonesia, en zag non-coöperatie als een beginsel. Soekarno werd na zijn afstuderen de feitelijke leider van de club en ging krachtig propaganda maken voor het Indonesisch nationalisme.

\section{Mislukte communistische opstand}

Nadat het gouvernement Tan Malaka en Semaoen uit Indonesië verwijderd had, raakte de PKI meer en meer op drift. Hoewel haar aanhang sterk toenam, vooral in Bantam (West-Java) en Minangkabau, telde zij onder haar leden maar weinig ontwikkelden. Tot die laatsten behoorden wel twee nieuwe leiders die in 1924 lid van het bestuur werden, Alimin en Moeso. Alimin was in zijn jeugd door Hazeu (die toen Javaans doceerde) als pleegzoon aangenomen, had Europees onderwijs gevolgd, was journalist geworden en had een rol gespeeld in Boedi Oetomo, Insulinde, de ISDV en vooral in de Sarekat Islam. Moeso was eveneens een prominent SI-lid geweest. Van 1920 tot 1923 hadden Alimin en Moeso gevangen gezeten wegens de Afdeling B-affaire. Na hun gevangenschap keerden zij zich van de SI af en traden zij toe tot de PKI. Het gouvernement dreef sinds de spoorwegstaking van mei 1923 de PKI en 
de met haar verbonden vakbonden steeds meer in het nauw. De partijleiding voorzag dat de PKI niet lang als legale partij zou kunnen blijven bestaan. De partijleden waren revolutionair gestemd; zij wilden actie ter verdrijving van de westerse overheersers, niet in een verre toekomst maar op korte termijn. De partij besloot nu een clandestiene organisatie op te bouwen en een opstand voor te bereiden.

Tan Malaka, die als Komintern-agent voor Zuidoost-Azië afwisselend in China, de Filippijnen en Achter-Indië verbleef, probeerde herhaaldelijk de koers van de PKI te veranderen. Daartoe liet hij onder meer in april 1925 in Kanton een Nederlandstalige brochure drukken onder de titel Naar de 'Republiek-Indonesia'. Hij zette hierin uiteen hoe het Indonesische volk zich langs revolutionaire weg zou kunnen bevrijden van het koloniale juk. Daartoe zou de PKI zich niet alleen moeten richten op de arbeiders, maar ook de steun moeten verwerven van de boerenbevolking en de kleine burgerij. Er zou nog veel moeten gebeuren voordat een greep naar de macht zou worden gedaan. De dan te stichten Republiek Indonesia zou een federatieve republiek van de verschillende eilanden moeten worden; ook de Filippijnen zouden er deel van moeten uitmaken. Wat de internationale situatie betreft, deelde Tan Malaka de verwachting dat een oorlog tussen Japan en de Verenigde Staten op de duur onvermijdelijk was, maar het was onzeker of die oorlog aan Indonesië de onafhankelijkheid zou brengen. Het zou onjuist zijn de revolutionaire actie te koppelen aan het onbekende tijdstip van het uitbreken van een Pacific-oorlog.

Een nieuwe stakingsgolf in de tweede helft van 1925 leidde tot verder ingrijpen van het gouvernement. De PKI kreeg een vergaderverbod, een deel van de partijleiding werd gearresteerd. Alimin en Moeso vluchtten naar Singapore. Darsono, die tot de gearresteerden behoorde, werd op dezelfde voet als Semaoen uit Indonesië verbannen. Op 25 december kwamen elf nog op vrije voeten verkerende PKI-leiders bijeen bij de tempels van Prambanan (ten oosten van Jogjakarta). Zij besloten dat in 1926 tot opstand zou worden overgegaan. Die opstand zou moeten beginnen in Minangkabau; wanneer dan een deel van het koloniale leger daarheen zou zijn gegaan, zou vervolgens heel Java in opstand komen.

Het duurde enige maanden voordat het besluit van Prambanan aan Tan Malaka bekend werd. Hij zag het als een stap naar zelfvernietiging en ondernam verschillende pogingen om het ongedaan te maken. Alimin en enige andere leiders die aan het besluit vast wilden houden gaven zijn bezwaren niet aan de partij door. De partij stuurde Alimin en Moeso op reis om steun van de Komintern voor de opstand te verwerven. In de zomer wees de Komintern het opstandplan volstrekt af. Vergeefs probeerden Alimin en Moeso in Moskou maandenlang alsnog Komintern-steun te krijgen. Intussen werd de situatie in Indonesië steeds verwarder. Het gouvernement had lucht gekregen van de opstandplannen, nam het partij-archief van de PKI in beslag, verbood alle 


\title{
NAAR DE
}

\section{"REPUBLIEK-INDONESIA"}

\author{
DOOR
}

\section{T. MALACCA}

\section{Gedrukt eerst Canton April '25.}

Herdrukt TOKYO December' 25.

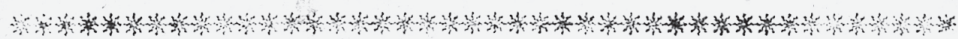

Tan Malaka (1897-1949) schreef in 1925, toen hij nog agent voor Zuidoost-Azië van de Communistische Internationale was, een brochure waarvan de titel destijds volkomen irreëel moet hebben geklonken maar die twintig jaar later profetisch bleek te zijn geweest. 
communistische persorganen en verbood alle gouvernementsdienaren om lid van de PKI of de Sarekat Rakjat te zijn. Tan Malaka wist eindelijk een aantal PKI-leiders te overreden het opstandplan op te geven. Maar nu vormden andere PKI-leiders buiten het partijbestuur om in Batavia een revolutionair comité dat het plan toch wilde doorzetten. Hoewel verscheidene partijdistricten, onder andere die van Semarang en Soerabaja, medewerking weigerden, gaf dit comité het parool uit dat de opstand in de nacht van 12 op 13 november moest beginnen.

De opstand werd een volledige mislukking. Het gouvernement kwam nog in de avond van 12 november op de hoogte van het uitgegeven parool, zodat het leger gealarmeerd kon worden. Omstreeks middernacht trokken groepen zwak-bewapende opstandelingen door Batavia; één groep bezette korte tijd de telefooncentrale, een andere probeerde vergeefs een gevangenis te veroveren. Tegen de ochtend was aan alle acties een eind gemaakt en waren ongeveer driehonderd rebellen gevangen genomen. Elders op Java vonden slechts hier en daar revolutionaire acties plaats. Het ernstigste waren die in Bantam, maar binnen enkele weken waren ook daar de acties volledig onderdrukt. In tegenstelling tot het oorspronkelijke plan had de PKI in Minangkabau zich van actie onthouden. $\mathrm{Na}$ anderhalve maand van aarzeling kwam zij op 1 januari 1927 alsnog in opstand. De opstandelingen in Minangkabau waren beter bewapend dan die op Java, maar ook hun verzet werd binnen twee weken gebroken.

Dit mislukte avontuur betekende de ondergang van de communistische beweging in Nederlands-Indië. Het gouvernement liet een 13.000 Indonesiërs en Chinezen oppakken van wie werd aangenomen dat ze tot die beweging behoorden. De PKI, de SR-bonden en de communistische vakbonden werden verboden. Van de gearresteerden werden uiteindelijk 7.700 weer vrijgelaten. Ongeveer 4.500 werden berecht en tot gevangenisstraf veroordeeld; dit waren over het algemeen personen die van rechtstreekse betrokkenheid bij gewelddadigheden verdacht werden. Ook werd een aantal doodvonnissen uitgesproken; vier ter dood veroordeelden werden opgehangen; de anderen kregen gratie, tot woede van een deel van de Nederlands-Indische pers. Er bleven nog ruim 800 gearresteerden over, die niet in aanmerking kwamen voor berechting, maar die niettemin als zeer gevaarlijk werden beschouwd. Het gouvernement verbande hen op grond van de exorbitante rechten naar Nieuw-Guinea. Later werd ook een deel van de veroordeelden daarheen verbannen, nadat ze hun gevangenisstraf hadden uitgezeten. Verder brak het gouvernement met het gebruik om aan prominente ballingen toe te staan Indonesië te verlaten.

$\mathrm{Na}$ het uitbreken van de PKI-opstand verklaarde de Komintern zich naar buiten toe solidair met de opstandelingen; de Nederlandse communistische partij sloot zich daarbij aan. De communistische propaganda gaf steeds een overdreven voorstelling van de schaal van de opstand.

Toen de opstand begon, waren Alimin en Moeso op terugreis uit Moskou. 
Zij werden in december 1926 in Singapore gearresteerd en enige maanden later door de Britse autoriteiten uitgewezen, verbleven een tijd lang in China en gingen tenslotte weer naar de Sovjetunie.

Tan Malaka brak in 1927 met de Komintern. In Bangkok richtte hij een niet van Moskou afhankelijke communistische partij-in-ballingschap op met de naam Partai Republik Indonesia (Pari). Deze partij kreeg in Indonesië nauwelijks een voet aan de grond.

\section{Boven-Digoel}

Het gouvernement besloot de gevaarlijke communisten die niet wegens de opstand voor berechting in aanmerking kwamen te interneren op een zo afgelegen mogelijke plaats, waar geen communistische invloed hen van buiten zou kunnen bereiken, waar de plaatselijke bevolking door haar lage beschavingspeil onvatbaar zou zijn voor hun denkbeelden en waar men met een minimum aan bewaking zou kunnen volstaan. Het koos daarvoor een plek in het binnenland van Nieuw-Guinea, 450 kilometer stroomopwaarts gelegen aan de rivier de Digoel op 75 kilometer van de grens met het Australische gebied. Met het oog daarop stelde het een district Boven-Digoel in, dat administratief onder de residentie Ambon viel. Het gouvernement besloot bovendien aan gezinsleden van ballingen toe te staan zich bij hen te voegen. Het ging er daarbij van uit dat de uitgekozen streek een gezond klimaat had en zich leende voor rijstbouw, zodat het interneringsoord zich zou kunnen ontwikkelen tot een landbouwkolonie, waarin de ballingen uiteindelijk in hun eigen onderhoud zouden kunnen voorzien. Dit bleek een misvatting. De streek had zwaar te lijden van malaria en de grond was ongeschikt voor rijstbouw.

Nadat op de uitgekozen plek een stuk oerbos was gekapt en enige barakken waren neergezet, werden in de loop van 1927 de eerste groepen ballingen hierheen gebracht. In 1929 waren er in Boven-Digoel ruim elfhonderd geïnterneerden met bijna duizend gezinsleden. In de jaren 1930-1932 werd de internering van ruim zeshonderd ballingen opgeheven. Tegelijk bracht men nieuwe ballingen binnen, waarvan de meesten niet als communisten beschouwd werden. Eind 1939 was het aantal in Boven-Digoel geïnterneerden teruggelopen tot ruim driehonderdvijftig.

Het interneringsoord beschikte over een ziekenhuis, een school, gebedshuizen en een gevangenis. De verbinding met de buitenwereld werd onderhouden door een eenmaal per maand arriverende boot van het gouvernement. De ballingen moesten hun eigen woningen bouwen en hun eigen groente kweken. Hun post werd gecensureerd. Een honderdtal als 'onverzoenlijk' beschouwde ballingen werd geïsoleerd in een speciaal interneringskamp 35 kilometer verder stroomopwaarts aan de rivier. 
Het interneringsoord was niet omgeven met prikkeldraad maar met oerwoud. In de zestien jaar dat het oord bestaan heeft zijn tal van vluchtpogingen ondernomen, maar geen daarvan is geslaagd. Sommige vluchtelingen kwamen om in de bossen en de moerassen, anderen werden gedood door de schaarse Papoeabevolking. Allen die er in slaagden Australisch gebied te bereiken, werden door de Australische autoriteiten uitgeleverd en naar Boven-Digoel teruggebracht, waar ze vervolgens gevangenisstraf kregen voor hun vluchtpoging.

\section{De vertrouwenspolitiek van De Graeff}

In september 1926 werd gouverneur-generaal Fock opgevolgd door A.C.D. de Graeff, die vroeger de rechterhand van gouverneur-generaal Van Limburg Stirum geweest was en diens opvattingen deelde. Zijn benoeming viel dan ook slecht bij de meeste Nederlanders in de kolonie. Naar zijn mening moest men onderscheid maken tussen revolutionaire en constructieve politieke bewegingen. Terwijl hij bereid was de eerste hard aan te pakken, zoals bleek uit zijn reactie op de communistische opstand, wilde hij de tweede welwillend tegemoettreden. Al kort na zijn aantreden verklaarde hij dat hij zich zou inspannen om de aanhangers van de non-coöperatiegedachte tot ander inzicht te brengen en om iedere aanleiding weg te nemen en te vermijden die aan non-coöperatie een schijnbaar redelijke grondslag zou kunnen geven. Hij meende dat het vertrouwen van de constructieve Indonesische nationalisten onder meer geschokt was door het besluit van het Nederlandse parlement om van de 61 Volksraadzetels slechts 25 voor Indonesiërs te bestemmen in plaats van 30 zoals de regering oorspronkelijk had voorgesteld. Daarom drong hij er bij de regering op aan te proberen dit besluit terug te draaien.

In dezelfde geest maakte De Graeff in het voorjaar van 1927 gebruik van zijn bevoegdheid tot het aanwijzen van leden voor de nieuwe Volksraad. Niet alleen benoemde hij enige Nederlanders die zich positief tegenover het Indonesisch nationalisme opstelden, onder wie J.A. Jonkman, maar ook bood hij de nationalistische leiders Tjokroaminoto en Soetomo zetels aan. Tjokroaminoto wees zijn benoeming meteen af. Soetomo raadpleegde zijn Studieclub en besprak de zaak met De Graeff zelf, maar weigerde uiteindelijk ook. In zijn plaats benoemde De Graeff de zakenman Mohammad Hoesni Thamrin, wethouder van Batavia en leider van de Kaoem Betawi, een organisatie voor de Indonesische bevolking van de hoofdstad.

Intussen wekte het beleid van De Graeff zo veel vertrouwen bij Tjipto Mangoenkoesoemo, dat deze pionier van de non-coöperatiepolitiek zich kandidaat liet stellen bij de verkiezingen voor de Volksraad. Hij kon zijn Volksraadzetel echter niet innemen, omdat hij onder verdenking kwam te staan nadat hij contact had gehad met enige militairen die een opstand wilden 
beginnen. De PID beschouwde hem als één van de gevaarlijkste Indonesische politici. In december interneerde De Graeff hem op de Banda-eilanden.

\section{De eerste nationalistische massabeweging: Soekarno's PNI}

De uitschakeling van de communistische beweging en de verzwakking van de Sarekat Islam schiepen ruimte voor de ontplooiing van een nieuwe Indonesische organisatie op zuiver nationalistische grondslag. Daar kwam ook meer ruimte voor door het beleid van gouverneur-generaal De Graeff. Intussen was de voorbereiding van een nieuwe nationalistische organisatie al voor de aankomst van De Graeff begonnen. Uit Nederland teruggekeerde leden van de Perhimpoenan Indonesia hadden daartoe in de zomer van 1926 in Bandoeng en enige andere steden comités opgericht. Het Bandoengse comité was nauw verbonden met de Bandoengse Studieclub en werd gedomineerd door ir. Soekarno en mr. Sartono, een jurist die met Hatta in het bestuur van de Perhimpoenan Indonesia gezeten had. Anders echter dan Hatta, die meende dat de nieuwe organisatie zich eerst alleen op kadervorming zou moeten richten en nog niet op het mobiliseren van de massa's, vonden Soekarno en Sartono dat men zowel het één als het ander moest doen.

Eind 1926 zette Soekarno zijn politieke denkbeelden in enige tijdschriftartikelen uiteen. Hij betoogde dat de drie stromingen binnen de Indonesische beweging - de islamitische, de marxistische en de nationalistische - niet onderling tegenstrijdig waren. Belangrijker dan hun verschilpunten was het doel dat ze alle drie nastreefden: het beëindigen van de koloniale overheersing. Ze zouden dan ook over hun verschillen moeten heenstappen en een gezamenlijk front tegen de overheersers moeten vormen. Zonder nationale eensgezindheid zou de onafhankelijkheid niet worden bereikt. Daarom was het van belang de nationale geest van de Indonesiërs aan te wakkeren.

Leden van het Bandoengse comité stichtten op 4 juli 1927 de Perserikatan Nasional Indonesia (Indonesische Nationale Vereniging), met Soekarno als voorzitter. Volgens haar statuten streefde deze nieuwe organisatie naar de onafhankelijkheid van Indonesië; ook verder stemde haar politieke ideologie overeen met die van de Perhimpoenan Indonesia. Naast politieke had zij sociale en economische programmapunten, die onder meer voorzagen in bestrijding van analfabetisme en woeker en in oprichting van scholen, coöperaties en poliklinieken. De vereniging hield haar eerste congres in mei 1928 en werd bij die gelegenheid omgedoopt in Partai Nasional Indonesia (PNI).

Men bouwde de organisatie zeer voorzichtig op, waarbij men onder meer probeerde zowel spionnen van het koloniale bestuur als oud-leden van de PKI te weren. Kandidaat-leden moesten een proeftijd van drie maanden doormaken voordat ze lid konden worden; ook de vorming van plaatselijke afdelingen 
was aan strikte voorwaarden gebonden. De PNI organiseerde basiscursussen voor hen die tot de partij wilden toetreden; daarnaast hield zij kadercursussen om toegelaten leden voor te bereiden voor leidende functies. Eind 1928 telde de partij nog geen 2800 leden. Daarna ging de groei iets sneller; tegen het eind van 1929 had zij ongeveer tienduizend leden. De PNI-afdeling in de hoofdstad noemde zich 'afdeling Djakarta'; dit was de eerste maal dat men weer de oude naam gebruikte in plaats van het Nederlandse 'Batavia'.

De zorgvuldige opbouw van de organisatie beantwoordde geheel aan de denkbeelden van Hatta, maar de PNI deed méér. Zij hield tal van openbare bijeenkomsten om haar visie onder het grote publiek te verbreiden, zonder dit onmiddellijk aan ledenwerving te koppelen. De belangrijkste spreker was altijd Soekarno. Nog veel meer dan zijn leermeester Tjokroaminoto verstond hij de kunst een massapubliek in zijn ban te brengen. Bovendien kende hij de voorstellingswereld van de Javaanse bevolking beter dan de politici die in Nederland gestudeerd hadden; hij knoopte in zijn toespraken graag aan bij bekende wajangverhalen. Hij beklemtoonde steeds, dat de koloniale overheersers zich uit eigenbelang van Indonesië meester hadden gemaakt en het nooit vrijwillig zouden prijsgeven. Hij riep op tot nationale eenheid en verkondigde keer op keer, dat de nationale geest moest leiden tot de nationale wil en uiteindelijk tot de nationale daad.

Gedurende het eerste jaar van het bestaan van de PNI gaven enige onverwachte gebeurtenissen aanleiding tot het organiseren van bijzondere manifestaties. In de zomer van 1927 waren dat eerst de huiszoekingen in Nederland bij voormannen van de Perhimpoenan Indonesia en vervolgens hun gevangenneming. In december was het de verbanning van Tjipto Mangoenkoesoemo naar de Banda-eilanden. Tenslotte leidde de vrijspraak van Hatta en zijn vrienden in maart 1928 tot nieuwe manifestaties, nu niet van protest maar van triomf.

Soekarno en zijn medestanders keerden zich niet alleen tegen de koloniale overheersing, maar ook tegen het inheemse feodalisme. Zij gaven hier uitdrukking aan door niet langer de traditionele Indonesische hoofddoek te dragen. In plaats daarvan droegen zij een rechte muts van zwart velours, die nu het symbool van de radicale nationalisten werd.

De nationalistische voormannen wilden in de jaren 1926-1927 niet alleen een eigen organisatie oprichten, maar ook een toenadering teweegbrengen tussen de bestaande groeperingen binnen de nationale beweging. Soekarno slaagde zowel op het eerste als op het tweede punt. In december 1927 kwam een federatie tot stand onder de naam Permoefakatan Perhimpoenan-Perhimpoenan Politik Kebangsaan Indonesia (PPPKI, Verbond van de Politieke Verenigingen van de Indonesische Natie). Hieraan namen deel: Boedi Oetomo, de Sarekat Islam, de PNI, de Soerabajase Studieclub, de Sumatranenbond, de Soendanese vereniging Pasoendan en de Bataviase vereniging Kaoem Betawi. Het was een zeer losse organisatie, die alleen met eenstemmigheid besluiten kon nemen en 
dan ook weinig eigen activiteiten aan de dag legde. Maar het belangrijke punt was dat alle deelnemende groeperingen, met inbegrip van Boedi Oetomo, nu uitdrukkelijk de doelstelling van Indonesische onafhankelijkheid onderschreven. Tegelijk waren ze overeengekomen, dat de PPPKI geen standpunten zou innemen over religieuze kwesties en over de kwestie van coöperatie tegenover non-coöperatie. Soetomo werd voorzitter van de federatie.

De totstandkoming van deze federatie was mogelijk, omdat oud-leden van de Perhimpoenan Indonesia nu zowel in Boedi Oetomo als in de Sarekat Islam belangrijke posities innamen. Een cruciale rol speelde Soekiman Wirjosandjojo, een arts in Jogja die in Nederland voorzitter van de PI geweest was. Hij leide nu de jonge garde in de SI en wist daar de weerstanden van Tjokroaminoto en Agoes Salim te overwinnen. Samen met Soekarno bereidde hij de federatie voor.

Intussen zag de Sarekat Islam zijn positie als leidende islamitische organisatie steeds verder afbrokkelen. Een deel van zijn leden vloeide weg naar de Moehammadiah, welker moderne islamitische opvattingen door velen binnen de SI werden gedeeld. Anderzijds riep de hervormingsgezinde stroming binnen de islam ook reacties onder de traditionele stroming op. Conservatieve moslimvoorgangers stichtten in 1926 een eigen organisatie, de Nahdatoel Oelama (Opleving der Schriftgeleerden), die zich gezagsgetrouw opstelde en al snel een grote aanhang kreeg.

\section{Het Indonesisch Jeugdcongres van 1928}

In dezelfde periode waarin de PNI en de federatie PPPKI tot stand kwamen, manifesteerde het streven naar nationale eenheid zich ook binnen de Indonesische jeugdorganisaties. De meeste van die organisaties berustten op etnische grondslag; de oudste en grootste daarvan was Jong Java. Intussen waren daarnaast ook organisaties gevormd die zich niet tot een etnische groep beperkten. Op aansporing van Agoes Salim was eind 1924 een JongIslamieten Bond opgericht. In 1926 stichtten studenten aan de hogescholen in Batavia en Bandoeng de Perhimpoenan Peladjar-Peladjar Indonesia (PPPI, Vereniging van Indonesische Studenten). Verder werd in 1927 onder auspiciën van de Bandoengse studieclub een nationalistische jeugdorganisatie gevormd, Pemoeda Indonesia (Indonesische Jongeren).

De studentenvereniging PPPI, wier politieke visie nauw aansloot bij die van de Perhimpoenan Indonesia, werd het kweekbed voor een nieuwe generatie leiders van de nationale beweging. Twee hiervan waren Amir Sjarifoeddin en Mohammad Yamin, die beiden in Batavia rechten studeerden. Sjarifoeddin, een Batakse moslim die in Nederland op school geweest was, ontpopte zich als een groot redenaar en organisator. Yamin, een Minangkabauer die 
voorzitter van de Jong-Sumatranen Bond geweest was, werd een bevlogen ideoloog van het Indonesisch nationalisme. In zijn visie zou het toekomstige onafhankelijke Indonesië niet alleen de hele archipel moeten omvatten (met inbegrip van Noord-Borneo en Oost-Timor), maar ook Singapore, Malakka en de Filippijnen.

Op initiatief van de journalist Moh. Tabrani vond in 1926 een eerste Indonesisch Jeugdcongres plaats, waar vertegenwoordigers van verschillende jongerenorganisaties met elkaar spraken over samenwerking ter bevordering van de Indonesische eenheid. Van groot belang voor de geschiedenis van Indonesië werd het in 1928 gehouden Tweede Indonesisch Jeugdcongres. Het was georganiseerd door de studentenvereniging PPPI en vond plaats in haar verenigingsgebouw in Batavia. De andere vertegenwoordigde organisaties waren Pemoeda Indonesia, de Jong-Islamieten Bond, Jong Java, Jong Celebes, de Jong-Sumatranen Bond, de Jong-Bataks Bond, de Bataviase jeugdbond en de Soendanese jeugdbond. Enige leiders van de PNI, onder wie Soekarno en Sartono, woonden het congres bij. De jongerenvertegenwoordigers besloten aan hun organisaties voor te stellen om de verschillende bonden te fuseren tot één Indonesisch jongerenverbond.

Op voorstel van Yamin nam het congres op de slotdag, 28 oktober 1928, een plechtige resolutie aan, luidende: 'Wij zonen en dochters van Indonesië erkennen één vaderland te hebben, Indonesië. Wij zonen en dochters van Indonesië erkennen één volk te zijn, het Indonesische volk. Wij zonen en dochters van Indonesië aanvaarden de eenheidstaal, het Indonesisch.' Met het Indonesisch (Bahasa Indonesia) bedoelde men het gemoderniseerde Maleis, dat zich in feite al tot algemene eenheidstaal had ontwikkeld. Deze resolutie is later bekend geworden als de Soempah Pemoeda (Eed van de Jeugd), die jaarlijks op 28 oktober herdacht wordt.

Op hetzelfde congres bracht de onderwijzer W.R. Soepratman een door hem gedicht en gecomponeerd lied ten gehore, 'Indonesia Raja' (Groot Indonesië) met vele malen het woord merdeka (vrij, onafhankelijk) in het refrein. Dit lied werd bijzonder populair bij de Indonesische nationalisten, die het telkens op hun bijeenkomsten zongen en het de status van een volkslied gaven.

Met uitzondering van de Jong-Islamieten Bond stemden alle op het congres vertegenwoordigde organisaties uiteindelijk in met de voorgestelde fusie. Op 1 januari 1931 gingen ze op in de nieuwe organisatie Indonesia Moeda (Jong Indonesië).

\section{De 'Inlandse meerderheid' in de Volksraad}

In 1927 diende de regering op aandrang van gouverneur-generaal De Graeff een wetsontwerp in, dat voor de samenstelling van de Volksraad terugkeerde 
naar de formule zoals die geluid had voordat het parlement bij amendement slechts 25 in plaats van 30 zetels voor Indonesiërs bestemd had. Het ontwerp voorzag bovendien in uitbreiding van de Raad van Indië van vijf tot zeven leden, teneinde daar ook twee Indonesische leden in op te kunnen nemen. Voorafgaande aan de behandeling van dit wetsontwerp in het parlement moesten eerst de Raad van Indië en de Volksraad er hun oordeel over geven.

Met de nu opnieuw voorgestelde formule voor een (relatieve) 'Inlandse meerderheid' had de Volksraad al in 1922 ingestemd, maar sindsdien was de stemming in de kolonie veranderd. Bovendien werd het nieuwe wetsontwerp na de communistische opstandpoging ingediend, toen de Europese gemeenschap erg gespannen was. Bij de Nederlanders, onder wie de Indische Nederlanders, wekte de formule nu een storm van protest. De campagne tegen de 'Inlandse meerderheid' werd aangevoerd door de president-directeur van de Javasche Bank, L.J.A. Trip, die onverbloemd sprak over de noodzaak 'de inlander eronder te houden'. Ruim twintigduizend personen ondertekenden een door hem opgestelde afwijzing van die formule. De voorgestelde uitbreiding van de Raad van Indië ontmoette minder bezwaar.

Het voorstel voor de samenstelling van de Volksraad kreeg in de Raad van Indië onvoldoende steun. Een belangrijke tegenstander was hier Ch.J.I.M. Welter, een voormalig BB-ambtenaar die als lid van de commissie-Carpentier Alting al blijk had gegeven van zijn conservatieve opvattingen, vervolgens de rechterhand van gouverneur-generaal Fock was geweest en in het kabinet-Colijn van 1925-1926 als minister van koloniën was opgetreden. In de Volksraad zelf steunde eind 1927 een ruime meerderheid het regeringsvoorstel. Naast de Indonesische leden stemden elf Nederlandse leden voor, onder wie Jonkman. Zestien Nederlandse leden stemden tegen, onder wie de leden van het IEV en de vertegenwoordiger van de BB-ambtenaren, J.W. Meyer Ranneft. Ook twee Chinese leden stemden tegen.

Zowel de tegenstanders als de voorstanders van de 'Inlandse meerderheid' richtten zich nu op beïnvloeding van het Nederlandse parlement. Hier verloren de tegenstanders uiteindelijk het pleit. De Tweede Kamer aanvaardde het wetsontwerp in 1928 met grote meerderheid; tot de voorstemmers behoorde ook het Kamerlid dat vroeger het initiatief genomen had om het aantal Indonesische zetels te beperken. In de Eerste Kamer ontmoette het ontwerp meer verzet, maar werd het tenslotte in 1929 toch aanvaard. De leider van de ARP, Colijn, behoorde tot de tegenstemmers.

Eind 1929 werden Achmad Djajadiningrat en Koesoemo Joedo tot lid van de Raad van Indië benoemd. De 'Inlandse meerderheid' in de Volksraad werd ingevoerd bij de nieuwe samenstelling in 1931.

Overigens benoemde de regering in 1929 Welter tot vice-president van de Raad van Indië en Meyer Ranneft tot voorzitter van de Volksraad. Welter 
keerde enige jaren later naar Nederland terug, waar hij voorzitter werd van de Ondernemersraad voor Nederlandsch-Indië. Trip werd in 1931 president van de Nederlandsche Bank. Van 1933 tot 1936 was Meyer Ranneft vice-president van de Raad van Indië. Verder verminderde de regering in 1933 het aantal Indonesische leden van deze Raad van twee tot één.

\section{De Vaderlandsche Club}

De campagne tegen de 'Inlandse meerderheid' bereikte haar doel niet, maar leidde wel tot een verdere politisering van de in Indonesië werkende Nederlanders. Daarvan getuigde de snelle groei van een nieuwe organisatie die opkwam voor onverkorte handhaving van het koloniale bestel, de Vaderlandsche Club (VC). Het initiatief hiertoe stamde van een paar journalisten en figuren uit de suikerindustrie in Soerabaja en kreeg veel bijval in de Nederlands-Indische pers. Ten tijde van de officiële oprichting in oktober 1929 had de VC al meer dan zesduizend leden en gaf zij een eigen orgaan uit met een oplaag van tienduizend. Binnen een jaar bereikte zij een omvang van negenduizend leden. Zij ging nu ook als politieke partij optreden. Bij de verkiezingen voor de Volksraad van 1931 verkreeg zij vijf zetels.

De VC was vooral een organisatie van Nederlanders die van plan waren na een loopbaan in de kolonie naar Nederland terug te keren ('trekkers'). Het 'vaderland' waar de naam naar verwees was niet Indonesië, maar Nederland. Terwijl alle eerder door Nederlanders in de kolonie opgerichte politieke partijen (behalve het door Indische Nederlanders gevormde IEV) ook Indonesiërs als lid toelieten, stond het lidmaatschap van de VC alleen voor Nederlanders open.

De VC omschreef haar uitgangspunt in de statuten als volgt: 'De Vaderlandsche Club, zich stellende op den grondslag der onverbreekbaarheid van den band, welke de verschillende delen van het Koninkrijk der Nederlanden tezamen houdt, zooals uitgedrukt in artikel 1 van de Grondwet, heeft ten doel te ageeren tegen alle invloeden, welke dit beginsel aantasten'. De VC spoorde dan ook aan tot hard optreden tegen de Indonesische nationale beweging. Tegelijk richtte zij zich consequent op behartiging van de belangen van de Nederlandse bovenlaag. Zo stelde zij voor geen studiebeurzen meer te verlenen en alle hoger onderwijs in de kolonie af te schaffen, omdat ze de hogescholen op Java als broeinesten van anti-Nederlandse agitatie beschouwde, terwijl ze de functies waar die toe opleidden liever door Europeanen vervuld zag.

De VC vond grote weerklank onder de Nederlandse trekkers, omdat velen daarvan hun toekomst bedreigd zagen door de opkomst van het Indonesisch nationalisme en fel gekant waren tegen de vertrouwenspolitiek van De Graeff. 
Binnen deze kring groeide in die tijd ook waardering voor het Europese fascisme en nationaal-socialisme. Enige jaren na haar oprichting verloor de VC een deel van haar aanhang aan de Nederlands-Indische afdeling van de NSB (de voornaamste nationaal-socialistische organisatie in Nederland). Bovendien nam haar aanhang af omdat aan de vertrouwenspolitiek een vroegtijdig einde kwam, zodat de VC geen oppositie tegen het gouvernement meer behoefde te voeren. Het ledental slonk tot ongeveer tweeduizend, maar nam later weer toe. In de Volksraad behield de VC vier zetels. Tot aan de Japanse tijd bleef de VC de belangrijkste politieke organisatie van de Nederlandse bovenlaag.

\section{Rijkseenheid}

Lange tijd was het 'bezit' van Nederlands-Indië een vanzelfsprekendheid voor de overgrote meerderheid van de Nederlandse bevolking, zowel in de kolonie als in het moederland. In de jaren 1926-1929 werd deze zekerheid verstoord, eerst door de communistische opstanden, daarna door het resolute ageren van de Perhimpoenan Indonesia onder Hatta en de Partai Nasional Indonesia onder Soekarno voor onafhankelijkheid voor Indonesië. In reactie hierop legden meer en meer Nederlanders zich vast op het standpunt, dat noch deze kolonie noch enig ander overzees gebiedsdeel zich van het Nederlandse koninkrijk los zou mogen maken. Zo kwam tegenover de leuze 'Indonesia merdeka' de leuze 'Rijkseenheid' te staan.

Deze koloniale conservatieven behandelden de politieke kwestie van de toekomstige verhouding tussen Nederland en Indonesië bij voorkeur in morele en juridische termen. De manier waarop de Vaderlandsche Club haar uitgangspunt formuleerde was typerend voor hun opstelling. Door de wens tot handhaving van het rijk als een 'beginsel' te presenteren trok men die kwestie in de morele sfeer. Verzaken van dit beginsel door Nederlanders zou gelijk staan aan landverraad. Tegelijk hanteerde men ook tegenover Indonesiërs het juridische argument van een beroep op de Nederlandse grondwet, alsof die universeel geldende normen inhield.

In Nederland vormde de Utrechtse indologiefaculteit het ideologische centrum van de koloniaal-conservatieve richting. Sinds 1929 beschikte die richting over een eigen orgaan, dat een jaar later De Rijkseenheid ging heten. Het openingsnummer bevatte onder meer een artikel waarin betoogd werd dat het Nederlandse volk recht op Indië had, niet alleen krachtens bezit, omdat het er al sinds lang over heerste, maar ook krachtens auteursrecht, omdat het Indië gemaakt had tot wat het was.

De koloniaal-conservatieve richting ontkende het bestaan van een Indonesische natie en verzekerde dat de grote meerderheid van de inheemse bevolking niet naar nationale onafhankelijkheid verlangde. Dit was ook te 
vinden in brochures die Treub en Colijn in 1927 en 1928 publiceerden. Colijn wees Hatta en Soekarno uitdrukkelijk aan als belangrijke nationalistische leiders, maar vond hun beweging 'geenszins een echte volksbeweging, veeleer een actie waar in werkelijkheid slechts een bovenlaagje der bevolking, dun als het zilvervliesje van de rijstkorrel, direct bij betrokken is'. Treub noemde het Indonesisch nationalisme 'ontoelaatbaar' en stelde, dat elke actie die erop gericht was het Nederlandse gezag in Indonesië te ondermijnen zo nodig met geweld onderdrukt moest worden, 'zelfs indien zij een gezonden ondergrond had'.

In de jaren dertig won het koloniaal-conservatisme steeds meer terrein binnen de Nederlandse christelijke en liberale politieke partijen. Terwijl het woord 'rijkseenheid' in 1929 nog niet in hun verkiezingsprogramma's voorkwam, kreeg dit in 1937 uitdrukkelijk een plaats in de programma's van drie van die partijen.

\section{De Stuw-groep}

Dat veel Nederlanders in Indonesië de ethische politiek afwezen betekent niet, dat die politiek daar helemaal geen aanhangers meer had. Enige van deze aanhangers richtten begin 1930 een vereniging op die een veertiendaags tijdschrift ging uitgeven met de naam De Stuw. Het initiatief berustte in hoofdzaak bij hoogleraren van de Rechtshogeschool in Batavia en enkele hoofdambtenaren, onder wie Jonkman en Van Mook. Volgens haar beginselverklaring was de vereniging bedoeld voor Nederlanders die het als hun plicht zagen mee te werken 'aan de verdere uitvoering van Nederland's koloniale taak'; die taak zou voltooid zijn 'wanneer een Indisch Gemeenebest in de rij der zelfstandige volken een eigen plaats inneemt'. Men sprak van een 'Indisch' en niet een 'Indonesisch' gemenebest om aan te geven, dat het niet alleen aan Indonesiërs plaats zou moeten bieden maar ook aan Nederlandse 'blijvers', Indo-Europeanen, Chinezen en Arabieren. Verder streefde men ernaar dat dit gemenebest duurzame banden met Nederland zou onderhouden, maar het zou vrij moeten zijn om hier wel of niet voor te kiezen; men onderschreef dus niet de rijkseenheidsidee. Desgevraagd verklaarde het bestuur zich uitdrukkelijk voor onafhankelijkheid voor het Indisch gemenebest, al liet het zich niet uit over de vraag wanneer men die tegemoet zou kunnen zien. Het tijdschrift De Stuw behandelde voornamelijk politieke en economische onderwerpen. Het bestreed het koloniaal-conservatisme, volgde het werk van de Volksraad en gaf aandacht aan ontwikkelingen in het buitenland die voor de toekomst van Indonesië van belang waren.

De totstandkoming van de Stuw-groep was een reactie op de trend naar rechts binnen de Nederlandse gemeenschap, zoals gebleken uit de opkomst 
van de Vaderlandsche Club. Haar activiteiten leidden soms tot woede in de kringen van de VC en van het Indo-Europees Verbond. De groep telde slechts een paar honderd leden. Tot haar actieve leden behoorden, naast Jonkman en Van Mook, de hoogleraren J.H.A. Logemann en F.M. van Asbeck, de bestuursambtenaar Ch.O. van der Plas en de leraar P.J. Koets. In 1932 werd Logemann voorzitter en Koets secretaris-penningmeester. Hoewel de groep de Indonesische nationale beweging positief tegemoet wilde treden, hadden de meeste leden daar nauwelijks contact mee.

De politieke betekenis van de Stuw-groep was groter dan haar omvang; onder meer hadden enkele van haar leden zitting in de Volksraad. Jonkman verliet de Volksraad in 1931, omdat hij officier van justitie in Makassar werd. In zijn plaats benoemde gouverneur-generaal De Graeff nu Van Mook, een typische vertegenwoordiger van de Nederlandse 'blijvers'. In de Volksraad keerde Van Mook zich stelselmatig tegen achterstelling van de belangen van de kolonie bij die van Nederland.

Ten tijde van haar oprichting stond de Stuw-groep achter de vertrouwenspolitiek van De Graeff. Na diens vertrek in 1931 kwam zij steeds meer tegenover het gouvernement te staan. Het gouvernement zelf was niet gesteld op openlijke kritiek door ambtenaren. De aanhang van de groep liep terug. Enige van haar meest actieve leden konden weinig medewerking meer verlenen omdat zij niet langer in Batavia werkten; het tijdschrift dreef nu grotendeels op de bijdragen van Van Mook. Eind 1933 werd de uitgifte van De Stuw gestaakt en hield ook de vereniging op te bestaan. In het voorjaar van 1934 trok Van Mook zich uit de Volksraad terug.

\section{Het proces-Soekarno}

In 1928 en 1929 ging Soekarno door met het houden van politieke toespraken, zowel in openbare vergaderingen als in besloten bijeenkomsten. De vertrouwenspolitiek van De Graeff beantwoordde hij niet met tegemoetkomendheid. In overeenstemming met de doctrine van de Perhimpoenan Indonesia richtte hij zich juist op verscherping van de tegenstellingen tussen de koloniale overheersers en de overheersten, door hem vaak aangeduid als sana (ginds) en sini (hier). Hij verklaarde dat de Indonesische vrijheidsstrijd deel uitmaakte van een grotere beweging in Azië en dat alle Aziatische nationalisten moesten samenwerken in hun verzet tegen het imperialisme. Om het de Nederlandse ambtenaren moeilijker te maken hem het spreken te beletten, verpakte hij zijn politieke boodschap vaak in beeldspraak, toespelingen en suggestieve vragen.

Eén van Soekarno's favoriete thema's was de 'Pacific-oorlog'. Hoewel Japan in de Wereldoorlog de kant van Groot-Brittannië en Amerika gekozen had, waren sommigen zich al kort na die oorlog gaan afvragen of men niet binnen afzienbare tijd een conflict van deze landen mét Japan moest verwachten. Die 
gedachte leidde onder meer tot speculaties in communistische kring, waar Tan Malakka al in 1925 op gereageerd had in zijn brochure Naar de 'RepubliekIndonesia'. In datzelfde jaar publiceerde een Britse marine-deskundige, Hector Bywater, een spannende toekomstroman onder de titel The Great Pacific War; A history of the American Japanese Campaign of 1931-1933. Hij beschreef daar een oorlog in die zou beginnen met een Japanse verrassingsaanval waarbij onder meer de Amerikaanse Pacific-vloot totaal vernietigd zou worden; het zou de Verenigde Staten veel moeite kosten zich te herstellen, maar na jaren van harde strijd zouden ze toch de overwinning behalen. De mogelijkheid van een Pacific-oorlog kwam nu ook in de Nederlands-Indische pers en in de Volksraad ter sprake. Soekarno gaf in woord en geschrift te kennen dat hij een oorlog tussen Amerika, Groot-Britannië en Japan om de macht in de Pacific onvermijdelijk achtte. In een artikel schreef hij onder meer: 'Wij kunnen het woeden van de storm nu al horen. [...] Zal ons land niet meegesleept worden in de botsing van de giganten? Laten wij niet onvoorbereid zijn als binnenkort onze vijanden dicht bij ons land en misschien ook binnen onze landsgrenzen een strijd op leven en dood voeren.'

Soekarno knoopte ook graag aan bij een in zijn tijd populaire versie van de Djojobojo-profetie, die voorspelde dat de blanke overheersers zouden worden verdreven door vreemdelingen van gele huidskleur, maar dat het volk van Java kort daarna zijn vrijheid zou herwinnen. Sinds de spectaculaire opkomst van Japan verbreidde zich de veronderstelling, dat die vreemdelingen Japanners zouden zijn. Verder leidde het geloof in de Djojobojo-profetie ertoe, dat sommige Javanen nu in Soekarno de ratoe adil gingen zien.

In zijn toespraken tartte Soekarno het koloniale bestel door onafhankelijkheid te eisen voor het Indonesische volk en door de spot te drijven met de koloniale heersers. Hij bracht daarbij zijn toehoorders in vervoering en raakte ook zelf in vervoering. Zijn optreden werd steeds uitdagender. Verscheidene andere nationalistische leiders vreesden dat deze confrontatiekoers op een botsing met het gouvernement zou uitlopen die de nationale beweging ernstige schade zou kunnen toebrengen. Vanuit zijn ballingsoord Banda drong Tjipto Mangoenkoesoemo er bij Soekarno op aan zich te matigen. Hatta deed hetzelfde vanuit Nederland. Ook onder nationalistische studentenleiders bestond kritiek op Soekarno's optreden. Zij waren teleurgesteld dat hij de uitvoering van het sociale en economische programma van de PNI verwaarloosde en zich vrijwel alleen op politieke agitatie richtte.

Soekarno liet zich noch door adviezen van zijn politieke vrienden noch door waarschuwingen van het gouvernement uit zijn koers brengen. In de loop van 1929 gaf de Nederlands-Indische pers uiting aan toenemende verontwaardiging over de agitatie van de PNI en over de passiviteit van het gouvernement daartegenover. Ook de meeste bestuursambtenaren waren voor krachtig optreden tegen de PNI (die ze voornamelijk als een voortzetting van 


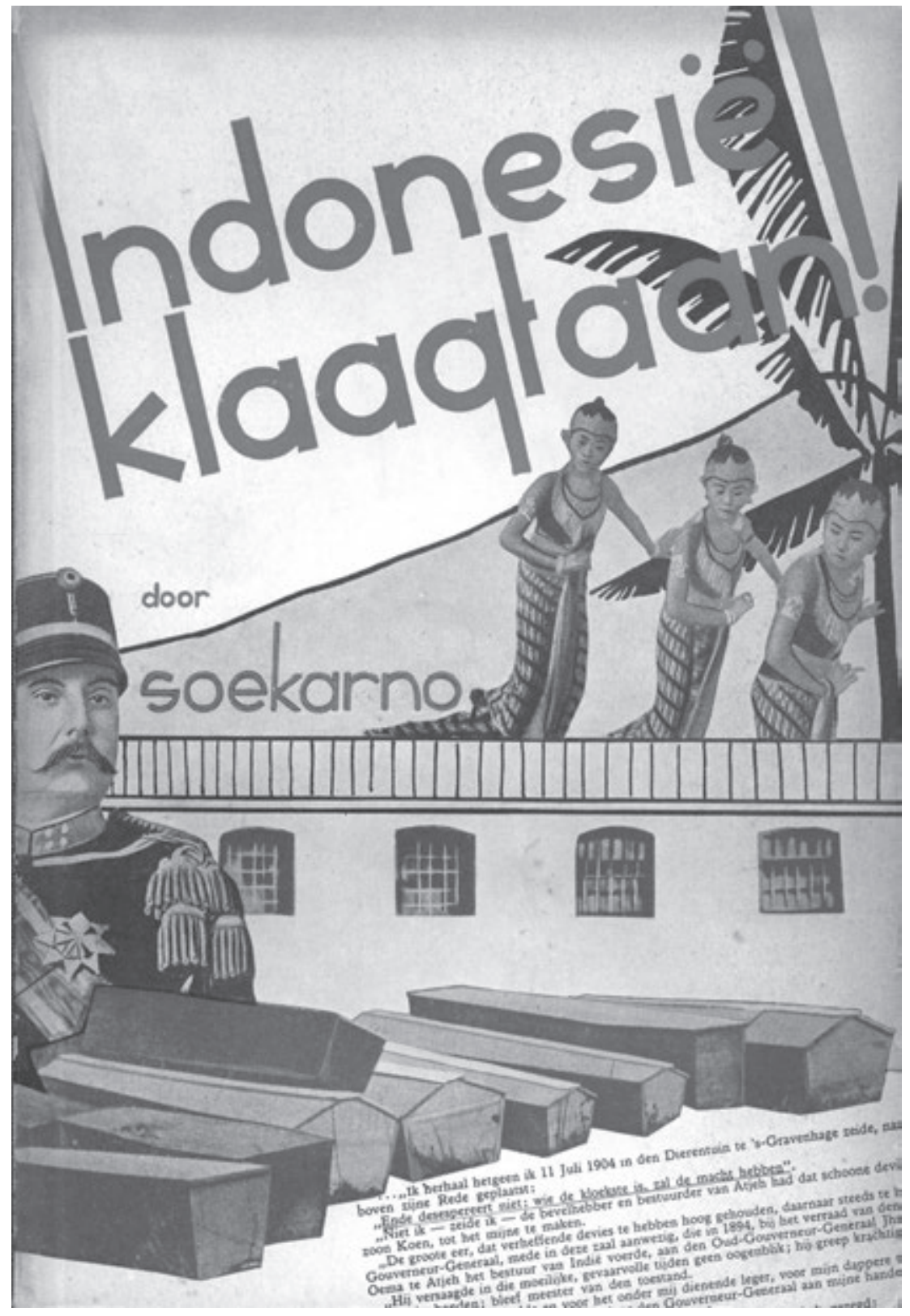

Soekarno (1901-1970) stond in 1930 in Bandoeng terecht en legde toen evenals Hatta een in gevangenschap geschreven principiële pleitrede over, maar anders dan Hatta werd hij tot vier jaar gevangenschap veroordeeld. Zijn rede, die in Indonesië niet in druk kon verschijnen, werd in Nederland door de Arbeiderspers gepubliceerd. 
de PKI zagen), maar gouverneur-generaal De Graeff hield dit lange tijd tegen. Pas toen hem eind december geruchten bereikten over door de PNI geïnspireerde plannen voor omstreeks de jaarwisseling te beginnen opstandige acties, machtigde hij het bestuur om in te grijpen.

Tijdens een razzia in heel Java in de vroege ochtend van 29 december 1929 arresteerde de politie honderden PNI-leiders en -propagandisten en verrichtte zij huiszoekingen in hun woningen en in de PNI-kantoren. De meeste arrestanten werden al gauw weer vrijgelaten, maar Soekarno en drie anderen bleven gevangen. De Graeff verklaarde dat hij dit maal geen gebruik zou maken van zijn exorbitante rechten maar dat het viertal berecht zou worden. De huiszoekingen bleken overigens geen bewijzen op te leveren voor de verdenking van voorbereiding van een opstand. De aanklagers baseerden hun beschuldiging nu in de eerste plaats op een strafbepaling tegen het deelnemen aan een vereniging die het plegen van misdrijven tot oogmerk had, en in de tweede plaats op het in 1926 ingevoerde 'haatzaai-artikel' tegen uitingen waarin, zij het ook zijdelings, voorwaardelijk of in bedekte termen, verstoring van de openbare orde of omverwerping van het gevestigde gezag werd aangeprezen (zie p. 137). Voor de bewijsvoering werd onder meer gebruik gemaakt van aantekeningen uit besloten kadercursussen van de PNI.

Het proces tegen de vier PNI-leden vond in Bandoeng plaats en begon in augustus 1930. Hun verdedigers waren drie Indonesische advocaten (onder wie Sartono) die in Nederland tot de Perhimpoenan Indonesia behoord hadden. In navolging van Sneevliet en Hatta schreef Soekarno een lange verdedigingsrede; het uitspreken daarvan nam twee dagen in beslag. Het einddoel van zijn partij omschreef hij als een 'Federatieve Republiek Indonesië'. In december volgde het vonnis. Soekarno werd veroordeeld tot vier jaar gevangenisstraf met aftrek van voorarrest, de anderen kregen lagere gevangenisstraffen. Nadat het vonnis in april 1931 in hoger beroep was bevestigd, bracht men Soekarno over naar de nieuwe gevangenis in Soekamiskin.

Het vonnis was bijna geheel gewijd aan het eerste punt van de beschuldiging en leek daardoor meer op een veroordeling van de PNI dan van de individuele verdachten. De misdrijven die de PNI volgens de rechters tot oogmerk had waren: opstand en aanslag op de staatsorde, het organiseren van stakingen ter verstoring van de openbare orde en het onrust verwekken onder de bevolking door het verspreiden van een leugenachtig bericht. Het laatste punt baseerden zij op de 'volkomen ongegrondheid' van de voorspelling dat binnenkort een Pacific-oorlog zou uitbreken.

Soekarno's in het Indonesisch uitgesproken verdedigingsrede kon in Indonesië niet in druk verschijnen. In Nederland publiceerde de SDAP een bekorte Nederlandse vertaling onder de titel Indonesie klaagt aan! Daarentegen verscheen in Indonesië wel een door de Stuw-groep uitgegeven brochure die het vonnis aan scherpe kritiek onderwierp en in strijd met de wet noemde. 
Kort voordat gouverneur-generaal De Graeff zijn ambt in september 1931 neerlegde, maakte hij gebruik van zijn recht van gratie om de gevangenisstraf van Soekarno van vier tot twee jaar te verminderen, zodat deze eind december vrij zou komen.

\section{Hergroeperingen binnen de Indonesische nationale beweging}

Het optreden van het gouvernement van eind 1929 tegen de PNI bracht een slag toe aan de non-coöperatieve vleugel van de nationalistische beweging. Eén van de gevolgen daarvan was dat de coöperatieve vleugel van die beweging sterker naar voren trad. Onder de inheemse leden van de Volksraad bevonden zich verscheidene nationalisten, maar die behoorden tot verschillende politieke partijen of waren partijloos. Tien van hen besloten eind januari 1930 te gaan samenwerken als Nationale Fractie. Zij duidden hun doel aan als de zo spoedig mogelijke 'zelfstandigheid' van Indonesië. Fractievoorzitter was Thamrin, een coöperator die ook met non-coöperatieve politici op goede voet stond. Het meest prominente fractielid was de oud-regent Koesoemo Oetojo, voorzitter van Boedi Oetomo en vice-voorzitter van de Volksraad. Later sloot ook de leider van de Soendanese bond Pasoendan, Oto Iskandar Dinata, zich bij de fractie aan. De Nationale Fractie deed in 1932 een verdere stap door haar doel te omschrijven als de zo spoedig mogelijke 'onafhankelijkheid' van Indonesië. Daarmee maakte zij duidelijk dat het verschil tussen de coöperatieve en de non-coöperatieve vleugel van de beweging alleen de methodiek en niet het einddoel betrof. De overige inheemse Volksraadleden onderschreven deze doelstelling niet, maar voelden gewoonlijk wel voor een zelfstandiger status van Indonesië binnen het Nederlandse Koninkrijk. Veel van deze leden waren hoge bestuursambtenaren, zoals de Soendanees Wiranatakoesoema, de Balinees Soekawati en, sinds 1931, de Javaan Soetardjo.

De ingreep van eind 1929 liet de non-coöperatieve vleugel van de nationale beweging ontredderd achter. De arrestatie van Soekarno leidde niet tot massale protesten onder de Indonesische bevolking - evenmin als de bevolking van India in 1922 in beweging gekomen was tegen de gevangenneming van Gandhi. Wel belegde de federatie PPPKI een protestbijeenkomst in Batavia, die onder meer werd toegesproken door Agoes Salim en Soetomo. De PNI schortte al haar politieke activiteiten op. Ook op het vonnis van december 1930 volgden nauwelijks openbare protesten. Doordat dit vonnis de PNI aanmerkte als een vereniging die het plegen van misdrijven beoogde, werd het deze partij onmogelijk nog politiek te functioneren. Het bestuur van de PNI besloot daarom de partij te ontbinden, nadat het vonnis in april 1931 in hoger beroep was bevestigd. Tegelijk richtte men een nieuwe partij op, de Partai Indonesia, met een doelomschrijving die niet wezenlijk van die van de PNI 
verschilde. Sartono werd voorzitter van deze nieuwe partij, die men gewoonlijk als Partindo betitelde.

De door Soekarno in 1927 bewerkstelligde samenwerking binnen de nationale beweging ging tijdens zijn gevangenschap meer en meer verloren. Soetomo zette zijn Soerabajase Studieclub in 1930 om in een eigen politieke partij, de Persatoean Bangsa Indonesia (PBI, Unie van het Indonesische Volk). De Sarekat Islam, in ledental nog steeds de grootste partij, raakte in conflict met Soetomo en trad uit de federatie PPPKI. Het beleid van het PNI-bestuur verwierf niet de instemming van alle PNI-leden; een aantal van hen sloot zich dan ook niet bij de Partindo aan. De scherpste kritiek kwam uit Nederland van Hatta. In de gang van zaken sinds eind 1929 zag hij al zijn bezwaren bevestigd tegen de door Soekarno gevolgde koers. Naar zijn mening had deze zich te veel gericht op het kweken van een revolutionaire stemming onder de massa's zonder eerst een sterke basis op te bouwen; toen het er op aankwam was die stemming dan ook weinig waard gebleken. Hatta vond het onjuist dat het PNI-bestuur de partij zelf ontbonden had. Hij was niet bereid zich bij de Partindo aan te sluiten en keurde het af dat men het woord 'nationaal' in de naam van de nieuwe partij had laten vallen.

Terwijl de Partindo in de tweede helft van 1931 snel groeide, hielden Hatta's geestverwanten in Indonesië zich bezig met de vorming van een andere organisatie, die zich zou moeten richten op stelselmatige scholing om de massa's tot nationale bewustwording op te voeden. Deze organisatie, die zich aanvankelijk als een 'club' aandiende, kreeg eind van het jaar vorm onder de naam Pendidikan Nasional Indonesia (Nationale Indonesische Scholing). Men noemde haar meestal de PNI Baroe (Nieuwe PNI).

In deze verwarde situatie organiseerde de PPPKI een congres dat van 3 tot 5 januari 1932 in Soerabaja plaatsvond onder de naam Kongres Indonesia Raja (Congres van Groot Indonesië). Men had deze data gekozen om Soekarno, die op 31 december uit gevangenschap vrijkwam, in staat te stellen er aan deel te nemen. Bij zijn vrijlating werd Soekarno afgehaald door Thamrin, samen met enige Partindo-leiders. De volgende dag reisde hij eerst naar Jogja, waar hij een bezoek bracht aan één van de pioniers van de nationale beweging, $\mathrm{Ki}$ Hadjar Dewantoro, die vroeger Soewardi Soerjaningrat heette, maar ook als leider van de Taman Siswa-scholen steeds in contact met de beweging was gebleven. Op 2 januari reisde hij door naar Soerabaja. De hele treinreis werd een triomftocht; op alle stations juichten menigten hem toe. Op het congres zei hij zich te zullen inzetten om een eind te maken aan de verdeeldheid die in de nationale beweging was ontstaan.

In de daarop volgende maanden probeerde Soekarno de Partindo en de PNI Baroe tot elkaar te brengen. Hij sprak daartoe onder meer met Sjahrir, die na zijn terugkeer uit Nederland de leiding van de PNI Baroe op zich had genomen. Na een half jaar gaf Soekarno zijn pogingen op en trad hij toe tot de 
Partindo. De partij stelde hem aan als leider van de propaganda. Kort daarna keerde Hatta uit Nederland terug en werd hij voorzitter van de PNI Baroe, die nu ging optreden als een concurrerende politieke partij. Deze partij stelde zich op socialistische grondslag en stond in dat opzicht links van de Partindo.

Intussen verschilde het politieke klimaat aanzienlijk van dat voor Soekarno's gevangenschap. In september 1931 was De Graeff opgevolgd door B.C. de Jonge. Deze kende Indonesië nauwelijks, al had hij er eens samen met F.C. Gerretson enkele weken rondgereisd. Tijdens de Eerste Wereldoorlog was hij enige tijd minister van oorlog geweest, daarna had hij leidende functies vervuld bij grote oliemaatschappijen. Anders dan De Graeff, die geprobeerd had het vertrouwen van de Indonesische nationalisten te winnen, wilde de nieuwe gouverneur-generaal juist vertrouwen vinden bij de Europese bevolkingsgroep. Voor het Indonesisch nationalisme toonde hij geen begrip. Keer op keer zei hij, dat de Nederlanders al driehonderd jaar in Indië waren en er zeker nog wel driehonderd jaar zouden blijven. Toen Thamrin in 1932 in de Volksraad verklaarde, dat de Nationale Fractie zich de zo spoedig mogelijke onafhankelijkheid van Indonesië ten doel stelde, liet De Jonge weten dat Indonesische onafhankelijkheid voor het gouvernement onbespreekbaar was en dat opwekkingen daartoe buiten de Volksraad een strafbaar feit konden opleveren. Tijdens zijn bewind werd het zowel bij de Nederlands-Indische overheid als in de Nederlands-Indische pers gebruikelijk om de term 'extremisten' te gebruiken voor alle Indonesiërs die zich voor nationale onafhankelijkheid inzetten, ook als zij, zoals Thamrin, bereid waren in vertegenwoordigende lichamen plaats te nemen.

Ook in een ander opzicht was er een groot verschil met de tijd waarin de PNI actief was geweest. In die jaren draaide de economie in de kolonie op volle toeren. Inmiddels was de wereldcrisis ingetreden, die juist Indonesië bijzonder ernstig trof, omdat het in uitzonderlijke mate van export afhankelijk was. De totale waarde van de Indonesische export daalde in enkele jaren tot een kwart. Honderdduizenden Indonesiërs en duizenden Europeanen (onder wie veel Indo-Europeanen) werden ontslagen. Lonen en salarissen gingen drastisch omlaag. Terwijl het gouvernement tijdens de hoogconjunctuur niet evenredig had kunnen meedelen in de winsten van de westerse ondernemingen, werd het nu wel getroffen door een dramatische terugval van zijn inkomsten. Daardoor gedwongen bracht het de overheidsuitgaven in vier jaar tot minder dan de helft terug. De verdere maatregelen die het gouvernement nam om de gevolgen van de crisis op te vangen strekten in de eerste plaats tot bescherming van de Europese bevolking en de westerse ondernemingen. Men ging ervan uit dat de inheemsen zich gemakkelijker konden aanpassen, omdat hun levensstandaard lager was en zij konden terugvallen op de agrarische dorpseconomie met haar productie voor eigen behoeften. De crisis leidde dan ook tot een ingrijpende verarming van de Indonesische bevolking. 
De nationalistische beweging (voorzover niet in etnisch of religieus verband georganiseerd) was in deze tijd belichaamd in drie partijen: de PBI van Soetomo, de Partindo van Sartono en Soekarno en de PNI-Baroe van Hatta en Sjahrir. De PBI had haar aanhang voornamelijk in Oost-Java en hield zich in het bijzonder bezig met de vorming van inheemse instellingen op economisch, sociaal en cultureel gebied. Zonder zich op non-coöperatie vast te leggen beklemtoonde zij het belang van Indonesische zelfwerkzaamheid. De Partindo en de PNI Baroe stonden op een strikt non-coöperatiestandpunt en richtten zich in de eerste plaats op politiek werk. Daarbij hechtte de Partindo veel belang aan bewustmaking van de bevolking, terwijl de PNI Baroe het accent op kadervorming legde. De verstandhouding tussen deze drie partijen en hun leiders was gespannen. Uit ergernis over kritiek van Soekarno trad Soetomo af als voorzitter van de federatie PPPKI (de door vrijwel alle groeperingen gewaardeerde Thamrin volgde hem op). In hun partijbladen lazen Soekarno en Hatta elkaar de les over de juiste toepassing van de noncoöperatiepolitiek.

In tegenstelling tot de Partindo plaatste de PNI Baroe de vrijheidsstrijd in het kader van de klassenstrijd en veroordeelde zij niet alleen het uitheemse maar ook het inheemse kapitalisme. Soekarno wilde tegenover Hatta's socialisme een eigen ideologie stellen. Hij kende de voornaamste rol in de vrijheidsstrijd toe aan de minst bedeelde Indonesiërs zoals boeren en arbeiders, voerde de naam Marhaen in voor de Indonesische 'kleine man' en betitelde zijn politieke filosofie als 'marhaenisme'. In zijn openbare toespraken wist hij zijn toehoorders als vanouds tot grote geestdrift te brengen. De meeste toespraken hield hij in Bandoeng, maar hij maakte ook propagandareizen door Midden- en Oost-Java.

Hoewel Soekarno voor het grote publiek het boegbeeld van de Partindo was, had hij binnen die partij niet meer zo'n overheersende positie als vroeger in de PNI. De leiding berustte nu grotendeels bij oud-leden van de Perhimpoenan Indonesia. Ook de studentenleiders Amir Sjarifoeddin en Yamin speelden een belangrijke rol. Pas een Partindo-congres van april 1933 koos Soekarno tot partijvoorzitter; Amir Sjarifoeddin werd toen vice-voorzitter. Wel had Soekarno de leiding over het partijdistrict Bandoeng stevig in handen. Hij was daar actief als spreker, als redacteur van partij-organen en als leider van een kaderschool; ook spande hij zich in om het ledental van zijn district hoog op te voeren. In totaal bereikte de Partindo in 1933 een omvang van twintigduizend leden.

Het ledental van de PNI Baroe bleef beperkt tot ongeveer duizend. In het voorjaar van 1933 vergezelde Hatta een bevriende zakenman op een reis van enige maanden door Japan. Bij zijn aankomst werd hij in de Japanse pers als de 'Gandhi van Java' aangeduid, maar zelf ging hij politieke contacten uit de weg. 


\section{Verzet tegen de wilde-scholenordonnantie}

Bij zijn pogingen om de invloed van het Indonesisch nationalisme terug te dringen richtte het gouvernement zich onder meer op de wilde scholen. Sinds 1923 beschikte het over wettelijke mogelijkheden om het onderwijs op die scholen te controleren en om docenten te verbieden daar les te geven. Het wilde nu een stap verder gaan en ontwierp een ordonnantie die bepaalde, dat ongesubsidieerde particuliere scholen en daar werkende docenten voortaan vergunningen van het bestuur nodig zouden hebben. Als één van de argumenten daarvoor voerde men aan, dat zulk een vergunningenstelsel nodig was om de kwaliteit van het onderwijs te waarborgen. Dit argument klonk weinig overtuigend, omdat het gouvernement kort daarvoor juist besloten had de officiële Hollandsch-Inlandsche Scholen niet verder uit te breiden. De Volksraad bracht in het vergunningenstelsel enige beperkingen aan en aanvaardde daarna de ordonnantie met ruime meerderheid. De ordonnantie zou op 1 oktober 1932 van kracht worden; scholen en docenten zouden daarna nog een half jaar de tijd krijgen om vergunningen aan te vragen.

Deze 'wilde-scholenordonnantie' stuitte op fel verzet bij de veelsoortige organisaties die zich met particulier onderwijs bezighielden. Ki Hadjar Dewantoro stuurde op 1 oktober een telegram aan gouverneur-generaal De Jonge, waarin hij de ordonnantie een 'misgreep' noemde en 'hardnekkig lijdelijk verzet' aankondigde. Van vele kanten kreeg hij steuntoezeggingen, onder meer van Soekarno, Soetomo en Thamrin. Het gouvernement probeerde Dewantoro tot andere gedachten te brengen met toezeggingen over de manier waarop het de ordonnantie zou uitvoeren, maar hij bleef erbij dat de ordonnantie moest worden ingetrokken.

Het verzet tegen de ordonnantie breidde zich als een vloedgolf uit. Onderwijzers-, studenten- en vrouwenorganisaties namen er aan deel naast politieke organisaties, zowel non-coöperatieve als coöperatieve. Boedi Oetomo en Pasoendan dreigden uit de Volksraad en andere vertegenwoordigende lichamen te zullen stappen als de ordonnantie niet voor 1 april 1933 ingetrokken werd. Het verzet leefde niet alleen in kringen van de nationale beweging maar ook bijzonder sterk binnen moslim-organisaties, die de ordonnantie als anti-islamitisch beschouwden. Bovendien kreeg het verzet steun van de kant van Chinezen en Arabieren. De tegenstanders van de ordonnantie vormden overal plaatselijke comités en belegden talloze protestvergaderingen.

Ki Hadjar Dewantoro groeide uit tot een nationale figuur. Naar zijn richtlijnen zou het lijdelijk verzet bestaan in de weigering van alle onder de ordonnantie vallende scholen en docenten om een vergunning aan te vragen, ook als men er zeker van kon zijn zulk een vergunning te zullen krijgen. Daarop zou het gouvernement de docenten en schoolbesturen moeten vervolgen; dezen zouden de hun opgelegde boetes niet betalen; het gouvernement zou de wan- 
betalers in hechtenis moeten nemen; de gevangenissen zouden overvol raken en vrijwilligers zouden de plaats van de gearresteerde docenten innemen.

Hoewel sommige adviseurs van de gouverneur-generaal betoogden dat het gouvernement niet voor druk moest wijken, voelde De Jonge er niet voor de zaak op de spits te drijven en daarmee 'van Dewantoro een Gandhi te maken'. Op basis van een voorstel van Wiranatakoesoema in de Volksraad werd de ordonnantie begin 1933 buiten werking gesteld. Daarna kwamen gouvernement en Volksraad een nieuwe regeling overeen, die in feite naar het stelsel van 1923 terugkeerde. De nationale beweging had in ongewone eensgezindheid een overwinning op het gouvernement behaald.

\section{Muiterij op 'De Zeven Provinciën'}

Dat Soekarno zijn opzwepende agitatie hervat had en dat de wildescholenordonnantie op massaal verzet stuitte, vergrootte de spanning onder de Europese bevolking van Indonesië. In februari 1933 sloeg de spanning bij een aanzienlijk deel van die bevolking om in paniek als gevolg van een incident waar de Indonesische nationale beweging niet rechtstreeks bij betrokken was: een muiterij van marinepersoneel die voortkwam uit protestacties tegen salariskortingen.

De economische crisis bracht het gouvernement sinds 1930 tot rigoureuze bezuinigingen, niet alleen op de civiele uitgaven zoals die voor onderwijs en volksgezondheid, maar ook op de militaire uitgaven. Zo werd de sterkte van het koloniale leger in enkele jaren verminderd van 37.000 tot 31.000 man. In 1931 gingen zowel de overheidssalarissen als de traktementen bij leger en marine tweemaal met 5\% omlaag. Het lagere marinepersoneel was één van de best georganiseerde beroepsgroepen in Nederlands-Indië. Veel Europese schepelingen behoorden tot vakbonden die hun hoofdzetel in Nederland hadden en verbonden waren met de SDAP. Daarnaast bestonden er Inlandse matrozenbonden, waarvan de grootste eveneens socialistisch georiënteerd was. Eind 1932 verkeerde men bij de marine in spanning over nieuwe salariskortingen. Voor het overheidspersoneel was toen juist een verdere korting van $7 \%$ aangekondigd, maar het was onzeker of dit ook voor de marine zou gelden. Nadat honderden korporaals en manschappen in Soerabaja tegen zulk een korting gedemonstreerd hadden, wekte een officiële verklaring bij de jaarwisseling de indruk dat de marinetraktementen niet verder omlaag zouden gaan. Enige weken later bleek dat deze traktementen toch verlaagd werden, en wel met $4 \%$ voor het Europese en met $7 \%$ voor het Inlandse personeel. Dit leidde in Soerabaja niet alleen tot nieuwe demonstraties maar ook tot dienstweigering op grote schaal. Bijna vijfhonderd marinemensen, merendeels Inlanders, werden daarop gearresteerd. 
Het pantserschip 'De Zeven Provinciën' was een groot maar verouderd oorlogsschip, dat voor de opleiding van marinepersoneel gebruikt werd. Op 2 januari 1933 was het van Soerabaja vertrokken voor een oefenreis rond Sumatra, met aan boord 256 Inlandse en 141 Europese schepelingen, onder wie dertig officieren. Toen het schip zich ter hoogte van Noord-Sumatra bevond, vernam de bemanning uit telegrammen zowel van de nieuwe salariskortingen als van de dienstweigeringen en de arrestaties in Soerabaja. Kort daarna ging het schip voor anker voor Koetaradja. Op zaterdagavond 4 februari, terwijl een deel van de bemanning zich aan wal bevond, onder wie ook de commandant en verscheidene andere officieren, maakten Inlandse schepelingen zich van het schip meester en isoleerden zij de aan boord zijnde officieren op het achterschip. Een deel van het lagere Europese personeel sloot zich bij de muiters aan. Bestuurd door Inlands personeel voer 'De Zeven Provinciën' weg. De volgende ochtend maakten de muiters radiografisch bekend, dat zij het schip tijdelijk hadden overgenomen, dat ze opstoomden naar Soerabaja, dat ze geen geweld beoogden en dat hun actie bedoeld was als protest tegen de salariskortingen en tegen de arrestatie van marinemensen in Soerabaja.

Het nieuws van de muiterij schokte veel Nederlanders in de kolonie buitengewoon. Hun veiligheid was in het geding als men de gewapende macht niet meer vertrouwen kon. Bovendien werd hun nationale gevoel gekwetst, omdat de marine bij uitstek een symbool van Nederlands grootheid was. Verder waren velen pijnlijk verrast omdat Inlanders blijk gaven een groot schip te kunnen besturen. Hoewel de muiterij werd aangediend als een actie in het kader van een loonconflict, vatten de meeste Nederlanders haar op als een politiek gemotiveerde aanslag op het koloniale gezag. Men wist trouwens de eerste dagen nog niet, dat ook Europees marinepersoneel aan de actie deelnam. Omdat men de muiterij als een politieke opstand opvatte, vreesde men voor verdere opstandige acties in de kolonie.

Op 7 februari vond in Batavia voor het paleis van de gouverneur-generaal een grote betoging plaats waarin duizenden (voornamelijk Nederlanders en Indische Nederlanders) getuigden van hun trouw aan het gezag en van hun liefde voor vorstin en vaderland. Muziekkorpsen speelden het 'Wien Nêerlands bloed' en het 'Wilhelmus'. De betogers keerden zich niet alleen tegen het Indonesisch nationalisme, maar ook tegen socialisme en communisme.

Intussen naderde 'De Zeven Provinciën' langs de westkust van Sumatra. Enige personeelsbonden boden aan tussen de muiters en de marineleiding te bemiddelen. De gouverneur-generaal en de commandant van de zeemacht sloegen dit af; zij wensten onvoorwaardelijke capitulatie. Om de discipline binnen de marine te herstellen waren zij bereid het pantserschip zelf op te offeren en het leven van de opvarenden op het spel te zetten, met inbegrip van de door de muiters vastgehouden officieren. Omdat het schip beschikte over zwaarder scheepsgeschut dan de andere marineschepen maar niet over 
luchtafweergeschut, bereidde men zich er op voor het eerst met vliegtuigbommen en dan met torpedo's aan te vallen. Op 10 februari verscheen 'De Zeven Provinciën' bij Straat Soenda. Op een sommatie om zich over te geven reageerde de leiding van de muiterij negatief. Volgens de instructies moest een vliegtuig daarop voor het schip een 'waarschuwingsbom' neerwerpen, maar de bom trof 'De Zeven Provinciën' zelf en doodde drieëntwintig opvarenden, onder wie de voornaamste actieleider. Onmiddellijk hierna gaven de muiters zich over.

Het bericht van hun capitulatie wekte uitbundige vreugde onder de Nederlanders in de kolonie. De manier waarop aan de muiterij een eind gemaakt was oogstte bewondering. Tegelijk verbreidde zich het gevoel dat een keerpunt bereikt was en dat het tijd was voor een radicale afrekening met alle politieke agitatie die het koloniale gezag ondermijnde.

Het strafrechterlijk onderzoek van de muiterij bracht geen nationalistisch of communistisch complot aan het licht. Bijna de helft van de bemanningsleden werd veroordeeld tot gevangenisstraffen, die uiteenliepen van enkele maanden tot achttien jaar. In 1937 stelde de regering allen die nog gevangen zaten in vrijheid ter gelegenheid van het huwelijk van prinses Juliana.

De affaire van 'De Zeven Provinciën' leidde ook in Nederland tot emotionele reacties. Een meerderheid stond achter het harde optreden van het gouvernement; een minderheid toonde zich ontsteld over de bom. Rechtse politici zagen de dienstweigeringen en de muiterij als symptomen van een gezagscrisis en riepen op tot strenge maatregelen. Colijn, de leider van de $\mathrm{ARP}$, had trouwens al meteen gezegd dat men het schip desnoods met een torpedo tot zinken moest brengen. Sommige socialistische politici en persorganen toonden sympathie voor de muiters. Officieel veroordeelde de SDAP de muiterij, maar keurde zij de gewelddadige beëindiging af. Communisten en andere links-radicalen vatten de muiterij op als gericht tegen het koloniale bestel en verheerlijkten de muiters als revolutionaire helden. Sneevliet (die intussen met Moskou gebroken had) riep het Nederlandse marinepersoneel op het voorbeeld van hun kameraden in Indonesie te volgen; hij kreeg daarvoor vijf maanden gevangenisstraf. De regering verbood alle militairen lid te zijn van of steun te verlenen aan de SDAP of andere sociaal-democratische organisaties en verklaarde alle socialistische dagbladen en andere publicaties tot voor de militairen verboden geschriften. In dit klimaat van verscherpte politieke tegenstellingen vonden in april 1933 verkiezingen voor de Tweede Kamer plaats. De SDAP leed verlies, maar zowel de communistische partij als de ARP boekte winst. Als lid van de communistische fractie kreeg voor het eerst een Indonesiër zitting in het parlement, namelijk Roestam Effendi, oudvoorzitter van de Perhimpoenan Indonesia. Na de verkiezingen kwam een nieuwe regering tot stand onder Colijn, de man van de gezagshandhaving. Hij ging ook het ministerie van koloniën beheren. 
Als minister van koloniën hoefde Colijn het gouvernement niet aan te sporen om het gezag met harde hand te handhaven, want daar ging het uit zichzelf al toe over. Zijn bemoeienis met het beleid in Nederlands-Indië strekte er voornamelijk toe de overheidsuitgaven zo ver mogelijk te verlagen. Daarbij verlangde hij nog rigoureuzere bezuinigingen dan waar gouverneur-generaal De Jonge toe bereid was. Colijn gaf geen uitvoering aan zijn vroegere denkbeelden om de staatsinrichting van de kolonie in federale zin te hervormen (zulk een hervorming zou trouwens hoge uitgaven hebben meegebracht). Wel zorgde hij voor een naamsverandering van het koloniale leger, waarin hij zijn loopbaan begonnen was. In aanmerking nemende dat de marine vanouds Koninklijke Marine heette en dat men het Nederlandse leger al enige tijd Koninklijke Landmacht was gaan noemen, verzocht hij het gouvernement het leger in Nederlands-Indië voortaan als Koninklijk Nederlands-Indisch Leger aan te duiden. In de afgekorte vorm KNIL raakte deze nieuwe naam van het koloniale leger al snel ingeburgerd. Overigens was dit leger sinds de Wereldoorlog van karakter veranderd; het was hervormd tot een politieleger. $\mathrm{Nu}$ het bezuinigingsbeleid leidde tot een aanzienlijke inkrimping van de legersterkte, maakte de legerleiding daarvan gebruik om alle militairen die zij niet volledig vertrouwde te ontslaan.

\section{Onderdrukking van de Indonesische vrijheidsbeweging}

Al in juni 1932 had gouverneur-generaal De Jonge in de Volksraad gewaarschuwd dat het gouvernement van plan was 'elke verstoring van rust en orde met kracht tegen te gaan'. Sindsdien was de politie harder gaan optreden tegen uitlatingen die zij opruiend achtte. In september keerde De Jonge zich scherp tegen politieke activiteiten van personen in gouvernementsdienst. Daartoe zond hij een nieuwe 'muilkorfcirculaire' uit, waarbij een loyaliteitsverklaring was gevoegd die ambtenaren desgevraagd zouden moeten ondertekenen. De verklaring hield in, dat de betrokkene zich zou onthouden van elke daad, met inbegrip van propaganda of bevordering van propaganda, die ondermijning van het overheidsgezag of ontwrichting van de openbare orde ten doel had of die daartoe leidde, en dat hij wist het gevaar te lopen te worden ontslagen als hij deze belofte niet zou nakomen.

De muiterij op 'De Zeven Provinciën' overtuigde het gouvernement ervan dat bijzondere maatregelen nodig waren tot herstel en handhaving van het gezag. Een van zijn eerste daden was een opdracht aan alle gouverneurs en residenten om strenger op te treden tegen politieke vergaderingen waarin actie tegen overheidsmaatregelen gevoerd werd. Toen Soekarno en andere leiders van de Partindo in februari en maart 1933 een propagandatournee door Midden-Java maakten, ontbond de politie de meeste bijeenkomsten voortijdig, 
terwijl sommige bijeenkomsten al van te voren verboden werden. Ook de PNI Baroe en de Sarekat Islam waren het doelwit van repressieve maatregelen. In april interpelleerde Thamrin het gouvernement in de Volksraad over het verscherpte politie-optreden. Hij legde daarbij een lange lijst over van arrestaties en huiszoekingen, van het verbieden of uiteenjagen van vergaderingen en van inbeslagneming of verbod van persorganen. Bij de beantwoording van deze interpellatie noemde het gouvernement de Partindo, de PNI Baroe en de Sarekat Islam 'onmiskenbaar extremistisch' en verklaarde het dat de genomen maatregelen noodzakelijk waren geweest om opruiing tegen te gaan.

De Partindo hanteerde na haar partijcongres van april 1933 dikwijls de leuze 'Repoeblik Indonesia'. Dit bleek bijzondere aanstoot te geven aan veel Nederlanders bij wie verabsolutering van de Rijkseenheid hand in hand ging met verheerlijking van het koningshuis. Het gouvernement gaf opdracht vergaderingen onmiddellijk zonder voorafgaande waarschuwing te sluiten wanneer deze term gebruikt werd.

In juni werd het aan alle overheidsdienaren verboden lid te zijn van de Partindo of de PNI Baroe. Intussen bleken de veelvuldige ingrepen van het bestuur bij toespraken van Soekarno zijn populariteit eerder te vergroten dan te schaden. Het gouvernement besloot nu hem uit de Nederlands-Indische samenleving te verwijderen. Op 1 augustus 1933 werd hij in Batavia gearresteerd na een vergadering ten huize van Thamrin.

Soekarno, die weer naar de gevangenis in Soekamiskin werd overgebracht, wist dat hem geen nieuw proces wachtte, maar dat men hem op grond van de exorbitante rechten wilde interneren. In het vooruitzicht de rest van zijn leven in Boven-Digoel te moeten doorbrengen kreeg hij een volledige morele inzinking. Hij schreef brieven aan het gouvernement waarin hij spijt betuigde van zijn daden en beloofde zich geheel uit de politiek terug te trekken als hij zou worden vrijgelaten; bovendien machtigde hij het gouvernement dit bekend te maken. Hij onderstreepte zijn 'bekering' door uit de Partindo te treden. Soekarno's ommezwaai verbijsterde de nationale beweging. Hatta verklaarde dat de politicus Soekarno had afgedaan, maar dat men zijn vroegere verdiensten voor de beweging nooit zou vergeten. Het gouvernement ging echter niet op Soekarno's aanbod in en besloot in december hem wel degelijk te verbannen, weliswaar niet naar Boven-Digoel maar naar het eiland Flores. Die verbanning hielp veel van zijn bewonderaars om zijn knieval voor het koloniale bestuur te vergeven en te vergeten; bovendien nam Tjipto Mangoenkoesoemo het voor hem op. Sommige andere politici konden deze episode minder gemakkelijk vergeten.

In 1933 werd ook de vice-voorzitter van de Partindo, Amir Sjarifoeddin, gearresteerd. Anders dan Soekarno werd hij wel berecht; hij kreeg anderhalf jaar gevangenisstraf.

De leiders van de PNI Baroe meenden dat de maatregelen van het gou- 
SOEWARSIH DJOJOPOESPITO

Buiten het Gared

INDONESISCHE ROMAN

MET EEN INLEIDING VAN

E. DU PERRON

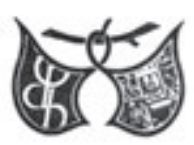

UITGEVERSMAATSCHAPPIJ W. DE HAAN N,V.

UTRECHT

Deze door de Soendanese onderwijzeres Soewarsih Djojopoespito (1912-1977) in het Nederlands geschreven roman over het leven van een nationalistisch echtpaar tijdens de onderdrukking van de Indonesische vrijheidsbeweging werd in Nederland gepubliceerd in november 1940, toen het land al door Duitsland bezet was. 
vernement aantoonden hoe onverantwoordelijk de Partindo had gehandeld door opnieuw de weg van grootscheepse agitatie op te gaan. Zij dachten zelf met hun concentratie op kadervorming minder risico te lopen. Dit was een misvatting. Het gouvernement vond de socialistische PNI Baroe in wezen gevaarlijker dan de burgerlijke Partindo. De PID beschouwde Hatta en Sjahrir als crypto-communisten wegens hun contacten in Europa met leden van de communistische beweging. In oktober 1933 kreeg zowel de PNI Baroe als de Partindo een volledig vergaderverbod, ook voor besloten vergaderingen. Op 24 februari 1934 voerde de politie een razzia tegen de PNI Baroe uit, met tientallen huiszoekingen en tal van arrestaties. Verscheidene voormannen van de partij werden na verhoor weer vrijgelaten, maar zeven, onder wie Hatta en Sjahrir, bleven in hechtenis. Zij werden wél naar Boven-Digoel verbannen. Sjahrir was ten tijde van zijn arrestatie 24 jaar oud en stond toen op het punt naar Nederland terug te keren om zijn rechtenstudie voort te zetten.

Het gouvernement duldde geen acties voor nationale onafhankelijkheid meer. Het richtte zich daarbij niet alleen op de politieke partijen, maar ook op de jeugdbeweging, de studentenbeweging en de scholen. Weliswaar had het moeten afzien van een vergunningenstelsel voor de wilde scholen, maar ook de bestaande regeling bood ruime mogelijkheden om nationalistische propaganda op zulke scholen tegen te gaan. Zo kregen tal van nationalistische docenten een onderwijsverbod.

Hoewel de bestaande wetgeving de koloniale overheid vele instrumenten verschafte om politieke activiteiten te onderdrukken, vond het gouvernement het nodig dit wettelijk instrumentarium verder uit te breiden. Zo kwam er in 1934 naast de regeling voor het ongesubsidieerde particuliere onderwijs ook een ordonnantie voor het gesubsidieerde particuliere onderwijs. Daarin werd de gouverneur-generaal gemachtigd om aan een docent een onderwijsverbod op te leggen als hij in of buiten de school blijk gaf van een mentaliteit 'strijdig met de verschuldigde gehoorzaamheid aan de wetten des lands'. Tevens zou het gouvernement voortaan de subsidiëring kunnen beëindigen van particuliere scholen waarvan hoofden of bestuurders blijk gaven van een mentaliteit 'onverenigbaar met de gehoorzaamheid en de eerbied aan het overheidsgezag verschuldigd'. Om nationalistische agitatie op de hogescholen tegen te gaan werd bovendien een ordonnantie voor het hoger onderwijs ingevoerd, die de gouverneur-generaal machtigde om aan studenten voor een tijdvak van vijf jaar de toegang tot de hogescholen te verbieden.

De meest repressieve wetgeving kwam begin 1935 tot stand. Een nieuwe ordonnantie machtigde de gouverneur-generaal om 'ter verzekering van de openbare orde en rust' censuur in te stellen op het post-, telegraaf- en telefoonverkeer. Hierbij kregen de censuurambtenaren niet alleen het recht om van de inhoud van brieven, telegrammen en telefoongesprekken kennis te nemen, maar ook om, ter voorkoming van 'gevaar voor de openbare orde en rust', 
brieven aan te houden of te vernietigen, telegrammen niet te verzenden en telefoongesprekken te beletten of af te breken. Een andere ordonnantie voerde verdere beperkingen op de vrijheid van vereniging en vergadering in. Terwijl tot dan toe alleen het Hooggerechtshof een vereniging kon verbieden, werd nu de gouverneur-generaal zelf bevoegd om 'in het belang van de openbare orde' verenigingen te verbieden. Verder kreeg de politie voortaan ook vrije toegang tot besloten vergaderingen van politieke aard.

De gouverneur-generaal had voor de uitoefening van al de hierboven genoemde bevoegdheden geen instemming van de Raad van Indië nodig. Ook werd er niet voorzien in enigerlei toetsing door de rechterlijke macht. In de Volksraad werden al deze ordonnanties met ruime meerderheid aanvaard. Tegenstemmen kwamen vrijwel alleen van de Nationale Fractie. De Vaderlandsche Club had overigens nog een stap verder willen gaan. Zij stelde in 1934 voor om Thamrin en andere 'extreem-nationalisten' uit de Volksraad te weren.

Voor de onderdrukking van de Indonesische onafhankelijkheidsbeweging beschikte het gouvernement niet alleen over uitzonderlijke wettelijke bevoegdheden, maar ook over een gespecialiseerde organisatie in de vorm van de Politieke Inlichtingen Dienst (PID, zie pp. 167-8). Terwijl de gewone politie en het KNIL in de crisisjaren door bezuinigingen getroffen werden, breidden de activiteiten van de PID zich sterk uit. De agenten van de PID leken alomtegenwoordig. Zij schaduwden nationalistische politici, verhoorden en vermaanden politieke activisten, controleerden en ontbonden vergaderingen, deden invallen in redactiebureaus en schoollokalen, onderschepten correspondentie en infiltreerden met spionnen in besturen en actiegroepen. De leiding van de PID zorgde voor de politieke voorlichting van het gouvernement.

Voor het gouvernement was het Indonesische onafhankelijkheidsstreven geen politiek probleem meer, maar nog alleen een 'politioneel' probleem. Voor de inheemse bevolking was de kolonie een politiestaat geworden.

\section{Einde van de non-coöperatiepolitiek}

In december 1934 overleed Tjokroaminoto, 52 jaar oud. Hoewel zijn ster als volksleider verbleekt was en hij politiek op een zijspoor geraakt was, werd hij nu van vele kanten gehuldigd als pionier van de nationale beweging. Zijn dood leek het einde te markeren van een ruim twintigjarig tijdvak van onstuimige activiteit voor de politieke emancipatie van de Indonesische bevolking.

De sinds 1933 door het gouvernement genomen maatregelen maakten het aan non-coöperatieve partijen als de Partindo en de PNI Baroe moeilijk nog zinvol te functioneren. Door het hun opgelegde vergaderverbod en door talrijke verschijningsverboden voor hun partij-organen konden zij hun publiek 
nauwelijks meer bereiken. Wanneer zij toch nog politiek werk probeerden te doen, werd dit door de PID vaak als ondergrondse actie opgevat, wat dan tot verdere repressie leidde.

De uitschakeling van deze partijen vergrootte het belang van de Volksraad als platform voor de nationale beweging, want hier kon men zich nog openlijk voor een onafhankelijk Indonesië uitspreken zonder strafrechtelijke vervolging te riskeren. Thamrin, voorzitter van de Nationale Fractie, werd nu de meest gezaghebbende voorman van de nationale beweging. Hij was in 1931 opnieuw tot lid van de Volksraad benoemd en maakte sindsdien ook deel uit van het College van Gedelegeerden. In 1935 en 1939 keerde hij als gekozen lid in de Volksraad terug en in 1939 werd hij vice-voorzitter. Thamrin was een strijdvaardige debater en een harde werker, die beginselvastheid met pragmatisme combineerde en de kunst verstond ook met politieke tegenstanders een goede persoonlijke verstandhouding te bewaren.

De belangrijkste Indonesische fractie naast de Nationale Fractie was die van de Perhimpoenan Pegawai Bestuur Boemipoetra (PPBB, Vereniging van Inheemse Bestuursambtenaren), een in 1929 door Wiranatakoesoema opgerichte organisatie van bestuursambtenaren van alle rangen. De opvattingen van de PPBB en van de nationalisten liepen dikwijls uiteen, maar niet altijd. Zo stelde de PPBB-fractie in 1932 voor, in alle officiële stukken de term 'Inlander' door 'Indonesiër' te vervangen. Verder telde de Volksraad drie christelijke Indonesiërs wier politieke opvattingen dikwijls dicht bij die van de nationalisten lagen: de Batak T.S.G. Moelia, de Menadonees G.S.S.J. Ratoelangie (leider van de Minahasa-bond) en de Javaan Ignacius Kasimo (leider van de Indonesische katholieke partij).

Binnen de coöperatieve vleugel van de nationalistische beweging vond in 1935 een bundeling van krachten plaats. Boedi Oetomo, dat al enkele jaren eerder van karakter was veranderd door zijn lidmaatschap open te stellen voor Indonesiërs van alle landaarden, ging nu een fusie aan met de Persatoean Bangsa Indonesia en enkele kleinere bonden. De nieuwe organisatie heette Partai Indonesia Raja (Groot-Indonesië Partij) en werd meestal Parindra genoemd. Voorzitter was Soetomo, die niet alleen de PBI had opgericht maar bovendien in 1908 tot de oprichters van Boedi Oetomo had behoord. Ook Thamrin trad tot de nieuwe partij toe. De statutaire doelomschrijving van de Parindra sprak niet over onafhankelijkheid maar over een 'luisterrijk en volmaakt Indonesië', te bereiken door versterking van de nationale geest, volledige politieke rechten en een op nationalisme en democratie gebaseerd regeersysteem. De activiteiten van de partij lagen grotendeels op sociaal en economisch terrein.

Intussen was de leiding van de Partindo gaan twijfelen aan het nut van voortzetting van de non-coöperatiepolitiek. Nu de verscherpte repressie geen ruimte meer liet voor de vroegere actiemethodieken, zou deelname aan officiele verkiezingen juist een belangrijk actiemiddel kunnen worden. Bovendien 
had het gouvernement vrijheid van vergadering toegezegd aan partijen die zitting in de Volksraad namen. Vanuit Nederland ging nu ook de Perhimpoenan Indonesia pleiten voor beëindiging van de non-coöperatie. De Partindo kreeg echter geen kans meer zulk een koerswijziging door te voeren. $\mathrm{Zij}$ mocht geen partijcongres houden en werd getroffen door nieuwe huiszoekingen en arrestaties. Wegens deze uitzichtloze situatie hief de Partindo zichzelf in 1936 op.

De PNI Baroe bleef formeel bestaan, maar kon vrijwel niets meer uitrichten. Tweemaal werd de hele leiding van de partij gearresteerd en naar BovenDigoel verbannen. Telkens namen anderen de opengevallen plaatsen weer in.

Voor de meeste aanhangers van de Partindo die de non-coöperatie wilden opgeven, was de Parindra te rechts. Zij gingen daarom in 1937 over tot de vorming van een nieuwe organisatie, de Gerakan Rakjat Indonesia (Indonesische Volksbeweging), ook wel Gerindo genoemd. Eén van de initiatiefnemers, de jonge medicus Adnan K. Gani, werd de eerste voorzitter; zijn opvolger was Amir Sjarifoeddin. Ook Yamin en Sartono kwamen in de leiding. De Gerindo erkende de waarde van de non-coöperatiepolitiek in het verleden, maar vond dat daar tactisch nu geen plaats meer voor was. $Z$ ij verklaarde te streven naar een samenleving waarin het Indonesische volk politiek, sociaal en economisch over eigen lot zou kunnen beschikken. Volgens Yamin zou Indonesië in eerste aanleg genoegen kunnen nemen met een status als die van de dominions binnen het Britse Gemenebest.

De leiding van de Gerindo had ook internationaal-politieke redenen om samenwerking met Nederland onder de huidige omstandigheden niet meer af te wijzen. Terwijl sommige voormannen van de Parindra veel bewondering voor Japan koesterden, was de Gerindo uitgesproken anti-fascistisch en antiJapans.

De pro-Japanse gevoelens van figuren als Soetomo hingen samen met de Nederlandse houding tegenover de Indonesische bevolking. Volgens de meeste Nederlanders zou die bevolking nog heel lang niet voldoende capabel zijn om een moderne samenleving te laten functioneren. Velen van hen geloofden trouwens dat alleen blanken hiertoe in staat waren en dat Indonesiërs dit nooit zouden kunnen omdat zij tot een inferieur ras behoorden. Japan vormde een levende weerlegging van deze Nederlandse pretenties. In een halve eeuw hadden de Japanners op eigen kracht een modernisering van hun land tot stand gebracht die alles ver achter zich liet wat de Nederlanders op dit punt in Indonesië gepresteerd hadden. Bovendien had Japan, terwijl het zich de verworvenheden van de westerse beschaving eigen maakte, niettemin zijn eigen cultuur bewaard en zijn eigen tradities gehandhaafd. Deze aspecten van het Japanse fenomeen maakten het tot een hoopgevend voorbeeld voor veel Indonesische nationalisten. Binnen de Gerindo was men echter meer onder de indruk van een ander aspect. Na 1930 had één van de Japanse tradities, de militaristische, de overhand gekregen. De leiders van de strijdkrachten 
hadden zich meester gemaakt van de staatsmacht en waren een politiek van agressie begonnen. In 1931 onderwierpen zij Mandsjoerije; in de volgende jaren bezette Japan een deel van Sjanghai en trok het Noord-China binnen en in 1937 begon het een algehele oorlog tegen China, waarbij het binnen een jaar de meeste grote steden veroverde. Voor de Gerindo was het duidelijk dat het Japanse militarisme ook Indonesië bedreigde, vooral omdat dit over grondstoffen beschikte waar Japan grote behoefte aan had. Onmiddellijke volledige onafhankelijkheid van Indonesië zou in de huidige situatie betekenen dat het weerloos aan Japan overgeleverd zou zijn. Buiten de Gerindo deelden slechts weinig nationalistische politici dit inzicht.

In tegenstelling tot de vroegere aanhang van de Partindo, die zich nu in de Gerindo verenigd had, bleef de Sarekat Islam aan de non-coöperatiepolitiek vasthouden. Aan de SI was geen algemeen vergaderverbod opgelegd, maar wel een verbod van politieke vergaderingen. Daarom richtte zij zich nu voornamelijk op sociale en economische kwesties. De partij kampte echter voortdurend met innerlijke verdeeldheid. Al in 1933 was Soekiman geroyeerd na een conflict met Salim en Tjokroaminoto. In 1935 en 1936 streed men in de partij over de vraag of men de non-coöperatiepolitiek moest prijsgeven. De voorzitter Agoes Salim was hiervoor geporteerd, maar stond daarmee onder meer tegenover zijn medebestuursleden Kartosoewirjo en Abikoesno Tjokrosoejoso (een jongere broer van Tjokroaminoto). Salim trad af toen de meerderheid hem niet steunde, maar bleef ijveren voor zijn visie, samen met onder meer Mohammad Roem. In 1937 werden Salim en zijn medestanders uit de Sarekat Islam gezet. Zij stichtten toen een nieuwe islamitische partij, die tot coöperatie bereid was. Ruim een jaar later richtte ook Soekiman een eigen islamitische partij op, die eveneens coöperatief gezind was en nauw verbonden was met de Moehammadiah. Binnen de Sarekat Islam zelf ontstond in 1939 opnieuw onenigheid, omdat Kartosoewirjo aan de non-coöperatiegedachte een radicaal-islamitische uitwerking wilde geven. Onder meer verzette hij zich tegen samenwerking van de SI met coöperatief gezinde partijen en pleitte hij voor de vorming van een uitsluitend op de islam gebaseerde Indonesische staat. Dit leidde wederom tot een scheuring, waarbij nu Kartosoewirjo en zijn aanhangers uit de partij werden gestoten. Zij vormden daarop een concurrerende Sarekat Islam.

De vele strubbelingen binnen de politieke islamitische beweging verhinderden overigens niet, dat niet-politieke islamitische organisaties in deze zelfde periode zeer actief waren en dat zowel de Moehammadiah als de Nahdatoel Oelama gestadig groeide. In 1937 voerden de islamitische organisaties een massale protestactie tegen een plan van het gouvernement om nieuwe regels in te voeren voor het sluiten en ontbinden van huwelijken van niet-Europeanen. Dit plan, dat beoogde de rechtspositie van islamitische gehuwde vrouwen te verbeteren, moest wegens het islamitisch verzet worden opgegeven. De triomferende organisaties stichtten daarop een federatief ver- 
band met de Arabische naam Madjlisoel Islamil A'laa Indonesia (MIAI, Hoge Islamitische Raad van Indonesië). De daarbij aangesloten bonden vertegenwoordigden tezamen honderdduizenden leden.

\section{India, Birma en de Filippijnen op weg naar dekolonisatie}

De ontwikkeling van Nederlands-Indië naar meer zelfstandigheid was na 1929 - toen het Nederlandse parlement de 'Inlandse meerderheid' in de Volksraad aanvaardde - volledig stil komen te staan. Sommige koloniën van andere landen maakten in deze tijd wel duidelijke voortgang in de richting van dekolonisatie.

De Britse regering verklaarde in 1929 dat de natuurlijke uitkomst van de staatkundige ontwikkeling van India de status van dominion zou zijn en dat zij van plan was een Ronde Tafel Conferentie bijeen te roepen voor overleg over de eerste stappen daarheen. De Britse dominions (zoals Australië en Canada) genoten zowel intern zelfbestuur als autonomie in externe zaken, onder handhaving van een gezamenlijke band met de Britse kroon, maar met het recht om die band te verbreken. Aan de Conferentie konden leiders van de Indiase partijen en van de zelfbesturende vorstendommen deelnemen op voet van gelijkheid met vertegenwoordigers van de Britse regering en van de Britse partijen. De Ronde Tafel Conferentie hield drie zittingen, in 1930, 1931 en 1932. De eerste zitting werd geboycot door het Indian National Congress. Dit was in 1930 een grote campagne van 'burgerlijke ongehoorzaamheid' begonnen, ingeleid met een mars van Gandhi naar de kust om daar zelf zout te winnen in strijd met het zoutmonopolie van de koloniale overheid. De campagne, die minder geweldloos verliep dan beoogd was, leidde tot een honderdduizend arrestaties. Ook Gandhi belandde weer in de gevangenis. De Britse onderkoning liet hem echter begin 1931 vrij en voerde een reeks gesprekken met hem, die tot enig wederzijds vertrouwen leidden. Gandhi nam daarop in het najaar van 1931 zelf in Londen deel aan de tweede zitting van de Ronde Tafel Conferentie als vertegenwoordiger van het Congress.

De Conferentie bereikte overeenstemming over belangrijke uitgangspunten, maar leverde uiteindelijk geen definitief akkoord op. De voornaamste struikelblokken betroffen niet de verhouding met het Britse Rijk maar interne Indiase problemen, zoals de vrees van de moslims voor overheersing door de hindoes en de onwil van met zelfbestuur beklede vorsten om hun autocratische positie op te geven. Op basis van het overleg in de Ronde Tafel Conferentie nam het Britse parlement in 1935 een nieuwe Government of India Act aan, die het bestuur over de Indiase provincies vrijwel geheel in Indiase handen bracht, de bevoegdheden van de centrale wetgevende raad uitbreidde en de weg opende naar een Indiase federatie met dominion-status. In 1937 vonden verkiezingen plaats waarbij het Indian National Congress de meerderheid 
veroverde in een groot aantal provincies.

Eveneens in 1937 voerde Groot-Brittannië een scheiding door tussen India en Birma, waarbij Birma een eigen Huis van Afgevaardigden kreeg dat geheel uit gekozen leden bestond. Het land werd voortaan bestuurd door een uit Birmanen bestaande regering onder een Birmaanse minister-president. De Britse gouverneur behield slechts bepaalde bevoegdheden op het gebied van de externe verdediging en de binnenlandse veiligheid.

Intussen berustte de wetgevende macht in de Filippijnen al sinds 1916 bij een gekozen volksvertegenwoordiging, die beheerst werd door een naar onafhankelijkheid strevende nationalistische partij. De voornaamste leider van die partij, Manuel Luis Quezon, was in het begin van de eeuw nog officier geweest in het tegen Amerika vechtende opstandelingenleger. In de Verenigde Staten zelf stond onafhankelijkheid voor de Filippijnen op het programma van de Democratische Partij. De Amerikaanse voorstanders van Filippijnse onafhankelijkheid werden overigens niet alleen door idealistische motieven gedreven maar ook door Amerikaanse belangen, zoals de mogelijkheid om Filippijnse importen en Filippijnse immigratie te beperken en het vermijden van een oorlog met Japan over het bezit van de Filippijnen. De meeste Amerikaanse militaire deskundigen meenden, dat men de Filippijnen niet tegen een Japanse aanval zou kunnen verdedigen.

Begin 1933 nam het Amerikaanse congres een wet aan die voorzag in de opstelling van een grondwet door het Filippijnse volk zelf, vervolgens de instelling van een vrijwel autonoom Filippijns Gemenebest onder een gekozen president, en tenslotte na tien jaar de verlening van volledige onafhankelijkheid. Quezon had bezwaren tegen sommige onderdelen van de wet en wist de inwerkingstelling ervan tegen te houden. Een enigszins gewijzigde versie werd in 1934 definitief van kracht. Op 15 november 1935 kwam het Filippijnse Gemenebest officieel tot stand. Quezon werd president en betrok het paleis waarin vroeger de Spaanse en Amerikaanse gouverneurs gezeteld hadden. In plaats van een gouverneur had Amerika nu in Manila een Hoge Commissaris. Verder was er een bevelhebber van de Amerikaanse troepen, generaal Douglas MacArthur. Hij achtte de Filippijnen wél verdedigbaar en belastte zich op verzoek van Quezon met de opbouw van het nieuwe Filippijnse leger.

Indonesische nationalisten volgden de staatkundige ontwikkelingen met betrekking tot andere Aziatische koloniën uiteraard oplettend. Hun meeste belangstelling ging naar India uit, maar zij gaven ook aandacht aan de Filippijnen. Naar aanleiding van de eerste Amerikaanse wet stuurde de Partindo in 1933 een felicitatietelegram naar Quezon en belegde zij een druk bezochte vergadering in Batavia, waar Yamin en Amir Sjarifoeddin het woord voerden. In 1935 kreeg de uitroeping van het Filippijnse Gemenebest grote publiciteit in de Indonesische pers. Op initiatief van Thamrin (die persoonlijk met Quezon bevriend was) vond in Batavia opnieuw een speciale bijeenkomst 
plaats, waar onder meer Boedi Oetomo en Pasoendan aan deelnamen en waarbij wederom een gelukwens aan Quezon werd gezonden.

De Nederlanders, zowel die in Indonesië als die in Nederland, schonken in overgrote meerderheid geen enkele aandacht aan de staatkundige ontwikkeling van India en de Filippijnen. Voorzover zij dit wel deden, vonden zij het Britse en Amerikaanse beleid meestal onverstandig en onverantwoord. Bij voorkeur publiceerden zij in Indonesië geen informatie over de ontwikkeling van de Filippijnen. In de Volksraad noemde de woordvoerder van het gouvernement medio 1935 de aan de Filippijnen toegezegde onafhankelijkheid een 'onrijpe vrucht' waarvan de Filippijnse bevolking 'gaarne verlost' zou worden. Bij de proclamatie van het Filippijnse Gemenebest later in dat jaar kreeg de regering in Manila gelukwensen van de Britse, de Duitse, de Franse, de Japanse en de Spaanse regering, maar niet van de Nederlandse. Later verzette de Nederlandse regering zich herhaaldelijk tegen plannen van president Quezon om een bezoek aan Indonesië te brengen.

\section{De petitie-Soetardjo}

De voortgang van India, Birma en de Filippijnen op de weg naar dekolonisatie trok onder de Indonesiërs niet alleen de aandacht van westers opgeleide intellectuelen, maar ook van sommige leden van de traditionele aristocratie. Eén van hen was het Javaanse Volksraadslid Soetardjo Kartohadikoesoemo. Hij behoorde niet tot een politieke partij, maar was voorzitter van de ambtenarenbond PPBB. Zijn politieke denkbeelden verschilden aanzienlijk van die van de radicale nationalisten. Hij was conservatief gezind en beschouwde de leden van de inheemse adel als de natuurlijke leiders van de Indonesische bevolking. Naar zijn mening werd hun gezag echter voortdurend ondermijnd omdat het gouvernement hen niet als een brug naar die bevolking gebruikte maar als een buffer ertegen. Soetardjo was geporteerd voor afschaffing van het dubbele stelsel van het BB, opdat Indonesiërs ook bestuursfuncties zouden kunnen vervullen die nu voor Nederlanders gereserveerd waren. Hij was gegriefd door de vernederingen die inheemse bestuursambtenaren vaak van Nederlandse kant ondervonden en wilde de term 'Inlander' zien verdwijnen. Hij betreurde het dat Indonesiërs telkens weer gepasseerd werden voor de vervulling van verantwoordelijke posten. Een voorbeeld hiervan was het besluit van de regering in 1933 om niet twee Indonesiërs maar slechts één tot lid van de Raad van Indië te benoemen. Een ander voorbeeld was de benoeming van de voorzitter van de Volksraad in 1935. De Volksraad had hiervoor zelf drie kandidaten aanbevolen, namelijk Koesoemo Oetojo, Wiranatakoesoema en Jonkman (in die volgorde). De Nederlandse regering vond dat de Raad hiermee zijn bevoegdheden overschreden had en benoemde de Indische Nederlander W.H. van 
Helsdingen, die vroeger secretaris van de Raad was geweest.

Op 15 juli 1936 diende Soetardjo een voorstel in dat inhield dat de Volksraad een petitie zou richten tot de regering van het Koninkrijk en het Nederlandse parlement. Daarin zou worden gevraagd om bijeenroeping van een conferentie van vertegenwoordigers van Nederland en Nederlands-Indië om op voet van gelijkheid een plan op te stellen teneinde aan Nederlands-Indië binnen tien jaar langs de weg van geleidelijke hervorming de staat van zelfstandigheid toe te kennen binnen de grenzen van artikel 1 van de Grondwet. Het denkbeeld van een conferentie op voet van gelijkheid was kennelijk geïnspireerd door de Londense Ronde Tafel Conferentie over India, de termijn van tien jaar door het voorbeeld van de Filippijnen. Naar artikel 1 van de Grondwet verwees het voorstel niet alleen omdat men de band met het Koninkrijk wilde handhaven, maar ook omdat Soetardjo en andere Indonesiërs meenden dat de in 1922 ingevoerde nieuwe tekst van dat artikel meebracht, dat Nederlands-Indië binnen het Rijk ten opzichte van Nederland niet meer een ondergeschikte maar een nevengeschikte positie innam.

Het voorstel ging vergezeld van een uitvoerige toelichting. Vijf andere Volksraadsleden traden als mede-indieners op, namelijk Kasimo en Ratoelangie benevens een Minangkabauer, een Arabier en een Chinees. Volgens de toelichting had de historie van eeuwen de materiële en ideële belangen van Nederland en Nederlands-Indië dusdanig met elkaar verweven, dat een uiteengaan van deze landen ernstige gevolgen zou hebben. In het belang van de opbouw van beide landen was een innige en hartelijke samenwerking nodig. De daarvoor benodige bezieling zou alleen gewekt kunnen worden als men doelbewust en volgens een vooraf opgezet plan zou aansturen op een verhouding tussen Nederlands-Indië en het Moederland die kon voldoen aan de nationale, culturele, economische en staatkundige behoeften van dat deel van beide volken dat de door de historie geboden samenwerking aanvaardde.

De leden van de Nationale Fractie hadden gemengde gevoelens over dit voorstel. Een conferentie op voet van gelijkheid ter bespreking van de toekomstige verhouding tussen Nederland en Indonesië zou op zichzelf wel een belangrijke stap vooruit betekenen, maar het door Soetardjo aangegeven einddoel beantwoordde niet aan de door hen nagestreefde nationale onafhankelijkheid. Aan de andere kant ging dit einddoel de meeste Nederlandse Volksraadsleden juist veel te ver, zeker binnen de korte termijn van tien jaar. Ook enkele Indonesische leden hadden tegen die termijn bezwaar.

Het werd duidelijk dat het voorstel-Soetardjo in de Volksraad geen kans maakte als de woorden 'binnen tien jaar' in de ontwerp-petitie bleven staan. De indieners vervingen die woorden daarom door 'binnen zoodanige tijd als de conferentie voor de uitvoering van de gedachte mogelijk zal achten'. Van groot belang was, dat nu ook de fractie van het Indo-Europeesch Verbond bereid tot steun bleek. Op 29 september 1936 nam de Volksraad het aldus 
gewijzigde voorstel aan met 26 tegen 20 stemmen. Van de Nationale Fractie stemden zes leden voor (onder wie Thamrin, Koesoemo Oetojo en Iskandar Dinata) en vier leden tegen.

Soetardjo's voorstel had in het begin weinig publieke belangstelling ontmoet, maar dit werd anders toen de Volksraad de petitie eenmaal had vastgesteld en aan de koningin en het Nederlandse parlement had gezonden. Veel Indonesiërs wachtten met spanning af of Nederland de gevraagde conferentie bijeen zou willen roepen. Sommigen meenden dat zo'n conferentie in elk geval tot wederzijds begrip en vertrouwen zou kunnen bijdragen, ook al zou ze geen concrete resultaten boeken. Soetardjo en zijn mede-indieners publiceerden een brochure onder de titel Indonesië zelfstandig, met een uitvoerige uitleg en verdediging van hun initiatief. Toen een antwoord van Nederland uitbleef, vormden zij in oktober 1937 een centraal comité om actie te voeren ter beïnvloeding van de Nederlandse opstelling. Ook enige anderen namen plaats in dit comité, onder wie de bekende politici Agoes Salim en Sartono. Verscheidene Indonesische organisaties schaarden zich achter de actie. Onder de vleugels van het centrale comité belegden plaatselijke comités een groot aantal openbare bijeenkomsten waarin men er bij Nederland op aandrong de petitie in te willigen. De Parindra en de Gerindo steunden de actie niet, omdat zij wel instemden met het verzoek om een conferentie, maar niet met het in de petitie aangeduide einddoel.

De overgrote meerderheid van de Nederlanders in Indonesië ging niet of nauwelijks op de petitie-Soetardjo in, omdat men die onzinnig en onbehoorlijk vond. De zeer kleine Indische Sociaal-Democratische Partij was de enige Nederlandse organisatie die zich ten gunste van de petitie uitsprak.

Op aandrang van Soetardjo werd ook in Nederland een comité gevormd om actie te voeren voor inwilliging van de petitie. Het bekendste lid van dit comité was de vroegere voorzitter van de ISDP, ir. Cramer, die van 1918 tot 1923 in de Volksraad had gezeten (waar hij onder meer met Tjokroaminoto en Tjipto Mangoenkoesoemo had samengewerkt) en die van 1923 tot 1937 de Indonesië-expert van de SDAP in het Nederlandse parlement was geweest.

Eén van de redenen waarom de Nederlandse regering lange tijd niet op de petitie antwoordde, was dat zij wachtte op een advies van het NederlandsIndische gouvernement. Aan het hoofd hiervan stond nu A.W.L. Tjarda van Starkenborgh Stachouwer, die B.C. de Jonge in september 1936 was opgevolgd. De nieuwe gouverneur-generaal was commissaris van de koningin in Groningen en gezant in Brussel geweest, maar wist van Nederlands-Indië niets en had er ook nooit belang in gesteld. Al kort na de ontvangst van de Volksraadspetitie in Den Haag vroeg de regering hem hier advies over uit te brengen, maar hij maakte daar niet de minste haast mee.

Overigens bleek ook zonder officiële reactie, dat aan Nederlandse kant weinig bereidheid bestond om op de petitie-Soetardjo in te gaan. Hoewel de 
petitie uitging van handhaving van de rijkseenheid, stonden de koloniaalconservatieve kringen rondom de Utrechtse indologiefaculteit er volstrekt afwijzend tegenover. In februari 1937 kwam de petitie vrijblijvend in het parlement ter sprake bij de behandeling van de Indische begroting. Colijn noemde Nederlands-Indië nog lang niet rijp voor zelfstandigheid en vond daarbij zowel de christelijke als de liberale partijen aan zijn zijde. Alleen de SDAP en de CPN pleitten voor aanvaarding van de petitie. De kans op aanvaarding werd er niet beter op nadat in 1937 verkiezingen voor de Tweede Kamer hadden plaatsgevonden, want die gaven een verdere verschuiving naar rechts te zien. Colijn vormde een nieuw kabinet, waarin het departement van koloniën nu werd toebedeeld aan oud-minister Welter, tevens oud-voorzitter van de Ondernemersraad voor Nederlandsch-Indië. Welter toonde zich niet minder conservatief dan Colijn. Een nieuwe gedachtenwisseling over de petitie-Soetardjo tijdens de begrotingsbehandeling in 1938 leverde dan ook slechts een bevestiging op van de in 1937 ingenomen standpunten.

Wat het koloniaal beleid betreft, tekende de verschuiving naar rechts zich overigens niet alleen af in de verkiezingsresultaten van 1937, maar ook in de opstelling van de politieke partijen zelf. Verschillende christelijke en liberale partijen spraken zich uitdrukkelijker dan vroeger uit voor handhaving van de rijkseenheid. Ook de SDAP was opgeschoven. Sinds de maatregelen die de regering na de muiterij op De Zeven Provinciën tegen haar genomen had, was zij beducht geraakt voor de roep onvoldoende vaderlandslievend te zijn; ir. Cramer keerde in 1937 niet meer in het parlement terug. De CPN stelde zich minder scherp op in verband met de in 1935 door de Komintern afgekondigde 'Volksfrontpolitiek', die de communistische partijen voorschreef toenadering te zoeken tot sociaal-democraten en andere gematigd-linkse groeperingen teneinde een gezamenlijk front te vormen tegen de dreiging van fascisme en nationaal-socialisme. Wegens het Japanse gevaar drong de CPN niet langer aan op onmiddellijke onafhankelijkheid voor Indonesië en liet zij daarom aan het slot van haar leuze 'Indonesië los van Holland nu!' het woordje 'nu' vervallen. De nauw met de CPN samenwerkende Perhimpoenan Indonesia ging nog een stap verder en schrapte het laatste woord uit de titel van haar orgaan Indonesia Merdeka.

Colijn en Welter betoogden steeds dat Nederlands-Indië geen staatkundige hervormingen aan de top nodig had, maar dat voortgang naar meer zelfstandigheid allereerst op plaatselijk en regionaal niveau moest worden bevorderd. Daarbij was Colijn er voorstander van om sommige onder rechtstreeks bestuur staande gebieden buiten Java weer onder zelfbesturende vorsten te plaatsen. Tijdens zijn ministerschap werd een bescheiden begin gemaakt met zulk een herstel van inheemse vorstendommen, in de hoop daarmee de nationalistische beweging terug te dringen. De belangrijkste gebieden waar deze refeodalisering plaatsvond waren Zuid-Celebes in 1936 en Bali in 1938. 
Het Balinese lid van de Volksraad Soekawati, die zelf behoorde tot een oud vorstengeslacht, betwijfelde overigens of dit nieuwe zelfbestuur wel een stap vooruit betekende.

Op aandrang van het Nederlandse parlement zette de regering bovendien weer een stap op de weg naar het invoegen van een nieuwe bestuurslaag tussen het centrale gouvernement en de residenten. Medio 1938 kwamen nieuwe bestuurseenheden tot stand voor Sumatra, Borneo en de Grote Oost (een benaming voor heel Nederlands-Indië ten oosten van Java en Borneo), waarnaar bepaalde taken van het gouvernement werden overgeheveld. Deze nieuwe bestuurseenheden, elk onder een gouverneur, kregen geen belangrijke autonome bevoegdheden, evenmin als de tien jaar eerder op Java in het leven geroepen provincies. Het wekte aan Indonesische kant enige irritatie dat Nederland wel tot zulke bestuurshervormingen overging maar niet op de petitie-Soetardjo reageerde.

Toen de Volksraad na ruim twee jaar nog steeds geen antwoord op de petitie had ontvangen, stelde Soetardjo op 22 oktober 1938 schriftelijke vragen aan het gouvernement. Ongerustheid uitend over de internationale toestand wegens de koloniale verlangens van onder meer Duitsland en Japan, vroeg hij of het gouvernement zijn mening deelde, dat het met het oog hierop wenselijk was spoedig aan de petitie gevolg te geven. Tegelijk opperde hij dat dan na de voorgestelde conferentie een gezamenlijke verklaring zou worden uitgegeven waaruit de wil van de bevolking van Nederlands-Indië zou moeten blijken om integraal in het Nederlandse staatsverband te blijven.

Het gouvernement antwoordde hierop op 29 oktober dat het voor de hier bedoelde ongerustheid geen enkele grond aanwezig achtte, dat het dus het uitgangspunt van de vragen niet aanvaardde en dat het overigens van oordeel was, dat de wil van de bevolking van Nederlands-Indië om integraal in het Nederlandse staatsverband te blijven niet twijfelachtig was en geen bevestiging behoefde.

Anderhalve maand voordat Tjarda dit antwoord liet geven, had hij eindelijk zijn advies aan de Nederlandse regering uitgebracht. In overeenstemming hiermee stelde minister Welter nu aan de koningin voor, de petitie af te wijzen. Hij schreef daarbij dat men 'uit de aard der zaak' niet kon denken aan inwilliging van het verzoek van de Volksraad, 'noch zelfs aan enige poging om in de richting van dat verzoek een of meer bescheiden stappen te doen'. Binnen het kader van de bestaande staatsinstellingen was er immers voldoende ruimte voor krachtige uitgroei van de autonomie; elk toegeven aan 'overspannen verlangens of verwachtingen' zou de normale groei van het staatkundige leven in Indië belemmeren.

Op 16 november 1938 ondertekende koningin Wilhelmina het besluit tot afwijzing van de petitie. Dit besluit hield onder meer in, dat de petitie in haar formulering de klaarheid van doelstelling miste die door het gewicht van 
het daarin behandelde onderwerp geboden was, dat de bijeenroeping van een conferentie als in de petitie beoogd strijdig zou zijn met het geldende staatsrecht, dat de zelfstandigheid die Nederlands-Indië in het Nederlandse staatsbestel bezat of zou kunnen krijgen niet werd geregeld in artikel 1 van de Grondwet maar in de artikelen 62 tot en met 64, dat de bestaande grondwettelijke en wettelijke bepalingen ruimte boden voor verdere opbouw en vervollediging van autonomie op democratische grondslag en dat verhaasting van de ontwikkeling, al dan niet binnen een bepaalde termijn en al dan niet volgens een bepaald schema, niet in het belang van Nederlands-Indië zou zijn.

\section{Het eenheidsfront Gapi en de campagne 'Indonesië parlementair'}

In de jaren 1936-1938 trad het gouvernement iets minder repressief op dan in de jaren 1933-1935. Terwijl het merendeel van de uit de samenleving verwijderde politici in Boven-Digoel geïnterneerd bleef, werden Hatta en Sjahrir in 1936 naar de Banda-eilanden overgebracht. Zij deelden dit ballingsoord met twee andere voormannen van de nationale beweging. Eén van hen was Tjipto Mangoenkoesoemo, nationalist van het eerste uur, die hier al acht jaar geïnterneerd zat. De ander was Iwa Koesoema Soemantri, een oud-voorzitter van de Perhimpoenan Indonesia die na zijn studie in Nederland een tijd lang in Moskou verbleven had, door het gouvernement als een communistische intrigant werd gezien en in 1930 naar Banda verbannen was. Intussen verkeerde Soekarno op Flores in een veel ernstiger isolement. In 1938 besloot het gouvernement zijn situatie te verlichten door hem te interneren in Benkoelen aan de westkust van Sumatra. Tjipto, wiens gezondheid sterk achteruitging, werd eind 1939 naar Makassar overgebracht.

De aanhang van de Indonesische vrijheidsbeweging viel moeilijk te peilen, nu alle politieke manifestaties verboden waren. Maar dat Soekarno nog steeds grote faam genoot, ook buiten Java, bleek toen hij in maart 1938 per trein door Zuid-Sumatra naar zijn nieuwe ballingsoord werd gebracht: de plaatselijke bevolking verzamelde zich bij de stations om hem eer te bewijzen. Enige maanden later werd Soerabaja het toneel van een andere demonstratie van politieke betrokkenheid toen Soetomo, slechts vijftig jaar oud, onverwacht overleed: aan de uitvaart van deze grote pionier van de nationale beweging namen vijftigduizend mensen deel.

Niettemin schreef minister Welter in november 1938 aan koningin Wilhelmina over de politieke situatie in Indonesië onder meer: 'Verlangens naar staatkundige zelfstandigheid leven nog slechts bij een uiterst dunne laag van meer-ontwikkelden'.

Intussen was de nationale beweging bezig zich te herstellen van de ontreddering die de scherpe repressie teweeg had gebracht. De negatieve Nederlandse reactie op de petitie-Soetardjo versterkte het besef van saamhorigheid aan 
Indonesische kant. Begin 1939 zorgde de regering voor verdere teleurstelling door tot voorzitter van de nieuwe Volksraad alweer geen Indonesiër te benoemen. Zowel de Volksraad als de gouverneur-generaal had hiervoor Hoesein Djajadiningrat aanbevolen, die sinds 1935 het enige Indonesische lid van de Raad van Indië was. Als tweede en derde keus had de Volksraad Moelia en Jonkman aanbevolen. De regering benoemde Jonkman. De Volksraad zelf koos Thamrin tot vice-voorzitter.

De herlevende politieke belangstelling werd in deze tijd ook bevorderd door andere ontwikkelingen. Het dieptepunt van de economische crisis was voorbij, de werkgelegenheid nam toe. Modern opgezette organisaties, zoals jeugdbonden en vrouwenbonden, groeiden in aantal en omvang; het alfabetisme en de kennis van de Nederlandse taal verbreidden zich in hoog tempo, vooral dank zij de wilde scholen. De Indonesische pers had honderdduizenden lezers. Daarnaast speelden sinds 1938 ook twee Nederlandstalige periodieken een stimulerende rol. Eén daarvan was Nationale Commentaren, geleid door Ratoelangie, die inmiddels geen lid van de Volksraad meer was. Het andere was Kritiek en Opbouw, opgericht door de Nederlandse socialist D.M.G. Koch. Dit was voor het eerst sinds het verdwijnen van De Stuw weer een blad onder Nederlandse leiding dat zich stelselmatig tegen het koloniale conservatisme keerde.

Terwijl de in 1927 door Soekarno gestichte federatie PPPKI de scherpe repressie niet overleefd had, besloten verschillende politieke groeperingen nu opnieuw een samenwerkingsverband tot stand te brengen. Dit verband werd in mei 1939 opgericht onder de naam Gaboengan Politik Indonesia (Indonesische Politieke Federatie), kortweg Gapi genoemd. Haar beginselverklaring sprak niet van onafhankelijkheid maar wel van nationale eenheid, democratie en zelfbeschikkingsrecht. Tot de deelnemende organisaties behoorden onder meer de Parindra, de Gerindo, de Sarekat Islam, de Pasoendan en ook Ratoelangie's Minahasa-bond en Kasimo's katholieke partij, die destijds niet aan de PPPKI hadden meegedaan. De dagelijkse leiding berustte bij een driemanschap bestaande uit Thamrin (Parindra), Amir Sjarifoeddin (Gerindo) en Abikoesno (Sarekat Islam). De Gapi trad actief op als eenheidsfront van de nationale beweging. Zij kondigde onder meer aan een Indonesisch Volkscongres te zullen beleggen.

De grotere bereidheid van Indonesische politici tot onderlinge samenwerking werd ook beïnvloed door de gespannen internationale situatie. In OostAzië voerde Japan al jarenlang oorlog met China. In 1936 had het een politiek pact met Duitsland gesloten en Italië had zich daarbij aangesloten; men noemde dit de As Berlijn-Rome-Tokio. Het was duidelijk dat de As-mogenheden op expansie uit waren. Italië had zich al meester gemaakt van Abessinië, de laatste grote onafhankelijke staat in Afrika. Met hulp van Duitsland en Italië won generaal Franco de in 1936 door hem begonnen burgeroorlog in Spanje. In 
maart 1938 lijfde Duitsland Oostenrijk in. In september werd Tsjechoslowakije tot gebiedsafstand aan Duitsland gedwongen; niettemin maakte Duitsland in maart 1939 alsnog een eind aan de Tsjechoslowaakse onafhankelijkheid. De bezorgdheid onder Indonesische intellectuelen voor het gevaar, dat Japan zou proberen Indonesië in zijn macht te krijgen, werd nu nog vergroot door de vrees dat Nederland in de greep van Duitsland zou komen.

De in de Gapi samenwerkende organisaties besloten een grote campagne te gaan voeren onder de leuze 'Indonesia berparlemen' ('Indonesië voorzien van een parlement' ofwel 'Indonesië parlementair'). Zowel voorstanders van volledige onafhankelijkheid als voorstanders van behoud van een band met Nederland konden zich scharen achter de doelstelling van deze campagne: de instelling van een uit en door de bevolking gekozen parlement met een daaraan verantwoordelijke regering. Deze doelstelling kwam overeen met wat al in 1918 door de Radicale Concentratie in de Volksraad was bepleit; zij lag bovendien in de lijn van wat de commissie-Carpentier Alting al in 1920 had voorgesteld.

In september 1939 lanceerde de Gapi de campagne formeel met een manifest. De Tweede Wereldoorlog was toen al begonnen met de Duitse inval in Polen en de daarop gevolgde oorlogsverklaringen van Frankrijk en GrootBrittannië aan Duitsland. Volgens het Gapi-manifest was samenwerking tussen het Indonesische volk en het Nederlandse volk gewenst, omdat de internationale gebeurtenissen een steeds groter gevaar vormden voor de veiligheid van het gezag in Nederlands-Indië en voor de Indonesische maatschappij. Met het oog daarop zou het Indonesische volk nieuwe rechten moeten krijgen door de instelling van een volwaardig parlementair stelsel. Als hieraan voldaan werd, zou de Gapi bereid zijn het Indonesische volk op te wekken tot het verlenen van de meest uitgebreide steun.

Het gouvernement beschouwde deze voorwaarde als chantage en waarschuwde Ratoelangie en Thamrin onmiddellijk, dat zij en hun organisatie zich moesten hoeden voor het wekken van de indruk dat men aan het gouvernement wensen onder bedreiging voorlegde.

Overigens omvatten de wensen van de Gapi niet méér dan Amerika al in 1916 aan het Filippijnse volk gegund had. Omdat Thamrin er niet op vertrouwde dat Nederland Indonesië tegen Japan zou kunnen beschermen, vestigde hij zijn hoop nu in de eerste plaats op de Verenigde Staten. In oktober 1939 brachten Thamrin, Ratoelangie en Soetardjo in het diepste geheim een bezoek aan het Amerikaanse consulaat. Zij stelden daar voor dat, indien Nederland door Duitsland bezet zou worden en niet langer als een onafhankelijke staat zou voortbestaan, Amerika een protectoraat over Indonesië zou vestigen, dat bij referendum aan de goedkeuring van het Indonesische volk onderworpen zou worden. De Amerikaanse regering ging niet op dit voorstel in.

De actie 'Indonesië parlementair' kreeg zeer veel steun. De federatie van vakbonden van inheems overheidspersoneel sloot zich erbij aan, evenals de 
Hoge Islamitische Raad van Indonesië (MIAI), die zich meer en meer op politiek terrein begon te bewegen. Ook Soetardjo stelde zich erachter. Overal, zowel binnen als buiten Java, werden plaatselijke actiecomités gevormd. In december belegde de Gapi in Batavia het al aangekondigde Indonesische Volkscongres. Negentig verenigingen namen eraan deel. Het congres ondersteunde niet alleen de actie voor een nationaal parlement, maar besloot ook tot aanvaarding van de roodwitte vlag als Indonesische eenheidsvlag, van de Bahasa Indonesia als eenheidstaal en van het 'Indonesia Raja' als eenheidslied. Het noemde zijn vergaderplaats niet Batavia, maar Djakarta.

De Nederlandstalige dagbladen schonken weinig aandacht aan de activiteiten van de Indonesische nationale beweging. Het Nederlands-Indische persbureau Aneta had zelfs het Gapi-manifest van september niet gepubliceerd. De in de Gapi samenwerkende organisaties richtten nu een eigen persbureau op onder de naam Antara.

Minister Welter had eerder verklaard dat zelfstandigheid van NederlandsIndië binnen het rijksverband het doel van Nederland's koloniale politiek was, maar de zelfstandigheid die hij bedoelde was niet dezelfde als die beoogd werd met de actie voor een parlementair Indonesië. In zulk een Indonesië zou de dienst immers niet door Nederlanders maar door Indonesiërs worden uitgemaakt. Het verontrustte Welter dat ook de vakbonden van inheems overheidspersoneel zich achter de actie schaarden. Hij wilde de Gapi-campagne dan ook het liefst een halt toeroepen voordat het te laat was. Meyer Ranneft, die na zijn pensionering naar Nederland teruggekeerd was, schreef dat de actie streefde naar ontwrichting van de bestaande orde.

Intussen was in augustus 1939 een nieuw Nederlands kabinet aangetreden, waar nu ook twee voormannen van de SDAP deel van uitmaakten, maar waarin Welter minister van koloniën gebleven was. In februari 1940 kwam de Gapi-campagne ter sprake in het Nederlandse parlement. Welter verklaarde dat er geen sprake zou kunnen zijn van een aan een Indisch parlement verantwoordelijke Indische regering, zolang de Nederlandse verantwoordelijkheid voor Nederlands-Indië in stand zou blijven. De SDAP-fractie gaf geen steun aan de actie van de Gapi. Wel diende zij een motie in waarin de regering werd uitgenodigd de mogelijkheid te onderzoeken van toekenning van ruimere staatkundige bevoegdheden aan Nederlands-Indië. Het parlement verwierp deze motie met grote meerderheid.

Overigens was de politieke repressie in de kolonie sinds het begin van 1939 weer verscherpt. Dat organisaties als de Parindra en de Gerindo zich op coöperatie-standpunt stelden, vrijwaarde hen niet van streng politie-optreden. De politie greep veelvuldig in tijdens politieke bijeenkomsten; herhaaldelijk werden vergaderingen ontbonden en werden sprekers gerechtelijk vervolgd. Het gouvernement kon echter het streven naar een parlement voor Indonesië moeilijk verbieden en de Gapi ging dan ook door met haar campagne. In 
maart 1940 bestonden er al ongeveer honderdendertig comités in het kader van de actie 'Indonesië parlementair'. De actieleiders wilden dit aantal in de loop van het jaar verveelvoudigen, maar het uitbreken van de oorlog met Duitsland doorkruiste deze plannen.

\section{De maatschappelijke positie van de Indonesiërs omstreeks 1940}

Toen in 1939 de Tweede Wereldoorlog uitbrak, waren bijna vier decennia verstreken sinds de Nederlandse regering in 1901 een wijziging van het koloniaal beleid had verkondigd die ervan uitging dat Nederland tegenover de bevolking van Nederlands-Indië een zedelijke roeping te vervullen had (de 'ethische politiek'). Op de weg naar maatschappelijke emancipatie van de inheemse bevolking waren sindsdien slechts bescheiden vorderingen gemaakt. Het koloniale bestel was in 1940 nog steeds gebaseerd op het onderscheid tussen Inlanders en Europeanen, dat voor de Indonesiërs verschillende vormen van rechtsongelijkheid en achterstelling meebracht (zie pp. 132-3). Dit was een bron van frustratie en ergernis voor alle ontwikkelde Indonesiërs, ook voor hen die de band met Nederland wilden handhaven. Wat bijvoorbeeld de rechtsbedeling betreft, kwamen zaken tegen Europeanen in de regel voor andere rechterlijke organen dan zaken tegen Indonesiërs. Terwijl tal van Nederlandse rechters aan de berechting van Indonesiërs deelnamen, werden Indonesiërs bijna nooit tot rechter benoemd bij organen die Europeanen berechtten. Op het gebied van huiszoeking, voorarrest en bewijsvoering genoten Europese verdachten bepaalde waarborgen die niet voor Indonesische verdachten golden. De Nederlandse wetgeving kende aan Indonesiërs niet de Nederlandse nationaliteit toe, maar maakte hen tot tweederangsburgers als 'Nederlandse-onderdanen-niet-Nederlanders'.

Terwijl de Britse autoriteiten bij het Brits-Indische bestuurskorps steeds meer inheemse Indiërs aanstelden, liet Nederland nog steeds geen Indonesiërs toe tot het centrale deel van het Binnenlands Bestuur, het Europese korps. Wat andere bestuursfuncties betreft, bekleedden Indonesiërs slechts zelden betrekkingen waarin zij Nederlanders als ondergeschikten hadden. Westerse ondernemingen benoemden Indonesiërs niet in leidende posities. Kortom, evenals in de negentiende eeuw kregen Indonesiërs verantwoordelijke functies vrijwel alleen als leden van het Inlandse korps van het Binnenlands Bestuur of als feodale zelfbestuurders. Onder het hoger personeel in dienst van het gouvernement liep het percentage van de Indonesiërs omstreeks 1940 zelfs terug.

Er waren enkele uitzonderingen. In 1939 werd voor het eerst een Indonesiër tot burgemeester benoemd, namelijk van de Oost-Javaanse stad Madioen; in 1941 kreeg ook Buitenzorg een Indonesische burgemeester. Hoesein Djajadiningrat, die vijf jaar lang lid van de Raad van Indië geweest was, werd in 1940 aangesteld als hoofd van het departement van onderwijs en eredienst; 
daarmee kreeg voor het eerst een Indonesiër de leiding over een departement van het centrale bestuur. Zijn opvolger in de Raad van Indië werd Soejono, oud-regent en oud-lid van de Volksraad. In mei 1941 benoemde de regering Hoesein Djajadiningrat opnieuw tot lid van de Raad van Indië, die nu dus eindelijk weer twee Indonesische leden ging tellen. Hoesein's broer Loekman Djajadiningrat volgde hem op als directeur van onderwijs en eredienst.

De sociale kloof tussen de Indonesische en de Nederlandse bevolking van de kolonie was tegen 1940 wijder geworden dan ooit tevoren. Nog nooit was een zo groot deel van de Nederlandse ingezetenen in Nederland zelf opgegroeid; nog nooit waren er zoveel volledig Nederlandse echtparen en gezinnen geweest. De blanke bevolking woonde nu grotendeels in aparte villawijken in de steden en beperkte haar sociale omgang gewoonlijk tot de eigen kring. Zij beschikte over eigen clubs, zwembaden en tennisbanen, waar Indonesiërs meestal niet welkom waren. Veel westerlingen kenden Indonesiërs alleen als personeel. Het kwam zelden voor dat Nederlanders op voet van gelijkheid met Indonesiërs omgingen.

Ook op dit patroon bestonden uitzonderingen. De socialist D.M.G. Koch bijvoorbeeld, die zowel lid was geweest van de commissie-Carpentier Alting als van de Bandoengse Studieclub en die in 1938 het blad Kritiek en Opbouw oprichtte, telde ook radicale nationalisten onder zijn vrienden. Jonkman, de voorzitter van de Volksraad, onderhield goede betrekkingen met enige Indonesiërs die hij in Nederland in het Indonesisch Verbond van Studeerenden had leren kennen, onder wie Ki Hadjar Dewantoro, Moelia en Ratoelangie; bovendien genoot hij het vertrouwen van Thamrin. Ter bevordering van een 'Indische' cultuur waaraan alle bevolkingsgroepen deel zouden kunnen hebben richtte P.J. Koets, leraar en oud-secretaris van de Stuw-groep, eind 1940 het maandblad De Fakkel op dat zowel Nederlandse als Indonesische redacteuren had. Een ander oud-lid van de Stuw-groep dat probeerde de verschillende bevolkingsgroepen nader tot elkaar te brengen was de arabist Ch.O. van der Plas, sinds 1936 gouverneur van Oost-Java. Hij gold als een kenner zowel van de islam als van verschillende Indonesische talen en culturen en had veel Indonesische contacten, vooral in de kringen van de ambtsaristocratie. Juist wegens die contacten werd hij in mei 1941 tot lid van de Raad van Indië benoemd.

\section{Nederland in oorlog met Duitsland}

Nederland bleef in de Tweede Wereldoorlog eerst neutraal, maar daar kwam op 10 mei 1940 een eind aan toen Duitsland het land binnenviel. Na vijf dagen moest het Nederlandse leger de strijd opgeven en begon de Duitse bezetting van Nederland. Koningin Wilhelmina en haar ministers waren intussen naar Londen gegaan en vormden nu een regering in ballingschap. 
Voor de Nederlandse ingezetenen van Indonesië betekende de val van het moederland een geweldige schok. Zij schaarden zich massaal achter het gouvernement. Ook veel Indonesische organisaties riepen hun leden op tot loyale steun aan het Nederlands-Indische gezag. Niettemin bleef een groot deel van de Indonesische bevolking vrij onverschillig. De Indonesiërs die zich het lot van Nederland het meest aantrokken waren vooral zij die een westerse opleiding gevolgd hadden; daartoe behoorden ook vooraanstaande nationalisten. Onmiddellijk na de Duitse inval kreeg het gouvernement steun van de twee Indonesische voormannen die zich in 1912 als eersten voor onafhankelijkheid voor Indonesië hadden uitgesproken: Soewardi Soerjaningrat en Tjipto Mangoenkoesoemo. Soewardi, nu als Ki Hadjar Dewantoro leider van de Taman Siswa-scholen, zond een boodschap aan gouverneur-generaal Tjarda waarin hij zich solidair met Nederland verklaarde. Tjipto, sinds 1927 geïnterneerd, publiceerde een oproep aan de nationale beweging om zich naast Nederland op te stellen tegenover het Japanse gevaar. Het gouvernement reageerde niet op hun solidariteitsbetuigingen.

Sinds 10 mei 1940 gold in Nederlands-Indië de staat van beleg. Alle openbare politieke vergaderingen werden verboden; voor besloten politieke vergaderingen was voortaan toestemming van het bestuur vereist. Er kwam censuur op het particuliere berichtenverkeer.

Verder ging het gouvernement op 10 mei over tot de arrestatie en internering van alle Duitse mannen die zich in de kolonie bevonden, bijna 2800 in totaal. Tot hen behoorden ook personen die geen enkele band met het nazi-regime hadden, onder wie joodse Duitsers, missionarissen, zendelingen, gepensioneerde gouvernementsdienaren en Indo-Europeanen die zelfs geen Duits kenden. Vooral in het begin werden veel gearresteerden slecht behandeld. Het gouvernement hield de Duitsers eerst op verschillende plaatsen in de archipel gevangen; later bracht het hen over naar een speciaal daarvoor gebouwd interneringskamp in Noord-Sumatra. Naast de Duitsers werden in mei 1940 ook andere Europeanen gearresteerd die van sympathie voor de vijand werden verdacht, onder wie ruim vijfhonderd Indische NSB'ers. De meesten hiervan werden op Java gevangen gehouden.

$\mathrm{Nu}$ Nederland door Duitsland bezet was, verwachtten Tjarda en vele anderen dat de regering naar Nederlands-Indië zou verhuizen. Die verwachting vond ook steun in artikel 21 van de Grondwet dat bepaalde: 'In geen geval kan de zetel der Regeering buiten het Rijk worden verplaatst'. In overeenstemming daarmee stelden de ministers in juni 1940 aan de koningin voor om de regeringszetel in Bandoeng te vestigen. Koningin Wilhelmina, die de kolonie tijdens de ruim veertig jaar van haar koningschap nog nooit had willen bezoeken en ook niet gewild had dat de kroonprinses er een bezoek bracht, wees dit af. In de Volksraad vroegen Thamrin en Yamin (die in 1939 tot lid gekozen was) of de vestiging van de regering in Londen wel te rijmen viel met 
de Grondwet; het gouvernement antwoordde dat de regering haar zetel niet verplaatst had, maar alleen tijdelijk haar functies elders uitoefende. Overigens brachten de minister van koloniën Welter en de minister van buitenlandse zaken E.N. van Kleffens in het voorjaar van 1941 een bezoek van enige weken aan Nederlands-Indië.

In de nieuwe situatie als gevolg van de Duitse bezetting van Nederland stond het gouvernement voor de taak het hoofd te bieden aan de Japanse dreiging. In Japan werd al enige tijd verkondigd dat dit land in Oost-Azië een 'sfeer van gemeenschappelijke welvaart' tot stand moest brengen die niet alleen Japan en China zou omvatten maar ook de Filippijnen, Indonesië en AchterIndië (Indochina, Thailand, Birma en Malakka). Al kort nadat Nederland bezet was, vroeg de Japanse regering het gouvernement om grote leveringen van aardolie en bauxiet (twee grondstoffen die Japan tot dan tot voornamelijk uit de Verenigde Staten betrok). Tegelijk stelde zij voor algemene onderhandelingen te voeren over de betrekkingen tussen Japan en Nederlands-Indië. Deze onderhandelingen begonnen in september 1940 in Batavia. Van Mook, die sinds 1937 directeur van het departement van economische zaken was, leidde de Nederlandse delegatie; ook Hoesein Djajadiningrat was deel van de delegatie. De Japanse onderhandelingsdelegatie werd geleid door een minister van handel. De besprekingen gingen in hoofdzaak over allerlei grondstoffen, maar de Japannners verlangden ook dat het gouvernement zou optreden tegen antiJapanse artikelen in de Nederlands-Indische pers. Omdat het gouvernement weinig aan de Japanse wensen tegemoetkwam, keerde de Japanse delegatieleider na een maand naar Tokio terug.

Intussen werd de situatie steeds dreigender. Na de nederlaag van Frankrijk was daar een nieuwe regering gevormd die aan de macht van Duitsland onderworpen was maar door het bestuur van de Franse kolonie Indochina gehoorzaamd werd. Dit bestuur verzette zich niet toen Japanse troepen in september 1940 het noorden van Indochina bezetten. De Japanse regering zei openlijk dat Indochina én Indonesië tot de sfeer van gemeenschappelijke welvaart behoorden en dat hun betrekkingen met Japan daarom grondig veranderd moesten worden. De Japanse pers beschuldigde het NederlandsIndische gouvernement van tegenwerking. Eind december arriveerde in Batavia een nieuwe Japanse delegatieleider, een oud-minister van buitenlandse zaken. Naast economische wensen legde Japan nu ook tal van politieke verlangens op tafel; onder meer zou Nederlands-Indië zich in een politieke verklaring aan de kant van Japan moeten opstellen. Het gouvernement liet zich niet intimideren en wees na vijf maanden onderhandelen vrijwel alle eisen af, waarop Japan de besprekingen beëindigde. De bekwame manier waarop Van Mook de onderhandelingen gevoerd had kwam zijn reputatie in de kolonie zeer ten goede.

Eind juli 1941 bezette Japan het zuiden van Indochina. De Verenigde Staten 
en Groot-Britannië reageerden hierop met een algeheel embargo op de uitvoer naar Japan. De Nederlandse regering in Londen sloot zich daarbij aan.

\section{De defensiecapaciteit van Nederlands-Indië}

De taak om Nederlands-Indië tegen buitenlandse aanvallen te verdedigen was toevertrouwd aan het koloniale leger en aan het in de kolonie gestationeerde deel van de Nederlandse marine. Het opperbevel over deze strijdkrachten berustte krachtens de Indische Staatsregeling bij de gouverneur-generaal; onder hem stonden de commandant landmacht (de legercommandant van het KNIL) en de commandant zeemacht-in-Indië. Als Japan zich met militair geweld zou willen verschaffen wat het met politieke druk niet van NederlandsIndië had kunnen verkrijgen, zouden deze strijdkrachten niet in staat zijn de kolonie zelfstandig te verdedigen.

Sinds de Japanse overwinning op Rusland in 1905 waren alle Nederlandse plannen voor de verdediging van de kolonie altijd uitgegaan van één mogelijke agressor: Japan. Voor 1914 had men er nog over gedacht de externe defensie van de kolonie te verzekeren door de opbouw van een grote zeemacht die tegen een Japanse invasievloot opgewassen zou zijn, maar die gedachte was weer snel verlaten. Regering en parlement waren het er over eens dat Nederland te klein was om het reusachtige gebied van zijn Aziatische kolonie op eigen kracht te kunnen verdedigen. Tegelijk waren zij ervan overtuigd dat Nederland in die verdediging nooit alleen zou staan, want dat een Japanse aanval altijd ook Groot-Brittannië in de oorlog zou betrekken en wellicht ook Frankrijk en de Verenigde Staten. De externe defensietaak van de Nederlandse strijdkrachten werd daarom teruggebracht tot het vertragen van een aanval en het toebrengen van zo veel mogelijk schade aan de aanvaller in afwachting van bijstand door anderen. De verwerping van de ontwerp-vlootwet in 1923 beperkte de mogelijkheden nog verder. Pas in de jaren dertig kwam er meer vaart in de opbouw van de Nederlandse marine. In 1940 beschikte die marine in de Nederlands-Indische wateren over drie kruisers, een dertigtal kleinere oppervlakteschepen, vijftien onderzeeboten en ongeveer vijftig vliegtuigen.

Wat de landstrijdkrachten betreft, was het koloniale leger traditioneel noch uitgerust noch geoefend voor oorlogvoering tegen een modern bewapende buitenlandse vijand. Na de afronding van het koloniale rijk was het een politieleger geworden; hiervan bevond zich de helft op Java en de andere helft in de buitengewesten. In de jaren twintig besloot de regering het leger op Java ook een taak te geven voor de externe verdediging: het zou in staat moeten zijn een buitenlandse aanval van ongeveer vierduizend man af te slaan. Van de uitvoering van dit plan kwam in de crisisjaren weinig terecht. Als gevolg van radicale 
bezuinigingen zakte de sterkte van het KNIL tot minder dan 31.000 man. De zwakte van de externe defensie wekte vooral onder Europeanen verontrusting. Jaar na jaar nam de Volksraad moties aan waarin op versterking van de defensie werd aangedrongen. In 1937 verzamelde de Vaderlandsche Club zelfs 84.000 handtekeningen onder een petitie van dezelfde strekking aan het Nederlandse parlement. Omstreeks diezelfde tijd begon het gouvernement meer geld voor de defensie beschikbaar te stellen. De sterkte van het KNIL steeg weer boven de 40.000 man, tanks en pantserwagens werden aangeschaft en men maakte een begin met de vorming van gemotoriseerde eenheden. Bovendien kreeg het KNIL de beschikking over meer vliegtuigen, waaronder honderd bommenwerpers en jagers. Buiten Java bleef het een licht bewapend politieleger.

Het KNIL was een beroepsleger dat voor een kwart uit Europeanen en voor driekwart uit Indonesiërs bestond. Daarnaast was in 1917 in Nederlands-Indië dienstplicht voor Nederlanders ingevoerd. In 1940 waren er in de kolonie tienduizenden dienstplichtige Nederlanders die enige militaire oefening hadden ontvangen; zij werden overigens voorlopig niet gemobiliseerd. Verder beschikte het gouvernement nog over diverse lokale hulpkorpsen, maar die waren voor de externe verdediging niet relevant.

Nadat Nederland door Duitsland bezet was, spande het gouvernement zich krachtig in om de defensie te versterken. Het bestelde in de Verenigde Staten honderden tanks, pantserwagens en vliegtuigen, tienduizenden geweren en grote hoeveelheden munitie. Maar de Amerikaanse oorlogsindustrie had toen nog pas een beperkte omvang en moest in de eerste plaats voorzien in de defensiebehoeften van Amerika zelf en van Groot-Brittannië, zodat slechts een zeer klein deel van het bestelde werd geleverd. Intussen vond er ook in de kolonie zelf militaire productie plaats, onder meer van kleine marineschepen, zeemijnen en munitie. Verder werden militaire versterkingen en vliegvelden aangelegd, ook in de buitengewesten. Legereenheden werden overgebracht naar twee aardoliecentra in Oost-Borneo die wellicht het eerste doelwit van een Japanse aanval zouden vormen. Omdat de officiersopleiding in Nederland weggevallen was, kreeg het KNIL nu een eigen officiersopleiding in de vorm van een Koninklijke Militaire Academie in Bandoeng, terwijl in Soerabaja een officiersopleiding voor de marine werd gevestigd.

Hoewel de Nederlandse plannen voor de verdediging van Indonesië al heel lang uitgingen van Brits-Nederlandse samenwerking, had de neutraliteitspolitiek tot 1940 belet over zulke militaire samenwerking overleg met de Britten te voeren. Dit beletsel was vervallen sinds Nederland door de Duitse inval een bondgenoot van Groot-Brittannië geworden was. Van het najaar van 1940 af vonden in Zuidoost-Azië besprekingen plaats tussen vertegenwoordigers van de Britse, de Australische en de Nederlandse strijdkrachten; in het voorjaar van 1941 gingen ook Amerikaanse vertegenwoordigers hieraan deelnemen. De in Singapore gestationeerde Britse vloot was overigens kleiner 
dan de Nederlandse zeemacht in de Indische wateren. Het in de Filippijnen gestationeerde deel van de Amerikaanse marine was weliswaar iets sterker, maar beschikte evenals de Britse en de Nederlandse vloot niet over slagschepen, slagkruisers of vliegkampschepen. Daarentegen maakten zulke zware oorlogsschepen wel deel uit van de Amerikaanse Pacific-vloot, die haar basis had in Pearl Harbor op de Hawaii-eilanden.

De Europese gemeenschap in Indonesië was vervuld van een krijgshaftige geest en bracht vrijwillig grote bedragen bijeen voor militaire aanschaffingen. De pers berichtte voortdurend over de paraatheid van de strijdkrachten en wekte de indruk dat de kolonie tot de tanden bewapend was. Die indruk was onjuist; in het bijzonder de landmacht was zwak in omvang en bewapening, had weinig artillerie en zeer weinig luchtafweergeschut. Dat de externe defensie van Nederlands-Indië ontoereikend was, had overigens niet zozeer een financiële als wel een politieke reden. Nederland had het steeds politiek te riskant gevonden om de inheemse bevolking massaal te betrekken bij de verdediging van de archipel. Pas in het midden van 1941 werd een vorm van dienstplicht voor Indonesiërs ingevoerd, maar dit betrof slechts een paar duizend man en droeg niet wezenlijk tot de defensie bij.

De door de pers bevorderde overdreven voorstelling van het defensieve vermogen van Nederlands-Indië droeg ertoe bij dat veel Europese ingezetenen de verdediging tegen een Japanse aanval allerminst kansloos achtten. Voor een deel lieten zij zich daarbij leiden door rationele overwegingen: zij dachten dat Japan maar een beperkte strijdmacht tegen Indonesië zou kunnen inzetten omdat het grootste deel van zijn leger gebonden was door de zich voortslepende oorlog in China, en zij dachten dat de Japanse marine te kampen zou hebben met lange verbindingslijnen die een gemakkelijk doelwit zouden vormen voor de Amerikaanse vloot. Maar voor een deel lieten zij zich ook leiden door racistische vooroordelen. Zo zei men dat Japanners niet goed in staat waren om vliegtuigen te besturen en om geschut te richten. Meer in het algemeen was men ervan overtuigd, dat Japanners weliswaar knap waren in het nabootsen van westerse voorbeelden maar dat zij niet over eigen creativiteit beschikten. Dezelfde vooroordelen leefden ook sterk aan Britse, Amerikaanse en Australische kant.

Bij de inheemse ingezetenen van Indonesië speelden zulke vooroordelen geen rol. Hoewel ook zij vaak een overdreven voorstelling hadden van de defensiecapaciteit van de kolonie, geloofden velen tegelijk in de onoverwinnelijkheid van Japan. Op Java werd dat geloof bovendien gestimuleerd door de Djojobojo-profetie die verkondigde dat een volk van gele huidskleur de blanke overheersers zou verslaan, maar dat de inheemse bevolking spoedig daarna baas in eigen huis zou worden. 


\section{Bevriezing van het koloniale bestel}

In de eerste tijd nadat Nederland door Duitsland bezet was verwachtten veel ontwikkelde Indonesiërs een toenadering tussen de Nederlandse overheersers en de inheemse bevolking van de kolonie. Zij dachten dat de Nederlanders het Indonesische vrijheidsstreven beter zouden begrijpen nu hun eigen moederland onder vreemde overheersing was komen te staan. Bovendien hadden veel Indonesische organisaties zich in reactie op de Duitse overval solidair met Nederland verklaard; daar waren zelfs nationalistische partijen bij als de Parindra en de Sarekat Islam. Men verwachtte dat het gouvernement zich voortaan welwillender zou opstellen tegenover de nationale beweging. Het zou misschien het interneringskamp in Boven-Digoel opheffen of op zijn minst een eind maken aan de internering van de niet-communistische nationale leiders. In het bijzonder hoopte men op stappen van het gouvernement tot verkleining van de achterstelling van de inheemse onderdanen en tot vergroting van hun zeggenschap over het bestuur van het land.

Het optreden van het gouvernement beantwoordde niet aan deze verwachtingen. Boven-Digoel bleef bestaan. Ook de internering van Hatta, Sjahrir en Soekarno bleef gehandhaafd, hoewel zij in de nu woedende wereldoorlog de kant van de democratieën tegenover de dictaturen hadden gekozen. Wel beëindigde het gouvernement in oktober 1940 de internering van Tjipto Mangoenkoesoemo, maar die was te zeer verzwakt om na zijn terugkeer op Java nog een actieve politieke rol te kunnen spelen. Tot stappen ter verandering van het bestaande koloniale bestel was het gouvernement niet geneigd, evenmin als de regering in Londen. Gouverneur-generaal Tjarda verklaarde al in juni 1940 dat discussies over wijziging van staat en maatschappij beter konden blijven rusten tot na de oorlog.

Dit 'politieke moratorium' stelde de politiek bewuste Indonesiërs teleur. De Gapi zond daarom een telegram aan de koningin in Londen, dat aandrong op hervorming van de Volksraad tot een parlement waarvan de leden uit en door het volk gekozen zouden worden en waaraan de hoofden van de departementen verantwoordelijk zouden zijn. De Gapi gaf hier veel publiciteit aan en vroeg om schriftelijke betuigingen van instemming. Zij kreeg daarop schriftelijke bijval van meer dan tweehonderd Indonesische organisaties en meer dan twintigduizend individuele Indonesiërs. De regering in Londen liet het telegram onbeantwoord.

Enkele Nederlands-Indische kranten en tijdschriften betreurden de negatieve houding van het gouvernement tegenover de Indonesische nationale beweging. Zij meenden dat men een kans gemist had door met geen enkele tegemoetkoming te reageren op de solidariteit die van die kant jegens Nederland aan de dag was gelegd.

De kwestie van wijziging van het koloniale bestel kwam overigens in 
augustus 1940 uitgebreid in de Volksraad aan de orde bij de behandeling van drie moties die al dateerden van voor de bezetting van Nederland. De belangrijkste daarvan was in februari ingediend door het lid Wiwoho, samen met Kasimo en Soekawati. De motie-Wiwoho pleitte niet voor onafhankelijkheid maar combineerde de gedachten van de vroegere petitie-Soetardjo met die van de campagne 'Indonesië parlementair'. De motie verzocht het gouvernement onder meer zich er bij de regering van het Koninkrijk voor in te zetten, dat Nederlands-Indië op basis van de Grondwet van 1922 zelfstandig zou worden binnen het Rijksverband, dat het ledental en de bevoegdheden van de Volksraad zouden worden uitgebreid en dat de departementshoofden daar als ministers verantwoordelijk aan zouden worden. De twee andere moties waren al in augustus 1939 voorgesteld, maar de behandeling ervan was meermalen uitgesteld. Soetardjo had een (ook door Moelia en Thamrin ondertekende) motie ingediend die vroeg om bestudering van de mogelijkheid van spoedige invoering van een Indisch burgerschap. Zulk een burgerschap zou op gelijke voet voor Nederlanders en Indonesiërs moeten gelden en daardoor breken met de rechtsongelijkheid op basis van ras die ten grondslag lag aan het koloniale rechtsbestel. Tenslotte was er een motie van Thamrin, mede-ondertekend door Soetardjo en Soekawati, die vroeg om in wetten, ordonnanties en andere officiële stukken in plaats van de termen 'Nederlands-Indië', 'Inlander' en 'Inlands' voortaan de termen 'Indonesië', 'Indonesiër' en 'Indonesisch' te gebruiken.

In de Volksraad ontmoetten deze moties kritiek van een aantal Nederlandse leden. Zij betoogden onder meer dat uitvoering van de moties onder de heersende omstandigheden onmogelijk was, omdat dit wetgeving vereiste die zonder medewerking van het Nederlandse parlement niet tot stand kon komen. De voorstellers stelden daar tegenover, dat men zich nu niet op het formele staatsrecht maar op staatsnoodrecht moest baseren, op basis waarvan ook de Nederlandse regering in Londen wetgeving uitvaardigde zonder medewerking van het parlement.

Eind augustus deelde de woordvoerder van het gouvernement in de Volksraad mee, dat het gouvernement niet aan het debat over de moties van Wiwoho en Soetardjo wenste deel te nemen, al zou het wel zijn algemene houding tegenover de besproken onderwerpen uiteenzetten. Los van de vraag van de bevoegdheden krachtens staatsnoodrecht noemde het gouvernement het een eis van goede trouw tegenover het Nederlandse volk om niet buiten het Nederlandse parlement om principiële wijzigingen aan te brengen in de Nederlands-Indische staatsrechtelijke structuur. Zelfs voorbereiding van zulke wijzigingen, waarbij Volksraad en gouvernement hun mening zouden vastleggen, diende achterwege te blijven zolang de moederlandse organen uitgeschakeld waren. Het gouvernement geloofde overigens niet dat de kolonie op korte termijn rijp zou zijn voor de invoering van een volledig parlementair stelsel. 
Hoewel het gouvernement het nu niet de tijd vond om plannen voor staatkundige veranderingen vast te leggen, zag het wel nut in het verzamelen van gegevens en gedachten ten behoeve van de latere oordeelsvorming. Het was van plan daartoe een kleine commissie in te stellen. Wat de motie-Thamrin betreft, had het gouvernement ernstig bezwaar tegen vervanging van de gebiedsaanduiding 'Nederlands-Indië' door 'Indonesië'. Wel was het bereid te zijner tijd mee te werken aan het verwijderen van de termen 'Inlander' en 'Inlands' uit de wetgeving en zou het nu al voorschrijven dat die termen in ambtelijke mededelingen zoveel mogelijk zouden worden vervangen door hetzij 'Indonesiër' en 'Indonesisch' hetzij 'Inheemse' en 'Inheems'.

De voorstellers van de moties toonden zich diep gegriefd door deze verklaring van het gouvernement. Wiwoho deelde namens alle ondertekenaren mee, dat zij hun moties introkken omdat er een zo grote kloof bestond tussen hun standpunt en dat van het gouvernement dat een verdere gedachtewisseling nu geen zin had. Zij behielden zich overigens het recht voor, de voor hen brandende kwesties te allen tijde weer ter sprake te brengen.

In september 1940 stelde het gouvernement de aangekondigde commissie in, die een onderzoek zou moeten instellen naar de bij de verschillende groeperingen levende wensen en meningen over de staatkundige ontwikkeling van Nederlands-Indië. Ook zou zij moeten studeren op de eventuele instelling van een Indisch burgerschap en de vervanging van de termen 'Inlander' en 'Inlands' in de wetgeving door andere termen. De commissie bestond uit drie Nederlanders, drie Indonesiërs en een Chinees. Voorzitter was F.H. Visman, lid van de Raad van Indië; de Indonesische leden waren Moelia, Soejono en Soepomo, een docent aan de Rechtshogeschool.

In het najaar van 1940 leverde Thamrin in de Volksraad ongewoon scherpe kritiek op het koloniale beleid. Hij zei dat de Nederlanders het totalitaire systeem wel veroordeelden, maar er in de kolonie zelf gebruik van maakten. Indonesië werd volstrekt autocratisch bestuurd door mensen uit een ander land ten bate van dat andere land. De Nederlanders wilden hun macht niet met de Indonesiërs delen, omdat zij hun winsten uit de kolonie niet wilden prijsgeven. De woordvoerder van het gouvernement uitte zich eveneens ongewoon scherp. Hij verklaarde dat het gouvernement met alle beslistheid het recht van Nederlandse onderdanen ontkende om een gebiedsdeel uit het verband van het Koninkrijk los te scheuren. Daarom moest het elke discussie over onafhankelijkheid categorisch afwijzen. Hij voegde daaraan toe dat, wanneer de nationalisten op onafhankelijkheid uit waren, zij het door hen bepleite volwaardige parlement met een daaraan verantwoordelijke regering kennelijk bedoelden als een fase in de strijd, als een machtsoverheveling om tot het einddoel van de onafhankelijkheid te komen. Een gezonde democratische ontwikkeling zou dan in een machtsstrijd ontaarden. Het gouvernement, aldus de woordvoerder, zou zijn standpunt daarin weten te bepalen. 
Op 6 januari 1941 doorzocht de politie het huis van Thamrin en werd hijzelf, die toen ziek te bed lag, onder huisarrest geplaatst. Vijf dagen later overleed hij, slechts 46 jaar oud. Tienduizenden namen deel aan zijn begrafenis, die daarmee uitgroeide tot de laatste nationalistische massademonstratie onder het koloniale bestuur. Het gouvernement wilde niet meedelen wat de reden voor het optreden tegen Thamrin geweest was; het duidde alleen vaag aan dat hij verdachte Japanse contacten onderhouden had. Tijdens zijn huisarrest waren ook Ratoelangie en E.F.E. Douwes Dekker gearresteerd. De eerste werd al gauw vrijgelaten, maar Douwes Dekker, die rapporten voor het Japanse consulaat bleek te hebben opgesteld, bleef gevangen. Het gouvernement interneerde hem samen met de in 1940 gearresteerde NSB'ers.

Door de dood van Soetomo en Thamrin bleef er maar één nationalistische leider over die onder de Indonesische bevolking algemene bekendheid en aanzien genoot: Soekarno. Gouverneur-generaal Tjarda liet hem in het voorjaar van 1941 weten, dat hij naar Java zou kunnen terugkeren mits hij in publicaties het gouvernement zou steunen, maar Soekarno weigerde hierop in te gaan. Overigens publiceerde hij tijdens zijn ballingschap in Benkoelen verschillende artikelen waarin hij zich tegen de As-mogendheden keerde.

$\mathrm{Na}$ de instelling van de commissie-Visman was de Gapi eerst niet bereid daaraan mee te werken omdat zij er alleen een afleidingsmanoeuvre in zag, maar later werd toch besloten een stuk voor die commissie op te stellen. In februari 1941 overhandigde Abikoesno haar namens de Gapi een memorandum over de staatkundige constructie van Indonesië. Als einddoel duidde het memorandum een zelfstandige staat aan met een uit twee kamers bestaand parlement en een gekozen staatshoofd; dit zelfstandige Indonesië zou dan samen met Nederland een statenbond vormen. Als stap naar het einddoel zou de kolonie binnen vijf jaar, desnoods met toepassing van staatsnoodrecht, moeten veranderen in een gebied met volledig zelfbestuur. Daarbij zou onder meer de Nederlandse gouverneur-generaal een plaatsvervanger naast zich moeten krijgen in de persoon van een Indonesische luitenant-gouverneurgeneraal.

Enige maanden later kreeg de Gapi steun van de islamitische federatie MIAI, die in beginsel instemde met de in het Gapi-memorandum voorgestelde staatkundige constructie, maar wilde dat het staatshoofd en tweederde van de ministers islamieten zouden zijn en dat er een speciaal ministerie voor islamitische zaken zou komen. Onder de vele aan de commissie-Visman overgelegde politieke stellingnames was ook een advies van de Vaderlandsche Club, dat onder meer verklaarde dat elke gedachte aan liquidatie van het Nederlandse gezag buiten debat behoorde te blijven als in wezen neerkomende op landverraad. 
Het rapport van de commissie-Visman verscheen overigens pas in december 1941, zodat het in de kolonie geen rol in de discussies meer heeft kunnen spelen. De meest opvallende constatering van de commissie was, dat zij geen wensen gehoord had die zich richtten op verbreking van de band met Nederland. Aan de andere kant meldde zij dat alle door haar gehoorde Indonesiërs, Chinezen en Arabieren over hun maatschappelijke achterstelling klaagden en volledige rechtsgelijkheid met de Europeanen wensten.

In de eerste helft van 1941 botsten de Indonesische nationalisten met het gouvernement over de kwestie van inheemse dienstplicht. Deze kwestie, die al tijdens de Eerste Wereldoorlog in de 'Indië Weerbaar'-campagne tot controverses geleid had, was na de bezetting van Nederland opnieuw in discussie gekomen, waarbij de standpunten weinig verschilden van die van een kwart eeuw daarvoor. Hoewel er aan Nederlandse kant weinig voor werd gevoeld de inheemse bevolking op grote schaal van militaire opleiding en uitrusting te voorzien, vond men inheemse dienstplicht wel aantrekkelijk om de strijdkrachten op een goedkopere manier te versterken dan door uitbreiding van het beroepsleger. Daarentegen zagen de meeste nationalisten de Nederlandse belangstelling voor inheemse dienstplicht in de eerste plaats als een mogelijkheid tot het verkrijgen van politieke concessies. In dat verband hadden leden van de Nationale Fractie voor de oorlog herhaaldelijk in de Volksraad voor de invoering van zulke dienstplicht gepleit, maar het gouvernement wilde er toen niet van weten. $\mathrm{Nu}$ echter legde het gouvernement in januari 1941 aan de Volksraad een plan voor dat voorzag in de opbouw van een inheemse militie die in de eerste fase 7.000 man zou tellen en na tien jaar een uiteindelijke sterkte van 33.000 man zou bereiken. Dit plan stuitte op aanzienlijk verzet in de Indonesische pers. De in de Gapi samenwerkende organisaties verklaarden dat zij de invoering van inheemse dienstplicht afwezen, tenzij die zou worden ingesteld door een volwaardige volksvertegenwoordiging. Bij de behandeling van de dienstplicht-ordonnantie in de Volksraad in juli bleken de meeste Indonesische leden die wel te steunen. De Raad nam haar dan ook met ruime meerderheid aan; alleen de acht met de Gapi verbonden leden stemden tegen of namen niet aan de stemming deel. Tot ergernis van het gouvernement stuurden de Gapi en de MIAI daarna een telegram aan de koningin in Londen om de inwerkingtreding van de ordonnantie tegen te houden. De koningin bekrachtigde de ordonnantie in september. Nog in diezelfde maand werden op Java zesduizend inheemse dienstplichtigen opgeroepen, waarvoor overigens maar drieduizend geweren beschikbaar waren.

Hoewel het gouvernement zich in het najaar van 1940 tegenover de meeste Indonesische politieke wensen onbuigzaam had opgesteld, bleven sommige nationalisten hopen dat de regering in Londen daar meer open voor zou staan. Zij koesterden daarom verwachtingen van het bezoek dat minister Welter in april 1941 aan de kolonie bracht. Tot hun teleurstelling ging hij contacten met 
de Gapi uit de weg en verklaarde ook hij dat er pas sprake zou kunnen zijn van staatsrechtelijke hervormingen wanneer de oorlog afgelopen was en het Nederlandse staatsbestel weer normaal functioneerde.

Op 10 mei 1941 sprak koningin Wilhelmina in Londen een radiorede uit waarin zij ook een zin wijdde aan 'de aanpassing van de structuur der overzeese gebiedsdelen en de bepaling van hun plaats in het Koninkrijk overeenkomstig de gewijzigde omstandigheden'. Zij zei dat zij van plan was ruime gelegenheid te scheppen om wensen en opvattingen daarover te harer kennis te brengen en dat zij bereid zou zijn die aandachtig te overwegen. Een maand later deelde gouverneur-generaal Tjarda in de Volksraad mee, dat de regering daartoe na de bevrijding van het moederland een conferentie wilde bijeenroepen van vooraanstaande personen uit de verschillende delen van het Koninkrijk.

Ook voor die Indonesiërs die prijs stelden op behoud van een band met Nederland vormden deze toezeggingen een teleurstelling. Soetardjo zei in de Volksraad, dat de in uitzicht gestelde rijksconferentie de Indonesische beweging niet bevredigde. Hij spoorde het gouvernement aan niet te wachten totdat het te laat zou zijn. Men moest met spoed maatregelen nemen ter voorbereiding van staatkundige hervormingen, in de eerste plaats om de Indonesiërs op te heffen uit hun positie van overheerst volk en van tweederangsburgers. Dat zou ook bijdragen tot hun bereidheid om zich in te zetten voor de verdediging van het land. Een innerlijk verdeeld Indonesië zou onherroepelijk ten prooi vallen aan het agressieve buitenland. In dezelfde zitting spraken radicale nationalisten zich weer uit voor zelfbeschikking en onafhankelijkheid.

De woordvoerder van het gouvernement wees spoedige staatkundige hervormingen opnieuw van de hand. Aan het adres van de nationalisten uitte hij dreigende taal. Hun acties, zoals de campagne voor een parlement en het verzet tegen inheemse dienstplicht, konden een situatie scheppen die het gezag tot een straffere houding zou noodzaken. Het gouvernement respecteerde het nationalisme voorzover dit er op gericht was het gebied uit een status van ondergeschiktheid tot grotere zelfstandigheid te leiden. Twee zaken dienden echter buiten discussie te staan: de handhaving van het Koninkrijk der Nederlanden als een onverbrekelijk staatsverband en het erfelijk recht van koningin Wilhelmina en haar nakomelingen op de kroon van dat staatsverband. Het gouvernement, aldus de woordvoerder, zou deze essentiële zaken met alle middelen - ook de scherpste - beschermen tegenover ieder die deze zou willen aantasten.

Kritiek op de starre opstelling van het gouvernement verscheen medio 1941 zelfs in het conservatieve deel van de Nederlands-Indische pers. De voorzitter van de Volksraad, Jonkman, probeerde op eigen gezag de strekking van de toezeggingen van de regering te verruimen. In een toespraak op 31 augustus ter gelegenheid van de verjaardag van de koningin zei hij dat uit haar woor- 
den volgde, dat Indonesië en Nederland binnen het rijk gelijkwaardig zouden worden en dat de Indonesiërs en de Nederlanders gelijke rechten zouden krijgen. Het hinderde gouverneur-generaal Tjarda dat Jonkman de indruk wekte hiermee een officiële uitleg te geven. Zelf verklaarde hij bij dezelfde gelegenheid, dat de plaats van het moederland in het rijksverband de overzeese gebiedsdelen verplichtte tot beteugeling van hun vernieuwingsdrang.

Intussen hadden Churchill en Roosevelt op 15 augustus 1941 het Atlantisch Handvest wereldkundig gemaakt dat een reeks gemeenschappelijke beginselen bevatte. Eén daarvan was de eerbiediging van het recht van alle volkeren om de regeringsvorm te kiezen waaronder zij wilden leven. Een week later dienden Soetardjo en zevenentwintig andere Indonesische leden van de Volksraad een schriftelijke vraag in, waarin zij aandrongen op een spoedige en duidelijke uiteenzetting of de Nederlandse regering de Brits-Amerikaanse verklaring aanvaardde en wat daarvan de consequenties waren voor de Indonesische bevolking. Het gouvernement antwoordde in november, dat de regering het Atlantisch Handvest inderdaad onderschreef, dat dit Handvest richtlijnen aangaf voor de internationale verhoudingen en zich dus niet direct inliet met de interne verhoudingen van rijken wier bestaan zich in de geschiedenis had bevestigd, dat de regering overigens de in het Handvest vervatte beginselen al lang binnen het Koninkrijksverband toepaste voorzover die daarvoor in aanmerking kwamen, en dat zij daarom in haar instemming met dat Handvest geen aanleiding zag tot heroverweging van haar beleid ten aanzien van de onder Nederlands bestuur staande inheemse volkeren van Nederlands-Indië.

De steeds scherpere tegenstelling tussen het gouvernement en de nationale beweging leidde ertoe, dat de gelederen zich binnen die beweging steeds meer sloten. Dat bleek onder meer in augustus 1941 toen vrijwel alle Indonesische leden van de Volksraad de vraag over het Atlantisch Handvest ondertekenden. Het bleek opnieuw toen in september 1941 in Jogjakarta een tweede Indonesisch Volkscongres bijeenkwam, als vervolg op het congres dat in december 1939 had plaatsgevonden. Niet alleen waren alle in de Gapi verenigde organisaties hier vertegenwoordigd, maar ook alle groeperingen die in de islamitische federatie MIAI samenwerkten. Bovendien nam nu ook de PPBB (Soetardjo's bond van inheemse bestuursambtenaren) er aan deel, naast de federatie van vakbonden van inheems overheidspersoneel. Nog nooit was de eenheid binnen de nationale beweging zo groot geweest. Het congres besloot tot de oprichting van een Madjelis Rakjat Indonesia (MRI, Raad van het Indonesische Volk). Deze Raad zou optreden als vertegenwoordigend lichaam van het Indonesische volk en onder meer grote vergaderingen beleggen waarop dit volk besluiten zou kunnen nemen over alle zaken die zijn belangen raakten. Het congres plaatste de MRI aldus als voorstadium voor een volwaardig parlement tegenover de door Nederland in het leven geroepen Volksraad. 
Sinds mei 1940 had noch het Nederlands-Indisch gouvernement noch de regering in Londen daadwerkelijk tegemoet willen komen aan Indonesische wensen tot verandering van het koloniale bestel. Iedere tegemoetkoming zagen zij als een gevaarlijke concessie. Daardoor was er tussen de koloniale overheersers en de overheersten geen toenadering maar een ongekende verwijdering ontstaan. De oprichting van de MRI bezegelde de breuk tussen de nationale beweging en het Nederlandse gezag. Het gouvernement reageerde met een radicale maatregel: op 15 oktober 1941 kondigde het een totaal verbod op politieke bijeenkomsten af.

\section{Nederland in oorlog met Japan}

Omdat Japan voor zijn grondstoffenvoorziening in hoge mate van invoer afhankelijk was, kwam het in een dwangpositie door het in juli 1941 ingestelde Amerikaanse, Britse en Nederlandse handelsembargo. Het moest in ieder geval een uitweg vinden voordat zijn olievoorraden opraakten. Het kon die uitweg zoeken in een politiek akkoord teneinde opheffing van het embargo te verkrijgen, maar daartoe zou het zijn expansionistische ambities grotendeels moeten prijsgeven. Het kon de uitweg ook zoeken in het voeren van oorlog teneinde zich met geweld toegang tot de grondstoffen van Zuidoost-Azië te verschaffen. Wat Indonesië betreft, leken verschillende Japanse acties al uit te gaan van de tweede mogelijkheid. Japanse radio-uitzendingen in het Maleis verkondigden niet alleen de leuze 'Azië voor de Aziaten', maar voorspelden ook dat Japan een eind zou maken aan het Nederlandse koloniale bewind. Verder keerden tussen augustus en november een zesduizend in Indonesië wonende Japanners met Japanse schepen naar Japan terug.

Met instemming van gouverneur-generaal Tjarda besloot de Nederlandse regering dat, wanneer er oorlog zou uitbreken tussen Japan en het Britse Rijk en/of de Verenigde Staten, Nederland meteen aan Japan de oorlog zou verklaren. In het kader van de bondgenootschappelijke samenwerking stelde de Nederlandse marine eind november enige onderzeeboten en verkenningsvliegtuigen ter beschikking van het Britse opperbevel in Singapore. Begin december kwamen een Brits slagschip en een Britse slagkruiser de daar gestationeerde Britse vloot versterken.

Terwijl Japan nog in onderhandeling met de Verenigde Staten was over opheffing van het handelsembargo, opende het de oorlog met een verrassingsaanval op de marinebasis Pearl Harbor. Bij die aanval, op zondag 7 december plaatselijke tijd, schakelde het een groot deel van de Amerikaanse Pacific-vloot uit, waaronder vijf van haar acht slagschepen. Tezelfdertijd gingen Japanse troepen aan land op het schiereiland Malakka. Twee dagen na de overval op Pearl Harbor brachten Japanse vliegtuigen het Britse slagschip en de Britse 
slagkruiser tot zinken toen die de invasievloot bij Malakka wilden bestrijden. Op dezelfde dag gingen Japanse troepen aan land op de Filippijnen. Tot verbazing van veel Amerikanen, Britten en Nederlanders bleken Japanners wel degelijk vliegtuigen te kunnen besturen en geschut te kunnen richten. Hun jachtvliegtuigen en hun torpedo's waren bovendien beter dan die van de geallieerden. Sinds de eerste dagen van de oorlog bezat Japan zowel ter zee als in de lucht een volstrekt overwicht. Al spoedig beschikte het zowel op Malakka als op de Filippijnen over vliegvelden van waaraf het ook Indonesië kon bestrijken.

Op het tijdstip van de aanval op Pearl Harbor was het in Indonesië (gelegen ten westen van de datumlijn) maandag 8 december. Het gouvernement nam die dag een aantal stappen die al waren voorbereid. Tjarda deelde in een radiotoespraak mee dat Nederland de wapens opnam tegen Japan nu dit land onverhoeds Amerikaanse en Britse gebieden had aangevallen terwijl de Japanse veroveringslust zich zeker ook op Nederlands-Indië richtte. Van de dienstplichtige Nederlanders werden er vijfentwintigduizend gemobiliseerd om het KNIL te versterken. Ter verdediging van Malakka, Singapore en Brits-Borneo kreeg het Britse opperbevel de beschikking over nog meer Nederlandse marineschepen en over het grootste deel van de luchtmacht van het KNIL. Alle Nederlands-Indische koopvaardijschepen kwamen onder bevel van de Nederlandse marine te staan. Verder gaf het gouvernement opdracht alle nog niet gerepatrieerde Japanners te interneren. Evenals het geval was geweest bij de internering van de Duitsers in 1940 ging de uitvoering van deze opdracht gepaard met fouten en onnodige grofheden. Er werden ongeveer tweeduizend personen opgepakt, maar velen van hen waren geen echte Japanners maar Taiwanezen; verder waren er Chinezen en Indonesiërs bij die voor Japanners gewerkt hadden en Chinese en Indonesische vrouwen die met Japanners getrouwd waren.

Het gouvernement liet ook een aantal Indonesiërs arresteren die in nauw contact met Japanners hadden gestaan en sloot het persbureau Antara van de in de Gapi samenwerkende nationalistische organisaties. Voor de nationale beweging betekende het uitbreken van de Pacific-oorlog de bevestiging van een voorspelling die in die kring al ruim tien jaar gemeengoed was. Overigens waren de meeste leiders van die beweging niet pro-Japans gezind; de Gerindo was zelfs uitgesproken anti-Japans. Veel ontwikkelde Indonesiërs waren ervan op de hoogte dat Japan de bevolking van de geannexeerde gebieden Korea en Taiwan hardvochtig onderdrukte en dat het Japanse leger in China bijzonder wreed optrad. De eenvoudige Indonesiërs wisten hier zelden van; bij hen genoten de Japanners in het algemeen een veel betere reputatie dan de Chinezen.

$\mathrm{Na}$ het uitbreken van de Pacific-oorlog keerde Hatta zich in krantenartikelen tegen de misvatting dat het er niet toe deed of Nederlanders dan wel 
Japanners de baas in Indonesië waren en riep hij op tot bestrijding van het Japanse imperialisme. Van de kant van de Gapi en de MRI verscheen een manifest dat enerzijds de Indonesiërs opriep volledig mee te werken met het gouvernement bij het weerstaan van de buitenlandse aanval en anderzijds het gouvernement aanspoorde om samen met de Indonesische volksbeweging een nieuwe democratische orde op te bouwen. Tjarda bleef van mening dat politieke concessies aan de nationale beweging uit den boze waren, maar liet wel aan de Gapi en de MRI weten dat hij bereid was hen te betrekken bij overleg over verhoging van de oorlogsinspanning. Een in januari 1942 gevoerd gesprek tussen vertegenwoordigers van het gouvernement en van deze organisaties leidde tot niets wegens de onverenigbare uitgangspunten.

Overigens had dit manifest desastreuze gevolgen voor de zo kort daarvoor bereikte eenheid binnen de nationale beweging. Noch Abikoesno noch de bestuursraad van de MRI was namelijk in de opstelling ervan gekend. Vooral bij de Sarekat Islam bestond bezwaar tegen de in het manifest vervatte oproep tot medewerking met het gouvernement. Een en ander leidde ertoe dat de Sarekat Islam uit de Gapi trad en dat de MIAI zich terugtrok uit de MRI.

Bij het uitbreken van de oorlog was Van Mook formeel geen directeur economische zaken meer, maar minister van koloniën. In oktober was Welter namelijk afgetreden (om redenen die geen verband hielden met het koloniaal beleid) en Tjarda had toen Van Mook als diens opvolger aanbevolen. Wegens zijn Stuw-verleden stuitte dit eerst op bezwaren bij de minister-president in Londen, P.S. Gerbrandy, een partijgenoot en geestverwant van Colijn. Pas nadat Van Mook uitdrukkelijk verklaard had achter de beleidslijn te staan dat de staatkundige toekomst van Nederlands-Indië eerst na de oorlog aan de orde zou komen, werd hij tot minister benoemd. Op 8 december was hij echter nog niet naar Londen vertrokken. In de door de oorlog geschapen nieuwe situatie stelde Tjarda voor om Van Mook als zijn plaatsvervanger aan te stellen. De regering stemde hiermee in, ontsloeg Van Mook uit zijn ministersambt en benoemde hem per 1 januari 1942 tot luitenant-gouverneur-generaal, terwijl Gerbrandy zelf het ministerie van koloniën onder zijn hoede nam. Van Mook vertrok begin januari naar Washington om daar te pleiten voor ruimere en snellere hulp voor de verdediging van Indonesië.

\section{Verwijdering van niet-Indonesische geïnterneerden uit Nederlands-Indië}

Na het uitbreken van de oorlog met Japan besloot het gouvernement de geïnterneerde Duitsers, Japanners en onbetrouwbaar geachte Nederlanders uit Nederlands-Indië te verwijderen om te voorkomen dat ze in handen van de vijand zouden vallen. Bijna honderdvijftig Nederlanders die van landverraderlijke gezindheid werden verdacht, onder wie Douwes Dekker, werden 
in januari 1942 naar Suriname overgebracht. Dit gebeurde met een koopvaardijschip waarvan het dek tot een soort kooi was gemaakt. De Nederlandse marine droeg de kapitein op om in geval van een vijandelijke aanval het schip samen met de gevangenen tot zinken te brengen en alleen de bemanning en de bewaking gelegenheid te geven zich te redden. Er kwam geen aanval en de gevangenen bereikten veilig Suriname, waar ze de oorlogsjaren in gevangenschap doorbrachten onder een kampcommandant die hen zeer vijandig behandelde.

Het gouvernement liet de geïnterneerde echte en niet-echte Japanners, waaronder ruim vijfhonderd vrouwen en kinderen, in twee koopvaardijschepen naar Australië overbrengen. Tijdens de reis werden ze niet gelucht en kregen ze weinig te drinken; enkelen stierven tijdens het transport. In Australië werden ze weer in een interneringskamp ondergebracht.

Omdat de geïnterneerde Duitsers in Noord-Sumatra gevangen zaten, werd besloten hen naar India over te brengen. Nadat eind december en begin januari de eerste twee transporten vertrokken waren, waaronder zich degenen bevonden die men het meest gevaarlijk achtte, bleef er een restgroep over van 473 man. Daartoe behoorden alle bejaarde geïnterneerden, een groot aantal IndoEuropeanen, bijna tachtig zeelieden van Duitse schepen die op 10 mei 1940 in Indonesische havens hadden gelegen, tientallen zendelingen en priesters, enige kunstenaars en geleerden, verscheidene joden aan wie het nazi-regime hun staatsburgerschap ontnomen had, een aantal andere anti-nazi gezinden en tenslotte acht verpleegden uit een krankzinnigengesticht. Midden januari bracht men hen aan boord van het KPM-schip de 'Van Imhoff', waarvan men de ruimen en een deel van het dek met behulp van prikkeldraad in kooien verdeeld had. De kapitein wees de marineleiding er op dat het schip te weinig reddingsboten had voor zoveel opvarenden. Hij kreeg alleen ten antwoord dat hij alle Duitsers onmiddellijk aan boord moest nemen.

De 'Van Imhoff' vertrok op 18 januari, maar werd de volgende dag in de buurt van het eiland Nias door een Japans vliegtuig aangevallen. Het schip kreeg een lek en de kapitein liet noodseinen uitzenden. Een uur later, toen het schip slagzij begon te maken, gingen de bemanning en de bewaking aan boord van vijf sloepen. De opgesloten Duitsers slaagden er in door de prikkeldraadversperring heen te breken en zagen de sloepen zonder hen wegvaren. Ongeveer honderdzeventig probeerden zich te redden met de twee overgebleven boten en de reddingsvlotten. Vijf uur later zonk de 'Van Imhoff' met nog ruim driehonderd Duitsers aan boord. De Nederlandse marinestaf, die niet wist wat er sinds de ontvangst van de noodseinen gebeurd was, zond de volgende dag een ander KPM-schip uit voor een reddingsactie. De kapitein daarvan kreeg opdracht eerst de bemanning en de bewaking te redden en daarna, op aanwijzing van de militaire commandant, 'betrouwbare elementen' onder de Duitsers; de overige Duitsers moest hij beletten aan land te komen. In het 
gebied van de ramp trof hij in de twee boten en op reddingsvlotten ongeveer negentig Duitsers aan, maar hij liet hen aan hun lot over omdat hij niet wist wie van hen betrouwbaar was. Ruim tweederde van deze schipbreukelingen wist Nias te bereiken, waar het Nederlandse bestuur hen opnieuw gevangen zette; de overigen kwamen om. De bemanning en de bewaking van de 'Van Imhoff' waren intussen op een ander eiland aangeland; zij werden naar Sumatra overgebracht en kregen bevel het gebeurde geheim te houden.

Naast de niet-Indonesische geïnterneerden, die het gouvernement buiten bereik van de vijand wilde houden, bevonden zich in Nederlands-Indië nog honderden Indonesische geïnterneerden. Dit waren enerzijds personen die het gouvernement al voor de oorlog met Japan uit de samenleving had verwijderd (meestal naar Boven-Digoel), anderzijds personen die het na het uitbreken van die oorlog had laten oppakken. Onder de eerste groep was er één die zelf te kennen gaf niet in Japanse handen te willen vallen. Dit was Soekarno, die vergelding vreesde voor zijn anti-Japanse uitlatingen. Toen de Japanse troepen in februari naderbij kwamen, vroeg hij per telegram aan de gouverneur-generaal hem naar Australië te laten afvoeren. Tjarda besloot echter Soekarno op Sumatra te laten blijven. Hij handhaafde ook de internering van Hatta en Sjahrir, die hij kort daarvoor van Banda had laten overbrengen naar Soekaboemi in West-Java.

Verloop van de oorlog tot maart 1942

De militaire situatie in Zuidoost-Azië werd van de eerste oorlogsdagen af steeds ongunstiger voor Nederland en zijn bondgenoten. Op Malakka rukte het Japanse leger langzaam maar onweerstaanbaar op in de richting van Singapore. Midden december gingen Japanse troepen ook in Brits-Borneo aan land. De Britse kolonie Hongkong gaf zich op 25 december over. Het Japanse luchtoverwicht dwong de Amerikaanse luchtmacht en marine de Filippijnen te verlaten. Japan kreeg belangrijke delen van de Filippijnen in handen en bezette op 2 januari Manila; ten westen daarvan verschansten Amerikaanse en Filippijnse troepen onder generaal MacArthur zich op het schiereiland Bataan. Nederlandse vliegtuigen en onderzeeboten schakelden verscheidene Japanse schepen en vliegtuigen uit, maar leden zelf zware verliezen.

Om de operaties van de Amerikaanse, Britse, Nederlandse en Australische strijdkrachten in Zuidoost-Azië beter te coördineren besloot men daar een gemeenschappelijk opperbevel in te stellen, het American-British-DutchAustralian Command. Het zou zijn aanwijzingen krijgen van het hoogste geallieerde opperbevel, de Combined Chiefs of Staff in Washington, die rechtstreeks onder Churchill en Roosevelt stonden. ABDA Command werd gevestigd in Lembang bij Bandoeng en trad op 15 januari in werking onder leiding 
van generaal Wavell, de Britse opperbevelhebber in India. De Nederlandse legercommandant, luitenant-generaal $\mathrm{H}$. ter Poorten, en de commandant zeemacht, vice-admiraal C.E.L. Helfrich, werden nu aan hem ondergeschikt. Ter Poorten was pas eind oktober 1941 legercommandant geworden, nadat zijn voorganger was omgekomen bij een vliegongeluk. Hij had aan de wieg gestaan van het luchtwapen van het KNIL en was zich ervan bewust dat de mogelijkheden om de Japanse opmars te stuiten ernstig beperkt werden door het Japanse luchtoverwicht. Helfrich tilde hier minder zwaar aan en pleitte bij zijn Britse en Amerikaanse collega's voor een meer offensieve inzet van de zeestrijdkrachten. Op zijn aandrang werden de belangrijkste bovenwaterschepen van de vier marines bijeengebracht in een gezamenlijk eskader onder commando van de Nederlandse schout-bij-nacht Karel Doorman. Bovendien kreeg hijzelf in februari het bevel over alle ABDA-zeestrijdkrachten.

Toen de geallieerden besloten tot de instelling van ABDA Command, meenden zij nog de Japanners uit Java te kunnen weren. In verband daarmee werden ook Britse, Australische en Amerikaanse strijdkrachten naar Java overgebracht en werd een deel van de uit de Filippijnen teruggetrokken Amerikaanse vloot in Soerabaja gestationeerd. De vooruitzichten voor het behoud van Java gingen echter snel achteruit. Al voordat ABDA in werking trad landden Japanse strijdkrachten ook op Nederlands-Indisch grondgebied, namelijk op 11 januari, zowel bij Menado in Noord-Celebes als op het eiland Tarakan, een aardoliecentrum voor de kust van Oost-Borneo. Nadat de Japanners bij de verovering van het vliegveld van Menado zware verliezen hadden geleden, doodden zij daar alle overlevende verdedigers; het KNIL trok zich in het binnenland terug. Op Tarakan moest het KNIL na ruim een dag capituleren, maar intussen waren al voor de Japanse landing alle boorputten en olietanks vernield. Het Japanse leger dreigde daarop met scherpe represailles als ook de olie-installaties van Balikpapan vernield zouden worden, het grootste oliecentrum in Oost-Borneo. Voor de Nederlanders was dit dreigement aanleiding om deze vernielingen zo snel mogelijk uit te voeren. Op 24 januari veroverde het Japanse leger Balikpapan. Het voerde zijn dreigement uit door een openbare executie van bijna tachtig Europese burgers en militairen. Het derde voor Japan belangrijke aardoliegebied was dat van Djambi en Palembang op Sumatra. Om vernielingen vóór te zijn voerden de Japanners daar op 14 februari een aanval met parachutisten uit; zij kregen een deel van de olietanks en raffinaderijen ongeschonden in handen.

Intussen had Japan ook andere delen van de buitengewesten bezet, waaronder Ambon en Makassar. De snelle Japanse opmars in de Indonesische buitengewesten bracht de geallieerden ernstig in het nauw, maar nog veel ernstiger was het dat Singapore op 15 februari moest capituleren. Singapore gold als een onneembare vesting en was door veel Britten en Nederlanders gezien als de hoeksteen van de verdediging van Zuidoost-Azië. Enkele dagen 
na de val van Singapore nestelde Japan zich bovendien op Bali en Timor. Java werd nu zo bedreigd dat het voor de geallieerden niet meer verantwoord was hun gemeenschappelijk hoofdkwartier daar te handhaven. ABDA Command werd op 25 februari opgeheven; generaal Wavell keerde naar India terug. Ter Poorten kreeg het bevel over alle geallieerde landstrijdkrachten op Java, Helfrich over alle geallieerde zeestrijdkrachten in dit gebied.

Van het geallieerde eskader onder schout-bij-nacht Doorman was in de afgelopen weken veel gevergd. Het was zowel in de richting van Zuid-Celebes als van Zuid-Sumatra gedirigeerd en was zwaar bestookt door Japanse vliegtuigen, maar had zelf de Japanse strijdkrachten geen schade kunnen toebrengen. Dit laatste was vooral te wijten aan het ontbreken van doeltreffende luchtverdediging en luchtverkenning. Het was de vraag of het eskader nog moest worden ingezet tegen de nu te verwachten invasie op Java. Uit zuiver militair oogpunt leek het verstandiger deze oorlogsschepen uit het gebied terug te trekken om ze te behouden voor latere fasen van de oorlog. Uit politiek oogpunt was het voor Helfrich en Tjarda ondenkbaar dat de Nederlandse marine de Nederland-Indische wateren zou verlaten zonder slag te hebben geleverd voor het behoud van Java.

Op 26 februari zag een Nederlands marinevliegtuig op de Javazee ten westen van Makassar een Japans konvooi van tientallen transportschepen dat onder escorte van oorlogsschepen in de richting van Java voer. Helfrich droeg Doorman in Soerabaja op met zijn eskader dit convooi te vernietigen. Het eskader kon het konvooi niet vinden, maar raakte in de middag van de volgende dag slaags met het Japanse marine-escorte. Er volgde een langdurige zeeslag, waarbij Doorman de Japanse oorlogsschepen bleef opzoeken en aanvallen tot hij tegen middernacht zelf met zijn schip ten onder ging. Van het geallieerde eskader gingen tijdens de slag en de twee daarop volgende dagen in totaal vijf kruisers en vier torpedobootjagers verloren. Daarentegen werd aan Japanse kant alleen één torpedobootjager tijdelijk uitgeschakeld. Verder leidde het optreden van het eskader tot één dag uitstel van de Japanse landingen op de Javaanse kust.

\section{De Nederlandse capitulatie}

Na de val van Singapore ging het gouvernement ervan uit dat Japan zich spoedig ook van Java meester zou willen maken. Wegens de kwetsbare ligging van Batavia besloot men in de eerste plaats de belangrijkste delen van het centrale bestuur naar Bandoeng te verplaatsen; ook gouverneur-generaal Tjarda ging daarheen. Veel Nederlanders dachten dat men de tussen bergen gelegen hoogvlakte van Bandoeng nog maandenlang tegen de Japanners zou kunnen verdedigen. Zowel het gouvernement als de regering in Londen besefte echter 
dat men hoe dan ook rekening moest houden met een Japanse verovering van heel Java. Men besloot dat de gouverneur-generaal en de Nederlandse ambtenaren dan op hun post zouden blijven om duidelijk te maken dat Nederland Nederlands-Indië niet in de steek liet. Slechts enkele tientallen sleutelfiguren en specialisten zouden, zonder hun gezinnen, geëvacueerd moeten worden om te helpen bij de voortzetting van de oorlog en de behartiging van de belangen van het rijksdeel. Verder zou men een geheime organisatie moeten opbouwen die de regering zou kunnen inlichten over de situatie in het door Japan bezette gebied. Tenslotte verwachtte de regering van het KNIL dat het onder een Japanse bezetting de strijd zoveel mogelijk zou voortzetten in de vorm van guerrilla-oorlogvoering.

Met het opbouwen van een geheime inlichtingenorganisatie belastte zich Van der Plas, lid van de Raad van Indië, samen met het hoofd van de dienst Oost-Aziatische zaken, A.H.J. Lovink. Er kwam weinig van terecht, onder meer omdat men er veel te laat mee begon. Eén van hun contactpersonen was Amir Sjarifoeddin, de vroegere leider van de Gerindo. Deze had zich in 1940 uit de politiek teruggetrokken, was christen geworden en was bij het departement van economische zaken in dienst getreden. Van der Plas zorgde ervoor dat Amir een bedrag van vijfentwintigduizend gulden kreeg voor het opzetten van een illegale organisatie.

Over de keuze van de te evacueren deskundigen pleegde Tjarda overleg met Van Mook, die op 20 februari terugkeerde uit de Verenigde Staten. Hij had daar bij leidende figuren (tot en met president Roosevelt) aangedrongen op zo krachtig mogelijke steun voor de verdediging van Nederlands-Indië. Van Mook, wiens terugreis bijna twee weken geduurd had, was niet op de hoogte van de laatste ontwikkelingen en dacht dat het nog mogelijk was Bali te heroveren en Java te behouden.

In feite had het hoogste geallieerde opperbevel Java toen al opgegeven en besloten daar geen troepen meer heen te sturen. Sinds begin februari bestookte de Japanse luchtmacht er havens en vliegvelden. Zij maakte de haveninstallaties van Soerabaja en Tandjong Priok grotendeels onbruikbaar en bracht ook schepen tot zinken (waaronder de oude 'De Zeven Provinciën'). Op de vliegvelden vernielde zij meer dan de helft van de Nederlandse en bijna de helft van de Amerikaanse bommenwerpers, terwijl er ook vele in de lucht werden neergeschoten; eind februari besloten de Amerikanen de resterende Amerikaanse vliegtuigen naar Australië terug te trekken. Na de slag op de Javazee weken de nog intact gebleven geallieerde oorlogsschepen uit naar Australië en Ceylon. Helfrich legde het commando over de geallieerde zeestrijdkrachten neer en vertrok op last van Tjarda naar Ceylon om daar een nieuwe hoofdkwartier voor de Nederlandse marine in te richten. Wat de landstrijdkrachten betreft beschikte men op Java over slechts drieentwintigduizend man aan gevechtstroepen (waaronder een Australisch contingent 
van ruim tweeduizend man, aangevuld met ruim vijfhonderd Britten en Amerikanen), zodat men grote delen van het eiland onverdedigd moest laten. Bovendien had de strijd op Malakka, op de Filippijnen en in de Indonesische buitengewesten laten zien dat de landmacht weinig kon uitrichten als gevolg van het Japanse luchtoverwicht. In de buitengewesten was verder gebleken dat veel inheemse KNIL-soldaten zich al spoedig aan de strijd onttrokken en dat de inheemse bevolking de zegevierende Japanners soms hartelijk verwelkomde. In dat licht leek langdurige guerrilla-oorlogvoering nauwelijks denkbaar, want dat zou alleen mogelijk zijn als de plaatselijke bevolking bereid zou zijn de guerrillastrijders te steunen en daarvoor risico's te lopen.

Binnen de Japanse strijdkrachten was de verovering van Java opgedragen aan het Zestiende Leger onder luitenant-generaal Hitoshi Imamura. De invasiemacht telde ongeveer vijfenveertigduizend man, ondergebracht in twee konvooien waarvan het ene ten westen en het andere ten oosten van Borneo naar Java voer. Het oostelijke convooi werd op 26 februari door een Nederlands vliegtuig waargenomen, wat leidde tot de slag op de Javazee en tot één dag uitstel van de landingen. In de vroege uren van zondag 1 maart gingen Japanse troepen aan land op vier plaatsen aan de noordkust van Java, bij Merak en Bantam in het uiterste westen, bij Eretan (negentig kilometer ten noordoosten van Bandoeng) en bij Rembang (tussen Semarang en Soerabaja). Zij konden de weinige tegenstand die ze er ontmoetten gemakkelijk overwinnen. Nederlandse en Britse vliegtuigen vielen de konvooien en de ontschepingen herhaaldelijk aan, maar brachten geen zware verliezen toe.

Van de kant van Bantam begonnen de Japanners op te rukken naar Batavia en naar Buitenzorg, van de kant van Rembang zowel naar Soerabaja als naar Tjilatjap aan de zuidkust. Daarbij ondervond hun opmars meer vertraging door wegversperringen en vernielde bruggen dan door gevechten. Waar zij op krachtig verzet stuitten, riepen zij de hulp van de luchtmacht in om het verzet te breken.

De landing bij Eretan had in de eerste plaats ten doel een militair vliegveld in handen te krijgen, gelegen bij Kalidjati in de kustvlakte ten noorden van het bergplateau van Bandoeng. De afstand over de weg tussen de landingsplaats en dit vliegveld bedroeg negentig kilometer. Zondagochtend vertrokken duizend Japanse soldaten daarheen, van wie achthonderd per fiets en de anderen in vier vrachtauto's. Samen met enkele tanks bereikten zij om elf uur het vliegveld, dat na een korte strijd vrijwel ongeschonden in hun handen viel. De volgende dag stationeerde de Japanse luchtmacht er jagers en bommenwerpers. Alle pogingen die het KNIL tot en met dinsdag ondernam om het vliegveld te heroveren liepen spaak.

Ten behoeve van die pogingen werden ook strijdkrachten onttrokken aan de Nederlandse en geallieerde troepen die zich ten westen van het plateau van Bandoeng bevonden. De commandant van deze troepen, generaal 
W. Schilling, had een offensief willen openen tegen de bij Bantam gelande invasiemacht, maar moest daar nu van afzien. Vervolgens kreeg hij op woensdag opdracht zijn troepen in hun geheel naar het plateau van Bandoeng over te brengen, want de legertop had besloten Batavia en Buitenzorg prijs te geven teneinde Bandoeng zo lang mogelijk te kunnen verdedigen. De overbrenging van de troepen van generaal Schilling nam de hele donderdag en vrijdag in beslag, waardoor ze niet meer konden deelnemen aan de strijd.

De Japanse landingen op Java maakten het dringend nodig de door Tjarda en Van Mook uitgekozen deskundigen naar Australië te laten vertrekken. Verscheidene van de aangezochte personen hadden het voorstel tot evacuatie afgewezen omdat zij hun gezin niet in de steek wilden laten. Uiteindelijk vertrokken er ongeveer twintig, onder wie Van der Plas, Lovink, Soejono, Loekman Djajadiningrat en de KNIL-kapiteins S.H. Spoor en D.C. Buurman van Vreeden.

Tjarda en Ter Poorten wisten dat een totale Japanse overwinning op Java niet meer te vermijden was. De regering in Londen verbood een algehele capitulatie van Nederlands-Indië echter categorisch en gelastte Tjarda zijn functie van opperbevelhebber neer te leggen opdat hij niet zelf tot zulk een capitulatie gedwongen zou kunnen worden. Tjarda voldeed woensdag aan deze opdracht zonder overleg met Ter Poorten, op wie het opperbevel over de landstrijdkrachten nu overging. Ter Poorten verklaarde vervolgens per telegram aan alle commandanten van het KNIL dat, als hij ooit bevel tot capitulatie zou geven, zij ervan uit moesten gaan dat zulk een bevel onder dwang gegeven en daarom ongeldig was.

Nadat het KNIL zich uit Batavia had teruggetrokken, liet het gemeentebestuur donderdag aan het Japanse leger weten dat de stad niet verdedigd zou worden. De Japanse troepen trokken 's avonds Batavia binnen. Op diezelfde dag bezetten zij Buitenzorg. In Oost- en Midden-Java ontruimde het KNIL donderdag Soerabaja en vrijdag Tjilatjap.

Intussen had Van Mook er bij Tjarda op aangedrongen dat deze Java zou verlaten en hemzelf daar laten blijven, maar Tjarda stond er op zelf te blijven en Van Mook ter beschikking van de Nederlandse regering te stellen. Op vrijdagavond vertrok Van Mook naar Australië met één van de laatste vliegtuigen die nog konden wegkomen.

In Batavia kondigde het Japanse leger zaterdag zijn eerste verordeningen af. De Japanners namen de Nederlandse burgemeester en verscheidene andere bestuursfunctionarissen gevangen omdat ze weigerden trouw aan het Japanse leger te zweren.

De uit Kalidjati oprukkende Japanse troepen begonnen zaterdag Bandoeng te naderen. Tjarda wilde niet dat de burgerbevolking het slachtoffer van luchtbombardementen zou worden. Tegen de avond bood Ter Poorten de commandant van deze Japanse troepen de overgave aan van de Nederlandse 
strijdkrachten op het plateau van Bandoeng. De Japanse commandant liet het vuren staken en deelde mee dat de capitulatie de volgende dag nader zou worden geregeld.

Op zondag 8 maart deelde de Japanse legerleiding mee dat generaal Imamura in Kalidjati een gesprek wenste te hebben met zowel de gouverneurgeneraal als de legercommandant. Dezen vermoedden dat Imamura geen genoegen nam met een gedeeltelijke capitulatie. Tjarda weigerde eerst te gaan, maar zwichtte voor een Japans dreigement met een bombardement op Bandoeng. In Kalidjati eiste Imamura inderdaad algehele overgave. Tjarda zei dat hij geen opperbevelhebber meer was en daarom niet bevoegd was hierover te spreken. Uiteindelijk aanvaardde Ter Poorten de Japanse eis, maar hij wees er ook op dat hij donderdag bevel had gegeven geen rekening te houden met een eventueel door hem uit te geven opdracht om de wapens neer te leggen. Imamura antwoordde dat hij hem gelegenheid zou geven bekend te maken dat hij zijn bevel van donderdag introk.

Op maandag 9 maart maakte Ter Poorten via radio en pers bekend dat hij samen met de gouverneur-generaal gesproken had met de Japanse opperbevelhebber en dat hij zich genoodzaakt had gezien in te stemmen met onvoorwaardelijke capitulatie. Hij gaf daarom opdracht onmiddellijk de strijd te staken, de witte vlag te hijsen, alle troepen te ontwapenen en contact op te nemen met de dichtstbijzijnde Japanse commandant. Tenslotte deelde hij mee dat dit bevel ook gold voor de Nederlandse marine.

De Japanse soldaten trokken Bandoeng binnen. Ter Poorten werd krijgsgevangene. Tjarda kreeg voorlopig huisarrest. In Batavia werd het paleis van de gouverneur-generaal ingericht als ambtswoning voor Imamura.

\section{Aantekeningen bij hoofdstuk IV}

\section{Literatuuroverzicht}

De eerste gedetailleerde studie over de Indonesische nationale beweging verscheen in 1931, toen deze beweging nog volop in ontwikkeling was. Dit was De nationalistische beweging in Nederlandsch-Indië door J.Th. Petrus Blumberger (in 1987 herdrukt met een inleiding van H.A. Poeze). Voordien waren in Nederland wel enige polemische geschriften over het Indonesisch nationalisme verschenen, zowel van tegenstanders als van voorstanders. De belangrijkste uit de eerste categorie waren Het gist in Indië; Een analyse der hedendaagsche nationalistische beweging (1927) door M.W.F. Treub en Koloniale vraagstukken van heden en morgen (1928) door H. Colijn. De belangrijkste uit de tweede categorie waren Indonesië vrij (1928) door Mohammad Hatta en Indonesië klaagt aan! (1931) door Soekarno. Deze laatste twee publicaties bevatten de pleitredes die Hatta en Soekarno geschreven hadden toen zij wegens hun politieke activiteiten terechtstonden. Petrus Blumberger, een ambtenaar van het Nederlands-Indisch gouvernement en later van het Nederlandse departement van koloniën, schreef 
ook werken over de communistische beweging en de Indo-Europese beweging in Nederlands-Indië. Verder werden in Nederland voor de Tweede Wereldoorlog geen serieuze studies over het Indonesisch nationalisme gepubliceerd.

In Indonesië zelf publiceerde L.M. Sitorus in 1947 het eerste historische overzicht van de nationale beweging: Sedjarah pergerakan kebangsaan Indonesia (Geschiedenis van de Indonesische nationale beweging). Hierop volgden Sedjarah pergerakan rakjat Indonesia (Geschiedenis van de Indonesische volksbeweging, 1949) door A.K. Pringgodigdo en Om de vrijheid (1950) door D.M.G. Koch. In Nederland zelf publiceerde J.M. Pluvier in 1953 zijn Overzicht van de ontwikkeling der nationalistische beweging in Indonesië in de jaren 1930 tot 1942, dat een voortzetting vormde van het door Petrus Blumberger begonnen werk.

In de eerstvolgende jaren richtten Nederlandse historici zich, wat de vooroorlogse politieke ontwikkelingen in Indonesië betreft, in hoofdzaak op het Nederlandse beleid en de rol van Nederlandse politici. Voorbeelden hiervan zijn een boek van B.J. Brouwer uit 1958 over Idenburg en Colijn, een in 1961 door H. Baudet en I.J. Brugmans gepubliceerde artikelenbundel onder de titel Balans van beleid; Terugblik op de laatste halve eeuw van Nederlands-Indië, en een in 1964-1965 door S.L. van der Wal uitgegeven bronnenpublicatie over De Volksraad en de staatkundige ontwikkeling van NederlandsIndië. In dezelfde lijn passen het boek van J.C.H. Blom uit 1975 over de muiterij op 'De Zeven Provinciën', dat van P.J. Drooglever uit 1980 over de Vaderlandsche Club, dat van E.B. Locher-Scholten uit 1981 over de ethische politiek en dat van E. Henssen uit 1983 over Gerretson.

Daarentegen richtten verscheidene historici buiten Nederland zich vooral op de rol van de Indonesiërs zelf in de vooroorlogse ontwikkelingen binnen Indonesië. Al in 1952 publiceerde G.McTurnan Kahin Nationalism and revolution in Indonesia, waarvan de eerste honderd pagina's aan de vooroorlogse nationale beweging gewijd waren. In 1960 verscheen een studie van R. Van Niel over de opkomst van de moderne Indonesische elite. In 1964 werd de ideologie van de nationale beweging door B. Dahm behandeld in zijn boek over Soekarno's strijd om de onafhankelijkheid. R. McVey publiceerde in 1965 een boek over de opkomst van het Indonesische communisme, A. Nagazumi in 1972 een overzicht van de eerste tien jaar van Boedi Oetomo, K. Tsuchiya in 1987 een studie over de opkomst van de Taman Siswa-beweging en T. Shiraishi in 1990 een meer algemene studie over de opkomst van de nationale beweging. S. Abeyasekere behandelde in publicaties van 1973 en 1976 de geschiedenis van de Indonesische nationale beweging tijdens de periode 1936-1941. Van J. Ingleson verschenen in 1975 en 1979 belangrijke studies over de Perhimpoenan Indonesia en over de nationalistische beweging in het tijdvak 1923-1934. Verder publiceerden auteurs als J.D. Legge, R. Mràzek, C.L.M. Penders en M. Rose biografieën van leidende figuren van die beweging, onder wie Hatta, Sjahrir en Soekarno.

In Indonesië zelf bestonden na 1950 de bijdragen tot de geschiedschrijving van de nationale beweging vooral uit memoires van personen die in die beweging een rol gespeeld hadden, zoals Abu Hanifah, Hatta, Iwa Kusuma Sumantri, Adam Malik, Mohammad Roem, Ali Sastroamidjojo en Achmad Subardjo. Een eerdere bijdrage was de in 1947-1948 door Tan Malaka geschreven autobiografie onder de titel Dari pendjara ke pendjara (Van gevangenis naar gevangenis). Verder verschenen er, naast de hierboven al genoemde werken van Sitorus en Pringgodigdo, nog andere algemene overzichten, zoals Sedjarah pergerakan nasional Indonesia (Geschiedenis van de 
Indonesische nationale beweging) door Susanto Tirtoprodjo (1962b), Sedjarah revolusi Indonesia (Geschiedenis van de Indonesische revolutie) door Iwa Kusuma Sumantri (1966-1969) en Sejarah pergerakan nasional (Geschiedenis van de nationale beweging) door Sartono Kartodirdjo (1989).

Intussen was men ook in Nederland meer aandacht gaan geven aan de geschiedenis van de Indonesische nationale beweging. Op basis van materiaal in Nederlandse overheidsarchieven verscheen in 1967 onder redactie van S.L. van der Wal een publicatie van interne documenten onder de titel De opkomst van de nationalistische beweging in Nederlands-Indië. Dit werk werd voortgezet door R.C. Kwantes in de vorm van een vierdelige bronnenpublicatie, getiteld De ontwikkeling van de nationalistische beweging in Nederlands-Indië (1978-1982). Deze publicaties bevatten zeer veel gegevens over de maatregelen van het Nederlands-Indische gouvernement tegenover die beweging en haar leiders. Een bijdrage van heel andere aard was een in 1976 door H.A. Poeze gepubliceerde beschrijving van het leven van Tan Malaka tot aan 1945, in feite na het werk van Pluvier de eerste studie waarin een Nederlandse historicus de Indonesische vrijheidsbeweging van binnenuit behandelde. Van de hand van A.P.E. Korver verscheen in 1982 een studie over de opkomst en bloei van de Sarekat Islam. In hetzelfde jaar begon H.A. Poeze met de uitgave van een nieuwe bronnenpublicatie, Politiekpolitioneele overzichten van Nederlandsch-Indië. Dit betrof maandelijkse geheime overzichten die het justitie-apparaat van Nederlands-Indië in de periode 1927-1941 had opgesteld ten behoeve van de hoogste functionarissen van het Nederlands-Indische gouvernement; de vier delen van deze bronnenpublicatie, telkens van inleidingen en overzichten voorzien, verschenen in 1982, 1983, 1988 en 1994.

Gebruik makend van het talrijke ter beschikking gekomen materiaal schreef L. de Jong een veelomvattend overzicht van de Indonesische nationale beweging, dat in 1984 in druk verscheen in de vorm van de hoofdstukken 6, 7 en 10 van deel 11a van zijn standaardwerk Het Koninkrijk der Nederlanden in de Tweede Wereldoorlog. Over de vroege fase van die beweging nam F. Tichelman tal van gegevens op in zijn boek van 1985 over de Indische Sociaal-Democratische Vereeniging. Een verdere bijdrage tot kennis van de nationale beweging werd geleverd door het in 1986 door H.A. Poeze gepubliceerde boek In het land van de overheerser - I. Indonesiërs in Nederland 1600-1950; de beweging dankte haar ontstaan immers ten dele aan Indonesiërs die in Nederland studeerden. Een andere bijdrage tot die kennis was de bloemlezing De roep om merdeka; Indonesische vrijheidlievende teksten uit de twintigste eeuw, verschenen in 1995 onder redactie van H.A. Poeze en H. Schulte Nordholt.

Ook verder hebben Nederlandse auteurs zich herhaaldelijk met de Indonesische nationale beweging beziggehouden. Zo publiceerde H. van Miert in 1995 een studie over onder meer de Indonesische jeugdbeweging in de periode 1918-1930. H.W. van den Doel wijdde een hoofdstuk aan de nationalistische beweging in zijn in 1996 verschenen Het Rijk van Insulinde. Een boek van M. Maters uit 1998 over de behandeling van de pers in het vooroorlogse Nederlands-Indië is eveneens voor de geschiedenis van die beweging relevant. B. Hering publiceerde in 1997 een biografie van Thamrin en in 2002 een biografie van Soekarno (tot eind 1945). Ook verscheen er in 1999 en 2001 een tweedelige biografie van Soekarno door L.J. Giebels.

Het ontluiken van de Indonesische drang naar mondigheid Over Abdul Rivai en het tijdschrift Bintang Hindia zie Poeze 1986. 
Boedi Oetomo en andere organisaties op etnische grondslag

Zie Petrus Blumberger 1931:19-54 en Nagazumi 1972. Over de theosofische beweging zie De Tollenaere 1996. Over E.F.E. Douwes Dekker zie Glissenaar 1999 en Van der Veur 2006. Over Tjipto Mangoenkoesoemo zie Shiraishi 1990:117-27. Over Soetomo zie Van der Veur 1987.

Het gebouw waarin de STOVIA gevestigd was in de eerste decennia van de twintigste eeuw huisvest tegenwoordig het Museum Kebangkitan Nasional (Museum van het Nationale Ontwaken),

Vakverenigingen

Zie Petrus Blumberger 1931:129-44, Tichelman 1985:14-7 en Ingleson 1986.

De Indische Partij en het Comité Boemi Poetra

Zie Petrus Blumberger 1939:32-9, Koch 1950:30-43, Glissenaar 1999:77-101, Van der Veur 2006:183-236 en Van Dijk 2007:45-71. Zie Van der Wal 1967:152-5 voor het gesprek van Douwes Dekker met gouverneur-generaal Idenburg. Voor de tekst van de brochure van Soewardi zie Poeze en Schulte Nordholt 1995:34-8. Voor het verblijf van de drie ballingen in Nederland zie Poeze 1986:91-5, 116-9, 137-40.

\section{De Sarekat Islam}

Zie Petrus Blumberger 1931:55-89, Korver 1982 en Shiraishi 1990:41-90. Zie Van der Wal 1967:161-4 voor het gesprek van gouverneur-generaal Idenburg met het bestuur van de Sarekat Islam.

Sneevliet en de Indische Sociaal-Democratische Vereeniging

Zie Petrus Blumberger 1931:106-10, 1935:1-8, 1939:41-4, McVey 1965:13-47 en Tichelman 1985:4-17, 25-9, 51-2. Zie over Semaoen ook Shiraishi 1990:98-103. Voor de verdedigingsrede van Sneevliet zie Baars en Sneevliet 1991. Over het proces-Sneevliet zie De Meij 2004:16-17.

Hoewel men ook binnen de reformistische rechtervleugel van de socialistische beweging soms wel naar de theorieën van Karl Marx verwees, zal de term 'marxisten' in dit boek uitsluitend gebruikt worden voor de leden van de radicale linkervleugel.

De Politieke Inlichtingen Dienst

Zie Tichelman 1985:463-4 en Poeze 1994.

De Indië Weerbaar-campagne

Zie Van der Wal 1967:459-89, Kwantes 1975:94-103, Tichelman 1985:21-4, 48-51, Poeze 1986:112-6 en Van Dijk 2007:255-86, 472-4, 579-90.

De instelling van de Volksraad

Over gouverneur-generaal Van Limburg Stirum zie Locher-Scholten 1981:55-117.

Uitzicht op geleidelijke dekolonisatie

Vergelijk Koch 1956:98-103, 116-25 en Van Dijk 2007:596-602. Voor de 'november-beloften' van gouverneur-generaal Van Limburg Stirum zie Van der Wal 1964:253-4, 604-5. 
Studenten in Nederland; de Indische Vereeniging en het Indonesisch Verbond van Studeerenden Over de Indische Vereeniging zie Poeze 1986:63-81, 104-12, 134-40, 163. Over Noto Soeroto zie Karels 2010. Over Ratoelangie zie Van Klinken 2003:85-113. Over het Indonesisch Verbond van Studeerenden zie Poeze 1986:127-34, 157-62 en Jonkman 1971:32-6.

Van Mook was op Java geboren en opgegroeid. Zijn ouders waren zelf in Nederland geboren, maar waren na hun huwelijk naar Indonesië gegaan om daar in het onderwijs te werken. Van Mook kwam pas op achttienjarige leeftijd in Nederland, studeerde daar eerst scheikunde en zwaaide vervolgens over naar de opleiding voor de Indische bestuursdienst. Na zes jaar verblijf in Nederland keerde hij in 1918 naar Indonesië terug. Steeds bleef Van Mook zich meer verbonden voelen met zijn Indonesische geboorteland dan met zijn Nederlandse vaderland.

Verharding van het Nederlands koloniaal beleid

De belangrijkste brochures waren Colijn 1918 en Treub 1923. Zie ook Brouwer 1958 en Henssen 1983. De in 1923 ingevoerde strafbepaling tegen het aanzetten tot staking was artikel 161 bis van het Wetboek van strafrecht voor Nederlandsch-Indië.

Het Indo-Europeesch Verbond

Zie Petrus Blumberger 1939:49-62.

De Nationaal-Indische Partij

Zie Petrus Blumberger 1939:45-8, Glissenaar 1999:125-38 en Van der Veur 2006:40340.

De wilde scholen

Zie Groeneboer 1993:365-8. Over de Moehammadiah zie Petrus Blumberger 1931:92-8; over het schoolsysteem van Tan Malaka zie Poeze 1976:121-33; over de Taman Siswascholen zie Tsuchiya 1987, over het Ksatrian Instituut zie Van der Veur 2006:471-537.

De machtsstrijd tussen de Sarekat Islam en de marxisten

Zie Petrus Blumberger 1931:64-79, 1935:15-47, McVey 1965:48-197 en Poeze 1976:14166. Zie over de Sarekat Islam Afdeling B ook Kwantes 1975:136-97. Zie over de vakbeweging en de pandhuisstaking ook Ingleson 1986:124-7, 214-6, 220-7.

Hervorming van het Nederlands-Indische staatsbestel

Vergelijk Koch 1956:123-5. Over het Comité voor de Autonomie van Indië zie Van der Wal 1964:504-6. Voor de 'Indische Staatsregeling' van 1925 zie Engelbrecht 1939:3771.

De Ondernemersraad voor Nederlandsch-Indië en de Utrechtse indologenopleiding

Over de Ondenemersraad zie Taselaar 1998:108-18, 156-60. Over de Utrechtse opleiding zie Hekman 1981:6-7, Henssen 1983:51-65 en Fasseur 1993:412-33. Voor de opmerkingen van Snouck Hurgronje zie zijn artikel 'Vergeten jubilés'. Voor de opening van de nieuwe opleiding in Utrecht zie Kohlbrugge 1927. 
Studenten in Nederland; de Perhimpoenan Indonesia

Zie onder meer Hatta 1928, Petrus Blumberger 1931:183-96, Ingleson 1975 en Poeze 1986:175-82, 186-92, 209-20, 244-50, 257-73. Voor biografieën van Hatta zie Noer 2002 en Rose 1987; voor een biografie van Sjahrir zie Mrázek 1994. De drie in 1927 samen met Hatta gearresteerde PI-leiders waren Ali Sastroamidjojo, Abdoelmadjid Djojoadhiningrat en Mohammad Nazir Datoek Pamontjak. Voor het vonnis van de Haagse rechtbank uit maart 1928 zie Petrus Blumberger 1931:438-43. Voor het procesSneevliet zie ook De Meij 2004:26-32.

De studieclubs van Soetomo en Soekarno

Zie Petrus Blumberger 1931:197-203. Over Soetomo zie Van der Veur 1987. Biografieën van Soekarno zijn onder meer Dahm 1964, Giebels 1999, Hering 2002, Legge 1972 en Penders 1980. Zie voor invloeden op zijn politieke vorming vooral Dahm en Hering.

Soekarno had geen voornaam. Dat zijn naam niettemin soms als Achmed Soekarno wordt weergegeven gaat terug op de tijd kort na de Tweede Wereldoorlog, toen Amerikaanse journalisten in Batavia door hun redacties werden aangemaand om Soekarno's naam volledig weer te geven en daarom de voornaam Achmed kozen om van deze aanmaningen verlost te worden.

Mislukte communistische opstand

Zie Petrus Blumberger 1935:55-106, McVey 1965:257-355 en Poeze 1976:294-360.

Boven-Digoel

Zie Petrus Blumberger 1935:107-23 en Salim 1973.

De vertrouwenspolitiek van De Graeff

Zie Ingleson 1979:36-45. Over Thamrin zie Hering 1997. Over de internering van Tjipto Mangoenkoesoemo zie Kwantes 1978:578-88.

De eerste nationalistische massabeweging: Soekarno's PNI

Zie Petrus Blumberger 1931:204-49, Ingleson 1975:44-9 en 1979:29-100 en verder Hering 2002:129-84. Over de PPPKI zie Petrus Blumberger 1931:250-74 en Ingleson 1979:46-52, 69-74.

Het Indonesisch Jeugdcongres van 1928

Zie Petrus Blumberger 1931:390-5 en Van Miert 1995:327-34. Over Amir Sjarifoeddin zie Van Klinken 2003:115-50. Voor een algemene beschrijving en analyse van de positie van de Indonesische intellectuelen in de kolonie Nederlands-Indië voor de Tweede Wereldoorlog zie Dolk 1993:6-11.

De 'Inlandse meerderheid' in de Volksraad

Zie Brouwer 1958:123-9 en Van der Wal 1965:1-67.

De Vaderlandsche Club

Zie Drooglever 1980. 
Rijkseenheid

Zie onder meer Treub 1927:53, 56, Colijn 1928:45 en Nederburgh 1929. Zie over De Rijkseenheid ook Hekman 1981:8-10 en Taselaar 1998:327-32. Nederburgh was in Batavia president van het Hooggerechtshof en directeur van het departement van justitie geweest.

De Stuw-groep

Zie Locher-Scholten 1981:118-49.

Het proces-Soekarno

Over kritiek van andere nationalisten op het provocatieve optreden van Soekarno zie Ingleson 1979:82-89. Over het proces zie Hering 2002:185-213 en De Meij 2004:35-42. Voor Soekarno's eigen pleitrede zie Soekarno 1931. De in 1930 samen met Soekarno berechte PNI-leiders waren Gatot Mangkoepradja, Maskoen en Soepriadinata. Voor een uittreksel uit het vonnis van de landraad in Bandoeng zie Petrus Blumberger 1931:444-53. Voor de door de Stuw-groep uitgegeven brochure Het vonnis in de P.N.I. zaak door J.M.J. Schepper zie Locher-Scholten 1981:125-6.

Hergroeperingen binnen de Indonesische vrijheidsbeweging

Zie Pluvier 1953:45-52 en Ingleson 1979:141-175. Verscheidene cursisten van Soekarno's kaderschool in Bandoeng, onder wie Soekarni, Trimoerti en Wikana, speelden later een belangrijke rol in de nationale beweging en kwamen daarbij soms tegenover Soekarno te staan.

Verzet tegen de wilde-scholenordonnantie

Zie Pluvier 1953:53-7 en Kwantes 1981:678-81. Voor de mening van gouverneurgeneraal De Jonge over het risico dat Dewantoro een Gandhi zou worden zie Van der Wal 1968:152.

Muiterij op 'De Zeven Provinciën'

Zie Blom 1975.

Onderdrukking van de Indonesische vrijheidsbeweging

Zie Pluvier 1953:57-63. Over de eerdere muilkorfcirculaire zie p. 137. Over Soekarno's morele inzinking zie Hering 2002:233-6. Voor de tekst van Soekarno's brieven van september 1933 zie Kwantes 1982:37-43. Over de PID zie Idenburg 1984:142-4 en Poeze 1994. Over de politieke voorlichting van het gouvernement door de PID-leiding zie Poeze PPO I:vii-ix. Zie voor een beeld van de nationale beweging in dit tijdsgewricht ook Soewarsih Djojopoespito 1940.

Het einde van de non-coöperatiepolitiek

Zie Pluvier 1953:57-63 en 94-117. De Sarekat Islam had haar naam in 1930 gewijzigd in Partai Sarekat Islam Indonesia (PSII). Over Kartosoewirjo zie Van Dijk 1981:20-40.

India, Birma en de Filippijnen op weg naar dekolonisatie Zie onder meer Bootsma 1986. 
De petitie-Soetardjo

Zie Pluvier 1953:118-29, Van der Wal 1965:219-318, 377-403, Abeyasekere 1973 en Gouka 2001. Over het herstel van inheemse vorstendommen zie Kleintjes 1938.

Het eenheidsfront Gapi en de campagne 'Indonesië parlementair'

Zie Pluvier 1953:130-47, Van der Wal 1965:403-22, 492-535, Abeyasekere 1976:1148 en L. de Jong 1984:432-9. Over het verblijf van Hatta en Sjahrir op de Bandaeilanden vergelijk Sjahrazad 1945; daarin wordt Hatta aangeduid als 'Hafil', Tjipto Mangoenkoesoemo als 'Soeribno' en Iwa Koesoema Soemantri als 'Soebana'. Over de verwelkoming van Soekarno in Zuid-Sumatra zie Jaquet 1978:23. Over Kritiek en Opbouw zie Locher-Scholten 1981:150-75.

De maatschappelijke positie van de Indonesiërs omstreeks 1940

Vergelijk Beynon 1995. Veel gegevens hierover zijn ook te vinden in de memoires van prominente Indonesiërs, waaronder verschillende in Memoar. Voor de tijdschriften Kritiek en Opbouw en De Fakkel zie Dolk 1993:75-95.

Nederland in oorlog met Duitsland

Over de onwil van koningin Wilhelmina om in te stemmen met een bezoek van kroonprinses Juliana aan Nederlands-Indië zie Van der Wal 1968:77, 88.

De defensiecapaciteit van Nederlands-Indië

Zie L. de Jong 1984:600-62.

Bevriezing van het koloniale bestel

Zie Pluvier 1953:167-78, Van der Wal 1965:551-3, 597-603, 651-3, 680-9, Jonkman 1971:167-8, 178-83, 188-90, 231 en Abeyasekere 1976:54-69. Voor de rede van Thamrin zie Handelingen Volksraad 1940-1941:782-5; vergelijk Poeze PPO IV:382-4.

De laatste confrontaties tussen de nationale beweging en het koloniale gezag

Zie Pluvier 1953:178-93, Abeyasekere 1976:69-83 en L. de Jong 1984:571-99.

Nederland in oorlog met Japan

Zie L. de Jong 1984:696-727. Over de houding van de Indonesische nationalisten L. de Jong 1984:942-56, Abeyasekere 1976:83-5 en Touwen-Bouwsma 1992.

Verwijdering van niet-Indonesische gë̈nterneerden uit Nederlands-Indië

Zie Van Heekeren 1983 en L. de Jong 1984:727-39. Zie over de overbrenging van de Nederlandse geïnterneerden naar Suriname ook Glissenaar 1999:185-95 en Van der Veur 2006:575-98.

Verloop van de oorlog tot maart 1942

Zie L. de Jong 1984:712-968.

De Nederlandse capitulatie

Zie L. de Jong 1984:1-18 en 969-1038. 


\section{HOOFDSTUK V}

\section{Indonesië onder Japanse bezetting}

\section{Inleiding en overzicht}

De Japanse bezetting van Indonesië veroorzaakte een radicale breuk met de voordien in Nederlands-Indië heersende maatschappelijke orde. Terwijl het falen van het koloniale leger bij de verdediging van het gebied het Nederlandse prestige onder de inheemse bevolking al zwaar beschadigd had, verloren de Nederlanders tijdens de bezetting hun vroegere positie volledig. De bezettingsmacht ontsloeg hen niet alleen uit hun betrekkingen, maar verwijderde hen zelfs geheel uit de samenleving door hen in interneringskampen op te sluiten, voorzover ze al niet eerder als krijgsgevangenen weggevoerd waren. Ook de Nederlandse vrouwen en kinderen werden geïnterneerd. Zowel bij de overheid als bij de bedrijven gingen de meeste functies die de Nederlanders bekleed hadden op Japanners en Indonesiërs over. Verder voerden de bezetters tal van Japanse termen en gebruiken in en schakelden zij de Nederlandse taal uit; het Indonesisch werd nu de algemene verkeerstaal.

Dat veel Indonesiërs functies te vervullen kregen die vroeger in Nederlandse handen waren en dat de Indonesische taal de rol van het Nederlands overnam, versterkte uiteraard het Indonesisch nationaal bewustzijn. Daarentegen kwam het Japanse beleid aanvankelijk volstrekt niet tegemoet aan de verlangens naar onafhankelijkheid voor Indonesië, want de bezetters koesterden plannen om dit land tezijnertijd als een kolonie bij Japan in te lijven. Zij stonden dan ook geen nationalistische activiteiten toe en verboden zowel de rood-witte vlag als het 'Indonesia Raja'. Bovendien traden zij dikwijls bruut tegen de bevolking op. Niettemin toonden de meeste Indonesische nationalisten zich bereid tot samenwerking met de Japanse autoriteiten. Hetzelfde gold voor vrijwel alle Indonesische bestuursambtenaren en andere gezagsdragers, met inbegrip van vooraanstaande Indonesiërs die voor de oorlog als steunpilaren van het Nederlandse bewind beschouwd waren.

Terwijl de bezetters alle zelfstandige politieke activiteiten onderdrukten, brachten zij anderzijds de bevolking van Java in massa-organisaties bijeen ter ondersteuning van de Japanse oorlogsinspanning en bedreven zij continu anti-westerse propaganda. Zij spanden zich bijzonder in om de jeugd te indoc- 
trineren en te militariseren. Honderdduizenden jongeren werden opgenomen in semi-militaire korpsen en zelfs jonge kinderen werden militair gedrild. In een latere fase van de bezetting richtte het Japanse bestuur bovendien een Indonesisch vrijwilligersleger op, van eenzelfde omvang als het vooroorlogse KNIL.

Teneinde de inheemse bevolking voor de Japanse doeleinden te mobiliseren maakte de bezettingsmacht op Java dankbaar gebruik van het gezag van de nationalistische leiders Soekarno en Hatta. Soekarno verwachtte dat Japan uiteindelijk de oorlog zou winnen en zette zich volledig voor de Japanse propaganda in, denkend daarmee de kans op onafhankelijkheid voor Indonesië te bevorderen. $\mathrm{Na}$ anderhalf jaar bezetting kwam het Japanse bestuur wat meer aan de Indonesische aspiraties tegemoet. Onder meer stelde het Soekarno aan als voorzitter van een overwegend uit Indonesiërs samengestelde adviesraad, die vergaderde in het gebouw van de vroegere Volksraad.

Japan gaf de plannen tot inlijving van Indonesië pas op toen het duidelijk bezig was de oorlog tegen de geallieerden te verliezen. In september 1944 verklaarde Tokio dat de Indonesische bevolking tezijnertijd onafhankelijk zou worden. Het verbod op de rood-witte vlag en het 'Indonesia Raja' werd opgeheven, maar het duurde nog ruim een half jaar voordat men begon met daadwerkelijke voorbereidingen voor de onafhankelijkheid. Die voorbereidingen waren nog niet afgesloten, toen Japan op 15 augustus 1945 capituleerde.

\section{Afronding van het Japanse offensief}

Het op 8 december 1941 geopende Japanse offensief in de Stille Oceaan en Zuidoost-Azië was drie maanden aan de gang toen het Koninklijk NederlandsIndische Leger capituleerde. Op dat moment had Japan de doelstellingen van zijn offensief al grotendeels bereikt, in minder tijd en met minder verliezen dan zijn plannenmakers hadden verwacht. Ter afronding van dit offensief moest het nog enige delen van de Filippijnen, Indonesië en Birma bezetten.

Het was eerst onzeker of de op 9 maart 1942 door legercommandant Ter Poorten bekend gemaakte algehele en onvoorwaardelijke capitulatie van het KNIL ook gold voor de ruim veertienduizend Amerikaanse, Australische en Britse militairen die zich toen nog op Java bevonden. Hun commandanten ondertekenden drie dagen later eveneens een onvoorwaardelijke overgave. Aan deze overgave onttrok zich een groep van bijna honderd Australiërs en Britten die zich in het bergland van Zuidwest-Java terugtrokken onder leiding van luitenant-kolonel Laurens Van der Post, een tot de Britse Inlichtingendienst behorende Zuid-Afrikaan. In de loop van de volgende maanden schakelden Japanse patrouilles hen allen uit; Van der Post zelf werd eind april gevangen genomen. 
Buiten Java gaven ook verscheidene groepen KNIL-militairen zich na 9 maart nog niet aan de Japanse strijdkrachten over. Zij volgden daarbij een van de Nederlandse regering in Londen afkomstige richtlijn die inhield dat, waar men de Japanners niet kon tegenhouden, men moest terugtrekken teneinde de strijd als guerrilla voort te zetten. $\mathrm{Zij}$ handelden bovendien in overeenstemming met de eerder door Ter Poorten verspreide verklaring waarin hij een eventueel door hem uit te geven capitulatiebevel bij voorbaat als ongeldig bestempeld had. De meeste van deze militairen konden zich niet lang handhaven. Bij gebrek aan steun door de inheemse bevolking was effectieve guerrillaoorlogvoering tegen de Japanse bezettingsmacht praktisch onmogelijk.

Van het eiland Sumatra was op 9 maart alleen het zuidelijke deel in Japanse handen. In Midden- en Noord-Sumatra bevonden zich nog enige duizenden KNIL-militairen. Intussen had een aantal Atjehers al in februari, in nauwe samenwerking met de Japanse strijdmacht in Malakka, een anti-Nederlandse opstand voorbereid. Deze verzetsbeweging had haar aanhang in hoofdzaak in Atjeh, maar telde ook leden in andere gebieden zoals Deli en Minangkabau. In Atjeh begonnen de opstandelingen eind februari met sabotagedaden tegen bruggen, wegen en telefoonlijnen; op 10 maart overvielen zij enige plaatsen aan de westkust. Twee dagen later gingen Japanse troepen aan land op verschillende plaatsen aan de noord- en oostkust van Sumatra. Het KNIL ontruimde Koetaradja en Medan en probeerde zich terug te trekken in het bergland. Dit werd bemoeilijkt door de opstandelingen, die overigens over weinig vuurwapens beschikten en zware verliezen leden. Verscheidene KNIL-eenheden gaven zich binnen een week aan de Japanners over. Eind maart besloten ook de hoogste KNIL-commandanten op Sumatra te capituleren.

Op Borneo, waar het Japanse leger al in januari en februari de voornaamste plaatsen veroverd had, trokken ongeveer honderd KNIL-militairen het binnenland in. In de periode maart-augustus gaven enkelen van hen zich alsnog over en werden alle anderen gedood, hetzij door de Japanners hetzij door de Dajaks.

Ook de belangrijkste delen van Celebes waren begin maart al in Japanse handen. De Japanse troepen hadden hier aanzienlijke steun gekregen van de plaatselijke bevolking; in enkele gebieden zette deze de Nederlandse bestuursambtenaren al voor de komst van de Japanners af. In Zuid-Celebes hielden ongeveer driehonderd KNIL-militairen de strijd nog vol; zij capituleerden kort na 9 maart. In Midden-Celebes trokken ongeveer honderddertig KNILmilitairen zich in het binnenland terug. De Japanners namen hen in augustus gevangen en doodden vervolgens alle officieren en onderofficieren.

Van de kleinere eilanden ten oosten van Java en Celebes waren Bali, Ambon en Timor op 9 maart al in Japanse handen; de andere werden in de loop van de volgende maanden bezet. Overigens was Timor nog niet volledig door de Japanse troepen veroverd. Met steun uit Australië wisten enige hon- 
derden Nederlandse en Australische militairen zich daar nog tot eind 1942 te handhaven; zij werden uiteindelijk met geallieerde schepen naar Australië geëvacueerd.

In de loop van april bezette Japan de voornaamste plaatsen in het noordwesten en noorden van Nieuw-Guinea. Pas in 1943 drongen Japanse strijdkrachten dieper door in het binnenland van Nederlands-Nieuw-Guinea. De enige daar nog functionerende Nederlandse bestuursambtenaar week toen uit naar de bergen; ruim een jaar later haalde een Nederlands vliegtuig hem weg. Japan zag ervan af de zuidkust van Nederlands-Nieuw-Guinea te bezetten, zodat Merauke tijdens de hele oorlog onder Nederlands gezag bleef. Dit gold ook voor Boven-Digoel; overigens bracht men de daar geïnterneerde Indonesiërs in 1943 naar Australië over om te voorkomen dat ze in Japanse handen zouden vallen.

Wat de rest van Zuidoost-Azië betreft, was Japan op 9 maart 1942 heer en meester over Hongkong, Indochina, Thailand, Malakka, Singapore, BritsBorneo en belangrijke delen van Birma en de Filippijnen. Thailand had al op de eerste dag van het Japanse offensief besloten zich niet te verzetten. Van Thailand uit waren de Japanse strijdkrachten begin 1942 Birma binnengevallen, samen met een klein Birmaans opstandelingenleger onder de nationalistische leider Aung San. Op 8 maart veroverden zij de hoofdstad Rangoon; begin mei hadden zij vrijwel heel Birma in handen. Op de Filippijnen hadden de Japanners de hoofdstad Manila al begin januari bezet; sindsdien belegerden zij de Amerikaanse en Filippijnse troepen die zich verschanst hadden op het schiereiland Bataan en in het op een eiland daarvoor gelegen fort Corregidor. In opdracht van president Roosevelt verliet generaal MacArthur op 11 maart Corregidor om in Australië het opperbevel op zich te nemen over de geallieerde troepen in het zuidwestelijke deel van de Stille Oceaan. De verdedigers van Bataan capituleerden in april; op 6 mei viel Corregidor. Wat de Stille Oceaan betreft hadden de Japanse strijdkrachten al in de eerste oorlogsmaanden een aantal belangrijke Amerikaanse, Britse en Australische eilanden veroverd. Al met al wist Japan alle doelstellingen van zijn offensief binnen vijf maanden te verwezenlijken. Die doelstellingen omvatten nog geen verovering van India, Australië of Nieuw-Zeeland.

Tijdens dit offensief bevestigden de Japanse strijdkrachten de reputatie van wreedheid die zij al in China verworven hadden. Zij doodden een deel van hun gevangenen, onder meer door onthoofding en verdrinking. Mishandeling en marteling van gevangenen kwamen veelvuldig voor. Door de verdedigers geboden hardnekkige tegenstand, zoals op Bataan, leidde herhaaldelijk tot Japanse wraakacties (maar het gebeurde ook dat Japanners respect toonden voor moedige tegenstanders). Nog vaker reageerde het Japanse leger met wraak op door de verdedigers aangerichte vernielingen van militair belangrijke objecten. In Indonesië werden vooral Nederlandse bestuursambtenaren 
en andere burgers het slachtoffer van zulke wraakoefeningen. Tegenover de inheemse burgerbevolking gedroegen de Japanse militairen zich over het algemeen correct.

\section{Inheemse reacties op de Japanse verovering van Indonesië}

Tijdens hun verovering van de Indonesische archipel werden de Japanse strijdkrachten door de inheemse bevolking meestal niet als vijanden maar als vrienden ontvangen. Herhaaldelijk kwam het voor dat terugtrekkende KNILeenheden menigten Indonesiërs moesten passeren die al klaarstonden om de oprukkende Japanners feestelijk te verwelkomen. Deze hartelijke ontvangst verschilde opmerkelijk van de vijandigheid die de Japanse militairen van de bevolking in China gewend waren en ook van de gereserveerde opstelling van de Filippijnse bevolking, die zich in het algemeen solidair met Amerika voelde. Overigens betekenden deze Indonesische huldeblijken niet dat de hele inheemse bevolking de Japanners welgezind was; er waren ook anti-Japanse Indonesiërs, onder meer binnen de linkervleugel van de nationale beweging.

Hoewel veel Indonesiërs wel verwacht hadden dat de Nederlandse strijdkrachten in een confrontatie met Japan het onderspit zouden delven, wekte de snelheid waarmee de Nederlandse verdediging instortte algemene verbijstering. Dit was onder meer te wijten aan de officiële voorlichting, die voor het uitbreken van de oorlog de Nederlands-Indische defensiecapaciteit sterk overdreven had en tijdens de oorlog de Japanse successen stelselmatig verzwegen of gebagatelliseerd en de eigen successen geflatteerd had. De verbazing over het Nederlandse falen werd nog versterkt door de weinig indrukwekkende aanblik van de binnentrekkende Japanse troepen: in plaats van zware tanks en gemotoriseerde colonnes zag men gewoonlijk licht bewapende en soms haveloos geklede soldaten op fietsen. De blamage van de snelle Nederlandse capitulatie werd des te groter toen bleek dat Amerikaanse en Filippijnse troepen de strijd op de Filippijnen maandenlang volhielden.

Het beeld dat de Indonesiërs hadden van het optreden van de NederlandsIndische strijdkrachten tegen de Japanners was onvolledig en daardoor niet helemaal billijk. Zowel lucht- als zeestrijdkrachten hadden zich met moed en doodsverachting in de strijd geworpen, maar dit had zich ver van de grote bevolkingsconcentraties afgespeeld en gedeeltelijk zelfs buiten het grondgebied van Nederlands-Indië. Verder waren er hier en daar in de archipel nog KNIL-militairen die weigerden zich over te geven, maar ook dit onttrok zich aan de waarneming van het gros van de bevolking. Wat de bevolking van de Nederlandse verdedigingsactiviteiten tegen Japan had waargenomen bestond in hoofdzaak uit vernielingen en terugtrekkingen. Terwijl die vernielingen het verloop van de strijd weinig beïnvloed hadden, bezorgden ze de inheemse 
bevolking wel schade en ongemak. Onder meer waren rijstpellerijen en suikerfabrieken vernield en voedselvoorraden vernietigd.

Vanaf het begin van het offensief in december 1941 had de Japanse propaganda krachtig ingespeeld op de in Indonesië levende verlangens naar onafhankelijkheid. Dit gebeurde vooral in de op Indonesië gerichte radiouitzendingen, die steeds eindigden met het 'Indonesia Raja'. De Japanse propaganda knoopte uitdrukkelijk aan bij de Djojobojo-profetie en gaf te kennen dat het Indonesische volk onder een eigen regering zou komen te staan wanneer Japan een eind gemaakt zou hebben aan de Nederlandse koloniale overheersing. Ondanks deze propaganda onthield de overgrote meerderheid van de inheemse bevolking zich van verzet tegen het Nederlandse gezag. Opstanden tegen dat gezag voor de komst van de Japanse strijdkrachten deden zich vrijwel alleen op Sumatra en Celebes voor; ook werden incidenteel enkele bestuursambtenaren gedood. Los hiervan leidde herhaaldelijk een door terugtrekking van het KNIL veroorzaakt gezagsvacuüm tot plundering van huizen en winkels door Indonesiërs, die zich daarbij overigens meer tegen Chinezen dan tegen Europeanen keerden.

Intussen waren veel Indonesische nationalisten zich na het begin van de oorlog wel gaan voorbereiden op een mogelijke Nederlandse nederlaag. Met het oog daarop richtten zij vooral op Java en Sumatra tientallen plaatselijke organisaties op, onder allerlei benamingen zoals 'volkscomité' of 'Indonesisch comité'. De bedoeling daarvan was bij wegvallen van het Nederlandse gezag de leiding over te nemen, niet alleen van de Nederlanders zelf maar ook van hun traditionele steunpilaren: de inheemse ambtsaristocratie en de feodale hoofden en vorsten. De initiatiefnemers dachten dat de Japanse bezetters graag met deze comités zouden samenwerken, waarvan de meeste trouwens pas bij de komst van de Japanse troepen als welkomstcomités in de openbaarheid traden. Enkele van de comités werden door bekende figuren geleid. Zo was in Solo een Komite Nasional Indonesia gevormd onder Ki Hadjar Dewantoro, nationalist van het allereerste uur en stichter van het Taman Siswa-onderwijs. In Jogjakarta trad een soortgelijk comité op onder leiding van Mansoer, een kiai (godsdienstleraar) die in Kairo had gestudeerd maar ook een rol in Soekarno's PNI had gespeeld en nu voorzitter was van de invloedrijke moslimbeweging Moehammadiah. In Batavia werd het comité geleid door Achmad Soebardjo, een jurist die in Nederland voorzitter van de Perhimpoenan Indonesia geweest was en ook enige tijd in Moskou verbleven had, later in Tokio als correspondent voor een Indonesische krant gewerkt had en uiteindelijk in dienst was getreden bij het Nederlands-Indische gouvernement.

Tussen deze uit plaatselijke en regionale initiatieven voortgekomen volkscomités bestond weinig onderling verband. Op landelijk niveau kwamen dergelijke initiatieven lange tijd niet van de grond, omdat eind december grote onenigheid binnen de nationale beweging was ontstaan naar aanleiding 
van de oproep van de GAPI en de MRI tot steun aan het gouvernement (zie p. 259). Eén van degenen die zich scherp tegen die oproep gekeerd hadden was Abikoesno Tjokrosoejoso, leider van de Sarekat Islam. Op zijn initiatief kwamen nationalisten uit verschillende groeperingen op 9 maart (de dag van de bekendmaking van de Nederlandse capitulatie) in Batavia bijeen ter voorbereiding van een Indonesische regering. Zij stelden een lijst op van ruim veertig kandidaten voor ministersposten en andere hoge functies. Abikoesno overhandigde deze lijst aan het Japanse militaire bestuur.

\section{Enige kenmerken van het Japanse beleid tegenover Indonesië}

Als bezettende macht van Indonesië voerde Japan geen rechtlijnig, eenvormig en consequent beleid. Dit had verschillende oorzaken.

In de eerste plaats was het Japanse staatsbestel wel een volstrekte autocratie, maar stond het niet onder eenhoofdige leiding. In naam geschiedde alles volgens de wil van de keizer, maar in werkelijkheid ging van de keizer zelf weinig leiding uit. Bovendien was de macht van de regering beperkt; zij had geen zeggenschap over de strijdkrachten. De chef van de landmachtstaf en de chef van de marinestaf stonden rechtstreeks onder de keizer; verder wezen de strijdkrachten zelf de ministers van oorlog en marine aan. Maar hoewel leger en marine van eenzelfde militaristisch chauvinisme bezield waren en een gezamenlijk hoofdkwartier hadden, stonden zij bij de beleidsbepaling dikwijls tegenover elkaar en hielden zij veel informatie zowel voor elkaar als voor de regering verborgen. Soms schiepen ze voldongen feiten om een bepaalde koers af te dwingen. Zo was de landmacht in 1940 buiten medeweten van de regering en van de marine overgegaan tot de bezetting van het noorden van Indochina. Overleg over gewichtige beleidszaken vond plaats in een contactraad, bestaande uit de minister-president, de ministers van buitenlandse zaken, financiën, oorlog en marine en de leiders van de strijdkrachten. Onderlinge onenigheid tussen de verschillende machtscentra had vaak tot gevolg dat zulk overleg eerst laat tot besluiten leidde. Was men het eenmaal eens geworden en ging het over zeer belangrijke zaken, dan placht men de formele besluiten pas te nemen in vergaderingen met de keizer, die daarbij als regel zelf niet aan de discussie deelnam.

Een tweede oorzaak van uiteenlopend beleid was, dat de Japanse autoriteiten gewoon waren besluiten en instructies in zeer algemene termen te formuleren en een grote vrijheid aan de uitvoerders te laten bij de concrete uitwerking ervan. Het feit dat sommige besluiten op compromissen berustten droeg nog verder bij tot formuleringen die voor verschillende uitleg vatbaar waren.

In de derde plaats waren er, wat Indonesië betreft, geen duidelijke beleids- 
lijnen voor een langdurige militaire bezetting uitgezet omdat zo' $n$ lange bezetting niet was voorzien. De Japanse leiders hadden verwacht dat welslagen van het grote offensief zou leiden tot een spoedig vredesakkoord en dat daarbij ook de definitieve status van de in de oorlog bezette gebieden zou worden geregeld, zodat Japan dan niet langer als bezettingsmacht zou optreden.

Een vierde oorzaak voor het ontbreken van een eenvormig bezettingsbeleid hing hier nauw mee samen. Ten behoeve van de bezetting splitste het Japanse hoofdkwartier het grondgebied van Indonesië in drieën. Sumatra kwam samen met Brits-Malakka onder bestuur van het 25ste Leger te staan, het bestuur over Java en Madoera werd aan het 16de Leger opgedragen en de Japanse marine kreeg het bestuur over de rest van de archipel. Een extra complicatie was hierbij dat dit marinebestuur rechtstreeks onder de marinestaf in Tokio viel, terwijl het 25e en 16e Leger ressorteerden onder het (eerst in Singapore en later in Saigon zetelende) opperbevel voor de 'zuidelijke gebieden'.

Op 20 november 1941, enkele weken voor het begin van het offensief in Zuidoost-Azië, had de contactraad in Tokio richtlijnen vastgesteld voor het beleid in de te bezetten gebieden. Deze hielden onder meer het volgende in. Voorlopig zouden in de bezette gebieden militaire besturen worden ingesteld; over de uiteindelijke status van de gebieden zou later worden beslist. Die besturen zouden zoveel mogelijk gebruik moeten maken van de bestaande bestuursorganen, met eerbiediging van de bestaande structuren en de inheemse gebruiken. De militaire besturen zouden het verwerven van voor de defensie nodige hulpbronnen moeten bevorderen en ervoor moeten zorgen dat de in hun gebieden gelegerde Japanse strijdkrachten in eigen behoeften konden voorzien; een en ander zou desnoods ten koste van het levenspeil van de inheemse bevolking mogen gaan. Men zou Amerikaanse, Britse en Nederlandse burgers ertoe brengen met het militaire bestuur samen te werken; tegen hen die daar niet toe bereid zouden zijn zou men maatregelen treffen zoals deportatie. Men zou de inheemse bevolking een gevoel van vertrouwen in de Japanse strijdkrachten moeten bijbrengen en men zou een voortijdige aanmoediging van inheemse onafhankelijkheidsbewegingen moeten vermijden.

Op sommige punten is het feitelijke bezettingsbeleid in Indonesië van deze richtlijnen afgeweken. In het bijzonder zijn de geallieerde burgers behandeld op een manier die daar niet in was voorzien.

Met het oog op het te voeren bezettingsbeleid was het een belangrijke vraag, wat de toekomstige status van Indonesië zijn zou, maar juist hierover konden de Japanse leiders het lange tijd niet eens worden. De keus ging daarbij tussen onafhankelijkheid en annexatie. Bij het eerste dacht men aan formele onafhankelijkheid gepaard met feitelijke afhankelijkheid, zoals gold voor de door Japan gecreëerde staat Mandsjoekwo en voor de Chinese staat die Japan 
in het bezette deel van China in het leven had geroepen, met Nanking als hoofdstad. Daarentegen hield annexatie in dat Indonesië naar het voorbeeld van Korea en Formosa (Taiwan) een Japanse kolonie zou worden, waar Japanners de sleutelposities in het bestuur en de economie zouden bezetten en de Indonesiërs tweederangsburgers zouden worden.

Binnen de regering leek men ervoor te voelen een deel van Indonesië onafhankelijk te maken. Zo voorzagen plannen van het ministerie van buitenlandse zaken in het scheppen van een onafhankelijke federatieve staat die in elk geval Java, Sumatra en Celebes zou omvatten, terwijl andere delen van de archipel onder rechtstreeks Japans bestuur zouden kunnen komen. De leiders van de strijdkrachten wilden daarentegen het hele gebied onder Japans bestuur brengen, vooral wegens zijn belang als leverancier van voor Japan onmisbare grondstoffen. Omdat de contactraad hier geen overeenstemming over bereikt had, spraken de richtlijnen van 20 november 1941 alleen van het vermijden van een 'voortijdige' aanmoediging van inheemse onafhankelijkheidsbewegingen.

Nadat Java bezet was, ontstond in de loop van 1942 bij de leiding van het 16de Leger enig onbehagen over de getroffen regelingen. $\mathrm{Zij}$ wees Tokio op de ondoelmatigheid van de administratieve splitsing van de archipel en sneed de mogelijkheid aan om over het verlenen van onafhankelijkheid te spreken. Dit stuitte af op verzet van de generale staven van landmacht en marine. In de eerste helft van 1943 hield de contactraad zich enige malen met de toekomstige status van de bezette gebieden bezig. Men besloot aan Birma en de Filippijnen onafhankelijkheid te verlenen, maar de generale staven volhardden in hun verzet tegen onafhankelijkheid voor Indonesië. In mei 1943 werd de knoop tenslotte doorgehakt: de contactraad besloot dat Indonesië uiteindelijk bij het grondgebied van Japan ingelijfd zou worden. Men hield het principebesluit tot annexatie echter voorlopig geheim.

In 1944 werden in Tokio pogingen ondernomen om dit annexatiebesluit te herzien. In het midden van dat jaar staakte de landmachtstaf zijn verzet tegen Indonesische onafhankelijkheid, maar de marine bleef dit afwijzen voor gebieden onder haar gezag. Uiteindelijk verklaarde de Japanse regering in september 1944 dat zij besloten had de onafhankelijkheid van 'de Oostindische bevolking' in de toekomst te erkennen, maar zij zweeg daarbij over het tijdstip waarop dit zou gebeuren en over het gebied waaruit de nieuwe staat zou bestaan. Pas in het voorjaar van 1945, toen Amerika de Filippijnen heroverd had, gaf de marinestaf zijn verzet tegen onafhankelijkheid voor Indonesië op. Toch duurde het nog tot juli 1945 voordat de Japanse leiding formeel besloot dat die onafhankelijkheid het hele grondgebied van Nederlands-Indië zou betreffen. Dit besluit was nog niet uitgevoerd toen Japan capituleerde. 


\section{De beginfase van de Japanse bezetting}

De drie door Japan in Indonesië ingestelde militaire besturen keerden zich tegen de hier levende verlangens naar onafhankelijkheid, in weerwil van de eerst door de Japanse propaganda daaraan gegeven steun. Eén van de eerste daden van het Japanse bestuur op Java was de uitvaardiging van een algemeen verbod op verenigingen en vergaderingen. Indonesische nationalisten konden wel denken dat dit slechts een tijdelijke ordemaatregel was (ook scholen, banken en rechtbanken bleven voorlopig gesloten), maar het verbod was wel degelijk definitief bedoeld en ook tegen hen gericht. Op 20 maart kondigde het bestuur een verbod af op het uitsteken van de nationalistische rood-witte vlag en op het zingen van het 'Indonesia Raja'. Bovendien werd het verboden om besprekingen te voeren of voorstellen te doen over de inrichting van het landsbestuur. Aanleiding voor dit laatste waren in de pers verschenen berichten over het door Abikoesno gevoerde overleg ter voorbereiding van een Indonesische regering.

De Japanse bezetters waren volstrekt niet van plan zo'n regering aan te stellen en wilden bovendien liever steunen op de traditionele ambtsaristocratie dan op de nationalistische politici. Zij handhaafden de inheemse bestuursambtenaren dan ook in hun functies, ook degenen die door volkscomités waren afgezet. Zelfs de Nederlandse ambtenaren moesten hun werk voortzetten, al werden de hogere functionarissen zoals gouverneurs, residenten, burgemeesters en rechters al snel van hun taak ontheven. Het militaire bestuur verving deze Nederlandse functionarissen meestal niet door Indonesiërs, maar door Japanners. Vooral de aanstelling van Japanse burgemeesters schokte de nationalisten. Op plaatselijk niveau probeerden sommige volkscomités zich nog voor de bezetters verdienstelijk te maken, maar die gingen daar nauwelijks op in. Binnen enkele maanden was aan al deze comités een eind gemaakt. Een bijzonder bittere teleurstelling wachtte de nationalisten die op Sumatra en Celebes tegen het koloniale gezag waren opgestaan. De Japanners herstelden niet alleen de door hen afgezette hoofden in hun functies, maar namen zelfs verscheidene leiders van de opstandelingen gevangen.

De bezettingsautoriteiten wilden geen voedsel geven aan het Indonesisch nationalisme. Zij vermeden dan ook het woord Indonesië en duidden de archipel aan als To-Indo (Oost-Indië). De bevolking van de archipel zou zich niet op Indonesië maar op Japan moeten oriënteren. Terwijl de bezetters zowel de Nederlandse als de Indonesische vlag verboden, verplichtten zij de bevolking om bij allerlei gelegenheden de Japanse vlag uit te steken. Alle openbare bijeenkomsten moesten beginnen met een buiging in de richting van Tokio, als eerbetoon aan de keizer. Op straat moest men buigen voor iedere Japanse officier en iedere Japanse schildwacht. Eind maart werden de klokken gelijk gezet met die van Tokio, zodat de zon voortaan niet meer om zes uur maar 
om half acht opging. Een maand later werd de Japanse jaartelling ingevoerd, die op de westerse jaartelling 660 jaar voor lag, zodat men van 1942 overstapte naar 2602.

Volgende stappen waren de verwijdering van Nederlandse opschriften, de sluiting van in het Nederlands verschijnende kranten en een verbod op het gebruik van de Nederlandse taal in correspondentie en telegrammen. Het belangrijkste dagblad op Java werd de in het Indonesisch verschijnende AsiaRaya (Groot-Azië). De uitschakeling van het Nederlands betekende niet dat het Indonesisch daar zonder meer voor in de plaats trad, want Japan wilde nu het Japans zo snel mogelijk tot de algemene verkeerstaal van Zuidoost-Azië maken. Overal in de archipel werden spoedcursussen Japans geopend. Bij de reorganisatie van het bestuur voerden de bezetters Japanse termen in voor de territoriale indeling en voor de leidende functies. Hetzelfde gebeurde bij de reorganisatie van de rechterlijke macht. In de steden kregen sommige belangrijke straten volledig Japanse namen.

De bezettingsautoriteiten probeerden alle verwijzingen naar de Nederlandse monarchie uit het openbare leven te verwijderen. Het Koningsplein in Batavia ging Gambir heten, een al langer bij de inheemse bevolking in zwang zijnde naam voor dit stadsdeel. Verder verbood het Japanse bestuur van begin af aan naar buitenlandse radiostations te luisteren en liet het vervolgens de radiotoestellen zo verzegelen dat ze niet op zulke stations afgestemd konden worden.

De bezetters voerden tal van Japanse feestdagen in. De geforceerde japanisering bereikte een voorlopig hoogtepunt met de verjaardag van de Japanse keizer op 29 april. Drie dagen achtereen moest men van alle huizen de Japanse vlag uitsteken. De kranten (ook de toen nog bestaande Nederlandse) moesten beschouwingen afdrukken op basis van de Japanse staatsideologie, onder meer over het goddelijke karakter van de keizer en de goddelijke oorsprong van de Japanse vlag. De verjaardag werd overal gevierd met het Japanse volkslied en met parades, optochten en sportwedstrijden. Ook maakten de bezetters op deze dag allerlei maatregelen bekend, zoals gedeeltelijke vrijlating van inheemse krijgsgevangenen, gedeeltelijke hervatting van de rechtspraak en heropening van de inheemstalige basisscholen (voortaan met Japans als verplicht vak). Het onderwijs op westerse grondslag werd niet hervat.

Terwijl de nationalisten ontgoocheld waren door de onderdrukking van hun politieke aspiraties, verloor het gros van de Indonesische bevolking ook om andere redenen haar sympathie voor de Japanse bezetters. De verplichting om in de richting van Tokio te buigen ergerde de moslims, voor wie juist het rituele buigen naar Mekka bijzondere betekenis had. Nog algemener ergernis wekte het brute optreden van veel Japanse militairen. Voor de oorlog had het gedrag van de in Indonesië wonende Japanners zich juist door hoffelijkheid gekenmerkt, maar nu kreeg men met Japanners te maken die schreeuwden, 
sloegen en schopten. Alle bevolkingsgroepen van Indonesië vonden dit gedrag kwetsend, ook al was het binnen de Japanse strijdkrachten heel gebruikelijk in de omgang van meerderen met minderen. In het bijzonder beschouwden de Indonesiërs slaan tegen het hoofd vanouds als een uitzonderlijke belediging; de Europeanen plachten hier rekening mee te houden, de Japanners niet.

\section{De inrichting van het bezettingsbestuur}

De commandant van het 16e Leger, generaal Imamura, verplaatste zijn hoofdkwartier op 16 maart van Bandoeng naar Batavia, waar hij zijn intrek nam in het voormalige paleis van de gouverneur-generaal. Intussen had hij al voor de Nederlandse capitulatie zijn eerste decreet voor Java en Madoera uitgevaardigd. Het hield onder meer in dat een militair bestuur werd ingesteld, dat de legercommandant alle bevoegdheden van de gouverneur-generaal overnam, dat alle in het bezette gebied bestaande bestuursorganen, wetten en regelingen voorlopig van kracht zouden blijven voorzover ze niet strijdig waren met de uitoefening van het militaire bewind, en dat zowel de ambtenaren als de bevolking hun gewone bezigheden dienden te hervatten. Overeenkomstige decreten werden afgekondigd in de andere delen van de archipel die onder Japans militair bestuur kwamen te staan.

Hoewel volgens dit decreet ook de Nederlandse ambtenaren met hun werk moesten doorgaan, namen de bezetters al in de eerste weken een aantal van hen gevangen. Op 22 april werden de Europese ambtenaren op Java officieel ontslagen, met uitzondering van de lager betaalden (meestal IndoEuropeanen). Bovendien werden de Nederlandse ambtenaren nu grotendeels geïnterneerd. Het bezettingsbestuur verving de ontslagen Nederlanders deels door Japanse militairen of burgerambtenaren, deels belastte het IndoEuropeanen of Indonesiërs met de waarneming van hun functies en deels liet het de functies voorlopig onvervuld. Overigens hield het een beperkt aantal Nederlandse ambenaren nog in dienst omdat het ze moeilijk missen kon.

Toen het 16e Leger Java bezette had het slechts een bescheiden aantal Japanse burgerambtenaren bij zich, maar men was van plan die spoedig uit Japan aan te vullen met honderden onder meer technisch, economisch en juridisch geschoolde deskundigen, grotendeels Japanners die al voor de oorlog in Indonesië gewerkt hadden. Deze aanvulling kon slechts in beperkte mate doorgaan, omdat de Amerikaanse marine het schip tot zinken bracht dat de belangrijkste groep deskundigen uit Japan vervoerde. Het militaire bestuur vertrouwde daarom in 1942 meer belangrijke functies aan Indonesiërs toe dan eerst beoogd was. In $1943 \mathrm{kreeg}$ het bestuur alsnog de beschikking over grote aantallen Japanse burgers, die nu in veel gevallen de plaatsen van Indonesiërs innamen. Dit wekte ongenoegen onder de laatsten, te meer omdat deze 
Japanners meestal weinig competent waren en alleen Japans kenden, zodat het eigenlijke werk toch op de schouders van het Indonesische personeel neerkwam. Later, vooral in het laatste oorlogsjaar, kregen Indonesiërs op Java in ruimere mate verantwoordelijke posten toebedeeld.

Op Sumatra schakelde het 25e Leger al in een vroeg stadium meer Indonesiërs in, omdat het nauwelijks over Japanse burgerambtenaren beschikte en het bovendien niet alleen de Nederlanders maar ook de Indo-Europeanen interneerde. Sumatra vormde eerst samen met Malakka één bestuursgebied, maar werd daar in 1943 van losgemaakt; het militaire bestuur zetelde sindsdien in Boekittingi (het vroegere Fort de Kock). De commandanten van het 16e en het 25e Leger hielden zich niet zelf met het dagelijkse bestuurswerk bezig. Zowel op Java als op Sumatra trad de stafchef van het leger op als hoofd van het militaire bestuur.

Ook in de gebieden onder marinebestuur werden zowel Nederlanders als Indo-Europeanen al in het begin geïnterneerd. Hier echter vertrouwde de marine de uitoefening van het bestuur juist aan Japanse burgerambtenaren toe, omdat zij ervan uitging dat deze gebieden voorgoed bij Japan ingelijfd zouden worden. Dit Japanse burgerbestuur had zijn hoofdzetel in Makassar op Celebes, waar aanvankelijk ook de Japanse marinecommandant zijn hoofdkwartier had (later verhuisde het marinehoofdkwartier naar Soerabaja). De marine vestigde een liaisonbureau in Batavia voor coördinatie met het 16e Leger.

De bezettingsautoriteiten voerden diverse bestuurlijke reorganisaties uit. Meestal betroffen die meer de terminologie dan de grondslagen van het door Nederland opgebouwde stelsel. Het belangrijkste verschil was de afschaffing van de Volksraad en de andere vertegenwoordigende raden. Daarentegen namen de bezetters het dubbele stelsel van het Binnenlands Bestuur over, dat een wezenskenmerk vormde van het Nederlandse koloniale bewind. De functies van het Inlandse korps bleven uitgeoefend door Indonesische bestuursambtenaren. Zij legden allen een eed van trouw aan Japan af, evenals de Midden-Javaanse vorsten en de andere feodale zelfbestuurders. De vroegere functies van het Europese korps gingen in de regel op Japanners over. Het militaire bestuur verdeelde het grondgebied van Java en Madoera (buiten de Midden-Javaanse vorstendommen) in zeventien residenties, grotendeels overeenkomstig de indeling onder het Nederlandse bewind. Gepensioneerde Japanse officieren en uit Taiwan en Korea overgeplaatste Japanse ambtenaren werden daar als residenten aangesteld. Pas eind 1943 benoemde het bestuur enkele Indonesiërs tot resident.

De bezettingsautoriteiten brachten op Java verscheidene veranderingen aan in de organisatie van het centrale bestuur. Het meest ingrijpend was de instelling van twee nieuwe departementen, namelijk van politie en van voorlichting. Het machtigste orgaan onder eerstgenoemd departement was de Kempeitai, 
een militaire politiedienst die zich vooral op de opsporing en vervolging van anti-Japanse activiteiten toelegde en daarbij veelvuldig gebruik maakte van foltering. Deze dienst kon personen die als vijand van Japan beschouwd werden eventueel zelf executeren. De Kempeitai vergrootte haar effectiviteit door het niet-Europese personeel van de PID over te nemen. De anti-nationalistische en anti-communistische instelling van de PID sloot goed aan bij die van de Kempeitai, maar onder het Nederlandse bewind plachten PID-agenten niet te folteren; in Japanse dienst deed een aantal van hen dit wel.

Het departement van voorlichting, de Sendenbu, hield zich onder meer bezig met controle op de pers en met het voeren van propaganda. Terwijl de Kempeitai tot taak had alle anti-Japanse activiteiten te onderdrukken, was het de taak van de Sendenbu een pro-Japanse geest onder de bevolking aan te kweken: zij was het belangrijkste instrument voor de beoogde japanisering. Overigens bevonden zich onder het Indonesische personeel van dit departement nog al wat jongeren die deel van de nationale beweging hadden uitgemaakt. De Sendenbu maakte voor de uitoefening van haar taak onder meer gebruik van de pers, de radio, films en toneel.

De bezettingsautoriteiten stelden sommige particuliere ondernemingen onder beheer van de centrale overheid. Zo brachten zij alle spoorwegondernemingen op Java bijeen in één overheidsbedrijf. Anderzijds kwamen ook veel westerse ondernemingen onder beheer van Japanse concerns.

De uitschakeling van de Nederlandse rechters dwong het militaire bestuur tot een vereenvoudiging van de rechtspleging, ook al werden zij gedeeltelijk door Japanse rechters vervangen. Bij de reorganisatie van de rechterlijke macht verdwenen de organen die vroeger belast waren met de berechting in eerste aanleg van Europeanen. Daarmee verdween tegelijk de raciale discriminatie die het vroegere stelsel gekenmerkt had, toen Europeanen berecht werden door andere organen dan niet-Europeanen en op basis van een met meer waarborgen omkleed strafprocesrecht. Bij de gewone rechtspleging voerden de bezetters bovendien de scheiding tussen rechterlijke en uitvoerende macht verder door dan in het Nederlands-Indische bestel het geval was geweest. Dit gold echter niet voor de rechtspleging ten aanzien van personen die van anti-Japanse activiteiten verdacht werden; zij werden berecht door Japanse militaire rechtbanken die nauw verbonden waren met de Kempeitai.

Hoewel het Japanse leger zich voor het besturen van Java op het koloniale overheidsapparaat baseerde, knoopte het daarnaast toch enige banden aan met de Indonesische nationale beweging. Dit betrof in de eerste plaats Mohammad Hatta, die door het Nederlands-Indische gouvernement in Soekaboemi geïnterneerd was: het militaire bestuur haalde hem naar Batavia en stelde hem aan als algemeen adviseur. Het wist niet dat Hatta nog in december had opgeroepen tot bestrijding van het Japanse imperialisme. Hatta aanvaardde zijn benoeming pas nadat hij garanties verkregen had voor een voldoende 
onafhankelijke positie. Hij kon een eigen staf vormen waarin hij verscheidene nationalisten opnam, onder wie Soebardjo, wiens vroegere verblijf in Tokio nu het contact met Japanners vergemakkelijkte, en professor Soepomo, die aan de Rechtshogeschool gedoceerd had en lid van de commissie-Visman geweest was. De Kempeitai betreurde de inschakeling van Hatta; evenals destijds de PID beschouwde zij hem als een communist.

Onder de Japanners die tijdens de bezetting functies op Java uitoefenden waren er enkelen die een bijzondere rol gespeeld hebben door hun contacten met nationalisten. Eén van hen was S. Miyoshi, een consulair ambtenaar die voor de oorlog enige jaren in Den Haag en vele jaren in Nederlands-Indië gediend had, die Nederlands en Indonesisch sprak en goed op de hoogte was van de Indonesische nationale beweging. Hij had deelgenomen aan de Nederlands-Japanse onderhandelingen in Batavia in 1940-1941 (zie pp. 246) en aan de capitulatiebespreking op 8 maart 1942 op het vliegveld Kalidjati (zie p. 267). Tijdens de bezetting was hij de voornaamste contactpersoon tussen het Japanse bestuur en prominente Indonesiërs. Miyoshi was een nuchtere man die vooral met Hatta een nauwe band kreeg. Een heel andere figuur was S. Nishijima, die als burger-ambtenaar aan het liaisonbureau van de Japanse marine verbonden was. Hij was een voormalige communist die voor de oorlog enige jaren voor een Japanse firma op Java gewerkt had; hij had toen zowel Nederlands als Indonesisch geleerd en een goede verstandhouding met sommige nationalisten opgebouwd, in het bijzonder met Soebardjo. In de derde plaats moet zijn chef worden vermeld, T. Maeda. Deze was voor de oorlog marine-attaché in Den Haag geweest, had in 1940-1941 ook deel uitgemaakt van de Japanse delegatie tijdens de onderhandelingen in Batavia en had toen contacten met Indonesische nationalisten gelegd. In het najaar van 1942 keerde hij in Batavia terug als liaisonofficier van de marine, met de rang van schout-bij-nacht (gelijk aan generaal-majoor bij de landmacht). Maeda verstond geen Indonesisch, maar in tegenstelling tot de marineleiding stelde hij zich positief op tegenover de Indonesische nationale beweging. Soebardjo kende hij al uit zijn tijd als marine-attaché in Den Haag. Toen deze begin 1943 door de Kempeitai gevangen gezet was, nam Maeda hem na zijn vrijlating zelf in dienst.

\section{De Tiga A Beweeging}

De door de bezetters beoogde japanisering van Indonesië bracht zowel de invoering van Japanse elementen mee als de verwijdering van Nederlandse en andere westerse elementen. Toch betekende dit geen verdwijning van alles wat westers was, aangezien de Japanse cultuur zelf allerlei westerse elementen in zich opgenomen had, niet alleen op technisch en militair maar ook op artistiek 
en ideologisch terrein. Zo was de stijl van het Japanse propagandamateriaal duidelijk geïnspireerd door Europese en Amerikaanse voorbeelden. Tegelijk kenmerkte het Japan van de jaren dertig zich door een massale mobilisering van de bevolking die veel overeenkomst vertoonde met wat toen in Europese totalitaire landen als Italië, Duitsland en Rusland plaatsvond. Daaraan lag een visie op de verhouding tussen staat en individu ten grondslag die sterk verschilde van de opvattingen die in Nederland en Nederlands-Indië gangbaar waren.

Het Nederlands-Indische bestel kende een duidelijk onderscheid tussen overheid en onderdaan. Weliswaar had dit bestel voor de inheemse bevolking het karakter van een politiestaat met een ernstige beknotting van de politieke vrijheid (zie pp. 227-8), maar voorzover de onderdanen zich aan de voorgeschreven regels hielden, liet de overheid hen met rust. Particuliere burgers konden zich verenigen in organisaties als zij dit wilden; particuliere (niet-gouvernementele) organisaties waren in beginsel vrijwillige organisaties. De Japanse machthebbers gingen van een heel andere visie uit. Zij waren niet bereid de onderdanen met rust te laten als die zich aan de regels hielden: de onderdanen moesten actief meedoen met de overheid en moesten daartoe van bovenaf georganiseerd worden. De Japanse bezetters lieten de bevolking veelvuldig in theatrale manifestaties bijeenkomen om te defileren, te zingen, te juichen, te buigen, met vlaggetjes te zwaaien en naar toespraken te luisteren. Op Java installeerden zij in steden en dorpen duizenden publieke radioluidsprekers; de bevolking werd van tijd tot tijd verplicht zich bij die luidsprekers te verzamelen om bekendmakingen en redevoeringen aan te horen. De bezetters probeerden voortdurend de bevolking in georganiseerde verbanden onder te brengen; daarbij vervaagde het onderscheid tussen gouvernementele en nietgouvernementele organisaties. Zo plaatste het militaire bestuur herhaaldelijk overheidsfunctionarissen in de leiding van particuliere organisaties en richtte het soms zelf particuliere organisaties op.

De eerste onderneming in dit kader was een door de Sendenbu ontworpen campagne onder de leuze 'Japan is het licht van Azië, Japan is de beschermer van Azië, Japan is de leider van Azië'. De Sendenbu noemde deze leuze 'de drie A's' (in het Indonesisch Tiga A). De campagne begon op Java al enige weken na de Nederlandse capitulatie. Het AAA-symbool verscheen op spandoeken en gebouwen. De Japanse propagandisten wilden onder deze leuze een massabeweging vormen en zochten daartoe steun bij de Parindra, voor de oorlog de meest op Japan georiënteerde van de politieke partijen. De Tiga A Beweging begon haar bestaan op 29 april, de verjaardag van de keizer. Een vooraanstaand Parindra-lid werd de officiële leider, maar de werkelijke leiding bleef in Japanse handen. Verscheidene plaatselijke Tiga A-afdelingen zagen het licht; ze hielden zich onder meer bezig met politieke indoctrinatie en Japanse taallessen. De beweging richtte een algemene jeugdbond op, opende 
enige scholen voor jeugdleiders en probeerde overal jeugd-, vrouwen- en sportgroepen te vormen. Op haar initiatief kwam een unie van christelijke organisaties tot stand, geleid door onder meer Moelia en Amir Sjarifoeddin. Ook stelde zij een commissie onder Abikoesno in ter voorbereiding van een organisatie voor alle moslims. De beweging wilde haar vleugels niet alleen over inheemse Indonesiërs uitstrekken, maar ook over Indo-Europeanen, Chinezen en Arabieren. Onder haar auspiciën werden een Chinezenbond en een Arabierenbond gesticht.

Intussen verzachtte het militaire bestuur in juni zijn verbod op verenigingen. Politieke organisaties bleven streng verboden, maar verenigingen op het gebied van ontspanning, lichamelijke oefening, wetenschap en kunst werden weer toegestaan, al moest men daar wel van geval tot geval vergunning voor aanvragen. Het bestuur moedigde particuliere verenigingen aan om zich bij de Tiga A aan te sluiten.

Ondanks haar tomeloze organisatorische activiteiten bleek de Tiga A Beweging geen succes. Onder de bevolking vond zij weinig weerklank en noch de inheemse bestuursaristocratie noch de nationalisten gaven haar krachtige steun. De militaire besturen op Sumatra en in het marinegebied waren niet bereid zich bij de actie aan te sluiten. In oktober 1942 werd de Tiga A Beweging opgeheven.

\section{Japan in het defensief}

Het op 8 december 1941 geopende Japanse offensief in de Stille Oceaan en Zuidoost-Azië had binnen vijf maanden al zijn strategische doelstellingen bereikt, maar meteen daarna kwam er een eind aan Japan's militaire successen. Al op 7 en 8 mei 1942 leed de Japanse marine ernstige verliezen in een zeeslag ten oosten van Nieuw-Guinea. Intussen hadden Amerikaanse bommenwerpers op 18 april Tokio gebombardeerd. Om herhaling hiervan te voorkomen wilden de Japanse militaire leiders de tussen Japan en Hawaii gelegen basis Midway veroveren. Zij stuurden daar een grote strijdmacht heen, maar de Amerikaanse marine bracht deze strijdmacht begin juni een verpletterende nederlaag toe. Japan verloor onder meer vier vliegdekschepen, een groot aantal vliegtuigen en de geoefende kern van zijn marine-luchtmacht. Het kwam dit verlies niet meer te boven en werd in het defensief gedrongen.

In het Australische deel van Nieuw-Guinea dreven Australische en Amerikaanse strijdkrachten sinds juli de Japanse troepen naar het noorden terug. Ten oosten van Nieuw-Guinea landden Amerikaanse mariniers in augustus op het eiland Guadalcanal, dat een belangrijk Japans vliegveld herbergde. Het duurde tot februari 1943 voordat Guadalcanal definitief in Amerikaanse handen was, maar in de loop van 1943 wisten de geallieerden 
steeds meer door Japan bezette eilanden te heroveren. Amerikaanse onderzeeboten bestookten onafgebroken de Japanse transportvloot. Het verlies van de Japanse heerschappij ter zee bemoeilijkte voortaan de verbindingen tussen Japan en de bezette gebieden in Zuidoost-Azië en ook tussen die gebieden onderling.

\section{De Japanse behandeling van de krijgsgevangenen}

Tijdens de strijd in Indonesië maakten de Japanse strijdkrachten tienduizenden krijgsgevangenen, onder wie ongeveer 40.000 blanke Nederlanders en Indische Nederlanders, ruim 50.000 Indonesiërs en ruim 20.000 Britten, Australiërs en Amerikanen. De Nederlandse groep telde een 15.000 beroepsmilitairen en een 25.000 gemobiliseerden. Enkele duizenden Nederlandse en Indonesische KNIL-militairen hadden zich aan krijgsgevangenschap weten te onttrekken.

Tot de krijgsgevangenen behoorde ook gouverneur-generaal Tjarda van Starkenborgh Stachouwer, die het opperbevel over de Nederlands-Indische strijdkrachten op 6 maart in opdracht van zijn regering had neergelegd en die na de capitulatie eerst huisarrest in Bandoeng gekregen had. De Japanse autoriteiten stelden echter vast dat het opperbevel volgens de Nederlandse wet bij de gouverneur-generaal berustte, dat het neerleggen ervan dus niet rechtsgeldig was en dat men Tjarda daarom als krijgsgevangene moest beschouwen. Zij sloten hem begin april in de Soekamiskin-gevangenis op en brachten hem vervolgens naar een kazerne in Batavia over. Later werd hij samen met andere hoge ambtsdragers en officieren eerst op Taiwan en uiteindelijk in Mandsjoerije gevangen gehouden.

De krijgsgevangenen werden in eerste aanleg in hun kazernes geïnterneerd. In het begin kwam het herhaaldelijk voor dat gevangenen deze terreinen verlieten, hetzij om te vluchten hetzij alleen maar om hun gezin op te zoeken, maar de Japanse bevelvoerders maakten hier hardhandig een eind aan. Niet alleen sloten ze de terreinen met bamboe en prikkeldraad af, maar ook lieten ze tientallen gepakte kampverlaters ter dood brengen. Meestal gebeurde dat met bajonetsteken en altijd moesten de medegevangenen daarbij toekijken.

De Japanse autoriteiten scheidden de Nederlandse en geallieerde van de Indonesische krijgsgevangenen. Van de laatsten hielden zij de Ambonese, Menadonese en Timorese KNIL-militairen voorlopig gevangen, terwijl ze de anderen meestal vrijlieten, met uitzondering van de officieren. Een groot deel van de vrijgelaten soldaten ronselden zij voor dienstneming als Heiho (hulpsoldaat) in het Japanse leger. Later dwongen zij ook de meeste Ambonese, Menadonese en Timorese krijgsgevangenen om tot de heiho-formaties toe te treden; die dwang bestond vaak uit mishandeling en soms uit terechtstelling 
van hen die weigerden. De hulpsoldaten maakten deel uit van de Japanse strijdkrachten en konden overal heen worden gestuurd, vaak als ongewapende arbeidskrachten. In totaal zijn ongeveer vijftienduizend voormalige KNILmilitairen als heiho ingezet; bijna de helft daarvan is niet teruggekeerd.

De Nederlandse en geallieerde krijgsgevangenen op Java werden in de loop van 1942 op vier plaatsen bijeengebracht. In het najaar begon Japan de krijgsgevangenen, zowel die op Java als die daarbuiten, als arbeidskrachten in te zetten. Men gebruikte hen vooral voor de uitvoering van grote werken, zoals de aanleg van vliegvelden, wegen en spoorwegen, en voor arbeid in mijnen en op scheepswerven. Daartoe transporteerde men hen naar allerlei gebieden binnen en buiten de archipel. De eerste transporten uit Java vonden in september 1942 plaats. Nederlandse krijgsgevangenen werden aldus onder meer ingezet op Sumatra, Ambon en Flores en in Japan, Thailand en Birma. Op Sumatra werkten zij in het bijzonder aan de aanleg van een spoorlijn en van een autoweg dwars over het eiland. Het grootste Japanse project was de aanleg van een spoorlijn van Thailand naar Birma. In beide gevallen ging het om vervanging van verbindingen overzee die Japan niet goed meer gebruiken kon wegens het verlies van zijn maritieme overwicht.

De krijgsgevangenen werden hard aangepakt. Het werk was zwaar, de verzorging slecht. Velen vonden de dood door uitputting, ziekte en ondervoeding of door mishandelingen en terechtstellingen. Bovendien kwamen duizenden tijdens de transporten om het leven als gevolg van torpedering door de geallieerden van de schepen waarmee zij vervoerd werden. Uiteindelijk heeft een vijfde van de Nederlandse krijgsgevangenen de oorlog niet overleefd.

\section{Internering van de Nederlandse burgers}

Gedurende de bezetting beroofde Japan de Nederlanders in Indonesië van hun vrijheid en verwijderde het hen uit de samenleving. Zulk een radicale uitschakeling hadden zij niet verwacht. Velen van hen hadden gedacht dat de koloniale maatschappij zonder hun medewerking niet zou kunnen functioneren. Bovendien hadden in het door Duitsland bezette Nederland zowel ambtenaren als burgers hun bezigheden gewoon kunnen voortzetten. Belangrijker was nog dat hetzelfde gold voor de Franse ambtenaren en particulieren in het door Japan bezette Indochina, waar zelfs de Franse gouverneur-generaal zijn functie behouden had.

Terwijl enerzijds de Fransen in Indochina waren gebleven, hadden anderzijds in de eerste fase van de oorlog met Japan de meeste Britse niet-militairen de Britse gebieden verlaten voordat deze in vijandelijke handen kwamen. Dit betrof vooral vrouwen en kinderen, maar ook zakenlieden en ambtenaren; zij trokken zich grotendeels naar India en Australië terug. Ook werd in diezelfde 
tijd het merendeel van de Amerikaanse burgers uit de Filippijnen geëvacueerd. Daarentegen bleven vrijwel alle blanke Nederlanders en hun gezinnen in Nederlands-Indië. Eén reden daarvoor was dat zij niet naar hun moederland konden terugkeren nu dit door Duitsland bezet was. Het ging om bijna 90.000 mensen; men kon die ook niet zomaar naar India, Australië of Zuid-Afrika overbrengen. Daarvoor zou trouwens niet genoeg scheepsruimte beschikbaar zijn geweest, nog los van de vraag of men bij zo'n evacuatie wel onderscheid had mogen maken tussen blanke en Indische Nederlanders. Een belangrijker reden voor het blijven van de Nederlanders was de overtuiging dat Nederlands-Indië bij Nederland hoorde en dat men het daarom niet in de steek mocht laten. De opstelling van het Nederlands-Indische gouvernement werd geheel door deze overtuiging bepaald. Het verleende dan ook geen medewerking aan vertrek van Nederlanders uit de archipel (behalve in enkele bijzondere gevallen) en gaf alle ambtenaren de strikte opdracht om op hun post te blijven. Wel werden buiten Java soms groepen Nederlandse burgers, in het bijzonder vrouwen en kinderen, naar veilig geachte plaatsen binnen de archipel geëvacueerd.

In de door Japan veroverde Britse gebieden en op de Filippijnen interneerden de bezetters al spoedig alle Britse, Amerikaanse en Nederlandse burgers die zij daar aantroffen, in totaal ongeveer 15.000 personen. Hetzelfde deden zij op Sumatra en in de door de marine bestuurde delen van Indonesië; dit betrof ruim 17.000 personen. Daarbij interneerde men niet alleen blanke Nederlanders, maar ook veel Indische Nederlanders.

Op Java vond daarentegen in de eerste fase geen massale internering van Nederlandse en geallieerde burgers plaats. Het probleem had hier een andere dimensie, want als de bezetters dezelfde criteria toepasten zouden zij op Java 200.000 à 250.000 personen moeten interneren. Ook als zij de Indische Nederlanders hiervan zouden uitzonderen zou het nog om ruim 70.000 personen gaan. Generaal Imamura, die tot november 1942 het opperbestuur over Java voerde, vond dit niet verantwoord. Internering van een paar duizend sleutelfiguren uit bestuur en economie leek hem voldoende.

$\mathrm{Al}$ in de loop van maart werden in Batavia belangrijke personen uit bestuur, rechterlijke macht, politie, hoger onderwijs, bankwezen en handel gearresteerd. De bezetters plaatsten hen in een gevangenis en motiveerden dit als vergelding voor de internering van Japanse burgers in december 1941. Intussen bevond het merendeel van de hoogste Nederlands-Indische functionarissen zich in Bandoeng, waarheen ze voor de capitulatie geëvacueerd waren. Dit betrof onder meer departementshoofden, leden van de Raad van Indië en de voorzitter van de Volksraad. $\mathrm{Nu}$ de gouverneur-generaal onder huisarrest stond en zijn functie niet meer kon uitoefenen terwijl zijn plaatsvervanger Van Mook buitenslands was, berustte de hoogste verantwoordelijkheid bij de vicevoorzitter van de Raad van Indië, H.J. Spit. Op diens initiatief kwamen enige tientallen hoge functionarissen herhaaldelijk bijeen voor overleg over de vraag 
hoe men in de nieuwe situatie moest handelen. Allen, onder wie Jonkman, werden eind maart als samenzweerders door de Kempeitai gearresteerd; zij werden in de Soekamiskin-gevangenis opgesloten.

In samenhang met het ontslag van de ambtenaren volgde eind april op heel Java de gevangenneming van duizenden Nederlandse mannen, onder wie alle ambtenaren met een maandsalaris van tenminste $f 300$. Sommigen kwamen al spoedig weer vrij; dit betrof zowel Indische Nederlanders als deskundigen die hun werk in opdracht van de bezetters moesten hervatten.

In april verplichtte het militaire bestuur alle Europeanen op Java zich te laten registreren en daarbij trouw te zweren aan het Japanse leger. Iedere geregistreerde kreeg een persoonsbewijs met foto en vingerafdruk, waarop onder meer vermeld stond of men volbloed Europeaan dan wel Indo-Europeaan was. De registratieplicht gold ook voor Chinezen en Arabieren. Veel Nederlanders verwachtten van het bezit van zulk een persoonsbewijs een zekere bescherming, maar die verwachting werd niet bewaarheid.

Tot eind april konden de meeste Nederlanders op Java hun gewone leven nog min of meer voortzetten en daarbij lag het niet in hun aard zich uiterlijk als verslagenen te gedragen. Aan Japanse kant wekte dit irritatie, ook bij het hoofdkwartier voor de zuidelijke gebieden in Singapore en onder hoge bezoekers uit Japan. Men vond Imamura's aanpak te zacht. Daar kwam bij dat Tokio de omvang van de bezettingsmacht op Java drastisch wilde verminderen omdat de soldaten aan het front nodig waren. Hoewel Imamura zich er op kon beroepen dat de richtlijnen van 20 november 1941 in het geheel niet voorzagen in totale internering van de Nederlanders, zag hij zich toch genoopt stappen in die richting te doen. Hij besloot nu tot internering van alle werkloze blanke Nederlandse mannen van 17 tot 60 jaar. Dit besluit werd op een chaotische manier uitgevoerd, in de eerste plaats door razzia's in de steden waarbij men mannen op straat oppakte of uit hun huizen haalde. Daarnaast riep men in sommige plaatsen de betrokkenen op zichzelf te melden. De razzia's vonden van mei tot oktober plaats en werden meestal uitgevoerd door Indonesisch politiepersoneel dat nog kort daarvoor het Nederlands-Indisch gouvernement gediend had. In de periode waarin deze actie liep nam het aantal werkloze Nederlanders voortdurend toe, omdat de meesten nu ook uit particuliere betrekkingen ontslagen werden. Aldus belandden tienduizenden Nederlandse burgers in gevangenschap. Uiteindelijk bleven er slechts enkele duizenden over die in opdracht van de bezettingsmacht aan het werk dienden te blijven. $\mathrm{Zij}$ moesten een witte armband dragen met een rode bal en diverse Japanse stempels. Hoewel ze niet geïnterneerd werden, werd op de duur ook hun bewegingsvrijheid beperkt.

De gevangengenomen mannen werden in het begin grotendeels ondergebracht in gebouwen als scholen, hotels of fabrieken die als interneringsoorden werden ingericht. In de loop van 1943 concentreerde men hen in een 
klein aantal plaatsen in barakken die vrijkwamen door de overbrenging van krijgsgevangenen naar gebieden buiten Java. De leiding van de kampen was gewoonlijk in Japanse handen; de bewaking bestond uit Indonesische politie.

Behalve dat de Nederlandse mannen geïnterneerd werden, was ook de betaling van hun salarissen en pensioenen stopgezet, wat leidde tot verpaupering van de achtergebleven Nederlandse vrouwen. In een aantal steden verplichtten de bezetters deze vrouwen in het najaar van 1942 om met hun kinderen te verhuizen naar beschermde woonwijken. Eerst was dit nog geen internering en konden de vrouwen die wijken nog verlaten om inkopen te doen, maar in 1943 kwam hier een eind aan: de wijken werden afgesloten en met bamboe en prikkeldraad omheind. Naast de aldus gevormde interneringskampen werden in Midden-Java nog aparte vrouwenkampen in oude kazernes ingericht. Alle Nederlandse vrouwen en kinderen op Java moesten voortaan in interneringskampen wonen. Ook hier bestond de bewaking uit Indonesische politie onder Japanse leiding. Verder werden nu ook de mannen van ouder dan 60 jaar geïnterneerd.

Wat hierboven over Nederlanders vermeld is, gold uiteraard ook voor blanken die onderdaan waren van andere landen in oorlog met Japan, zoals Amerikanen, Australiërs en Britten. Onderdanen van neutrale of met Japan verbonden landen, zoals Zwitsers en Duitsers, bleven vrij. Anderzijds werd op Java ook een aantal prominente Chinezen geïnterneerd. Indo-Europeanen vielen op Java in beginsel buiten de internering. In 1942 was het hiertoe voldoende dat men één Indonesische voorouder had, maar in 1943 veranderde dit: ieder waarvan meer dan de helft van de voorouders blank was werd alsnog geïnterneerd.

In april 1944 kwamen alle burgerinterneringskampen op Java en Sumatra onder rechtstreeks bestuur van het leger te staan. Sindsdien verslechterde de situatie aanzienlijk. De leiding berustte nu bij Japanse officieren en onderofficieren, terwijl soldaten (merendeels Koreanen, deels ook Indonesische heihohulpsoldaten) de bewaking overnamen van de politie. De geïnterneerden werden voortaan als krijgsgevangenen behandeld en aan een strenger regime onderworpen. Zowel mannen als vrouwen moesten arbeid voor het leger verrichten. Alle jongens van elf jaar en ouder werden uit de vrouwenkampen naar mannenkampen of aparte jongenskampen overgebracht. De bezetters verkleinden het aantal kampen, zodat die steeds voller werden. Bovendien ging de voeding sinds midden-1944 sterk achteruit. Een en ander leidde tot ziekte en ondervoeding op grote schaal en vooral in 1945 tot aanzienlijke sterfte. Ook in de kampen in het marinegebied was de situatie meestal slecht.

In totaal zijn tijdens de Japanse bezetting bijna honderdduizend burgers in Indonesië geïnterneerd geweest. Daarvan is een zesde deel tijdens de internering overleden. 


\section{Terugkeer van Soekarno naar Java}

Soekarno, die sinds 1938 als balling in Benkoelen in Zuidwest-Sumatra woonde, was na het uitbreken van de oorlog bang geweest om in Japanse handen te vallen omdat hij zich in persartikelen tegen Japan had gekeerd. Hij had daarom in februari 1942 een dringend beroep op de gouverneur-generaal gedaan om hem naar Australië af te voeren, maar deze had besloten hem in Sumatra te laten zitten. Intussen had het plaatselijke BB in afwachting van Tjarda's beslissing Soekarno al met zijn vrouw en enkele huisgenoten naar de havenstad Padang overgebracht. De Japanse troepen trokken daar op 17 maart binnen. Soekarno's vrees bleek ongegrond; kennelijk waren de bezettingsautoriteiten evenmin van zijn artikelen op de hoogte als van Hatta's anti-Japanse publicaties. Soekarno werd voorzitter van het Padangse volkscomité en verklaarde zich tegenover het militaire bestuur bereid om Japan actief te steunen mits hij zijn streven naar Indonesische onafhankelijkheid niet hoefde op te geven.

Een en ander was aan de bevolking op Java niet bekend, maar wel vroegen enige jongerenorganisaties het militaire bestuur in Batavia om Soekarno uit zijn ballingschap te laten terugkeren. Daartoe aangemoedigd door sommige adviseurs, onder wie Hatta, wilde generaal Imamura hier gevolg aan geven omdat hij profijt hoopte te kunnen trekken van Soekarno's populariteit. Hij had hiertoe de medewerking nodig van de opperbevelhebber voor de zuidelijke gebieden, generaal Terauchi, onder wie ook het 25e Leger op Sumatra ressorteerde. Terauchi raadde het eerst af, maar gaf na verdere aandrang van Imamura toe. Japanse politie bracht Soekarno daarop per motorboot naar Batavia, waar hij op 9 juli aankwam en werd afgehaald door Hatta en enige andere bekenden. Die avond bezochten enkele nationalistische voormannen, onder wie Yamin, Sartono en Sjahrir, hem in Hatta's huis. Na vertrek van de anderen voerden Soekarno, Hatta en Sjahrir nog een lang gesprek. Daarbij bleek Soekarno er volstrekt van overtuigd te zijn dat Japan en Duitsland de oorlog zouden winnen, terwijl Hatta en Sjahrir dachten dat ze die uiteindelijk zouden verliezen. Niettemin hoopte Hatta in het belang van de Indonesische bevolking een goede invloed op de Japanse bezetters te kunnen uitoefenen. Sjahrir wilde daarentegen op geen enkele manier met de bezetters samenwerken. De volgende dag werd Soekarno door Imamura ontvangen. Deze zei geen toezeggingen te kunnen doen over de toekomstige status van Indonesië, maar de opvattingen van Soekarno te kennen en te respecteren. Soekarno verklaarde zich bereid het volk in Japanse richting te leiden, mits men hem na de oorlog geen beperkingen zou opleggen.

In juli-augustus maakte Soekarno samen met Sartono een rondreis van enige weken door Java. Hij bezocht alle grote steden en werd overal door grote menigten verwelkomd. In Jogjakarta bracht hij een bezoek aan Ki Hadjar Dewantoro; bij hem sprak hij ook met de moslimleider kiai Mansoer. Na zijn 
terugkeer in Batavia voerde hij verder overleg met het militaire bestuur. Dit was teruggekomen van de exclusieve japaniseringskoers die onder meer geleid had tot het onderdrukken van de nationale beweging en tot het lanceren van de Tiga A Beweging. Men wilde meer gebruik gaan maken van figuren uit de nationale beweging om steun onder de inheemse bevolking te verwerven of te behouden. Het belang van die steun nam toe nu het voor Japan ongunstige verloop van de oorlog leidde tot inkrimping van de bezettingsmacht. Intussen was het bezettingsbestuur niet van plan aan de nationalisten echte bestuurstaken te geven; die gaf het alleen aan leden van de traditionele ambtsaristocratie, terwijl het aan de nationalisten slechts raadgevende functies toebedeelde. Soekarno werd nu op dezelfde voet als Hatta algemeen adviseur. Hij mocht door Java reizen en toespraken houden, die overigens vooraf door Japanners gecensureerd werden.

Eind september besloot het militaire bestuur een Japans-Indonesische adviesraad in te stellen die traditionele gebruiken en instellingen zou moeten bestuderen, maar ook zou moeten proberen onder het publiek levende gevoelens te verwoorden. Deze raad werd begin november geïnstalleerd en kreeg een Japanse voorzitter. Tot de Indonesische leden behoorden Soekarno, Hatta, Abikoesno, Dewantoro, Hoesein Djajadiningrat, Mansoer, Moelia en Soepomo. De adviesraad kwam tweemaal per maand bijeen en gaf aldus enige leidende Indonesische politici gelegenheid elkaar regelmatig te ontmoeten. Bovendien deed het bezettingsbestuur een verdere stap terug van het japaniseringsbeleid door in de meeste steden Indonesische bestuursambtenaren tot burgemeester te benoemen.

Eveneens in het najaar stelde het militaire bestuur een taalcommissie in, die ook Soekarno en Hatta onder haar leden telde. Hoewel de commissie in de eerste plaats ingesteld was om het moderne Maleis te zuiveren van Nederlandse en andere westerse termen, bouwde zij in feite voort op het werk dat het koloniale bestuur al had verricht ter bevordering van een algemeen bruikbare Indonesische taal. Terwijl deze commissie werkte aan de ontwikkeling van de woordenschat en de grammatica van het Indonesisch, namen de bezetters verdere maatregelen om het Nederlands uit te bannen. De radio zond niet meer in het Nederlands uit en er kwam een verbod op het gebruik van Nederlands of Engels in telefoongesprekken. Intussen bleek de Japanse taal veel te moeilijk om op korte termijn de rol van het Nederlands te kunnen overnemen. Het Indonesisch werd daardoor tijdens de Japanse bezetting de overheersende verkeerstaal, wat onvermijdelijk het Indonesisch nationaal bewustzijn versterkte.

Het voornaamste doel waarvoor het militaire bestuur Soekarno wilde gebruiken was het aanvoeren van een nieuwe beweging om de massa's te mobiliseren ten behoeve van de Japanse oorlogsinspanning. In november belastte het hem tezamen met Hatta, Mansoer en Dewantoro met de voorbe- 
reiding van zulk een volksbeweging. Op 8 december 1942, bij de herdenking van het begin van de Pacific-oorlog, maakte het militaire bestuur bekend dat het deze vier personen erkende als leiders van de inheemse bevolking van Java. Bij dezelfde gelegenheid kondigde Soekarno op een massabijeenkomst in Batavia aan, dat de nieuwe volksorganisatie op 1 januari 1943 zou gaan functioneren. Ook deelde hij mee dat het bestuur besloten had aan de stad Batavia haar oude naam Djakarta terug te geven. In een door de Sendenbu georganiseerde publiciteitscampagne werd het door het bestuur aangewezen viermanschap betiteld als de Empat Serangkai (letterlijk 'vier-aan-één-tros').

Intussen was aan Imamura's functie als hoofd van het militaire bestuur over Java en Madoera een eind gekomen, omdat hij in november belast werd met het commando over de legers op de eilanden ten oosten van NieuwGuinea, het meest bedreigde deel van het Japanse front. Zijn opvolger, generaal Harada, was een aanhanger van de harde lijn. Niettemin handhaafde deze aanvankelijk de meer liberale koers die Imamura tegenover de Indonesische nationale beweging was ingeslagen.

\section{De 7-december-rede van koningin Wilhelmina}

Nadat luitenant-gouverneur-generaal Van Mook Nederlands-Indië kort voor de capitulatie verlaten had, bleef hij een maand in Australië om enigszins orde op zaken te stellen. Met machtiging van de Nederlandse regering installeerde hij in Melbourne een commissie ter behartiging van de Nederlands-Indische belangen in Australië en Nieuw-Zeeland. Van de niet-militaire functionarissen die in februari en maart 1942 op last van het gouvernement uit NederlandsIndië naar Australië uitgeweken waren, stuurde hij een deel naar Londen door, terwijl hij Van der Plas naar de Verenigde Staten dirigeerde. Er bevonden zich drie Indonesiërs onder de prominente figuren uit Nederlands-Indië die nu in het buitenland waren, namelijk de directeur onderwijs Loekman Djajadiningrat, het lid van de Raad van Indië Soejono en de bestuursambtenaar Abdoelkadir Widjojoatmodjo. Loekman bleef in Melbourne, Soejono ging naar Londen en Abdoelkadir was al in februari naar Amerika vertrokken om te werken bij het Netherlands Information Bureau in New York.

In de tweede helft van april reisde Van Mook via Amerika zelf naar Londen. Zowel koningin Wilhelmina als minister-president Gerbrandy wantrouwde hem als iemand voor wie Indië boven Nederland ging. Hij wilde in Australië een soort Nederlands-Indisch gouvernement-in-ballingschap opzetten, maar de Nederlandse regering stemde daar niet mee in, omdat zij vreesde daar weinig greep op te zullen hebben. Uiteindelijk aanvaardde Van Mook een andere constructie, namelijk dat hij zou worden ontheven van zijn functie van luitenant-gouverneur-generaal en weer benoemd tot minister van koloniën, de 


\title{
DAAR WÈRD WAT GROOTS
}

\section{VERRICHT....}

\section{Nederlandsch-Indië in de $\mathrm{xx}^{\text {ste }}$ eeuw}

\author{
SAMENGESTELD EN VERZORGD ONDER LEIDING VAN
}

Mr. W. H. VAN HELSDINGEN

OUD-VOORZITTER VAN DEN VOLKSRAAD

BIJGESTAAN DOOR

Mr. Dr. H. HOOGENBERK

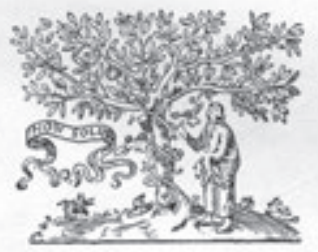

Met talrijke zwarte en gebleurde afbeeldingen in en buiten den tekst

AMSTERDAM - N.V. UITGEVERS-MAATSCHAPPIJ „ELSEVIER" - 1941

In 1941 verscheen in het toen door Duitsland bezette Nederland dit van trots op de Nederlandse prestaties in Indie vervulde verzamelwerk dat veel aspecten van de kolonie behandelde, maar de namen van Hatta en Soekarno kwamen er niet in voor 
functie die hij op papier ook al eind 1941 bekleed had. Als voorwaarde hiervoor liet Gerbrandy hem schriftelijk zijn instemming betuigen met enige politieke uitgangspunten, waarvan het eerste luidde: 'Er zal gevoerd worden een politiek waarbij Indië om het kort uit te drukken in direct Rijksverband blijft, een politiek welke Indië nimmer op zichzelf stelt, maar altijd als deel van het gehele Koninkrijk der Nederlanden'. Op 21 mei werd Van Mook als minister beëdigd. Voorlopig zou de minister van koloniën ook de bevoegdheden van het bestuur over Nederlands-Indië uitoefenen, maar zonder zeggenschap over de strijdkrachten. Op 9 juni werd op aandrang van Van Mook ook Soejono in het kabinet opgenomen, en wel als minister zonder portefeuille. Het was de eerste en de laatste keer dat een Indonesiër deel uitmaakte van de regering van het Koninkrijk der Nederlanden. Zijn ministerschap was van korte duur: Soejono stierf op 5 januari 1943 aan een hartaanval.

Eén van de eerste zaken waar Van Mook zich als minister aan wijdde betrof de verhouding tot Amerika. Nu het koninkrijk vrijwel al zijn machtsmiddelen verloren had, was dit voor het herstel van zijn gezag in Nederlands-Indië praktisch volledig afhankelijk geworden van de Verenigde Staten. Over de bereidheid van de Amerikanen om zich hiervoor in te zetten had Van Mook tijdens zijn doorreis door de Verenigde Staten alarmerende berichten vernomen. De daar al op grond van de nationale geschiedenis bestaande anti-koloniale gezindheid was door het verloop van de oorlog in Zuidoost-Azië versterkt. Men stelde de snelle ineenstorting van de Britse en Nederlandse verdediging tegenover het maandenlange standhouden van de Amerikaanse en Filippijnse soldaten. Het Filippijnse volk dat op de drempel van de onafhankelijkheid stond had zich tegen Japan verzet, terwijl de inheemse bevolking van de Britse en Nederlandse koloniën deels passief gebleven was en deels de Japanners zelfs verwelkomd had. Veel Amerikanen vonden dat het Britse en Nederlandse kolonialisme na de oorlog plaats zou moeten maken voor zelfbeschikking en dat men geen Amerikaanse mensenlevens moest opofferen om dat kolonialisme te herstellen.

Het ging niet alleen om een stemming onder het Amerikaanse publiek, maar ook om een officiële beleidslijn van zowel de Amerikaanse als de Britse regering. In hun Atlantisch Handvest van 15 augustus 1941 hadden president Roosevelt en premier Churchill al gesproken over 'the right of all peoples to choose the form of government under which they will live'. In maart 1942 beloofde de Britse regering dat India na de oorlog een dominion zou kunnen worden, dus eenzelfde internationale status zou krijgen als Australië en Canada, met inbegrip van het recht om de band met de Britse kroon te verbreken. De Amerikaanse onderminister van buitenlandse zaken Sumner Welles verklaarde in een rede op 30 mei 1942: 'Our victory must bring in its train liberation for all peoples. The age of imperialism is ended.'

Om de Nederlandse positie in Amerika te verbeteren zou het goed zijn 
blijk te geven van bereidheid tot beëindiging van de koloniale verhouding. Tot nu toe was de regering niet verder gegaan dan de aankondiging dat men na de oorlog een conferentie van vooraanstaande personen uit de verschillende delen van het koninkrijk zou bijeenroepen om te beraadslagen over een bij de veranderde omstandigheden passende structuur van het rijk en zijn delen. De Nederlandse ambassadeur in Washington bepleitte nu, dat men een vastomlijnd ontwerp voor de herstructurering van het koninkrijk zou publiceren dat zou voorzien in uitgebreide medezeggenschap voor de bevolking van de overzeese gebiedsdelen. In juli kreeg koningin Wilhelmina tijdens een bezoek aan Amerika ook van president Roosevelt de raad zich duidelijk uit te spreken over de toekomst van Nederlands-Indië.

In oktober hield de ministerraad zich verscheidene malen uitvoerig met deze kwestie bezig. Van Mook had een ontwerp-regeringsverklaring opgesteld met concrete plannen voor een herstructurering van het koninkrijk. De onderschikking van de overzeese rijksdelen aan Nederland zou plaats moeten maken voor nevenschikking; het rijk zou voortaan bestaan uit vier gelijkwaardige delen met volledige autonomie voor hun inwendige aangelegenheden. Nederlands-Indië zou Indonesië gaan heten en de Volksraad zou worden omgezet in een parlement met een 'stevige Indonesische meerderheid'. Discriminatie op grond van rasverschil zou verdwijnen. Boven de vier rijksdelen zou een rijksregering komen met een rijksparlement. Buitenlandse zaken en defensie zouden voortaan door rijksministers worden behartigd.

Van Mook's ontwerp stuitte op verzet bij de andere Nederlandse ministers. Zij wilden in de beoogde regeringsverklaring geen concrete plannen opnemen maar alleen algemene beginselen, zoals gelijkwaardigheid voor de rijksdelen. Van Mook legde zich hier uiteindelijk bij neer. Verder liet men de gedachte van een schriftelijk stuk varen en besloot men dat het beleid zou worden uiteengezet in een radiorede van de koningin, uit te spreken aan de vooravond van de herdenking van de aanval op Pearl Harbor.

Minister Soejono nam in de discussies een heel eigen standpunt in, waarmee hij tegenover al zijn collega's kwam te staan. Hij stelde dat Nederland zeer vergaande concessies over de status van Nederlands-Indië zou moeten doen als het wilde dat de belangrijkste groepen Indonesiërs die status vrijwillig zouden aanvaarden. Daarom zou het centrale element van een nieuwe beleidsverklaring de erkenning moeten zijn van het zelfbeschikkingsrecht van het Indonesische volk. Volgens Soejono leefde in Indonesië de wens om baas in eigen huis te zijn niet alleen bij enkele radicale politici, maar ook bij de politiek ongeschoolde massa. Hij wees op de internationale ontwikkelingen, onder meer met betrekking tot de Filippijnen en Brits-Indië. Hij waarschuwde voor de psychologische gevolgen van de Japanse bezetting. Hij betoogde dat het vooral in het belang van Nederland zelf was om het Indonesische recht op onafhankelijkheid in beginsel te erkennen, daar de vooruitzichten voor 
de Indonesische nationalisten toch al gunstig waren, gezien bijvoorbeeld de Amerikaanse steun die ze konden verwachten. Ook herinnerde Soejono eraan dat het partijprogramma van de SDAP (de Nederlandse socialistische partij) het recht van het Indonesische volk op onafhankelijkheid onvoorwaardelijk erkende.

Alle Nederlandse ministers, met inbegrip van Van Mook en de uit de SDAP afkomstige ministers, wezen een erkenning van het zelfbeschikkingsrecht in de beleidsverklaring van de hand. Men hanteerde daarvoor diverse argumenten. Zo betoogde de minister van justitie dat dit recht niet aan Indië toekwam omdat het inbreuk zou maken op de Nederlandse soevereiniteit. De uiterste concessie waartoe men bereid bleek was het opnemen van een zinsnede volgens welke politieke verbondenheid op den duur niet zou kunnen blijven bestaan als die niet gedragen werd door vrijwillige aanvaarding.

Toch stond Soejono in Londen met zijn afwijkende zienswijze niet volstrekt alleen. Het hoofd van de juridische afdeling van het ministerie van koloniën uitte namelijk nog radicalere opvattingen. Dit was W.G. Peekema, die vroeger in Batavia woordvoerder van het gouvernement in de Volksraad geweest was. Voordat de discussie in de ministerraad plaatsvond schreef hij aan Van Mook, dat men in Indië na de verdrijving van de Japanners vermoedelijk te doen zou hebben met een bevolking die in beginsel al onafhankelijk was en na enige jaren van afscheiding van Nederland onmogelijk zou kunnen terugkeren tot 'de oude toestand, die wij legitiem noemen'. Hij achtte het aannemelijk dat die bevolking bij volkomen vrije meningsvorming geneigd zou zijn tot herstel van een aanzienlijke mate van cultureel, economisch en staatkundig verband met Nederland. Maar om dit te bevorderen zou het Nederlandse beleid zich volgens hem niet moeten baseren op moeilijk houdbare legitimiteitsaanspraken, maar op het uitgangspunt 'dat er na de oorlog zal zijn een Indisch land en volk in het bezit van soevereiniteit en onafhankelijkheid'.

De kloof tussen de opvattingen van Peekema en Soejono enerzijds en de Nederlandse ministers en de koningin anderzijds was onoverbrugbaar. Op 6 december 1942 sprak koningin Wilhelmina haar voor het Amerikaanse publiek bedoelde radiorede uit. De verhouding tussen Nederland en Nederlands-Indië voor de oorlog met Japan werd daarin als volgt gekenschetst: 'After an age-old historical solidarity, which had long passed the era of colonial relationship, we stood on the eve of a collaboration on a basis of equality'. De koningin deelde mee dat na de bevrijding een ronde-tafel-conferentie zou plaatsvinden waarin vertegenwoordigers van de overzeese rijksdelen met vertegenwoordigers van Nederland zouden beraadslagen over de structuur van het koninkrijk en zijn delen 'in order to adapt it to the changed circumstances'. Zij merkte op dat het noch juist noch mogelijk zou zijn om de nieuwe structuur nu al nauwkeurig te omschrijven. Maar wel verklaarde zij het volgende: 
I am convinced, and history as well as reports from the occupied territories confirm me in this, that after the war it will be possible to reconstruct the Kingdom on the solid foundation of complete partnership. [...] I know that no political unity nor national cohesion can continue to exist which are not supported by the voluntary acceptance and the faith of the great majority of the citizenry. [...] I visualize, without anticipating the recommendations of the future conference, that they will be directed towards a commonwealth in which the Netherlands, Indonesia, Surinam and Curaçao will participate, with complete self-reliance and freedom of conduct for each part regarding its internal affairs, but with the readiness to render mutual assistance. [...] This would leave no room for discrimination according to race or nationality; only the ability of the individual citizen and the needs of the various groups of the population will determine the policy of the government.

Hoewel de rede op 6 december uitgesproken was, heeft men die verder altijd aangeduid als de '7-december-rede'. De inhoud had betrekking op de naoorlogse toekomst, maar bevatte één element waarvan de uitvoering al meteen kon beginnen: de afschaffing van discriminatie naar ras of landaard. In Australië en aan boord van Nederlandse schepen bevonden zich namelijk honderden Indonesiërs in Nederlandse dienst die als 'Inlanders' voor gelijk werk lagere lonen dan 'Europeanen' kregen. Met verwijzing naar de koninklijke rede verlangden zij nu gelijke beloning, maar de regering was hier niet toe bereid. Hetzelfde gold voor Indonesische militairen in Nederlandse dienst.

\section{De Poetera-beweging}

Hoewel Soekarno op 8 december 1942 had aangekondigd dat de nieuwe volksbeweging bij de aanvang van het nieuwe jaar zou gaan functioneren, duurde het nog drie maanden voordat die beweging officieel werd opgericht. De vertraging was het gevolg van diverse politieke problemen. Om het draagvlak voor de beweging te verbreden stelde het militaire bestuur in december een voorbereidingscommissie in, waarin naast de Empat Serangkai ook andere bekende Indonesiërs zitting hadden. De Indonesische voorbereiders streefden ernaar de organisatie een uitgesproken nationaal karakter te geven. Onder meer wilden zij het woord Indonesia in de naam van de beweging opnemen en de rood-witte vlag als eigen vlag en het 'Indonesia Raja' als eigen lied van de beweging invoeren. Op grond van het in Tokio bepaalde beleid wees het militaire bestuur deze wensen af. Wel stemde het in met de wens dat het lidmaatschap alleen voor inheemse Indonesiërs zou openstaan. De afwijzing van alle nationale symboliek stelde extra teleur, omdat de Japanse regering eind januari 1943 verklaarde dat zij besloten had Birma en de Filippijnen onafhankelijk te maken. 
Intussen had het militaire bestuur ook te kampen met weerstanden in eigen kring. Het Inlandse BB vreesde van de nieuwe organisatie een bedreiging van zijn gezag en de Japanse residenten deelden die vrees. De Kempeitai waarschuwde dat de beweging een anti-Japanse invloed zou kunnen uitoefenen. Haar argumentatie werd versterkt toen zij in januari een Indonesische verzetsgroep wist te ontmantelen. Eén van de leiders daarvan bleek namelijk Amir Sjarifoeddin te zijn, die tegelijk betrokken was bij de voorbereiding van de volksbeweging.

Uiteindelijk werd de beweging op 9 maart 1943 gelanceerd tijdens een massale bijeenkomst in Djakarta ter herdenking van de Nederlands-Indische capitulatie. Zij werd gelanceerd onder de Indonesische naam Poesat Tenaga Rakjat (Centrum van Volkskracht), met als officiële afkorting Poetera (het Indonesische woord voor zoon). De organisatie had ook een Japanse naam, die 'beweging voor totale volksmobilisatie' betekende. De statuten waren vastgesteld door het militaire bestuur. Volgens deze statuten had de beweging ten doel een krachtig nieuw Java te scheppen door Japan te helpen bij het bereiken van de eindoverwinning en door de werkzaamheden van het militaire bestuur te bevorderen. Daartoe moest zij onder meer Amerikaanse, Britse en Nederlandse invloeden uitschakelen, aan de verdediging van Groot-OostAzië meewerken, de bestudering van het Japans en de verbreiding van het Maleis aanmoedigen, zuinigheid aankweken en productieverhoging en efficiëntere arbeid bevorderen. Verder verklaarden de statuten dat de beweging op de gehele inheemse bevolking van Java gebaseerd was en geen individuele leden had.

Soekarno was voorzitter, met Hatta, Dewantoro en Mansoer als vice-voorzitters. Zij kregen beschikking over een eigen staf. Verder kwam er een raad van bijstand, die enige Japanse en bijna dertig Indonesische leden telde. De Poetera begon haar bestaan met ambitieuze plannen. Zij wilde allerlei activiteiten ondernemen op zulke terreinen als cultuur, onderwijs, sport, volksgezondheid, sociale bijstand, de jeugdbeweging en de vrouwenbeweging. Hoewel de organisatie geen individuele leden had, was het wel de bedoeling in de residenties regionale afdelingen te stichten, met plaatselijke onderafdelingen. De regionale hoofden zouden door Soekarno worden aangesteld, onder voorbehoud van goedkeuring door de Japanse residenten. Al spoedig kregen tal van bekende Indonesiërs een plaats in de centrale organisatie. Zo zaten Kasimo, Ratoelangie, Agoes Salim, Soekiman en Soetardjo in de raad van bijstand en stond Iskandar Dinata aan het hoofd van de sportafdeling. Soekarno zelf leidde de afdeling voor pers en propaganda, Hatta die voor planning en ontwikkeling, Dewantoro die voor cultuur en Mansoer die voor volkswelzijn. De beweging vormde een koepel boven allerlei bestaande of nieuwe organisaties die met haar verbonden werden, zoals coöperaties, beroepsverenigingen en sportbonden. Hatta's afdeling ontwikkelde zich ten 
dele tot een soort klachtenbureau; er kwamen duizenden brieven van particulieren binnen, die Hatta verwerkte in rapporten aan het militaire bestuur. Overigens hief dit bestuur nu het onder Hatta ressorterende adviesorgaan op, dat het in het begin van de bezetting had ingesteld.

De Poetera vond meer weerklank dan de Tiga A, maar toch beantwoordden de resultaten niet aan haar verwachtingen. Op regionaal en plaatselijk niveau kreeg zij weinig medewerking van het bestuur en zelfs op centraal niveau werkte het bestuur niet volop mee. Zij mocht bijvoorbeeld geen eigen blad uitgeven. Het lukte haar slechts in beperkte mate om regionale afdelingen op te zetten en ook van de voorgenomen maatschappelijke activiteiten kwam minder terecht dan beoogd was. In de praktijk hield de Poetera zich dan ook vooral met propaganda bezig. Soekarno zette daar al zijn volksmennerstalenten voor in. Hij verheerlijkte Japan en hitste de bevolking tegen de geallieerden op. Daartoe introduceerde hij onder meer een rijmpje luidende 'Amerika kita seterika, Inggeris kita linggis' (Wij strijken de Amerikanen plat; wij verbrijzelen de Britten). Zo vervulde de Poetera de functie waar de bezettingsmacht haar voor bedoeld had: het mobiliseren van inheemse steun voor de Japanse oorlogsinspanning. Voor Soekarno zelf had de Poetera de functie van een platform dat hem mogelijkheden bood tot vergroting van zijn eigen gezag bij de inheemse bevolking en tot versterking van haar nationaal bewustzijn. Terwijl de Japanse bezetting was begonnen met het stopzetten van alle politieke activiteiten, bestond er nu op Java één politieke beweging en die werd door hem geleid. Hij had meer contact met de massa's dan hij ooit onder het koloniaal bestuur genoten had, vooral nu zijn redevoeringen regelmatig door de radio werden uitgezonden. Omdat zijn publiek hem kende als voorvechter van de Indonesische onafhankelijkheid, droeg zijn optreden tot versterking van dat ideaal bij, ook al kon hij zich daar nu niet openlijk voor uitspreken. Hij gebruikte trouwens in zijn toespraken herhaaldelijk de term Indonesië, die de bezetters zo zorgvuldig uit de naam en de statuten van de beweging geweerd hadden.

In maart 1943 stierf Soekarno's oude vriend en leermeester, Tjipto Mangoenkoesomo. Evenals Sjahrir had hij zich onthouden van samenwerking met de Japanse bezetters. Later in hetzelfde jaar scheidde Soekarno van de vrouw met wie hij sinds zijn studententijd getrouwd was en hertrouwde hij met een jonge vrouw die hij in Benkoelen had leren kennen, Fatmawati.

\section{Mobilisatie van de jeugd}

De Japanse bezetters spanden zich bijzonder in om de jeugd voor hun doeleinden te mobiliseren. Daarmee begaven zij zich niet op onbetreden terrein. $\mathrm{Al}$ voor de oorlog streefden verschillende emancipatiebewegingen in Nederlands- 
Indië ernaar de jeugd voor zich te winnen; veel politieke, godsdienstige en etnische organisaties beschikten dan ook over eigen jeugdafdelingen.

Op Java richtte het militaire bestuur zich in de eerste plaats op het onderwijs. Al in de eerste maanden van de bezetting, toen alle scholen nog gesloten waren, begon men met herscholing van onderwijzers en herziening van leermiddelen. De inheemstalige basisscholen werden eind april heropend met een sterk gewijzigd programma, waarin het leren van Japans een belangrijke plaats innam, naast lichaamsoefening, handenarbeid en het zingen van Japanse liederen. In augustus ging ook een deel van de middelbare scholen weer open, met Maleis als voertaal. De Japanse taal, de Japanse zeden en gewoonten en de Japanse geschiedenis werden delen van de leerstof. Verder kregen alle scholieren een semi-militaire scholing, waarbij zij veelvuldig moesten marcheren en met houten namaakwapens moesten oefenen. Intussen mocht het onderwijs op geen enkel niveau meer gebruik maken van Nederlands- of Engelstalige leermiddelen. Een groot deel van het voortgezet en hoger onderwijs werd dan ook niet meer hervat. Onder de Indonesische jongeren haalde dit een streep door de toekomstplannen van duizenden leerlingen en honderden studenten. Wel kwam er na een jaar weer medisch en technisch hoger onderwijs, nu gedoceerd in het Japans door Japanse hoogleraren.

De bezettingsmacht hechtte ook groot belang aan het mobiliseren van de jeugd buiten schoolverband. In juni 1942 richtte de Tiga A een algemene jeugdbond op waarvan de kern gevormd werd door de jeugdafdeling van de Parindra, de voornaamste politieke partij op de rechtervleugel van de nationale beweging. De leiders van deze bond kregen hun vorming op twee speciale opleidingsscholen. Bovendien stichtte de propaganda-afdeling van het militaire bestuur, de Sendenbu, eind 1942 een instituut in Djakarta voor de opleiding van jongeren tot propagandist, de Asrama Angkatan Baroe (Internaat voor de Nieuwe Generatie). Aan het hoofd van de opleiding stonden twee Indonesische leden van de Sendenbu die vroeger tot de linkervleugel van de nationale beweging behoord hadden: de Javaan Soekarni, oud-cursist van Soekarno's kaderschool in Bandoeng en oud-voorzitter van de nationalistische jeugdbond Indonesia Moeda, en de Sumatraan Chairoel Saleh, oud-voorzitter van de radicaal-nationalistische studentenvereniging PPPI.

Intussen bereidde het militair bestuur een jeugkorps naar Japans model voor, dat de jeugdbond van de Tiga A moest vervangen. Op 29 april 1943, de verjaardag van de keizer, werd het officieel opgericht onder de Japanse naam Seinendan. Het korps was bestemd voor jongens van veertien tot en met tweeëntwintig jaar. Seinendan-afdelingen moesten gevormd worden in alle steden, alle regentschappen en alle bedrijven met meer dan vijfhonderd arbeiders. Er kwamen tientallen kaderscholen voor de vorming van de leiders. Het hoofd van het militaire bestuur had zelf de opperste leiding van de Seinendan, die verder op alle niveaus rechtstreeks onder het Binnenlands 
Bestuur ressorteerde. Weliswaar zette ook de Poetera een jeugdorganisatie op, maar die werd volledig terzijde geschoven. De opbouw van de Seinendan nam veel tijd in beslag. Uiteindelijk werden er een half miljoen jongeren in opgenomen. Zij werden zowel militair gedrild als politiek geïndoctrineerd. Ook werden ze onder meer voor verhoging van de productie ingeschakeld, deels als controleurs, deels rechtstreeks als arbeidskrachten. Aldus ontwikkelde dit jeugdkorps zich meer en meer tot een soort arbeidsdienst.

\section{Verruiming van Indonesische medezeggenschap}

Hatta en Soekarno werkten met de Japanse bezettingsmacht samen, omdat zij hoopten daardoor te bevorderen dat Indonesië een onafhankelijke staat zou worden. Het kon hun niet verborgen blijven dat er aan Japanse kant ook plannen bestonden om Indonesië geheel of gedeeltelijk als een kolonie bij Japan in te lijven. Beiden beklemtoonden zij in openbare uitspraken dat hun land nooit meer een kolonie zou mogen worden. Toen de Japanse minister-president Tojo eind januari 1943 bekendmaakte dat Birma en de Filippijnen in de loop van dat jaar onafhankelijk zouden worden, protesteerden zij terstond bij het hoofd van het militaire bestuur tegen deze achterstelling van Indonesië. Ook in verdere contacten met Japanse leiders betoogden zowel zij als Mansoer en Dewantoro (de twee andere leden van de Empat Serangkai), dat Indonesië evenzeer als Birma en de Filippijnen voor onafhankelijkheid in aanmerking kwam. Zij vroegen om herstel van de bestuurseenheid van de archipel en om verlof voor het zingen van het 'Indonesia Raja' en het tonen van de rood-witte vlag.

Ook na de totstandkoming van de Poetera was het optreden van het militaire bestuur soms verontrustend voor de nationalisten. Een voorbeeld hiervan was de oprichting, buiten de Poetera om, van het geheel op Japanse leest geschoeide jeugdkorps Seinendan. In mei 1943 richtten de Empat Serangkai zich in een brief gezamenlijk tot minister-president Tojo. Zij drongen daarin aan op een duidelijke uitspraak van de Japanse regering over de politieke toekomst van heel Indonesië (niet alleen Java) en op intrekking van het verbod op het 'Indonesia Raja' en de rood-witte vlag. Ook bekritiseerden zij het gedrag van de Japanners op Java. De Empat Serangkai verzonden hun brief niet via de commandant van het bezettingsleger, maar via het liaisonbureau van de Japanse marine, dat ervoor wist te zorgen dat de brief inderdaad in handen van Tojo kwam.

Eind mei 1943 besprak de contactraad in Tokio opnieuw de toekomstige status van Indonesië. Tojo pleitte voor onafhankelijkheid, daarbij gesteund door de minister van buitenlandse zaken. Maar ofschoon Tojo zowel ministerpresident als minister van defensie én generaal was, moest hij zwichten voor 
de annexatiewensen van leger- en marinestaf. De contactraad besloot nu formeel dat men Indonesië na de oorlog bij Japan zou inlijven, maar bepaalde tegelijk dat men dit besluit voorlopig geheim zou houden en dat men de bevolking intussen wel enige medezeggenschap zou kunnen geven. Midden juni verklaarde Tojo in het Japanse parlement dat de inheemse bevolking van Malakka, Sumatra, Java, Borneo en Celebes nog in de loop van het jaar gelegenheid zou krijgen om deel te nemen aan het bestuur en dat men daarbij met Java zou beginnen. Kort daarop belegden de Poetera en de moslim-federatie MIAI, daartoe geprest door het militaire bestuur, een massabijeenkomst in Djakarta om hiervoor dank aan Japan te betuigen. Van 7 tot 10 juli bracht Tojo een bezoek aan Java. Soekarno hield een toespraak waarin hij er op wees, dat Indonesië vroeger nooit door een Nederlandse minister-president bezocht was. Anderzijds zei hij in een gesprek met Tojo, dat de nu toegezegde deelname aan het bestuur slechts een eerste stap was naar het door het Indonesische volk gewenste einddoel.

Het bezettingsbestuur gaf die deelname in de eerste plaats vorm door de instelling van een Centrale Adviesraad voor Java en van enige tientallen regionale en stedelijke adviesraden. Verder kregen de centrale bestuursdepartementen Indonesische adviseurs; zo werd Soepomo adviseur van het departement van justitie en Yamin van het departement van voorlichting. Bovendien kwam één Indonesiër zelf aan het hoofd van een departement te staan, namelijk Hoesein Djajadiningrat, die nu directeur werd van het departement van eredienst (overigens een bescheiden positie in vergelijking met de functies die hij voor de Japanse bezetting al bekleed had als directeur van het departement van onderwijs én eredienst en vervolgens als lid van de Raad van Indië). Ook namen de departementen in het algemeen meer Indonesiërs in hun staf op. Tenslotte stelde het militaire bestuur twee leden van de Indonesische ambtsaristocratie aan als resident, een functie die vroeger alleen aan Nederlanders voorbehouden was. Eén van hen was Soetardjo (in 1936 de initiatiefnemer van de bekende Volksraadsmotie), die nu resident van Djakarta werd.

De leden van de verschillende adviesraden werden deels gekozen en deels benoemd, evenals het geval was geweest met de Volksraad en de regionale en stedelijke raden in het Nederlands-Indische bestel. De verkiezingen waren weinig vrij: verkiezingscampagnes waren verboden en het bestuur wees de kiezers aan. Generaal Harada installeerde de Centrale Adviesraad op 16 oktober 1943. Dit orgaan telde vijfenveertig leden, veertig Indonesiërs en vijf Chinezen; later werden ook een Arabier en een Indische Nederlander tot lid benoemd. Ruim de helft van de Indonesische leden behoorde tot de nationale beweging. Voorzitter werd Soekarno, vice-voorzitter Koesoemo Oetojo (die ook al vice-voorzitter van de Volksraad geweest was). De Raad vergaderde in het vroegere gebouw van de Volksraad, maar had veel minder bevoegdheden dan de Volksraad had bezeten. In hoofdzaak moest hij 
antwoord geven op door het Japanse bestuur voorgelegde vragen, zoals hoe men de arbeidskrachten het beste kon mobiliseren en hoe men de productie kon uitbreiden. De antwoorden werden voorbereid door een secretariaat dat grotendeels uit Japanners bestond. Voor de bevolking had deze Adviesraad vooral symbolische betekenis: in het Volksraadgebouw zetelde nu een vertegenwoordigend lichaam dat overwegend uit Indonesiërs bestond en dat werd voorgezeten door Soekarno. Voor de leden had de Raad voornamelijk nut als gelegenheid om elkaar te ontmoeten. Hij kwam overigens maar eens per kwartaal enkele dagen bijeen, veel minder frequent dan de in november 1942 ingestelde adviesraad voor traditionele gebruiken en instellingen, die nu opgeheven werd.

Al met al stelde de uitvoering van de Japanse toezegging van medezeggenschap de nationalisten teleur. Intussen was Birma in augustus 1943 formeel onafhankelijk geworden, in oktober gevolgd door de Filippijnen. Van 5 tot 8 november belegde de Japanse regering een conferentie in Tokio van de staten die nu deel uitmaakten van de Groot-Oostaziatische Welvaartssfeer: Japan, Mandsjoekwo, Nanking-China, Thailand, Birma en de Filippijnen. Indonesië kreeg zelfs geen gelegenheid waarnemers naar deze conferentie te zenden. Het militaire bestuur in Djakarta bewerkstelligde echter dat Soekarno en Hatta een officieel bezoek aan Japan konden brengen, samen met de moslimleider Ki Bagoes Hadikoesoemo (die Mansoer als voorzitter van de Moehammadiah was opgevolgd). Nadat zij eerst in Singapore de opperbevelhebber voor de zuidelijke gebieden, generaal Terauchi, bezocht hadden, verbleven zij van 13 november tot 3 december in Japan. Daarbij werden zij door keizer Hirohito ontvangen en kregen zij van hem hoge onderscheidingen. Verder spraken zij onder meer met minister-president Tojo, aan wie zij wederom vergeefs vroegen om uitzicht op onafhankelijkheid, herstel van de bestuurseenheid van de archipel en opheffing van het verbod op het 'Indonesia Raja' en de rood-witte vlag. Hoewel dit bezoek aan Japan in politiek opzicht niets opleverde, had het toch één politiek relevant gevolg. De Kempeitai in Djakarta had namelijk kort daarvoor besloten Hatta uit te schakelen; zij was inmiddels op de hoogte van zijn oproep uit december 1941 tot strijd tegen het Japanse imperialisme. De aan Hatta uitgereikte keizerlijke onderscheiding dwong de Kempeitai nu van deze actie af te zien.

Terwijl de uitvoering van de toezegging van medezeggenschap op Java tegenviel, had die uitvoering in de rest van Indonesië nog minder om het lijf. Op Sumatra en in de gebieden onder marinebestuur stelden de Japanse autoriteiten een aantal regionale en stedelijke adviesraden in die voornamelijk uit inheemse bestuurders bestonden, zelden bijeenkwamen, door Japanners werden voorgezeten en alleen antwoord mochten geven op vragen van het Japanse bestuur. Verder benoemde het marinebestuur twee bekende nationalisten tot adviseurs, de Menadonees Ratoelangie en de uit Zuid-Borneo afkom- 
stige Tadjoeddin Noor, die evenals Ratoelangie lid van de Volksraad geweest was. Beiden moesten daartoe van Java naar Makassar verhuizen, maar werden daar nauwelijks geraadpleegd.

\section{De hulpsoldaten, de hulppolitie en het vrijwilligerskorps Peta}

In de loop van de bezetting werden Indonesiërs in verschillende hulporganen van het Japanse machtsapparaat ingeschakeld.

Dit gebeurde in de eerste plaats door inlijving als heiho, hulpsoldaten van de Japanse landmacht en marine. Al kort na de verovering van de archipel ronselden de bezetters hiervoor krijgsgevangen KNIL-militairen. Later wierven zij ook niet-militairen aan voor dienstneming bij de heiho-formaties; soms werden werkloze jongemannen daar tegen hun wil bij ingelijfd. De hulpsoldaten maakten deel uit van de Japanse strijdkrachten en stonden onder Japans commando. Zij kregen een militaire opleiding, maar velen van hen bleven onbewapend en werden als arbeidskrachten ingezet, onder meer voor de aanleg van verdedigingswerken en voor het vervoer van militaire goederen naar de frontgebieden. Zij werden vaak slecht behandeld en aan grote gevaren blootgesteld. Een deel van de heiho's werd naar strijdgebieden overgebracht; andere werden toegevoegd aan het bezettingsleger op Java; ook werden sommigen bij de bewaking van interneringskampen ingeschakeld. In totaal hebben de Japanse strijdkrachten waarschijnlijk meer dan vijftigduizend Indonesiërs in hun heiho-formaties opgenomen.

In de tweede plaats gingen de bezetters over tot de vorming van hulppolitiekorpsen. Voor Java werd de oprichting van zulk een korps, met de Japanse naam Keibodan, tegelijk met de oprichting van het jeugdkorps Seinendan bekendgemaakt op 29 april 1943. In elk dorp en in elke stadswijk werd een groep hulppolitie gevormd van vijftig à honderdvijftig mannen, die niet bezoldigd werden en geen vuurwapens kregen. Tweemaal per maand moesten ze voor oefening bijeenkomen; verder konden ze op allerlei tijdstippen worden ingezet. De Keibodan ressorteerde op basisniveau onder het plaatselijke bestuur en op hoger niveau onder de gewone politie. Men gebruikte deze hulppolitie onder meer voor het bewaken van bruggen en andere vitale punten, nachtelijke wachtdiensten, brandbestrijding, luchtbeschermingswerk, kustbewaking, prijscontroles, de invordering van levensmiddelen en het signaleren van verdachte personen en ongewone activiteiten. Uiteindelijk werden op Java bijna een miljoen man bij de Keibodan ingeschakeld.

In de derde plaats richtte het militaire bestuur op Java na anderhalf jaar bezetting een echte inheemse strijdmacht op, de Peta. Hier was een langdurige interne discussie aan voorafgegaan. Het steeds verder opdringen van de geallieerden in de Stille Oceaan had het Japanse opperbevel gedwongen tot ver- 
zwakking van de bezettingsmacht op het eiland. De Japanse landstrijdkrachten telden hier nog slechts dertienduizend man, grotendeels oudere militairen die bovendien onvoldoende bewapend waren. Tegelijk moest de legerleiding steeds meer rekening houden met de mogelijkheid van geallieerde landingen op Java. In die situatie zou het van nut kunnen zijn over inheemse hulptroepen te beschikken. Zou het Japanse leger er niet in slagen een invasie af te slaan, dan zouden juist inheemse troepen een guerrillastrijd kunnen voeren om de geallieerde strijdkrachten zo veel mogelijk te binden en te verzwakken. Aan de andere kant moest men de voordelen van een bewapend inheems hulpleger afwegen tegen het nadeel, dat zo'n leger gevaren zou kunnen meebrengen voor de handhaving van het Japanse oppergezag.

Nadat minister-president Tojo tenslotte met het plan had ingestemd, zorgde het militaire bestuur ervoor dat in september 1943 verklaringen in de pers verschenen waarin vooraanstaande Indonesiërs aandrongen op de vorming van een inheems korps om Japan te helpen bij de verdediging van Java. Op 3 oktober maakte generaal Harada bekend dat hij hieraan gevolg gaf. Dit werd de Barisan Soekarela Pembela Tanah Air (Korps van Vrijwilligers ter Verdediging van het Vaderland), dat als Peta bekend geworden is; de leden van het korps werden ook wel soekarela genoemd.

In afwachting van de beslissing op hoog niveau was het militaire bestuur al eerder in 1943 met de voorbereiding van de Peta begonnen. Daartoe had men in het geheim ongeveer honderd jongemannen getraind om later als onderofficieren aan de opleiding van de vrijwilligers deel te nemen. Ook was men al begonnen met de selectie van toekomstige officieren, zodat de officiersopleiding voor de Peta meteen in oktober kon beginnen. Op 8 december 1943, de tweede verjaardag van het begin van de Pacific-oorlog, vond in Djakarta de plechtige beëdiging plaats van de eerste groep bataljons- en compagniescommandanten. Daarna begon de eigenlijke opbouw van de strijdmacht, die uiteindelijk zesenzestig bataljons ging tellen. Bovendien werden ook op Bali drie bataljons gevormd. De Peta-bataljons waren 535 man sterk. Omdat ze voor de lokale verdediging bestemd waren, werden ze in beginsel gestationeerd in dezelfde residentie als waar ze gerecruteerd waren. De Peta had geen eigen opperbevel; de afzonderlijke bataljons waren steeds ondergeschikt aan het Japanse leger in hun residentie.

Anders dan de heiho-hulpsoldaten stonden de Peta-soldaten onder hun eigen kader, al waren aan elk bataljon Japanse officieren en onderofficieren als adviseurs en instructeurs toegevoegd. Alle Peta-officieren kregen een zwaard, maar van kleiner formaat dan de Japanse officierszwaarden. De uitrusting van de Peta kwam in beginsel uit voorraden die op de geallieerden buitgemaakt waren. De Peta-uniformen hadden dan ook dezelfde kleur als de KNIL-uniformen. De bewapening was gebrekkig. Tijdens de eerste opleiding moesten de soldaten met houten geweren oefenen. De training werd sterk toegespitst 
op guerrilla-oorlogvoering. Bij het einde van de Japanse bezetting bedroeg de sterkte van de Peta ongeveer 35.000 man (vergelijkbaar met de sterkte van het vooroorlogse KNIL), maar hun bewapening omvatte slechts 17.000 geweren, 900 mitrailleurs en 90 lichte mortieren.

Omdat een bewapende inheemse strijdmacht een risico voor het Japanse gezag kon inhouden, probeerde het militaire bestuur aanhangers van de nationale beweging zo veel mogelijk uit de Peta te weren. Al bij de voorbereiding van de eerste trainingen zocht het jongemannen uit die geen banden met politieke organisaties onderhielden. Vervolgens recruteerde het de Petaofficieren bij voorkeur uit de kringen van de ambtsaristocratie, de politie en het onderwijs, met inbegrip van het islamitische godsdienstonderwijs. Inheemse bestuursambtenaren adviseerden bij de selectie van de gewone Peta-soldaten, wat eveneens de toetreding van nationalisten belemmerde. Naar de opzet van het militaire bestuur moest, naast het Japanse militarisme, niet het Indonesisch nationalisme maar de islam de belangrijkste inspiratiebron van de Peta vormen. Het door dit bestuur aan de Peta gegeven vaandel toonde niet het nationalistische rood-wit, maar de halve maan van de islam en de rijzende zon van Japan tegen een groene achtergrond. Al deze Japanse voorzorgsmaatregelen konden niet verhinderen, dat de Peta bij uitstek een kweekbed van militant nationalisme werd.

In dezelfde tijd waarin op Java de Peta werd opgebouwd, ging ook het militaire bestuur van Sumatra tot de vorming een inheemse strijdmacht over, de Laskar Rakjat (Volksleger). In verschillende delen van het eiland werden daartoe eenheden samengesteld, grotendeels onder Japanse leiding. De uiteindelijke sterkte van de Laskar Rakjat bedroeg bijna een derde van die van de Peta.

De Japanse marine onthield zich in het door haar bestuurde gebied van Indonesië van het vormen van inheemse strijdkrachten. De Peta-bataljons op Bali vielen onder het 16e leger.

\section{De Masjoemi}

De Japanse bezetters hadden verschillende redenen om de Indonesische nationale beweging te wantrouwen. In beginsel was die tegen elke vreemde overheersing gekant, dus ook tegen Japanse overheersing. Bovendien hadden bijna alle actieve leden van de beweging enigerlei vorm van westers onderwijs genoten; terwijl zij onvoorwaardelijk anti-koloniaal waren, waren zij meestal niet anti-westers gezind en vaak niet eens anti-Nederlands. Daarentegen was een anti-westerse gezindheid wijd verbreid onder de islamitische schriftgeleerden en godsdienstleraren. Het militaire bestuur op Java spande zich van begin af aan in voor een goede verstandhouding met deze groep, die over veel 
gezag bij de moslimbevolking beschikte; het schakelde daartoe ook Japanse moslims in. Overigens stond de Japanse staatsideologie zelf een hartelijke verstandhouding in de weg, vooral door het vergoddelijken van de Japanse keizer, het voorschrift om in diens richting te buigen en het verheffen van de Japanse taal boven het Arabisch. Vooraanstaande moslims drongen er vergeefs op aan, de plicht om naar Tokio te buigen in ieder geval voor godsdienstige bijeenkomsten op te heffen.

Het militaire bestuur wilde alle moslims op Java in één organisatie bijeenbrengen die zich op Japan zou moeten richten. Medio 1942 belastte de Tiga A Beweging een commissie onder Abikoesno met de voorbereiding daarvan. Intussen beschikten de Indonesische islamitische organisaties al sinds 1937 in de MIAI over een overkoepelend verband. Het gezamenlijke ledental van de daarbij aangesloten bonden naderde een half miljoen; de belangrijkste bonden waren de in religieus opzicht hervormingsgezinde Moehammadiah en de meer conservatieve Nahdatoel Oelama. Na de opheffing van de Tiga A Beweging kwam de door het militaire bestuur gewenste voorbereiding van een eigen islamitische eenheidsorganisatie voorlopig stil te liggen. Wel versterkte het bestuur zijn greep op de MIAI door haar hoofdkwartier van Soerabaja naar Djakarta over te brengen en door Japanse ambtenaren van het departement van eredienst aan de leiding toe te voegen. Begin $1943 \mathrm{kreeg}$ de MIAI verlof om een eigen blad uit te geven.

In oktober 1943 schafte het militaire bestuur de verplichte buiging naar Tokio eindelijk voor islamitische bijeenkomsten af, maar tegelijk zette het zijn plannen voor een islamitische eenheidsorganisatie alsnog door. Het ontbond de MIAI en stichtte in november een nieuw lichaam onder de naam Madjelis Sjoero Moeslimin Indonesia (Adviesraad van Indonesische Moslims; anders dan bij de Poetera mocht het woord 'Indonesia' hier wel in de naam voorkomen).

De nieuwe organisatie kwam als Masjoemi bekend te staan. Haar eerste voorzitter was Hoesein Djajadiningrat, die tegelijk hoofd van het departement van eredienst was. Alle eerder bij de MIAI aangesloten bonden werden nu in de Masjoemi bijeengebracht. Hoewel die een 'adviesraad' heette te zijn, was zij in werkelijkheid een massaorganisatie met vertakkingen in heel Java. Zij oefende toezicht uit op de godsdienstleraren en schriftgeleerden en riep evenals de Poetera op tot steun aan de Japanse oorlogvoering. Het Japanse bestuur verving Hoesein Djajadiningrat in 1944 door een hoogbejaarde schriftgeleerde die aan de wieg van de Nahdatoel Oelama had gestaan. De feitelijke leiding van de Masjoemi berustte sindsdien bij diens zoon, kiai Wahid Hasjim. 


\section{De Djawa Hokokai}

Hoewel het Japanse bestuur op Java de Poetera zelf had opgericht, gaf het haar geen gelegenheid zich overeenkomstig haar oorspronkelijke opzet te ontplooien. Onder meer stichtte het herhaaldelijk eigen organisaties en instellingen op gebieden die tot het werkterrein van de Poetera behoorden, zoals cultuur, sport, jeugdbeweging en vrouwenbeweging. Het stond de Poetera niet toe een eigen orgaan uit te geven. Het betrok de Poetera niet bij de organisatie van de verkiezingen in het kader van de door Tokio toegezegde medezeggenschap. Ook de vorming van de Peta gebeurde volledig buiten de Poetera om. Bovendien richtte het bestuur naast de Poetera de islamitische massaorganisatie Masjoemi op. Ten tijde van de oprichting van de Poetera hadden de bezetters die vooral bedoeld als een instrument voor propaganda ten bate van de Japanse oorlogvoering. Soekarno makkte zulke propaganda inderdaad, maar versterkte daarbij tegelijk de nationalistische geest. Dit laatste strookte niet met de bedoelingen van de bezetters, die zich trouwens in de loop van 1943 steeds terughoudender tegenover het Indonesisch nationalisme opstelden. Daar kwam bij dat het militaire bestuur zijn greep op de bevolking van Java wilde versterken, nu het steeds meer rekening moest houden met een Amerikaanse invasie. Het besloot de Poetera te vervangen door een nieuwe overkoepelende eenheidsorganisatie en begon in december met de voorbereiding daarvan. Weliswaar betrok het Soekarno en de andere leden van de Empat Serangkai bij deze voorbereidingen, maar hun invloed was gering. Hun pleidooi om de term Indonesia in de naam van de organisatie op te nemen vond wederom geen gehoor.

De installatieplechtigheid van de nieuwe organisatie vond plaats op 9 maart 1944 bij de herdenking van de Nederlandse capitulatie. Officieel had zij evenals de Poetera zowel een Indonesische als een Japanse naam, maar in de praktijk gebruikte men algemeen de laatste, namelijk Djawa Hokokai (JavaBond voor Dienstbetoon). Zij verschilde in meerdere opzichten van de Poetera. Zij stond niet onder Indonesische, maar onder Japanse leiding; het hoofd van het militaire bestuur bekleedde zelf het voorzitterschap. Onder deze Japanse leiding ressorteerden een bureau en een adviesorgaan. Soekarno werd directeur van het bureau, Hatta vice-voorzitter van het adviesorgaan. Terwijl de Poetera uitsluitend een organisatie voor de inheemse bevolking geweest was, was de Hokokai ook bedoeld voor Japanners, Chinezen, Arabieren en IndoEuropeanen. Anders dan de Poetera kende zij individuele leden; overigens hadden die toestemming van de autoriteiten nodig om toe te treden.

Zoals de naam al aangaf was de Hokokai bovenal gericht op dienstbaarheid ter ondersteuning van de Japanse oorlogvoering. $\mathrm{Zij}$ moest onder meer het besef van de rechtvaardigheid van die strijd verdiepen en de bereidheid om zich daarvoor op te offeren versterken. $\mathrm{Zij}$ vormde afdelingen in de resi- 
denties en op plaatselijk niveau, tot in de stadswijken en de dorpen, en bovendien afdelingen in de grote bedrijven. Allerlei bestaande organisaties werden bij de Hokokai ondergebracht. Ook de Chinezenbond en de Arabierenbond behoorden hiertoe; verder kwam nu in dit kader ook een organisatie van IndoEuropeanen tot stand, die een eigen vertegenwoordiger kreeg in de Centrale Adviesraad van het militaire bestuur. De Masjoemi was de enige massa-organisatie die naast de Hokokai zelfstandig bleef bestaan.

De Indonesische nationalisten hadden binnen de Hokokai een veel zwakkere positie dan binnen de Poetera. De meeste functies waren in handen van Japanse en inheemse bestuursambtenaren. Alleen Soekarno kon een prominente rol blijven spelen in zijn dubbele rol van voorzitter van de Centrale Adviesraad en directeur van het bureau van de Hokokai; hij reisde door Java en sprak overal de inheemse bevolking toe. Het viermanschap Empat Serangkai hield op te bestaan; kiai Mansoer trok zich wegens ziekte uit zijn politieke activiteiten terug.

De Djawa Hokokai was opgezet naar het voorbeeld van een in 1940 in Japan gevormd 'Verbond ter ondersteuning van het Keizerlijke bewind', waarin toen alle Japanse maatschappelijke organisaties verenigd waren.

\section{Het Tonarigumi-stelsel}

Ten behoeve van de totale mobilisatie van de bevolking voerde het militaire bestuur op Java ook een ander stelsel van Japanse origine in. Dit was het buurtschappen- of Tonarigumi-stelsel, dat in de jaren dertig in Japan was opgericht. Op Java begon de invoering van dit stelsel al in april 1943; de Indonesische naam werd Roekoen Tetangga. Daarbij organiseerde men de bevolking in buurtschappen die tien tot twintig gezinnen omvatten. De bestaande dorpsen wijkhoofden wezen de buurthoofden aan en elk buurthoofd moest een aantal assistenten en plaatsvervangers aanstellen. Deze buurtorganisaties kregen de verantwoordelijkheid voor allerlei taken, zoals de bekendmaking van overheidsinstructies, de distributie van goederen, het bevorderen van spaarzaamheid, het verhogen van de voedselproductie, het deelnemen aan de luchtbescherming en het signaleren van afwijkend gedrag. Het buurthoofd moest de leden van de buurtschap maandelijks in vergadering bijeenroepen voor het verdelen van de opdrachten; ook deze vergaderingen begonnen met een buiging in de richting van Tokio. Op hun beurt moesten de buurthoofden zelf geregeld vergaderen met het dorps- of wijkhoofd. De leden van de buurtschappen controleerden elkaar, wat het ondernemen van anti-Japanse activiteiten haast onmogelijk maakte.

Velen zagen het Tonarigumi-stelsel als een verlengstuk van de massaorganisatie Djawa Hokokai, maar in feite voegde het aan het bestaande 
bestuursapparaat een onderste laag van onbetaalde overheidsdienaren toe. Dit vergrootte de macht van de inheemse bestuursambtenaren, wier bevoegdheden onder het Japanse bestuur ook al toenamen door hun zeggenschap op plaatselijk niveau over de Hokokai alsmede over de hulppolitie Keibodan en het jeugdkorps Seinendan. Hun sterkere machtspositie kon echter niet verhinderen dat hun gezag bij een deel van de bevolking om verschillende redenen achteruitging. In de eerste plaats waren de inheemse bestuursambtenaren met de uitvoering belast van vrijwel alle onaangename maatregelen die het Japanse bestuur de bevolking oplegde. In de tweede plaats behandelde dit bestuur hen minder omzichtig dan het koloniale bestuur placht te doen. Het Nederlandse gouvernement onthief bijna nooit een regent van zijn functie; het Japanse bestuur verving in enkele jaren de helft van de regenten.

\section{Economische ontreddering}

In economisch opzicht was de Japanse bezetting een ramp voor Indonesië. Voor de oorlog berustte de economie van Nederlands-Indië bovenal op de export van landbouwproducten en delfstoffen naar Europa en Amerika. Door de bezetting viel die export volledig weg. De productie van onder meer suiker, koffie, thee, tabak en rubber kwam grotendeels stil te liggen; honderdduizenden Indonesiërs verloren daardoor hun werk. Alleen Japan zelf bleef over als belangrijke afnemer van Indonesische producten, maar dit betrof voornamelijk de voor de oorlogvoering belangrijke delfstoffen aardolie, bauxiet, nikkel en mangaan. Behalve dat Indonesië schade leed door het verlies van het leeuwendeel van zijn export, werd het ook gedupeerd door het wegvallen van belangrijke importen. Onder meer hield de invoer van katoen op, wat in de loop van de bezetting leidde tot een nijpende textielschaarste. Ook miste Indonesië nu de invoer van Europese en Amerikaanse industrieproducten, terwijl de invoer van Japanse industrieproducten grote hinder ondervond, eerst omdat de haveninstallaties vernield waren en vervolgens omdat de Amerikaanse marine de Japanse transportvloot steeds meer schade toebracht.

De economie van Indonesië leed niet alleen onder het verlies van zijn toegang tot de wereldmarkt, maar ook onder de verdeling van zijn grondgebied tussen drie Japanse militaire besturen. Deze beheerden hun bestuursgebieden op basis van zelfverzorging en stelden geen scheepsruimte beschikbaar voor het gebruikelijke vervoer tussen die gebieden onderling. Daardoor kreeg bijvoorbeeld Java geen aardolie en steenkool meer uit Sumatra en Borneo en miste het oosten van Indonesië de invoer van suiker en zout uit Java.

Verder ondervond de economie van Indonesië ook nadeel van de vernielingen die de Nederlanders tijdens de Japanse invasie hadden aangericht. 
Het duurde bijvoorbeeld meer dan anderhalf jaar voordat men alle vernielde bruggen hersteld had.

Een heel andere oorzaak van economische achteruitgang was de abrupte uitschakeling van een schat aan deskundigheid en ervaring door de internering van de Nederlanders. Hun functies in dienst van de koloniale overheid en de westerse ondernemingen gingen grotendeels over op Japanse militairen, Japanse ambtenaren en employés van Japanse ondernemingen, bijgestaan door Indo-Europeanen, Chinezen en Indonesiërs. De meeste van deze Japanners kenden geen andere taal dan Japans en velen waren weinig deskundig. Zij konden de door de internering van de blanken geschapen leemten niet adequaat opvullen. Bovendien stelden zij allen de belangen van Japan boven de belangen van de bevolking van Indonesië.

Dit laatste was ook een vast uitgangspunt van de militaire besturen. De al in 1941 door de hoogste Japanse leiding uitgegeven richtlijnen voor het bezettingsbeleid bepaalden niet alleen, dat deze besturen de verwerving van voor de defensie nodige hulpbronnen moesten bevorderen en de zelfvoorziening van de in hun gebieden gelegerde Japanse strijdkrachten moesten verzekeren, maar ook dat een en ander ten koste van het levenspeil van de inheemse bevolking zou mogen gaan. De Japanse strijdkrachten kregen dan ook altijd voorrang bij bijvoorbeeld de beschikbaarstelling van transportmiddelen, brandstoffen en levensmiddelen en bij de inzet van arbeidskrachten.

Door het optreden van de bezettingsautoriteiten raakte de voedselvoorziening op Java ernstig in het ongerede. Voor de oorlog produceerde men hier nauwelijks voldoende rijst om de bevolking van dit dichtbevolkte eiland te voeden. De bezetters ondernamen ambitieuze pogingen om de rijstproductie op te voeren, maar slaagden daar niet in, ook al kwam een deel van de vroegere suikerplantages nu voor rijstbouw beschikbaar. Verder verplichtten zij alle rijst verbouwende boeren om een deel van hun oogst tegen vaste prijzen aan de overheid te leveren. De bezettingsmacht stelde het grootste deel van de aldus verkregen rijst beschikbaar voor de bevolking, terwijl zij een ander deel zelf gebruikte voor het Japanse militaire en burgerlijke personeel op Java. Het resultaat van de verplichte leveringen bleef ver achter bij de Japanse plannen, onder meer omdat de daarvoor betaalde prijzen altijd beneden de marktprijzen lagen. Het deel van de rijst dat de bezettingsmacht zelf nodig had nam geleidelijk toe, omdat zij daarmee ook haar inheemse arbeiders moest voeden van wie het aantal in de honderdduizenden ging lopen. Bovendien moest zij sommige Japanse strijdkrachten buiten Java helpen bevoorraden. De voor de bevolking beschikbare hoeveelheid rijst liep terug.

De voedselsituatie verslechterde aanzienlijk na oktober 1943, toen het militaire bestuur alle particulier vervoer tussen de residenties verbood. De achtergrond hiervan was een reorganisatie van de Japanse verdediging van Java met het oog op een eventuele geallieerde invasie. Het accent kwam daarom 
op lokale verdediging te liggen, waarbij de strijdkrachten in iedere residentie op zelfverzorging aangewezen zouden zijn. Voortaan bepaalden de bezettingsautoriteiten hoeveel rijst nog uit residenties die daar veel van produceerden moest worden overgebracht naar residenties waar weinig rijst verbouwd werd. De overheid ging de rijst volgens een rantsoeneringsstelsel onder de bevolking distribueren. Deze centrale regulering bleek weinig doeltreffend en in verscheidene gebieden ontstonden grote rijsttekorten. Bovendien daalde ook de productie van mais en andere voedingsgewassen. De officiële voedselrantsoenen verschilden sterk van plaats tot plaats. Zowel in als buiten de steden maakte de voedselnood tienduizenden slachtoffers, vooral onder de allerarmsten.

De uitvoering van al de hier genoemde maatregelen berustte bij de inheemse bestuursambtenaren. Zij waren belast met de invordering van de verplichte leveranties. Zij bepaalden wat de boeren moesten leveren om te voldoen aan de door de bezetters vastgestelde normen. Zij moesten waken tegen clandestiene opslag, verkoop en vervoer. Zij waren verantwoordelijk voor de distributie van rijst en andere schaarse goederen.

De economische ontreddering betrof niet alleen de voedselvoorziening. Wegens het gebrek aan steenkool en aardolie op Java lieten de bezettingsautoriteiten op grote schaal hout als brandstof gebruiken, waartoe veel bos werd gekapt. Het aardolietekort leidde ook tot een gebrek aan smeerolie. Het militaire bestuur verplichtte de bevolking daarom tot het verbouwen van djarakplanten, waaruit een vervangend smeermiddel kon worden gewonnen. In 1944 kwam de eerste verantwoordelijkheid voor de naleving van deze verplichting te liggen bij de buurtorganisaties onder het Tonarigumi-stelsel.

Het tekort aan ijzer bracht het bezettingsbestuur op Java tot radicale maatregelen. Het liet ijzeren hekken en brugleuningen en soms ook tram- en spoorrails weghalen en dwong de bevolking tot inlevering van een deel van haar ijzeren en koperen gebruiksvoorwerpen. Ook kwamen er inzamelingen van goud, zilver en edelstenen. De uitvoering van deze maatregelen berustte weer bij het inheemse bestuursapparaat.

De voorrang voor de behoeften van de Japanse oorlogvoering leidde verder tot het achterwege laten van onderhoud aan infrastructurele voorzieningen zoals irrigatie- en rioleringsstelsels.

\section{De romusha's}

Hoewel de Japanse strijdkrachten een deel van hun inheemse hulpsoldaten (de heiho's) lichamelijk werk lieten doen, ging hun behoefte aan inheemse arbeidskrachten daar ver bovenuit. Al van begin af aan plachten zij plaatselijke bestuurders op te dragen werkers te leveren voor bijvoorbeeld het 
herstel van bruggen en het aanleggen van wegen en vliegvelden. Ook kwam het voor dat zij mannen eenvoudig oppakten om hen voor zulk werk in te zetten. Geleidelijk werd de inzet van inheemse arbeidskrachten ten behoeve van de Japanse oorlogvoering meer stelselmatig georganiseerd. Deze arbeidskrachten kwamen bekend te staan als romusha's, naar een Japanse term voor 'arbeider'.

Men kan de romusha's niet zonder meer als dwangarbeiders aanduiden, want voor een deel traden zij vrijwillig in Japanse dienst. Gewoonlijk werd aan deze vrijwilligers een goede betaling en behandeling toegezegd, maar werden ze in de praktijk buitengewoon slecht behandeld. Bovendien bracht men velen van hen naar verre streken over, zowel binnen als buiten Indonesië. Ook als ze een contract voor slechts drie maanden gesloten hadden, waren ze vaak na een jaar nog niet teruggekeerd. Naarmate een en ander onder de bevolking bekend werd, nam de animo voor vrijwillige dienstneming af.

Eind 1943 voerden de bezettingsautoriteiten op Java de recrutering van romusha's sterk op, nadat op hoger niveau besloten was dat het arbeidspotentieel van Java ten dienste moest staan van alle legers in de zuidelijke gebieden. De bezetters schakelden het hele inheemse bestuursapparaat hiervoor in. Van ieder gebied werd bepaald hoeveel arbeiders het moest leveren; de plaatselijke bestuurders moesten die aanwijzen en kregen daarvoor premies naar verhouding van de door hen geleverde aantallen. Sommige van de aldus gerecruteerde romusha's werden in hun eigen streek aan het werk gezet, maar vele anderen werden weggevoerd zonder dat hun familie wist waar ze heen gingen.

Meestal werden de romusha's bruut behandeld en zwaar afgebeuld en kregen ze weinig voedsel en geen enkele medische zorg. De Japanners gebruikten een deel van hen voor werk op Java zelf (bijvoorbeeld op rijstvelden en in bruinkoolmijnen), maar transporteerden ook honderdduizenden naar elders, zoals Sumatra, Borneo, Oost-Indonesië, Indochina, Malakka en Thailand. De romusha's werkten onder meer aan de aanleg van dezelfde nieuwe spoorlijnen waarvoor Japan ook krijgsgevangenen inschakelde. Zowel op Java als elders kwamen velen om door uitputting, honger en ziekte. Dit lot trof de uit Java weggevoerde romusha's het zwaarst; de meerderheid van hen keerde niet terug; in sommige groepen overleefde slechts tien tot twintig procent. In totaal zijn meer dan driehonderdduizend Indonesiërs in romusha-dienst omgekomen.

De inschakeling van het inheemse bestuursapparaat op Java leverde meer romusha's op dan het Japanse bezettingsbestuur verwacht had. Niettemin liet dit bestuur de recrutering vergezeld gaan van grootscheepse propagandacampagnes. De belangrijkste propagandist was Soekarno. Zo spoorde hij de Indonesiërs veelvuldig in radiotoespraken aan om als romusha dienst te nemen en liet hij zichzelf ten behoeve van de Japanse propaganda als romusha gekleed fotograferen. 
Na de verovering van Indonesië door Japan wilde luitenant-gouverneur-generaal Van Mook een Nederlands-Indisch gouvernement-in-ballingschap gaan leiden met zetel in Australië, maar de Nederlandse regering in Londen stemde daar niet onmiddellijk mee in. In plaats daarvan nam zij Van Mook in haar midden op als minister van koloniën, onder ontheffing uit zijn functie van luitenant-gouverneur-generaal. Wel zou hij voorlopig ook de bevoegdheden van het bestuur over Nederlands-Indië moeten uitoefenen. De zeggenschap over de strijdkrachten was daarvan uitgezonderd; die berustte formeel bij de op Ceylon gestationeerde vice-admiraal Helfrich, die door de regering benoemd was tot Bevelhebber Strijdkrachten Oosten. Nederland beschikte overigens nauwelijks over strijdkrachten in het gebied van Azië en de Pacific en voorzover die beschikbaar waren stonden ze operationeel niet onder Helfrich maar onder geallieerde opperbevelhebbers. Dat waren de Amerikaanse generaal Douglas MacArthur voor de South-West Pacific Area (SWPA) en sinds augustus 1943 de Britse admiraal Louis Mountbatten voor het South-East Asia Command (SEAC). Ook het grondgebied van Nederlands-Indië was tussen deze twee bevelsgebieden verdeeld: Sumatra viel onder SEAC en de rest onder SWPA.

Tijdens zijn ministerschap was Van Mook soms langdurig niet op zijn departement in Londen. Zo verbleef hij van november 1942 tot februari 1943 in de Verenigde Staten en van december 1943 tot mei 1944 in Amerika, Australië, Ceylon en India. Tijdens zijn reizen sprak hij herhaaldelijk met hoge gezagsdragers zoals Roosevelt, MacArthur en Mountbatten. In Australië bevond zich het merendeel van het onder hem ressorterende personeel. Al in april 1942 had hij in Melbourne een commissie voor de behartiging van de NederlandsIndische belangen ingesteld, die met veel improvisatie de kern van een ambtelijk apparaat opbouwde. Een jaar later begon men ook met een noodopleiding voor nieuwe bestuursambtenaren.

Op basis van voorstellen van Van Mook stelde de regering eind 1943 de opzet vast van een overgangsregeling voor het algemeen bestuur van Nederlands-Indië, in afwachting van het herstel van de vooroorlogse situatie. Enige maanden later stelde Van Mook weer departementen onder directeuren in, zoals ook het centrale bestuur in Batavia georganiseerd geweest was. Onder meer benoemde hij Van der Plas tot directeur binnenlands bestuur. De commissie werd opgeheven en Van der Plas, die de commissie sinds eind 1942 had voorgezeten, trad nu op als voorzitter van de raad van departementshoofden (behalve wanneer Van Mook deze raad zelf voorzat). Ook luitenant-generaal L.H. van Oyen, sinds 1943 legercommandant van het KNIL, maakte als hoofd van het departement van oorlog deel uit van deze raad.

De in 1943 vastgestelde overgangsregeling trad pas op 14 september 1944 
formeel in werking. Ze hield onder meer in dat het algemeen bestuur zou worden uitgeoefend door een luitenant-gouverneur-generaal, die in overeenstemming met de raad van departementshoofden ordonnanties (wetsbesluiten) zou kunnen vaststellen. Van Mook werd opnieuw tot luitenant-gouverneur-generaal benoemd; hij vertrok nog dezelfde maand naar Australië. Het Nederlands-Indisch gouvernement-in-ballingschap was daarmee een feit. Overigens bleef Van Mook voorlopig nog minister van koloniën, omdat de regering met de benoeming van een opvolger wilde wachten tot de bevrijding van Nederland, die men toen op korte termijn tegemoetzag. In december 1944 begon het gouvernement weer een Staatsblad van Nederlands-Indië uit te geven.

Alle overheidsorganen die zich in Australië op de terugkeer naar Nederlands-Indië voorbereidden kregen in de zomer van 1944 de beschikking over een eigen behuizing, Camp Columbia, een complex kantoren en barakken nabij Brisbane. Op de duur verbleven daar ongeveer tweeduizend personen, namelijk bijna vijfhonderd personeelsleden van de departementen (onder wie ook Australiërs), ruim duizend KNIL-militairen en enige honderden Indonesische hulpkrachten. Van deze Indonesiërs was een aantal afkomstig uit het interneringskamp Boven-Digoel. Om te voorkomen dat de daar geïnterneerden in Japanse handen zouden vallen, had men hen medio 1943 naar Australië overgebracht en daar opnieuw geïnterneerd. Dit had tot protesten van het Australische publiek geleid, waarop de Nederlandse regering eind 1943 onder druk van de Australische regering bijna alle geïnterneerden had vrijgelaten. Verscheidenen van hen waren al sinds 1927 geïnterneerd geweest.

Toen de regering de overgangsregeling formeel in werking stelde, functioneerde al enige maanden een onder Van Mook vallende bestuursorganisatie op Nederlands-Indisch grondgebied, in de delen van Nieuw-Guinea waar de geallieerde strijdkrachten de Japanners uit hadden verdreven. Dit was de Netherlands Indies Civil Administration (NICA). Van Mook had deze organisatie kunnen opzetten, omdat de regering hem gemachtigd had regelingen te treffen voor de uitoefening van het militair gezag in de bevrijde gebieden. In maart 1944 waren Van Mook en MacArthur, ervan uitgaande dat de soevereiniteit over Nederlands-Indië onverminderd bij Nederland berustte, overeengekomen dat MacArthur tijdens de herovering daarvan het hoogste gezag in de strijdgebieden zou uitoefenen, maar dat aan zijn strijdkrachten Nederlands-Indische bestuursambtenaren zouden worden toegevoegd voor de uitoefening van het bestuur over de burgerbevolking en de vervulling van andere civiele taken. (Een soortgelijk akkoord kwam Van Mook enige maanden later met Mountbatten overeen.) De terstond daarna gevormde NICA was een volledig gemilitariseerde organisatie, ook al had zij in hoofdzaak civiele taken; alle bij haar ingedeelde deskundigen kregen een militaire rang. Het 
eerste NICA-detachement ging op 24 april 1944 aan land bij Hollandia, kort nadat Amerikaanse strijdkrachten dit hadden bezet. In de volgende maanden veroverden de geallieerden het eiland Biak en bezetten zij nog meer plaatsen aan de kust van Nieuw-Guinea, en in september landden zij op het NoordMolukse eiland Morotai; steeds kwamen NICA-detachementen mee. Hun omvang varieerde van enkele tientallen tot bijna honderd man, onder wie bestuurders, tolken, gidsen, verplegers, politiebeambten en inlichtingenpersoneel. Zij hielden zich onder meer bezig met medische zorg, verstrekking van voedsel en kleding, huisvesting van vluchtelingen, invoering van nieuw geld en herinrichting van het inheemse bestuur De NICA had een vertegenwoordiger bij het Amerikaanse hoofdkwartier met de titel Senior Officer NICA (Sonica). In het najaar werd Abdoelkadir in deze functie benoemd, nadat hij daarvoor het NICA-detachement op Biak had geleid; hij kreeg de rang van kolonel. Medio 1945 telde de NICA bijna vijfhonderd man.

De gezagsverhoudingen ten aanzien van de NICA waren niet volledig duidelijk. Formeel was de NICA ondergeschikt aan het Amerikaanse opperbevel voor de South-West Pacific Area. Niettemin achtte het Nederlands-Indische gouvernement in Australië zich bevoegd haar rechtstreeks aanwijzingen te geven. In het algemeen lieten de Amerikaanse bevelhebbers het civiele bestuur in de bevrijde Nederlands-Indische gebieden volledig aan de NICA over. Bovendien presenteerden de NICA-detachementen zich in deze gebieden met een proclamatie die begon met de woorden 'Uit naam van de Koningin'. MacArthur stond dit toe, hoewel hij wist dat de Amerikaanse legerleiding in Washington hier bezwaar tegen had.

\section{De NEFIS}

De Nederlandse autoriteiten waren slecht op de hoogte van wat zich in Indonesië onder de Japanse bezetting afspeelde. De kort voor de Nederlandse capitulatie door het gouvernement ondernomen poging om een geheime inlichtingenorganisatie op te zetten was mislukt; het in dat kader door Amir Sjarifoeddin op touw gezette netwerk werd door de Kempeitai opgerold voordat het iets had kunnen doen. (Een Japanse rechtbank veroordeelde hem begin 1944 ter dood; op aandrang van Hatta en Soekarno zette generaal Harada dit vonnis om in levenslange gevangenisstraf.) In de eerste maanden van de bezetting hadden verschillende individuele Nederlanders nog geprobeerd radiocontact met Australië tot stand te brengen, maar ook deze pogingen waren niet geslaagd. De geallieerde inlichtingendiensten beschikten zelf niet over betrouwbare contacten in bezet Indonesië. Weliswaar probeerden deze diensten herhaaldelijk eigen agenten in bezet gebied te laten infiltreren (meestal door hen met onderzeeboten naar de kust te brengen), maar bijna 
al deze pogingen liepen op een fiasco uit. Alle op Sumatra, Java, Borneo en Celebes achtergelaten infiltranten kwamen daarbij om het leven. De veronderstelling van de inlichtingendiensten, dat de inheemse bevolking bereid zou zijn zichzelf in gevaar te brengen om zulke infiltranten te helpen en uit Japanse handen te houden, was ongegrond.

Terwijl de geallieerden dus geen geheime informatie uit bezet Indonesië ontvingen, was ook hun toegang tot open bronnen beperkt. Zij beschikten niet over daar verschijnende kranten en tijdschriften. Het beluisteren van officiële radiouitzendingen werd dan ook vrijwel hun enige inlichtingenbron, maar gedurende meer dan een jaar kon men die uitzendingen slecht ontvangen. Pas in april 1943 kwam er in het noorden van Australië een luisterpost die in staat was uitzendingen uit Bandoeng redelijk op te vangen. Overigens werden deze uitzendingen slechts gedeeltelijk beluisterd en in vertaling weergegeven, waarbij de nadruk lag op militair relevante informatie. Daarnaast had men soms incidentele informatiebronnen, zoals enkele Nederlanders die in 1942 uit Java wisten te ontsnappen, enige uit Indonesië afkomstige schepelingen die door de geallieerde marine aangehouden waren en een aantal in de frontgebieden aangetroffen heiho's en romusha's. Bovendien vond men in $1944 \mathrm{op}$ Nieuw-Guinea een uitvoerig Kempeitai-rapport over anti-Japans verzet op Java. Uit alle verzamelde informatie concludeerden de inlichtingendiensten in het algemeen, dat de Indonesische bevolking de Japanners hartgrondig haatte en dat zij verlangend uitzag naar de terugkeer van het Nederlandse gezag.

Van de politieke ontwikkelingen op Java drong weinig tot de Nederlandse autoriteiten door. De meesten van hen wisten trouwens te weinig over de vooroorlogse nationale beweging om de uit Indonesië opgevangen informatie adequaat te kunnen interpreteren. Van der Plas, die beter op de hoogte was en zich intensief met het inlichtingenwerk bezighield, werd verontrust toen hem medio 1943 bleek dat de Japanners erin geslaagd waren vrijwel alle Indonesiërs van naam te verenigen in een met hen samenwerkende organisatie, de Poetera. Hij uitte die verontrusting echter niet in het openbaar. Eigenlijk trok alleen het optreden van Soekarno enige aandacht; in de uitzendingen uit Java werd hij nu eenmaal veel genoemd en was hij ook vaak zelf te horen. De meeste Nederlanders waren zich overigens niet of nauwelijks bewust van het bestaan van een politiek probleem; zij dachten dat men in Nederlands-Indië na de verdrijving van de Japanners de draad weer zou kunnen oppakken op het punt waar men gebleven was. Het sprak vanzelf dat dan voor Soekarno geen genade zou gelden.

Afgezien van enkele inlichtingendiensten die tot Amerikaanse of Britse organisaties behoorden, was het belangrijkste informatiecentrum over Indonesië de Netherlands Forces Intelligence Service (NEFIS). Dit was een in 1942 opgericht militair bureau, bestaande uit officieren van het KNIL en de Koninklijke Marine naast enige Britse en Australische officieren en een aantal 
burgers. De NEFIS had drie afdelingen. De eerste afdeling moest alle over Nederlands-Indië voorhanden kennis beschikbaar maken voor de geallieerde oorlogvoering. Zij bracht in het bijzonder een grote hoeveelheid militairgeografische gegevens bijeen. Terwijl de verzamelde documentatie in hoofdzaak van voor 1942 dateerde, werd die ook geregeld aangevuld met nieuwere gegevens, vooral over het oosten van de archipel. Verder gaf deze afdeling een maandoverzicht van ontvangen inlichtingen uit, bijna uitsluitend op militair terrein. De tweede afdeling van de NEFIS hield zich bezig met interne beveiliging, de derde afdeling met geheime operaties in bezet gebied. Alleen in het oosten van de archipel boekte deze afdeling enige successen.

De eerste afdeling stond tot eind 1943 onder de KNIL-kapitein S.H. Spoor. Hij had zich voor de Nederlandse capitulatie beziggehouden met publieksvoorlichting over de Nederlands-Indische defensie en behoorde tot de kleine groep personen die het gouvernement na de Japanse landingen naar Australië gestuurd had. Na 1943 kreeg hij de leiding over de hele NEFIS.

\section{De Japanse toezegging van onafhankelijkheid}

Het hoogste Japanse beleidsorgaan, de contactraad, had in mei 1943 besloten dat Indonesië na de oorlog bij Japan ingelijfd zou worden - tegen het advies van onder meer minister-president Tojo, die dit gebied juist onafhankelijkheid had willen verlenen. Omdat de contactraad het besluit geheim hield, bleef de deur open voor pogingen het ongedaan te maken. De voortgaande achteruitgang van Japan's strategische positie versterkte de argumenten daarvoor. Japan zou een geallieerde invasie op Java niet meer kunnen beletten; daarom zou het in geval van zulk een invasie moeten proberen door een volksguerrilla zoveel mogelijk geallieerde strijdkrachten op het eiland te binden; de kansen voor het voeren van een effectieve volksguerrilla zouden aanzienlijk stijgen als men de inheemse bevolking uitzicht op onafhankelijkheid bood. Medio 1944 staakte de landmachtstaf dan ook zijn verzet tegen Indonesische onafhankelijkheid. De marine bleef dit echter afwijzen voor de gebieden onder haar gezag.

De geallieerde successen in de Stille Oceaan leidden in juli 1944 tot het aftreden van Tojo. Zijn opvolger als minister-president, generaal Koiso, verving de contactraad door een kleiner orgaan dat minder door de militairen overheerst werd, de 'opperste oorlogsraad'. Koiso wist te bereiken dat het besluit over de toekomst van Indonesië kwam te vervallen. Op 7 september verklaarde hij in het parlement, dat Japan in de toekomst de onafhankelijkheid van de bevolking van 'Oost-Indië' zou goedkeuren. Deze verklaring werd gelijktijdig in Djakarta bekendgemaakt door het militaire bestuur, dat intussen van hogerhand nauwkeurige instructies gekregen had over de consequenties van het nieuwe beleid. 
Enerzijds zouden nationalistische activiteiten voortaan worden toegestaan, met inbegrip van het zingen van het 'Indonesia Raja', het tonen van de rood-witte vlag en het gebruik van de term 'het Indonesische volk'. Anderzijds zou men voorlopig niet mogen spreken over het tijdstip waarop de onafhankelijkheid zou ingaan, over het gebied waarop die betrekking zou hebben en over de staatsvorm van de te vormen nieuwe staat. Verder zou men geen onderscheid mogen maken tussen inheemsen en ingezetenen van ander ras.

Dagenlang was de Japanse toezegging aanleiding voor tal van ceremonies en feestelijkheden op Java, naar aanwijzingen van het militaire bestuur. Op 8 september vond in Djakarta in het vroegere paleis van de gouverneur-generaal een bijeenkomst plaats waarin generaal Harada plechtig mededeling deed van het besluit over onafhankelijkheid voor Oost-Indië. Hij waarschuwde dat die onafhankelijkheid niet zou doorgaan als Japan de oorlog zou verliezen. Soekarno sprak namens het Indonesische volk een dankbetuiging uit en ging het gezelschap voor in het brengen van hulde aan de Japanse keizer. Enige dagen later zat hij een vergadering van de Centrale Adviesraad voor, waarin deze raad Japan 'duizendmaal dankte', van bereidheid getuigde om op leven en dood naast Japan te strijden en verklaarde zich met alle kracht te zullen inzetten voor versterking van de vrijwilligers- en hulpkorpsen, voor vergroting van de productie en voor uitbreiding van het aantal romusha's.

Hoezeer Japan militair verzwakt was bleek op 24 september, toen twee Nederlandse bommenwerpers ongehinderd boven Djakarta en andere WestJavaanse plaatsen honderdduizenden pamfletten afwierpen. Een deel daarvan bevatte een boodschap van Van der Plas, waarin deze verzekerde dat Japan's nederlaag nu snel naderbij kwam en dat daarna alle Indische bevolkingsgroepen samen een 'nieuw Indonesië' zouden opbouwen. Dit pamflettenbombardement leidde tot verhevigde inspanningen van het Japanse propaganda-apparaat. Zo werden begin november tijdens een massademonstratie in Djakarta na een toespraak van Soekarno drie grote poppen verbrand die Roosevelt, Churchill en Van der Plas voorstelden.

Intussen ondernam het militaire bestuur van Java slechts weinig om aan de verklaring van Koiso nadere uitwerking te geven. Het benoemde nog twee Indonesiërs tot departementshoofden en het stelde nu bij alle departementen Indonesische adviseurs aan. Bovendien bracht het deze adviseurs eind 1944 bijeen in een nieuw lichaam: het college van adviseurs, dat negentien leden telde. Voorzitter was Soekarno; leden waren onder anderen Abikoesno, Dewantoro, Hatta, Iskandar Dinata, Sartono, Soepomo en Yamin. Terwijl men de eind 1943 gevormde centrale adviesraad als een voorstadium voor een parlement kon zien, leek dit nieuwe college op een vooroefening voor een ministerraad. Verder benoemde het militaire bestuur geleidelijk meer Indonesiërs tot assistent-residenten. Tenslotte begon men in maart 1945 met een opleiding voor nieuwe bestuursambtenaren. 
Het militaire bestuur van Sumatra deed nog minder naar aanleiding van de verklaring van Koiso: het beperkte zich tot opheffing van het verbod op het 'Indonesia Raja' en de rood-witte vlag. Het bestuur van het marinegebied deed tot eind april 1945 zelfs dit niet.

Totaal anders was de opstelling van de marinevertegenwoordiger in Djakarta, schout-bij-nacht Maeda. Hij richtte daar in oktober 1944 een nieuw opleidingsinstituut voor Indonesische jongeren op, de Asrama Indonesia Merdeka. De leiding van deze opleiding gaf hij aan Soebardjo en Wikana, onder toezicht van zijn medewerker Nishijima. Soebardjo was de oud-voorzitter van de Perhimpoenan Indonesia die voor de oorlog zowel in Moskou als in Tokio had verbleven en tijdens de Japanse bezetting eerst voor Hatta had gewerkt, daarna enige tijd gevangen had gezeten en uiteindelijk door Maeda in dienst was genomen. Wikana, oud-cursist van Soekarno's kaderschool in Bandoeng en oud-voorzitter van de jeugdbond Indonesia Moeda, had in de links-nationalistische partij Gerindo nauw samengewerkt met Amir Sjarifoeddin. De legerleiding in Djakarta was ongelukkig met dit nieuwe opleidingsinstituut, naast het al in 1942 onder haar eigen auspiciën opgerichte instituut Asrama Angkatan Baroe, maar zij kon het niet tegenhouden. Overigens waren verscheidene bekende Indonesiërs aan beide Asrama's als docent verbonden. Het voornaamste verschil op dit punt was dat op Maeda's instituut ook Sjahrir doceerde, de enige belangrijke nationalistische voorman die zich steeds van samenwerking met de bezetters onthouden had.

\section{De Barisan Pelopor}

Ter verdere bevordering van een doeltreffende volksguerrilla in geval van een geallieerde invasie op Java stemde het militaire bestuur midden 1944 in met de vorming van een eigen weerbaarheidsorganisatie van de nationalisten. Dit was de Barisan Pelopor (Voortrekkers-Korps); de officiële oprichting vond in september plaats na de verklaring van minister-president Koiso. Het korps stond onder commando van Soekarno zelf. De leden moesten een verklaring afleggen, inhoudende dat zij alle Indonesiërs wilden vormen tot één volk met één land en één taal, dat zij offers zouden brengen voor de verwezenlijking en het behoud van Indonesië's onafhankelijkheid en dat zij de rood-witte nationale vlag en het volkslied 'Indonesia Raja' zouden verdedigen.

Het korps was bestemd voor jongeren van twintig jaar en ouder. Het bestond uit eenheden van vijftig leden, die op hoger niveau compagnieën en bataljons vormden. Zij werden militair gedrild en politiek geïndoctrineerd, maar anders dan bij het jeugdkorps Seinendan was die indoctrinatie nu niet op Japan maar op Indonesië gericht. Bij gebrek aan vuurwapens oefenden de leden met bamboesperen. Overigens schakelde men de leden ook, evenals 
die van de Seinendan, voor allerlei praktische taken in. Bij het einde van de Japanse bezetting bedroeg de sterkte van de Barisan Pelopor waarschijnlijk ruim vijftigduizend man.

Enige tijd na de oprichting van de Barisan Pelopor gingen de Japanse autoriteiten op Java ertoe over, uit leden van de Seinendan nog een andere inheemse weerbaarheidsorganisatie te vormen, de Barisan Brani Mati (Bereidom-te-sterven Korps). Enkele duizenden jonge mannen en vrouwen werden opgenomen in dit korps, dat meer in Japanse geest werd opgeleid.

\section{De Hizboellah}

Bij de oprichting van de Peta had het Japanse bestuur zich beijverd om het kader van dat vrijwilligersleger vooral uit moslimkringen aan te trekken en om de islam (en niet het Indonesisch nationalisme) tot zijn belangrijkste inspiratiebron te maken. Niettemin drong de leiding van de Masjoemi in 1944 bij de bezettingsmacht aan op toestemming voor de vorming van een eigen strijdmacht. Deze wens van de Masjoemi verontrustte sommige nationalistische leiders, omdat zij wisten dat men binnen die organisatie ernaar streefde de toekomstige Indonesische staat op exclusief-islamitische grondslag te vestigen. Ondanks de bezwaren uit nationalistische hoek willigde generaal Harada de wens van de Masjoemi in december 1944 in. De nieuwe strijdmacht ging Hizboellah (Leger van Allah) heten. In februari 1945 begon de training van een eerste groep van vijfhonderd leerlingen van islamitische internaten; in mei verspreidden die zich over Java om de opleiding van nieuwe groepen op zich te nemen. Evenals de Barisan Pelopor kreeg de Hizboellah geen vuurwapens. Bij het einde van de Japanse bezetting telde het korps enige tienduizenden leden.

\section{Anti-Japanse activiteiten}

Van eind 1943 af nam de ergernis onder de Indonesiërs over het bezettingsregime sterk toe. Terwijl de Japanse propaganda de lof zong van de 'GrootOostaziatische Gemeenschappelijke Welvaartssfeer', kampte de overgrote meerderheid van de bevolking met armoede, textielschaarste en voedselgebrek en zakte haar levensstandaard ernstig beneden die onder het Nederlandse bewind. Het verbod op particulier vervoer tussen de residenties van Java, de verplichte rijstleveranties en de gedwongen inleveringen van ijzer en koper wekten veel weerstand. De geforceerde recrutering van romusha's en hun dikwijls onmenselijke behandeling leidden tot groeiende verontwaardiging. Het door de Kempeitai uitgeoefende schrikbewind zaaide angst en afkeer. Het 
Tonarigumi-stelsel zorgde ervoor, dat de macht van het bezettingsregime zich op Java tot in de gezinnen deed gelden. De ellende die een groot deel van de bevolking teisterde werd nog verergerd doordat de bezettingsmacht haar geen rust gunde, maar haar voortdurend met agitatie en propaganda bestookte.

Het leven onder het Japanse bewind stak in tal van opzichten ongunstig af tegenover dat onder het vroegere Nederlandse bewind. Een deel van de bevolking begon dan ook terug te verlangen naar de koloniale tijd, die men nu vaak als 'de normale tijd' aanduidde. Toch betekende de ergernis over het bezettingsregime bij veel Indonesiërs geen eerherstel voor het koloniale regiem. Zij weten de ellende waar het Indonesische volk in terechtgekomen was juist aan het falen van de Nederlandse overheersers om dat volk tegen een buitenlandse aanval te verdedigen. Steeds meer vestigden zij hun hoop op de Verenigde Staten als de enige macht die in staat was Indonesië van de Japanse overheersing te bevrijden.

Ondanks de wijdverbreide anti-Japanse gezindheid vonden slechts op bescheiden schaal anti-Japanse activiteiten plaats. Zulke activiteiten bestonden meestal daarin, dat gelijkgezinden onder elkaar de bezettingsmacht bekritiseerden, de officiële propaganda bestreden, naar buitenlandse radiouitzendingen luisterden, het daaruit verkregen nieuws over het verloop van de oorlog verspreidden en met elkaar over de politieke toekomst discussieerden. Het stelselmatig onderhouden van zulke contacten gebeurde vooral door activisten die al onder het Nederlandse koloniale bewind ervaring met clandestien politiek werk hadden opgedaan. Onder meer behoorden communisten hiertoe, zowel volgelingen van Moskou als aanhangers van Tan Malaka, die in 1927 met Moskou gebroken had (zie p. 202). Anderzijds behoorden hier leden toe van de in 1932-1933 door Hatta en Sjahrir geleide partij PNI Baroe (zie p. 217). Sjahrir hield zich persoonlijk met dit werk bezig. Hij behoorde tot een welgestelde familie, wat het hem gemakkelijker maakte zich van samenwerking met de bezetters te onthouden. Hij reisde veel door Java en kon over twee woningen beschikken, één in Djakarta en één tussen Bogor en Bandoeng. Hij bouwde een netwerk van contactpersonen op en hield zich steeds op de hoogte van clandestien opgevangen nieuwsberichten van geallieerde radiozenders. Van begin af aan was hij ervan overtuigd dat Japan de oorlog zou verliezen, omdat het uiteindelijk niet opgewassen zou zijn tegen het economische potentieel van de Verenigde Staten.

Daadwerkelijk anti-Japans verzet was door de meedogenloze repressie bijna onmogelijk. Niettemin kwamen op verschillende plaatsen in de archipel incidentele verzetsdaden voor. De belangrijkste incidenten speelden zich op Java af. Zo kwam in februari 1944 in West-Java een plaatselijke groep met bamboesperen en messen in verzet nadat de Kempeitai hun leider gearresteerd en mishandeld had. In eerste aanleg wist zij haar leider te bevrijden en de Kempeitai te verdrijven. Twee weken later kwam de Kempeitai versterkt terug 
en werd het oproer in felle gevechten onderdrukt. Ruim vijftig Japanners en meer dan honderd opstandelingen vonden daarbij de dood; ongeveer vierhonderd opstandelingen werden gevangen genomen; ruim tachtig werden ter dood veroordeeld. Enige tijd later deden zich meer dan eens soortgelijke ongeregeldheden voor in een ander deel van West-Java, dat geteisterd werd door hongersnood. Boeren verzetten zich tegen de gedwongen rijstleveranties en verdreven inheemse bestuursambtenaren die de leveranties kwamen controleren, onder wie de regent. In augustus brak hier een zo grote opstand uit dat het Japanse leger sterke troependetachementen moest inzetten om het verzet neer te slaan. Bij alle verzetsactiviteiten in West-Java speelden islamitische voormannen een leidende rol. Eén van de reacties van het militair bestuur hierop was Hoesein Djajadiningrat te ontslaan als directeur van het departement van eredienst; zijn werk werd overgenomen door de feitelijke leider van de Masjoemi, kiai Wahid Hasjim.

De meest spectaculaire anti-Japanse verzetsactie speelde zich in februari 1945 af in Blitar in Oost-Java. Enige jonge officieren van een hier gelegerd Petabataljon hadden een samenzwering tegen de bezettingsmacht op touw gezet. Het was de bedoeling van de samenzweerders dat, wanneer hun bataljon de wapens opnam tegen het Japanse gezag, dit het signaal zou vormen voor een Peta-opstand die zich over heel Java zou uitbreiden. Zij gingen echter voortijdig tot actie over wegens een gerucht dat tegenmaatregelen ophanden waren. Ongeveer vierhonderd van de ruim vijfhonderd militairen van het bataljon namen aan de actie deel. Nadat zij zich meester hadden gemaakt van de munitievoorraad en enkele vrachtauto's, bezetten zij in de stad onder meer het politiebureau, het bureau van de Kempeitai, de gevangenis en het telefoonkantoor. Tien Japanners werden tijdens deze actie gedood. De opstand vond echter geen steun, zodat de rebellen alleen kwamen te staan. Voor de onderdrukking van de opstand zetten de Japanse autoriteiten in hoofdzaak nabij gelegerde Peta-bataljons in, die de opstandelingen moesten overhalen hun strijd te staken. De meesten gaven zich inderdaad over; kleine groepen trokken de bergen in, maar werden daar in de volgende weken uitgeschakeld. Een Japanse militaire rechtbank, waar enkele Indonesiërs aan waren toegevoegd (onder anderen Soepomo), berechtte in april ruim vijftig officieren en onderofficieren van het opstandige bataljon; zes daarvan kregen de doodstraf.

\section{Eerste stappen ter inlossing van de Japanse toezegging}

De Japanse regering had weliswaar op 7 september 1944 verklaard, dat de bevolking van 'Oost-Indië' in de toekomst onafhankelijk zou worden, maar de militaire besturen in Indonesië mochten nog geen discussie toestaan over het tijdstip waarop dit zou gebeuren, het gebied waarvoor dit zou gelden en 
de staatsvorm die daarbij zou worden gekozen. De reden hiervoor was, dat in Tokio zelf grote onenigheid over deze kwesties bestond. Sommigen wilden de onafhankelijkheid bijvoorbeeld beperken tot Java, anderen wilden Sumatra wel onafhankelijk maken maar dan als een afzonderlijke staat, en velen vonden dat de bevolking van het oosten van de archipel nog niet aan onafhankelijkheid toe was. Toen Japan in 1943 eerst Birma en vervolgens de Filippijnen onafhankelijk maakte, had het in elk van die landen enige maanden eerder een nationale commissie ingesteld om de staatsregeling en de bestuursoverdracht voor te bereiden. Het militaire bestuur op Java kreeg echter geen toestemming een soortgelijke voorbereidingscommissie in te stellen zolang het overleg in Tokio niet tot resultaat had geleid. Dat overleg sleepte zich vruchteloos voort, terwijl Japan intussen bezig was de oorlog te verliezen. Sinds eind oktober bevochten de geallieerden de Japanners op de Filippijnen, eind december heroverden de Britten een deel van Birma en in februari 1945 veroverden de Amerikanen Manila. Dat intussen op Java zelf de politieke spanning opliep, bleek dezelfde maand uit de Peta-opstand in Blitar.

Toen bijna een half jaar sinds de toezegging van premier Koiso was verstreken zonder dat Tokio ook maar één stap ter inlossing daarvan had gezet, vond het militaire bestuur op Java dat men niet langer kon wachten. Het mocht dan wel geen commissie van voorbereiding instellen, maar het maakte nu op 1 maart 1945 bekend dat het een commissie in het leven zou roepen tot onderzoek van de maatregelen die ter voorbereiding van de onafhankelijkheid nodig zouden zijn. Dit eigenmachtige optreden leidde eerst tot boze reacties in Tokio en op het hoofdkwartier voor de zuidelijke gebieden in Saigon, maar uiteindelijk kreeg het militaire bestuur in Djakarta verlof om op deze weg door te gaan. Overigens was de traagheid waarmee men in Tokio de kwestie van Indonesische onafhankelijkheid behandelde des te meer onbegrijpelijk, omdat Japan in maart wel onafhankelijkheid verleende aan twee delen van Indochina, namelijk Annam en Kambodja.

Het militaire bestuur op Java vroeg nu eerst het college van adviseurs om voorstellen voor de taakstelling en de samenstelling van de onderzoekscommissie. Het college voldeed begin april aan dit verzoek, maar pas op 28 april maakte het bestuur bekend wie het in de commissie benoemde. Soekarno had er de voorkeur aan gegeven niet zelf als voorzitter op te treden, teneinde vrijer voor zijn eigen opvattingen te kunnen uitkomen. Voorzitter werd nu één van de meest gerespecteerde pioniers van de nationale beweging, de vijfenzestig jaar oude Javaanse arts Radjiman Wediodiningrat, die in 1908 bij de oprichting van Boedi Oetomo betrokken was geweest en daar later voorzitter van geworden was. Hij had in Nederland gestudeerd, had van 1918 tot 1931 in de Volksraad gezeten en was onder het Japanse bewind onder meer lid van de Centrale Adviesraad geworden. Na 28 april breidde het militaire bestuur de commissie nog enigszins uit; in haar uiteindelijke vorm telde ze drieënzestig 
gewone leden, namelijk zevenenvijftig Indonesiërs, vier Chinezen, een Arabier en een Indo-Europeaan, plus acht Japanners als buitengewone leden. Onder de leden waren twee vrouwen, maar geen jongeren; de twee door het militaire bestuur aangewezen jongerenvertegenwoordigers wezen hun benoeming af.

Zowel bij de samenstelling als bij de taakstelling van de onderzoekscommissie week het militaire bestuur op verschillende punten af van de voorstellen van het college van adviseurs. Zij kreeg tot taak vijf kwesties met betrekking tot de nieuw te vormen staat te onderzoeken, namelijk de staatsvorm, de leidende beginselen, de positie van de islam, het staatsburgerschap en de grenzen. Haar mandaat bleek niet tot Java beperkt te zijn, maar heel Indonesië te betreffen. Hoewel de commissie al begin mei informeel bijeenkwam, vond haar officiële installatie pas plaats op 28 mei, bijna drie maanden nadat ze was aangekondigd en bijna negen maanden na de verklaring van premier Koiso. Het was bovendien drie weken nadat aan de oorlog in Europa een einde was gekomen door de capitulatie van Duitsland.

Intussen was generaal Harada eind april naar Japan overgeplaatst. Zijn opvolger als opperbevelhebber op Java, generaal Nagano, werd geïnstalleerd op 29 april, de verjaardag van de Japanse keizer. Hij maakte bij die gelegenheid bekend dat het woord Indonesië voortaan ook in staatkundige zin gebruikt mocht worden en dat alle organisaties, bestuurders en adviesorganen hun denkbeelden over de structuur van de onafhankelijkheid zouden kunnen meedelen aan de onderzoekscommissie.

Ook het marinegebied had inmiddels een nieuwe commandant gekregen. Het Japanse bestuur werkte daar nu eindelijk mee aan het nieuwe beleid en maakte op 29 april bekend dat de rood-witte vlag en het 'Indonesia Raja' niet langer verboden waren. Bovendien stond het aan Soekarno en Hatta toe om het marinegebied te bezoeken. Soekarno reisde naar Zuid-Celebes en later ook naar Bali, Lombok en Soembawa; hij werd daar vooral door jongeren toegejuicht, terwijl de traditionele bestuurders hem koel ontvingen. Hatta bezocht Zuid-Borneo. Daarentegen kregen Soekarno en Hatta geen toestemming om Sumatra te bezoeken. Het militaire bestuur daar beoogde de schepping van een onafhankelijke Sumatraanse staat en wilde het Indonesisch nationalisme daarom niet aanmoedigen. Het stelde nu voor Sumatra ook een centrale adviesraad in, die overigens pas eind juli bijeenkwam.

\section{Radicalisering van de nationalistische jongeren}

In de eerste helft van 1945 wezen verschillende tekenen op een veranderende geest onder de nationalistische jongeren, waarbij die zich tegenover de Japanse bezetters minder volgzaam opstelden dan de oudere politici. Dit gold vooral voor de studenten en andere hoogopgeleide jongeren. $\mathrm{Zij}$ zagen met 
ongeduld uit naar het eind van de Japanse overheersing, maar wilden geen herstel van de vooroorlogse verhoudingen. Terwijl het voor de maatschappelijke positie van de meeste Indonesiërs weinig verschil maakte of hun land wel of niet onafhankelijk zou worden, was dat verschil voor deze jongeren bijzonder groot. Werd Indonesië onafhankelijk, dan mochten zij verwachten daarin leidende functies te zullen bekleden, maar keerde het Nederlandse koloniale bestel terug, dan leek de kans daarop miniem. Hoewel het op Java om nauwelijks duizend hoogopgeleide jongeren ging, ontwikkelden zij zich tot een politieke factor van betekenis, ook door de invloed die zij binnen een veel ruimere kring van jongeren uitoefenden. Hun bijzondere positie was ten dele te danken aan gelijksoortige omstandigheden als die vroeger de STOVIA (de artsenschool in Batavia) tot een kweekbed van politieke bewustwording gemaakt hadden. De Japanse propaganda en indoctrinatie hadden hun strijdvaardigheid versterkt, maar bleken hun nationalistische gezindheid niet in de weg te staan.

Sommige nationalistische jongeren werkten trouwens zelf bij het departement van voorlichting en propaganda, de Sendenbu. Ook enige andere nationalisten stonden in dienst daarvan. Zo was de officiële adviseur van dat departement, Mohamad Yamin, voor de oorlog een belangrijke ideoloog van de nationale beweging geweest. Soekarni en Chairoel Saleh, die aan het hoofd van de opleiding stonden in het door de Sendenbu gestichte instituut Asrama Angkatan Baroe, waren eveneens afkomstig uit de nationale beweging en wel uit de linkervleugel daarvan. Hun instituut werd een centrum waar gelijkgezinden elkaar ontmoetten. Twee belangrijke figuren uit deze kring waren de journalisten Adam Malik en Burhanuddin Diah. Malik, een Batak, had tot de volgelingen van Tan Malaka behoord en was in 1940 medeoprichter van het nationalistische persbureau Antara geweest; hij werkte nu bij het Japanse persbureau Domei, dat Antara had overgenomen, en had daardoor toegang tot meer informatie dan op Java bekend werd gemaakt. Diah, een Atjeher, was redacteur bij het door de Sendenbu opgerichte dagblad Asia Raya.

In 1942 had het militaire bestuur aanvankelijk al het hoger onderwijs stopgezet. Het volgende jaar kwamen er weer opleidingen voor arts en ingenieur, nu op Japanse voet. Het internaat van de medische hogeschool in Djakarta werd een tweede nationalistisch centrum. Veel studenten, zowel daar als elders, stonden open voor linkse denkbeelden. Onder hen had vooral Sjahrir aanzienlijke invloed. Enkele van Sjahrir's volgelingen onder de studenten probeerden zelfs Soekarno te bewegen niet meer samen te werken met de Japanse bezettingsmacht.

Het in oktober 1944 door de Japanse marine-officier Maeda opgerichte instituut Asrama Indonesia Merdeka, waarin Soebardjo en Wikana aan het hoofd van de opleiding stonden, vormde een derde nationalistisch centrum. Evenals de Asrama Angkatan Baroe telde dit instituut voormannen van de 
nationale beweging zoals Soekarno en Hatta onder zijn docenten; bovendien trad ook Sjahrir hier als docent op. Beide instituten hadden bijzondere banden met de linkervleugel van de beweging en met de nationalistische jongeren. De verschillende jongerengroepen stonden ook met elkaar in verbinding en sommige groepen beschikten bovendien over contacten binnen de Peta en de Barisan Pelopor, organisaties die zelf al kweekbedden van militant nationalisme waren.

Intussen was in het midden van 1944 in het kader van de Hokokai een organisatie voor ontwikkelde jongeren opgericht, de Angkatan Moeda (Jonge Generatie). Verscheidene links-nationalistische figuren bekleedden daarin leidende posities. Zo zaten Soekarni en Saleh in het bestuur van de afdeling Djakarta en werd de afdeling Soerabaja geleid door Roeslan Abdoelgani, die voor de oorlog (evenals Soekarni en Wikana) voorzitter van de jeugdbond Indonesia Moeda geweest was.

Onder de ontwikkelde jongeren ontstond in het voorjaar van 1945 grote onvrede over de voorbereiding van de onafhankelijkheid. Een deel van hen ergerde zich eraan, dat de Japanse autoriteiten daar weinig haast mee maakten. Omgekeerd was een ander deel juist ongerust over het vooruitzicht dat Indonesië die onafhankelijkheid uit Japanse handen zou ontvangen. Zij verwachtten dat Japan de oorlog zou verliezen en dat het voor Indonesië beter zou zijn als het zich op eigen kracht onafhankelijk zou maken.

In mei belegde de Sendenbu een congres in Bandoeng voor kaderleden van de Angkatan Moeda. Door de kritische opstelling van de jongeren verliep dit congres anders dan de organisatoren beoogd hadden. Aan het slot nam het onder meer een resolutie aan die inhield dat de onafhankelijkheid nu snel tot stand moest komen. Een kort daarna door de Angkatan Moeda in Soerabaja belegde bijeenkomst liep nog meer uit de hand. Eén van de sprekers zei dat de Indonesiërs wel moesten vechten voor hun onafhankelijkheid, maar niet tegen de geallieerden; hierop kreeg hij grote bijval.

Een incident in begin juli getuigde van de groeiende verwijdering tussen de oude garde en de jongeren. Met steun van het militaire bestuur was Soekarno in die tijd bezig met het opzetten van een nieuwe massaorganisatie ter vervanging van de Djawa Hokokai, die al te zeer een Japans stempel droeg. Hij belegde nu in het Volksraadgebouw een vergadering met vertegenwoordigers van allerlei groeperingen om het statuut van deze nieuwe organisatie vast te stellen. De groep van Adam Malik stelde voor, daarin te verwijzen naar 'de Republiek Indonesië'. Een Japanse functionaris waarschuwde Soekarno dat het ontoelaatbaar was aldus vooruit te lopen op een beslissing van de Japanse keizer; Soekarno gaf deze waarschuwing zonder meer door. Dit leidde tot felle protesten en uiteindelijk verliet een aantal jongeren, onder wie Soekarni, Chairoel Saleh en Diah, demonstratief de zaal. De Japanse autoriteiten vonden dit een affront. Soekarni en Chairoel Saleh, die bovendien kort daarvoor 
geweigerd hadden om zitting te nemen in de onderzoekscommissie voor de onafhankelijkheid, kregen ontslag als medewerkers van de Sendenbu.

\section{Nederlandse voorbereidingen voor de terugkeer naar Indië}

Voor de Nederlandse autoriteiten bracht de voorbereiding van het herstel van het Nederlandse gezag over Indonesië veel problemen met zich mee. Nederland beschikte niet over militaire machtsmiddelen om dat herstel zelf te bewerkstelligen en was daarvoor dus geheel afhankelijk van zijn bondgenoten de Verenigde Staten, Groot-Brittannië en Australië. Maar ook wanneer die eenmaal aan de Japanse bezetting een eind gemaakt zouden hebben, zou het Nederlands-Indische gouvernement het bestuur van de kolonie niet meteen op de oude voet kunnen hervatten. De Nederlandse ambtenaren waren immers, evenals de andere Nederlanders, door de bezetters weggevoerd naar internerings- en krijgsgevangenenkampen, ten dele zelfs buiten de archipel. Het gouvernement zou het daarom voorlopig moeten stellen zonder de bovenlaag van zijn vroegere bestuursapparaat en bovendien, wegens de uitschakeling van het KNIL, zonder zijn vroegere machtsapparaat ter ondersteuning van het gezag.

Na de nederlaag van maart 1942 bevonden zich in Australië nog enkele restanten van het KNIL, waaronder enige daarheen gestuurde stafofficieren, twee daar toevallig terechtgekomen infanteriecompagnieën en een klein aantal daarheen uitgeweken vliegtuigen. In de loop van de volgende drie jaren kon men de KNIL-landmacht geleidelijk uitbreiden tot bijna drieduizend man, onder meer met uit Timor teruggetrokken guerrillastrijders, in Australië en Amerika gemobiliseerde Nederlanders, uit de scheepvaart afkomstige Indonesiërs en op Nieuw-Guinea aangeworven Papoea's. Ook kon het KNIL zijn luchtmacht versterken met vliegtuigen die het al eerder in Amerika besteld had maar die nu pas geleverd werden. Daarmee werd onder meer een eskader bommenwerpers gevormd, dat als onderdeel van de geallieerde luchtmacht sinds 1943 Japanse schepen en installaties bestookte. Buiten Australië kwam in de loop van de oorlog een Nederlandse landmachtbrigade tot stand, namelijk de al in 1941 in Groot-Brittannië opgerichte Irene-brigade. De Nederlandse marine, die in de strijd met Japan grote verliezen geleden had, bleef met al haar beschikbare schepen aan de geallieerde oorlogvoering deelnemen; daarbij opereerden die schepen voornamelijk op het Europese strijdtoneel. De belangrijkste Nederlandse bijdrage aan de geallieerde oorlogvoering leverde de koopvaardijvloot, die zevenentwintig grote transportschepen bevatte met een gezamenlijke capaciteit voor het vervoer van ongeveer zestigduizend militairen. De Nederlandse regering stelde deze vloot volledig ter beschikking van het geallieerde opperbevel voor de duur van de oorlog en de eerste zes maanden daarna. 
Als algemene strategie waren de bondgenoten met elkaar overeengekomen, dat zij zich in de eerste plaats zouden richten op het verslaan van Duitsland en Italië en pas daarna op de onderwerping van Japan. De Nederlandse regering wilde dat Nederlandse strijdkrachten een duidelijk aandeel zouden krijgen in de strijd tegen Japan. Van Mook (die tot februari 1945 deel van die regering uitmaakte) wilde dat ook, maar over de vraag wat in dit verband wenselijk was liepen de meningen al in 1943 ver uiteen. Sommige ministers, onder wie minister-president Gerbrandy, meenden dat na de overwinning op Duitsland de onderwerping van Japan nog zo veel tijd zou vergen, dat het bevrijde Nederland daaraan nog met modern uitgeruste en geoefende strijdkrachten zou kunnen deelnemen. In dat kader werden in Londen plannen opgesteld voor een naar het Aziatische strijdtoneel uit te zenden 'expeditionaire macht' in de vorm van een legerkorps van tenminste vier divisies van elk twintigduizend man. Van Mook voerde daartegen aan, dat men niet mocht uitgaan van een lange periode tussen de bevrijding van Nederland en de herovering van Indonesië. Hij verwachtte dat die herovering in hoofdzaak het werk van de bondgenoten zou worden en dat Nederlandse strijdkrachten daarbij alleen een aanvullende rol zouden kunnen vervullen. Zijns inziens zou de Nederlandse oorlogstaak na de bevrijding van het moederland niet gelegen zijn in het deelnemen aan een eventuele invasie binnen Japan zelf, maar in het opruimen van Japanse verzetshaarden in Indonesië en het daar verzekeren van orde en veiligheid. Met het oog daarop drong hij aan op de vorming van betrekkelijk eenvoudig uitgeruste mobiele strijdkrachten in de vorm van bataljons (van ongeveer duizend man), wat veel minder tijd zou vergen dan de vorming van moderne divisies of legerkorpsen. Binnen de regering overheerste echter de voorkeur voor volwaardige divisies. In augustus 1943 besloot zij met het oog op de strijd tegen Japan te streven naar de oprichting van een expeditionaire macht, bestaande uit een legerkorps van drie divisies, en daarnaast naar de vorming van een mariniersbrigade (van ruim vijfduizend man) en vijftien 'gezagsbataljons'. Daarbij ging zij ervan uit, dat Nederland alleen de mankracht voor deze strijdkrachten zou leveren, terwijl de bondgenoten voor de bewapening en uitrusting zouden zorgen. In de waardering van de Nederlandse militaire deskundigen stonden de gezagsbataljons op het tweede plan. De marine weigerde daarvoor eigen personeel beschikbaar te stellen.

Van Mook had zijn collega-ministers al in het voorjaar van 1943 gewaarschuwd dat, als Nederland niet dadelijk bij de bevrijding van Indonesië in staat zou zijn tot hervatting van het bestuur, er daar een geallieerd (Amerikaans) bestuur zou komen, waardoor de hele kwestie van het herstel van het Nederlandse gezag op de tocht zou komen te staan. Hij hechtte dan ook bijzonder belang aan de opbouw van de organisatie die de hervatting van het bestuur ter hand zou moeten nemen, de latere NICA. Omdat het uitermate moeilijk was daarvoor voldoende deskundige krachten bijeen te brengen, 
stelde hij in najaar 1943 onder meer voor, ook marine-officieren en ander marinepersoneel bij deze organisatie in te schakelen. De marine verzette zich hiertegen, al beschikte zij bijvoorbeeld in Zuid-Afrika en de Verenigde Staten over enige honderden van het marine-etablissement in Soerabaja afkomstige technici die vrijwel niets te doen hadden. Onder zware druk van de regering stond zij eind 1944 uiteindelijk honderdtwintig man voor de NICA af. In het voorjaar van 1945 nam de noodzaak tot uitbreiding van de NICA sterk toe, omdat de bevrijding van Indonesië voor de deur leek te staan. Men ging ervan uit meer dan honderd detachementen nodig te zullen hebben. Het Nederlands-Indische gouvernement in Australië betoogde, dat de vorming van nieuwe NICA-eenheden voorrang moest hebben boven de vorming van nieuwe gevechtseenheden en probeerde opnieuw daartoe medewerking van de marine te verkrijgen. De marine bleef medewerking afwijzen. Ook de leiding van het KNIL verklaarde geen man te kunnen missen.

In de tweede helft van 1944 kwamen het gouvernement en de marineleiding nog op een ander punt tegenover elkaar te staan. Generaal MacArthur drong er in die tijd op aan, dat de Nederlandse marine substantieel zou deelnemen aan de militaire operaties in de Indonesische archipel, en beloofde daarbij omvangrijke steun met het oog op de terugkeer van het Nederlandse gezag. Substantiële deelname aan die operaties strookte echter niet met de plannen van de Nederlandse marine. Omdat een positieve reactie uitbleef, zond Van der Plas namens het gouvernement hierover nog in februari 1945 een dringend telegram naar Londen. Gelet op het feit dat de toegezegde gezagsbataljons vermoedelijk niet tijdig beschikbaar zouden komen om aan de bevrijding van Java deel te kunnen nemen, wees hij op het risico dat Indonesische nationalisten samen met de Amerikanen die bevrijding vrijwel zonder de Nederlanders tot stand zouden brengen. Volgens zijn telegram zou het integraal herstel van Indië onder Nederlandse leiding in gevaar komen als de Nederlandse marine wegbleef. Daarentegen zou, als de marine wél meedeed, de Nederlandse positie op Java zowel internationaal als tegenover de nationalisten sterker worden. Bovendien zou de marine dan in het oosten van de archipel zelf gebieden kunnen bevrijden die nu nog geheel pro-Nederlands waren. Ook deze noodkreet bracht geen verandering in de opstelling van de marineleiding.

Intussen was er sinds de zomer van 1944 veel veranderd. Na de invasie in Normandië in juni hadden de geallieerden in september de Duitsers uit het zuiden van Nederland verdreven. Het geallieerde offensief was echter vastgelopen, zodat de Duitse bezetting in het noorden van Nederland nog voortduurde. De Nederlandse regering bleef voorlopig in Londen. Zij stelde in september formeel weer een Nederlands-Indisch gouvernement in en benoemde Van Mook tot hoofd daarvan met de titel van luitenant-gouverneur-generaal. Eerst wilde zij de benoeming van een nieuwe minister van koloniën uitstellen totdat heel Nederland bevrijd zou zijn, maar later besloot zij daar niet meer op 
te wachten. In verband daarmee keerde Van Mook in december naar Londen terug. Voor de ministerspost ging zijn voorkeur uit naar prof.dr. J.H.A. Logemann, met wie hij vroeger in de Stuw-groep nauw had samengewerkt, maar deze bevond zich nog in bezet gebied. Eind januari 1945 ging Van Mook naar het Europese vasteland, onder meer voor overleg met het hoofdkwartier van de geallieerde strijdkrachten in Europa onder generaal Eisenhower. In het bevrijde zuiden van Nederland sprak hij met prof.dr. J.I.J.M. Schmutzer, een mineraloog die vroeger in Nederlands-Indië lid van de Volksraad geweest was; deze bleek bereid hem als minister op te volgen. Schmutzer werd op 23 februari in Londen geïnstalleerd als 'minister van overzeese gebiedsdelen' (op aandrang van Van Mook was de naam van de functie gewijzigd). Van Mook zelf keerde daarna naar Australië terug. In mei werd ook het noordelijk deel van Nederland bevrijd en eindigde de oorlog in Europa door de capitulatie van Duitsland. Logemann volgde Schmutzer op 24 juni als minister op.

Het in 1943 door de regering vastgestelde plan voor de opbouw van de Nederlandse strijdkrachten bestond lange tijd voornamelijk op papier. Alleen voor de mariniersbrigade werd al sinds eind 1943 in de Verenigde Staten een kernkadergroep opgeleid, onder meer samengesteld uit mariniers die zich na mei 1940 buiten Nederland bevonden. De Amerikaanse marine gaf hieraan volle medewerking. Wat betreft de expeditionaire macht zei de Britse regering in 1944 toe, na de bevrijding van Nederland te zullen helpen bij de opleiding van officieren en kader en vervolgens kampen beschikbaar te zullen stellen voor de basisopleiding van de troepen. Overigens gaf de Nederlandse regering het plan voor een legerkorps op en richtte zij zich vooreerst op de vorming van één divisie. Verder beloofde Groot-Brittannië personeel te zullen opleiden voor de luchtmacht van het KNIL. De Australische regering verklaarde zich in het najaar van 1944 in beginsel bereid te zorgen voor de huisvesting van dertigduizend Nederlandse militairen, bestemd voor inzet in Indonesië. Zij dacht daarbij aan kampen in West-Australië. Ook stelde zij medewerking in het vooruitzicht bij de opleiding en uitrusting. Van Mook ging ervan uit dat de gezagsbataljons in deze kampen een opleiding van twee maanden zouden kunnen krijgen.

Pas na de bevrijding van het zuiden van Nederland kon men op grotere schaal beginnen met de recrutering van vrijwilligers en dienstplichtigen voor de strijdkrachten en de NICA. Er meldden zich tienduizenden vrijwilligers, maar hun opvang en opleiding plaatste de autoriteiten voor grote problemen. In de oplossing daarvan slaagde de marine het best; tussen november 1944 en mei 1945 wist zij al vijfentwintighonderd vrijwilligers voor de mariniersbrigade over te brengen naar het opleidingskamp in Amerika. Daarentegen kostte het de landmacht veel moeite om de eerste militaire eenheden te formeren. Bovendien wilde het geallieerde hoofdkwartier van generaal Eisenhower zulke eenheden in beginsel alleen in Europa inzetten. Het verlangde dat 
Nederland daartoe onder meer een aantal lichte infanteriebataljons zou leveren. De regering zei hiervoor negentienduizend man toe, maar wenste ook een dertienduizend man voor inzet in Azië te bestemmen. Met moeite kreeg Van Mook in februari 1945 gedaan dat het Europese hoofdkwartier akkoord ging met spoedig vertrek uit Nederland van vierduizend man voor de gezagsbataljons, negentienhonderd man voor de KNIL-luchtmacht en zeshonderd man voor de NICA-detachementen. Ten tijde van de Duitse capitulatie in mei 1945 waren uit Nederland nog pas negenhonderd voor Azië bestemde militairen in Groot-Brittannië aangekomen, onder wie vierhonderd man voor de gezagsbataljons en driehonderd voor het kernkader van de expeditionaire macht.

$\mathrm{Na}$ de nederlaag van Duitsland kon men eindelijk in heel Nederland gaan werven, zowel voor de reguliere strijdkrachten, de gezagsbataljons en de NICA-detachementen als voor de vrouwenkorpsen van marine en KNIL en de inzetploegen van het Rode Kruis. Binnen drie maanden meldden zich bijna tweehonderdduizend mannen en vrouwen, een veelvoud van wat men nodig had. Terwijl een deel van hen die zich voor mei 1945 gemeld hadden alleen gedacht hadden aan inzet in Europa, ging het de latere vrijwilligers welbewust om deelname aan de strijd tegen Japan en de bevrijding van Indië.

De voorbereiding van de terugkeer van het Nederlandse gezag naar Indonesië vereiste niet alleen het recruteren van personeel maar ook de aanschaf van goederen. Men wist dat de bevolking ernstig gebrek leed en wilde die terugkeer dan ook vergezeld doen gaan van hulpverlening op grote schaal. Bovendien zouden de gezagsorganen zelf moeten kunnen beschikken over bijvoorbeeld transport- en verbindingsmiddelen. Het Nederlands-Indische gouvernement in Australië schafte dan ook grote voorraden aan van onder meer textiel, levensmiddelen, medicijnen, kantoor- en schoolbehoeften, drukpersen, radiozenders en vrachtauto's. In afwachting van de bevrijding van Indonesië sloeg men die goederen op in pakhuizen in de drie grootste havensteden van Australië.

\section{Problemen tussen Nederland en zijn bondgenoten}

Bij de voorbereiding van de terugkeer naar Indië kampten de Nederlandse autoriteiten niet alleen met onderlinge onenigheid maar ook met problemen in hun betrekkingen met de bondgenoten. Zo waren Van Mook en Van der Plas ongerust over het vooruitzicht dat de Verenigde Staten na de bevrijding van Indonesië daar misschien de dienst zouden uitmaken, omdat zij wisten dat binnen de Amerikaanse bevolking en de Amerikaanse regering bedenkingen leefden tegen herstel van het Nederlandse koloniale bewind. Dit was opnieuw gebleken nadat Van Mook en MacArthur in maart 1944 een akkoord hadden bereikt over de uitoefening van het burgerlijk bestuur in de bevrijde gebieden 
van Indonesië. Het akkoord had de vorm van een tussen de Nederlandse en de Amerikaanse regering te sluiten overeenkomst die ervan uitging dat de soevereiniteit over Nederlands-Indië onverminderd bij Nederland berustte. Deze ontwerp-overeenkomst kreeg niet de goedkeuring van de Amerikaanse minister van buitenlandse zaken. Pas nadat deze voor een nieuwe minister plaats gemaakt had, konden MacArthur en Van Mook de overeenkomst op 10 december 1944 namens hun regeringen ondertekenen. (Overigens verzuimde ook de Britse regering de gelijksoortige ontwerp-overeenkomst te formaliseren die Van Mook met Mountbatten had opgesteld, maar dit verzuim had geen politieke motieven.)

Bedenkingen tegen herstel van het Nederlandse koloniale bewind bestonden ook in Australië. De Australische minister van buitenlandse zaken drong er al in 1943 op aan, dat koloniaal bestuurde gebieden als Nederlands-Indië en Frans-Indochina na de oorlog onder trusteeship (voogdij) zouden worden geplaatst van verder ontwikkelde landen, waaronder Australië. Toen de Nederlandse regering hier bezwaar tegen maakte, verklaarde de Australische premier dat zijn regering de Nederlandse soevereineit respecteerde. Niettemin stelde zijn minister van buitenlandse zaken vervolgens voor, dat Australië na de oorlog Nederlands-Timor en Nederlands-Nieuw-Guinea langdurig zou mogen pachten. Op het punt van het herstel van het Nederlandse gezag over Indonesië beschouwde de Nederlandse regering dan ook alleen GrootBrittannië als een betrouwbare bondgenoot.

Generaal MacArthur hechtte groot belang aan de herovering van Indonesië en begon na de bevrijding van de Filippijnen in begin 1945 met de voorbereiding van landingen op Java. De hoogste militaire leiding in Washington dacht hier echter anders over en droeg hem in april op, Java links te laten liggen en zich voor te bereiden op de verovering van Japan zelf. In de Indonesische archipel zou hij zich moeten beperken tot operaties tegen de oliecentra van Oost-Borneo. Voor Nederland was dit een teleurstelling, maar het kreeg nu wel meer tijd voor de vorming van NICA-detachementen en gezagsbataljons. Wat Oost-Borneo betreft maakten Australische troepen zich meester van Tarakan in april en van Balikpapan in juli; verder werd geen Indonesisch grondgebied meer op de Japanners veroverd.

Van eind april tot eind juni 1945 vond in San Francisco de grote conferentie plaats tot oprichting van de Organisatie der Verenigde Naties. Van Mook nam daar enige tijd aan deel als lid van de Nederlandse delegatie, die geleid werd door de minister van buitenlandse zaken Van Kleffens. Namens de regering keerde hij zich krachtig tegen voorstellen van Australië en Nieuw-Zeeland om onder meer Nederlands-Indië onder voogdij van de Verenigde Naties te plaatsen.

Eind mei vernamen Van Mook en Van Kleffens in San Francisco, dat het hoogste geallieerde opperbevel voorlopig geen toestemming gaf voor het 
vervoer van militairen uit Nederland naar Australië, ondanks het met het Europese hoofdkwartier gesloten akkoord. Nu de oorlog in Europa geëindigd was, meende men alle beschikbare scheepsruimte nodig te hebben voor de repatriëring van de geallieerde militairen en voor de voorbereiding van het slotoffensief tegen Japan. Van Mook en Van Kleffens reisden hierop naar Washington, maar slaagden er niet in het opperbevel tot andere gedachten te brengen. Voor de regering was dit extra bitter, omdat zij zelf aan dat opperbevel Nederlandse scheepsruimte beschikbaar gesteld had van een veel grotere capaciteit dan zij voor het vervoer van haar eigen militairen nodig had.

Een nieuwe tegenslag trof de regering in juli 1945, toen de Australische premier die de Nederlandse soevereiniteit wilde eerbiedigen wegens ziekte niet langer in functie was. In gewijzigde samenstelling kwam de Australische regering nu terug van haar in 1944 in beginsel toegezegde medewerking voor de huisvesting en opleiding van tienduizenden Nederlandse militairen in Australische kampen. De Nederlandse plannen voor de inzet van gezagsbataljons kwamen hierdoor op losse schroeven te staan.

\section{De Indonesische onderzoekscommissie voor de onafhankelijkheid}

De op 28 mei 1945 op Java geïnstalleerde commissie tot onderzoek van de maatregelen ter voorbereiding van de onafhankelijkheid heeft twee formele zittingen gehouden, van 29 mei tot 1 juni en van 10 tot 15 juli. De ruim zestig leden tellende commissie werd voorgezeten door Radjiman Wedioningrat en vergaderde in het gebouw van de vroegere Volksraad. Zij heeft in korte tijd veel tot stand gebracht.

De eerste zitting was gewijd aan algemene beschouwingen, waarbij zeer uiteenlopende opvattingen naar voren kwamen. Pas op de vierde dag nam Soekarno het woord. Hij knoopte daarbij aan bij voorstellen van Yamin en van Soepomo (de jurist die lid van de Commissie-Visman geweest was). Soekarno gaf vijf leidende beginselen aan voor de te vormen nieuwe staat, namelijk nationalisme (in de zin van het besef tot één Indonesische natie te behoren), internationalisme of menselijkheid (in de zin van verbondenheid met de gehele mensheid), democratie (in de zin van streven naar consensus), sociale rechtvaardigheid en tenslotte geloof in God. In zijn toelichting bij het laatste beginsel zei hij onder meer, dat christenen, moslims en boeddhisten God volgens hun eigen voorschriften moesten belijden. Hij noemde deze vijf beginselen de pantja sila (vijf zuilen). In de commissie kreeg Soekarno's betoog veel bijval, al beviel het sommige orthodox-islamitische leden niet dat hij andere godsdiensten daarin op één lijn met de islam geplaatst had.

Aan het eind van haar eerste zitting belastte de onderzoekscommissie een kleine subcommissie onder Soekarno met de uitwerking van concrete voor- 
stellen, waaronder een ontwerp-grondwet. Het schrijven van dat ontwerp gebeurde grotendeels door Soepomo. Ook vond in juni informeel overleg plaats tussen leden die de toekomstige Indonesische staat op exclusief-islamitische grondslag wilden vestigen en leden die, zoals Soekarno en Hatta, de staat een seculier karakter wilden geven. Dit overleg leidde tot een compromis in de vorm van een ontwerp voor de inleiding van de grondwet, dat later bekend is geworden als het Piagam Djakarta (Handvest van Djakarta). Het bevatte enige bepalingen die er op gericht waren de streng-islamitische stroming wat tegemoet te komen. In de opsomming van de pantja sila was het geloof in God vooraan geplaatst in plaats van achteraan; de belijders van de islam zouden verplicht zijn de islamitische wetten na te leven en de president van de republiek zou een moslim moeten zijn.

Aan de hand van de door de subcommissie opgestelde concepten nam de onderzoekscommissie in juli besluiten over alle voorgelegde kwesties, met dien verstande dat deze besluiten slechts de status hadden van voorstellen ten behoeve van hen die later de onafhankelijke Indonesische staat in het leven zouden roepen.

Wat de staatsvorm betreft, moest men in de eerste plaats kiezen tussen republiek en monarchie. Enkele leden stelden voor dat Indonesië een koninkrijk zou worden, met de sultan van Jogjakarta als koning. De commissie koos met overweldigende meerderheid voor een republiek.

De tweede kwestie met betrekking tot de staatsvorm was de keuze tussen eenheidsstaat en bondsstaat. In de jaren twintig hadden verscheidene nationalisten, onder wie Hatta, Soekarno en Tan Malaka, een federaal Indonesië voorgestaan, maar sindsdien was de federatievorm bij de nationalisten in diskrediet geraakt. De commissie koos met duidelijke meerderheid voor een eenheidsstaat.

Wat de omvang van het grondgebied betreft, legde de voorzitter aan de commissie twee opties voor: of het gebied van het voormalige NederlandsIndië, òf dit gebied plus dat van Malakka, Noord-Borneo, Nieuw-Guinea, Timor en de omringende eilanden. Op voorstel van Hatta voegde men hier een derde optie aan toe, namelijk het gebied van het voormalige NederlandsIndië plus Malakka maar zonder Nieuw-Guinea. De eerste optie kreeg 19 stemmen, de tweede 39 stemmen en de derde 6 stemmen. Soekarno steunde de zegevierende tweede optie, maar vond dat dit Groot-Indonesië eigenlijk ook de Filippijnen zou moeten omvatten.

Ten aanzien van het staatsburgerschap ging de discussie over de vraag, of alleen de inheemse Indonesiërs dan wel ook de in Indonesië geboren Arabieren, Chinezen en Indo-Europeanen dit automatisch zouden krijgen. De commissie besloot dat vooreerst alleen inheemsen het burgerschap zouden krijgen en dat men later bij wet het burgerschap voor andere bevolkingsgroepen zou regelen. 
De subcommissie had de leidende beginselen van de nieuwe staat overeenkomstig Soekarno's pantja sila verwerkt in haar ontwerp voor een grondwet. Dit ontwerp hield overigens een autocratisch staatsbestel in met grote macht voor het staatshoofd. De volkssoevereiniteit zou komen te berusten bij een Madjelis Permoesjawaratan Rakjat (Congres voor Volksoverleg) dat ten minste eens per vijf jaar bijeen zou komen, voornamelijk om de president en de vice-president van de republiek te kiezen. Er zou daarnaast een Dewan Perwakilan Rakjat (Raad van Volksvertegenwoordigers) komen als wetgevend lichaam, maar de president zou een recht van veto hebben over alle besluiten van die Raad en hij zou in een noodtoestand ook buiten die Raad om bij decreet kunnen regeren. De president zou ministers aanstellen; daarnaast zou hij worden bijgestaan door een Hoge Adviesraad. Het opperbevel over de strijdkrachten zou bij de president berusten. Het ontwerp voorzag verder onder meer in de invoering van dienstplicht en in de erkenning van vrijheid van vereniging en vergadering, vrijheid van meningsuiting, vrijheid van godsdienst en recht op onderwijs.

Over de meeste onderdelen van het voorgestelde staatsbestel kon men het in de onderzoekscommissie wel eens worden, maar er was één ideologische kwestie die diepe verdeeldheid veroorzaakte: de positie van de islam. Sommige leden namen geen genoegen met het in juni opgestelde compromis hierover en bleven verlangen dat het nieuwe Indonesië op de islam gegrondvest zou worden. Soekarno verzette zich tegen dit islamitisch exclusivisme; tegelijk beklemtoonde hij zijn eigen gehechtheid aan de islam. Uiteindelijk bleken de meeste Masjoemi-vertegenwoordigers alsnog bereid genoegen te nemen met de compromistekst, zodat de commissie haar werkzaamheden toch nog met een grote mate van overeenstemming kon afsluiten.

\section{Laatste stappen ter inlossing van de Japanse toezegging}

In juli 1945 was het ook aan de meeste Indonesiërs wel duidelijk dat Japan de oorlog zou verliezen, maar vrijwel niemand verwachtte dit op korte termijn. Zowel in Indonesië als elders nam men toen algemeen aan, dat de geallieerden daarvoor een invasie in Japan zelf zouden moeten uitvoeren. De geallieerde oorlogvoering tegen Duitsland had laten zien, dat zulk een invasie een langdurige voorbereiding vergde en dat het ook daarna nog lang kon duren voordat de overwinning werd behaald; de strijd was toen tot in de straten van Berlijn voortgezet. Van de Japanse soldaten was bekend dat zij zich zelden overgaven, ook als hun positie hopeloos was. Het leek dan ook redelijk te veronderstellen dat Japan de oorlog nog wel tenminste een jaar zou volhouden.

Daarentegen verwachtten velen wel op korte termijn een geallieerde invasie op Java. Onder de radicale jongeren speelde men met de gedachte in dat 
geval een algemene opstand tegen de Japanse bezettingsmacht te beginnen en eenzijdig de onafhankelijkheid van Indonesië uit te roepen.

Soekarno bleef intussen geloven in nauwe samenwerking met Japan als de snelste weg naar de onafhankelijkheid. Hij hield zich nu zowel bezig met de inrichting van het toekomstige Indonesische staatsbestel als met de oprichting van een massaorganisatie die dat staatsbestel zou moeten ondersteunen (zie p. 334). Eind juli kwam deze organisatie formeel tot stand onder de naam Gerakan Rakjat Baroe (Nieuwe Volksbeweging). Het was de bedoeling dat zowel de Djawa Hokokai als de Masjoemi hierin zou opgaan, maar voorlopig bleven deze beide organisaties nog bestaan.

In deze zelfde periode bereikten de verschillende machtscentra in Tokio eindelijk overeenstemming over de uitwerking van de aan 'Oost-Indië' toegezegde onafhankelijkheid. Op 17 juli besloot het hoogste Japanse beleidsorgaan, de opperste oorlogsraad, dat die onafhankelijkheid voor het hele grondgebied van de vroegere Nederlandse kolonie zou gelden en dat men nu de gebruikelijke voorbereidingscommissie kon instellen. Over de uitvoering van dit besluit vond eind juli in Singapore overleg plaats tussen de militaire autoriteiten die met het bestuur over de verschillende delen van dat gebied belast waren. Op grond daarvan maakten deze autoriteiten op 7 augustus zowel op Java als op Sumatra en in het marinegebied bekend, dat heel Indonesië een nieuwe, vrije en soevereine staat zou worden en dat men daartoe een Commissie ter Voorbereiding van de Onafhankelijkheid zou instellen.

Soekarno verwelkomde deze aankondiging in een radiorede waarin hij zich fel tegen Nederland keerde. In reactie op verklaringen in Nederlandse radiouitzendingen uit Australië, dat Indonesiërs na de oorlog meer hoge posten in Nederlands-Indië zouden kunnen krijgen dan vroeger, zei hij:

Wij willen geen Indonesiër als luitenant-gouverneur-generaal of zelfs als gouverneur-generaal. Wat wij willen is een volledig onafhankelijk Indonesië. Als Van Mook en Van der Plas onze harten trachten te winnen, moeten wij hun antwoorden: 'Neen, gaat u alstublieft naar Nederland terug. De Indonesiërs willen onafhankelijk zijn. Probeer ons niet met woorden te misleiden. Onze keuze is: de onafhankelijkheid of de dood!'

Kort daarna deelde het militaire bestuur op Java aan Soekarno, Hatta en Radjiman mee dat zij per vliegtuig naar Indochina moesten reizen om nadere aanwijzingen te ontvangen van maarschalk Terauchi, de opperbevelhebber voor de zuidelijke gebieden.

Sjahrir en de radicale jongerenleiders in Djakarta waren diep ongelukkig over deze gang van zaken. In hun ogen zou de Indonesische onafhankelijkheid besmet zijn als men die nu als een geschenk van de Japanse overheersers zou aanvaarden. Bovendien zouden de geallieerden zulk een onafhankelijkheidsverlening waarschijnlijk niet erkennen omdat zij er alleen maar een vijan- 
delijke manoeuvre in zouden zien. Sjahrir probeerde daarom op 8 augustus in een lang gesprek Hatta over te halen op een breuk met Japan aan te sturen.

Hatta liet zich echter niet van de ingeslagen weg afbrengen en vertrok met Soekarno en Radjiman naar Indochina. Op 11 augustus werden zij ontvangen door Terauchi, die hun het keizerlijke besluit over de verlening van onafhankelijkheid officieel meedeelde en Soekarno en Hatta aanwees als voorzitter en vice-voorzitter van de voorbereidingscommissie. De commissie zou bestaan uit Indonesiërs uit verschillende delen van de archipel en zou nauw moeten samenwerken met een uit Japanners bestaande begeleidingscommissie. De nieuwe staat zou niet de omvang van een Groot-Indonesië krijgen, maar hetzelfde grondgebied omvatten als Nederlands-Indië. Het onafhankelijke Indonesië zou Japan moeten steunen bij de voortzetting van de oorlog. Terauchi zinspeelde er met geen woord op, dat de positie van zijn land hopeloos was.

Op dinsdag 14 augustus keerde het drietal in Djakarta terug. Op dezelfde dag maakte het militaire bestuur de samenstelling bekend van de Panitia Persiapan Kemerdekaan Indonesia (PPKI, Commissie ter Voorbereiding van de Onafhankelijkheid van Indonesië). Naast Soekarno en Hatta telde de commissie tien leden voor Java, drie voor Sumatra, vijf voor de rest van de archipel en één voor het Chinese volksdeel. Leden waren onder meer Iskandar Dinata, Radjiman, Soetardjo, de moslimleiders Bagoes Hadikoesoemo en Wahid Hasjim en twee vooraanstaande christenen, de Molukker Latuharhary en de Menadonees Ratoelangie. Verder was Soebardjo als speciaal adviseur aan de commissie toegevoegd. De commissie zou op 18 augustus geïnstalleerd worden.

\section{Ontvoering van Soekarno en Hatta door militante jongeren}

Op 6 en 9 augustus 1945 wierp Amerika atoombommen op Japanse steden. Bovendien verklaarde de Sovjet-Unie op 9 augustus de oorlog aan Japan en viel het Mandsjoerije binnen. Al op 10 augustus deelde Japan aan de geallieerden mee, dat het bereid was tot overgave mits de keizer zijn positie zou mogen behouden. De Japanse autoriteiten hielden dit vredesaanbod voor hun eigen bevolking geheim, maar de geallieerde nieuwsmedia maakten het terstond bekend. Washington antwoordde dat de Japanse keizer ondergeschikt zou worden aan de opperbevelhebber van de geallieerde strijdkrachten. Daarna besloot Tokio op 14 augustus definitief tot capitulatie; de Japanse bevolking zou hier de volgende dag over worden ingelicht door een radioboodschap van de keizer zelf.

Toen Soekarno en Hatta op 14 augustus van hun bezoek aan maarschalk Terauchi terugkeerden, circuleerden in Djakarta al enige dagen geruchten dat 


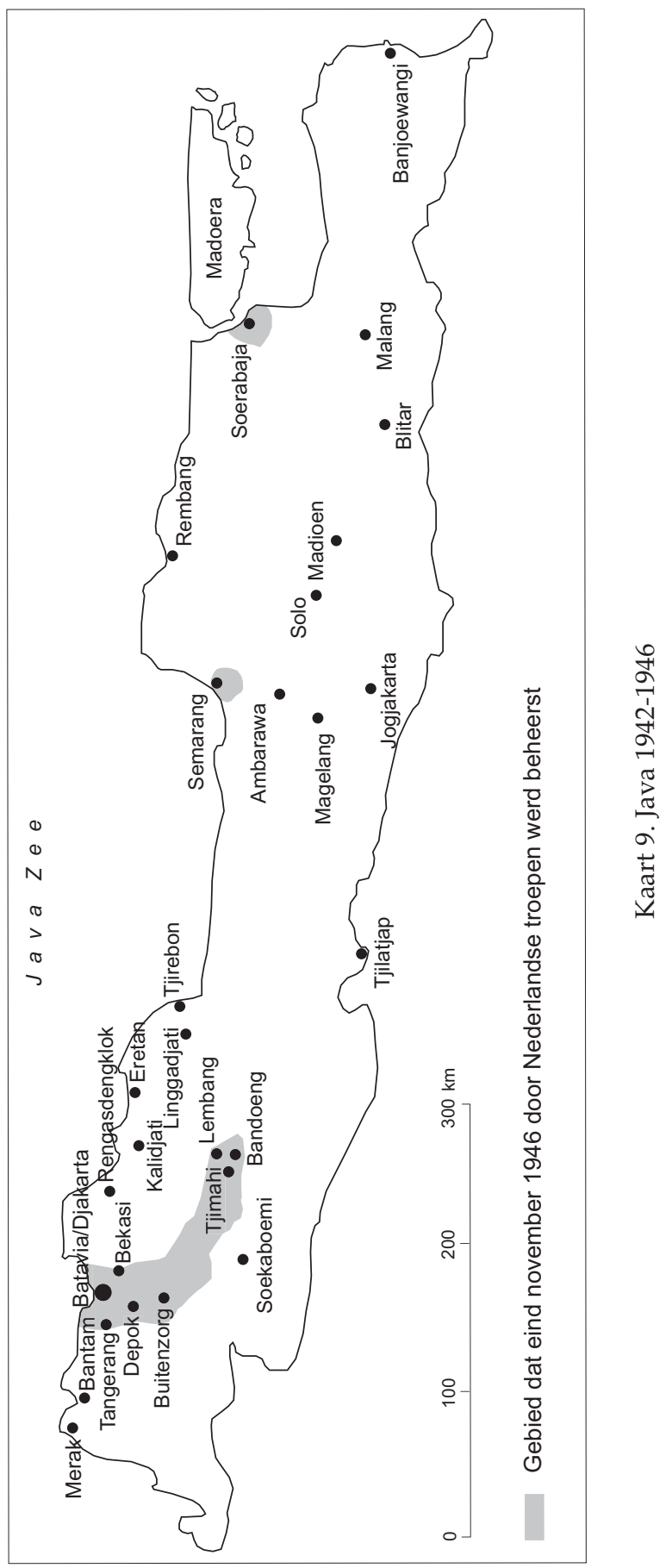


Japan op het punt stond de strijd te staken. Sjahrir besprak de nieuwe situatie nog diezelfde dag met hen beiden. Hij betoogde dat men de onafhankelijkheid nu meteen buiten de Japanse autoriteiten om moest uitroepen. Hatta en Soekarno wilden echter niet vooruitlopen op de bijeenkomst van de PPKI en twijfelden bovendien aan de betrouwbaarheid van de geruchten. Om zekerheid te krijgen over de vraag of de oorlog afgelopen was, wendden zij zich op woensdag 15 augustus zowel tot het militaire bestuur als tot de Japanse marinevertegenwoordiger Maeda. Zij kregen geen bevestiging, maar leidden uit de reacties af dat Japan inderdaad gecapituleerd had. Intussen waren de meeste van buiten Java afkomstige leden van de PPKI al in Djakarta aangekomen. Hatta en Soekarno besloten nu niet meer te wachten op de officiële installatie van de commissie, maar haar al de volgende ochtend bijeen te laten komen. Hatta zou een onafhankelijkheidsproclamatie opstellen aan de hand van de preambule van de ontwerp-grondwet.

Aan de andere kant bereidden radicale jongeren zich in Djakarta al enige dagen voor op een eenzijdige uitroeping van de onafhankelijkheid; Sjahrir had daartoe een proclamatie in anti-Japanse geest ontworpen. Tal van militante jongeren, onder meer behorende tot de Barisan Pelopor, waren bereid aan riskante acties deel te nemen. $\mathrm{Zij}$ dachten daarbij te kunnen rekenen op steun van de in en nabij Djakarta gelegerde Peta- en Heiho-eenheden, waarvan de getalssterkte die van de Japanse militairen ver overtrof. De gespannen sfeer werd nog verscherpt door de omstandigheid dat deze week binnen de islamitische vasten viel, waardoor moslims overdag niet mochten drinken of eten.

Op de avond van 15 augustus kwam een aantal belangrijke jongerenleiders in vergadering bijeen. Door hun relaties bij het persbureau Domei wisten ze dat Japan gecapituleerd had; zij vonden dat het Indonesische volk nu zijn lot in eigen handen moest nemen. Tegelijk beseften ze dat een vrijheidsproclamatie weinig indruk zou maken als die alleen van henzelf uitging, want de bevolking kende hen niet. Zij stuurden daarom een delegatie naar Soekarno om hem ertoe te brengen de door Japan uitgestippelde procedure te verlaten en uiterlijk de volgende dag op eigen gezag de onafhankelijkheid uit te roepen. De delegatie arriveerde tegen tien uur 's avonds bij Soekarno's woning. Ondanks harde woorden van Wikana, die de delegatie leidde, hield Soekarno er aan vast dat hij niet buiten de PPKI om wilde handelen. Hij kreeg daarbij steun van Hatta en enkele andere nationalisten, die zich bij het twistgesprek voegden. De delegatie moest met lege handen vertrekken.

Na middernacht begon een tweede ronde van discussies tussen de jongerenleiders. Ondanks de mislukking van hun poging Soekarno en Hatta aan hun kant te krijgen, besloten zij hun plannen toch door te zetten. Men kwam nu op de gedachte deze twee sleutelfiguren uit Djakarta weg te voeren. Men zou hen daardoor beletten het door Japan opgestelde scenario verder af te werken en men zou bovendien voorkomen dat zij door de Japanners als gijze- 
laars zouden worden gebruikt tegen de beoogde opstand. Een aan het beraad deelnemende Peta-officier bood zijn medewerking voor de ontvoering aan; Soekarni nam de leiding ervan op zich. Tegelijk zou Chairoel Saleh ervoor zorgen dat de strijdgroepen zich gereedmaakten voor acties, zoals de bezetting van het radiostation.

Omstreeks vier uur 's nachts verschenen de ontvoerders bij Hatta en Soekarno. Zij zeiden dat ze hen terwille van hun eigen veiligheid buiten de stad zouden brengen omdat militante jongeren op het punt stonden een opstand te beginnen. De twee leiders lieten zich in auto's wegvoeren; Soekarno nam ook zijn vrouw en zoontje mee. Men bracht hen naar een kazerne van de Peta in het plaatsje Rengasdengklok, zeventig kilometer ten oosten van Djakarta. De ontvoering bracht geen verandering in de opstelling van Soekarno en Hatta. $\mathrm{Zij}$ vonden de opstandplannen van de jongeren volstrekt onverantwoord, omdat het Japanse leger naar hun mening zo'n opstand meedogenloos zou neerslaan.

Intussen wachtten in Djakarta de leden van de PPKI 's ochtends vergeefs op Soekarno en Hatta. Schout-bij-nacht Maeda droeg Nishijima en Soebardjo op te onderzoeken wat er met hen gebeurd was. $\mathrm{Zij}$ vernamen onder meer dat Soekarno de vorige avond een twist had gehad met Wikana, hun naaste collega aan de Asrama Indonesia Merdeka. Uiteindelijk wisten zij Wikana ertoe over te halen mee te werken aan de terugkeer van de twee leiders naar Djakarta, nadat Maeda had laten weten dat hij dan persoonlijk steun zou geven aan het uitroepen van de onafhankelijkheid. Daarbij garandeerde hij de betrokkenen dat ze veilig zouden zijn tegenover de Kempeitai en stelde hij zijn eigen woning als vergaderplaats beschikbaar. Soebardjo vertrok tegen het eind van de middag naar Rengasdengklok. Hij kon daar onder meer bevestigen dat Japan gecapituleerd had. Soekarni beëindigde de ontvoering, waarna het hele gezelschap 's avonds naar Djakarta terugkeerde. Soekarno en Hatta waren nu bereid samen met de PPKI op eigen gezag de onafhankelijkheid uit te roepen en lieten via Soebardjo de leden van de commissie oproepen om naar het huis van Maeda te komen.

\section{De opstelling van de onafhankelijkheidsproclamatie}

Tegen de avond van 16 augustus verzamelden militante jongeren zich op verschillende punten van Djakarta. Een deel van hen was gewapend met bamboesperen en messen; enkelen beschikten over vuurwapens. Ook arriveerden die avond de leden van de PPKI in het huis van Maeda, maar het duurde nog lang voordat zij met Soekarno en Hatta konden spreken. Dezen brachten namelijk met bemiddeling van Maeda nog na middernacht een bezoek aan het Japanse militaire bestuur. $\mathrm{Zij}$ probeerden daarvan een verzekering te krijgen dat dit 
niet tegen de beoogde uitroeping van de onafhankelijkheid zou optreden. Het militaire bestuur ging er echter van uit dat Japan zich door de capitulatie verplicht had de status quo in de bezette gebieden te handhaven. Eveneens na middernacht ondernam Soekarni samen met Nishijima een rondrit door Djakarta om de militante jongerengroepen aan te zeggen dat die niet meer in actie hoefden te komen.

$\mathrm{Na}$ hun onbevredigend bezoek aan het militaire bestuur gingen Soekarno en Hatta naar de ambtswoning van Maeda, waar de leden van de PPKI op hen wachtten, terwijl bovendien nog verschillende andere figuren uit de nationale beweging zich bij het gezelschap voegden. In het bijzonder verschenen hier enige jongerenleiders, onder wie Diah en Chairoel Saleh en ook Soekarni na zijn rondrit langs de jongerengroepen. In deze vergrote kring voerden Soekarno en Hatta overleg over de tekst van de onafhankelijkheidsproclamatie, waarvoor al verschillende ontwerpen waren opgesteld. De jongeren hadden bezwaar tegen iedere formulering die impliceerde dat de onafhankelijkheid aan Japan te danken was; de ouderen wezen alle anti-Japanse formuleringen af. Het eindresultaat was een uit twee korte zinnen bestaande tekst waar allen wel mee konden leven. Eén van de laatste kwesties betrof de formule 'overdracht van de macht' in het ontwerp. Impliciet zou daarmee aan de Japanse bezettingsmacht een actieve rol worden toegekend. Dit strookte niet met de zienswijze van de jongeren, maar was evenmin in het belang van de Japanners zelf, nu die verplicht waren de politieke status te handhaven en ze de macht dus uitsluitend aan de Geallieerden mochten overdragen. De jongeren wilden een formulering die aangaf dat het volk de macht zou moeten 'grijpen'. Men vond elkaar op de neutrale formule 'overgang van de macht'.

Tenslotte rees nog onenigheid over de ondertekening. Het oorspronkelijke plan was dat alle aanwezigen de proclamatie gezamenlijk zouden ondertekenen als 'vertegenwoordigers van het Indonesische volk'. De jongeren weigerden echter dit samen met de leden van de PPKI doen. Uiteindelijk kwam men overeen dat alleen Soekarno en Hatta hun handtekening zouden plaatsen. Nadat de proclamatie in aangepaste vorm was uitgetikt, ondertekenden de twee leiders die 'uit naam van het Indonesische volk'.

Het was de bedoeling geweest de onafhankelijkheid publiekelijk uit te roepen tijdens een massabijeenkomst op het centrale plein van Djakarta (het vroegere Koningsplein, dat nu Gambir heette), maar gezien de opstelling van het militaire bestuur zou dit nu te provocerend zijn. Bovendien bevond zich daar al een groot aantal Japanse soldaten, onder meer ter beveiliging van het radiostation. Men sprak daarom af dat de ceremonie de volgende ochtend zou plaatsvinden voor Soekarno's woonhuis op het adres Pegangsaän Oost 56. Tegen vijf uur in de ochtend keerden Soekarno en Hatta naar hun woningen terug. 


\section{Aantekeningen bij hoofdstuk $V$}

\section{Literatuuroverzicht}

De eerste studies over deze episode verschenen in Nederland. In 1954 publiceerde A.A. Zorab De Japanse bezetting van Indonesië en haar volkenrechtelijke zijde, dat vooral de organisatie en het beleid van het bezettingsbestuur op Java behandelde. Een jaar later verscheen Japan's colonialism and Indonesia van M.A. Azis. In 1960 zag een ruim 600 pagina's beslaande bronnenpublicatie het licht, Nederlandsch-Indië onder Japanse bezetting; Gegevens en documenten over de jaren 1942-1945, onder leiding van I.J. Brugmans samengesteld door H.J. de Graaf samen met medewerkers van het Rijksinstituut voor Oorlogsdocumentatie. Verder publiceerden tientallen voormalige krijgsgevangenen en burger-geïnterneerden hun ervaringen uit de Japanse kampen. Het wetenschappelijke standaardwerk over de interneringskampen is De Japanse interneringskampen voor burgers gedurende de Tweede Wereldoorlog door D. van Velden (1963). Aan de andere kant zijn in 1988 twee dagboeken gepubliceerd die tijdens de bezetting waren bijgehouden door Nederlanders die op Java buiten de kampen gebleven waren, van J. Bouwer, een journalist die ondergedoken geweest was, en van L.F. Jansen, een ambtenaar die voor de Japanse radiodienst gewerkt had. Het dagboek van Bouwer verscheen onder de titel Het vermoorde land; dat van Jansen onder de titel In deze halve gevangenis.

In Japan namen enkele voormalige functionarissen van het Japanse bezettingsbestuur het initiatief tot het verzamelen van officiële documenten over de bezetting van Indonesië, wat leidde tot een in 1958 in Tokio gepubliceerde studie. Op basis hiervan verscheen in de Verenigde Staten in 1965 een Engelstalige publicatie, Japanese military administration in Indonesia; Selected documents, onder redactie van H.J. Benda, J.K. Irikura en K. Kishi. Bovendien werden in Japan ook persoonlijke herinneringen gepubliceerd van Japanners die aan de bezetting deelgenomen hadden. Een Engelstalige bundel van zulke herinneringen verscheen in 1986 eveneens in Amerika, The Japanese experience in Indonesia; Selected memoirs of 1942-1945, onder redactie van A. Reid en A. Oki. Verder hebben Japanse historici verscheidene studies met betrekking tot de bezetting van Indonesië verricht; nadere gegevens hierover zijn onder meer te vinden in Japan, Indonesia and the war; Myths and realities, themanummer onder redactie van P. Post en E. Touwen-Bouwsma van Bijdragen tot de Taal-, Land- en Volkenkunde, jaargang 1996, vierde aflevering.

Het belangrijkste overzichtswerk over de Japanse bezetting van Indonesie is The Japanese occupation of Indonesia; Prelude to independence van de uit Hawaii afkomstige G.S. Kanahele, die hierop in 1967 in de Verenigde Staten promoveerde. Dit werk, dat zowel op schriftelijke bronnen gebaseerd was als op gesprekken met tal van personen in Indonesië, Nederland en Japan, is merkwaardigerwijze nooit in druk verschenen. Daarentegen zijn in Amerika wel boeken gepubliceerd die zich met deelaspecten van het onderwerp bezighouden, zoals The crescent and the rising sun; Indonesian Islam under the Japanese occupation, 1942-1945 van H.J. Benda, Java in a time of revolution; Occupation and resistance 1944-1946 van B.R. O'G. Anderson en The blue-eyed enemy; Japan against the West in Java and Luzon 1942-1945 van Th. Friend.

Wat geschriften van Indonesiërs betreft valt in de eerste plaats op te merken, dat de memoires van vrijwel allen die een rol in de nationale vrijheidsstrijd gespeeld hebben ook stilstaan bij de episode van de Japanse bezetting. Verder publiceerde A.B. Lapian 
in 1988 allerlei persoonlijke herinneringen van tweeënveertig personen die deze tijd hadden meegemaakt onder de titel Di bawah pendudukan Jepang (Onder de Japanse bezetting). Voor het overige bestaan er vrij weinig bijdragen van Indonesische historici over de Japanse bezetting. De voornaamste zijn die van Nugroho Notosusanto, waaronder het in 1979 in Engelse vertaling verschenen The PETA army during the Japanese occupation of Indonesia.

In Nederland heeft L. de Jong het tijdvak van de Japanse bezetting uitvoerig behandeld in Het Koninkrijk der Nederlanden in de Tweede Wereldoorlog, voornamelijk in deel 11 b (1985) wat betreft de ontwikkelingen binnen Indonesië zelf en in deel 11 c (1986) wat betreft hetgeen aan Nederlandse kant buiten Indonesië gebeurde. Verder zijn ook van medewerkers van het Rijksinstituut voor Oorlogsdocumentatie enige publicaties over deze episode verschenen, zoals Indonesië; De laatste etappe naar de vrijheid 19421945 door R. de Bruin (1982) en Nederlands-Indië 1940-1945, deel II: Japans intermezzo door J. Zwaan (1981). Bovendien verzorgde het Instituut in 1999 onder de redactie van R. Raben de uitgave van Beelden van de Japanse bezetting van Indonesië; Persoonlijke getuigenissen en publieke beeldvorming in Indonesië, Japan en Nederland. Intussen was in 1995 al een bundel Indonesische herinneringen verschenen onder de titel Wisseling van de wacht; Indonesiërs over de Japanse bezetting 1942-1945 onder redactie van H. Maier, D. van Minde en H. Poeze.

Afronding van het Japanse offensief

Vergelijk L. de Jong 1984:1042-7, 1054-73, 1077-81.

Inheemse reacties op de Japanse verovering van Indonesië

Zie Kanahele 1967:23-33, L. de Jong 1984:1048-54, 1073-7, 1985:193-7 en TouwenBouwsma 1992:63-73.

Enige kenmerken van het Japanse beleid tegenover Indonesië

Zie Kanahele 1967:37-40 en L. de Jong 1985:140-152. Voor de richtlijnen voor het Japanse beleid in de bezette gebieden zie Benda, Irikura en Kishi 1965:1-3.

De beginfase van de Japanse bezetting

Zie Kanahele 1967:33-6; vergelijk L. de Jong 1985:197 en Groen en Touwen-Bouwsma 1992:67-9.

De inrichting van het bezettingsbestuur

Zie Zorab 1954:30-66, Kanahele 1967:41-2, 58-65, en L. de Jong 1985:207-27. Zie over de rechtspleging ook B. Pompe in Post en Touwen-Bouwsma 1996 en Han Bing Siong 1998. Over Hatta zie Kanahele 1967:41-2 en L. de Jong 1985:198-9.

De Tiga A Beweging

Zie Kanahele 1967:45-9 en L. de Jong 1985:238-44. Zie De Bruin 1982:62 over de herkomst van de benaming 'Drie A'. Voorbeelden van het westerse karakter van sommig Japans propagandamateriaal zijn te vinden in Zwaan 1981. Zie over het contrast tussen de Nederlandse en de Japanse stijl van regeren ook Anderson 1972:31-3. 
Japan in het defensief

Vergelijk L. de Jong 1985:11-44.

De Japanse behandeling van de krijgsgevangenen

Zie L. de Jong 1985:561-733.

Internering van de Nederlandse burgers

Zie Van Velden 1963 en L. de Jong 1985:734-843.

Terugkeer van Soekarno naar Java

Zie Kanahele 1967:52-7, 66-73 en L. de Jong 1985:264-74. Voor de instelling van de adviesraad over traditionele gebruiken enzovoort zie Benda, Irikura en Kishi 1965:133-5.

De 7-december-rede van koningin Wilhelmina

Zie L. de Jong 1986:11-2, 37-9, 65-93 en Fasseur 1995:215-33. Voor de tekst van de radiorede zie onder meer Wolf 1948:189-91 en Yong Mun Cheong 1982:200-2; voor een Nederlandse vertaling onder meer Stempels 1950:293-6 en NIB I:75-7.

De Poetera-beweging

Zie Kanahele 1967:72-80, 96-8 en L. de Jong 1985:274-81, 916-9. Voor de instelling en de organisatie van de Poetera zie Benda, Irikura en Kishi 1965:136-43.

Mobilisatie van de jeugd

Vergelijk over de vooroorlogse jeugdbeweging Petrus Blumberger 1931:164-79 en Van Miert 1995. Over de Seinendan zie Anderson 1972:26-7 en Kanahele 1967:81-4.

Verruiming van Indonesische medezeggenschap

Zie Kanahele 1967:89-115 en L. de Jong 1985:894-910, 964-7. Over de brief van de Empat Serangkai aan premier Tojo zie ook Nishijima in Reid en Oki 1986:271-5. Voor de verklaring van Tojo van juni 1943 zie Benda et al. 1965:51. Over het complot van de Kempeitai tegen Hatta ook Miyoshi in Reid en Oki 1986:122-5.

De hulpsoldaten, de hulppolitie en het vrijwilligerskorps Peta

Zie L. de Jong 1985:927-49, en verder over de Heiho: Kanahele 1967:119 en Anderson 1972:25-6; over de Keibodan: Kanahele 1967:84-5; over de Peta: Kanahele 1967:116-29, Anderson 1972:20-5 en Nugroho Notosusanto 1979.

De Masjoemi

Zie Benda 1958:150-67 en L. de Jong 1985:912-6.

De Djawa Hokokai

Zie Kanahele 1967:133-8, 142-4 en L. de Jong 1985:920-2. Voor de instelling en de organisatie van de Hokokai zie Benda, Irikura en Kishi 1965:148-63. 
Het Tonarigumi-stelsel

Zie Kanahele 1967:142, 144-5 en L. de Jong 1985:922-7. In Bandoeng was het Tonarigumistelsel al in april 1943 ingevoerd, zie Bouwer 1988:172. Overigens is dit stelsel ondanks zijn Japanse herkomst na het einde van de Japanse bezetting in de Republiek Indonesië gehandhaafd.

Economische ontreddering

Zie L. de Jong 1985:497-560.

De romusha's

Zie Kanahele 1967:140-1 en L. de Jong 1985:515-25.

Van Mook en de NICA

Zie L. de Jong 1986:323-8, 331-3, 343-61.

De NEFIS

Zie L. de Jong 1986:239-76.

De Japanse toezegging van onafhankelijkheid

Zie Kanahele 1967:161-83 en L. de Jong 1985:953-67. Voor de verklaring van Koiso van september 1944 zie Benda, Irikura en Kishi 1965:259. Over de Asrama Indonesia Merdeka zie Kanahele 1967:172-5 en Nishijima in Reid en Oki 1986:302-9.

De Barisan Pelopor

Zie Kanahele 1967:166-7 en Anderson 1972:29-30. Vergelijk Benda, Irikura en Kishi 1965:164-5.

De Hizboellah

Zie Benda 1958:178-9 en Van Dijk 1981:43, 72-3.

Anti-Japanse activiteiten

Vergelijk Kanahele 1967:156-60, Anderson 1972:35-8 en L. de Jong 1985:968-70. Zie ook Kanahele 1967:139-42 (over de incidenten in West-Java) en 1967:185-9 (over de opstand in Blitar).

Eerste stappen tot inlossing van de Japanse toezegging

Zie Kanahele 1967:184-97, 220-3, 231-2 en L. de Jong 1985:983-9. De officiële naam van de onderzoekscommissie was Badan Penjelidik Oesaha-oesaha Persiapan Kemerdekaan Indonesia (BPOPKI, Lichaam tot Onderzoek van de Maatregelen ter Voorbereiding van de Onafhankelijkheid van Indonesië).

Radicalisering van de nationalistische jongeren

Vergelijk Anderson 1972:39-60 en Kanahele 1967:153-7, 201-8. Zie Soedjatmoko 1988:13-3 over de poging van enkele studenten om Soekarno af te brengen van zijn samenwerking met Japan. 
Nederlandse voorbereidingen voor de terugkeer naar Indie

Zie L. de Jong 1986:363-421, 432-8, 477-91.

Problemen tussen Nederland en zijn bondgenoten

Zie L. de Jong 1986:347-8, 443-58, 543-7.

De Indonesische onderzoekscommissie voor de onafhankelijkheid

Zie Kanahele 1967:197-200, 208-14. Over de eerste zitting van de onderzoekscommissie zie Yamin 1959:61-135; over de tweede zitting Yamin 1959:143-396. Vergelijk Logemann 1962, Van Dijk 1981:47-9 en L. de Jong 1985:989-97.

Artikel 31, lid 1, van de ontwerp-grondwet luidde: 'Tiap-tiap warga negara berhak mendapat pengadjaran' ('Iedere Staatsburger heeft recht op het krijgen van onderwijs'). Terwijl dit ontwerp dus voorzag in een 'recht op onderwijs', staat in het aangehaalde werk van L. de Jong op p. 994 dat het ontwerp voorzag in 'leerplicht'. Degeen die deze onjuiste vertaling aan De Jong heeft aangereikt was kennelijk niet bekend met het grote belang dat de Indonesische nationale beweging aan de aanspraak op onderwijs hechtte.

Laatste stappen ter inlossing van de Japanse toezegging

Zie Kanahele 1967:214-9 en L. de Jong 1985:998-1004. Over de PPKI vergelijk Anderson 1972:62-66.

Ontvoering van Soekarno en Hatta door militante jongeren

Er bestaan verscheidene uiteenlopende lezingen over wat zich van 14 tot en met 17 augustus 1945 in Djakarta afgespeeld heeft, onder meer van Hatta en Soekarno zelf en van Sjahrir, Soebardjo, Adam Malik, Sidik Kertapati en S.K. Trimurti, bovendien ook van Nishijima in Reid en Oki 1986:313-24. Voor een overzicht van die controverses zie Han Bing Siong 2000:234-44. Deze paragraaf volgt in hoofdzaak de lezing van Anderson 1972:66-77.

De opstelling van de onafhankelijkheidsproclamatie

Vergelijk Anderson 1972:77-84. Ten onrechte gewagen Nederlandse en Engelse vertalingen van de Onafhankelijkheidsproclamatie meestal van 'overdracht' ('transfer') van de macht, terwijl Soekarno in de door hemzelf opgeschreven tekst het woord penjerahan ('overdracht') juist heeft doorgestreept en door pemindahan ('overgang') heeft vervangen.

De laan met de naam Pegangsaän Oost liep in het verlengde van Laan Tjikini ten oosten van de spoorlijn Djakarta-Buitenzorg. De door Soekarno bewoonde villa lag aan de westzijde van die laan; de achterkant van het erf grensde aan de spoorlijn. Aan de andere kant van die spoorlijn liep een laan met de naam Pegangsaän West. 
HOOFDSTUK VI

\title{
Het conflict tussen Nederland en de Republiek Indonesië
}

\author{
Eerste fase \\ Indonesië onder tijdelijk Brits gezag
}

\section{Inleiding en overzicht}

Op 17 augustus 1945, twee dagen na de capitulatie van Japan, riepen Indonesische nationalisten de onafhankelijkheid van Indonesië uit; één dag later stichtten ze de Republiek Indonesië met Soekarno en Hatta als president en vice-president. Ze sloten daarbij aan op voorbereidingen die onder Japans toezicht getroffen waren.

Het duurde enige tijd voordat het tot Nederland doordrong dat zich in de kolonie Nederlands-Indië een onafhankelijke Indonesische republiek gepresenteerd had. Het Nederlandse publiek was hier volstrekt niet op voorbereid. Het was er aan gewend 'Indië' als Nederlands grondgebied te zien; voor velen vormde de band ermee een wezenlijk bestanddeel van de Nederlandse identiteit. Bijna niemand wist dat in deze kolonie al voor de oorlog een krachtige beweging ontstaan was die zich op onafhankelijkheid richtte. Men zag dan ook vrijwel algemeen in de Republiek niets meer dan een Japanse politieke tijdbom die men snel uit de weg moest ruimen.

Voorlopig was Nederland echter niet in staat de Republiek uit de weg te ruimen. Ten eerste had het daar niet de militaire middelen voor. Ten tweede was tussen de Nederlandse en de Britse regering overeengekomen dat het Britse opperbevel voor Zuidoost-Azië ook nog tijdens de overgangsfase na de Japanse capitulatie het hoogste gezag in Indonesië zou uitoefenen. Het zou daar verantwoordelijk zijn voor de afvoer van de Japanse militairen, de bescherming van de Europese geïnterneerden en de voorbereiding van het burgerlijk bestuur. Dit opperbevel kon echter niet meteen na de capitulatie de macht in Indonesië overnemen. Het droeg daarom de Japanse bezettingsmacht 
op, het bestuur te blijven uitoefenen tot de komst van de geallieerde troepen. Pas eind september kwamen zulke troepen in Batavia aan; later vestigden de Britten nog enkele andere bruggehoofden op Java en Sumatra. In het oosten van de archipel namen Australische strijdkrachten de macht over.

Het lange uitstel van de Britse bezetting stelde de Republiek in staat haar gezag op Java te consolideren. De Japanse bezettingsmacht ondernam weinig om dit tegen te gaan. De komst van de Britten bracht geen breuk met deze ontwikkeling. De Britse regering wilde haar soldaten niet gebruiken voor het onderdrukken van vrijheidsbewegingen in de koloniën van andere landen. Zij drong er dan ook op aan dat Nederland met Soekarno overleg zou plegen over een politieke oplossing.

De Nederlandse regering onder premier Schermerhorn weigerde te praten met lieden die door Japan in het zadel gezet waren. Bovendien wees zij onafhankelijkheid voor Indonesië categorisch af. Zij was alleen bereid tot overleg over een gelijkwaardige status voor Indonesië binnen het Koninkrijk der Nederlanden. Het Nederlands-Indische gouvernement onder luitenantgouverneur-generaal Van Mook vestigde zich in oktober weer in Batavia, maar was daar voorlopig ondergeschikt aan het Britse opperbevel. Bovendien zetelde de regering-Soekarno in dezelfde stad.

Intussen veranderde de situatie op Java dramatisch door het optreden van Indonesische jongeren die onder de Japanse bezetting op grote schaal gemilitariseerd waren. Hun agressieve optreden escaleerde in oktober tot een storm van geweld, gericht zowel tegen Japanners als tegen Nederlanders en verder tegen allen die geacht werden de terugkeer van het koloniale bestuur te steunen. Indonesische strijders kregen een groot deel van de Japanse bewapening in handen. Zij leverden ook felle strijd tegen de Brits-Indische troepen die probeerden de Europese geïnterneerden in veiligheid te brengen. De leiders van de Republiek bleken hun eigen aanhang niet in de hand te kunnen houden.

De Nederlandse regering nam in november een besluit dat verreikende gevolgen zou hebben. Ten behoeve van de gezagshandhaving in Indonesië had zij al eerder uit oorlogsvrijwilligers een aantal bataljons gevormd waarvan de verscheping in oktober was begonnen. $\mathrm{Zij}$ besloot nu een veel grotere troepenmacht op de been te brengen, maar volgens een schema waardoor die troepenmacht pas eind 1946 in Indonesië op sterkte zou kunnen zijn.

Van Britse kant bleef men aandringen op overleg tussen Nederland en de Republiek. Teneinde Nederland daartoe onder druk te zetten liet men zelfs de Nederlandse oorlogsvrijwilligers niet tot Indonesië toe, maar legerde hen voorlopig in Malakka. Intussen werd het voor de Nederlandse regering minder bezwaarlijk om met de Republiek te praten omdat daar in november een nieuw kabinet aantrad onder leiding van Sjahrir, een nationalist die zowel de collaboratie met Japan als de geweldpleging door jongeren scherp veroordeeld had. 
Binnen Nederland bestonden grote meningsverschillen over het in Indonesië te voeren beleid. Velen vonden dat de regering geen overleg moest plegen met de opstandige beweging die zich Repubiek Indonesië noemde; eerst diende men de opstand te dempen en de orde en rust te herstellen; pas daarna zou men over een nieuwe opzet van het Koninkrijk mogen praten. Vele anderen hadden geen bezwaar tegen overleg met de Republiek mits dit ertoe zou leiden dat die haar aanspraak op onafhankelijkheid opgaf en mits het Koninkrijk in enigerlei vorm in stand zou blijven. Nog anderen waren bereid onafhankelijkheid voor Indonesië te aanvaarden.

Binnen de Nederlandse regering leefden eveneens verschillende opvattingen. Daardoor kwam zij moeilijk tot een standpunt over wat een akkoord met de Republiek zou kunnen inhouden. Eind 1945 stemde zij in met een voorstel van Van Mook om Indonesië te hervormen tot een federatie van autonome deelstaten, wat de mogelijkheid zou openen de Republiek daar als een deelstaat in op te nemen. Pas in februari 1946 erkende zij in beginsel het Indonesische recht van zelfbeschikking. In Batavia kwamen nu onderhandelingen op gang met de Republiek, die haar zetel inmiddels naar Jogjakarta verplaatst had. Het Britse opperbevel hield de Nederlandse troepenaanvoer niet langer tegen; de in Malakka vastgehouden vrijwilligers konden eindelijk in Indonesië aan land gaan. Sjahrir bood concessies aan in ruil voor erkenning van de Republiek als het de facto gezag over Java en Sumatra. Uiteindelijk was de Nederlandse regering echter niet bereid met de Republiek een formele overeenkomst in deze zin te sluiten, zodat de onderhandelingen in april tot stilstand kwamen. Enige tijd later werden in Nederland verkiezingen gehouden en maakte het kabinet-Schermerhorn plaats voor een nieuw kabinet onder premier Beel.

Ook binnen de Republiek bestond diepe verdeeldheid over het tegenover Nederland te voeren beleid. Terwijl Sjahrir de positie van de Republiek veilig wilde stellen door middel van diplomatiek overleg, zagen vele anderen in gewapende strijd het middel bij uitstek om de nationale revolutie te verdedigen. Deze tweespalt leidde bijna tot een burgeroorlog, maar Soekarno bleef Sjahrir de hand boven het hoofd houden.

De Nederlandse regering had de Britse regering bereid gevonden haar militaire presentie in Indonesie nog enige tijd te handhaven om Nederland in staat te stellen zijn troepenmacht daar op sterkte te brengen. Intussen hadden Nederlandse bestuurders en militairen weer vaste voet gekregen in de gebieden waar het Australische leger in 1945 de macht overgenomen had: in het oosten van de archipel en op Borneo. Op 15 juli droeg het Britse opperbevel het gezag over die gebieden over aan het Nederlands-Indische gouvernement. In aansluiting daarop belegde Van Mook een bijeenkomst met vertegenwoordigers uit die gebieden in Malino op Celebes, waar hij brede steun kreeg voor de door hem voorgestane federale opbouw van het toekomstige Indonesië. 
De Britse regering besloot haar verantwoordelijkheid voor Indonesië eind november 1946 te beëindigen. In de loop van oktober en november trok zij haar laatste troepen uit Java en Sumatra terug; tegelijk kwam in Indonesië een Nederlandse divisie van dienstplichtigen aan. In deze zelfde periode werd het politieke overleg tussen Nederland en de Republiek hervat. Oud-premier Schermerhorn trad nu als voorzitter van de Nederlandse delegatie op. Medio november bereikten de delegaties in het plaatsje Linggadjati overeenstemming over een ontwerp-akkoord. Dit hield onder meer in dat Indonesië in de toekomst geen deel meer zou uitmaken van het Koninkrijk der Nederlanden maar samen met dat Koninkrijk een Nederlands-Indonesische Unie zou vormen. Het ontwerp had nog niet de goedkeuring van de Nederlandse regering verkregen toen de Nederlandse ondergeschiktheid aan het Britse gezag op 30 november ten einde kwam.

\section{De geboorte van de Republiek Indonesië}

In de vroege ochtend van vrijdag 17 augustus 1945 verspreidde zich onder nationalisten in Djakarta het bericht dat de uitroeping van de Indonesische onafhankelijkheid zou plaatsvinden voor de woning van Soekarno op het adres Pegangsaän Oost 56. In aanwezigheid van enige tientallen begon daar om tien uur een eenvoudige ceremonie. Soekarno, staande naast Hatta, hield een korte toespraak en las vervolgens de 's nachts opgestelde proclamatie voor:

Wij, het Indonesische volk, proclameren hierbij de onafhankelijkheid van Indonesië. Zaken betreffende de overgang van de macht en dergelijke worden op ordelijke wijze en binnen zo kort mogelijke tijd geregeld.

Daarna werd een rood-witte vlag gehesen (die door Soekarno's vrouw gemaakt was) en zong men het 'Indonesia Raja'. Omdat de islamitische vastentijd nog gold moest een meer feestelijke viering tot na zonsondergang wachten.

De onafhankelijkheid was uitgeroepen in weerwil van de uitdrukkelijke verklaring van het Japanse militaire bestuur dat het geen medewerking kon geven aan verandering van de politieke status quo. De door dat bestuur beheerste nieuwsmedia zouden daarom over die uitroeping moeten zwijgen. Niettemin wisten de nationalisten er ruime bekendheid aan te geven. In de eerste plaats kregen zij hulp van het liaisonbureau van de Japanse marine, waar al 's ochtends pamfletten met de tekst van de proclamatie werden gedrukt, die men op grote schaal in de stad verspreidde. Verder zetten nationalisten die aan het Japanse persbureau Domei verbonden waren de proclamatie op het telexnet toen het Japanse personeel tijdens de middagpauze afwezig was; het bericht bereikte aldus terstond alle aangesloten redacties. Bovendien slaagden enige bij de radio werkende jongeren erin, de proclamatie tijdens radio-uit- 
zendingen voor te lezen. Op verschillende plaatsen in Indonesië, zowel binnen als buiten Java, werd het bericht van de onafhankelijkheidsverklaring dan ook nog dezelfde dag bekend.

De leden van de Panitia Persiapan Kemerdekaan Indonesia (PPKI, Commissie ter Voorbereiding van de Onafhankelijkheid van Indonesië) kwamen de volgende dag opnieuw bijeen. Het Japanse militaire bestuur had die leden weliswaar aangewezen, maar had de commissie zelf nog niet formeel geïnstalleerd. De PPKI beklemtoonde nu haar zelfstandigheid door haar samenstelling met zes leden uit te breiden, onder wie Ki Hadjar Dewantoro, Iwa Koesoema Soemantri en Wiranatakoesoema. Ook de speciale adviseur van de commissie, Soebardjo, werd nu gewoon lid. De onderwijsvernieuwer Dewantoro was al in 1912 een voorman geweest van de naar onafhankelijkheid strevende Indische Partij, had in 1932 het verzet tegen de wilde-scholenordonnantie geleid (de enige actie waarbij de nationale beweging een overwinning op het Nederlands-Indische gouvernement behaalde) en was onder de Japanse bezetting als één van de vier leiders van de Poetera opgetreden. Iwa Koesoema Soemantri was een linkse nationalist die, evenals Hatta en Soebardjo, in Nederland de Perhimpoenan Indonesia had voorgezeten; in Indonesië had het gouvernement hem in 1930 naar Banda verbannen, waar hij tot 1941 geïnterneerd had gezeten. Wiranatakoesoema behoorde tot de ambtsaristocratie en was onder meer regent van Bandoeng en een vooraanstaand lid van de Volksraad geweest.

De PPKI had ook de jongerenleiders Chairoel Saleh, Soekarni en Wikana in haar midden willen opnemen, maar die weigerden toe te treden. Naar hun mening moest niet een door de Japanse bezettingsmacht gecreëerde commissie maar een op eigen gezag optredend nationaal comité vorm geven aan de Indonesische onafhankelijkheid. Hatta stelde dat de commissie in feite al zo'n comité was.

Voor een goed begrip van deze discussie is het nuttig te weten, dat de oprichting van zelfstandige comités een al langer binnen de nationale beweging gebruikte actievorm was. Eind 1932 waren zulke comités voor het eerst ten tonele verschenen in het kader van het verzet tegen de wilde-scholenordonnantie. Dit was in de jaren 1938-1940 gevolgd door het optreden van meer dan honderd politieke comités, verspreid over de hele archipel, ter ondersteuning eerst van de petitie-Soetardjo en vervolgens van de actie 'Indonesië parlementair'. In 1942 waren na de Japanse inval soortgelijke comités opgericht, nu met de bedoeling om bij het wegvallen van het Nederlandse gezag de leiding over te nemen, maar aan het bestaan van die comités hadden de Japanse bezetters al snel een eind gemaakt.

De afwezigheid van jongerenvertegenwoordigers maakte het voor de PPKI gemakkelijker om met haar werk voortgang te maken. Bovendien waren de strenge islamieten in deze commissie minder sterk vertegenwoordigd dan 
in de onderzoekscommissie. In haar vergadering van 18 augustus stelde de PPKI de grondwet van de republiek vast, in hoofdzaak op basis van het in juli door de onderzoekscommissie opgestelde ontwerp (zie pp. 342-3). Men vreesde echter dat de bijzondere plaats die dat ontwerp aan de islam toekende christelijke Indonesiërs (vooral Menadonezen en Molukkers) in de armen van Nederland zou kunnen drijven. Daarom liet men in de grondwet de eis vervallen dat de president een moslim zijn moest, evenals de bepaling dat moslims de wetten van de islam moesten naleven. Het in juni op dit punt bereikte compromis was hiermee van de baan. Verder verwijderde men uit de preambule alle loftuitingen aan het adres van Japan.

Tenslotte voegde men aan de grondwet enige overgangsbepalingen toe die het volgende inhielden. De PPKI zou zelf de overdracht van de macht aan de Indonesische regering regelen. Alle bestaande overheidsinstellingen, wetten en regelingen zouden van kracht blijven tot hun vervanging in overeenstemming met de grondwet. De PPKI zou zelf de eerste maal de president en de vice-president kiezen. Zo lang het Congres voor Volksoverleg, de Raad van Volksvertegenwoordigers en de Hoge Adviesraad nog niet waren samengesteld, zou de president ook de bevoegdheden van die organen kunnen uitoefenen, daarbij bijgestaan door een Nationaal Comité. Bovendien zou de president gedurende zes maanden volmacht hebben om alle zaken te regelen die in de grondwet werden voorzien.

Deze eerste Indonesische grondwet had een voorlopig karakter. Volgens haar slotbepaling zou het Congres voor Volksoverleg de definitieve grondwet opstellen.

Nadat de PPKI de grondwet formeel had vastgesteld, koos zij Soekarno en Hatta bij acclamatie tot president en vice-president. Na afloop van de vergadering lichtten dezen de buiten de zaal wachtende journalisten in over de genomen besluiten.

\section{Japanse reacties op de onafhankelijkheidsverklaring}

Na de vergadering waarin de PPKI de grondwet van de Republiek Indonesië in werking had gesteld liet generaal Yamamoto, het hoofd van het Japanse bestuur op Java, Soekarno en Hatta bij zich komen. Met nadruk verklaarde hij dat Japan de capitulatievoorwaarden van de geallieerden aanvaard had en daarom geen medewerking aan de onafhankelijkheid kon geven. Het Japanse militaire bestuur van Java zou in functie blijven onder handhaving van de status quo en zou orde en rust blijven verzekeren tot aan de overdracht aan de geallieerden.

De opstelling van Yamamoto was tweeslachtig. Hoewel hij liet weten het bijeenkomen van de PPKI af te keuren, belette hij haar vergaderingen niet. 
Bovendien hield hij de berichtgeving over de onafhankelijkheidsverklaring niet langer tegen. Terwijl de Kempeitai op 17 augustus de pamfletten met de proclamatie nog had proberen te verwijderen, konden de kranten op Java van 19 augustus af vrijelijk over de onafhankelijkheid berichten. Al op die dag drukte het door de Sendenbu opgerichte dagblad Asia Raya onder meer de grondwet van de Republiek af.

Volgens de capitulatievoorwaarden moesten de Japanse autoriteiten tot aan de komst van de geallieerden de orde en rust verzekeren en de politieke status quo handhaven, terwijl zij bovendien de Japanse strijdkrachten moesten ontwapenen. In de bijzondere situatie die op Java ontstaan was meende het militaire bestuur niet tegelijkertijd volledig aan deze drie verantwoordelijkheden te kunnen voldoen. Zou het echt proberen de politieke status quo te handhaven door aan de Republiek Indonesië een eind te maken, dan moest het grote uitbarstingen van geweld tegemoetzien. Intussen had dit bestuur al op 15 augustus besloten tot ontbinding van de Peta, het inheemse hulpleger van ruim vijfendertigduizend man. Dit besluit werd nu binnen enkele dagen uitgevoerd. Daartoe liet men de Peta-militairen eerst hun wapens inleveren en zond men hen vervolgens naar huis, onder uitbetaling van zes maanden soldij. Binnen een week werden ook de ongeveer vijfentwintigduizend man tellende Heiho-eenheden (inheemse hulpsoldaten binnen het Japanse leger) ontwapend en ontbonden.

Generaal Nagano, de opperbevelhebber van het 16e Leger dat het bestuur over Java uitoefende, maakte op 21 augustus eindelijk de capitulatie van Japan bekend. Op dezelfde dag vergaderde hij met zijn ondercommandanten. Er bevonden zich in die tijd op Java ongeveer vijftigduizend Japanse militairen; de meeste daarvan waren pas in de loop van 1945 hierheen overgebracht uit verder oostelijk gelegen gebieden waar de Japanse strijdkrachten zich uit terugtrokken. Men besloot nu de op Java gelegerde Japanse militairen in afwachting van hun repatriëring bijeen te brengen in een aantal landelijke gebieden. Hun bewapening zou worden opgeslagen, maar elke militair zou voor zijn eigen veiligheid één vuurwapen en vijf patronen mogen behouden. In de steden zou men slechts kleine legerdetachementen achterlaten ter ondersteuning van de Kempeitai en de Indonesische politie.

Nagano en zijn ondercommandanten waren het er over eens dat men niet tegen de Republiek zou optreden.

\section{De Nederlandse opstelling tegenover de onafhankelijkheidsverklaring}

Gedurende een volle maand wekte de Indonesische onafhankelijkheidsverklaring geen reactie bij de bevolking van Nederland, omdat die daarvan geheel onkundig was. Pas op 17 september viel in sommige Nederlandse kranten te 
lezen dat de nationalistische leider Soekarno op 17 augustus een Indonesische republiek had uitgeroepen. Het Nederlandse publiek was hier volstrekt niet op voorbereid. Voor een goed begrip van de reacties van dat publiek is het nuttig wat dieper op de Nederlandse houding tegenover Indonesië in te gaan. Omdat die houding zich grotendeels al tegen het eind van de negentiende eeuw gevormd had, zullen hieronder ook enige zaken worden behandeld die al eerder in hoofdstuk III zijn vermeld in verband met de betekenis van Indonesië voor het Nederlandse zelfbewustzijn.

De Nederlandse houding tegenover Indonesië aan de vooravond van de Tweede Wereldoorlog

Voor bijna alle Nederlanders was het een vast gegeven dat Indonesië bij Nederland hoorde. Van jongs af leerden zij Indië als Nederlands grondgebied te zien. Wandkaarten van Nederlands-Indië hingen evenals wandkaarten van Nederland in alle basisscholen. Voor de meeste Nederlanders waren plaatsnamen als Medan en Makassar niet minder vertrouwd dan Dordrecht en Deventer. In het Nederlandse zelfbewustzijn nam het 'bezit' van Indië een fundamentele plaats in. Daarbij ging het om veel meer dan alleen het directe belang daarvan voor de Nederlandse economie, ook al dacht men algemeen dat 'verlies' van Indië die economie ernstig zou verzwakken.

De betekenis van het bezit van Indië voor het nationale zelfbewustzijn betrof in de eerste plaats de internationale politieke en economische status van Nederland. Het land bevond zich op dit punt in een andere positie dan bijvoorbeeld Frankrijk en Groot-Brittannie, die nu eenmaal grote mogendheden waren, ook zonder hun koloniën. Nederland was daarentegen een klein land dat geen actieve rol in de internationale politiek speelde, maar dank zij Indië bezette het de derde plaats op de wereldranglijst van de koloniale mogendheden en nam het een vooraanstaande plaats in de wereldeconomie in. De psychologische betekenis van Indië voor Nederland was bovendien veel groter dan die van bijvoorbeeld India voor Groot-Brittannië of van Indochina voor Frankrijk. Deze mogendheden beheersten destijds nog vele andere gebieden in verschillende delen van de wereld, terwijl het Nederlandse imperium naast Indië alleen Suriname en de Nederlandse Antillen omvatte. Die psychologische betekenis was ook groter omdat de Nederlandse dominantie in de Indische archipel al ruim een eeuw langer bestond dan de Britse in India en twee eeuwen langer dan de Franse in Indochina.

Ook los van prestigegevoelens voelden veel Nederlanders de band met Indië als een verruiming van hun horizon. Dat land had immers de afmetingen van een werelddeel, het herbergde een bonte verscheidenheid van culturen, het had gebergten en vulkanen en een fascinerende tropische fauna en flora. Het bezit van Indië leek daarom aan Nederland een allure te geven die dit kleine vlakke land uit zichzelf niet bezat. Bovendien bood de kolonie aan individuele 
Nederlanders ruimere mogelijkheden tot ontplooiing dan hun eigen land. Jonge Nederlanders kregen in Indië als bestuursambtenaar, als militair, als planter of als ingenieur vaak verantwoordelijkheden te dragen die zij in Nederland nooit of alleen tegen het eind van hun loopbaan zouden bereiken.

Voor tal van Nederlanders had de band met Indië een bijzondere gevoelswaarde: zij waren sterk aan dat land gehecht. Dit gold zowel voor het merendeel van hen die er hun jeugd hadden doorgebracht als voor velen die er gewerkt hadden en er hun beste krachten aan hadden gegeven. Hoewel de Nederlanders in Indië nauwelijks een duizendste deel van de totale bevolking uitmaakten, voelden zij zich daar meestal gemakkelijk thuis. Hiertoe droeg ook de omstandigheid bij dat hun bevolkingsgroep omringd werd door de veel grotere groep van de Indische Nederlanders, voor wie Indië het eigen thuisland was. Die 'Indische Nederlanders' of 'Indo-Europeanen' waren personen van gemengde Indonesisch-Europese afstamming die formeel met de blanken gelijkgesteld waren. Er bestond geen scherpe scheiding tussen deze bevolkingsgroep en de blanke Europeanen; onderlinge huwelijken waren niet ongewoon en sommige Indo-Europeanen behoorden zelf tot de koloniale bovenlaag.

De sterke persoonlijke band met Indië van de Nederlanders die daar leefden of geleefd hadden beïnvloedde ook de gevoelens van velen in het moederland die de kolonie nooit hadden bezocht. Het belang dat men in Nederland aan Indië hechtte als bestanddeel van de nationale identiteit leefde overigens veel sterker onder het protestantse dan onder het katholieke deel van de bevolking. In protestantse kring dacht men graag met trots aan de stichting van het Nederlandse imperium in Zuidoost-Azië door de VOC, maar ten tijde van de VOC hadden de katholieken in Nederland een onderdrukte minderheid gevormd. Ook in de twintigste eeuw bekleedden katholieken nog steeds weinig leidinggevende functies in het koloniale Nederlands-Indië.

Tegenstanders van het kolonialisme vond men in Nederland vrijwel alleen in communistische kring en bij de linkervleugel van de socialistische beweging. De meeste Nederlanders, met inbegrip van veel socialisten, koesterden geen principiële bezwaren tegen de koloniale verhouding met Indië. Zij gingen ervan uit dat die verhouding niet alleen het moederland maar ook de kolonie zelf tot voordeel strekte. Al sinds het begin van de eeuw zag men dat wat Nederland in Indië tot stand bracht graag als de vervulling van een zedelijke roeping tegenover de inheemse bevolking. Daarbij waren velen ervan overtuigd dat het Nederlandse koloniale bewind in dit opzicht beter was dan dat van de andere koloniale landen.

De Nederlandse trots op de eigen prestaties overzee ging gewoonlijk vergezeld van een superioriteitsgevoel tegenover de 'Inlanders'. Men meende dat de gekleurde bevolking nu eenmaal op het punt van intelligentie, daadkracht en organisatievermogen achterstond bij het blanke ras. Veel Nederlanders zagen iedere fabriek, ieder ziekenhuis en iedere spoorbrug in Indië als een 
bewijs van eigen kunnen en eigen onmisbaarheid. Zij beseften daarbij niet dat de inheemse bevolking stelselmatig uit leidende functies geweerd werd, zodat ze geen gelegenheid kreeg haar capaciteiten te tonen. Alleen op het terrein van het bestuur werden Indonesiërs tot hogere functies toegelaten, maar ook daar was hun rol meestal beperkt tot de uitvoering van beleid dat door Nederlanders bepaald werd.

Voorzover men in Nederland aan de mensen in Indië dacht, gingen de gedachten in de eerste plaats uit naar de daar wonende Nederlanders. Dat was nu eenmaal de categorie waar men het meest over vernam en onder wie men familieleden of kennissen telde. De Indonesiërs en de Chinezen kwamen op het tweede plan; zij maakten deel uit van het decor waartegen het leven van de blanken zich afspeelde. In de Nederlandse beeldvorming figureerden Indonesiërs hoofdzakelijk als huispersoneel, plantagearbeiders en kleine boeren. Men zag hen als bescheiden mensen met weinig materiële behoeften en nam meestal aan dat zij ontzag hadden voor het koloniale bewind en eerbied voor koningin Wilhelmina. Rust en tevredenheid tekenden dan ook het Nederlandse beeld van de inheemse bevolking.

Slechts weinigen in Nederland waren ervan op de hoogte dat in de kolonie een krachtige nationale beweging ontstaan was die zich op onafhankelijkheid voor Indonesië richtte. De overgrote meerderheid van de Nederlandse bevolking wist hier niets van. Deze onbekendheid met het Indonesisch nationalisme werd in de jaren dertig bevorderd door de houding van de Nederlandse regering en het Nederlands-Indische gouvernement, die dat nationalisme niet als een politiek maar alleen als een politioneel probleem behandelden. De namen Soekarno en Hatta waren dan ook in Nederland bij het grote publiek vrijwel onbekend. Het paradoxale feit deed zich voor dat het Nederlandse publiek wél de figuur Gandhi kende en daardoor wist van het bestaan van een nationale beweging in Brits-Indië. Men nam er overigens geen notitie van dat Groot-Brittannië die beweging een eind tegemoetkwam en in 1935 de weg opende naar het veranderen van deze kolonie in een autonome dominion die zelfs vrij zou zijn om de band met de Britse kroon te verbreken. Evenmin drong het tot het Nederlandse publiek door dat de Filippijnen sinds 1935 geen Amerikaanse kolonie meer waren maar zelfbestuur genoten onder een Filippijnse president en volgens een besluit van het Amerikaanse Congres na tien jaar volledig onafhankelijk zouden worden.

Het bestaan van nationalistische aspiraties binnen de inheemse bevolking van Nederlands-Indië was in het moederland weliswaar onder politici iets meer bekend dan onder het grote publiek, maar veel aandacht gaven zij er niet aan. Indië-deskundigen verzekerden dat zulke aspiraties voornamelijk leefden bij een klein aantal ontwortelde intellectuelen die niet representatief waren voor het gros van de bevolking. Wel bracht de opkomst van dit Indonesisch nationalisme sommige politici ertoe zich op het standpunt vast te leggen, dat 
de overzeese rijksdelen zich onder geen beding los zouden mogen maken van het Nederlandse koninkrijk. 'Rijkseenheid' luidde de leuze die dit standpunt verwoordde. In de tweede helft van de jaren dertig tekende zich bovendien in de Nederlandse politiek een verschuiving naar rechts af die ook het Indiëbeleid beïnvloedde. Verschillende christelijke en liberale partijen spraken zich uitdrukkelijker dan vroeger uit voor handhaving van de rijkseenheid. De grootste socialistische partij, de SDAP, had weliswaar in 1930 het recht van het Indonesische volk op onafhankelijkheid onvoorwaardelijk erkend, maar achtte de tijd voor uitoefening van dat recht nog lang niet gekomen.

De houding van de Nederlandse politici kwam onder meer tot uiting naar aanleiding van de in 1936 door de Nederlands-Indische Volksraad aangenomen petitie-Soetardjo (zie pp. 234-9). Hierin vroeg de Volksraad om bijeenroeping van een conferentie waarin vertegenwoordigers van Nederland en Nederlands-Indië op voet van gelijkheid een plan zouden opstellen teneinde aan Indië langs de weg van geleidelijke hervorming de staat van zelfstandigheid toe te kennen binnen de grenzen van artikel 1 van de Grondwet. In het Nederlandse parlement pleitten alleen de SDAP en de CPN voor aanvaarding van deze petitie. Alle andere partijen wezen haar af. Kennelijk putten die partijen geen inspiratie uit het Britse beleid ten aanzien van India en het Amerikaanse beleid ten aanzien van de Filippijnen. Voorzover dit beleid al in deze kring bekend was, vond men het onwijs en onverantwoord.

\section{De Nederlandse houding tegenover Indonesië tijdens de Duitse bezetting}

Hoewel de bezetting van Nederland door nazi-Duitsland in mei 1940 het contact met de kolonie verbrak, werd de betekenis van de band met Indië voor het Nederlandse zelfbewustzijn door die bezetting eerder versterkt dan verzwakt. $\mathrm{Nu}$ Nederland zich onder vreemde overheersing bevond, putte dat zelfbewustzijn kracht uit de gedachte dat men in Zuidoost-Azië met nog geen honderdduizend Nederlanders de leiding had over een bevolking van ruim zeventig miljoen, die men had ingeschakeld in de wereldeconomie en had binnengeleid in de moderne beschaving. Die gedachte vond bevestiging in een boek dat in 1941 in bezet Nederland verscheen onder de titel Daar wèrd wat grootsch verricht...; Nederlandsch-Indië in de xxste eeuw. Hierin behandelden veertig deskundigen in ruim vijfhonderd pagina's vrijwel alle aspecten van de Nederlandse kolonie in Azië. De namen Soekarno en Hatta kwamen in het hele boek niet voor.

De manier waarop men in bezet Nederland over Nederlands-Indië dacht veranderde niet veel nadat die kolonie zelf in 1942 door Japan bezet was. De overtuiging bleef wijdverbreid dat Nederland niet buiten Indië kon en Indië niet buiten Nederland. Slechts weinigen vroegen zich af of de Nederlandse nederlaag tegen Japan afbreuk zou doen aan het vroeger onaantastbaar geachte gezag van Nederland bij de inheemse bevolking. Men verwachtte in bezet 
Nederland meestal niet dat de Japanse bezetting een wig zou drijven tussen de blanke en de inheemse bevolking van Indonesië. Eerder nam men aan dat die twee groepen nader tot elkaar zouden komen nu ze beide te lijden hadden van dezelfde onderdrukker.

Voorzover men zich in bezet Nederland een voorstelling maakte van de toestand in bezet Indonesië deed men dat aan de hand van de eigen situatie. Eén aspect van de Nederlandse oorlogssituatie was dat de meerderheid van de bevolking er aan gewend raakte de eigen landgenoten in twee politieke categorieën in te delen die tegelijk morele categorieën waren. Wie tegen de Duitse vijand was gold als 'goed', wie voor de vijand was gold als 'fout'. De tweede categorie was die van de 'collaborateurs'; daartoe rekende men allen die de vijand actief steunden, hetzij om ideologische hetzij om opportunistische redenen. Zulke verraders van de eigen natie bleken in alle door Duitsland bezette gebieden te vinden te zijn. In Nederland was de leider van de NSB, Mussert, de meest prominente handlanger van het nazi-regime. Dat regime wees hem aan als 'leider van het Nederlandse volk' maar gaf hem geen functie in het bestuur van het land. Daarentegen legde nazi-Duitsland in sommige andere bezette gebieden het burgerlijk bestuur wel in handen van plaatselijke geestverwanten. Het eerst gebeurde dit in bezet Noorwegen; daar installeerde Duitsland een marionettenregering onder de Noorse nazi Quisling. Terwijl men er in bezet Nederland gewoonlijk van uitging dat de Indonesische bevolking in meerderheid Nederlandsgezind bleef, lag het tegelijk voor de hand te verwachten dat Japan onder die bevolking wel een aantal handlangers zou vinden. Evenzeer leek het aannemelijk dat het gros van de bevolking die zetbazen van Japan zou verfoeien en dat zulke verraders na de oorlog hun gerechte straf niet zouden kunnen ontlopen.

Men hield zich in bezet Nederland weinig met de vraag bezig of het Nederlandse koloniale bestel na de oorlog verandering zou moeten ondergaan. Daarentegen besprak de Nederlandse regering in Londen deze kwestie in 1942 uitvoerig, onder meer omdat de anti-koloniale stemming in de Verenigde Staten het wenselijk maakte bereidheid tot verandering te tonen (zie pp. 302-4). Het resultaat hiervan was dat koningin Wilhelmina op 6 december 1942 een voor het Amerikaanse publiek bedoelde radiorede uitsprak waarin zij onder meer zei, dat de historische verbondenheid van Nederland met Nederlands-Indië al lang geen koloniale verhouding meer was en dat de beide gebieden bij het uitbreken van de oorlog aan de vooravond van een samengaan op voet van gelijkheid hadden gestaan. Na de oorlog zou een ronde-tafel-conferentie plaats vinden waarin vertegenwoordigers van de overzeese rijksdelen (Indonesië, Suriname en de Nederlandse Antillen) samen met vertegenwoordigers van Nederland zouden beraadslagen over de structuur van het Koninkrijk en zijn delen teneinde die aan te passen aan de veranderde omstandigheden. De koningin sprak de overtuiging uit dat het rijk dan zou 
worden gebouwd op de grondslag van volledig deelgenootschap, waarbij elk van de vier rijksdelen zijn eigen inwendige aangelegenheden zelfstandig zou behartigen. Zij sprak niet over een recht op onafhankelijkheid, maar merkte wel op dat geen politieke eenheid en verbondenheid op de duur kunnen blijven bestaan die niet gedragen worden door de vrijwillige aanvaarding en de trouw van de overgrote meerderheid van de burgerij.

Deze gewoonlijk als '7-december rede' aangeduide toespraak had weinig invloed op het denken in bezet Nederland over de verhouding tot Indonesië, onder meer omdat die rede in het Engels uitgesproken was en bijna niemand wist wat de koningin precies gezegd had. Wel droeg de rede ertoe bij dat enige illegaal verschijnende periodieken iets meer aandacht aan die verhouding gaven. Het uit de kring van de Anti-Revolutionaire Partij voortgekomen illegale blad Trouw wijdde daar in december 1943 zelfs een apart nummer aan. (De orthodox-protestantse ARP was zowel de partij van H. Colijn, Nederlands minister-president in de jaren 1933-1939, als van P.S. Gerbrandy, in 1940-1945 minister-president van de Nederlandse regering in Londen.) Hoewel het commentaar in Trouw zich formeel niet tegen de rede keerde, nam het impliciet afstand van de daarin aan Indië toegezegde gelijkwaardigheid en zelfstandigheid. Het ontkende het bestaan van een Indonesische natie en karakteriseerde Indië als niet meer dan 'een groep eilanden, bijeengebracht en bijeengehouden door het Nederlandse gezag'. Over het streven naar zelfstandigheid schreef het onder meer: 'Een kind dat graag groot wil zijn heeft daarmee nog niet het vermogen van een man'. Enige tijd later schreef het blad bovendien: 'Instelling van een democratisch bestuur in Indië, d.w.z. instelling van een zelfstandige Indische regering, verantwoordelijk aan een door de Indische bevolking gekozen Volksraad, is onmogelijk. Dit zou in feite betekenen: Indië los van Nederland, d.w.z. de vernietiging van alles wat daar aan goeds is tot stand gebracht.'

Weliswaar was in de radiorede van de koningin niet gesproken over het instellen van een Indische regering die verantwoording verschuldigd zou zijn aan een door de bevolking gekozen parlement, maar dit was wel een denkbeeld dat leefde bij H.J. van Mook, destijds minister van koloniën van de regering in Londen en later als luitenant-gouverneur-generaal hoofd van het in Australië zetelende Nederlands-Indische gouvernement. Anders dan de meeste Nederlanders was hij wel degelijk op de hoogte van het bestaan van de Indonesische nationale beweging en beschouwde hij het Nederlandse gezag niet als onaantastbaar. Hetzelfde gold voor de tweede man van zijn gouvernement, Ch.O. van der Plas, die evenals Van Mook in Indië geboren en opgegroeid was. Beiden hadden in het begin van de jaren dertig deel uitgemaakt van de Stuw-groep (zie pp. 211-2), een vereniging die stelde dat het koloniaal beleid zich moest richten op de totstandkoming van een 'Indisch Gemenebest' dat een eigen plaats zou innemen in de rij der zelfstandige volkeren. Van der 
Plas veronderstelde al in het voorjaar van 1944 dat Japan, wanneer het zich gedwongen zou zien Indonesië te verlaten, er onafhankelijkheid aan zou toekennen onder een soort Quisling-regering. Van Mook vreesde dat leidende Indonesiërs zouden gaan twijfelen aan het nut van de band met Nederland als dit de bevrijding en het herstel in hoofdzaak aan de geallieerden zou overlaten. Van Mook en Van der Plas uitten hun bezorgdheden echter niet in het openbaar; bovendien miskenden zij zelf hoezeer het politieke klimaat in Indonesië tijdens de Japanse bezetting veranderd was.

Eind september 1944, toen het zuiden van Nederland al bevrijd was en de ondergang van nazi-Duitsland nabij leek, spoorde de regering in Londen op verzoek van Van Mook de Nederlandse illegale pers aan tot het voeren van een campagne met het oog op de werving van vrijwilligers voor de bevrijding van Nederlands-Indië. De samenwerkende verzetsorganisaties besloten hiertoe een gezamenlijke oproep uit te geven en stelden ter voorbereiding daarvan een commissie in met vertegenwoordigers van verschillende illegale bladen, waaronder zowel het anti-revolutionaire Trouw als het communistische blad De Waarheid. In de commissie zat ook de Indonesiër Setiadjit, marxist en voorzitter van de Perhimpoenan Indonesia. Het duurde enige tijd voordat men een tekst geredigeerd had waar allen zich achter konden stellen; pas in april 1945 verscheen de oproep in de ondergrondse pers. De commissie legde daarin nadruk op de vrijwilligheid van het samengaan van Indonesië met Nederland en verklaarde aanknopend bij de rede van de koningin onder meer: 'Ons verbindt het vertrouwen dat bij de beslissing over de toekomstige structuur van het koninkrijk [...] de Indonesische volkeren in een toenemende vrijwillige samenwerking en in een volledig deelgenootschap tussen het Nederlandse volk en hen de beste waarborg zullen zien voor het herstel van hun vrede en voor de toename van hun voorspoed'. De commissie was voorgezeten door Willem Schermerhorn, een hoogleraar in de landmeetkunde die binnen de Nederlandse verzetsbeweging veel vertrouwen genoot. Hij legde zich graag toe op het overbruggen van tegenstellingen; zo was hij in de laatste jaren voor de oorlog voorzitter geweest van een organisatie die alle democratische groeperingen bijeen probeerde te brengen in een gezamenlijk front tegen het totalitarisme van rechts en van links.

\section{De Nederlandse houding tegenover Indonesië na de bevrijding van Nederland}

In mei 1945 werd heel Nederland bevrijd en kwam er een eind aan de oorlog in Europa. Op verzoek van koningin Wilhelmina stelde Schermerhorn samen met de SDAP-voorman Willem Drees een nieuw kabinet samen, dat het kabinet-Gerbrandy op 25 juni afloste. Minister-president werd Schermerhorn zelf; minister van overzeese gebiedsdelen werd J.H.A. Logemann, oud-hoogleraar aan de Rechtshogeschool in Batavia en oud-voorzitter van de Stuw-groep. Op 17 juli sprak minister Logemann een radiorede uit waarin hij onder meer zei, 
dat zowel de koningin als de regering en het Nederlandse volk alleen bereid waren Nederlands bloed te storten voor een zelfstandig Indonesië en niet voor herstel van een koloniale overheersing.

Logemann vermeldde niet dat Japan intussen met voorbereidingen bezig was om aan Indonesië onafhankelijkheid te verlenen. Dank zij uit Indonesië opgevangen radiouitzendingen waren de Nederlands-Indische autoriteiten in Australië hier wel van op de hoogte; ook een in Londen verschijnend Nederlands weekblad had er al over bericht. Die voorbereidingen wekten echter weinig verontrusting bij de Nederlanders die ervan wisten; men nam aan dat een door Japan ingestelde Indonesische regering nauwelijks steun onder de inheemse bevolking zou vinden. Ook Van Mook zag het eventuele optreden van zulk een regering wel als een complicatie, maar tilde er niet zwaar aan. Hij dacht dat Soekarno zijn krediet bij het gros van de Indonesiërs verspeeld had door zich volledig met de Japanse zaak te vereenzelvigen. Naar hij nog op 12 augustus in een telegram aan Logemann meedeelde, toen bekend was dat Japan de strijd wilde staken, verwachtte hij omtrent de houding van de bevolking 'geen te grote moeilijkheden op Java, met uitzondering van de kans op plaatselijke roverijen ten gevolge van het tijdelijk ontbreken van gezag'.

Over de onafhankelijkheidsverklaring van 17 augustus kreeg Van Mook aanvankelijk onnauwkeurige inlichtingen. Op 20 augustus seinde hij aan Logemann, dat de Japanse opperbevelhebber die dag een Republiek Indonesia zou uitroepen met Soekarno als president en Hatta als vice-president. Enkele dagen later voegde hij hieraan toe, dat men hen als collaborateurs kon behandelen en dat men van hun regering geen notitie hoefde te nemen. De voorlichtingsdienst van zijn gouvernement gaf voorlopig geen publiciteit aan deze politieke ontwikkelingen op Java. In Nederland voerde minister-president Schermerhorn sinds begin augustus herhaaldelijk overleg over problemen in verband met het herstel van het Nederlands gezag in Indonesië, maar daarbij ging het telkens om andere problemen dan het optreden van een onafhankelijke Indonesische regering.

De verklaring van de illegale pers in april en de verzekering van minister Logemann in juli hadden getuigd van een bereidheid tot vernieuwing waar de meeste Nederlanders nog niet aan toe waren. Met betrekking tot Indië dachten die gewoonlijk aan niet meer dan aan herstel van de vooroorlogse situatie. Om deze mentaliteit te veranderen besloten enige Nederlanders en Indonesiërs die tijdens de bezetting aan illegaal werk hadden deelgenomen een vereniging op te richten ter bestrijding van het koloniale conservatisme. Dit werd de Vereniging Nederland-Indonesië, met als doelstellingen onder meer het feitelijk en definitief opheffen van de koloniale status en het bevorderen van blijvende vriendschap en samenwerking tussen de volken van Nederland en Indonesië. Tijdens de oprichtingsvergadering op 29 augustus verzond men een telegram waarin men koningin Wilhelmina bedankte voor het duide- 
lijk aangeven van de weg voor toekomstige samenwerking tussen de beide volken. De aan de vergadering deelnemende leden van de Perhimpoenan Indonesia wisten toen nog niet welke ingrijpende veranderingen zich op het politieke toneel in hun geboorteland hadden voltrokken.

Tot het midden van september hielden de Nederlandse voorlichtingsdiensten voor het Nederlandse publiek verborgen, dat zich op Java een onafhankelijke Indonesische republiek gepresenteerd had. Toen dit nieuws in de tweede helft van september eindelijk tot de bevolking doordrong, leek het geen moeilijke vraag hoe men zich daartegenover diende op te stellen. Die republiek bleek te worden geleid door politici die tijdens de oorlog stelselmatig hadden geheuld met Japan, de gemeenschappelijke vijand van Nederland en Indonesië. $\mathrm{Zij}$ was dus niet meer dan een door de vijand achtergelaten politieke tijdbom of booby-trap, die men snel onschadelijk moest maken.

\section{Tijdelijke plaatsing van Indonesië onder Brits militair gezag}

Tijdens de oorlog hadden de geallieerden het strijdtoneel in Azië en de Stille Oceaan in verschillende gezagsgebieden verdeeld. Daarbij hadden zij Indonesië met uitzondering van Sumatra ingedeeld bij de South-West Pacific Area (SWPA) onder de Amerikaanse generaal Douglas MacArthur; Sumatra was samen met Birma, Malakka en Singapore ingedeeld bij het South-East Asia Command (SEAC) onder de Britse admiraal Louis Mountbatten. Medio augustus 1945 veranderde dit: de hele archipel kwam nu onder de verantwoordelijkheid van Mountbatten. Dit was het gevolg van een op 24 juli genomen besluit van de Amerikaanse president Truman en de Britse regeringsleider Churchill om het SEAC-gebied met ingang van 15 augustus uit te breiden met Indonesië, Thailand en de zuidelijke helft van Indochina. (De noordelijke helft van Indochina kwam onder het militaire gezag van China.)

Deze grenswijziging tussen de gezagsgebieden had ernstige gevolgen voor de terugkeer van het Nederlandse gezag in Indonesië. Het Nederlands-Indische gouvernement onder Van Mook had sinds 1944 een nauwe samenwerking opgebouwd met het hoofdkwartier van MacArthur, onder meer wat betreft het functioneren van de Netherlands Indies Civil Administration (NICA, zie pp. 322-3) in bevrijd gebied. Ten behoeve van het herstel in Indonesië had het bij dat hoofdkwartier gedetailleerde bestellingen van uitrusting en hulpgoederen ingediend. MacArthur beschikte over strijdkrachten voor een snelle bezetting van Java en had daartoe al voorbereidingen laten treffen. Aan Britse kant was daarentegen op dit punt nauwelijks iets voorbereid.

De Nederlandse regering maakte tegen de grenswijziging van de gezagsgebieden geen bezwaar. Volgens premier Schermerhorn had die wijziging ook positieve kanten, omdat de Britten de Nederlandse positie beter zouden 
begrijpen dan de vaak anti-koloniaal ingestelde Amerikanen. Wel was het nu nodig met Groot-Brittannië een formele overeenkomst te sluiten over de verhouding tussen het Britse militaire gezag en het Nederlandse bestuur in Indonesië. Van Mook en Mountbatten hadden daarvoor al in mei 1944 een regeling ontworpen, maar die had nog geen rechtskracht. Op 24 augustus zetten de beide regeringen door een officiële notawisseling de ontwerp-regeling om in een bindende overeenkomst.

De regeling bepaalde dat tijdens de eerste fase van de militaire operaties het hoogste gezag bij de geallieerde opperbevelhebber zou berusten, terwijl Nederlands-Indische (NICA) functionarissen aan zijn strijdkrachten zouden worden toegevoegd om het bestuur over bevrijd Nederlands-Indisch gebied te voeren, onder toezicht van de commandant van de geallieerde strijdkrachten in het betreffende gebied. Zo spoedig als praktisch mogelijk zou het NederlandsIndische gouvernement weer volledige verantwoordelijkheid voor het burgerlijk bestuur van Nederlands-Indisch gebied op zich nemen; daartoe zou de geallieerde opperbevelhebber, zo spoedig en zo volledig mogelijk als de militaire situatie dit naar zijn oordeel toeliet, de luitenant-gouverneur-generaal in kennis stellen van de mate waarin zulke verantwoordelijkheid weer ware te aanvaarden. In de notawisseling legden de beide regeringen nog vast, dat de regeling een zuiver tijdelijk karakter droeg en op geen enkele wijze de Nederlandse soevereiniteit aantastte.

Overigens was deze regeling in 1944 ontworpen voor de situatie waarin de strijd met Japan nog gaande was. Nu Japan gecapituleerd had was er een wezenlijk andere situatie ontstaan, maar de Nederlandse regering zag geen aanleiding tot wijziging van de regeling. Niemand vermoedde dat het Nederlandse gezag in Indonesië uit kracht van deze overeenkomst tot eind november 1946 aan het Britse gezag ondergeschikt zou blijven.

Doordat de datum waarop de uitbreiding van het Britse gezagsgebied inging onverwacht was samengevallen met de capitulatie van Japan, had Mountbatten plotseling de taak gekregen in dit hele gebied de overgave van de Japanse strijdkrachten te regelen, de verantwoordelijkheid voor de openbare orde en veiligheid over te nemen, de geallieerde krijgsgevangenen en geïnterneerden te helpen en de terugkeer van het burgerlijke bestuur voor te bereiden. Aan Britse kant beschikte men hiertoe niet over voldoende militair en burgerlijk personeel. Daarom belastte men het Australische leger met deze taken voor alle delen van Indonesië buiten Sumatra, Java, Bali en Lombok.

Wat de door SEAC zelf uit te voeren taken betreft, beschikte Mountbatten niet over genoeg transportmiddelen om al de nu onder zijn verantwoordelijkheid komende gebieden in één keer van troepen te voorzien. Hij besloot Britse militairen begin september in de eerste plaats te sturen naar Bangkok en Saigon (per vliegtuig) en Singapore (per schip). Ook dirigeerde hij extra troepen naar Birma. Pas daarna zouden Malakka, Java, Sumatra en Hongkong 
aan de beurt komen. Wat Java betreft zouden de eerste troepen volgens deze plannen op 4 oktober bij Batavia en op 16 oktober bij Soerabaja aan land gaan. Intussen sloot Mountbatten al op 27 augustus in Rangoon een voorlopige overeenkomst met vertegenwoordigers van maarschalk Terauchi, de in Saigon zetelende Japanse opperbevelhebber voor de zuidelijke gebieden. Daarbij droeg hij Terauchi onder meer op, in de onder hem vallende gebieden het bestuur te blijven uitoefenen tot de komst van de geallieerde troepen.

Voor het Nederlands-Indisch gouvernement in ballingschap bracht de wijziging van de gezagsgebieden de noodzaak mee, onverwijld nauwe samenwerking te zoeken met de Britse autoriteiten aan wie nu de verantwoordelijkheid voor Indonesië toevertrouwd was. Eind augustus reisde Van Mook samen met Van der Plas van Australië naar Ceylon, waar het hoofdkwartier van SEAC gevestigd was. Op 4 september pleegde hij daar uitvoerig overleg met Mountbatten. Zij spraken onder meer af dat Van Mook zelf de functie van opperste chef van de NICA voor heel Nederlands-Indië op zich zou nemen en in die hoedanigheid verantwoording verschuldigd zou zijn aan Mountbatten, terwijl hij tegelijkertijd als waarnemend hoofd van het Nederlands-Indisch gouvernement de Nederlandse regering zou vertegenwoordigen en aan die regering verantwoording verschuldigd zou zijn. Dit gouvernement zou van Australië naar Batavia verhuizen zodra de geallieerden die stad bezet zouden hebben.

Een ander voorwerp van overleg was de actuele politieke situatie op Java. Van Mook verschafte hierover uitvoerige documentatie. Daarin kenschetste hij Soekarno als iemand met een typische Quisling-mentaliteit en beschreef hij de Republiek Indonesië als een door Japan opgericht marionetten-regime waarvan te betwijfelen viel of het veel aanhang had. Niettemin noemde hij het belangrijk dat deze organisatie in geen enkel opzicht erkend zou worden. Hij vroeg Mounbatten daarom een algemene instructie uit te geven tot nieterkenning van deze zogenaamde Republiek en haar regering. Hiertoe was Mountbatten echter niet bereid. Wel besloot hij zich tot maarschalk Terauchi te richten, maar daarbij baseerde hij zich op onjuiste gegevens. In de door Van Mook verschafte documentatie stond namelijk dat Terauchi zelf op 19 augustus Indonesië onafhankelijk verklaard en Soekarno tot president benoemd had en dat de Japanners bekendgemaakt hadden het bestuur verder aan Soekarno en de zijnen over te laten. Mountbatten eiste nu dat Terauchi een en ander ongedaan zou maken. Deze antwoordde dat hij de hem toegeschreven daden niet verricht had en dat het militair bestuur over Java nog functioneerde. 


\section{Andere onafhankelijkheidsbewegingen binnen het Britse gezagsgebied}

Van de onder bevel van Mountbatten staande Britse militairen was een klein deel uit Groot-Brittannië afkomstig en de overgrote meerderheid uit India. $\mathrm{Nu}$ was in India tijdens de oorlog een scherp conflict uitgebroken tussen de nationalistische Congres-partij en de Britse autoriteiten. De Britse regering had zich in 1942 bereid verklaard na de oorlog stappen te nemen voor het verlenen van onafhankelijkheid aan India, mits de Congres-partij zich achter de Britse oorlogsinspanning zou scharen en mits zij ermee zou instemmen dat delen van het land die voornamelijk door moslims bewoond werden zich van India zouden mogen afscheiden. De Congres-partij had dit verworpen en had geëist dat de Britten het land onmiddellijk zouden verlaten; pas daarna zou een onafhankelijk India zich in de oorlog achter Groot-Brittannië kunnen scharen. $\mathrm{Zij}$ had deze eis met een scherpe massa-actie kracht bijgezet. Hierop had het Britse bestuur alle leidende figuren van de Congres-partij gevangen genomen, onder wie Gandhi en Nehru; zij bleven tot het eind van de oorlog geïnterneerd. Deze politieke situatie in India was van belang nu Mountbatten's strijdkrachten voor een groot deel uit Indiërs bestonden, want hij kreeg binnen het SEAC-gebied zowel in Indonesië als elders met onafhankelijkheidsbewegingen te maken.

In Birma had een opstandelingenleger onder de nationalistische leider Aung San in 1942 de Japanse strijdkrachten gesteund bij hun inval in het land. Japan had in het volgende jaar een formeel onafhankelijke staat Birma gesticht en Aung San was daarin minister van defensie en commandant van het nationale leger geworden. In maart 1945 was hij met dit leger naar de Britten overgelopen toen die bezig waren de Japanners uit Birma te verdrijven, maar hij bleef zich inzetten voor onafhankelijkheid.

Wat de Franse kolonie Indochina betreft, had de communistische leider Ho Chi Minh al in 1941 een bond voor de onafhankelijkheid van Vietnam opgericht, de Vietminh. Deze beweging was in 1943 een guerrilla begonnen tegen de Japanse strijdkrachten in de kolonie, die toen nog onder Frans bestuur stond. In maart 1945 had Japan dit bestuur afgezet, de Fransen geïnterneerd en Indochina onder Japans militair bestuur geplaatst, maar het slaagde er niet in de guerrillabeweging terug te dringen. Toen Japan capituleerde beheerste de Vietminh al een groot deel van het noorden van Vietnam; daarna nam zij ook in delen van het zuiden de macht over. Op 18 augustus vormde zij een eigen regering in Hanoi en op 2 september riep Ho Chi Minh daar een onafhankelijke ‘Democratische Republiek Vietnam' uit. 


\section{Geleidelijke consolidering van het Republikeinse gezag op Java}

De PPKI, de voorbereidingscommissie die de grondwet van de Republiek Indonesië had uitgevaardigd en de president en de vice-president had gekozen, kwam van 18 tot 27 augustus vrijwel dagelijks bijeen. In een groot aantal vaak gedetailleerde besluiten legde zij de grondslagen voor de nieuwe staat. Zij begon ook met de uitgave van een staatscourant, de Berita Republik Indonesia.

De PPKI kwam overeen dat ter ondersteuning van de Republiek overal in Indonesië nationale comités gevormd zouden worden die de formele bestuursorganen op regionaal en lokaal niveau zouden bijstaan bij de vervulling van hun taken. Zelf zou de PPKI in functie blijven tot aan de oprichting van het centrale nationale comité dat de president zou bijstaan. Dit centrale comité zou later plaats maken voor een gekozen volksvertegenwoordiging.

De PPKI stelde de territoriale indeling van de Republiek vast: er werden acht grote provincies gevormd: West-Java, Midden-Java, Oost-Java, Sumatra, Borneo, Celebes, de Molukken (met inbegrip van westelijk Nieuw-Guinea) en de kleine Soenda-eilanden. De provincies zouden worden bestuurd door gouverneurs; binnen de provincies bleef de bestaande bestuursindeling gehandhaafd. Verder bepaalde de PPKI over welke ministeriële departementen de centrale regering zou beschikken; op aandrang van haar christelijke leden besloot zij dat er geen departement voor godsdienstzaken zou komen.

De PPKI stemde in met de ontbinding van de Peta- en Heiho-eenheden. De belangrijkste pleitbezorger hiervan was Iskandar Dinata, die nauwe banden met de Japanse legerleiding onderhield en betoogde dat de geallieerden deze eenheden als franc-tireurs zouden behandelen. Maar terwijl men erkende dat de Republiek nu nog geen strijdmacht ter verdediging tegen een externe vijand nodig had, meende men dat zij ter verzekering van de interne veiligheid toch over een eigen machtsapparaat zou moeten beschikken naast de bestaande politie. Daartoe richtte de commissie een nieuw korps op onder de naam Badan Keamanan Rakjat (BKR, Volksveiligheidskorps).

Op voorstel van Soekarno besloot de PPKI tot de oprichting van een eenheidspartij die de Republiek politiek zou moeten ondersteunen. Deze organisatie kwam grotendeels overeen met de al in juli gevormde Gerakan Rakjat Baroe, maar kreeg een andere naam. Zij ging Partai Nasional Indonesia (PNI) heten, net als de partij die Soekarno in 1927 had opgericht.

Op 23 augustus richtte Soekarno zich in een grote radiorede tot de bevolking van Indonesië (die hij steeds als 'mijn volk' aansprak). Hij riep zijn toehoorders op tot nationale eenheid, drong aan op de vorming van nationale comités en maakte propaganda voor de nieuwe PNI. Ook spoorde hij de voormalige Peta- en Heiho-soldaten aan om tot de BKR toe te treden; hij voegde daaraan toe dat men later een beroep op hen zou doen om strijders te 
worden in het nationale leger van Indonesië.

Intussen vond intensief overleg plaats over de samenstelling van het centrale nationale comité dat in de overgangsbepalingen van de grondwet was voorzien. Dit Komite Nasional Indonesia Poesat (KNIP, Centraal Indonesisch Nationaal Comité) kwam te bestaan uit honderdzevenendertig leden. Naast een meerderheid van bestuursambtenaren en nationalistische politici telde het ruim twintig jongerenvertegenwoordigers en bijna twintig moslimleiders. Verder bevonden zich ook enige christenen onder de leden, onder wie de politieke leider van de Indonesische katholieken, het vroegere Volksraadslid Kasimo. Een belangrijk punt was dat men in het KNIP ook de twee voornaamste politici opnam die niet met de Japanse bezetters hadden samengewerkt, namelijk Sjahrir en Amir Sjarifoeddin. Op 27 augustus keurde de PPKI deze samenstelling goed en hief zij zichzelf op. Intussen waren vijf van haar leden aangesteld als gouverneurs van de provincies buiten Java. Op 29 en 30 augustus hield het KNIP zijn eerste zitting; daarbij bekrachtigde het de door de PPKI aangenomen grondwet. Overigens woonde noch Sjahrir noch Sjarifoeddin deze zitting bij.

Van 30 augustus tot 2 september vond in Djakarta een conferentie plaats van Indonesische bestuursambtenaren uit heel Java en Madoera. Met steun van Soetardjo en Wiranatakoesoema, zelf vooraanstaande leden van de ambtsaristocratie en oud-leden van de Volksraad, beijverde Soekarno zich om de bestuurders voor het nieuwe bewind te winnen. Hij verzekerde hun dat de leiders van de Republiek de status van het bestuurscorps niet wilden aantasten en verklaarde dat de nationale comités zich niet op het terrein van het bestuur zouden begeven. De conferentiedeelnemers legden een gezamenlijke gelofte van trouw aan de Republiek af. In de eerste weken van september schaarden ook de vorsten van de Midden-Javaanse vorstenlanden zich achter de Republiek.

$\mathrm{Na}$ afloop van de conferentie van de bestuursambtenaren deed Soekarno een aantal belangrijke benoemingen. Wat het bestuursniveau beneden de provincies betreft, had het Japanse bewind op Java tot nu toe slechts in drie residenties Indonesiërs tot resident benoemd; alle andere residenties werden bestuurd door een Japanse resident met een Indonesische assistent-resident. Soekarno stelde deze drie Indonesische residenten nu aan als gouverneurs van de Javaanse provincies (Soetardjo werd daarbij gouverneur van West-Java) en bevorderde alle assistent-residenten tot resident. Voor het Indonesische bestuurscorps betekende dit een aanzienlijke statusverhoging, omdat onder het koloniale bewind alleen Nederlanders de functies van gouverneur en resident hadden kunnen bekleden.

Inmiddels hadden de Republikeinse leiders stappen ondernomen tot vorming van de beoogde eenheidspartij PNI. Al snel brak echter het besef door dat de oprichting van deze organisatie een misgreep was. De partij zou een slechte indruk maken op de westerse democratische landen, die haar zou- 
den vergelijken met de eenheidspartijen onder de totalitaire regimes van Duitsland en Italië. Bovendien was het onduidelijk hoe deze partij zich zou verhouden tot het KNIP en tot de regionale en plaatselijke nationale comités. Op 31 augustus besloot Soekarno de opbouw van de PNI-organisatie te staken en alle activiteiten op de nationale comités te concentreren. Kort daarvoor was ook de Djawa Hokokai formeel opgeheven. Op plaatselijk niveau namen veel voormalige Hokokai-voormannen nu zitting in de nationale comités.

Omdat het Japanse bestuur de vorming van een onafhankelijke Republiek eigenlijk niet mocht toestaan, gingen Soekarno en Hatta behoedzaam te werk teneinde dat bestuur niet tot een reactie te dwingen. Daarom hadden zij de Republiek nog niet meteen van een eigen strijdmacht willen voorzien en hadden zij in de beginfase nog geen kabinet gevormd. Men verwachtte toen nog algemeen dat de geallieerden het bestuur eind augustus van de Japanners zouden overnemen. $\mathrm{Nu}$ dit langer bleek te gaan duren, benoemde Soekarno op 4 september zijn eerste kabinet. Het telde negen vakministers, onder wie Soebardjo (buitenlandse zaken), Wiranatakoesoema (binnenlandse zaken), Soepomo (justitie), Dewantoro (onderwijs), Amir Sjarifoeddin (voorlichting), Iwa Koesoema Soemantri (sociale zaken) en Abikoesno (verkeer en openbare werken), en vijf ministers zonder portefeuille, onder wie Iskandar Dinata en de Menadonese christen A.A. Maramis. De post van minister van defensie bleef voorlopig onvervuld.

Onder deze ministers was Amir Sjarifoeddin de enige die niet nauw met de Japanse bezettingsmacht had samengewerkt. (Hij was zelfs wegens antiJapanse activiteiten ter dood veroordeeld, maar zijn vonnis was na tussenkomst van Hatta en Soekarno veranderd in levenslange gevangenisstraf. Ten tijde van zijn benoeming was hij nog niet teruggekeerd uit Oost-Java waar hij tot eind augustus gevangen had gezeten.) Alle andere ministers hadden belangrijke functies in Japanse dienst vervuld; de meesten waren ten tijde van hun benoeming hetzij hoofd hetzij adviseur van één van de departementen van het militaire bestuur. Daardoor ontstond een dubbelzinnige situatie: aan Japanse kant kon men de ambtsuitoefening door deze functionarissen opvatten als nog steeds verricht namens het Japanse bestuur, terwijl men die aan Indonesische kant zag als verricht namens de Republiek. Soekarno beoogde deze onduidelijkheid bewust en sprak openlijk van een 'dubbelbestuur'. Het stelde de Republiek in staat op Java het bestuur onopvallend van de Japanse bezettingsmacht over te nemen.

In de eerstvolgende weken ontving de Republikeinse regering loyaliteitsbetuigingen uit allerlei delen van het land. Daar kwam nog bij dat de Japanners die bij de verschillende diensten en bedrijven werkten sinds de capitulatie op hun repatriëring wachtten; zij hadden daarom weinig animo meer om op Java de dienst uit te maken en droegen op grote schaal hun werk aan Indonesiërs over. Indonesiërs bezetten hier dan ook eind september 1945 vrijwel volledig 
de plaats die de Nederlanders onder het koloniale bestel hadden ingenomen.

Anders echter dan Soekarno aan het traditionele bestuurscorps had toegezegd, oefenden de Republikeinse nationale comités wel degelijk bestuursfuncties uit. Deze regionale en lokale comités vormden een belangrijk instrument van de nationalistische revolutie, ze waren bedoeld om zo snel mogelijk in het hele land geweldloos de leiding over te nemen. Weliswaar had de PPKI slechts verklaard dat de comités de formele bestuursorganen zouden 'bijstaan', maar op veel plaatsen ontwikkelde de verhouding tussen de comités en de formele organen zich aldus dat de comités het beleid bepaalden en dat de organen het beleid uitvoerden. De positie van de regionale comités werd verder versterkt doordat ze de supervisie kregen over het veiligheidskorps BKR.

Dat het bestuur op Java in de loop van september steeds meer namens de Republiek uitgeoefend werd, betekende niet dat de Republikeinse leiders de macht daar stevig in handen hadden. Integendeel, de nationalistische revolutie ging al spoedig in een gewelddadige fase over waar deze leiders weinig greep op hadden (zie onder meer pp. 399-403 en 411-8).

\section{Verspreide steun voor de Republiek buiten Java}

Het nieuws over de uitroeping van de onafhankelijkheid en de stichting van de Republiek werd buiten Java op sommige plaatsen in de archipel snel bekend, maar drong tot andere plaatsen pas weken later door. Ook de reacties op dit nieuws vertoonden geen vast patroon. Een en ander was niet alleen te wijten aan de enorme uitgestrektheid van het gebied, maar ook aan de slechte staat van de verbindingen in deze eerste periode na de Japanse capitulatie. Verder stond Sumatra onder bestuur van een ander Japans leger dan Java en ressorteerde de rest van de archipel onder de Japanse marine. Bovendien hadden deze Japanse autoriteiten daar tijdens de oorlog nauwelijks ruimte gelaten voor nationalistische propaganda, terwijl het bestuur op Java daartoe sinds 1944 juist wel gelegenheid geboden had. Wat Sumatra betreft, bevond het merendeel van de hier geboren prominente nationalisten zich trouwens niet op dit eiland maar op Java, zoals Agoes Salim, Hatta, Sjahrir, Amir Sjarifoeddin, Yamin, Chairoel Saleh, Adam Malik en B.M. Diah.

In het algemeen duurde het tot september voordat men op verscheidene plaatsen buiten Java steun aan de Republiek betuigde, vooral door het hijsen van rood-witte vlaggen, het houden van demonstraties en het oprichten van nationale comités. Deze steunbetuigingen hoefden niet te betekenen dat de hele inheemse bevolking zich achter de Republiek schaarde. Degenen die daar negatief tegenover stonden demonstreerden nu eenmaal gewoonlijk niet. Dit betrof bijvoorbeeld Indonesiërs die volledige verbreking van de banden met Nederland niet in het belang van hun land achtten, of die van een Republikeins 
regime gevaar voor hun eigen positie verwachtten, of die vreesden dat zo'n regime tot Javaanse overheersing zou leiden.

Tot gouverneur van Sumatra had de Republiek de Atjeher Mohammed Hassan benoemd, een in Nederland opgeleide jurist. Hij kwam eind augustus in Medan aan, maar zijn pogingen om voor die provincie een nationaal comité samen te stellen stuitten aanvankelijk af op aarzeling onder de benaderde personen. Pas nadat zo'n comité eind september alsnog tot stand was gekomen begon Hassan formeel als gouverneur op te treden, onder meer door het aanstellen van residenten en burgemeesters. Intussen bestond toen in het gebied van Padang (Minangkabau) al een krachtig nationaal comité dat zelf een resident voor dit gebied had aangewezen. Ook in het gebied van Palembang functioneerde al een Republikeins bestuur; resident was hier de arts A.K. Gani, voor de oorlog één van de leiders van de nationalistische partij Gerindo.

De voor Borneo benoemde gouverneur slaagde er niet in zijn provincie te bereiken. Niettemin ontplooide zich op dit eiland het begin van een Republikeinse bestuursorganisatie in de vorm van twee door residenten geleide comités, één in Pontianak voor West-Borneo en één in Bandjermasin voor Zuid- en Oost-Borneo.

Tot gouverneur van Celebes was de Menadonese politicus Ratoelangie benoemd, die voor de oorlog lid van de Volksraad geweest was. In verschillende delen van het eiland en vooral in Zuid-Celebes kreeg de Republiek aanzienlijke steun, zowel onder de bevolking als onder de plaatselijke bestuurders. Hiertoe behoorden ook de zelfbestuurders van enige in ZuidCelebes gelegen vorstendommen die pas in het begin van de twintigste eeuw onder Nederlands gezag gebracht waren. Ratoelangie arriveerde eind augustus in Makassar, maar kwam niet toe aan de vorming van een effectieve Republikeinse bestuursorganisatie, onder meer omdat hij daartoe geen gelegenheid kreeg van het Australische leger dat al in september de macht in Makassar overnam.

De voor de kleine Soenda-eilanden benoemde gouverneur, Ketoet Poedja, begaf zich naar Bali, maar verwierf buiten dat eiland geen daadwerkelijk gezag. Op de Molukken kreeg de Republiek vrijwel alleen enige steun onder de moslims (die daar een minderheid vormden). Weliswaar wilde een nationalistisch bestuurshoofd op Ambon dit eiland tot Republikeins gebied uitroepen, maar onder druk van christelijke Ambonezen zag hij hiervan af. De voor de Molukken benoemde gouverneur, de Ambonese arts en politicus Latuharhary, kon zijn ambtsgebied niet bereiken. 


\section{De Nederlandse krijgsgevangenen en geïnterneerden}

Toen Japan in augustus 1945 capituleerde, hield het in kampen en gevangenissen meer dan 120.000 Nederlanders vast, ruim 85.000 burger-geïnterneerden en bijna 35.000 krijgsgevangenen. Van de burger-geïnterneerden bevond de overgrote meerderheid zich op Java. De meeste mannen en jongens zaten in en nabij Bandoeng vast, de meeste vrouwen en kleine kinderen in en nabij Djakarta, Semarang en Ambarawa. Buiten Java bevatten ook Sumatra en Celebes grote kampen voor burger-geïnterneerden. In tegenstelling tot de burger-geïnterneerden waren de Nederlandse krijgsgevangenen ook buiten Indonesië als arbeidskrachten ingezet; op het eind van de oorlog waren de meesten verspreid geraakt over Sumatra, Singapore, Thailand, Indochina, Mandsjoerije en Japan. Overigens bestond de meerderheid van de krijgsgevangenen niet uit beroepsmilitairen maar uit Nederlandse burgers die eind 1941 voor krijgsdienst opgeroepen waren. Van de geïnterneerde en krijgsgevangen Nederlanders was slechts een gering deel van Indonesisch-Europese afkomst; het hoogste percentage Indische Nederlanders bevond zich onder de krijgsgevangen beroepsmilitairen.

Op het eind van de oorlog waren de meeste krijgsgevangenen en burgergeïnterneerden er slecht aan toe. De krijgsgevangenen waren al sinds het begin van hun gevangenschap hardvochtig behandeld, de burgers vooral sinds hun kampen in 1944 onder rechtstreeks bestuur van het leger waren komen te staan. Alle kampen waren overvol; de voeding was steeds minder geworden; uitputting, ondervoeding en ziekte hadden steeds meer slachtoffers gemaakt. Een vijfde van de Nederlandse krijgsgevangenen en een zesde van de burger-geïnterneerden had de oorlog niet overleefd.

$\mathrm{Na}$ de capitulatie van Japan richtte het South-East Asia Command een eigen organisatie op voor het opvangen en evacueren van de geallieerde krijgsgevangenen en burger-geïnterneerden binnen zijn gebied, de RAPWI (Recovery of Allied Prisoners of War and Internees). Met het oog op een snelle hulpverlening stelde de RAPWI enige tientallen teams samen, bestaande uit officieren en andere militairen, die men per parachute samen met zendapparatuur bij de kampen zou kunnen neerlaten. Toen Mountbatten op 27 augustus in Rangoon een voorlopig akkoord sloot met de vertegenwoordigers van de Japanse strijdkrachten binnen zijn gezagsgebied, droeg hij de Japanse commandanten ook op voor de bescherming van de geallieerde krijgsgevangenen en geïnterneerden te zorgen en daarbij de aanwijzingen van de RAPWI op te volgen.

Van eind augustus af wierpen geallieerde viegtuigen bij verschillende kampen hulpgoederen af. Ook verspreidden ze strooibiljetten waarin de gevangenen en geïnterneerden onder meer het consigne kregen voorlopig in de kampen te blijven. Intussen hadden tientallen hun kamp al op goed geluk verlaten 
om naar huis terug te keren of om naar gezinsleden te zoeken. Ook nadat het geallieerde consigne bekend geworden was gingen verscheidenen toch uit de kampen weg. In deze eerste naoorlogse weken ontmoetten de meeste uit de kampen komende blanken weinig of geen vijandigheid van de kant van de Indonesische bevolking. Zij konden ongehinderd in treinen reizen en in hotels logeren; bij hen die hun oude woning weer wisten te betrekken trad vroeger huispersoneel soms opnieuw in dienst. Daarentegen gingen ontwikkelde Indonesiërs dikwijls de contacten met Nederlanders uit de weg.

In het algemeen wisten de krijgsgevangenen en geïnterneerden bijzonder weinig van de politieke ontwikkelingen die zich tijdens de Japanse bezetting op Java en Sumatra hadden voltrokken. De meesten verwachtten dat men zonder ernstige problemen tot de vooroorlogse situatie kon terugkeren. Enige honderden vooraanstaande Nederlanders, die in een kamp in Tjimahi bij Bandoeng verbleven, hadden zich er al op voorbereid het gezag van de Japanse autoriteiten over te nemen en sleutelposities te bezetten bij het bestuur en de politie (functies die nu grotendeels door Indonesiërs vervuld werden). Zij werden geleid door de vice-voorzitter van de Raad van Indië, H.J. Spit, die binnen het Nederlands-Indische staatsbestel de hoogste verantwoordelijkheid droeg bij afwezigheid van de gouverneur-generaal en de luitenant-gouverneur-generaal.

$\mathrm{Na}$ de Japanse capitulatie probeerde Spit contact te krijgen met generaal Nagano, de Japanse opperbevelhebber, maar hij kreeg daar geen gelegenheid toe. Wel werd hij samen met anderen ontboden door generaal Yamamoto, het hoofd van het Japanse bestuur, voor besprekingen over de positie van de geïnterneerden en krijgsgevangenen op Java. Aan die besprekingen namen niet alleen vertegenwoordigers van de Nederlandse geïnterneerden en krijgsgevangenen deel maar ook van de Amerikaanse, Australische en Britse krijgsgevangenen. Eén van hen was luitenant-kolonel Laurens Van der Post, de tot de Britse Inlichtingendienst behorende Zuid-Afrikaan die in 1942 door de Japanners gevangen genomen was in het West-Javaanse bergland waar hij zich met een aantal geallieerde militairen had teruggetrokken (zie p. 276). Van der Post, die naast Engels en Nederlands ook enig Japans en Indonesisch kende, had bij de Japanse autoriteiten een bevoorrechte positie gekregen.

De voor de hulpverlening op Java en Sumatra samengestelde RAPWIteams bestonden zowel uit Britse als Nederlandse militairen. Eind augustus en begin september werden de eerste teams op Sumatra ingezet. Gelet op de toenemende politieke spanning achtte de RAPWI de situatie van de krijgsgevangenen en geïnterneerden in de bestaande kampen op Sumatra riskant. Ter verhoging van hun veiligheid en ter vereenvoudiging van de hulpverlening bracht zij hen allen op drie plaatsen bijeen, namelijk in Medan, Padang en Palembang.

Op Java arriveerde het eerste RAPWI-team op 8 september, per parachute 
op het vliegveld van Djakarta. Het team telde zeven leden en werd geleid door een Britse majoor en een Nederlandse luitenant. Deze twee officieren brachten een bezoek aan generaal Nagano en konden vervolgens deelnemen aan een bespreking van het Japanse bestuur met vertegenwoordigers van de krijgsgevangenen en geïnterneerden, onder wie Spit en Van der Post. De RAPWI-teamleider deelde mee dat een met hulpgoederen beladen Britse kruiser, de 'Cumberland', uit Ceylon vertrokken was en omstreeks 15 september in Batavia zou aankomen, maar dat het overigens nog wel weken zou duren voordat Java door geallieerde troepen bezet kon worden. In de volgende dagen bezochten de RAPWI-officieren bijna alle kampen op Java. Met medewerking van zowel Japanse als Indonesische autoriteiten zetten zij een grote hulporganisatie op. Tegelijk constateerden zij bij de ontwikkelde Indonesiërs een weinig welwillende houding tegenover het Nederlandse gezag. De Britse teamleider adviseerde daarom de eerste fase van de bezetting voornamelijk door Britse strijdkrachten te laten uitvoeren.

\section{Tegenstellingen tussen de Republikeinse leiders en de militante jongeren}

Bij de vestiging van het Republikeinse gezag speelden militante jongeren een belangrijke rol. Het was vooral aan hen te danken dat het bericht van de onafhankelijkheidsverklaring tot de bevolking doordrong en dat aan steeds meer openbare gebouwen de rood-witte nationale vlag kwam te hangen. Niettemin bleef er wrijving bestaan tussen hun leiders en de voormannen van de Republiek. Op de dag na de proclamatie hadden jongerenvertegenwoordigers geweigerd zitting te nemen in de PPKI. Een dag later had Soekarno een aanvaring met een aantal jongerenleiders gehad tijdens een bijeenkomst in de medische hogeschool. Onder meer hadden die zich gekeerd tegen de ontbinding van Peta en Heiho, omdat die formaties naar hun mening juist de basis van een nationaal leger moesten vormen. Volgens Adam Malik was een staat zonder leger geen echte staat. Soekarno en de zijnen stelden de oprichting van een nationaal leger welbewust uit omdat zij conflicten met de bezettingsmacht wilden vermijden; zij zagen niet Japan maar Nederland als de tegenstander waartegen de Republiek zich te weer moest stellen. Daarentegen zochten de militante jongeren welbewust naar confrontaties met de bezettingsmacht, omdat zij vonden dat men de macht op de Japanners moest veroveren in plaats van haar vreedzaam over te nemen.

Terwijl de PPKI voorzichtig bouwde aan de nieuwe staat, werkten de radicale jongerenleiders aan de opbouw van een eigen machtscentrum. Onder leiding van Wikana, Chairoel Saleh, Soekarni en Adam Malik richtten zij op 1 september een nieuwe organisatie op, de Angkatan Pemoeda Indonesia (API, Generatie van de Indonesische Jongeren). Deze API vestigde haar hoofdkwar- 
tier in het gebouw van de Asrama Angkatan Baroe, een tijdens de bezetting door de Japanse propagandadienst opgericht opleidingsinstituut (zie p. 307), op het adres Menteng 31. De leiding van de nieuwe organisatie berustte bij een actiecomité dat een strijdlustig manifest publiceerde. Daarin stond onder meer dat Japan geen recht meer had om gezag uit te oefenen over Indonesisch grondgebied, dat het volk zich meester moest maken van de wapens van de Japanners en dat het volk de Japanners uit alle kantoren en bedrijven moest verjagen en zelf het beheer daarvan moest overnemen.

Het laatste werd overigens vergemakkelijkt doordat veel Japanners zelf al geneigd waren zich uit dit beheer terug te trekken. Op aansporing van het actiecomité nam Indonesisch personeel begin september namens de Republiek het beheer over van de tram- en spoorwegen in het gebied van Djakarta. Kort daarna verwijderde men de Japanners ook uit andere openbare nutsbedrijven en uit het radiostation. Hetzelfde gebeurde bij het dagblad Asia Raya; het personeel doopte deze krant vervolgens om in Merdeka (dat zowel 'Vrij' als 'Vrijheid' betekent) en maakte B.M. Diah tot hoofdredacteur.

'Pemoeda' werd in deze tijd de standaard-aanduiding voor militante jongeren. Zij spraken elkaar vaak aan als 'boeng' (broer, kameraad) en gebruikten de leuze 'merdeka!' als onderlinge groet. Vrijwel alle pemoeda's hadden tijdens de Japanse bezetting enigerlei vorm van militaire training en indoctrinatie ondergaan. Velen hadden toen deel uitgemaakt van militaire of paramilitaire organisaties zoals de Peta, de Heiho, de Barisan Pelopor, de Hizboellah, het jeugdkorps Seinendan en de hulppolitie Keibodan. Met fanatisme zetten zij zich in voor de nieuwe onafhankelijkheid. Naast voorlichting en overreding behoorde ook intimidatie tot de in hun kring toegepaste actiemethodes. Zo kwam het veelvuldig voor dat pemoeda's met geweld dreigden om het uitsteken van de rood-witte vlag af te dwingen. In Djakarta verspreidden zij in felle taal vervatte anti-Nederlandse affiches.

Midden september leek het moment te naderen dat het Japanse bestuur het gezag over Java aan de geallieerden zou overdragen; de eerste Britse en Nederlandse vertegenwoordigers daarvan arriveerden al in Djakarta (zie p. 381). De jongerenleiders besloten nu een massale steunbetoging voor de Republiek te organiseren. Het nationale comité van de stad Djakarta kondigde aan dat de demonstratie op 19 september zou plaatsvinden op het Ikada-terrein, een binnen het vroegere Koningsplein gelegen sportveld waar Soekarno tijdens de bezetting herhaaldelijk massabijeenkomsten had toegesproken. De Japanse opperbevelhebber op Java, generaal Nagano, reageerde met een proclamatie waarin hij sympathie betuigde voor het Indonesische onafhankelijkheidsstreven maar de bevolking streng verbood een betoging te houden of wapens te dragen. Niettemin stroomden op 19 september tienduizenden mensen naar het centrum van de stad; sommigen van hen hadden wapens zoals bamboesperen bij zich. Een deel van de demonstranten werd 
met vrachtauto's uit omliggende plaatsen aangevoerd. Het militaire bestuur stelde pantserwagens en machinegeweren rondom het terrein op, maar hield de menigte niet tegen.

Soekarno en Hatta wilden dat de initiatiefnemers de betoging zouden afgelasten, maar de jongerenleiders gaven hier geen gevolg aan. Toen het Soekarno en Hatta duidelijk werd dat afgelasten niet meer mogelijk was, lichtten zij Nagano hierover in en gingen zij samen met hun ministers naar het Ikadaterrein, waar nu bijna honderdduizend demonstranten bijeen waren. In een korte rede vroeg Soekarno hen om vertrouwen te hebben in de regering van de Republiek en om rustig naar huis te gaan. De menigte ging daarop ordelijk en vreedzaam uiteen. Het gevaar van een bloedige botsing tussen de betogers en de Japanse militairen was bezworen.

Voorzover de gebeurtenissen van 19 september een krachtmeting tussen de jongerenleiders en Soekarno inhielden, waren er geen verliezers. De jongerenleiders hadden getoond in staat te zijn op korte termijn een grotere mensenmassa bijeen te brengen dan ooit aan een betoging in Indonesië had deelgenomen. Soekarno had laten zien dat zijn gezag bij de bevolking onverminderd was. De betogers zelf hadden blijk gegeven van overweldigende steun voor de Republiek. Een en ander maakte niet alleen indruk op de Japanse bezettingsmacht, maar ook op enige Britse vertegenwoordigers die de betoging van nabij hadden kunnen gadeslaan. Daarentegen drong de betekenis van het gebeurde niet tot de Nederlandse autoriteiten door.

\section{Terugkeer van Tan Malaka in de Indonesische politiek}

Enige tijd na de totstandkoming van de Republiek keerde een legendarische revolutionair terug in de arena van de Indonesische politiek: Tan Malaka (zie pp. 184, 188 en 199-202). Eens was hij voorzitter geweest van de Indonesische communistische partij, maar in 1922 had het gouvernement hem uit Indonesië verbannen. Na een verblijf in Nederland was hij eerst naar Moskou gegaan en had hij vervolgens als Komintern-agent voor Zuidoost-Azië afwisselend in China, de Filippijnen en Achter-Indië verbleven. Al in 1925 had hij een brochure gepubliceerd onder de titel Naar de 'Republiek-Indonesia'. Twee jaar later had hij met Moskou gebroken, maar daarna was hij als onafhankelijk communist politiek actief gebleven en had hij, rondtrekkend in ballingschap, niettemin binnen Indonesië een bescheiden aanhang verworven. Ook jongerenleiders als Adam Malik en Soekarni hadden tot die kring behoord. Sinds het midden van de jaren dertig was echter niets meer van hem vernomen. Niemand wist dat Tan Malaka in 1942, nadat Zuidoost-Azië in Japanse handen was gevallen, clandestien Indonesië had weten te bereiken en sindsdien onder een schuilnaam in West-Java had gewoond. Eind augustus 1945 maakte 
hij zich in Djakarta bekend aan Soebardjo die hij nog van vroeger kende. Begin september bezocht hij Soekarno.

Soekarno had respect voor Tan Malaka, in feite de enige Indonesische nationalist van eenzelfde politiek gewicht als Hatta en hijzelf, nu Soetomo, Thamrin en Tjipto Mangoenkoesoemo niet meer leefden. Tijdens hun eerste ontmoeting spraken hij en Tan Malaka onder meer over de gevaren die dreigden als Nederland en zijn bondgenoten straks zouden proberen met geweld aan de Republiek een eind te maken. Ook de vrijheid en het leven van Soekarno en Hatta zelf stonden dan op het spel. In Nederlandse radiouitzendingen uit Australië waren al zware dreigementen geuit tegen degenen die met de Japanse bezetters geheuld hadden. Soekarno wilde daarom afspreken dat Tan Malaka zijn plaats zou innemen als hij en Hatta uitgeschakeld zouden worden. Hatta zelf stemde echter niet met deze afspraak in. Uiteindelijk werd men het eens over een viermanschap als opvolgers, namelijk Tan Malaka, Sjahrir, Iwa Koesoema Soemantri en Wongsonegoro (een vooraanstaand lid van de ambtsaristocratie). Hierop ondertekenden Soekarno en Hatta een politiek testament waarin zij verklaarden dat dit viertal de leiding van de strijd om onafhankelijkheid zou overnemen wanneer zij zelf niet meer in staat zouden zijn die strijd te leiden. Het testament werd niet gepubliceerd. Gedurende het najaar voerde Tan Malaka tal van gesprekken met andere politici en reisde hij veel door Java, maar trad hij nog niet in het openbaar op.

\section{Brits-Nederlands vlootbezoek aan Batavia}

Op zaterdag 15 september ging de Britse kruiser 'Cumberland' voor anker op de rede van Batavia, kort daarna gevolgd door de Nederlandse kruiser 'Tromp' en enige vrachtschepen. Dit eskader kwam van Ceylon via Singapore en stond onder bevel van de Britse schout-bij-nacht Patterson, aan wie Van der Plas als adviseur was toegevoegd. Eén van de doeleinden van dit vlootbezoek was het leggen van rechtstreeks contact tussen het South-East Asia Command en het Japanse militaire bestuur op Java ter voorbereiding van de landing van de eerste geallieerde troepen. Aan boord van de 'Cumberland' bevond zich onder meer een centrale RAPWI-staf voor Java en een beperkt contingent militairen ter bewaking van de gebouwen die de RAPWI in gebruik zou nemen. Verder vervoerden de schepen hulpgoederen voor de geallieerde krijgsgevangenen en burger-geïnterneerden.

Al op de dag van aankomst ontving Patterson aan boord van zijn schip het hoofd van het Japanse bestuur op Java, generaal Yamamoto; ook in de volgende dagen voerden hij en zijn medewerkers besprekingen met Yamamoto en diens staf. Daarentegen had Patterson geen ontmoeting met de Japanse opperbevelhebber, generaal Nagano. Het Japanse bestuur verstrekte onder meer 
gegevens over de kampen en de aantallen krijgsgevangenen en geïnterneerden, over de maatregelen die het genomen had uit hoofde van de capitulatie en over de binnenlandse politieke situatie. Patterson gaf dit bestuur opdracht tot ontwapening van alle Japanse militairen die niet voor het bewaren van orde en rust nodig waren en tot strikte bewaking van de wapendepots. Over de politieke situatie liet hij zich ook voorlichten door al op Java aanwezige RAPWI-officieren en door enige Britse officieren die zelf op Java krijgsgevangen waren geweest, onder wie de Zuid-Afrikaan Laurens Van der Post.

Het geallieerde vlootbezoek had een belangrijk nevengevolg. Van nu af aan kwamen er ook westerse journalisten op Java; een deel van hen behoorde trouwens tot de opvarenden van de 'Cumberland'. Naar aanleiding hiervan schreef Van Mook spijtig dat 'oorlogscorrespondenten [...] geheel valsch beeld kunnen krijgen en zonder censuur de wereld inseinen'. Tot dusver hadden de Nederlandse autoriteiten het voor het publiek in Nederland verborgen gehouden dat zich in Indonesië een onafhankelijke staat gepresenteerd had, maar dit viel nu niet langer vol te houden. Het eerste nieuws hierover verscheen in de Nederlandse avondbladen van 17 september in de vorm van een bericht van een Brits persbureau, dat meldde dat de leider van de Indonesische nationalisten, Soekarno, op 17 augustus op Java een Indonesische Republiek had uitgeroepen. Berichten van journalisten, verspreid via radio en drukpers, beïnvloedden ook in de volgende maanden de politieke ontwikkelingen met betrekking tot Indonesië. Meer dan eens werd daarbij het geven van persconferenties en interviews zelf een vorm van politiek bedrijven.

Een tweede gevolg van het vlootbezoek was dat enige naaste medewerkers van Van Mook nu zelf met de situatie op Java kennis konden maken. Behalve Van der Plas, lid van de Raad van Indië en hoofd van het departement van binnenlandse bestuur, betrof dit onder meer de deputy chief commanding officer NICA, kolonel Abdoelkadir Widjojoatmodjo, die op 16 september per vliegtuig aankwam. Zij troffen een Batavia aan vol rood-witte vlaggen en vol Engelstalige opschriften over het recht op vrijheid van de Indonesische natie. Van der Plas sprak in Batavia met tal van Nederlandse en Indonesische bekenden; Abdoelkadir reisde ook naar Soerabaja en Semarang. Beiden vonden de politieke toestand veel ongunstiger dan zij verwacht hadden. Het Nederlands-Indisch gouvernement had de invloed van de tijdens de Japanse bezetting gevoerde anti-Nederlandse propaganda ernstig onderschat. De Indonesische bevolking haatte weliswaar de Japanners, maar ook haat tegen de Nederlanders bleek onder die bevolking wijd verbreid te zijn, vooral onder de jeugd. Gewapende jongeren gedroegen zich agressief en vielen soms zelfs Japanners aan. Soekarno's Republiek werd gesteund door vrijwel alle Indonesische bestuursambtenaren. Veel vooraanstaande Indonesiërs hadden tijdens de bezetting openbare functies bekleed.

Het werd Van der Plas en Abdoelkadir nu duidelijk dat het onverstandig 
was geweest dat zij in radiouitzendingen uit Australië dreigende taal hadden gebruikt tegen allen die met het bezettingsregime gecollaboreerd hadden. Abdoelkadir adviseerde geen aanvallen meer via de radio op de Republiek of op Soekarno te doen. Ook meende hij dat men de rood-witte vlag beter niet kon verbieden. Een gesprek met zijn broers in Semarang had hem geleerd hoezeer rood-wit het symbool van de nationale identiteit geworden was, ook voor Indonesiërs die voor samenwerking met Nederland te vinden waren. Van der Plas verwachtte dat Nederland de zaken toch nog in de hand zou kunnen krijgen mits aan bepaalde voorwaarden werd voldaan. Onder meer zou de bezetting spoedig moeten plaatsvinden, daaraan zouden naast Britse ook zo veel mogelijk Nederlandse troepen moeten deelnemen, men zou aan de bevolking voldoende voeding en kleding moeten kunnen verstrekken, men zou de gevaarlijkste Republikeinse voormannen onmiddellijk moeten uitschakelen en men zou aan de Indonesiërs perspectief moeten bieden op het dragen van eigen gezag en verantwoordelijkheid.

Mountbatten had Patterson voor diens vertrek naar Batavia op het hart gedrukt, dat het uiterst gevaarlijk zou zijn als Britse troepen in de koloniën van anderen vrijheidsbewegingen zouden gaan onderdrukken, hoe onecht die ook zouden mogen zijn. Anderzijds moest Patterson elke schijn van erkenning van het Soekarno-bewind vermijden; hij deed daarom alleen zaken met Japanse autoriteiten. Daarentegen meenden de RAPWI-officieren hun werk niet te kunnen verrichten zonder contact met functionarissen van de Republiek.

De massale steunbetoging voor de Republiek op 19 september was voor generaal Nagano aanleiding om te bepleiten, dat de geallieerden zich zouden onthouden van drastische stappen tegen het Republikeinse bestuur; hij vreesde dat zulke stappen tot een gewelddadig conflict zouden leiden waarbij de Japanse militairen tussen twee vuren terecht zouden komen. Van der Plas, die de betoging van 19 september alleen maar als een fiasco voor Soekarno beschouwde, wilde hier niet op ingaan. Hij stelde voor SEAC een plan op om bij de geallieerde bezetting van Batavia een eind aan de Republiek te maken. Het Japanse bestuur zou vierentwintig uur voor de geallieerde landing een beperkt aantal Republikeinse voormannen moeten oppakken, volgens een lijst waarover Van der Plas ook met Van der Post overleg gepleegd had. Na de landing zouden de geallieerden terstond alle departementen van het centrale bestuur moeten overnemen. Patterson stemde met het plan in, ervan uitgaande dat niet hijzelf maar de commandant van de landingstroepen verantwoordelijk zou zijn voor de opdracht tot preventieve arrestaties. Overigens drong hij er herhaaldelijk bij Van der Plas op aan, dat Nederland een datum zou noemen waarop Indonesië onafhankelijk zou worden. 


\section{Anti-Nederlandse schepenboycot in Australië}

Het Nederlands-Indisch gouvernement in Australië was al lange tijd bezig de terugkeer van het Nederlandse gezag voor te bereiden. Omdat de bevolking van Indonesië als gevolg van de Japanse bezetting ernstig gebrek leed, wilde men die terugkeer vergezeld doen gaan van hulpverlening op grote schaal. Bovendien zouden de gezagsorganen zelf over bijvoorbeeld transport- en verbindingsmiddelen moeten beschikken. Het gouvernement had dan ook grote voorraden aangeschaft van onder meer textiel, levensmiddelen, medicamenten, kantoor- en schoolbehoeften, drukpersen, radiozenders en vrachtauto's. Naast goederen zou men ook mensen naar Indonesië moeten overbrengen. Dit betrof zowel het gouvernementspersoneel als het militaire personeel dat zich in Australië bevond. Voor al deze transporten beschikte het gouvernement over voldoende scheepsruimte in de vorm van schepen van de Koninklijke Paketvaart Maatschappij (KPM), de rederij die voor de oorlog het verkeer binnen de Indonesische archipel verzorgde. Maar toen de transporten begonnen kwam er van onverwachte kant een kink in de kabel. Eind september besloten de Australische havenarbeiders de Nederlandse schepen te boycotten wegens de Nederlandse weigering om de Republiek Indonesië te erkennen. Deze boycot had een lange voorgeschiedenis.

Al enige tijd was in Australië een kritische houding tegenover Nederland ontstaan. Eén van de aanleidingen hiertoe hield verband met de ontruiming van Boven-Digoel, het interneringskamp in het oerwoud van Nieuw-Guinea waar het Nederlands-Indisch gouvernement zonder vorm van proces honderden Indonesiërs gevangen had gehouden die het als een gevaar voor zijn gezag beschouwde (zie pp. 202-3). Medio 1943 had het gouvernement de inwoners van dit kamp naar Australië overgebracht en daar opnieuw geïnterneerd. Dit leidde tot protesten van het Australische publiek, waarna de Nederlandse autoriteiten onder druk van de Australische regering bijna alle geïnterneerden vrijlieten. Een andere aanleiding betrof een reeks arbeidsconflicten bij de KPM. Deze rederij weigerde lange tijd de lonen van haar Indonesisch personeel op te trekken tot het voor blanken en Chinezen geldende loonpeil. Dit leidde tot verscheidene stakingen, waarbij de Indonesiërs steun kregen van de Australische vakbonden van zeelieden en van havenarbeiders.

De tijdens de oorlog in Australië verblijvende Indonesiërs omvatten naast zeelieden en voormalige politieke gevangenen nog enige andere groepen, waaronder militairen van het KNIL. Binnen al deze groepen nam de antikoloniale gezindheid toe, ook uit ergernis over discriminerend gedrag van in Australië verblijvende Nederlanders. De Indonesische onafhankelijkheidsproclamatie van 17 augustus 1945 werd in Australië veel eerder bekend dan in Nederland. Op 1 september publiceerde een Indonesisch comité hier een manifest waarin het verklaarde dat het volk van Indonesië herstel van het 
ondemocratische en onbarmhartige Nederlandse bestuur nooit zou aanvaarden; ook riep het de Australiërs op om de vrijheidsstrijd van dit volk te steunen. Terwijl de Ambonese KNIL-militairen in het algemeen trouw bleven aan de Nederlandse vlag, schaarde de meerderheid van de Indonesische KNILmilitairen in Australië zich nu achter de Republiek, tezamen met een deel van het Indonesische marinepersoneel en van het Indonesische KPM-personeel. Deze KNIL-militairen en marinemannen werden door de Nederlandse autoriteiten ontwapend en in een kamp opgesloten; de KPM-zeelieden werden ontslagen en eveneens in een Nederlands kampement geïnterneerd. In totaal zagen binnen enkele weken bijna zevenhonderd Indonesiërs zich van hun vrijheid beroofd omdat zij de Republiek steunden.

Enkele dagen nadat een eerste KPM-schip zonder problemen vertrokken was verlieten de Indonesische zeelieden op 24 september alle KPM-schepen in de haven van Brisbane. In aansluiting daarop kondigden de Australische havenarbeiders een algemene boycot voor Nederlandse schepen af zolang Nederland de Republiek Indonesië niet erkende. Met moeite slaagde het Nederlands-Indisch gouvernement er in nog twee schepen te laten vertrekken nadat men KNIL-militairen voor het laden had ingezet. Daarna hield het Nederlandse vervoer over zee van Australië naar Indonesië geheel op; de door het gouvernement opgeslagen hulpgoederen bleven in de pakhuizen liggen.

De Australische vakbondscentrale stelde zich achter de boycot. De Australische regering, die berustte op de met die centrale verbonden Australische arbeiderspartij, gaf de Nederlandse regering geen medewerking om aan de boycot een eind te maken. Afgezien van een korte onderbreking in juni-juli 1947 is deze boycot tot mei 1948 voortgezet.

\section{Britse neiging tot de facto erkenning van de Republiek Indonesië}

Evenals de Nederlandse regering in Londen was de regering-Schermerhorn ervan uitgegaan dat men op Groot-Brittannië kon rekenen als een betrouwbare bondgenoot bij het herstel van het Nederlandse gezag in Indonesië. Om verschillende redenen was dit uitgangspunt te simpel.

In de eerste plaats ging men er aan voorbij dat het Britse koloniale beleid aanzienlijk van het Nederlandse verschilde, in elk geval wat Brits-Indië betrof. Terwijl Nederland in de jaren dertig de Indonesische verlangens naar meer zeggenschap stelselmatig had afgewezen, had Groot-Brittannië in dezelfde periode het bestuur binnen India grotendeels in Indiase handen gelegd en aan Birma volledig zelfbestuur verleend (zie pp. 232-3). Vervolgens had het zich in 1942 onder bepaalde voorwaarden bereid verklaard India na de oorlog onafhankelijk te maken, een bereidverklaring die veel verder ging dan de toezeggingen voor Indonesië in de 7-december-rede van koningin Wilhelmina. 
In de tweede plaats had men zich verkeken op de Britse binnenlandspolitieke constellatie. Verlangens naar behoud van het Britse wereldrijk leefden vooral binnen de door Churchill geleide conservatieve partij. De andere grote partij, de Labour Party, was in beginsel antikoloniaal. In juli 1945 vonden in Groot-Brittannië verkiezingen plaats die door de conservatieven verloren werden. De toen aan de macht gekomen Labour-regering onder Attlee was vastbesloten India, Birma en Ceylon naar onafhankelijkheid te leiden. Men kon van de Labour Party moeilijk verwachten dat ze zou instemmen met Brits gewapend optreden tegen de Indonesische vrijheidsbeweging tot herstel van het Nederlandse koloniale gezag. Mountbatten's persoonlijke opvattingen lagen dichter bij die van Labour dan bij die van de conservatieven. Volgens hem zou het uiterst gevaarlijk zijn als Britse troepen in de koloniën van andere landen vrijheidsbewegingen zouden gaan onderdrukken, zelfs als die onecht zouden zijn. De inlichtingen die hij van Nederlandse kant ontving stelden de Republikeinse beweging inderdaad als onecht voor: de Republiek zou slechts een Japans maaksel zijn dat al bij een beperkt geallieerd machtsvertoon als een kaartenhuis ineen zou storten en de wens naar onafhankelijkheid zou voornamelijk bij een klein aantal ontwortelde intellectuelen leven, terwijl anderzijds de massa van de bevolking Soekarno zou haten en reikhalzend zou uitzien naar de terugkeer van het Nederlandse gezag. Daarentegen kreeg Mountbatten uit Britse bronnen steeds meer aanwijzingen dat de Republiek een echte massabeweging vertegenwoordigde en stevig geworteld was en dat Soekarno onder de bevolking groot gezag genoot. Bovendien kreeg hij in de laatste week van september bezoek van de Britse minister van oorlog, Lawson, die hem namens premier Attlee meedeelde dat zijn regering onder geen beding in een koloniale oorlog in Indonesië verwikkeld wilde raken. In dit verband hechtte Mountbatten bijzonder belang aan de berichtgeving van Laurens Van der Post, die meende dat de Indonesiërs in staat zouden zijn tot gewapend verzet op grote schaal.

In het licht van de door hem ontvangen berichten nam Mountbatten twee besluiten. Enerzijds vervroegde hij de eerste geallieerde troepenlandingen in Batavia, die volgens de plannen pas op 4 oktober plaats zouden vinden, naar eind september. Anderzijds besloot hij aan Nederland duidelijk te maken dat het een politieke oplossing moest zoeken voor de problemen die uit de oprichting van de Republiek Indonesië voortvloeiden. Hiertoe sprak hij samen met Lawson op 27 en 28 september in Singapore met Van der Plas, die uit Batavia overgekomen was. Bij een deel van de gesprekken was ook luitenant-generaal Christison aanwezig, die was aangewezen als commandant van de geallieerde bezettingsmacht in Indonesië.

Mountbatten deelde Van der Plas als onherroepelijk besluit van de Britse regering mee, dat men geen enkele Britse soldaat zou mogen gebruiken tot herstel van het Nederlands gezag. De Britse troepen op Java zouden uitslui- 
tend worden ingezet voor hulp aan krijgsgevangenen en geïnterneerden en voor het bezetten van sleutelposities in Batavia en Soerabaja. Het was aan Nederland om de rest van Java te bezetten. Zolang het dit niet kon, zouden de Japanners namens de geallieerden het bestuur blijven voeren.

Van der Plas protesteerde heftig tegen deze beleidslijn, maar Mountbatten bleef onwrikbaar. Hij verklaarde dat er maar één oplossing was: Nederland moest in overleg treden met Soekarno, zoals hij ook zelf had gedaan met de Birmese leider Aung San die tijdens de oorlog onder Japanse supervisie hoge functies had bekleed. Van der Plas betoogde dat de Nederlandse regering volstrekt zou weigeren met Soekarno te onderhandelen. Mountbatten zei daarop: 'Ik zeg $\mathrm{u}$ dat $\mathrm{u}$ Indië op deze wijze verspeelt'. Hij voegde eraan toe dat, als Nederland geen besprekingen met Soekarno wilde openen, hij Christison zou opdragen dit zelf te doen en dat hij dan bovendien Nederland geen hulp zou geven als het door zijn negatieve houding in moeilijkheden zou raken. Uiteindelijk staakte Van der Plas zijn verzet. Hij zei toe dat hij Van Mook machtiging zou vragen om contact op te nemen met vertegenwoordigers van alle groeperingen en richtingen, de groep van Soekarno niet uitgesloten.

Nog op 28 september zond Van der Plas uit Singapore een telegram aan Van Mook, met kopie aan Logemann die zich toen in Londen bevond. Hij berichtte over wat hem als onherroepelijk Brits regeringsbesluit was meegedeeld en vroeg machtiging om besprekingen met Soekarno en Hatta te beginnen. Daarbij verklaarde hij de toestand zo dringend te achten dat hij van plan was dit voornemen al bij de aankomst van de bezettingstroepen bekend te maken, behoudens tegenorder van Van Mook. Vervolgens vloog hij naar Batavia terug. Hij begreep dat zijn plan voor de arrestatie van Republikeinse leiders niet door zou gaan. Van het Britse bataljon dat voor de bezetting van Batavia bestemd was gingen de eerste tweehonderd man nog diezelfde avond aan land. Eveneens op 28 september zei minister Lawson op een persconferentie in Singapore, dat de verplichtingen van Groot-Brittannië jegens zijn bondgenoten niet meebrachten dat het de bevolking van Java en Indochina zou moeten bevechten ten behoeve van Nederland en Frankrijk.

Generaal Christison had tijdens de oorlog het Britse leger in Birma aangevoerd. Indonesië kende hij niet. Hij kreeg nu als commandant van de Allied Forces in the Netherlands East Indies (AFNEI) een uitvoerige instructie mee. Enerzijds bevatte die de opdracht nauw samen te werken met de NICA. Anderzijds stond daarin: 'You will do everything possible consistent with carrying out your objectives to avoid clashes with the local population and to refrain from intervening in political matters.' Op 29 september sprak Christison in Singapore met journalisten voordat hij naar Batavia vertrok. Hij vertelde dat de onder zijn bevel staande strijdkrachten zich op Java en Sumatra zouden beperken tot het bezetten van Batavia, Soerabaja, Medan en Padang. Zij zouden zich bezighouden met de bescherming en evacuatie van 
krijgsgevangenen en geïnterneerden en met de ontwapening en repatriëring van Japanse militairen. Buiten de door de geallieerden bezette zones zouden de huidige Indonesische autoriteiten verantwoordelijk blijven voor het bestuur in de gebieden onder hun gezag. De Britse bezettingsmacht zou zich niet met de interne politiek bemoeien. De generaal wilde de Indonesische leiders vragen hem als gast te beschouwen en hem bij te staan bij zijn taak. Ook zou hij Indonesische en Nederlandse vertegenwoordigers bij elkaar willen brengen om over de toekomst te praten.

Wat Christison precies gezegd heeft is onzeker, omdat hij later verklaard heeft door journalisten verkeerd geciteerd te zijn. Hoe dit ook zij, de berichten over zijn uitlatingen wekten zowel in Indonesië als in Nederland sensatie, te meer omdat hij volgens sommige berichten het Republikeinse bewind zou hebben aangeduid als 'de Indonesische regering'. Van der Plas protesteerde bij Mountbatten tegen de aan Christison toegeschreven uitlatingen, onder meer omdat die zijn eigen positie ondermijnden.

Toen Van der Plas op 1 oktober nog geen reactie had ontvangen op het telegram dat hij uit Singapore aan Van Mook gestuurd had, gaf hij een persconferentie waarin hij zei dat hij met vertegenwoordigers van de verschillende politieke schakeringen zou willen spreken over de toekomst van Indonesië en dat hij daartoe ook Soekarno en Hatta zou uitnodigen.

\section{Verwerping van de Republiek door de Nederlandse regering}

Het duurde lang voordat de Nederlandse regering reageerde op de stappen die op 17 en 18 augustus 1945 in Djakarta waren gezet: de uitroeping van de Indonesische onafhankelijkheid en de stichting van de Republiek Indonesië. Pas op 26 september vond hierover een korte gedachtewisseling plaats tussen minister-president $W$. Schermerhorn en enige van zijn ministers, op 30 september werd de kwestie voor het eerst in de ministerraad besproken en op 1 oktober publiceerde de regering er een officiële verklaring over.

Het sinds eind juni functionerende kabinet had geen nauwe banden met de Nederlandse politieke partijen. De meest ervaren politicus binnen de regeringsploeg was de minister van sociale zaken, $W$. Drees, die het kabinet samen met Schermerhorn had samengesteld. De minister van buitenlandse zaken, E.N. van Kleffens, oefende zijn functie al sinds 1939 uit en was tijdens de oorlog lid van de regering in Londen geweest. De regeringsploeg bevatte nog een tweede diplomaat, J.H. van Roijen, die als minister zonder portefeuille in het kabinet was opgenomen. De meeste andere ministers hadden weinig politieke ervaring. Bijna iedere minister werd op het terrein van zijn departement in beslag genomen door dringende problemen van herstel en vernieuwing binnen het door vijf jaar Duitse bezetting ontregelde Nederland. Slechts één minister 
was enigszins bekend met de vooroorlogse Indonesische vrijheidsbeweging: de minister van overzeese gebiedsdelen, J.H.A. Logemann, die in NederlandsIndië bestuursambtenaar en vervolgens hoogleraar staatsrecht geweest was maar zich tijdens de oorlog in Nederland bevonden had. Enkele andere ministers hadden vroeger een tijd lang in Indië gewerkt en Schermerhorn zelf had daar leiding gegeven aan de luchtkartering van Nieuw-Guinea.

Binnen deze regering vond in augustus en september herhaaldelijk overleg plaats over problemen in verband met het herstel van het Nederlandse gezag in Nederlands-Indië, maar meestal ging het daarbij om andere problemen dan het optreden van een Indonesisch-nationalistische afscheidingsbeweging. Het eerste bericht dat bij de Nederlandse regering binnenkwam over de vorming van een nationale Indonesische regering was bovendien niet geheel juist. Dit was het telegram van 20 augustus waarin Van Mook berichtte dat de Japanse opperbevelhebber op die dag een Republiek Indonesië zou uitroepen. De kwestie wekte toen geen ernstige verontrusting, ook omdat Van Mook er zelf niet zwaar aan tilde. De in zijn eerste berichten vervatte misvatting als zou de Republiek formeel door het Japanse leger ingesteld zijn werkte overigens nog lange tijd door.

Dat de Nederlandse ministerraad zich tot eind september niet met het optreden van de Republiek Indonesië bezighield was ten dele te wijten aan het feit dat Logemann zelf bijna de hele maand niet in Nederland was. Op 4 september was hij naar Australië vertrokken voor overleg met het NederlandsIndische gouvernement. Van 10 tot 24 september had hij in Camp Columbia gelegenheid met Van Mook en diens medewerkers te spreken. Pas op 30 september keerde hij in Nederland terug.

Logemann en Van Mook waren gelijkgezinden op het terrein van het koloniaal beleid. In 1930 hadden zij behoord tot de oprichters van de Stuw-groep, een kleine vereniging die zich keerde tegen het koloniaal-conservatisme dat onder de Nederlanders in Indië de boventoon voerde. Ook Van der Plas was lid van die groep geweest. $\mathrm{Nu}$ in 1945 dachten zij alle drie vrijwel gelijk over de wenselijkheid van staatkundige hervormingen in Nederlands-Indië. Daarbij dachten zij in de eerste plaats aan een flinke uitbreiding van de inheemse vertegenwoordiging in de Volksraad, aan opheffing van alle wettelijke discriminatie van de inheemse bevolking en aan afschaffing van het dualistische bestuursstelsel (waarbij geen Indonesiërs werden opgenomen in het leidende korps van het Binnenlands Bestuur). Van Mook was trouwens al op die afschaffing vooruitgelopen door Abdoelkadir tot resident van de Molukken te benoemen.

Tijdens zijn verblijf in Camp Columbia wist Logemann nog weinig over de politieke situatie op Java en Sumatra. Pas kort voor zijn terugreis kon hij kennis nemen van de eerste brieven die Van der Plas en Abdoelkadir uit Batavia aan Van Mook hadden gezonden. Omstreeks dezelfde tijd ontving hij van kolonel 


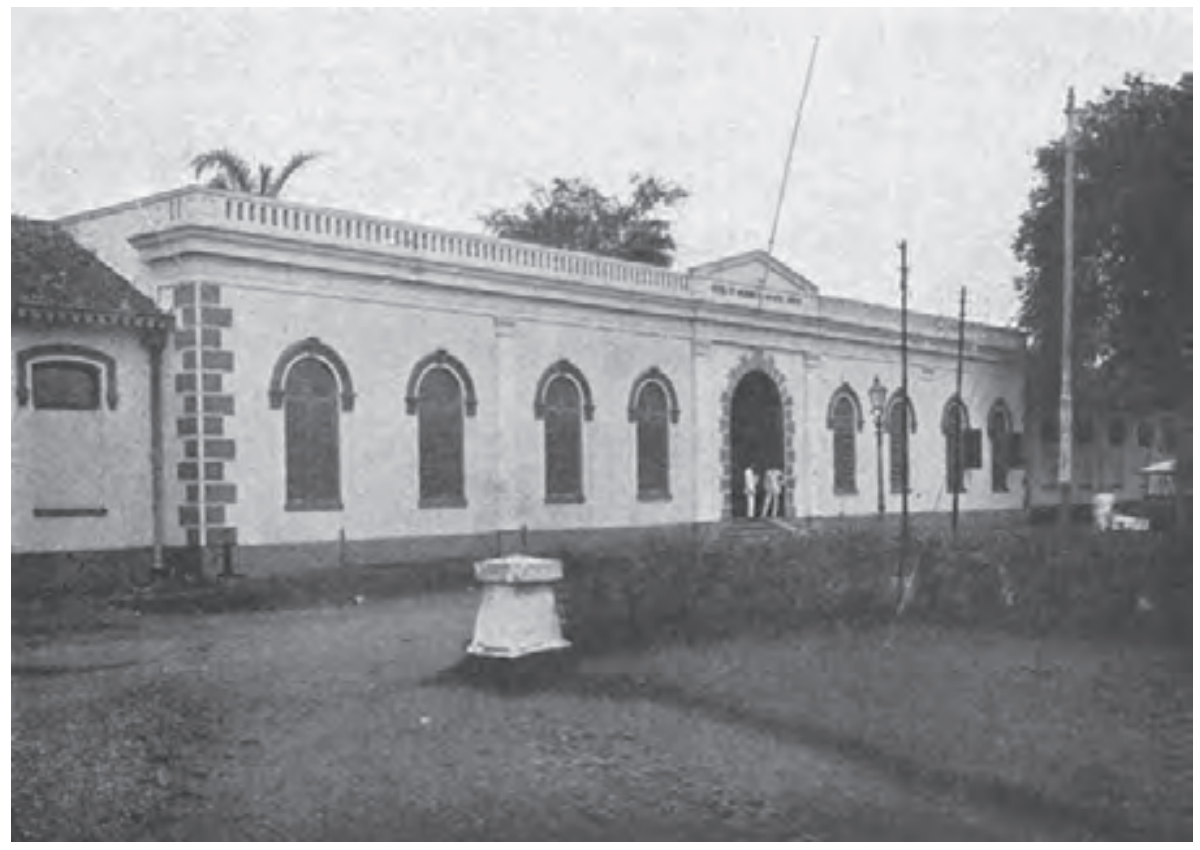

De STOVIA (School Tot Opleiding Van Inlandse Artsen). Leerlingen hiervan namen in 1908 het initiatief tot oprichting van de eerste Indonesische emancipatiebeweging. Het gebouw huisvest nu het Museum van het Nationale Ontwaken.

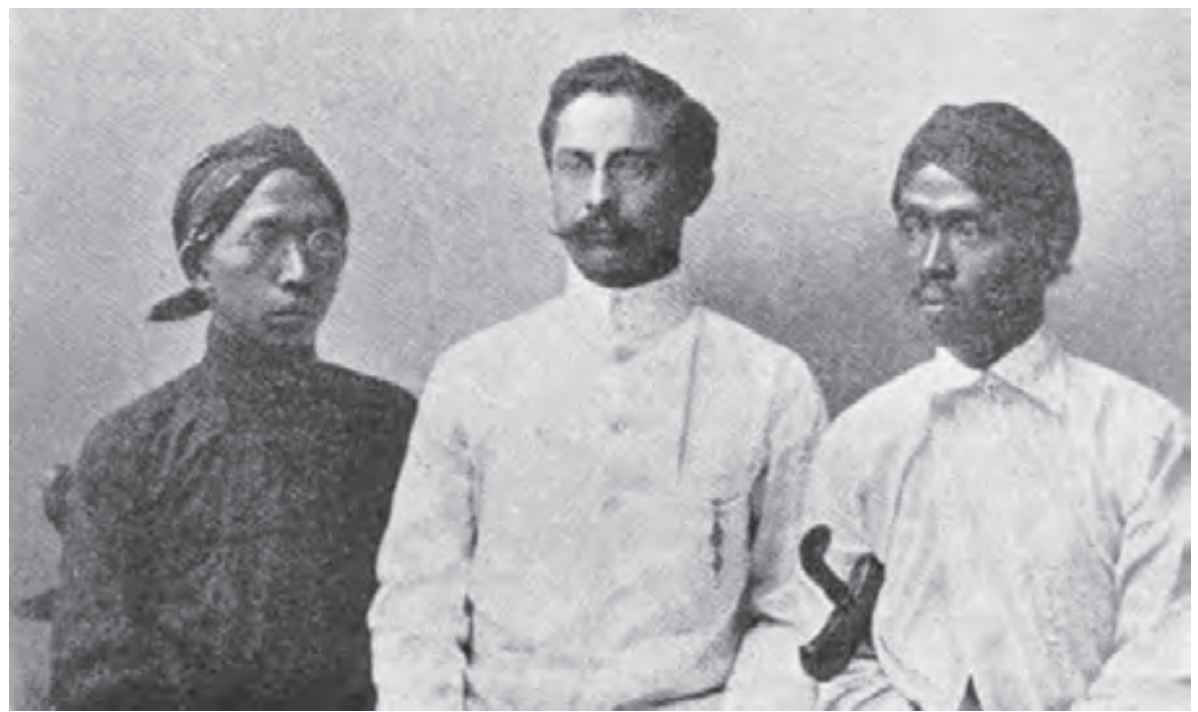

Soewardi Soerjaningrat, E.F.E. Douwes Dekker en Tjipto Mangoenkoesoemo, in 1911 de leiders van de Indische Partij die naar een onafhankelijk Indië streefde. 


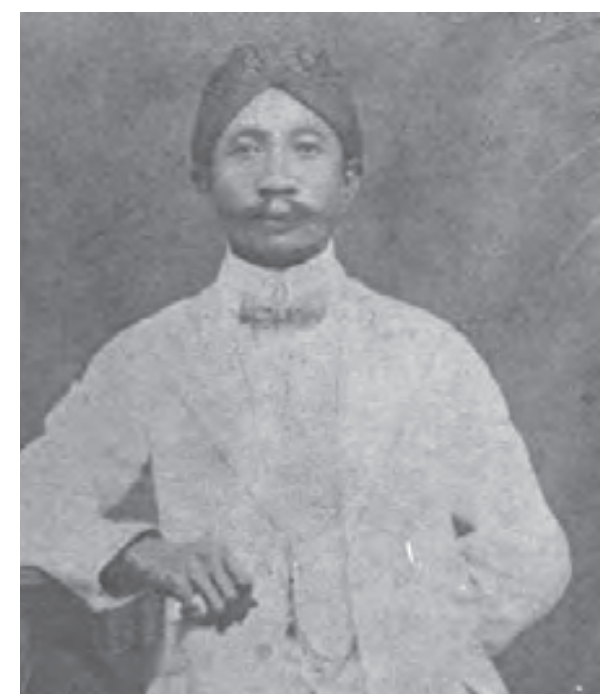

O.S. Tjokroaminoto

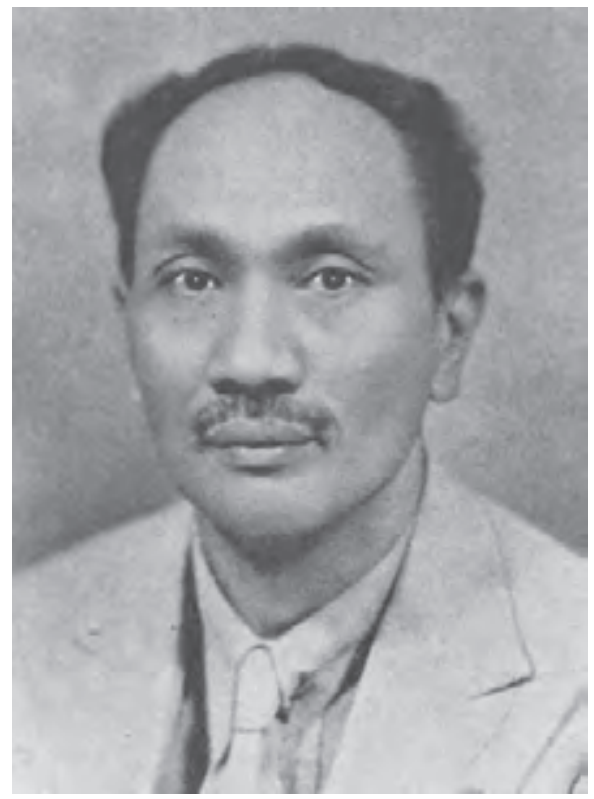

dokter Soetomo

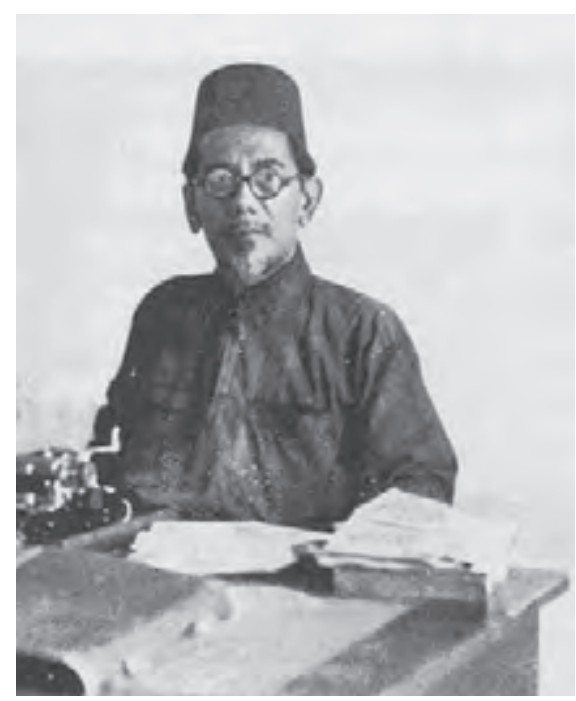

Agoes Salim

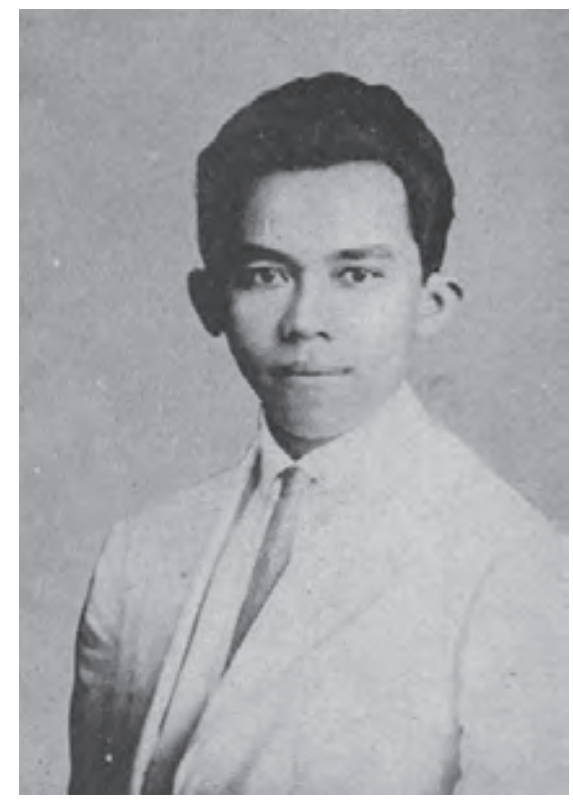

Tan Malaka 


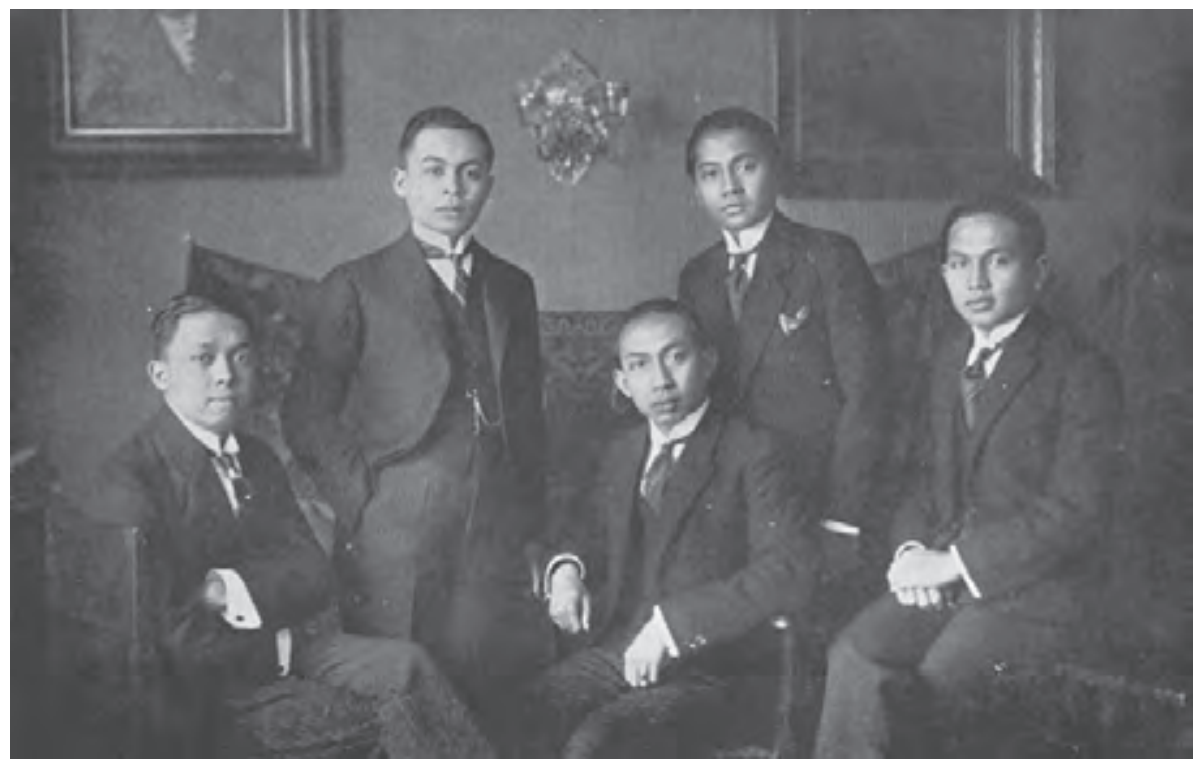

Het bestuur van de Indonesische Vereeniging in 1923, met Iwa Koesoema Soemantri (midden) als voorzitter en Hatta (linksboven) als penningmeester.

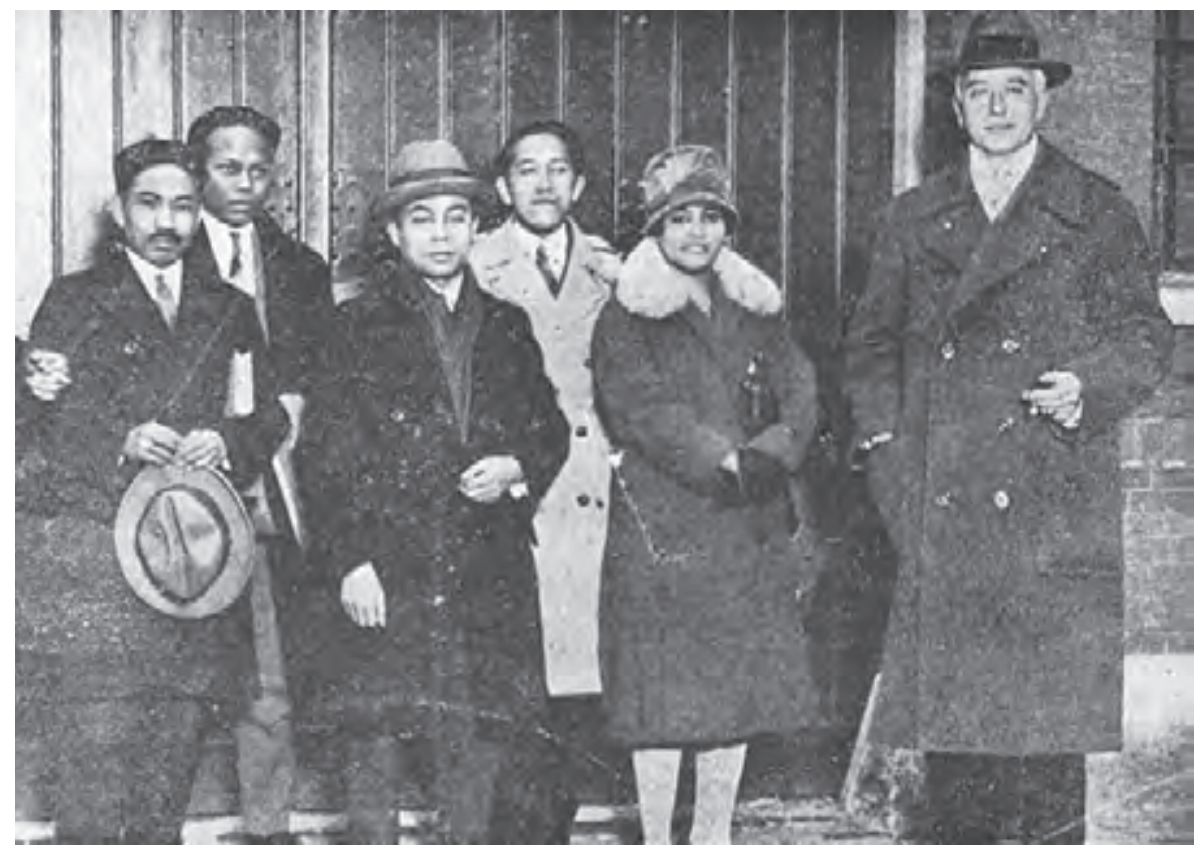

Maart 1928: De gevangengenomen leiders van de Perhimpoenan Indonesia na hun vrijlating: Pamontjak, Abdoelmadjid, Hatta en Ali Sastroamidjojo. Naast hen de vrouw van Ali Sastroamidjojo en de Nederlandse advocaat J.E.W. Duys. 


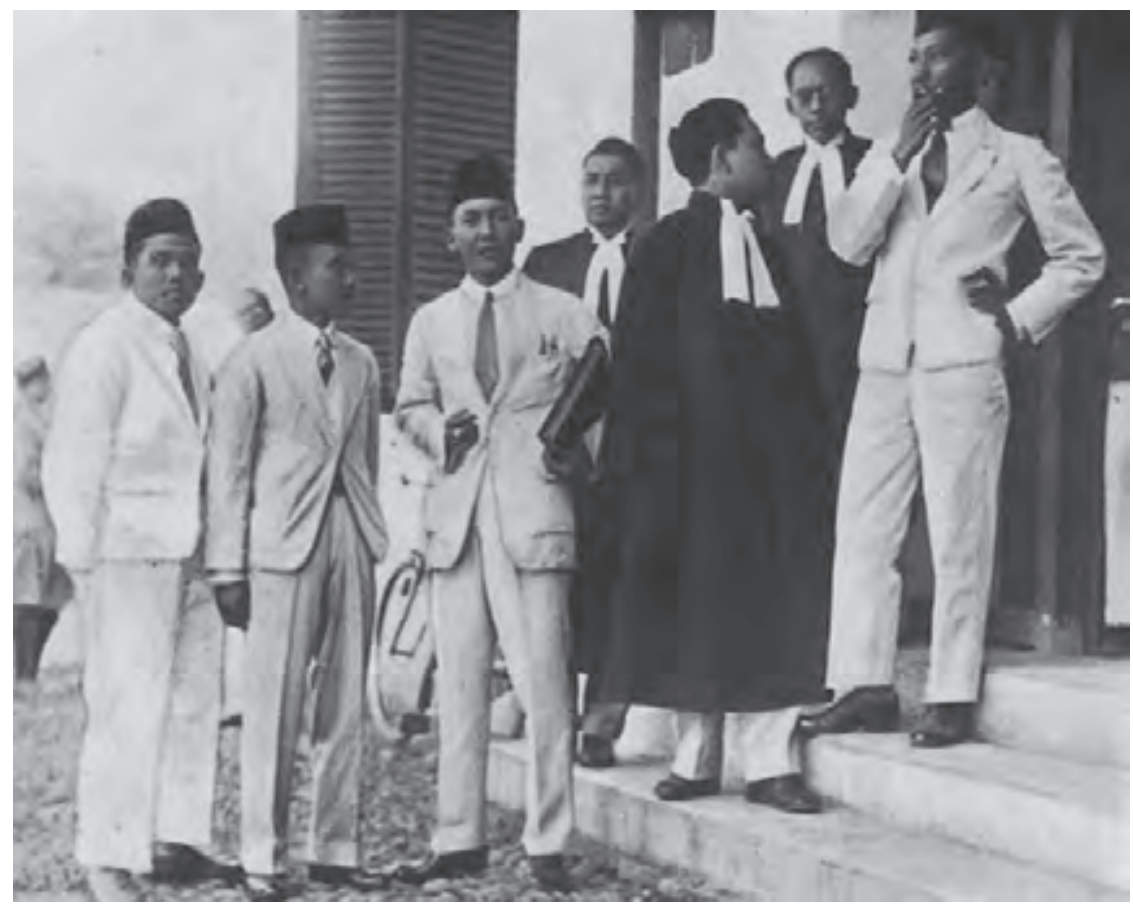

Augustus 1930: Begin van het proces tegen Soekarno en drie andere PNI-leiders. De beschuldigden met hun advocaten voor het gerechtsgebouw in Bandoeng.

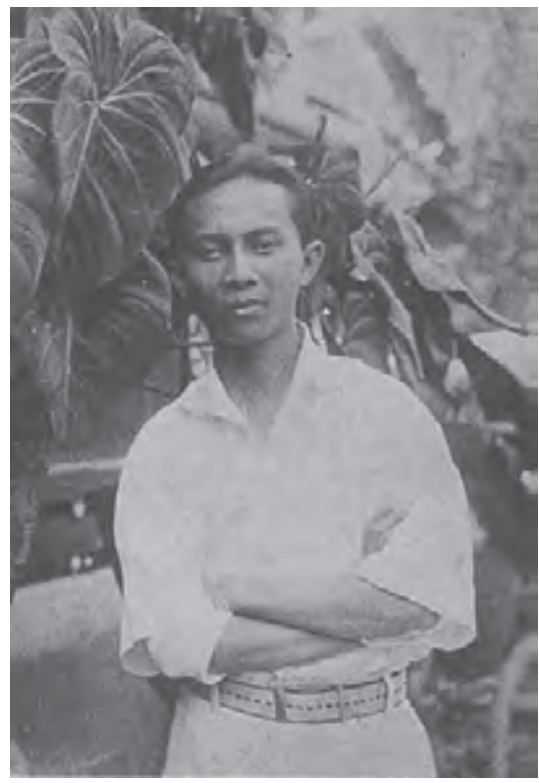

1935: Sjahrir in het interneringskamp Boven-Digoel op Nieuw-Guinea, waarheen hij samen met Hatta was verbannen. 


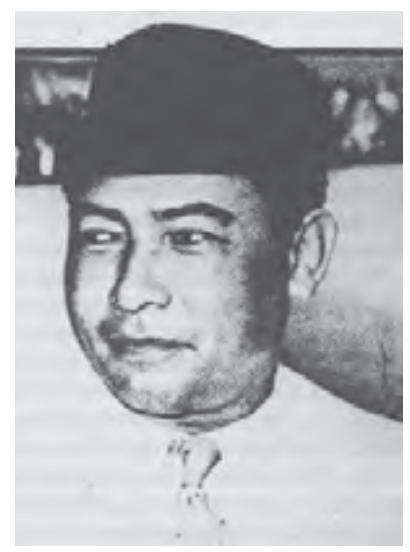

M.H. Thamrin

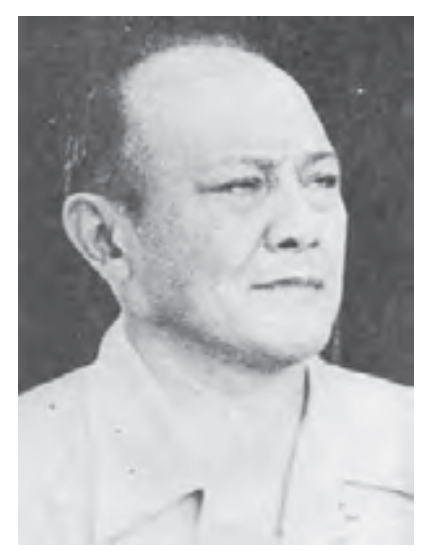

G.S.S.J. Ratoelangie

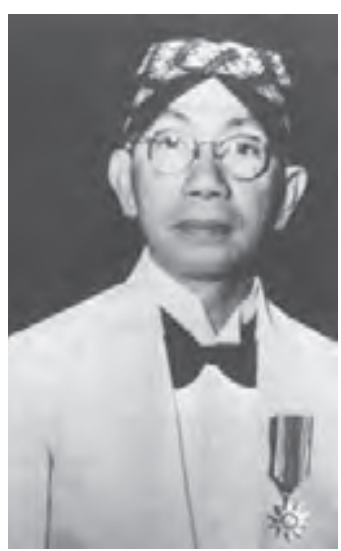

Soetardjo Kartohadikoesoemo

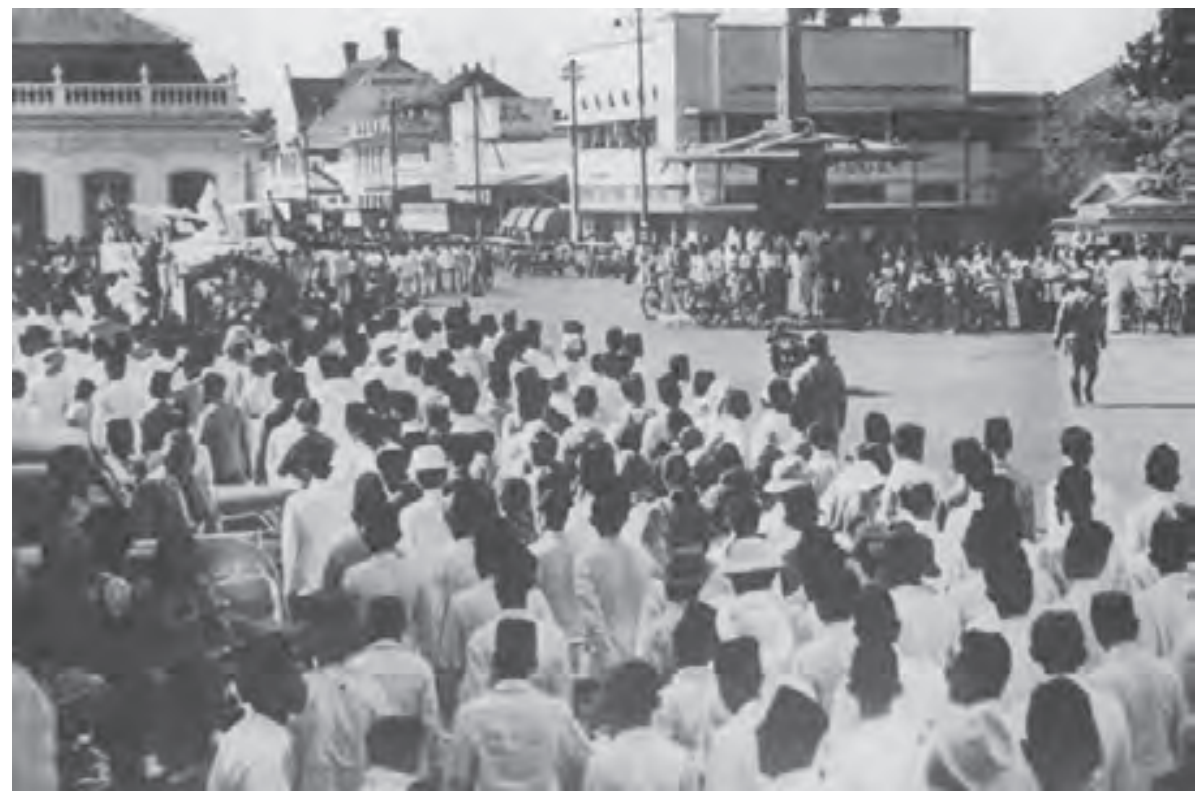

Januari 1941: De begrafenis van Thamrin groeide uit tot de laatste nationalistische massademonstratie onder het koloniale bestuur. 


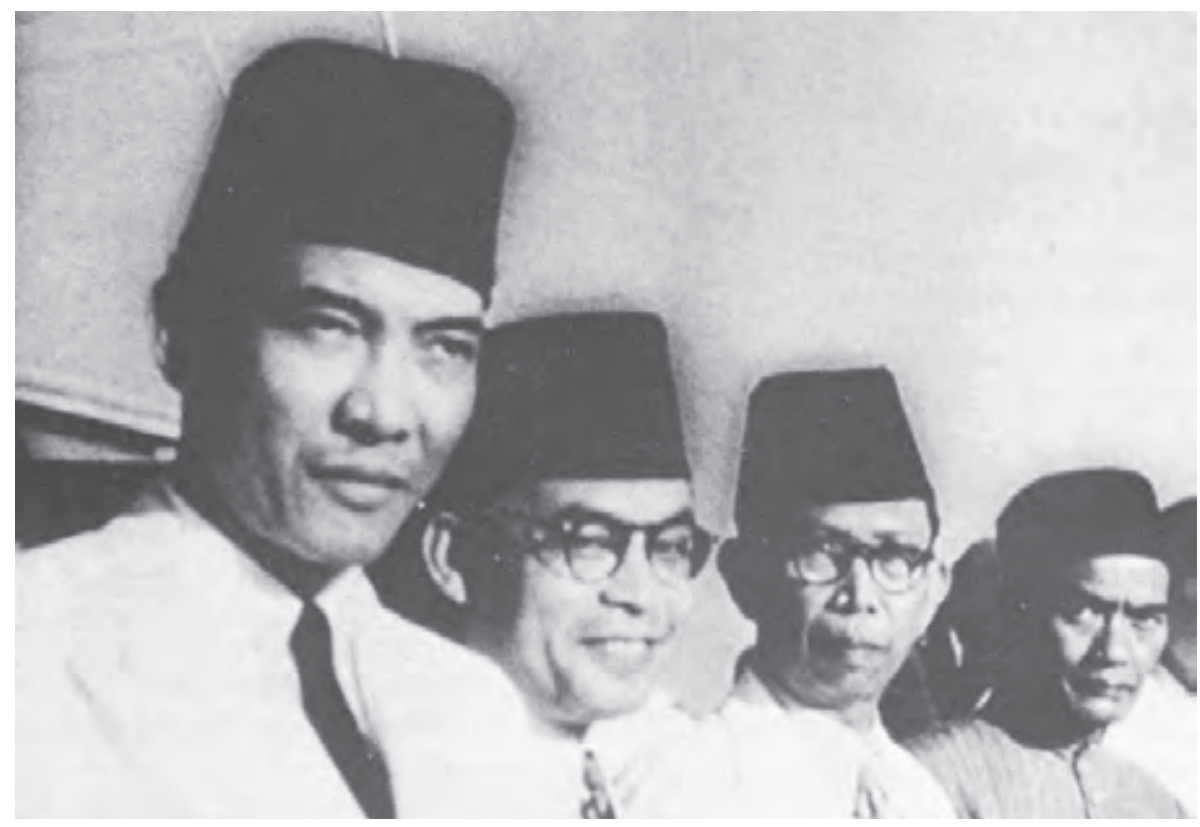

Soekarno, Hatta, Dewantoro en Mansoer, in december 1942 door het Japanse bezettingsbestuur aangewezen als leiders van de inheemse bevolking van Java.

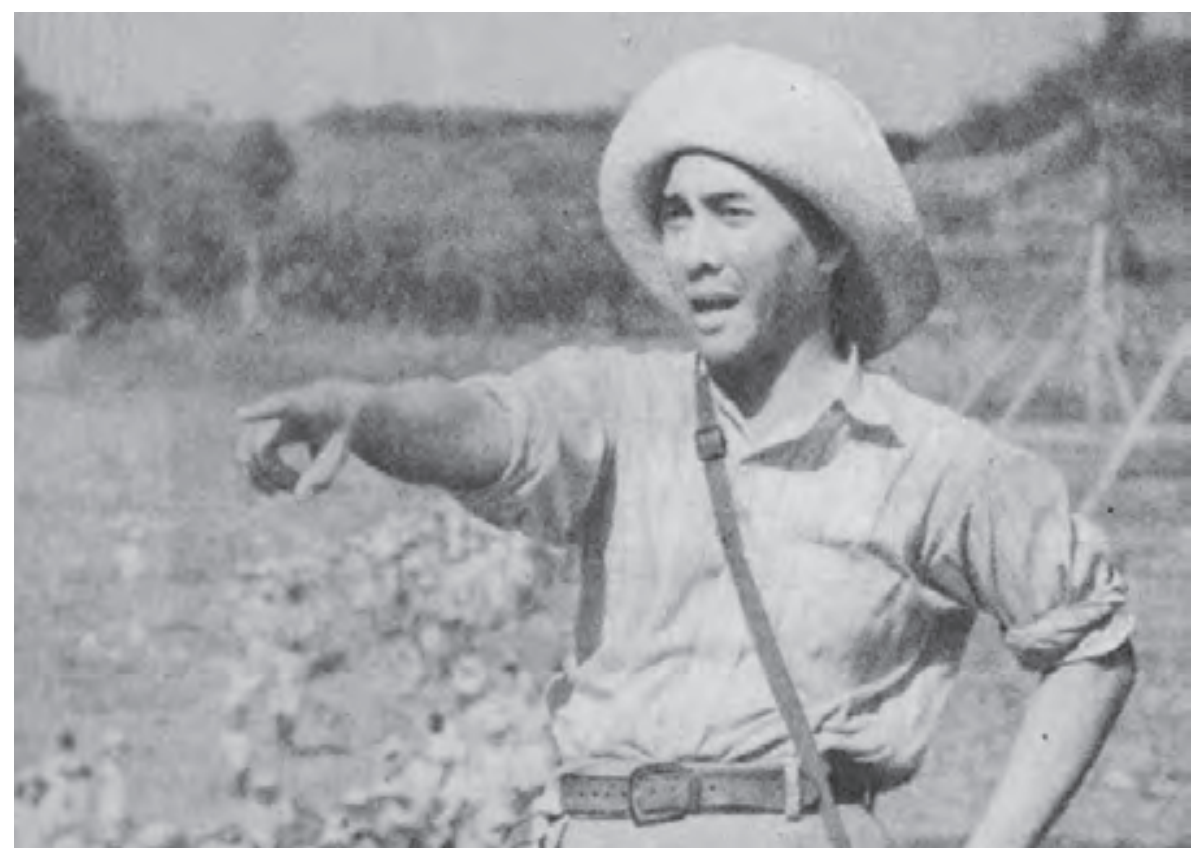

Oktober 1944: Soekarno als propagandist voor de Japanse arbeidsdienst. 
Trothlamasi.

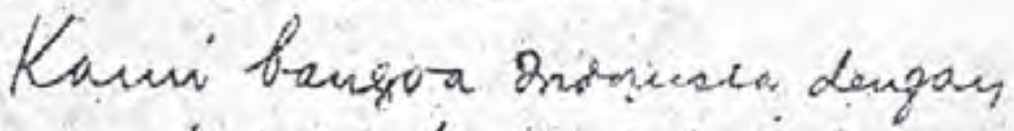
mi onenjitakes kenterdeharg monia.

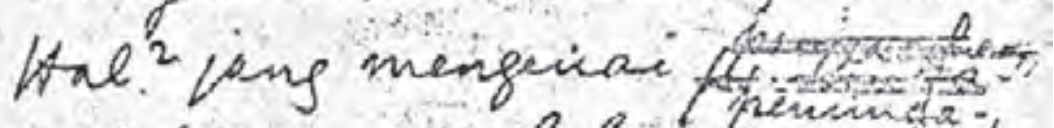
has kebaraseas d.l.l., dinizing dengas tjara saksama das dalak tempoth jeng sesinghat singhal inga.

Djabantid $17-8$ or

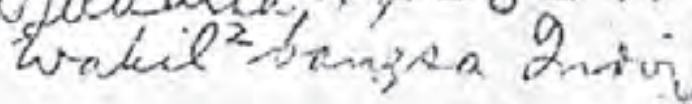

17 augustus 1945: Het door Soekarno geschreven ontwerp (met tekstveranderingen) voor de onafhankelijkheidsproclamatie.

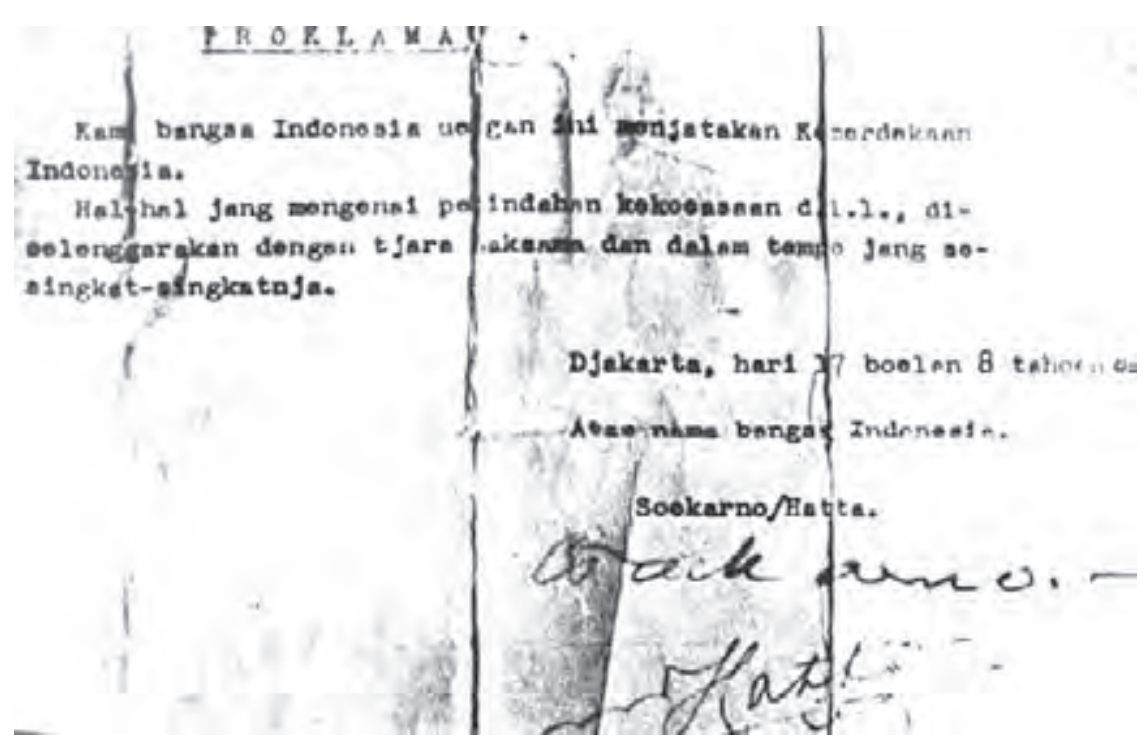

De uitgetypte en door Soekarno en Hatta ondertekende tekst van de proclamatie. 


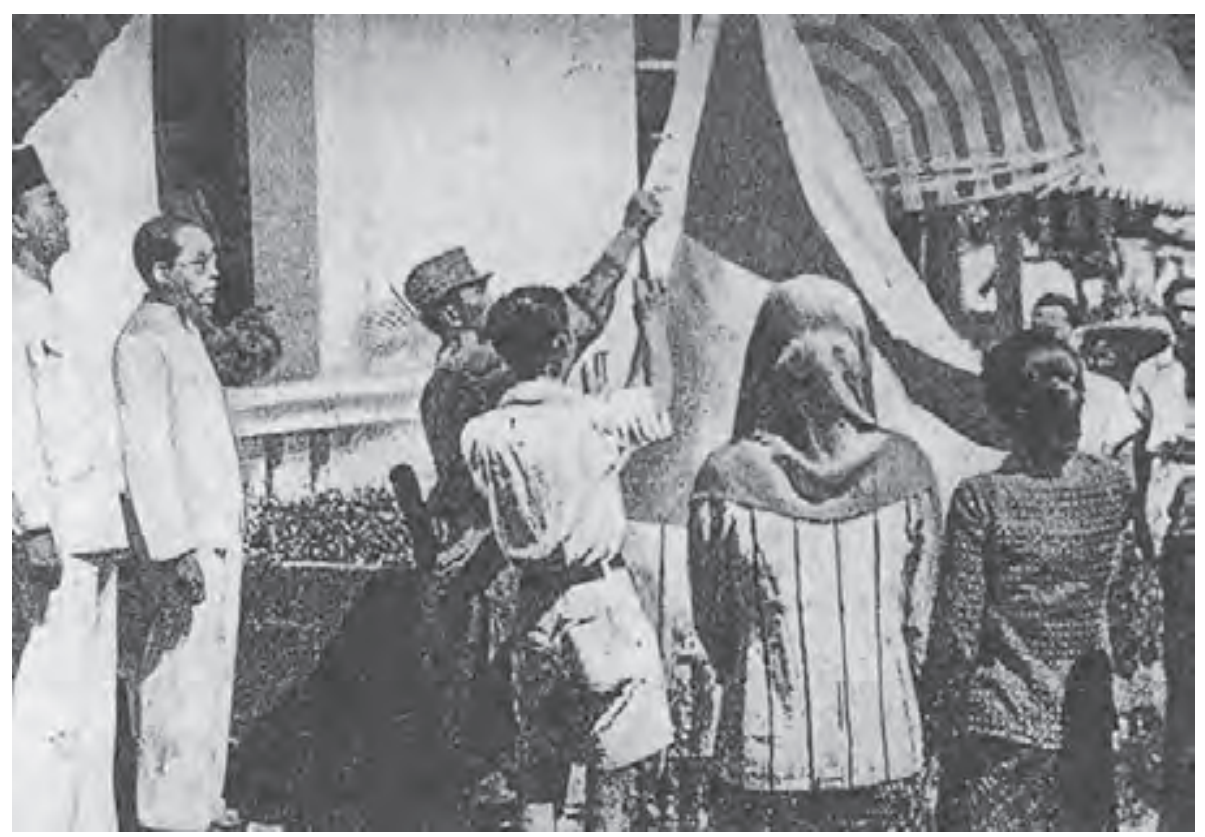

17 augustus 1945: Het hijsen van de roodwitte vlag na de voorlezing van de proclamatie door Soekarno voor het huis aan Pegangsaän Oost 56.

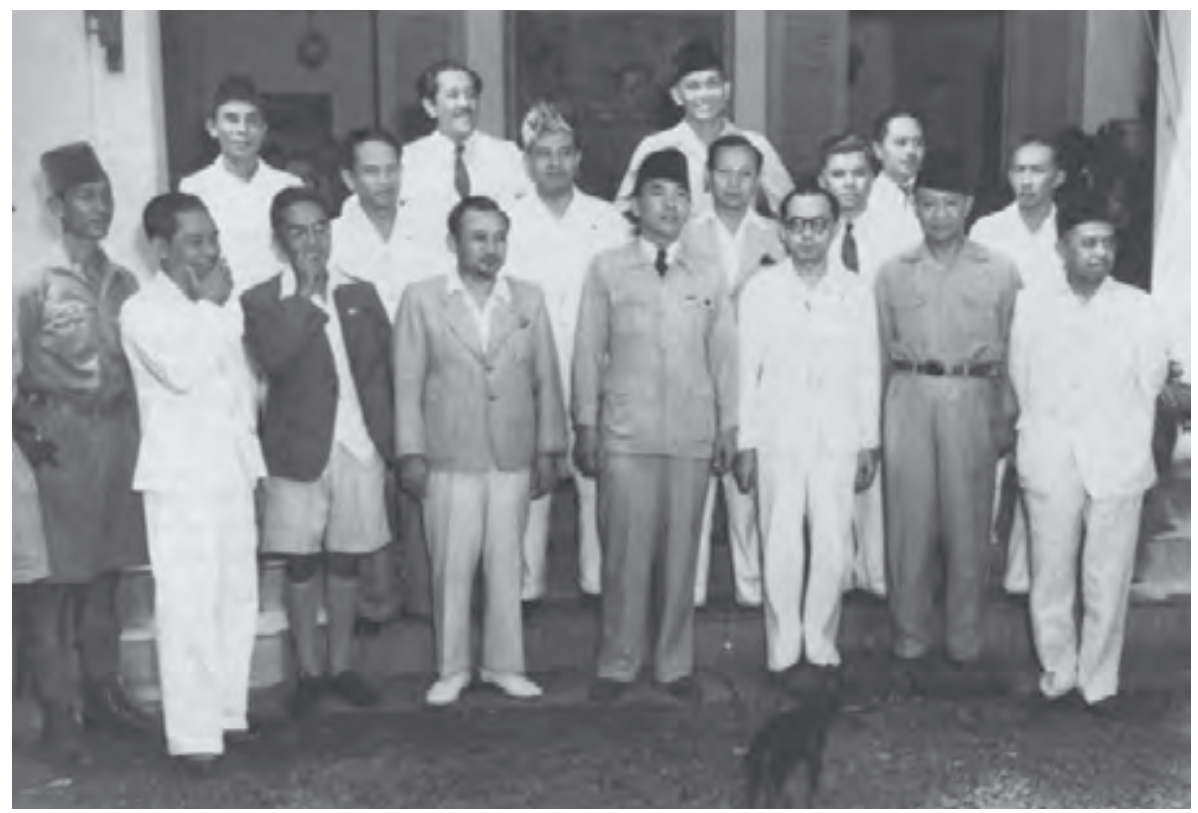

4 september 1945: Voor hetzelfde huis presenteert Soekarno zijn kabinet, met o.m. aan zijn linkerhand Hatta en Wiranatakoesoema en aan zijn rechterhand Soebardjo. 


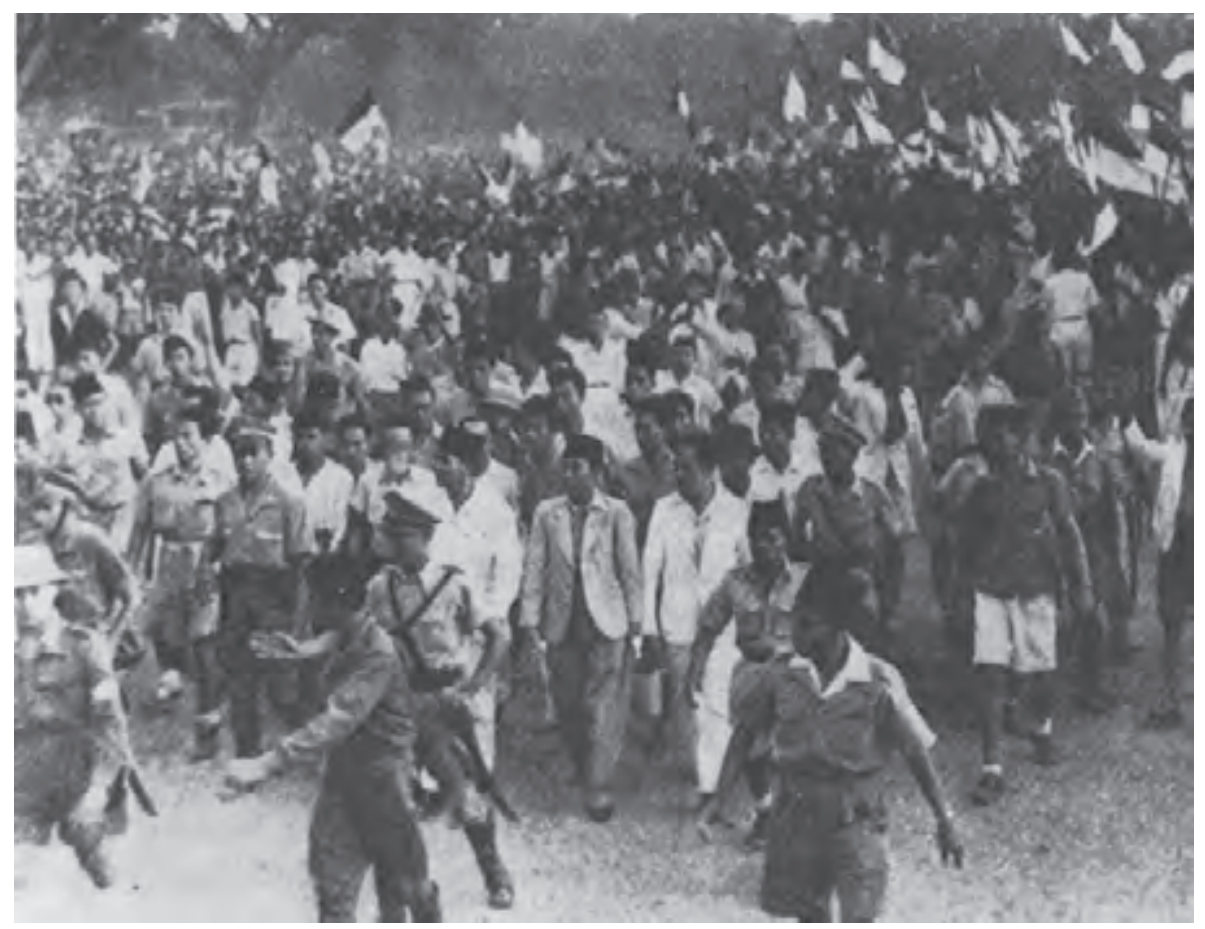

19 september 1945: Soekarno arriveert bij de massabetoging op het Ikada-terrein.

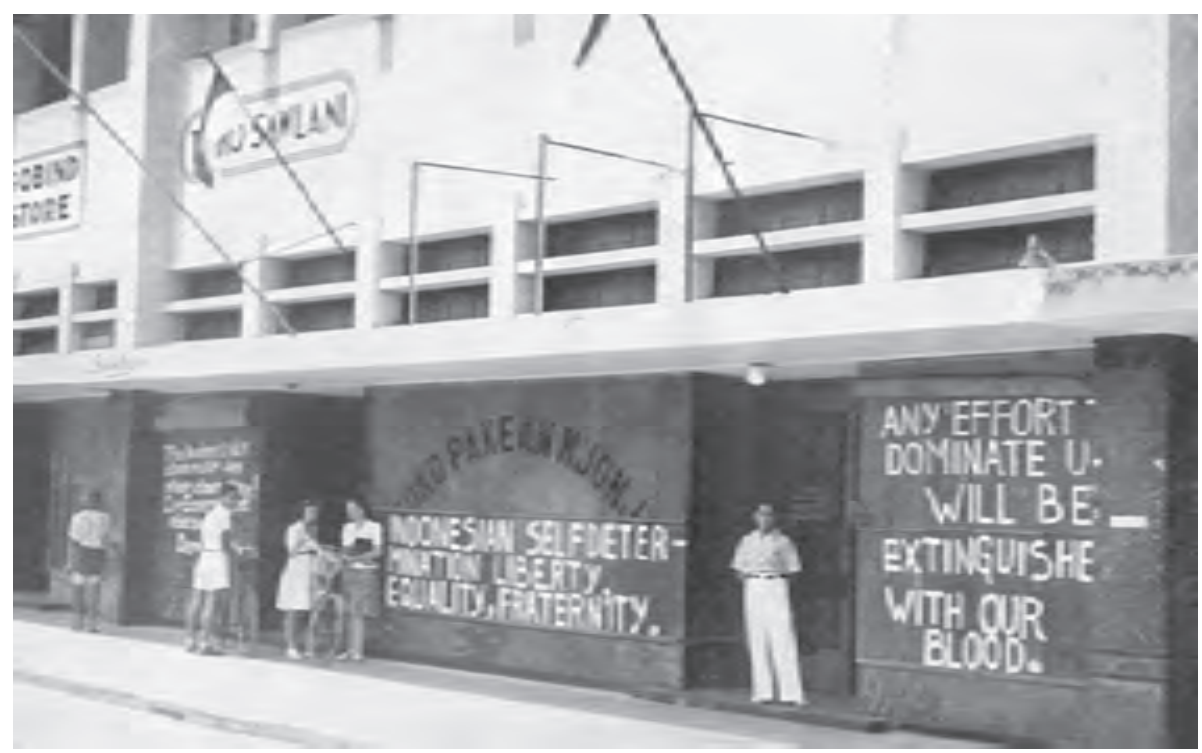

September-oktober 1945: Djakarta volgeschilderd met Engelstalige leuzen van de onafhankelijkheidsbeweging. 


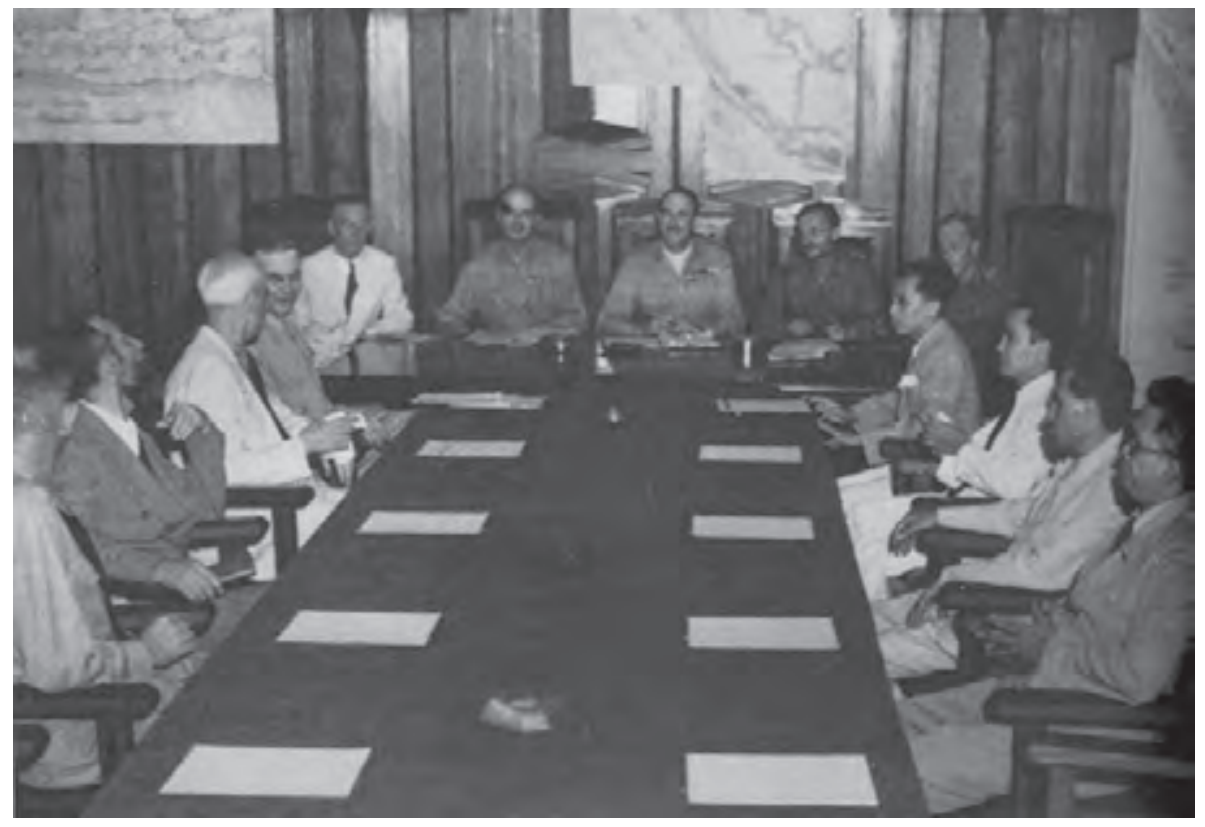

17 november 1945: Eerste bespreking tussen Van Mook en Sjahrir onder leiding van generaal Christison, de commandant van de Britse bezettingsmacht.

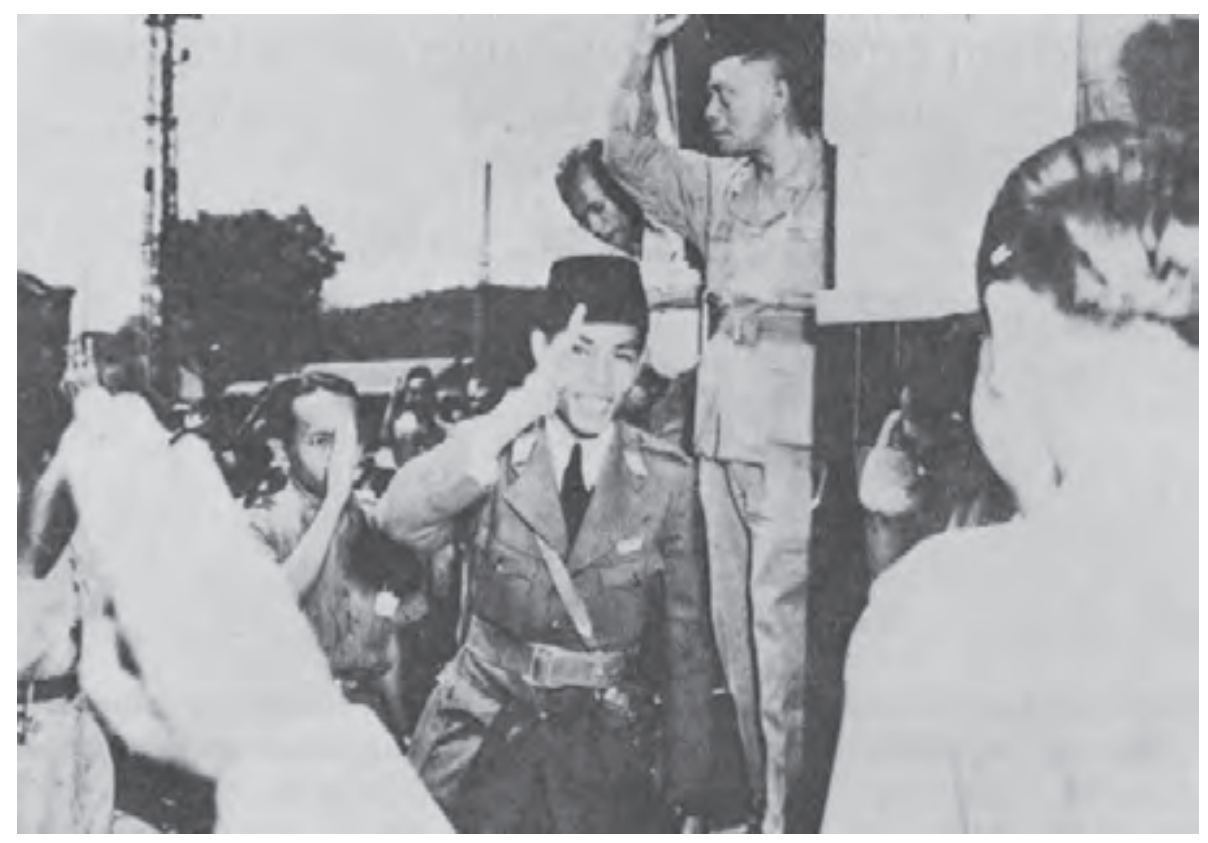

15 oktober 1946: Generaal Soedirman arriveert in Batavia voor overleg op het Britse hoofdkwartier. Staande achter hem: stafchef Oerip Soemohardjo. 


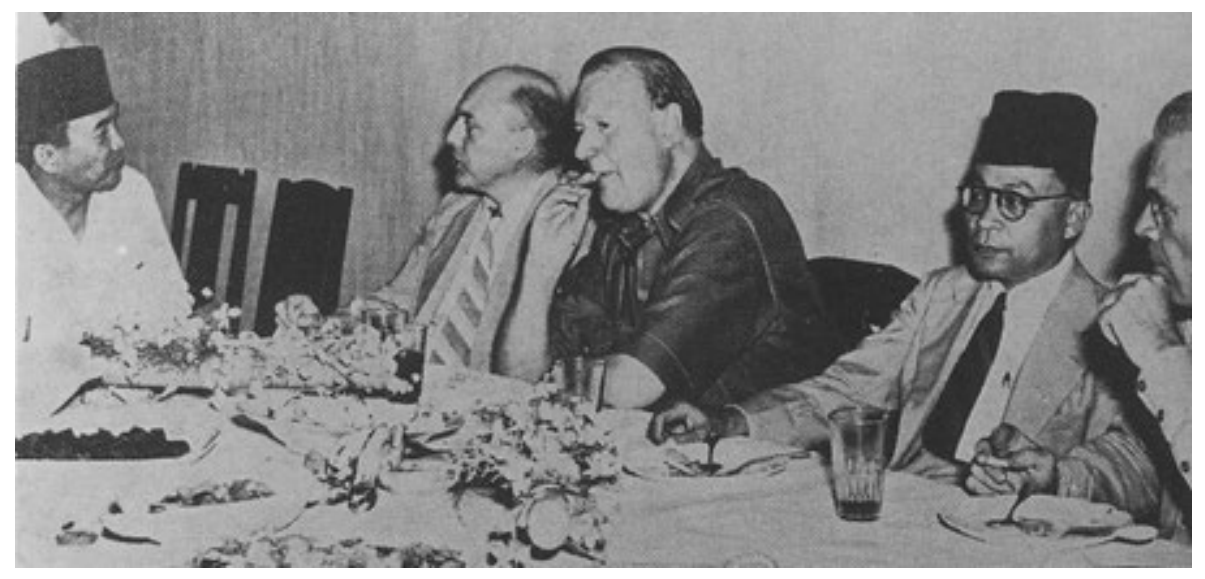

11 november 1946: Door Soekarno aangeboden diner in Linggadjati.

Van links naar rechts: Soekarno, Schermerhorn, Killearn, Hatta en Van Mook.

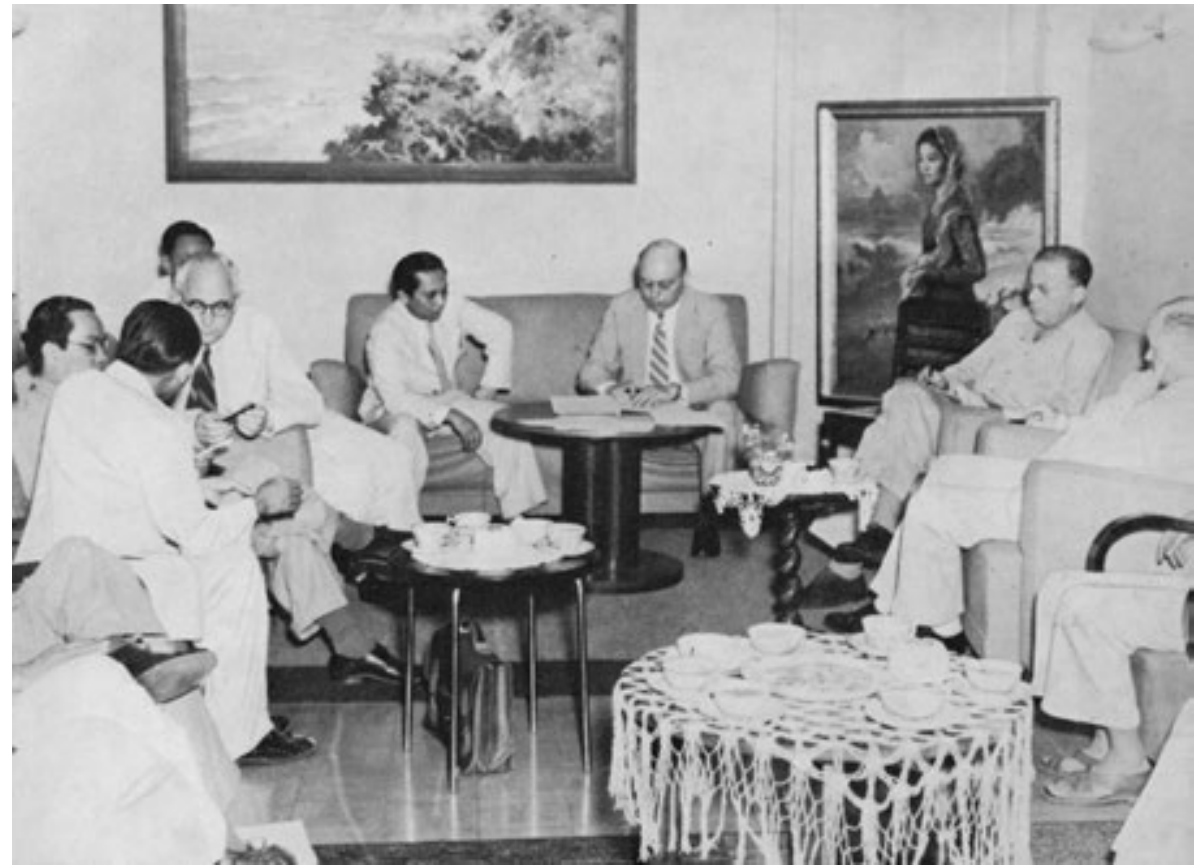

15 november 1946: Parafering van het ontwerpakkoord van Linggadjati in Batavia. Op de bank: Sjahrir en Schermerhorn; rechts daarvan Van Mook. 


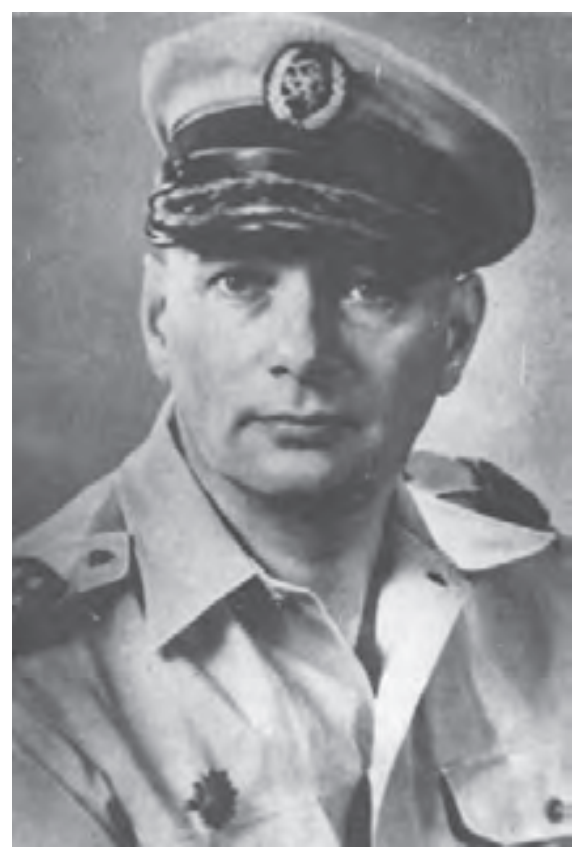

Luitenant-generaal S.H. Spoor

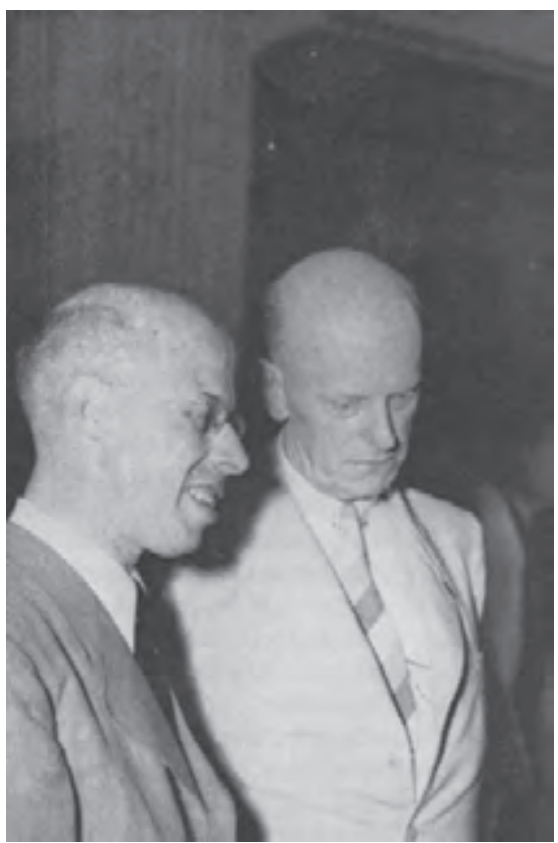

Minister-president L.J.M. Beel en minister J.A. Jonkman

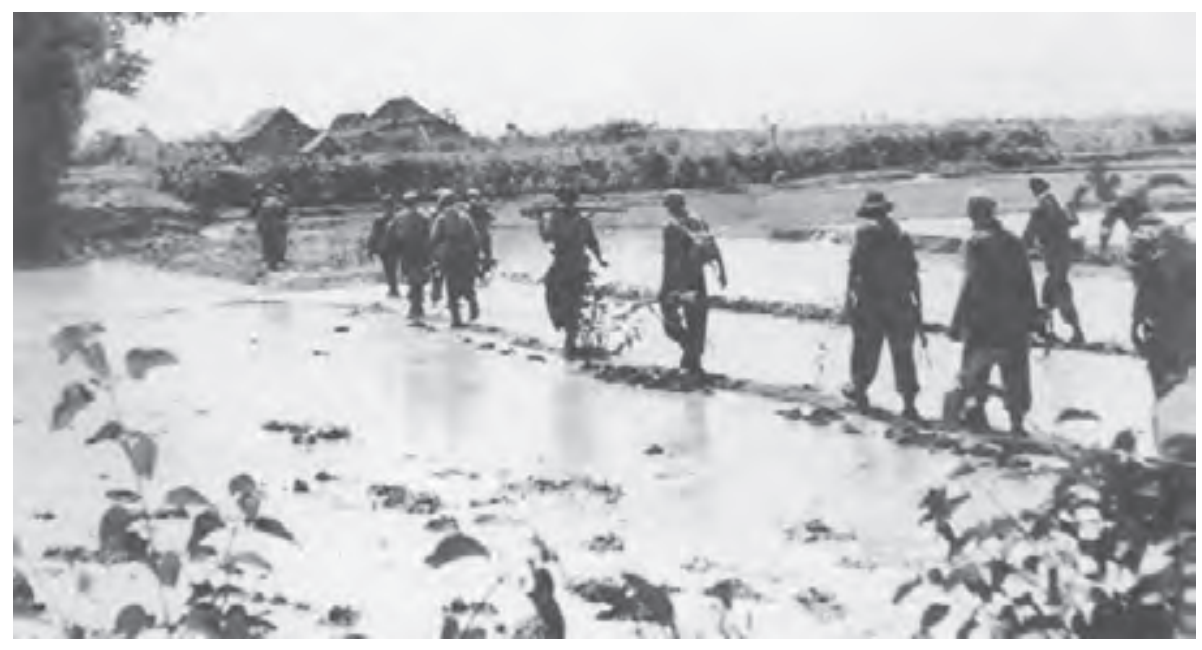

Nederlandse soldaten op patrouille. 


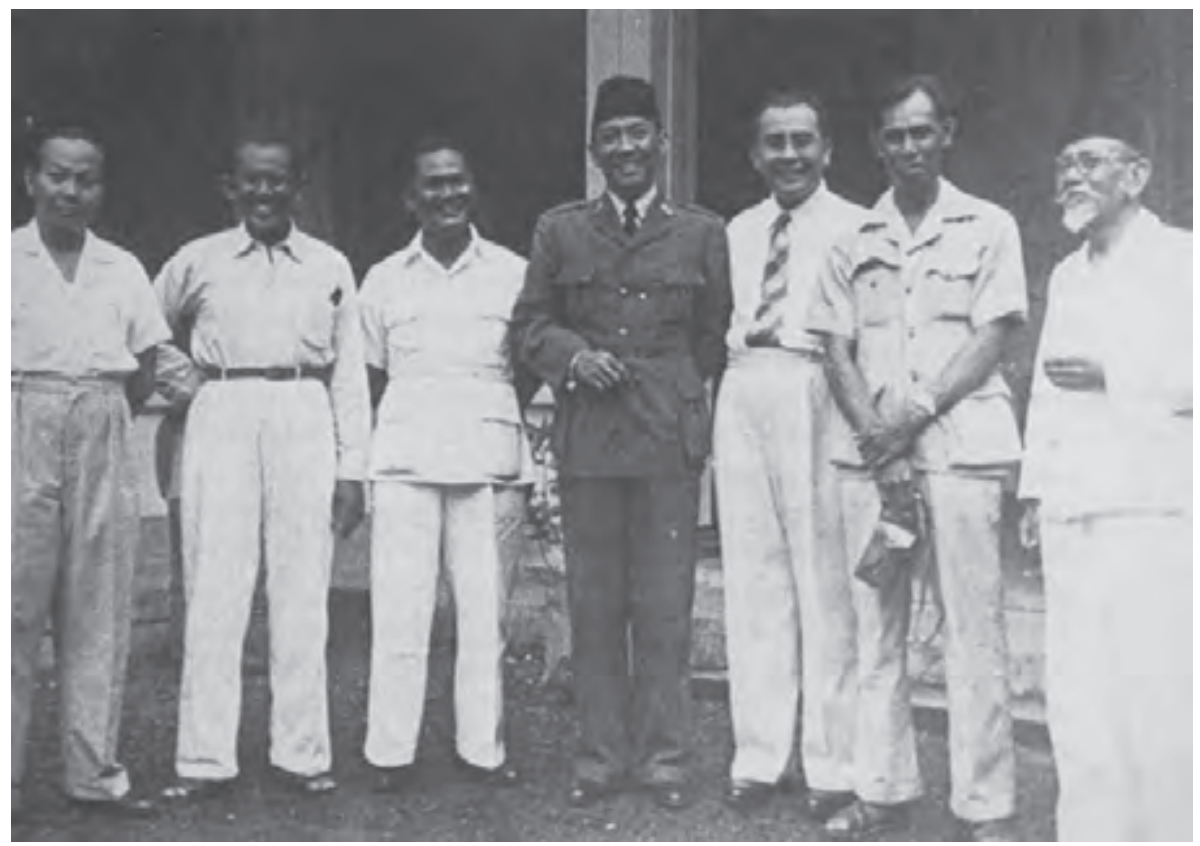

Soekarno, die door Nederland op Bangka was geïnterneerd, ontvangt daar in maart 1949 een delegatie van de BFO. Rechts van hem Anak Agoeng, Leimena en Agoes Salim.

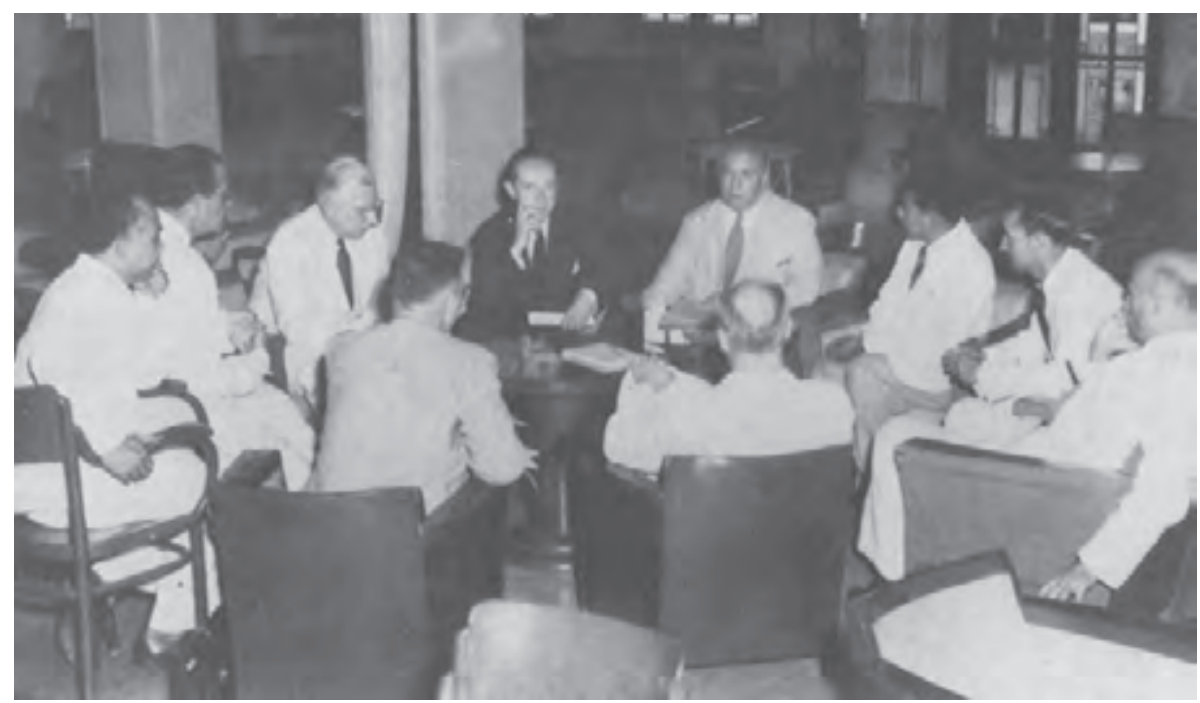

Politiek overleg tussen Nederland en de Republiek in Batavia in april-mei 1949 onder leiding van de Amerikaan M. Cochran, hier zittend tussen de Nederlandse delegatieleider J.H. van Roijen en de Republikeinse delegatieleider M. Roem. 


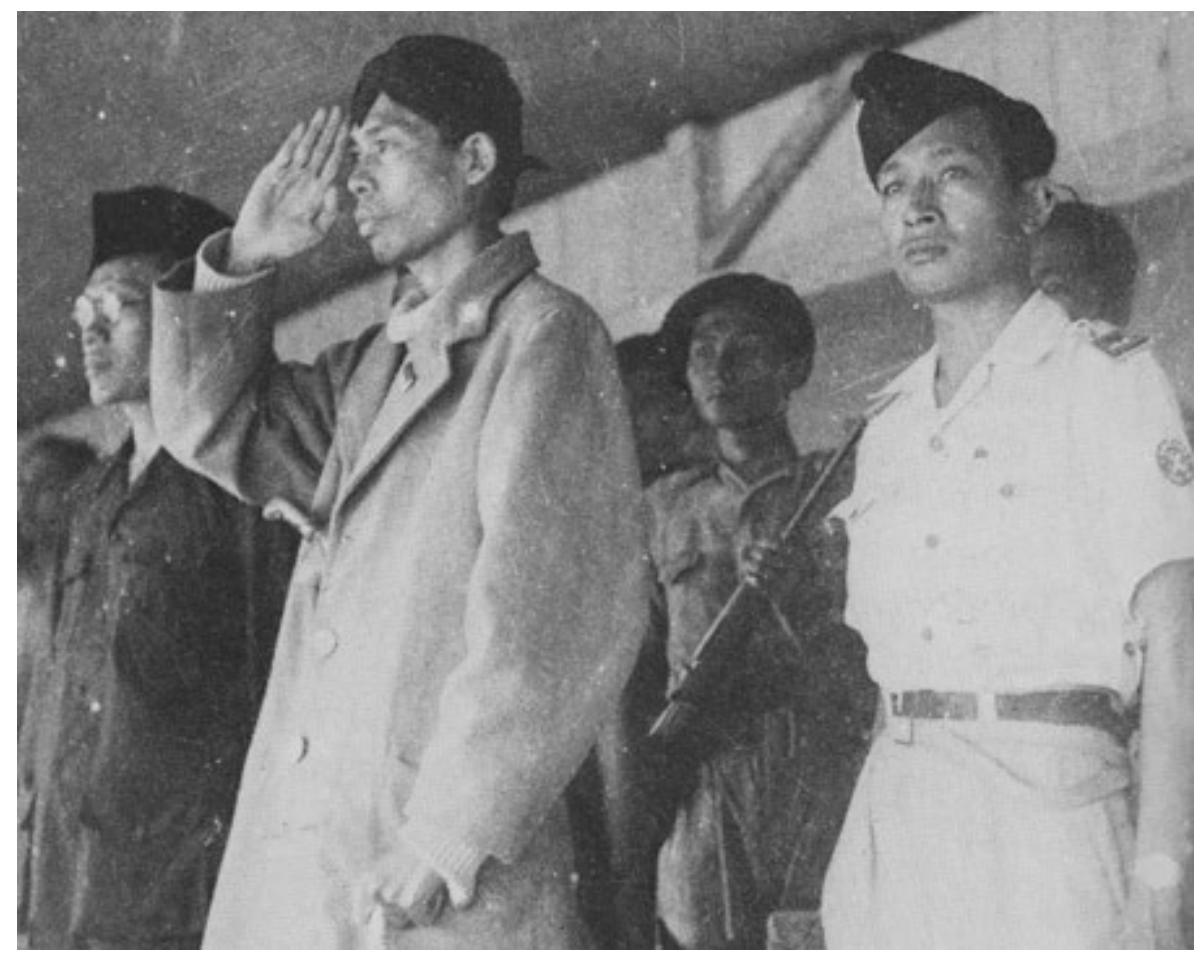

10 juli 1949: Na de terugkeer van de Republikeinse regering in Jogja neemt generaal Soedirman daar een parade af, staande naast luitenant-kolonel Soeharto.

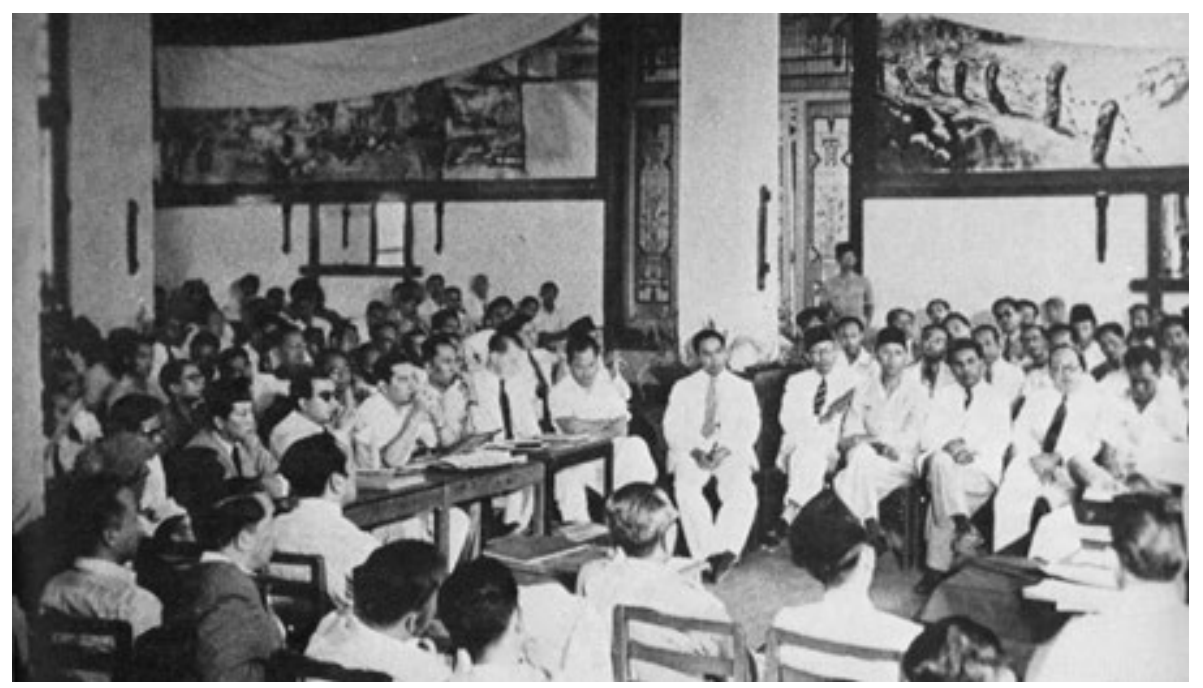

Opening in Jogja van de in juli-augustus 1949 gehouden Inter-Indonesische Conferentie die leidde tot een politiek akkoord tussen de Republiek en de federalisten. 


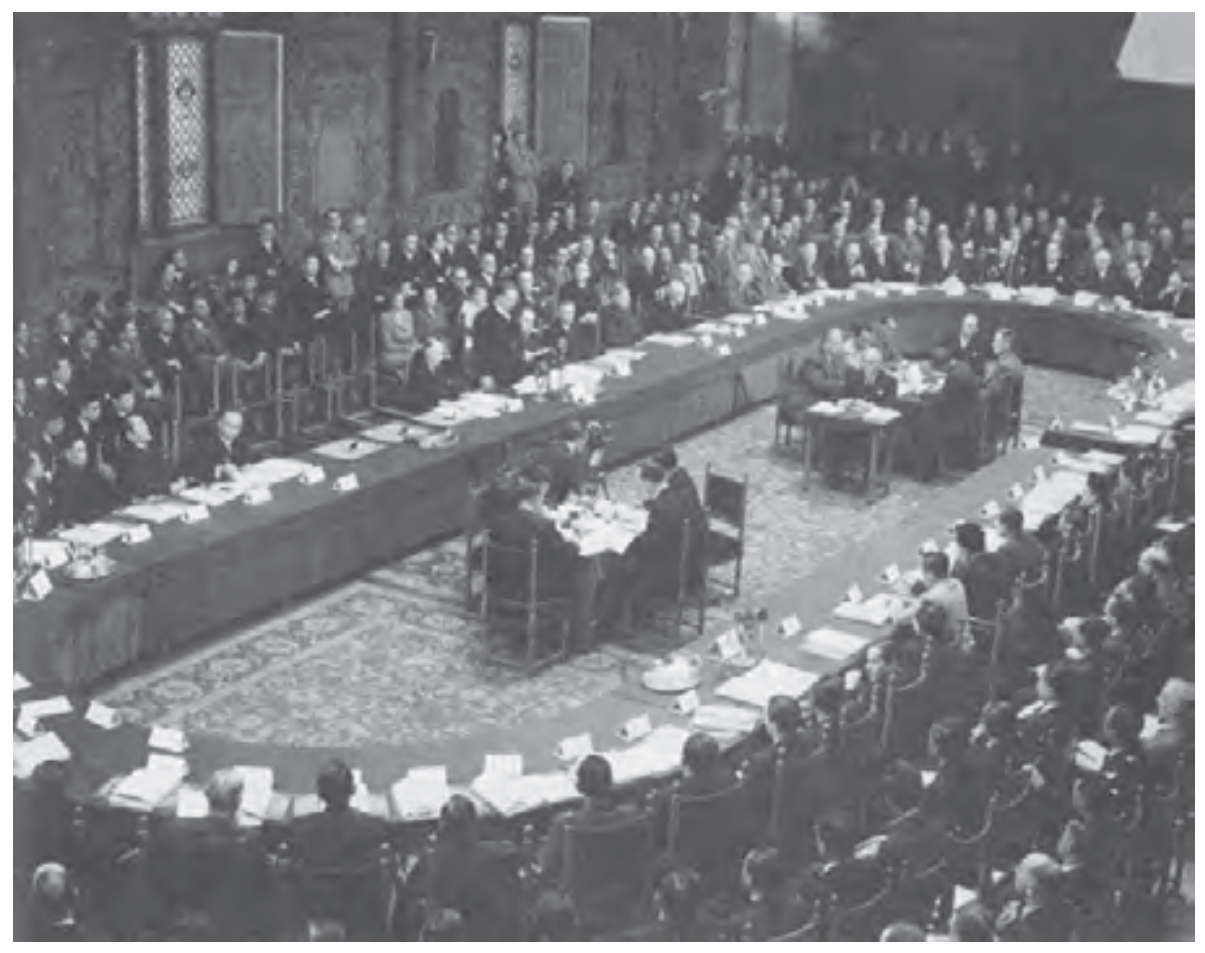

2 november 1949: Slotzitting van de Rondetafelconferentie in Den Haag.

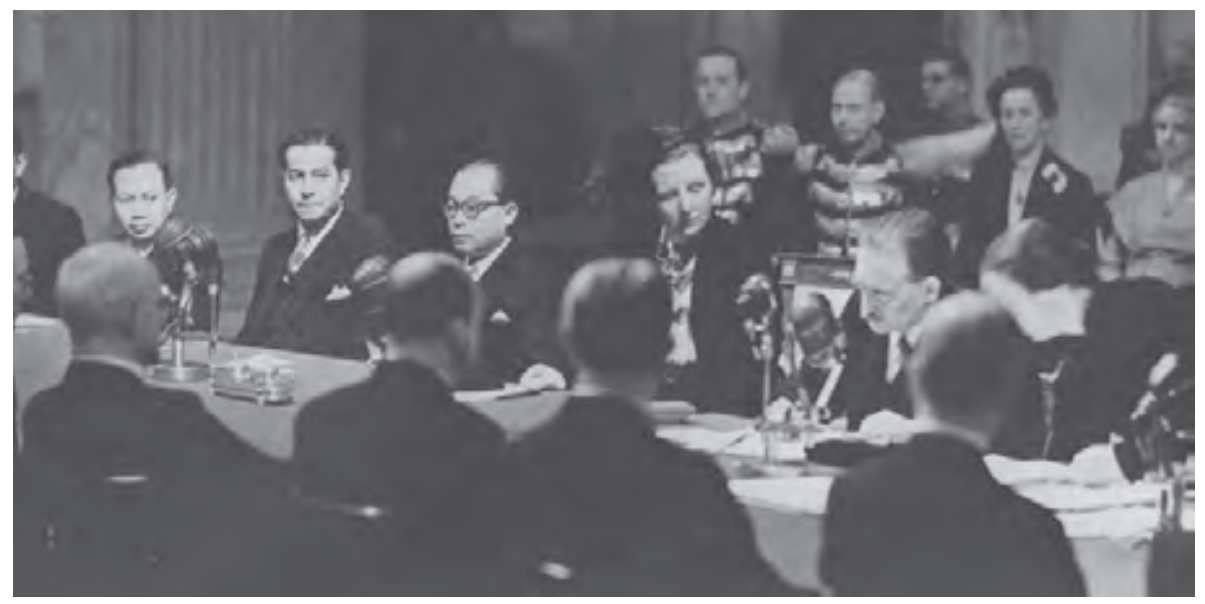

27 december 1949: De Nederlandse soevereiniteitsoverdracht in Amsterdam. Drees ondertekent; naast hem koningin Juliana, Hatta, sultan Hamid en Soepomo. 


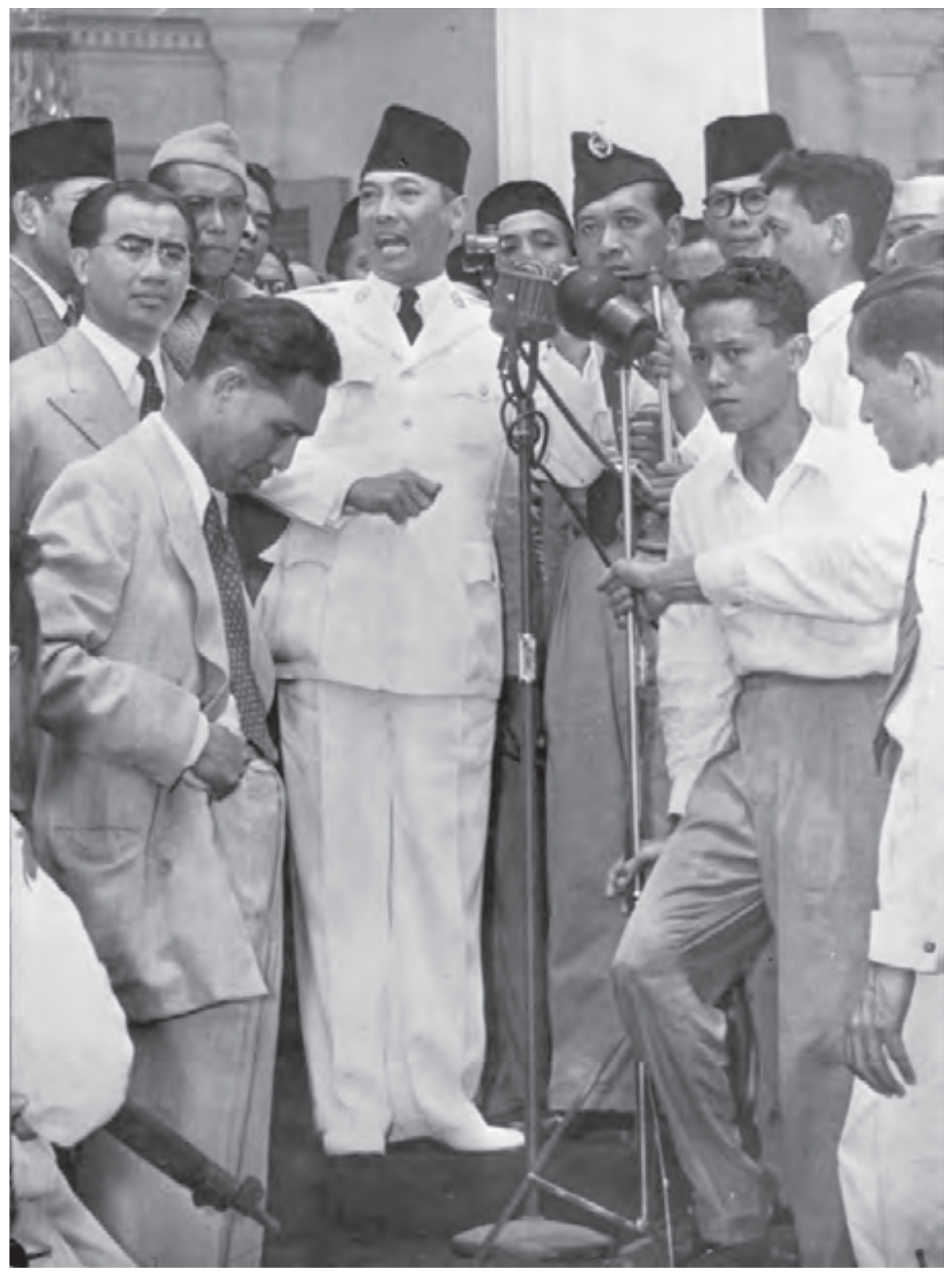

28 december 1949: Na aankomst in Djakarta spreekt president Soekarno de menigte toe vanaf het bordes van het vroegere paleis van de gouverneurs-generaal. Links van hem Anak Agoeng (met bril), daarvoor Leimena, rechts boven de microfoons de sultan van Jogja. 
S.H. Spoor, de directeur van de NEFIS, een rapport met bijzonderheden over de tijdens de oorlog door de Japanse bezettingsmacht op Java gevormde politieke en militaire organisaties. Het rapport, opgesteld op basis van opgevangen radiouitzendingen, waarschuwde naar aanleiding van de vorming van de Republiek Indonesië dat men nog geen voorspelling kon doen over de graad van fanatisme van enige wanhopige leiders en groepen en over de daden die daaruit zouden kunnen voortvloeien. Maar tegelijk concludeerde dit NEFISrapport: 'De radioberichten [...] maken zeker niet den indruk, dat de bevolking bezield is door een fanate bereidheid achter deze collaboristen-leiders te staan in een strijd voor een geheel zelfstandig Indonesië. Integendeel, afgaande op de officeele berichten is het zelfs moeilijk de onafhankelijkheidsbeweging geheel au serieux te nemen.' Logemann keerde naar Nederland terug met de vaste overtuiging dat de Republiek uitsluitend een Japans maaksel was, dat de meeste Indonesiërs de regering-Soekarno als een groep Japanse marionetten beschouwden en dat een spoedig en krachtig optreden tegen deze regering weinig van haar invloed onder de bevolking zou overlaten.

In de Nederlandse pers verschenen intussen berichten over de verwarde toestand op Java en ook over de in Singapore door minister Lawson en generaal Christison gedane uitlatingen. De strekking van die uitlatingen werd bevestigd door het telegram dat Van der Plas op 28 september uit Singapore verstuurd had, waarin hij Van Mook inlichtte over een onherroepelijk Brits regeringsbesluit om geen Britse troepen te gebruiken voor het onderdrukken van opstanden in Nederlands-Indië en waarin hij machtiging vroeg om besprekingen met Soekarno en Hatta te beginnen. Logemann gaf de inhoud van dit telegram onmiddellijk aan Schermerhorn door.

Het was duidelijk dat een reactie van de Nederlandse regering dringend nodig was. Schermerhorn belegde op 29 september een bespreking met enkele ministers en vervolgens op zondag 30 september een spoedvergadering van de ministerraad. Aan beide vergaderingen werd deelgenomen door de gouverneur-generaal van Nederlands-Indië, A.W.L. Tjarda van Starkenborgh Stachouwer, die tijdens de oorlog in Japanse krijgsgevangenschap verkeerd had maar midden september in Nederland teruggekeerd was. Men werd het erover eens dat Nederland in de huidige situatie geen enkele politieke concessie aan de Indonesische nationalisten moest doen omdat dit het Nederlandse gezag alleen maar zou verzwakken. Tjarda ging hierin het verst. Hij zei: 'Of de Britten ons op de troon willen helpen, is hun zaak. Doen zij het niet, dan zijn wij Nederlands-Indië kwijt, doch dat mag ons niet verleiden ons nu in dit stadium zwak te tonen.' Men zond een instructie aan Van Mook die als hoofdlijn aangaf 'dat Soekarno-incident moet worden beschouwd en behandeld als nagalm van Japanse agressie' en aan Van Mook opdroeg in zijn houding en zijn uitlatingen duidelijk te maken dat politieke beloften nu niet aan de orde waren.

Intussen kwam een uitvoerig telegram van Van Mook zelf binnen. Daarin 
vroeg hij de regering terstond een wijziging van de Britse houding te bewerkstelligen; tegelijk pleitte hij er ook voor zich duidelijker uit te spreken over de toekomstige status van Nederlands-Indië, bijvoorbeeld als deelgenoot in het Koninkrijk met een eigen verantwoordelijke regering, te bereiken in vijfentwintig jaar. Zijns inziens zou men het begin van die ontwikkeling kunnen onderstrepen door enkele concrete daden zoals opheffing van het dualistische bestuursstelsel en van de tweedeling in de rechtspraak. Logemann, die aan de vergadering van 30 september deelnam, wilde op Van Mook's gedachte ingaan, maar kreeg hiervoor geen enkele steun. Schermerhorn en Tjarda bleven van mening dat men uitspraken over hervormingen pas zou mogen doen na herstel van het Nederlandse gezag.

Het beraad leidde tot het uitgeven van een officiële verklaring waarin de regering het voeren van besprekingen met het 'zogenaamde Soekarno-bewind' volstrekt afwees. Soekarno, aldus de verklaring, was een fascistisch georiënteerde man die zich ertoe geleend had werktuig en marionet der Japanners te zijn; met deze figuur zouden vertegenwoordigers van het wettig gezag niet om de tafel kunnen zitten. De regering zou zich niet af laten brengen van het beleid zoals aangegeven in de rede van de koningin van 7 december 1942, waarin volledig deelgenootschap van Nederlands-Indië in het Koninkrijk en zelfstandigheid in inwendige aangelegenheden in uitzicht waren gesteld.

Deze regeringsverklaring verscheen op 1 oktober in de Nederlandse pers. Logemann was toen in Londen voor overleg met de Britse regering. Intussen berichtten de nieuwsmedia dat Van der Plas diezelfde dag in Batavia had aangekondigd Soekarno en Hatta te zullen uitnodigen voor gesprekken over de toekomst van Indonesië. 's Avonds verklaarde Logemann aan journalisten in Londen dat Van der Plas hiertoe niet bevoegd geweest was en dat de Nederlandse regering hem onmiddellijk tot de orde zou roepen. Logemann's desavouering van Van der Plas trok meer aandacht dan de Nederlandse regeringsverklaring van 30 september.

Op 3 oktober gaf de regering een nieuwe verklaring uit, opgesteld door Schermerhorn, Logemann en de minister van binnenlandse zaken, L.J.M. Beel. In deze tweede verklaring herhaalde zij haar weigering van contact met lieden die door Japan in het zadel waren gezet, maar deed zij tegelijk een beroep op alle Indonesiërs om in gezamenlijk overleg te blijven werken aan de nieuwe status van het Koninkrijk. Daarbij zou de eenheid van het rijk echter onbestreden moeten vaststaan; zonder deze gemeenschappelijk aanvaarde grondslag zou iedere gedachtewisseling onmogelijk zijn.

De politieke strekking van deze regeringsverklaring ging aanzienlijk verder dan die van de vorige. Zij betekende dat de regering niet slechts overleg met Soekarno weigerde, maar dat zij onafhankelijkheid voor Indonesië categorisch afwees en aan de bevolking van dat land het recht op zelfbeschikking ontzegde. 
Het standpunt van de regering vond steun bij vele maar niet bij alle delen van het Nederlandse publiek. Een veel positievere opstelling tegenover het Indonesisch nationalisme werd onder meer bepleit door Het Parool, een invloedrijk dagblad van socialistische signatuur dat uit het verzet tegen de Duitse onderdrukking voortgekomen was. Intussen verscheen in de pers een verklaring van de Indonesische vereniging Perhimpoenan Indonesia, waarin zij weliswaar Soekarno's samenwerking met Japan afkeurde maar ook zei vast te houden aan haar doelstelling van Indonesische onafhankelijkheid, terwijl zij met klem tegensprak dat de Republiek slechts een minderheid van het Indonesische volk zou vertegenwoordigen. Deze vereniging belegde op 4 oktober een demonstratieve bijeenkomst in het Amsterdamse Concertgebouw, waar tweeduizend Nederlanders en Indonesiërs aan deelnamen die onder meer werden toegesproken door de hoofdredacteur van Het Parool en de hoofdredacteur van het eveneens uit het verzet voortgekomen weekblad Vrij Nederland.

Onder de Nederlanders in Indonesië was een positieve houding tegenover het Indonesisch nationalisme nog zeldzamer dan onder die in Nederland, maar totaal afwezig was zo'n houding niet. Hiervan getuigde een verklaring die een groep Nederlandse sociaal-democraten in Indonesië op 3 oktober aan minister Drees zond met verzoek die door te geven aan het partijbestuur van de SDAP. Eén van de ondertekenaars was Ch.G. Cramer, die van 1918 tot 1923 lid van de Volksraad geweest was en vervolgens tot 1937 in het Nederlandse parlement als Indonesië-expert van de SDAP was opgetreden. Een andere ondertekenaar was J. de Kadt, die tijdens de oorlog in Japanse kampen geïnterneerd was geweest maar voor zijn internering nog contact had gehad met Sjahrir, met wie hij al bevriend was geraakt toen deze in Nederland studeerde. In haar verklaring aan het SDAP-bestuur herhaalde de groep onder meer de principiele opvatting dat het Indonesische volk recht had op volledige onafhankelijkheid. Zij meende dat Nederland onmiddellijk een volledig zelfbestuur van Indonesië in het vooruitzicht moest stellen. Het gouverneur-generaalschap diende te verdwijnen; in plaats daarvan zou er in Indonesië een Nederlandse Hoge Commissaris en in Den Haag een Indonesische Hoge Commissaris moeten komen. Volgens de groep kon de Soekarno-Hatta-beweging beschouwd worden als de voornaamste vertegenwoordiging van het Indonesische volk. Wel zouden deze leiders zich duidelijk moeten uitspreken over hun houding tijdens de Japanse overheersing.

\section{Eerste geallieerde troepenlandingen in Indonesië na de Japanse capitulatie}

Het Britse South-East Asia Command was sinds 15 augustus binnen zijn gezagsgebied, waaronder Indonesië, verantwoordelijk voor de ontwapening en repatriëring van de Japanse militairen, de opvang en bescherming van 
de geallieerde krijgsgevangenen en geïnterneerden en de voorbereiding van de terugkeer van het burgerlijk bestuur. Omdat men aan Britse kant hiertoe niet over voldoende mankracht beschikte, was het Australische leger met deze taken belast voor alle delen van Indonesië buiten Sumatra, Java, Bali en Lombok. Dit leger kon deze taken vrij gemakkelijk uitvoeren omdat het zich al met twee divisies in of nabij de toegewezen gebieden bevond en omdat die gebieden geen grote bevolkingsconcentraties bevatten. Bovendien waren enkele delen hiervan al voor het eind van de oorlog in geallieerde handen en bevonden zich hier ook verscheidene KNIL-eenheden die aan de strijd met de Japanners hadden deelgenomen.

Het Australische leger nam in de loop van september en de eerste helft van oktober in oostelijk Indonesië en op Borneo de macht over van de Japanse marine. De Australische bezettingseenheden werden steeds vergezeld door NICA-teams; soms namen ook Nederlandse KNIL- of marine-eenheden aan de bezetting deel. De Australische landingen ontmoetten geen verzet van de bevolking.

In vergelijking met de Australiërs hadden de Britten een veel omvangrijkere taak: zij moesten niet alleen naar Indonesië bezettingstroepen zenden, maar ook naar Birma, Thailand, Malakka, Singapore, Indochina en Hongkong. Volgens de aanvankelijke plannen bestemde SEAC voor Sumatra en Java twee infanteriedivisies die daar pas in oktober-november aan land zouden gaan en zich zouden beperken tot het bezetten van sleutelposities in Medan, Padang, Batavia en Soerabaja. Later besloot men de landing bij Batavia te vervroegen naar eind september. Bovendien werd het in oktober duidelijk dat men niet met de bezetting van de vier genoemde plaatsen kon volstaan, omdat de geïnterneerden het doelwit werden van een golf van revolutionair geweld (zie p. 400). SEAC besloot daarom ook in Palembang, Buitenzorg, Bandoeng, Semarang en Malang troepen te legeren en aan de militaire leiding in Londen toestemming te vragen om nog een derde infanteriedivisie en een pantserbrigade naar Indonesië te dirigeren.

Overigens bezetten de Britten al op 3 september een stukje NederlandsIndisch grondgebied, namelijk het ten noorden van Atjeh gelegen eiland met de haven van Sabang. Dat gebeurde echter niet in het kader van de herbezetting van Indonesië, maar in dat van de herbezetting van Malakka en Singapore. Wel werd hier terstond de Nederlandse vlag gehesen

De eerste geallieerde landing op Java vond op 28 en 29 september plaats, toen een uit Schotten bestaand bataljon van achthonderd man ontscheept werd in de haven van Batavia. Ook mocht een honderdtal Nederlandse mariniers dat zich aan boord van de kruiser 'Tromp' bevond nu aan wal gaan om aan de bezetting deel te nemen. De geallieerde militairen werden door de inheemse bevolking zwijgend ontvangen. Het Schotse bataljon vormde slechts een voorhoede; het hoofdbestanddeel van de bezettingsmacht voor Batavia 
werd gevormd door twee voornamelijk uit Indiërs bestaande brigades, waarvan de eerste enkele dagen later aankwam. Britse militairen bezetten verschillende punten binnen de stad. Christison zelf nam zijn intrek in de vroegere ambtswoning van de Britse consul-generaal (waarin tot voor kort de Japanse schout-bij-nacht Maeda gewoond had).

In Batavia arriveerden bovendien in de eerste helft van oktober verscheidene Nederlandse legereenheden, deels per vliegtuig, deels per schip. Dit waren zeven uit Borneo en Australië overgebrachte KNIL-compagnieën van elk ongeveer honderd man, voornamelijk Ambonezen, Menadonezen en Surinamers, en een in Singapore uit ex-krijgsgevangenen gevormd KNILbataljon van ongeveer zeshonderd man. Christison stelde deze eenheden ten zuiden van de stad op. Het bevel over dit Nederlandse contingent werd opgedragen aan generaal-majoor W. Schilling, die ook in maart 1942 in de strijd tegen Japan troepen in het westen van Java aangevoerd had en die na terugkeer uit krijgsgevangenschap korte tijd aan de staf van Mountbatten toegevoegd geweest was.

Na de geallieerde bezetting van Batavia kwam eerst Sumatra aan de beurt. Begin oktober vloog Christison hierheen en bezocht hij er het Japanse hoofdkwartier; ook sprak hij met de Republikeinse gouverneur Hassan. Vervolgens gingen Britse troepen op 10 oktober bij Padang en bij Medan aan land. In beide plaatsen ontmoetten ze geen verzet en bezetten ze een deel van de stad. In dezelfde geest volgde anderhalve week later een landing bij Palembang. Bovendien landde toen een uit Batavia vertrokken detachement Nederlandse mariniers samen met een NICA-team op het tin-eiland Biliton, de eerste geheel door Nederlanders uitgevoerde herbezetting. In het kader van de verdere bezetting van Java begaven twee Britse bataljons zich midden oktober van Batavia over de weg en per spoor naar Buitenzorg en Bandoeng en ging op 19 oktober een Brits bataljon in Semarang aan land. Tenslotte landde op 25 oktober een Britse brigade in Soerabaja. Zowel de in Semarang als de in Soerabaja ontscheepte troepen raakten al spoedig verwikkeld in hevige gevechten met Indonesische strijdgroepen (zie pp. 411-7). De derde infanteriedivisie, die in november beschikbaar kwam, werd daarom naar Soerabaja gedirigeerd. Van de bezetting van Malang moest men afzien.

Onder de geallieerde troepen die met de bezetting van Indonesië begonnen bevonden zich, zoals vermeld, ook enige Nederlandse KNIL- en marineeenheden die uit Australië en Azië afkomstig waren. Daarentegen namen nog in het geheel geen Nederlandse troepen uit Europa aan die bezetting deel. Weliswaar had de Nederlandse regering al voor de Japanse capitulatie plannen gemaakt om uit vrijwilligers een aantal bataljons te vormen voor de gezagshandhaving in Indonesië, maar zij was bij de uitvoering van die plannen op moeilijkheden gestuit. Als gevolg daarvan konden de eerste voor Indonesië bestemde Nederlandse bataljons pas in oktober uit Europa vertrekken. 


\section{Terugkeer van Van Mook in Batavia}

Op 2 oktober kwam Van Mook met enkele medewerkers per vliegtuig in Batavia aan. Zij vestigden zich in het paleis van de gouverneur-generaal dat intussen door de Japanse opperbevelhebber verlaten was. Verder arriveerde op 4 oktober een groep NICA- en NEFIS-personeel met één van de laatste KPM-schepen die uit Australië hadden kunnen vertrekken.

Op het punt van zijn bevoegdheden was de positie van Van Mook tweeslachtig. Hij vervulde de functie van opperste chef van de NICA en was in die hoedanigheid verantwoording verschuldigd aan Mountbatten, maar tegelijkertijd was hij waarnemend hoofd van het Nederlands-Indische gouvernement, in welke hoedanigheid hij de Nederlandse regering vertegenwoordigde en aan die regering verantwoording verschuldigd was. Een soortgelijke tweeslachtigheid gold voor het onder hem staande NICA-personeel: men kon dat als een civiel onderdeel van de Britse bezettingsmacht zien, maar ook als een orgaan van het Nederlands-Indische gouvernement.

In zijn Nederlandse functie beschikte Van Mook over bijna dictatoriale bevoegdheden dank zij een in 1943 door hemzelf ontworpen en door de regering in Londen vastgestelde overgangsregeling (zie pp. 321-2). Onder de voor de oorlog geldende Indische Staatsregeling had de gouverneur-generaal ook al grote macht bezeten, maar voor tal van besluiten was toen instemming van de Raad van Indië nodig, terwijl wetgeving alleen met medewerking van de Volksraad tot stand kon komen. Daarentegen machtigde de overgangsregeling de luitenant-gouverneur-generaal om bij ontbreken van de Volksraad en de Raad van Indië zelf ordonnanties (wetsbesluiten) en andere belangrijke besluiten vast te stellen mits de raad van departementshoofden daarmee instemde. Dit laatste was geen ingrijpende beperking, daar deze raad geen onafhankelijk orgaan was maar alleen een college van hoge ambtenaren. Een belangrijkere beperking was dat de luitenant-gouverneur-generaal ook onder de overgangsregeling verplicht bleef de aanwijzingen van de Nederlandse regering in acht te nemen.

Voorlopig kon Van Mook echter met zijn grote bevoegdheden weinig beginnen. Op Java was het feitelijke bestuur vrijwel overal in handen van de Republiek Indonesië; ook in Batavia beheerde de Republiek alle departementen en vitale diensten. Het straatbeeld werd er overheerst door rood-witte vlaggen en nationalistische opschriften. Hoewel de nationalistische revolutie een steeds gewelddadiger karakter kreeg, zowel in als buiten Batavia, onderhield de Republiek goede relaties met de internationale pers; Soekarno zelf stelde zich graag open voor contacten met buitenlandse journalisten. De berichten over de uitlatingen van Christison en Lawson hadden intussen het zelfvertrouwen van de Republikeinse leiders zeer versterkt. Weliswaar had Christison sindsdien gezegd dat hij verkeerd geciteerd was en dat hij de 
Nederlandse soevereiniteit volledig erkende, maar dit maakte weinig indruk meer: de nationalisten gingen er nu van uit dat Groot-Brittannië zijn militaire macht niet zou gebruiken om de Nederlandse overheersing te herstellen. Tegelijk was de Britse bezettingsmacht zelf op Republikeinse medewerking aangewezen omdat alle openbare diensten door de Republiek werden beheerd. Zo was de voorziening van Batavia met drinkwater en elektriciteit afhankelijk van buiten de stad gelegen installaties.

Van Mook zag met ongeduld uit naar de KPM-schepen die de in Australië bijeengebrachte hulpgoederen zouden aanvoeren, maar de boycot van de Australische havenarbeiders duurde voort en de hulpgoederen kwamen niet. Ook zag hij uit naar de komst van de infanteriebataljons uit Nederland, maar begin oktober waren zelfs de eerste daarvan nog niet naar Indonesië vertrokken. Intussen was hijzelf in pijnlijke mate afhankelijk van het Britse bezettingsbestuur. Na zijn terugkeer in Batavia duurde het bijvoorbeeld enige dagen voordat dit bestuur toestemming gaf tot het hijsen van de Nederlandse vlag op het paleis van de gouverneur-generaal. Nog ernstiger was het dat dit bestuur voorlopig niet bereid was de NICA op Java in te schakelen.

Bij de opbouw van zijn eigen bestuur liet Van Mook zich voornamelijk bijstaan door mensen met wie hij eerder in Australië had samengewerkt. Hij wilde geen gebruik maken van de door Spit geleide groep Nederlanders die zich al tijdens hun internering er op hadden voorbereid het bestuur van de Japanners over te nemen. Naar zijn mening hadden deze lieden geen besef van de volkomen veranderde politieke constellatie. Nog op 26 september had Spit hem gerapporteerd dat de grote massa van de inheemse bevolking en zelfs de gematigde nationalisten niet achter de Republiek stonden. Overigens was Spit formeel geen vice-president van de Raad van Indië meer omdat zijn ambtstermijn was verstreken.

\section{De gewelddadige fase van de Indonesische revolutie}

Kort na de capitulatie van Japan had het Japanse militaire bestuur van Java zowel de Peta- als de Heiho-eenheden ontwapend en ontbonden; op Sumatra waren overeenkomstige maatregelen genomen. De Japanse bestuurders konden echter niet ongedaan maken dat ze tijdens de bezetting Indonesische jongeren op grote schaal militair getraind en geïndoctrineerd hadden. Sinds eind augustus ontstonden op Java en Sumatra ontelbare zelfstandige strijdgroepen, grotendeels bestaande uit militante jongeren (pemoeda's). Soms vormden exPeta-officieren zulke groepen uit hun vroegere soldaten; soms kwamen zulke groepen voort uit de Barisan Pelopor of andere paramilitaire organisaties. Al deze strijdgroepen schaarden zich fanatiek achter de onafhankelijkheid van Indonesië; verscheidene hadden bovendien een ideologische grondslag zoals de islam of het marxisme. 
Gedurende de eerste weken na de Japanse capitulatie had in Indonesië een redelijke mate van veiligheid en orde geheerst. Nederlanders die de interneringskampen op Java en Sumatra verlieten ontmoetten toen weinig vijandigheid van de kant van de Indonesische bevolking en konden bijvoorbeeld ongehinderd in treinen reizen. Een maand later was dit niet meer mogelijk. Terwijl de ijzeren greep van het Japanse bezettingsbestuur verslapte, stelden de pemoeda's zich steeds agressiever op en gingen zij vaker tot geweld over. In oktober zwol dit op Java aan tot een storm van gewelddadigheid, gericht zowel tegen Japanners als tegen Europeanen en Indo-Europeanen en bovendien tegen Indonesiërs die geacht werden de terugkeer van het koloniale bestuur te steunen. Zowel om elkaar aan te vuren als om elkaar te waarschuwen gebruikten de pemoeda's veelvuldig de kreet 'Bersiap!' (Wees paraat!), dikwijls verkort tot 'siap'. Naar die strijdkreet is deze episode bekend geworden als de 'bersiap-tijd'.

Al in de beginfase van de Republiek was het optreden van de militante jongeren soms van bedreigingen vergezeld gegaan. De eerste gevallen van daadwerkelijk geweld betroffen voornamelijk vlagincidenten, zoals botsingen met Japanners die de Republikeinse vlag verwijderden of met IndoEuropeanen die de Nederlandse vlag wilden hijsen. Tot gewelddadigheid op grotere schaal kwam het eind september toen de Republikeinse strijders zich er op richtten zo veel mogelijk wapens van de Japanners in handen te krijgen. Zowel individuele Japanse militairen als kleine legereenheden werden aangevallen en ontwapend, er vonden overvallen plaats op wapendepots en op tal van plaatsen kwam het voor dat een met bamboesperen en kapmessen bewapende menigte een Japanse post of kazerne belegerde om die tot overdracht van wapens te dwingen. Overigens nam de bereidheid aan Japanse kant om wapens over te dragen aanmerkelijk toe nadat generaal Christison gezegd had dat de Indonesische autoriteiten voor het bestuur verantwoordelijk waren; veel Japanse autoriteiten achtten zich daardoor van hun verantwoordlijkheid voor de openbare orde ontslagen.

Begin oktober dachten veel Indonesiërs dat het Nederlandse koloniale bestuur op het punt stond de macht weer in handen te nemen. Het door de pemoeda's ontketende geweld escaleerde nu tot een teugelloze terreur tegen blanke en Indische Nederlanders. Strijdgroepen omsingelden en belegerden de interneringskampen, zodat de geïnterneerden voor hun bescherming afhankelijk werden van dezelfde Japanse vijand die hen eerst opgesloten en bewaakt had. Ook Indische Nederlanders die tijdens de bezetting niet geïnterneerd geweest waren zochten nu dikwijls bescherming in die kampen. Van de Nederlanders die zich buiten de kampen bevonden werden velen gedood of gevangen genomen; de gevangenen stonden vaak aan mishandeling bloot. De acties van de pemoeda's richtten zich ook tegen Indonesiërs die van een proNederlandse gezindheid verdacht werden, zoals Ambonese en Menadonese 
KNIL-militairen en hun gezinnen. Herhaaldelijk stonden ook Chinezen bloot aan geweld.

De bersiap-terreur vertoonde anarchistische trekken. De pemoeda's in verschillende delen van het land hadden onderling wel contact, maar hun activiteiten werden niet uit één centraal punt geleid. Zij toonden weinig bereidheid zich te voegen naar de aanwijzingen van de Republikeinse bestuursambtenaren en nationale comités. Binnen de jongerengroepen drongen de meest radicale en fanatieke leden de meer gematigde figuren naar de achtergrond. Vaak gaven die fanatici zowel blijk van doodsverachting als van grote wreedheid. De pemoeda's belemmerden ook het werk van de RAPWI die zij gewoonlijk zagen als een voorhoede van het koloniale bestuur. Zij namen herhaaldelijk Nederlands en soms zelfs Brits RAPWI-personeel gevangen. De Britse verantwoordelijkheid voor de veiligheid van de geïnterneerden leidde vooral in Midden-Java en Soerabaja tot hevige gewapende conflicten tussen Britten en Indonesiërs (zie pp. 411-7).

$\mathrm{Nu}$ en dan raakten losse strijdgroepen onderling slaags. De toestand werd verder gecompliceerd door het optreden van gewone roversbenden die profiteerden van de algemene gezagscrisis. Zo raakten revolutionair geweld en pure criminaliteit met elkaar vermengd. Dit gold ook voor de praktijk van veel pemoeda's om goederen die zij nodig meenden te hebben zonder vergoeding in beslag te nemen. Zij achtten zich hiertoe gerechtigd omdat zij de nationale onafhankelijkheid verdedigden zonder soldij te ontvangen, maar intussen schiep deze praktijk ook gelegenheid voor pure roof onder de dekmantel van de rood-witte vlag.

Hoewel Batavia zelf onder Brits gezag stond, bleef het niet verschoond van de storm van geweld. Er ging vrijwel geen dag voorbij zonder schietpartijen, moorden en ontvoeringen. Nederlanders liepen alleen in bepaalde stadswijken geen of weinig gevaar. Buiten de stad was het zeer onveilig. Zo werden soms Nederlanders die per spoor van Bandoeng naar Batavia onderweg waren op een tussenstation uit de trein gehaald en gedood. Ten westen en ten zuiden van Batavia vochten pemoeda's met de KNIL-troepen van generaal Schilling. Tegelijk keerden zij zich ook hier tegen Indonesiërs die zij voor pro-Nederlands hielden. Halverwege Batavia en Buitenzorg woonde in Depok een Indonesische christengemeenschap die al uit de achttiende eeuw dateerde (zie p. 52) en nu ruim tweeduizend personen telde. Pemoeda's overvielen deze gemeenschap, sloten de vrouwen en kinderen op en voerden alle mannen weg. Pas nadat Britse militairen midden oktober Buitenzorg hadden bezet konden de beide groepen worden bevrijd. Van de mannen waren toen al tientallen afgeslacht.

Soekarno en Hatta probeerden vergeefs de vloedgolf van geweld in te dammen. In een uitvoerige oproep van 27 oktober keerden zij zich tegen ieder eigenmachtig optreden in de vorm van bedreiging, dwang, gevangenneming 
of executie. Zij waarschuwden dat zulk optreden een chaos veroorzaakte die het voortbestaan van de Republiek in gevaar bracht. De veiligheid van allen die zich op Republikeins gebied bevonden, met inbegrip van Nederlanders en Indo-Europeanen, diende gewaarborgd te zijn. Gevangenen, onverschillig van welke nationaliteit, moesten menselijk behandeld worden.

Deze oproep had weinig effect. De pemoeda's bleven eigenmachtig optreden tegen allen die zij als vijanden van de onafhankelijkheid beschouwden. Vaak keerden zij zich ook tegen de traditionele Indonesische ambtsaristocratie. Verscheidene regenten en andere bestuursambtenaren werden door hen afgezet, sommigen werden gevangen genomen, sommigen vermoord. De bersiap-furie maakte zelfs slachtoffers onder de nationalistische leiders. Eén van hen was minister Oto Iskandar Dinata, die in Bandoeng tussen het Japanse bestuur en de plaatselijke strijdgroepen bemiddeld had. Hij werd door pemoeda's ontvoerd en gedood.

Soms leidde het door de pemoeda's ontketende geweld tot felle tegenacties. Eén daarvan werd eind november ondernomen door Ambonese KNILmilitairen die met hun vrouwen en kinderen in Batavia gelegerd waren: toen enige van hun gezinnen op weg naar een kerkdienst waren beschoten uit een politiepost, doodden zij de volledige bezetting van die post. Van Britse kant werd op 12 december een zware represaille uitgevoerd in Bekasi, een plaats van een paar duizend inwoners ten oosten van Batavia waar ook al eens reizigers uit de trein gehaald en gedood waren. Eind november had een Brits militair vliegtuig in deze streek een noodlanding gemaakt. De inzittenden, vijf Europese Britten en achttien Brits-Indiërs, waren door de bevolking gevangen genomen en naar Bekasi weggevoerd, waar ze enkele dagen later ten aanschouwe van een grote menigte verminkt en gedood werden. Het duurde enige tijd voordat in Batavia bekend werd wat er gebeurd was. Generaal Christison besloot een afschrikwekkend voorbeeld te stellen en liet een groot deel van Bekasi, waarvan de bevolking intussen gevlucht was, door Britse militairen in brand steken.

De bersiap-furie bleef niet tot Java beperkt. Ook delen van Sumatra raakten in de greep van extreem geweld, ook daar omsingelden en bedreigden pemoeda's de internerings- en krijgsgevangenenkampen. Er waren echter belangrijke verschillen met de situatie op Java. In feite keerde het geweld van de pemoeda's zich op Sumatra in hoofdzaak tegen Indonesiërs. De voornaamste uitbarstingen vonden hier in de eerste maanden van 1946 plaats, toen de storm op Java al geluwd was. In Atjeh leidde dit tot uitschakeling van de feodale volkshoofden, waarna het bestuur geheel bij radicale moslimvoorgangers kwam te berusten. In Deli en sommige andere gebieden aan de oostkust richtten pemoeda's een bloedbad aan onder de plaatselijke vorsten en hun families. Zulke omwentelingen, waarbij een traditionele bestuurselite van haar macht beroofd werd, kwamen bekend te staan als 'sociale revoluties'. Ook op Java kwam dit voor. 
Het totale aantal slachtoffers van de bersiap-furie is niet bekend; aan Nederlandse kant lag het dodental boven de vijfendertighonderd. Deze storm van gewelddadigheid had bovendien van begin af aan belangrijke politieke gevolgen. In de eerste plaats deed zij afbreuk aan het internationale aanzien van Soekarno en zijn regering. Die bleken immers geen werkelijk gezag te kunnen uitoefenen over de militante jongeren en de hierdoor opgezweepte delen van de bevolking. De door de nationalistische leiders zorgvuldig voorbereide politieke omwenteling die in augustus gestalte had gekregen in de stichting van de Republiek Indonesië leek in oktober en november te worden overspoeld door het anarchistische geweld dat de pemoeda's hadden ontketend.

Nog ernstiger was het effect van de bersiap-terreur op de publieke opinie in Nederland. Bij een groot deel van de Nederlandse bevolking werd het beeld van de situatie op Java overheerst door de berichten over het geweld dat daar woedde onder aanvoering van door de Japanners geïndoctrineerde jongerengroepen. Bijzondere ontzetting wekten de tegen de bewoners van Depok gepleegde wandaden, een drama dat het eerst door Nederlandse journalisten aan het licht was gebracht en dat bovendien christenen betrof. Voor veel Nederlanders leek het duidelijk dat in Indonesië sprake was van een terreur waar men alleen met hardhandig ingrijpen een eind aan zou kunnen maken. Vaak maakten zij daarbij geen onderscheid tussen de geweldplegers zelf en de leiders van de Republiek. De meeste van deze Nederlanders hadden tot september 1945 niets geweten over de al lang voor de oorlog bestaande Indonesische vrijheidsbeweging en over de voormannen daarvan. Daarom zagen zij Soekarno en Hatta uitsluitend als zetbazen van Japan en hielden zij hen voor de eigenlijke aanstichters van het op Java woedende geweld.

Logemann schreef op 9 november aan Van Mook: 'De verhalen over het lijden der Nederlanders hebben een Lombokexpeditie-stemming doen ontstaan, een Teukoe Oemar psychologie'. Hij doelde daarmee op de uitbarstingen van volkswoede waarmee men in Nederland een halve eeuw eerder gereageerd had op tegenslagen bij de vestiging van het Nederlandse gezag in de Indische archipel, tegenslagen die men destijds (zie pp. 112, 118 en 124) betiteld had als 'het verraad van Lombok' en 'het verraad van Teukoe Oemar'. Maar ook Nederlanders die de Indonesische vrijheidsbeweging goed gezind waren werden door dit geweld voor een dilemma geplaatst. Het ging nu niet om de vraag of men Indonesië in de toekomst onafhankelijkheid gunde, maar om de acute vraag hoe men mensenlevens kon beschermen in gebied waarvoor Nederland nog steeds de verantwoordelijkheid droeg. 


\section{Oprichting van het Republikeinse leger}

In augustus hadden de stichters van de Republiek er om tactische redenen mee ingestemd dat het Japanse militaire bestuur de Peta- en de Heiho-eenheden ontwapende en ontbond. Tegelijk hadden zij op Java een nieuw gewapend korps opgericht, de Badan Keamanan Rakjat (BKR, Volksveiligheidskorps, zie p. 378). De voormalige Peta- en Heiho-militairen werden aangemoedigd om tot dit korps toe te treden. Deze BKR was opgezet op residentie-basis, waardoor ze in feite uit los van elkaar staande formaties bestond onder leiding van de nationale comités van de afzonderlijke residenties.

Hoewel de BKR in de loop van september geleidelijk van de grond kwam, ontwikkelde zij zich niet echt tot de sterke arm van de Republiek. Slechts een deel van de vroegere Peta- en Heiho-soldaten trad tot haar gelederen toe. Tegelijkertijd verslechterde de openbare veiligheid door het agressieve optreden van veel autonome strijdgroepen. Terwijl de BKR geen overwicht op die strijdgroepen kreeg, had de Republikeinse regering zelf weinig zeggenschap over de BKR, die nu eenmaal niet onder centrale leiding stond.

Op 5 oktober besloot deze regering de BKR te vervangen door een centraal geleideorganisatie, de Tentara Keamanan Rakjat(TKR, Volksveiligheidsleger). Tot opperbevelhebber benoemde zij een Peta-officier die in februari de antiJapanse opstand in Blitar (zie p. 330) geleid had en sindsdien vermist werd, maar die volgens geruchten nog in leven zou zijn. Als chef-staf stelde zij een voormalige KNIL-officier aan, Oerip Soemohardjo, één van de zeer weinige Indonesiërs die in het koloniale leger de rang van majoor bereikt hadden. Kort voor de oorlog had hij ontslag uit dat leger genomen, tijdens de Japanse bezetting had hij zich onthouden van samenwerking met de bezetters en had hij zich ontwikkeld tot een overtuigd nationalist. Als chef-staf bleek Oerip een goede organisator te zijn die enige orde wist te scheppen in de chaos van los van elkaar optredende strijdformaties en aldus de grondslag legde voor een nationaal Indonesisch leger. Vooral in het begin verliep de opbouw van dit leger moeizaam, omdat de afzonderlijke formaties op hun zelfstandigheid gesteld waren terwijl binnen die formaties vaak een sterke vertrouwensband tussen aanvoerder en manschappen bestond. Meer dan eens toonden onderdelen van de TKR zich niet bereid een van hogerhand benoemde commandant te aanvaarden en stonden ze er op zelf hun aanvoerders te kiezen.

Het centrale hoofdkwartier van de TKR werd in Jogjakarta gevestigd. In naam leek het nieuwe leger evenals de BKR tot taak te hebben de interne veiligheid te verzekeren, maar in feite was het bedoeld voor de externe verdediging van de Republiek. Weliswaar konden de Republikeinse leiders ervan uitgaan dat Groot-Brittannië niet bereid was zijn militaire macht te gebruiken om de Republiek uit de weg te ruimen, maar zij hadden alle reden om aan te 
nemen dat Nederland daar wel degelijk toe bereid zou zijn wanneer het over voldoende machtsmiddelen beschikte.

Voor de opbouw van een eigen strijdmacht kon de Republiek uit een groot reservoir aan mankracht putten. Java alleen telde al ruim vijftigduizend uit de Peta- en Heiho-formaties afkomstige ex-militairen en daarnaast miljoenen jongeren die onder de Japanse bezetting een paramilitaire scholing hadden ontvangen. Daar kwam nog bij dat enige honderden Japanse militairen uit het Japanse leger deserteerden en zich bij de Indonesische strijders voegden. Het officierskorps van de TKR kwam in grote meerderheid uit voormalige Petaofficieren te bestaan, naast enige tientallen ex-KNIL-officieren die hoofdzakelijk staffuncties te vervullen kregen.

Een moeilijker probleem was het verkrijgen van uitrusting en bewapening. Met uitzondering van de politie beschikte men aan Indonesische kant in de eerste weken van de Republiek nauwelijks over vuurwapens. Zulke wapens waren weliswaar op Java in ruime mate voorhanden, maar die berustten bij het Japanse leger. Nog voor de oprichting van de TKR kwam hier verandering in omdat zowel BKR-formaties als zelfstandige strijdgroepen er in slaagden veel van die wapens goedschiks of kwaadschiks in handen te krijgen. Dit betrof niet alleen wapens die de Japanners in augustus van de Peta- en Heihoformaties ingenomen hadden, maar ook eigen bewapening van het Japanse leger, met inbegrip van zwaar materieel zoals geschut, tanks en pantserwagens.

\section{Britse druk tot overleg tussen Nederland en de Republiek}

Mountbatten was ingenomen geweest met de verklaring van Van der Plas op 1 oktober, dat hij Soekarno en Hatta wilde uitnodigen voor gesprekken over de toekomst van Indonesië. Het ergerde hem dan ook bijzonder dat de Nederlandse regering Van der Plas meteen gedesavoueerd had. Intussen ging de situatie op Java snel achteruit. Op 10 en 11 oktober besprak Mountbatten het verder te voeren beleid met Van Mook tijdens overleg in Singapore waar onder meer ook Patterson, Christison, Helfrich en Van der Plas aan deelnamen.

Van Mook hekelde de aan Christison toegeschreven uitlatingen en zei dat er in Indonesië twijfel bestond over de vraag of hijzelf eigenlijk wel door de Britse regering erkend werd. Mountbatten verzekerde dat de Britse regering in Indonesië geen andere autoriteiten dan de Nederlandse erkende, maar hamerde er op dat Nederland overleg moest openen met Soekarno. Hij verwees nu niet alleen naar zijn eigen contacten met de Birmaanse leider Aung San maar ook naar onderhandelingen die de Fransen in Indochina waren begonnen met de Republiek Vietnam. Hij stelde dat zijn mandaat hem niet machtigde de verantwoordelijkheid voor orde en rust in heel Java op zich te 
nemen. Helfrich en Van Mook wezen op de ernstig bedreigde positie van de geïnterneerden en drongen er op aan de inzet van geallieerde troepen in ieder geval uit te breiden tot Buitenzorg, Bandoeng, Semarang en Malang. Dit bleek het uiterste te zijn waartoe Mountbatten in de huidige situatie bereid was. Hij zei aan zijn regering geen enkele aanbeveling tot verdere versterking van de militaire presentie op Java te kunnen doen zolang geen realistische onderhandelingen tussen Nederland en de Indonesische Republiek ophanden waren.

Van Mook verzette zich langdurig tegen het aanvaarden van Soekarno als onderhandelingspartner, maar toonde zich uiteindelijk bereid hiervoor een oplossing te zoeken. Mountbatten erkende dat het voor het bereiken van een nuttig onderhandelingsresultaat van belang was de wederpartij militair onder druk te kunnen zetten.

Een ander probleem dat Mountbatten ter sprake bracht was het Indonesische verzet tegen de Netherlands Indies Civil Administration (NICA). Zijns inziens was een organisatie voor niet-militaire zaken zeker nodig, maar zou men daar beslist een andere naam voor moeten vinden.

$\mathrm{Na}$ het overleg in Singapore werd de aanvoer van Britse militairen naar Java inderdaad versneld, werden Britse troepen naar Buitenzorg, Bandoeng en Semarang gedirigeerd en werden de in Batavia aangekomen KNIL-eenheden bij de beveiliging van de bezettingszone ingeschakeld. Het Britse opperbevel liet Van Mook echter weten dat men pas bereid zou zijn verdere Nederlandse troepen tot Java toe te laten wanneer dit niet zou leiden tot een verslechtering van de situatie. In feite hanteerde Mountbatten twee drukmiddelen om Nederland te bewegen tot onderhandelingen met de Republiek: zolang Nederland zulke onderhandelingen afwees weigerde hij niet alleen de Britse militaire presentie op Java te versterken maar hield hij ook de aanvoer van Nederlandse troepen tegen.

Aan de andere kant liet Mountbatten ook de Republiek onder druk zetten. Eén van zijn politieke adviseurs, M. Dening, zette op 23 oktober in Batavia de Britse opstelling uiteen aan een gezelschap van Republikeinse voormannen, onder wie Soekarno en Hatta. Hij merkte op dat de Republiek met Japanse medewerking was opgericht en daarom in de wereld niet op ruime sympathie kon rekenen. Nederland en Groot-Brittannië waren bondgenoten in de wereldoorlog geweest en Groot-Brittannië erkende onverminderd de soevereiniteit van Nederland over Indonesië. De Britse regering hoopte dat de Indonesiërs hun legitieme desiderata langs wettige weg zouden nastreven. Als zij er niet aan wilden meewerken de huidige spanning uit de weg te ruimen, zou dit alleen kunnen leiden tot het gebruik van geweld met onvoorzienbare gevolgen. De Republikeinse leiders ervoeren de uiteenzetting van Dening als een koude douche.

Tenslotte werd de NICA op 31 oktober omgezet in een nieuwe organisatie onder de naam Allied Military Administration Civil Affairs Branch 
(AMACAB). De nieuwe naam moest duidelijk maken dat het om een onderdeel van het Britse bezettingsbestuur ging, maar dit had geen effect. De Republikeinen bleven de organisatie als een werktuig van het Nederlandse koloniale bestuur zien. Bovendien bleef de naam NICA algemeen in zwang en beschouwde het AMACAB-personeel zelf de organisatie eveneens als een dienst onder het Nederlands-Indische gouvernement. Van Indonesische kant gebruikte men voor dit personeel dikwijls de scheldnaam andjing NICA (NICA-honden).

\section{Eerste ontmoeting van Van Mook met Soekarno}

Toen Van Mook op 2 oktober in Batavia aankwam stond hij onder instructies van zijn regering die het hem bijzonder moeilijk maakten politieke activiteiten te ondernemen in reactie op de oprichting van de Republiek Indonesië. Niet alleen mocht hij niet met vertegenwoordigers van die Republiek spreken, maar ook mocht hij tegenover niemand uitspraken over de toekomstige status van Nederlands-Indië doen die meer inhielden dan vervat was in de radiorede van de koningin uit december 1942. In de loop van de maand kwam er enige beweging in de opstelling van de regering. Logemann wilde het Indonesisch nationalisme in een positieve geest tegemoet treden en vond daar nu begrip voor bij Schermerhorn en de meeste andere leden van het kabinet.

Het eerste punt waarop Van Mook meer ruimte kreeg betrof het formuleren van politieke programmapunten ter uitwerking van de radiorede van 1942. Het ging daarbij onder meer om afschaffing van de discriminatie in rechtspraak en bestuur en uitbreiding van de inheemse meerderheid in de Volksraad. Al in 1920 had de door het Nederlands-Indisch gouvernement ingestelde commissie-Carpentier Alting hiertoe voorstellen gedaan, maar die waren destijds door regering en parlement van Nederland niet overgenomen (zie pp. 173-4 en 190). Over deze programmapunten mocht Van Mook ook praten met personen die tot de kring van de Republiek behoorden zolang het niet Soekarno of 'andere onverzoenlijken' betrof.

De wijziging in de opstelling van de regering was voor Tjarda aanleiding ontslag te nemen als gouverneur-generaal. De regering benoemde geen opvolger. Hoewel Van Mook formeel luitenant-gouverneur-generaal bleef, was hij nu in feite geen plaatsvervanger meer maar was hij voortaan zelf de landvoogd.

De ruimere instructies die Van Mook in de loop van oktober ontving liepen achter bij de door hemzelf en zijn naaste medewerkers gevolgde praktijk. Van der Plas had al eind september over de toekomstige status van Indonesië gesproken met prominente Indonesiërs zoals Hoesein Djajadiningrat (die voor de oorlog lid van de Raad van Indië geweest was en vervolgens ook onder de 
Japanse bezetting hoge functies vervuld had). Abdoelkadir ging nog een stap verder. Op 8 oktober sprak hij drie uur lang met Soekarno en Hatta, waarbij hij betoogde dat Indonesië alleen via politieke onderhandelingen onafhankelijk kon worden. Soekarno liet zich niet overtuigen, maar stelde zich niet onverzoenlijk op. Hij zei wel degelijk voor samenwerking tussen Indonesië en Nederland te zijn, mits op dezelfde voet als tussen de Filippijnen en de Verenigde Staten.

Na het overleg met Mountbatten in Singapore op 10 en 11 oktober hield ook Van Mook zich niet meer aan de aanwijzing uit Den Haag om niet te spreken met 'Soekarno of andere onverzoenlijken'. Op 15 oktober zei hij aan journalisten dat hij bereid was te onderhandelen met Indonesische leiders van alle schakeringen en te zijner tijd ook met Soekarno. De Nederlandse regering reageerde op dit bericht uit Batavia nog dezelfde dag met een verklaring dat dit op een misverstand moest berusten daar Van Mook instructie had niet met Soekarno te spreken. De volgende dag gaf Abdoelkadir een persconferentie waarin hij onthulde zelf al urenlang met Soekarno te hebben gesproken.

De kloof tussen het optreden van Van Mook en dat van de regering werd zeer wijd. Van 16 tot 18 oktober vond in Den Haag een parlementair debat over de toestand in Nederlands-Indië plaats. Overigens bestond er toen in Nederland geen formeel bevoegd parlement, want het mandaat van de voor de oorlog gekozen Tweede-Kamerleden was al vier jaar verstreken; het debat vond nu plaats in een romp-parlement, bestaande uit de personen die in 1937 gekozen waren voorzover ze sindsdien niet gestorven waren of in de oorlog de kant van de vijand gekozen hadden. Logemann verklaarde onder meer dat de regering het Indonesisch nationalisme wenste te erkennen, dat zij wilde werken aan een nieuwe structuur van het Koninkrijk waarin de oude koloniale verhouding niet zou mogen terugkeren en dat zij Van Mook gemachtigd had over concrete punten van hervorming met Indonesische voormannen te spreken. Bij dit laatste bracht hij één belangrijke beperking aan: de regering vond 'praten met het Soekarno-regime even onwaardig als onvruchtbaar'. Onwaardig omdat Soekarno zich met het Japanse bewind geïdentificeerd had en volstrekt vijandig tegenover Nederland stond. Onvruchtbaar omdat 'met dezen leider - met niets minder tevreden dan volstrekte onafhankelijkheid' geen gemeenschappelijke basis van bespreking te vinden kon zijn.

In het debat bleek dat de opstelling van de regering tegenover het Indonesisch nationalisme een deel van het gehoor veel te ver ging. De sprekers voor de protestants-christelijke partijen en voor de rechts-liberale partij wezen alle tegemoetkomingen aan dat nationalisme af zo lang het Nederlandse gezag niet hersteld was. Steun kreeg de regering van de kant van de katholieke partij en de links-liberale partij: Nederland zou niet mogen praten met Soekarno en de zijnen maar wel met andere Indonesische nationalisten. De spreker uit de SDAP leek hiermee in te stemmen, al noemde hij het onjuist Soekarno op één 
lijn met Mussert te stellen. Hij steunde de plannen voor een gelijkwaardige plaats van Indonesië binnen het Koninkrijk en repte niet van een recht van het Indonesische volk op onafhankelijkheid. De vertegenwoordiger van de communistische partij liet een heel ander geluid horen. Dit was de Indonesiër Roestam Effendi, oud-voorzitter van de Perhimpoenan Indonesia en sinds 1933 lid van de Tweede Kamer. In een felle redevoering stelde hij het Nederlandse kolonialisme aan de kaak en schaarde hij zich achter de Republiek.

In het debat ging veel aandacht uit naar de mogelijkheid om op Java Nederlandse militairen in te zetten, vooral wegens de bedreigde situatie van tienduizenden geïnterneerden op Republikeins gebied, onder wie veel vrouwen en kinderen. Logemann zei dat de regering liefst geen militair geweld wilde gebruiken, maar dat men geweld niet tot elke prijs vermijden kon. Aan het adres van de parlementariërs die volstrekte voorrang aan gezagsherstel wilden geven zei hij, dat wie de opstandigheid zonder meer wilde neerslaan niet het diepe probleem zag dat in Indonesië aan de orde was.

Eén van de redenen voor de bijna algemene afwijzing van overleg met het Soekarno-regime was gelegen in de misvatting dat de Republiek een puur Japans maaksel was. Logemann zei zelf in zijn rede dat de Republiek geproclameerd was door de Japanse opperbevelhebber in Zuidoost-Azië. Hoewel de regering over veel meer informatie beschikte dan de Tweede Kamer en het Nederlandse publiek, wist zelfs zij na twee maanden nog steeds niet dat de Indonesische nationalisten uiteindelijk eigenmachtig tot de stichting van de Republiek waren overgegaan.

De communicatie van de regering met Van Mook vertoonde ook gebreken. Hij wist bijvoorbeeld niet dat de regering zich in het romp-parlement volstrekt tegen overleg met Soekarno uitgesproken had. Zelf bereidde hij in deze dagen een ontmoeting met de Republikeinse leiders voor en probeerde hij Logemann's instemming te krijgen om Soekarno daar niet van uit te sluiten. Logemann seinde nog op 29 oktober dat Soekarno als deelnemer aan zulke besprekingen onaanvaardbaar was. Van Mook legde deze aanwijzing naast zich neer.

De ontmoeting met de Republikeinse leiders vond uiteindelijk op de avond van 31 oktober plaats in een paviljoen van de ambtswoning van Christison. Van Mook kwam samen met Van der Plas en zijn kabinetschef P.J.A. Idenburg, terwijl Soekarno en Hatta zich lieten vergezellen door Soebardjo, Amir Sjarifoeddin en Agoes Salim. De sfeer was correct, de voertaal was Nederlands en Soekarno beperkte zich tot luisteren. Van de Indonesiërs was hij de enige die nooit in Nederland geweest was. Amir Sjarifoeddin was in Nederland school gegaan en had in Batavia onder Van Mook gewerkt; tijdens de Japanse bezetting had hij een geheime organisatie opgezet met geld dat hij van Van der Plas gekregen had; hij was door de Japanners gevangen genomen, gemarteld en ter dood veroordeeld, maar Soekarno en Hatta had- 
den de voltrekking van dit vonnis kunnen voorkomen. Agoes Salim had al voor de Eerste Wereldoorlog op het Nederlandse consultaat in Arabië gewerkt en had na die oorlog deel uitgemaakt van de commissie-Carpentier Alting; in de jaren twintig was hij lid van de Volksraad en een prominent leider van de Sarekat Islam geweest. Tijdens het gesprek gaf Van Mook de gedachten van zijn regering weer over de vorming van een zelfstandig Indonesië binnen een hervormd Koninkrijk. Agoes Salim betoogde dat die gedachten volkomen achterhaald waren. Verder vertelden de Indonesiërs een en ander over wat er tijdens en na de Japanse bezetting op Java gebeurd was. Het gesprek leidde niet tot enigerlei overeenstemming, maar daar was men ook niet op uit. In de huidige fase hadden beide partijen er belang bij tegenover Mountbatten te tonen dat men bereid was met elkaar te praten.

Het bericht over de ontmoeting tussen Van Mook en Soekarno sloeg in Den Haag in als een bom. De ministerraad kwam op 1 november bijeen en besloot dat Van Mook moest worden ontslagen. Dezelfde dag publiceerde de regering een verklaring waarin zij het optreden van Van Mook volledig desavoueerde. Het ontslag ging echter niet door, omdat koningin Wilhelmina er niet mee instemde. Zij vond dat Van Mook een grote fout had begaan, maar noemde het onjuist om in de hitte van het gevecht van opperbevelhebber te wisselen.

In feite had de insubordinatie van Van Mook de Nederlandse regering uit een onmogelijke situatie verlost. Als zij zelf toestemming had gegeven voor contact met Soekarno zou dit waarschijnlijk hebben geleid tot een woedende reactie onder het Nederlandse publiek die zij niet had kunnen overleven. Het kabinet-Schermerhorn had dan vermoedelijk plaats moeten maken voor een kabinet dat in de Indonesië-politiek de lijn van Tjarda zou zijn gaan volgen. Aan de andere kant had Van Mook contact met Soekarno niet langer kunnen afhouden omdat hij geen conflict met Mountbatten kon riskeren. Daarmee zou hij in de eerste plaats het lot van bijna honderdduizend Nederlanders op het spel gezet hebben die zich in kampen en gevangenissen op Republikeins gebied bevonden. In de tweede plaats zou hij de kans op verdere Britse politieke en militaire steun voor de Nederlandse positie in Indonesië verspeeld hebben.

Het door de Nederlandse regering uitgegeven desaveu maakte overigens bij de Britse regering en bij Mountbatten het gunstige effect van Van Mook's handelen gedeeltelijk ongedaan. De Britten zetten weliswaar hun militaire optreden ten behoeve van de geïnterneerden krachtig voort, maar hielden versterking van de Nederlandse militaire presentie op Java en Sumatra tegen nu Nederland bleef weigeren om met het Soekarno-bewind te onderhandelen. Op 12 oktober waren de eerste vier bataljons Nederlandse oorlogsvrijwilligers uit Engeland vertrokken. Volgens de plannen hadden ze op 10 november in Indonesië zullen aankomen; in plaats daarvan dirigeerde SEAC ze naar Malakka. 


\section{Strijd in Midden-Java}

Ten tijde van de Japanse capitulatie huisden ruim vijfentwintigduizend Nederlanders, voornamelijk vrouwen en kinderen, in interneringskampen in Midden-Java. Drie van die kampen lagen in Semarang, zes ongeveer $35 \mathrm{~km}$ ten zuiden daarvan in en nabij Ambarawa. In de tweede helft van september ging de RAPWI zich met de geïnterneerden in Midden-Java bezighouden. Omdat de Britse plannen toen nog niet voorzagen in de vestiging van een bruggenhoofd in Semarang wilde de RAPWI de geïnterneerden via Soerabaja evacueren. In eerste aanleg liet zij bijna tweeduizend vrouwen en kinderen per trein hierheen overbrengen. Verder bracht zij bijna drieduizend zieke geïnterneerden voorlopig in hospitalen onder in Magelang, ongeveer $40 \mathrm{~km}$ van Ambarawa halverwege de weg naar Jogjakarta. In Magelang bevond zich ook het hoofdkwartier van de Japanse troepen in Midden-Java.

Begin oktober stonden Japanse legereenheden in verscheidene Middenen Oost-Javaanse plaatsen op ruime schaal wapens aan Indonesiërs af. De Japanse garnizoenscommandant van Semarang toonde zich bereid aan de BKR de wapens over te dragen die in augustus van de Peta waren ingenomen. Verder wilde hij echter niet gaan, ook niet nadat op 12 oktober een grote menigte zich om zijn kampement had verzameld met de eis alle militair materieel uit te leveren. Omstreeks dezelfde tijd werd het bekend dat in West-Java de ontwapening van de Japanners grotendeels mislukt was en dat Japanse militairen een eind gemaakt hadden aan de macht van de strijdgroepen in Bandoeng. Een aantal Midden-Javaanse strijdgroepen besloot nu harde acties tegen de Japanners te ondernemen en tegelijk alle potentiële tegenstanders van de Republiek in hechtenis te nemen. Als eerste stap schakelden zij het Japanse hoofdkwartier in Magelang uit; na een urenlange belegering gaf dit zich op 13 oktober over. De volgende dag werden in Midden-Java duizenden Nederlanders en andere veronderstelde vrienden van het koloniale gezag gevangen genomen. In en bij Ambarawa omsingelden strijdgroepen de interneringskampen; ze beletten de aanvoer van voedsel en sneden soms de wateren de elektriciteitsvoorziening af. Het Japanse garnizoen van Ambarawa gaf zich op 15 oktober over.

In Semarang arresteerden pemoeda's en politieagenten in de vroege ochtend van 14 oktober ruim vijfentwintighonderd Europeanen, Ambonezen en Menadonezen. In de loop van de dag werd het RAPWI-kantoor bezet en leeggehaald en werd ook het vliegveld bezet. De Japanse bewaking daarvan werd weggevoerd, terwijl later ook Japanse burgers gevangen genomen werden. De strijdgroepen maakten zich op voor een aanval op het Japanse garnizoen, maar anders dan zijn superieur in Magelang gaf de Japanse garnizoenscommandant van Semarang zich niet gewonnen. Hoewel hij over maar vijfhonderd man beschikte waarmee hij het moest opnemen tegen duizenden gewapende 
Indonesiërs, ging hij in de vroege ochtend van 15 oktober zelf tot de aanval over. In een harde, vijf dagen durende strijd wist zijn bataljon de hele stad weer in handen te krijgen. Daarbij bevrijdde het ook de meeste gevangenen, maar in één van de gevangenissen trof het de stoffelijke resten aan van bijna honderd Japanners die daar op bloedige manier waren afgemaakt.

Deze 'Vijfdaagse Strijd' (15-19 oktober 1945) wordt in Indonesië herdacht als de eerste grote slag in de nationale vrijheidsstrijd.

Op 19 oktober, toen Semarang juist weer in Japanse handen was, ging daar een Brits-Indische brigade aan land. Deze operatie, waartoe Mountbatten besloten had tijdens zijn recente overleg met Van Mook, had ten doel de geïnterneerden in Midden-Java te hulp te komen. De Britten spraken met de Japanse commandant af dat diens troepen voorlopig de kampen in Semarang en de belangrijkste toegangswegen zouden blijven bewaken. Ook openden zij overleg met Indonesische bestuurders en pemoeda-leiders. Dit leidde onder meer tot hervatting van de drinkwater- en voedselvoorziening aan de interneringskampen en tot vrijlating van de gevangen genomen RAPWI-medewerkers en Japanners. De Britse brigade legerde detachementen in Ambarawa en Magelang.

De TKR-leiding in Jogjakarta aanvaardde echter niet dat de Britten hun sterkte in het nabij gelegen Magelang tot die van een bataljon opvoerden. Op 31 oktober openden TKR-troepen en pemoeda's daar een algemene aanval op het Britse garnizoen. Generaal Christison deed een beroep op president Soekarno, die enkele dagen eerder al in Soerabaja tussenbeide was gekomen (zie de volgende paragraaf). Soekarno vloog naar Semarang en reisde vandaar naar Jogjakarta. Met zijn bemiddeling kwam op 2 november een akkoord tot stand dat onder meer inhield dat de Britten hun troepen uit Magelang zouden terugtrekken na de evacuatie van de daar ondergebrachte zieke geïnterneerden.

Dit akkoord hield echter niet lang stand, vooral onder invloed van de gelijktijdige gebeurtenissen in Soerabaja waar op 10 november een volledige Britse divisie in de aanval ging. Op 18 november begon ook in het gebied van Semarang, Ambarawa en Magelang een algemene strijd tussen Britten en Japanners enerzijds en pemoeda's en TKR-troepen anderzijds. In hun militaire acties opereerden de pemoeda's meestal onder vaste regie van de TKR, maar dit weerhield sommigen niet van wreedheden tegenover non-combattanten. Zo richtte een strijdgroep die een kamp bij Ambarawa binnengedrongen was een bloedbad aan door een aantal vrouwen en kinderen eerst bijeen te drijven en daarna met handgranaten te bestoken.

De strijd ging door tot 14 december. In het begin raakten de Britse troepen in Semarang zelf in een zo benarde positie dat Christison ook vliegtuigen en marineschepen inzette om de Indonesische stellingen met luchtbombardementen, raketbeschietingen en scheepsgeschut te bestoken. Na vier dagen slaagden de Britten er in de stad weer in handen te krijgen. Daarentegen zagen ze 
zich tegelijkertijd gedwongen zich uit Magelang terug te trekken. Wel was het hun gelukt alle daar nog verblijvende ex-geïnterneerden te evacueren, maar ze moesten een vijfentwintighonderd Indo-Europese, Ambonese, Menadonese en Chinese vluchtelingen aan hun lot overlaten die bij het Britse garnizoen bescherming hadden gezocht. In en om Ambarawa woedde een wekenlange zware strijd waarbij de kampen en hun Britse en Japanse verdedigers een tijd lang alleen nog uit de lucht bevoorraad konden worden. De Britten voerden overzee versterkingen aan, waaronder eind november een volledige brigade. Nadat ze daarmee een doorbraak naar Ambarawa tot stand gebracht hadden, konden ze eindelijk beginnen met de ontruiming van de kampen. Op 13 december arriveerden de laatste ex-geïnterneerden in Semarang; een dag later trokken ook de laatste Britse troepen zich uit Ambarawa daarheen terug. Het Britse bezettingsleger handhaafde hierna in Midden-Java alleen nog het bruggenhoofd Semarang.

\section{Strijd in Soerabaja}

Soerabaja, de belangrijkste havenstad van Indonesië, had in 1945 een half miljoen inwoners, onder wie een omvangrijk proletariaat dat door armoede en werkloosheid werd geteisterd. De plaatselijke Indonesische bestuurders stelden zich in september achter de Republiek. Daarnaast kwam een nationaal comité (KNI) tot stand dat nauw met dit bestuur samenwerkte. Verder richtte men een BKR-korps op; in oktober ging dit over naar de TKR. Binnen de stad bevonden zich twee Japanse hoofdkwartieren, één van het leger voor OostJava en één van de marine voor de hele archipel.

Bij het eind van de oorlog waren er in Oost-Java geen interneringskampen meer; het bezettingsbestuur had alle geïnterneerden in Midden- en West-Java bijeengebracht. Daarentegen begon de RAPWI eind september Nederlandse kampbewoners uit Semarang en Ambarawa met het oog op hun evacuatie naar villawijken in Soerabaja over te brengen. De bevolking ontving deze exgeïnterneerden, voornamelijk vrouwen en kinderen, bijzonder vijandig en de RAPWI zag zich na 2 oktober gedwongen de transporten te staken omdat de toestand te onveilig geworden was.

Onder de inheemse bevolking van Soerabaja ontwikkelde zich in de loop van september een sterk anti-Nederlandse stemming. Ten dele was dit een reactie op het optreden van uit de kampen teruggekeerde Nederlanders die zonder meer uitgingen van voortzetting van de vooroorlogse koloniale verhoudingen. Ten dele was het ook een reactie op de uitgesproken antiRepublikeinse opstelling van de meeste Indische Nederlanders. De gegroeide spanning ontlaadde zich op 19 september in een grote vechtpartij tussen jonge Indonesiërs en Indische Nederlanders, toen op het belangrijkste hotel van de 
stad een Nederlandse vlag gehesen werd waarvan Indonesiërs vervolgens de blauwe baan afscheurden. Enige dagen later richtten Indonesische jongeren een eigen organisatie op, de Pemoeda Repoeblik Indonesia (PRI, Jongeren van de Republiek Indonesië). Deze organisatie ontwikkelde zich tot een zelfstandig machtscentrum naast het Republikeinse bestuur, het KNI en de BKR. Zij richtte zich allereerst op het voorbereiden van een opstand tegen de Japanse bezettingsmacht.

Eind september werd het straatbeeld in Soerabaja overheerst door groepen gewapende jongeren; hun bewapening bestond voornamelijk uit slag- en steekwapens. De hoogste macht in de stad berustte nog steeds bij de Japanse bezetters, maar binnen enkele dagen ging die macht volledig in Republikeinse handen over. Het begon ermee dat duizenden Indonesiërs onder aanvoering van de pemoeda's Japanse arsenalen en andere militaire instellingen belegerden en uitlevering van de zich daar bevindende wapens eisten. De meeste Japanse leger- en marine-onderdelen lieten zich vrij snel ontwapenen en tenslotte capituleerde op 2 oktober ook de Kempeitai. Een dag later gaven de Japanse legercommandant en de Japanse marinecommandant zich formeel over aan de geallieerden, vertegenwoordigd door een Nederlandse marineofficier die namens SEAC naar Soerabaja gestuurd was. Het Republikeinse bestuur maakte bekend dat de Japanners geïnterneerd zouden worden, dat de BKR zijn hoofdkwartier in het voormalige Kempeitai-gebouw zou vestigen en dat de PRI de BKR zou bijstaan.

Het materieel dat door deze machtsovername in Indonesische handen viel was zeer omvangrijk: grote voorraden munitie, tienduizenden geweren en pistolen en verder machinegeweren, geschut, tanks, pantserauto's en vrachtauto's. Overigens beperkten de Indonesische acties zich niet tot de verwerving van Japanse wapens, maar kwam het op veel plaatsen bovendien tot antiJapanse wraakacties van de kant van de bevolking; talrijke Japanners werden daarbij vermoord.

De PRI vestigde haar hoofdkwartier nu in de Simpang-club, voor de oorlog de belangrijkste sociëteit van de stad. Intussen bereidde men zich voor op de komst van de Britse bezettingstroepen. Terwijl de Republikeinse autoriteiten wel geneigd waren tot samenwerking met de Britten, meende de PRI dat met Britse steun een Nederlandse machtsovername van de stad voorbereid werd. Op instigatie van de PRI zette het bestuur de RAPWI-staf gevangen. Ook de Nederlandse SEAC-vertegenwoordiger en zijn staf belandden in de gevangenis. Vervolgens besloot de PRI-leiding alle Nederlandse mannen gevangen te nemen (vrijwel gelijktijdig met soortgelijke acties van de strijdgroepen in Midden-Java). Op 15 oktober liet zij ongeveer vijfendertighonderd blanke en Indische Nederlanders, zowel mannen als jongens, uit hun huizen halen en in vrachtauto's wegvoeren. De meesten bracht men rechtstreeks naar gevangenissen over; voor de poort van de grootste gevangenis werd een deel van 
hen aangevallen door een woedende volksmassa; tientallen vonden hierbij de dood en honderden raakten ernstig gewond voordat ze de poort in konden vluchten. Een aantal Nederlanders die de PRI van bijzondere banden met het koloniale bestuur verdacht werd naar de Simpang-club gebracht voor 'verhoor en berechting'. Ook voor dit gebouw stond een bloeddorstige menigte. De verhoren binnen het gebouw ontaardden in zware mishandelingen; ruim veertig Nederlanders overleefden dit niet, de overigen werden naar een gevangenis afgevoerd. In de volgende dagen keerde de volkswoede zich ook tegen Ambonezen en Menadonezen.

Nadat Britse strijdkrachten zich op 19 oktober in Semarang ontscheept hadden, ging eindelijk op 25 oktober een Britse brigade in de haven van Soerabaja aan land. Deze brigade, die evenals de in Semarang ingezette Britse troepen in hoofdzaak een humanitaire taak had, telde bijna vierduizend Indiase soldaten en stond onder bevel van brigade-generaal Mallaby. Na moeizame besprekingen met de Republikeinse autoriteiten kon de brigade de volgende dag de ten zuiden van de haven gelegen stad intrekken. Mallaby liet zijn militairen een groot aantal punten bezetten, met inbegrip van het vliegveld en de wijken waar de RAPWI de ex-geïnterneerde vrouwen en kinderen ondergebracht had. Die ten zuiden van het centrum gelegen wijken waren nu opvangkampen geworden; hier bevonden zich ook veel vrouwen en kinderen van de op 15 oktober gevangen genomen Nederlanders. In de avond bevrijdde een Brits peleton de SEAC-vertegenwoordigers en de RAPWI-staf uit hun gevangenschap. De volgende dag strooiden Britse vliegtuigen biljetten over de stad uit waarin alle niet tot de politie behorende Indonesiërs gesommeerd werden binnen achtenveertig uur hun wapens in te leveren; wie daarna nog wapens droeg zou kunnen worden neergeschoten. Het Republikeinse bestuur achtte dit in strijd met wat het met de Britse brigadeleiding had afgesproken. De oproep was niet van Mallaby zelf afkomstig maar van de Britse divisiecommandant die zijn chef was.

Eén dag later, op zondagmiddag 28 oktober tussen vier en vijf uur, vielen Indonesiërs gelijktijdig alle Britse posten buiten het havengebied aan. Onder de aanvallers bevonden zich vele duizenden uit Japanse voorraden bewapende strijders van PRI en TKR, bijgestaan door tienduizenden andere stadgenoten met slag- en steekwapens. De Indiase soldaten verzetten zich hardnekkig, maar raakten soms snel door hun munitie heen zodat de aanvallers veel kleine posten konden uitschakelen. Ook werden vrijwel alle Britse militairen afgemaakt die in de stad aan het passagieren waren. Het brigadehoofdkwartier en enige andere grote afdelingen konden zich nog handhaven, waaronder de detachementen die de opvangkampen beschermden. Daarentegen werd een Brits convooi met enige honderden Nederlandse vrouwen en kinderen tussen die kampen door een menigte aangevallen; velen van hen kwamen daarbij om het leven, samen met bijna alle soldaten die hen verdedigden. 
De massale Indonesische aanval bedreigde Mallaby's brigade met de ondergang. Dit ging lijnrecht in tegen het beleid van de leiders van de Republiek die de Britse goodwill juist niet wilden verspelen. De Britse legerleiding in Batavia vond Soekarno en Hatta dan ook bereid zelf naar Soerabaja te gaan om aan de strijd een eind te maken. Een militair vliegtuig bracht hen daar op 29 oktober heen, samen met minister Amir Sjarifoeddin. De volgende ochtend namen zij deel aan een bespreking met generaal Mallaby en de eveneens overgekomen divisiecommandant, samen met plaatselijke vertegenwoordigers van het Republikeinse bestuur, het KNI, de TKR en de PRI. Men kwam overeen dat men de strijd zou staken, dat men de gevangenen zou vrijlaten, dat de TKR en haar hulporganen hun wapens zouden kunnen behouden, dat de Britten het havengebied en de opvangkampen zouden bewaken en dat zij de ingezetenenen van die kampen ongehinderd naar de haven zouden kunnen evacueren. $\mathrm{Na}$ het bereiken van dit akkoord vlogen de Republikeinse leiders en de Britse divisiecommandant naar Batavia terug.

Ondanks het akkoord vonden er telkens weer schietpartijen en botsingen plaats. Zo belegerde een menigte gewapende Indonesiërs nog diezelfde middag een Britse compagnie in een gebouw in het centrum van de stad. Generaal Mallaby ging daar met enige Indonesische voormannen heen om aan die confrontatie een eind aan te maken. Hierbij werd hijzelf dodelijk getroffen.

Tot nu toe had de internationale pers weinig aandacht geschonken aan de gewapende conflicten tussen Indonesiërs en de Britse bezettingstroepen op Java. Zelfs in Nederland was men hier slechts fragmentarisch van op de hoogte. Dit veranderde op slag met de dood van de Britse brigadecommandant; dit was wereldnieuws.

Op 31 oktober veroordeelde generaal Christison in een scherpe bekendmaking zowel de onverhoedse aanval op zijn troepen van zondag als de bestandsschendingen en de moord op generaal Mallaby van dinsdag. Daarbij verklaarde hij onder meer: 'unless the Indonesians who have committed these acts surrender to my forces, I intend to bring the whole weight of my sea, land and air forces and all the weapons of modern war against them until they are crushed'.

Op dezelfde dag droeg Soekarno in een radiorede de Indonesiërs op alle vijandelijkheden tegen de geallieerden te staken. Hij beklemtoonde dat Indonesië niet in oorlog met de geallieerden was. Over het eigenmachtige optreden aan Indonesische kant zei hij dat, zoals één korrel arsenicum een heel glas water kon vergiftigen, ook de fouten van een enkeling het hele bouwsel van de staat konden beschadigen.

Het werd nu rustiger in Soerabaja. De Britse brigade kon duizenden ingezetenen van de opvangkampen naar het havengebied overbrengen in een reeks transporten onder geleide van de TKR. Na enige dagen begon in de haven de ontscheping van de extra divisie waarover admiraal Mountbatten 
de beschikking had gekregen, in totaal ongeveer vierentwintigduizend man, ondersteund met tanks en geschut. Van Indonesische kant schonk men hier weinig aandacht aan. Het dreigement van Christison nam men niet serieus. De gevangen genomen Nederlanders liet men niet vrij, maar hield men als gijzelaars vast. Een aantal prominente pemoeda's verliet de stad om deel te nemen aan een groot jongerencongres dat op 10 en 11 november in Jogjakarta zou worden gehouden. Ook Soekarno en Hatta begaven zich daarheen; het was voor hen van belang de verstandhouding met hun achterban te verbeteren nu die ernstig beschadigd was door hun afwijzing van de anti-Britse acties in Midden-Java en Soerabaja en door hun ontmoeting met Van Mook.

Op 9 november trokken de Britten zich terug uit het laatste nog door hen beschermde opvangkamp in het zuiden van de stad. Diezelfde dag strooiden Britse vliegtuigen biljetten uit met een ultimatum: voor de volgende ochtend zes uur zouden alle Indonesische leiders zich onvoorwaardelijk moeten overgeven en zouden alle Indonesiërs die niet tot de politie of de TKR behoorden hun wapens moeten inleveren. Het Republikeinse bestuur maakte via de radio bekend dit ultimatum te verwerpen. Onmiddellijk na het verstrijken van het ultimatum opende de Britse divisie een groot offensief. De strijdkrachten die uit het havengebied naar het zuiden optrokken stuitten op felle tegenstand en soms zelfs op zelfmoordaanvallen van de pemoeda's. De Britten namen weinig risico's meer; om het verzet te breken zetten zij niet alleen hun artillerie in maar ook hun marine en luchtmacht. De inheemse bevolking vluchtte massaal weg. In zware straatgevechten die negentien dagen duurden werd de stad stukje bij beetje veroverd. Op 29 november was Soerabaja eindelijk volledig in Britse handen, maar intussen waren grote delen van de stad verwoest, vooral volkswijken die deels door de verdedigers zelf in brand waren gestoken om de Britse opmars te vertragen. Bij de aanvang van het offensief hadden de Britten het merendeel van de Nederlanders weten te bevrijden die op 15 oktober gevangen genomen waren, maar hun verdere pogingen tot redding van Nederlandse ingezetenen en vluchtelingen waren grotendeels mislukt; de Indonesische strijders hadden duizenden daarvan naar het binnenland weggevoerd.

Een groter en bloediger veldslag dan deze strijd om Soerabaja heeft nooit meer in de Indonesische vrijheidsstrijd plaatsgevonden, ook niet in de oorlog met Nederland. De datum waarop de slag begon, 10 november, wordt nog jaarlijks in Indonesië als 'Heldendag' gevierd.

Eén van de meest fanatieke leiders van de strijd in Soerabaja was de 25-jarige journalist Soetomo, meestal Boeng Tomo genoemd. In oktober richtte hij zowel een eigen strijdgroep op als een eigen radiozender, Radio Pemberontakan (Radio van de Opstand). Na de val van Soerabaja bleef hij met zijn strijdgroep en zijn zender in Oost-Java actief. Boeng Tomo was een meeslepend redenaar die voortdurend opriep tot onverzoenlijke strijd tegen de vijanden van de 
nationale revolutie. Aan zijn radiozender werkte ook een Britse vrouw mee die zich voor de oorlog op Bali gevestigd had en daar de naam K'toet Tantri aangenomen had. Zij had zich nu bij de Indonesische vrijheidsbeweging aangesloten en spoorde de Britse militairen voortdurend aan om geen strijd tegen die beweging te voeren. Onder deze militairen kreeg zij de bijnaam 'Surabaya Sue'.

\section{Nederlands besluit tot uitzending van een grote troepenmacht naar Indonesië}

In november 1945 nam de Nederlandse regering een besluit dat verreikende gevolgen zou hebben. $\mathrm{Zij}$ besloot voor inzet in Indonesië een grote troepenmacht bijeen te brengen en zij besloot dit te doen volgens een schema waardoor die troepenmacht pas eind 1946 op sterkte zou kunnen zijn.

Sinds de oorlog hadden de militaire plannen voor het herstel van het Nederlandse gezag in Indonesië al diverse wijzigingen ondergaan. In 1943 had de regering in Londen besloten tot oprichting van een expeditionaire macht van drie divisies en tot vorming van een mariniersbrigade en vijftien gezagsbataljons (zie p. 336). De divisies en de mariniersbrigade zouden aan de strijd tegen Japan moeten deelnemen; de gezagsbataljons zouden in Indonesië de binnenlandse orde moeten herstellen na de uitschakeling van de Japanse strijdkrachten. De opleiding van de mariniersbrigade zou in de Verenigde Staten plaatsvinden, die van de gezagsbataljons in Australië en die van de eerste divisie van de expeditionaire macht in Groot-Brittannië. Eind 1943 begon in Amerika inderdaad de opleiding van de mariniersbrigade. De vorming van de gezagsbataljons en de expeditionaire macht moest wachten tot de bevrijding van Nederland zelf, maar ondervond toen verschillende tegenslagen. De Australische regering trok in juli 1945 een vroegere toezegging in om te zullen zorgen voor de huisvesting en opleiding van de Nederlandse gezagsbataljons (zie p. 341). In Groot-Brittannië begon in augustus 1945 de opleiding van de officieren en onderofficieren voor de eerste divisie van de expeditionaire macht; de opleiding van de manschappen zou in december beginnen, maar na de capitulatie van Japan liet de Britse regering weten dat zij nog alleen het kader wilde opleiden en niet de manschappen.

Voor de vorming van de expeditionaire macht betekende het wegvallen van de mogelijkheid de manschappen in Groot-Brittannië op te leiden een vertraging van vijf maanden, want binnen Nederland zou men daartoe niet voor mei 1946 over voldoende kazerneruimte beschikken. Dit leek de Nederlandse militaire autoriteiten niet al te bezwaarlijk. Nu Japan gecapituleerd had was de urgentie van de vorming van deze legermacht vervallen. Zij zou nu niet meer naar Azië worden uitgezonden, maar de basis gaan vormen voor de landmacht in Europa. Omdat de opleiding van de manschappen pas 
in mei 1946 zou kunnen beginnen, zag men er ook van af de eerste divisie van deze legermacht uit vrijwilligers samen te stellen; in plaats daarvan zou men dienstplichtigen oproepen.

Daarentegen vormde de Australische weigering om het personeel van de gezagsbataljons op te leiden wel een ernstige tegenslag, vooral toen de capitulatie van Japan het gezagsherstel in Indonesië tot een dringende zaak maakte. De Nederlandse regering ging daarom in eigen land lichte infanteriebataljons voor die taak gereed maken. Voor een deel kon zij daarbij beschikken over eenheden die al na de bevrijding van het zuiden van Nederland gevormd waren en nu in Duitsland gelegerd waren. De regering vond inmiddels het oorspronkelijk beoogde aantal van vijftien gezagsbataljons onvoldoende en besloot daarom tot vorming van in totaal zevenentwintig lichte infanteriebataljons, die tussen september 1945 en februari 1946 naar Indonesië zouden moeten vertrekken. De bataljons werden uit oorlogsvrijwilligers samengesteld.

Deze infanteriebataljons vertegenwoordigden een sterkte van ongeveer 22.000 man. De in Amerika opgeleide mariniersbrigade van 5000 man zou eind 1945 ter beschikking komen. Verder hoopte men de sterkte van het KNIL binnen enkele maanden te kunnen opvoeren tot 12.000 man, grotendeels uit beroepspersoneel dat uit krijgsgevangenschap terugkeerde. Alles bijeen leek het in oktober 1945 aannemelijk dat Nederland in het voorjaar van 1946 ter vervanging van de Britse en Australische strijdkrachten in Indonesië zou kunnen beschikken over een troepenmacht van bijna 40.000 man. Bovendien waren er al voorbereidingen getroffen om de infanteriebataljons medio 1946 aan te vullen met onder meer artillerie, tanks, genietroepen en verbindingspersoneel, wat nog een uitbreiding met een 10.000 man zou meebrengen

De feitelijke ontwikkelingen in Indonesië sinds eind september dwongen de Nederlandse autoriteiten echter de behoefte aan militaire middelen opnieuw te bezien. Vice-admiraal Helfrich, de Bevelhebber Strijdkrachten Oosten, en luitenant-generaal Van Oyen, de legercommandant van het KNIL,verklaarden begin november in een gezamenlijk rapport een sterkte van 75.000 man nodig te achten 'om geheel Nederlandsch Indië te beheerschen en pacificeeren'. Van Mook gaf dit rapport aan de regering door en nam daarbij geen afstand van het getal van 75.000, maar merkte onder verwijzing naar de strijd in Soerabaja wel op dat Helfrich en Van Oyen zijns inziens de weerstand van de Indonesische bevolking onderschatten.

Schermerhorn besprak het rapport op 12 november 1945 met de meest betrokken ministers en de top van de Nederlandse landmacht. Dit overleg leidde tot de conclusie dat men de genoemde troepensterkte kon bereiken door de in oktober 1946 beschikbaar komende eerste divisie van de expeditionaire macht (20.000 man) niet in Duitsland maar in Indonesië in te zetten. Een consequentie van dit schema was dat men de Britse regering bereid zou moeten vinden haar troepen nog tot die tijd in Indonesië te handhaven. Eén 
van de deelnemers aan het overleg (die commandant Oost-Java van het KNIL geweest was) pleitte vergeefs voor een andere aanpak. Indien pas in begin 1947 een troepenmacht van redelijke sterkte aanwezig zou zijn, achtte hij de Nederlandse zaak verloren.

Van Oyen, Helfrich en Van Mook reageerden negatief op het in Den Haag opgestelde schema. Zij berichtten aan de regering dat ze het onjuist vonden een divisie te vormen die pas eind 1946 in Indonesië zou arriveren. Huns inziens moesten hier zo spoedig mogelijk kleine, mobiele, krachtig bewapende eenheden beschikbaar zijn. Met klem wezen zij er op dat een binnen enkele maanden beschikbaar bataljon een veelvoud waard was van een bataljon waar men pas na zes of meer maanden over zou kunnen beschikken. De regering besloot echter aan het schema van 12 november vast te houden. Dit betekende dat Nederland pas in 1947 met eigen troepen zijn gezag over Indonesië zou kunnen herstellen. De officieren en onderofficieren die in Groot-Brittannië voor de expeditionaire macht opgeleid werden waren blij dat hun divisie toch in Indonesië zou worden ingezet in plaats van naar Duitsland te gaan. De minister van oorlog maakte dit zelf in hun trainingscentrum bekend. Daarbij omschreef hij het doel van die inzet als handhaving van de rijkseenheid en zei hij dat 'de rijkseenheid het grootste goed is dat wij door de strijd onzer vaderen eeuwen geleden verworven hebben en dat wij nu ons waard moeten tonen te mogen behouden'.

Overigens hadden Van Oyen en Helfrich hun streefgetal van 75.000 man op vrij optimistische veronderstellingen gebaseerd. Beiden geloofden zij dat de overweldigende meerderheid van de Indonesische bevolking pro-Nederlands was en dat het aan Indonesische kant op gang gekomen geweld voor een groot deel niet uit politieke motieven voortkwam maar uit de lust tot moorden en roven van ongeregelde benden. $\mathrm{Zij}$ waren dan ook tegen onderhandelingen met de Republiek. Pas na herstel van orde en rust zou politiek overleg aan de orde kunnen komen.

Generaal-majoor Schilling, de commandant van de KNIL-troepen op Java, had een heel andere visie, zoals bleek uit een door hem op verzoek van Van Mook opgesteld memorandum van 25 november. Hij merkte op dat de kracht van het verzet de verwachtingen verre overtrof, naar uit de gevechten rondom Batavia, in Midden-Java en in Soerabaja was gebleken. Om Java en Sumatra weer volledig in handen te krijgen zou op zijn minst een troepenmacht van 75.000 à 100.000 man nodig zijn gedurende minstens drie jaar en ook daarna zou Nederland een aanzienlijke militaire inspanning moeten blijven opbrengen. Schilling betwijfelde of het Nederlandse volk de daarvoor vereiste personele en materiële middelen kon opbrengen. Ook wees hij op de veranderende internationale situatie. Naar zijn mening was het daarom beter zich aan de politiek van de Britten aan te passen en op Java 'verlies te nemen'. Schilling achtte onderhandelen met de Republiek dan ook onontkoombaar. 
Daarentegen was de visie van kolonel Spoor, de directeur van de NEFIS, nog optimistischer dan die van Helfrich en Van Oyen. Hij meende nog op 23 november dat, wanneer de Britten hun bruggehoofden handhaafden, de zevenentwintig Nederlandse bataljons ook in ongeoefende vorm voldoende waren om Java te zuiveren. De haarden van verzet waren zijns inziens bekend; door opruiming van de afzonderlijke haarden zou de hele situatie weer in Nederlandse handen komen.

\section{Hervorming van het staatsbestel van de Republiek}

In oktober 1945 voltrok zich een ingrijpende hervorming van het Republikeinse staatsbestel zonder formele wijziging van de grondwet.

Zowel voor als na de totstandkoming van de Republiek was al gebleken dat haar oprichters geen onvoorwaardelijke steun kregen in de kring van de nationalistische jongeren. Onder meer vond men daar dat zij te veel aan de leiband van de Japanse bezettingsmacht hadden gelopen. Dat gold ook voor de meeste ministers in Soekarno's kabinet. Verder hadden velen bezwaar tegen het autocratische karakter van het in de grondwet neergelegde staatsbestel, dat nog verscherpt was door de daaraan toegevoegde overgangsbepalingen. Die bepaalden onder meer dat, zo lang de in de grondwet voorziene parlementaire organen nog niet waren samengesteld, de president ook de bevoegdheden van die organen kon uitoefenen. Weliswaar was daaraan toegevoegd dat hij dit doen zou 'met bijstand van een nationaal comité', maar wat die bijstand zou inhouden was niet nader bepaald. Ter uitvoering van deze bepaling was er nu het Komite Nasional Indonesia Poesat (KNIP, Centraal Indonesisch Nationaal Comité), dat uit honderdzevenendertig door de president benoemde leden bestond en eind augustus zijn eerste zitting hield.

Het stoorde de critici van het geldende staatsbestel vooral dat de regering geen verantwoording aan een volksvertegenwoordiging verschuldigd was. Zulk een verantwoordingsplicht was juist de centrale eis geweest van de kort voor de oorlog tegen het koloniale bestel gevoerde campagne 'Indonesië parlementair' (zie pp. 241-2). Maar zelfs onder dat bestel had het koloniale gouvernement voor wetgeving nog de medewerking van de Volksraad nodig gehad; van de eigen Republiek mocht men verlangen dat die niet autocratischer zou zijn dan het koloniale bestel. Onder de nationalisten leefde deze kritiek vooral bij westers georiënteerde intellectuelen; het model waar zij van uitgingen was dat van de parlementaire democratie op basis van een meerpartijenstelsel zoals in Nederland.

In de kring van deze critici genoot Sjahrir groot gezag. Hij behoorde wel tot de vooroorlogse nationalistische leiders, maar was wat jonger dan de meesten van hen. Er kon geen twijfel bestaan aan zijn nationalistische overtuiging, 
waarvoor hij acht jaar lang van zijn vrijheid beroofd was geweest, maar hij had niet samengewerkt met de Japanse bezettingsmacht en evenmin deelgenomen aan de opstelling van de grondwet. Ook na de uitroeping van de onafhankelijkheid bleef hij nog een tijd lang afzijdig. Hoewel hij tot lid van het KNIP benoemd was, woonde hij de openingszitting niet bij. Wel voerde hij in deze tijd allerlei politieke gesprekken, onder meer met de Nederlandse socialist J. de Kadt die hem aanspoorde weer een actieve rol te gaan spelen. Ook reisde hij enige weken door Java; daarbij constateerde hij dat Soekarno ondanks diens nauwe samenwerking met de Japanners een haast onaantastbaar krediet bij de bevolking genoot.

Op 7 oktober dienden veertig leden van het KNIP, onder wie verscheidene vrienden van Sjahrir, bij Soekarno en Hatta een petitie in waarin zij voorstelden dat het KNIP voorlopig de bevoegdheden van de in de grondwet voorziene parlementaire organen zou gaan uitoefenen en dat het daarbij zijn dagelijkse werk zou delegeren aan een uit zijn midden te kiezen Werkcomité. Dit laatste voorstel volgde het voorbeeld van de koloniale Volksraad, die tweemaal per jaar bijeen placht te komen maar tussen die zittingen het dagelijkse werk overliet aan een uit zijn midden gekozen College van Gedelegeerden. Soekarno en Hatta namen de voorstellen volledig over. Op 16 en 17 oktober kwam het KNIP in plenaire zitting bijeen. Soekarno was afwezig; Hatta nam zijn functie waar en kondigde een presidentieel besluit af overeenkomstig de petitie. Het KNIP benoemde daarop Sjahrir en Amir Sjarifoeddin tot formateurs van het Werkcomité. Verder stelde het een uitbreiding van zijn eigen omvang tot honderdvijfenzeventig leden voor. Het Werkcomité kwam uit vijftien leden te bestaan, met Sjahrir en Amir Sjarifoeddin als voorzitter en vice-voorzitter. Veel van die leden waren medestanders van Sjahrir; hetzelfde gold voor het merendeel van de achtendertig nieuwe leden waarmee het KNIP vervolgens zelf werd uitgebreid.

Het door Hatta op 16 oktober afgekondigde presidentiële besluit is bekend geworden als 'Besluit no. X'. Op grond van dit besluit zou het KNIP voortaan kunnen deelnemen aan de wetgeving en aan het bepalen van de grote lijnen van het regeringsbeleid, maar het Werkcomité ging nog wat verder. Het verklaarde dat de Republiek diende over te gaan op een meerpartijenstelsel en pleitte voor de invoering van een stelsel van ministeriële verantwoordelijkheid. Daartoe zou men het presidentiële kabinet moeten vervangen door een nieuw kabinet dat verantwoording verschuldigd zou zijn aan het KNIP. Ook op deze punten kreeg het Werkcomité al spoedig zijn zin. Op 3 november verscheen een regeringsbesluit dat opriep tot de vorming van politieke partijen en op 14 november een besluit tot invoering van ministeriële verantwoordelijkheid.

Hierbij valt te bedenken dat Sjahrir en de zijnen hun voorstellen deden in een periode waarin de leiders van de Republiek verwikkeld waren in over- 
leg met Britse en Nederlandse vertegenwoordigers. Op 23 oktober hoorden Soekarno en Hatta de 'koude douche' van Dening aan, op 31 oktober ontmoetten zij Van Mook. Zij wisten hoe nadelig het voor de Republiek was dat die als een Japans maaksel werd gezien.

Soekarno en Hatta stemden ook in met een door het Werkcomité opgestelde uiteenzetting van de hoofdlijnen van het beleid van de Republiek. Deze uiteenzetting werd op 1 november door Hatta gepubliceerd en is sindsdien bekend geworden als het 'Politiek Manifest'. Het manifest nam scherp afstand van het Japanse bezettingsregime en noemde de Japanse onderdrukking harder en wreder dan het Nederlandse kolonialisme van de voorafgegane decennia. Tegelijk wees het er op dat de Nederlanders een zware verantwoordelijkheid droegen omdat ze een volk van zeventig miljoen aan het Japanse militarisme overgeleverd hadden zonder het in staat te stellen zichzelf te verdedigen. De Nederlanders hadden dan ook niet het recht om verwijten te maken aan het adres van die Indonesische nationalisten die zich gedwongen hadden gezien met de Japanners samen te werken. Verder spande het manifest zich in om steun voor de Republiek te verwerven in de westerse wereld en vooral in Amerika. Het beklemtoonde de behoefte van Indonesië aan buitenlandse deskundigheid en buitenlands kapitaal en verzekerde dat de Republiek de schulden van het Nederlands-Indisch gouvernement zou overnemen en de rechten van buitenlandse ondernemingen zou eerbiedigen. Het manifest sprak zelfs een voorkeur uit voor samenwerking met Nederlanders omdat die met het land vertrouwd waren. Maar zulke samenwerking zou alleen mogelijk zijn als Nederland zich bereid toonde de Republiek te erkennen.

Hoewel het Politiek Manifest zich duidelijk ook tot Nederland richtte, drong het belang ervan niet tot Van Mook door en lichtte hij zijn regering er nooit over in. Daarentegen schonk men in Nederland wel aandacht aan een door Sjahrir op 10 november onder eigen naam gepubliceerde brochure met de titel Onze strijd. Het was opmerkelijk dat Sjahrir hierin niet alleen het Nederlandse kolonialisme krachtig veroordeelde, maar ook scherpe kritiek uitte aan het adres van de Indonesiërs zelf. De vrijheidsstrijd zou volgens hem op fascisme kunnen uitlopen als die strijd uitsluitend op nationalisme gebaseerd werd. Daarom zou de nationale revolutie ook een democratische en sociale revolutie moeten zijn. Sjahrir keerde zich fel tegen alle 'overblijfselen van het Japanse fascisme' in de Indonesische samenleving. Hij schreef dat de jeugd tijdens de bezetting uitsluitend had geleerd om te gehoorzamen, te buigen en te verafgoden en niet om eigen verantwoordelijkheid te dragen. Hij hekelde de door de bezetters aangekweekte haat tegen Nederlanders, Indo-Europeanen, Ambonezen, Menadonezen en Chinezen en veroordeelde de steeds toenemende moord- en roofpartijen. De gedachte dat jongerenorganisaties de vrijheidsstrijd zouden moeten leiden deed hij af als een misvatting die deze strijd alleen maar kon schaden. Bijzonder bitter liet hij zich uit over 


\section{Soetan Sjahrir}

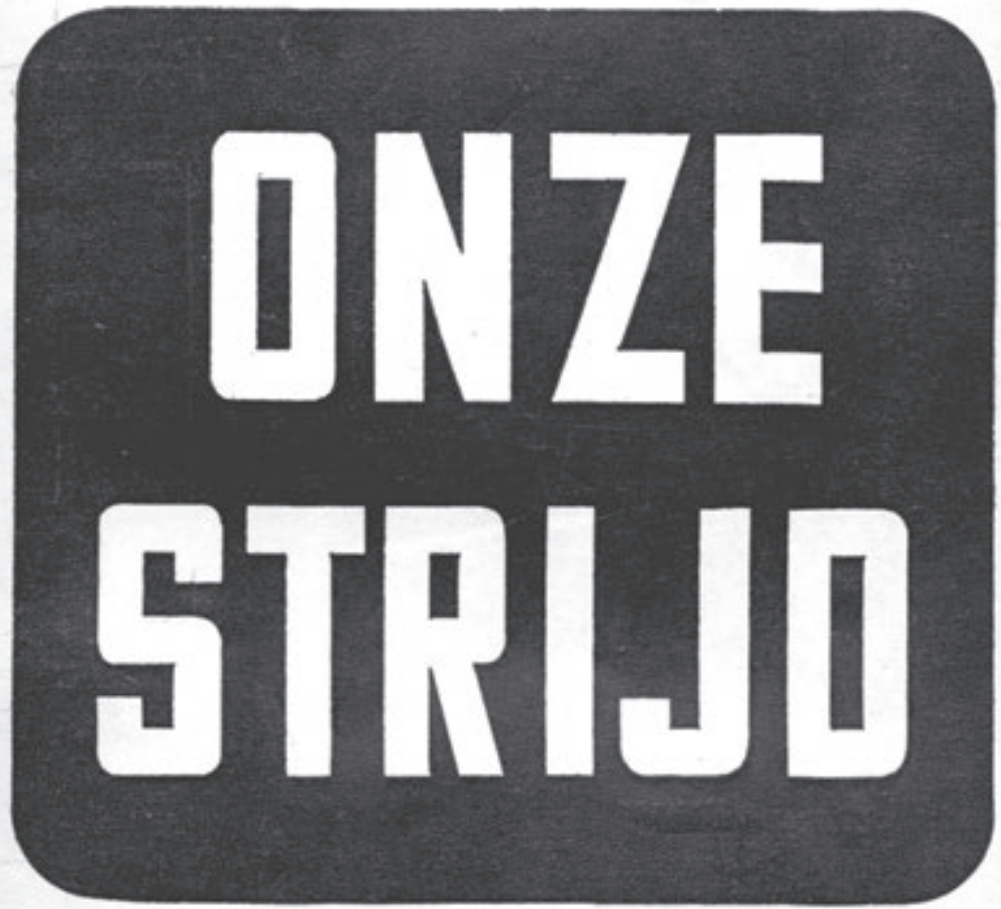

„Onze kraeht moet bestaan in het aankweken van geveelens van rechtvaarigheid en menselijkheid. Alleen een nationalisme, dat gedragen wordt door deze gevoelens. kan ous in de wereldgesehiedenis voeruitbrengen*"

Begin 1946, toen Sjahrir (1909-1966) premier van de Republiek Indonesië was, verscheen in Nederland een vertaling van zijn geruchtmakende brochure Perdjoeangan kita uit november 1945, waarin hij zich onder meer had gekeerd tegen alle 'overblijfselen van het Japanse fascisme' in de Indonesische samenleving. 
allen die hand- en spandiensten aan de Japanse bezettingsmacht hadden verleend; degenen die aan de Japanse propaganda hadden meegewerkt noemde hij zelfs 'verraders van onze strijd'. Verder verklaarde hij onder meer dat er een eind moest komen aan het feodalisme en aan de feodale bureaucratie. Ook waarschuwde hij tegen het gevaar van het militarisme. De Republiek had een leger nodig, maar de Indonesiërs zouden geen knechten van dat leger mogen worden.

De voornaamste richtsnoeren voor het beleid die Sjahrir in Onze strijd aangaf betroffen het elimineren van Japanse invloeden, het aankweken van gevoelens van rechtvaardigheid en menselijkheid, het democratiseren van het regeringsapparaat en het bestrijden van de bandeloosheid onder de bevolking. Hoewel hij in zijn analyse soms socialistische uitgangspunten hanteerde, bepleitte hij voor de naaste toekomst geen socialistisch program. Hij merkte integendeel op dat Indonesië zich voorlopig in een Brits-Amerikaanse imperialistisch-kapitalistische sfeer bevond en daar zelf geen verandering in kon brengen. Daarom moest het ervoor waken niet in vijandschap met die kapitalistische wereld te raken. Het zou zich juist zoveel mogelijk als arbeidsterrein voor die wereld open moeten stellen, mits het welzijn van de bevolking daar niet door werd aangetast.

De aansporing van het Werkcomité tot het vormen van politieke partijen viel in vruchtbare aarde (sommige voorbereidingen van partijvorming waren trouwens al eerder begonnen). Zo verschenen in de loop van november twee socialistische partijen op het toneel. De ene was opgericht door vertrouwelingen van Amir Sjarifoeddin, onder meer afkomstig uit de vooroorlogse Gerindo; de andere door geestverwanten van Sjahrir, onder meer uit de vooroorlogse PNI Baroe. In december fuseerden deze partijen tot één Partai Sosialis (PS). De communistische partij PKI, die na de mislukte opstand van 1926 van het toneel was verdwenen, verscheen in november weer in de openbaarheid. In dezelfde maand werd een grote moslimpartij opgericht die besloot zich Masjoemi te noemen, hoewel het in feite niet ging om voortzetting van de door de Japanse bezetters onder die naam gestichte massaorganisatie maar veeleer om herleving van de vooroorlogse Sarekat Islam. Leider van deze Masjoemi werd de arts Soekiman, die in de jaren twintig en dertig een prominente rol in de Sarekat Islam gespeeld had maar zich tijdens de Japanse bezetting op de achtergrond gehouden had. Daarnaast werden ook een rooms-katholieke en een protestants-christelijke partij opgericht, de Partai Katolik Repoeblik Indonesia en de Partai Kristen Indonesia (afgekort Parkindo). De eerste werd geleid door de Javaanse landbouwdeskundige Ignatius Kasimo, de tweede door de Ambonese arts Johannes Leimena. Nog verscheidene andere partijen zagen in deze periode het licht. Enige daarvan fuseerden in januari 1946 tot een partij die de naam Partai Nasional Indonesia aannam, dezelfde naam als die van Soekarno's eerste partij uit 1928. De leiding van deze nieuwe PNI 
berustte bij voormannen van de vooroorlogse Partindo zoals Sartono; de partij kreeg veel aanhang onder bestuurders en ambtenaren.

In de tijd waarin deze partijen werden opgericht dacht men in de Republiek algemeen dat begin 1946 verkiezingen zouden plaatsvinden voor de in de grondwet voorziene volksvertegenwoordiging, hoewel die grondwet zelf niet van verkiezingen repte. Niemand vermoedde dat zulke verkiezingen nog bijna tien jaar op zich zouden laten wachten.

\section{Aantreden van het kabinet-Sjahrir}

Begin november 1945 bevond Soekarno zich in een lastig parket. Op het internationale toneel werd zijn prestige belast door het feit dat bijna al zijn ministers hoge functies bekleed hadden in dienst van de Japanse bezettingsmacht. Op het binnenlands-politieke toneel had zowel zijn stellingname tegen de anti-Britse acties in Midden-Java en Soerabaja als zijn ontmoeting met Van Mook zijn gezag bij de militante jongeren ernstig geschaad. Ook het door Hatta uitgegeven Politiek Manifest was daar slecht gevallen. Evenals Hatta en Sjahrir was Soekarno zich bewust van de noodzaak de Britse goodwill niet te verspelen. Daarnaast wist hij dat Sjahrir wegens zijn onbesmet verleden tijdens de Japanse bezetting een aanvaardbare gesprekspartner voor Nederland was. In deze situatie bood het voorstel van het Werkcomité van het KNIP een welkome uitweg.

Op 11 november kreeg Sjahrir opdracht een nieuw kabinet samen te stellen. Drie dagen later had hij de formatie voltooid. Zijn regeringsploeg telde elf ministers, onder wie geen personen die al te nauw met de Japanners hadden samengewerkt. Sjahrir was zelf zowel minister-president als minister van buitenlandse zaken en minister van binnenlandse zaken. Amir Sjarifoeddin was zowel minister van voorlichting als minister van 'volksveiligheid' (in feite minister van defensie). Naast hen telde het kabinet geen andere prominente figuren uit de nationale beweging; ook bevatte het geen bekende moslimleider en geen vertegenwoordiger van de militante jongeren. Vier ministers waren christenen, onder wie Amir en het vroegere Volksraadslid Moelia, die Dewantoro als minister van onderwijs opvolgde. Overigens weigerden de ministers van het oude kabinet ontslag te nemen, zodat Soekarno hen uitdrukkelijk moest ontslaan. Voor ambitieuze figuren als Soebardjo, Iwa Koesoema Soemantri en Abikoesno, met een lange staat van dienst binnen de nationale beweging, was het moeilijk te verteren dat zij op zo abrupte manier aan de kant werden gezet. Bovendien was de in Sjahrir's brochure vervatte kritiek op samenwerking met Japan bij uitstek op Soekarno zelf van toepassing.

De ontvangst van het kabinet-Sjahrir in de Indonesische pers liep uiteen van vriendelijk tot vijandig. Niettemin sprak het KNIP, dat van 25 tot 27 
november opnieuw plenair vergaderde, met grote meerderheid zijn vertrouwen in het kabinet uit. Ook stemde het in met de invoering van ministeriële verantwoordelijkheid en de aanmoediging van partijvorming. Omdat vier van de ministers afkomstig waren uit het in oktober gevormde Werkcomité verving het KNIP dit door een nieuw comité. Het nieuwe Werkcomité bestond uit vijfentwintig leden en was veelzijdiger van samenstelling dan het vorige; zo telde het onder zijn leden ook Adam Malik en Soekarni, die aanhangers van Tan Malaka waren.

Het vertrouwensvotum van het KNIP betekende nog niet dat de regeringSjahrir de teugels in de Republiek vast in handen had. Over de bestuursambtenaren behoefde zij zich weinig zorgen te maken; die waren in de regel loyaal aan het boven hen gestelde gezag, of dit nu Nederlands, Japans of Republikeins was. Daarentegen kon zij minder zeker zijn van de op regionaal en lokaal niveau gevormde nationale comités; die zouden zich zelfs kunnen ontwikkelen tot kernen van verzet tegen het regeringsbeleid. De gebeurtenissen in Soerabaja hadden het belang van een sterkere greep van de regering op het regionale en plaatselijke beleid onderstreept. De eerste legislatieve daad van de regering-Sjahrir bestond dan ook in de uitvaardiging van een wet die de zelfstandige positie van de regionale comités beknotte. De comités werden omgezet in vertegenwoordigende lichamen onder voorzitterschap van de door de regering aangestelde regionale bestuurshoofden, terwijl de door de comités zelf gekozen voorzitters gedegradeerd werden tot vice-voorzitters. De werkzaamheden van deze lichamen dienden zich te beperken tot regionale zaken en mochten niet in strijd komen met regelingen van bestuursorganen op hoger niveau of van de centrale regering.

Dat de macht van de regering-Sjahrir nog zeer beperkt was, kwam vooral door de talloze autonome strijdgroepen die weinig geneigd waren zich aan hoger gezag te onderwerpen. Een bijna even moeilijk probleem was de zeggenschap van de regering over de officiële strijdkrachten. De officieren van de TKR waren grotendeels afkomstig uit de Peta, waarin ze tijdens hun opleiding vertrouwd waren geraakt met de ideologie van het Japanse militarisme. Die ideologie had aan de strijdkrachten een functie in de maatschappij toegekend die ver boven de zuiver militaire functie uitging. In het Japanse staatsbestel hadden de strijdkrachten dan ook destijds niet onder maar naast de regering gestaan; ze hadden bovendien in die regering zelf de ministers van oorlog en marine aangewezen. Ook het Republikeinse leger zag zich niet als ondergeschikt aan de regering, maar kende zich binnen het kader van de nationale revolutie een zelfstandige rol toe. Het waren dit soort opvattingen die Sjahrir ertoe gebracht hadden in zijn brochure te waarschuwen tegen de gevaren van het militarisme. 


\section{Benoeming van Soedirman tot Republikeins opperbevelhebber}

Terwijl de regering-Soekarno de post van minister van defensie voorlopig had opengelaten, had zij het opperbevel over de TKR in eerste aanleg toegewezen aan de officier die de anti-Japanse opstand in Blitar geleid had maar sindsdien vermist werd. Al spoedig werd het duidelijk dat hij niet meer in leven was. De hoogste officieren van de TKR besloten nu tijdens een vergadering in Jogjakarta op 12 november zelf uit hun midden de minister van defensie en de panglima besar (opperbevelhebber) te kiezen. Voor de laatste post gingen de meeste stemmen naar generaal Soedirman, een divisiecommandant in Midden-Java die kort daarvoor een leidende rol gespeeld had in de strijd bij Magelang en Ambarawa. Tot minister van defensie koos men de sultan van Jogja, Hamengkoe Boewono IX, die als generaal-titulair aan de vergadering deelnam.

De op 14 november optredende regering-Sjahrir zag zich dus terstond geconfronteerd met twee besluiten van de legertop die inbreuk maakten op de bevoegdheden van de president en de centrale regering. Met moeite wist zij te bereiken dat het leger toch Amir Sjarifoeddin in plaats van de sultan als minister van defensie aanvaardde. Ten aanzien van Soedirman moest zij echter voor de druk van het leger zwichten; na vijf weken bekrachtigde zij diens benoeming. Zijn benoeming had belangrijke politieke consequenties als gevolg van zijn persoonlijke eigenschappen en opvattingen.

Soedirman, geboren en opgegroeid in Midden-Java en nu ruim dertig jaar oud, was een voormalige onderwijzer die in de Japanse tijd bataljonscommandant bij de Peta geworden was. Hij leed aan tuberculose, maar paarde zijn zwakke gezondheid aan een sterke wil en een ascetische levensstijl. Zijn deskundigheid op militair gebied was beperkt, maar hij was een inspirerende aanvoerder, geliefd bij zijn soldaten en officieren en zeker van hun trouw. Soedirman beschouwde zijn uitverkiezing als een heilige opdracht in dienst van de nationale onafhankelijkheid. Evenals de autonome strijdgroepen zag hij de verdediging van die onafhankelijkheid bovenal als een zaak van strijd en niet als een zaak van diplomatie. Hiervan had hij al blijk gegeven toen hij de Britse troepen in Midden-Java bevocht terwijl Soekarno zich juist voor een goede verstandhouding met de Britten inspande. Dit verschil in visie op het te voeren beleid was van politiek belang omdat Soedirman meende als opperste legeraanvoerder op gelijke voet met de regering te staan.

\section{Eerste overleg tussen Van Mook en Sjahrir}

Het aantreden van het kabinet-Sjahrir bracht een verandering teweeg in de Nederlandse opstelling tegenover de Republiek Indonesië. Men kon die niet 
meer louter als een product van de vijand zien nu daar een kabinet optrad dat van Japanse smetten vrij was. De nieuwsmedia citeerden uitvoerig uit de brochure Onze strijd, waaruit bleek dat Sjahrir zowel de collaboratie met Japan als de geweldpleging door jongeren scherp veroordeelde. Daar kwam nog iets bij. Kort daarvoor was een Nederlands tijdschrift begonnen met de publicatie van een geschrift dat in november 1945 onder de titel Indonesische overpeinzingen ook als boek verscheen. Het had de vorm van dagboekaantekeningen uit de jaren dertig van een Indonesische nationalist, genaamd Sjahrazad, die door het Nederlands-Indische gouvernement gevangen genomen en verbannen was. Deze figuur bleek een westers georiënteerde, erudiete intellectueel en bovendien een principiële democraat te zijn. Al spoedig nadat Sjahrir minister-president geworden was werd het bekend dat hij met een Nederlandse vrouw getrouwd was en dat de onder de naam Sjahrazad gepubliceerde belevenissen en beschouwingen afkomstig waren uit brieven die hij haar tijdens zijn gevangenschap en ballingschap geschreven had.

Hoewel Soekarno president bleef, ruimde de totstandkoming van het kabinet-Sjahrir dus aan Nederlandse kant een belangrijke blokkade tegen overleg met de Republiek uit de weg. Dit betekende echter nog niet dat er een materiele grondslag voor politiek overleg bestond. De standpunten van Nederland en de Republiek lagen ver uiteen.

Op basis van instructies uit Den Haag had Van Mook's gouvernement op 6 november een uitvoerige verklaring over de Nederlandse opstelling gepubliceerd. Onder verwijzing naar de rede van de koningin uit 1942 stelde deze verklaring aan Indonesië een volledig deelgenootschap binnen het Koninkrijk in het vooruitzicht, te regelen door de Nederlandse wetgever op basis van een tussen alle rijksdelen te houden ronde-tafel-conferentie. Vooruitlopend daarop bevatte het stuk slechts enige bekende punten zoals uitbreiding van de inheemse meerderheid in de Volksraad en afschaffing van de discriminatie in rechtspraak en bestuur. Wat de naaste toekomst betreft stelde de verklaring onder meer dat de door de Japanners wederrechtelijk aan onbevoegden uitgeleverde wapens moesten worden overgedragen aan de geallieerden. Over de Republiek en haar regering repte de verklaring met geen woord. Ook voorzag ze niet in een recht van Indonesië om te kiezen voor een onafhankelijk bestaan buiten het Nederlandse Koninkrijk. De verklaring kwam er in feite op neer dat Nederland van de Indonesische nationalisten verlangde hun Republiek op te geven, hun wapens in te leveren en terug te keren onder de Nederlandse vlag in een gemoderniseerd koloniaal bestel met uitzicht op een meer zelfstandige positie binnen het rijksverband in de toekomst.

Op uitnodiging en onder voorzitterschap van generaal Christison sprak een delegatie onder Van Mook op 17 november voor het eerst met een delegatie onder Sjahrir. Deze bespreking leidde tot niets. Christison prees de Nederlandse verklaring van 6 november en vroeg de Indonesische delegatie 
er op in te gaan. Sjahrir was daar niet toe bereid. Hij voerde hierbij onder meer aan dat hij er nog geen overleg over had kunnen plegen met zijn pas gevormde kabinet.

Hoewel de bespreking van 17 november niets opleverde was ze van politiek belang, omdat men er algemeen uit opmaakte dat de Nederlandse regering nu officieel met de Republikeinse regering in contact getreden was. Deze conclusie was echter voorbarig, zoals eind november bleek uit een interview van Logemann met de Britse radio-omroep BBC. Daarin verklaarde hij niet alleen opnieuw dat zijn regering nooit met Soekarno zou onderhandelen, maar ook dat zij met Sjahrir slechts sprak als leider van de Indonesische nationalisten en niet als minister-president van de Republiek. Verder zei hij onder meer dat over onafhankelijkheid niet te praten viel en dat onderhandelingen onmogelijk waren zolang men de extremisten niet onderworpen en ontwapend had.

De Britse regering was ontsteld over Logemann's uitspraken. Ze vormden ook een onprettige verrassing voor Van Mook, wiens overleg met Sjahrir hierdoor op losse schroeven kwam te staan. Overigens was Sjahrir in deze fase toch al niet bereid tot voortzetting van het officiële overleg, al voerde hij wel enkele informele gesprekken met Van Mook. In feite vond hij het nog te vroeg om naar een akkoord met Nederland te streven. Eerst moest zijn regering haar eigen positie consolideren en moest zij proberen binnen de Republiek orde op zaken te stellen, vooral door een betere disciplinering van de jongeren en van het leger. Een andere reden om geen haast te maken was de verwachting dat de Britse troepen Indonesië al spoedig zouden verlaten, wat de Nederlandse onderhandelingspositie zou verzwakken. In maart 1946 zouden in India verkiezingen plaatsvinden en het leed geen twijfel dat de Congrespartij die zou winnen. De leider daarvan, Nehru, zou in geen geval instemmen met het gebruik van Indiase soldaten voor het onderdrukken van de Indonesische vrijheidsbeweging. Nehru kende Hatta overigens al sinds 1927 toen zij beiden in het bestuur zaten van de internationale Liga tegen Imperialisme en Koloniale Onderdrukking (zie p. 195).

Het hoofdkwartier van SEAC verhuisde eind november van Ceylon naar Singapore. Op 6 december sprak Mountbatten daar uitvoerig met Van Mook over het in Indonesië te voeren militaire en politieke beleid. Bij die gelegenheid zei hij dat men de Indiase troepen na maart 1946 niet meer op Java zou kunnen handhaven tenzij er dan een politieke regeling met de nationalisten bereikt zou zijn, want alleen dan zou men duidelijk kunnen maken dat die troepen daar alleen nog bleven voor de vervulling van humanitaire taken. Mountbatten was geërgerd over de negatieve opstelling van de Nederlandse regering en voerde met deze aankondiging de druk op Nederland zo hoog mogelijk op. 


\section{Van Mook's keuze voor federalisering van Indonesië}

Ook los van de Britse druk vond Van Mook een politiek akkoord met de Republiek noodzakelijk. Zijns inziens zou het voor Nederland een onaanvaardbare last betekenen om te proberen het conflict langs militaire weg op te lossen. Van der Plas, Abdoelkadir, Idenburg en Schilling waren dezelfde mening toegedaan. Bovendien dacht Van Mook dat de internationale gemeenschap Nederland niet zou toestaan een langdurige 'koloniale' oorlog te voeren.

Bij dit alles ging het echter vooral om de situatie op Java. In andere delen van Indonesië stonden de zaken er anders voor. Op Java was de inheemse bevolking op grote schaal gepolitiseerd en gemilitariseerd; het onafhankelijkheidsstreven had er massale aanhang verworven en de nationalisten beschikten er nu over grote voorraden wapens; de Britse troepen hadden zelfs moeite zich in hun enclaves te handhaven. Heel anders was de situatie in de gebieden die door de Japanse marine bestuurd geweest waren, in Borneo en het oostelijke deel van de archipel. Niet alleen waren die gebieden in vergelijking met Java dun bevolkt, maar ook had het Japanse bestuur de bevolking daar niet massaal gepolitiseerd en had het er vrijwel geen nationalistische propaganda toegelaten. De Australische troepen hadden dan ook in het merendeel van deze gebieden het gezag zonder veel problemen van de Japanners kunnen overnemen; bovendien hadden ze de NICA hier op ruime schaal bij het bestuur ingeschakeld. De situatie op Sumatra was minder eenvoudig. Het nationalisme leefde daar sterk; het Japanse leger dat dit eiland bestuurde had er wel inheemse strijdgroepen georganiseerd en de Britse troepen hadden er tot nu toe alleen enkele enclaves bezet. Daar stond echter tegenover dat deze inheemse strijdgroepen numeriek en in bewapening zwakker waren dan die op Java.

Van Mook vond dat men aan Nederlandse kant zijn aandacht niet uitsluitend op Java moest richten, maar dat men gebruik moest maken van de mogelijkheden actief in andere delen van Indonesië op te treden. Australië wilde zijn strijdkrachten graag uit Borneo en de oostelijke archipel terugtrekken; het voornaamste probleem was dat zich in dit gebied honderzeventigduizend Japanners bevonden die men nog niet had kunnen afvoeren. Nederland zou met betrekkelijk weinig troepen kunnen volstaan om het gebied van de Australiërs over te nemen. Daarnaast achtte Van Mook het uitvoerbaar spoedig gebieden aan de oostkant van Sumatra met Nederlandse troepen te bezetten. Zulk een herstel van het Nederlandse gezag over grote delen van de archipel zou onder meer betekenen dat Nederland de meeste productiegebieden van aardolie, tin, rubber en tabak zou beheersen, wat de Republiek economisch in een moeilijk parket zou brengen. Verder zou zulk gezagsherstel het volgens Van Mook mogelijk maken aanschouwelijke bewijzen te leveren van nieuwe vormen van Nederlands-Indonesische samenwerking. Een en ander zou de 
Nederlandse onderhandelingspositie ten goede komen voor het bereiken van een akkoord met de Republiek.

Ten aanzien van de vraag wat zo'n akkoord zou kunnen inhouden liet Van Mook zich door verschillende overwegingen leiden. Hij begreep dat de Nederlandse verklaring van 6 november geen reële basis voor overleg met de Republiek zijn kon. Als Nederland werkelijk naar een akkoord wilde streven zou het méér moeten bieden. Op grond van zijn informele gesprekken met Sjahrir meende Van Mook daartoe wel mogelijkheden te zien. Voor de oplossing van het conflict achtte hij het noodzakelijk de Indonesiërs uitzicht op onafhankelijkheid te bieden. Verder ging hij ervan uit dat men van de Republikeinen niet kon vergen de Republiek formeel op te heffen; erkenning van de Republiek was ook voor de regering-Sjahrir een voorwaarde voor een politiek akkoord. Aan de andere kant overwoog hij dat men weliswaar de Republiek op Java niet militair kon onderwerpen, maar dat het wel mogelijk was het Nederlandse gezag te herstellen over de oostelijke archipel en Borneo en wellicht ook over de economisch waardevolste delen van Sumatra. Dit bracht hem op de gedachte dat het voor de oplossing van het conflict gunstig zou zijn het centralistische staatsbestel van Nederlands-Indië te vervangen door een federaal bestel. De kolonie zou dan worden hervormd tot een federatie van deelstaten, waarbij de Republiek gelegenheid zou krijgen een plaats onder die deelstaten in te nemen.

Van Mook dacht dat deze federale formule Nederland in staat zou stellen de Indonesische nationalisten halverwege tegemoet te komen. Nederland zou dan uitzicht kunnen bieden op onafhankelijkheid, echter niet voor de Republiek maar voor de Indonesische federatie en niet onmiddellijk maar in de toekomst. Het zou de Republiek erkenning kunnen geven door met haar een overeenkomst te sluiten, echter niet als vertegenwoordigster van heel Indonesië maar als vertegenwoordigster van een samenstellend deel.

De gedachte van vervanging van het centralistische Nederlands-Indische bestel door een federaal bestel was op zichzelf niet nieuw. Zulk een federalisering was al na de Eerste Wereldoorlog bepleit door Nederlandse politici die de opkomst van het Indonesisch nationalisme wilden tegengaan (zie p. 179). Later had de federatiegedachte ook onder de nationalisten zelf aanhang verworven; nog in 1930 had Soekarno zich een 'Federatieve Republiek Indonesië' ten doel gesteld. Maar toen de nationalisten in 1945 de grondwet van de Republiek opstelden wees de meerderheid de federatiegedachte af (zie p. 342). De figuur van een overeenkomst tussen de Nederlandse staat en een Indonesische deelstaat was evenmin nieuw. Ook in het koloniale bestel was de positie van verschillende zelfbestuursgebieden zoals de Midden-Javaanse vorstendommen geregeld in overeenkomsten met het Nederlandse oppergezag.

Bij zijn beoordeling van de politieke situatie in Indonesië verdeelde Van Mook de nationalisten - zoals toen zowel aan Nederlandse als aan Britse kant 
gebruikelijk was - in twee categorieën, namelijk de gematigden en de extremisten. Voor de oorlog was de term 'extremisten' onder Nederlanders in zwang geweest ter aanduiding van alle voorstanders van volledige Indonesische onafhankelijkheid (zie p. 218). Na de oorlog verschoof de betekenis van deze term; 'extremisten' noemde men nu vooral diegenen die de onafhankelijkheid niet door politieke middelen maar door gewapende strijd tot stand wilden brengen. Onder 'gematigden' placht men nu niet alleen die Indonesiërs te verstaan die prijs stelden op behoud van een band met Nederland, maar ook die voorstanders van volledige onafhankelijkheid die hun doel langs politieke weg wilden verwezenlijken, zelfs als ze het standpunt huldigden dat de onafhankelijkheid al bereikt was door de stichting van de Republiek. Intussen vertrouwde Van Mook er op dat men zulke gematigde Republikeinen toch wel bereid zou kunnen vinden om met minder dan volledige en onmiddellijke onafhankelijkheid genoegen te nemen. Verder dacht hij dat het democratisch gezinde kabinet-Sjahrir misschien de laatste kans bood op een akkoord met Nederland; zou dit kabinet vallen dan zou de leiding waarschijnlijk in handen komen van extremisten waarmee niet meer te praten viel. Ter versterking van Sjahrir's positie achtte Van Mook het van belang de invloed van de extremisten krachtig terug te dringen. Hij was daarom geporteerd voor een grote geallieerde militaire actie tegen de strijdgroepen in West-Java opdat daar een veilige zone tot stand zou komen waar gematigde nationalisten zich vrij zouden voelen om met Nederlandse vertegenwoordigers te onderhandelen.

\section{Overleg van Van Mook in Den Haag en Londen}

Op 15 december 1945 vertrok Van Mook naar Nederland om te proberen de regering voor zijn benadering te winnen. Hij hoopte dat vervolgens ook de Britse regering zich daarachter zou willen plaatsen en stelde daarom voor dat de beide regeringen op hoog niveau met elkaar overleg zouden plegen over het ten aanzien van Indonesië te voeren beleid.

In de dagen voor Kerstmis nam Van Mook in Den Haag deel aan een reeks besprekingen binnen de regering. Daarbij slaagde hij niet volledig in zijn opzet. De meeste ministers leken nog weinig te beseffen wat er in Indonesië aan de hand was. Bovendien vond op 21 december een parlementair debat over het Indonesië-probleem plaats waarin verscheidene sprekers ernstige kritiek leverden op het standpunt van minister Logemann over de noodzaak van een politieke oplossing.

Van Mook's overleg met de regering leidde niet tot het bieden van een duidelijk uitzicht op Indonesische onafhankelijkheid. Zowel hij als Logemann wilde er geen twijfel aan laten bestaan dat Indonesië in de toekomst, bijvoorbeeld over vijfentwintig jaar, vrij zou zijn om de band met Nederland te verbreken. 
Enige andere ministers, onder wie de minister van binnenlandse zaken Beel, vonden dat men bij het overleg met de nationalisten zou moeten uitgaan van de eenheid en niet van de ontbinding van het Koninkrijk. Sommige ministers erkenden in beginsel wel dat Indonesië uiteindelijk het recht op afscheiding moest krijgen, maar vonden het niet juist dit nu al openlijk te verklaren.

Daarentegen stemde het kabinet zonder discussie in met de door Van Mook bepleite federale opzet voor het toekomstige Indonesische staatsbestel. Als voornaamste argument daarvoor had Van Mook aangevoerd dat men overheersing van Java over de rest van de archipel moest voorkomen. Logemann voorzag overigens veel praktische moeilijkheden bij de uitwerking van de federale gedachte.

Van Mook repte met geen woord van de mogelijkheid dat de Republiek zelf een deelstaat binnen de Indonesische federatie zou worden. Hij noemde de Republiek ook nooit als onderhandelingspartner, maar sprak alleen over overleg met 'de nationalisten' of met 'de groep-Sjahrir'. Lieftinck, de minister van financiën, wilde dat de nationalisten de Republiek zouden opgeven en het rijksgezag zouden erkennen voordat ze aan besprekingen in Nederland zouden mogen deelnemen. Volgens Van Mook kon men dit niet van hen vergen. Overigens had hij zelf tot de opstelling van Lieftinck bijgedragen. In zijn streven om een mandaat voor overleg los te krijgen had hij namelijk aan het kabinet verklaard dat de groep-Sjahrir de Republiek als 'onwerkbaar' zag en dat zij Indonesische onafhankelijkheid en eenheid nu 'onverwezenlijkbaar' achtte.

Op 24 december bereikte de ministerraad overeenstemming aan de hand van een door Logemann opgesteld stuk over de toekomstige staatkundige structuur van Indonesië en van het Koninkrijk. De Republiek Indonesië werd in dat stuk niet vermeld.

Op 27 december vond op het buitenverblijf van de Britse premier te Chequers bilateraal regeringsoverleg plaats over het in Indonesië te voeren militaire en politieke beleid. De Nederlandse delegatie bestond uit Schermerhorn, Logemann, Van Mook, Van Roijen en de Nederlandse ambassadeur; premier Attlee liet zich onder meer door het hoofd van de Britse generale staf bijstaan. Bevin, de minister van buitenlandse zaken, was niet aanwezig, maar met hem voerde Van Mook begin januari alsnog een gesprek. Te Chequers lichtte Schermerhorn het program van zijn regering voor de politieke ontwikkeling van Indonesië toe. Aan Britse zijde nam men aan dat de Nederlanders hun kolonie in navolging van de Britten tot dominion wilde verheffen. Attlee toonde zich tevreden over de intentie van de Nederlandse regering om met de Indonesische nationalisten een politiek akkoord tot stand te brengen. Hij waarschuwde echter dat de Britse regering haar troepen alleen op Java liet blijven om zo'n akkoord bereikt te zien en niet om het Nederlandse bewind te herstellen ongeacht de wensen van de Indonesiërs. Hij zei overigens niet 
dat men die troepen zou weghalen als zo'n akkoord eind maart nog niet tot stand gekomen zou zijn. Hoewel te Chequers van Britse kant nauwelijks enige toezegging werd gedaan, droeg het overleg toch bij tot een betere verstandhouding tussen de beide regeringen. De Britse regering besloot bovendien een hoge Britse diplomaat naar Batavia te zenden om bijstand te verlenen bij de Nederlands-Indonesische besprekingen.

\section{Samenwerking van de regering-Sjahrir met de Britse bezettingsmacht}

De op 14 november aangetreden regering-Sjahrir toonde zich bereid tot loyale samenwerking met het Britse hoofdkwartier in Batavia. Dit bleek al binnen een week toen zij gevolg gaf aan een eis van generaal Christison dat alle eenheden van de TKR, het Republikeinse leger, de stad zouden verlaten wegens het toenemende aantal incidenten waar militairen van de verschillende partijen bij betrokken waren. Christison eiste destijds ook van het KNIL dat het al zijn inheemse (voornamelijk Ambonese) militairen uit Batavia zou weghalen, maar hun vertrek werd uitgesteld totdat ze eind december waren afgelost door een in Amerika opgeleid bataljon Nederlandse mariniers; daarna werden deze KNIL-militairen ten zuiden van Batavia opgesteld.

Terwijl de Republikeinse regering zelf goede betrekkingen met het Britse hoofdkwartier onderhield, ging de TKR in Midden-Java en in Soerabaja door met haar strijd tegen de Britse troepen. In West-Java beschikten de Indonesische strijdgroepen over veel minder wapens dan in Midden- en OostJava, maar ook hier bleven zij de geallieerde strijdkrachten bestoken, onder meer door het beschieten van konvooien tussen Buitenzorg en Bandoeng. Eind november opende de TKR zelfs een algemene aanval op het Britse garnizoen in Bandoeng. Door bemiddeling van de Republikeinse regering en in het bijzonder van Amir Sjarifoeddin, de minister van defensie, kwam na enkele weken een eind aan deze strijd. Amir riep ook op tot beëindiging van het schieten op de wegkonvooien en regelde dat een geallieerde bevoorradingstrein onder escorte van de TKR naar Bandoeng kon rijden. Overigens leidde het conflict in Bandoeng tot een etnische tweedeling: terwijl ongeveer zestigduizend Europeanen en Indo-Europeanen onderdak vonden in het door de Britse troepen beheerste noordelijke stadsdeel, concentreerde de inheemse bevolking zich in het zuidelijke deel.

Samen met Soekarno maakten Sjahrir en Amir Sjarifoeddin in de tweede helft van december een uitgebreide reis door Midden- en Oost-Java om de steun voor hun regering te vergroten. De vijandelijkheden tussen Indonesische en Britse strijdkrachten namen in deze tijd sterk af. Intussen hield Christison er rekening mee dat zijn Brits-Indische troepen eind maart naar India zouden moeten terugkeren zonder dat hij zich hadden kunnen kwijten van 
zijn taak alle Japanners af te voeren en alle ex-geïnterneerden in veiligheid te brengen. Het Britse hoofdkwartier opende daarom overleg met de TKR over een regeling waarbij het Republikeinse leger de Japanners en de geïnterneerden uit Republikeins gebied naar de Britse enclaves over zou brengen. De Nederlandse autoriteiten waren ontsteld over dit overleg, waar zij pas achteraf van vernamen. Eveneens bleek hun pas achteraf dat de Britse regering geen toestemming gaf voor de door Van Mook bepleite grote militaire actie om in West-Java een veilige zone tot stand te brengen. Wel gaf Londen machtiging voor een beperkte zuiveringsoperatie tegen ongeregelde strijders in en rondom Batavia. Nadat het Britse garnizoen daar met twee brigades versterkt was, voerde Christison deze operatie eind december uit. Daarbij deed hij een beroep op de Indonesische leiders om hieraan mee te werken en hiervoor ook TKR-eenheden beschikbaar te stellen.

\section{Verplaatsing van de hoofdzetel van de Republiek naar Jogjakarta}

In de laatste maanden van 1945 werd de veiligheid van de Indonesische leiders in Batavia steeds meer een probleem wegens de fel anti-Republikeinse stemming onder veel Nederlandse, Indo-Europese en Ambonese ingezetenen. Er vonden herhaaldelijk aanslagen op Republikeinse voormannen plaats. Bovendien viel te verwachten dat de Republikeinse regering in een moeilijke positie zou komen te verkeren als de Britse strijdkrachten Batavia in het voorjaar zouden verlaten, want dan zou zij rechtstreeks geconfronteerd worden met het Nederlands-Indische gouvernement dat haar als onwettig beschouwde. De Republikeinse leiders maakten daarom graag gebruik van een uitnodiging van sultan Hamengkoe Boewono IX om de hoofdzetel van de Republiek naar Jogjakarta te verplaatsen. In de loop van december begon men al met de overbrenging van enige regeringsdiensten naar de nieuwe hoofdstad. In de nacht van 3 op 4 januari vertrokken Soekarno en Hatta en een aantal ministers en hun gezinnen met een speciale trein naar Jogja.

Sjahrir bleef met enkele medewerkers in Batavia achter met het oog op zijn besprekingen met Britse en Nederlandse autoriteiten, hoewel hij zelf al het doelwit van aanslagen door KNIL-militairen geweest was. De villa van Soekarno aan Pegangsaän Oost gebruikte hij voortaan als ambtswoning en kantoor. Gewoonlijk reisde hij op het eind van de week naar Jogja om daar op zaterdag met zijn kabinet te vergaderen.

Verder handhaafde het Republikeinse ministerie van voorlichting een bureau in Batavia dat zich richtte op het Nederlandse en het buitenlandse publiek. Nadat Van Mook's gouvernement in januari 1946 een weekblad was gaan publiceren onder de titel Uitzicht, reageerde dit bureau binnen een week met de uitgave van een eigen weekblad onder de titel Het Inzicht. 


\section{Benoeming van Spoor tot Nederlands opperbevelhebber in Indonesië}

In december 1945 en januari 1946 vonden in Batavia enige belangrijke personeelswisselingen plaats. Dit betrof allereerst Van der Plas, die door veel Nederlanders diep gewantrouwd werd en bovendien ook aan Indonesische kant weinig vertrouwen genoot. Hij nam ontslag als lid van de Raad van Indië en als hoofd van het departement van binnenlands bestuur; overigens bleef hij Van Mook als adviseur terzijde staan. De Britse regering verving generaal Christison, wiens optreden in veler ogen er sterk toe bijgedragen had de Republiek in het zadel te helpen. Aldus verdwenen twee figuren van het toneel die stenen des aanstoots gevormd hadden voor de conservatieven die niet van concessies aan de Republiek wilden weten. Aan de andere kant verving de Nederlandse regering zelf twee personen die deze conservatieve opstelling bij uitstek vertegenwoordigden, namelijk vice-admiraal Helfrich, Bevelhebber Strijdkrachten Oosten (BSO), en luitenant-generaal Van Oyen, legercommandant van het KNIL. De regering hief de functie van BSO op en belastte Helfrich met het commando over de marine in Nederland. Tot marinecommandant in Indonesië benoemde zij A.S. Pinke, die in zijn opvattingen weinig van Helfrich verschilde maar een buigzamer karakter had. Tot opvolger van Van Oyen benoemde zij het hoofd van de NEFIS, kolonel S.H. Spoor, die nu luitenant-generaal werd.

Voor de functie van legercommandant had Van Mook aanvankelijk voorkeur gehad voor generaal Schilling, wiens visie op de militaire en politieke situatie met de zijne overeenkwam en die lange tijd in Atjeh gediend had waardoor hij over praktijkervaring beschikte in de bestrijding van gewapend volksverzet. In militaire kringen bestonden echter weerstanden tegen Schilling; zijn mening dat het ondoenlijk was de Republiek met militaire middelen uit te schakelen vond men defaitistisch; bovendien was hij al vijfenvijftig jaar oud. Van Mook had uiteindelijk zelf de twaalf jaar jongere Spoor aanbevolen. Diens benoeming tot opperbevelhebber had belangrijke politieke consequenties als gevolg van zijn persoonlijke eigenschappen en opvattingen.

Spoor, zoon van een concertmeester van het Concertgebouworkest, was onder de beroepsofficieren van het KNIL een uitzonderlijke figuur. Hij was erudiet, geestig en snel van begrip. Anders dan Schilling beschikte hij niet over praktijkervaring op het gebied van de contraguerrilla; daarentegen had hij wel enige ervaring op het gebied van politiek en propaganda. In de periode voor de Japanse bezetting was hij betrokken geweest bij de zeer rooskleurige publieksvoorlichting over de defensiecapaciteit van Nederlands-Indië. Na de Japanse landingen op Java was hij samen met kapitein Buurman van Vreeden naar Australië gezonden, waar hij later hoofd was geworden van de Nederlandse militaire inlichtingendienst NEFIS. Hij leek niet gebukt te gaan onder het feit dat deze dienst er destijds niet in geslaagd was een adequaat beeld te krijgen 
van de politieke ontwikkelingen op Java onder Japans bestuur. Integendeel, hij was de Republiek als een Japans maaksel blijven zien en toonde weinig begrip voor het Indonesisch nationalisme. Nog in december noemde hij de nationale beweging 'voor 3\% nationalistisch en voor 97\% Japans met een sterk communistische inslag'.

Als legercommandant werd Spoor tegelijk hoofd van het departement van oorlog en daardoor lid van het Nederlands-Indische gouvernement. In zijn nieuwe positie ontpopte Spoor zich als een bij uitstek politieke generaal die niet alleen grote populariteit verwierf onder zijn soldaten en officieren maar ook graag gebruik maakte van zijn talenten om het publiek te bespelen. Zowel bij journalisten als bij politici wist hij zijn meningen met verve naar voren te brengen. Die meningen wortelden steeds in zijn overtuiging dat het wel degelijk mogelijk was de Republiek met militaire middelen uit te schakelen.

In februari benoemde de regering Buurman van Vreeden tot chef-staf van het KNIL, met de rang van generaal-majoor. Evenals in de Republiek al het geval was werd nu ook aan Nederlandse kant een inspirerende legeraanvoerder bijgestaan door een nuchtere organisator.

\section{Formele Nederlandse erkenning van het Indonesisch zelfbeschikkingsrecht}

Eind december 1945 had de Nederlandse regering in overleg met Van Mook overeenstemming bereikt over een program voor de politieke ontwikkeling van Indonesië (zie p. 434). Evenals de koninklijke rede van december 1942 en de regeringsverklaring van 6 november 1945 richtte dit program zich op zelfstandigheid van Indonesië in inwendige aangelegenheden en ontwikkeling naar volledig deelgenootschap binnen het Koninkrijk. Het stuk ging vrij gedetailleerd op de nabije toekomst in, maar slechts vaag op het verderweg liggende perspectief. Wat het eerste betreft waren de voornaamste verschillen met de verklaring van 6 november, dat Indonesië een federatie zou moeten worden, opgebouwd uit landen met een uiteenlopende mate van autonomie, dat het parlement van die federatie zou worden samengesteld uit vertegenwoordigers van de autonome landen en van de minderheden, dat deze federatie lid van de Verenigde Naties zou worden en dat in de overkoepelende regering van het Koninkrijk acht ministers uit Nederland en vijf ministers uit Indonesië zitting zouden hebben. Wat het verderweg liggende perspectief betreft bevatte het stuk de cryptische mededeling, dat 'na verloop van een aantal jaren' de constructie van het Koninkrijk zou 'worden overwogen op de grondslag van een volledig en vrijwillig deelgenootschap'.

Toen Van Mook in Batavia teruggekeerd was, bleek dat al zijn adviseurs het Haagse stuk niet geschikt vonden om als regeringsstandpunt gepubliceerd te worden en als uitgangspunt voor besprekingen te dienen. Hun voornaam- 
ste bezwaar was dat het geen ondubbelzinnige erkenning bevatte van een Indonesisch recht op zelfbeschikking aan het einde van de termijn. Van Mook pleegde hierop telegrafisch overleg met Logemann, hetgeen leidde tot geheim beraad tussen de regering en het parlement. Het resultaat was een vereenvoudigde en aangepaste versie, die op 10 februari in Batavia en in Den Haag als Nederlandse regeringsverklaring gepubliceerd werd.

De regering stelde zich hierin uitdrukkelijk 'op het standpunt, dat de bevolking van Indonesië na een begrensde periode van voorbereiding in vrijheid over haar staatkundig lot zal moeten kunnen beslissen'. De hierboven vermelde cryptische formule was verdwenen; volgens de nieuwe tekst zouden de deelgenoten aan het einde van de periode 'zelfstandig beslissen omtrent de voortzetting hunner betrekkingen op de grondslag van een alsdan volledig en vrijwillig deelgenootschap'. Ook de achterstelling van Indonesië binnen de rijksregering kwam in de nieuwe tekst niet meer voor. Zowel Van Mook als Logemann sprak op 10 februari een radiorede uit; beiden repten daarin uitdrukkelijk van het aan Indonesië toekomende 'recht van zelfbeschikking'.

Het standpunt van de Nederlandse regering verwees de uitoefening van het recht van zelfbeschikking overigens naar een verre toekomst. Eerst zou men overeenstemming met Indonesische nationalisten moeten bereiken over de hoofdpunten van de voorgestelde nieuwe staatsregeling. Vervolgens zou een Rijksconferentie, waaraan ook Suriname en de Nederlandse Antillen zouden deelnemen, de nieuwe structuur van het Koninkrijk moeten uitwerken. Voor de verwezenlijking van die structuur zou daarna nog Nederlandse wetgeving en wijziging van de Nederlandse grondwet nodig zijn. Pas na de inwerkingtreding van de nieuwe structuur zou de 'begrensde periode' ingaan aan het einde waarvan het recht van zelfbeschikking aan de orde zou komen. De regeringsverklaring voegde hier echter aan toe dat, als Nederland en Indonesië dan van mening zouden verschillen over de vraag of men die periode alsnog zou moeten verlengen, dit geschil zo nodig aan arbitrage zou worden onderworpen. Over de duur van de 'begrensde periode' liet de Nederlandse regering zich niet uit.

Hoewel de nieuwe regeringsverklaring evenals die van 6 november met geen woord van de Republiek Indonesië repte, maakte ze wel de weg vrij voor hervatting van het overleg met de Republiek. Intussen had de Britse regering ten dienste van dit overleg een ervaren diplomaat ter beschikking gesteld, A. Clark Kerr, die ambassadeur in Moskou geweest was en nu bestemd was om ambassadeur in Washington te worden. Op de ochtend van 10 februari zat hij een bijeenkomst voor waarin Van Mook aan Sjahrir de Nederlandse regeringsverklaring overhandigde die later op die dag gepubliceerd zou worden. 


\section{Eerste bemoeienis van de Verenigde Naties met de kwestie-Indonesië}

In januari 1946 begon in Londen de eerste zitting van de Algemene Vergadering der Verenigde Naties, terwijl ook de Veiligheidsraad daar toen zijn bijeenkomsten hield. Eén van de eerste kwesties die de Raad te behandelen kreeg betrof Indonesië. De Oekraïne, destijds een onderdeel van de Sovjet-Unie dat zelfstandig lid van de VN was, legde deze kwestie aan de Raad voor met het argument dat de sinds enige maanden in Indonesië plaatsvindende militaire acties tegen de bevolking, waaraan zowel Britse als Japanse strijdkrachten deelnamen, een bedreiging vormden van de internationale veiligheid en vrede. De Veiligheidsraad wijdde tussen 7 en 13 februari een zestal besprekingen aan deze kwestie. Nederland was destijds zelf lid van de Raad.

De Oekraïense vertegenwoordiger vroeg de Veiligheidsraad een onderzoek in te stellen en betoogde onder meer dat het Britse optreden tegen de Indonesische nationale beweging strijdig was met het aan alle volkeren toekomende zelfbeschikkingsrecht. De Britse minister van buitenlandse zaken, Bevin, en zijn Nederlandse collega, Van Kleffens, betoogden uitvoerig dat dit optreden niet tegen de nationale beweging gericht was. Van Kleffens noemde het Indonesisch nationalisme een gezonde ontwikkeling en zei dat Nederland daar ten volle rekening mee wilde houden. Hoewel hij er op zichzelf geen bezwaar tegen had dat de Veiligheidsraad het optreden van de Britse strijdkrachten in Indonesië besprak, verzette hij zich categorisch tegen bemoeienis van de Raad met het overleg tussen de Nederlandse autoriteiten en de Indonesische nationalistische leiders. Dit betrof, aldus Van Kleffens, een interne kwestie als bedoeld in artikel 2 sub 7 van het Handvest van de VN en viel daarom buiten de bevoegdheid van de Verenigde Naties.

Het Oekraïense voorstel kreeg in de Veiligheidsraad alleen uit het Sovjetblok krachtige steun. Geen enkele andere delegatie vond dat er in Indonesië sprake was van een bedreiging van de internationale veiligheid en vrede. Verscheidene sprekers spraken de hoop uit dat het Nederlandse overleg met de nationalistische leiders tot een bevredigende oplossing zou leiden. Overigens keerde de Egyptische delegatie zich uitdrukkelijk tegen het standpunt dat dit overleg een zuiver interne kwestie vormde waar de VN zich niet mee zou mogen bemoeien. Uiteindelijk verklaarde Van Kleffens dat hij de buitenlandse belangstelling voor dit onderwerp kon begrijpen en dat hij daarom aan zijn regering zou voorstellen om als een gebaar van hoffelijkheid de Veiligheidsraad te zijner tijd in te lichten over het resultaat van het overleg.

Het voorstel van de Oekraïne kwam op 13 februari in stemming. Intussen was het bekend dat de Nederlandse regering het Indonesisch zelfbeschikkingsrecht officieel erkend had. De Veiligheidsraad verwierp het Oekraïense voorstel; alleen Polen en de Sovjet-Unie stemden voor. 


\section{Toenemende verdeeldheid in Nederland over het beleid tegenover de Republiek}

Binnen Nederland kwamen de standpunten over het in Indonesië te voeren beleid steeds scherper tegenover elkaar te staan. $\mathrm{Al}$ in de laatste maanden van 1945 kwam dit tot uiting in een stroom van debatten, demonstraties, open brieven, persartikelen, brochures en affiches.

In het begin waren het vooral voorstanders van een positieve houding tegenover het Indonesisch nationalisme die van zich lieten horen. Hiertoe behoorden veel socialisten maar ook personen uit de kring van de protestantschristelijke zending, naast de communisten die altijd al voor Indonesische onafhankelijkheid geweest waren. Onder de niet-communistische kranten getuigde Het Parool het meest van begrip voor de Indonesische nationalisten, onder meer in een lange reeks uit Java ontvangen artikelen van J. de Kadt. Hoofdredacteur van dit dagblad was G.J. van Heuven Goedhart, die in 1944 minister geweest was in de Nederlandse regering in Londen. De Perhimpoenan Indonesia (PI) belegde in oktober en november zowel in Amsterdam als in andere steden demonstratieve bijeenkomsten. Tegelijk werden tal van activiteiten ondernomen door de Vereniging Nederland-Indonesië (VNI), voorgezeten door de Leidse hoogleraar J.P.B. de Josselin de Jong (zie p. 369). Een met de VNI verbonden actiecomité overhandigde op 20 oktober namens tweehonderd ondertekenaars aan de regering een petitie waarin gepleit werd voor overleg met het republikeinse bewind ten behoeve van een vreedzame oplossing van de moeilijkheden in Indonesië. Dit actiecomité bestond uit Van Heuven Goedhart, H. van Randwijk, hoofdredacteur van Vrij Nederland, Setiadjit, voorzitter van de PI, G.H. Slotemaker de Bruïne, bestuurslid van de SDAP, en J.A. Verdoorn, zendingsarts. Op 2 januari 1946 publiceerde de VNI een manifest dat opnieuw de noodzaak beklemtoonde van een snelle vreedzame oplossing van het conflict; het manifest was door een groot aantal bekende Nederlanders ondertekend. Hierna organiseerde de VNI een massale manifestatie in Amsterdam onder de leuze 'Geen oorlog van volk tegen volk, maar vrijwillige samenwerking'. De legerleiding verbood alle militairen aan deze bijeenkomst deel te nemen. De manifestatie vond op 2 februari plaats in de Markthallen en werd bijgewoond door ongeveer twintigduizend personen; zij werden toegesproken door onder meer Van Heuven Goedhart, dominee J.J. Buskes en Eveline Poetiray, bestuurslid van de PI. Bij acclamatie nam men een resolutie aan tegen wapengeweld en voor overleg met de regering-Sjahrir.

Een heel ander geluid viel te horen uit de hoek van de koloniaal-conservatieve richting, die in Nederland al voor de oorlog haar voornaamste bolwerken had in de Utrechtse indologiefaculteit en het blad De Rijkseenheid (zie p. 210-1). De Utrechtse hoogleraar F.C. Gerretson publiceerde vanaf eind oktober een reeks artikelen waarin hij het regeringsbeleid fel aanviel. Hij betoogde dat men nooit met opstandelingen mocht onderhandelen en keerde zich in 
het bijzonder tegen Logemann en Van Mook. Omdat beiden vroeger hadden behoord tot de Stuw-groep (zie pp. 211-2), die zich had uitgesproken voor een Indisch gemenebest dat uiteindelijk onafhankelijk zou kunnen worden, vond Gerretson dat zij het in feite met Soekarno eens waren over het einddoel. Andere prominente critici van het regeringsbeleid waren W.K.H. Feuilletau de Bruyn, J.W. Meijer Ranneft en Ch.J.I.M. Welter. De eerste was een oudKnilofficier die voor de Vaderlandsche Club in de Volksraad had gezeten (zie pp. 209-10). Meijer Ranneft was een voormalige voorzitter van de Volksraad en vice-president van de Raad van Indië; in Nederland was hij in augustus 1945 tot lid van de Raad van State benoemd. Welter was zowel vice-president van de Raad van Indië als minister van Koloniën geweest; in november werd hij lid van de voorlopige Eerste Kamer. Al deze critici hadden zich al in de jaren twintig gekant tegen de invoering van een 'Inlandse meerderheid' in de Volksraad (zie pp. 208-9); nu ageerden zij in toespraken en brochures tegen politieke concessies aan het Indonesisch nationalisme.

Begin januari 1946 werd een stichting opgericht onder de naam 'Indië in nood .... geen uur te verliezen', die zich met opvallende advertenties en affiches tot de bevolking richtte. Bovendien kwam in april een andere stichting tot stand onder de naam 'Rijkseenheid'. De twee stichtingen gingen nauw samenwerken bij het beleggen van openbare bijeenkomsten en het verspreiden van bulletins en brochures. Als tegenhanger van het in januari door de VNI gepubliceerde manifest verscheen nu een 'Oproep aan het Nederlandsche Volk', ondertekend door onder meer Feuilletau de Bruyn, Gerretson en Meijer Ranneft.

Welter was katholiek, maar in het algemeen leefde de koloniaal-conservatieve opstelling het sterkst in de kring van de orthodox-protestanten, hoofdzakelijk verenigd in de Anti-Revolutionaire Partij (die tussen de beide wereldoorlogen de partij van Colijn geweest was). In de landelijke dagbladpers werd deze opstelling dan ook het scherpst uitgedragen in het met de ARP verbonden dagblad Trouw. Zo schreef deze krant begin januari 1946 dat Van Mook naar Nederland gekomen was 'met een plan in zijn zak om Java aan Sjahrir uit te leveren' en dat de ondertekenaars van het VNI-manifest het Koninkrijk 'een dolkstoot in de rug' toebrachten.

De regering-Schermerhorn had in de kwestie-Indonesië niet alleen te maken met een actieve buitenparlementaire oppositie, maar had het ook moeilijk in het parlement zelf. Zo vond midden januari in de Tweede Kamer een debat over het Indonesië-beleid plaats, waarbij de kritiek in het algemeen scherper was dan in oktober en december het geval was geweest. Die kritiek richtte zich vooral op Van Mook, die ervan verdacht werd een eigen koers te varen zonder daarover opening van zaken te geven. De ARP-fractie vroeg dan ook uitdrukkelijk om zijn terugroeping. De binnen de Kamer in brede kring gedeelde indruk dat men onvoldoende werd ingelicht leidde tot een motie 
waarin werd besloten een commissie uit de Staten-Generaal naar Indonesië af te vaardigen om informatie te vergaren. De motie was ingediend door een vertegenwoordiger van de Katholieke Volkspartij (KVP), Max van Poll, die op zichzelf niet tegen onderhandelingen met de nationalisten was. Hoewel Logemann de motie had ontraden, werd ze met 50 tegen 29 stemmen aangenomen. De SDAP, die tegen de motie gestemd had, wilde niet aan de commissie meedoen; deze kwam uiteindelijk te bestaan uit vier personen, onder wie Welter en Van Poll, en vertrok in maart naar Batavia.

Ondanks de in de Tweede Kamer geleverde kritiek bleef de regering doorgaan op de ingeslagen weg. Daarbij valt te bedenken dat het parlement destijds geen volwaardige volksvertegenwoordiging was, maar een voorlopig parlement waarvan het onzeker was in hoever het de in Nederland levende politieke opvattingen vertegenwoordigde. De kern ervan werd gevormd door hen die in mei 1940 parlementslid geweest waren, voorzover die sindsdien niet waren gestorven of in de oorlog de kant van de vijand hadden gekozen; de daardoor opengevallen plaatsen waren in november 1945 opgevuld met door de regering benoemde leden. Pas in mei 1946 zouden weer normale verkiezingen voor de Tweede Kamer plaatsvinden. In de voorlopige Tweede Kamer ontleenden de meeste leden hun positie dus nog aan de verkiezingen van 1937. Binnen Nederland dachten velen dat de wereldoorlog sindsdien geleid had tot aanzienlijke veranderingen in het binnenlands-politieke patroon. Die gedachte vond ook steun in wat in Groot-Brittannië gebeurd was, waar de eerste verkiezingen na de oorlog op een nederlaag voor de conservatieven waren uitgelopen. Tegen deze achtergrond was een groep politici rondom Schermerhorn begonnen met de voorbereiding van een nieuwe politieke partij, waarvan de kern gevormd zou worden door een fusie van de SDAP met diverse links-liberale groeperingen. Deze nieuwe partij, de Partij van de Arbeid, werd midden februari opgericht. Zeven ministers uit het kabinet meldden zich als lid. Volgens een destijds gehouden opinie-onderzoek zou de nieuwe partij bij de verkiezingen 46 procent van de stemmen kunnen vergaren.

Toenemende verdeeldheid in de Republiek over het beleid tegenover Nederland; aantreden van het tweede kabinet-Sjahrir

Terwijl het Nederlandse publiek steeds dieper verdeeld raakte over de Indonesische kwestie, verscherpten zich ook de tegenstellingen binnen de Republiek over het tegenover Nederland te voeren beleid. In beide gevallen ging het vooral om de keuze tussen vechten en praten of, zoals men in Indonesië placht te zeggen, tussen perdjoeangan (strijd) en diplomasi (diplomatie). Voor de meeste aanhangers van de Republiek leed het geen twijfel 
dat Nederland zijn koloniaal gezag over de archipel wilde herstellen en dat de Britse bezettingsmacht daartoe de weg moest banen. De Indonesische legereenheden en strijdgroepen die tegen de bezettingsmacht vochten golden daarom als verdedigers van de onafhankelijkheid. Veel nationalisten konden niet begrijpen waarom Soekarno, Hatta, Amir Sjarifoeddin en Sjahrir deze strijd afwezen en zich bereid toonden tot overleg met Britse en Nederlandse gezagsdragers.

Overigens stapte de regering eind januari 1946 af van de fictie dat de hoofdtaak van het Republikeinse leger zou bestaan in het verzekeren van de interne veiligheid. Dat zijn hoofdtaak wel degelijk de externe verdediging betrof liet zij uitkomen door de naam van het leger van Tentara Keamanan Rakjat (TKR, Volksveiligheidsleger) te veranderen in Tentara Republik Indonesia (TRI, Leger van de Republiek Indonesië).

Het kabinet van Sjahrir en Amir Sjarifoeddin kampte met het probleem dat het slechts een smalle maatschappelijke basis bezat. De in december 1945 door hun medestanders gevormde Partai Sosialis (PS) had haar aanhang voornamelijk onder jonge intellectuelen. Andere politieke groeperingen dan de PS waren nauwelijks in het kabinet vertegenwoordigd. Wel werd zijn politieke basis in januari enigszins verbreed doordat Mohammad Natsir, één van de jongere voormannen van de Masjoemi, toetrad als minister van voorlichting. Veel bestuurders en politici die met de Japanse bezetters samengewerkt hadden voelden zich gegriefd door Sjahrir's scherpe veroordeling van de collaboratie met Japan. Het kabinet werd gewantrouwd door de legerleiding en door een groot deel van de losse strijdgroepen. Niettemin kreeg het steun van een nieuwe jongerenorganisatie die zelf uit een aantal strijdgroepen was voortgekomen. Deze strijdgroepen, waaronder de API uit Djakarta en de PRI uit Soerabaja, hadden zich in november tijdens het jongerencongres in Jogjakarta verenigd tot de Pemoeda Sosialis Indonesia (Socialistische Jongeren van Indonesië), gewoonlijk aangeduid als Pesindo. De Pesindo, die geleid werd door Wikana, ontwikkelde zich met steun van Amir Sjarifoeddin's departement van defensie tot een goed-bewapend machtsinstrument buiten het officiële leger.

De onvrede over de door Soekarno, Hatta en de regering-Sjahrir ingeslagen koers vond een belangrijke vertolker in Tan Malaka. Terwijl hij zich in de eerste maanden van de Republiek op de achtergrond had gehouden, publiceerde hij begin december een brochure onder de titel Moeslihat (Tactiek), die men als een tegenhanger kon zien van Sjahrir's geschrift Onze strijd. Hij betoogde daarin onder meer dat het voortbestaan van de Republiek niet afhing van buitenlandse erkenning maar van de strijdbaarheid van het eigen volk. Vervolgens trad hij begin januari op als voornaamste spreker op twee door zijn medestanders belegde conferenties in Midden-Java waar een groot aantal politieke en militaire organisaties aan deelnam. De tweede conferentie werd 
ook door generaal Soedirman toegesproken; daarentegen woonden Soekarno, Hatta en de ministers de conferenties niet bij. Tan Malaka maakte diepe indruk op zijn gehoor. Hij keerde zich tegen het voeren van onderhandelingen zo lang zich nog Britse of Nederlandse militairen op Indonesische bodem bevonden en riep op tot de vorming van een overkoepelend eenheidsfront op basis van een gezamenlijk minimum-program. De conferenties leidden tot de oprichting van zo'n front onder de naam Persatoean Perdjoeangan (PP, Strijd-Unie). Het program van deze PP behelsde in de eerste plaats dat onderhandelingen alleen zouden plaatsvinden op basis van de erkenning van 100\% onafhankelijkheid; verder voorzag het onder meer in confiscatie van alle 'vijandelijke' (bedoeld werden Nederlandse en andere westerse) ondernemingen.

Hoewel het minimum-program van de PP minder radicaal was dan Tan Malaka bepleit had, was het moeilijk verenigbaar met het beleid dat Soekarno en Hatta wilden voeren. In de huidige fase hechtten zij groot belang aan een goede verstandhouding met Groot-Brittannië en de Verenigde Staten, terwijl de Republiek zich door confiscatie van de westerse ondernemingen juist de vijandschap van die landen op de hals zou halen. Ook wilden Soekarno en Hatta de handen vrij houden voor politiek overleg met Nederland. In het openbaar namen zij echter geen stelling tegen het program.

De PP leek overweldigend succes te hebben. Zij ging op grote schaal actie voeren, zowel met massale betogingen als via pers en radio. Niet alleen tegen het kabinet gekante groeperingen sloten zich bij haar aan, maar ook de nauw met Sjahrir en Sjarifoeddin verbonden Pesindo. De leiding van de PP was echter niet alleen uit op wijziging van het regeringsbeleid, maar ook op vervanging van de regering zelf. $\mathrm{Zij}$ riep op tot de vorming van een meer representatieve regering en kreeg daarbij steun van vele kanten, onder meer van de Masjoemi, de PNI en de PKI. Midden februari drong ook het Werkcomité van het KNIP bij Soekarno aan op wijziging van de samenstelling van het kabinet. Sjahrir's binnenlands-politieke positie was nu zeer zwak geworden.

Het KNIP zelf, dat sinds 27 november niet meer plenair vergaderd had, kwam op 28 februari in Solo opnieuw bijeen. Terwijl deze vierde plenaire zitting eigenlijk bijeengeroepen was om te beraadslagen over de vraag hoe men moest reageren op de Nederlandse voorstellen van 10 februari, leek het aannemelijk dat het KNIP nu het toneel zou worden van een open confrontatie tussen Sjahrir en Tan Malaka. De zaken liepen echter anders. Bij de opening van de zitting verraste Soekarno de leden van het KNIP met de mededeling dat het kabinet-Sjahrir was afgetreden. Sjahrir verdedigde het door hem gevoerde beleid; daarentegen kwam Tan Malaka niet in de vergadering hoewel hij als spreker uitgenodigd was. Wel sprak Soedirman het KNIP toe. Soekarno nodigde de leiding van de PP uit mee te werken aan de samenstelling van een representatief nieuw kabinet. Het overleg met de PP leidde echter niet tot resultaat, onder meer omdat Tan Malaka en zijn medestanders onvoorwaar- 
delijk vasthielden aan hun minimum-program. Na de mislukking van dit overleg belastte Soekarno op 2 maart wederom Sjahrir met de vorming van een kabinet. Hatta deelde dit aan het KNIP mee en maakte daarbij ook een uit vijf punten bestaand mandaat voor de nieuwe regering bekend, waaronder als eerste punt het voeren van onderhandelingen op basis van $100 \%$ erkenning van de Republiek. Het KNIP ging uiteen zonder concrete politieke besluiten te nemen.

Op 12 maart kwam het tweede kabinet-Sjahrir tot stand. Bijna alle ministers uit het vorige kabinet keerden hierin terug, maar er waren ook enkele leden van de PNI en de Masjoemi in opgenomen naast nog een paar bekende politici. Terwijl Sjahrir het ambt van minister-president bleef combineren met dat van minister van buitenlandse zaken, trad nu Agoes Salim als vice-minister van buitenlandse zaken aan. De nieuwe vice-minister van financiën, Sjafroeddin Prawiranegara, behoorde evenals Natsir tot de jongere voormannen van de Masjoemi. Leimena, de leider van de protestants-christelijke partij, was viceminister van gezondheid geworden. Wikana was in het kabinet opgenomen als minister voor jongerenzaken.

Na de beëdiging van het nieuwe kabinet keerde Sjahrir naar Djakarta terug. Zijn politieke positie was aanzienlijk versterkt, zowel door de mislukking van de poging een kabinet met de PP te vormen als door de ruggensteun die hij van Soekarno en Hatta had gekregen en de bredere basis van zijn kabinet. Overigens was ook Soekarno's positie binnen de Republiek sterker dan enige maanden eerder het geval was geweest ten tijde van de strijd in Midden-Java en Soerabaja. Dit was onder meer te danken aan zijn verhuizing van Djakarta naar Jogjakarta, die hem bijvoorbeeld ruime gelegenheid gaf om met vurige toespraken in het binnenland zijn banden met de bevolking aan te halen.

De leiding van de PP reageerde furieus op de totstandkoming van het nieuwe kabinet. Aan de andere kant traden de Pesindo en sommige andere organisaties uit het eenheidsfront. Het was duidelijk dat het verzet van de PP-leiding tegen het beleid van diplomasi ook tegen Soekarno en Hatta zelf gericht was. De regering besloot nu hier hardhandig tegen op te treden. Met hulp van eenheden van de Pesindo ging zij op 17 maart over tot arrestatie van Tan Malaka en enige van zijn medestanders, onder wie Chairoel Saleh, Soekarni, Yamin en Abikoesno. De gearresteerden werden in een bergoord bij Solo geïnterneerd.

De internering van Tan Malaka en enkele andere voormannen van de PP betekende niet dat de regering-Sjahrir nu kon rekenen op algemene steun voor haar beleid van diplomasi, waarvan een goede verstandhouding met het Britse bezettingsbestuur een belangrijk onderdeel vormde. Dit bleek pijnlijk duidelijk in Bandoeng waar Brits-Indische troepen sinds december het stadsdeel ten noorden van de spoorlijn bezet hielden en bescherming gaven aan tienduizenden Europeanen, Indo-Europeanen en Chinezen. Niet alleen werden 
de Britse konvooien tussen Buitenzorg en Bandoeng weer door TRI-militairen beschoten, maar bovendien hervatten Republikeinse strijders uit het zuidelijke deel van Bandoeng in maart hun aanvallen op de Britse enclave zelf, onder meer met mortiervuur op opvangkampen van de RAPWI. Het Britse bestuur besloot nu ook dit stadsdeel te bezetten, maar pleegde hierover eerst overleg met de Republikeinse burgemeester en met vertegenwoordigers van de TRI en de Pesindo. De strijders trokken zich inderdaad uit het zuidelijke stadsdeel terug, maar staken tegelijkertijd grote delen daarvan in brand. Deze episode uit de vrijheidsstrijd is in Indonesië in herinnering gebleven onder de benaming Bandoeng laoetan api (Bandoeng vuurzee).

\section{Aankomst op Java van de eerste brigades oorlogsvrijwilligers uit Nederland}

De Nederlandse bereidheid tot politiek overleg met de Indonesische nationalisten, zoals kenbaar gemaakt in de regeringsverklaring van 10 februari 1946, was reden voor Mountbatten om de binnenkomst van Nederlandse troepen op Java niet langer tegen te houden. Sinds begin november had hij zeventien uit Nederland afkomstige bataljons oorlogsvrijwilligers van de Koninklijke Landmacht (KL) laten onderbrengen in Britse oefenkampen in Malakka. Hetzelfde was gebeurd met de uit de Verenigde Staten aangevoerde mariniersbrigade (behalve één bataljon daaruit dat eind december in Batavia ontscheept was ter vervanging van de inheemse KNIL-militairen die de stad op bevel van Christison moesten verlaten). Bovendien hield Mountbatten in Thailand en Singapore nog duizenden uit krijgsgevangenschap bevrijde KNIL-militairen vast. Deze boycot van de Nederlandse troepenaanvoer naar Indonesië vormde een bron van ergernis die de Nederlands-Britse betrekkingen ernstig belastte. Beëindiging van de boycot was uit Brits oogpunt ook wenselijk met het oog op de repatriëring van de in Indonesië ingezette Brits-Indische militairen.

Een klein deel van de in Malakka en Thailand gelegerde oorlogsvrijwilligers en KNIL-militairen werd al eind februari in Indonesië ingezet voor de bezetting van de eilanden Bangka en Bali. De rest, in totaal ruim vijftienduizend man, ging tussen 9 en 29 maart op Java aan land. De daarna nog uit Nederland aangevoerde vrijwilligersbataljons konden in en na april rechtstreeks in Indonesië van boord gaan.

Uit militair oogpunt was het gedwongen verblijf van de oorlogsvrijwilligers in Malakka niet alleen maar verloren tijd geweest. Ten eerste waren zij daar gewend aan het tropische klimaat en hadden zij een aanvullende opleiding in guerrillabestrijding gekregen. Ten tweede was hun bewapening en uitrusting aanzienlijk versterkt, onder meer met zware mitrailleurs en mortieren. Ook had Nederland in Malakka aan de vrijwilligersbataljons ondersteunende eenheden toegevoegd van onder meer artillerie, tanks, genie, vrachtauto's en 
verbindingspersoneel. Samen met deze eenheden waren de bataljons drie aan drie bijeengevoegd tot brigades. De staven hiervan bestonden vrijwel geheel uit KNIL-officieren. De aldus gevormde brigades van KL-personeel onder KNIL-leiding kregen aanduidingen met hoofdletters uit het alfabet, te beginnen met de letter T. Daarnaast duidde men de tot de Koninklijke Marine (KM) behorende mariniersbrigade soms als de M-brigade aan.

De Nederlandse vrijwilligers wisten vrijwel niets van de politieke ontwikkelingen die zich in Indonesië tijdens en na de Tweede Wereldoorlog hadden voltrokken. Zij waren geneigd hun inzet in Indonesië als een voortzetting van die oorlog te zien, als een laatste fase van de strijd tegen Japan. In hun verwachting op Java als bevrijders te worden verwelkomd werden zij meestal teleurgesteld. De Indonesische bevolking ontving hen in het algemeen even stuurs als ze de Britse troepen gedaan had. Wel leidde hun komst tot grote opluchting onder de Europese bevolking. $\mathrm{Al}$ in april droegen de Britten het militaire commando over Bandoeng aan de Nederlanders over, in mei ook over Semarang en Soerabaja. Vanaf juni waren er in Midden- en Oost-Java geen Britse militairen meer. Semarang en Soerabaja werden de eerste plaatsen op Java waar Nederlanders zowel het militaire als het civiele bestuur volledig overnamen. In Semarang zette de Nederlandse brigadecommandant het Republikeinse bestuur af; in Soerabaja functioneerde al sinds eind 1945 geen Republikeins bestuur meer. De in november uit Soerabaja gevluchte inheemse bevolking was intussen grotendeels teruggekeerd.

De kijk van de vrijwilligers op het conflict met de Republiek werd sterk beïnvloed door de bij het KNIL gangbare opvattingen. In het algemeen beschouwden zij zich niet als in oorlog met het leger van een andere natie. De leiding van de Nederlandse strijdkrachten placht de Republikeinse tegenstanders aan te duiden als 'extremisten', 'terroristen' of 'kwaadwilligen' en dit taalgebruik werd algemeen overgenomen. Ook het uit de negentiende eeuw stammende gebruik (zie p. 111) om opstandelingen te betitelen als orang djahat (slechte mensen, misdadigers) vond weer ingang. Daarnaast raakte een nieuwe term in zwang, namelijk 'plopper'. Oorspronkelijk had dit woord gedoeld op de leden van het paramilitaire korps Barisan Pelopor, maar onder de Nederlandse soldaten werd het populair als aanduiding voor alle Republikeinse strijders.

Het bij het KNIL gangbare vijandbeeld vond steun in de nog verse herinnering aan de gruwelen die tijdens de bersiap-furie gepleegd waren. Dat men in deze visie de tegenstanders als criminelen beschouwde en niet als de strijdmacht van een natie, had overigens ook gevolgen voor de manier waarop men hen behandelde. Het werkte praktijken in de hand die in een oorlog tussen staten als oorlogsmisdaden gelden, in het bijzonder het doden van tegenstanders die zich hadden overgegeven en het mishandelen van gevangenen om inlichtingen los te krijgen. 


\section{Voorlopig akkoord tussen Van Mook en Sjahrir}

Sjahrir was na de installatie van zijn nieuwe kabinet uit Jogja naar Batavia teruggekeerd. Op 13 maart overhandigde hij daar aan Van Mook, in een door Clark Kerr voorgezeten bijeenkomst, het antwoord van zijn regering op de Nederlandse regeringsverklaring van 10 februari. De Republikeinse regering sprak hierin voldoening uit voor het in die verklaring vervatte uitgangspunt dat de bevolking van Indonesië in vrijheid over haar staatkundig lot moest kunnen beslissen, maar kon niet instemmen met de gedachte dat die bevolking voorlopig nog niet rijp voor onafhankelijkheid zou zijn. Zij beantwoordde de Nederlandse voorstellen nu met een uit twaalf punten bestaand tegenvoorstel. In de eerste plaats zou Nederland de Republiek moeten erkennen als draagster van de soevereiniteit over het gebied van het voormalige Nederlands-Indië. De Republiek zou de vooroorlogse schulden van Nederlands-Indië overnemen; ook zou zij met Nederland afspraken maken voor een billijke regeling van de Nederlandse belangen. Verder zouden Nederland en de Republiek voor een bepaalde periode een federatief verbond moeten aangaan. Daarbij zou de leiding van de buitenlandse betrekkingen en van de defensie van beide landen worden toevertrouwd aan een uit Nederlanders en Indonesiërs samengesteld federaal lichaam.

De deelnemers aan de bijeenkomst van 13 maart spraken af dat het Republikeinse document vertrouwelijk moest blijven omdat publicatie ervan voortzetting van de onderhandelingen onmogelijk zou maken. Inderdaad leek het voorstel voor een federatief verbond moeilijk te rijmen met de eis van $100 \%$ merdeka. Men kon deze tegemoetkomende opstelling niet los zien van het feit dat SEAC de uit Nederland aangevoerde strijdkrachten nu niet langer uit Java weerde. Het document van 13 maart stelde trouwens voor dat tijdens de besprekingen alle troepenbewegingen zouden worden gestaakt en dat de Nederlandse troepen onmiddellijk na het ingaan van de overeenkomst uit Indonesië zouden worden teruggetrokken.

De Republikeinse voorstellen boden geen aanknopingspunt voor de door Van Mook beoogde oplossing, die inkapseling van de Republiek inhield als deelstaat in een Indonesische federatie. Na 13 maart sleepten de besprekingen zich moeizaam voort, gedeeltelijk in een uit medewerkers van Sjahrir en Van Mook bestaande subcommissie. Voortzetting van de onderhandelingen was een politieke noodzaak, vooral nu de Britse regering daartoe Clark Kerr naar Batavia had gezonden, maar de Nederlandse delegatie had in die onderhandelingen niets zinvols te bieden omdat zij strikt gebonden was aan de verklaring van 10 februari. Van Mook achtte het riskant de regering in Den Haag formeel om verruiming van zijn mandaat te vragen en stelde daarom voor dat Logemann met nog enige andere ministers naar Batavia zou overkomen. De regering wees dit voorstel af omdat zo'n reis de indruk zou kunnen wekken 
dat zij tot concessies bereid was. Daarop koos Van Mook een andere weg. Hij besloot om, zo nodig met overschrijding van zijn mandaat, eerst te zoeken naar een redelijk compromis tussen Nederland en de Republiek en vervolgens dit compromis pas aan Den Haag voor te leggen als overeenstemming met de regering in Jogja vrijwel zeker was. Hij meende hierbij een bruikbaar aanknopingspunt te hebben in een overeenkomst die Frankrijk kort daarvoor gesloten had met de Republiek Vietnam.

Vietnam was een deel van de Franse kolonie Indochina, samen met Laos en Cambodja. Ho Chi Minh, leider van de verzetsbeweging Vietminh, had op 2 september 1945 een onafhankelijke Republiek Vietnam uitgeroepen (zie p. 373). Wat sindsdien in Indochina gebeurd was vertoonde zowel overeenkomsten als verschillen met de ontwikkelingen in Indonesië. Volgens de door de geallieerde leiders voor de Japanse capitulatie genomen besluiten was alleen de zuidelijke helft van de kolonie onder Brits militair gezag gesteld, terwijl de noordelijke helft onder het militaire gezag van China kwam te staan. De Republiek Vietnam had haar regeringszetel in Hanoi in de noordelijke zone. In de zuidelijke zone hadden Britse bezettingstroepen midden september samen met Franse militairen de macht overgenomen in Saigon, de hoofdstad van Indochina. In de maanden daarna wisten Britse en Franse troepen met Japanse steun een overwicht te verkrijgen op de strijders van de Vietminh in het zuiden. Mountbatten had op grote schaal Franse troepen tot Indochina toegelaten, maar ook aangedrongen op Frans overleg met Ho Chi Minh. Op 4 maart droegen de Britten hun verantwoordelijkheid voor Indochina geheel aan de Fransen over. Op 6 maart sloot de Franse regering een formeel akkoord met de Vietnamese regering, dat onder meer inhield dat zij de Republiek Vietnam erkende als een vrije staat met zijn eigen regering, parlement en leger en dat die staat deel zou uitmaken van een Indochinese federatie die op haar beurt deel zou zijn van de Franse Unie; anderzijds verklaarde de regering van Vietnam zich bereid het Franse leger vriendschappelijk te ontvangen ter aflossing van de Chinese troepen.

Van Mook liet de tekst van dit akkoord ronddelen in een formele bijeenkomst met de Republikeinse delegatie. Kort daarna stelde hij zelf aan de hand van dit voorbeeld een schets op van een overeenkomst tussen Nederland en de Republiek Indonesië. De schets hield onder meer in dat de Nederlandse regering de huidige regering van de Republiek zou erkennen als de facto het gezag uitoefenend over Java, met uitzondering van de door het geallieerde militaire bestuur bezette gebieden, en dat de regering van de Republiek zou meewerken aan de opbouw van een Indonesische federatie die alle delen van Nederlands-Indië zou omvatten en die deelgenoot in het Koninkrijk zou zijn overeenkomstig de beginselen van de Nederlandse regeringsverklaring van 10 februari. Op 25 maart gaf Van Mook deze schets aan Sjahrir als een informele discussiebijdrage. Sjahrir was bereid op deze basis naar overeenstemming te 
zoeken. De schets werd vervolgens besproken en enigszins gewijzigd door de subcommissie van de delegaties. Onder meer bracht men daarbij ook Sumatra onder het de facto gezag van de Republiek en verving men de woorden 'deelgenoot in het Koninkrijk' door 'deelgenoot in een staatsverband mede omvattende Nederland, Suriname en Curaçao'.

Tenslotte vond op 30 maart weer een formele bijeenkomst plaats onder Clark Kerr. Van Mook verklaarde dat de standpunten elkaar nu zo dicht genaderd waren dat het nodig was naar Nederland te gaan om te zien in hoever de Nederlandse regering bereid was deze grondslag van overeenstemming te aanvaarden. Overigens merkte hij op dat hij zich niet zelf aan het concept van de subcommissie kon binden omdat dit zijn mandaat te buiten ging. Op zijn verzoek wees Sjahrir drie delegatieleden aan om met hem mee te gaan. De volgende dag lichtte Van Mook een en ander in een persconferentie toe. Daarin zei hij onder meer dat het voorbeeld van de door Frankrijk gesloten overeenkomst het vinden van een oplossing vergemakkelijkt had, ook al waren de omstandigheden in Indochina anders.

Er bestonden inderdaad diverse verschillen tussen de Indochinese en de Indonesische kwestie. In de eerste plaats trad de Republiek Vietnam alleen namens het Vietnamese volk op en maakte zij geen aanspraak op gezag over Laos en Cambodja; wat haar gebiedsaanspraken betreft zou zij dus geen concessie doen door samen met die twee landen een federatie te vormen. Daarentegen zou het voor de Republiek Indonesië wel een stap terug betekenen om haar gezag alleen voor een deel van het Nederlands-Indische grondgebied erkend te zien. In de tweede plaats mocht men de Republiek Vietnam als rechtsopvolger van het keizerrijk Annam beschouwen, dat een Frans protectoraat geweest was. Omdat de Franse relatie met dit protectoraat op een verdrag berust had, betekende het voor Frankrijk geen juridisch probleem om ook met de Republiek Vietnam een verdrag sluiten. Daarentegen was het wel een probleem welke juridische betekenis men zou moeten toekennen aan een verdrag tussen Nederland en de Republiek Indonesië. Daarnaast bestond er een belangrijk verschil tussen de twee kwesties in het licht van de Nederlandse opvattingen over 'goed' en 'fout' in de afgelopen wereldoorlog. De Republiek Vietnam was de schepping van een anti-Japanse verzetsbeweging, terwijl de Republiek Indonesië uit collaboratie met Japan voortgekomen was. Dit kwam scherp naar voren bij een vergelijking van de beide presidenten: Ho Chi Minh had Japan tijdens de oorlog vurig bestreden, terwijl Soekarno zich volop achter Japan had geschaard. Tenslotte was er nog een ander politiek-psychologisch verschil. De betekenis van Indochina voor het Franse zelfbewustzijn was niet te vergelijken met die van Nederlands-Indië voor het Nederlandse zelfbewustzijn. Daarom was het voor de Fransen veel minder pijnlijk om Vietnam los te laten dan het voor de Nederlanders zijn zou om Indië los te laten. 


\section{De conferentie op de Hoge Veluwe}

Op 4 april vertrok Van Mook met enkele adviseurs naar Nederland, samen met Clark Kerr en drie vertegenwoordigers van de Republiek: de minister van justitie Soewandi, de minister van binnenlandse zaken Soedarsono en de secretaris van de regering A.K. Pringgodigdo. Zij waren allen vol goede moed over het beraad met de Nederlandse regering. Van Mook had in zijn persconferentie de verwachting uitgesproken dat het overleg in Nederland ongeveer een week zou duren en dat de uiteindelijke overeenkomst niet in Den Haag maar in Batavia zou worden gesloten. Ook de Nederlandse regering bleek optimistisch over de mogelijkheid van een doorbraak. Minister-president Schermerhorn, vice-premier Drees en de ministers Logemann en Van Roijen zouden aan het overleg deelnemen. Een luxueus maar afgelegen jachtslot op het landgoed De Hoge Veluwe werd als plaats voor de conferentie gereedgemaakt, met een strenge militaire bewaking om aanslagen te voorkomen. De Nederlandse pers gaf blijk van grote verwachtingen. Zo bracht het katholieke dagblad De Volkskrant een foto van het jachtslot met het bijschrift 'Hier wordt over Indonesië beslist'. Overigens had de regering besloten Clark Kerr niet aan het overleg op de Hoge Veluwe te laten deelnemen; anders dan van Britse kant verwacht was beschouwde ze zijn missie als voltooid.

Het voorstel van Van Mook om samen met Indonesische vertegenwoordigers in Nederland overleg te voeren op regeringsniveau had de instemming van de regering gekregen op basis van zijn berichtgeving over de besprekingen in Batavia. Die berichtgeving was echter gekleurd en onvolledig geweest, omdat Van Mook het waagstuk ondernam pas na aankomst in Nederland de regering concreet over het ontworpen compromis in te lichten. Dit waagstuk pakte verkeerd uit. De Nederlandse ministers bleken onoverkomelijke bezwaren te hebben tegen de tekst die Van Mook uit Batavia meebracht, vooral tegen de voorgestelde vorm van een overeenkomst tussen gelijkwaardige partijen. Men achtte het politiek ondenkbaar dat Nederland een verdrag met Soekarno zou sluiten. De regering besloot de voor haar aanvaardbare elementen van de in Batavia ontworpen constructie in een andere vorm te redigeren, namelijk als een protocol van de besprekingen tussen de beide delegaties.

Eén van de redenen voor het afwijzen van de verdragsvorm was het feit dat op 17 mei de eerste naoorlogse verkiezingen voor de Tweede Kamer zouden plaatsvinden. In afwachting daarvan zou de regering-Schermerhorn nu geen hoogst controversiële stap kunnen zetten. Een na de verkiezingen te vormen regering met een stevige parlementaire basis zou daar beter toe bevoegd zijn. Een heel andere overweging was dat Nederland weliswaar nu over geen machtsmiddelen tegenover de Republiek beschikte, maar dat dit tegen het eind van het jaar anders zou worden. Dan kwam immers de landmachtdivisie waarvan de opleiding in mei zou beginnen beschikbaar voor inzet in 
Indonesië. Bovendien had men inmiddels besloten meteen daarna een tweede divisie van dienstplichtigen te vormen die in voorjaar 1947 naar Indonesië zou vertrekken.

De negatieve reactie van de Nederlandse ministers had op Van Mook een ontmoedigend effect. Naar zijn mening vertegenwoordigde het in Batavia ontworpen compromis het uiterste dat de groep-Sjahrir voor haar rekening kon nemen en zette Sjahrir hiermee zelfs zijn leven op het spel. Bovendien meende Van Mook dat, ook als Sjahrir er niet in zou slagen dit compromis in de Republiek aanvaard te krijgen, de internationaal-politieke positie van Nederland toch versterkt zou zijn als het zich daar zelf wel toe bereid getoond had.

Intussen moesten de vertegenwoordigers van de Republiek dagenlang wachten op het begin van hun overleg met de Nederlandse regering. Nadat het beraad binnen het Nederlandse kabinet was afgerond vond op 12 april in Londen nog een Nederlands-Britse bespreking op regeringsniveau plaats. Het belangrijkste gespreksonderwerp was de terugtrekking van de Britse strijdkrachten uit Indonesië. De Britse regering zei uiteindelijk toe op Java een Britse bezetting te zullen handhaven totdat die eind 1946 zou worden afgelost door de nog te vormen Nederlandse divisie.

Op zondag 14 april begon eindelijk de conferentie op de Hoge Veluwe. De Nederlandse delegatie deelde het door haar opgestelde ontwerp-protocol uit; het week niet alleen naar vorm maar ook naar inhoud af van de in Batavia opgestelde tekst. Zo was Sumatra weer uitgezonderd van de erkenning van het Republikeinse de facto gezag en had de Republiek een zwakkere positie gekregen binnen de beoogde Indonesische federatie. De Republikeinse delegatie meende vrijwel terstond dat het overleg tot mislukking gedoemd was. Zij kon de verdragsvorm onmogelijk opgeven, want voor de Republiek zou die het voornaamste pluspunt zijn tegenover het afzien van volledige erkenning. Schermerhorn merkte op dat, als men niet tot overeenstemming kon komen, Nederland gedwongen zou kunnen worden tot het aangaan van een militair conflict. Soewandi antwoordde dat men aan zijn kant de alternatieven zeer wel besefte. Tot teleurstelling van de Republikeinse delegatie spande Van Mook zich niet in om de in Batavia overeengekomen tekst te verdedigen. Hij verliet de conferentie al in een vroeg stadium en vertrok voor vakantie naar het buitenland.

Op maandagochtend verscheen in De Volkskrant onder de kop 'Week der schande' een hoofdartikel dat zich fel tegen de conferentie keerde. Het artikel was geschreven door de politiek hoofdredacteur C.P.M. Romme, die minister onder Colijn geweest was en binnen de Katholieke Volkspartij veel gezag genoot. Zijn stellingname had een zware politieke lading. Destijds stond in Nederland de socialistische Partij van de Arbeid positief tegenover het sluiten van een politiek akkoord met de Republiek, terwijl de protestants-christelijke 
partijen en de rechts-liberale partij dat beslist afwezen; daarentegen had de KVP hierover nog geen definitief standpunt ingenomen. Omdat de socialisten geen meerderheid vormden, was de regering voor het tot stand brengen van zo'n akkoord vooral afhankelijk van steun uit de hoek van de KVP. Romme's aanval hield de dreiging in dat die partij zich met haar volle gewicht aan de kant van de oppositie zou scharen.

Tijdens de conferentie op de Hoge Veluwe kreeg de Republikeinse delegatie advies van drie Indonesische nationalisten die de oorlog in Nederland hadden doorgebracht, onder wie Setiadjit. Anderzijds traden aan Nederlandse kant drie Indonesische KNIL-officieren als adviseurs op, onder wie de sultan van Pontianak, Hamid II Alkadrie, en de Ambonese kapitein J.W. Tahija, adjudant van generaal Spoor. Na 15 april voerde Logemann eerst een reeks informele gesprekken met de vertegenwoordigers van de Republiek. Vervolgens werd de conferentie op 21, 22 en 24 april onder leiding van Schermerhorn voortgezet en afgerond. Van Mook en Drees woonden dit deel van de conferentie niet bij. De discussies vonden gedeeltelijk plaats aan de hand van een door Pringgodigdo opgestelde analyse van de verschillen tussen de in Batavia opgestelde tekst en het Nederlandse ontwerp-protocol. Pringgodigdo stelde onder meer dat Nederland een 'Colijnse opdeling van Indonesië' voorstond. Hamid en Tahija verklaarden dat men in Borneo en de Molukken niet graag zou zien dat het gezag van de Republiek van buitenaf opgelegd zou worden.

De besprekingen leidden niet tot overeenstemming maar wel tot enige toenadering op bepaalde punten. Schermerhorn gaf te kennen dat zijn regering een nieuw voorstel zou uitwerken. De conferentie werd zonder gemeenschappelijke slotverklaring beëindigd. De Republikeinse delegatie keerde naar Java terug; de drie Indonesiërs die als haar adviseurs waren opgetreden reisden met haar mee.

In overleg met Van Mook, die inmiddels van vakantie was teruggekeerd, stelde de Nederlandse ministerraad een nieuwe versie van het ontwerp-protocol vast, die op de hoofdpunten weinig van het eerdere ontwerp afweek maar in haar formulering meer rekening hield met de Republikeinse opvattingen. Logemann lichtte de Tweede Kamer in over het op de Hoge Veluwe besprokene. Daarbij zei hij onder meer dat de Republiek, los van haar wijze van ontstaan, in nationalistische kringen op Java algemeen, en ten dele ook buiten Java, beschouwd werd als de vertolking van het diepe verlangen naar nationale zelfexpressie en zelfstandigheid. Hij bevestigde dat de regering bereid was de Republiek te erkennen als onderdeel van een federatief Indonesië binnen het Koninkrijk.

Op 6 en 7 mei vond het laatste Tweede-Kamerdebat over Indonesië plaats voor de verkiezingen. De Kamer beschikte intussen ook over een verslag van de uit vier parlementsleden samengestelde commissie-Van Poll over haar bezoek aan Indonesië. In feite had deze commissie daar noch met Indonesische nati- 
onalisten noch met medewerkers van Van Mook contact gezocht; haar verslag was dan ook voornamelijk een weergave van de onder Nederlanders op Java levende kritiek op het gouvernement. In het Kamerdebat werd het Indonesiëbeleid van de regering scherp aangevallen, maar Van Poll zelf speelde een verzoenende rol. Hij stelde een motie op die de regering in staat stelde de besprekingen voort te zetten. De motie werd aangenomen met voorstemmen van de Partij van de Arbeid, de communistische CPN en bijna de hele KVPfractie.

De verklaringen van Logemann in het parlement hadden blijk gegeven van een soepeler opstelling van de Nederlandse regering tegenover de Republiek Indonesië. Niettemin lag die opstelling nog steeds ver verwijderd van de Republikeinse aspiraties. Schermerhorn en zijn ministers konden zich de oplossing van de Indonesische kwestie niet anders voorstellen dan in het kader van de koninklijke rede van 1942. Zij waren bereid Indonesië een grote mate van zelfstandigheid te gunnen, maar Indonesië zou wel deel moeten blijven uitmaken van het Koninkrijk der Nederlanden. Men had het Indonesisch zelfbeschikkingsrecht weliswaar formeel erkend, maar men zag dit als iets voor de verre toekomst en nam aan dat Indonesië ook dan de banden met Nederland niet echt zou willen verbreken. Het in het Nederlandse ontwerpprotocol geschetste politieke akkoord met de Republiek had ten doel de weg te banen naar de rijksconferentie die de nieuwe opzet van het Koninkrijk zou uitwerken; in die conferentie zou de bevolking van Indonesië ook door anderen dan de Republikeinen vertegenwoordigd worden. Overigens wilde het kabinet dit politieke akkoord alleen aangaan als Soekarno van het toneel zou verdwijnen. Verder stelde men zich de nieuwe opzet van het Koninkrijk als een aanzienlijk zwaardere constructie voor dan die van het Britse Gemenebest. Zo meende men dat het Koninkrijk niet alleen over een eigen marine en luchtmacht maar ook over een eigen landmacht zou moeten beschikken. Volgens Van Mook zou in dat kader steeds een kern zuiver Nederlandse troepen in Indonesië aanwezig moeten zijn.

Zou de Republiek bereid zijn langs de lijnen van het ontwerp-protocol mee te werken aan de voorbereiding van de rijksconferentie, dan zou het kabinet dit uiteraard toejuichen. Zou zij daar uiteindelijk niet toe bereid blijken, dan zou Nederland militaire macht moeten aanwenden om de weg naar de rijksconferentie te banen. Ook op dit punt had de opstelling zowel van het kabinet als van Van Mook een ontwikkeling doorgemaakt. In december 1945 was Van Mook nog van mening geweest dat het voor Nederland een onaanvaardbare last zou betekenen om te proberen het conflict met de Republiek langs militaire weg op te lossen, maar nu sloot hij zo'n oplossing niet langer uit. Destijds had hij de mening gedeeld van generaal Schilling, maar zijn belangrijkste militaire adviseur was nu generaal Spoor die ervan overtuigd was dat het mogelijk was de Republiek met militaire middelen uit te schakelen. 
Na de Hoge Veluwe-conferentie besloot het kabinet-Schermerhorn in overleg met Van Mook om in 1947 nog een derde en een vierde divisie voor uitzending naar Indonesië gereed te maken. Daarbij ging het ervan uit dat een groots opgezette militaire campagne pas in april 1947 zou kunnen beginnen en dat men dan nog zou moeten rekenen op een duur van anderhalf tot twee jaar. Overigens had de chef-staf in Batavia, generaal Buurman van Vreeden, ook plannen ontworpen voor meer beperkte operaties die Nederland eventueel al eerder op Java zou kunnen uitvoeren.

Begin mei legde Logemann het regeringsstandpunt vast in een instructie voor Van Mook die onder meer het volgende inhield:

- bij zijn overleg met de Republikeinen over het neerleggen van de wapens en de deelneming aan de rijksconferentie zou Van Mook niet verder mogen gaan dan aangegeven in het ontwerp-protocol;

- Van Mook zou de eliminatie van Soekarno uit de regering van de Republiek moeten bevorderen; erkenning van de Republiek zou niet geschieden zolang daarin erkenning van Soekarno in enig regeringsambt besloten zou liggen;

- indien de pogingen om tot overeenstemming te komen definitief zouden falen, zou Nederland overgaan tot gewapende actie tot herstel van het wettig gezag.

\section{Terugkeer van het Nederlandse gezag in de archipel buiten Java en Sumatra}

Het Britse South East Asia Command (SEAC) was sinds augustus 1945 in de Indonesische archipel verantwoordelijk voor onder meer de verwijdering van de Japanse militairen, de bescherming van de geallieerde geïnterneerden en de voorbereiding van het burgerlijk bestuur. Omdat aan Britse kant niet over voldoende mankracht werd beschikt, had men het Australische leger met deze taken belast voor Borneo en de oostelijke archipel. De Australiërs hadden hier in de loop van september en oktober de macht van de Japanse marine overgenomen (zie p. 396). Omdat men in Australië uitkeek naar een spoedige thuiskomst van de soldaten die aan de oorlog tegen Japan hadden deelgenomen, wilde de Australische legerleiding de haar in Indonesië opgedragen taken graag snel beëindigen. Ter aflossing van de Australiërs stelde SEAC tijdelijk een Brits-Indische brigade beschikbaar die uit Indochina naar Celebes overgeplaatst werd. Het Australische leger trok zich daarop in de eerste maanden van 1946 uit Indonesië terug.

Voor het overnemen van de bezettingstaak beschikte men aan Nederlandse kant in het begin alleen over KNIL- en marine-eenheden die al voor de Japanse capitulatie aan de geallieerde oorlogvoering deelgenomen hadden, maar al spoedig kon men ook KNIL-militairen inzetten die uit Japanse krijgsgevangenschap terugkeerden. Tegen eind 1945 waren ongeveer tienduizend 
ex-krijgsgevangenen in nieuwe KNIL-eenheden georganiseerd. In het voorjaar van 1946 schakelde SEAC de Nederlandse militairen steeds meer voor de bezetting van dit deel van de archipel in. Bovendien vond in deze periode eindelijk de repatriëring plaats van de tienduizenden hier nog verblijvende Japanse krijgsgevangenen. Een en ander stelde SEAC in staat de hier gestationeerde Brits-Indische brigade begin juli terug te trekken.

De Australische landingen op Indonesisch grondgebied hadden in september en oktober 1945 geen tegenstand van de bevolking ontmoet. Weliswaar gaf men op sommige plaatsen met rood-witte vlaggen blijk van Republikeinse gezindheid, maar het kwam ook voor dat bezettingseenheden werden verwelkomd met de rood-wit-blauwe Nederlandse vlag. In de loop van de volgende maanden ontstonden hier en daar wel conflicten tussen de geallieerde bezetters en aanhangers van de Republiek. Vooral de Nederlandse militairen kregen te maken met vaak hardnekkig gewapend verzet, onder meer in ZuidBorneo, in Zuid-Celebes en op Bali. Een afzonderlijk incident deed zich in februari voor in Menado (Noord-Celebes), waar een aantal inheemse KNILmilitairen zich achter de Republiek schaarde en de Nederlandse officieren en ambtenaren gevangen zette. Het duurde enige weken voordat het KNIL Menado weer in handen had.

Van begin af aan werden de Australische bezettingseenheden vergezeld door teams van de Netherlands-Indies Civil Administration (NICA) die tot taak hadden het burgerlijk bestuur in handen te nemen. De Australische commandanten verlangden van de Indonesische gezagsdragers medewerking met de NICA. Op sommige plaatsen werd die medewerking zonder probleem verleend, op andere plaatsen toonden de Indonesische functionarissen zich daar niet onmiddellijk toe bereid. Daarbij verklaarden zij soms dat ze wel met de NICA wilden samenwerken als die alleen een uitvoerend orgaan van het geallieerde legercommando was, maar niet als die namens het NederlandsIndische gouvernement optrad. In dit licht is het relevant dat de NICA (zoals vermeld op pp. 406-7) eind oktober 1945 werd omgezet in een nieuwe organisatie onder de naam Allied Military Administration Civil Affairs Branch (AMACAB). De naam NICA bleef echter algemeen in zwang.

In de praktijk functioneerde de NICA als bestuursapparaat van het Nederlands-Indische gouvernement. Daar waar Nederlandse militaire eenheden de Australische bezettingseenheden aflosten gingen de Indonesische functionarissen meestal wel met de NICA samenwerken. In Zuid-Celebes bestonden de NICA en het Republikeinse bestuur aanvankelijk als concurrerende organisaties naast elkaar. Nadat het geallieerde gezag daar van Australische in Britse handen overgegaan was, schakelde de NICA het Republikeinse bestuur uit. Op 5 april arresteerde zij Ratoelangie, de Republikeinse gouverneur van Celebes, samen met enige andere Republikeinse leiders. Er bleef echter in Zuid-Celebes verzet bestaan tegen de terugkeer van het Nederlandse gezag, 
zowel onder de militante jongeren als in de vorstenfamilies.

Volgens de Nederlands-Britse overeenkomst van 24 augustus 1945 (zie p. 371) moest de geallieerde opperbevelhebber Nederland in de gelegenheid stellen weer de volledige verantwoordelijkheid voor het burgerlijk bestuur over Nederlands-Indisch gebied op zich te nemen zodra de militaire situatie dit naar zijn oordeel toeliet. Mountbatten, die zijn functie eind mei zou neerleggen, kwam met Van Mook overeen dat men deze bepaling in juli zou toepassen op alle Nederlands-Indisch gebied buiten Java, Sumatra en de Riouw-archipel.

Met ingang van zondag 14 juli werd de Britse verantwoordelijkheid voor al deze delen van Nederlands-Indië beëindigd. De volgende dag vond in Makassar een ceremonie plaats waarin de commandant van AFNEI (Allied Forces in the Netherlands Indies) het gezag aan Van Mook overdroeg. Dat het Nederlandse gezag binnen dit gebied niet langer aan Brits oppergezag ondergeschikt was betekende tevens, dat het Nederlands-Indisch bestuursapparaat hier niet meer onder $A M A C A B$ viel en dat het Nederlandse militaire personeel er geen deel van AFNEI meer uitmaakte.

\section{Nieuw overleg tussen Sjahrir en Van Mook}

Hoewel Sjahrir in maart 1946 een politieke overwinning op Tan Malaka en het eenheidsfront PP geboekt had, bleef zijn op diplomasi gerichte beleid in de Republiek zeer omstreden. Weliswaar was Tan Malaka in maart samen met enige politieke vrienden geïnterneerd, maar het door hem gelanceerde minimum-program genoot nog steeds brede instemming, onder meer bij de Republikeinse legerleiding. Ook hadden hij en de zijnen in hun interneringsoord bij Solo ruime gelegenheid tot contact met de buitenwereld. De stad Solo zelf, hoofdstad van het onder vorstenbestuur staande gebied Soerakarta, was al sinds maanden het belangrijkste bolwerk van de radicale nationalisten binnen de Republiek. Deze radicalen schoven hier in april het vorstenbestuur terzijde; het lukte de centrale regering in Jogja niet deze 'sociale revolutie' geheel ongedaan te maken.

De onduidelijke machtsverhoudingen in sommige delen van de Repubiek op Java staken nog gunstig af bij de situatie op Sumatra, waar zich een politieke chaos ontwikkelde doordat aanhangers van de Republiek er onderling slaags raakten. Een missie onder leiding van Amir Sjarifoeddin slaagde er eind april in daar weer enigszins orde op zaken te stellen.

Terwijl de regering-Sjahrir op binnenlands-politiek gebied met tal van moeilijkheden kampte, kon zij zich in haar externe betrekkingen verheugen in een goede verstandhouding met de Britse autoriteiten. Aan Britse kant waardeerde men de bereidheid tot concessies die Sjahrir aan de dag had 
gelegd in het overleg onder leiding van Clark Kerr; tegelijk betreurde men het dat de Nederlandse regering Clark Kerr van de conferentie op de Hoge Veluwe geweerd had en dat die conferentie zelf tot niets geleid had, waardoor de Britse inspanningen om de partijen tot elkaar te brengen nutteloos waren gebleken. Mountbatten maakte eind april persoonlijk met Sjahrir kennis tijdens een bezoek aan Batavia. Sjahrir wist de externe positie van zijn regering verder te verbeteren door aan te bieden dat de Republiek rijst zou leveren aan India waar in die tijd hongersnood heerste. De regering in New Delhi zond een vertegenwoordiger naar Batavia om hierover overleg te voeren.

De positieve Britse opstelling bleek ook uit een in april door het Britse bezettingsbestuur met het Republikeinse leger gesloten overeenkomst over de evacuatie van Japanse krijgsgevangenen en Europese geïnterneerden uit Republikeins gebied. Tot de tweede categorie behoorden niet alleen ruim vierduizend die al onder de Japanse bezetting geïnterneerd waren, maar ook tienduizenden (vooral Indo-Europeanen) die in de bersiap-tijd hetzij door de Indonesiërs geïnterneerd waren hetzij zelf bescherming in de opvangkampen gezocht hadden. Ten behoeve van de evacuatietransporten en de bewaking daarvan stelden de Britten vrachtauto's en wapens ter beschikking van de TRI. Het Republikeinse leger had al begin 1946 een speciale organisatie (POPDA) opgericht ten behoeve van deze evacuaties.

Een goede verstandhouding met Groot-Brittannië was weliswaar een belangrijk element van Sjahrir's diplomasi-beleid, maar belangrijker was het bereiken van een politiek akkoord met Nederland over de onafhankelijkheid van Indonesië. Hoewel de mislukking van de Hoge Veluwe-conferentie de kansen hierop verkleind had, was voortzetting van het overleg voor beide partijen een politieke noodzaak. Na zijn terugkeer uit Nederland sprak Van Mook op 19 mei weer met Sjahrir. Daarbij overhandigde hij hem het in Den Haag vastgestelde ontwerp-protocol, dat voornamelijk een vriendelijkere versie was van het op de Hoge Veluwe gepresenteerde Nederlandse ontwerp.

Eind mei verscherpte zich in de Republiek de controverse over strijd of diplomatie. Sommigen verwachtten dat Sjahrir zou aftreden. Ook kwam nu voor het eerst de Hoge Adviesraad van de Republiek bijeen; voorzitter hiervan was Wiranatakoesoema (voor de oorlog invloedrijk lid van de Volksraad, na de oorlog minister in de eerste regering van de Republiek). Soekarno en Hatta voerden uitvoerig overleg met het kabinet-Sjahrir over het verder te voeren beleid. Men verwierp het Nederlandse voorstel en bereikte overeenstemming over de opstelling van een nieuw tegenvoorstel.

Overigens vond in deze dagen een incident plaats dat de naam van de Republiek geen goed deed. Eind mei hadden Nederlandse troepen ten westen van Batavia een deel van het stadje Tangerang bezet, terwijl de TRI zich enige kilometers daarvan teruggetrokken had. Al sinds eeuwen woonden in en bij Tangerang veel Chinezen. In het door de terugtrekking van de TRI ontstane 
niemandsland keerden talrijke Indonesiërs zich plunderend, brandstichtend en moordend tegen de Chinese bevolking. De bersiap-terreur leek te zijn teruggekeerd. Vele honderden Chinezen werden gedood, duizenden vluchtten naar het door Nederlandse en Britse militairen beheerste gebied. Deze 'Chinezenmoord van Tangerang' kreeg veel aandacht in de Nederlandse en de internationale pers. De regering van de Republiek gaf een verklaring uit waarin zij de gewelddadigheden afkeurde; Sjahrir betuigde in een radiotoespraak zijn leedwezen aan de Chinese gemeenschap.

Na het overleg in Jogja diende Sjahrir bij brief van 15 juni het Republikeinse tegenvoorstel in. Het had de vorm van een ontwerp-overeenkomst die oppervlakkig wel leek op het eind maart opgestelde ontwerp-akkoord, maar er op hoofdpunten sterk van afweek. Ze hield geen instemming meer in met een federale opbouw van de toekomstige Indonesische staat, noch met een deelgenootschap van Indonesië in een staatsverband met Nederland, Suriname en Curaçao. Op één punt kwam het nieuwe voorstel zelfs minder aan Nederland tegemoet dan het oorspronkelijke Republikeinse voorstel van 13 maart. Dat had nog een federatief verbond tussen Indonesië en Nederland voorgesteld, waarbij de leiding van het buitenlands beleid en de defensie aan een federaal lichaam toevertrouwd zou worden. Daarentegen voorzag het nieuwe voorstel alleen in een volkenrechtelijk bondgenootschap tussen de beide landen. Aan de andere kant verlangde dit voorstel niet dat Nederland de Republiek onmiddellijk zou erkennen als draagster van de soevereiniteit over het voormalige Nederlands-Indië, maar verlangde het wel erkenning van haar de facto gezag over heel Java en Sumatra. Verder hield het voorstel onder meer in dat de beide partijen de vijandelijkheden zouden staken, dat de Republiek geen nieuwe soldaten meer zou werven en dat Nederland in Indonesië geen nieuwe troepen meer zou binnenbrengen.

Op 23 juni sprak Van Mook opnieuw met Sjahrir. Zijn mandaat stond hem niet toe over de politieke elementen van het Republikeinse voorstel te onderhandelen. Overigens was er toch al geen ruimte voor serieuze onderhandelingen, omdat er na de Nederlandse verkiezingen van 17 mei nog steeds geen nieuwe regering gevormd was en het demissionaire kabinet-Schermerhorn geen gewichtige besluiten nemen kon. $\mathrm{Nu}$ een politiek akkoord voorlopig onbereikbaar was, richtte Sjahrir zich op een ander element van het voorstel, namelijk dat over het staken van de vijandelijkheden. Dit was urgent omdat de aflossing van de Britse bezettingsmacht door Nederlandse troepen zich sinds maart in hoog tempo voltrok en tot opleving van de strijd leidde. Bovendien was in Nederland zelf al de opleiding begonnen van de eerste voor inzet in Indonesië bestemde divisie van dienstplichtigen. Sjahrir polste Van Mook nu over de mogelijkheid op korte termijn een afzonderlijke wapenstilstand te sluiten. De volgende dag diende hij daartoe een schriftelijk voorstel in dat onder meer inhield, dat beide partijen geen nieuwe strijdkrachten meer zou- 
den aanwerven of recruteren en geen nieuwe troepen meer aan land zouden brengen. Meteen daarop vertrok hij voor een reis van een week naar Middenen Oost-Java.

\section{Poging tot staatsgreep in de Republiek}

De regering van de Republiek had de inhoud van de in april op de Hoge Veluwe besproken voorstellen steeds zorgvuldig geheim gehouden. Evenmin maakte zij de inhoud bekend van het tegenvoorstel dat Sjahrir midden juni aan Van Mook voorlegde. Ten gevolge van berichten uit Nederlandse bron circuleerden echter al spoedig geruchten in de Republiek over dit nieuwe voorstel. Vooral het gerucht dat daarin alleen erkenning van het Republikeinse gezag over Java en Sumatra gevraagd was wekte opschudding. Dit leek immers lijnrecht in strijd met het aan de regering-Sjahrir gegeven mandaat op basis van $100 \%$ erkenning van de Republiek. Het werd een onderwerp van levendige gedachtenwisseling tussen een aantal tegenstanders van het diplomasi-beleid, onder wie de nabij Solo geïnterneerde voormannen van de PP, enige andere politici zoals Soebardjo en Iwa Koesoema Soemantri en enkele hoge militairen, onder wie opperbevelhebber Soedirman en generaal-majoor Soedarsono, divisiecommandant in Jogjakarta. In deze kring zag men Hatta, Sjahrir en Amir Sjarifoeddin liefst van het politieke toneel verdwijnen en plaats maken voor een nieuwe leiding met een belangrijke rol voor Tan Malaka.

Op donderdag 27 juni bevestigde Hatta in een openbare rede dat het nieuwe voorstel als eerste stap voorzag in Nederlandse erkenning van het Republikeinse gezag over Java en Sumatra. Deze bevestiging lokte een politieke kettingreactie uit die later bekend is geworden als de '3-juli affaire'.

Sjahrir, die op deze donderdag uit Oost-Java terugkeerde en in een hotel in Solo overnachtte, werd daar op bevel van generaal Soedarsono gevangen genomen en naar een geheime plaats weggevoerd. De regering in Jogja onder leiding van Amir Sjarifoeddin vernam vrijdagochtend van deze ontvoering, maar gaf er nog geen ruchtbaarheid aan. De volgende dag maakte zij bekend dat Soekarno tijdelijk de volledige regeringsmacht op zich nam in verband met gebeurtenissen die de staatsveiligheid in gevaar brachten. Soekarno gaf zelf een persconferentie; onder meer sprak hij daarin duidelijk steun uit voor het aan Nederland voorgelegde voorstel. Zaterdagavond maakte de regering eindelijk de ontvoering van Sjahrir bekend, die zij veroordeelde als een misdadig optreden waar alleen Nederland profijt van trekken kon. Zondag 30 juni verlangde Soekarno van opperbevelhebber Soedirman dat deze voor Sjahrir's vrijlating zou zorgen. Toen ook die avond nog steeds niet bekend was waar Sjahrir werd vastgehouden, deed Soekarno via de radio een klemmend beroep op de bevolking van de Republiek om de regering tegen deze poging 
tot staatsgreep te steunen. Sjahrir werd daarop door zijn bewakers vrijgelaten. Maandagochtend 1 juli verscheen hij weer in Jogja; na overleg met Soekarno en zijn kabinet keerde hij nog diezelfde dag per vliegtuig naar Batavia terug. In Jogja liet de regering in de nacht van maandag op dinsdag tientallen leden van de oppositie arresteren.

In de nacht van dinsdag op woensdag ging generaal Soedarsono samen met Yamin van Solo naar Jogja, waar hij allereerst de politici uit de gevangenis haalde die de vorige nacht door de regering gearresteerd waren. Medewerkers van Soedarsono probeerden tegen de ochtend minister Amir Sjarifoeddin te ontvoeren; twee van diens lijfwachten werden daarbij gedood, maar zelf wist hij te ontsnappen en naar het paleis van Soekarno te vluchten. Amir en Soekarno lieten daarop de bewaking van het paleis versterken met Pesindoeenheden.

Enige uren later verscheen Soedarsono bij het paleis, samen met Yamin en de uit de gevangenis gehaalde politici. Hij verlangde Soekarno te spreken, maar werd pas na lang wachten en zonder begeleiders bij deze toegelaten, die hem samen met Hatta en Amir Sjarifoeddin ontving. Soedarsono legde Soekarno ter ondertekening vier door Yamin opgestelde besluiten voor, die onder meer inhielden dat hij het kabinet-Sjahrir zou ontbinden, dat hij zijn bevoegdheden op het gebied van defensie en veiligheid zou overdragen aan generaal Soedirman en dat hij zijn andere bevoegdheden zou overdragen aan een Politieke Bestuursraad, bestaande uit tien met name genoemde politici onder wie Tan Malaka. Soekarno ging niet op de eisen in en liet Soedarsono en zijn gezelschap gevangen nemen.

Dit was het einde van deze dilettantistische poging tot staatsgreep. Het optreden van aan Amir Sjarifoeddin trouwe Pesindo-eenheden had belangrijk tot de mislukking bijgedragen. Daarentegen had opperbevelhebber Soedirman tijdens de hele crisis niets tegen de coupplegers ondernomen. Op 3 juli verscheen hij pas tegen de avond in Jogja. Daar bood hij Soekarno zijn ontslag aan, maar dit werd hem geweigerd. De staat van beleg bleef voorlopig gehandhaafd. In afwachting van het herstel van de normale toestand zouden de ministers van het kabinet-Sjahrir hun werkzaamheden voortzetten als 'helpers' van de president.

De Republiek leek aan een burgeroorlog te zijn ontsnapt. Bijna honderd personen werden gevangen gezet op verdenking van betrokkenheid bij de couppoging. Verscheidene van hen waren prominente figuren uit de nationale beweging, zoals Iwa Koesoema Soemantri, Malik, Soebardjo en Yamin. Volgens de regering was er sprake geweest van een complot met als uiteindelijk doel Soekarno door Tan Malaka te vervangen. Het is aannemelijk dat sommige verdachten plannen in die zin hebben gehad, maar het is onaannemelijk dat zij daartoe voldoende steun zouden hebben gekregen. Per saldo leidde de ontvoeringsaffaire tot een aanzienlijke versterking van Soekarno's positie. 


\section{Aantreden van het Nederlandse kabinet-Beel}

Op 17 mei 1946 vonden in Nederland voor het eerst sinds 1937 weer verkiezingen voor de Tweede Kamer plaats. Voor de aanhangers van de Partij van de Arbeid was de uitslag bijzonder teleurstellend. In plaats van de drie maanden eerder voorspelde $46 \%$ kreeg de partij slechts $28 \%$ van de stemmen. De nieuwe zetelverdeling in de Kamer werd 29 voor de PvdA, 32 voor de KVP, 13 voor de ARP, 8 voor de CHU, 2 voor de Staatkundig-Gereformeerde Partij (SGP, een zeer conservatieve protestants-christelijke partij), 6 voor de Partij van de Vrijheid (PvdV, de rechts-liberale partij) en 10 voor de CPN. De KVP-fractie was dus de grootste fractie geworden; zij koos Romme tot haar voorzitter. Twaalf dagen later werden verkiezingen voor de Provinciale Staten gehouden; de PvdA ging hierbij nog verder achteruit en behaalde nog geen $26 \%$ van de stemmen. De Provinciale Staten kozen vervolgens een nieuwe Eerste Kamer; nu had Nederland voor het eerst sinds de oorlog weer een geheel gekozen parlement.

$\mathrm{Na}$ de verkiezingen voor de Tweede Kamer werd minister Beel met de vorming van een nieuw kabinet belast; hij richtte zich op een coalitie van de KVP met de PvdA. De verkiezingsuitslag liet de PvdA slechts de keus tussen samenwerken met de KVP of buiten de regering blijven. In het laatste geval zouden aan de nieuwe regering partijen gaan deelnemen die het Indonesiëbeleid van de regering-Schermerhorn steeds hadden bestreden; het viel dan te verwachten dat gezagsherstel met militair geweld de voorrang zou krijgen boven politieke tegemoetkomingen. Los van de Indonesische kwestie had de PvdA echter nog een tweede reden om voor samenwerking met de KVP te kiezen. Zij meende haar doelstellingen op maatschappelijk gebied alleen te kunnen verwezenlijken als zij zelf in de regering zat. Tot 1939 was Nederland bijna het enige Europese land geweest waar socialisten nog nooit deel van de regering hadden uitgemaakt. Zou de PvdA nu niet tot de nieuwe regering toetreden, dan vreesde zij zich weer lange tijd tot de rol van oppositiepartij te moeten beperken. De angst om haar positie van regeringspartij te verliezen heeft de opstelling van de PvdA ten aanzien van Indonesië ook later nog jarenlang beïnvloed.

Voor de KVP was een coalitie met de PvdA om verschillende redenen aantrekkelijk. Zo gaf het feit dat zij ook een regering met andere partijen kon vormen haar tegenover deze coalitiepartner een bijzondere machtspositie. De Indonesische kwestie hoefde samenwerking niet in de weg te staan. Ten eerste had Beel zelf in het kabinet-Schemerhorn aan de beleidsbepaling hierover deelgenomen. Ten tweede konden ook de leiders van de PvdA zich de dekolonisatie van Indonesië niet anders voorstellen dan via de in 1942 aangekondigde Rijksconferentie. Wat Romme betreft, deze wilde weliswaar Indonesië beslist binnen het Koninkrijk houden en betreurde daarom dat de regerings- 
verklaring van 10 februari 1946 een recht op afscheiding erkend had, maar hij begreep dat Nederland die erkenning niet meer kon intrekken. Verder waren veel KVP-parlementsleden in de Indonesische kwestie minder conservatief dan Romme en was oud-minister Welter niet in de Eerste Kamer teruggekeerd. Bij de opstelling van het regeringsprogram bereikte Beel overeenstemming met de PvdA over het Indonesiëbeleid op basis van de koninklijke rede van december 1942 en de regeringsverklaring van februari 1946. Verder kwam in deze paragraaf van het program te staan dat de beoogde Rijksconferentie ook zou plaats vinden als vertegenwoordigers van de Republiek er niet aan zouden willen deelnemen. Bovendien voorzag die paragraaf in de opbouw van een gezagsapparaat dat onder meer zou moeten dienen voor de vestiging en handhaving van een rechtsorde waarvoor het Koninkrijk de verantwoordelijkheid kon dragen.

De opstelling van het regeringsprogram en de samenstelling van de ministersploeg namen veel tijd in beslag. Pas op 3 juli werd het nieuwe kabinet beëdigd. Het bevatte vijf ministers uit de KVP en vijf uit de PvdA naast vier partijloze ministers. Beel zelf werd minister-president; Drees, de politieke strateeg van de PvdA, bleef vice-premier en minister van sociale zaken. De politieke strateeg van de KVP, Romme, maakte daarentegen geen deel van de regering uit maar bleef parlementslid. Schermerhorn en Logemann keerden niet in de regering terug. Voor Schermerhorn had men een nieuwe functie op het oog in het kader van het Indonesië-beleid. Logemann, wiens pogingen om begrip voor het Indonesisch nationalisme te wekken bij een deel van het Nederlandse publiek slecht waren gevallen, werd nu lid van de Tweede Kamer. Daar stond tegenover dat de portefeuille van overzeese gebiedsdelen opnieuw aan een persoon uit de kring van de PvdA werd toevertrouwd.

Deze nieuwe minister was J.A. Jonkman, die in Nederland geboren en opgegroeid was, maar wiens loopbaan zich in Indonesië afgespeeld had. In het begin van de jaren dertig had hij samen met onder meer Van Mook en Logemann tot de Stuw-groep behoord die zich tegen het koloniale conservatisme keerde. Van 1939 tot aan de Japanse bezetting was hij voorzitter van de Volksraad geweest; in die tijd was hij het niet eens geweest met de starre houding van het gouvernement tegenover de Indonesische nationale beweging. De bezettingstijd had hij in Japanse gevangenschap doorgebracht; eind 1945 was hij in Nederland teruggekeerd. De in 1946 door hem gehuldigde opvattingen over de toekomst van Indonesië waren gecompliceerd. Na zijn aantreden als minister verklaarde hij enerzijds dat hij het streven van de Indonesische volkeren om een eigen staatsverband te hebben als volkomen rechtmatig erkende, maar anderzijds dat Nederland een wereldrijk moest blijven en dat men Nederlands taak overzee ten volle moest handhaven.

Met de totstandkoming van het kabinet-Beel was in Nederland de eerste verantwoordelijkheid voor het Indonesiëbeleid volledig bij de KVP en de 
PvdA komen te liggen. Deze politieke constellatie leek een sterk contrast te vormen met het vooroorlogse verleden, toen het Nederlandse koloniale beleid in hoofdzaak door protestanten en conservatieven bepaald werd. (De rol van de katholiek Welter als hoge functionaris van het Nederlands-Indisch gouvernement en als minister van koloniën was een uitzondering geweest.) Nog steeds leefde de betekenis van 'Indië' als bestanddeel van de Nederlandse identiteit veel sterker onder het protestantse deel van de bevolking dan onder het katholieke deel waar de KVP haar aanhang had. Bovendien stamde de aanhang van de PvdA grotendeels uit de hoek van de socialistische partij SDAP, die voor de oorlog het Indonesische recht op onafhankelijkheid in beginsel erkend had. Het contrast was echter minder sterk dan men op grond van deze feiten zou kunnen verwachten.

De katholieken waren in Nederland lange tijd achtergesteld geweest en waren daar pas tegen het eind van de negentiende eeuw een zelfstandige politieke factor geworden. Sinds 1918 had hun grootste politieke partij regelmatig aan de regering deelgenomen en enige malen zelfs de minister-president geleverd, maar toch waren zij in vergelijking met de protestanten en liberalen nog steeds nieuwkomers in het centrum van de nationale macht. Tegen die achtergrond leken katholieke politici zoals Romme iedere indruk te willen vermijden dat hun loyaliteit meer op het Vaticaan dan op de Nederlandse staat gericht was. Dit leidde er aan KVP-zijde onder meer toe dat men zich intensief met Indonesië ging bezighouden, waarbij men vooral streefde naar behoud van Nederlandse invloed en naar handhaving van een staatsrechtelijke band tussen Indonesië en Nederland. Romme formuleerde het eens aldus, dat het abandonnement van Indië niet op een katholieke naam zou mogen staan.

Een soortgelijke vrees voor de verdenking van onvoldoende nationale gezindheid speelde een rol bij de PvdA, en zelfs in nog sterkere mate. Nu de socialisten na de Tweede Wereldoorlog eindelijk ook een plaats in het centrum van de nationale macht verworven hadden, vormde het voor hen een belasting dat het socialisme oorspronkelijk een politieke leer geweest was die zich tegen de bestaande maatschappelijke orde keerde en die in beginsel zowel de monarchie als het kolonialisme afwees. Veel leidende figuren binnen de PvdA wilden graag laten zien dat de zorg voor het nationale belang ook bij hen in goede handen was. Dit werkte een voorzichtige opstelling in de Indonesiëpolitiek in de hand. Weliswaar telde de partij ook enige prominente leden die bereid waren aanzienlijk ruimer aan het Indonesisch nationalisme tegemoet te komen, maar zij vonden weinig gehoor. Daar kwam nog bij dat sommige PvdA-figuren die wél een belangrijke invloed op het Indonesiëbeleid uitoefenden, zoals Schermerhorn, Lieftinck en Jonkman, helemaal niet uit de socialistische achterban van de partij afkomstig waren. 


\section{De conferentie van Malino}

Al in november 1945 was bij Van Mook de gedachte gerezen dat herstel van het Nederlandse gezag in de archipel buiten Java en Sumatra het mogelijk zou maken aanschouwelijke bewijzen te leveren van nieuwe vormen van Nederlands-Indonesische samenwerking (zie pp. 431-2). In het bijzonder dacht hij aan de vorming van deelstaten die te zijner tijd deel zouden uitmaken van een Indonesische federatie waarin men ook de Republiek zou kunnen opnemen. Na de Hoge Veluwe-conferentie was deze gedachte actueel geworden omdat het einde van het Britse oppergezag over dit deel van Indonesië in zicht kwam. Daarom wijdde Van Mook zich toen intensief aan de voorbereiding van een bijeenkomst met representatieve Indonesiërs uit de weer onder Nederlands gezag komende gebieden om hen voor zijn conceptie te winnen.

$\mathrm{Na}$ de formele gezagsoverdracht in Makassar op 15 juli (zie p. 458) vond de door Van Mook belegde conferentie van 16 tot 24 juli plaats in Malino, een bergoord ten oosten van Makassar. Er namen negenendertig vertegenwoordigers uit de betrokken gebieden aan deel. Sommigen van hen waren door plaatselijke organen afgevaardigd; de meesten waren op voordracht van Nederlandse bestuursambtenaren uitgenodigd. Ruim een kwart van de vertegenwoordigers bestond uit feodale zelfbestuurders. Eén daarvan was Hamid II Alkadrie, sultan van Pontianak. Hij was een in Nederland opgeleide KNIL-officier die behoorde tot een sultansfamilie van Arabische afkomst; zijn mannelijke familieleden waren onder de Japanse bezetting ter dood gebracht; kort na de oorlog had hij op Nederlandse aandrang de opvolging als sultan aanvaard; tijdens de Hoge Veluwe-conferentie was hij als adviseur van de Nederlandse regering opgetreden; hij was toen bovendien benoemd tot adjudant in bijzondere dienst van koningin Wilhelmina. De meest ervaren politicus onder de vertegenwoordigers was Tjokorde Gde Rake Soekawati, een Balinese aristocraat die voor de oorlog een prominent lid van de Volksraad geweest was. Een andere belangrijke deelnemer was Nadjamoeddin Daeng Malewa uit Zuid-Celebes; onder de Japanse bezetting was hij burgemeester van Makassar geweest. De leiding van de conferentie berustte bij Van Mook. Hij liet zich bijstaan door een omvangrijke ambtelijke staf, onder wie zijn nieuwe kabinetschef P.J. Koets, die in de jaren dertig secretaris van de Stuwgroep geweest was.

Men kon de in Malino verzamelde vertegenwoordigers niet volledig representatief achten voor de bevolking van hun gebieden. Zo ontbrak de belangrijkste politicus van Celebes, Ratoelangie, voormalig leider van de Minahasa-bond, oud-lid van de Volksraad, mede-oprichter van de Republiek en door haar tot gouverneur van Celebes benoemd. Hij was in april door het Nederlandse bestuur gevangen genomen (evenals in juni de Republikeinse gouverneur van de kleine Soenda-eilanden, Poedja). Dit betekende echter 
niet dat Republikeinse gezichtspunten in Malino in het geheel niet naar voren kwamen. Een aanzienlijke minderheid van de vertegenwoordigers gaf blijk van sympathie voor de Republiek. Dit gold voor verscheidene deelnemers uit Riouw, Bangka, Biliton, Zuid-Borneo, Oost-Borneo, Zuid-Celebes, de NoordMolukken en Timor. Bovendien werd de conferentie ook door Republikeinse journalisten bijgewoond.

De conferentie vond plaats in een welwillende sfeer. De vertegenwoordigers bleken gevoelig voor het feit dat er nu ook eens aandacht aan hun gebieden besteed werd en niet alleen aan Java en Sumatra. Men voelde zich niet in zijn vrijheid van meningsuiting beperkt. Al in het begin van de conferentie protesteerde Nadjamoeddin tegen de mening dat Indonesië nog niet rijp voor zelfbestuur zou zijn en dat het vrijheidsideaal zich tot een dunne bovenlaag van de bevolking zou beperken. Hij noemde het absurd dat een klein land aan de Noordzee over het lot van het grote Indonesië zou beslissen.

De conferentie werd een groot succes voor Van Mook. Alle vertegenwoordigers, ook de Republikeinsgezinde, steunden de door hem bepleite federale inrichting van het toekomstige Indonesië. Met wat meer moeite kreeg hij steun voor de gedachte dat aan de zelfstandigheid van Indonesië een periode van voorbereiding binnen het Koninkrijk vooraf zou moeten gaan. Van hen die zich over de duur van die periode uitlieten vond een deel vijf jaar genoeg terwijl een ander deel aan hooguit tien jaar dacht. Overigens onderschreef men algemeen de wenselijkheid van voortgezette samenwerking tussen Nederland en Indonesië na afloop van de voorbereidingsperiode. Ten aanzien van de staatkundige vorm van die toekomstige samenwerking liepen de standpunten uiteen. Ongeveer twee derde van de vertegenwoordigers was voor een gelijkgerechtigd deelgenootschap van Indonesië binnen het Koninkrijk, ongeveer een derde (de Republikeinsgezinden) was voor een bilaterale verdragsverhouding tussen Indonesië en het Koninkrijk.

Eén van de omstreden kwesties was uit welke delen de Indonesische federatie zou moeten bestaan. Van Mook pleitte voor deelstaten van grote omvang; Java, Sumatra, Borneo en Oost-Indonesië. De meeste vertegenwoordigers konden zich daar wel in vinden. De conferentie besloot dat er spoedig een tweede conferentie moest komen die geheel uit gekozen vertegenwoordigers zou moeten bestaan en die concrete stappen zou nemen voor de staatkundige hervorming van Borneo en Oost-Indonesië.

Van Mook drong er bij Jonkman op aan dat de regering de conclusies van de conferentie van Malino zou onderschrijven, maar Jonkman toonde hier weinig belangstelling voor. Daarentegen reageerde hij op hetgeen in Malino over onafhankelijkheid gezegd was met een uitdrukkelijke aanwijzing aan Van Mook. Volgens die aanwijzing kon 'de Nederlandse politiek niet gericht zijn op volkomen onafhankelijkheid van Indonesië, waardoor de band met Nederland verbroken zou worden'. 


\section{Verheviging van de strijd op Java}

Het gedwongen verblijf in Malakka van de Nederlandse oorlogsvrijwilligers behoorde sinds maart 1946 tot het verleden; tegen het eind van die maand waren zij allen, zowel KL-militairen als mariniers, naar Indonesië overgebracht. Bovendien arriveerden in april-juli op Java nog zes bataljons vrijwilligers rechtstreeks uit Europa. Daarmee steeg het aantal KL-militairen in Indonesië tot ruim twintigduizend, naast de ongeveer drieduizend militairen van de mariniersbrigade.

Ook het KNIL groeide in omvang. De ruim zesduizend KNIL-militairen die bij het eind van de oorlog met Japan in actieve dienst waren werden aangevuld met een tienduizend beroeps- en dienstplichtige militairen die uit Japanse krijgsgevangenschap terugkeerden. Bovendien sloot een deel van de Indonesische KNIL-militairen die de Japanse bezetting niet in krijgsgevangenschap hadden doorgebracht zich opnieuw bij het KNIL aan (terwijl een ander deel tot het Republikeinse leger toetrad). Verder begon het KNIL ook weer nieuw personeel te werven, vooral onder Ambonezen en Menadonezen.

Een groot deel van de KNIL-militairen bevond zich buiten Java. Op Java zelf combineerde de legerleiding de KNIL-militairen met de Nederlandse oorlogsvrijwilligers in acht brigades (samen 30.000 man). Verder bracht men die brigades in twee divisies onder, die men als A-Divisie en B-Divisie betitelde. De uit Nederlandse dienstplichtigen samen te stellen divisie die in het najaar zou aankomen duidde men daarom als C-divisie aan. Na het vertrek van die C-divisie zou in Nederland de opleiding beginnen van een tweede divisie van dienstplichtigen, die in het voorjaar van 1947 naar Indonesië zou gaan. Verder was besloten in 1947 nog een derde en een vierde divisie voor inzet in Indonesië gereed te maken, ook ter aflossing van de oorlogsvrijwilligers, onder wie een deel al sinds begin 1945 onder de wapenen was en nog aan de strijd tegen Duitsland deelgenomen had.

Terwijl Nederland dus in 1947 in Indonesië over een aanzienlijke strijdmacht zou gaan beschikken, bleef de Nederlandse militaire sterkte daar voorlopig nog ver onder die van de Britse troepenmacht die men in 1946 moest vervangen. Het Nederlands-Indische gouvernement raakte hierover zeer verontrust en vroeg de regering in Den Haag op korte termijn extra troepen voor bewakingstaken beschikbaar te stellen. Daarop besloot de regering eind mei om twaalf bataljons die voor de bezetting van Duitsland bestemd waren aan die bestemming te onttrekken en naar Indonesië uit te zenden, en wel zes in oktober 1946 en zes in april 1947. Overigens betekende dit wederom, evenals in november 1945, dat de regering wel gevolg gaf aan aandrang uit Batavia om troepen te sturen maar in een aanzienlijk later stadium dan men daar bedoeld had.

De opbouw van de strijdmacht van de Republiek ging gepaard met proble- 
men van andere aard. Eén daarvan was het verschil in opvatting tussen de regering en de legerleiding over de plaats van het leger binnen het Republikeinse staatsbestel. In de visie van Sjahrir en Amir Sjarifoeddin behoorden de strijdkrachten een werktuig van de regering te zijn; in Soedirman's visie was het leger niet ondergeschikt aan de regering maar stond het als belichaming van de nationale revolutie naast de regering.

Een ander probleem vormden de tegenstellingen tussen de uit de Peta en de uit het KNIL afkomstige officieren. Veel ex-Peta-officieren wantrouwden de plannen van Amir Sjarifoeddin om het leger van Japanse invloeden te zuiveren. Onder de zeven divisies van de TRI was er maar één waar de regering onvoorwaardelijk op vertrouwen kon. Dit was een in West-Java gelegerde divisie waarvan de leiding in handen lag van jonge ex-KNIL-officieren die voor de oorlog op de militaire academie in Bandoeng opgeleid waren en die nu goede contacten onderhielden met de politieke achterban van Sjahrir en Amir Sjarifoeddin. Met hulp van Amir's ministerie van defensie ontwikkelde deze divisie zich tot het best geoutilleerde en best gedisciplineerde deel van de TRI. Op de ontvoering van Sjahrir reageerde ze door posities nabij Jogja in te nemen. Sinds mei 1946 stond ze onder bevel van de uit Sumatra afkomstige generaal-majoor A.H. Nasoetion. Ook vele anderen van haar leidende officieren waren niet van Javaanse landaard. De lagere rangen van deze divisie werden grotendeels door Soendanezen bezet (terwijl de andere TRI-divisies overwegend uit Javanen bestonden). Zij kreeg later de naam Siliwangi-divisie, naar een legendarische koning Siliwangi die over een Soendanees rijk geregeerd had.

Tussen april en juni 1946 droeg het Britse bezettingsleger het grootste deel van zijn posten op Java aan de Nederlandse brigades over. Dit luidde een verheviging in van de gevechten met het Republikeinse leger en de autonome strijdgroepen.

Ten dele was dit een gevolg van het optreden van de Nederlandse troepen zelf, die weliswaar formeel nog aan het Britse commando ondergeschikt waren maar in het begin veel vrijheid kregen om in en buiten de bezette sectoren naar eigen inzicht te handelen. Het Britse bezettingsleger was na de hevige gevechten van najaar 1945 tot een statische vorm van verdediging overgegaan waarbij het alleen in actie kwam wanneer het aangevallen werd, zoals in maart 1946 in Bandoeng gebeurde. De Brits-Indische militairen, die ongewild betrokken waren geraakt bij een conflict waar ze zelf geen partij bij waren, zagen uit naar hun repatriëring. De Nederlandse militairen hadden uiteraard een heel andere opvatting van hun eigen rol en traden al spoedig veel actiever op, onder toepassing van de bij het KNIL gebruikelijke methodieken. Voorzover hun sterkte ter plaatse dit toeliet patrouilleerden ze stelselmatig buiten de bezette sectoren en breidden ze het bezette gebied uit.

Het oplaaien van de strijd was echter ook het gevolg van een verandering 
in optreden aan Republikeinse kant. Het Britse bezettingsleger had in de eerste maanden van 1946 (afgezien van het conflict in Bandoeng) weinig aanvallen meer te verduren gehad. Soekarno en Sjahrir hadden steeds betoogd dat dit leger geen vijand van de Republiek was; bovendien wist men dat de Britse bezetting een aflopende zaak was. Daarentegen werden de in maart op Java aangekomen Nederlandse troepen terstond het doelwit van Republikeinse aanvallen, want die troepen golden voor de Republiek als de echte vijand. Daar kwam bij dat de Nederlandse strijdmacht voorlopig nog bescheiden van omvang was; pas in het najaar zou dit anders worden met de komst van de eerste divisie van dienstplichtigen. Daarom achtten sommige Indonesiërs de omstandigheden nu gunstig om die strijdmacht op Java een beslissende nederlaag toe te brengen. De slechts vier jaar oude herinnering aan het debacle van de Nederlandse verdediging van Java tegen Japan droeg tot deze gedachte bij. Zo pleitte Boeng Tomo in mei voor een 'algemene aanval' om de Nederlandse troepen uit Java te verdrijven. Voor de Republikeinse legerleiding vormde dit het logische militaire alternatief tegenover Sjahrir's diplomasi-beleid. Al in mei en juni voerden TRI-formaties en autonome strijdgroepen hun aanvallen op de Nederlandse posten op. Uiteindelijk kreeg generaal Soedirman een schriftelijk bevel van Soekarno tot herovering van de bezette gebieden.

De 'algemene aanval' (ook wel aangeduid als de 'stormloop op de bruggehoofden') werd een mislukking. Het Republikeinse leger was nog onvoldoende georganiseerd en geschoold voor het ondernemen van een goed gecoördineerd offensief. In manschappen had het weliswaar een groot overwicht, maar slechts een deel van de soldaten beschikte over vuurwapens. Een zorgvuldig doordacht operatieplan ontbrak. De TRI-formaties bestookten de Nederlandse troepen in de enclaves zowel met guerrilla-acties als met grootschalige frontale aanvallen, maar slaagden er niet in de Nederlandse linies te doorbreken. Voorzover ze de Nederlandse militairen in het defensief wisten te dringen, bleken die vaak al spoedig in staat zelf tot het offensief over te gaan. Op tal van plaatsen slaagden de Nederlandse troepen er in de enclaves uit te breiden. De TRI leed ernstige verliezen, zowel in mensen als in munitie en materieel. Zij zag zich tenslotte genoodzaakt op een defensieve strategie terug te vallen.

Het eindresultaat was dat de Nederlandse troepen medio augustus op Java meer gebied beheersten dan in maart in handen was geweest van het numeriek sterkere Britse bezettingsleger. De enclave Batavia-Buitenzorg (de enige enclave die ook nog door Britse troepen verdedigd werd) was westwaarts tot Tangerang en oostwaarts tot Bekasi uitgebreid. Voorbij Buitenzorg konden de Nederlandse strijdkrachten de wegverbinding met Bandoeng nu overdag voldoende beveiligen. De omvang van de enclave Bandoeng zelf was vergroot, evenals die van de enclave Semarang. De enclave Soerabaja was zowel naar het westen als naar het zuiden aanzienlijk uitgebreid. De commandant van de 
Britse bezettingsmacht kreeg nu echter opdracht van zijn superieuren een eind te maken aan het expansieve optreden van de Nederlandse strijdkrachten. Hij verbood grote operaties uit te voeren zonder zijn toestemming en verkleinde de afstand tot waar patrouilles buiten de enclaves mochten plaatsvinden.

Hoewel Van Mook formeel het opperbevel over de Nederlandse strijdkrachten in Indonesië voerde, hadden de bevelhebbers van landmacht en marine hem slechts onvolledig ingelicht over de door hun strijdkrachten ondernomen acties. Dit betrof onder meer de gebiedsuitbreidingen rondom Bandoeng en Soerabaja, maar ook enige acties die een zeer ongunstig gevolg hadden voor een deel van de Europese geïnterneerden die binnen Republikeins gebied op hun evacuatie wachtten. Begin juli hadden Nederlandse schepen en vliegtuigen een zware beschieting uitgevoerd op de Oost-Javaanse havenstad Banjoewangi; omstreeks dezelfde tijd had een Nederlands vliegtuig nabij Madoera een veerboot vol vrouwen en kinderen tot zinken gebracht. De regering van de Republiek vroeg enige malen om garanties tegen herhaling van zulke daden. Toen zij hierop geen reactie kreeg, schortte zij op 24 juli de evacuatie van de geïnterneerden op. Tot dan toe waren 21.000 geïnterneerden door de TRI naar geallieerd gebied overgebracht, maar er bleef nog een groot aantal achter, onder wie velen die al onder de Japanse bezetting geïnterneerd waren.

Een ander gevolg van de beschieting van Banjoewangi was, dat de commandant van de Britse bezettingsmacht de Nederlandse marine verbood binnen een afstand van vijf mijl van deze en enige andere Republikeinse havens op Java te komen.

\section{Instelling van de Nederlandse commissie-generaal}

Terstond na haar aantreden besloot de regering-Beel het voeren van onderhandelingen over de toekomst van Indonesië op te dragen aan een driemanschap van hoog niveau onder de naam 'commissie-generaal'; later besloot zij bovendien dat Van Mook ambtshalve lid van dit orgaan zou worden. Het duurde tot september voordat de regering de leden van de commissie benoemde, namelijk Willem Schermerhorn, Max van Poll en Feike de Boer; daarbij benoemde zij Schermerhorn tot voorzitter. Van Poll was de zoon van een officier uit het koloniale leger, maar was zelf in Nederland opgegroeid; hij was journalist van beroep en was al sinds 1929 parlementslid voor de katholieke politieke partij; in maart en april 1946 had hij Indonesië bezocht aan het hoofd van een parlementaire commissie. De Boer had een groot deel van zijn leven in Indonesië doorgebracht en was daar onder meer bestuurslid van de Vaderlandsche Club geweest; hij was oud-directeur van één van de grootste scheepvaartondernemingen die het verkeer tussen Nederland en Indonesië 
verzorgden en was na de Tweede Wereldoorlog waarnemend burgemeester van Amsterdam geworden.

De achtergrond van het besluit tot instelling van de commissie-generaal was tweeledig. Enerzijds placht Van Mook zelf te klagen dat hij voor het nemen van politiek belangrijke besluiten altijd afhankelijk was van ruggenspraak met de regering in Den Haag, maar dat deze de ontwikkelingen in Indonesië onvoldoende kon beoordelen; hij had daarom herhaaldelijk aangedrongen op overkomst van één of meer ministers om samen met hem zulke besluiten te kunnen nemen. Anderzijds vonden velen dat Van Mook te veel geneigd was zijn regering voor voldongen feiten te plaatsen. Het kabinet-Beel was oorspronkelijk van plan geweest een commissie-generaal in te stellen die náást Van Mook zou functioneren en het politieke overleg van hem zou overnemen. Pas nadat Van Mook had laten weten ontslag te zullen nemen als men hem aldus onder curatele zou stellen, had het kabinet hem ambtshalve lid van dit orgaan gemaakt.

De benamingen 'commissie-generaal' en 'commissaris-generaal' waren ontleend aan de geschiedenis van het Nederlandse koloniale bestuur in de negentiende eeuw. Onder die benamingen had de regering toen enige malen gezagsdragers benoemd die met betrekking tot Nederlands-Indië bevoegdheden kregen die verder gingen dan die van de gouverneurs-generaal. Het bekendste daarvan was een eveneens uit drie personen bestaande commissiegeneraal die van 1816 tot 1818 op Java verbleef om na het Britse tussenbewind het nieuwe Nederlandse koloniale bestuur te organiseren (zie pp. 74-5).

De regering-Beel koos voor het instellen van de nieuwe commissie-generaal de weg van een formele wet, hoewel dit noch juridisch noch politiek noodzakelijk was. De wet trad op 2 september in werking; de commissie-generaal werd op 10 september benoemd en vertrok op 14 september naar Batavia, met een uitvoerige instructie die de dag daarvoor bij koninklijk besluit was vastgesteld. Noch de (openbare) wet noch de (niet-openbare) instructie maakte duidelijk of de commissie-generaal bevoegd was besluiten te nemen die de regering zouden binden. Daarentegen luidde één van de richtlijnen uit de instructie: 'de vaststelling van wat de Commissie afspreekt en voorbereidt zal vervolgens van de samenwerking van Nederlandsche Regeering en StatenGeneraal afhankelijk zijn'.

Wat de taak van de commissie-generaal betreft vermeldde de wet in het bijzonder 'de voorbereiding van een nieuwe staatkundige ordening voor Nederlandsch-Indië en in verband daarmede van de Rijksconferentie'. Uit de wet en de instructie viel af te leiden dat die nieuwe staatkundige ordening alleen gestalte zou mogen krijgen binnen het Koninkrijk en dus niet de vorm zou mogen hebben van een onafhankelijk Indonesië dat alleen door een volkenrechtelijk bondgenootschap met Nederland verbonden zou zijn. Overigens bepaalde de instructie dat de commissie-generaal de regering zou moeten 
raadplegen in geval van ernstige twijfel over de betekenis ervan en dat zij zo nodig om wijziging of aanvulling van de instructie zou kunnen vragen.

De instelling van de commissie-generaal hield minder verband met de politieke situatie in Indonesië dan met de politieke situatie in Nederland. Zij werd niet ingesteld om een ruimere mogelijkheid te openen voor politieke tegemoetkomingen aan de Republiek ter wille van een vreedzame oplossing van het geschil. Haar voornaamste functie was om, als het lukken zou een oplossing langs de door de regering aangegeven lijnen te vinden, daarvoor binnen Nederland brede steun te verwerven. Zulke steun zou vooral nodig zijn omdat men voor het tot stand brengen van een nieuwe relatie met Indonesië de bestaande Nederlandse grondwet zou moeten wijzigen, waarin de koloniale verhouding nu eenmaal uitdrukkelijk vastgelegd was. Voor grondwetswijziging was een parlementaire meerderheid van twee derden nodig, maar KVP en PvdA beschikten daar samen niet over. Omdat het niet aantrekkelijk was voor het bereiken van zo'n meerderheid afhankelijk van de communisten te zijn, lag het voor de hand steun in de eerste plaats bij de liberalen te zoeken. Daartoe zou vooral de figuur van De Boer kunnen bijdragen; men mocht verwachten dat hij onder meer bij de Nederlandse ondernemers en bij de Nederlanders in Indonesië vertrouwen zou genieten.

Dat de PvdA-vertegenwoordigers in regering en parlement instemden met een mandaat voor de commissie-generaal dat iedere oplossing buiten het verband van het Koninkrijk leek uit te sluiten, stond in duidelijke tegenstelling tot de bereidheid van een aantal bekende Nederlanders om zo'n oplossing wel degelijk onder ogen te zien. Die bereidheid bleek uit een verklaring van 17 juli 1946 van het bestuur van de Vereniging Nederland-Indonesië (VNI), waarin aanbevolen werd de onderhandelingen te hervatten met als uitgangspunten enerzijds de in mei door de Nederlandse regering in het parlement afgelegde verklaring en anderzijds de in juni door de regeringSjahrir ingediende voorstellen. De VNI-verklaring zei uitdrukkelijk dat men een vasthouden aan het Rijksverband niet als onafwijsbare voorwaarde behoorde te stellen bij het zoeken naar nieuwe vormen van samenwerking met een zelfstandig Indonesië; dit zou ook in strijd komen met de uitspraak van koningin Wilhelmina over 'vrijwillige aanvaarding' in haar radiorede van 1942. De VNI-verklaring werd onder meer gesteund door talrijke personen uit de kring van de protestants-christelijke zending en door een aantal prominente leden van de PvdA. Over het algemeen waren dit Nederlanders die zeer aan de banden met Indonesië gehecht waren, maar die meenden dat men bereid moest zijn Indonesië staatsrechtelijk los te laten om toch nog iets van die banden te behouden.

Overigens ging het VNI-bestuur later nog een stap verder door op 17 augustus een telegram aan minister-president Sjahrir te sturen, waarin het zijn vreugde uitsprak over het feit dat het Indonesische volk één jaar daarvoor 
zijn recht op zelfbeschikking ter hand genomen had. Het voorzitterschap van de VNI was inmiddels overgegaan op Van Randwijk; hij werd in het najaar opgevolgd door Van Heuven Goedhart.

\section{Britse aandrang tot hervatting van het overleg met de Republiek}

De tijdrovende procedure tot instelling van de commissie-generaal bracht met zich mee dat er lange tijd geen politieke onderhandelingen tussen Nederland en de Republiek meer plaatsvonden. De Britse regering betreurde dit bijzonder en drong voortdurend bij Nederland aan op hervatting van het overleg. $\mathrm{Zij}$ wees opnieuw een Britse diplomaat aan om bij dat overleg behulpzaam te zijn, ambassadeur M.W.L. Killearn, die benoemd was tot bijzonder commissaris voor Zuidoost-Azië met standplaats in Singapore. De Nederlandse regering lichtte haar opstelling begin augustus toe in een uitvoerig aide-memoire voor de Britse regering. Daarin schreef zij de stagnatie van de besprekingen voornamelijk toe aan interne ontwikkelingen in de Republiek en stelde zij haar bereidheid tot voortzetting van het politieke overleg afhankelijk van hervatting van de evacuatie van de Nederlandse geïnterneerden.

Aan Britse kant was men niet gelukkig met de Nederlandse opstelling. Men vreesde dat de kans op een voor Nederland gunstig akkoord met de Republiek kleiner werd naarmate de tijd verstreek. Men vond het onjuist dat de Nederlandse regering geen zaken met Soekarno wilde doen en dat zij een akkoord met de Republiek niet de vorm van een formele overeenkomst wilde geven. De Britse regering was zelf druk bezig met de voorbereiding van onafhankelijkheid voor India en Birma. Zij moest rekening houden met de opvattingen van Nehru, die op 2 september minister-president van de interimregering van India werd. Intussen hadden de Verenigde Staten op 4 juli al volledige onafhankelijkheid aan de Filippijnen verleend. Het Britse onbehagen werd versterkt door achterdocht over de Nederlandse militaire bedoelingen. Men kon sommige Nederlandse militaire acties van juli en augustus moeilijk in overeenstemming brengen met het verlangen van Nederland naar een oplossing door onderhandelingen. Men vroeg zich af of Nederland er op uit was tijd te rekken teneinde later op uitgebreide schaal tot militaire actie over te gaan. Men vreesde dat de Nederlanders hun militaire kracht overschatten en die van de Indonesiërs onderschatten, in het bijzonder de kracht van voortgezette guerrilla-actie, zoals onder meer in Ierland was gebleken. De Britten hechtten dan ook grote waarde aan het tot stand komen van een politiek akkoord tussen Nederland en de Republiek voor de beëindiging van het Britse oppergezag over Indonesië.

Killearn bracht eind augustus een bezoek van enige dagen aan Java, waarbij hij zowel met Van Mook in Batavia als met Sjahrir in Jogja sprak. Namens zijn 
regering deelde hij mee dat de Britse troepen Indonesië uiterlijk 30 november zouden verlaten.

\section{Eerste uitzending van Nederlandse dienstplichtigen naar Indonesië}

De opleiding van de eerste voor inzet in Indonesië bestemde divisie van Nederlandse dienstplichtigen naderde in augustus 1946 haar voltooiing. De regering besloot de divisie de naam ' 7 December' te geven ter herinnering aan de in december 1942 door koningin Wilhelmina uitgesproken radiorede. Die naam moest doen uitkomen dat de divisie niet diende tot behoud van het koloniale bestel maar tot bevordering van een nieuw bestel waarin Indonesië en Nederland gelijkwaardige delen van het Koninkrijk zouden vormen. De verscheping zou in september beginnen.

Terwijl de uitzending van dienstplichtige militairen naar Indonesië naderbij kwam, openbaarde zich grote verdeeldheid hierover binnen de Nederlandse bevolking. Bij een in juli gehouden opinie-onderzoek over de vraag of men voor of tegen deze uitzending was, bleek van de ondervraagde mannen $50 \%$ voor en $41 \%$ tegen te zijn en van de ondervraagde vrouwen $36 \%$ voor en $44 \%$ tegen. De Vereniging Nederland-Indonesië (VNI) zond begin september een telegram aan de regering waarin zij verklaarde dat de voortgezette uitzending van troepen de missie van de commissie-generaal al bij voorbaat dreigde te doen mislukken. Niet alleen zou men het aan Indonesische kant bestaande wantrouwen daardoor juist vergroten, maar ook was er geen waarborg dat die troepen enkel voor het officieel aangegeven doel zouden optreden, daar er sterke stromingen bestonden, ook in het leger, die de troepen graag gebruikt zouden willen zien voor doeleinden die de VNI ontoelaatbaar achtte. Naast dit telegram voerde de VNI een massale handtekeningenactie voor een aan regering en parlement aan te bieden petitionnement dat aandrong op 'een overeenkomst met een gelijkwaardig Indonesië, waarin de wezenlijke elementen van de democratie worden gewaarborgd en de Indonesische verlangens naar onafhankelijkheid worden bevredigd'. Hoewel verscheidene prominente PvdA-leden de VNI-verklaring van 17 juli ondertekend hadden, gaf de PvdA aan deze actie geen steun. Onder de Nederlandse politieke organisaties werd het verzet tegen de uitzending van dienstplichtigen uitsluitend gedragen door de CPN. Zowel in de Eerste als in de Tweede Kamer diende zij moties in tot opschorting van de troepentransporten; deze moties werden door alle andere partijen verworpen.

Op 3 september vertrok een beperkt aantal kwartiermakers van de 7 December-divisie naar Indonesië. Vier dagen later hield de PvdA een partijcongres over de Indonesische kwestie, maar dit had geen praktische consequenties voor de uitzending van dienstplichtigen, die nu eenmaal berustte 
op besluiten van het kabinet-Schermerhorn. Het congres sprak weliswaar de overtuiging uit 'dat tussen Nederland en Indonesië geen oorlog kan of mag worden gevoerd', maar verklaarde verder dat men het sluiten moest bevorderen van een wapenstilstand 'op in onderling overleg te bepalen voorwaarden' en dat men de uitzending van troepen 'dienovereenkomstig' moest regelen.

De militairen van de 7 December-divisie kregen voor hun vertrek naar Indonesië een inschepingsverlof van tien dagen. Toen de soldaten van het eerste grote contingent zich op 17 september weer in de kazerne moesten melden, bleek 38\% niet terug te zijn gekomen. De dag daarna was nog steeds ruim 30\% afwezig. De chef van de generale staf richtte zich daarop via de radio zowel tot de soldaten als tot hun familieleden. Hij verklaarde dat de deserteurs straffen riskeerden die hun leven konden verwoesten. Niettemin bleef meer dan $10 \%$ zich aan uitzending onttrekken; het eerste grote troepentransport vertrok op 24 september uit Amsterdam met een tekort van 15\%.

Drie dagen daarvoor vond in Amsterdam een demonstratie tegen de troepenzending plaats die uitliep op een rel; daarbij werd door de politie geschoten, wat een demonstrant het leven kostte. De CPN en de met haar verbonden vakcentrale EVC riepen daarop op tot een proteststaking op 24 september. In Amsterdam staakten die dag onder meer het trampersoneel en een deel van de havenarbeiders; ook in Rotterdam en Zaandam werd gestaakt. De volgende dag vond in de Tweede Kamer een door de CPN aangevraagd spoeddebat plaats waarin alle andere partijen de uitzending van de dienstplichtigen verdedigden.

De verscheping van de divisie werd dan ook volgens schema voortgezet. In oktober vertrokken bovendien zes van de extra beschikbaar gestelde bewakingsbataljons die eveneens uit dienstplichtigen bestonden. Deze bataljons kregen ook het predicaat '7 December' en werden voortaan als '7 Decemberbataljons' aangeduid.

Terwijl de beroering over de troepentransporten geen gevolgen voor het regeringsbeleid had, gaf ze wel een bijzondere stimulans aan de handtekeningenactie van de VNI. Toen de VNI deze actie eind september afsloot had zij ruim 233.000 handtekeningen verzameld.

In totaal hebben in 1946 en volgende jaren ongeveer zesduizend Nederlandse dienstplichtigen geweigerd aan de strijd in Indonesië deel te nemen, deels door in Nederland te deserteren, deels door gewetensbezwaren aan te voeren tegen de militaire dienst in het algemeen. Verreweg de meeste weigeraars kwamen uit de drie noordelijke provincies of uit Amsterdam. Van de gewetensbezwaarden kreeg minder dan de helft officiële erkenning. Van de deserteurs werd de overgrote meerderheid vroeger of later gearresteerd; de meesten daarvan toonden zich uiteindelijk toch bereid naar Indonesië te vertrekken. Ongeveer honderd weigeraars kwamen voor de krijgsraad; ruim een kwart daarvan kreeg gevangenisstraffen van meer dan drie jaar. 
In 1946 betoogden sommige tegenstanders van de troepentransporten dat die een schending van de Nederlandse Grondwet inhielden. Artikel 192 daarvan luidde namelijk: 'De dienstplichtigen te land mogen niet dan met hunne toestemming naar Nederlandsch-Indië, Suriname en Curaçao worden gezonden'. Tijdens de Tweede Wereldoorlog had de in Londen zetelende Nederlandse regering deze bepaling buiten werking gesteld. Zij had zich daartoe bevoegd geacht op grond van de redenering dat de oorlogstoestand haar toestond in geval van nood van de Grondwet af te wijken. Volgens sommigen ging deze redenering na de capitulatie van Japan niet meer op. De naoorlogse regeringen stelden zich echter op het standpunt dat de oorlogstoestand nog niet geëindigd was. Wel namen zij stappen om de Grondwet aan te passen. De daartoe gevolgde procedures waren zo tijdrovend dat pas in januari 1947 een Grondwetswijziging van kracht werd die inhield dat dienstplichtigen van land- en luchtmacht alleen krachtens een wet naar de overzeese gebiedsdelen mochten worden gezonden. Vervolgens duurde het nog tot augustus 1947 voordat een wet in werking trad die alsnog uitdrukkelijk voorzag in gedwongen uitzending overzee van Nederlandse dienstplichtigen (van wie zich toen al twee divisies en twaalf extra bataljons in Indonesië bevonden en aan grootscheepse militaire operaties deelnamen).

\section{Aantreden van het derde kabinet-Sjahrir}

Eind juni 1946 was in de Republiek de staat van beleg uitgeroepen waardoor de staatsmacht volledig bij de president was komen te berusten; de ministers hadden hun werkzaamheden sindsdien voortgezet als 'helpers' van de president (zie p. 462). Midden augustus verklaarde het Werkcomité van het KNIP dat de buitengewone toestand die tot de staat van beleg geleid had niet meer bestond zodat het verantwoord was weer een aan het KNIP verantwoordelijk kabinet in te stellen; dit kabinet zou een brede samenstelling moeten hebben. Soekarno gaf de opdracht tot vorming hiervan opnieuw aan Sjahrir. De formatie van het nieuwe kabinet kostte ongeveer evenveel tijd als de formatie van het Nederlandse kabinet-Beel; pas op 2 oktober werd het geïnstalleerd.

Het derde kabinet-Sjahrir bestond uit dertien vakministers, zes ministers zonder portefeuille en twaalf vice-ministers. Er behoorden leden van verschillende politieke partijen toe, waaronder de Partai Sosialis, de Masjoemi, de PNI en de protestants-christelijke partij Parkindo; ook de vrouwenbeweging was in het kabinet vertegenwoordigd en verder bevatte het onder meer een Chinees, een Arabier en een Indo-Europeaan. Sjahrir bleef het premierschap combineren met de portefeuille van buitenlandse zaken en hield in de laatste functie Agoes Salim als vice-minister naast zich. Amir Sjarifoeddin bleef minister van defensie. Als minister van economische zaken trad een belangrijk PNI-lid tot 
de regering toe, A.K. Gani, voor de oorlog oprichter van de Gerindo, onder de Republiek vice-gouverneur voor Zuid-Sumatra. Drie ministers behoorden tot de Masjoemi: Mohammad Natsir, die minister van voorlichting bleef, Sjafroeddin Prawiranegara, die tot minister van financiën bevorderd was, en Mohammad Roem, die minister van binnenlandse zaken werd. Onder de viceministers bevonden zich twee Indonesiërs die tijdens de Tweede Wereldoorlog in Nederland aan het anti-Duitse verzet deelgenomen hadden; één van hen was Setiadjit die de Hoge Veluwe-conferentie als adviseur bijgewoond had. Het kabinet bevatte enige uiterst linkse politici, maar ook de meest gezaghebbende aristocraat van Indonesië, de sultan van Jogja, Hamengkoe Boewono IX; hij was toegetreden als minister van staat. Het Indo-Europese kabinetslid was Multatuli's achterneef Setiaboedi, nu eveneens minister van staat. Als E.F.E. Douwes Dekker had hij in 1912 de eerste partij opgericht die zich op nationale onafhankelijkheid voor Indonesië richtte (zie p. 160-3); later was hij een politieke mentor van Soekarno in diens studententijd geweest; tijdens de Tweede Wereldoorlog had de Nederlandse regering hem in Suriname gevangen gehouden.

Het feit dat verscheidene kabinetsleden tot politieke partijen behoorden hield overigens geen formele steun van die partijen zelf in. De leiding van de PNI bleef gekant tegen onderhandelingen met Nederland zolang dit zijn troepen niet uit Indonesië terugtrok; hetzelfde gold voor een belangrijk deel van de Masjoemi.

De in augustus door het KNIP uitgesproken voorkeur voor een kabinet met brede basis kwam deels voort uit de veronderstelling dat die onderhandelingen een beslissend stadium zouden ingaan nu men in Nederland bezig was daartoe een speciaal orgaan van hoog niveau in te stellen. De mislukking van het Republikeinse offensief tegen de geallieerde enclaves vergrootte de bereidheid om weer de weg van de diplomasi in te slaan. Veel voorstanders van die weg koesterden hoge verwachtingen van het optreden van Schermerhorn en de door hem te leiden commissie-generaal.

\section{Het eerste bestand tussen Nederland en de Republiek}

De commissie-generaal kwam op 18 september in Batavia aan; enkele dagen later arriveerde Killearn. Al voordien had men van Nederlandse, Republikeinse en Britse kant een en ander ondernomen om de nieuwe onderhandelingsronde voor te bereiden. Zo hadden medewerkers van Van Mook en Sjahrir de te volgen procedures besproken. De Britse commandant had het optreden van de Nederlandse strijdkrachten nog nauwer aan banden gelegd; die mochten nu niet verder dan twee kilometer buiten de begrenzing van de enclaves patrouilleren. Ook voerde de Britse bezettingsmacht overleg met de TRI over de evacu- 
atie van de Europese geïnterneerden. De Nederlandse regering had hervatting van die evacuatie als voorwaarde gesteld voor de voortzetting van het politieke overleg; voor eind september werd de evacuatie inderdaad hervat.

Tot verbetering van het politieke klimaat droeg ook een bezoek bij dat zes hoge Nederlandse functionarissen uit Batavia van 15 tot 20 september aan de Republiek brachten onder leiding van Koets, de kabinetschef van Van Mook. Zij reisden daar uitvoerig rond, spraken meermalen met Hatta en brachten ook een beleefdheidsbezoek aan Soekarno. Volgens hun bevindingen heersten binnen de Republiek betrekkelijk ordelijke toestanden. Het Republikeinse gezag was zich aan het verstevigen. Er heerste geen voedselnood. De houding van de bevolking getuigde van een nieuw zelfbewustzijn. De bezoekers hadden geen vijandigheid ontmoet, maar een algemene wens om tot een vergelijk met Nederland te komen, echter onder volstrekte verwerping van terugkeer naar koloniale toestanden.

Sjahrir verbleef eind september enkele dagen in Batavia, onder meer voor informeel overleg met Schermerhorn, en keerde daarna naar Jogja terug voor de installatie van zijn nieuwe kabinet. Vervolgens ging de commissie-generaal naar Pangkalpinang op Banka om het begin bij te wonen van een door Van Mook belegde conferentie met vertegenwoordigers van de voornaamste in Indonesië wonende minderheidsgroepen: de Arabieren, de Chinezen en de Nederlanders (vooral de Indische Nederlanders). Pas hierna vond op 7 oktober onder voorzitterschap van Killearn de eerste formele vergadering van de commissie-generaal met de Republikeinse delegatie plaats.

Op initiatief van Killearn probeerde de commissie-generaal allereerst overeenstemming te bereiken over beëindiging van de vijandelijkheden. De eerder door de Republiek gedane voorstellen voor een politiek akkoord hadden daar al passages over bevat; in juni had Sjahrir voorgesteld er een afzonderlijke overeenkomst over te sluiten (zie p. 460). Zijn voorstel had onder meer voorzien in stopzetting van de aanvoer van Nederlandse troepen. Van Britse kant hechtte men belang aan de sluiting van een bestand omdat het Britse gezag over Indonesië binnenkort zou aflopen: zo' $n$ bestand zou dan kunnen voorkomen dat Nederland daarna grote militaire operaties tegen de Republiek zou beginnen. Midden september had de Britse bevelhebber een eerste bespreking hierover belegd met vertegenwoordigers van de TRI, maar die hadden vastgehouden aan de eis dat een bestand gepaard moest gaan met beëindiging van de Nederlandse troepenaanvoer.

Nadat de commissie-generaal de behandeling van het staken van de vijandelijkheden had overgenomen, wisten Schermerhorn en Killearn uiteindelijk Sjahrir te overreden deze eis op te geven. Zij wezen er op dat het in september door de Britse bevelhebber aan de Nederlandse troepen opgelegde feitelijke bestand uiterlijk eind november zou vervallen; daarom zou de Republiek wel degelijk baat hebben bij een formele bestandsovereenkomst 
met Nederland. Men bereikte nu in beginsel overeenstemming op basis van stabilisering van de bestaande militaire posities en van de bestaande numerieke verhouding van geallieerde en Republikeinse strijdkrachten op Java en Sumatra. Die troepensterkte werd door de betrokken partijen als volgt opgegeven: Britse militairen 40.500, plus 5000 Japanse militairen (die nog olievelden op Sumatra bewaakten); Nederlandse militairen per 1 oktober 55.650 en per 30 november 91.200, van wie 56.000 in West-Java; Republikeinse militairen 140.000 op Java en 60.000 op Sumatra. De autonome strijdgroepen in de Republiek werden niet door deze opgave bestreken. De versterking van de Nederlandse troepen tussen 1 oktober en 30 november (de 7 December-divisie en een deel van de 7 December-bataljons) was numeriek geringer dan het aantal Britse en Japanse militairen dat Indonesie in die tijd zou verlaten. Dat er geen verdere versterking zou plaatsvinden werd in de tekst als volgt vastgelegd: 'As both parties wish the Truce as a first step to the peaceful solution of the present political conflict, it is obvious that the present military strength on both sides must be considered as a maximum which will be reduced as the Truce itself succeeds and the political situation clears'.

$\mathrm{Na}$ ruggespraak met de militaire top in Jogja deelde Sjahrir mee een bestandsakkoord op deze basis te kunnen aanvaarden mits Nederland nog een teken zou geven van bereidheid tot vermindering van de troepensterkte. Van Nederlandse kant kwam men hieraan tegemoet door aan de bovenstaande volzin een tot niets verplichtende verwijzing toe te voegen naar een categorie Nederlandse militairen over wie kort daarvoor ook in de conferentie te Pangkal Pinang gesproken was. Het ging om bijna tienduizend Nederlanders die in 1941 op grond van de in Nederlands-Indië geldende dienstplicht onder de wapenen geroepen waren, vervolgens drieënhalf jaar in Japanse krijgsgevangenschap doorgebracht hadden en daarna niet gedemobiliseerd waren maar verplicht waren in het KNIL door te dienen. De verwijzing kwam als volgt te luiden: 'The fact that a large number of N.E.I. troops consists of militia, who have been mobilised for a long time, is a further inducement to speed up such a peaceful solution, which will make possible their demobilisation'.

De bestandsovereenkomst voorzag verder in de instelling van een gemengde commissie die op de uitvoering ervan zou toezien. De overeenkomst kreeg de vorm van een resolutie met bijlagen, die op 14 oktober werd ondertekend door Van Mook en de commissarissen-generaal, door Sjahrir met zijn delegatie en door Killearn. De volgende dag kwam generaal Soedirman uit Jogja naar Batavia en bezocht hij daar het Britse hoofdkwartier; hij ondernam vervolgens een rondreis langs zijn divisiecommandanten om het bestand toe te lichten.

De totstandkoming van de bestandsovereenkomst betekende nog geen onmiddellijke staking van de vijandelijkheden. Eerst moesten de troepencommandanten van beide partijen op plaatselijk niveau afspraken maken, in het bijzonder over de demarcatielijnen op basis van de situatie op 14 oktober; pas 
daarna zouden de opperbevelhebbers het bevel tot 'staakt-het-vuren' geven. Over de uitvoering van dit deel van de overeenkomst rezen tal van moeilijkheden. In feite bestond zowel bij de Nederlandse als bij de Republikeinse strijdkrachten veel tegenzin tegen het hun door de politieke onderhandelaars opgedrongen bestand. Slechts op weinig plaatsen bereikte men overeenstemming over de demarcatielijnen. De TRI-leiding verklaarde herhaaldelijk meer tijd nodig te hebben om de wapenstilstand voor te bereiden. Eind november, toen het Britse oppergezag werd beëindigd, had generaal Soedirman nog geen bevel tot 'staakt-het-vuren' gegeven en had generaal Buurman van Vreeden de Nederlandse divisiecommandanten opgedragen de demarcatielijnen eenzijdig vast te stellen.

\section{Het overleg in Linggadjati}

Na de ondertekening van de bestandsovereenkomst richtte de commissiegeneraal zich op het tot stand brengen van een politiek akkoord. Hiertoe voerde zij een reeks bilaterale gesprekken met de Republikeinse delegatie, dus zonder Britse deelname; wel liet Killearn zich van de voortgang van het overleg op de hoogte houden. Tot de Republikeinse delegatie behoorden naast Sjahrir onder meer de ministers Gani, Roem en Amir Sjarifoeddin. De twee delegaties vergaderden afwisselend in het paleis van de gouverneur-generaal en in het huis van de Republikeinse vertegenwoordiging (Pegangsaän Oost 56). Het eerste van deze gesprekken vond plaats op 22 oktober, ruim een maand na de aankomst van de commissarissen-generaal in Batavia. De intussen verstreken tijd was echter geen verloren tijd geweest, in het bijzonder omdat het onderlinge contact tussen de leden van de commissie-generaal geleid had tot een opmerkelijke toenadering van hun standpunten. Zo was Van Poll, die zich eerst zeer conservatief opstelde, nu de opvattingen van Van Mook en Schermerhorn dicht genaderd. Verder had de commissie-generaal het Nederlandse kabinet weten te bewegen haar te machtigen om zo nodig ook met Soekarno zelf te onderhandelen.

De commissie-generaal wilde een politiek akkoord tot stand brengen voordat het Britse oppergezag zou aflopen. Vooral Schermerhorn vreesde dat anders daarna grootschalig militair ingrijpen van de Nederlandse strijdkrachten nauwelijks meer te vermijden zou zijn. Dit zou de internationale reputatie van Nederland grote schade toebrengen, want het zou lijken alsof de tot nu toe getoonde onderhandelingsbereidheid alleen bedoeld was om tijd te winnen teneinde na het vertrek van de Britten te kunnen toeslaan. Tegelijk beschouwde Schermerhorn de opbouw van een sterke Nederlandse troepenmacht als een belangrijke steun voor de Nederlandse onderhandelingspositie.

Het bij de commissie-generaal levende gevoel van urgentie ontbrak bij de 
regering in Den Haag. Wel had de minister van financiën Lieftinck gewaarschuwd dat er een grens was aan het vermogen van Nederland om zijn militaire aanwezigheid in Indonesië te bekostigen.

In de aanpak van de nieuwe onderhandelingsronde lieten de commissarissen-generaal zich grotendeels leiden door de denkbeelden van Van Mook. Daarbij waren zij bereid tot een ruime interpretatie van hun onderhandelingsmandaat. De commissie-generaal vond dat men de weg van het aanbieden van kleine concessies moest verlaten en al meteen moest komen met een ruimhartig aanbod dat echter op de hoofdpunten niet voor onderhandeling vatbaar zou zijn. Verder wilde zij zich allereerst richten op de uiteindelijke verhouding tussen Nederland en Indonesië; zou men hierover met de Republikeinse delegatie overeenstemming kunnen bereiken, dan zou het eenvoudiger zijn van daaruit terug te werken naar het heden.

Wat die uiteindelijke verhouding betreft leek een strikte interpretatie van het mandaat iedere oplossing uit te sluiten waarbij Indonesië geen deel meer zou uitmaken van het Koninkrijk der Nederlanden; daarentegen wilde de Republiek op dit punt niet verder gaan dan een volkenrechtelijk bondgenootschap tussen twee onafhankelijke staten. Als uitweg uit dit dilemma bedacht Van Mook een constructie tussen die beide posities in: het toekomstige Indonesië zou zelf geen deel van het Koninkrijk uitmaken, maar zou wel met dit Koninkrijk een bijzondere band aangaan in de vorm van een Nederlands-Indonesische Unie. Deze formule lag dicht bij het in maart in Batavia opgestelde compromis (zie pp. 450-1), waarin sprake was geweest van Indonesië als 'deelgenoot in een staatsverband mede omvattende Nederland, Suriname en Curaçao'. In de nu door Van Mook bepleite nieuwe constructie zou de koning van Nederland aan het hoofd van de Nederlands-Indonesische Unie staan. Het Koninkrijk zou dan alleen Nederland, Suriname en Curaçao omvatten; het toekomstige Indonesië zou een federatieve staat zijn waarvan de Republiek een deelstaat zou vormen.

$\mathrm{Al}$ in een vroeg stadium van het politieke overleg legde de commissiegeneraal dit denkbeeld aan de Republikeinse delegatie voor; pas daarna lichtte zij Jonkman er over in. Korte tijd later besloot zij bovendien dat een politiek akkoord tussen Nederland en de Republiek de vorm zou kunnen krijgen van een bilaterale overeenkomst, in afwijking van het onderhandelingsmandaat dat op dit punt slechts voorzag in de vorm van protocollen van de besprekingen. De commissie-generaal gaf het Nederlandse kabinet weinig gelegenheid op haar aanpak te reageren. Binnen het kabinet bestond ergernis over haar eigenmachtige optreden, maar het verbood haar niet op de ingeslagen weg voort te gaan. Voor één lid van het kabinet was dit reden om ontslag te nemen; dit was de partijloze minister van openbare werken en wederopbouw Ringers, die zich al steeds tegen concessies aan de Republiek had verzet.

Van 4 november af onderhandelden de delegaties aan de hand van een door 
de commissie-generaal ingediend ontwerp voor een overeenkomst. Volgens dit ontwerp zou de Nederlandse regering de regering van de Republiek erkennen als de facto het gezag uitoefenend over Java en Sumatra met uitzondering van de door geallieerde of Nederlandse troepen bezette gebieden. Nederland en de Republiek zouden samenwerken tot de vestiging van een vrije, democratische staat op federatieve grondslag, genaamd de Verenigde Staten van Indonesië; evenzo zouden zij samenwerken tot de vorming van een Nederlands-Indonesische Unie; daarbij zouden zij ernaar streven dat één en ander voor 1949 zijn beslag zou krijgen.

In de besprekingen ondersteunde de Republikeinse delegatie het denkbeeld van een federatieve Indonesische staat. Sjahrir had hier ook al tijdens het overleg in maart mee ingestemd. Daarbij valt te bedenken dat, als de Republiek in die federatie de plaats zou innemen van een heel Java en Sumatra omvattende deelstaat, zij vier vijfde van de Indonesische bevolking zou vertegenwoordigen en zelfs meer dan vier vijfde van de Indonesische export. Dit maakte het voor de Republikeinse leiders gemakkelijker om de federale staatsvorm te aanvaarden; de Republiek zou immers in de federatie toch wel een leidende positie krijgen.

Daarentegen maakte de Republikeinse delegatie bezwaar tegen de voorgestelde Unie. Vooral de bepaling dat de Nederlandse koning aan het hoofd van die Unie zou staan ontmoette ernstig verzet, omdat Indonesië aldus geen gelijkwaardige plaats binnen de Unie zou krijgen. De commissie-generaal toonde zich echter op het punt van de Unie en de positie van de Nederlandse 'kroon' tot geen enkele concessie bereid en verklaarde de besprekingen te zullen beëindigen als de Republikeinse delegatie deze voorstellen niet zou aanvaarden. Wel verzekerde Schermerhorn dat de Unie alleen als een samenwerkingsverband bedoeld was en geen 'superstaat' zou worden. Overigens stelde Sjahrir voor, in de omschrijving van de federatieve Indonesische staat het woord 'vrij' te vervangen door 'soeverein' om beter te doen uitkomen dat deze staat waarlijk onafhankelijk zou zijn. Verder streefde zijn delegatie ernaar om, zo lang die staat nog niet gevormd was, de positie van de Republiek zoveel mogelijk in stand te houden. Ook hechtte zij er belang aan dat de overeenkomst zou voorzien in vermindering van de troepensterkte.

De besprekingen bereikten een punt waarop het leek dat men alleen verder kon komen als men Soekarno en Hatta nauwer bij het overleg betrok. Daartoe zouden de delegaties enkele dagen op Republikeins gebied kunnen vergaderen. De keus viel op Linggadjati, een bergoord nabij de havenstad Tjirebon halverwege tussen Batavia en Jogjakarta. Minister Jonkman stemde ermee in dat de commissie-generaal naar Linggadjati zou gaan, maar weigerde haar te machtigen tot ondertekening van een akkoord volgens de door haar voorgestelde lijnen.

Op 11, 12 en 13 november voerden de twee delegaties moeizame bilaterale 
besprekingen in Linggadjati. Soekarno en Hatta verbleven in de naburige plaats Koeningan; zij namen geen deel aan de formele besprekingen maar hadden wel verscheidene ontmoetingen met Killearn en met de Nederlandse en de Republikeinse delegatieleden. Het rechtstreekse contact van de commissie-generaal met de leiders van de Republiek leidde op de tweede dag tot een onverwachte doorbraak. Toen Van Mook en Schermerhorn aan Soekarno meedeelden dat zij konden instemmen met vervanging van de term 'vrije staat' door 'soevereine staat' in de omschrijving van het toekomstige Indonesië, verklaarde Soekarno zich namelijk bereid dan zijn volle gezag voor de ontworpen overeenkomst in te zetten.

Sjahrir en Roem, die niet bij dit gesprek aanwezig waren geweest, vonden dat Soekarno te veel had weggegeven omdat hun delegatie nog verscheidene bezwaren tegen het Nederlandse ontwerp had. In verdere besprekingen met de commissie-generaal wist de delegatie te bewerkstelligen dat de tekst nog op enige punten meer met haar zienswijze in overeenstemming werd gebracht. Zo had het Nederlandse ontwerp gesteld dat 'de staats- en volkenrechtelijke positie van het Koninkrijk der Nederlanden gehandhaafd' zou blijven tot de totstandkoming van de Indonesische bondsstaat en de Nederlands-Indonesische Unie. Tijdens het laatste overleg in Linggadjati werd dit geschrapt. Een andere belangrijke wijziging was de opneming van een arbitrageclausule.

Kort na de terugkeer van de delegaties in Batavia bereikten zij algehele overeenstemming over de tekst van het politieke akkoord, dat de geschiedenis zou ingaan als 'het akkoord van Linggadjati'. De Nederlandse delegatie moest echter voorlopig van ondertekening afzien omdat minister Jonkman haar daar niet toe had willen machtigen. Teneinde het onderhandelingsresultaat niettemin formeel vast te leggen parafeerden de delegaties op 15 november de tekst van het overeengekomen ontwerp. Schermerhorn hoopte dat men de overeenkomst toch nog voor het eind van de maand zou kunnen ondertekenen in een door Killearn voor te zitten bijeenkomst. Hij en de andere commissarissengeneraal vertrokken naar Nederland om de regering tot aanvaarding van het akkoord te bewegen.

\section{Tekst van het ontwerp-akkoord van Linggadjati}

De tekst van de ontwerp-overeenkomst van Linggadjati, zoals door de Nederlandse regering ter kennis gebracht van het Nederlandse parlement, luidde als volgt: 


\author{
De Nederlandsche regeering, \\ ten deze vertegenwoordigd door de Commissie-Generaal, \\ en \\ de regeering van de Republiek Indonesië, \\ ten deze vertegenwoordigd door de Indonesische delegatie,
}

het oprechte verlangen koesterend de goede betrekkingen tusschen de volkeren van Nederland en Indonesië te verzekeren in nieuwe vormen van vrijwillige samenwerking, welke de beste waarborgen bieden voor een goede en krachtige ontwikkeling van beide landen in de toekomst en die het mogelijk maken de relatie tusschen beide volkeren op nieuwe grondslagen te vestigen;

spreken het navolgende af en zullen deze overeenkomst op den kortst mogelijken termijn aan de goedkeuring van de volksvertegenwoordigingen onderwerpen:

\title{
Artikel 1
}

De Nederlandsche regeering erkent de regeering van de Republiek Indonesië als de facto uitoefenende het gezag over Java, Madoera en Sumatra. De door de geallieerde of Nederlandsche troepen bezette gebieden zullen geleidelijk, door wederzijdsche samenwerking, in het republikeinsche gebied worden ingevoegd. Hiertoe zal aanstonds een aanvang worden gemaakt met de noodige maatregelen zoodat, uiterlijk op het tijdstip in artikel 12 genoemd, de invoeging zal zijn voltooid.

\section{Artikel 2}

De Nederlandsche regeering en de regeering van de Republiek werken samen tot de spoedige vestiging van een souvereinen, democratischen staat op federatieve grondslag, genaamd de Vereenigde Staten van Indonesië.

\section{Artikel 3}

De Vereenigde Staten van Indonesië zullen omvatten het geheele grondgebied van Nederlandsch-Indië, met dien verstande, dat, indien de bevolking van eenig gebiedsdeel, ook na overleg met de overige gebiedsdeelen, langs democratischen weg te kennen geeft niet of nog niet tot de Vereenigde Staten van Indonesië te willen toetreden, voor dat gebiedsdeel een bijzondere verhouding tot deze Staten en het Koninkrijk der Nederlanden in het leven kan worden geroepen.

\section{Artikel 4}

1. Samenstellende delen van de Vereenigde Staten van Indonesië zullen zijn de Republiek, Borneo en de Groote Oost, onverminderd het recht van de bevolking van eenig gebiedsdeel om langs democratischen weg te kennen te geven dat zij haar plaats in de Vereenigde Staten van Indonesië op anderen voet geregeld wenscht te zien.

2. Onverminderd het bepaalde in artikel 3 en in het eerste lid van dit artikel, kunnen de Vereenigde Staten van Indonesië een bijzondere regeling treffen ten aanzien van het grondgebied van haar hoofdstad. 
Artikel 5

1. De Grondwet van de Vereenigde Staten van Indonesië zal worden vastgesteld door een constitueerende vergadering, die zal zijn samengesteld uit op democratische wijze aangewezen vertegenwoordigers van de Republiek en van andere toekomstige deelgenooten der Vereenigde Staten, met inachtneming van het bepaalde in het volgende lid van dit artikel.

2. Partijen zullen in overleg treden omtrent de wijze van deelneming aan deze constitueerende vergadering door de Republiek, door de niet tot het gezagsgebied van de Republiek behoorende gebiedsdeelen en door de niet of onvoldoende vertegenwoordigde bevolkingsgroepen, een en ander met inachtneming van de onderscheiden verantwoordelijkheid van de Nederlandsche regeering en van de regeering van de Republiek.

\section{Artikel 6}

1. De Nederlandsche regeering en de regeering van de Republiek zullen ter behartiging van de gemeenschappelijke belangen van Nederland en Indonesië samenwerken tot de vorming van een Nederlandsch-Indonesische Unie, waardoor het Koninkrijk der Nederlanden, omvattende Nederland, NederlandschIndië, Suriname en Curaçao, wordt omgezet in genoemde Unie, bestaande uit eenerzijds het Koninkrijk der Nederlanden, omvattende Nederland, Suriname en Curaçao, en anderzijds de Vereenigde Staten van Indonesië.

2. Het vorenstaande laat onverkort de mogelijkheid tot nadere regeling van de verhouding tusschen Nederland, Suriname en Curaçao.

\section{Artikel 7}

1. Ter behartiging van de in het voorgaande artikel genoemde belangen zal de Nederlandsch-Indonesische Unie beschikken over eigen organen.

2. Deze organen zullen worden samengesteld door de regeeringen van het Koninkrijk der Nederlanden en van de Vereenigde Staten van Indonesië, eventueel mede door de volksvertegenwoordigingen dier landen.

3. Als gemeenschappelijke belangen zullen worden aangemerkt samenwerking inzake buitenlandsche betrekkingen, defensie en, voor zoover noodig, financiën, alsmede nopens onderwerpen van economischen en cultureelen aard.

\section{Artikel 8}

Aan het hoofd van de Nederlandsch-Indonesische Unie staat de Koning der Nederlanden. De besluiten ter behartiging van de gemeenschappelijke belangen zullen door de organen der Unie worden genomen in naam des Konings.

\section{Artikel 9}

Ter behartiging van de belangen der Vereenigde Staten van Indonesië in Nederland en van het Koninkrijk der Nederlanden in Indonesië zullen door de onderscheiden regeeringen Hooge Commissarissen worden benoemd.

Het Statuut van de Nederlandsch-Indonesische Unie zal voorts onder meer bepalingen bevatten over: 
a. de verzekering van de rechten van beide partijen jegens elkander en de waarborgen voor de nakoming hunner onderlinge verplichtingen;

$b$. de wederzijdsche uitoefening van het staatsburgerschap door Nederlandsche en Indonesische staatsburgers;

c. een regeling, houdende voorziening voor het geval in de organen der Unie geen overeenstemming kan worden verkregen;

$d$. een regeling van de wijze, waarop en de voorwaarden waaronder de organen van het Koninkrijk der Nederlanden bijstand zullen verleenen aan de Vereenigde Staten van Indonesië, zoolang deze niet of onvoldoende over eigen organen beschikken;

e. de verzekering in beide deelen van de Unie van de fundamenteele menschelijke rechten en vrijheden, waarnaar ook het Handvest der Vereenigde Naties verwijst.

Artikel 11

1. Het Statuut zal worden ontworpen door een conferentie tusschen vertegenwoordigers van het Koninkrijk der Nederlanden en van de toekomstige Vereenigde Staten van Indonesië.

2. Het Statuut treedt in werking na goedkeuring door de onderscheiden volksvertegenwoordigingen.

Artikel 12

De Nederlandsche regeering en de regeering van de Republiek zullen ernaar streven, dat de vestiging van de Vereenigde Staten van Indonesië en van de Nederlandsch-Indonesische Unie haar beslag krijgt vóór 1 Januari 1949.

\section{Artikel 13}

De Nederlandsche regeering zal onmiddellijk stappen nemen opdat, na de totstandkoming van de Nederlandsch-Indonesische Unie, de Vereenigde Staten van Indonesië als lid van de organisatie der Vereenigde Naties worden toegelaten.

\section{Artikel 14}

De regeering van de Republiek erkent de aanspraken van alle niet-Indonesiërs op herstel in hun rechten en teruggave van hun goederen, voor zoover deze worden uitgeoefend of zich bevinden in gebied, waarover zij de facto gezag uitoefent. Een gemengde commissie zal worden ingesteld om dit herstel of deze teruggave te bewerkstelligen.

\section{Artikel 15}

Ten einde de Indische regeering te hervormen op zoodanige wijze, dat zij in haar samenstelling en werkwijze zoo goed mogelijk aansluit op de erkenning van de Republiek en op de ontworpen staatsrechtelijke structuur, zal de Nederlandsche regeering bevorderen, dat aanstonds wettelijke maatregelen worden getroffen om, in afwachting van de totstandkoming der Vereenigde Staten van Indonesië en der Nederlandsch-Indonesische Unie, de staats- en volkenrechtelijke positie van het Koninkrijk der Nederlanden daarop te laten aansluiten. 
Artikel 16

Aanstonds na het totstandkomen van deze overeenkomst zullen beide partijen overgaan tot vermindering van de troepensterkte aan beide zijden. $\mathrm{Zij}$ zullen in overleg treden omtrent de mate en het tempo van deze vermindering en omtrent de samenwerking op militair gebied.

\section{Artikel 17}

1. Voor de in deze overeenkomst beoogde samenwerking tusschen de Nederlandsche regeering en de regeering der Republiek zal een organisatie in het leven worden geroepen, bestaande uit een door elk van beide regeeringen aan te wijzen delegatie, met een gemeenschappelijk secretariaat.

2. De Nederlandsche regeering en de regeering der Republiek zullen alle geschillen, welke naar aanleiding van deze overeenkomst mochten rijzen en die niet door partijen in onderling overleg in een conferentie tusschen genoemde delegaties tot een oplossing kunnen worden gebracht, door arbitrage doen beslechten. In dat geval zal die conferentie worden aangevuld met een door de genoemde delegaties in onderling overleg of, mocht dit overleg geen resultaat opleveren, door den Voorzitter van het Internationale Hof van Justitie te benoemen Voorzitter van andere nationaliteit met beslissende stem.

Slotbepaling

Deze overeenkomst wordt opgesteld in het Nederlandsch en in het Indonesisch. Beide teksten hebben gelijk gezag.

Batavia, 15 November 1946.

\section{Einde van het tijdelijke Britse gezag over Indonesie}

In oktober en november 1946 kwam schip na schip met Nederlandse militairen in Indonesië aan, terwijl de Britse militairen de archipel verlieten. Het merendeel van de uit Nederland aangekomen eenheden werd in de enclaves op Java gestationeerd. De Nederlandse legerleiding kon nu ook troepen naar Sumatra dirigeren, die daar in de loop van november de Britse posities overnamen. Op Java nam de Britse bezettingsmacht al sinds juli alleen nog posities in de enclave Batavia-Buitenzorg in; ook hiervan droeg zij in de loop van november het commando aan Nederland over. In de laatste dagen van de maand volgde de ontruiming van het Britse hoofdkwartier in Batavia en het vertrek van het laatste Britse troepencontingent.

Met ingang van 1 december 1946 beëindigde Groot-Brittannië zijn verantwoordelijkheid voor Indonesië uit hoofde van de in 1945 gesloten NederlandsBritse overeenkomst (zie p. 371). Die verantwoordelijkheid had lasten meegebracht die niemand voorzien had. Zo waren bijna duizend leden van de Britse bezettingsmacht bij de uitoefening van hun taak gedood of vermist.

Deze bezettingsmacht, de Allied Forces in the Netherlands East Indies 
(AFNEI), hield nu op te bestaan. Eén van de consequenties hiervan was dat het daaronder ressorterende burgerlijke bestuursapparaat, dat eerst NICA en later AMACAB geheten had, veranderde in een zuiver Nederlands-Indische organisatie. Om de indruk te vermijden dat het koloniale bestel zonder meer terugkeerde, vermeed het gouvernement echter de term 'Binnenlands Bestuur'. Het noemde deze organisatie nu 'Tijdelijke Bestuursdienst'.

De beëindiging van het Britse oppergezag betekende overigens niet dat Nederland voortaan vrij was om binnen de enclaves op Java en Sumatra alle publieke taken op zich te nemen. Met de Britten was afgesproken dat de status quo op dit terrein gehandhaafd bleef. Het Nederlandse bestuur zou de taken overnemen waarover Britten de supervisie hadden gehad, maar niet de functies die tot nu toe onder verantwoordelijkheid van de Republiek werden uitgeoefend. In Djakarta/Batavia had dit onder meer tot gevolg dat er een Republikeinse burgemeester naast een Nederlandse burgemeester bleef optreden en dat sommige openbare diensten, waaronder het trambedrijf en het academisch ziekenhuis, onder Republikeins beheer bleven. Ook in de andere door Nederland bezette steden bleef een Republikeins bestuur bestaan, behalve in Semarang en Soerabaja waar al sinds lang geen Republikeins bestuur meer functioneerde.

\section{Aantekeningen bij hoofdstuk VI}

\section{Literatuuroverzicht}

Over het in 1945 uitgebroken conflict tussen Nederland en de Republiek Indonesië bestaat zeer veel literatuur. Naast talrijke tijdens het conflict uitgegeven polemische geschriften verscheen in Nederland al eind 1946 Het Indonesische probleem; De feiten door G.W. Overdijkink, dat men als een eerste bijdrage tot geschiedschrijving beschouwen kan; in 1948 publiceerde Overdijkink een vervolg hierop onder de titel Het Indonesische probleem; Nieuwe feiten. In 1948 verschenen ook twee belangrijke bijdragen van de hand van buitenlandse waarnemers, The birth of Indonesia door David Wehl, die als Brits inlichtingenofficier tot de staf van Mountbatten behoord had, en The Indonesian story; The birth, growth and structure of the Indonesian republic door Charles Wolf, die in 19461947 Amerikaans vice-consul in Batavia geweest was. Vervolgens werden begin 1949 in Nederland twee boeken gepubliceerd die een duidelijk politiek oogmerk hadden maar ook als geschiedschrijving van belang waren, namelijk Indonesië, Nederland en de wereld door H.J. van Mook, dat vooral een beschrijving en verdediging van het door hem gevoerde beleid bevatte, en De Indonesische tragedie; Het treurspel der gemiste kansen door J. de Kadt, waarin het Nederlandse Indonesië-beleid scherp afgekeurd werd.

$\mathrm{Al}$ deze publicaties waren geschreven terwijl het conflict nog in volle gang was. Pas nadat dit eind 1949 door de Nederlandse soevereiniteitsoverdracht tot een voorlopige afsluiting gekomen was, werd het mogelijk er een samenvattende beschrijving van te geven. Dit was de opzet van twee in 1952 verschenen boeken die daarna nog jarenlang standaardwerken op dit gebied gebleven zijn. Het ene is Nationalism and revolution 
in Indonesia door G. McT. Kahin, een Amerikaan die van midden 1948 tot midden 1949 op Java had verbleven en het onderwerp vooral uit Republikeins gezichtspunt behandelde. Het andere boek is De Indonesische quaestie; De wordingsgeschiedenis der souvereiniteitsoverdracht door C. Smit, een Nederlander die voor de oorlog in Indonesië gewoond en gewerkt had. Hoewel Smit wel enig gebruik maakte van Indonesische bronnen en van de boeken van Wehl en Wolf, behandelde hij het onderwerp toch overwegend uit Nederlands gezichtspunt; daarbij sloot hij nauw aan bij de visie van Van Mook. Dertig jaar later nam de Nederlandse historica P.A.M. van Vught deze twee boeken als uitgangspunt voor een diepgaande analyse en inventarisatie van de Nederlandse, Indonesische en buitenlandse geschiedschrijving over het conflict van 1945-1949 (Van Vught 1982).

Kahin werd hoogleraar aan Cornell University in de Verenigde Staten en stichtte daar een centrum voor de bestudering van Indonesië, dat de verschijning van tal van artikelen en monografieën stimuleerde waarvan verscheidene het dekolonisatieconflict betroffen. Tot de belangrijkste hiervan behoren Bandung in the early revolution, 1945-1946 door J.R.W. Smail (1964) en Java in a time of revolution; Occupation and resistance 1944-1946 door B.R. O'G. Anderson (1972). Het centrum ging ook een tweemaal per jaar verschijnend tijdschrift Indonesia uitgeven. De met het centrum verbonden onderzoekers hadden in de regel eigen onderzoek in Indonesië verricht; sommige van hen waren zelf Indonesiër, zoals I.N. Djajadiningrat, die een scriptie schreef over het overleg op de Hoge Veluwe. Aan andere Amerikaanse universiteiten ging men zich eveneens met Indonesië bezighouden. Verder verscheen in 1960 Indonesian independence and the United Nations door A.M. Taylor, een Canadees die het conflict van nabij had meegemaakt als staflid van de Verenigde Naties en die niet alleen de bemoeienissen van de VN beschreef maar ook de impliciete bedoelingen van het Nederlandse beleid analyseerde.

Een andere ontwikkeling was dat Indonesië ook in Australië een object van wetenschappelijke studies werd. Sommige daarvan richtten zich op de vooroorlogse Indonesische vrijheidsbeweging (waaronder de al in het literatuuroverzicht bij hoofdstuk IV vermelde publicaties van S. Abeyasekere, J. Ingleson, J.D. Legge en C.L.M. Penders), andere op de ontwikkelingen na de Tweede Wereldoorlog. Zo publiceerde A.J.S. Reid, een in Australië werkende Nieuw-Zeelander, in 1974 een nieuwe beschrijving van de Indonesische vrijheidsstrijd (met weinig aandacht voor de Nederlandse kant van het conflict), The Indonesian national revolution 1945-1950. Zie Bootsma 1995 voor een uitvoerig overzicht van de bestudering van de Indonesische dekolonisatie in de Verenigde Staten, Australië en andere westerse landen.

In Indonesië zelf publiceerde Muhammad Dimyati al in 1951 een eerste beschrijving van de vrijheidsstrijd, Sedjarah perdjuangan Indonesia (Geschiedenis van de strijd van Indonesië). In 1953 leverde Osman Raliby een waardevolle bijdrage tot de geschiedschrijving door de publicatie van documenten uit de eerste jaren van de Republiek. Verdere historische bijdragen waren aanvankelijk vooral afkomstig van Indonesiërs die zelf een rol in de gebeurtenissen gespeeld hadden, zoals Tan Malaka, Adam Malik, Ruslan Abdulgani en T.B. Simatupang. Laatstgenoemde publiceerde onder meer in 1960 een boeiend verslag over het laatste jaar van de vrijheidsstrijd. Van de hand van Susanto Tirtoprodjo verscheen in 1962 een kort overzicht van het conflict, Sedjarah revolusi nasional Indonesia; Tahapan revolusi bersendjata 1945-1950 (Geschiedenis van de Indonesische nationale revolutie; Het stadium van de gewapende revolutie 
1945-1950). Enige jaren later publiceerde Iwa Kusuma Sumantri Masa revolusi bersendjata (De periode van de gewapende revolutie) als tweede deel van zijn geschiedwerk Sejarah revolusi Indonesia (Geschiedenis van de Indonesische revolutie). Daarnaast zagen nog tal van memoires het licht van prominente figuren zoals Hatta, Roem en Ali Sastroamidjojo, terwijl Soekarno aan Cindy Adams een fantasierijke autobiografie dicteerde. Intussen werkten historici onder leiding van Sartono Kartodirdjo aan een nieuwe beschrijving van de Indonesische geschiedenis van de prehistorie af tot aan het heden (Sejarah nasional Indonesia); het zesde deel daarvan, dat het tijdvak van de Japanse bezetting en het conflict met Nederland behandelde, verscheen in 1975 . Oud-generaal A.H. Nasution, die al in 1953 een werk over de methodiek van de vrijheidsstrijd geschreven had, publiceerde tussen 1977 en 1979 een compilatiewerk in elf delen dat vooral als bronnenpublicatie waarde heeft: Sekitar perang kemerdekaan Indonesia (Rondom de Indonesische onafhankelijkheidsoorlog). Een niet-Republikeinse Indonesiër die eveneens in 1946-1949 een belangrijke rol gespeeld had en zich later aan geschiedschrijving wijdde was Ide Anak Agung Gde Agung.

In Nederland zelf werd na De Indonesische quaestie van C. Smit gedurende de jaren vijftig en zestig weinig meer over het dekolonisatieconflict gepubliceerd. In 1956 verscheen Om een rode of groene merdeka; 10 jaren binnenlandse politiek Indonesië 1943-1953 door H.J.H. Alers, die het gebeurde als een confrontatie tussen conservatieve en revolutionaire tendenzen binnen de Indonesische samenleving interpreteerde en het conflict tussen Nederland en de Republiek naar het tweede plan verwees. Smit zelf publiceerde in 1959 een monografie over het akkoord van Linggadjati op basis van een in 1946-1947 door de Nederlandse onderhandelaar Schermerhorn bijgehouden dagboek. Vervolgens kwam Smit in 1962 met een nieuw boek onder de titel De liquidatie van een imperium; Nederland en Indonesie 1945-1962; hij had intussen kennis genomen van het boek van Taylor en toonde zich nu kritischer tegenover het Nederlandse beleid dan in zijn eerdere boeken. Andere Nederlandse bijdragen tot geschiedschrijving over het dekolonisatiedrama bleven in deze tijd achterwege. Voor veel Nederlanders was het 'verlies van Indië' een pijnlijke ervaring die men moeilijk kon verwerken, zodat men weinig behoefte voelde om op dit stuk geschiedenis terug te kijken. Bovendien was de verstandhouding tussen Nederland en het onafhankelijke Indonesië intussen grondig verziekt, vooral (maar niet alleen) als gevolg van het Nederlandse vasthouden van Nieuw-Guinea. Ook na de beëindiging van het geschil over Nieuw-Guinea in 1962 toonde men in Nederland nog weinig belangstelling voor de geschiedenis van de dekolonisatie.

Het Nederlandse stilzwijgen strekte zich ook uit over de tijdens het conflict in Indonesië van Nederlandse kant begane wreedheden, hoewel tienduizenden veteranen hier iets van wisten. Begin 1969 werd het zwijgen over dit stukje eigen geschiedenis doorbroken door enkele televisie-uitzendingen die een schokeffect teweegbrachten (zie VARA 1969). Dit had verschillende gevolgen. De Nederlandse regering liet een archiefonderzoek over de kwestie verrichten en legde op basis daarvan aan het parlement een uitvoerige nota over die bekend is geworden als de Excessennota. Twee sociaal-wetenschappelijk geschoolde veteranen, J.A.A. van Doorn en W.J. Hendrix, die al tijdens hun militaire dienst in Indonesië gegevens over oorlogsmisdaden verzameld hadden, publiceerden in 1970 een uitvoerige studie onder de titel Ontsporing van geweld; Over het Nederlands/Indisch/Indonesisch conflict. Los hiervan had de regering al in 1969 opdracht gegeven tot het uitgeven van interne documenten over het dekoloni- 
satieconflict. Het resultaat hiervan was dat tussen 1971 en 1996 een serie van twintig dikke delen verscheen onder de titel Officiële bescheiden betreffende de NederlandsIndonesische betrekkingen 1945-1950 (hier verder aangeduid als NIB). Deze ruim vijftienduizend pagina's beslaande serie, van 1979 af onder redactie van P.J. Drooglever, bevat een schat aan bronnenmateriaal over het Nederlandse Indonesiëbeleid, niet alleen in de vorm van officiële bescheiden zoals verslagen en instructies, maar ook in die van persoonlijke brieven en andere niet-offficiële stukken.

In de jaren zeventig werd in Nederland de psychologische afstand tot de gebeurtenissen van 1945-1949 voldoende groot om de confrontatie met het 'onverwerkte verleden' aan te kunnen, zoals uit verscheidene artikelen en boeken bleek. D. van der Meulen publiceerde in 1977 een persoonlijke terugblik onder de titel Hoort gij de donder niet? Begin van het einde der Nederlandse gezagsvoering in Indië. Er verschenen ook twee beknopte maar rijk geillustreerde uitgaven voor het grote publiek: De politionele acties door P. Heijboer (1979), over de militaire kant van het conflict, en Onze laatste oorlog; De voorgeschiedenis van en de strijd om de onafhankelijkheid van Indonesië door A. Verhoog (1982). Intussen waren de betrekkingen tussen Nederland en Indonesië genormaliseerd en hadden deze twee landen een cultureel verdrag gesloten dat samenwerking op het gebied van de geschiedschrijving stimuleerde. In dit kader vonden sinds 1976 verscheidene conferenties van Indonesische en Nederlandse historici plaats. Bovendien liet Anak Agung in 1980 in Nederland een boek verschijnen onder de titel 'Renville' als keerpunt in de Nederlands-Indonesische onderhandelingen.

In de jaren 'tachtig publiceerden Nederlanders verscheidene boeken en artikelen over het dekolonisatiedrama, grotendeels op basis van nieuw bronnenonderzoek. Zo publiceerde L.G.M. Jaquet in 1982 Minister Stikker en de souvereiniteitsoverdracht aan Indonesië. Van J. Bank verscheen in 1983 Katholieken en de Indonesische revolutie, dat niet alleen de rol van Nederlandse en Indonesische katholieken belichtte maar ook ruime aandacht aan de Indonesische revolutie zelf schonk. R. Gase publiceerde in 1986 Beel in Batavia; Van contact tot conflict; Verwikkelingen rond de Indonesische kwestie in 1948. Terwijl de genoemde werken van Anak Agung, Jaquet en Gase alleen betrekking hebben op het tijdvak na het eerste Nederlandse offensief van juli 1947, publiceerde J.J.P. de Jong in 1988 een veelomvattende studie over het voorafgaande tijdvak onder de titel Diplomatie of strijd; Een analyse van het Nederlands beleid tegenover de Indonesische revolutie 1945-1947. Zijn boek geeft meer dan de titel doet vermoeden, want het gaat ook uitvoerig in op het Britse beleid en op de politieke ontwikkelingen binnen de Republiek.

Kon men het destijds onbevredigend vinden dat deze studies slechts deelaspecten betroffen en dat een samenhangende beschrijving van het hele dekolonisatiedrama ontbrak die rekening hield met de intussen beschikbaar gekomen gegevens, medio 1988 werd daarin voorzien door L. de Jong, die in het slotdeel van zijn twaalfdelige serie Het Koninkrijk der Nederlanden in de Tweede Wereldoorlog een hoofdstuk van 387 pagina's opnam onder de titel 'De worsteling met de Republiek Indonesië'. Enkele jaren eerder had hij in het elfde deel van zijn serie al ruime aandacht gegeven aan de aanloop tot de Republiek en aan de eerste Nederlandse reacties op haar totstandkoming. Anders dan de hierboven genoemde werken van onder meer Jaquet, Bank en J.J.P. de Jong was het nieuwe hoofdstuk van L. de Jong voornamelijk op secundaire bronnen gebaseerd.

In deze zelfde periode werden in Nederland verscheidene symposia en andere bijeenkomsten over de dekolonisatie van Indonesië gehouden. Bovendien gingen 
Nederlandse historici zoals P.M.H. Groen en J.A. de Moor zich ook in de militaire aspecten van het conflict verdiepen. Een bundeling van drie uitvoerige studies van Groen verscheen in 1991 onder de titel Marsroutes en dwaalsporen; Het Nederlands militair-strategisch beleid in Indonesië 1945-1950. B. Bouman, een Nederlandse oudofficier die zelf in 1946-1949 aan de strijd tegen de Republiek deelgenomen had, publiceerde studies over de Republikeinse kant van de strijd, waaronder Ieder voor zich en de Republiek voor ons allen (2006) over de logistiek achter de Indonesische revolutie. Verder vond in 1996 in verband met de voltooiing van de NIB-serie een congres in Den Haag plaats waar zowel Nederlandse en Indonesische historici als historici uit derde landen aan deelnamen; de congresbijdragen zijn onder redactie van Drooglever en Schouten gepubliceerd onder de titel De leeuw en de banteng. Tenslotte verscheen in 2000 voor het eerst weer een samenvattend Nederlands geschiedwerk over het dekolonisatieconflict: Afscheid van Indië; De val van het Nederlandse imperium in Azië door H.W. van den Doel. Bovendien leverde H.A. Poeze in 2007 een bijzondere bijdrage tot begrip van de Indonesische politieke ontwikkelingen tijdens de vrijheidsstrijd met zijn omvangrijke biografie Verguisd en vergeten; Tan Malaka, de linkse beweging en de Indonesische revolutie, 1945-1949.

Een veelomvattende bibliografie over de Indonesische vrijheidsstrijd, met inbegrip van het tijdvak van de Japanse bezetting, is in 1995 gepubliceerd door H.A.J. Klooster.

\section{De geboorte van de Republiek Indonesië}

Zie Kahin 1952:136-8 en Anderson 1972:83-8. Vergelijk Sidik Kertapati 1957, Malik 1948, Trimurti 1993:201-3, 225-6, en Giebels 1999:356-61, 366-8. Voor de commissievergadering op 18 augustus zie Yamin 1959:397-473. Voor de tekst van de grondwet zie Raliby 1953:489-94, Wolf 1948:165-71, Yamin 1959:17-56 of A.B. Nasution 1992:4439 .

Japanse reacties op de onafhankelijkheidsverklaring

Zie Anderson 1972:85, 102. Zie voor de berichtgeving over de onafhankelijkheidsproclamatie in de Indonesische pers ook L. de Jong 1985: foto na 1010.

\section{De Nederlandse opstelling tegenover de onafhankelijkheidsverklaring}

Voor de op 6 december 1942 door koningin Wilhelmina uitgesproken radiorede zie onder meer Wolf 1948:189-91; voor een Nederlandse vertaling onder meer NIB I:75-7. Over de Nederlandse houding ten aanzien van Indonesië tijdens de Duitse bezetting zie L. de Jong 1986:425-30 en De Blauw en Severein 1980:13-8; over de verklaring van de samenwerkende verzetsorganisaties zie L. de Jong 1986:431-2. Voor het bericht in het te Londen verschenen Nederlandse weekblad van juni 1945 zie Zwaan 1981:232. Over de oprichting van de Vereniging Nederland-Indonesië zie De Blauw en Severein 1980:51-4.

Tijdelijke plaatsing van Indonesië onder Brits militair gezag

Voor de voorgeschiedenis van het besluit tot plaatsing van heel Indonesië onder SEAC zie L. de Jong 1986:458-76. Voor de tekst van de overeenkomst van 24 augustus 1945 zie Indisch Staatsblad 1946 no 111. Zie over de sluiting hiervan door de Nederlandse regering ondanks de Japanse capitulatie ook Smit 1962:16. Voor het overleg van Van 
Mook met Mountbatten op 4 september 1945 zie L. de Jong 1986:550-7. Van Mook was op 1 september aangekomen, niet omstreeks 24 augustus zoals door hemzelf gesteld in Van Mook 1949:77.

Andere onafhankelijkheidsbewegingen binnen het Britse gezagsgebied

Zie L. de Jong 1985:154-65, 176-7.

Geleidelijke consolidering van het Republikeinse gezag op Java

Zie Kahin 1952:139-40 en Anderson 1972:88-113; vergelijk Giebels 1999:368-70. Voor de radiotoespraak van Soekarno op 23 augustus zie Raliby 1953:17-22. L. de Jong 1985 geeft op pg. 1015-6 enige citaten uit deze toespraak; één daarvan, beginnend met 'Wij hebben nu al vijf-en-twintig jaar gesmeekt', kwam echter in die toespraak niet voor, maar was een aan de verbeeldingskracht van Van der Plas ontsproten reconstructie van wat Soekarno gezegd zou kunnen hebben. Zie Parlementaire Enquête Regeringsbeleid 1940-1945, deel VIIIc:1378 voetnoot.

De Nederlandse krijgsgevangenen en geïnterneerden

Vergelijk L. de Jong 1986:504-26, 532-8. Over de burger-geïnterneerden zie Van Velden 1963; zie ook Touwen-Bouwsma 1996.

Tegenstellingen tussen de Republikeinse leiders en de militante jongeren

Zie Anderson 1972:118-24, L. de Jong 1986:599-600, J.J.P. de Jong 1988:69 en Han Bing Siong 2000:246. Over de massameeting op het Ikada-terrein zie Poeze 2007:70-96. Volgens een hardnekkige misvatting zou Lapangan Ikada (Ikada-terrein) tijdens de Japanse bezetting de naam geweest zijn van het vroegere Koningsplein (dat sinds 1950 Medan Merdeka heet). Dit is onjuist; het Koningsplein heette toen Gambir; Lapangan Ikada was een daarop gelegen sportveld met stadion. Ikada was geen Japans woord, maar een acroniem voor Ikatan Atletik Djakarta. Vergelijk Jansen 1988:85, Idris 2000:43, 195 en Poeze 2007:72.

Terugkeer van Tan Malaka in de Indonesische politiek

Zie Kahin 1952:148-50, Anderson 1972:276-83 en Poeze 2007:1-187. Over het 'politiek testament' van Soekarno zie Poeze 2007:50-63.

Brits-Nederlands vlootbezoek aan Batavia

Vergelijk L. de Jong 1986:587-98, 605-9. Voor Van Mook's opmerking over oorlogscorrespondenten zie NIB I:108. Voor de censuur door de Nederlandse voorlichtingsdienst zie Fabricius 1947:11-2. Voor de eerste berichten van Van der Plas en Abdoelkadir uit Indonesië: NIB I:121-31, 157-9. Vergelijk ook Van der Post 1996.

Het Japanse bezettingsbestuur verving eind september de in maart 1942 ingevoerde Tokio-tijd door de voordien op Java geldende uurtijd.

Anti-Nederlandse schepenboycot in Australië

Over de totstandkoming van de Australische schepenboycot zie L. de Jong 1986:11946, 609-15 en Lockwood 1970.

Britse neiging tot de facto erkenning van de Republiek

Voor het overleg van Van der Plas in Singapore op 27 en 28 september zie NIB I:229232. Voor zijn telegram van 28 september NIB I:182. 
Verwerping van de Republiek door de Nederlandse regering

Over het overleg van Logemann in Camp Columbia zie L. de Jong 1986:603-4. Voor de conclusie van het NEFIS-rapport zie NIB I:216. Voor de uitlating van Tjarda NIB I:185. Voor de instructie aan Van Mook NIB I:187-8. Voor de op 30 september uitgegeven regeringsverklaring NIB I:198-9. Voor Logemann's verklaring van 1 oktober in Londen NIB I:183 (noot). Logemann reageerde toen op een uitspraak van Van der Plas van diezelfde dag (er was zeven uur tijdsverschil tussen Batavia en Londen). De NIB-serie, die bijna geen vergissingen bevat, geeft ten onrechte 29 september als datum van Logemann's desaveu. Anders dan soms gesteld was dit desaveu niet de eerste publieke reactie van de Nederlandse regering op de Indonesische revolutie: die regering had daar al met haar verklaring van 30 september op gereageerd. Voor de tweede regeringsverklaring zie NIB I:221-2. Voor de door Nederlandse socialisten uit Indonesië op 3 oktober aan Drees gezonden verklaring NIB I:225-6.

Eerste geallieerde troepenlandingen in Indonesië na de Japanse capitulatie Vergelijk L. de Jong 1986:623-4, 627.

\section{Terugkeer van Van Mook in Batavia}

Zie Van Mook 1949:94-5 en NIB I:401-8. Vergelijk L. de Jong 1986:627-30. Voor de mededeling van Spit van 26 september zie NIB I:163. Voor een karakterschets van Van Mook zie Van Vredenburch 1985:282-6.

De gewelddadige fase van de Indonesische revolutie

Bussemaker 2005 geeft een gedetailleerde beschrijving van de bersiap-furie op Java en Sumatra. Zie verder Wehl 1948:16-8, 47-9, Anderson 1972:108-9, 180, 183-9, L. de Jong 1988:718-28 en J.J.P. de Jong 1988:68-71, 82-8, 96, 111. Over de relatie tussen revolutionaire en criminele activiteiten zie Cribb 1991. Over het Depok-drama zie Fabricius 1947:100-9. Voor de oproep van Soekarno en Hatta van 27 oktober zie Raliby 1953:519-20. Over de tegenactie van KNIL-militairen in Batavia zie NIB II:147; over het Bekasi-drama zie Wehl 1948:78-81; over Bandoeng zie Smail 1964:55-97; over Soerabaja zie Frederick 1989:193-255; over Sumatra zie Reid 1979. Over de spanning tussen de burgerlijke en de gewelddadige revolutie zie J.J.P. de Jong 1988:85, 138. Over de indruk op de Nederlandse publieke opinie zie J.J.P. de Jong 1988:226-30. Voor de opmerking van Logemann van 9 november zie NIB II:2.

Oprichting van het Republikeinse leger

Zie Anderson 1972:104-6, 232-42, Said 1991:22-36 en Bouman 2006:57-160. Over de uit het KNIL afkomstige Republikeinse officieren zie Bouman 1995:209-330.

Britse druk tot overleg tussen Nederland en de Republiek

Voor een verslag van het overleg op 10 en 11 oktober in Singapore zie NIB I:300-18. Voor de verklaring van Dening van 23 oktober NIB I:439-41. Vergelijk J.J.P. de Jong 1988:103-7.

Eerste ontmoeting van Van Mook met Soekarno

Vergelijk J.J.P. de Jong 1988:112-20. Over het gesprek van Abdoelkadir met Soekarno op 8 oktober zie NIB I:373-4 (noot). Voor de verklaring van Van Mook van 15 okto- 
ber en de tegenspraak daarvan door de Nederlandse regering NIB I:370 (noot). Voor de verklaring van Logemann op 16 oktober over de onmogelijkheid van praten met het Soekarno-regime NIB I:584. Over het gesprek van Van Mook op 31 oktober met Republikeinse leiders onder wie Soekarno NIB I:489-90, 505-8, Hatta 1981:247-9 en Van Mook 1949:104. Voor het desaveu door de Nederlandse regering op 1 november NIB I:506 (noot). Van Mook noemt in Van Mook 1949 ten onrechte niet 31 maar 23 oktober als datum van zijn eerste ontmoeting met Soekarno; Hatta's memoires bevatten dezelfde vergissing.

Strijd in Midden-Java

Zie Anderson 1972:143-51, Groen 1985, Touwen-Bouwsma 1996:25-9, 36-7 en Han Bing Siong 1996.

\section{Strijd in Soerabaja}

Zie Wehl 1948:50-67, Nugroho Notosusanto 1970, Anderson 1972:126-9, 151-66, J.J.P. de Jong 1988:120-6, 129-30, Frederick 1989:182-279, Touwen-Bouwsma 1996:29-35 en Han Bing Siong 2000:247-65. Voor de radiotoespraak van Soekarno op 31 oktober met zijn opmerking over een korrel arsenicum zie Raliby 1953:521-2.

Nederlands besluit tot uitzending van een grote troepenmacht naar Indonesië Voor het rapport van Van Oyen en Helfrich zie NIB II:15-7. Voor het besluit van de Nederlandse regering tot uitzending van een grote troepenmacht NIB II:42-50, 127-9. Voor de reactie uit Batavia NIB II:121. Voor de uitspraak van de Nederlandse minister van oorlog zie Schulten 1986:16. Voor de zienswijze van generaal Schilling zie NIB II:161-5 en Groen 1991:46-50; voor de zienswijze van Spoor zie Groen 1991:50.

Hervorming van het staatsbestel van de Republiek

Vergelijk Kahin 1952:151-154, Anderson 1972:170-7, 181-182, 190, 202-31 en J.J.P. de Jong 1988:139-40. Voor het Republikeinse ‘Besluit no. X' zie Raliby 1953:511 of A.B. Nasution 1992:437. Voor het Politiek Manifest zie Raliby 1953:525-8 of A.B. Nasution 1992:438-42; een ingekorte versie staat in Wolf 1948:172-5. Over het verzuim van Van Mook om de Nederlandse regering over dit manifest in te lichten zie NIB IV:425.

Aantreden van het kabinet-Sjahrir

Vergelijk Kahin 1952:169-71 en Anderson 1972:178, 196-200, 298. Over de weigering van de ministers om zelf ontslag te nemen zie Soedjatmoko 1988:16. Voor het wetsbesluit over de nationale comités zie Raliby 1953:541.

Benoeming van Soedirman tot Republikeinse opperbevelhebber

Zie Anderson 1972:243-50 en Said 1991:54-7.

Eerste overleg tussen Van Mook en Sjahrir

Voor de verklaring van het Nederlands-Indisch gouvernement van 6 november zie NIB I:588-92. Voor het gesprek met Sjahrir op 17 november zie NIB II:98-107. Voor Logemann's BBC-interview NIB II:264-5. Voor het overleg in Singapore op 6 december NIB II:302-17. Vergelijk J.J.P. de Jong 1988:145-8 en Groen 1991:51-3. 
Het gesprek van Van Mook met Sjahrir op 17 november 1945 vond plaats in de destijds door generaal Christison gebruikte ambtswoning van de Britse consul-generaal (Nassau Boulevard 1). Tijdens de Japanse bezetting was dat de ambtswoning geweest van schout-bij-nacht Maeda. Daardoor vond dit gesprek plaats in hetzelfde huis en aan dezelfde tafel waar drie maanden eerder de Indonesische onafhankelijkheidsproclamatie was opgesteld.

Van Mook's keuze voor federalisering van Indonesië

Voor de unanieme mening van Van Mook en zijn voornaamste medewerkers zie NIB II:172-3; vergelijk J.J.P. de Jong 1988:134-5, 148-9. Over de situatie buiten Java onder meer NIB II:171, 208, 323-4. Over de informele gesprekken met Sjahrir ook J.J.P. de Jong 1988:460, noot 13. Over het uitzicht bieden op onafhankelijkheid onder meer NIB II:172, 330. Over de federale constructie NIB II:172, 350, 396. Over gematigden en extremisten onder meer NIB II:309. Over de wenselijkheid van een militaire actie in West-Java NIB II:305-6, 323. Vergelijk J.J.P. de Jong 1988:144-6 en Groen 1991:43-4.

Overleg van Van Mook in Den Haag en Londen

Voor Van Mook's besprekingen met de Nederlandse regering zie NIB II:397-403, 40812, 419-21. Voor zijn tendentieuze berichtgeving over de houding van Sjahrir NIB II:209, 288, 329, 395; vergelijk hierover J.J.P. de Jong 1988:150. Voor het op 24 december overeengekomen document zie NIB II:422-5. Voor het overleg te Chequers NIB II:45360.

Samenwerking van de regering-Sjahrir met de Britse bezettingsmacht

Over de strijd bij Bandoeng zie Smail 1964:99-116. Over het overleg van het Britse hoofdkwartier met de Republikeinse regering zie NIB II:451-3, 469-70, NIB III:163-7, 242-5. Over de Britse militaire actie van eind december zie Wehl 1948:94 en J.J.P. de Jong 1988:153. Voor het beroep van Christison op de Indonesische leiders zie NIB II:452.

Verplaatsing van de hoofdzetel van de Republiek naar Jogjakarta

Zie Anderson 1972:299-302 en J.J.P. de Jong 1988:163-4. De weekbladen Uitzicht en Het Inzicht zijn tot voorjaar 1947 blijven bestaan. Zie over deze weekbladen Dolk 1993: 102-28.

Benoeming van Spoor tot Nederlands opperbevelhebber in Indonesië Zie De Moor 2011 en Groen 1991:59-60. Voor Spoor's mening over het karakter van de nationalistische beweging zie NIB II:475.

Formele Nederlandse erkenning van het Indonesisch zelfbeschikkingsrecht

Voor de verklaring van de Nederlandse regering van 10 februari 1946 zie NIB III:703-4. Voor de instructie van Clark Kerr NIB III:215-7.

Eerste bemoeienis van de Verenigde Naties met de kwestie-Indonesië Zie BZ 1947:7-18 en Taylor 1960:14-8. 
Toenemende verdeeldheid in Nederland over het beleid tegenover de Republiek

Zie De Blauw en Severein 1980:55-8 en Hekman 1981:15-21. Een merkwaardige bijzonderheid is dat het in november 1945 tot stand gekomen voorlopige parlement vier Indonesische leden telde. In de Tweede Kamer waren Setiadjit en de SDAP'er L.N. Palar tot lid benoemd naast de in 1937 gekozen Roestam Effendi, terwijl tot lid van de Eerste Kamer Nazir Pamontjak benoemd was, die in 1928 samen met Hatta terecht had gestaan in het proces tegen leiders van de Perhimpoenan Indonesia (zie p. 195).

Toenemende verdeeldheid in de Republiek over het beleid tegenover Nederland; aantreden van het tweede kabinet-Sjahrir

Zie Overdijkink 1946:76-9, Kahin 1952:172-8, Anderson 1972:255-60, 270-1, 284-95, 306, 310, 319-31, Tan Malaka 1991:109-32 en Poeze 2007:189-306. Over 'Bandoeng vuurzee' zie Smail 1964:147-154.

Aankomst op Java van de eerste brigades oorlogsvrijwilligers uit Nederland

Zie Cats 1961:7-10. Over de beïnvloeding van de Nederlandse vrijwilligers door de opvattingen binnen het KNIL ook J.J.P. de Jong 1988:228, 252-3.

Voorlopig akkoord tussen Van Mook en Sjahrir

Voor de Republikeinse verklaring van 13 maart 1946 zie NIB III:564-7. Over Vietnam vergelijk Van den Doel 2000:112. Voor de op 25 maart door Van Mook aan Sjahrir gegeven schets voor een compromis zie NIB III:652-3. Voor de door de subcommissie ontworpen versie van het compromis NIB III:666-7.

De conferentie op de Hoge Veluwe

Voor de bespreking van het ontwerp-compromis in de Nederlandse ministerraad zie NIB IV:74-5, 85-91, 100-6. Voor het Nederlandse ontwerp-protocol NIB IV:106-7. Voor de besprekingen op de Hoge Veluwe NIB IV:116-30, 140-57, 162-6. Vergelijk Djajadiningrat 1958. Voor de nieuwe versie van het ontwerp-protocol zie NIB IV:188-90. Voor de mening van Van Mook dat ook in de toekomstige opzet van het Koninkrijk steeds een kern van zuiver Nederlandse troepen in Indonesië aanwezig zou moeten zijn NIB IV:221. Voor het regeringsoverleg over verdere troepenzendingen NIB IV:2207. Voor de instructie aan Van Mook van begin mei NIB IV:312.

Terugkeer van het Nederlandse gezag in de archipel buiten Java en Sumatra

Over de bereidheid tot samenwerking met de NICA als orgaan van het geallieerde bestuur maar niet als orgaan van het Nederlands-Indische gouvernement zie NIB I:456, III:106. Over de overdrachtsceremonie in Makassar op 15 juli zie Van Mook 1949:142-4.

Nieuw overleg tussen Van Mook en Sjahrir

Over de situatie in Solo zie Kahin 1952:185-7 en Anderson 1972:357-69; over de missie van Amir Sjarifoeddin op Sumatra zie Kahin 1952:181-3. Over het akkoord met het Britse hoofdkwartier inzake de afvoer van Japanners en geïnterneerden en over de organisatie van de POPDA zie Van Delden 2007:305-21. POPDA was de afkorting voor Panitia Oeroesan Pengangkoetan Djepang dan APWI (Comité tot regeling van het vervoer van Japanners en APWI). Over Tangerang zie Wehl 1948:124 en Anderson 
1972:367. Voor het Republikeinse tegenvoorstel van 15 juni zie NIB IV:467-70. Voor het voorstel van Sjahrir over staking van de vijandelijkheden NIB IV:519.

Poging tot staatsgreep in de Republiek

Zie Anderson 1972:370-403, Said 1991:62-5 en Poeze 2007:307-492.

Aantreden van het Nederlandse kabinet-Beel

Vergelijk Bank 1983:179-85. Over Jonkman zie diens Memoires 1971 en 1977. Voor zijn opvatting dat Nederland een wereldrijk moest blijven zie NIB V:60-1. Over de achtergrond van de conservatieve opstelling van de KVP en de PvdA vergelijk Poeze 1980, Bank 1983:489 en L. de Jong 1988:1070-4. Voor de uitlating van Romme zie NIB XVI:18.

De conferentie van Malino

Voor een verslag van de conferentie zie Van Goudoever 1946 en NIB V:5-15, 18-28, 36-45, 69-77. Vergelijk J.J.P. de Jong 1988:243-5 en Van den Doel 2000:141-4. Voor de door Jonkman gegeven instructie dat de Nederlandse politiek niet gericht kon zijn op volkomen onafhankelijkheid van Indonesië zie NIB V:227-8.

Verheviging van de strijd op Java

Zie J.J.P. de Jong 1988:245-53. Voor de rol van de bataljons oorlogsvrijwilligers zie Cats 1961:12-5. Voor het besluit van de Nederlandse regering nog twaalf bataljons extra naar Indonesië te sturen zie NIB IV:333. De Republikeinse militaire operaties van medio 1946 worden uitvoerig beschreven in Nasution 1977-1979 deel 3. Over het falen van de 'algemene aanval' ook Nasution 1965:15, 31. Over het onvolledig inlichten van Van Mook door de Nederlandse militaire bevelhebbers zie NIB V:198. Over de beschieting van Banjoewangi NIB V:212-4. Zie hierover en over het tot zinken brengen van een veerboot en de Republikeinse opschorting van de evacuatie van geïnterneerden ook Overdijkink 1948:82.

Instelling van de Nederlandse commissie-generaal

Vergelijk Bank 1983:190-3. Voor de wet tot instelling van de Commissie-Generaal zie Nederlands Staatsblad 1947:G 233 of Schermerhorn 1970:864-6. Voor de instructie van de Commissie-Generaal zie Schermerhorn 1970:867-71. Vergelijk J.J.P. de Jong 1988:266. Over de VNI-verklaring zie De Blauw en Severein 1980:66.

Britse aandrang tot hervatting van het overleg met de Republiek

Vergelijk J.J.P. de Jong 1988:259-64. Voor het Nederlandse aide-memoire zie NIB $\mathrm{V}: 188-92$. Over de Britse ongerustheid inzake de Nederlandse opstelling NIB V:229$32,266-8$.

Eerste uitzending van Nederlandse dienstplichtigen naar Indonesië

Zie Schulten 1986:20-34 en L. de Jong 1988:799-806. Over de handtekeningenactie en het telegram van de VNI zie De Blauw en Severein 1980:67-9, 72-3. Over de Nederlandse dienstweigeraars zie Morriën 1985, Bals en Gerritsen 1989 en Zwart 1995. 
Eerste bestand tussen Nederland en de Republiek

Vergelijk J.J.P. de Jong 1988:275-81. Over de Britse beperking van het Nederlandse militaire optreden zie NIB V:347, 514-6. Over de missie-Koets NIB V:371-3. Over de conferentie te Pangkalpinang NIB V:534-535. Voor de eerste formele vergadering van de Commissie-Generaal met de Republikeinse delegatie NIB V:502-10. Zoals daar vermeld op pagina 510 vond deze vergadering plaats in de ambtswoning van de Britse consul-generaal (Nassau Boulevard 1); niet op het Britse consulaat-generaal zoals op pagina 502 wordt gesteld. Men vergaderde dus in hetzelfde huis en aan dezelfde tafel waar in de vroege ochtend van 17 augustus 1945 de Indonesische onafhankelijkheidsproclamatie opgesteld was.

Zie over de sluiting van het bestand NIB V:519-21, 536-7, 545-7. Voor de Nederlandse opdracht tot eenzijdige vaststelling van de demarcatielijnen zie NIB VI:376-7.

\section{Het overleg in Lingadjati}

Vergelijk Smit 1959:42-72 en J.J.P. de Jong 1988:281-95. Voor het politiek overleg tussen de Commissie-Generaal en de Republikeinse delegatie zie NIB V:605-8, 629-32 en NIB VI:62-6, 114-9, 202-17, 234-6, 258-63. Voor de door Van Mook voorgestelde en door de Commissie-Generaal overgenomen aanpak van deze onderhandelingsronde NIB V:410-7, 603-4. Voor de door de Commissie-Generaal ingediende ontwerp-overeenkomst NIB VI:103-106.

Om te verhullen dat de Commissie-Generaal regelmatig in de vroegere woning van Soekarno vergaderde duidden Nederlandse functionarissen die woning sinds najaar 1946 stelselmatig aan als 'het huis van Sjahrir'. Deze onjuiste voorstelling van zaken is in de geschiedschrijving blijven voortleven. In werkelijkheid woonde Sjahrir destijds elders, terwijl hij de villa aan Pegangsaan Oost 56 als ambtswoning en kantoor gebruikte. In die villa bevond zich onder meer een schilderijenverzameling van Soekarno; de Commissie-Generaal parafeerde daar het akkoord van Linggadjati dan ook onder een groot portret van mevrouw Soekarno.

Afgezien van Jonkman 1977:97 is mij geen boek of artikel bekend dat er op wijst, dat het huis waar Schermerhorn het politiek overleg tussen de delegaties voorzat en waar op 15 november 1946 de tekst van het akkoord geparafeerd werd hetzelfde huis was waarvoor op 17 augustus 1945 de Indonesische onafhankelijkheid geproclameerd was.

\section{Tekst van het ontwerp-akkoord van Linggadjati}

Het is van belang te beschikken over de letterlijke tekst van het akkoord van Linggadjati om te kunnen beoordelen in hoever Nederland en de Republiek zich aan de overeenkomst gehouden hebben. De tekst is onder meer te vinden in NIB VI:753-6, in Stempels 1950:297-302, in Smit 1959:52-63 (waar de door de Commissie-Generaal voorgestelde tekst en de uiteindelijk ondertekende tekst tegenover elkaar afgedrukt staan) en in Schermerhorn 1970:872-81 (waar eveneens beide teksten tegenover elkaar staan). Mij is verder geen Nederlands geschiedwerk over de dekolonisatie van Indonesië bekend dat de volledige tekst van het akkoord bevat. Van Mook liet op pagina 244-6 van zijn boek uit 1949 een merkwaardig gekortwiekte tekst afdrukken waaruit alle verwijzingen naar de Republiek geschrapt waren. Daarentegen is de tekst van het akkoord wel afgedrukt in de boeken van Wehl, Wolf, Taylor en Yong Mun Cheong. 
Einde van het tijdelijke Britse gezag over Indonesië

Over de Tijdelijke Bestuursdienst zie L. de Jong 1988:857. Over de handhaving van de status quo van functies onder Republikeinse verantwoordelijkheid vergelijk Van Mook 1949:165, NIB IX:5-7 en Cribb 1986:141-2. 


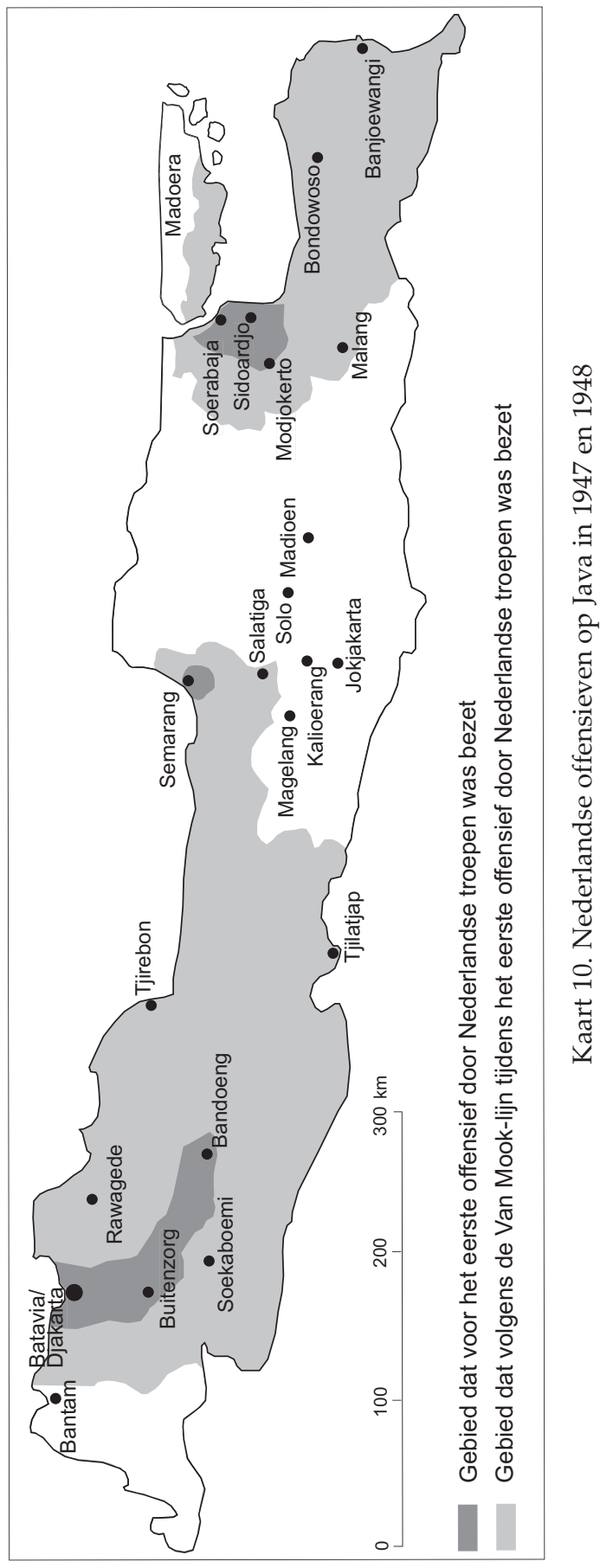


HOOFDSTUK VII

\title{
Het conflict tussen Nederland en de Republiek Indonesië
}

\author{
Tweede fase \\ Nederlandse pogingen tot beslechting van \\ het conflict op basis van militaire macht
}

\section{Inleiding en overzicht}

Het in november 1946 in Linggadjati tot stand gekomen ontwerp-akkoord was een echt compromis: voor beide partijen hield het aanzienlijke concessies in. Nederland zou aanvaarden dat de Republiek het feitelijk gezag over Java en Sumatra uitoefende (voorlopig met uitzondering van de door Nederlandse troepen bezette enclaves) en zou eraan meewerken dat zijn kolonie Nederlands-Indië binnen enkele jaren plaats zou maken voor een soevereine Indonesische bondsstaat, met de Republiek als belangrijkste bestanddeel. De Republiek zou aanvaarden dat Indonesië geen eenheidsstaat maar een bondsstaat zou worden en dat Indonesië met Nederland verbonden zou blijven in een Unie, terwijl het daarin geen gelijkwaardige positie zou innemen omdat de Nederlandse koning aan het hoofd van die Unie zou staan.

Het akkoord wekte zowel in Nederland als in de Republiek hevig verzet, uiteraard om tegengestelde redenen. De Nederlandse regering paste een kunstgreep toe om de overeenkomst toch te kunnen ondertekenen. Zij verklaarde dat die ondertekening haar tot niets meer zou verbinden dan zij neerlegde in een eigen interpretatie van het akkoord die de strekking ervan in Nederlandse zin omboog; door deze 'aankleding' van Linggadjati verwierf zij voldoende steun in het Nederlandse parlement.

Op 25 maart 1947 werd het akkoord eindelijk namens de beide regeringen ondertekend. Intussen hadden de omstandigheden zich sinds november 1946 ingrijpend gewijzigd. Het Nederlandse gezag stond in Indonesië niet langer onder Britse supervisie en de door Nederland geleidelijk in Indonesië 
opgebouwde strijdmacht naderde het stadium waarin ze in staat zou zijn tot grootschalig optreden. Van nu af aan ging de beschikbaarheid van deze strijdmacht invloed uitoefenen op de politieke ontwikkelingen. Daarbij zou het Nederlandse beleid zich steeds meer los maken van de inhoud van het gesloten akkoord, tot en met een poging eind 1948 om de Republiek geheel uit de weg te ruimen. Ondanks deze voortgaande afbraak van Linggadjati bleven de Nederlandse beleidsmakers de mening uitdragen dat zij aan de uitgangspunten van het akkoord vasthielden.

Het besluit om in Indonesië een grote strijdmacht op te bouwen was in november 1945 door de Nederlandse regering genomen toen Java zich in de greep van de bersiap-furie bevond. Ondanks dringende adviezen om zo snel mogelijk versterkingen naar Indonesië te sturen had zij toen besloten pas eind 1946 een eerste divisie van dienstplichtigen naar Indonesië over te brengen, zodat de beoogde strijdmacht pas in 1947 inzetbaar zou worden. Volgens de oorspronkelijke bedoeling had die strijdmacht moeten dienen om het Nederlandse gezag in Indonesië te herstellen. Maar in het voorjaar van 1947 was er sprake van een andere situatie: de bersiap-furie behoorde tot het verleden en Nederland had nu een akkoord met de Republiek gesloten. De regering kon zich echter slecht veroorloven de uitgezonden militairen weer naar Nederland terug te halen zonder dat hun uitzending enig tastbaar resultaat had bewerkstelligd. In de nieuwe situatie zou het de functie van de strijdmacht kunnen zijn de Nederlandse onderhandelingspositie tegenover de Republiek te versterken teneinde een voor Nederland bevredigende oplossing te bereiken. Men sloot echter niet de mogelijkheid uit om de in de Nederlandse enclaves opgesloten strijdmacht alsnog militair in te zetten. Onder meer meenden velen dat de politieke leiders van de Republiek er door hun eigen gewapende achterban van weerhouden werden op een redelijke manier met Nederland samen te werken. Inzet van de Nederlandse strijdmacht zou daarom nodig kunnen zijn, hetzij om de Republiek met een beperkte militaire actie tot samenwerking te dwingen, hetzij om haar geheel uit te schakelen.

$\mathrm{Al}$ voor de ondertekening van de overeenkomst gingen sommige Nederlandse beleidsmakers de term 'Linggadjati' gebruiken op een manier die zich nog verder van het oorspronkelijke akkoord verwijderde dan de eerder door de Nederlandse regering verrichte aankleding. Zij meenden dat men het schema van Linggadjati desnoods ook zonder de Republiek zou kunnen uitvoeren. In die context doelde de term dus niet meer op samenwerking tussen Nederland en de Republiek ter oplossing van hun onderlinge conflict, maar alleen op de ontworpen hervorming van het Koninkrijk tot een Unie tussen een verkleind Koninkrijk en een zelfstandige Indonesische federatie. Met de opbouw van die federatie had Nederland intussen zelf al een begin gemaakt door de oprichting van de deelstaat Oost-Indonesië.

Het Nederlandse beleid tegenover de Republiek werd destijds niet alleen 
beïnvloed door de opinies in Nederland zelf, maar ook door die van de Nederlanders in Indonesië, onder wie in het bijzonder de bestuursambtenaren, de KNIL-officieren, de ondernemers en de Nederlanders van gedeeltelijk Aziatische afstamming. Dit beleid was niet gericht op volledige dekolonisatie van Indonesië, maar op een beperkte dekolonisatie onder blijvende Nederlandse regie. Onder meer stelde men zich voor dat niet de TNI maar het KNIL de kern zou worden van het leger van de toekomstige Indonesische bondsstaat.

Het akkoord van Linggadjati was zeer summier en moest in overleg tussen de beide partijen nader uitgewerkt worden. Dit overleg begon eind maart 1947 en verliep moeizaam. Eén van de oorzaken hiervan was dat men het akkoord aan Nederlandse kant interpreteerde op een manier die niet met de tekst overeenkwam. Men dacht dat de Republiek daarin de Nederlandse soevereiniteit over Indonesie erkend had, dat zij haar eigen aanspraak op soevereiniteit over heel Indonesië prijsgegeven had en dat zij alleen nog maar aanspraak maakte op feitelijke gezagsuitoefening over Java en Sumatra. De Nederlandse delegatie zag daarom verscheidene van de Republikeinse voorstellen en daden als bewijzen van onwil om Linggadjati loyaal uit te voeren. Al begin mei kwam zij tot de conclusie dat bij de Republiek sprake was van een gezindheid die niet meer op samenwerking gericht was en dat men zich daarom zou moeten voorbereiden op de noodzaak van een militaire actie.

Vooral om economische en financiële redenen meende men aan Nederlandse kant een beslissing over inzet van de strijdmacht niet lang te kunnen uitstellen. Het meest nijpende probleem was dat de regering met een tekort aan deviezen kampte. Zij meende dat die deviezennood alleen verholpen zou kunnen worden door snelle hervatting van de Nederlandse export uit Indonesië. Daartoe zouden de ondernemers spoedig naar hun bedrijven op Republikeins gebied moeten kunnen terugkeren.

Eind mei legde Nederland aan de Republiek een reeks voorstellen voor waarop het op korte termijn antwoord verlangde. Er volgde een verwarde periode waarin de Republiek telkens iets verder aan de Nederlandse eisen tegemoetkwam. Uiteindelijk bleef er slechts één kwestie over waarover de standpunten onverzoenlijk waren, de mogelijkheid dat Nederlandse militairen tot Republikeins gebied zouden worden toegelaten tot herstel en handhaving van orde en veiligheid.

Op 21 juli 1947 begon Nederland een groot offensief, dat de regering als 'politionele actie' betitelde. De Nederlandse troepen veroverden in twee weken aanzienlijke delen van de Republiek, maar lieten het Republikeinse kerngebied rondom Jogja ongemoeid. Deze beperking van de actie berustte op een compromis tussen de KVP-ministers en de PvdA-ministers in het Nederlandse kabinet: wel militaire actie, maar geen liquidatie van de Republiek. Nederland kreeg door dit offensief belangrijke productiegebie- 
den in handen, maar slaagde er niet in de Republikeinse strijdkrachten uit te schakelen. Bovendien leidde het offensief tot bemoeienis van de Verenigde Naties, die nu gingen proberen een politieke oplossing van het geschil tussen Nederland en de Republiek te bevorderen.

Niettemin bleef de politieke situatie in Indonesië onder de schaduw staan van de mogelijkheid dat Nederland zijn offensief zou hervatten om alsnog het Republikeinse kerngebied te bezetten. Acute vrees hiervoor bracht de Republiek in januari 1948 ertoe in te stemmen met een nieuw beginselakkoord (het Renville-akkoord), dat voor haar ongunstiger was dan het akkoord van Linggadjati. Onder meer aanvaardde zij de begrenzing van de in 1947 door Nederland veroverde gebieden als nieuwe bestandslijn. Vervolgens voerde Nederland in het voorjaar van 1948 opnieuw onderhandelingen met de Republiek, waarbij het eisen stelde die aanzienlijk verder gingen dan die het in 1947 naar voren gebracht had. Onder meer verlangde het nu dat de Republiek haar eigen strijdkrachten zou ontbinden. De Nederlandse beleidsmakers gingen er hierbij van uit dat men de soevereiniteit pas zou kunnen overdragen wanneer de politieke leiders van de Republiek zich niet meer in de greep van hun gewapende achterban bevonden.

Intussen stichtte Nederland in de loop van 1948 een aantal nieuwe deelstaten binnen de in 1947 op de Republiek veroverde gebieden. Dit betekende een verdere ontmanteling van het akkoord van Linggadjati. Terwijl Nederland vroeger met de vorming van deelstaten beoogd had tegenwichten tegen de Republiek op te bouwen, kreeg deze federalisering nu het karakter van een alternatief voor de Republiek. In overleg met 'federalistische' Indonesiërs ging Nederland de vorming van een Indonesische bondsstaat voorbereiden die ook zonder de Republiek tot stand zou kunnen komen.

In deze zelfde periode liepen binnen de Republiek de interne spanningen hoog op. In september brak er zelfs een communistische opstand uit, maar Soekarno en Hatta slaagden er in deze opstand binnen korte tijd te onderdrukken.

Eind 1948 stevende het conflict tussen Nederland en de Republiek op een nieuwe climax af. De regering van de Republiek kon onmogelijk aan de eis voldoen dat zij haar eigen strijdkrachten zou ontbinden. Aan de andere kant kon Nederland de krijgsmacht waarover het in Indonesië beschikte niet onbeperkt in stand houden. De noodzaak om de uit Nederland aangevoerde militairen te repatriëren bracht het moment naderbij waarop die krijgsmacht niet meer tot grootschalig optreden in staat zou zijn. De Nederlandse regering kon zich echter moeilijk veroorloven haar soldaten naar huis te sturen zonder ook maar geprobeerd te hebben het verzet van de Republiek te breken met volledig gebruik van het Nederlandse militair-technische overwicht.

Evenals in juni-juli 1947 speelde zich in de laatste maanden van 1948 opnieuw een verwarde episode af, waarin de Republiek telkens wat verder 
aan de Nederlandse wensen tegemoet kwam, zonder dat zij daarmee uiteindelijk een nieuwe Nederlandse actie kon voorkomen. Binnen de Nederlandse regering verzetten nu ook de PvdA-ministers zich niet meer tegen een aanval op het Republikeinse regeringscentrum. Op 19 december lanceerde Nederland een groot offensief (de tweede 'politionele actie'), waarbij het al op de eerste dag Jogja bezette en de politieke leiders van de Republiek gevangen nam. Een belangrijk deel van de Nederlandse beleidsmakers dacht dat de Republiek hiermee als politieke factor uitgeschakeld was. Dat zij zich hierin ernstig vergisten bleek zowel uit de reacties van de Verenigde Naties als uit die van de Indonesische federalisten.

\section{Aankleding van Linggadjati}

De in Linggadjati bereikte overeenstemming wekte in november 1946 geen geestdrift binnen het Nederlandse kabinet. Verscheidene ministers waren niet alleen ongelukkig over het eigengereide optreden van de commissie-generaal, maar ook over de inhoud van de ontworpen overeenkomst. Daarentegen kreeg Linggadjati in het buitenland een warm onthaal. De Amerikaanse regering drong bij Nederland aan op snelle formalisering van het akkoord. Minister Van Kleffens, die in New York aan de Algemene Vergadering van de Verenigde Naties deelnam, waarschuwde minister-president Beel dat wijziging van het akkoord op wezenlijke punten uitgesloten moest worden geacht, zowel tegenover de Republiek Indonesië als tegenover de internationale publieke opinie. Afwijzing van het akkoord zou volgens hem leiden tot 'een oorlog van volk tegen volk met een voor ons te verwachten verlies van elke band met Indië'. Van Kleffens sprak de hoop uit dat Nederland niet dezelfde tactiek zou volgen als na de Belgische opstand van 1830 (zie p. 85-6), 'welke tactiek ons niets dan materieele en moreele schade heeft berokkend'.

De meeste leden van het kabinet lieten zich echter vooral door binnenlandspolitieke overwegingen leiden. Daarbij ging het in de eerste plaats om de vraag hoe de regering steun kon krijgen van een meerderheid in het parlement. Van de fractieleden van de PvdA mocht men aannemen dat ze het akkoord van Linggadjati wilden aanvaarden, maar binnen de KVP-fractie bestonden er ernstige bezwaren tegen. De protestants-christelijke en liberale fracties wezen Linggadjati volstrekt af. Zou de KVP zich hierbij aansluiten, dan zou dit echter het einde betekenen van de regeringscoalitie tussen PvdA en KVP. Het kabinet besloot nu het akkoord van Linggadjati te aanvaarden mits men het zo zou kunnen uitwerken en interpreteren dat 'een redelijke invloed van Nederland in Indië' gehandhaafd zou worden. De uit Java teruggekeerde commissarissengeneraal werkten nauw met het kabinet samen bij deze 'aankleding' van het akkoord. Zij schreven een ruim twintig pagina's tellende toelichting die er op 
gericht was de ontwerp-overeenkomst zo verteerbaar mogelijk te maken voor Nederlanders die er in eerste aanleg niet voor voelden.

De politieke leider van de KVP, Romme, hechtte grote waarde aan de instandhouding van het Koninkrijk en was daarom eerst tegen het akkoord van Linggadjati geweest. Gedeeltelijk uit tactische motieven wilde hij de regering toch in staat stellen tot ondertekening ervan. Eén van die motieven was het belang van het behoud van de coalitie; ook kon de KVP moeilijk haar eigen Indonesië-expert Van Poll afvallen. Een heel andere overweging was dat de tekst van Linggadjati, in tegenstelling tot de Nederlandse regeringsverklaring van 10 februari, niet repte van een recht op afscheiding na afloop van een zekere termijn. De commissie-generaal merkte in haar commentaar hierover op: 'daarmede is de tijdbom weggenomen, die een blijvend samengaan bedreigde'.

Medio december werd het akkoord van Linggadjati in de Tweede Kamer besproken; het volledige kabinet woonde deze bespreking bij. Minister Jonkman deelde mee dat de regering van plan was de overeenkomst te ondertekenen, maar dat dit haar tot niets meer of anders zou verbinden dan wat volgens de toelichting van de commissie-generaal overeengekomen was en wat de regering nu zelf hierover in het parlement zou verklaren. Voortbouwend op die toelichting deed Jonkman op 10 en 19 december een aantal uitspraken waarvan sommige aan het akkoord nieuwe elementen toevoegden, andere de strekking ervan in Nederlandse zin ombogen en enkele een duidelijke wijziging van het ontwerp inhielden. De gelijkwaardigheid tussen de contracterende partijen, die voor de Republiek één van de belangrijkste aspecten van Linggadjati vormde, werd in die uitspraken sterk teruggedrongen. Jonkman duidde de delegatie van de Republiek aan als 'een Indonesische delegatie'; verder sprak hij herhaaldelijk over 'de Indonesische volkeren', maar nooit over 'het Indonesische volk'. Hij omschreef de Nederlands-Indonesische Unie als een 'staatsverband' en gaf er een zwaarder karakter aan dan de commissie-generaal in Linggadjati aangeduid had. Hij stelde dat de huidige staats- en volkenrechtelijke positie van het Koninkrijk in het ontwerp-akkoord erkend werd. In afwijking van de artikelen 3 en 4 van het ontwerp verklaarde hij dat Nieuw-Guinea een eigen status zou moeten kunnen krijgen ook zonder uitspraak hierover van de bevolking van het gebied; de regering vond dit nodig, aldus Jonkman, om daar de mogelijkheid open te houden voor volksplantingen van Indische Nederlanders die onder eigen bestel zouden willen leven. Wat betreft de positie van de bezette gebieden en de functie van de Nederlandse troepen maakte de regering een voorbehoud dat de letterlijke betekenis van het woord 'aanstonds' in de artikelen 1 en 16 ontkrachtte. Zij verklaarde namelijk dat de voorbereiding van de nieuwe rechtsorde op voldoende machtsmiddelen zou moeten steunen en dat men niet tot verzwakking of vermindering daarvan zou mogen overgaan voordat de waarborgen van een rechtsorde aanwezig zouden zijn. Verder verkleinde de regering het 
bereik van de arbitrageclausule uit artikel 17. Ook verklaarde zij dat het politieke akkoord aangevuld zou moeten worden worden met een akkoord over economische en financiële kwesties.

Aan het slot van het debat behandelde de Tweede Kamer een motie die was ingediend door Romme samen met M. van der Goes van Naters, de fractievoorzitter van de PvdA. Volgens die motie verenigde de Kamer zich met het voornemen van de regering om met de Republiek Indonesië een wederzijdse verbintenis aan te gaan tot niets meer of anders dan volgens de toelichting van de commissie-generaal te Linggadjati was overeengekomen en met onverkorte inachtneming van de regeringsverklaringen van 10 en 19 december. De Kamer nam de motie op 20 december met vijfenzestig tegen dertig stemmen aan. De voorstemmen kwamen niet alleen van de fracties van de PvdA en de KVP (behalve één KVP-lid dat tegenstemde), maar ook van de CPN. Daarbij verklaarde de CPN-fractie uitdrukkelijk dat haar voorstem alleen betrekking had op de ondertekening en niet op de aankleding van het akkoord.

\section{Nederlands verzet tegen Linggadjati}

Al sinds het najaar van 1945 bestonden in Nederland diepe meningsverschillen over het in Indonesië te voeren beleid (zie pp. 441-3). In september 1946 was dit opnieuw gebleken bij de uitzending van dienstplichtigen (zie p. 475). Onder meer had de Vereniging Nederland-Indonesië (VNI) toen ruim 233.000 handtekeningen verzameld onder een petitionnement dat aandrong op een vreedzame oplossing van het geschil met de Republiek. In november deed de ontwerp-overeenkomst van Linggadjati de tweedracht in Nederland zo hoog oplaaien dat commissaris-generaal De Boer deze kenschetste als 'bijna een godsdienstoorlog'. Regering en parlement werden bedolven onder een stortvloed van brieven en telegrammen die opriepen tot verwerping van het akkoord. Tot de afzenders behoorden ook oud-ministers, leden van de Raad van State en de president van de Hoge Raad. De hoogste chefs van de Nederlandse landmacht en zeemacht, generaal Kruls en admiraal Helfrich, gaven op 19 november in een brief aan het kabinet uiting aan hun ernstige ongerustheid 'over de dreigende verminking van het Koninkrijk'. Zij verklaarden daarbij dat de Nederlandse strijdkrachten de recente gang van zaken moeilijk konden verwerken. Ook kondigden zij aan misschien ontslag te zullen nemen als het beleid in dezelfde richting zou doorgaan. Een dag later legden zij hun zorgen persoonlijk voor aan koningin Wilhelmina; bovendien lichtten zij de pers hierover in.

Het hevige karakter van het verzet betekende niet dat dit representatief was voor de Nederlandse bevolking. Bij een opinie-onderzoek in begin december (dus nog voor de 'aankleding' van het akkoord) verklaarde 38\% van de 
ondervraagden zich voor Linggadjati en 36\% tegen, terwijl 26\% nog geen standpunt innam.

Zij die tegen Linggadjati ageerden trokken soms parallellen met het Nederlandse verzet tegen de Duitse overheersing. Meijer Ranneft vergeleek de parafering van het ontwerp met de Nederlandse capitulatie in mei 1940. De stichting 'Indië in nood ... geen uur te verliezen' stuurde een telegram aan de leden van het parlement met als tekst: 'Wilt gij Hitler terug? Wilt gij Mussert terug? Waarom zoudt ge dan zeventig miljoen Indonesiërs aan Soekarno uitleveren?'

Het protest tegen Linggadjati werd op 2 december versterkt door een felle radiorede van P.S. Gerbrandy, oud-minister-president uit de jaren 1940-1945; veel Nederlanders kenden zijn stem nog van de toespraken die hij in de oorlogsjaren uit Londen tot bezet Nederland had gericht. Volgens Gerbrandy was Linggadjati een ramp voor Indië en moest het roer radicaal om. Naar aanleiding van deze rede begon Feuilletau de Bruyn een handtekeningen-actie voor een 'smeekschrift' onder het motto 'Wij eisen handhaving van de Rijkseenheid'. Binnen enkele weken kreeg dit smeekschrift 300.000 handtekeningen.

Op 14 december werd een Nationaal Comité Handhaving Rijkseenheid opgericht met Gerbrandy als voorzitter. Tot de leden hiervan behoorden niet alleen bekende aanvoerders van de buitenparlementaire oppositie, zoals Welter en Meijer Ranneft, maar ook de politieke leiders van de ARP, de CHU en de PvdV. Een ander prominent lid was generaal Winkelman, die in 19391940 opperbevelhebber van het Nederlandse leger geweest was. Later trad ook admiraal Helfrich tot het Comité toe. Het Nationaal Comité organiseerde talrijke protestbijeenkomsten en wekelijkse radiotoespraken en verspreidde brochures, pamfletten en affiches. Het nam het personeel, het kapitaal en het propagandablad over van de stichting 'Indië in nood ... geen uur te verliezen'. De aankleding van Linggadjati bracht geen verandering in de opstelling van het Comité; het wenste onder geen beding te aanvaarden dat Indonesië in de toekomst geen deel van het Koninkrijk meer zou zijn.

De agitatie tegen Linggadjati kreeg geen gelijkwaardig tegenspel van de kant van de VNI. Deze vereniging begon eind 1946 haar karakter van breed samengestelde actiegroep voor de vrijheid van Indonesië te verliezen, omdat steeds meer niet-communisten het bezwaarlijk vonden in de VNI met communisten samen te werken terwijl Moskou bezig was de volken van Oost-Europa van hun vrijheid te beroven.

\section{Indonesisch verzet tegen Linggadjati}

Kort na de parafering van de ontwerp-overeenkomst van Linggadjati begon de leiding van de Republiek een grote campagne om dit akkoord tegenover haar eigen aanhang te verdedigen. Hoewel Soekarno en Hatta persoonlijk 
aan de campagne deelnamen, was die verdediging geen eenvoudige zaak. In maart 1946 had het KNIP de regering gemachtigd tot het voeren van onderhandelingen op basis van $100 \%$ erkenning van de Republiek. Het akkoord van Linggadjati voldeed duidelijk niet aan dit criterium. Nederland zou volgens artikel 1 alleen het de facto gezag van de Republiek erkennen en alleen over een deel van het Indonesische grondgebied. Bovendien zou de Republiek volgens artikel 4 in de toekomstige soevereine Indonesische federatie nog slechts de status van een deelstaat hebben, naast de deelstaten Borneo en Oost-Indonesië.

Bij hun pogingen steun voor Linggadjati te krijgen betoogden de Republikeinse leiders dat het bij dit akkoord niet om een definitieve regeling ging. Zij legden uit dat de Republiek haar aanspraak op het de jure gezag geenszins had opgegeven, noch met betrekking tot Java en Sumatra, noch met betrekking tot de rest van Indonesië. De nog te vormen Verenigde Staten van Indonesië behandelden zij als een nieuwe verschijningsvorm van de Republiek. Ondertekening van Linggadjati stelden zij voor als een tactische manoeuvre die de Republiek een zekere adempauze zou verschaffen. Hatta noemde het akkoord een springplank voor de volgende fase van de strijd.

Deze betoogtrant had slechts beperkt succes. Ten eerste was de overtuiging dat men de onafhankelijkheid niet door onderhandelingen maar door strijd moest verzekeren nog steeds wijd verbreid, ook al had de regering in het voorjaar het eenheidsfront PP uitgeschakeld dat die overtuiging bij uitstek vertegenwoordigde (zie p. 446). Maar ook onder hen die onderhandelingen niet bij voorbaat afwezen vonden velen dat in Linggadjati te veel concessies gedaan waren. Het pijnlijkste punt was dat de Nederlandse koning volgens artikel 8 aan het hoofd zou staan van de tussen Indonesië en Nederland te vormen Unie, waardoor Indonesië duidelijk tegenover de vroegere overheerser een ondergeschikte positie zou innemen.

Het akkoord van Linggadjati werd uitdrukkelijk verworpen door een aantal belangrijke partijen en groepen waaronder de PNI en de Masjoemi (hoewel hun prominente leden Gani en Roem zelf aan de onderhandelingen deelgenomen hadden). Medio december richtten ze een overkoepelende antiLinggadjati-organisatie op onder de naam Benteng Repoeblik (BR, Burcht van de Republiek). Voorzitter hiervan werd Boeng Tomo, de gedreven volksmenner uit Soerabaja. De Benteng Repoeblik organiseerde massale protestbijeenkomsten in heel Java.

Tot aanvaarding van het akkoord van Linggadjati was slechts een minderheid van politieke partijen en groeperingen bereid, waaronder de Partai Sosialis, de Partai Boeroeh (Arbeiderspartij), de communistische PKI, de katholieke partij, de protestants-christelijke partij en de jongerenorganisatie Pesindo. De linkse partijen en groeperingen die Linggadjati steunden vormden een samenwerkingsverband dat zich Sajap Kiri (Linker-Vleugel) noemde. 
Overigens werd de kloof tussen deze organisatie en de Benteng Repoeblik kleiner toen bekend werd dat de Nederlandse regering achteraf bij het akkoord van Linggadjati een reeks voorbehouden gemaakt had en nu van de Republiek verlangde dat zij die voorbehouden zou onderschrijven. De aanhangers van de Sajap Kiri waren wel bereid ondertekening van het 'naakte' Linggadjati te ondersteunen, maar wezen de Nederlandse 'aankleding' daarvan af als een onaanvaardbaar dictaat.

\section{Oprichting van de deelstaat Oost-Indonesië}

Aan het slot van de conferentie van Malino (zie pp. 466-7) was besloten dat men in een tweede conferentie concrete stappen zou nemen voor de vorming van een deelstaat Borneo en een deelstaat Oost-Indonesië. Van Mook wilde hier haast mee maken om tegenover de Republiek over gelijkwaardige bouwstenen te beschikken voor de opbouw van de beoogde Indonesische federatie. Overigens zouden die deelstaten alleen formeel gelijkwaardig aan de Republiek kunnen zijn, omdat vier vijfde van de bevolking van de archipel zich op Java en Sumatra bevond.

Intussen bleek het moeilijk om een deelstaat Borneo tot stand te brengen. De aanhang van de Repubiek in Zuid- en Oost-Borneo was zo groot dat het onwaarschijnlijk leek dat een representatieve afvaardiging uit deze gebieden daaraan zou willen meewerken. De vervolgconferentie, die van 7 tot en met 24 december 1946 in Denpasar op Bali bijeenkwam, was dan ook uitsluitend gericht op de oprichting van een deelstaat Oost-Indonesië. Naast vertegenwoordigers van het Nederlands-Indische gouvernement namen er zeventig afgevaardigden uit het oostelijke deel van de archipel aan deel; anders echter dan in Malino was hier nu geen vertegenwoordiger uit Nieuw-Guinea bij. Van deze zeventig afgevaardigden waren er vijfenvijftig door plaatselijke organen gekozen, onder wie wederom de conservatieve aristocraat Tjokorde Gde Rake Soekawati uit Bali en de nationalist Nadjamoeddin Daeng Malewa uit ZuidCelebes. Een flink deel van de afgevaardigden was Republikeins gezind. De belangrijkste daarvan was Tadjoeddin Noor, een advocaat uit Makassar die voor de oorlog lid van de Volksraad geweest was en na de oorlog nauw had samengewerkt met Ratoelangie, de door de Republiek aangestelde gouverneur van Celebes. Intussen bevond Ratoelangie zelf zich al een half jaar op een eiland bij Nieuw-Guinea, waar het Nederlands bestuur hem na zijn gevangenneming geïnterneerd had (zie p. 516).

De conferentie in Denpasar beraadslaagde aan de hand van een door het gouvernement opgesteld ontwerp voor een voorlopige constitutie. Van Mook had de begindatum van 7 december gekozen in de verwachting dat het akkoord van Linggadjati voordien in Nederland goedgekeurd zou zijn, 
maar nu het akkoord daar nog in behandeling was, stelde hij zijn vertrek naar Denpasar voorlopig uit. De conferentie begon daarom met een informele fase waarin de afgevaardigden uit de oostelijke archipel het ontwerp bespraken met ambtenaren van het gouvernement. Het feit dat het slechts om een voorlopige regeling ging vergemakkelijkte het bereiken van overeenstemming. De conferentie werd het eens over de algemene opzet van de nieuwe negara (deelstaat), met een president, ministers en een parlement en met Makassar als hoofdstad. Daarentegen rees ernstig verzet tegen een bepaling in het ontwerp die Nieuw-Guinea van het grondgebied uitsloot. Uiteindelijk legde men zich hierbij neer onder het aannemen van een motie die aandrong op spoedig onderzoek naar de mogelijkheid van aansluiting van Nieuw-Guinea bij Oost-Indonesië. Een ander punt van kritiek was dat het ontwerp tientallen onderwerpen opsomde die buiten de bevoegdheid van de deelstaat zouden vallen, zoals de buitenlandse betrekkingen, het geldwezen, de defensie en het toezicht op zee. Ook hier moesten de afgevaardigden zich uiteindelijk bij neerleggen. Eén van de actieve deelnemers aan het overleg was de Balinese afgevaardigde Ide Anak Agoeng Gde Agoeng; onder meer keerde hij zich zowel tegen de uitsluiting van Nieuw-Guinea als tegen de beperking van de bevoegdheden van de deelstaat.

Hoewel de Republikeinsgezinde afgevaardigden zich in Denpasar coöperatief opstelden, beschouwde men in de Republiek zelf de conferentie als een schending van de geest van Linggadjati. Volgens artikel 2 van dat akkoord zouden Nederland en de Republiek immers samenwerken tot de vestiging van de Indonesische federatie, maar over de opzet van Denpasar had noch de commissie-generaal noch Van Mook's gouvernement enig overleg met de Republiek gevoerd.

Op 18 december opende Van Mook het formele deel van de conferentie. Men kon nu de nodige besluiten nemen. Onder meer besloot men dat de afgevaardigden naar deze conferentie zelf het voorlopige parlement van de deelstaat zouden vormen. Nadat de conferentie de constitutie van OostIndonesië definitief had vastgesteld, vond op de laatste dag de verkiezing van het staatshoofd plaats. Hierbij won Soekawati na drie stemronden met een kleine meerderheid van Tadjoeddin Noor. In de hierna volgende verkiezing voor de voorzitter van het parlement behaalde Tadjoeddin daarentegen een ruime meerderheid tegenover de Ambonese KNIL-kapitein J. Tahija, een adjudant van generaal Spoor. Voordat de conferentie uiteenging maakte president Soekawati bekend dat hij Nadjamoeddin tot kabinetsformateur benoemde.

De formele stichting van de Negara Oost-Indonesië gebeurde door een ordonnantie die Van Mook op 24 december ondertekende en die nog diezelfde dag in werking trad. De ordonnantie verwees naar een in 1944 door de Nederlandse regering in Londen vastgestelde overgangsregeling waarbij Van Mook bijna dictatoriale bevoegdheden gekregen had (zie pp. 321-2). Uit 
staatsrechtelijk oogpunt was de negara een totaal nieuwe constructie, op geen enkele manier voorzien in de geldende staatsregeling voor Nederlands-Indië. Na de conferentie van Malino was Van Mook oorspronkelijk van mening geweest dat voor de oprichting van zulke deelstaten een nieuwe Nederlandse machtigingswet nodig zou zijn. Omdat zulk een wet onmogelijk tijdig tot stand kon komen, had hij na overleg met Jonkman besloten de schepping van Oost-Indonesië toch op de regeling uit 1944 te baseren.

\section{Nederlandse terreur in Zuid-Celebes}

Terwijl de conferentie van Denpasar besloot dat het in Zuid-Celebes gelegen Makassar de hoofdstad van de nieuwe deelstaat zou worden, voerde Van Mook's gouvernement een meedogenloze campagne tegen het anti-koloniale verzet in dat gebied zelf (een gebied ruim anderhalf keer zo groot als Nederland en met een bevolking van vier miljoen). Dit verzet had een lange voorgeschiedenis. Hoewel de havenstad Makassar al in de zeventiende eeuw door de VOC veroverd was, had het Nederlandse gezag zich in de rest van Zuid-Celebes nooit stevig kunnen vestigen (zie pp. 79, 90 en 125). Pas in 1905 slaagde het koloniale leger er in de hier gelegen vorstendommen definitief te onderwerpen, maar ook daarna bleef in dit gebied verzet bestaan. Na het uitbreken van de Pacific-oorlog koos een deel van de bevolking partij voor Japan; begin 1942 nam men in Zuid-Celebes zelfs al vóór de komst van de Japanse strijdkrachten een aantal Nederlandse bestuursambtenaren en militairen gevangen.

Tijdens de oorlog werd Celebes bestuurd door de Japanse marine. Dit bestuur stelde in 1943 twee Indonesische politici als adviseurs aan, Ratoelangie en Tadjoeddin Noor. Beiden waren lid van de Volksraad geweest. Ratoelangie, een in 1890 geboren Menadonese christen, had in Nederland en Zwitserland gestudeerd en kende Jonkman en Van Mook al sinds 1918; in Indonesië was hij leider van de Minahasa-bond geworden; in de Volksraad had hij in 1936 de petitie-Soetardjo mede-ingediend.

Na de capitulatie van Japan nam Ratoelangie in Djakarta deel aan de oprichting van de Republiek Indonesië; daarna werd hij door Soekarno benoemd tot gouverneur van de provincie Celebes. Eind augustus keerde hij naar Makassar terug en nam hij contact op met verschillende politici en bestuurders. De Japanners droegen begin september bijna al hun bestuursfuncties op Celebes aan Indonesiërs over. In Zuid-Celebes schaarden zowel de Indonesische ambtenaren als de feodale vorsten en volkshoofden zich in grote meerderheid achter Ratoelangie en de Republiek. Ratoelangie ging echter niet over tot de vorming van een provinciaal Nationaal Comité. In plaats daarvan richtte hij eind oktober een organisatie op met de naam Poesat Keselamatan Rakjat 
Soelawesi (Centrum voor Volkswelzijn van Celebes).

Intussen was in de loop van september een nieuwe situatie ontstaan door de terugkeer in Makassar van voormalige krijgsgevangenen en geïnterneerden uit Japanse kampen en door de komst van een Australische brigade. Nederlandse ambtenaren gingen hun oude functies weer uitoefenen en werden al spoedig als NICA-personeel ingeschakeld door de Australische bezettingsmacht. Er braken gevechten uit tussen Ambonese KNIL-militairen en aanhangers van de Republiek. De NICA probeerde de Indonesische bestuurders weer achter de Nederlandse vlag te krijgen, maar stuitte daarbij op veel tegenwerking en soms op gewapend verzet. Eind oktober ondernamen nationalistische jongeren zelfs een grootscheepse aanval op het NICA-kantoor, de politiekazerne en andere gebouwen in Makassar; zij hesen er de rood-witte vlag en bezetten het radiostation, maar werden al snel door Australische en Nederlandse militairen verdreven.

Formeel was de NICA de civiele arm van de geallieerde bezettingsmacht, maar in Zuid-Celebes trad zij in de praktijk op als een voortzetting van het vooroorlogse Nederlands-Indische bestuur. In de laatste maanden van 1945 kwam zij in dit gebied grotendeels te bestaan uit BB-ambtenaren die hier al voor de oorlog gediend hadden. Evenals de officieren van het KNIL traden deze ambtenaren de nieuwe politieke situatie meestal met dezelfde termen en begrippen tegemoet als zij ook vroeger op anti-koloniale bewegingen plachten toe te passen (vergelijk p. 111). Het sprak voor hen vanzelf dat het Nederlandse gezag het wettige gezag was; verzet daartegen was per definitie misdadig. Wie zich verzette was een 'extremist'; wie daarbij geweld gebruikte was een 'terrorist'. Verzetsgroepen heetten 'benden', verzetsleiders heetten 'bendeleiders'. Dat verzet tegen de terugkeer van het koloniale bestel geïnspireerd kon zijn door een politiek onafhankelijkheidsideaal, wilde men niet geloven; men schreef dit verzet uitsluitend toe aan Japanse indoctrinatie en aan zucht naar persoonlijk gewin. Om het woord 'Republikeinen' te vermijden sprak men van 'non-coöperatoren'.

Dat de Republiek op Celebes wel degelijk een sterke aanhang bezat, bleek uit een in november aan de Australische commandant overhandigd verzoekschrift dat door 391 vorsten, volkshoofden en leiders van politieke, sociale en religieuze groeperingen ondertekend was en waarin onder meer verklaard werd dat Celebes een onafscheidelijk deel van de Republiek Indonesië vormde. Overigens hadden niet alle vooraanstaande Indonesiërs op Celebes dit geschrift ondertekend; er waren er ook die de voorkeur gaven aan samenwerking met het Nederlandse bestuur.

In de laatste maanden van 1945 werd de geallieerde bezettingsmacht in Zuid-Celebes met vijf KNIL-compagnieën uitgebreid. Dit stelde de NICA in staat haar druk op de Indonesische bestuurders te vergroten, ook omdat het anti-koloniale verzet over weinig vuurwapens beschikte. $Z \mathrm{ij}$ wist verscheidene 
vorsten ertoe te brengen hun loyaliteit aan het Nederlandse gezag te betuigen door ondertekening van de vernederende 'Korte Verklaring' (zie pp. 121-2). In januari 1946 kwamen nog enige duizenden KNIL-militairen in Zuid-Celebes aan. Eind januari werd de Australische brigade door een Britse brigade vervangen.

Van 1 februari tot 14 juli stond Celebes onder Brits militair gezag, maar dit gezag liet de dagelijkse bestuurlijke en militaire taken geheel aan de NICA en het KNIL over. Intussen bleef het door Ratoelangie geleide Centrum zich op het standpunt stellen dat de NICA geen voorbereiding mocht zijn op de terugkeer van het Nederlands-Indische gezag. Onder meer verwierp het daarom een door de NICA afgekondigde belastingmaatregel als onwettig. Daarop nam de NICA op 5 april zowel Ratoelangie als zes andere Republikeinse voormannen gevangen. Zij werden beschuldigd van 'poging tot omverwerping van het gezag' en van 'het aanzetten tot opstand en bedrog'. Wat Ratoelangie betreft klonk dit wat ondermaats; hij behoorde immers zelf tot de leiders van de opstand die belichaamd was in de Republiek Indonesië. In politiek opzicht viel zijn arrestatie moeilijk te rijmen met het feit dat officiële vertegenwoordigers van die Republiek, onder wie twee ministers, toen juist samen met Van Mook naar Nederland onderweg waren voor overleg met de Nederlandse regering (zie p. 452). Het gouvernement in Batavia achtte berechting van Ratoelangie en zijn lotgenoten niet opportuun. Daarom werden zij in juni op een eiland bij Nieuw-Guinea geïnterneerd. De politieke leiding van de Republikeinse beweging op Celebes was intussen overgegaan op Tadjoeddin Noor.

Van 14 juli af stond Celebes formeel weer onder louter Nederlands gezag. Het KNIL beschikte nu in het zuiden over 2700 man. In het afgelopen halfjaar had het in vele delen van dit gebied verzetsgroepen bestreden; het had verscheidene daarvan in het defensief gedrongen, terwijl tegelijk de NICA haar greep op de lokale gezagsdragers versterkt had. Het gebied leek dan ook stevig in Nederlandse handen te zijn toen daar in de tweede helft van juli de conferentie van Malino plaatsvond. Die indruk was bedrieglijk. Juist in deze tijd begon het verzet steun uit Java te krijgen, zowel van het Republikeinse leger als van de KRIS, een militante organisatie van op Java verblijvende personen uit Celebes, eind 1945 opgericht door een dochter van Ratoelangie. Met kleine boten bracht men strijders naar Zuid-Celebes over, onder wie officieren die deskundig waren op het terrein van de guerrilla-oorlog. Ook kwam nu een bundeling van de talrijke verzetsgroepen tot stand. Die groepen waren van velerlei soort; verscheidene werden geleid door leden van vorstenfamilies, sommige hadden een islamitische basis, terwijl de bekendste leider van het verzet in Makassar zelf een eenentwintigjarige Menadonese christen was, Wolter Monginsidi. Ter voorbereiding op grootschalig optreden legde de verzetsbeweging zich er nu vooral op toe meer vuurwapens in handen te krijgen, onder meer door overvallen op wapendepots. 
In de loop van juli-november breidde het verzet zich sterk uit. Het was nu beter georganiseerd, bewapend en geoefend, maar ook radicaler en onverzoenlijker. Monginsidi dreigde dat Makassar het 'graf der Hollanders' zou worden als het KNIL de strijd niet zou staken. Het verzet richtte zich erop het gebied voor de Nederlanders onbestuurbaar te maken. Bestuurskantoren werden in brand gestoken, wegen geblokkeerd, bruggen vernield, telefoonkabels doorgesneden. Stelselmatig werden Indonesiërs die met het koloniale gezag meewerkten vermoord, soms samen met hun vrouwen en kinderen; ook werden vaak hun huizen verbrand. Op veel plaatsen sympathiseerde de bevolking met de verzetsbeweging, maar tegelijk leed zij onder de door het verzet veroorzaakte maatschappelijke ontwrichting; bovendien oefenden strijdgroepen druk op de bevolking uit voor het verschaffen van voeding, onderdak of geldelijke steun.

Ook de KNIL-militairen traden hardhandig op. Midden november bleek het KNIL het echter in Zuid-Celebes niet meer te kunnen bolwerken. De verzetsbeweging beheerste grote delen van het gebied. In Makassar zelf ondernam zij beschietingen en overvallen. De stad raakte geïsoleerd; de buitenwegen kon men alleen nog in konvooi onder militair escorte berijden. Van Mook's gouvernement moest de mogelijkheid onder ogen zien dat het zich in Zuid-Celebes niet zou kunnen handhaven. De politieke consequenties hiervan zouden dramatisch zijn. Juist omdat Makassar bestemd was de hoofdstad van Oost-Indonesië te worden, zou verlies van Zuid-Celebes de pas afsnijden aan de voorgenomen federale herinrichting van Indonesië en daarmee de bodem wegslaan onder de door Van Mook bedachte oplossing voor het conflict met de Republiek. Om de crisis het hoofd te bieden besloot het gouvernement tot drie maatregelen: afkondiging van de staat van oorlog, waardoor de autoriteiten buitengewone bevoegdheden zouden krijgen, versterking van de Nederlandse troepenmacht met een KL-bataljon van duizend man, en inzet van een kleine KNIL-eenheid die speciaal voor guerrillabestrijding opgeleid was. Deze eenheid bestond uit honderddertig man, in meerderheid Ambonezen, en werd geleid door kapitein R.P.P. Westerling, een Nederlander die in Turkije geboren en opgegroeid was. Hij kreeg van zijn superieuren de vrije hand om het verzet in Zuid-Celebes te breken.

Het doel van de campagne werd niet omschreven als verdediging van het Nederlandse gezag tegen een politiek gemotiveerde verzetsbeweging, maar als bescherming van de bevolking tegen misdadige terreur. Van Mook stelde de campagne uit tot na het begin van de conferentie van Denpasar. Op 11 december kondigde hij voor de belangrijkste delen van Zuid-Celebes de staat van oorlog af. Al één dag eerder begon Westerling zijn eerste actie. Om het vertrouwen van de bevolking terug te winnen had hij een eigen methode bedacht, waarvan de kern bestond uit het doden van mensen ten overstaan van een menigte die gedwongen was hierbij toe te zien. Een actie begon meest- 
al 's nachts met het omsingelen van enkele dorpen, waarna de bewoners op één plaats werden bijeengebracht; wie zich verzette of vluchtte werd neergeschoten. Op de verzamelplaats scheidde men de mannen van de vrouwen en kinderen. De ontruimde huizen werden doorzocht. Daarna begon overdag de eigenlijke 'zuivering' in de vorm van tientallen openbare 'executies'. Volgens Westerling betrof dit moordenaars, rovers, brandstichters, bendeleiders en leden van 'extreme' partijen. Soms werden mannen gedood die men al op grond van eerder verkregen inlichtingen daartoe bestemd had, soms mannen in wier huizen verdacht materiaal aangetroffen was. Het kwam ook voor dat personen uit de verzamelde menigte onder bedreiging met de dood gedwongen werden uit hun eigen midden 'terroristen' aan te wijzen, die vervolgens meteen werden doodgeschoten. Bij verscheidene acties werden groepen mensen gedood die men daartoe van te voren uit gevangenissen gehaald had. Gewoonlijk werd een actie afgesloten met het in brand steken van huizen of zelfs hele dorpen waarvan de bewoners verdenking gewekt hadden. Als verdacht materiaal golden ook messen, zaklantaarns en grijsgroene kleding. Met tientallen van zulke acties 'zuiverde' Westerling's eenheid, soms samen met andere legeronderdelen, verschillende delen van Zuid-Celebes.

Deze acties richtten zich niet rechtstreeks tegen de verzetsgroepen zelf, maar hadden tot doel de verzetsbeweging te verlammen door haar van steun uit de bevolking te beroven. Hoewel de in december afgekondigde staat van oorlog aan de militairen buitensporige bevoegdheden toekende, behoorde daartoe niet het doden van mensen zonder formele beschuldiging en zonder gelegenheid tot verweer. Niettemin toonden verscheidene zowel burgerlijke als militaire autoriteiten zich ingenomen met Westerling's optreden. Zij namen graag aan dat de door hem ondernomen executies op ernstige verdenkingen berustten. De procureur-generaal in Batavia beschouwde zijn optreden als 'in noodrecht gegronde militaire actie'. In Zuid-Celebes kregen ook enige andere officieren toestemming om de methode-Westerling toe te passen; generaal Buurman van Vreeden gaf hier een uitdrukkelijke machtiging voor.

Van Mook zelf was lange tijd niet op de hoogte van de door Westerling gevolgde methode. Hij kwam hier pas achter nadat Tadjoeddin Noor (intussen voorzitter van het parlement van Oost-Indonesië geworden) er bij hem tegen geprotesteerd had. Van Mook concludeerde eind januari dat aan deze manier van optreden zo snel mogelijk een eind moest komen, waarbij hij opmerkte 'dat dergelijke methoden, die ten nauwste verwant zijn met de Duitse en Japanse, slechts onder de meest dringende omstandigheden nog enige verontschuldiging kunnen vinden'. Het duurde enige tijd voordat aan zijn aanwijzing gevolg werd gegeven. Spoor annuleerde op 21 februari de machtiging van Buurman van Vreeden en riep Westerling's eenheid naar Java terug. Westerling verliet Makassar op 4 maart, van Nederlandse kant overladen met dank en lof. De in Zuid-Celebes zowel door zijn eenheid als 
door andere eenheden van leger en politie uitgeoefende terreur had intussen duizenden het leven gekost.

De in december begonnen Nederlandse campagne was gedeeltelijk in haar opzet geslaagd. Dit betrof vooral het door een schrikbewind afdwingen van de gehoorzaamheid van de niet-combattante bevolking. De eigenlijke verzetsbeweging was niet uitgeschakeld, maar wel in het defensief gedrongen. Verscheidene belangrijke verzetsleiders, onder wie Monginsidi, waren in Nederlandse handen gevallen. Veel verzetsgroepen trokken zich in het bergland terug. Het ontvangen van steun overzee uit Java werd moeilijker. Het werd betrekkelijk rustig in Zuid-Celebes.

Van wat hier van december tot eind februari gebeurd was drong weinig tot de buitenwereld door. In Nederland werd er pas in juli 1947 iets van bekend door publicaties in het weekblad Vrij Nederland.

\section{Nederlandse marineblokkade van de Republiek}

Toen het Britse oppergezag over Java en Sumatra op 30 november 1946 eindigde, annuleerde de Nederlandse marinecommandant, vice-admiraal Pinke, terstond het door dat gezag aan de marine opgelegde verbod om binnen vijf mijl van bepaalde Republikeinse havens te komen (zie p. 471). Voor Nederland was het van groot belang het zeeverkeer van de Republiek te kunnen verhinderen. Daarbij ging het onder meer om het vervoer van wapens naar Republikeins gebied en om het vervoer van strijders en wapens uit Java naar andere delen van de archipel zoals Zuid-Celebes, Zuid-Borneo en Bali. Daarnaast ging het om de uitvoer uit Republikeins gebied van producten als rubber, suiker, palmolie en tabak. Door schaarste op de wereldmarkt was de vraag hiernaar groot. Op Java en Sumatra bevonden zich grote voorraden hiervan, deels nog daterend uit de tijd van voor de Japanse bezetting. Vooral uit Sumatra vond veel uitvoer van zulke producten naar Singapore en Malakka plaats; de Republiek verkreeg hiermee deviezen waarmee zij onder meer de aankoop van wapens kon financieren. Nederland beschouwde dit als smokkelhandel. Daarentegen had het Britse bezettingsbestuur de Republiek niet het recht willen ontzeggen om buitenlandse handel te bedrijven en had het de levering van rijst door de Republiek aan India actief bevorderd.

Volgens Pinke volgde uit het in oktober 1946 overeengekomen bestand dat alle zeevaart voor Republikeinse strijdkrachten verboden was, evenals alle vervoer overzee van Republikeinse militairen, wapens en propagandamateriaal. Verder gingen de Nederlandse autoriteiten ervan uit dat zij het recht hadden alle scheepvaart in de territoriale wateren van Nederlands-Indië te controleren, ook langs de kusten van gebied dat de facto onder Republikeins gezag stond. Al in de eerste week van januari 1947 bracht de Nederlandse marine op 
de rede van Tjirebon het vlaggenschip van de Republikeinse marine tot zinken omdat het niet voldeed aan een Nederlands commando om te stoppen. De Republiek noemde dit een ernstige schending van het bestand.

Eind januari 1947 kondigde Van Mook's gouvernement ingrijpende regelingen voor de in- en uitvoer af. Invoer van militaire goederen werd verboden; invoer van een reeks andere goederen werd alleen nog toegestaan met vergunning van het gouvernement; uitvoer werd voor de meeste producten eveneens van een gouvernementele vergunning afhankelijk. Hierbij aansluitend kondigde Pinke een scheepvaartverordening af. Ieder schip dat uit het buitenland goederen naar een Republikeinse haven wilde vervoeren moest zich eerst onderwerpen aan onderzoek in een Nederlandse controlehaven; ieder schip dat goederen uit de Republiek wilde uitvoeren moest eerst een Nederlandse controlehaven aandoen om een uitvoervergunning aan te vragen.

Hoewel deze regelingen formeel geen blokkade inhielden, kwamen ze er in de praktijk wel op neer. Een Amerikaans schip dat in Tjirebon rubber en suiker ingeladen had waarvoor de reder geen uitvoervergunning wilde aanvragen werd begin maart door de Nederlandse marine naar de haven van Batavia opgebracht; de lading werd verbeurd verklaard. Ook tegen enige schepen onder Britse vlag trad de marine krachtig op. Een en ander leidde weliswaar tot protesten van de Amerikaanse en de Britse regering, maar dit bracht geen verandering in het Nederlandse optreden. De marineblokkade slaagde er dan ook in de buitenlandse handel van de Republiek drastisch te beperken.

\section{Ondertekening van het akkoord van Linggadjati}

$\mathrm{Na}$ een afwezigheid van anderhalve maand keerde de commissie-generaal op 9 januari 1947 in Batavia terug. Tijdens haar afwezigheid hadden zich tal van problemen voorgedaan die de tenuitvoerlegging van het in oktober 1946 gesloten bestand niet ten goede kwamen. Bij de meeste enclaves hadden de plaatselijke commandanten van de Nederlandse en Republikeinse troepen geen overeenstemming over de vaststelling van demarcatielijnen bereikt. De stafchefs van de beide legers, generaal Buurman van Vreeden en generaal Oerip Soemohardjo, waren daarop samen met de Republikeinse minister van defensie Amir Sjarifoeddin en met plaatsvervangers van Van Mook langs de fronten op Java en Sumatra gereisd, maar ook zij hadden niet alle moeilijkheden kunnen oplossen. De Republikeinse opperbevelhebber Soedirman had nog geen bevel tot 'staakt-het-vuren' gegeven. Van Republikeinse kant vonden beschietingen en overvallen plaats, van Nederlandse kant 'zuiveringsacties' en gebiedsuitbreidingen. Het ernstigste incident was in december in Buitenzorg voorgevallen; daar had de Nederlandse troepencommandant de door de Republiek aangestelde resident, burgemeester en politiechef gevangen geno- 
men op verdenking van betrokkenheid bij anti-Nederlandse acties. Generaal Soedirman had hier met een felle radiotoespraak op gereageerd, waarna vooral op Sumatra de strijd weer opgelaaid was. In het licht van deze algemene verslechtering van het politieke klimaat hield de commissie-generaal zich na haar terugkeer intensief bezig met pogingen tot bemiddeling bij militaire confrontaties. Zij slaagde hier slechts ten dele in. Onder meer kon zij niet verhinderen dat Nederlandse troepen bij Soerabaja tot grote operaties overgingen waarbij ze het bezette gebied uitbreidden tot voorbij de stadjes Sidoardjo en Modjokerto.

Intussen was het de hoofdtaak van de commissie-generaal te bewerkstelligen dat het akkoord van Linggadjati zou worden ondertekend, onder aanvaarding door de Republiek van alles wat in december van Nederlandse kant was neergelegd in de toelichting van de commissie-generaal zelf en in de verklaringen van minister Jonkman. De Nederlandse regering bond haar bereidheid tot ondertekening bovendien aan nog twee andere voorwaarden: officiële afkondiging van het Republikeinse bevel tot staakt-het-vuren en medewerking aan de terugkeer van de nog binnen de Republiek vastgehouden geïnterneerden.

De Republikeinse delegatie verklaarde zich zonder meer bereid tot ondertekening van het geparafeerde akkoord, maar niet tot aanvaarding van de Nederlandse aankleding ervan. Niettemin had Schermerhorn nog goede hoop dat men de Republikeinse regering hier toch wel toe zou kunnen overhalen. Hij beschouwde de toelichting van de commissie-generaal als een redelijke weergave van de strekking van het akkoord en dacht dat de problemen voor de Republiek hoofdzakelijk betrekking hadden op enkele punten uit de verklaringen van Jonkman, zoals de uitzondering van Nieuw-Guinea. In werkelijkheid gaapte er een veel wijdere kloof tussen de Nederlandse en de Republikeinse kijk op het akkoord van Linggadjati. De Nederlandse beleidsmakers plachten daar namelijk iets in te lezen dat er niet in stond. Zij dachten dat de Republiek daarin de Nederlandse soevereiniteit over Indonesië erkende, dat zij haar eigen aanspraak op de soevereiniteit en dus op de jure gezag over heel Indonesië prijsgaf en dat zij alleen nog maar aanspraak maakte op de facto gezag over Java, Madoera en Sumatra.

Al op 10 december had Jonkman tijdens de parlementaire behandeling van het akkoord van Linggadjati gesteld, dat daarin de eerbiediging van de bestaande staatsrechtelijke en volkenrechtelijke positie van het Koninkrijk erkend werd, 'in het bijzonder in de artikelen 15, 1, 5 en 11'. Dit was een vreemde stelling, want geen van deze artikelen hield zo'n erkenning in. Blijkbaar konden de Nederlandse beleidsmakers zich moeilijk verplaatsen in de Indonesische zienswijze op basis van de onafhankelijkheidsverklaring van 17 augustus 1945. Aangezien die verklaring de staats- en volkenrechtelijke positie van het Koninkrijk principieel aanvocht, zou erkenning door de Republiek van de Nederlandse soevereiniteit over Indonesië eigenlijk zijn neergekomen op intrekking van de onafhankelijkheidsverklaring. Daarentegen verleende 
het ontwerp van Linggadjati juist een zekere status aan die Republiek, onder meer door te spreken van haar 'regering' en haar 'vertegenwoordigers'. De regering-Sjahrir handelde al in strijd met haar door het KNIP goedgekeurde onderhandelingsmandaat (zie p. 446), omdat zij bereid was een akkoord te sluiten dat niet voorzag in Nederlandse erkenning van de soevereiniteit van de Republiek. In haar visie hoefde echter het bestaan van conflicterende soevereiniteitsaanspraken geen beletsel te vormen voor een akkoord over de weg waarlangs de revolutionaire situatie zou kunnen overgaan in een door beide partijen erkende legale situatie.

De ongegronde stelling dat de Republiek in Linggadjati de Nederlandse soevereiniteit erkend zou hebben is ook in de verdere ontwikkeling van het conflict tussen Nederland en de Repubiek een belangrijke rol blijven spelen. De Nederlandse beleidsmakers baseerden die stelling in het bijzonder op artikel 15 van het akkoord. Deze uitleg van dat artikel was strijdig zowel met de tekst als met de ontstaansgeschiedenis ervan.

Artikel 15 betrof de overgangsperiode voor de totstandkoming van de Verenigde Staten van Indonesië en van de Nederlands-Indonesische Unie. Het was ontleend aan een door de Republikeinse delegatie voorgestelde tekst, die in de plaats was gekomen van een Nederlands voorstel over dit onderwerp. In beide teksten was sprake van hervorming van het Nederlands-Indische gouvernement teneinde dit in zijn samenstelling en werkwijze zo goed mogelijk te laten aansluiten op de erkenning van de Republiek en op de ontworpen staatsrechtelijke structuur. Volgens het oorspronkelijke Nederlandse voorstel zou in die overgangsperiode 'de staats- en volkenrechtelijke positie van het Koninkrijk der Nederlanden gehandhaafd blijven'. De Republikeinse delegatie had hier ernstig bezwaar tegen gemaakt. Amir Sjarifoeddin had opgemerkt dat hier soevereiniteit van het Nederlands-Indische gouvernement werd vastgelegd over het de facto gezagsgebied van de Republiek. Sjahrir had gezegd dat de Republiek aanstonds een duidelijke internationale status wilde hebben en niet wenste te worden teruggedrongen in de positie van een autonome provincie. De Republikeinse delegatie had daarna een alternatief voorstel ingediend waarin de geciteerde passage was vervallen. De commissie-generaal had het Republikeinse voorstel aanvaard; zij dacht dat het alleen om een redactionele wijziging ging en zag niet in dat de nieuwe tekst de strekking van het artikel wezenlijk veranderde.

Terwijl de Nederlandse regering aan het akkoord van Linggadjati een eigen aankleding had gegeven, gingen Schermerhorn en Van Mook bovendien de term 'Linggadjati' gebruiken op een manier die zich nog verder van het oorspronkelijke akkoord verwijderde. Bezorgd over het hevige verzet in Nederland tegen iedere constructie waarbij Indonesië geen deel van het Koninkrijk meer zou vormen (zie pp. 509-10), bepleitten zij dat de regering zich zou vastleggen op de uitvoering van het schema van Linggadjati ook als 
men daartoe geen medewerking van de Republiek zou krijgen. In die context doelde de term dus niet meer op samenwerking tussen Nederland en de Republiek ter oplossing van hun onderlinge conflict, maar alleen nog op de ontworpen hervorming van het Koninkrijk tot een Unie tussen een verkleind Koninkrijk en een zelfstandige Indonesische federatie. 'Linggadjati' werd daardoor vrijwel een synoniem van 'Malino'.

Schermerhorn en Van Mook kwamen tot hun voorstel om 'Linggadjati' eventueel ook zonder de Republiek uit te voeren, omdat zij rekening hielden met de mogelijkheid van een Nederlandse militaire actie die hetzij een eind zou maken aan de Republiek zelf hetzij een eind zou maken aan haar bereidheid tot uitvoering van het akkoord. Schermerhorn was er steeds van uitgegaan dat men bij het streven naar een politiek akkoord met de opstandige Republiek over een militair alternatief moest beschikken. Toen zijn regering in 1945 met deze opstand geconfronteerd werd, ontbraken haar de machtsmiddelen om daar tegen op te treden, maar de opbouw van de Nederlandse strijdmacht in Indonesië had de situatie geleidelijk veranderd. Men mocht aannemen dat de komst van de Nederlandse vrijwilligersbataljons in het voorjaar van 1946 al had bijgedragen tot de totstandkoming van het Hoge Veluwe-overleg en dat de komst van de eerste divisie van dienstplichtigen in het najaar het overleg in Linggadjati had bevorderd. Nu naderde men in de eerste maanden van 1947 het stadium waarin de Nederlandse strijdmacht in staat zou zijn tot grootschalig militair optreden.

Zelf waren Schermerhorn en Van Mook in deze fase geen voorstanders van een militaire campagne gericht op volledige uitschakeling van de Republiek. Zij vreesden daarvan langdurige schade voor de betrekkingen tussen het Nederlandse en het Indonesische volk. Nog steeds hoopten zij dat het mogelijk zou zijn het in Linggadjati overeengekomen plan samen met de Republiek uit te voeren. Niettemin hadden zij geen principieel bezwaar tegen het toebrengen van een 'harde klap' in de vorm van een beperkte militaire actie. Dit zou de regering-Sjahrir misschien tot een meer coöperatieve houding kunnen brengen, vooral als zij daardoor sterker zou komen te staan tegenover generaal Soedirman en de militante jongeren. Generaal Spoor pleitte in januari 1947 persoonlijk bij de Nederlandse regering voor het toebrengen van zo'n harde klap op een politiek geschikt moment. Zowel Schermerhorn en Van Mook als Spoor waren echter van mening, dat een militair optreden tegen de Republiek de Nederlandse positie op het internationaal-politieke toneel ernstige schade zou toebrengen als Nederland voordien het akkoord van Linggadjati niet had willen ondertekenen terwijl de Republiek daar wel toe bereid was.

Het werd duidelijk dat de Nederlandse regering zichzelf in een impasse gemanoeuvreerd had met haar eis dat de Republikeinse regering de aankleding van het akkoord moest aanvaarden. Zij kwam steeds meer onder druk te staan. De Republiek bemoeilijkte de voedselaanvoer naar de Nederlandse 
enclaves. Aan de andere kant gaf Soedirman op 15 februari eindelijk het lang verwachte officiële bevel tot staakt-het-vuren en werden er goede vorderingen gemaakt met de evacuatie van de geïnterneerden, zodat aan de twee aanvullende voorwaarden van de Nederlandse regering was voldaan. Bovendien nam de leiding van de Republiek stappen om haar beleid te laten onderschrijven door het KNIP, dat sinds maart 1946 niet meer plenair bijeengekomen was.

Dit was geen simpele zaak, want in het bestaande KNIP hadden de tegenstanders van Linggadjati de meerderheid. Eind december maakte Soekarno echter gebruik van het feit dat al eerder in het jaar besloten was de samenstelling van dit lichaam te vernieuwen maar dat men over de invulling hiervan geen overeenstemming bereikt had. Hij hakte nu de knoop door en breidde het KNIP tot vijfhonderdveertien leden uit, wat meer dan een verdubbeling inhield. Van de nieuwe leden werd een deel uitdrukkelijk aangewezen als vertegenwoordigers voor Sumatra, Borneo, Celebes, de kleine Soendaeilanden en de Molukken. Op 25 februari kwam het KNIP in Malang in zijn oude samenstelling bijeen. De oppositie verzette zich fel tegen het besluit tot uitbreiding, maar staakte uiteindelijk haar verzet toen Hatta dreigde dat hij en Soekarno zouden aftreden als men die uitbreiding niet aanvaardde. Van 1 tot 5 maart behandelde het KNIP in zijn nieuwe samenstelling het regeringsbeleid met betrekking tot Linggadjati. Sjahrir noemde het ontwerp-akkoord een middel tot vereniging van heel Indonesië onder de Republiek. Uiteindelijk keurde het KNIP het beleid goed met 284 stemmen voor en 2 tegen; de fracties van PNI en Masjoemi namen niet aan de stemming deel.

Midden maart deed de regering-Sjahrir een kleine handreiking aan Nederland. Zij verklaarde dat zij er geen bezwaar tegen had de toelichting van de commissie-generaal en de verklaringen van minister Jonkman op te vatten als de weergave van datgene waaraan Nederland zich door ondertekening van het akkoord gebonden zou achten, zonder dat zij zichzelf aan die stukken bond. Hierop liet de Nederlandse regering haar eis eindelijk vallen en machtigde zij de commissie-generaal tot ondertekening. Op 25 maart werd het akkoord van Linggadjati in een paleis van het gouvernement ondertekend door Schermerhorn, Van Mook en Van Poll enerzijds en Sjahrir, Roem en Gani anderzijds. De Boer deed hier niet aan mee; hij was als lid van de commissiegeneraal afgetreden nadat de regering overstag gegaan was.

\section{Dekolonisatie in andere delen van Azië}

Terwijl de ontvoogding van Indonesië in Nederland zoveel verzet opriep dat de regering het akkoord van Linggadjati niet onvoorwaardelijk wilde aanvaarden, bevonden sommige andere Aziatische landen zich al een stuk verder op de weg naar dekolonisatie. Overigens waren de koloniale overheersers van 
deze landen daar nooit zo nauw mee verweven geweest als de Nederlanders met Indonesië.

De Filippijnen, die in 1898 een kolonie van de Verenigde Staten waren geworden, hadden de weg naar dekolonisatie intussen al geheel achter zich. Het Amerikaanse congres had in 1933 besloten dat dit land zelfbestuur zou krijgen onder een eigen president en vervolgens na tien jaar onafhankelijk zou worden (zie p. 233). De Tweede Wereldoorlog, waarin de Filippijnen door Japan veroverd werden en de Filippijnse president Quezon naar de Verenigde Staten uitweek, had dit schema slechts weinig vertraagd. Overigens had de Japanse regering in 1943 zelf de Filippijnen formeel onafhankelijk gemaakt, maar aan deze schijnonafhankelijkheid kwam een eind toen de Amerikaanse strijdkrachten het land begin 1945 heroverden. Terstond na de oorlog bereidden de Verenigde Staten de definitieve machtsoverdracht voor; op 4 juli 1946 verleenden ze de Filippijnen volledige onafhankelijkheid. Quezon was inmiddels gestorven; tot nieuwe president werd een man gekozen die tijdens de oorlog met Japan gecollaboreerd had, maar niettemin steun kreeg van generaal MacArthur. Overigens werd het land nu geteisterd door een intern conflict tussen een linkse verzetsbeweging die tijdens de oorlog tegen de Japanse bezetters gestreden had en de Filippijnse grootgrondbezitters die de staatsmacht grotendeels in handen hadden.

De Filippijnen waren vooralsnog het enige Aziatische land dat na de wereldoorlog definitief gedekoloniseerd was. In de Franse kolonie Indochina, bestaande uit Cambodja, Laos en Vietnam, was het uitzicht op vreedzame dekolonisatie in het voorjaar van 1947 aanzienlijk minder gunstig geworden dan een jaar daarvoor. Er was nu een complete oorlog aan de gang tussen het Franse leger en de strijdkrachten van de Democratische Republiek Vietnam, die in september 1945 uitgeroepen was door de communistische verzetsleider Ho Chi Minh. Zoals op p. 450 vermeld, had de Franse regering in maart 1946 een akkoord met hem gesloten dat onder meer inhield dat zij deze Republiek als een vrije staat erkende en dat die staat deel zou uitmaken van een Indochinese federatie die op haar beurt deel zou zijn van een Franse Unie. De Republiek had daarop Franse militairen tot het noordelijke deel van Vietnam toegelaten. Na dit veelbelovende begin was de verhouding echter snel verslechterd. Om de uitwerking van het akkoord te bespreken was Ho Chi Minh zelf naar Frankrijk gegaan; de Franse regering had hem met veel eer ontvangen, maar ondanks langdurig overleg bereikte men geen overeenstemming. Eén van de struikelblokken was de soevereiniteitskwestie. De Republiek Vietnam nam het standpunt in dat zij onafhankelijk was en aanspraak kon maken op diplomatieke betrekkingen; de Franse regering wees dit af. Het feit dat de Republiek onder communistische leiding stond droeg ook tot verkoeling van de verstandhouding bij, nu de Koude Oorlog op gang begon te komen. Intussen voerden ambtenaren van het Franse koloniale bestuur in Indochina een eigen 
beleid. Ze richtten in het zuiden van Vietnam een aparte deelstaat op onder een Fransgezinde regering en met Saigon als hoofdstad. Met hulp van het Franse leger werden ook Cambodja en Laos tot Fransgezinde deelstaten hervormd. Ho Chi Minh keerde naar het noordelijke deel van Vietnam terug. Na een reeks bloedige incidenten tussen Vietnamezen en Fransen riep hij zijn volgelingen op 21 december 1946 op tot een nationale verzetsoorlog tegen Frankrijk.

Heel anders verliepen de ontwikkelingen in Birma. Zoals op p. 233 vermeld, had deze Britse kolonie al in 1937 zelfbestuur gekregen, met een gekozen parlement en een uit Birmanen bestaande regering. Niettemin had een inheems opstandelingenleger onder Aung San de Japanse strijdkrachten gesteund toen die het land in 1942 veroverden. In 1943 had de Japanse regering Birma evenals de Filippijnen formeel onafhankelijk gemaakt; Aung San was toen minister van defensie en commandant van het nationale leger geworden. In maart 1945 was hij echter met zijn leger naar de Britten overgelopen, toen dezen de Japanners uit Birma verdreven. Hoewel Aung San onder Japanse supervisie veel zwaardere functies bekleed had dan Soekarno en Hatta, besloot Mountbatten na de oorlog met hem in overleg te treden. De Britse regering stelde onafhankelijkheid in het vooruitzicht. In 1946 werd Aung San zelf minister-president. In 1947 versnelden de Britten de voorbereiding van de onafhankelijkheid en bepaalden zij dat die op 4 januari 1948 zou ingaan. Overigens leed Birma evenals de Filippijnen onder ernstige interne verdeeldheid. Een uiterst rechtse groepering pleegde op 19 juli 1947 een aanslag op de regering terwijl die in vergadering bijeen was; Aung San en zes van zijn ministers vonden daarbij de dood.

Diepe interne verdeeldheid heerste ook in India; de laatste jaren was dit zelfs de voornaamste hindernis op de weg naar onafhankelijkheid. De Britse regering had zich in 1942 bereid verklaard na de oorlog stappen te nemen voor het verlenen van onafhankelijkheid, mits de nationalistische Congres-partij zich nu achter de Britse oorlogsinspanning zou scharen en mits zij ermee zou instemmen dat delen van het land die voornamelijk door moslims bewoond werden zich van India zouden mogen afscheiden (zie p. 373). De Congres-partij had dit verworpen en had geëist dat de Britten het land onmiddellijk zouden verlaten; zij had deze eis met een scherpe massa-actie kracht bijgezet. Het Britse bestuur had daarop de leiders van de Congres-partij, onder wie Gandhi en Nehru, gevangen genomen; zij bleven tot het eind van de oorlog geïnterneerd. Een en ander versterkte de invloed van de Moslim-Liga onder Jinnah.

$\mathrm{Na}$ de oorlog ontwierp de Britse regering een plan voor een Indiase federatie waarin de hindoeprovincies en de moslimprovincies een eigen positie zouden krijgen, maar dit plan werd zowel door de Congres-partij als door de Moslim-Liga verworpen. Jinnah wilde een eigen onafhankelijke staat voor de door moslims bewoonde delen van het land. Midden 1946 begon de Liga een massa-actie die op verschillende plaatsen leidde tot bloedige gevechten tussen 
hindoes en moslims. In september stelde het Britse bestuur een Indiase interimregering in met Nehru als minister-president. Enige tijd later trad ook de Moslim-Liga tot deze regering toe, maar de twee partijen bleven het volstrekt oneens over de toekomst van het land.

De Britse regering besloot niet langer op overeenstemming tussen hindoes en moslims te wachten. Op 20 februari 1947 maakte premier Attlee bekend dat Groot-Brittannië de soevereiniteit over het Indiase subcontinent op 30 juni 1948 zou overdragen, ongeacht of er dan wel of niet één inheemse regering zijn zou. Louis Mountbatten, de voormalige opperbevelhebber van South-East Asia Command, werd tot onderkoning van India benoemd met de taak de machtsoverdracht voor te bereiden. Terwijl het land opnieuw door botsingen tussen de bevolkingsgroepen geteisterd werd wist Mountbatten de leiders van de Congres-partij ertoe over te halen toch in te stemmen met verdeling van het subcontinent in twee soevereine staten. Een buitengewone versnelling van de machtsoverdracht stond hier tegenover: al op 15 augustus 1947 zou het hele gebied onafhankelijk worden in de vorm van twee nieuwe dominions onder de Britse kroon: India en Pakistan.

Een afzonderlijke regeling werd met Ceylon getroffen; het zou in februari 1948 onafhankelijk worden.

Invloed van de koloniale troika en van de Indische Nederlanders op het Nederlandse beleid

De Nederlandse opstelling tegenover de Republiek stond in 1947 sterk onder invloed van bepaalde groepen Nederlanders wier leven en loopbaan nauw met Indonesië verbonden waren. Het ging hierbij vooral om de Nederlandse ambtenaren van het Binnenlands Bestuur, de Nederlandse beroepsofficieren van het KNIL en de Nederlandse eigenaren en leidende functionarissen van de grote productieondernemingen (de 'ondernemers'). Die drie groepen worden wel eens als de 'koloniale troika' aangeduid. Daarnaast ging ook invloed uit van de Nederlanders van gemengde Europees-Aziatische afstamming, de 'Indische Nederlanders'.

De BB-ambtenaren en de KNIL-officieren vormden zozeer een bestanddeel van het koloniale bestel, dat volledige Indonesische onafhankelijkheid hen van hun bestaansgrond zou beroven. Zij zouden dan ook het liefst het vooroorlogse bestel hebben zien terugkeren, al begrepen ze wel dat dit nu niet meer mogelijk was. Het was in hun kring ongebruikelijk om politieke motieven te erkennen voor verzet tegen het koloniale gezag; men placht zulk verzet als 'verstoring van de orde en rust' te betitelen en het niet als een politiek maar als een 'politioneel' probleem te behandelen. Ook vergeleek men de verhouding tussen de inheemse bevolking en het koloniale gezag graag met 
die tussen onmondige kinderen en hun opvoeders. Dit bleek onder meer uit het in hun kring gangbare gebruik om militair optreden tegen inheems verzet aan te duiden als 'slaan', in overeenstemming met de opvoedkundige theorie dat lijfelijke tuchtiging een doeltreffend middel was om volgzaamheid en zelfs aanhankelijkheid aan te kweken.

De BB-ambtenaren en KNIL-officieren waren er algemeen van overtuigd dat de grote meerderheid van de inheemse bevolking Nederlandsgezind was. In hun ogen vertegenwoordigde de Republiek een ontoelaatbare rebellie die eigenlijk terstond onderdrukt had moeten worden; in 1945 en 1946 was dit door gebrek aan machtsmiddelen en door Britse tegenwerking onmogelijk geweest, maar nu de Britten vertrokken waren en Nederland over een krachtige strijdmacht beschikte lag de zaak anders. In het algemeen waren deze ambtenaren en officieren dan ook gekant tegen het met de rebellen gesloten akkoord van Linggadjati.

De BB-ambtenaren waren gewoonlijk paternalistisch ingesteld. Zij waren verknocht aan 'Indië' (waar velen van hen ook geboren waren) en wilden er graag hun beste krachten aan wijden; tegelijkertijd waren ze ervan overtuigd dat de inheemse bevolking zelf de capaciteiten miste om het land behoorlijk te laten functioneren. In hun ogen was het daarom in het belang van die bevolking dat Nederlanders ook in de toekomst een leidende rol in het land zouden spelen. Deze ambtenaren waren gewend de feodale elementen binnen de inheemse samenleving als de natuurlijke bestuurselite van het land te zien. Vol aandacht voor de verschillen tussen de vele volkeren binnen de archipel waren zij geneigd het bestaan van een Indonesische natie te ontkennen. Zij steunden graag het denkbeeld van een federale structuur voor de toekomstige Indonesische staat. Die zou bij voorkeur moeten bestaan uit etnisch van elkaar verschillende eenheden, geleid door 'goedwillende' (dat wil zeggen Nederlandsgezinde) aristocraten met steun van Nederlandse deskundigen.

De KNIL-officieren zagen de Republiek in de eerste plaats als een product van Japanse indoctrinatie en communistische opruiing. Zij zouden deze Republiek bij voorkeur met militaire middelen willen uitschakelen, in lijn met de lange traditie van het koloniale leger bij het onderdrukken van verzet tegen het Nederlandse gezag. Men zou het Republikeinse bestuur dan kunnen vervangen door Indonesiërs die Nederland welgezind waren. Het was bemoedigend voor de KNIL-officieren dat het beroepskader van de Nederlandse landmacht en marine hun visie deelde. Verder hadden zij er persoonlijk belang bij dat hun professionele leger niet als gevolg van de nieuwe staatkundige constructie zou moeten verdwijnen. $\mathrm{Zij}$ gingen er dan ook algemeen van uit dat zij met dit leger zouden overgaan naar de te vormen nieuwe staat, de Verenigde Staten van Indonesië. Het geïmproviseerde leger van de Republiek, waarvoor zij weinig respect hadden, zou ontbonden moeten worden.

Van de binnen het KNIL gangbare visie op het conflict met de Republiek 
ging een aanzienlijke invloed op het beleid uit dank zij het optreden van de legercommandant, generaal Spoor, die in Nederland groot gezag genoot. Herhaaldelijk voerde hij in Den Haag uitvoerig overleg met de regering, onder meer in juli-augustus 1946 en in januari 1947. Sommige van zijn denkbeelden legde hij rechtstreeks aan minister-president Beel voor. Zo schreef hij eind december 1946 aan Beel onder meer dat in de nabije toekomst alleen onder Nederlands gezag iets van Indonesië terecht zou kunnen komen, dat men de uitwerking van het akkoord van Linggadjati niet aan de commissie-generaal moest toevertrouwen en dat hij zelf misschien ontslag zou nemen als de nu gevolgde lijn ongewijzigd doorgetrokken werd. Spoor had ook goede contacten met Nederlandse politici; daartoe behoorden zowel de KVP-leider Romme die een steunpilaar van de regeringscoalitie was als de leiders van de ARP die het Indonesiëbeleid van de regering fel bestreden. Verder maakte Spoor graag gebruik van de nieuwsmedia om zijn zienswijze te verbreiden. Tijdens zijn bezoek aan Nederland in januari 1947 verklaarde hij bijvoorbeeld op een persconferentie, dat de Nederlandse strijdmacht sterk genoeg was om bij nietondertekening van het akkoord van Linggadjati de rust en orde in Indonesië te verzekeren. Verder schetste hij een alarmerend beeld van de Republikeinse bestandsschendingen, waarbij hij zei er niet voor te voelen 'directeur van een schiettent' te worden.

De politieke visie van het KNIL bereikte Nederland ook nog langs een andere weg. Onder de legercommandant functioneerde een uitgebreide voorlichtingsdienst die onder meer belast was met de politieke voorlichting van de naar Indonesië overgebrachte vrijwilligers en dienstplichtigen van de KL en de mariniersbrigade. Deze dienst vermeed het te spreken van een 'Republikeins leger', maar hanteerde een vijandbeeld dat de tegenstanders stelselmatig als terroristen en bandieten voorstelde. Volgens deze voorlichting leed de bevolking op Republikeins gebied onder de terreur van de nationalistische extremisten en waren de Nederlandse troepen naar Indonesië gekomen om die bevolking daarvan te bevrijden. De overgrote meerderheid van de vrijwilligers en dienstplichtigen nam deze voorstelling van zaken over; voor hen was dit de enige aannemelijke rechtvaardiging voor hun verblijf aan de andere kant van de aardbol. Zij zouden dat verblijf als een zinloze tijdverspilling ervaren als ze uiteindelijk onverrichterzake zouden moeten terugkeren. Hun frustraties werden verscherpt door de onprettige omstandigheden waarin ze verkeerden, massaal opgesloten in een klein aantal enclaves die aan vijandelijke beschietingen blootstonden. De visie van deze militairen op het conflict in Indonesië klonk door in hun brieven aan familie en vrienden en oefende daardoor ook invloed uit op de opvattingen in Nederland.

Formeel waren de opvattingen van de KNIL-officieren en de bestuursambtenaren van ondergeschikt belang, want het was niet hun taak om het beleid te bepalen. Maar dit waren wel de mensen waarmee men het beleid moest uitvoe- 
ren. Hun opvattingen beperkten onder meer de beleidsruimte van Van Mook. Een frontale botsing met Spoor zou zijn eigen positie in gevaar brengen, want Spoor genoot wel maar hijzelf niet het vertrouwen van de Nederlandse regering. Bovendien plaatsten zowel de officieren als de ambtenaren Van Mook herhaaldelijk voor voldongen feiten met ernstige politieke consequenties.

Ook aan de zienswijze van de andere Nederlanders in Indonesië kon men niet zonder meer voorbijgaan. De overgrote meerderheid daarvan was tegen het akkoord van Linggadjati en hoopte op militaire uitschakeling van de Republiek. Onder deze Nederlanders vormden de ondernemers een belangrijke pressiegroep. Dit derde bestanddeel van de koloniale troika had zijn basis in de op export uit Indonesië gerichte productieondernemingen. Dit betrof vooral agrarische producten zoals suiker, koffie, thee, tabak en rubber, maar ook minerale producten als aardolie en tin. De ondernemers hadden in de koloniale samenleving een invloedrijke positie bekleed; al sinds de negentiende eeuw hadden ze grote samenwerkingsverbanden gevormd voor de behartiging van hun belangen (zie p. 192). Door de oorlog was de export uit Indonesië abrupt als Nederlandse inkomstenbron weggevallen. Onder de Japanse bezetting was het werk op een deel van de plantages en fabrieken stil komen te liggen, terwijl het op sommige andere onder Japanse en Indonesische leiding voortgezet was. Nu de oorlog voorbij was, hadden de ondernemers er belang bij snel weer over hun bedrijven in Indonesië te kunnen beschikken. Hun belang liep hierin parallel met dat van de Nederlandse regering, die meende dat Nederland een rampzalige toekomst tegemoet ging als het de Indonesische exportproductie als bron van inkomsten en vooral als bron van buitenlandse deviezen zou moeten missen.

Vertegenwoordigers van de ondernemers hadden veel contact met de Nederlandse regering en met het Nederlands-Indische gouvernement. In theorie was de exploitatie van de productiebedrijven niet van het koloniale bestel afhankelijk, maar zou die ook in een onafhankelijk Indonesië kunnen plaatsvinden. De Republiek had daar in haar Politiek Manifest van 1 november 1945 al op gewezen. De ondernemers waren hier echter weinig ontvankelijk voor. In het tijdperk tussen de beide wereldoorlogen hadden ze al een bolwerk van koloniaal-conservatisme gevormd; het lag voor de hand dat ze nu geen vertrouwen in de Republiek hadden. Bovendien bestond in die Republiek een actieve vakbeweging die streefde naar verbetering van de beloning en de arbeidsomstandigheden van de plantage- en fabrieksarbeiders, terwijl sommige politici zelfs voor onteigening van de westerse productiebedrijven pleitten. De Nederlandse ondernemers verwachtten van hun regering dat die haar militaire macht zou gebruiken om hen in staat te stellen de exploitatie van hun bedrijven te hervatten. Ze verlangden bovendien dat de regering ervoor zou zorgen dat men die exploitatie ook in de toekomst in veiligheid zou kunnen voortzetten. 
De vierde groepering in Indonesië die de Nederlandse opstelling tegenover de Republiek beïnvloedde werd niet gekenmerkt door haar beroepsuitoefening maar door haar afstamming en rechtspositie. Zij omvatte die personen van gemengde Europees-Aziatische afkomst die in het koloniale rechtsbestel de status van Europeanen genoten. Deze Indo-Europeanen vormden een bevolkingsgroep van aanzienlijk grotere omvang dan de blanke Europeanen. In overgrote meerderheid bezaten zij de Nederlandse nationaliteit en werden zij daarom 'Indische Nederlanders' genoemd. Omdat het koloniale bestel de Europeanen in allerlei opzichten tegenover de 'Inlanders' bevoorrechtte (zie pp. 132-3), hadden deze Nederlanders bij de dekolonisatie veel te verliezen. Hun toekomst stond daarbij zelfs ernstiger op het spel dan die van de blanke Nederlanders; de laatsten konden immers naar Nederland terugkeren, maar voor de Indische Nederlanders was Indonesië het eigen thuisland. In het tijdvak tussen de beide wereldoorlogen had een groot deel van hen zich tegen het Indonesische onafhankelijkheidsstreven gekeerd (zie p. 180). In de laatste maanden van 1945 had de tegenstelling tussen deze Nederlanders en de Indonesische nationalisten zich verscherpt, toen de eersten bij uitstek het doelwit van de bersiap-terreur vormden (zie p. 400). Slechts weinig Indische Nederlanders traden de Repubiek positief tegemoet; de meesten waren haar vijandig gezind.

Intussen drong het besef door dat het koloniale bestel hoe dan ook gedoemd was te verdwijnen. Veel Indische Nederlanders zagen er tegen op te moeten leven in een door de Indonesiërs zelf geleide onafhankelijke staat. Men zou zich daaraan kunnen onttrekken door naar Nederland te verhuizen, maar meestal wilde men liever in dit deel van de wereld blijven. Emigratie naar Australië of Nieuw-Zeeland was echter voor de meeste van deze Nederlanders onmogelijk, omdat die landen geen immigranten van Aziatische afkomst toelieten. Een en ander leidde tot groeiende belangstelling voor een andere oplossing: vestiging in Nieuw-Guinea. Al voor de oorlog was onder de Indische Nederlanders een beweging ontstaan voor transmigratie naar dat uitgestrekte maar dun bevolkte gebied. In de naoorlogse situatie dachten velen dat NieuwGuinea een nieuw thuisland voor hun bevolkingsgroep zou kunnen worden, mits de band van dat gebied met Nederland gehandhaafd bleef en het dus geen deel zou uitmaken van de komende onafhankelijke Indonesische staat.

\section{Nederlands-Indonesisch overleg over de uitvoering van Linggadjati}

De Nederlandse houding na de ondertekening van de overeenkomst van Linggadjati op 25 maart 1947 stelde de leiders van de Republiek teleur. In tegenstelling tot hun verwachtingen werd de Nederlandse blokkade van de Republikeinse havens niet opgeheven. De Republikeinse gouverneurs 
van Celebes en de kleine Soenda-eilanden en de Republikeinse resident van Buitenzorg, die door het Nederlandse bestuur van hun vrijheid beroofd waren, kwamen niet vrij. Overal waar dit bestuur de Indonesische rood-witte vlag en het Indonesische volkslied 'Indonesia Raja' verboden had, bleven die verboden van kracht. De na het bestand van oktober door Nederlandse troepen uitgevoerde gebiedsuitbreidingen, zoals die bij Sidoardjo en Modjokerto, bleven gehandhaafd. Terwijl bij dat bestand een vermindering van de Nederlandse troepensterkte in uitzicht was gesteld, maakte Nederland nu een nieuwe divisie voor uitzending gereed.

De op 25 maart ondertekende basisovereenkomst bestond uit een beperkt aantal bepalingen, waarvan de meeste vrij beknopt geformuleerd waren en in overleg tussen de beide partijen nader uitgewerkt moesten worden. Bovendien verlangde Nederland dat men het politieke akkoord zou aanvullen met een akkoord over economische en financiële kwesties. De commissie-generaal (nu nog alleen bestaande uit Schermerhorn, Van Mook en Van Poll) en de door Sjahrir geleide Republikeinse delegatie begonnen daarom na de ondertekening met overleg over die uitwerking en aanvulling. Daarbij sprak men nog niet over de toekomstige inrichting van de Verenigde Staten van Indonesië en van de Nederlands-Indonesische Unie. Men hield zich alleen bezig met de overgangsperiode voor de totstandkoming van de VSI en de Unie, een periode die volgens artikel 12 niet veel langer dan anderhalf jaar zou behoeven te duren. De Nederlandse voorstellen richtten zich in hoofdzaak op de buitenlandse betrekkingen en op economische onderwerpen zoals de invoer en uitvoer, het deviezenregime, de voedselvoorziening, de teruggave van de onder Republikeins beheer staande ondernemingen en de opheffing van de Australische boycot. Ook opende men besprekingen over militaire samenwerking en over de invoeging van de bezette gebieden in het Republikeinse gebied. Over de hervorming van het Nederlands-Indische gouvernement als bedoeld in artikel 15 werden nog geen voorstellen gedaan.

Het overleg speelde zich in drie fasen af. Nadat eind maart de eerste besprekingen hadden plaatsgevonden, volgde een onderbreking van twee weken. Sjahrir en enige andere leden van zijn delegatie namen toen in Delhi deel aan een Inter-Aziatisch Congres waartoe de Republiek uitgenodigd was door de interim-regering van India. Vervolgens vergaderden de twee delegaties een week lang intensief in het midden van april. Tijdens een tweede onderbreking pleegde de Republikeinse delegatie ruggenspraak in Jogja met de voltallige regering en met Hatta. Pas op 3 mei kwamen de delegaties opnieuw bijeen.

Evenals bij de besprekingen die in het voorjaar en het najaar van 1946 met de Republiek gevoerd waren, liet de Nederlandse regering haar onderhandelaars vrijwel geen onderhandelingsruimte. Niettemin leek de eerste fase van het overleg veelbelovend. Men gaf een gezamenlijke verklaring uit dat niemand vervolgd of geschaad zou mogen worden omdat hij zich bij één 
van de partijen aangesloten had. Ook kwam men overeen dat het gebied van Modjokerto gedemilitariseerd zou worden, terwijl het gezag daar zou worden uitgeoefend door Republikeinse burgerlijke autoriteiten. De verdere besprekingen verliepen echter uitermate moeizaam.

Hoewel de onderhandelaars op sommige punten wel nader tot elkaar kwamen, leidde het overleg over de meeste kwesties uiteindelijk niet tot overeenstemming. Een tijdens de tweede fase door Van Mook geopperd compromis werd zowel in Den Haag als in Jogja afgewezen. De hoofdreden voor het uitblijven van overeenstemming was het fundamentele meningsverschil over het oppergezag in de overgangsperiode (zie pp. 521-2). De Nederlandse voorstellen gingen ervan uit dat de Republiek in artikel 15 aanvaard had dat de soevereiniteit over heel Indonesië tijdens die periode bij Nederland bleef. Zowel voor als na de ondertekening van de basisovereenkomst had de Republikeinse delegatie bezwaar tegen deze uitleg gemaakt, maar dit werd van Nederlandse kant volstrekt genegeerd. Terwijl Sjahrir verklaard had dat de Republiek een internationale status wilde hebben en niet wenste te worden teruggedrongen in de positie van een autonome provincie, kenden de Nederlandse voorstellen aan de Republiek een plaats toe die ondergeschikt was aan het Nederlandse gezag. Zo zou zij haar externe economische belangen uitsluitend via de organen van het Nederlands-Indische gouvernement moeten behartigen. Ook werd de Republiek in die voorstellen op één lijn gesteld met de door het gouvernement gecreëerde deelstaat Oost-Indonesië, waarvan de autonomie toen nog weinig inhoud had. Daarentegen gingen de Republikeinse voorstellen ervan uit dat zich op het grondgebied van Indonesië gedurende de overgangsperiode twee regeringen bevonden, de Republikeinse regering voor het de facto onder haar gezag staande gebied op Java, Madoera en Sumatra en het Nederlands-Indische gouvernement voor de rest. Bovendien had de Republiek nooit formeel afgezien van haar aanspraken op de buiten Java, Madoera en Sumatra gelegen delen van de archipel (die men in die tijd gewoonlijk als de 'Malino-gebieden' betitelde).

De Nederlandse interpretatie van de overeenkomst bracht mee dat men verschillende van de Republikeinse voorstellen beschouwde als bewijzen van onwil om het akkoord van Linggadjati loyaal uit te voeren. Ook bracht die interpretatie mee dat men het als een schending van Linggadjati beschouwde dat de Republiek aanspraak bleef maken op het hebben van eigen vertegenwoordigers in het buitenland. Hetzelfde gold voor het handhaven van de functies van gouverneurs voor de Republikeinse provincies buiten Java en Sumatra. De commissie-generaal toonde zich dan ook niet bereid tot vrijlating van de Republikeinse gouverneurs voor Celebes en de kleine Soenda-eilanden zo lang de Republiek hen niet van hun gouverneursfuncties onthief. Ook verlangde zij opheffing van de organisaties in de Republiek die bestemd waren voor het voeren van actie in de Malino-gebieden. 
Er was nog een tweede reden voor de toenemende ontstemming bij de commissie-generaal: zij had de indruk dat de Republikeinse delegatie de besprekingen opzettelijk traineerde. Onder meer wekte het ergernis dat de Republiek voorwaarden wilde verbinden aan de teruggave van de ondernemingen als bedoeld in artikel 14. Zelf stond de commissie-generaal onder tijdsdruk, want om financiële en economische redenen meende zij dat een Nederlandse militaire actie als alternatief nog slechts gedurende enkele maanden mogelijk was. Daarentegen leek de tijd in het voordeel van de Republiek te werken. De ondertekening van het akkoord van Linggadjati had haar internationale positie versterkt; onder meer was zij daarna de facto erkend door de Amerikaanse, de Australische, de Britse en de Chinese regering. Nehru, de leider van de interim-regering van India, had Sjahrir tijdens het Inter-Aziatisch Congres als een collega behandeld. Na dit congres was de vice-minister van buitenlandse zaken, Agoes Salim, doorgereisd naar het Midden-Oosten waar hij door verscheidene regeringen werd ontvangen.

Intussen had de Republiek verschillende redenen om ongerust te zijn over de Nederlandse bedoelingen. Zo omzeilde Nederland de in artikel 4 neergelegde afspraak dat Borneo één van de samenstellende delen van de Indonesische federatie zou worden. Uitvoering van die afspraak kon voor de Republiek gunstig zijn, omdat zij vooral in Zuid- en Oost-Borneo over een sterke aanhang beschikte. Voor Van Mook was dat echter aanleiding om West-Borneo uit dit verband te lichten en er een aparte status aan te geven als een autonoom gebied dat op dezelfde voet als een deelstaat aan de vorming van de Indonesische federatie zou kunnen meewerken. Zonder overleg met de Republiek werd dit deel van Borneo op 12 mei omgezet in een daerah istimewa ('bijzonder gebied') onder leiding van sultan Hamid van Pontianak.

Nog veel verontrustender waren de Nederlandse inspanningen om delen los te maken van het gebied waarover in Linggadjati het de facto gezag van de Republiek erkend was. Al voor de ondertekening van het akkoord hadden sommige Nederlanders hun gedachten laten gaan over de mogelijkheid afscheidingsbewegingen binnen de Republiek te bevorderen. Daarbij dacht men onder meer aan de belangrijkste niet-Javaanse volkeren op Java, de twaalf miljoen Soendanezen die een groot deel van West-Java bewoonden en de ruim vier miljoen Madoerezen die zowel op het eiland Madoera woonden als in het meest oostelijke deel van Java. Al in november 1946 was een beweging ten tonele verschenen die de vorming propageerde van een Soendanese deelstaat onder de naam Pasoendan. Hoewel Van Mook hier zelf destijds niets voor voelde, genoot deze beweging de steun van hooggeplaatste BB-ambtenaren en KNIL-officieren; daarentegen vond zij weinig weerklank bij Soendanese politici. Niettemin riep zij op 4 mei 1947 in betogingen in Bandoeng en Buitenzorg de staat Pasoendan uit. Daarbij werden haar aanhangers met Nederlandse legerauto's vervoerd en deelden Nederlandse militairen Pasoendan-vlaggetjes 
uit. Het bleef eerst bij woorden, maar enkele weken later bezette de beweging enige Republikeinse kantoren in Buitenzorg, wederom met Nederlandse militaire steun. Pas daarna maakte Van Mook aan deze acties een eind. Intussen kwam nu ook een Madoerese afscheidingsbeweging op gang.

Eén van de belangrijkste elementen van Linggadjati voor de Republiek was de in artikel 16 neergelegde verplichting van de beide partijen om aanstonds tot vermindering van hun troepensterkte over te gaan. Weliswaar gold deze verplichting wederzijds, maar in de praktijk strekte ze tot voordeel van de Republiek: die zou een vermindering van haar troepensterkte vrij gemakkelijk ongedaan kunnen maken, terwijl het Nederland veel moeilijker zou vallen opnieuw troepen overzee aan te voeren wanneer de repatriëring van Nederlandse troepen eenmaal begonnen was. Sjahrir liet zijn Nederlandse gesprekspartners herhaaldelijk weten dat zijn regering zich in de andere kwesties tegemoetkomender zou kunnen opstellen als Nederland een duidelijk begin met de troepenvermindering maakte. Het overleg met de commissie-generaal over de uitvoering van artikel 16 gaf de Republiek echter op dit punt weinig hoop.

Schermerhorn verklaarde onverbloemd dat Nederland moest blijven beschikken over een militaire macht voor het geval dat de Republikeinse regering bij haar achterban geen voldoende steun zou vinden voor samenwerking op de basis van Linggadjati. Ook gaf de commissie-generaal te kennen het met het oog op de externe verdediging van Indonesië niet verantwoord te achten om hier geen Nederlandse troepen meer te laten. Wat de nabije toekomst betreft stelde de commissie-generaal voor te beginnen met de organisatie van een efficiënte politiemacht. In een volgende fase zouden dan de troepen van beide partijen in garnizoenen worden teruggetrokken. Waar Nederlandse troepen een bepaald gebied zouden ontruimen, zouden Republikeinse troepen dit niet terstond moeten overnemen. De Republikeinse delegatie ging met veel van deze voorstellen akkoord, maar stelde tegelijk een stopzetting voor van nieuwe troepenzendingen en nieuwe recruteringen. Ook bleek zij er wel degelijk van uit te gaan dat de Nederlandse troepen in de bezette gebieden door Republikeinse troepen zouden worden vervangen.

$\mathrm{Al}$ in de eerste week van de besprekingen was de commissie-generaal tot de overtuiging gekomen, dat deze overlegronde belangrijke beslissingen van de Nederlandse regering nodig zou maken die niet zouden kunnen wachten op een nieuw bezoek van de commissie-generaal aan Den Haag. Daarom drong zij er bij premier Beel en minister Jonkman op aan zelf naar Indonesië te reizen. De ministers kondigden aan op 7 mei in Batavia te zullen aankomen. Twee dagen voor hun komst maakte de commissie-generaal intern de balans op van het sinds eind maart gevoerde overleg. Zelf dacht zij vrij ver te zijn gegaan in haar pogingen om de wederpartij tegemoet te komen. Daarentegen meende zij dat bij de Republiek sprake was van een gezindheid die niet meer op samenwer- 
king gericht was. Men zou zich daarom moeten voorbereiden op de noodzaak van een militaire actie. Volgens Van Mook zou eind juni daarvoor de meest geschikte tijd zijn. Voor die tijd zou men de druk op de Republiek zo sterk mogelijk moeten opvoeren om haar alsnog tot medewerking te brengen.

\section{Verdeeldheid in Nederland over het gebruik van geweld tegen de Republiek}

In november 1945 had de Nederlandse regering besloten in Indonesië een grote strijdmacht bijeen te brengen volgens een schema waardoor die strijdmacht pas eind 1946 op sterkte zou zijn. Dit bracht mee dat Nederland niet voor 1947 in staat zou zijn met eigen machtsmiddelen zijn gezag over Indonesië te herstellen (zie pp. 419-20). Voor de opbouw van de Nederlandse strijdmacht bracht de regering zowel vrijwilligers als dienstplichtigen naar Indonesië over (zie pp. 447-8 en 475-7). In het voorjaar van 1947 werd het stadium bereikt dat deze strijdmacht volledig inzetbaar was. De vraag was nu of ze inderdaad tegen de Republiek zou worden ingezet.

Voor de leiders van de Nederlandse strijdkrachten in Indonesië was dit geen vraag. Hierop hadden ze zich voorbereid, hiervoor stonden ze klaar. Zij twijfelden niet aan de uitvoerbaarheid van een grootschalige militaire actie; aan de strijdkrachten van de Republiek kenden ze weinig gevechtswaarde toe. De meeste Nederlandse bestuursambtenaren gingen er eveneens van uit dat de tijd gekomen was om het Nederlandse gezag over Java en Sumatra met harde hand te herstellen.

In Nederland zelf liepen de meningen over de wenselijkheid van een grote militaire actie tegen de Republiek sterk uiteen. Duidelijk hiervoor geporteerd waren de partijen ter rechterzijde van de regeringscoalitie, de protestants-christelijke ARP, CHU en SGP en de rechts-liberale PvdV. Deze partijen hadden steeds het standpunt ingenomen dat Nederland eerst zijn gezag in Indonesië moest herstellen voordat het over politieke hervormingen zou mogen spreken. Hun opstelling, die uitdrukking vond in de leuze 'Niet onderhandelen, maar handelen!', werd geruggensteund door de hoogste chefs van de Nederlandse landmacht en zeemacht en sterk aangemoedigd door de buitenparlementaire oppositie van het Comité Handhaving Rijkseenheid (zie p. 510). De voorzitter van dit Comité, oud-premier Gerbrandy, werd steeds radicaler; in de eerste maanden van 1947 onderzocht hij zelfs de mogelijkheid van een staatsgreep om de eenheid van het Koninkrijk te redden. Nadat de regering het akkoord van Linggadjati had laten ondertekenen, organiseerde het Comité een handtekeningenactie voor een nieuw 'smeekschrift'. Daarin werd gevraagd om gerechtelijke vervolging van alle leden van het kabinetBeel wegens schending van de Nederlandse grondwet. Dit smeekschrift kreeg 240.000 handtekeningen. 
Het volkomen tegendeel van de opstelling van de rechtse partijen was die van de communisten, de partij ter linkerzijde van de regeringscoalitie. Zij waren zonder meer voor Indonesische onafhankelijkheid, tegen de uitzending van troepen naar Indonesië en tegen een militaire actie tegen de Republiek.

De opvattingen binnen de partijen van de regeringscoalitie, de Katholieke Volkspartij (KVP) en de Partij van de Arbeid (PvdA), waren minder eenvoudig. In de KVP stond een kleine groep, onder wie oud-minister Welter, op hetzelfde standpunt als de protestants-christelijke partijen; daarentegen had de meerderheid geen bezwaar tegen overleg met de Indonesische nationalisten. Wat de toekomstige verhouding met Indonesië betreft huldigden veel KVP-leden echter conservatieve opvattingen. Dat gold in het bijzonder voor de partijleider Romme. Weliswaar had hij zich niet tegen het akkoord van Linggadjati verzet, maar in zijn visie was geen plaats voor Indonesische onafhankelijkheid. Zijn opstelling tegenover Linggadjati was beïnvloed door generaal Spoor, die hem al in de zomer van 1946 gezegd had dat Nederland om internationaal-politieke redenen eerst een overeenkomst met de Republiek zou moeten sluiten voordat het militair zou kunnen optreden. In Romme's visie zou de Nederlands-Indonesische Unie een onopzegbaar staatsverband moeten zijn dat in verschillende opzichten de rol van het Koninkrijk zou overnemen. Hij verwachtte niet dat de Republiek bereid zou zijn tot medewerking aan de door hem beoogde hervorming van het Rijk en ging er dan ook van uit dat Nederland daartoe zijn militaire macht zou moeten gebruiken.

Terwijl in het voorjaar van 1947 binnen de KVP zeker steun te vinden was voor een grote militaire actie tegen de Republiek, leek het aannemelijk dat de PvdA zich daartegen zou verzetten. In september 1946 had een congres van deze partij de overtuiging uitgesproken 'dat tussen Nederland en Indonesië geen oorlog kan of mag worden gevoerd'. Een groot deel van de PvdAaanhang kwam uit de hoek van de vooroorlogse socialistische partij, de SDAP, waar men traditioneel afkerig was van koloniale oorlogen. Het akkoord van Linggadjati was in de PvdA geestdriftig ontvangen. Niettemin lag de kwestie van een eventuele inzet van de Nederlandse strijdmacht in Indonesië ook bij deze partij gecompliceerd. Zowel binnen de leiding als binnen de aanhang van de partij waren er velen die een militaire actie niet onder alle omstandigheden zouden afwijzen als die niet het karakter van een koloniale oorlog zou dragen. In feite stond slechts een minderheid van de partijaanhang echt positief tegenover het Indonesische onafhankelijkheidsstreven, een gezindheid die voornamelijk tot uitdrukking kwam in het dagblad Het Parool en het weekblad Vrij Nederland.

Binnen de regering stelden de vijf tot de KVP behorende ministers zich tegenover de Republiek hard op. Premier Beel zelf hechtte veel belang aan de meningen van Romme en van generaal Spoor. Van de tot de PvdA behorende ministers in dit kabinet hadden er vier ook deel van het kabinet-Schermerhorn 
uitgemaakt, waardoor zij medeverantwoordelijk waren voor de door dat kabinet ondernomen stappen tot opbouw van een grote strijdmacht in Indonesië. De vijfde PvdA-minister, Jonkman, was weliswaar al sinds zijn studietijd geporteerd voor ontvoogding van Indonesië, maar richtte zich niet op volkomen onafhankelijkheid voor dat land. Hoewel hij oorlog in Indonesië liefst zou willen vermijden, had hij geen principieel bezwaar tegen inzet van de Nederlandse militaire macht als het onmogelijk zou blijken via overleg met de Republiek tot een duurzame vorm van Nederlands-Indonesische samenwerking te komen. Overigens telde het kabinet inmiddels nog een zesde PvdAminister: L. Neher, opvolger van de in november afgetreden minister Ringers; zijn houding in de kwestie-Indonesië was overwegend conservatief.

Het coalitie-probleem lag voor de PvdA heel anders dan voor de KVP. Bij verbreking van de coalitie zou de PvdA niet meer in de regering kunnen terugkeren; daarentegen zou de KVP dan deel van de regering blijven uitmaken in een coalitie met rechtse partijen. Toegespitst op de kwestie van een grote militaire actie in Indonesië betekende dit dat, zelfs als PvdA-ministers zich daartegen zouden willen verzetten ten koste van de val van het kabinet, zij zo'n actie toch niet zouden kunnen tegenhouden.

\section{Ultimatieve voorstellen van Nederland aan de Republiek}

Het feit dat de Nederlandse strijdmacht in Indonesië in het voorjaar van 1947 volledig inzetbaar geworden was, betekende op zichzelf niet dat de regering nu moest beslissen over de vraag of men die strijdmacht daadwerkelijk tegen de Republiek zou inzetten. Politiek leek dit zelfs ongerijmd, daar men zojuist met die Republiek een basisovereenkomst gesloten had en het overleg over de uitvoering daarvan pas kort aan de gang was. De regering zag zich echter voor economische en financiële problemen geplaatst waardoor zij meende die beslissing niet lang te kunnen uitstellen. Eén van die acute problemen betrof de voedselsituatie in de door Nederland bezette enclaves op Java en Sumatra. Deze werden door de Republiek geblokkeerd in antwoord op de Nederlandse marineblokkade; de hier nog aanwezige voedselvoorraden dreigden binnen enkele maanden uitgeput te raken. Het meest nijpende financiële probleem was dat de regering kampte met een tekort aan Amerikaanse en Britse deviezen. Zulke deviezen waren onder meer nodig voor het naoorlogse herstel van Nederland; het tekort werd verergerd door de hoge kosten van de Nederlandse strijdmacht in Indonesië. In april hield de regering zich intensief met deze kwestie bezig. Beel merkte daarbij op: 'Als we Indië loslaten is Nederland failliet'. Men meende dat de deviezennood alleen verholpen kon worden door snelle hervatting van de export uit Indonesië. Daartoe zouden de ondernemers op korte termijn moeten kunnen terugkeren naar hun bedrij- 
ven op Republikeins gebied. Niet alleen zouden dan deviezen beschikbaar komen door verkoop van de daar nog voorradige en van de nieuw te winnen producten, maar ook zou de regering dan zelf veel meer kans maken op het verkrijgen van buitenlandse kredieten.

Van 7 tot 23 mei brachten Beel en Jonkman een bezoek aan Indonesië. Zij voerden daar een groot aantal gesprekken met de commissie-generaal en met gouvernementsambtenaren, militairen en ondernemers. Ook hadden zij enkele ontmoetingen met Sjahrir en zijn delegatie. Verder bezochten ze Soerabaja en Makassar en woonden ze in Pontianak de formele oprichting bij van het nieuwe autonome gebied West-Borneo. Met de commissie-generaal en de top van het Nederlands-Indisch gouvernement voerden zij onder meer overleg over het militaire alternatief als overeenstemming met de Republiek zou uitblijven.

Bij dit overleg waarschuwden enkele medewerkers van Van Mook dat een geslaagde militaire actie geen garantie voor een bevredigende politieke oplossing inhield. Zij wezen er onder meer op dat Nederland met zo'n actie de achter Sjahrir staande intellectuelen van zich zou vervreemden, dat zowel de jongeren als de georganiseerde arbeiders zich massaal tegen Nederland zouden keren en dat men op korte termijn geen figuren van formaat zou vinden om samen met Nederland het akkoord van Linggadjati uit te voeren. Niettemin leidde dit overleg tot overeenstemming tussen de commissie-generaal en de ministers over de noodzaak om de Nederlandse militaire macht op korte termijn tegen de Republiek in te zetten tenzij deze haar houding drastisch zou wijzigen. Spoor merkte hierbij op dat, uit zuiver strategisch oogpunt bezien, bezetting van Jogja het natuurlijke doel van een militaire actie zou zijn. Men wilde de Republiek echter in dit stadium niet volledig uitschakelen. De Nederlandse militaire actie zou er vooral op gericht worden zowel in Westen Oost-Java als in Zuid- en Oost-Sumatra belangrijke productiegebieden in handen te krijgen. Beel vond dat men terstond daarna in West- en Oost-Java nieuwe staatkundige eenheden moest vormen.

Of men de arbitragebepaling van Linggadjati (artikel 17, tweede lid) met zo'n militair optreden zou schenden, kwam in dit overleg niet ter sprake. Wel bleek men zich ervan bewust dat de militaire actie een politiek presentatieprobleem meebracht. Aan het publiek in binnen- en buitenland zou men moeilijk kunnen uitleggen, waarom de regering er vier maanden over gedaan had om te besluiten tot ondertekening van de basisovereenkomst met de Republiek en vervolgens al enkele maanden later tot de conclusie kwam dat zij tegen deze wederpartij ten strijde moest trekken. Tegenover de buitenwereld kon Nederland zijn economische en financiële noodsituatie niet als rechtvaardiging voor de beoogde actie aanvoeren. Ten behoeve van een meer overtuigende presentatie besloot men de Nederlandse wensen met betrekking tot de uitvoering van Linggadjati in een overzichtelijk stuk samen te vatten; de 
Republiek zou dan een korte termijn krijgen waarbinnen zij die wensen moest aanvaarden. Een bijkomend politiek probleem was dat Nederland in het overleg over de uitvoering van Linggadjati nog geen enkel voorstel gedaan had over de hervorming van het Nederlands-Indische gouvernement als voorzien in artikel 15, laat staan over de toekomstige inrichting van de Indonesische federatie en de Nederlands-Indonesische Unie. Men besloot daarom in de aan de Republiek voor te leggen nota alsnog een voorstel voor een soort interimregering op te nemen. Van Mook's adviseur Abdoelkadir opperde de gedachte daarin de hoogste binnenlandse functie aan Hatta aan te bieden, maar Beel en Jonkman vonden dit voorbarig.

Overigens kwam tijdens het bezoek van de ministers nog op één punt overeenstemming tussen Nederland en de Republiek tot stand, namelijk over een gezamenlijke oproep tot opheffing van de Australische schepenboycot. Verder voltooide de Republiek in de loop van mei de evacuatie van de nog binnen haar gebied geïnterneerde Nederlanders en hief zij de POPDA (de met die evacuatie belaste organisatie) op.

De ultimatieve nota werd na het vertrek van de ministers voltooid en op 27 mei bij de Republikeinse delegatie bezorgd. Aan het slot van dit stuk verklaarde de commissie-generaal dat zij binnen veertien dagen antwoord verlangde en dat $\mathrm{zij}$, als dit antwoord niet bevredigend was, de vraag wat verder te gebeuren stond zou voorleggen aan de Nederlandse regering. $\mathrm{Zij}$ stelde in de nota voorop dat 'krachtens de overeenkomst' gedurende de overgangstijd de Nederlandse soevereiniteit over Indonesië de jure gehandhaafd bleef. Verder noemde zij het van het grootste belang dat het gebied van de Republiek weer opengesteld zou worden en dat daar die voorwaarden van recht en veiligheid hersteld zouden worden die onmisbaar waren voor een gezonde economische en sociale ontwikkeling. De Nederlandse regering, aldus de nota, was op dit punt tot samenwerking bereid en meende te mogen verlangen dat die samenwerking in het belang van het land en zijn bewoners aanvaard zou worden.

Wat de interim-regering betreft bevatte de nota van 27 mei een uiterst vaag voorstel voor de vorming van een Federale Raad, bestaande uit 'vertegenwoordigingen van de staatkundige organisaties in Indonesië' en 'de vertegenwoordiger van de Kroon'; daarbij zou de laatste een bijzondere positie 'met beslissingsbevoegdheden' krijgen. Over de militaire samenwerking verklaarde de nota onder meer dat men de kwestie van de vermindering van de Nederlandse strijdkrachten zou moeten toetsen aan de defensiebehoeften van Indonesië; een deel van die strijdkrachten zou voorlopig ter beschikking van dit land moeten blijven. Naast militaire samenwerking zou er op de kortst mogelijke termijn ook politionele samenwerking moeten komen om zowel aan binnenlandse als buitenlandse belangen de nodige bescherming te verlenen. Daartoe voorzag de nota in de vorming van een gemeenschappelijk directoraat voor de binnenlandse veiligheid, dat onder de interim-regering 
zou moeten ressorteren en dat de veiligheidstaak van de militaire organisaties zou moeten overnemen. Voor de uitvoering van die taak zou dit directoraat de beschikking krijgen over een gezamenlijke gendarmerie, die voor de helft uit Nederlanders en voor de helft uit Indonesiërs samengesteld zou worden. Verder bevatte de nota onder meer een reeks voorstellen op economisch en financieel gebied en herhaalde ze de eis tot opheffing van alle functies en organisaties die impliceerden dat het gezag van de Republiek zich ook over de Malino-gebieden uitstrekte. Ook zou de Republiek haar ministerie van buitenlandse zaken moeten afschaffen.

Vroeger had de commissie-generaal in haar correspondentie met de delegatie van de Republiek deze steeds als 'de Indonesische delegatie' aangeduid. In de ultimatieve nota liet zij die terminologie varen; voortaan betitelde zij haar onderhandelingspartner consequent als 'de Republikeinse delegatie'. In de Nederlandse visie vertegenwoordigde die delegatie immers niet Indonesië, maar slechts een deelstaat daarvan.

In overeenstemming met de na 25 maart met de Republiek gevoerde besprekingen hadden de ultimatieve voorstellen alleen betrekking op de overgangsperiode voor de totstandkoming van de soevereine Verenigde Staten van Indonesië. Blijkbaar hechtte de Nederlandse regering er zoveel belang aan om voor de duur van die periode haar eigen conceptie door te zetten dat zij bereid was daartoe oorlog te voeren. Dit kan vreemd lijken omdat die periode volgens de bedoeling van Linggadjati maar van korte duur zou zijn; de beide regeringen zouden er immers volgens artikel 12 naar streven dat de VSI al voor 1 januari 1949 tot stand zou komen. Tot goed begrip van de Nederlandse opstelling dient men in de eerste plaats in het oog te houden dat de in artikel 12 genoemde datum slechts een streefdatum was. Belangrijker is dat de Nederlandse regering gedurende die overgangsperiode juist wilde verzekeren dat Nederland ook daarna een tastbare invloed op de gang van zaken binnen Indonesië zou behouden; daartoe zocht zij staatsrechtelijke, financiële, economische en militaire waarborgen. Men moet de ultimatieve voorstellen van 27 mei dan ook zien in het licht van de destijds aan Nederlandse kant bestaande denkbeelden over de toekomstige inrichting van de VSI en van de Nederlands-Indonesische Unie.

Die denkbeelden richtten zich niet op echte dekolonisatie, maar op een beperkte dekolonisatie onder blijvende Nederlandse regie. De regering zag de Unie als een duurzaam staatsverband dat in verschillende opzichten de rol van het Koninkrijk zou overnemen. Jonkman vond bijvoorbeeld dat er binnen de Unie eenheid van buitenlands beleid zou moeten bestaan. Bijzonder verhelderend waren de Nederlandse plannen voor wat men de 'militaire samenwerking' noemde. Die plannen kwamen grotendeels uit de koker van generaal Spoor, maar hadden op hoofdpunten de instemming van Van Mook, Schermerhorn, Beel en Jonkman. 
Uitgangspunt was dat de verdediging van Indonesië tegen buitenlandse vijanden voor $100 \%$ een Uniebelang was en dat het minstens vijftien jaar zou duren voordat de VSI daar zelf toe in staat zou zijn. Daarom zou de 'strategisch-mobiele' verdediging voorlopig moeten worden verzekerd door een in Indonesië te stationeren Nederlandse land-, lucht- en zeemacht, die daar over eigen bases zou kunnen beschikken. Wat marinebases betreft dacht men onder meer aan Sabang, Bangka, Lombok, Ambon en Morotai. Naast deze door Nederland te leveren strijdmacht zouden in de deelstaten van de VSI inheemse legereenheden worden gevormd als grondslag voor de opbouw van een federaal VSI-leger; voorlopig zou dat alleen dienen voor de 'statischterritoriale' verdediging. De Nederlandse strijdmacht en de VSI-strijdkrachten zouden samen onder leiding staan van een 'daartoe meest bekwaam geachte' operationele bevelhebber die door de Nederlandse koning benoemd zou worden. Spoor had deze positie kennelijk aan zichzelf toegedacht, naar het voorbeeld van de positie die generaal MacArthur vroeger in de Filippijnen bekleed had (zie p. 233).

De buitengewone nadruk in deze Nederlandse plannen op de externe verdediging van Indonesië was om verschillende redenen opmerkelijk. Ten eerste had Nederland juist op dit punt in 1942 jammerlijk gefaald, ondanks de toen al decennia lang bestaande Japanse dreiging. Ten tweede was er in 1947 juist geen sprake meer van een externe dreiging en leek die ook voor de eerstkomende vijftien jaar niet te verwachten. De handhaving van een Nederlandse strijdmacht binnen de VSI zou echter nog een ander gevolg hebben. Volgens Van Mook zou men aldus een machtsmiddel behouden dat Nederland geruime tijd in staat zou stellen zijn invloed op de gang van zaken in Indonesië kracht bij te zetten.

De gedachte dat Nederland de externe verdediging van de VSI zou moeten verzekeren bracht met zich mee, dat er al tijdens de overgangsperiode Nederlandse strijdkrachten in Indonesië zouden moeten blijven. Dit werd ook in de ultimatieve nota aangestipt. Op Java en Sumatra zou hun legering zich dan niet meer hoeven te beperken tot de van de Britten overgenomen enclaves. Wat Java betreft dacht Spoor onder meer aan legering in Malang en Magelang; hij merkte hierbij op dat het voorlopig uit gevoelsoverweging aanbeveling verdiende geen Nederlandse garnizoenen in Jogja en Solo te vestigen.

Naast militaire samenwerking voorzagen de Nederlandse ultimatieve voorstellen in politionele samenwerking in de vorm van een gezamenlijke 'gendarmerie'. Dit was het meest cruciale onderdeel van het Nederlandse eisenpakket. Het ging daarbij in de eerste plaats om de beveiliging van de westerse productiebedrijven op Republikeins gebied. Wegens het deviezenprobleem wilde de Nederlandse regering dat de ondernemers spoedig naar hun plantages en fabrieken zouden terugkeren, maar de ondernemers zelf waren daar niet toe bereid zonder bescherming door de Nederlandse 
militaire macht. Hoewel de ultimatieve nota van een 'gendarmerie' sprak, beschikte men aan Nederlandse kant niet over genoeg politiepersoneel voor de bemanning daarvan. In eerste aanleg zou het Nederlandse aandeel van de gendarmerie dus vooral uit militairen moeten bestaan. De eis dat Nederlandse militairen tot herstel en handhaving van orde en veiligheid zouden worden toegelaten tot Republikeins gebied viel slecht te rijmen met de erkenning van het Republikeinse de facto gezag volgens het akkoord van Linggadjati. Men kon zelfs stellen dat dit in feite zou neerkomen op capitulatie van het Republikeinse leger. Beziet men deze Nederlandse denkbeelden over militaire en politionele samenwerking in het licht van de destijds op Java en Sumatra bestaande feitelijke situatie, dan lijken ze eerder een vorm van 'beperkte rekolonisatie' in te houden dan van 'beperkte dekolonisatie'.

In Nederland gaf de VNI een pamflet uit waarin zij de ultimatieve nota van 27 mei afwees en aandrong op spoedige vermindering van de Nederlandse troepenmacht.

\section{Vaste Nederlandse denkpatronen in Batavia}

Door de Nederlandse voorstellen van 27 mei 1947 nam de dreiging van een gewelddadige confrontatie sterk toe. Onder de Nederlandse beleidsmakers in Batavia leek de gespannen sfeer gepaard te gaan met een zekere verstarring van het denken. Dit gold zowel voor Schermerhorn en Van Poll als voor Van Mook en zijn naaste medewerkers: ook waar zij de problemen vroeger op een meer genuanceerde manier plachten te bezien bleken ze nu geneigd zich op enige vaste denkpatronen vast te leggen.

Eén daarvan was de mening dat Nederland de overeenkomst van Linggadjati eerlijk wilde uitvoeren, maar dat de Republiek daar niet toe bereid was gebleken. Zowel op het eerste als op het tweede deel van deze mening valt een en ander af te dingen.

De Nederlandse regering had haar bereidheid om Linggadjati uit te voeren al voor de ondertekening geclausuleerd door haar 'aankleding' van het akkoord. Na de ondertekening had Nederland verdere stappen gedaan die zich van de inhoud van het overeengekomene verwijderden. Terwijl artikel 16 bepaalde dat beide partijen aanstonds tot vermindering van hun troepensterkte zouden overgaan, voerde Nederland de eigen sterkte juist op door in juni een nieuwe divisie dienstplichtigen naar Indonesië over te brengen. Terwijl artikel 1 bepaalde dat men aanstonds maatregelen zou nemen om de Nederlandse enclaves op Java en Sumatra in het Republikeinse gebied in te voegen, maakten de Nederlandse beleidsmakers juist plannen om delen van het Republikeinse gebied af te scheiden. In strijd met de in artikel 4 neergelegde afspraak dat de VSI samengesteld zou worden uit de Republiek, Borneo 
en Oost-Indonesië streefden zij nu naar de vorming van een groter aantal deelstaten. Het Nederlandse beleid werd er op gericht de Republiek terug te dringen in een ondergeschikte positie binnen een Indonesische federatie waarin Nederland een belangrijke invloed zou behouden. De in Linggadjati tot uitdrukking gebrachte gelijkwaardigheid van de overeenkomstsluitende partijen speelde in de Nederlandse denkbeelden geen rol meer.

Wat de bereidheid van de Republiek betreft om Linggadjati uit te voeren is het van belang onderscheid te maken tussen enerzijds de bepalingen over de vorming van een Indonesische federatie (de VSI) en een NederlandsIndonesische Unie en anderzijds de bepalingen over de overgangsperiode voor de vorming van VSI en Unie. Men kon onmogelijk stellen dat de Republiek niet bereid was gebleken het eerstgenoemde deel van de overeenkomst uit te voeren, want sinds de ondertekening van het akkoord had Nederland hierover nog geen enkel overleg met haar gevoerd. Tot nu toe had alleen overleg over de overgangsperiode plaatsgevonden. Dit had weinig resultaat opgeleverd, maar de voornaamste oorzaak hiervan was de Nederlandse misvatting dat de Republiek in Linggadjati de Nederlandse soevereiniteit zou hebben erkend en haar aanspraken op de 'Malino-gebieden' zou hebben prijsgegeven. Dezelfde misvatting leidde ertoe dat Nederland de Republiek ervan beschuldigde Linggadjati te schenden, omdat zij nog steeds buitenlandse betrekkingen onderhield en haar gouverneurs voor de provincies buiten Java en Sumatra niet van hun functies onthief. Ten onrechte zag het een en ander als een bewijs van onwil om het akkoord van Linggadjati uit te voeren.

De aan Nederlandse kant levende mening dat Nederland het akkoord wel degelijk wilde uitvoeren steunde bovenal op een vervorming van het begrip 'Linggadjati'. Men zag de wezenlijke inhoud daarvan nog vrijwel uitsluitend als het veranderen van Nederlands-Indië in een zelfstandige federatie van deelstaten en het samenvoegen van die federatie met Nederland, Suriname en de Antillen tot een Unie. Dit was ook de grondslag van de gedachte dat het mogelijk was 'Linggadjati' uit te voeren zonder de Republiek. Voor het geval Nederland tot militaire actie zou overgaan bezat deze voorstelling van zaken grote propagandistische waarde, zowel tegenover het buitenland als tegenover dat deel van het eigen publiek dat bereid was het Indonesisch nationalisme welwillend tegemoet te treden. Het maakte immers wezenlijk verschil of militair geweld zou dienen voor het onderdrukken van een anti-koloniale beweging dan wel voor het verwerkelijken van een in vrijheid met die beweging overeengekomen dekolonisatieplan.

Opdat Nederland zijn eigen conceptie van 'Linggadjati' zou kunnen verwezenlijken langs de weg van geweld tegen de Republiek, zou het nodig zijn daar voldoende personen van formaat te vinden die dan toch bereid zouden zijn aan die conceptie mee te werken. Op dit punt zochten de Nederlandse beleidsmakers steun bij een andere stereotiepe gedachte, namelijk dat het cen- 
trale probleem niet lag bij de Nederlandse interpretatie van Linggadjati, noch bij de politieke leiding van de Republiek, maar bij de overmachtige positie die de autonome strijdgroepen en het leger in de Republiek verworven hadden tijdens de gewelddadige fase van de nationalistische revolutie. Men meende dat de politici waarmee men tot nu toe onderhandeld had, zoals Sjahrir en zijn ministers maar ook Soekarno en Hatta, persoonlijk wel bereid zouden zijn de Nederlandse conceptie te aanvaarden, maar daarvan werden weerhouden door hun gewapende achterban. De werkelijke politieke macht zou bij de strijdgroepen en het leger berusten. Om overeenstemming met de Republiek mogelijk te maken zou men de positie van de politieke gesprekspartners moeten versterken door die achterban te verzwakken of uit te schakelen.

Het was een al langer levende gedachte; eind 1945 had Van Mook al bij de Britten gepleit voor een militaire actie tegen de strijdgroepen in West-Java teneinde Sjahrir's positie te versterken (zie p. 433). Nu dacht men dat, als een Nederlandse militaire actie de machtspositie van leger en strijdgroepen zou breken, de weg vrij zou kunnen komen voor een bevredigend akkoord, hetzij met de huidige hetzij met een nieuwe Republikeinse regering. Wat het laatste betreft dachten sommigen in het bijzonder aan een regering die zou steunen op de PNI en de Masjoemi, ook al hadden juist deze partijen zich tegen het akkoord van Linggadjati gekeerd. Men meende namelijk dat de door deze partijen vertegenwoordigde conservatieve en islamgetrouwe groeperingen bijzonder bevreesd waren voor een marxistische machtsovername en daarom niet afkerig zouden zijn van een Nederlandse ingreep die dit gevaar zou afwenden.

Het is waar dat Sjahrir, Hatta en Soekarno bereid waren zeer ver te gaan om een oorlog met Nederland te vermijden; het is ook waar dat hun beleidsruimte beperkt werd door de opstelling van hun militante achterban. Maar de gedachte dat leidende Republikeinse politici na een Nederlandse aanval bereid zouden zijn alsnog de Nederlandse wensen in te willigen was een zeer gewaagde speculatie. Ongetwijfeld bestonden er binnen de Republiek ernstige politieke tegenstellingen, maar het voor de verhouding met Nederland belangrijkste geschilpunt, namelijk de keuze tussen 'diplomatie' of 'strijd', was alleen een controverse over middelen, niet over doeleinden. Het onomstreden doel bleef waarachtige onafhankelijkheid voor heel Indonesië.

Een ander stereotiep beeld dat de Nederlanders in Batavia graag gebruikten was dat van de 'droomwereld van Jogja'. Zij meenden dat de Republikeinse leiding door haar zelfgekozen isolement in het Javaanse binnenland bezig was haar contact met de werkelijkheid te verliezen, dat zij slachtoffer werd van haar eigen propaganda en dat zij de positie van de Republiek zwaar overschatte. Volgens sommigen zou een harde klap nuttig kunnen zijn om de Republikeinse leiders 'uit de droom' te helpen. De gedachte dat men zich in Jogja onvoldoende rekenschap gaf van de werkelijke stand van zaken vormde 
ook de achtergrond van een bezoek dat enige Nederlandse ambtenaren eind mei aan die stad brachten. De groep werd geleid door Idenburg, hoogste ambtenaar van het gouvernement en plaatsvervanger van Van Mook. Het was de bedoeling geweest dat men aan de Republikeinse leiders een toelichting zou geven op de kort daarvoor overhandigde ultimatieve voorstellen van de commissie-generaal. Hoewel Idenburg onder meer vier uur lang met Soekarno sprak, kwam van die bedoeling niets terecht; de Republikeinse leiders voelden er niet voor de voorstellen met deze ambtenaren te bespreken. Het rapport van Idenburg over zijn missie bevestigde in het algemeen het beeld van de 'droomwereld van Jogja'. Het week opvallend af van het positieve rapport dat de missie-Koets acht maanden eerder over haar bezoek aan de Republiek had uitgebracht (zie p. 479). Toch verschilde de algemene situatie in de Republiek niet veel van die in september 1946, al ging men hier nu wel gebukt onder de Nederlandse marineblokkade. Wat het 'zelfgekozen isolement in het Javaanse binnenland' betreft is het vermeldenswaard, dat Soekarno er juist op aandrong in het kader van de uitvoering van artikel 1 van Linggadjati allereerst Bandoeng aan de Republiek over te dragen, waarna hij de Republikeinse regeringszetel daarheen wilde overbrengen.

Er was nog een vierde stereotiep denkpatroon dat bij de Nederlandse beleidsmakers een rol speelde: de gedachte dat men bij afwijzing van de Nederlandse voorstellen geen andere keus zou hebben dan 'slaan', dus oorlog met de Republiek. Merkwaardig is dat deze gedachte ook leefde bij sommigen, onder wie Van Mook, Schermerhorn en Idenburg, die vroeger gemeend hadden dat zo'n oorlog desastreus zou zijn voor de verstandhouding tussen Nederland en Indonesië, maar die daar nu blijkbaar minder schade van vreesden. Nog merkwaardiger is dat dit idee van 'geen keus' ook leefde bij enkelen die van een militair optreden alleen maar onheil verwachtten. Zo verklaarde Van Poll begin juni 'dat een militair optreden op het ogenblik een ramp geacht moet worden voor beide volkeren, maar dat deze ramp helaas onontkoombaar lijkt'. Het verdient een nadere beschouwing, waar deze overtuiging van onvermijdelijkheid op berustte.

De stelling dat Nederland geen andere keus dan oorlog had placht men destijds te beargumenteren met een soort bewijs uit het ongerijmde. De argumentatie luidde dan dat er maar twee andere alternatieven bestonden, namelijk 'internationalisering' en 'abandonnering', maar dat die allebei niet uitvoerbaar waren. Dit waren inderdaad geen reële beleidsopties, ook al kwamen ze binnen de Nederlandse regering wel eens ter sprake. Men negeerde echter een ander beleidsalternatief dat aanzienlijk minder irreëel was. Dat was: aan de Republiek vertrouwen schenken, niet langer haar formele onderwerping aan het Nederlandse oppergezag eisen, de marineblokkade opheffen, aanvaarden dat Indonesië werkelijk onafhankelijk zou worden en proberen op die basis een vreedzame oplossing te vinden. Dat zo'n oplossing wel degelijk mogelijk 
was, is in 1949 gebleken. Er was echter één onoverkomelijk beletsel om deze weg nu in te slaan, namelijk de aanwezigheid in de Nederlandse enclaves op Java en Sumatra van ongeveer vijfenzeventigduizend Nederlandse militairen die men naar Indonesië overgebracht had. Als er nu toch nog een vreedzame oplossing tot stand kwam, zou men genoodzaakt zijn die militairen weer in troepenschepen te laden en 'onverrichterzake' naar Nederland te laten terugkeren. Geen regering zou zich dit hebben kunnen veroorloven. Voor de opbouw en instandhouding van deze krijgsmacht overzee had Nederland zich enorme financiële offers getroost en waren tienduizenden Nederlanders uit hun gezin, hun huis en hun werk weggehaald en naar de tropen gebracht. Het was ondenkbaar dat dit allemaal voor niets geweest was.

De aanloop naar het Nederlandse offensief; aantreden van het kabinet-Amir Sjarifoeddin

Op 2 juni 1947 legde premier Beel aan de Nederlandse ministerraad de vraag voor, wat er moest gebeuren bij een onbevredigend antwoord op de ultimatieve voorstellen van 27 mei. De raad besloot met algemene stemmen een militaire actie dan niet bij voorbaat te verwerpen. Beel had met aftreden gedreigd als dit besluit niet unaniem genomen werd. Vice-premier Drees merkte op: 'de Nederlandse troepen zijn nu eenmaal niet voor niets naar Indië gegaan'. Aan de andere kant besloot de raad dat zo'n actie zich niet op de bezetting van het Republikeinse regeringscentrum zou mogen richten. Dit tweeledige besluit hield een compromis tussen de KVP-ministers en de PvdA-ministers in: wél militaire actie, maar geen liquidatie van de Republiek.

Tussen dit beginsel-besluit en het daadwerkelijke begin van het Nederlandse offensief verstreken zeven weken, waarin de voorbereide militaire actie bovendien tweemaal op een laat moment werd afgelast. Verschillende factoren droegen tot deze gang van zaken bij.

In de eerste plaats telde het kabinet-Beel enkele PvdA-ministers die oorlog met de Republiek eigenlijk verwerpelijk vonden en daarom herhaaldelijk pleitten voor verdere pogingen om een vreedzame oplossing te vinden. Bovendien moesten alle PvdA-ministers rekening houden met de binnen hun eigen partij bestaande weerstanden tegen een koloniale oorlog.

In de tweede plaats kwam de Republiek steeds verder aan de Nederlandse wensen tegemoet. Uiteindelijk bleef er slechts één kwestie over waarover de standpunten onverzoenlijk waren: de toelating van Nederlandse militairen tot Republikeins gebied in het kader van de handhaving van orde en veiligheid. Overigens wantrouwde men aan Nederlandse kant de tegemoetkomingen van de Republiek; men verdacht haar ervan vooral op tijdwinst uit te zijn in de verwachting dat Nederland zijn troepenmacht in Indonesië om financiële 
redenen niet lang meer zou kunnen handhaven. Sommige reacties in Batavia gaven blijk van ergernis omdat zulke tegemoetkomingen het moeilijker maakten de beoogde militaire actie aan te vangen.

Een derde factor was buitenlandse bemoeienis met het conflict. Daarbij ging nu naast de Britse regering ook de Amerikaanse regering een actieve rol spelen. Beide regeringen wilden een oorlog in Indonesië graag voorkomen. Beel voelde niets voor Britse of Amerikaanse bemiddeling omdat dit de handen van zijn regering zou binden, maar was wel gesteld op steun voor de Nederlandse ultimatieve voorstellen. Inderdaad gaf men van Britse en Amerikaanse kant herhaaldelijk aan de Republiek te kennen die voorstellen redelijk te vinden. Daarbij ging men er zonder meer van uit dat de Republiek de Nederlandse soevereiniteit al in Linggadjati uitdrukkelijk erkend had, zoals de Nederlandse regering steeds verzekerde.

Intussen bleek op verschillende manieren dat de Republiek haar aanspraken op grond van de proclamatie van 17 augustus 1945 niet had opgegeven. Onder meer bleek dit uit een naamsverandering van haar leger. De regering in Jogja had zich al maanden lang ingespannen om meer greep te krijgen op de in 1945 gevormde autonome strijdgroepen. Een aantal daarvan had zij weten te ontbinden; een aantal andere nam zij in het reguliere leger op. Het aldus uitgebreide en gereorganiseerde leger kreeg op 3 juni de naam Tentara Nasional Indonesia (TNI) in plaats van Tentara Republik Indonesia (TRI). De nieuwe naam maakte duidelijk dat deze strijdmacht als nationaal leger voor heel Indonesië bedoeld was en niet slechts als het leger van een deelstaat.

Bovendien zette de naar het Midden-Oosten gereisde vice-minister van buitenlandse zaken, Agoes Salim, zijn diplomatieke activiteiten voort. Nadat hij al een overeenkomst met de Arabische Liga tot stand gebracht had, vond hij de Egyptische regering bereid de Republiek formeel als staat te erkennen. Dit leidde begin juni tot de sluiting van een vriendschapsverdrag tussen de Republiek en Egypte. Aan Nederlandse kant beschouwde men dat als een flagrante schending van Linggadjati.

Wat de gang van zaken betreft in de weken na het Nederlandse regeringsbesluit van 2 juni valt in het bijzonder het volgende te vermelden. Op de Nederlandse ultimatieve voorstellen van 27 mei antwoordde de Republikeinse delegatie met een nota van 7 juni. Daarin betuigde zij instemming met het voorstel tot vorming van een interim-regering, maar tegelijk stelde zij voor dat die regering voor tenminste de helft uit vertegenwoordigers van de Republiek zou bestaan en haar besluiten met meerderheid van stemmen zou nemen. Dit betekende dat de Republiek daarin de dienst zou uitmaken, in tegenstelling tot het Nederlandse voorstel dat de beslissingsmacht juist aan de Nederlandse vertegenwoordiger toebedeelde. Verder verklaarde de delegatie in te stemmen met een aantal voorstellen op economisch gebied, maar daar gaf zij in feite een nieuwe inhoud aan door haar andere opzet van de interim-regering. 
Op de voorstellen voor gezamenlijke handhaving van orde en veiligheid op Republikeins gebied reageerde zij met de opmerking: 'De handhaving van rust en orde in het gebied van de Republiek is de taak der Republikeinse politie en niet die van het Nederlandse leger'. Verder bevatte de nota nog verscheidene andere punten die van de Nederlandse zienswijze afweken. Intussen bereidde men zich aan Republikeinse kant al enige tijd op een Nederlandse militaire actie voor. Onder meer legde men versterkingen, versperringen en tankvallen aan. In de afgelopen maanden was al vaak met een tactiek van 'verschroeide aarde' gedreigd in geval van een Nederlandse aanval; in dat kader vernielde men nu ook installaties van westerse ondernemingen.

$\mathrm{Na}$ de ontvangst van het Republikeinse antwoord liep de spanning in Nederland verder op. De voorzitter van het Comité Handhaving Rijkseenheid, oud-premier Gerbrandy, hield tal van toespraken waarin hij tot vernietiging van de Republiek opriep. Zijn partijgenoot Bruins Slot, parlementslid en hoofdredacteur van het dagblad Trouw, spoorde de regering voortdurend tot een mars naar Jogja aan. Daar stond tegenover dat in Amsterdam een betoging met vijftienduizend deelnemers plaatsvond onder de leuze 'Tegen geweld en voor overleg'. De betoging was belegd door de Vereniging NederlandIndonesië en werd onder meer toegesproken door haar voorzitter, Van Heuven Goedhart, hoofdredacteur van het dagblad Het Parool.

De commissie-generaal concludeerde uit de Republikeinse nota van 7 juni dat er geen basis voor verdere besprekingen meer was en legde aan de Nederlandse regering de vraag voor wat verder te gebeuren stond. Voor Van Mook persoonlijk was het grievend dat de Republikeinse voorstellen hem geen enkele rol binnen de interim-regering toedachten.

Terwijl het Nederlandse kabinet zich nog beraadde over de volgende stap, hield Sjahrir op 19 juni een radiorede in Batavia, waarin hij zonder ruggenspraak met zijn regering meedeelde te kunnen instemmen met het Nederlandse voorstel over de positie van de vertegenwoordiger van de Kroon in de interim-regering. Hij stelde voor terstond overleg te openen opdat die regering nog voor midden juli aan het werk zou kunnen gaan. Kort daarna besloot het Nederlandse kabinet aan de Republiek een laatste oproep tot aanvaarding van de voorstellen van 27 mei te doen en Van Mook te machtigen om bij uitblijven van een bevredigend antwoord de beoogde militaire actie te beginnen. Op 23 juni overhandigde Van Mook de oproep van zijn regering aan Sjahrir; daarbij verlangde hij antwoord binnen vier dagen en eiste hij bovendien staking van de vernielingen.

Dit gesprek bleek echter het laatste contact met Sjahrir te zijn geweest in diens functie van premier van de Republiek. Kort daarna reisde Sjahrir naar Jogja, waar hij van alle kanten kritiek kreeg op zijn eigenmachtige concessie van 19 juni. Omdat ook zijn eigen partij hem niet steunde, trad hij op 27 juni af. Soekarno nam het regeringsgezag voorlopig over en zond nog dezelfde 
dag een antwoord aan Van Mook. Daarin stemde de Republiek wel in met een Nederlandse vertegenwoordiging in de interim-regering, maar zonder beslissingsbevoegdheden; ook herhaalde zij haar afwijzing van het voorstel voor een gemengde gendarmerie.

Van Mook had het Nederlandse offensief op 30 juni willen openen, maar op 27 juni deed zich nog een andere ontwikkeling voor die de politieke situatie wijzigde. De Amerikaanse regering richtte zowel tot de Nederlandse regering als tot de Republiek een dringende oproep om een interim-regering te vormen langs de door Nederland voorgestelde lijnen; bovendien verklaarde zij zich bereid daarna financiële hulp te geven voor het economische herstel van Indonesië. Van Mook gelastte het Nederlandse offensief nu af, omdat hij vond dat men de Republiek niet kon aanvallen voordat zij had kunnen reageren op de Amerikaanse stap.

Vervolgens richtte Van Mook op 29 juni in opdracht van zijn regering een brief aan Soekarno waarin binnen een week een uitspraak van de Republiek werd verlangd over vijf punten. Het eerste punt betrof de handhaving van de Nederlandse soevereiniteit en verantwoordelijkheid gedurende de overgangsperiode, het tweede betrof de buitenlandse betrekkingen, het derde de door Nederland voorgestelde federale organen, het vierde de terugkeer naar de ondernemingen en het vijfde de gemengde gendarmerie. Hieraan voegde Van Mook nog een reeks specifieke eisen toe, waaronder staking van alle vijandelijkheden, met inbegrip van de vernielingen, de voedselblokkade en de bouw van versterkingen.

Op 3 juli werd in de Republiek opnieuw een kabinet geïnstalleerd, nu met Amir Sjarifoeddin als premier en Gani en Setiadjit als vice-premiers. Amir bleef daarnaast minister van defensie. Agoes Salim werd volwaardig minister van buitenlandse zaken; intussen bevond deze zich nog steeds in het MiddenOosten, waar hij juist de vorige dag een nieuw succes geboekt had door een vriendschapsverdrag tussen de Republiek en Syrië te ondertekenen. Sjahrir zelf behield overigens een invloedrijke positie omdat Soekarno hem tot zijn bijzonder adviseur benoemd had.

De tegen Sjahrir aangevoerde bezwaren bleken meer zijn manier van optreden te betreffen dan de inhoud van zijn beleid, want de nieuwe regering haastte zich Sjahrir's eigenmachtige concessie van 19 juni officieel te bevestigen. Zij deed dit in een brief van 5 juli waarin zij nog enige stappen verder ging, onder meer door zich bereid te verklaren tot aanvaarding van de Nederlandse soevereiniteit in de overgangsperiode. Daarentegen verklaarde zij, evenals Sjahrir al gedaan had, wel in te stemmen met een gemeenschappelijk directoraat voor de binnenlandse veiligheid maar niet met de voorgestelde gemengde gendarmerie.

Aan Nederlandse kant schonk men nauwelijks aandacht aan Amir Sjarifoeddin's concessie over de soevereiniteit; men bleef de opstelling van 
de Republiek onbevredigend vinden. Niettemin neigde Schermerhorn er nu toe 'de sprong te wagen' en aanstonds tot vorming van een interim-regering over te gaan, maar in deze neiging stond hij vrijwel alleen. Van Mook en zijn omgeving vonden dat de Republiek niet met woorden maar met daden blijk moest geven van bereidheid tot samenwerking, in het bijzonder door gevolg te geven aan de gestelde specifieke eisen. De Nederlandse regering gaf opnieuw een machtiging tot militair optreden. Van Mook trof voorbereidingen om het offensief omstreeks 13 juli te openen.

De regering-Amir Sjarifoeddin liet het echter niet bij haar brief van 5 juli, maar ondernam wanhopige pogingen om een militaire krachtmeting met Nederland te voorkomen. Vooral vice-premier Setiadjit, die lang in Nederland gewoond had en Schermerhorn persoonlijk kende, spande zich hiervoor in. Op 8 juli gaf de Republikeinse regering in een nieuwe brief positief antwoord op alle punten uit de Nederlandse brief van 29 juni, behalve ten aanzien van de gemengde gendarmerie; bovendien hief zij de functies op van de gouverneurs voor provincies buiten Java en Sumatra en riep zij Agoes Salim terug. Voor Van Mook was dit reden om het offensief opnieuw af te gelasten. Bij de leiding van de Nederlandse strijdkrachten, die nu al wekenlang in staat van paraatheid verkeerden, veroorzaakte dit ernstige spanningen.

Politiek gezien leek het er nu alleen nog om te gaan een oplossing te vinden voor de kwestie van de gendarmerie. Drees en Jonkman wilden dit desideratum eigenlijk niet tot breekpunt maken, omdat het niet op het akkoord van Linggadjati berustte. In Batavia hield men er echter aan vast; het was nauw verbonden met de meest urgente Nederlandse doelstelling, hervatting van de exploitatie van de westerse ondernemingen op Republikeins gebied. Van Mook had al ingestemd met een plan van Spoor dat inhield dat de Republiek in het kader van een vreedzame regeling haar leger en haar strijdgroepen uit bepaalde gebieden zou moeten terugtrekken, terwijl detachementen Nederlandse troepen in die gebieden gestationeerd zouden worden totdat hun taak door de te vormen gendarmerie kon worden overgenomen. Spoor noemde dit 'vreedzame bezetting'; een oplossing zonder dat Nederlandse troepen Republikeins gebied zouden binnengaan kwam voor hem niet in aanmerking.

Op 14 en 15 juli voerde Amir Sjarifoeddin samen met Setiadjit, Gani en Leimena overleg met de commissie-generaal. Wat de zorg voor orde en veiligheid betreft kwam men een enigszins andere regeling overeen, die een inzet van Nederlands personeel op Republikeins gebied niet volstrekt uitsloot, maar geen melding meer maakte van een 'gemengde gendarmerie'. Tegelijk legde Van Mook de Republiek enige zeer harde eisen voor, waaronder een onmiddellijke staking van alle vijandelijkheden, gevolgd door terugtrekking van alle Republikeinse formaties tot tenminste tien kilometer van de demarcatielijnen (waardoor ze bijna al hun stellingen zouden prijsgeven). Amir Sjarifoeddin zei zich in Jogja voor aanvaarding hiervan in te zullen zetten. Schermerhorn 
hoopte dat oorlog nu definitief voorkomen was. Spoor hoorde pas achteraf van de Nederlandse concessie over de gemengde gendarmerie; hij werd hier zo boos over dat hij aankondigde ontslag te zullen nemen.

Deze laatste poging van Amir Sjarifoeddin om een Nederlandse aanval af te wenden slaagde echter niet. Zijn beraad in Jogja met de andere regeringsleden en met het Werkcomité van het KNIP leidde er uiteindelijk toe, dat men de Nederlandse eisen tot eenzijdige staking van de vijandelijkheden en eenzijdige terugtrekking afwees; ook hield men eraan vast dat de zorg voor de binnenlandse veiligheid uitsluitend een taak van de Republiek zelf was. In de nacht van 16 op 17 juli maakte Amir Sjarifoeddin dit in een radiorede bekend.

Met instemming van Schermerhorn en Van Poll stelde Van Mook nu aan Den Haag voor tot de afgesproken actie over te gaan. De ministerraad besloot nog op 17 juli hiertoe machtiging te verlenen en daarbij te bepalen dat de actie 'van politionele aard' moest zijn en 'zo beperkt mogelijk' gehouden moest worden. Overigens had de Republikeinse afwijzing Schermerhorn zo geschokt dat hij, in afwijking van zijn eigen vroegere adviezen en van het kabinetsbesluit van 2 juni, in een apart telegram betoogd had: 'Een militaire actie zal, aangezien Djocja de geestelijke pesthaard is, alleen doeltreffend zijn, indien deze republiek daaraan ten gronde gaat.' Dit telegram droeg ertoe bij om tegenstand tegen de actie onder de PvdA-leden in kabinet en parlement te overwinnen.

Bij brief van 20 juli deelde Van Mook de regering van de Republiek mee, dat zijn regering zich niet meer gebonden achtte aan het bestand van oktober 1946 noch aan de overeenkomst van Linggadjati, dat zij derhalve haar vrijheid van handelen hernam en dat zij maatregelen zou treffen om die voorwaarden van orde en veiligheid te scheppen die de uitvoering van het programma van Linggadjati mogelijk zouden maken

\section{Het eerste Nederlandse offensief (de eerste 'Politionele Actie')}

Het Nederlandse offensief begon in de nacht van zondag 20 op maandag 21 juli 1947. In de Nederlandse enclaves bezetten militairen om elf uur 's avonds de onder de Republiek ressorterende gebouwen en instellingen; in Batavia betrof dit onder meer het perceel Pegangsaän Oost 56 dat als zetel van de Republikeinse delegatie diende. Tegelijk werden enige honderden Indonesiërs tijdelijk in hechtenis genomen, onder wie vice-premier Gani. Na middernacht overschreden Nederlandse troepen de demarcatielijnen. In Nederland maakte premier Beel drie uur later in een radiotoespraak bekend dat de regering Van Mook gemachtigd had om met zijn strijdmacht tot 'politioneel optreden' over te gaan.

De term 'politioneel' was bewust gekozen. Tot voor kort had men bij overleg over het tegenover de Republiek te voeren beleid de gewelddadige variant 
steeds als 'militaire actie' aangeduid. Pas onlangs had de regering besloten in plaats daarvan van 'politionele actie' te spreken, vooral om tegenover het buitenland te onderstrepen dat het om een interne maatregel ging. Voor dit 'beperkte politionele optreden' maakte de Nederlandse strijdmacht volledig gebruik van haar militair-technische overwicht te land, ter zee en in de lucht. In totaal omvatte die strijdmacht nu ongeveer honderdvijftigduizend man, van wie ruim honderdduizend op Java en Sumatra (door recente aanvullingen beschikte zij daar over meer personeel dan het bij het bestand van oktober 1946 opgegeven maximum). Het Republikeinse leger, de TNI, met inbegrip van de daarmee verbonden autonome strijdgroepen, omvatte ongeveer tweehonderdduizend man op Java en ongeveer honderdduizend op Sumatra. De bewapening en uitrusting daarvan waren ver inferieur aan die van de Nederlandse strijdmacht; het merendeel van de Republikeinse militairen had geen vuurwapens.

Generaal Spoor volgde een 'speerpunten-strategie' waarbij de inzet van tanks en ander rollend materieel het mogelijk maakte in korte tijd grote afstanden af te leggen; ook vonden vanuit zee verscheidene landingsoperaties plaats. Sommige Republikeinse strijdkrachten boden hevige tegenstand, maar de meeste trokken zich in het zijterrein terug. Hoe verder de Nederlandse troepen in Republikeins gebied doordrongen, des te minder last ondervonden ze van vernielingen en versperringen. Binnen twee weken bereikten ze het merendeel van hun operatiedoelen. Op Sumatra betrof dit voornamelijk een gebied ten noorden en ten zuiden van Medan en een gebied ten westen en ten zuiden van Palembang. Op Java betrof het enerzijds een gebied dat heel West-Java behalve Bantam omvatte plus een daarbij aansluitend stuk van Midden-Java, anderzijds het oostelijke deel van Oost-Java; de Nederlandse troepen bezetten daarbij onder meer de steden Soekaboemi, Tjirebon, Tjilatjap, Magelang, Salatiga, Malang en Banjoewangi.

De Nederlandse verliezen tijdens de actie waren gering; er sneuvelden daarbij honderdnegenenzestig militairen. De Republikeinse verliezen waren van een andere orde van grootte; er sneuvelden aan die kant duizenden strijders en er vielen ook tal van slachtoffers onder de burgerbevolking.

De actie was redelijk geslaagd voorzover ze met economische motieven ondernomen was. Zo bevond het grootste deel van de suiker-, thee-, koffie- en rubberplantages en van de aardoliebronnen en kolenmijnen zich nu in Nederlandse handen, evenals enige belangrijke rijstgebieden. Wel waren er vernielingen aangericht in het kader van de Republikeinse 'verschroeideaarde-politiek', maar die betroffen vooral fabrieksinstallaties en slechts in geringe mate de voorradige producten. De actie was niet geslaagd voorzover ze ten doel had de Republikeinse strijdkrachten uit te schakelen. In de 'veroverde' gebieden beheersten de Nederlandse troepen wel de steden en de grote wegen, maar hadden hun tegenstanders zich in het achterland kun- 
nen handhaven. Of de actie bijdroeg tot het verwerven van sympathie onder de Indonesische bevolking werd niet duidelijk. Dicht bij de demarcatielijnen werden de Nederlandse militairen vaak vreugdevol door inheemsen begroet, maar dieper in het Republikeinse gebied ontmoetten zij meestal een zwijgende vijandigheid.

In het niet door Nederlandse troepen bezette gebied van de Republiek leidde de actie in eerste aanleg tot meer eensgezindheid tussen de verschillende politieke groeperingen. Sjahrir en velen die zijn diplomasi-beleid gesteund hadden waren bitter gestemd omdat Nederland ondanks alle Republikeinse concessies toch tot de aanval overgegaan was. De regering verklaarde dat het akkoord van Linggadjati zijn gelding verloren had nu Nederland het eenzijdig had verbroken. De Nederlandse verzekeringen dat de actie slechts beperkt bedoeld was vonden geen geloof; algemeen nam men aan dat Nederland de Republiek volledig wilde onderwerpen. Dit bevorderde geen concessiebereidheid bij de politieke leiders. De regering trof voorbereidingen om haar zetel in geval van nood naar Sumatra te verplaatsen; Hatta bevond zich daar al sinds eind mei. In een radiotoespraak deed Soekarno een beroep op de Verenigde Staten onder verwijzing naar de Amerikaanse vrijheidsstrijd na de onafhankelijkheidsverklaring van 1776.

De Nederlandse aanval op de Republiek vormde wereldnieuws. In de meeste landen was de publieke opinie op de hand van de Republiek. De Australische havenarbeiders hervatten hun boycot van Nederlandse schepen. De regering van India sloot het Indiase luchtruim voor Nederlandse vliegtuigen. De Britse regering stelde een embargo in op militaire leveranties aan Nederland voor gebruik in Indonesië.

In Nederland zelf riep de 'politionele actie' weinig heftige reacties op. Er kwam geen grote proteststaking. Veel Nederlanders die tegen een gewelddadige aanpak geweest waren legden zich gelaten bij de genomen beslissing neer. Premier Beel had trouwens verklaard dat zijn regering aan de beginselen van Linggadjati bleef vasthouden en dat zij zich volstrekt niet wilde keren tegen 'het gezonde nationalistische streven' dat zich in Indonesië geopenbaard had. Uitgaande van de berichtgeving in de nieuwsmedia twijfelden de meeste Nederlanders er niet aan dat Nederland zich ernstig ingespannen had om tot een goede uitvoering van het akkoord van Linggadjati te geraken, maar dat de Republiek daartoe niet bereid of in staat was gebleken. Velen lieten zich ervan overtuigen dat de Republiek zelf, onder meer door ontelbare bestandsschendingen, een onhoudbare toestand had geschapen die Nederland gedwongen had in te grijpen. Slechts een minderheid vond de inzet van de Nederlandse strijdmacht fundamenteel verkeerd. Van Randwijk schreef in zijn weekblad Vrij Nederland een geladen protest onder de kop 'Omdat ik Nederlander ben'. Enige prominente PvdA-leden publiceerden een gezamenlijke verklaring tegen de actie (één van hen was J.M. den Uyl, 
die in 1973 Nederlands minister-president geworden is). Zevenduizend leden van de PvdA zegden uit protest hun partijlidmaatschap op; onder hen waren Van Heuven Goedhart en de Indonesiër L.N. Palar, die tegelijk ook als lid van het Nederlandse parlement aftrad. In Batavia legde de secretaris van de commissie-generaal, Piet Sanders, uit protest zijn functie neer; hij had zich tot het laatst ingespannen om een gewapende krachtmeting te voorkomen.

In haar machtiging aan Van Mook had de regering aangegeven dat men de actie zo beperkt mogelijk moest houden, maar deze richtlijn was in de praktijk niet opgevolgd. Het Nederlandse offensief had meer gebied bestreken dan oorspronkelijk bedoeld was en in feite een goede uitvalsbasis geschapen om in een vervolgoperatie het centrum van de Republiek aan te vallen. Spoor had nooit zijn mening verborgen dat bezetting van Jogja het natuurlijke doel van een militaire actie zou moeten zijn. Al op de zesde dag na het begin van de actie begon Van Mook bij de regering te pleiten voor een opmars naar Jogja; Schermerhorn en Van Poll sloten zich daarbij aan. De regering besloot op 30 juli aan deze aandrang geen gevolg te geven.

\section{De reactie van de Verenigde Naties op het Nederlandse offensief}

Al in februari 1946 had de Veiligheidsraad van de Verenigde Naties over de situatie in Indonesië vergaderd (zie p. 440). In juli 1947 bracht de Nederlandse aanval op de Republiek zowel Australië als India ertoe de Veiligheidsraad te vragen zich hier wederom mee bezig te houden. De Raad besprak de nieuwe problemen in eerste aanleg op 31 juli en 1 augustus. Het feit dat de kwestie aan de VN voorgelegd was had de doorslag gegeven voor het besluit van de Nederlandse regering van 30 juli om geen toestemming te geven voor een vervolgoperatie tegen het centrum van de Republiek.

Anders dan in 1946 was Nederland in 1947 geen lid van de Veiligheidraad. Bij de behandeling van de Indonesische kwestie werd het opnieuw vertegenwoordigd door Van Kleffens, die tot eind juni minister in het kabinet-Beel geweest was maar nu ambassadeur in Washington was. Van Kleffens (die zelf tegen een militaire aanpak van de Republiek gekant geweest was) betoogde namens zijn regering dat de Veiligheidsraad niet bevoegd was zich met het conflict tussen Nederland en de Republiek bezig te houden omdat dit een interne kwestie binnen het Koninkrijk der Nederlanden betrof. Verder betoogde hij onder meer dat het arbitragebeding, vervat in artikel 17 van de overeenkomst van Linggadjati, nu niet van toepassing was omdat de problemen die Nederland ertoe gebracht hadden in te grijpen (waaronder bestandsschendingen, voedselblokkades en het vasthouden van gijzelaars) niet door de bepalingen van die overeenkomst werden bestreken. Deze redeneringen vonden in de Raad weinig weerklank. Op voorstel van Australië nam de Raad op 
1 augustus een resolutie aan waarin een beroep op Nederland en de Republiek Indonesië gedaan werd om hun vijandelijkheden terstond te staken en hun geschillen door arbitrage of andere vreedzame middelen te beslechten.

De Nederlandse regering handhaafde haar standpunt dat de Veiligheidsraad niet bevoegd was, maar besloot niettemin aan de oproep van de Raad te voldoen. Van Mook gaf opdracht de vijandelijkheden op 4 augustus om middernacht te staken. De Nederlandse troepen spanden zich in om voor dat tijdstip hun operatiedoelen zo volledig mogelijk te verwezenlijken; onder meer brachten ze langs Java's noordkust een verbinding tussen West-Java en Semarang tot stand en landden ze op het eiland Madoera. In Batavia werd de nog steeds in hechtenis verkerende vice-premier Gani nu vrijgelaten en kreeg de Republiek weer de beschikking over het perceel Pegangsaän Oost 56. In Jogja gaf president Soekarno op 4 augustus in een radiorede eveneens opdracht de vijandelijkheden om middernacht te beëindigen. Wel verklaarde de Republikeinse regering dat de Nederlandse troepen zich naar haar mening zouden moeten terugtrekken binnen de demarcatielijnen ten tijde van het bestand van 14 oktober 1946.

De staking van de vijandelijkheden was verre van volledig. Weliswaar schoven de Nederlandse troepen de frontlijnen niet verder op, maar Van Mook liet ze doorgaan met de bezetting van plaatsen 'gelegen binnen het gebied waar de Nederlandse macht zich uitstrekt'. Daartoe dienden die troepen 'zuiveringsoperaties' uit te voeren tegen de Republikeinse militairen die zich tussen de wegen en steden bevonden die tijdens het offensief in Nederlandse handen gekomen waren. Van hun kant grepen de Republikeinse strijders graag gelegenheden aan om de Nederlandse troepen schade toe te brengen; het was voor de verdedigers van de Republiek moeilijk te begrijpen waarom zij als aangevallenen op één lijn met de aanvallers gesteld werden. Overigens hadden de Nederlandse zuiveringsoperaties in deze fase een beperkt karakter, omdat Spoor een aanzienlijk deel van zijn troepen gereed hield voor de beoogde opmars naar Jogja. Dit gaf de Republikeinse strijdkrachten een zekere adempauze waarin ze hun verbroken verbanden konden herstellen en zich tussen de bevolking konden nestelen.

De Veiligheidraad liet het niet bij de besprekingen van 31 juli en 1 augustus, maar wijdde nog een reeks verdere vergaderingen aan de Indonesische kwestie. Intussen was Sjahrir door de Republiek aangewezen om haar in de Raad te vertegenwoordigen. Hij had op 22 juli kans gezien Java per vliegtuig te verlaten, had enige tijd in Delhi bij Nehru gelogeerd en was vervolgens naar Cairo doorgereisd; samen met Agoes Salim kwam hij nu naar New York. Op 14 augustus kreeg hij voor het eerst het woord in de Veiligheidsraad. Bij wijze van tegenzet had de Nederlandse regering de presidenten van Oost-Indonesië en West-Borneo naar Amerika overgebracht, maar de Veiligheidsraad gaf geen gevolg aan haar verzoek om ook hen aan de discussie te laten deelnemen. 
Sjahrir sprak de Raad herhaaldelijk toe. Hij vroeg de Raad aan Nederland op te dragen zijn troepen terug te trekken tot de posities van oktober 1946. Hij waarschuwde dat de Nederlandse strijdmacht er nog steeds op uit was de Republiek te vernietigen. Hij keerde zich tegen de aansporingen aan zijn regering om het bilaterale overleg met Nederland te hervatten; de Republiek had geen vertrouwen meer in de eerlijkheid en goede wil van de Nederlandse regering en wilde daarom dat de Raad zich zelf met de oplossing van het geschil zou bezighouden.

Voorstellen om de strijdende partijen op te dragen zich op hun vroegere posities terug te trekken kregen in de Veiligheidsraad onvoldoende steun. Daarentegen besloot de Raad wel tot een eigen rol ten behoeve van de vreedzame oplossing van het geschil. Op voorstel van de Verenigde Staten nam hij op 25 augustus een resolutie aan waarin hij zich bereid verklaarde hiertoe goede diensten te verlenen door middel van een commissie van drie leden uit de Raad, waarbij elke partij één lid zou kiezen en het derde lid zou worden aangewezen door de twee aldus verkozen leden.

Dit Amerikaanse voorstel hield rekening met de Nederlandse opstelling. In het algemeen voelden de Nederlandse beleidsmakers niets voor een internationale rol bij de oplossing van het conflict. Hun voornaamste bezwaren daartegen waren, ten eerste dat het conflict een interne kwestie binnen de Nederlandse staat vormde, ten tweede dat buitenlanders onvoldoende deskundig waren om de Indonesische situatie te kunnen beoordelen, en ten derde dat buitenlandse regeringen zich door eigen belangen en niet alleen door de belangen van Nederland en Indonesië lieten leiden. De reactie van de Veiligheidsraad op het juli-offensief maakte het echter onmogelijk iedere vorm van internationale bemoeienis met de oplossing af te wijzen. Om te voorkomen dat Nederland zich zou moeten onderwerpen aan buitenlandse bemiddeling, laat staan aan bindende arbitrage, had de regering zich daarom positief opgesteld tegenover de minder ver gaande figuur van 'goede diensten'.

Op 26 augustus deed de Veiligheidsraad bovendien een beroep op Nederland en de Republiek om zich strikt te houden aan zijn resolutie van 1 augustus. Deze oproep kwam voort uit ongerustheid dat Nederland zijn offensief zou heropenen. Die ongerustheid was volledig gegrond. Gedurende de afgelopen weken hadden de politieke en de militaire top in Batavia aanhoudend in Den Haag gepleit voor bezetting van het hart van de Republiek. $\mathrm{Zij}$ berichtten dat men in de nu veroverde gebieden op groeiend verzet stuitte waaraan alleen een eind gemaakt kon worden door de haard van het verzet in Jogja uit te schakelen. De opwinding in Batavia leidde tot het bewandelen van ongewone wegen. Vijftien van de hoogste ambtenaren en adviseurs van het gouvernement, onder wie Idenburg, zonden op 11 augustus een telegram aan koningin Wilhelmina waarin ze onder meer hun mening uitspraken 'dat liquidatie van de huidige Republiek door de grote meerderheid 
van de thans angstige en weifelende Indonesiërs met vreugde zal worden begroet'. Ook generaal Spoor en admiraal Pinke richtten zich tot de koningin zelf. Vervolgens liet Van Mook de regering weten eventueel zonder officiële toestemming tot de vervolgoperatie te willen overgaan. De beleidsmakers in Batavia, met inbegrip van Schermerhorn en Van Poll, hadden zich in een droomwereld opgesloten. Het feit dat India en Pakistan juist in deze dagen (op 15 augustus, zie p. 527) onafhankelijk werden, speelde in hun gedachten geen rol. Ook hielden zij geen rekening met mogelijke buitenlandse reacties op een nieuwe Nederlandse aanval. Zo zou Egypte het Suezkanaal voor Nederland kunnen sluiten en zou het verkrijgen van Amerikaans of Brits financieel krediet moeilijk of onmogelijk kunnen worden.

De Bataviase droomwereld had zijn tegenhanger in Den Haag, waar nu ook premier Beel de tijd gekomen achtte om de Republiek op te ruimen. Drees verzette zich hier hardnekkig tegen. Hij merkte op dat de nu op Java begonnen guerrilla al voor de actie van juli te voorzien geweest was en ook door bezetting van Jogja niet bedwongen zou kunnen worden. Uit Amerika waarschuwde Van Kleffens dat Nederland sanctiemaatregelen van de VN over zich zou afroepen als het de strijd tegen de Republiek zou hervatten. In de ministerraad staakten de stemmen toen Beel op 18 augustus uitdrukkelijk voorstelde Van Mook te machtigen naar Jogja op te rukken. Beel was daarop bereid het op een kabinetscrisis te laten aankomen. Dat het uiteindelijk zo ver niet kwam, was minder te danken aan het verzet van Drees en de waarschuwingen van Van Kleffens dan aan een ingreep van de Amerikaanse regering. Op 22 augustus liet deze aan Den Haag weten dat, als Nederland het offensief zou heropenen, men niet van de Verenigde Staten mocht verwachten dat die zich in de Veiligheidsraad tegen de afkondiging van anti-Nederlandse sancties zouden verzetten. Dit bleek uiteindelijk de harde klap te zijn die Beel en zijn medestanders uit de droom hielp. Enige dagen later bood de Veiligheidsraad zijn goede diensten aan. Op 27 augustus besloot de Nederlandse regering de resoluties van de Veiligheidsraad te aanvaarden.

\section{Uitbreiding van het Nederlandse bestuur op Java en Sumatra}

De bezetting van grote delen van het Republikeinse gebied door Nederlandse troepen bracht met zich mee dat het Nederlands-Indische gouvernement ook zijn bestuursorganisatie over die gebieden moest uitbreiden. Zoals op p. 489 vermeld noemde het deze organisatie sinds 1946 Tijdelijke Bestuursdienst in plaats van Binnenlands Bestuur, om de indruk te vermijden dat het koloniale bestel zonder meer terugkeerde. Aan de vooravond van het juli-offensief had Van Mook gouverneurs benoemd voor Oost- en Zuid-Sumatra en West-, Midden- en Oost-Java, maar om dezelfde reden gaf hij hun niet de titel van 
'gouverneur' maar van 'regeringscommissaris voor bestuursaangelegenheden', afgekort 'recomba'. Van meer gewicht dan deze naamsverandering was dat hij Abdoelkadir Widjojoatmodjo tot recomba voor West-Java benoemde; in het vooroorlogse bestel hadden immers alleen Nederlanders de functie van gouverneur kunnen bekleden.

Op 29 augustus 1947 vaardigde Van Mook een belangrijke verklaring uit over de consequenties van de 'politionele actie'. In de eerste plaats werden daarin de gebieden op Java en Sumatra omschreven waarbinnen 'de rechtstreekse verantwoordelijkheid voor recht en orde' nu bij het NederlandsIndische gouvernement berustte. In de tweede plaats werd daarin verklaard dat de ingezetenen van die gebieden ontslagen waren van iedere plicht tot gehoorzaamheid aan de huidige regering van de Republiek, dat het een ieder verboden was de bevelen van die regering op te volgen, dat de Republikeinse ambtenaren in die gebieden hun werkzaamheden konden voortzetten onder het gezag van het gouvernement en dat degenen die dit niet wensten geacht werden uit hun functies te zijn ontheven. Een en ander maakte duidelijk dat artikel 1 van de overeenkomst van Linggadjati voor Nederland geen enkele betekenis meer had.

De in de verklaring omschreven gebieden sloten ook de enclaves in die al voor de 'politionele actie' onder Nederlands gezag stonden. Tot voor kort waren daar nog sommige openbare functies onder verantwoordelijkheid van de Republiek uitgeoefend op grond van een in november 1946 met het Britse gezag gemaakte afspraak (zie p. 489). Aan deze situatie had het Nederlandse gezag na het begin van het juli-offensief in beginsel een eind gemaakt. Zo had Batavia nu niet langer een Republikeinse burgemeester naast de Nederlandse burgemeester en stonden daar bijna geen openbare diensten zoals het trambedrijf meer onder Republikeins beheer.

De in de verklaring omschreven gebiedsbegrenzing bestond grotendeels uit een verbinding tussen de uiterste posities die de Nederlandse troepen voor 5 augustus bereikt hadden. Deze begrenzing kwam al spoedig als de 'Van Mooklijn' bekend te staan. De Republiek wees die lijn categorisch af. Niet alleen vormde de vaststelling van de begrenzing een volstrekt eenzijdige daad, maar bovendien werden de aldus begrensde gebieden lang niet volledig door de Nederlandse troepen beheerst. Er bevonden zich daarbinnen zelfs nog tienduizenden TNI-militairen. Terwijl Nederland de oproep van de Veiligheidsraad tot staking van de vijandelijkheden aanvaard had, bleek het binnen de Van Mooklijn de vijandelijkheden voort te zetten, zij het dat het die hier als 'zuiveringsacties' betitelde. De Republikeinse regering legde zich hier niet bij neer en droeg haar militairen in deze gebieden op zich te verdedigen als ze werden aangevallen. In sommige streken werd een guerilla-oorlog gevoerd; op veel plaatsen vonden sabotagedaden plaats.

Wat de Republikeinse ambtenaren betreft: al voor de verklaring van Van 
Mook had Amir Sjarifoeddin hun in een radiorede verboden samen te werken met het Nederlandse bestuur. In de sinds 20 juli door Nederland bezette gebieden liepen de resultaten van deze tegenover elkaar staande instructies uit Jogja en Batavia sterk uiteen. In sommige streken kreeg het Nederlandse bestuur veel, in andere streken weinig medewerking van het plaatselijke overheidspersoneel. Verscheidene functionarissen toonden zich wel bereid hun werk voort te zetten mits ze niet geacht werden in dienst van het gouvernement te staan. Weigering van medewerking kwam zowel uit principiële en politieke bezwaren voort als uit vrees voor represailles. Vooral in streken waar de guerillastrijd in volle gang was liepen zij die met het Nederlandse gezag samenwerkten het risico ontvoerd of gedood te worden. Daar waar de Nederlandse strijdkrachten oppermachtig waren slaagde het Nederlandse bestuur meestal wel in het stapsgewijs opbouwen van een redelijk functionerende overheidsorganisatie met een daaraan onderhorig politieapparaat. Een bijzonder probleem betrof de westerse productieondernemingen die vaak ver van de stedelijke centra lagen. Aan Nederlandse kant beschikte men niet over voldoende militair en politiepersoneel om die afdoende te beschermen. Voor de beveiliging hiervan bevorderde het Nederlandse gezag daarom de vorming van particuliere ondernemingswachten die licht bewapend werden; zowel Indonesiërs als Chinezen traden hierbij in dienst.

\section{De VN-Commissie van Goede Diensten en het Renville-akkoord}

De internationale reacties op het juli-offensief verzwakten de politieke positie van Nederland en versterkten die van de Republiek. Dit gold in het bijzonder voor de reactie van de Verenigde Naties. Terwijl de Nederlandse regering het conflict met de Republiek als een intern probleem beschouwde dat zij zonder inmenging van buiten wilde oplossen, kreeg zij nu te maken met intensieve bemoeienis door de VN-Veiligheidsraad. Daarentegen had de Republiek gelegenheid gekregen haar zienswijze over het conflict aan het wereldforum voor te leggen; bovendien was haar politieke status verhoogd doordat de Veiligheidsraad haar en Nederland als conflictpartijen op gelijke voet behandelde.

De bemoeienis van de Veiligheidsraad omvatte trouwens meer dan alleen het oproepen tot staking van vijandelijkheden en het aanbieden van goede diensten. De Raad voorzag zich ook van eigen informatie door te vragen om rapportage door de consuls in Batavia van die landen die tevens lid van de Raad waren. Dit waren toen de consuls van Australië, België, China, Frankrijk, Groot-Brittannië en de Verenigde Staten; op grond van het verzoek van de Veiligheidsraad vormden zij een consulaire commissie. In de loop van september bezocht deze commissie verscheidene tijdens de Nederlandse actie bezette 
gebieden en ook enige niet-bezette delen van de Republiek; verder sprak ze met tal van Nederlandse en Republikeinse functionarissen, onder meer in Jogja met Soekarno en op Sumatra met Hatta. Vervolgens bracht ze een veelomvattend rapport uit waarin zowel de militaire situatie als de politieke en de economische situatie aan de orde kwamen.

Terwijl de politieke positie van de Republiek versterkt was, was haar materiële positie ernstig verzwakt. Als gevolg van de Nederlandse actie beheerste zij nu op Java weinig meer dan een derde van het eiland, maar dit was een bijzonder dicht bevolkt gebied dat bovendien grote aantallen vluchtelingen moest herbergen. Tegelijk waren belangrijke voedselproducerende streken in Nederlandse handen geraakt. Bovendien had het Republikeinse gebied na 1945 nog weinig gelegenheid gehad zich te herstellen van de economische ontreddering die de Japanse bezetting teweeggebracht had. De schaarste werd sinds begin 1947 verergerd door de Nederlandse blokkade die, zoals marinecommandant Pinke het formuleerde, ten doel had de Republiek 'ter zee te wurgen'. Overigens werd de economie van de Republiek ook verzwakt doordat een deel van de mannelijke bevolking tot het leger en de strijdgroepen behoorde en daardoor niet aan het normale productieproces deelnam. De zich verscherpende economische nood maakte verscheidene politieke leiders van de Republiek meer geneigd tot het zoeken van een uitweg door middel van een akkoord met Nederland.

De verlening van goede diensten op basis van de resolutie van de Veiligheidsraad van 25 augustus (zie p. 557) kwam moeizaam op gang. De Republiek koos Australië tot lid van de Commissie van Goede Diensten (CGD), Nederland koos België en de twee aldus gekozen landen kozen samen de Verenigde Staten als derde lid. Elk van de drie gekozen regeringen benoemde een vooraanstaande persoon om haar in de commissie te vertegenwoordigen. Aldus kwam de CGD in eerste aanleg te bestaan uit een Amerikaanse universiteitspresident, Frank Graham, een Australische rechter, Richard Kirby, en een Belgische oud-premier, Paul Van Zeeland. Op 27 oktober kwam dit drietal in Batavia aan. De commissie beschikte over een staf van $\mathrm{VN}$-ambtenaren en kreeg ook ondersteuning van de consulaire commissie en haar militaire medewerkers.

Van Mook verwachtte van de CGD geen enkel nut; in zijn ogen bestond die uit buitenstaanders die de bijzondere deskundigheid met betrekking tot Indonesië misten waarover hij en zijn medewerkers bij uitstek beschikten. Volgens de door hemzelf verbreide visie op de dekolonisatie van Indonesië (een visie die door veel Nederlandse politici werd overgenomen) ging het niet om een conflict tussen Nederland en Indonesië maar om een interne tegenstelling binnen Indonesië tussen de voorstanders van twee verschillende staatkundige concepties, die van de bondsstaat tegenover die van de eenheidsstaat.

Intussen was de Veiligheidsraad in oktober met een nieuwe serie debatten 
over de Indonesische kwestie begonnen naar aanleiding van de eerste rapportage van de consulaire commissie. In deze debatten werd de Republiek nu vertegenwoordigd door L.N. Palar, die nog tot juli lid van het Nederlandse parlement geweest was. De commissie had onder meer gerapporteerd dat het staakt-het-vuren gebrekkig nageleefd werd. De Veiligheidsraad nam op 1 november een nieuwe resolutie aan waarin hij onder meer aan de CGD verzocht Nederland en de Republiek bij te staan bij het bereiken van een akkoord om de naleving van het staakt-het-vuren te verzekeren. Dit hield een uitbreiding van het mandaat van de commissie in: zij zou zich dus niet alleen met het politieke geschil maar ook met de militaire situatie moeten bezighouden. In dezelfde resolutie verklaarde de Raad naar aanleiding van de Nederlandse 'zuiveringsacties' dat militaire actie door een partij ter uitbreiding van haar gezag over gebied dat zij op 4 augustus 1947 niet bezet had in strijd was met de Raadsresolutie van 1 augustus.

$\mathrm{Na}$ haar aankomst in Indonesië voerde de CGD diverse voorbereidende besprekingen in Jogja en Batavia. Omdat Nederland en de Republiek het niet eens konden worden over de plaats waar men het formele overleg zou voeren, stelde de Amerikaanse regering als neutraal terrein een marineschip beschikbaar, de 'Renville', die begin december zou aankomen en twee maanden zou kunnen blijven. Naar aanleiding van de nieuwe VR-resolutie belegde de CGD gesprekken tussen Nederlandse en Republikeinse vertegenwoordigers over een militair bestand. Daarbij bleek men van Nederlandse kant zo'n bestand te willen baseren op de Van Mooklijn, terwijl dit van Republikeinse kant werd afgewezen.

Het kabinet-Amir Sjarifoeddin kreeg begin november een bredere politieke basis omdat de Masjoemi er met vijf ministers aan ging deelnemen. Met het oog op het politieke overleg met Nederland benoemde de Republiek weer een delegatie van hoog niveau onder leiding van de premier. Daarentegen toonde de Nederlandse regering geen haast om een delegatie te benoemen voor de nieuwe overlegronde. De door Schermerhorn voorgezeten commissiegeneraal, die de onderhandelingen in Linggadjati gevoerd had, was in oktober opgeheven. Van Mook zelf wilde eigenlijk helemaal geen politiek overleg met de Republiek meer. Zijn beleid was er nu op gericht de Republiek zo veel mogelijk te verzwakken en te ontwrichten en tegelijkertijd een federale structuur op te bouwen in alle door Nederland beheerste delen van Indonesië, met inbegrip van de op Java en Sumatra veroverde gebieden. Als sluitstuk zou de Republiek dan een bescheiden plaats in die federatie kunnen krijgen, hetzij nadat ze gecapituleerd had, hetzij nadat zij door een nieuwe militaire actie bedwongen was.

Dit in wezen op onderwerping van de Republiek gerichte beleid kon rekenen op steun van de meeste, maar niet van alle Nederlanders in Indonesië. Een kleine groep met meer begrip voor de in de Republiek belichaamde natio- 
nale aspiraties richtte in november een Progressieve Concentratie op. Tot haar belangrijkste woordvoerders behoorden R.F. Beerling en G.J. Resink, beiden hoogleraar aan de Rechtshogeschool in Batavia. De opstelling van deze groep kwam overeen met die in Nederland van een groep prominente anti-communistische PvdA-leden, onder wie De Kadt en Den Uyl, die omstreeks dezelfde tijd in Nederland een brochure uitgaven waarin ze de militaire actie scherp afkeurden en onder meer voorstelden het Republikeinse bestuur te herstellen in de bij die actie veroverde gebieden.

Intussen vonden in deze periode enige gebeurtenissen plaats die de verstandhouding tussen Nederland en de Republiek verder verslechterden. Terwijl het Nederlandse leger tijdens de 'politionele actie' alleen een deel van het eiland Madoera bezet had, breidde het begin november zijn macht tot de rest van het eiland uit, een gebied dat expliciet buiten de Van Mooklijn lag. Volgens het gouvernement had de plaatselijke bevolking om Nederlandse hulp gevraagd, maar de hoofdreden voor deze bezettingsactie was dat zich in dit deel van Madoera de grootste zoutvoorraad van Indonesië bevond. Enige weken later deed zich een incident voor dat bekend werd als 'de dodentrein van Bondowoso'. Tijdens een door Nederlandse militairen begeleid transport van Republikeinse krijgsgevangenen van Bondowoso naar Soerabaja in overvolle en volledig afgesloten goederenwagons kwamen zesenveertig gevangenen door verstikking om het leven. Een andere schokkende gebeurtenis deed zich begin december in West-Java voor: Nederlandse militairen ondernamen een brute 'zuiveringsactie' in het dorp Rawagede dat als een centrum van verzet werd gezien. Daarbij kwamen volgens Nederlandse opgave honderdvijftig (volgens de Republiek meer dan driehonderd) Indonesische burgers om het leven, van wie ongeveer twintig door executie na ondervraging, terwijl in het dorp geen enkel wapen werd gevonden en aan Nederlandse kant niemand gedood of gewond werd.

Op 1 december, één dag voor de aankomst van de 'Renville', benoemde de Nederlandse regering eindelijk haar delegatie. Die werd niet voorgezeten door een oud-premier, zoals destijds de commissie-generaal, maar door een hoge ambtenaar, Abdoelkadir Widjojoatmodjo. Kort daarvoor was hij Idenburg opgevolgd als directeur-generaal algemene zaken en plaatsvervanger van Van Mook. Bovendien zaten in de delegatie meer Indonesiërs dan Nederlanders; zij kwamen uit verschillende delen van de archipel. Deze samenstelling moest doen uitkomen dat het in wezen om een intern conflict in Indonesië ging. Niettemin berustte de feitelijke leiding van de delegatie bij een Nederlandse ondervoorzitter, de diplomaat H.F.L.K. van Vredenburch.

Het formele overleg vond aan boord van de 'Renville' plaats op de rede van Batavia. In januari 1948 mondde dit overleg uit in een akkoord dat uit drie ongelijksoortige delen bestond, een militaire bestandsovereenkomst, twaalf politieke beginselen en zes aanvullende politieke beginselen. Dit vreemd 
geconstrueerde akkoord was op een ongewone manier tot stand gekomen.

Nederland en de Republiek waren het overleg ingegaan met sterk verschillende standpunten over de te volgen procedure. Nederland wilde niet over een politieke overeenkomst praten zo lang niet eerst een militaire bestandsovereenkomst gesloten was. Daarentegen wilde de Republiek zo'n bestand alleen overwegen als dit samen met een bevredigend politiek akkoord tot stand zou komen. In een boodschap van 26 december stelde de CGD als compromis voor, de militaire overeenkomst te combineren met een akkoord over beginselen die ten grondslag zouden moeten liggen aan de later te sluiten politieke overeenkomst. Een eerste schets van zulke beginselen legde zij in deze 'kerstboodschap' informeel aan de partijen voor. De schets kwam gedeeltelijk overeen met denkbeelden van de Nederlandse Progressieve Concentratie. Zij bevatte enerzijds een herbevestiging en uitwerking van bepaalde elementen van de overeenkomst van Linggadjati, maar anderzijds ook twee punten die sterk aan de Republiek tegemoetkwamen. Dit betrof onmiddellijke stopzetting van de voorbereiding van nieuwe deelstaten op Java, Madoera en Sumatra en, binnen drie maanden na ondertekening van de politieke overeenkomst, terugkeer van het Republikeinse bestuur in de sinds 20 juli 1947 bezette gebieden en terugtrekking daaruit van de Nederlandse troepen. Daarnaast voorzag de schets onder meer in vrije verkiezingen waarbij de bevolking zelf haar verhouding tot de Republiek en tot de Verenigde Staten van Indonesië zou kunnen bepalen.

Terwijl de CGD alleen een Nederlandse delegatie van secundair niveau als formele gesprekspartner had, deed het paradoxale feit zich voor dat zij in deze fase rechtstreeks contact kreeg met het hoogste Nederlandse beleidsniveau. Premier Beel en de ministers Drees, Jonkman en Neher brachten van midden december tot begin januari een bezoek aan Indonesië. Al bij het begin hiervan gebruikte Beel dreigende taal: in een radiorede zei hij dat de Republiek nog een laatste kans had om haar plaats als deelstaat van de Indonesische federatie in te nemen. Omstreeks de jaarwisseling voerden de Nederlandse ministers en Van Mook enige gesprekken met de CGD. Beel stelde zich hierbij bijzonder hard op en liet er weinig twijfel over bestaan dat Nederland overwoog weer tot militaire actie over te gaan als de Republiek niet op korte termijn zou instemmen met een bestand op basis van de Van Mooklijn. De ministers bespraken de mogelijkheid van een nieuwe militaire actie ook met generaal Spoor. Deze zette uiteen dat men zo'n actie nog tot 15 februari 1948 zou kunnen ondernemen, maar dat men die daarna in verband met troepenaflossingen zou moeten uitstellen tot april.

Op 2 januari legde Nederland via de CGD aan de Republikeinse delegatie twee teksten voor als een eindbod waarover niet meer te onderhandelen viel. De ene tekst betrof de militaire bestandsovereenkomst; de andere tekst was een lijst van twaalf politieke beginselen. Die lijst was gedeeltelijk op de 'kerstboodschap' van de CGD gebaseerd, maar repte niet van ontruiming van 
bezette gebieden; ook werd de Republiek er nergens in genoemd. In plaats van een stopzetting van de voorbereiding van nieuwe deelstaten voorzag de Nederlandse lijst juist in vrijheid voor 'volksbewegingen gericht op politieke organisatievormen in overeenstemming met de beginselen van Linggadjati'.

Een nieuwe ontwikkeling was dat de Amerikaanse regering zich actief met het overleg in Batavia ging bemoeien. Zij was ernstig verontrust door het vooruitzicht van een mislukking van dit overleg, waaraan zij haar prestige verbonden had door de 'Renville' beschikbaar te stellen. Bovendien liet zij zich in toenemende mate leiden door de wens een breed front te vormen tegen het expansiestreven van de Sovjet-Unie; daarom hechtte zij belang aan een sterke positie van Nederland in Europa en aan behoud van een zekere Nederlandse invloed in Indonesië. Ook het State Department ontwierp nu een schets van politieke beginselen; het Amerikaanse CGD-lid gaf die op 5 januari aan de Nederlanders door. In sommige opzichten was deze schets gunstiger voor de Republiek dan de Nederlandse lijst; aan de andere kant begon dit stuk met de uitspraak dat de soevereiniteit over geheel Indonesië tot aan de vorming van de Indonesische federatie bij Nederland bleef berusten. Washington gaf aan Den Haag te verstaan dat afwijzing van dit concept de verlening van Amerikaanse financiële steun aan Nederland in gevaar zou kunnen brengen. Ondanks verschillende bezwaren aanvaardde de Nederlandse regering het Amerikaanse concept. In overleg met de CGD werd het omgewerkt tot een lijst van zes 'aanvullende beginselen' die de CGD als een eigen voorstel aan de partijen zou voorleggen.

Intussen raakten zowel de Nederlandse beleidsmakers als de CGD in tijdnood; de Nederlanders wegens de door Spoor genoemde uiterste datum van 15 februari, de CGD door de wens voor het vertrek van de 'Renville' resultaat te behalen. Tegelijk kwam de Republiek onder druk te staan door de dreiging van een nieuw Nederlands offensief. Op 11 januari stelde de Nederlandse delegatie een ultimatum: uiterlijk 15 januari zou de Republiek moeten instemmen met de door Nederland voorgestelde bestandsovereenkomst en twaalf politieke beginselen en ook met de zes aanvullende beginselen van de CGD; zo niet dan zou zij de onderhandelingen beëindigen.

In de volgende dagen voerde de CGD een reeks gesprekken met de leiders van de Republiek in Kalioerang, een bergoord bij Jogja. Ook Soekarno nam hieraan deel, samen met Hatta die uit Sumatra teruggekeerd was. Onder sterke pressie van de CGD leidde dit beraad uiteindelijk tot het besluit voor de Nederlandse eisen te zwichten. Daarbij ging men ervan uit dat Nederland in staat was de Republiek op Java binnen enkele dagen te overweldigen; door nu toe te geven zou men in ieder geval tijd winnen. Ook bracht weigering het risico mee dat de Verenigde Staten zich tegen de Republiek zouden keren, terwijl de enige hoop voor het behoud van de Republiek juist gelegen leek in steun van de internationale gemeenschap. Een belangrijke verdere over- 
weging was dat de 'aanvullende beginselen' voorzagen in een volksstemming waarbij de verschillende gebieden op Java, Madoera en Sumatra zelf zouden kunnen bepalen of ze tot de Republiek wilden behoren. De Republikeinse leiders zagen het resultaat van zo'n volksstemming met vertrouwen tegemoet; zoals het Amerikaanse CGD-lid Graham hun voorhield zou de strijd zich op die manier verplaatsen van de bullets (kogels) naar de ballots (stembussen). Wat de korte termijn betreft leek aanvaarding van de beginselen ook uitzicht te bieden op opheffing van de Nederlandse economische blokkade.

Het grootste struikelblok werd gevormd door de aanhef van de aanvullende beginselen, volgens welke de soevereiniteit over heel Indonesië tijdens de overgangsperiode bij Nederland bleef. Betekende dit dat de Republiek moest afzien van haar eigen aanspraken, met inbegrip van het onderhouden van eigen buitenlandse betrekkingen en het beschikken over een eigen leger? In hun wens de Republiek tot aanvaarding van het Nederlandse ultimatum te brengen verklaarden alle drie de leden van de CGD dat deze bepaling geen verandering zou brengen in de bestaande status van de Republiek. Dit gaf uiteindelijk de doorslag.

De formalisering van het Renville-akkoord gebeurde in twee fasen. De bestandsovereenkomst en de twaalf beginselen werden op 17 januari 1948 namens de beide delegaties ondertekend; twee dagen later betuigden de delegaties schriftelijk hun instemming met de zes aanvullende beginselen. Daarbij verklaarde de Republikeinse delegatie deze te aanvaarden op basis van de door de CGD gegeven toelichtingen. Pas later werd bekend wat de CGD-leden in Kalioerang gezegd hadden. Aan Nederlandse kant reageerde men woedend; men voelde zich bedrogen en verlangde een rechtzetting door de CGD. Deze overreedde Soekarno alsnog schriftelijk te verklaren dat zijn regering de beginselen onvoorwaardelijk aanvaard had. In de praktijk had dit geen effect; aan Republikeinse kant bleef men ervan uitgaan dat het Renville-akkoord de status van de Republiek niet veranderd had.

Uiteindelijk hebben de achttien 'politieke beginselen' slechts een beperkte betekenis gehad voor de verdere ontwikkeling van de verhouding tussen Nederland en de Republiek. Daarentegen had de militaire bestandsovereenkomst ingrijpende gevolgen. Deze overeenkomst voorzag niet alleen in een staakt-het-vuren langs de Van Mooklijn (die hier als 'status quo-lijn' werd betiteld) en de instelling van gedemilitariseerde zones ter weerszijden ervan, maar ook in de ontruiming van het hele gebied aan de Nederlandse kant van de lijn door de zich daar bevindende Republikeinse strijdkrachten. Nederland zou hierdoor de vrije hand krijgen bij zijn militaire operaties binnen de Van Mooklijn; die konden immers niet meer als 'vijandelijkheden' worden aangemerkt wanneer de vijandelijke troepen dat gebied verlaten hadden. Al met al droeg het Renville-akkoord bij tot legitimering en consolidatie van het Nederlandse gezag in de sinds het juli-offensief bezette gebieden. 


\section{Tekst van het politieke deel van het Renville-akkoord}

De op 17 januari 1948 aan boord van de 'Renville' namens de Nederlandse regering, de regering van de Republiek Indonesië en de VN-Commissie van Goede Diensten ondertekende twaalf beginselen als basis voor de politieke besprekingen luidden in Nederlandse vertaling als volgt:

De Commissie van Goede Diensten heeft van de Delegatie van het Koninkrijk der Nederlanden en de Delegatie van de Republiek Indonesië vernomen, dat, na ondertekening van de Bestandsovereenkomst, haar Regeringen de navolgende beginselen aanvaarden als basis voor de politieke besprekingen:

1. Dat de Commissie van Goede Diensten haar bijstand zal blijven verlenen ten behoeve van het uitwerken en ondertekenen van een overeenkomst tot regeling van het politiek geschil met betrekking tot de eilanden Java, Sumatra en Madoera, welke zal zijn gebaseerd op de beginselen, welke ten grondslag liggen aan de Overeenkomst van Linggadjati.

2. Het is wel te verstaan, dat geen van beide partijen het recht heeft de vrije uiting van volksbewegingen, gericht op politieke organisatievormen, welke in overeenstemming zijn met de beginselen van de Overeenkomst van Linggadjati, te onderdrukken. Voorts is wel te verstaan, dat beide partijen de vrijheid van vergadering en van meningsuiting te allen tijde zullen verzekeren, met dien verstande, dat deze verzekering niet mag worden uitgelegd als mede betrekking hebbende op het bepleiten van geweld of vergeldingsmaatregelen.

3. Er is wel te verstaan, dat beslissingen betreffende wijziging in de bestuursvorm van gebieden slechts mogen worden genomen met volledige en vrijwillige instemming van de bevolking van deze gebieden en op een tijdstip, waarop de veiligheid en vrijheid van dwang van deze bevolking zullen zijn verzekerd.

4. Dat van het ondertekenen van de politieke overeenkomst af zal worden voorzien in de geleidelijke vermindering van de strijdmacht der beide partijen.

5. Dat zo spoedig mogelijk na het ondertekenen der Bestandsovereenkomst economische activiteit, handel, vervoer en verbindingen worden hersteld door samenwerking van beide partijen, waarbij in acht genomen dienen te worden de belangen van alle samenstellende delen van Indonesië.

6. Dat zal worden voorzien in een passende periode van ten minste zes maanden en ten hoogste een jaar na ondertekening der overeenkomst, gedurende welke tijd de bespreking en overweging van belangrijke problemen zonder dwang en vrijelijk zullen worden voortgezet. Aan het einde van deze periode zullen vrije verkiezingen worden gehouden tot zelfbepaling door het volk van zijn politieke verhouding tot de Verenigde Staten van Indonesië.

7. Dat langs democratische weg een constituerende vergadering zal worden gekozen, die een grondwet zal ontwerpen voor de Verenigde Staten van Indonesië.

8. Er is wel te verstaan, dat, indien na ondertekening van de overeenkomst, bedoeld in het eerste lid, één van beide partijen de Verenigde Naties zou verzoeken een orgaan ter beschikking te stellen, ten einde de toestand waar te 
nemen op enig tijdstip vóór dat, waarop de soevereiniteit door de Nederlandse Regering wordt overgedragen aan de Regering der Verenigde Staten van Indonesië, de andere partij dit verzoek in ernstige overweging zal nemen.

De volgende vier beginselen zijn ontleend aan de Overeenkomst van Linggadjati:

9. Onafhankelijkheid voor de volkeren van Indonesië.

10. Samenwerking tussen de volkeren van Nederland en Indonesië.

11. Een soevereine Staat op federale grondslag met een Grondwet, welke langs democratische weg tot stand gebracht zal worden.

12. Een Unie tussen de Verenigde Staten van Indonesië en andere delen van het Koninkrijk der Nederlanden onder de Koning der Nederlanden.

De op 17 januari 1948 aan boord van de 'Renville' door de VN-Commissie van Goede Diensten voorgestelde en op 19 januari door de partijen aanvaarde zes aanvullende beginselen luidden in Nederlandse vertaling als volgt:

De Commissie van Goede Diensten is van mening, dat de volgende beginselen onder meer een basis vormen voor de onderhandelingen om te komen tot een politieke oplossing:

1. De soevereiniteit over geheel Nederlandsch-Indië is en blijft berusten bij het Koninkrijk der Nederlanden totdat, na een bepaald tijdvak, het Koninkrijk der Nederlanden zijn soevereiniteit overdraagt aan de Verenigde Staten van Indonesië. Vóór de afloop van een zodanig tijdvak kan het Koninkrijk der Nederlanden daarvoor in aanmerking komende rechten, plichten en verantwoordelijkheden toekennen aan een voorlopige federale regering van de gebieden van de toekomstige Verenigde Staten van Indonesië. De Verenigde Staten van Indonesië zullen, na hun totstandkoming, vormen een soevereine en onafhankelijke Staat, in gelijkgerechtigd deelgenootschap met het Koninkrijk der Nederlanden, verbonden in een Nederlands-Indonesische Unie, aan het hoofd waarvan staat de Koning der Nederlanden. De status van de Republiek Indonesia zal zijn die van een deelstaat van de Verenigde Staten van Indonesië.

2. In enige voorlopige federale regering, ingesteld alvorens de constitutie van de toekomstige Verenigde Staten van Indonesië is geratificeerd, zal aan alle staten redelijke vertegenwoordiging worden aangeboden.

3. Vóór de ontbinding der Commissie van Goede Diensten kan elk der beide partijen verzoeken, dat de diensten der Commissie worden voortgezet tot bijstand bij het regelen van eventuele geschillen tussen beide partijen in de interimperiode met betrekking tot de politieke overeenkomst. De andere partij zal zich tegen een zodanig verzoek niet verzetten; dit verzoek zal alsdan worden voorgelegd aan de Veiligheidsraad der Verenigde Naties door de Nederlandse Regering.

4. Binnen een tijdvak van niet minder dan zes maanden en niet meer dan een jaar na de ondertekening van deze overeenkomst zal een plebisciet worden 
gehouden om te bepalen of de bevolking van de verschillende gebieden op Java, Madoera en Sumatra wenst, dat haar gebied deel zal uitmaken van de Republiek Indonesia of van een andere staat binnen de Verenigde Staten van Indonesië. Indien één van beide partijen overeenkomstig het gestelde sub 3 een daartoe strekkend verzoek heeft ingediend, zal dit plebisciet worden gehouden onder waarneming door de Commissie van Goede Diensten. Partijen kunnen overeenkomen, dat in plaats van een plebisciet een andere methode zal worden gevolgd voor het vaststellen van de wensen der bevolking.

5. Nadat volgens de procedure, omschreven sub 4, de begrenzing der staten is vastgesteld, zal een constituerende vergadering worden bijeengeroepen langs democratische weg om de Grondwet van de Verenigde Staten van Indonesië te ontwerpen. De vertegenwoordiging der verschillende staten in de constituerende vergadering zal zijn evenredig aan het bevolkingsaantal.

6. Indien enige staat besluit de Grondwet niet te ratificeren en overeenkomstig het aan de artikelen 3 en 4 van de Overeenkomst van Linggadjati ten grondslag liggende beginsel een bijzondere betrekking tot de Verenigde Staten van Indonesië en tot het Koninkrijk der Nederlanden wenst te bedingen, zal geen van beide partijen zich daartegen verzetten.

\section{Val van het kabinet-Amir Sjarifoeddin; aantreden van het kabinet-Hatta}

Naar aanleiding van het Renville-akkoord voltrok zich een verandering in de binnenlands-politieke constellatie van de Republiek. Zoals op pp. 511 vermeld was daar ruim een jaar eerder een polarisatie opgetreden, waarbij een groep linkse partijen het akkoord van Linggadjati steunde in een samenwerkingsverband onder de naam Sajap Kiri, terwijl twee grote meer conservatieve partijen, de PNI en de Masjoemi, deelnamen aan een anti-Linggadjati-organisatie onder de naam Benteng Repoeblik. Later hadden die laatste partijen zich minder afwijzend opgesteld en waren prominente leden ervan tot de regeringscoalitie toegetreden. Op 16 januari 1948 echter trok de Masjoemi haar ministers uit het kabinet-Amir Sjarifoeddin terug omdat de Republiek volgens haar in het Renville-akkoord te grote concessies ging doen. Daar de PNI eveneens aangaf het kabinet niet te willen steunen, terwijl ook Sjahrir's aanhangers zich tegen het akkoord keerden, diende Amir Sjarifoeddin op 23 januari zijn ontslag in. Soekarno droeg nu Hatta op een presidentieel kabinet te vormen.

Binnen een week kwam het kabinet-Hatta tot stand, dat met een aantal wijzigingen in zijn samenstelling tot eind 1949 in stand gebleven is. Het nieuwe kabinet steunde in hoofdzaak op de Masjoemi en de PNI, terwijl de Partai Sosialis, de Partai Boeroeh (de door Setiadjit geleide Arbeiderspartij) en de Partai Komunis Indonesia nu in de oppositie gingen. Vice-president Hatta trad zelf als premier en als minister van defensie op. Soekiman, de leider van de Masjoemi, werd minister van binnenlandse zaken; hij had al in de jaren twintig in de nationale beweging met Hatta en Soekarno samengewerkt. 
Tot een jongere garde onder de Masjoemi-politici behoorden de ministers Sjafroeddin Prawiranegara (economische zaken) en Natsir (voorlichting). De partijloze Agoes Salim bleef minister van buitenlandse zaken. Enige andere ministers die ook al in het vorige kabinet gezeten hadden waren Leimena (de leider van de protestants-christelijke partij), Kasimo (de leider van de rooms-katholieke partij) en Hamengkoe Boewono IX (de sultan van Jogja). De aanduiding 'presidentieel kabinet' betekende dat dit kabinet overeenkomstig het Amerikaanse model alleen aan de president verantwoording schuldig zou zijn. Overigens bleven Soekarno en Hatta streven naar steun voor hun beleid door een meerderheid binnen het KNIP.

Hoewel de Masjoemi en de PNI het kabinet-Amir Sjarifoeddin ten val gebracht hadden door bezwaar te maken tegen het Renville-akkoord, toonden ze zich bereid aan de uitvoering daarvan mee te werken nu de Republiek zich er eenmaal aan gebonden had. Die uitvoering was dan ook één van de voornaamste programmapunten van het nieuwe kabinet. Daarbij ging het in de eerste plaats om de evacuering van de Republikeinse militairen uit de gebieden binnen de 'status quo-lijn'. Hoewel hier onder de strijdkrachten grote bezwaren tegen bestonden, werkte opperbevelhebber Soedirman er loyaal aan mee. De evacuatie vond in februari plaats onder toezicht van vijfenvijftig buitenlandse militaire waarnemers; daarbij werden 35.000 militairen naar het kerngebied van de Republiek overgebracht. Tot de uit West-Java overgebrachte legereenheden behoorde ook de Siliwangi-divisie, die voornamelijk uit Soendanezen bestond maar nu in Javaanstalig gebied gelegerd werd. Intussen had chef-staf Oerip Soemohardjo, de eerste organisator van het Republikeinse leger, ontslag genomen omdat hij niet met het Renville-akkoord kon instemmen. Zijn taken werden overgenomen door Nasoetion, tot dan toe commandant van de Siliwangi-divisie.

Opperbevelhebber Soedirman was over de concessiebereidheid van de politici des te ernstiger verontrust omdat hij op de hoogte was van het plan van generaal Spoor uit medio 1947 voor Nederlands-Indonesische 'militaire samenwerking', een plan dat in feite neerkwam op langdurige handhaving van een Nederlands militair overwicht in Indonesië (zie p. 542). Namens alle commandanten van de Republikeinse strijdkrachten richtte hij daarom op 9 maart een brief aan Hatta waarin hij hun gezamenlijk standpunt over de toekomstige strijdmacht van het federale Indonesië samenvatte. Dit standpunt hield onder meer in, dat de federale strijdmacht uit Indonesiërs zou moeten bestaan, dat de TNI de kern van die strijdmacht zou moeten vormen, dat die strijdmacht onder Indonesisch commando en niet onder commando van een Nederlander zou moeten staan en dat het Nederlandse leger Indonesië zou moeten verlaten. Deze militaire standpuntbepaling is bekend geworden als de 'Zes Punten van Soedirman'.

In het kader van de uitvoering van het Renville-akkoord beëindigde Hatta 
het beleid van strikte non-coöperatie tegenover het Nederlandse gezag. Het werd Republikeinse ambtenaren niet langer verboden in de door Nederland bezette gebieden onder dat gezag te werken; ook zouden Republikeinse figuren voortaan mogen deelnemen aan door dat gezag georganiseerde conferenties en verkiezingen. Met het oog op de volksstemming die volgens het akkoord binnen een jaar na ondertekening van de nog te sluiten politieke overeenkomst zou moeten plaatsvinden, richtte men een 'plebiscietbeweging' op die in de bezette gebieden een zo groot mogelijke deelname aan de stemming en een zo groot mogelijke steun voor de Republiek zou moeten bevorderen.

Een ander belangrijk programmapunt van Hatta's kabinet was 'rationalisatie' van de strijdkrachten en van de overheidsuitgaven. De bedoeling hiervan was de omvang van de strijdkrachten en het ambtenarenkorps te verkleinen en tegelijk de daadkracht en de loyaliteit ervan te vergroten.

\section{Verscherping van de tegenstellingen binnen de Indonesische vrijheidsbeweging}

De medewerking door Masjoemi en PNI aan de uitvoering van het Renvilleakkoord maakte duidelijk dat hun bezwaren tegen dat akkoord niet de eigenlijke reden geweest waren om het kabinet-Amir Sjarifoeddin ten val te brengen. Een belangrijker reden hiervoor was dat de politieke opstelling van Amir Sjarifoeddin en zijn volgelingen zich in radicaal-socialistische richting was gaan ontwikkelen. In hun kring vond de gedachte ingang, dat een klassenstrijd tegen feodalisme en kapitalisme nodig was om de Indonesische samenleving naar socialistisch model te hervormen. Op het internationale vlak vestigden zij hun vertrouwen meer en meer op de Sovjet-Unie. De gang van zaken in de Veiligheidsraad droeg daar trouwens toe bij. Daar had de Sovjet-Unie de twee belangrijkste wensen van de Republiek ondersteund, namelijk terugtrekking van de Nederlandse troepen naar hun vroegere posities en beslechting van het politieke geschil door internationale arbitrage, terwijl de Amerikaanse regering in feite Nederland de hand boven het hoofd gehouden had door zich tegen die wensen te verzetten.

Door de radicalisering van Amir Sjarifoeddin en zijn aanhang begon de politieke polarisatie binnen de Republiek zich in te voegen in de sinds de Tweede Wereldoorlog op gang gekomen mondiale polarisatie tussen een oostelijk en een westelijk blok. In die 'Koude Oorlog' tussen de blokken had de Sovjet-Unie al in verschillende landen gebruik gemaakt van een samenwerkingsverband van socialistische en communistische partijen om daar zogenaamde 'volksdemocratieën' te vestigen, die in werkelijkheid geheel aan Moskou onderworpen dictaturen waren.

Sjahrir verwierp de denkbeelden van de kring rondom Amir Sjarifoeddin, zowel wat betreft de bevordering van een klassenstrijd in Indonesië als wat 
betreft de oriëntering op het Sowjetblok. Half februari verlieten hij en zijn aanhangers de Partai Sosialis en stichtten zij een nieuwe partij, de Partai Sosialis Indonesia (PSI). Deze partij had geen groot aantal leden, maar sommigen daarvan bezetten invloedrijke posities in de Republiek terwijl de partij ook aan het kabinet-Hatta deelnam.

Eind februari belegden aanhangers van Amir Sjarifoeddin massale protestbijeenkomsten tegen de nieuwe regering. In enige Oost-Javaanse steden, waaronder Madioen, werd Soekarno zelf door een vijandige menigte overschreeuwd. De Sajap Kiri (waarvan de volgelingen van Sjahrir nu geen deel meer uitmaakten) transformeerde zich in een nieuwe massa-organisatie onder de naam Front Demokrasi Rakjat (FDR, Volksdemocratiefront). Naast de Partai Sosialis, de Partai Komunis Indonesia en de Partai Boeroeh namen ook de militante jongerenorganisatie Pesindo en de vakbondscentrale SOBSI hieraan deel. In maart ging dit FDR propaganda voeren tegen het Renvilleakkoord. De rolwisseling tussen de vroegere Benteng Repoeblik en Sajap Kiri was daarmee compleet geworden. Als brede oppositiebeweging tegen het diplomasi-beleid van Hatta en Soekarno vervulde het FDR nu een soortgelijke rol als de Persatoean Perdjoeangan (PP) in begin 1946 en de Benteng Repoeblik in begin 1947.

Intussen zaten Tan Malaka en andere voormannen van de voormalige PP nog steeds gevangen. Een deel van hen (maar niet Tan Malaka) werd in het voorjaar van 1948 samen met generaal Soedarsono berecht wegens betrokkenheid bij de mislukte staatsgreep van 3 juli 1946. Soedarsono en Yamin kregen vier jaar gevangenisstraf, Soebardjo en Iwa Koesoema Soemantri drie jaar.

Naast de polarisatie tussen het kabinet-Hatta en het zich op Moskou richtende FDR leidde de Renville-overeenkomst ook tot een andere scheuring binnen de Indonesische vrijheidsbeweging. Toen het Republikeinse leger zich terugtrok uit de gebieden binnen de Van Mooklijn, deed een groot deel van de daar opererende autonome strijdgroepen hier niet aan mee omdat ze zich niet aan die overeenkomst gebonden achtten. In West-Java betrof dit vooral islamitische strijdgroepen zoals de Hizboellah (die al begin 1945 onder de Japanse bezetting opgericht was). Ze weigerden dan ook hun wapens over te dragen aan de naar Midden-Java vertrekkende Siliwangi-divisie. In februari 1948 besloten deze strijdgroepen in West-Java te gaan samenwerken als een zelfstandige strijdmacht, de Tentara Islam Indonesia (Islamitisch Indonesisch Leger). Vervolgens werd in deze kring ook het begin van een eigen bestuursorganisatie opgezet. Deze beweging, die zich in feite los maakte van de seculiere Republiek, noemde zich Daroel Islam (het Rijk van de Islam).

De Daroel Islam werd geleid door de politicus S.M. Kartosoewirjo, die al jarenlang streefde naar een uitsluitend op de islam gebaseerde Indonesische staat. Voor de Japanse bezetting was hij enige tijd vice-voorzitter van de Sarekat Islam geweest, maar hij was toen wegens zijn radicale opvattingen 
uit die partij gezet. Na de Japanse bezetting was hij in het bestuur van de Masjoemi gekomen, maar sinds de totstandkoming van het kabinet-Hatta verzette hij zich tegen de politieke lijn van deze partij. De door hem geleide Daroel Islam brak in 1948 nog niet formeel met Republiek Indonesië in Jogja, maar was wel bereid de strijd voor de onafhankelijkheid op eigen gezag voort te zetten als het Nederlandse leger de Republiek alsnog zou overmeesteren. Intussen ontwikkelde zij zich tot de belangrijkste kern van het anti-Nederlandse verzet in West-Java.

\section{Voortzetting van het Nederlandse federaliseringsbeleid}

Al voor de lancering van het juli-offensief was Beel er voorstander van in de te bezetten gebieden nieuwe staatkundige eenheden te vormen teneinde die gebieden van de Republiek af te scheiden. Na het offensief nam Van Mook de uitvoering hiervan voortvarend ter hand. Daarbij liet hij zijn vroegere gedachte varen dat de Indonesische federatie slechts uit enkele grote eenheden zou moeten bestaan. Zo zag eind januari 1948 de negara (deelstaat) Oost-Sumatra het licht, gevolgd door de negara Madoera in februari, de negara Pasoendan (West-Java) in april, de negara Zuid-Sumatra in augustus en de negara Oost-Java in november. De oprichting van deze deelstaten gebeurde volgens een eenvoudig patroon. Meestal vormde zich in een bepaalde regio met steun van Nederlandse bestuursambtenaren een comité van Indonesiërs dat voor een zelfstandige status van die regio pleitte. Vervolgens erkende het gouvernement dit comité, dan wel een op verzoek daarvan bijeengeroepen conferentie, als 'voorlopig vertegenwoordigend lichaam'. Daarna volgde dan een wetsbesluit van Van Mook waarbij de regio in een deelstaat met een eigen 'staatshoofd' werd omgezet.

Juridisch berustten al deze besluiten op de in 1943 door de Nederlandse regering in Londen vastgestelde tijdelijke regeling die aan Van Mook bijna dictatoriale bevoegdheden verleend had (zie pp. 321-2). Politiek waren ze in strijd met het derde van de twaalf door Nederland zelf voorgestelde beginselen van het Renville-akkoord. Dat beginsel bepaalde dat wijzigingen in de bestuursvorm van gebieden alleen met volle en vrije instemming van de bevolking tot stand mochten komen. Men kon bij de vorming van deze nieuwe deelstaten moeilijk van volle en vrije instemming spreken, aangezien ze gevormd werden in gebieden die gewapenderhand door Nederlandse strijdkrachten bezet waren, waar Republikeinse propaganda niet werd toegestaan, waar een deel van de Republikeinse politici geïnterneerd was terwijl een ander deel naar niet-bezet gebied was uitgeweken en waar, voorzover de roep om zelfstandigheid van conferenties uitging, de meeste deelnemers aan die conferenties door het Nederlandse bestuur aangewezen waren. 
Bijzonder summier was de procedure op Madoera. Op 22 januari (vijf dagen na de ondertekening van de Renville-beginselen) hield het Nederlandse bestuur hier een volksstemming over de vraag of het eiland zelfstandig zou moeten worden. Daarbij moesten de kiesgerechtigden hun mening kenbaar maken door in hun dorp aan de kant van de voorstanders of de tegenstanders te gaan staan; uiteraard leverde dit een overweldigende meerderheid voor zelfstandigheid op. Verantwoordelijk voor deze procedure was Van der Plas, die in augustus 1947 recomba van Oost-Java geworden was. Hoe de bevolking van Madoera er werkelijk over dacht bleek in april bij geheime verkiezingen voor het parlement van de nieuwe deelstaat: voorstanders van de Republiek wonnen toen eenendertig van de veertig verkiesbare zetels.

Bij de vorming van deelstaten en autonome gebieden zocht het Nederlandse bestuur vooral medewerking onder de traditionele feodale elite. In die kring zag men de Republiek vaak als een bedreiging voor de eigen positie, voorzover de nationale revolutie ook een sociale revolutie inhield. De eerste na het juli-offensief gevormde deelstaat, Oost-Sumatra, dankte zijn ontstaan aan een comité onder leiding van de chirurg Mansoer, een felle anti-Republikein die behoorde tot de vorstenfamilies in dit gebied van wie veel leden begin 1946 tijdens de bersiap-furie vermoord waren. De leden van zijn comité kwamen vrijwel uitsluitend uit de Maleise bevolkingsgroep die nog geen derde van de bevolking van Oost-Sumatra uitmaakte. Ondanks dit gebrek aan representativiteit erkende het gouvernement zijn comité al in oktober 1947 als voorlopig vertegenwoordigend lichaam. Nadat Mansoer als staatshoofd van OostSumatra geïnstalleerd was, stelde hij een regering samen die voornamelijk uit leden van de Maleise aristocratie bestond.

Het gouvernement stelde sommige deelstaten in staat om naast hun eigen politie-organen ook eigen militaire formaties te vormen. Dit waren lichtbewapende formaties die tot taak hadden bij te dragen tot de handhaving van de interne veiligheid en daarom 'veiligheidsbataljons' genoemd werden. Eind 1948 beschikten Oost-Sumatra, Pasoendan, Oost-Java en Madoera over zulke veiligheidsbataljons.

Met de vorming van nieuwe deelstaten wilde Nederland tegenwichten tegen de Republiek opbouwen, maar deze opzet slaagde niet volledig, vooral waar men in verband met de Renville-beginselen werkelijk democratische procedures toepaste. Dit bleek in april 1948 op Madoera; het was al eerder op sensationele manier gebleken aan het slot van een in februari-maart in Bandoeng gehouden conferentie ter voorbereiding van de staat Pasoendan. Van de afgevaardigden was een deel benoemd en een deel gekozen; onder deze laatsten bevond zich een aanzienlijke Republikeinsgezinde fractie. Alvorens uiteen te gaan moest de conferentie het staatshoofd van de nieuwe deelstaat kiezen. Tegenover de door het gouvernement gesteunde kandidaat Hilman Djajadiningrat, sinds november 1947 recomba van West-Java, werd één van 
de hoogste functionarissen van de Republiek kandidaat gesteld, namelijk Wiranatakoesoema, voor de oorlog regent van Bandoeng en vooraanstaand lid van de Volksraad, na de oorlog lid van het eerste Republikeinse kabinet en nu voorzitter van de Hoge Adviesraad in Jogja. Wiranatakoesoema werd gekozen; hij aanvaardde zijn benoeming, maar verklaarde ook dat hij niet in de afscheiding van West-Java zou berusten. Tot premier benoemde hij de leider van de Republikeinsgezinde fractie, Adil Poeradiredja.

Terwijl Van Mook nieuwe deelstaten in het leven riep op Sumatra, Java en Madoera en ook de federalisering van het Malinogebied voortzette door de vorming van nog meer autonome gebieden, werkte hij tegelijk aan de overkapping van de federale constructie. Bij besluit van 9 maart 1948 transformeerde hij zijn gouvernement in een Voorlopige Federale Regering. De departementshoofden kregen nu de titel secretaris van staat. Dank zij enkele nieuwe benoemingen bestond deze regering voor bijna een derde uit Indonesiërs. Eén van hen was Hoesein Djajadiningrat, die al voor de oorlog departementshoofd en lid van de Raad van Indië geweest was en ook onder de Japanse bezetting enige tijd een departement geleid had. Eind 1947 was hij voorzitter geworden van een comité van Nederlandsgezinde Indonesiërs dat op de vorming van een federale interim-regering aangedrongen had, een actie die overeenkomst vertoonde met de formule die bij de stichting van de deelstaten gevolgd werd.

De oprichting van deelstaten en de vorming van een voorlopige federale regering konden de indruk wekken dat het centralistische bestuursstelsel van het oude Nederlands-Indië al voor een gedecentraliseerd bestel plaats gemaakt had. Die indruk was maar ten dele juist. Bij de stichting van elke deelstaat werd telkens een groot aantal onderwerpen aangewezen die tot de bevoegdheid van het centrale bestuur bleven behoren; bovendien konden de deelstaten de functies die wel tot hun competentie behoorden pas gaan uitoefenen nadat het centrale bestuur ze had overgedragen en die overdracht liet vaak lang op zich wachten. De Voorlopige Federale Regering bestuurde het door Nederland beheerste deel van de archipel dan ook in hoofdzaak nog op dezelfde centralistische manier als vroeger het geval was; zij was in wezen een voortzetting van het bestaande gouvernement in een nieuwe aankleding.

Hoewel de deelstaten slechts over beperkte eigen bevoegdheden beschikten, had hun bestaan wel degelijk politieke consequenties. Dat Nederlandse ambtenaren Indonesische ministers moesten gehoorzamen vormde een frappant contrast met het koloniale verleden. Dat deelstaatregeringen de steun van hun parlementen nodig hadden, opende nieuwe politieke mogelijkheden. De ontwikkelingen in Oost-Indonesië, de eind 1946 gestichte eerste deelstaat (zie pp. 512-4), verdienen op dit punt bijzondere aandacht. Hoewel een flinke minderheid van de parlementariërs pro-Republikeins was, had de Republikeins-gezinde voorzitter Tadjoeddin Noor al in voorjaar 1947 moeten aftreden omdat de meerderheid hem het vertrouwen opzegde. Een half jaar 
later verdween ook premier Nadjamoeddin van het toneel, nadat hij van corruptie beschuldigd was. Vervolgens verspeelde zijn opvolger echter het vertrouwen van het parlement omdat hij zich al te nadrukkelijk achter de Nederlandse 'politionele actie' stelde. Daarop kwam in december 1947 een nieuw kabinet tot stand onder Ide Anak Agoeng Gde Agoeng, destijds pas 26 jaar oud. Anak Agoeng, een Balinese aristocraat die met een dochter van president Soekawati getrouwd was, had zich als minister van binnenlandse zaken in de vorige kabinetten al een krachtig bestuurder getoond. Hij was voor alle groeperingen aanvaardbaar en nam ook Republikeinsgezinde ministers in zijn kabinet op. De regering van de Republiek deelde hem in januari 1948 mee dat zij de staat Oost-Indonesië erkende. Het parlement van Oost-Indonesië besloot tot het afvaardigen van een goodwillmissie naar de Republiek.

Voor de Republiek bestond er een wezenlijk verschil tussen de staat OostIndonesië en de na het juli-offensief opgerichte deelstaten. De eerste was voorzien in het akkoord van Linggadjati; de laatste vormden een flagrante schending ervan.

\section{Verder overleg na het Renville-akkoord}

De Nederlanders in Indonesië verkeerden in het voorjaar van 1948 in een aanzienlijk gunstiger situatie dan een jaar daarvoor. Toen zaten ze op Java en Sumatra ingeklemd in zes enclaves, waar bovendien ernstige voedselnood dreigde en men voor water en elektriciteit vaak afhankelijk was van installaties op Republikeins gebied. $\mathrm{Nu}$ beheersten Nederlandse strijdkrachten het grootste deel van Java en de rijkste delen van Sumatra. Nederlandse bestuursambtenaren hadden daar de leiding weer in handen genomen. De acute economische nood was geweken, in sommige westerse ondernemingen kwam de productie weer op gang. De wegen waren opnieuw geasfalteerd, de huizen en gebouwen nieuw gewit. Voor veel Nederlanders begon het leven in de steden gelijkenis te vertonen met de tijd voor de Japanse bezetting. Er leek geen twijfel over mogelijk dat de 'politionele actie' de Nederlandse positie dramatisch verbeterd had. Van de negatieve buitenlandse reacties op die actie merkte men niet veel meer. Het Britse wapenembargo trok weinig aandacht. India had zijn luchtruim al in oktober 1947 weer voor Nederlandse vliegtuigen opengesteld. De Australische havenarbeiders beëindigden in mei 1948 hun boycot van Nederlandse schepen. De bemoeienis van de Verenigde Naties wekte aan Nederlandse kant wel wrevel, maar had niettemin door het Renville-akkoord bijgedragen tot consolidering van de Nederlandse bezetting van Republikeins gebied.

Terwijl men besefte dat het vooroorlogse Nederlands-Indië nooit meer zou terugkeren, leken er toch goede vooruitzichten te bestaan op de totstand- 
koming van een nieuw bestel waarin Nederlanders nog steeds een invloedrijke positie zouden innemen ook al zouden Indonesiërs er de belangrijkste openbare functies uitoefenen. Overal immers waar Nederland nu de macht in handen had, zowel in het Malinogebied als op Java en Sumatra, bleek men Indonesiërs te kunnen vinden die bereid waren tot samenwerking met het Nederlandse gezag. Kennelijk bevond dit gezag zich met zijn federaliseringsbeleid op de goede weg.

De ontwikkelingen in India, Pakistan en Birma sterkten velen in hun mening dat het Britse beleid van snelle dekolonisatie geen navolging verdiende. Nadat India en Pakistan in augustus 1947 hun onafhankelijkheid gekregen hadden, waren daar gevechten tussen hindoes en moslims uitgebroken die aan een half miljoen mensen het leven gekost hadden. Birma was al eerder aan intern geweld ten prooi gevallen; zelfs was de nationale leider Aung San daar met een deel van zijn regering door opstandelingen vermoord (zie p. 526). Tegelijk woedde ook in de Filippijnen een intern gewapend conflict. Een en ander gaf steun aan de overtuiging dat Nederland onverantwoordelijk zou handelen door Indonesië te 'abandonneren' en dat het door moest gaan op de weg naar een beperkte dekolonisatie die zou uitmonden in een nauw met Nederland verbonden federaal Indonesië.

Het enige struikelblok op deze weg leek te worden gevormd door het voortbestaan van de Republiek. Veel Nederlanders bleven deze Republiek als de 'geestelijke pesthaard' zien. Zij neigden ertoe onder de Indonesiërs slechts twee politieke categorieën te onderscheiden: de goedwillenden en de kwaadwilligen; de goedwillenden waren de federalisten, de kwaadwilligen waren de Republikeinen. Voorzover de Republiek steun bleef vinden in de door Nederland beheerste gebieden, schreef men dit hoofdzakelijk toe aan ophitsing, intimidatie en terreur. Ook onder Nederlandse bestuursambtenaren was deze demonisering van de Republiek zeer verbreid. Zij liet maar één conclusie toe: liquidatie van de Republiek was een noodzakelijke voorwaarde voor een gezonde oplossing van de Indonesische problemen.

De houding van de Nederlandse autoriteiten na de totstandkoming van het Renville-akkoord stelde de Republiek ernstig teleur, evenals in 1947 het geval geweest was na de ondertekening van het akkoord van Linggadjati. Anders dan men verwacht had op grond van het vijfde Renville-beginsel handhaafde Nederland zijn economische blokkade. Bij de vorming van nieuwe deelstaten trok het zich weinig van het derde beginsel aan. In strijd met het tweede beginsel werkte het de in februari opgerichte Republikeinse plebiscietbeweging stelselmatig tegen; onder meer verbood men zelfs een besloten bijeenkomst die deze beweging in mei in Batavia wilde houden in het gebouw van de Republikeinse vertegenwoordiging aan Pegangsaän Oost 56. Verder handhaafde Nederland in strijd met de bestandsovereenkomst nog militair personeel in zijn gedemilitariseerde zones. Het voornaamste positieve 
gevolg van het Renville-akkoord voor de Republiek was de vrijlating van een aantal Indonesiërs die wegens hun steun aan de Republiek gevangen gezet of geïnterneerd was. Daaronder was eindelijk ook Ratoelangie, de voormalige Republikeinse gouverneur van Celebes; hij werd nu in Jogja adviseur van de Republikeinse onderhandelingsdelegatie.

Het Renville-akkoord was bedoeld als uitgangspunt voor onderhandelingen over een politieke overeenkomst, maar het duurde twee maanden voordat die onderhandelingen op gang kwamen. In februari besprak de Veiligheidsraad het eerste rapport van de Commissie van Goede Diensten. Hierbij werd de Republiek vertegenwoordigd door haar minister van onderwijs, Ali Sastroamidjojo, die zelf aan de besprekingen op de 'Renville' deelgenomen had. Ali Sastroamidjojo, een voorman van de PNI, was een veteraan van de nationale beweging en had nog als student samen met Hatta in Den Haag terechtgestaan (zie p. 195). In de Veiligheidsraad protesteerde hij onder meer tegen de Nederlandse activiteiten tot oprichting van deelstaten in bezet Republikeins gebied. De Raad nam met voldoening kennis van het Renvilleakkoord en verzocht de CGD bijzondere aandacht te geven aan de politieke ontwikkelingen in West-Java en Madoera.

In deze zelfde tijd vervingen de regeringen van Australië, België en de Verenigde Staten hun oorspronkelijke vertegenwoordigers in de CGD. Kirby en Van Zeeland werden opgevolgd door hun plaatsvervangers, de diplomaten Critchley en Herremans; Graham maakte plaats voor Coert DuBois, een gepensioneerde ambtenaar die voor de oorlog consul in Batavia geweest was. De Republiek benoemde Mohammad Roem tot delegatieleider. Omdat de 'Renville' niet meer voor het overleg onder auspiciën van de CGD beschikbaar was, sprak men af dat men voortaan afwisselend in Batavia en Kalioerang zou vergaderen, telkens voor een periode van drie weken. Van Nederlandse kant huldigde men een zeer beperkte opvatting van de rol van de CGD. Men ging ervan uit dat zij alleen op basis van eenstemmigheid zou optreden en dat zij zelf geen voorkeur voor bepaalde politieke oplossingen kenbaar zou maken tenzij op gezamenlijk verzoek van de beide partijen.

Het politieke overleg werd op 18 maart geopend. Anders dan in het voorjaar van 1947 het geval geweest was (zie p. 532) spraken de delegaties nu ook over de toekomstige inrichting van de Verenigde Staten van Indonesië en van de Nederlands-Indonesische Unie. Terwijl zij elkaar hierover wel wat nader kwamen, verliep hun overleg veel moeilijker over de overgangsperiode voor de totstandkoming van VSI en Unie, in welke periode heel Indonesië door een interim-regering bestuurd zou worden. Hoewel men een groot aantal aspecten hiervan besprak en over sommige bijzaken wel toenadering bereikte, bleven de standpunten over de hoofdzaken onverenigbaar.

Al bij de totstandkoming van het Renville-akkoord had Nederland het voorbehoud gemaakt dat de Republiek pas na de sluiting van de politieke 
overeenkomst aan de interim-regering zou kunnen deelnemen. Nu stelde het als voorwaarde dat de Republiek in die overeenkomst afstand zou doen van de staatsbevoegdheden die zij zich eigenmachtig had aangemeten. Onder meer zou zij moeten afzien van eigen buitenlandse betrekkingen, een eigen krijgsmacht en een eigen geldwezen. Volgens Nederland volgde dit rechtstreeks uit het eerste aanvullende beginsel van het Renville-akkoord. Bovendien zou de Republiek als deelstaat niet over meer bevoegdheden mogen beschikken dan aan Oost-Indonesië verleend waren. Deze voorwaarden gingen aanzienlijk verder dan de eisen die Nederland in 1947 aan de Republiek gesteld had. Ze kwamen er op neer dat de Republiek haar identiteit moest prijsgeven voordat zij aan de voorbereiding van de soevereine VSI zou mogen meedoen. Wat door Nederland beschouwd werd als onderhandelen over een politiek akkoord hield uit het gezichtspunt van de Republiek weinig meer in dan onderhandelen over haar eigen capitulatie.

Omdat deze voorwaarden alleen de overgangsperiode betroffen, vroeg men van Republikeinse kant of men die periode niet kon overslaan, zodat de transformatie van de Republiek tot deelstaat zou samenvallen met de totstandkoming van de VSI. Het Nederlandse standpunt liet dit niet toe. De regering had zich op twee onwrikbare uitgangspunten vastgelegd: ten eerste dat een zelfstandig Indonesië alleen maar goed zou kunnen functioneren als het een federatie vormde, en ten tweede dat tussen de huidige situatie en de zelfstandighied een overgangsperiode nodig was. Hoe het eerste uitgangspunt te rijmen viel met het feit dat Nederland zelf de kolonie NederlandsIndië altijd centralistisch bestuurd had, legde de regering niet uit. Evenmin gaf zij overtuigende argumenten voor het tweede uitgangspunt. In feite ging het haar er om in de overgangsperiode waarborgen te scheppen voor het behoud van een duurzame Nederlandse invloed. In dat kader zou uitschakeling van het machtsapparaat van de Republiek de belangrijkste waarborg vormen. Als dat machtsapparaat na de repatriëring van de uit Nederland uitgezonden troepen nog zou blijven bestaan, zou de Republiek in de Indonesische federatie de dienst kunnen uitmaken. De uiteindelijke consequentie zou kunnen zijn dat de VSI dan in de Republiek zou opgaan in plaats van de Republiek in de VSI. Voor de Nederlandse beleidsmakers was opheffing van de TNI daarom de centrale kwestie van het geschil met de Republiek geworden. Tegelijkertijd beoogden zij de opbouw van een federaal leger met het KNIL als kern. Men zou daar na zorgvuldige screening en omscholing ook elementen van de TNI in kunnen opnemen, maar als machtsbasis van de Republiek diende de TNI te verdwijnen.

De Republiek wees de Nederlandse eis tot ontbinding van de TNI volstrekt af. Hatta noemde die eis ook irreëel: geen enkele Republikeinse regering zou daartoe in staat zijn, zelfs als zij zou willen. Dit betekende niet dat de Republikeinse delegatie Nederland op geen enkele manier tegemoet wilde 
komen. Zij verzette zich niet tegen formele erkenning van de Nederlandse soevereiniteit tijdens de overgangsperiode, als dit met een vrijwillige beperking van die soevereiniteit gepaard zou gaan waardoor de Republiek haar verworven positie niet zou hoeven prijs te geven. De Republiek zou dan delen van haar eigen soevereiniteit aan de interim-regering kunnen overdragen. Zo zou zij de TNI kunnen inbrengen als kernbestanddeel van het federale leger, mits dit leger niet onder Nederlands opperbevel zou staan.

In dezelfde geest bood de Republikeinse delegatie aan dat de Republiek haar buitenlandse relaties en vertegenwoordigers te zijner tijd bij de interimregering zou onderbrengen. Daarentegen was de Republiek niet bereid al voordien het netwerk van buitenlandse betrekkingen af te breken dat zij opgebouwd had. Wel verklaarde Roem dat men nu niet van plan was die betrekkingen verder uit te breiden. Eind mei werd echter in Moskou bekend gemaakt dat de Sovjet-Unie met de Republiek een akkoord over de aanstelling van consuls gesloten had. Het bleek ondertekend te zijn door Soeripno, een bestuurslid van de PKI die in Praag een Republikeins informatiebureau opgericht had en van Soekarno een onderhandelingsmandaat gekregen had. Voor de regering-Hatta kwam dit bericht ongelegen omdat het de relatie met de Verenigde Staten dreigde te ondermijnen. Aan Nederlandse kant wekte het akkoord grote verontwaardiging. Men dreigde de besprekingen af te breken als de Republiek er geen afstand van nam. Hatta volstond met de verklaring dat zijn regering het akkoord niet zou bekrachtigen; Soeripno werd uit Praag teruggeroepen.

Van Mook's gouvernement beschouwde de CGD als een storende factor en spande zich niet in om het haar naar de zin te maken. Het stelde haar ook nooit op de hoogte van de wetsbesluiten die het nam in het kader van het federaliseringsbeleid. Binnen de CGD groeide ernstig onbehagen over het verloop van het overleg. Hoewel er al zeven maanden verstreken waren sinds de commissie met haar werk begonnen was, bestond er nog geen enkel zicht op oplossing van het politieke geschil. Critchley en DuBois vonden de Nederlandse eisen tot opheffing van de krijgsmacht en de buitenlandse betrekkingen van de Republiek onredelijk. Zij vreesden bovendien dat Nederland een militaire liquidatie van de Republiek voorbereidde. Een en ander bracht hen ertoe zelf een ontwerp voor een politieke regeling op te stellen. Omdat zij hierover geen overeenstemming met Herremans konden bereiken, werd het geen gezamenlijk voorstel van de CGD. Op 10 juni legden zij hun ontwerp als een informeel werkdocument aan Van Mook en Hatta voor. Het was een buitengewoon uitvoerig stuk dat onder meer voorzag in het houden van verkiezingen in de hele archipel voor een voorlopig parlement, op basis waarvan een Indonesische interim-regering met volledige regeerbevoegdheden gevormd zou worden, terwijl de Nederlandse luitenant-gouverneur-generaal nog slechts zeer beperkte eigen bevoegdheden zou behouden. Nederland 
vond dat Critchley en DuBois volstrekt buiten hun bevoegdheden waren getreden en weigerde categorisch hun voorstel in overweging te nemen. De Republiek verklaarde zich hier wel toe bereid. Roem zei niet te begrijpen waarom de Nederlandse delegatie zich uitsluitend op formele gronden beriep en niet bereid was op de inhoud in te gaan.

Buiten de delegaties en de CGD om onderzocht Van Mook herhaaldelijk in gesprekken met Hatta of toch een compromis over de interim-regering mogelijk was. Deze gesprekken brachten geen oplossing. Het politieke overleg onder auspiciën van de CGD hield sinds midden juni weinig meer in. De Nederlandse delegatie deed geen nieuwe voorstellen. In juli zouden in Nederland verkiezingen plaatsvinden en men wist niet hoe die zouden uitvallen en wat het Indonesiëbeleid van het nieuwe kabinet zou inhouden. Aan de andere kant had Van Mook's gouvernement in mei zonder overleg met de Republiek een conferentie met vertegenwoordigers van de federale gebieden bijeengeroepen over de toekomstige staatsinrichting van Indonesië (zie p. 583). Eind juni keerde DuBois wegens ziekte naar de Verenigde Staten terug. Ook Van Vredenburch verliet Batavia omdat hij in een andere functie benoemd was. Op 23 juli schortte de Republiek het politieke overleg op, omdat de Nederlandse houding dit naar haar mening zinloos maakte.

\section{Wijziging van de Nederlandse grondwet}

Eind 1946 had de Nederlandse regering zich ertoe verbonden een einde te maken aan de koloniale status van 'Nederlands-Indië' als deel van het Koninkrijk der Nederlanden. Omdat die status uitdrukkelijk in de Nederlandse grondwet vastgelegd was, bracht dit de noodzaak mee deze grondwet te wijzigen. De in de grondwet zelf voorziene wijzigingsprocedure maakte dat niet eenvoudig. Wijzigingen moesten eerst worden vastgesteld door de beide kamers van het parlement en moesten vervolgens na verkiezingen door de kamers in hun nieuwe samenstelling opnieuw worden behandeld, waarbij echter voor definitieve aanneming een tweederde meerderheid vereist was. De coalitie van PvdA en KVP waar het kabinet-Beel op steunde beschikte in het parlement wel over een gewone meerderheid maar niet over een meerderheid van twee derde. Daarom zocht de regering voor de noodzakelijke grondwetswijziging steun buiten de coalitie. Na maandenlang voorbereidend overleg diende zij eindelijk op 2 april 1948 een voorstel tot wijziging bij het parlement in. In de redactie daarvan had zij sterk rekening gehouden met de opvattingen van twee partijen die het regeringsbeleid met betrekking tot Indonesië tot nu toe bestreden hadden, de protestants-christelijke CHU en de liberale Volkspartij voor Vrijheid en Democratie (VVD, opvolgster van de rechts-liberale PvdV). Inderdaad kreeg het wijzigingsvoorstel met steun van 
deze twee partijen een tweederde meerderheid in de beide kamers van het parlement, zowel voor als na de verkiezingen, die op 7 juli werden gehouden. De protestants-christelijke ARP en SGP en de communistische CPN stemden telkens tegen, de eerste twee omdat het voorstel hun veel te ver ging, de laatste omdat het haar niet ver genoeg ging. Op 3 september ondertekende koningin Wilhelmina de wet tot grondwetswijziging. Het was één van haar laatste regeringsdaden; de volgende dag werd haar dochter Juliana de nieuwe koningin.

De in de grondwet aangebrachte wijzigingen hielden het volgende in. Ten eerste was de term 'Nederlandsch-Indië' overal door 'Indonesië' vervangen; artikel 1 luidde nu: 'Het Koninkrijk der Nederlanden omvat het grondgebied van Nederland, Indonesië, Suriname en de Nederlandse Antillen'. Ten tweede was een nieuw hoofdstuk opgenomen dat inhield dat voor deze gebieden een nieuwe rechtsorde gevestigd zou worden. Daarin zou het Koninkrijk voortaan alleen Nederland, Suriname en de Nederlandse Antillen omvatten, terwijl er een Unie gevormd zou worden waaraan dit Koninkrijk en Indonesië als gelijkwaardige staten zouden deelnemen. Enige kenmerken van die rechtsorde werden in dit hoofdstuk omschreven. Ten derde werd daarin bepaald dat, voorzover de overgang naar deze nieuwe rechtsorde voorzieningen nodig maakte die afweken van de eerdere hoofdstukken van de grondwet, dit zou gebeuren door wetten waarvoor in het parlement een meerderheid van twee derde nodig zijn zou.

De aldus gewijzigde grondwet gaf dus wel een ruime machtiging tot het treffen van voorzieningen voor de dekolonisatie van Indonesië, maar maakte dit in feite ook in de naaste toekomst weer afhankelijk van de medewerking van VVD en CHU. Verder waren de in de grondwet omschreven kenmerken van de nieuwe rechtsorde vooral opgenomen om voldoende parlementaire steun voor deze grondwetswijziging te krijgen. Die kenmerken vermeldden bijvoorbeeld niet dat Indonesië soeverein en onafhankelijk zou zijn, maar wel dat het federatief opgebouwd zou zijn uit onderling gelijkwaardige deelstaten. Blijkbaar vond men het niet vreemd in de grondwet van de eigen staat voor te schrijven hoe een andere staat zich intern zou moeten inrichten.

Op 20 september 1948 werd de nieuwe grondwet van kracht en werd 'Indonesië' de officiële Nederlandse naam voor het vroegere Nederlands-Indië. Anderhalf jaar eerder had Nederland in de overeenkomst van Linggadjati de term 'de Indonesische delegatie' nog gebruikt voor de delegatie van de Republiek. Het was sindsdien ondenkbaar geworden dat Nederlandse autoriteiten het woord 'Indonesisch' nog in die zin zouden gebruiken, omdat zij de Republiek stelselmatig als niet meer dan een deelstaat behandelden. Daarentegen was Van Mook, vooruitlopend op de grondwetswijziging, al begonnen zijn eigen gouvernement als 'de Indonesische regering' aan te duiden, nadat dit in maart was getransformeerd in een Voorlopig Federale Regering (VFR). Deze nu ook met de grondwet overeenstemmende termino- 
logie paste bij de voorstelling van zaken, dat de opbouw van het nieuwe soevereine Indonesië zich niet onder Republikeinse leiding maar onder leiding van deze VFR voltrok.

\section{De Bijeenkomst voor Federaal Overleg (BFO)}

Op 27 mei 1948 opende Van Mook in Bandoeng een door de Voorlopige Federale Regering bijeengeroepen Federale Conferentie, bestaande uit vertegenwoordigers van de negara (deelstaten) en daerah (autonome gebieden) in de door Nederland beheerste delen van de Indonesische archipel. De conferentie was bedoeld als een semi-permanent orgaan waarin de VFR met deze staten en gebieden overleg zou voeren over de toekomstige staatkundige structuur van Indonesië, over de door Nederland en Indonesië te vormen Unie en over de weg die daarheen moest leiden. Over dezelfde onderwerpen sprak Nederland sinds maart onder auspiciën van de CGD met de Republiek, maar het kon hierover moeilijk samen met de Republiek definitieve besluiten nemen zonder overleg met de eveneens daarbij betrokken andere deelstaten en gebieden. Dit was de officiële reden voor de bijeenroeping van deze Federale Conferentie, waarvoor de Republiek dan ook niet uitgenodigd was.

Intussen was er reden om te denken dat Van Mook met de conferentie verder reikende bedoelingen had. Terwijl hij de vorming van deelstaten en autonome gebieden oorspronkelijk bevorderd had om tegenwichten tegen de Republiek op te bouwen, leek het er meer en meer op dat hij met deze federale opbouw een alternatief voor de Republiek beoogde. Zijn plaatsvervanger Abdoelkadir zei op 18 mei in een persinterview uitdrukkelijk dat de federalisten een federatie zonder de Republiek geenszins als een onmogelijkheid beschouwden. De Nederlandse pers noemde de Federale Conferentie dan ook een voorloper van de constituante voor de Verenigde Staten van Indonesië. De Republiek beschouwde de bijeenroeping van de conferentie als een schending van het Renville-akkoord en protesteerde ertegen bij de Veiligheidsraad.

Dertien negara en daerah namen aan de Federale Conferentie deel. Tot hun vertegenwoordigers tijdens de eerste zitting behoorden onder meer de premier van Oost-Indonesië, Anak Agoeng Gde Agoeng, het hoofd van het autonome gebied West-Borneo, sultan Hamid II, het hoofd van de deelstaat Oost-Sumatra, Mansoer, en de premier van Pasoendan, Adil Poeradiredja. De conferentie heeft veelvuldig vergaderd, maar haar politieke betekenis is volkomen overvleugeld door een onverwacht bijproduct, de Bijeenkomst voor Federaal Overleg (BFO).

Dit bijproduct dankte zijn ontstaan aan een initiatief dat Anak Agoeng en Adil Poeradiredja namen toen het politieke overleg tussen Nederland en de Republiek volledig tot stilstand gekomen was na het voorstel van Critchley en 
DuBois. Uit verontrusting over de ontstane crisis besloten zij de leiders van de negara en daerah uit te nodigen voor een onderlinge bijeenkomst in Bandoeng buiten aanwezigheid van vertegenwoordigers van de centrale regering. De bijeenkomst begon op 8 juli en mondde na een week uit in de aanneming van een krachtig geformuleerde resolutie. Die hield onder meer in dat er op korte termijn een Federale Interim-Regering moest komen, geleid door een geheel uit Indonesiërs bestaand directorium van tenminste drie leden, waarnaast een Nederlandse Hoge Commissaris zou staan met beperkte bevoegdheden. De deelnemers aan de bijeenkomst besloten hun resolutie zowel aan de VFR als aan de Republiek te presenteren. Ook wilden zij een delegatie naar Nederland sturen om de resolutie toe te lichten.

Anak Agoeng en zijn medestanders waren wel geporteerd voor een federale opbouw van het toekomstige Indonesië, maar betreurden het dat Nederland de keuze tussen een unitair of federaal stelsel tot een keuze voor of tegen de Republiek gemaakt had. Zij vreesden dat het federalisme aan kredietwaardigheid verloor nu Nederland het als wapen gebruikte om de Republiek in te sluiten en te ondermijnen. Zij hechtten wel belang aan duurzame samenwerking met Nederland, maar wilden niet als schaakstukken gebruikt worden in een door Nederland gevoerde verdeel-en-heers-politiek. Daarom hadden zij besloten tot nauwe onderlinge samenwerking in de BFO als een derde politieke factor naast Nederland en de Republiek.

Van Mook was geërgerd over het eigenmachtige optreden van de federale leiders en over de inhoud van de resolutie. Hij kon echter niet beletten dat de $\mathrm{BFO}$, die als een eenmalige bijeenkomst begonnen was, vrijwel meteen uitgroeide tot een permanent orgaan dat een eigen rol ging spelen. Al begin augustus kreeg een BFO-delegatie, onder meer bestaande uit Anak Agoeng, sultan Hamid en Adil Poeradiredja, gelegenheid de resolutie in Den Haag aan de Nederlandse regering toe te lichten.

\section{Aantreden van het Nederlandse kabinet-Drees}

Terwijl in mei 1946 in Nederland de eerste na-oorlogse verkiezingen voor de Tweede Kamer gehouden waren (zie p. 463), vonden op 7 juli 1948 nieuwe verkiezingen plaats wegens de wijziging van de grondwet. In de campagne die daaraan voorafging speelden verschillende strijdvragen een rol, maar de Indonesische kwestie nam daarin wel een belangrijke plaats in. Een merkwaardige bijzonderheid was dat tot de kandidaten ook drie leiders behoorden van de buitenparlementaire oppositie tegen het Indonesiëbeleid van de regering. Gerbrandy, voorzitter van het Comité Handhaving Rijkseenheid, was kandidaat gesteld door de ARP; Welter had de KVP verlaten en had zich met een eigen lijst kandidaat gesteld en ook Feuilletau de Bruyn was met een eigen 
lijst gekomen. De VVD maakte het Indonesiëbeleid tot hoofdpunt van haar campagne en verkondigde daarbij: 'Het roer moet om!' Ook de CHU zette zich voor een radicale wijziging van het Indonesië-beleid in; daarbij sprak zij zich evenals de VVD uit voor vervanging van Jonkman en Van Mook.

De verkiezingsuitslag gaf een lichte verschuiving naar rechts te zien. In de honderd zetels tellende Tweede Kamer verloor zowel de PvdA als de CPN twee zetels. De KVP bleef gelijk, maar daarnaast verkreeg Welter een zetel. Feuilletau de Bruyn haalde geen zetel. De VVD kreeg twee zetels meer dan haar voorgangster, de PvdV. De CHU won een zetel; de ARP en de SGP bleven gelijk. Deze verschuiving naar rechts betekende overigens niet dat de Nederlandse opvattingen ten aanzien van Indonesië in 1948 conservatiever waren dan in 1946. Terwijl een groot deel van de Nederlanders zich destijds nog niet losgemaakt had van de gedachte dat 'Indië' bij Nederland hoorde, was men er nu algemeen aan gewend dat Indonesië een zelfstandige staat worden zou. Het binnenlandse draagvlak voor een beleid dat aan de Indonesische nationale aspiraties tegemoetkwam was dan ook aanzienlijk breder geworden.

Omdat in de nieuwe Tweede Kamer de PvdA 27 zetels en de KVP 32 bezette, beschikten ze samen nog over een voldoende meerderheid om hun tweepartijencoalitie voort te zetten. De KVP was daar echter niet toe bereid. Na een maand werd men het eens over de vorming van een kabinet waar ook de VVD en de CHU aan deelnamen, in overeenstemming met de combinatie die de grondwetswijziging mogelijk gemaakt had. Naast enkele partijloze ministers telde dit kabinet zes ministers uit de KVP, vijf uit de PvdA, één uit de VVD en één uit de CHU. Drees werd de nieuwe minister-president. De nieuwe minister van overzeese gebiedsdelen was E.M.J.A. Sassen, een jonge KVP-politicus zonder Indische achtergrond. De leider van de VVD, D.U. Stikker, werd minister van buitenlandse zaken. De PvdA had nu binnen de regering geen directe bemoeienis met Indonesië meer. In de praktijk maakte dit minder verschil dan het leek, want Jonkman had al een jaar lang weinig invloed meer uitgeoefend; de centrale leiding van het Indonesiëbeleid had bij Beel zelf berust. In het nieuwe kabinet keerde Beel niet terug, maar bij de formatie was afgesproken dat hij op een nader te bepalen tijdstip Van Mook zou opvolgen.

Op 12 augustus sprak Drees in de Tweede Kamer de regeringsverklaring van het nieuwe kabinet uit. Hij verklaarde bij die gelegenheid dat de Verenigde Staten van Indonesië desnoods zonder de Republiek gevormd zouden worden. 


\section{Voortgezette aanwezigheid van de Nederlandse strijdmacht in Indonesië}

Tijdens het offensief van juli-augustus 1947 waren de Nederlandse strijdkrachten grote delen van Java binnengetrokken, maar hadden ze een kerngebied van de Republiek in Midden- en Oost-Java ongemoeid gelaten. Dit vloeide voort uit het compromis tussen de KVP-ministers en de PvdA-ministers in het Nederlandse kabinet, waarbij besloten was een militaire actie tegen de Republiek te ondernemen maar die niet op bezetting van het Republikeinse regeringscentrum te richten (zie p. 547). Al spoedig na het begin van het offensief waren de politieke en de militaire top in Batavia zich hevig tegen deze beperking gaan verzetten. $\mathrm{Zij}$ hadden er in Den Haag op aangedrongen hen alsnog te machtigen tot bezetting van het hart van de Republiek. Ministerpresident Beel had in augustus aan die aandrang gevolg willen geven; pas na een ernstige waarschuwing van de Amerikaanse regering had hij hiervan afgezien (zie p. 558). De Nederlandse regering had daarop de resoluties van de Verenigde Naties aanvaard die onder meer in een Commissie van Goede Diensten voorzagen.

Het besef dat men de bemoeienis van de $\mathrm{VN}$ niet kon afwijzen had echter weinig verandering gebracht in de opvattingen van de Nederlandse beleidsmakers over het conflict met de Republiek. In Batavia bleven het gouvernement en de legerleiding ervan overtuigd, dat uitschakeling van de Republikeinse politieke en militaire leiders het beste middel was om het nog steeds voortgaande verzet tegen het Nederlandse gezag te bedwingen. Men geloofde dat dit verzet voornamelijk aan Republikeinse ophitsing en terreur te wijten was, maar dat de meerderheid van de Indonesische bevolking niet achter de Republiek stond. Daarom nam men aan dat het verzet spoedig zou uitdoven wanneer men eenmaal aan de invloed van Jogja een eind gemaakt had. In Nederland dachten Beel en veel andere politici er niet anders over. Overmeestering van het Republikeinse kerngebied in Midden- en Oost-Java bleef daarom onverminderd een optie van het Nederlandse beleid.

Op het eerste gezicht leek dit voor de Nederlandse troepen een gemakkelijker opgave dan de in juli-augustus 1947 ondernomen actie. Toen was de Nederlandse uitgangspositie op Java beperkt geweest tot drie enclaves van waaruit men een vele malen groter gebied binnengetrokken was. Nu had men al bijna twee-derde van het eiland in handen. De indruk dat dit de verovering van het Republikeinse kerngebied gemakkelijker maakte was echter bedriegelijk. In veel van de in 1947 veroverde gebieden waren de Nederlandse troepen nu doorlopend verwikkeld in bestrijding van het plaatselijke verzet. Daarom zou men voor een nieuw offensief tegen de Republiek slechts een kleiner deel van de totale Nederlandse strijdmacht kunnen inzetten dan in juli 1947 beschikbaar geweest was.

Er was nog een tweede omstandigheid die het ondernemen van een nieuw 
offensief bemoeilijkte. De totale omvang van de Nederlandse strijdmacht was weliswaar niet verminderd (bijna honderdvijftigduizend man), maar belangrijke delen ervan waren in 1948 aan demobilisering of verlof toe. Dit betrof in de eerste plaats bijna tienduizend KNIL-militairen die in 1941 onder de wapenen geroepen waren op grond van de toen voor Nederlanders in Nederlands-Indië geldende dienstplicht, vervolgens enige jaren in Japanse krijgsgevangenschap doorgebracht hadden en daarna verplicht waren in het KNIL door te dienen. Hun demobilisatie was al in oktober 1946 in uitzicht gesteld bij de sluiting van het eerste bestand tussen Nederland en de Republiek (zie p. 480). De tweede categorie die voor spoedige demobilisering in aanmerking kwam bestond uit de Nederlandse oorlogsvrijwilligers die eind 1945 uit Europa en Amerika naar Azië overgebracht waren; een deel van hen was al sinds begin 1945 onder de wapenen. Een derde categorie werd gevormd door de dienstplichtige militairen van de 7 December-divisie; zij waren in het voorjaar van 1946 in Nederland onder de wapenen geroepen en in het najaar naar Indonesië gezonden. Zowel aan de vrijwilligers als aan de dienstplichtigen was toegezegd dat ze slechts twee jaar in de tropen zouden dienen. Met de repatriëring van de vrijwilligers was dan ook in het najaar van 1947 een begin gemaakt; de 7 December-divisie zou in beginsel in het najaar van 1948 gerepatrieerd moeten worden. Intussen was midden 1947 uit Nederland een tweede divisie dienstplichtigen naar Indonesië overgebracht. Die was oorspronkelijk bestemd om de hierboven genoemde KNIL-militairen en een deel van de oorlogsvrijwilligers af te lossen, maar was in hoofdzaak aan de aanwezige strijdmacht toegevoegd. Bovendien kwam van eind 1947 tot begin 1948 nog een derde divisie dienstplichtigen uit Nederland aan.

Het in 1948 acuut geworden demobilisatieprobleem had consequenties voor de gevechtskracht van de Nederlandse strijdmacht, ook indien al het te demobiliseren personeel door nieuw personeel afgelost werd. Ten eerste betekende dit steeds de vervanging van ervaren door onervaren militairen. Ten tweede gingen grote aflossingen gepaard met transporten en hergroeperingen die het moeilijk maakten gelijktijdig een grootscheeps offensief te ondernemen.

De mogelijkheid van een nieuwe militaire actie kwam onder meer eind december 1947 ter sprake tijdens het bezoek van de ministers Beel, Drees, Jonkman en Neher aan Batavia (zie p. 564). Generaal Spoor zei toen dat men zo'n actie nog tot 15 februari zou kunnen ondernemen, maar dat men die daarna wegens troepenaflossingen zou moeten uitstellen tot april. Dank zij het optreden van de CGD kwam enige weken nadien het Renville-akkoord tot stand, waardoor de kwestie van een nieuw Nederlands offensief naar de achtergrond verschoof. Vervolgens werden in de eerste maanden van 1948 eindelijk de dienstplichtige KNIL-militairen gedemobiliseerd.

In de na het Renville-akkoord gevoerde onderhandelingen eiste Nederland 
onder meer dat de Republiek haar eigen legermacht zou ontbinden. Toen het duidelijk werd dat Jogja niet aan deze eis zou voldoen, stelde Van Mook eind mei aan zijn regering voor om desnoods al op korte termijn tot militaire actie tegen de Republiek over te gaan. De regering besloot echter met een beslissing over zulk optreden te wachten tot na de in juli in Nederland te houden verkiezingen. Nadat die verkiezingen gehouden waren besloot zij tot teleurstelling van Van Mook en Spoor opnieuw een beslissing hierover uit te stellen. Er was toen een Amerikaans voorstel in de maak dat misschien een nieuwe opening zou bieden voor een politieke oplossing van het conflict met de Republiek. De regering verwachtte eind september te kunnen bezien of verder overleg met de Republiek nog zin had. In september-oktober zou bovendien nog een brigade van Nederlandse dienstplichtigen in Indonesië aankomen.

Intussen werd nu een groot deel van de oorlogsvrijwilligers gerepatrieerd. De legerleiding in Batavia meende daarom dat men een nieuw offensief tegen de Republiek het beste in het najaar kon ondernemen, wanneer de nieuwe brigade voldoende geoefend was en mits de repatriëring van de 7 Decemberdivisie uitgesteld werd. De soldaten van die divisie verlangden weliswaar naar hun vertrek, maar zouden volgens Spoor toch nog wel graag willen deelnemen aan het afmaken van het karwei dat in augustus 1947 om politieke redenen onvoltooid gebleven was. Onder invloed van de nog vers in het geheugen liggende Tweede Wereldoorlog zagen veel Nederlanders trouwens grootschalige actie als het eigenlijke militaire werk.

Bij het voorlopig uitblijven van een tweede grote actie concentreerde de rol van de Nederlandse strijdmacht in Indonesië zich sinds het offensief van 1947 op bestrijding van plaatselijk verzet, dat wil zeggen op het voeren van contra-guerrilla. Het was een heel ander soort strijd dan die op de slagvelden van de Tweede Wereldoorlog gevoerd was. De confrontatie van guerrilla en contra-guerrilla heeft onvermijdelijk een asymmetrisch karakter; guerrilla is een strijdwijze van de zwakkere tegen de sterkere. Terwijl het Indonesische verzet rechtstreekse confrontaties vermeed, probeerde het de positie van de Nederlandse militairen zo moeilijk mogelijk te maken, onder meer door beschietingen en aanslagen, door vernieling van bruggen en blokkering van wegen. Terwijl de Nederlandse troepen duidelijk zichtbaar waren, bleef het verzet zoveel mogelijk onzichtbaar. Het profiteerde daarbij van betere kennis van het terrein en van de mogelijkheid zich binnen de plaatselijke bevolking te verbergen. Voor de effectiviteit van de guerrilla was steun van de bevolking onmisbaar. Zulke steun werd deels vrijwillig, deels onvrijwillig verleend. De verzetsstrijders keerden zich niet alleen tegen de Nederlandse militairen, het Nederlandse bestuur en de Nederlandse ondernemingen maar ook tegen de Indonesiërs die samenwerkten met het Nederlandse gezag. Velen daarvan werden door hen ontvoerd of gedood.

De bestrijding van de guerrilla berustte in de eerste plaats op voortdurend 
patrouilleren in de gebieden waar het verzet actief was, zowel op Java als op Sumatra. Dag in dag uit namen tienduizenden Nederlandse militairen hieraan deel. De legerleiding beschouwde zichtbare aanwezigheid van de Nederlandse militaire macht als een voorwaarde voor het behoud van de loyaliteit van de bevolking. De patrouilles bestonden meestal uit enkele tientallen manschappen, soms geleid door een officier, vaak door een onderofficier en soms door een korporaal of zelfs een soldaat-eerste-klas. Zij trokken gewoonlijk te voet door het terrein. In de regel hadden ze tot opdracht gewapende tegenstanders op te sporen en te vernietigen en het vertrouwen van de bevolking te winnen. Onder meer doorzochten zij daarbij woningen en arresteerden zij verdachte personen.

In het algemeen koesterden de uit Nederland overgebrachte militairen geen haat jegens de Indonesische bevolking. Omdat hun was ingeprent dat die bevolking leed onder de terreur van nationalistische extremisten, bleven zij het als hun taak zien de bevolking daartegen te beschermen. Zij werden in die zienswijze gesterkt door de talrijke aanslagen en wraakoefeningen van guerrillastrijders tegen Indonesiërs die met het Nederlandse gezag samenwerkten. Bovendien waren deze Nederlandse militairen meestal niet behept met de sociale distantie die de in Indonesië opgegroeide Europeanen tegenover de inheemsen in acht plachten te nemen. Aan de andere kant beschouwden velen van hen de guerrillastrijders als terroristen en bandieten en vonden zij hun strijdwijze laf en verraderlijk. Dit droeg ertoe bij dat de strijd tegen het verzet met wreedheid gepaard ging. Vooral tijdens patrouilles kwam het voor dat Nederlandse militairen gevangen genomen tegenstanders afmaakten; vaak werden die zogenaamd bij een 'vluchtpoging' doodgeschoten, waarna men het aan de plaatselijke bevolking overliet om hun lijken te vinden, te identificeren en te begraven. Hulp uit de bevolking aan het verzet leidde soms tot Nederlandse represailles in de vorm van het in brand steken van huizen of dorpen.

De asymmetrie tussen guerrilla en contra-guerrilla deed zich het sterkste voor waar het om het vergaren van inlichtingen ging. De verzetstrijders beschikten over ruime mogelijkheden om gegevens over de Nederlandse krijgsmacht te verzamelen; tegelijk bestonden hun sterkste troeven uit hun eigen onzichtbaarheid en de onvoorspelbaarheid van hun optreden. Daarentegen kon men er aan Nederlandse kant moeilijk achter komen wie de verzetsstrijders waren, waar die zich bevonden en wat ze van plan waren. Mishandeling en marteling van gevangenen om inlichtingen los te krijgen werden in dat verband wijdverbreide praktijken binnen de Nederlandse krijgsmacht.

Terwijl de guerrilla als strijdwijze al in 1946 rondom de Nederlandse enclaves ingang gevonden had, kreeg zij pas een grote omvang na het Nederlandse offensief van juli-augustus 1947. De belangrijkste guerrillastrijders waren toen de tienduizenden TNI-militairen die zich binnen de Van Mooklijn bevonden. 
Na het Renville-akkoord van januari 1948 luwde de guerrilla enige tijd omdat het merendeel van die militairen de gebieden binnen deze lijn verliet. Wel bleven de daar nog aanwezige autonome strijdgroepen, zoals die van de Daroel Islam, de Nederlandse troepen bestoken. Daarentegen nam de guerrilla medio 1948 sterk toe nadat de spanning tussen Nederland en de Republiek weer was gaan stijgen. Ook keerden nu duizenden TNI-militairen terug in de gebieden binnen de formele demarcatielijn, gedeeltelijk met instructies en steun van de legerorganisatie op Republikeins gebied. Bovendien voerde de regering-Hatta sinds het voorjaar een grootscheepse reorganisatie uit die niet alleen ten doel had de TNI compacter, mobieler en efficiënter te maken, maar die er ook op gericht was dit leger stelselmatig voor te bereiden voor de guerrillastrijd als antwoord op een nieuw Nederlands offensief. Daartoe bouwde men onder leiding van Nasoetion een netwerk van guerrilla-eenheden op die in nauwe samenwerking met het plaatselijk bestuur zelfstandig zouden kunnen opereren.

\section{Anti-Republikeinse maatregelen in Batavia}

Medio 1948 begonnen Van Mook en zijn gouvernement zich steeds meer te ergeren aan de presentie van de Republiek in Batavia. Dit betrof vooral de Republikeinse delegatie die daar over enige kantoren beschikte waarvan het huis aan Pegangsaän Oost 56 het belangrijkste was; bovendien woonden sommige delegatieleden met hun gezinnen in de stad. De delegatie genoot een semi-diplomatieke status op grond van met de CGD getroffen afspraken. Verder had het gouvernement weliswaar na het offensief van 1947 de meeste Republikeinse overheidsinstellingen in Batavia overgenomen, maar het personeel van het academisch ziekenhuis stond daar nog steeds in Republikeinse dienst.

De Nederlandse ergernis gold in de eerste plaats de symbolische betekenis van deze banden met de Republiek, die er immers aanspraak op maakte heel Indonesië te vertegenwoordigen krachtens de op 17 augustus 1945 voor het huis aan Pegangsaän uitgesproken onafhankelijkheidsverklaring. Daarentegen betitelde Van Mook's gouvernement zich nu zelf als 'de Indonesische regering' en dacht het aan de Republiek op zijn hoogst een ondergeschikte positie als deelstaat toe.

In de tweede plaats kon dit gouvernement moeilijk aanvaarden dat de Republiek haar delegatie ook voor andere zaken dan het voeren van onderhandelingen gebruikte. De politieke onderhandelingen waren trouwens in juli volledig gestaakt; alleen over kwesties in verband met het bestand vond nog overleg tussen de delegaties plaats. Niettemin telde de Republikeinse delegatie met al het daartoe behorende personeel enige honderden personen. 
Het gouvernement beschikte over aanwijzingen dat sommige daarvan bij het organiseren van anti-Nederlandse verzetsacties betrokken waren.

Terwijl Van Mook al in juli maatregelen overwoog om de omvang en de bewegingsvrijheid van de delegatie in te perken, kreeg hij begin augustus concrete bewijzen dat ze als dekmantel voor niet-diplomatieke activiteiten gebruikt werd. Het betrof in dit geval de handel in opium. De Republikeinse regering beschikte namelijk over een voorraad van veertigduizend kilo opium die aan het vooroorlogse Nederlands-Indische gouvernement toebehoord had. Omdat zij in geldnood verkeerde, in het bijzonder wat buitenlandse valuta betrof, was zij ertoe overgegaan opium uit deze voorraad te verkopen; daarbij had zij ook gebruik gemaakt van de semi-diplomatieke status van haar delegatie in Batavia. De Nederlandse autoriteiten gaven veel publiciteit aan de 'opiumsmokkel' van de Republiek en toonden daarbij diepe morele verontwaardiging. Het laatste was vreemd, want de productie en verkoop van opium was tot aan de Japanse bezetting een belangrijke inkomstenbron van het Nederlands-Indische gouvernement geweest.

Toen de datum van de derde verjaardag van de onafhankelijkheidsverklaring naderde verbood het Nederlandse bestuur in Batavia openbare vieringen daarvan. Niettemin verzamelden zich op de avond van 16 augustus enige honderden personen, meest jongens en meisjes, binnen het Republikeinse perceel aan Pegangsaän Oost 56. Aan aanmaningen van de politie om het terrein te verlaten gaven ze geen gevolg; ze maakten een kampvuur achter het huis, zongen liederen en riepen 'merdeka'. Uiteindelijk probeerde de politie, die met karabijnen gewapend was, het terrein met geweld te ontruimen. Plotseling vielen er schoten; het schieten kostte één politieman en één jonge nationalist het leven. Wie het eerst geschoten had bleef onbekend. Onder de deelnemers aan de bijeenkomst werden geen vuurwapens aangetroffen; daarentegen bevonden zich kogelgaten in het dak en in de muren van het huis. Op last van het Nederlandse bestuur werd het pand doorzocht op bij het incident gebruikte vuurwapens. Dit leverde geen resultaat op, maar de politie maakte van de gelegenheid gebruik om een aantal documenten van de Republikeinse delegatie mee te nemen; een deel daarvan werd vervolgens door de Nederlandse inlichtingendiensten gefotokopieerd. De delegatie kreeg haar documenten enige dagen later terug, maar kreeg voortaan geen toegang meer tot het perceel.

De Republikeinse regering protesteerde hevig tegen de bezetting van Pegangsaän Oost 56, niet alleen omdat haar vertegenwoordiging daarin gehuisvest was maar ook omdat het voor de Republiek een 'symbool van de onafhankelijkheid' en een 'nationaal heiligdom' vormde. Zij verklaarde aan geen enkel overleg met Nederland meer te willen deelnemen zo lang het perceel niet aan haar teruggegeven was. Het gouvernement was niet tot teruggave bereid; wel bood het in september aan dat de Republiek het huis 
als logeergelegenheid voor haar delegatie zou kunnen gebruiken, maar de regering in Jogja ging hier niet op in.

Een week na de bezetting van het Republikeinse hoofdkwartier in Batavia deed het gouvernement een verdere stap. Op 24 augustus eiste het dat alle in Batavia wonende personen die in actieve dienst van de Republikeinse regering waren samen met hun gezinnen het onder Nederlandse controle staande gebied zouden verlaten. Leden van de Republikeinse delegatie zouden nog alleen voor vergaderingen met de CGD en met de Nederlandse delegatie op het onder Nederlandse controle staande gebied mogen komen. De Republikeinse regering wees deze eis af. Midden september maakte het gouvernement de uitwijzing bekend van tweeëndertig Republikeinse functionarissen met hun gezinnen; hiertoe behoorden zeer prominente personen, zoals de ministers Leimena, Natsir en Agoes Salim. De uitvoering van dit besluit werd overigens herhaaldelijk uitgesteld; pas in november vonden de eerste uitzettingen plaats.

Eveneens op 24 augustus besloot het gouvernement het academisch ziekenhuis over te nemen; daarbij werden de artsen en verplegers ontslagen die weigerden hun dienstverband met de Republiek te verbreken.

De regering van de Republiek noemde de Nederlandse maatregelen schendingen van de Renville-overeenkomst en weigerde categorisch nog met de Nederlandse delegatie te onderhandelen zo lang die maatregelen niet ongedaan gemaakt werden.

\section{Amerikaanse bemiddelingspoging}

Dat de Republiek in augustus 1948 weigerde verder te onderhandelen kwam aan Nederlandse kant niet ongelegen, want de Nederlandse delegatie was zelf in deze fase niet in staat politieke onderhandelingen te voeren. Al sinds juni had zij geen nieuwe voorstellen meer gedaan, omdat men toen wachtte op de Nederlandse verkiezingen. Sindsdien waren die verkiezingen gehouden en was het kabinet-Drees tot stand gekomen. De nieuwe minister van overzeese gebiedsdelen, Sassen, had zich meteen gezet aan de opstelling van een definitief voorstel aan de Republiek, maar het overleg hierover was eind augustus nog in volle gang.

Men richtte zich in deze fase aan Nederlandse kant vooral op het voorbereiden van een wettelijke regeling voor het bestuur over Indonesië tijdens de overgangsperiode die aan de vorming van de soevereine Verenigde Staten van Indonesië vooraf zou gaan. Als streefdatum voor de vorming van de VSI had de overeenkomst van Linggadjati 1 januari 1949 genoemd. Het was duidelijk dat men deze streefdatum niet zou halen, maar de regering wilde in elk geval de overgangsperiode uiterlijk op die datum laten ingaan. Zij zou 
de daarvoor vereiste wettelijke regeling dan nog in 1948 moeten afkondigen. Over de inhoud van die regeling liepen de meningen uiteen. Belangrijke discussiepunten waren de samenstelling van de interim-regering, de duur van de overgangsperiode en de bevoegdheden die de hoogste vertegenwoordiger van Nederland tijdens die periode in Indonesië zou kunnen uitoefenen. Volgens een ontwerp dat Van Mook in juli aan de regering in Den Haag zond zou de vertegenwoordiger van Nederland zelf aan het hoofd van de interimregering staan. Vrijwel tezelfdertijd kwam de Bijeenkomst voor Federaal Overleg in Bandoeng met een voorstel (zie p. 584) dat voorzag in een alleen uit Indonesiërs bestaande interim-regering, een korte duur voor de overgangsperiode en slechts beperkte bevoegdheden voor de vertegenwoordiger van Nederland. Vervolgens legde Sassen aan het kabinet een wetsontwerp voor dat de vertegenwoordiger van Nederland eveneens buiten de interimregering plaatste maar hem wel ingrijpende bevoegdheden toekende.

Van Nederlandse kant betrok men de Republiek niet bij dit overleg. Men ging ervan uit dat pas wanneer de inhoud van de overgangsregeling vast was komen te staan de Republiek de keus zou krijgen daar wel of niet aan mee te doen. Zo niet, dan zou men de regeling toch in werking stellen en een interimregering vormen zonder deelname van de Republiek. Intussen hoopte men op Amerikaanse steun om de Republiek ertoe te bewegen de door Nederland voorbereide regeling te aanvaarden.

In de afgelopen periode was de Nederlandse regering bij herhaling teleurgesteld in haar verwachting voor haar standpunten begrip te zullen vinden bij de Amerikaanse vertegenwoordigers in de CGD. Dit betrof zowel het eerste Amerikaanse commissielid, Graham, als zijn opvolger, DuBois. In juni had DuBois samen met het Australische commissielid Critchley een gedetailleerd voorstel voor een politieke oplossing gedaan. De Nederlandse regering vond dat Critchley en DuBois hiertoe niet bevoegd geweest waren en had geweigerd hun voorstel in overweging te nemen (zie p. 581). Vervolgens had zij zich echter bijzonder ingespannen om haar eigen visie op het Indonesische conflict duidelijk te maken aan de Amerikaanse regering. Dit leidde in juli tot een aanbod van het State Department om de opstelling van een nieuw Amerikaans voorstel te bevorderen dat meer aan Nederland zou tegemoetkomen dan het plan van Critchley en DuBois. Deze laatste had zich inmiddels uit de CGD teruggetrokken; een andere diplomaat, H. Merle Cochran, was tot zijn opvolger benoemd. De Nederlandse regering meende het aanbod van het State Department niet te kunnen afwijzen, hoewel het niet strookte met haar eigen restrictieve opvatting van de rol van de CGD. Van de actieve bemoeienis van het State Department verwachtte zij steun bij het overleg met de Republiek. Cochran pleegde begin augustus overleg in Den Haag voordat hij naar Indonesië vertrok, waar hij zich zowel in Batavia als in Jogja verder liet voorlichten. Als lid van de CGD nam hij al spoedig kennis van de protesten 
van de Republiek tegen de in Batavia genomen anti-Republikeinse maatregelen en tegen de vorming van de deelstaat Zuid-Sumatra. Nadat hij de laatste hand had gelegd aan het nieuwe Amerikaanse voorstel legde hij het op 10 september als een informele discussiebijdrage voor aan de delegaties van Nederland en de Republiek.

De inhoud van dit voorstel wekte ontsteltenis bij de Nederlandse beleidsmakers. Het had de vorm van een volledig uitgewerkte ontwerp-overeenkomst tussen Nederland en de Republiek en hield slechts in beperkte mate rekening met de Nederlandse bezwaren tegen het plan van Critchley en DuBois. Onder meer ging ook dit nieuwe plan uit van verkiezingen in de hele archipel voor een voorlopig parlement als basis voor de te vormen interim-regering. Bovendien bevatte het een strikt en zeer krap tijdschema: in januari 1949 zouden de verkiezingen moeten plaatsvinden, in februari zou de interim-regering gevormd moeten worden en op 31 juli zou Nederland de soevereiniteit over Indonesië moeten overdragen, waarmee de overgangsperiode dus zou eindigen. De Nederlandse regering besloot haar nieuwe minister van buitenlandse zaken, Stikker, naar Washington te sturen om uit te leggen dat Nederland onoverkomelijke bezwaren tegen het plan-Cochran had. Stikker sprak daar op 17 en 18 september met de Amerikaanse minister van buitenlandse zaken en zijn medewerkers, maar ontmoette weinig begrip voor de Nederlandse bezwaren. De Amerikaanse regering wilde op korte termijn een politiek akkoord tussen Nederland en de Republiek tot stand brengen. Zij stond volledig achter Cochran en was niet bereid diens voorstel ingrijpend te veranderen.

\section{De Madioenopstand}

Het besluit van de Amerikaanse regering om zich actief in te zetten voor een politiek akkoord was vooral ingegeven door ongerustheid over de binnenlands-politieke situatie in de Republiek. Zoals op p. 571 al vermeld, ontwikkelde zich daar een politieke polarisatie die zich invoegde in de mondiale polarisatie tussen een oostelijk en een westelijk blok. De communistische partij PKI en enige andere linkse partijen en organisaties waren in februari 1948 gaan samenwerken in een nieuwe massa-organisatie, het Front Demokrasi Rakjat (FDR), dat zich tegen de regering-Hatta en tegen het Renville-akkoord keerde. De belangrijkste voorman hiervan was oud-premier Amir Sjarifoeddin, leider van de Partai Sosialis. De PKI was ruim twee decennia eerder in het vooroorlogse Nederlands-Indië een belangrijke beweging geweest, maar was in 1927 ten onder gegaan nadat delen ervan tegen het Nederlandse gezag in opstand gekomen waren op instigatie van de partijleiders Alimin en Moeso (zie pp. 201-2). Sindsdien hadden deze twee leiders meestal in de Sovjet-Unie gewoond. Wel was Moeso omstreeks 1935 incognito in Indonesië geweest om 
daar een clandestiene organisatie op te zetten. Na de Tweede Wereldoorlog was Alimin in 1946 in Indonesië teruggekeerd en daar in de leiding gekomen van de opnieuw opgerichte PKI. Tan Malaka had zich in 1927 tegen de plannen van Alimin en Moeso gekeerd en had daarna met Moskou gebroken.

Het FDR kreeg veel aanhang als gevolg van een toenemende maatschappelijke onvrede binnen de Republiek. Die onvrede kwam allereerst voort uit de door de Nederlandse blokkade bevorderde economische ontwrichting, onder meer leidend tot voedselgebrek, textielschaarste en werkloosheid. Een andere bron van onvrede was de door de regering-Hatta aangevatte 'rationalisatie' van de strijdkrachten en het ambtenarenkorps, die gepaard ging met ontslagen, rangverlagingen en overplaatsingen en met de ontbinding van diverse strijdgroepen en TNI-formaties. Verder had het Renville-akkoord in ruime kring wantrouwen gezaaid tegen de Verenigde Staten die ervan verdacht werden Nederland stelselmatig tegenover de Republiek te ondersteunen.

Hoewel Tan Malaka's volgelingen veel opvattingen van het FDR deelden, sloten zij zich daar niet bij aan. Het FDR werd immers gedomineerd door Amir Sjarifoeddin, die Tan Malaka en zijn medestanders in 1946 vervolgd had, en door de PKI, die Tan Malaka brandmerkte als een afvallige communist. Naar de aanhang van Tan Malaka maakte het kabinet-Hatta een verzoenend gebaar door gratie te verlenen aan de voornaamste veroordeelden van het 3-juli-proces, onder wie Soedarsono, Yamin, Soebardjo en Iwa Koesoema Soemantri. Op 17 augustus 1948, de derde verjaardag van de onafhankelijkheidsproclamatie, werd bekendgemaakt dat Soekarno het resterende deel van hun gevangenisstraf kwijtgescholden had. Een maand later deelde Hatta bovendien mee dat Tan Malaka, Soekarni en Abikoesno niet meer gerechtelijk vervolgd zouden worden wegens de 3-juli-affaire. De eerste twee verlieten op 17 september de gevangenis; Abikoesno was al eerder vrijgekomen en was inmiddels vice-voorzitter van de Masjoemi geworden.

De opkomst van het FDR als links politiek blok binnen de Republiek vond plaats in een tijdsgewricht waarin de mondiale machtsstrijd tussen het oostelijk en het westelijk blok zich verhevigde. De onderwerping van Oost-Europa aan Moskou was in februari 1948 voltooid toen een staatsgreep een eind maakte aan de democratie in Tsjechoslowakije; vervolgens was de Sovjet-Unie in juni haar blokkade van West-Berlijn begonnen. In Azië streed het Vietnam van Ho Chi Minh tegen het Franse leger en kreeg Mao Tse-tung een steeds groter deel van China in handen; bovendien sloten de communisten in de Filippijnen zich bij een al bestaande verzetsbeweging aan en brak in Malakka een door communisten geleide anti-Britse opstand uit. Het werd voor de Verenigde Staten van vitaal belang te voorkomen dat de Indonesische nationalisten de kant van Moskou zouden kiezen. Op het State Department vreesde men dat dit wel eens het gevolg zou kunnen zijn van het harde Nederlandse beleid.

De politieke polarisatie in de Republiek kwam in een stroomversnelling 
nadat Moeso medio augustus onverwachts uit Moskou naar Java teruggekeerd was, als reisgezel van de uit Praag teruggeroepen Soeripno. Moeso bracht allereerst een bezoek aan Soekarno, die hij nog kende uit de tijd dat zij in Soerabaja in hetzelfde kosthuis gewoond hadden. Vervolgens begon hij een campagne die er kennelijk op gericht was de macht van Soekarno en Hatta over te nemen. Hij kreeg de leiding van de PKI in handen en schoof Alimin naar het tweede plan. Binnen enkele weken bereikte hij dat de andere in het FDR samenwerkende partijen een fusie met de PKI aangingen. Amir Sjarifoeddin verklaarde hierbij dat hij zelf al sinds 1935 geheim lid van de PKI geweest was. In september begon Moeso samen met Amir, Wikana en andere leiders van de vergrote PKI een propagandatoernee door de Republiek. In zijn toespraken viel hij het kabinet-Hatta aan en pleitte hij voor aansluiting bij het 'anti-imperialistische kamp' onder leiding van de Sovjet-Unie. Ook keerde hij zich bijzonder fel tegen Tan Malaka.

Terwijl de PKI-leiders door het land reisden, leidde de toenemende spanning tussen voor- en tegenstanders van de regering-Hatta tot gewelddadige incidenten. Dit gold onder meer voor Solo, al sinds lang het voornaamste links-radicale bolwerk binnen de Republiek. Hier bevonden zich nu ook delen van de Siliwangi-divisie, het best uitgeruste en meest loyale legeronderdeel waarover de regering beschikte. Deze voornamelijk uit Soendanezen bestaande divisie, die zich op grond van het Renville-akkoord uit West-Java teruggetrokken had, raakte in september in gewapend conflict met een eveneens in Solo gelegerde Javaanse divisie die nauwe banden met het FDR onderhield. Binnen enkele dagen won de Siliwangidivisie de strijd. Dit leidde tot een reactie van de kant van de PKI in Madioen, de op twee na grootste stad in het Republikeinse gebied en eveneens een links-radicaal bolwerk. Om te voorkomen dat de Siliwangidivisie ook hier de met het FDR verbonden strijdgroepen zou uitschakelen, namen die strijdgroepen op 18 september de macht in de stad over. Hun voorman maakte via de radio bekend dat voor de stad en het omliggende gebied een eigen bestuur werd ingesteld. Samen met Amir en andere PKIleiders ging Moeso terstond naar Madioen en nam daar de leiding over.

De volgende dag riep Soekarno in een dramatische radiorede de bevolking van de Republiek op te kiezen tussen hem en Moeso. Deze antwoordde enkele uren later met een radiorede waarin hij Soekarno en Hatta onder meer scherp aanviel wegens hun collaboratie met Japan. Verscheidene strijdgroepen en TNI-formaties stelden zich achter het FDR. Er ontbrandde nu een bloedige strijd tussen de opstandelingen en de regeringstroepen. De Siliwangi-divisie vormde de kern van deze troepen; zij werd ook door aanhangers van Tan Malaka gesteund. De regering kreeg al spoedig de overhand op de ontijdig uitgebroken opstand. Eind september had zij Madioen weer in handen; drie weken later heroverde zij de laatste nog door medestanders van Moeso bezette plaatsen. De opstandelingen waren intussen tot een guerrillastrijd 
overgegaan, maar de meerderheid van de bevolking steunde hen niet. Moeso werd eind oktober gedood; een maand later werd Amir Sjarifoeddin gevangen genomen. Begin december was de opstand volledig onderdrukt. De Republiek had de ernstigste crisis sinds haar oprichting doorstaan.

De geslaagde bestrijding van de Madioenopstand bezorgde Soekarno en Hatta groot politiek krediet bij de Amerikaanse regering. Het maakte in Washington diepe indruk dat voor het eerst een niet-westerse regering zich met succes tegen een communistische machtsgreep teweer had gesteld.

De Nederlandse regering had na het uitbreken van deze opstand overwogen de regering van de Republiek militaire hulp aan te bieden bij het bestrijden ervan. Hatta had aan die gedachte snel de pas afgesneden door in het openbaar te verklaren, dat zijn regering geen hulp nodig had en geen Nederlandse inmenging in interne problemen van de Republiek zou dulden. Overigens besloot de Nederlandse regering naar aanleiding van de opstand tot opschorting van de repatriëring van de laatste bataljons oorlogsvrijwilligers en de 7 December-divisie.

Tan Malaka, die één dag voor het uitbreken van de Madioenopstand zijn vrijheid teruggekregen had, onthield zich daarna weken lang van openbare politieke activiteiten. Intussen voerde hij wel veel overleg met geestverwante politici, evenals in de laatste maanden van 1945. Dit overleg leidde begin november tot de fusie van enige linkse partijen en groepen tot een nieuwe politieke partij, de Partai Murba (Partij van het Proletariaat). Tan Malaka domineerde het oprichtingscongres, maar nam geen plaats in het bestuur. $\mathrm{Na}$ het congres vertrok hij naar Oost-Java. Hij verwachtte een Nederlandse militaire aanval op de Republiek en wilde daarom werken aan de voorbereiding van het dan te voeren guerillaverzet. Zijn inspanningen leidden midden december tot de oprichting van een coördinatie-orgaan, de Gaboengan Pembela Proklamasi (Verbond van Verdedigers van de Proclamatie). Enige tientallen bataljons sloten zich hierbij aan.

\section{De aanloop naar het tweede Nederlandse offensief}

In september-december 1948 stevende het conflict tussen Nederland en de Republiek op een nieuwe climax af. Het was een verwarde episode waarin Nederlandse beleidsmakers vaak langs elkaar heen en tegen elkaar in werkten. Zowel van Nederlandse als van Republikeinse kant werden dramatische gestes gedaan die de verwachting wekten dat het conflict toch nog vreedzaam opgelost zou worden. Niettemin stond de uitslag van het drama al van te voren vast, al waren niet alle spelers op het politieke toneel zich daarvan bewust. Nederland had in Indonesië een grote strijdmacht bijeengebracht die in bewapening en uitrusting verre superieur was aan de strijdkrachten 
van de Republiek. Zowel om financiële als om sociale redenen kon het die strijdmacht, die grotendeels uit Nederlandse dienstplichtigen bestond, niet lang meer handhaven. Intussen eiste Nederland van de Republiek dat zij haar eigen strijdkrachten zou ontbinden. Geen Republikeinse regering kon zich veroorloven aan die eis te voldoen. Aan de andere kant kon geen Nederlandse regering zich veroorloven haar soldaten naar huis te sturen zonder ook maar geprobeerd te hebben het verzet van de Republiek te breken met volledig gebruik van het Nederlandse militair-technische overwicht. Een nieuwe krachtmeting was daarom onontkoombaar.

In het beraad binnen de Nederlandse regering werd de kwestie echter niet in die termen gesteld. Ook over de politieke doelstelling van een nieuwe militaire actie vond geen echte discussie plaats. Terwijl sommigen meenden dat een militaire ingreep nodig kon zijn om de Republiek tot een akkoord te bewegen, wilden anderen met zo'n optreden de Republiek als staatkundige organisatie liquideren.

In het Nederlandse parlement beschikten de partijen die duidelijk voor een nieuw offensief tegen de Republiek waren over een ruime meerderheid (65 van de 100 zetels in de Tweede Kamer). Omdat de PvdA zowel in het parlement als in het kabinet-Drees een minderheidspositie innam, kon zij zo'n offensief niet tegenhouden. Verzet ertegen zou alleen tot gevolg hebben dat zij de regering zou moeten verlaten, terwijl de militaire actie dan onder verantwoordelijkheid van een anders samengestelde regering toch door zou gaan. In feite echter hadden ook de leiders van de PvdA geen principiële bezwaren tegen zo'n actie, al dachten zij niet aan volledige liquidatie van de Republiek.

Onder het algemene Nederlandse publiek leefden zulke bezwaren nog minder dan in juli 1947 het geval geweest was. Men nam graag aan dat de regering op basis van de met de Republiek gesloten akkoorden oprecht naar een nieuwe verhouding met Indonesië streefde, maar daarbij van Republikeinse kant hardnekkige tegenwerking ondervond. Men zag de stichting van nieuwe deelstaten op voormalig Republikeins gebied als bewijs van de ernst van het Nederlandse dekolonisatiebeleid, zonder zich af te vragen hoe dit te rijmen viel met het akkoord van Linggadjati. Hetzelfde gold voor de bereidheid van het kabinet-Drees om de Verenigde Staten van Indonesië eventueel zonder de Republiek te vormen. Daarentegen wekten de voortdurende berichten over Republikeinse bestandsschendingen groeiende ergernis. Ook onder dat deel van het publiek waar de PvdA op steunde waren er nog maar weinigen die bereid waren de Republiek vertrouwen te schenken. Nog steeds was Het Parool het voornaamste dagblad dat van zo'n opstelling blijk gaf.

Wat de voornaamste spelers op het politieke toneel betreft vertoonde deze episode enige verschillen met de voorafgaande periode. Dit gold in het bijzonder voor Nederland. De nieuwe minister-president, Drees, hield zich minder persoonlijk met de Indonesische kwestie bezig dan zijn voorganger Beel, die 
de centrale regie van het Indonesië-beleid stevig in handen had gehad. Aan de andere kant trad de nieuwe minister van overzeese gebiedsdelen, Sassen, veel actiever op dan zijn voorganger Jonkman; daarbij liet hij zich niet remmen door zijn gebrek aan Indische ervaring en handelde hij stelselmatig buiten Van Mook om. Sassen was bij uitstek geporteerd voor spoedige militaire liquidatie van de Republiek teneinde heel Indonesië op te bouwen uit door federalisten geleide deelstaten. Hij zat daarmee op één lijn met zijn partijleider Romme, met oud-premier Beel en met generaal Spoor (die de Madioenopstand graag hadden willen benutten om de Republiek in de rug aan te vallen en op te ruimen).

De opvallendste verandering in deze periode was dat Van Mook in Batavia plaats maakte voor Beel, op grond van een bij de kabinetsformatie gemaakte afspraak. Hoewel het kabinet nog geen besluit over het tijdstip van zijn vervanging genomen had, vroeg Van Mook al in oktober zelf ontslag uit ergernis over het optreden van Sassen. Op 3 november droeg hij het bewind aan Beel over. Deze was niet tot luitenant-gouverneur-generaal benoemd maar tot Hoge Vertegenwoordiger van de Kroon, om te doen uitkomen dat de koloniale verhouding tussen Nederland en Indonesië nu spoedig in een andere relatie zou overgaan. Uit solidariteit met Van Mook nam zijn plaatsvervanger, Abdoelkadir, eveneens ontslag. Van Mook had graag in functie willen blijven tot aan de totstandkoming van de soevereine Verenigde Staten van Indonesië. Alleen om redenen van Nederlandse binnenlandse politiek moest hij eerder heengaan. Zijn vertrek was vooral een zoenoffer voor de achterban van de VVD en de CHU, nu die twee partijen gingen meewerken aan de losmaking van Indonesië uit het Koninkrijk. Voor het in de naaste toekomst te voeren beleid maakte de vervanging van Van Mook door Beel weinig uit. Beiden wilden ze de Nederlandse militaire macht inzetten om een zodanige inrichting van het nieuwe Indonesië door te drukken dat Nederland daar een duurzame invloed zou kunnen behouden.

Een verder verschil met de eerdere situatie was dat de nieuwe minister van buitenlandse zaken, Stikker, zich ook intensief met de kwestie-Indonesië bezighield. Stikker kwam uit de zakenwereld en stelde zich pragmatisch op. Hoewel de door hem geleide partij, de VVD, zich tijdens de verkiezingscampagne had ingezet voor een radicale breuk met het tot dan toe gevoerde Indonesiëbeleid, was hij zelf geneigd de beleidslijn van het vorige kabinet voort te zetten. Die beleidslijn sloot trouwens ook de optie in van een tweede offensief tegen de Republiek, maar Stikker merkte in zijn nieuwe functie al snel dat Nederland dan internationaal-politiek zwak zou staan.

Wat de Republiek betreft was het opmerkelijk dat Hatta in deze episode zelf als de voornaamste onderhandelaar optrad.

Onder de belangrijke spelers op het politieke toneel moet tenslotte ook het Amerikaanse CGD-lid Cochran vermeld worden, die zich in nauw overleg 
met zijn regering bijzonder inspande om tussen Nederland en de Republiek te bemiddelen.

$\mathrm{Na}$ de formatie van het kabinet-Drees streefde Sassen er in de eerste plaats naar zo veel mogelijk steun van de federalisten te krijgen, omdat hij de Republiek in het toekomstige Indonesië geheel wou elimineren. In september-oktober voerde hij in Den Haag overleg met de in de Bijeenkomst voor Federaal Overleg (BFO) verenigde leiders van deelstaten en autonome gebieden, wat leidde tot volledige overeenstemming over een regeling voor het bestuur in de overgangsperiode. De regering legde deze regeling, genaamd Bewind Indonesië in Overgangstijd (BIO), nog niet als wetsontwerp aan het parlement voor, omdat men daarover eigenlijk ook overleg met de Republiek zou moeten voeren. In plaats daarvan nam het parlement een noodwet aan die de regering tot het eind van het jaar machtigde zelf maatregelen op dit gebied te treffen. Het eerste op deze noodwet gebaseerde besluit betrof de nieuwe functie van Hoge Vertegenwoordiger van de Kroon (HVK), waarin Beel benoemd werd als opvolger van Van Mook.

Intussen was nu sinds juni met de Republiek geen politiek overleg meer gevoerd. De Amerikaanse regering drong herhaaldelijk aan op een Nederlandse reactie op het plan-Cochran van 10 september. De Republiek had al op 20 september verklaard dat zij bereid was op basis van dit plan, zonder zich aan de inhoud ervan te binden, het overleg onder auspiciën van de CGD te hervatten, mits van Nederlandse kant voldaan werd aan haar eerder voor hervatting van de onderhandelingen gestelde voorwaarden, zoals teruggave van Pegangsaän Oost 56 en intrekking van de uitwijzing van Republikeinse functionarissen en hun gezinnen. Binnen de Nederlandse regering was men het er over eens dat men zich noch nationaal noch internationaal kon veroorloven een militaire actie tegen de Republiek te beginnen zonder een laatste blijk van bereidheid om tot overeenstemming te komen. Op 4 oktober deelde de regering aan Cochran mee dat ook zij bereid was op basis van zijn plan besprekingen te voeren. Daarbij legde zij echter een tegenvoorstel over en stelde zij een aantal prealabele voorwaarden.

Deze stukken leken er op gericht te zijn verwerping door de Republiek uit te lokken. Onder meer bevatte het Nederlandse tegenvoorstel een voorlopige territoriale indeling waarin de Republiek volledig ontbrak (zo werd Java ingedeeld in West-Java, Batavia, Noord-Midden-Java, Zuid-Midden-Java en OostJava) en zouden alle door de Republiek uitgeoefende bevoegdheden overgaan op de voorlopige federale organen en de organen van het Koninkrijk. Verder verklaarde de regering in de aanbiedingsbrief dat de onderhandelingen slechts drie weken zouden moeten duren, terwijl zij tegelijk aan de Republiek specifieke eisen stelde als voorwaarden voor de hervatting van de onderhandelingen. Onder meer zou de Republiek via radio en pers moeten bekendmaken dat zij alle openlijke en subversieve vijandelijke acties en propaganda in en 
buiten Indonesië zou staken. Aan de andere kant verklaarde Nederland zich bereid de uitwijzing van functionarissen op te schorten en Pegangsaän Oost 56 als logeergelegenheid voor Republikeinse delegatieleden beschikbaar te stellen.

De Amerikaanse regering reageerde verontwaardigd op deze stukken, die zij beschouwde als verwerping van het plan-Cochran en als weigering van verdere onderhandelingen. Zij waarschuwde dat als Nederland in zijn houding volhardde de Veiligheidsraad zou kunnen besluiten de CGD nieuwe bevoegdheden te geven om een oplossing op te leggen. De Nederlandse regering trok zich van de Amerikaanse waarschuwingen weinig aan en handhaafde haar voorstel. Wel verving zij haar aanbiedingsbrief op 14 oktober door een nieuwe brief die minder ultimatief gesteld was. Pas hierna gaf Cochran de stukken door aan de Republiek. Deze herhaalde een week later dat zij bereid was de onderhandelingen te hervatten; daarbij sprak zij de hoop uit dat de door haar prealabel gestelde kwesties spoedig opgelost zouden worden. Op de specifieke Nederlandse eisen ging zij niet in; wel betoogde zij dat ze zich voortdurend inspande om de inachtneming van het bestand te verzekeren.

Terwijl de Nederlandse regering nu voor het dilemma stond of zij het overleg onder auspiciën van de CGD zou hervatten hoewel de Republiek niet aan haar specifieke eisen voldaan had, aanvaardde zij een voorstel van Stikker dat hij zelf naar Indonesië gaan zou om in rechtstreeks contact met Hatta te onderzoeken of er nog een basis voor onderhandelingen was. Van 4 tot 6 november sprak Stikker in Kalioerang met Hatta over de mogelijkheid van een akkoord voor de overgangsperiode. Hij werd daarbij vergezeld door enige hoge ambtenaren; na zijn terugkeer naar Batavia zetten zij het overleg nog met adviseurs van Hatta voort aan de hand van een lijst van vraagpunten die door de Republiek schriftelijk werden beantwoord. Op de meeste punten bereikte men overeenstemming. Belangrijke overblijvende verschilpunten waren dat de Republiek niet bereid was haar leger te ontbinden en niet wilde aanvaarden dat het oppergezag over alle strijdkrachten in Indonesië bij de HVK zou berusten. Voor zijn terugkeer naar Nederland sprak Stikker nog met Beel en Spoor. Deze laatste noemde 1 december de uiterste termijn voor het ondernemen van een nieuwe militaire actie.

Het overleg van Stikker met Hatta doorkruiste de bedoelingen van Sassen, die verwacht had dat men midden november tot militaire actie zou kunnen besluiten. Intussen had men binnen de regering bedacht dat het ontbreken van politieke overeenstemming niet voldoende zou zijn om zo'n actie te rechtvaardigen, maar dat men die alleen zou kunnen baseren op een onhoudbare toestand als gevolg van Republikeinse bestandsschendingen. Men was een publiciteitscampagne begonnen om meer aandacht op die toestand te vestigen. Tijdens de reis van Stikker had Sassen bovendien bewerkstelligd dat Nederland nu als prealabele voorwaarde voor politiek overleg eiste dat 
vooraf aan die schendingen een eind gekomen moest zijn. In feite was dit een onvervulbare voorwaarde, omdat juist het ontbreken van politiek overleg het voortgaan van de guerrilla in de hand werkte. Stikker was het er dan ook niet mee eens, maar in het parlement kreeg de nieuwe voorwaarde uitdrukkelijke steun van de VVD.

Na de terugkeer van Stikker was de regering ernstig verdeeld over de vraag hoe men verder moest. Uit Batavia spoorde Beel aan nu tot militair optreden te besluiten. Daarentegen vonden Stikker en Drees dat er toch nog uitzicht op een politiek akkoord was. Tenslotte besloot men een regeringsdelegatie onder leiding van Sassen en met Stikker en oud-minister Neher als leden naar Indonesië te sturen om een oplossing te zoeken. Als waarnemers nam men in de delegatie parlementsleden op uit KVP, PvdA, VVD, CHU en ARP, onder wie Romme en Van der Goes van Naters. Van 27 november tot 1 december pleegde de delegatie in Kalioerang overleg met Hatta; voor haar terugkeer naar Nederland voerde zij met hem op 4 december in Batavia nog een laatste gesprek. Dit alles bracht de standpunten over de voornaamste geschilpunten niet nader tot elkaar. De Republiek bleek niet bereid zichzelf voor de totstandkoming van de Verenigde Staten van Indonesië op te heffen.

Overigens leidde het bezoek van deze delegatie aan Indonesië tot een verwijdering tussen de Nederlandse regering en de federalisten. Ondanks aandrang van Anak Agoeng en sultan Hamid waren Sassen en Beel niet bereid om de BFO bij het overleg te betrekken noch om haar over de resultaten ervan in te lichten.

Romme maakte van zijn aanwezigheid in Batavia gebruik om met Beel af te spreken dat, als er in het kabinet-Drees geen meerderheid zou zijn voor de voorgenomen militaire actie tegen de Republiek, Beel die actie toch zou ondernemen.

Na de terugkeer van de ministers in Nederland besloot het kabinet op 13 december eenstemmig op voorstel van Drees om opdracht tot de militaire actie te geven. Men nam dit besluit in weerwil van het feit dat de Amerikaanse regering in een nota van 7 december in ongewoon harde termen tegen een aanval op de Republiek gewaarschuwd had. Ook oud-minister Van Kleffens had de actie ernstig ontraden. Niettemin waren de ministers van het kabinetDrees ervan overtuigd dat er geen alternatief was. Voor deze overtuiging bestond in december 1948 even weinig grond als in juli 1947.

Intussen was de regering zich wel bewust van het risico dat de Veiligheidsraad, die in Parijs in vergadering bijeen was, maatregelen tegen Nederland zou nemen. Beel kreeg daarom opdracht de actie niet eerder dan 16 december te beginnen, want men verwachtte dat de Veiligheidsraad dan voor een maand met reces zou gaan en hoopte de Republiek te kunnen verslaan en een Indonesische interim-regering te kunnen installeren voordat de Raad half januari weer bijeen zou komen. 
Nadat het besluit van 13 december genomen was ontstond er opnieuw grote onenigheid in het kabinet, toen bleek dat Hatta diezelfde dag een brief aan Cochran geschreven had met nog verdere tegemoetkomingen aan het Nederlandse standpunt. Dit leidde zelfs tot een korte kabinetscrisis en uiteindelijk tot het besluit de militaire actie enkele dagen uit te stellen en Hatta nog een laatste gelegenheid te geven tot formele aanvaarding van de Nederlandse wensen. Hiervan kwam niets meer terecht omdat Beel aan de boodschap voor Hatta een korte beantwoordingstermijn verbond en tegelijk die boodschap pas zo laat doorgaf dat tijdige beantwoording onmogelijk was.

Op zaterdagochtend 18 december gaf Drees definitief machtiging aan Beel om de actie te beginnen. In Batavia deelde de Nederlandse delegatie 's avonds laat aan Cochran en aan de Republikeinse delegatie mee dat Nederland het bestand met de Republiek met ingang van middernacht opzegde. Zij konden dit niet meer aan Jogja doorgeven omdat de telefoon- en telegraafverbindingen al verbroken waren.

\section{Het tweede Nederlandse offensief (de tweede 'Politionele Actie')}

Het tweede Nederlandse offensief (door de regering wederom als 'politionele actie' betiteld) begon in de nacht van zaterdag 18 op zondag 19 december 1948. Evenals in juli 1947 volgde generaal Spoor een 'speerpuntenstrategie' die ten doel had het Nederlandse militair-technische overwicht te benutten om in korte tijd de belangrijkste centra en verbindingswegen in handen te krijgen. Het meest spectaculaire onderdeel daarvan was zondagochtend de verovering van het vliegveld van Jogjakarta door parachutisten, gevolgd door de aanvoer per vliegtuig van enige duizenden militairen. Van hier rukten deze troepen op naar het zeven kilometer verder gelegen Jogja; in de middag bereikten ze het centrum van de stad. Soekarno vergaderde hier sinds de ochtend met een aantal ministers en andere politieke leiders; op zijn voorstel besloten zij te blijven en zich gevangen te laten nemen. Dit besluit stelde opperbevelhebber Soedirman teleur; zelf slaagde hij er in, evenals enige andere belangrijke militaire leiders, de stad tijdig te verlaten. Voordat de regering zich aan de Nederlandse militairen overgaf, vaardigde zij nog enige belangrijke instructies uit. De strijdkrachten kregen bevel de strijd voort te zetten; de minister van financiën, Sjafroeddin Prawiranegara, die zich op Sumatra bevond, kreeg opdracht daar een noodregering te vormen.

Op dezelfde dag drongen Nederlandse troepen over land en uit zee van vele kanten het kerngebied van de Republiek op Java binnen. Hun opmars verliep minder vlot dan de verovering van Jogja. Onder meer stuitten ze op ontelbare wegversperringen en vernielde bruggen, terwijl de TNI vooral de eerste dagen op sommige plaatsen hevige tegenstand bood. Pas na anderhalve 
week waren alle steden en grote wegen op Java in Nederlandse handen, zowel in het kerngebied van de Republiek als in het gebied van Bantam. De TNI had zich overal in het zijterrein teruggetrokken. Intussen waren veel vernielingen aangericht in het kader van de 'verschroeide-aarde'-politiek.

Op Sumatra veroverden de Nederlandse troepen binnen enkele dagen het Republikeinse bestuurscentrum Boekit Tinggi. Verder breidden ze het al bezette gebied aan de oostkust uit, bezetten ze verscheidene kustplaatsen vanuit zee en brachten ze enige verbindingen tussen de west- en de oostkust tot stand. Met inzet van parachutisten veroverden ze eind december de olievelden van Djambi. Daarentegen werd Atjeh geheel ongemoeid gelaten. Intussen had Sjafroeddin Prawiranegara met enige andere ministers inderdaad een nood-regering van de Republiek gevormd, zelfs al voor de opdracht uit Jogja hem bereikt had. Deze regering had Boekit Tinggi tijdig verlaten en zich elders in het Sumatraanse bergland gevestigd. Ze beschikte over een radio-installatie waarmee ze ook verbinding met Birma en India kon maken.

Behalve Soekarno en de samen met hem gevangen genomen leiders werden in Jogja nog tientallen andere vooraanstaande Republikeinen gearresteerd, onder wie enige nestoren van de nationale beweging: Setiaboedi (E.F.E. Douwes Dekker), Ki Hadjar Dewantoro en Ratoelangie. De meesten van hen kwamen vrij spoedig weer vrij.

Evenals bij de actie van juli 1947 liepen bij dit nieuwe offensief de Nederlandse en de Republikeinse verliezen ver uiteen. Terwijl het aantal gesneuvelden aan Nederlandse kant ongeveer honderd bedroeg, had het offensief vele duizenden slachtoffers gemaakt onder de militairen en de burgerbevolking aan Republikeinse kant.

De overgrote meerderheid van de uit Nederland afkomstige militairen was vol geestdrift over de nieuwe 'politionele actie', die een eind leek te maken aan een lange periode van stagnatie en frustratie. In Nederland zelf wekte de actie weinig verzet. Het publiek had hier steeds te horen gekregen dat de regering de met de Republiek getroffen overeenkomsten loyaal wilde uitvoeren, maar dat deze dit stelselmatig saboteerde. Men kon dan ook begrijpen dat de regering nu tot actie overging om de Republiek te dwingen de akkoorden van Linggadjati en de Renville uit te voeren. Ook de meeste parlementsleden van de PvdA steunden de regering. Toen J. de Kadt, die nu lid van de Tweede Kamer was, in de partijraad van de PvdA een motie indiende waarin de actie werd afgekeurd, werd zijn motie met 90 tegen 13 stemmen verworpen.

In het algemeen beschouwden de Nederlanders de actie als een geweldig succes. De actie was echter minder geslaagd dan het leek. Haar doel was niet in de eerste plaats de bezetting van Republikeins gebied geweest, maar vooral de uitschakeling zowel van de Republikeinse politieke en militaire leiders als van de Republikeinse strijdkrachten. De belangrijkste politieke leiders waren nu inderdaad in Nederlandse handen, maar op Sumatra functioneerde de 
noodregering van Sjafroeddin Prawiranegara. Bovendien waren op Java vijf Republikeinse ministers buiten Nederlandse handen gebleven, die daar nu als vertegenwoordigers van het centrale gezag optraden; tot hen behoorden Soekiman, de leider van de Masjoemi, en Kasimo, de leider van de katholieke partij. Nog belangrijker was het dat de militaire leiders op enkele uitzonderingen na niet waren uitgeschakeld. Hoewel opperbevelhebber Soedirman ernstig ziek was, had hij de strijdkrachten nog op 22 december via radio-Madioen toegesproken en werd hij sindsdien door zijn soldaten in een draagstoel voortgedragen en uit Nederlandse handen gehouden. Kolonel Nasoetion, commandant van de strijdkrachten op Java, kon al spoedig weer orders geven uit een nood-hoofdkwartier in de bergen; hij stelde nu heel Java onder militair gezag. Wat de Republikeinse strijdkrachten zelf betreft: die hadden wel verliezen geleden, vooral door luchtaanvallen, maar waren allerminst uitgeschakeld. Ze beheersten nog grote delen van het terrein en waren goed op het voeren van guerrilla voorbereid. Het sterkste deel van de TNI, de vooral uit Soendanezen bestaande Siliwangi-divisie, begon een terugmars dwars door de Nederlandse linies naar het Soendanese gebied in West-Java.

Tot de indirecte slachtoffers van het Nederlandse offensief behoorden ruim vijftig voormannen van de Madioenopstand, onder wie Amir Sjarifoeddin en Soeripno. Zij zaten in Solo gevangen, maar werden op last van de plaatselijke TNI-commandant gefusilleerd toen Nederlandse troepen de stad naderden.

\section{De reactie van de Verenigde Naties op het tweede Nederlandse offensief}

De Nederlandse aanval op de Republiek was met opzet pas ingezet nadat de Veiligheidsraad met reces gegaan was, omdat de regering verwachtte dat de Raad zich dan pas midden januari met de kwestie-Indonesië bezig zou houden. $\mathrm{Al}$ op de dag van de aanval bleek hoe wereldvreemd die verwachting was. Zowel de Amerikaanse en de Australische regering als de CGD vroegen nog diezelfde zondag om een spoedzitting van de Veiligheidsraad. De Raad kwam al de volgende dag weer in Parijs bijeen; omdat toen nog niet alle leden daar vertegenwoordigd waren verdaagde men de bespreking tot 22 december.

Nederland werd in de Raad vertegenwoordigd door oud-minister J.H. van Roijen, nu ambassadeur in Ottawa. Hij verklaarde dat het Nederlandse beleid nog steeds op onafhankelijkheid voor het Indonesische volk gericht was en dat de nu ondernomen actie alleen ten doel had bepaalde delen van MiddenJava en Sumatra van onverantwoordelijke en extremistische elementen te zuiveren. Verder betoogde hij dat de Veiligheidsraad niet bevoegd was zich met deze kwestie bezig te houden. Namens de Republiek voerde L.N. Palar het woord. Hij zei dat de Nederlandse militaire actie het sluitstuk was van een 
beleid gericht op vernietiging van de Republiek. Het betoog van Van Roijen maakte weinig indruk. Op voorstel van de Verenigde Staten nam de Raad op 24 december een resolutie aan waarin op de partijen een beroep werd gedaan om de vijandelijkheden onverwijld te staken en om de president en de andere sinds 18 december in hechtenis genomen politieke gevangenen onmiddellijk in vrijheid te stellen.

Het scheelde weinig of de Veiligheidsraad had een voor Nederland nog veel ongunstiger besluit genomen. De Amerikaanse delegatie had namelijk ook voorgesteld op beide partijen een beroep te doen om hun strijdkrachten achter de oude bestandslijn terug te trekken. In plaats daarvan stelde de Sovjetdelegatie voor dit alleen van Nederland te verlangen. Zowel het ene als het andere voorstel kreeg te weinig stemmen.

Nederland gaf aan de resolutie van de Veiligheidsraad geen gevolg. Het zette de militaire operaties voort en liet de belangrijkste Republikeinse leiders niet vrij. Nadat de in Jogja gevangen genomen leiders de eerste dagen huisarrest gekregen hadden, interneerde men negen van hen buiten Java. Daarbij bracht men Soekarno in Oost-Sumatra onder, samen met Agoes Salim en Sjahrir, terwijl men Hatta naar Bangka overbracht, samen met Roem, Ali Sastroamidjojo, Assaat (de voorzitter van het KNIP), Pringgodigdo (de secretaris van de regering) en Soeriadarma (de chef-staf van de luchtmacht).

$\mathrm{Na}$ Kerstmis zette de Veiligheidsraad de behandeling van de kwestie voort, met stijgende ergernis over het Nederlandse in gebreke blijven. De Raad nam nu scherpere resoluties aan waarin onder meer aan Nederland gevraagd werd binnen vierentwintig uur te rapporteren over de vrijlating van de president van de Republiek en de andere politieke gevangenen. Op 29 december deelde Van Roijen namens zijn regering mee, dat de Nederlandse actie voor 1 januari op Java en enkele dagen later op Sumatra zou eindigen, dat de vrijheidsbeperking van vooraanstaande personen dan zou worden opgeheven mits zij de openbare veiligheid niet in gevaar zouden brengen, en dat minister-president Drees naar Batavia zou gaan met het oog op de oprichting van een volledig Indonesische interim-regering.

De buitenlandse reacties op de Nederlandse aanval op de Republiek beperkten zich niet tot het optreden van de Veiligheidsraad. De Australische havenarbeiders hervatten hun boycot van Nederlandse schepen; ook in sommige andere landen kwam zo'n boycot op gang. De Amerikaanse regering zette haar economische steun aan Nederland stop voorzover die voor Indonesië bestemd was. Saoedi-Arabië, Pakistan, India, Ceylon en Birma sloten hun vliegvelden voor Nederlandse vliegtuigen. De Indiase ministerpresident Nehru nodigde een aantal voornamelijk Aziatische landen uit voor gezamenlijk beraad over de situatie in Indonesië.

Drees was van 6 tot 19 januari 1949 in Indonesië voor het voeren van oriënterend overleg. Hij sprak daarbij ook met enige vooraanstaande Republikeinen, 
onder wie Soepomo die in Kalioerang één van Hatta's belangrijkste adviseurs geweest was. Sjahrir, die in Oost-Sumatra geïnterneerd was maar zelf geen deel van de Republikeinse regering uitmaakte, bleek bereid over te komen voor een vrijblijvend gesprek; zijn vrijheidsbeperking werd opgeheven en hij betrok weer zijn woning in Batavia. Daarentegen kwam geen ontmoeting met Hatta tot stand; deze wilde wel met Drees spreken maar niet in Batavia.

Van 7 januari af zette de Veiligheidsraad de bespreking van de Indonesische kwestie voort, nu in Lake Success bij New York. In de loop van de debatten verklaarde Van Roijen onder meer dat zijn regering hoopte dat de Indonesische interim-regering voor 14 februari tot stand zou komen en dat nog in het derde kwartaal van 1949 algemene verkiezingen voor een Indonesisch vertegenwoordigend lichaam zouden plaatsvinden; nadat een door dit lichaam te ontwerpen grondwet goedgekeurd zou zijn door de deelstaten, zou nog een Ronde Tafel Conferentie tussen vertegenwoordigers van Nederland en Indonesië moeten plaatsvinden ter opstelling van het Statuut van de Nederlands-Indonesische Unie; tenslotte zou dan, bij voorkeur nog in 1950, de soevereiniteitsoverdracht plaatsvinden.

Van Roijen liet in het midden welke plaats de Nederlandse regering eigenlijk aan de Republiek toedacht. Voorzover zijn verklaring geschikt was om een gunstiger indruk van het Nederlandse beleid te wekken, werd die indruk al spoedig teniet gedaan door opschudding over de gevangenhouding van de Republikeinse leiders. Van Roijen had meermalen gezegd dat de op Bangka geïnterneerde leiders zich binnen het hele eiland vrij konden bewegen, maar toen de CGD op 15 januari zelf Bangka bezocht, bleek dit volstrekt onwaar te zijn. Hatta en de vijf andere hier geïnterneerde Republikeinen werden achter prikkeldraad gevangen gehouden in één gezamenlijke slaapkamer en één gezamenlijk dagverblijf. Deze onthulling vormde een klap voor de geloofwaardigheid van de Nederlandse regering; immers òf zij had gelogen òf zij had onvoldoende greep op haar eigen machtsapparaat. De blamage werd niet ongedaan gemaakt doordat de op Bangka geïnterneerde Republikeinen nu alsnog bewegingsvrijheid binnen het eiland kregen. Daarbij leidde de verschijning van Hatta in het openbaar herhaaldelijk tot oploopjes van 'merdeka!' roepende eilandbewoners.

Van 20 tot 23 januari vond in New Delhi de door Nehru bijeengeroepen Indonesiëconferentie plaats. Naast twaalf Aziatische en twee Afrikaanse landen nam ook Australië eraan deel. De conferentie deed een reeks aanbevelingen, onder meer dat het bestuursdistrict Jogjakarta onmiddelijk teruggegeven zou worden aan de Republiek, dat de Nederlandse strijdkrachten zich voor 16 maart 1949 zouden terugtrekken uit de gebieden die ze sinds de actie van december bezet hadden en dat Nederland de soevereiniteit over heel Indonesië op 1 januari 1950 volledig zou overdragen.

Intussen voerde de Amerikaanse delegatie in de Veiligheidsraad weken- 
lang overleg met andere delegaties over een alomvattende aanpak van het Indonesische probleem. Als resultaat daarvan nam de Raad op 28 januari, met enkele onthoudingen maar zonder tegenstemmen, een gedetailleerde resolutie aan die in feite tot strekking had Nederland onder internationale curatele te stellen.

In deze resolutie deed de Veiligheidsraad niet alleen opnieuw een beroep op Nederland om alle in december gearresteerde politieke gevangenen onvoorwaardelijk vrij te laten, maar ook om de Republikeinse overheidsfunctionarissen onmiddellijk naar Jogja te laten terugkeren, onder meer ter uitoefening van het bestuur over de stad en het omliggende gebied. Nederland en de Republiek zouden opnieuw moeten onderhandelen. De soevereiniteitsoverdracht zou niet later dan 1 juli 1950 moeten plaatsvinden. De Veiligheidsraad zette de Commissie van Goede Diensten om in een nieuwe commissie met dezelfde samenstelling maar grotere bevoegdheden, de United Nations Commission for Indonesia (UNCI). Deze commissie zou de partijen bijstaan bij de onderhandelingen en zou daarbij eigen aanbevelingen mogen doen. Zij zou vertegenwoordigers van deelstaten buiten de Republiek kunnen uitnodigen aan de onderhandelingen deel te nemen. Verder zou zij onder meer moeten adviseren over de geleidelijke terugkeer van het Republikeins bestuur in de sinds december door Nederland bezette gebieden. De belangrijkste versterking van de bevoegdheden was dat de UNCI haar besluiten bij meerderheid van stemmen zou nemen. In de praktijk bracht dit mee dat de Amerikaanse en de Australische vertegenwoordiger voortaan samen de dienst zouden uitmaken.

Terwijl veel Nederlanders het jaar 1949 waren ingegaan met de gedachte dat men in Indonesië een beslissende overwinning behaald had, betekende de Raadsresolutie van 28 januari voor Nederland een beslissende nederlaag op het internationaal-politieke toneel.

\section{De reactie van de federalisten op het tweede Nederlandse offensief}

In 1947 en 1948 geloofde een belangrijk deel van de Nederlandse beleidsmakers, dat de meerderheid van de Indonesische bevolking niet achter de Republiek van Soekarno en Hatta stond en dat het daarom mogelijk moest zijn een Indonesische tegenmacht tegenover die Republiek in het leven te roepen. Het scheppen van zo'n tegenmacht was de beweeggrond van het Nederlandse federaliseringsbeleid.

Naar de bedoeling van de Nederlandse regering moest de militaire actie van december 1948 de weg vrij maken voor een in hoofdzaak uit Indonesische federalisten samen te stellen interim-regering. De structuur en de bevoegdheden daarvan zouden gebaseerd worden op de in oktober in overleg met 
federalisten ontworpen regeling Bewind Indonesië in Overgangstijd (BIO). Met het oog hierop stelde de regering het BIO-besluit op 18 december, de dag voor het begin van de actie, in werking. Men sloot niet uit dat ook enkele uit de Republiek afkomstige prominente figuren aan de interim-regering zouden deelnemen, maar in de zienswijze van Beel en Sassen zouden zulke figuren dan niet als vertegenwoordigers van de Republiek kunnen optreden, want die zou als gevolg van de militaire actie niet langer bestaan.

De uitvoerbaarheid van dit politieke vervolg op de militaire actie was afhankelijk van de bereidheid van federalistische politici om er aan mee te werken. Op sommigen van hen kon de Nederlandse regering zeker rekenen. Dit gold onder meer voor het hoofd van West-Borneo, sultan Hamid II, en voor de leiders van de deelstaten Oost-Sumatra en Zuid-Sumatra. In verscheidene andere federale gebieden bestond daarentegen weinig steun voor een op liquidatie van de Republiek gericht beleid. Daartoe behoorden niet alleen enige andere delen van Borneo en de deelstaat Madoera, maar ook de twee grootste deelstaten: Oost-Indonesië en Pasoendan (West-Java). Het parlement van OostIndonesie had op 16 november een motie aangenomen die deelname van de Republiek aan de interim-regering aanmerkte als een belangrijke voorwaarde voor de stichting van de Verenigde Staten van Indonesië. Vervolgens had zowel de regering van Oost-Indonesië als de regering van Pasoendan besloten niet te zullen meedoen aan de vorming van een federale interim-regering zonder deelname van de Republiek. Minister Sassen had zelf op 8 december in het Nederlandse kabinet gezegd dat de meeste federalisten geen verantwoordelijkheid zouden willen aanvaarden voor een interim-regering zonder de Republiek. Dit was toen echter noch voor hem noch voor de rest van het kabinet een reden geweest om van een nieuwe 'politionele actie' af te zien. Men nam blijkbaar aan dat de federalisten toch wel met het Nederlandse bestuur zouden meewerken wanneer men de Republiek eenmaal uitgeschakeld had.

Toen Nederland tenslotte op 19 december de Republiek aanviel, reageerde zowel de regering van Oost-Indonesië als de regering van Pasoendan nog diezelfde dag door af te treden. Het parlement van Oost-Indonesië had trouwens al de vorige dag een motie aangenomen waarin het een eventuele militaire actie tegen de Republiek veroordeelde. Het feit dat de regeringen van de twee belangrijkste deelstaten nu demissionair waren maakte het voor het Nederlandse bestuur onmogelijk om op korte termijn tot vorming van een interim-regering over te gaan. Pas op 12 januari 1949 kwam in Oost-Indonesië een nieuw kabinet tot stand, weer onder leiding van Anak Agoeng. Kort daarvoor was in Pasoendan een nieuwe minister-president aangetreden met een kabinet dat niet minder Republikeinsgezind was dan zijn voorganger.

Onder de prominente figuren binnen de Republiek was er één die in de Nederlandse plannen een bijzondere plaats innam: de sultan van Jogja, Hamengkoeboewono IX. Nederlandse beleidsmakers hadden verwacht dat hij 
na de militaire actie een belangrijke rol zou kunnen spelen, hetzij als lid van de federale interim-regering hetzij aan het hoofd van een nieuwe deelstaat Midden-Java. In deze verwachtingen werden zij teleurgesteld: na de bezetting van Jogja onttrok de sultan zich stelselmatig aan politieke contacten met het Nederlandse bestuur.

De door de militaire actie geschapen nieuwe situatie maakte onderling overleg tussen de federalisten dringend gewenst. Onder voorzitterschap van sultan Hamid begon op 10 januari in Batavia een vergadering van de Bijeenkomst voor Federaal Overleg (BFO). Eerst leken voor- en tegenstanders van een interim-regering zonder Republiek elkaar in evenwicht te houden, maar dit veranderde toen Anak Agoeng uit Makassar aangekomen was na de installatie van zijn nieuwe kabinet. Op zijn voorstel besloot de BFO op 13 januari eerst met prominente personen uit andere gebieden overleg te plegen voordat men aan de vorming van een interim-regering zou meewerken. De Republiek werd in de tekst van het besluit niet met name genoemd, maar men sprak af dat het onder meer ging om Soekarno, Hatta, Agoes Salim en de sultan van Jogja.

Het BFO-besluit van 13 januari 1949 introduceerde een nieuw overlegkader over de toekomst van Indonesië. Van mei tot oktober 1948 had Nederland over die toekomst met de federalisten gesproken buiten de Republiek om. Vervolgens had het in november en december tijdens de bezoeken van Stikker en Sassen over hetzelfde onderwerp met de Republiek gesproken zonder de federalisten erbij te betrekken. $\mathrm{Nu}$ gingen federalisten en leiders van de Republiek onderling overleg plegen buiten Nederland om. Het was een gevolg dat de Nederlandse regering met de militaire actie allerminst beoogd had.

\section{Aantekeningen bij hoofdstuk VII}

\section{Literatuuroverzicht}

Dit hoofdstuk bestrijkt de periode van december 1946 tot januari 1949. Voor de literatuur hierover kan in de eerste plaats verwezen worden naar een aantal al eerder genoemde boeken: Kahin 1952, Smit 1952 en 1962, Nasution 1977-79, Bank 1983, J.J.P. de Jong 1988, L. de Jong 1988 en Van den Doel 2000. Bijzonder relevant voor deze periode zijn Indonesian independence and the United Nations (1960) door A.M. Taylor en Marsroutes en dwaalsporen (1991) door P.M.H. Groen. Politieke ontwikkelingen sinds eind 1947 worden behandeld in 'Renville' als keerpunt in de Nederlands-Indonesische onderhandelingen door Ide Anak Agung Gde Agung (1980). Dit boek bestrijkt meer dan de titel doet verwachten, al maakt het niet duidelijk waarom Renville een keerpunt in de onderhandelingen gevormd zou hebben; helaas behandelt het de periode voor de Renville-overeenkomst uitermate slordig. Beel in Batavia (1986) door R. Gase betreft vooral het Nederlandse beleid gedurende 1948. Minister Stikker en de souvereiniteitsoverdracht aan Indonesië (1982) door L.G.M. Jaquet behandelt Nederlandse verwikkelingen sinds het aantreden van het kabinet-Drees. Wat interne documenten betreft wordt de in dit hoofdstuk behandelde periode bestreken door de delen VI tot en met XVII van de 
bronnenpublicatie NIB (1976-92). Sommige van de in dit hoofdstuk vervatte gegevens zijn ontleend aan dagbladen uit de beschreven periode.

Tijdens de in dit hoofdstuk behandelde periode veranderde de spelling van de Indonesische taal. Al in 1947 besloot de regering van de Republiek de lettercombinatie OE te vervangen door de letter U. In 1948 werd deze spelling binnen de Republiek algemeen gevolgd en in september besloot Van Mook's gouvernement zich hierbij aan te sluiten. In het onder Nederlands bestuur staande gebied ging de nieuwe spelling op 1 januari 1949 in.

Deze door de Republiek ingevoerde en door het gouvernement overgenomen spellingswijziging betrof de algemene Indonesische taal (Bahasa Indonesia), maar geen afzonderlijke talen zoals het Javaans. Voor de spelling van eigennamen werd het aan de dragers zelf overgelaten of zij OE door $U$ wilden vervangen. Zo bleef bijvoorbeeld Soekarno zijn eigen naam als 'Soekarno' schrijven, terwijl de nieuwsmedia algemeen op de spelling 'Sukarno' overgingen. De nieuwe spellingsregel gold wel voor geografische namen, zodat 'Bandoeng' en 'Soerabaja' voortaan als 'Bandung' en 'Surabaja' geschreven moesten worden.

Ter vermijding van verwarring zal deze nieuwe spelling in dit boek alleen worden gevolgd in het laatste hoofdstuk, dat het tijdvak 1950-1963 behandelt. Overigens is in 1972 in Indonesië een veel ingrijpender wijziging van de spelling ingevoerd.

\section{Inleiding en overzicht}

Voor de invloed van de beschikbaarheid van de Nederlandse strijdmacht op de politieke ontwikkelingen zie ook Groen 1991:275, 294 en L. de Jong 1988:1075.

\section{Aankleding van Linggadjati}

Voor de waarschuwing van Van Kleffens zie NIB VI:293. Voor het besluit tot aankleding van Linggadjati NIB VI:363; voor de toelichting door de commissie-generaal NIB VI:756-78; voor de regeringsverklaring van 10 december NIB VI:778-84. Over de behandeling in de Tweede Kamer zie Stempels 1950:64-73. Zie verder Handelingen II voor het parlementaire debat en voor de afsluitende redevoering van Jonkman op 19 december en voor de motie van Romme en Van der Goes van Naters.

Nederlands verzet tegen Linggadjati

Zie L. de Jong 1988:781-3, Hekman 1981:24-33 en De Blauw en Severein 1980:82-3, 88.

Indonesisch verzet tegen Linggadjati

Zie Overdijkink 1948:113-9, Kahin 1952:199, J.J.P. de Jong 1988:316-8 en Poeze 2007:54350 .

Oprichting van de deelstaat Oost-Indonesië

Zie Van Goudoever 1947. Voor de verwachting van Van Mook dat Sumatra een afzonderlijke deelstaat zou worden zie NIB VI:61. Voor de ordonnantie van 24 december 1946 zie Indisch Staatsblad 1946, nr. 143.

\section{Nederlandse terreur in Zuid-Celebes}

Zie VARA 1969, IJzereef 1984 en De Moor 1999. Over de arrestatie van Nederlandse ambtenaren en militairen voor de komst van de Japanners in 1942 zie TouwenBouwsma 1992:64. Over de situatie in Zuid-Celebes in najaar 1945 zie NIB I:510-9 en 
Barbara S. Harvey in Audrey Kahin 1985:211-5. Over de kritieke situatie in november 1946 zie onder meer NIB VI:167-8, 267-8, 302-3, 423. KRIS was de afkorting van Kebaktian Rakjat Indonesia Soelawesi (Loyaliteit van de Indonesiërs uit Celebes). Voor de door Van Mook getrokken vergelijking met Duitse en Japanse methodes zie NIB VII:284.

Nederlandse marineblokkade van de Republiek

Zie Van Holst Pellekaan en De Regt 2003:64, 84-7, 137-40. Voor de in januari 1947 afgekondigde in- en uitvoerregelingen zie Indisch Staatsblad 1947, nrs. 17 en 18.

\section{Ondertekening van het akkoord van Linggadjati}

Over de door Nederlands en Republikeins militair optreden veroorzaakte problemen in het tijdvak tussen de ondertekening van het militaire bestand en van het politieke akkoord zie onder meer Smit 1959:92-7, J.J.P. de Jong 1988:308-9, 318-20, 323, 325-8 en Van den Doel 2000:175-82. Het Nederlandse voorstel dat aan artikel 15 voorafging (destijds artikel 16, lid 1) luidde: 'In afwachting van de totstandkoming van de Vereenigde Staten van Indonesië en van de Nederlandsch-Indonesische Unie zal de staats- en volkenrechtelijke positie van het Koninkrijk der Nederlanden gehandhaafd blijven, met dien verstande dat de Nederlandsche regeering zal bevorderen, dat aanstonds wettelijke maatregelen zullen worden getroffen, teneinde de Indische regeering te hervormen op zoodanige wijze, dat zij in haar samenstelling en werkwijze zoo goed mogelijk aansluit op de erkenning van de Republiek en op de ontworpen staatsrechtelijke structuur'. Over de totstandkoming van de definitieve tekst van artikel 15 zie NIB VI:215, 235, Smit 1970:115, 118-9, J.J.P. de Jong 1988:293-4 en Burgers 2008. Voor een adequatere uitleg van artikel 15 dan de officiële Nederlandse interpretatie zie Van Vredenburch 1985:235.

Voor de pleidooien van Schermerhorn en Van Mook om 'Linggadjati' desnoods zonder de Republiek uit te voeren zie onder meer NIB VI:75. Over de uitbreiding van het KNIP en de zitting in Malang zie Overdijkink 1948:118-22, Kahin 1952:199-206 en Poeze 2007:551-2, 559-68.

\section{Dekolonisatie in andere delen van Azië}

Zie Van den Doel 2000:110-2, 150-4, 196-7, 232-7.

Invloed van de koloniale troika en van de Indische Nederlanders op het Nederlandse beleid Het begrip 'koloniale troika' is ontleend aan Van Doorn en Hendrix 1983:101; vergelijk Simatupang 1985:130-1. Over de zienswijze van de KNIL-officieren zie onder meer J.J.P. de Jong 1988:227-30, 322 en Groen 1991:74, 103, 113. Voor de brief van Spoor aan Beel zie NIB VI:611-32. Over de aan de Nederlandse troepen in Indonesië gegeven voorlichting zie Schulte 1987:34-9. Vergelijk L. de Jong 1988:810-2.

Nederlands-Indonesisch overleg over de uitvoering van Linggadjati

Voor het Nederlands-Republikeinse overleg in maart-mei 1947 over de uitwerking van Linggadjati zie NIB VIII:29-31, 51-5, 214-25, 238-44, 263-86, 529-36, 673-4, 725-6 en NIB IX:45-6. Over de Republikeinse bezwaren tegen de Nederlandse uitleg van artikel 15 zie NIB VII:332-5 en NIB VIII:220.

Voor de mening van de commissie-generaal dat het militaire alternatief nog slechts enkele maanden beschikbaar was zie NIB VIII:306-7. Voor de vroege gedachten van 
Romme over de afscheiding van delen van de Republiek zie Bank 1983:274. Over de Pasoendan-affaire zie Wolf 1948:108-9, J.J.P. de Jong 1988:371 en Van den Doel 2000:179-82.

Voor de verklaring van Schermerhorn over handhaving van de Nederlandse militaire macht zie NIB VIII:240-1. Voor de Nederlandse en Republikeinse voorstellen over de uitvoering van artikel 16 zie NIB VIII:287, 673-4. Voor de balans van de CommissieGeneraal NIB VIII:539-50.

Verdeeldheid in Nederland over gebruik van geweld tegen de Republiek

Over de radicalisering van Gerbrandy zie L. de Jong 1988:790-4. Voor het vroege contact tussen Spoor en Romme over het nut van een akkoord met de Republiek zie Bank 1983:226.

\section{Ultimatieve voorstellen van Nederland aan de Republiek}

Voor een uiteenzetting over de Nederlandse deviezennood zie NIB VIII:313-9. Voor de opmerking van Beel NIB VIII:302. Voor de besprekingen van Beel en Jonkman met de Commissie-Generaal en met andere functionarissen in Batavia onder meer NIB VIII:646-58, 689-700, 748-61 en NIB IX 32-5. Over het politieke presentatieprobleem bij militaire actie NIB VIII:656-7, 698-9. Voor de oproep van Van Mook en Sjahrir tot opheffing van de Australische schepenboycot NIB IX:50 (noot 1), 59-61. Over de voltooiing van de evacuatie van de geïnterneerden zie NIB IX:72, 431-4 en Van Delden 2007:389-92.

Voor de tekst van de ultimatieve voorstellen van 27 mei 1947 zie NIB IX:749-66 of Smit 1959:202-30. Voor de opvatting van Jonkman over de 'eenheid van buitenlands beleid' van Nederland en de VSI zie NIB VIII:379.

Voor de Nederlandse plannen inzake 'militaire samenwerking' in Unieverband zie NIB VI:291 (noot 1), 339 (noot 1), NIB VIII:137-8, 174-7, 257-61, 359-60, 505-12, NIB IX:136-9. Zie ook Drooglever 1987 en De Moor 1997. Voor de opmerking van Van Mook over de betekenis van de Nederlandse strijdmacht voor invloed op de gang van zaken in Indonesië zie NIB VIII:177. Voor de gelijkstelling van gemeenschappelijke zorg voor orde en veiligheid met capitulatie van het Republikeinse leger zie Smit 1959:141, 169.

Over het pamflet van de VNI zie De Blauw en Severein 1980:93.

\section{Vaste Nederlandse denkpatronen in Batavia}

De in juni 1947 naar Indonesië overgebrachte divisie van Nederlandse dienstplichtigen was weliswaar bestemd voor aflossing van een deel der in 1946 daarheen gebrachte vrijwilligers, maar deze laatsten zouden pas na die aflossing gerepatrieerd worden. Over de plannen van Beel om delen van het Republikeinse gebied af te scheiden zie NIB VIII:693 en NIB IX:192. Over het streven om de betekenis van de Republiek zoveel mogelijk terug te dringen door naast haar onder Nederlandse invloed staande deelstaten tot stand te brengen zie Smit 1959:142.

Over de veronderstelde overmacht van het Republikeinse leger en de Republikeinse strijdgroepen over de politici zie J.J.P. de Jong 1988:408-11. Over de verwachte steun van de PNI en de Masjoemi zie NIB IX:450-2. Voor het rapport van Idenburg over zijn missie naar Jogja NIB IX:110-35.

Voor de verklaring van Van Poll (in een besloten vergadering van het KVPpartijbestuur) zie Bank 1983:289. 
Over het irreële karakter van internationalisering en abandonnering als beleidsalternatieven zie Maas en Van Oerle 1987:20-1. Over het vierde beleidsalternatief ook Van den Doel 2000:199 (daar als eerste keuzemogelijkheid genoemd). Voor de mening van Beel over afzien van het gebruik van de Nederlandse troepen zie NIB VIII:354. Voor de mening van Spoor NIB VIII:556-7.

\section{De aanloop naar het Nederlandse offensief}

Vergelijk Groen 1991:91-9, J.J.P. de Jong 1988:362-400 en Van Liempt 1994. Voor de besluiten van de Nederlandse ministerraad van 2 juni 1947 zie NIB IX:191-3. Voor de Republikeinse antwoordnota van 7 juni NIB IX:767-77. Voor het advies van de commissie-generaal aan de Nederlandse regering NIB IX:391-4. Voor de radiorede van Sjahrir NIB IX:422-4. Voor de op 23 juni aan Sjahrir overhandigde oproep van de Nederlandse regering NIB IX:434-6, 444-5. Voor het antwoord van Soekarno van 27 juni NIB IX:484-6. Voor de stappen van de Amerikaanse regering van 27 juni NIB IX:48993. Voor de brief van Van Mook aan Soekarno van 29 juni NIB IX:524-6. Voor de brief van Amir Sjarifoeddin aan Van Mook van 5 juli NIB IX:592-594. Voor de bereidheid van Schermerhorn tot vorming van een interim-regering NIB IX:602. Voor de brief van Amir Sjarifoeddin van 8 juli NIB IX:629-30. Voor de zienswijze van Jonkman en Drees over het ultimatief stellen van de gendarmerie-kwestie NIB IX:614, 653-4. Over het plan van Spoor voor 'vreedzame bezetting' NIB IX:637, 673, 692. Over het overleg van Amir Sjarifoeddin met de commissie-generaal op 14 en 15 juli NIB IX:671-2, 674-7.

Over de Republikeinse afwijzing van de eisen tot eenzijdige staking van de vijandelijkheden en eenzijdige terugtrekking NIB IX:704, 707-9. Voor het besluit van de Nederlandse ministerraad van 17 juli NIB IX:717-8. Voor het aparte telegram van Schermerhorn NIB IX:707. Voor de brief van Van Mook aan de Republikeinse regering van 20 juli NIB IX:738-9.

Het eerste Nederlandse offensief (de eerste 'Politionele Actie')

Vergelijk Groen 1991:100-109 en Heijboer 1979:32-98. Voor de radiotoespraak van Beel van 20 juli zie NIB X:715-8. Over de reacties in Nederland vergelijk L. de Jong 1988:831-3, De Blauw en Severein 1980:98-101 en Poeze 1980:16-8. Voor de zienswijze van Sanders zie NIB IX:746. Voor de pleidooien van Van Mook voor bezetting van Jogja zie NIB X:74, 101. Voor de mening van Schermerhorn en Van Poll NIB X:88. Voor het besluit van de Nederlandse ministerraad van 30 juli NIB X:120.

De reactie van de Verenigde Naties op het Nederlandse offensief

Vergelijk BZ 1947:19-65, Van den Doel 2000:222-4, 227-32 en Taylor 1960:47-55. Over de aandrang uit Batavia tot bezetting van Jogja zie onder meer Bank 1983:310-5 en Van den Doel 2000:226-31. Voor het telegram van Bataviase ambtenaren en adviseurs zie NIB X:335-7. Voor de boodschap van Spoor en Pinke NIB X:364-6. Voor Van Mook's dreigement met insubordinatie NIB X:367, 473.

Over de Haagse droomwereld zie J.J.P. de Jong 1988:333. Voor de opmerkingen van Drees zie NIB X:382-4. Voor de waarschuwing van Van Kleffens NIB X:395-6. Voor de stemming in de Nederlandse ministerraad van 18 augustus NIB X:495. Over de bereidheid van Beel tot een kabinetscrisis NIB X:635. Voor de waarschuwing van de Amerikaanse regering NIB X:567. Voor het besluit van de Nederlandse ministerraad van 27 augustus NIB X:664. 
Uitbreiding van het Nederlandse bestuur op Java en Sumatra

Over de Tijdelijke Bestuursdienst zie L. de Jong 1988:857-9. Voor de benoeming op 19 juli 1947 van vijf 'recomba's' zie NIB X:6. Voor de verklaring van Van Mook van 29 augustus NIB X:723-6. Voor de afwijzende reactie van de Republiek op 3 september zie BZ 1948a:162-3; zie ook BZ 1948a:9 voor het protest-telegram van de Republiek aan de Veiligheidsraad van 29 september. Over de niet door Nederlandse troepen bezette gebieden binnen de Van Mooklijn zie ook NIB XI:360.

\section{De VN-Commissie van Goede Diensten en het Renville-akkoord}

Voor de onwil van Van Mook om nog politiek met de Republiek te onderhandelen zie NIB XI:595 en NIB XII:292. Over de Progressieve Concentratie zie NIB XII:175-6. Voor de brochure van prominente PvdA-leden zie Barents et.al. 1947; vergelijk Daalder 2004:162-4. Voor de motivering van de Nederlandse bezetting van heel Madoera zie NIB XI:425. Over de 'dodentrein van Bondowoso' zie Excessennota 1995:82-3 en Van Liempt 1997. Over Rawagede zie Excessennota 1995:83, Scagliola 2002:113-4 en Scholtens 2007.

Voor de samenstelling van de Nederlandse delegatie zie NIB XII:39. Voor de 'kerstboodschap' van de CGD zie NIB XII:322-4; voor de CGD-schets van politieke beginselen NIB XII:326 (dezelfde teksten ook in BZ 1948b:90-4). Anak Agung 1980 bevat een onjuiste weergave van de kerstboodschap en laat de belangrijkste elementen daarvan weg. Voor de radiorede van Beel zie NIB XII:278. Voor de gesprekken van de CGD met Nederlandse ministers NIB XII:327-30, 397-403, 454-5. Voor het gesprek van de Nederlandse ministers met Spoor NIB XII:356-64. Voor de Nederlandse voorstellen van 2 januari 1948 NIB XII:408-11. Voor de motieven van de actieve bemoeienis van de Amerikaanse regering NIB XII:459-60. Voor de schets van het State Department NIB XII:455-6. Voor het Amerikaanse dreigement NIB XII:484. Voor de dreiging van een nieuwe Nederlandse aanval zie Taylor 1960:88 (noot 74) en Simatupang 1985:28, 111-2. Voor de verklaringen van de CGD-leden in Kalioerang zie NIB XII:532-7. Voor het voorbehoud van de Republikeinse regering NIB XII:563. Voor de schriftelijke verklaring van Soekarno NIB XII:625. Vergelijk over deze onderhandelingsfase ook Van Vredenburch 1985:297-332.

Voor de op 17 januari 1948 op de Renville ondertekende bestandsovereenkomst zie NIB XII:847-52. Zie de volgende paragraaf voor de toen ondertekende twaalf politieke beginselen en voor de op 19 januari aanvaarde zes aanvullende beginselen.

\section{Tekst van het politieke deel van het Renville-akkoord}

De op de Renville overeengekomen twaalf plus zes politieke beginselen waren alleen in het Engels gesteld. De hier afgedrukte tekst is een niet-officiële Nederlandse vertaling, ontleend aan BZ 1948b:127-30. De Engelse tekst is te vinden in NIB XII:853-5 en in BZ 1948b:119-20, 109-10. Daarentegen is de tekst wonderlijkerwijze niet te vinden in Anak Agung 1980.

Val van het kabinet-Amir Sjarifoeddin; aantreden van het kabinet-Hatta

Zie Kahin 1952:230-4, 258-60; vergelijk Swift 1989:5-50. Over de evacuatie van de Republikeinse militairen zie Taylor 1960:103-4. Voor de 'Zes Punten' van Soedirman zie NIB XIV:11 en NIB XVI:667-8. Over de opheffing van het verbod voor Republikeinse ambtenaren zie NIB XII:790-1. Over de oprichting van de plebiscietbeweging ib NIB XII:787, 791. Over de rationalisatie van de Republikeinse strijdkrachten vergelijk L. de Jong 1988:911-2 en Salim Said 1991:68-80. 
Verscherping van de tegenstellingen binnen de Indonesische vrijheidsbeweging

Zie Kahin 1952:256-72, Swift 1989:17-31 en Poeze 2007:678-9, 716-7. Over het 3-juliproces zie Poeze 2007:873-944. Over de Daroel Islam zie Kahin 1952:326-31 en Van Dijk 1981:18-9.

Voortzetting van het Nederlandse federaliseringsbeleid

Zie Bank 1983:327-34, L. de Jong 1988:844-97, Van den Doel 2000:260-2 en Taylor 1960:110-7. Over de procedure bij de vorming van nieuwe deelstaten ook Anak Agung 1980:183-4. Over de procedure op Madoera zie Kahin 1952:236-7. Over de transformatie van het gouvernement in de VFR zie Anak Agung 1980:147. Over de representativiteit van het comité van Djajadiningrat zie NIB XII:546-7. Over de late overdracht van bevoegdheden aan de deelstaten zie Taylor 1960:108. Over de erkenning van OostIndonesië door de Republiek zie NIB XII:795.

\section{Verder overleg na het Renville-akkoord}

Vergelijk Gase 1986:44-75 en Drooglever 1986:227-44. Over de opheffing van de Australische boycot zie NIB XIII:738. Over de tegenwerking van de plebisciet-beweging zie Kahin 1952:240-1 en NIB XII:787 en NIB XIII:708-9, 729. Over de handhaving van Nederlandse militairen in de gedemilitariseerde zones zie Taylor 1960:104. Over de vrijlating van gevangenen zie Taylor 1960:104. Over de behandeling van het eerste CGD-rapport in de Veiligheidsraad zie BZ 1948b:12-38 en Taylor 1960:98-100.

De politieke besprekingen werden onder meer bemoeilijkt doordat de Nederlandse regering verzuimde haar onderhandelingsdelegatie in Indonesië tijdig en voldoende van instructies te voorzien. Begin maart kreeg deze delegatie een voorlopige en onvolledige instructie; pas op 17 april (drie maanden na het Renvilleakkoord) kreeg zij een definitieve instructie over de Unie; een volledige instructie kreeg zij nooit (zie Van Vredenburch 1985:335-401). Bovendien verstrakte het standpunt van de regering steeds verder, in het bijzonder omdat minister Jonkman sinds maart regelmatig over het Indonesië-beleid overleg voerde met vertegenwoordigers van de oppositiepartijen ter rechterzijde van de regeringscoalitie. Zo maakte de regering er in mei bezwaar tegen dat haar delegatie de toekomstige Verenigde Staten van Indonesië niet alleen als 'soeverein' maar ook als 'onafhankelijk' had aangeduid (Van Vredenburch 1985:362-4).

Voor het eerste rapport van de consulaire commissie aan de Veiligheidsraad zie BZ 1948a:56-158. Voor de opmerking van Pinke zie NIB XII:619. Voor de werkzaamheden van de CGD in de periode oktober 1947-februari 1948 zie BZ 1948b:39-121; vergelijk Taylor 1960:66-97. Voor de behandeling van de Indonesische kwestie in de Veiligheidsraad in oktober-november 1947 zie BZ 1948a:9-55. Voor de VR-resolutie van 1 november 1947 zie BZ 1948a:55. Vergelijk Van Vredenburch 1985:335-401, Taylor 1960:58-65.

Voor de Nederlandse voorwaarde betreffende het opgeven van staatsbevoegdheden door de Republiek zie NIB XII:763. Voor de mening van H.N. Boon hierover zie NIB XIV:297. Over de bedoeling van de door Nederland gewenste overgangsperiode zie Smit 1962:115 en Drooglever 1986:242. Voor de eis van ontbinding van de TNI onder meer NIB XIII:551. Voor de opmerking van Hatta over de onmogelijkheid hiervan NIB XIII:779. Voor de Republikeinse gedachten over gedeeltelijke overdracht van de Republikeinse soevereiniteit aan de interim-regering onder andere NIB XIII:165, 257, 268. Over het akkoord met de Sovjet-Unie zie Poeze 2007:770-2. 
Over de Nederlandse bejegening van de CGD zie Taylor 1960:118. Voor het voorstel van Critchley en DuBois zie NIB XIV:73-85. Over de gesprekken van Van Mook met Hatta NIB XIII:192-5, 208, 216-8, 267, 385-6 en NIB XIV:145-6, 150-2. Voor de opschorting van het politiek overleg NIB XIV:439.

Wijziging van de Nederlandse grondwet

Zie Stempels 1950:135-44, 151-2 en Bank 1983:348-52.

$\mathrm{Na}$ de inwerkingtreding van de grondwetswijziging in september 1948 liet de postdienst van het gouvernement grote voorraden postzegels van een opdruk voorzien waardoor de naam 'Nederlands-Indië' vervangen werd door de nieuwe officiële naam 'Indonesië'. Meestal betrof dit postzegels met een beeltenis van koningin Wilhelmina. Ten onrechte zijn zulke postzegels een halve eeuw later meer dan eens in Nederlandse tentoonstellingen en televisiedocumentaires over de dekolonisatie getoond als een uitvloeisel van de soevereiniteitsoverdracht van eind 1949. De makers van die tentoonstellingen en documentaires wisten kennelijk niet dat Nederland de officiële naam 'Nederlands-Indië' zelf al in 1948 afgeschaft had. Overigens leken zij ook te vergeten dat ten tijde van de soevereiniteitsoverdracht niet Wilhelmina maar Juliana de Nederlandse koningin was.

\section{De Bijeenkomst voor Federaal Overleg (BFO)}

Voor de taakomschrijving van de Federale Conferentie zie NIB XIII:521. Voor de verklaring van Abdoelkadir NIB XIII:771 (noot 4). Voor het protest van de Republiek bij de Veiligheidsraad zie BZ 1948c:143-6. Voor de BFO-resolutie van 15 juli 1948 zie NIB XIV:377-80. Voor de reactie Van Mook NIB XIV:385. Vergelijk Anak Agung 1980:146, 184.

Aantreden van het Nederlandse kabinet-Drees

Zie Jaquet 1982:25-9, Bank 1983:361-74 en Van den Doel 2000:271-2.

\section{Voortgezette aanwezigheid van de Nederlandse strijdmacht in Indonesie}

Voor de Nederlandse verwachting dat het verzet spoedig zou uitdoven na de uitschakeling van Jogja zie Groen 1991:112-3. Over de Nederlandse aflossingsproblemen Groen 1991:119-20 en NIB XII:189-94; vergelijk L. de Jong 1988:900-2. Voor de verklaring van Spoor over de tijdsbeperking voor een nieuwe actie zie NIB XII:358. Voor het voorstel van Van Mook van eind mei NIB XIII:765, 776.

Over de confrontatie van guerrilla en contra-guerrilla zie Nasution 1965 en Van Doorn en Hendrix 1983:182-218. Over van Nederlandse kant begane oorlogsmisdaden zie laatstgenoemd werk (dat er volledig aan gewijd is) alsmede VARA 1969 en de in 1969 door de Nederlandse regering aan het parlement overgelegde Excessennota (heruitgegeven in 1995). Deze nota was gebaseerd op archiefonderzoek, een in dit geval ontoereikende onderzoeksmethode omdat de hier bedoelde daden slechts bij uitzondering in officiële documenten geregistreerd waren. Bovendien kan de term 'excessen' de indruk wekken dat het om daden ging die niet regelmatig, laat staan stelselmatig, gepleegd zouden zijn. Ondanks deze tekortkomingen is de nota met haar uitvoerige bijlagen een belangrijke bron. Vergelijk L. de Jong 1988:987-1034. Over de manier waarop Nederlandse politici, historici en oud-strijders de kwestie behandeld hebben zie Scagliola 2002. 


\section{Anti-Republikeinse maatregelen in Batavia}

Over de 'opiumsmokkel' zie NIB XIV:587, 596 en BZ 1949b:225-7. Over opium als inkomstenbron van het Nederlands-Indisch gouvernement zie Vanvugt 1985:129375. Over het incident bij Pegangsaän Oost 56 en de Nederlandse bezetting hiervan zie BZ 1949b:208-9, 219 en NIB XIV:613-4, 650, 685 (noot). Over het fotokopiëren van Republikeinse documenten zie NIB XIV:651-2 (noot). Over de uitwijzing van Republikeinse functionarissen NIB XIV:681-2. Over de overneming van het Republikeins academisch ziekenhuis NIB XIV:679-680. Voor de Republikeinse weigering verder te onderhandelen NIB XIV:685, 697-9 en BZ 1949b:212.

\section{Amerikaanse bemiddelingspoging}

Voor het ontwerp van Van Mook voor de bestuursregeling voor Indonesië in overgangstijd zie NIB XIV:390-5; voor het BFO-ontwerp NIB XIV:378-80; voor het ontwerp van Sassen NIB XIV:618-22. Voor het voorstel van Cochran voor de oplossing van het conflict tussen Nederland en Republiek zie NIB XV: 43-56. Over de besprekingen van Stikker in Washington NIB XV:129-32 en Jaquet 1982:57-62. Zie ook Drooglever 1988:39-52.

\section{De Madioenopstand}

Zie Kahin 1952:272-303, Swift 1989:51-80 en Poeze 2007:1079-1391. Zie onder meer Poeze 2007:945-50, 980 over de amnestie voor de 3-juli-affaire, Poeze 2007:1090-1117 over het optreden van Moeso, Poeze 2007:1117-27 over de onthulling van Amir Sjarifoeddin en Poeze 2007:1149-1208 over de gebeurtenissen in Solo en Madioen.

Zie over de mogelijkheid van Nederlandse hulp bij de bestrijding van de opstand onder meer NIB XV:150-7; voor Hatta's reactie NIB XV:163. Zie over Tan Malaka's activiteiten na zijn vrijlating Poeze 2007:980-1022, 1034-5, 1046-51.

\section{De aanloop naar het tweede Nederlandse offensief}

Vergelijk Jaquet 1982:71-153, Bank 1983:388-400, Gase 1986:198-276 en Groen 1991:14665, 173-8. Over de personeelswisselingen onder de Nederlandse leidende ambtsdragers zie Bank 1983:372-9, Jaquet 1992:32-50 en Gase 1986:128-75.

Voor de door Sassen in overleg met de BFO opgestelde BIO-regeling zie NIB XV:2959, 414 (noot), 604-5 (noot), 682-3 (noot). Voor het Nederlandse tegenvoorstel van 4 oktober tegen het Amerikaanse voorstel NIB XV:315-20; vergelijk het commentaar in Taylor 1960:153 en Smit 1962:129. Voor de reactie van de Verenigde Staten zie NIB XV:352-3; voor de reactie van de Republiek NIB XV:489-90. Over het overleg van Stikker en zijn adviseurs in Kalioerang NIB XV:580-99; voor de Nederlandse vraagpunten NIB XV:615-8; voor het antwoord van de Republiek NIB XV:632-5; voor het overleg van Stikker met Beel en Spoor NIB XV:636-9. Over de mening van de Nederlandse regering dat zij een nieuwe militaire actie alleen zou kunnen beargumenteren met het voortduren van de Republikeinse bestandsschendingen NIB XV:519, 522; over de publiciteitscampagne NIB XV:371-2, 593-4; over het prealabel stellen van een einde aan de bestandsschendingen zie Jaquet 1982:84.

Over het overleg van Sassen en Stikker in Kalioerang zie NIB XV:756-61, 770-85, 789-816. Over het overleg met Hatta in Batavia zie NIB XVI:34-40. Over het onbevredigende contact van Beel en Sassen met de BFO-leiders NIB XV:744-5 en NIB XVI:28-32. Voor de afspraak van Romme met Beel NIB XVII:17 (noot). Voor de Amerikaanse nota 
NIB XVII:55-8; voor de waarschuwing van Van Kleffens NIB XVII:84. Over de korte kabinetscrisis NIB XVII:147, 163; over Beel's behandeling van de boodschap van de Nederlandse regering aan Hatta NIB XVII:182, 194-5, 215-8.

Het tweede Nederlandse offensief (de tweede 'Politionele Actie')

Vergelijk Groen 1991:178-95, Heijboer 1979:126-50 en Simatupang 1985:27-48. Over de reacties in Nederland vergelijk L. de Jong 1988:951-2 en Poeze 1980:20-1. Over de Republikeinse noodregering ook NIB XVII:46 (noot).

De reactie van de Verenigde Naties op het tweede Nederlandse offensief

Vergelijk BZ 1949b:19-141, Taylor 1960:171-95, Anak Agung 1950:221-36 en Van den Doel 2000:292-7. Voor de VR-resolutie van 24 december 1948 zie BZ 1949b:52 en NIB XVI:327. Voor de VR-resolutie van 28 december over de vrijlating van de politieke leiders zie BZ 1949b:73-4 en NIB XVI: 400 (noot). Over het bezoek van Drees aan Batavia zie NIB XVI:609-13, 638-40, 649-652 en XVII:2-5. Voor de verklaring van Van Roijen in de VR zie BZ 1949b:599-600. Over het bezoek van de CGD aan Hatta op Bangka zie NIB XVII:42-50. Over de huisvesting van Hatta op Bangka: NIB XVII 86-7, 90-1, 99-102; vergelijk De Beus 1987:87-8. Voor de VR-resolutie van 28 januari 1949 zie NIB XVII:709-711.

De reactie van de federalisten op het tweede Nederlandse offensief

Zie Anak Agung 1980:193-4, 237-42. Over de sultan van Jogja zie Drooglever 1996. Voor de BFO-resolutie van 13 januari 1949 zie Anak Agung 1980:241; voor de nadere afspraak daarover NIB XVII:51 (noot). 

HOOFDSTUK VIII

\title{
Het conflict tussen Nederland en de Republiek Indonesië
}

\author{
Derde fase \\ Onvolledige politieke oplossing
}

\section{Inleiding en overzicht}

Het jaar 1949 bracht een grote wending in de verhouding tussen Nederland en de Republiek. In 1948 waren de Nederlandse beleidsmakers ervan uitgegaan dat men de soevereiniteit over Indonesië pas zou overdragen wanneer de Republiek geen eigen machtsapparaat meer zou bezitten. Begin 1949 dachten velen van hen dat de Republiek als politieke factor uitgeschakeld was door het in december tegen haar gelanceerde offensief (de tweede 'politionele actie'). Nederland had immers bijna al haar grondgebied bezet en had haar politieke leiders gevangen genomen. Maar eind 1949 droeg Nederland de soevereiniteit over aan een Indonesische federatie met Soekarno en Hatta als president en vicepresident en met het Republikeinse leger als kern van haar gewapende macht.

Deze paradoxale gang van zaken was in de eerste plaats te wijten aan het feit dat het decemberoffensief zowel militair als politiek een misgreep was. Militair, omdat de gevoerde 'speerpuntenstrategie' de Republikeinse strijdkrachten niet buiten gevecht kon stellen, maar ze juist bracht tot het voeren van een fellere en omvangrijkere guerrilla-oorlog dan ooit tevoren, waartegen de Nederlandse troepenmacht zich te weer moest stellen in een veel uitgestrekter gebied dan voordien. Politiek, omdat het offensief tot bijzonder ingrijpende bemoeienis van de Verenigde Naties leidde en omdat het een belangrijk deel van de Indonesische federalisten in de armen van de Republiek dreef.

Al kort na het begin van het offensief had de Veiligheidsraad Nederland opgeroepen tot staking van de vijandelijkheden en tot vrijlating van de gevangen genomen Republikeinse leiders. Omdat de Nederlandse regering hier 
nauwelijks gevolg aan gaf, nam de Raad op 28 januari 1949 een resolutie aan die Nederland in feite onder internationale curatele stelde. De Raad verlangde onder meer dat Nederland Soekarno en de zijnen onmiddellijk naar Jogja zou laten terugkeren. Verder zou Nederland opnieuw met de Republiek moeten onderhandelen. Die onderhandelingen zouden plaats moeten vinden onder auspiciën van een speciale VN-commissie voor Indonesië, de UNCI, die eigen aanbevelingen zou kunnen doen. De overdracht van de Nederlandse soevereiniteit aan de Verenigde Staten van Indonesië (VSI), de in het akkoord van Lingadjati voorziene Indonesische federatie, zou uiterlijk op 1 juli 1950 moeten plaatsvinden.

Terwijl Nederland dus op het internationaal-politieke toneel in een isolement beland was, raakte het ook geïsoleerd op het politieke toneel in Indonesië zelf. Sinds 1948 had de regering gedacht bij haar beleid tegenover de Republiek steeds te kunnen rekenen op steun van de leiders van de door Nederland gevormde deelstaten en autonome gebieden, de 'federalisten'. Maar na het decemberoffensief bleek de meerderheid van deze leiders niet bereid om buiten de Republiek om aan de vorming van de VSI mee te werken. Het werd duidelijk dat de Republiek niet als politieke factor uitgeschakeld was, ook al had het Nederlandse bestuur Soekarno, Hatta, Roem en enige andere Republikeinse voormannen op het eiland Bangka geïnterneerd.

Deze ontwikkelingen dwongen de Nederlandse regering tot het inslaan van een andere koers. Eind februari kwam zij met een nieuwe aanpak. Terwijl zij haar bezwaren tegen de resolutie van 28 januari handhaafde, verklaarde zij zich bereid de soevereiniteit al binnen enkele maanden over te dragen en nodigde zij zowel Soekarno als de federalisten uit om vertegenwoordigers aan te wijzen voor een in Den Haag te houden Rondetafelconferentie (RTC) over de voorwaarden voor die overdracht. Ook hief zij nu de internering van de Republikeinse leiders op, maar zij stond hen nog steeds niet toe naar Jogja te gaan.

Hierop besloten Soekarno en de zijnen op Bangka te blijven en geen gehoor te geven aan de uitnodiging voor de conferentie in Den Haag, zolang de Republikeinse regering niet naar Jogja kon terugkeren en zolang de UNCI niet de bevoegdheden zou kunnen uitoefenen die de Veiligheidsraad haar verleend had. Het overlegorgaan van de federalisten, de BFO, stelde zich achter de door Soekarno gestelde voorwaarden. Dit bracht de Nederlandse regering ertoe de mogelijkheid te onderzoeken om de Republikeinse leiders onder bepaalde voorwaarden toch naar Jogja te laten gaan. Onder auspiciën van de UNCI onderhandelde een door Van Roijen geleide delegatie van april tot juli in Batavia met een Republikeinse delegatie onder leiding van Roem. In mei leidde dit tot een voorlopig akkoord waarin de Nederlandse regering zich bereid verklaarde de Republikeinse leiders naar Jogja te laten terugkeren terwijl Soekarno en Hatta toezegden zich bij hun eigen regering te zullen 
inzetten voor beëindiging van de guerrilla-oorlog en voor deelname aan de RTC. Eind juni werd Jogja door de Nederlandse troepen verlaten, in juli keerden Soekarno en Hatta daar terug, begin augustus kondigden Nederland en de Republiek een bestand af en op 23 augustus begon de RTC in Den Haag. Daarbij leidde Hatta zelf de Republikeinse delegatie. Men streefde ernaar de soevereiniteitsoverdracht voor het eind van het jaar te doen plaatsvinden.

Voor een groot deel van het Nederlandse publiek viel deze gang van zaken moeilijk te begrijpen. Men dacht dat Nederland in de tweede 'politionele actie' een klinkende overwinning behaald had. De verovering van Jogja en de gevangenneming van Soekarno en Hatta golden als de grootste successen van die actie; het ongedaan maken daarvan wekte de indruk dat de actie nergens voor gediend had. Toch leidde de koerswijziging van de regering niet tot grootscheeps protest. Het conflict in Indonesië had nu al bijna vier jaar geduurd en de meeste Nederlanders waren het moe. Zij hoopten na deze onverwachte wending vooral op een spoedige thuiskomst van de uitgezonden militairen.

Anders dan in 1945 en 1946 was men er in Nederland nu algemeen aan gewend dat Indonesië een onafhankelijk land zou worden, hoe pijnlijk velen dit ook vonden. De jarenlang door het Nationaal Comité Handhaving Rijkseenheid aangevoerde oppositie tegen de dekolonisatie van Indonesië had in feite het pleit verloren. $\mathrm{Nu}$ deze oppositie de scheiding tussen het Koninkrijk en Indonesië op zichzelf niet meer kon tegenhouden, spande zij zich in om toch nog het meest oostelijke deel van de archipel binnen het Rijk te houden. Onder meer voerde zij propaganda-acties die de indruk wekten dat de bevolking van de Minahasa, de Molukken en Timor geen deel van de VSI wilde worden, maar met Nederland verbonden wilde blijven. Ook bevorderde zij acties voor handhaving van de band tussen Nederland en Nieuw-Guinea.

De RTC was formeel een conferentie tussen drie partijen: Nederland, de BFO en de Republiek. Van te voren hadden de BFO en de Republiek echter onderling overleg gepleegd, waardoor de kaarten voor de RTC al grotendeels geschud waren. Onder meer hadden ze afgesproken dat de naam van de te stichten onafhankelijke federale staat zou luiden Republiek der Verenigde Staten van Indonesië (RVI) en dat deze staat haar soevereiniteit niet alleen aan Nederland zou ontlenen maar ook aan de in 1945 gestichte Republiek Indonesië. Ook hadden ze besloten dat de Nederlandse landstrijdkrachten Indonesië volledig zouden moeten verlaten en dat de TNI de kern zou worden van de gewapende macht van de RVI.

De RTC duurde tot 2 november. Met hulp van de UNCI werden de delegaties het uiteindelijk eens over bijna alle kwesties die met de scheiding tussen Nederland en Indonesië verband hielden. De getroffen regelingen schiepen gunstige voorwaarden voor de voortzetting van de Nederlandse economische actitiviteiten in Indonesië. Aan de andere kant liet Nederland op staatkun- 
dig en militair gebied veel van zijn oorspronkelijke plannen varen. De al in het akkoord van Linggadjati voorziene Nederlands-Indonesische Unie werd slechts een licht samenwerkingsverband.

Over één kwestie werd men het op de RTC niet eens: de toekomst van Nieuw-Guinea. De achtergrond hiervan lag op het terrein van de parlementaire rekenkunde. Naar Nederlands staatsrecht kon de soevereiniteit over Indonesië niet worden overgedragen zonder instemming van een tweederde meerderheid in het parlement. Voor het behalen van die meerderheid was ook enige steun nodig van parlementariërs die Nieuw-Guinea bij Nederland wilden houden. Op de RTC nam Nederland daarom het standpunt in dat dit gebied van de overdracht uitgezonderd moest worden. Om de conferentie niet op dit ene punt te laten stranden besloten de delegaties deze kwestie een jaar uit te stellen.

Na de sluiting van de RTC bereidden vertegenwoordigers van de Republiek en de federalisten de stichting van de RVI voor. Daarbij kozen ze Soekarno en Hatta tot president en vicepresident. Op 27 december 1949 droeg Nederland de soevereiniteit over en maakte de Nederlandse rood-wit-blauwe vlag op het paleis in Batavia plaats voor de Indonesische rood-witte vlag. De volgende dag betrok Soekarno het paleis.

Het op de RTC getroffen complex van regelingen paste in het kader van het akkoord van Linggadjati. Er zijn geen aanwijzingen dat de Republiek in juli 1947 en in december 1948 niet bereid geweest zou zijn Nederland even ver tegemoet te komen als nu. Niettemin heeft de Nederlandse regering toen gemeend dat Nederland geen andere keus had dan een aanval op de Republiek. In 1947 en 1948 ontbrak aan Nederlandse kant dus nog de bereidheid tot een politieke oplossing als uiteindelijk in 1949 tot stand gekomen is. Twee factoren hebben daarbij een rol gespeeld. Ten eerste kostte het de meeste Nederlanders enige jaren om aan de gedachte te wennen dat Indonesië werkelijk onafhankelijk zou worden. Daarom waren de Nederlandse beleidsmakers ook na het akkoord van Linggadjati blijven streven naar staatsrechtelijke en militaire waarborgen om Nederland nog lange tijd invloed op de gang van zaken binnen Indonesië te geven. Ten tweede beschikte Nederland toen in Indonesië over een grote strijdmacht. Dit werkte de gedachte in de hand dat men het Nederlandse militair-technische overwicht kon benutten om de nagestreefde waarborgen te verkrijgen. Het Nederlandse offensief van december 1948 was de definitieve 'proef op de som'. Het bleek een fiasco te zijn.

Hoewel de meeste Nederlanders in 1949 wel inzagen dat de onafhankelijkheid van Indonesië onvermijdelijk was, betekende dit voor velen een traumatische ervaring. Voor een deel van hen leek het behoud van een stukje van het vroegere imperium de pijn wat te kunnen verzachten. De campagne voor handhaving van de band tussen Nederland en Nieuw-Guinea ontleende hieraan haar kracht. De in verband daarmee op de RTC gemaakte voorlopige 
uitzondering voor dat gebied had tot gevolg, dat het RTC-akkoord geen volledige oplossing inhield van het geschil tussen Nederland en de Republiek. Zij vormde het begin van het conflict over Nieuw-Guinea, dat noodlottig zou blijken voor het voortbestaan van een nauwe band tussen Nederland en Indonesië.

\section{De militaire situatie na het tweede Nederlandse offensief}

Al sinds begin december 1948 waren de politieke en militaire leiders van de Republiek ervan uitgegaan dat een groot Nederlands offensief voor de deur stond. Ze hadden echter niet verwacht dat Nederland zou aanvallen terwijl het nog betrokken was bij overleg met de Republiek via de Amerikaanse vertegenwoordiger Cochran. Daardoor was de aanval op 19 december toch als een verrassing gekomen; in het bijzonder was de hoofdstad Jogja weerloos geweest tegen de Nederlandse luchtoperatie. Daarentegen hadden de Republikeinse strijdkrachten tijdens het verdere verloop van het decemberoffensief en daarna veel baat gehad van eerder getroffen voorbereidingen. Vooral kolonel Nasoetion had zich in de loop van 1948 ingespannen om de tijdens het Nederlandse offensief van juli 1947 opgedane ervaringen te benutten voor de voorbereiding van doeltreffende guerrilla-oorlogvoering in geval van een nieuw offensief. Zo was aan ieder TNI-onderdeel een operatiegebied toegewezen waarheen het zich zou moeten terugtrekken wanneer Nederland de Republiek weer zou aanvallen. Het was de bedoeling dat de plaatselijke bevolking de militairen dan zou onderhouden; vaak ging het om gebieden waar veel leden van het onderdeel vandaan kwamen. De aangewezen operatiegebieden lagen niet alleen binnen het gebied dat na het offensief van 1947 onder Republikeins bestuur gebleven was, maar ook binnen het toen onder Nederlands bestuur gekomen gebied. De meest spectaculaire verplaatsing na het tweede Nederlandse offensief was die van de Siliwangidivisie, die er in de loop van twee maanden in slaagde zich met behoud van haar organisatiestructuur uit Midden-Java naar het Soendanese deel van West-Java terug te trekken.

Tussen de naar West-Java trekkende TNI-militairen bevond zich ook een Nederlandse dienstplichtige soldaat, Jan Princen (die zich vaak Poncke Princen noemde). Hij had van begin af aan sympathie voor de Indonesische vrijheidsstrijd gevoeld en was in oktober 1948 gedeserteerd en naar Republikeins gebied gegaan om zijn diensten in Jogja aan te bieden. Daar had men hem echter niet vertrouwd, met het gevolg dat hij gevangen gezet was. Toen Jogja op 19 december werd aangevallen, had een officier van de Siliwangidivisie hem vrijgelaten en voor de keus gesteld hetzij mee te trekken naar West-Java hetzij terug te keren naar het Nederlandse leger. Princen had het eerste geko- 
zen en zich bij de Republikeinse strijders gevoegd. In West-Java gaf hij onder meer leiding aan overvallen op ondernemingswachten en politieposten. Door vrijwillig gewapenderhand aan de Republikeinse strijd deel te nemen maakte hij zich bij een groot deel van de Nederlandse militairen uitzonderlijk gehaat.

Het feit dat de Nederlandse strijdkrachten de verplaatsing van de Siliwangidivisie naar West-Java niet konden verhinderen illustreert dat Nederland de militaire situatie na het decemberoffensief niet meester was. Terwijl het voordat het offensief begon al over te weinig troepen beschikt had om in de onder Nederlands bestuur staande gebieden een eind te maken aan het plaatselijk verzet, moest het nu met diezelfde troepenmacht een veel groter gebied bestrijken. Terwijl het reguliere Republikeinse leger sinds januari 1948 zelden openlijk aan anti-Nederlandse acties deelgenomen had omdat toen een formeel bestand van kracht was, kon de TNI zich nu volledig voor de strijd inzetten omdat Nederland dit bestand verbroken had. Na hun hergroepering kregen de Republikeinse troepen meestal voldoende steun van de bevolking om een doeltreffende guerrilla te voeren. Dit gold ook voor Oost-Java, waar de TNI nog kort tevoren de communistische Madioenopstand bloedig onderdrukt had.

Dat de guerrilla van nu af aan op Java en Sumatra veel meer gebied dan vroeger omvatte kwam niet alleen omdat de strijd zich uitbreidde tot die delen van de Republiek waar de Nederlandse troepen tijdens het decemberoffensief in doorgedrongen waren. De guerrilla leefde namelijk ook op in verscheidene gebieden die al lange tijd onder Nederlands bestuur stonden. Dit werd vergemakkelijkt door het feit dat sinds medio 1948 duizenden TNI-militairen in die gebieden geïnfiltreerd waren. Wel kampten de Republikeinse troepen met tekorten aan vuurwapens en munitie (dit was de hoofdreden voor hun overvallen op politieposten en ondernemingswachten), maar ze beschikten vaak over ruime voorraden explosieven, met inbegrip van landmijnen en vliegtuigbommen. Die gebruikten ze vooral voor het verstoren van de Nederlandse verbindingsroutes door het ondermijnen van wegen en opblazen van bruggen. De Nederlandse militairen konden deze routes, die als gevolg van het offensief sterk uitgerekt waren, niet afdoende beveiligen. Vaak gebeurde het dat een door de Nederlandse genie herstelde brug al binnen enkele dagen opnieuw vernield werd. Sommige Nederlandse posten raakten zo geïsoleerd dat men ze niet meer regelmatig kon bevoorraden.

Bij de voorbereiding van het decemberoffensief was generaal Spoor ervan uitgegaan dat hij het daarna nog resterende Republikeinse verzet in een periode van drie tot zes maanden zou kunnen bedwingen. Evenals de meeste KNIL-officieren en veel BB-ambtenaren dacht hij dat slechts een kleine minderheid van de Indonesische bevolking Republikeinsgezind was en dat de meerderheid alleen naar rust en orde verlangde. Daarom verwachtte hij dat de guerrilla grotendeels zou uitdoven wanneer Nederland het vijandelijke actiecentrum in Jogja eenmaal uitgeschakeld had. Geheel in strijd met deze ver- 
wachting bleek het decemberoffensief ertoe te leiden dat de Nederlandse troepen te maken kregen met een fellere en omvangrijkere guerrillastrijd dan ooit tevoren. Er sneuvelden nu ook meer militairen aan Nederlandse kant: ruim vijfhonderd in de eerste drie maanden van 1949 (terwijl er minder dan twaalfhonderd gesneuveld waren in de drie jaar voor de tweede politionele actie). Overigens waren de meeste slachtoffers van het Republikeinse verzet geen Nederlandse militairen maar Indonesische burgers die met het Nederlandse gezag samenwerkten. Dat zulke samenwerking voor die Indonesiërs het risico meebracht door het verzet uit de weg geruimd te worden maakte het voor de Nederlandse autoriteiten extra moeilijk om de tijdens het offensief bezette gebieden onder hun bestuur te brengen. Buiten de steden bleven grote delen van die gebieden onder Republikeins bestuur staan.

Ook bij de Indonesiërs die tegen Nederland streden deden zich onderlinge conflicten voor. In West-Java had de door Kartowoewirjo geleide Daroel Islam-beweging zich in de loop van 1948 tot de belangrijkste kern van het anti-Nederlandse verzet ontwikkeld, nadat het reguliere Republikeinse leger dit gebied op grond van het Renville-akkoord verlaten had (zie pp. 570). Na de bezetting van Jogja door het Nederlandse leger meende Kartosoewirjo dat de Republiek had opgehouden te bestaan en riep hij zijn aanhang op zich in te zetten voor de stichting van een Islamitische Indonesische staat. Toen de Siliwangidivisie begin 1949 in West-Java terugkeerde, raakte zij dan ook al spoedig in conflict met de strijdkrachten van de Daroel Islam. Dit groeide uit tot een soort driehoeksoorlog tussen de Daroel Islam, Nederland en de Republiek, maar het leidde ook tot toenadering tussen de Siliwangidivisie en de Republikeinsgezinde regering van de deelstaat Pasoendan.

In Oost-Java leidde een heel andere politieke tegenstelling tot een broederstrijd met Tan Malaka en diens aanhang. De regering van de Republiek had deze legendarische revolutionair kort voor het uitbreken van de Madioenopstand uit gevangenschap ontslagen. In november was hij zich gaan inzetten voor coördinatie van het guerillaverzet tegen de algemeen verwachte Nederlandse aanval op de Republiek. Het lukte hem in Oost-Java enige tientallen bataljons tot samenwerking te brengen in een verbond genaamd Gaboengan Pembela Proklamasi (GPP, Verbond van Verdedigers van de Proclamatie). Toen het Nederlandse leger in december Jogja veroverde en de leiders van de Republiek gevangen nam, dacht Tan Malaka evenals Kartosoewirjo dat hun rol uitgespeeld was. Onder bescherming van de GPP begon hij een felle propagandacampagne, waarin hij verklaarde dat de politiek van Soekarno en Hatta volledig gefaald had en dat hij nu de leiding van de vrijheidsstrijd op zich nam. Andere TNI-eenheden keerden zich tegen hem; in februari 1949 werd hij gevangen genomen en gefusilleerd, maar het duurde maanden voordat zijn dood bekend werd. Volgelingen van hem bleven in verschillende delen van Java actief met het organiseren van een linkse oppositie, 
soms opnieuw onder de naam Pembela Proklamasi, maar een belangrijke rol speelden ze niet meer.

De verheviging van de guerrillastrijd na het decemberoffensief logenstrafte de theorie dat dit offensief een eind aan de Republiek gemaakt had, maar van die verheviging drong in de eerste maanden weinig tot de buitenwereld door. Om voor meer publiciteit te zorgen pleegde de TNI een spectaculaire aanval op de bezette hoofdstad van de Republiek. Bij de voorbereiding daarvan voerden de sultan van Jogja en opperbevelhebber Soedirman overleg via de commandant van het operatiegebied, luitenant-kolonel Soeharto. In de vroege ochtend van 1 maart openden TNI-militairen die in het geheim de stad waren binnengegaan de aanval op de Nederlandse bezetting, terwijl deze ook van buiten de stad werd aangevallen. In totaal namen ongeveer tweeduizend Republikeinse soldaten aan de aanval deel. Zij leden zware verliezen, maar in het centrum van Jogja slaagden zij er in zich zes uur lang te handhaven; om hen te verdrijven moest het Nederlandse garnizoen versterkingen van elders aanvoeren. Militaire waarnemers van de UNCI waren getuigen van deze gebeurtenis en rapporteerden hierover aan de Veiligheidsraad.

\section{De politieke situatie na het tweede Nederlandse offensief}

Toen de Nederlandse regering in december 1948 besloot tot een grote militaire actie tegen de Republiek, ging zij er van uit dat die actie gevolgd zou worden door de instelling van een federale interimregering (FIR) op basis van de regeling Bewind Indonesië in Overgangstijd (BIO). Volgens deze regeling, afgekondigd aan de vooravond van de actie, zou de interimregering uit Indonesiërs bestaan, maar zou daarnaast een Nederlandse Hoge Vertegenwoordiger functioneren met belangrijke bevoegdheden, waaronder het opperbevel over de strijdkrachten en het recht om die ook zonder instemming van de interimregering in te zetten voor de handhaving van orde en veiligheid. De instelling van de FIR zou een overgangstijd inluiden die zou duren tot de formele oprichting van de soevereine Verenigde Staten van Indonesië.

Bij haar besluit tot militaire actie tegen de Republiek had de regering echter nagelaten duidelijk het politieke doel te bepalen waar die actie toe zou moeten dienen. Dit was niet onbelangrijk, want over de politieke doelstelling werd binnen de regering verschillend gedacht. Sommigen, onder wie de minister van buitenlandse zaken Stikker, zagen de militaire actie als middel om de Republiek van 'extremistische' elementen te zuiveren, waarna zij dan de haar toegedachte plaats zou kunnen innemen in de te vormen Indonesische federatie. Anderen, onder wie de minister van overzeese gebiedsdelen Sassen, zagen de actie als middel om de Republiek als staatkundige organisatie te liquideren teneinde de weg vrij te maken voor vorming van die federatie zonder de 
Republiek. Dit was ook precies wat Beel, de Hoge Vertegenwoordiger van de Kroon in Batavia, en Spoor, de legercommandant, met het december-offensief beoogd hadden. Daarentegen had minister-president Drees, onder wiens verantwoordelijkheid het besluit tot militaire actie genomen was, in het geheel geen politiek doel op het oog gehad. Naar hij later verklaarde ging het hem er niet om militair een politieke beslissing af te dwingen, maar wilde hij alleen dat er een eind zou komen aan de Republikeinse bestandsschendingen. Hoe weinig aandacht zijn regering destijds gegeven had aan het politieke vervolg op de voorgenomen militaire actie, blijkt ook uit het feit dat men zelfs niet besproken had wat men met de leiders van de Republiek zou doen als die in Nederlandse handen zouden vallen.

Toen het decemberoffensief eenmaal gelanceerd was, leidde het niet tot versterking maar tot ernstige verzwakking van de politieke positie van Nederland. Dit begon al met de scherpe reactie van de Verenigde Naties en de afhoudende opstelling van een deel van de federalisten (zie pp. 605-10). De Nederlandse regering had zowel het één als het ander kunnen voorzien. Begin december had de Amerikaanse regering haar op harde toon gewaarschuwd tegen een aanval op Jogja. In dezelfde tijd had Sassen voorspeld dat de meeste federalisten geen verantwoordelijkheid zouden willen nemen voor een interimregering zonder de Republiek. De regering had niettemin besloten tot de militaire actie die zij nu eenmaal onvermijdelijk vond. Het ontbreken van een vooraf overeengekomen politiek plan droeg ertoe bij dat zij nu zonder vaste lijn op de nieuwe ontwikkelingen reageerde. In de loop van enkele maanden zouden die ontwikkelingen, zowel op het internationaal-politieke toneel als binnen Indonesië zelf, haar tot beleidswijzigingen brengen in strijd met alles wat met het offensief beoogd was.

In januari 1949 beseften de meeste Nederlanders nog niet hoe zwak de Nederlandse positie geworden was. Beel nam het standpunt in dat de militaire actie een eind gemaakt had aan het bestaan van de Republiek als staatkundige organisatie, dat daardoor ook het geschil tussen Nederland en de Republiek had opgehouden te bestaan en dat daarmee automatisch de grond was ontvallen aan de bemoeienis van de Verenigde Naties met dat geschil. Hij wilde het hele grondgebied van de Republiek 'federaliseren' door het gedeeltelijk bij bestaande deelstaten en gedeeltelijk bij nog op te richten deelstaten onder te brengen. Met het oog daarop bereidden Nederlandse bestuursambtenaren en KNIL-officieren in de op de Republiek veroverde gebieden de vorming van nieuwe staatkundige eenheden voor. Generaal Spoor handhaafde zijn plannen voor de opbouw van de strijdkrachten van de VSI waarin hij geen enkele plaats aan de TNI toekende. De Nederlandse pers in Indonesië bracht alarmerende berichten over de op Republikeins gebied aangetroffen honger en ontwrichting; meestal schreef men deze toestanden niet toe aan de door Nederland tegen de Republiek toegepaste economische blokkade, maar aan 
wanbeheer van de Republikeinse autoriteiten. In aansluiting op die berichten werd met steun van de Nederlandse legerleiding een charitatieve campagne georganiseerd voor hulp aan de bevolking in de 'bevrijde' gebieden. Aan het hoofd van deze campagne kwam de echtgenote te staan van Abdoelkadir, de vroegere plaatsvervanger van Van Mook. De grote publiciteit die aan haar rol gegeven werd deed vermoeden dat de legerleiding aan haar man de toekomstige functie van president van Indonesië toegedacht had.

De toekomstplannen van Beel en Spoor misten echter voldoende reële basis. Zo kon men het geschil met de Republiek niet eenvoudig elimineren door op basis van de BIO-regeling een FIR in te stellen. Daartoe was men afhankelijk van de medewerking van de federalisten, maar die besloten al op 13 januari eerst met prominente Republikeinen te gaan praten. Te doen alsof de Republiek niet meer bestond was volstrekt irreëel, niet alleen omdat de Verenigde Naties haar nog steeds als partij bij het geschil met Nederland beschouwden, maar ook omdat zij nu eenmaal voor een groot aantal Indonesiërs de belichaming van hun streven naar nationale onafhankelijkheid vormde.

Bovendien was de Republiek niet alleen als idee maar ook als realiteit blijven bestaan. Afgezien van het feit dat de Nederlandse troepen het noordelijkste deel van Sumatra (Atjeh) in het geheel niet betreden hadden, hadden zij ook in de Republikeinse gebieden waarin ze wel doorgedrongen waren de TNI niet verslagen, noch op Sumatra noch op Java. In de meeste van die gebieden functioneerde buiten de steden nog het Republikeinse bestuur. Het centrale Republikeinse regeringsgezag werd vertegenwoordigd door de op Sumatra gevestigde noodregering van Sjafroedin Prawiranegara, die ook contact onderhield met Republikeinse vertegenwoordigers in het buitenland. Op Java werd dit gezag vertegenwoordigd door vijf ministers uit het kabinetHatta die na het decemberoffensief buiten Nederlandse handen gebleven waren; de noodregering benoemde dit vijftal tot commissariaat van de centrale regering, met Soekiman als voorzitter. Namens de zieke opperbevelhebber Soedirman nam zijn plaatsvervangend stafchef kolonel Simatoepang tijdelijk zijn functies waar, in overleg met kolonel Nasoetion, de commandant van de Republikeinse strijdkrachten op Java. Zowel op Java als op Sumatra beschikte men aan Republikeinse kant over verscheidene radiozenders; met behulp van die zenders en van talloze koeriers slaagden bestuurders en militairen er steeds beter in onderling contact te onderhouden.

\section{Nederlands aanbod tot vervroegde overdracht van de soevereiniteit}

De wijzigingen van het Nederlandse beleid in de eerste maanden van 1949 betroffen onder meer de formele opstelling tegenover de leiders van de Republiek. Beel ging er oorspronkelijk van uit dat er geen sprake meer kon 
zijn van politiek overleg met lieden als Soekarno en Hatta. Wel vond hij het wenselijk in de FIR ook enige uit de Republiek afkomstige figuren op te nemen, maar die zou men niet als vertegenwoordigers van de Republiek mogen behandelen omdat deze immers volgens hem had opgehouden te bestaan. Drees dacht hier tijdens zijn bezoek aan Batavia in januari anders over: hij vond het zo belangrijk de Republikeinse topfiguren bij het overleg over de toekomst van Indonesië te betrekken dat dit niet zou mogen afstuiten op het verwerpen van termen als 'Republikeinse regering' en dergelijke. Anderhalve maand later bleek Beel zijn mening te hebben herzien: op 26 februari richtte hij een brief aan 'de president van de Republiek Indonesia', waarin hij Soekarno uitnodigde op korte termijn een delegatie te vormen voor overleg met Nederland en de BFO.

Er was intussen van alles gebeurd. Op 28 januari had de Veiligheidsraad de resolutie aangenomen waarin hij de CGD omzette in de van grotere bevoegdheden voorziene United Nations Commission for Indonesia (UNCI) en waarin hij Nederland niet alleen opnieuw opriep om de geïnterneerde Republikeinse leiders vrij te laten, maar ook om hen naar Jogja te laten terugkeren. Tot dit laatste was de Nederlandse regering volstrekt niet bereid, maar Soekarno en Agoes Salim kregen wel toestemming zich bij de geïnterneerden op Bangka te voegen. Bij hun aankomst daar op 6 februari werden zij door een uitgelaten menigte verwelkomd. De geïnterneerden op Bangka hadden intussen van de Nederlandse autoriteiten comfortabelere huisvesting en bewegingsvrijheid binnen het eiland gekregen. Soekarno en Hatta konden nu politiek effectiever opereren omdat zij niet meer van elkaar geïsoleerd waren; ook kregen zij herhaaldelijk bezoek van Republikeinse politici uit Java. Bovendien spraken zij al op 7 februari met een contactcommissie van de BFO onder leiding van Anak Agoeng. Kort daarna ontvingen zij de UNCI. Zij waren zich dan ook goed bewust van hun sterke positie op grond van de besluiten van de BFO en de Veiligheidsraad.

De Nederlandse koerswijziging die ten grondslag lag aan Beel's brief aan Soekarno betrof niet alleen de formele opstelling tegenover de Republikeinse leiders. De regering besloot in de loop van februari tot een nieuwe politieke aanpak en wel op basis van een aanbod tot vervroegde overdracht van de Nederlandse soevereiniteit aan Indonesië. In januari had zij Van Roijen nog in de Veiligheidsraad laten verklaren dat zij hoopte de soevereiniteit voor eind 1950 te kunnen overdragen, maar nu dacht zij er over de overdracht al meteen in april of mei 1949 te doen plaatsvinden. Deze nieuwe aanpak was in eerste aanleg door Beel zelf voorgesteld en werd daarom het 'plan-Beel' genoemd. In de oorspronkelijke opzet was dit voornamelijk een optische manoeuvre om op een vlotte manier zowel van de Republiek als van de VN-bemoeienis af te komen. Het ging in die opzet namelijk niet alleen om een vervroegde maar ook om een beperkte soevereiniteitsoverdracht. Nederland zou wel op 


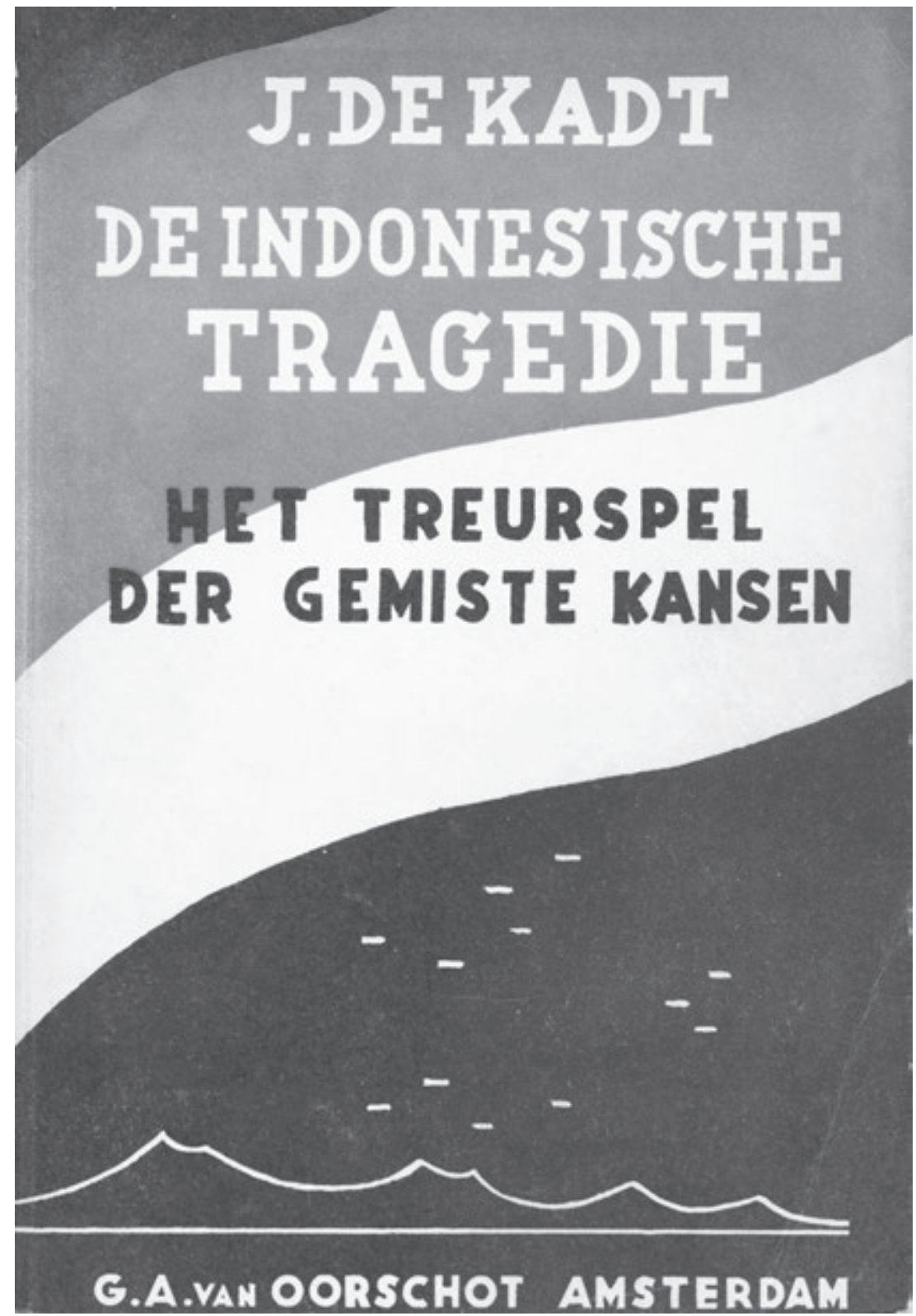

Deze felle kritiek op het Nederlandse Indonesiëbeleid werd begin 1949 gepubliceerd door de politicus Jacques de Kadt (1897-1988), die al voor de Tweede Wereldoorlog contact met Indonesische nationalisten had gehad, maar wiens pleidooien binnen de PvdA voor een ander beleid weinig steun hadden gevonden. 
korte termijn de soevereiniteit overdragen, maar daarna zou de Nederlandse Hoge Vertegenwoordiger nog een tijd lang dezelfde bijzondere bevoegdheden behouden als hem in de BIO-regeling werden toegekend. De nieuwe soevereine staat zou (naar een idee van Drees) de 'Republiek van de Verenigde Staten van Indonesië' gaan heten. De 'oude' Republiek zou alle staatsbevoegdheden die zij zich had aangemeten aan deze 'nieuwe' Republiek overdragen. Het geschil tussen Nederland en de oude Republiek zou dan niet langer bestaan en daarmee zou de reden voor de bemoeienis van de Verenigde Naties vervallen.

Beel bedoelde zijn plan in de eerste plaats als een tegenzet tegen de resolutie van de Veiligheidsraad van 28 januari. Hij legde het al eind januari aan de leiding van de BFO voor en besprak het midden februari persoonlijk met de regering in Den Haag. Dit leidde ertoe dat de regering het denkbeeld van een vervroegde soevereiniteitsoverdracht in aangepaste vorm overnam. De nieuwe aanpak leek een uitweg te bieden uit de problemen die in 1947 en 1948 een akkoord met de Republiek in de weg hadden gestaan. Die problemen waren immers in hoofdzaak voortgekomen uit de eisen die Nederland toen stelde met betrekking tot de overgangsperiode die aan de soevereiniteitsoverdracht vooraf zou gaan. Van Republikeinse kant was al in 1948 gevraagd of men die periode niet kon overslaan; binnen de BFO had ook Anak Agoeng dat bepleit. Nederland had daar toen echter niet van willen weten. De achtergrond hiervan was steeds geweest dat Nederland in de overgangsperiode waarborgen wilde scheppen voor het behoud van een duurzame Nederlandse invloed in Indonesië, in het bijzonder door een eind te maken aan de macht van het leger en de autonome strijdgroepen in de Republiek. Het was dan ook verrassend dat de regering nu alsnog bereid bleek van de overgangsperiode af te zien. In de oorspronkelijke opzet van het plan-Beel was dit vooral een zaak van optiek geweest: dat plan kwam in wezen neer op omkering van de volgorde tussen overgangsperiode en soevereiniteitsoverdracht, want Nederland zou na die overdracht toch nog tijdelijk een machtspositie behouden door bijzondere rechten voor zijn Hoge Vertegenwoordiger. Tijdens het overleg in Den Haag had Beel er echter mee ingestemd van het voorbehouden van zulke rechten af te zien; het ging nu dus toch om een reële soevereiniteitsoverdracht. Wel zou aan die overdracht overeenstemming moeten voorafgaan over het statuut van de Nederlands-Indonesische Unie en over tussen Nederland en Indonesië te sluiten overeenkomsten op financieel, economisch en militair gebied.

Voor de Nederlandse regering was de nieuwe aanpak vooral uit tactisch oogpunt aantrekkelijk, omdat zij met een aanbod om de soevereiniteit al op korte termijn over te dragen de Veiligheidsraad kon overtroeven die de datum van 1 juli 1950 als limiet gesteld had. Het Nederlandse publiek reageerde in het algemeen positief op het denkbeeld van een vervroegde overdracht. De opvattingen in Nederland ten aanzien van Indonesië hadden in de afgelopen jaren een grote ontwikkeling doorgemaakt. De meeste Nederlanders waren nu 
aan de gedachte gewend dat Indonesië een onafhankelijk land zou worden, hoe pijnlijk velen dit ook vonden. Aan de vraag welke plaats de Republiek daarin zou innemen hechtte men minder belang. Sinds de tweede 'politionele actie' (die men ten onrechte als een groot succes beschouwde) was men vooral geïnteresseerd in een spoedige repatriëring van de uit Nederland uitgezonden militairen.

Het feit dat de Nederlandse regering een nieuwe aanpak overwoog droeg ertoe bij dat de Veiligheidsraad besloot de kwestie-Indonesië pas in maart weer te bespreken. Tot op zekere hoogte was het ook aan de Koude Oorlog te danken dat Nederland zich voorlopig nog kon veroorloven geen volledig gevolg te geven aan de resoluties van de Raad. De Amerikaanse regering was in de eerste maanden van 1949 bezig samen met een aantal West-Europese landen een militair bondgenootschap (de latere NAVO) op te richten als tegenwicht tegen de machtsuitbreiding van de Sovjet-Unie. Omdat de Nederlandse regering hier een belangrijke rol bij speelde, kwam het Washington nu niet gelegen dat de $\mathrm{VN}$ dwangmaatregelen tegen Nederland zou nemen. Dit neemt niet weg dat de Amerikaanse regering in het kader van haar Aziëbeleid vertrouwen bleef stellen in Hatta en Soekarno als authentieke anticommunistische leiders en dat zij wel degelijk vond dat Nederland de VR-resolutie van 28 januari zou moeten aanvaarden.

Overigens was het overleg over het Indonesiëbeleid binnen de Nederlandse regering en tussen de regering en Beel in de loop van januari en februari met grote onenigheid gepaard gegaan. Dit leidde er onder meer toe dat minister Sassen op 14 februari ontslag nam; hij werd opgevolgd door de eveneens tot de KVP behorende minister van binnenlandse zaken, J.H. van Maarseveen. Deze verklaarde kort daarna in het parlement dat de regering haar fundamentele bezwaren handhaafde tegen verschillende delen van de VR-resolutie van 28 januari, waaronder het herstel van de Republikeinse regering in Jogja en het recht van de UNCI om met meerderheid van stemmen besluiten te nemen.

Omstreeks dezelfde tijd overwoog ook Beel ontslag te nemen, maar hij zag hiervan af omdat hij tijdens zijn overleg in Den Haag alsnog met de regering tot overeenstemming kwam. Men besloot toen zowel de federalisten als de Republikeinen uit te nodigen om in maart naar Den Haag te komen voor een Rondetafelconferentie (RTC) ter regeling van een vervroegde soevereiniteitsoverdracht. Als de Republikeinen die uitnodiging zouden afwijzen hoopte men de RTC toch te kunnen laten doorgaan. Verder besloot men de internering van de Republikeinse leiders op te heffen, maar hen niet toe te staan naar Jogja te gaan. Terwijl men de nieuwe bevoegdheden van de UNCI afwees besloot men haar wel uit te nodigen om bij de RTC 'goede diensten' te verlenen.

Na terugkeer in Batavia lichtte Beel op 26 februari zowel Soekarno als de BFO en de UNCI schriftelijk in over de voorgenomen RTC, die zo mogelijk 
op 12 maart zou moeten beginnen. Zijn kabinetschef Koets bracht twee dagen later een bezoek aan de Republikeinse leiders op Bangka, waarbij hij zich inspande hun wantrouwen tegen de Nederlandse bedoelingen zo veel mogelijk weg te nemen, maar ook meedeelde dat zijn regering hun terugkeer naar Jogja voorlopig niet zou toestaan. De formele opheffing van de internering betekende dus dat de Republikeinse leiders vrij waren om hetzij te gaan naar een plaats in Indonesië onder Nederlands bestuur, hetzij naar het door de Nederlandse troepen niet betreden Atjeh, hetzij naar het buitenland. Soekarno en de zijnen besloten van geen van die drie mogelijkheden gebruik te maken, maar op Bangka te blijven zo lang zij niet naar Jogja konden terugkeren. De Nederlandse regering bleef daardoor onder zo groot mogelijke druk staan om aan de resolutie van de Veiligheidsraad gevolg te geven, terwijl bij het publiek het beeld gehandhaafd bleef dat Nederland de Republikeinse leiders nog steeds gevangen hield.

Kort na het bezoek van Koets hadden Soekarno en Hatta gelegenheid het Nederlandse voorstel met invloedrijke federalisten te bespreken. Op 2 en 3 maart ontvingen zij op Bangka een delegatie van de BFO onder leiding van haar voorzitter sultan Hamid en haar vicevoorzitter Anak Agoeng. De Republikeinse voormannen zeiden geen gehoor te zullen geven aan de uitnodiging voor de RTC zolang de Republikeinse regering niet naar Jogja kon terugkeren en zolang het niet vaststond dat de UNCI de bevoegdheden zou kunnen uitoefenen die de Veiligheidsraad haar verleend had. Nadat de federalistische delegatie in Batavia teruggekeerd was vond daar een voltallige BFO-vergadering plaats. De leiders van sommige deelstaten verzetten zich hevig tegen tegemoetkomingen aan de Republiek, maar zij waren in de minderheid. Intussen werd ook het nieuws bekend over de TNI-aanval op Jogja die had aangetoond dat de Republiek militair nog geenszins verslagen was. Uiteindelijk nam men in de vroege ochtend van 4 maart eenstemmig een door Anak Agoeng voorgestelde resolutie aan waarin de BFO bepleitte dat de Nederlandse regering voldoen zou aan de door de Republikeinse leiders gestelde voorwaarden, namelijk gezagsherstel van de Republiek in Jogja en aanvaarding van de positie van de UNCI overeenkomstig de VR-resolutie van 28 januari. Beel was woedend over dit besluit, maar slaagde er niet in het ongedaan te maken. Iedere kans op een Nederlands akkoord met de federalisten buiten de Republiek om was nu voorgoed verkeken.

Eveneens op 4 maart schreef Soekarno aan Beel dat hij in beginsel met het doel van de voorgestelde Rondetafelconferentie instemde. Hij voegde hier echter aan toe dat hij in zijn huidige situatie geen besluiten kon nemen over deelname aan de RTC namens de Republiek; zulke besluiten zouden alleen genomen kunnen worden door een in Jogja gevestigde en daar volledig gezag bezittende Republikeinse regering. 


\section{Het akkoord tussen Roem en Van Roijen}

Het Nederlandse beleid had in februari 1949 een grote zwenking gemaakt door de uitnodiging aan Soekarno om een delegatie voor de RTC aan te wijzen. Daarna belandde dit beleid begin maart in een impasse omdat hij antwoordde dat alleen een in Jogja gevestigde Republikeinse regering daarover zou kunnen besluiten. Soekarno kon onmogelijk een ander standpunt innemen. Zolang de op Bangka verblijvende leiders geen toestemming kregen om naar Jogja terug te keren waren zij niet werkelijk vrij. Zouden ze onder die omstandigheden politiek overleg met Nederland voeren, dan zou hun achterban dit als verraad kunnen zien. Zij zouden een breuk riskeren met de leiders van de Republikeinse strijdkrachten en in het bijzonder met opperbevelhebber Soedirman. Formeel konden Soekarno en Hatta trouwens geen besluiten nemen die de Republiek zouden binden; de bevoegdheid daartoe hadden zij overgedragen aan de noodregering op Sumatra onder leiding van Sjafroedin Prawiranegara.

Aan de andere kant was het voor de Nederlandse regering bijzonder moeilijk om aan de wens van de Veiligheidsraad te voldoen tot herstel van de Republikeinse regering in Jogja. Uitschakeling van het Republikeinse actiecentrum was in december het hoofddoel van de tweede 'politionele actie' geweest. De Nederlandse verovering van Jogja en de gevangenneming van de Republikeinse leiders golden dan ook als de grootste successen van die actie. Het ongedaan maken van deze successen zou de indruk wekken dat de actie nergens voor gediend had. Voor een groot deel van het Nederlandse publiek was dit onbegrijpelijk; voor de leiding van de Nederlandse troepenmacht in Indonesië was het onverdraaglijk. Niettemin besloot de regering naar aanleiding van het BFO-besluit van 4 maart, waarin de federalisten het standpunt van de Republikeinse leiders ondersteunden, toch de mogelijkheid te onderzoeken om die leiders onder bepaalde voorwaarden naar Jogja te laten terugkeren. Eén van die voorwaarden zou moeten zijn dat zij hun gewapende achterban zouden opdragen de strijd te staken; verder dacht men onder meer aan een Republikeinse toezegging om aan de RTC deel te nemen en aan een regeling waarbij de Republiek in Jogja alleen burgerlijk bestuur zou uitoefenen terwijl de verantwoordelijkheid voor de handhaving van orde en veiligheid bij Nederland zou blijven berusten. Voordat de regering besloot de mogelijkheid van zo'n compromisoplossing te onderzoeken vergewiste zij zich ervan dat zij hiervoor op voldoende parlementaire steun kon rekenen. Zelfs Romme bleek zo'n oplossing niet bij voorbaat te verwerpen.

De bereidheid tot een voorwaardelijk herstel van de Republikeinse regering in Jogja betekende een drastische koerswijziging. De Nederlandse regering liet zich hierbij niet leiden door de betogen van Beel en Spoor, volgens wie de politieke en militaire situatie in Indonesië zich in voor Nederland gunstige zin 
ontwikkelde. Beel berichtte dat zich onder de bevolking van de nieuw bezette gebieden een wijdverbreid verlangen openbaarde om zich van de Republiek los te maken. Als Nederland nog een half jaar de tijd kreeg zou het volgens hem alsnog een bevredigende oplossing van het Indonesische probleem tot stand kunnen brengen. Spoor verklaarde dat de 'Soekarno-kliek' verrassend snel in het vergeetboek was geraakt. Volgens hem was de tweede 'politionele actie' geslaagd en maakte de Nederlandse legermacht nu goede vorderingen met de vierde en laatste fase van die actie, namelijk het opruimen van het nog resterende kleine verzet. Wel wees hij er op deze fase een extra grote inzet van militair personeel vergde. Hij vond daarom dat alle demobilisaties tot het eind van het jaar opgeschort moesten blijven, dat daarnaast nieuwe troepenaanvoer uit Nederland nodig was en dat troepenvermindering pas in 1951 zou kunnen plaatsvinden.

De Nederlandse regering dacht hier heel anders over. Zij wilde in ieder geval alle oorlogsvrijwilligers en de 7 December-divisie nog in 1949 gedemobiliseerd zien (volgens de oorspronkelijke toezeggingen had dat al in 1948 moeten gebeuren). Zij besefte dat Nederland niet voor onbepaalde tijd een grote troepenmacht in Indonesië op de been kon houden; het Nederlandse volk zou niet bereid zijn de daarvoor vereiste personele en materiële offers te brengen. Bovendien moest Nederland in het kader van het nieuwe NoordAtlantische bondgenootschap een militaire bijdrage gaan leveren aan de weerbaarheid van West-Europa. Verder kon de regering rekening houden met een veranderde opstelling van één van de bestanddelen van de 'koloniale troika', namelijk de ondernemers van de westerse productiebedrijven in Indonesië (vergelijk p. 530). In 1947 hadden zij verlangd dat de regering haar militaire macht gebruiken zou om de veilige exploitatie van die bedrijven te verzekeren; sinds het decemberoffensief was de situatie van die bedrijven dramatisch verslechterd, maar nu gaven de meeste ondernemers voorkeur aan beëindiging van de strijd door een politiek akkoord.

Terwijl de Nederlandse regering dus graag overleg wilde plegen over een compromisoplossing voor de terugkeer naar Jogja van de op Bangka vertoevende Republikeinse leiders, stuitte zij op het probleem dat deze leiders het zich politiek slecht konden veroorloven aan zulk overleg deel te nemen. Dit procedureel-politieke probleem werd opgelost door de Veiligheidsraad, die van 10 maart af een reeks besprekingen aan de Indonesische kwestie wijdde. Daarin werd Nederland weliswaar van vele kanten aangevallen, maar uiteindelijk bleken de meeste VR-leden geen bezwaar te hebben tegen voorbereidend overleg tussen Nederland en de Republiek, mits dat zou plaatsvinden binnen het kader van de VR-resoluties en onder auspiciën van de UNCI. Op 23 maart legde de Raad dit vast in een procedurele richtlijn waardoor de UNCI gemachtigd werd de partijen bij te staan om overeenstemming te bereiken over de uitvoering van de resolutie van 28 januari en over de voorwaarden en 
de datum van de voorgestelde conferentie in Den Haag.

De UNCI nodigde daarop beide partijen uit om op basis van deze richtlijn overleg in Batavia te voeren. Daarbij richtte zij de voor de Republiek bestemde uitnodiging aan Mohammad Roem, sinds 1948 voorzitter van de Republikeinse onderhandelingsdelegatie. Bij zijn aanvaarding van deze uitnodiging onderstreepte Roem dat het regeringsgezag van de Republiek aan de noodregering op Sumatra overgedragen was en dat hij daarom in eerste aanleg alleen zou kunnen praten over praktische aspecten van het herstel van de Republikeinse regering in Jogja.

De Nederlandse regering benoemde Van Roijen, destijds ambassadeur in Canada, tot voorzitter van haar delegatie in de door de UNCI bijeengeroepen voorbereidende conferentie. Van Roijen had de ontwikkeling van het geschil tussen Nederland en de Republiek van begin af aan meegemaakt. Als minister in het eerste naoorlogse kabinet had hij in april 1946 nog aan de conferentie op de Hoge Veluwe deelgenomen. Als vertegenwoordiger van Nederland in de Veiligheidsraad had hij het regeringsbeleid steeds trouw en bekwaam verdedigd, maar had hij ook ervaren hoe zwak Nederlands internationale positie was. In zijn nieuwe functie kwam hij op 12 april in Batavia aan. Tijdens zijn verblijf in Indonesië vormde hij zich een eigen oordeel over de politieke en militaire situatie en stelde hij zich kritisch op tegenover de door Spoor en Beel gegeven voorstelling van zaken.

De voorbereidende conferentie vond plaats in Hotel des Indes in Batavia en werd op 14 april geopend door Cochran, die ook verder in het overleg een actieve rol bleef spelen. Rekening houdend met de opstelling van Roem bespraken de delegaties in de volgende weken allereerst de kwestie van de terugkeer van de Republikeinse regering naar Jogja. Van Roijen had echter uitdrukkelijk instructie zich op dit punt niet te binden voordat men het in beginsel ook eens geworden was over twee andere onderwerpen: de beëindiging van de vijandelijkheden en de deelname aan de RTC. Behalve met Roem en diens delegatie voerde Van Roijen ook overleg met Hatta, die daartoe uit Bangka overkwam, en met de sultan van Jogja. Hij begon in tijdnood te raken omdat de Algemene Vergadering van de Verenigde Naties op 10 mei weer bijeen zou komen; Nederland zou daar in de beklaagdenbank terechtkomen als het overleg in Batavia dan nog geen resultaat geboekt had. Het lukte de delegaties echter tijdig beginselovereenstemming over alle drie onderwerpen te bereiken, waarna men dit op 7 mei in twee mondelinge verklaringen vastlegde.

Als eerste sprak Roem, die verklaarde dat Soekarno en Hatta hem gemachtigd hadden om hun persoonlijke verzekering te geven dat zij voorstander waren van:

1. het uitvaardigen van een bevel aan de gewapende aanhangers van de Republiek om de guerrilla-oorlog te staken; 
2. samenwerking gericht op het herstel van de vrede en het handhaven van orde en recht;

3. deelname aan een Rondetafelconferentie in Den Haag teneinde de onvoorwaardelijke overdracht van werkelijke en volledige soevereiniteit aan de Verenigde Staten van Indonesië te bespoedigen,

en dat zij zich verbonden sterk te zullen aandringen op aanvaarding van deze punten door de regering van de Republiek wanneer die weer in Jogja zou zetelen.

Hierna sprak Van Roijen een uit zeven punten bestaande verklaring uit. Die hield in de eerste plaats in dat zijn delegatie gemachtigd was in te stemmen met de terugkeer van de Republikeinse regering naar Jogja, waar zij vrij zou zijn om de haar toekomende functies uit te oefenen. Onder auspiciën van de UNCI zou men nader overleg plegen over de nodige voorbereidingen daartoe en over maatregelen om staking van de guerrillastrijd, herstel van de vrede en handhaving van orde en recht te verwezenlijken. Een ander punt van de verklaring was dat de Nederlandse regering geen nieuwe deelstaten of autonome gebieden zou instellen of erkennen binnen het gebied dat voor 19 december 1948 onder Republikeins gezag stond. Wat het doel van de RTC betreft bevestigde de verklaring dat het ging om onvoorwaardelijke overdracht van werkelijke en volledige soevereiniteit.

De twee op 7 mei door Roem en Van Roijen uitgesproken verklaringen vormden tezamen een akkoord dat de weg opende naar een politieke oplossing van het geschil tussen Nederland en de Republiek. Hierbij verdient het de aandacht dat Van Roijen's verklaring het functioneren van de Republikeinse regering in het over te dragen gebied niet beperkte tot de uitoefening van alleen burgerlijk bestuur, zodat die regering daar dus ook verantwoordelijk zou worden voor de handhaving van orde en veiligheid. Voordat de Nederlandse regering haar delegatie machtigde dit akkoord aan te gaan hadden Beel en Spoor zich er krachtig tegen verzet. Beel had onder meer willen vasthouden aan de vorming van nieuwe deelstaten op Republikeins gebied en had aan de Republikeinse regering op zijn hoogst een puur symbolische terugkeer naar Jogja willen toestaan. Omdat de regering de machtiging toch verleende nam hij ontslag als Hoge Vertegenwoordiger van de Kroon. Tot zijn opvolger benoemde de regering A.H.J. Lovink, destijds secretaris-generaal van het departement van buitenlandse zaken. Lovink, die voor de oorlog een hoge ambtenaar van het Nederlands-Indisch gouvernement in Batavia geweest was en later belangrijke ambassadeursposten bekleed had, was door zijn werk op het departement goed op de hoogte van de Indonesische kwestie en de internationale aspecten ervan. Hij trad op 2 juni aan als de nieuwe HVK.

Hoewel het akkoord van 7 mei in feite het failliet bezegelde van het door Spoor voorgestane beleid, besloot deze geen ontslag te nemen omdat hij zijn soldaten niet in de steek wilde laten. Intussen bleef hij ervan overtuigd dat hij 
met betrekking tot de militaire en politieke situatie in Indonesië geen enkele beoordelingsfout gemaakt had; de schuld voor wat er misgegaan was legde hij alleen bij de politici. Tot ieders verrassing verdween echter ook Spoor van het toneel omdat hij op 25 mei als gevolg van een hartaanval overleed. Zijn chef-staf, Buurman van Vreeden, werd door de regering tot zijn opvolger benoemd.

Het Nederlandse publiek reageerde gemengd op het tussen Van Roijen en Roem gesloten akkoord. Aan de ene kant was men opgelucht door het vooruitzicht op een vreedzame oplossing van het conflict in Indonesië; aan de andere kant was men geschokt dat de regering ondanks de klinkende overwinning op de Republiek nu toch Soekarno en Hatta naar Jogja wilde laten terugkeren; men kon dit alleen begrijpen als zwichten voor buitenlandse druk. Dat Nederland ook in Indonesië zelf onder druk stond, omdat zijn troepen steeds minder opgewassen waren tegen de Republikeinse guerrilla-oorlog, was bij het Nederlandse publiek in het geheel niet bekend. Overigens leidde het akkoord in Nederland niet tot grootscheeps protest zoals eind 1946 na het akkoord van Linggadjati gerezen was. Het conflict had nu al bijna vier jaar geduurd en de meeste Nederlanders waren het moe. Minister Van Maarseveen, die nog in februari in het parlement verklaard had dat zijn regering fundamenteel bezwaar had tegen terugkeer van de Republikeinse leiders naar Jogja, zei dat het nu om een andere zaak ging omdat deze leiders hun medewerking toegezegd hadden om aan de guerrilla-oorlog een eind te maken.

Aan Republikeinse kant stuitte het akkoord bij velen op wantrouwen en teleurstelling. Sjafroedin Prawiranegara, leider van de volledig gepasseerde noodregering op Sumatra, vond de toegezegde terugkeer naar Jogja een veel te kleine Nederlandse concessie tegenover de Republikeinse toezegging om de strijd te staken. Aan de andere kant wilde hij Soekarno en Hatta niet openlijk afvallen, want dat zou de positie van de Republiek alleen maar schaden. Hetzelfde gold voor Soedirman, die vond dat Soekarno en Hatta helemaal niet hadden moeten onderhandelen. Om meer begrip voor het akkoord te wekken bracht Hatta begin juni een bezoek aan Sumatra. Op Java besloten de partijbesturen van de Masjoemi en de PNI (de partijen van Roem en Ali Sastroamidjojo) het akkoord te steunen. De door volgelingen van Tan Malaka geleide linkse oppositie wees het akkoord af.

Het op 7 mei gesloten akkoord legde slechts een beginselovereenstemming vast die in overleg tussen de delegaties nader uitgewerkt moest worden. Daartoe stelde de voorbereidende conferentie twee subcommissies in. Eén hiervan bereidde de terugkeer naar Jogja voor; de sultan van Jogja leidde zelf de Republikeinse delegatie in dit orgaan. De andere subcommissie besprak de regeling van het staakt-het-vuren en het herstel van de vrede; de Republikeinse delegatie stond hier onder leiding van minister Leimena, die ook delegatieleider geweest was bij het overleg over militaire zaken na het Renville-akkoord. 
Het overleg tot uitwerking van het akkoord van 7 mei nam onverwacht veel tijd in beslag. In juni kreeg ook de BFO gelegenheid aan de voorbereidende conferentie deel te nemen. Op 22 juni nam zij met een delegatie onder sultan Hamid en Anak Agoeng voor het eerst aan een formele zitting deel. Van Roijen deelde in deze zitting mee dat de terugtrekking van de Nederlandse troepen uit Jogja op 24 juni zou beginnen en dat de Republikeinse regering daar een week later zou kunnen terugkeren. Verder verklaarden de delegaties overeenstemming bereikt te hebben over het programma voor de Rondetafelconferentie en over het staken van de vijandelijkheden.

Men kon het overleg over deze laatste kwestie echter pas voltooien nadat de regering van de Republiek zich weer in Jogja gevestigd had. Daarna werd de regeling voor het staken van de vijandelijkheden op 1 augustus formeel vastgesteld in een slotvergadering van de voorbereidende conferentie.

\section{Terugkeer van Soekarno en Hatta in Jogjakarta}

De op 28 januari 1949 door de Veiligheidsraad aangenomen resolutie had onder meer van Nederland verlangd, dat het de gevangen genomen Republikeinse leiders in de gelegenheid zou stellen terug te keren naar Jogjakarta en daar het bestuur uit te oefenen in de stad en haar onmiddellijke omgeving. In het op 7 mei tussen Roem en Van Roijen gesloten akkoord was echter overeengekomen dat het Republikeinse bestuur een groter gebied zou bestrijken, namelijk de hele 'residentie' Jogjakarta, een bestuursdistrict dat in feite samenviel met het grondgebied van het sultanaat Jogjakarta.

Bij het uitwerken van een regeling voor de overdracht van het gebied konden de onderhandelaars profijt trekken van het feit dat de sultan van Jogja, Hamengkoe Boewono IX, zowel in het koloniale als in het Republikeinse bestel een eigen plaats innam: als sultan werd hij door Nederland erkend, maar tegelijk maakte hij als minister zonder portefeuille deel uit van de regering van de Republiek. Men belastte hem nu met de verantwoordelijkheid voor de veiligheid in het gebied tijdens de overgangsfase. Daartoe kreeg hij onder meer de beschikking over een speciale politiemacht die gedeeltelijk door Nederland van wapens en vervoermiddelen voorzien werd.

Overigens was het akkoord van 7 mei aanleiding voor een uittocht van inwoners van het gebied die vreesden onder Republikeins bestuur niet meer veilig te zullen zijn. Nederlandse radiouitzendingen hadden die vrees sterk aangewakkerd. Deze uittocht, die zich eind mei en begin juni voltrok, betrof ruim veertigduizend personen, in hoofdzaak Chinese handelaren met hun gezinnen en Indonesiërs die nauw met het Nederlandse gezag samengewerkt hadden.

Op 23 juni vaardigde de sultan een dagorder uit waarin hij de Republikeinse 
militairen opdroeg zich van vijandelijkheden te onthouden tijdens de ontruiming van het gebied door de Nederlandse troepen. Zoals Van Roijen al aangekondigd had begon die ontruiming op 24 juni. Op 30 juni vertrokken de laatste Nederlandse soldaten, waarna de sultan de verantwoordelijkheid overnam. TNI-eenheden die aan de guerrilla-oorlog in het gebied deelgenomen hadden trokken Jogja binnen.

De weg was nu vrij voor de terugkeer van Soekarno en Hatta. Op 6 juli bracht een vliegtuig van de Verenigde Naties hen en de andere leiders uit Bangka terug. Hun intocht in Jogja werd een triomftocht.

Het was eerst nog onzeker of opperbevelhebber Soedirman bereid zou zijn zich weer onder Soekarno's gezag te schikken. Tot veler opluchting keerde hij op 10 juli in Jogja terug. Hij bracht daar eerst een bezoek aan Soekarno en Hatta en nam vervolgens een parade van Republikeinse soldaten af, niet gekleed in zijn generaalsuniform maar in sarong, trui en de legerjas die hij tijdens zijn omzwervingen sinds december gedragen had. Daarbij stond hij tussen luitenant-kolonel Soeharto en Sjafroeddin Prawiranegara, het op diezelfde dag uit Sumatra teruggekeerde hoofd van de noodregering.

Op 13 juli vond een zitting van het Republikeinse kabinet plaats waarin de uit Bangka teruggekeerde leiders voor het eerst bijeenkwamen met de leiding van de noodregering en van haar commissariaat op Java (van de vijf ministers die dit commissariaat gevormd hadden was intussen één gesneuveld). Nadat de noodregering en haar commissariaat verslag hadden uitgebracht over hun optreden, gaf Sjafroedin het mandaat van de noodregering terug. Het volledig herstel van de regering van de Republiek was hiermee een feit. Deze regering aanvaardde vervolgens de beleidspunten die vervat waren in de verklaring van Roem van 7 mei en waarvoor Soekarno en Hatta beloofd hadden zich sterk te zullen maken: staking van de guerrillastrijd en deelname aan de Rondetafelconferentie in Den Haag. Enige dagen later verwierf het nieuwe beleid ook steun van een meerderheid in het Werkcomité van het KNIP. Om het draagvlak voor dit beleid te versterken wijzigde Hatta de samenstelling van zijn regering. Onder meer werd de sultan van Jogja, die tot nu toe minister zonder portefeuille geweest was, minister van defensie in het nieuwe kabinet.

Het herstel van de Republikeinse regering in Jogja kreeg in het buitenland een gunstig onthaal als bewijs van een ommekeer in het Nederlandse beleid. Het leidde onder meer tot intrekking van de door verscheidene Aziatische landen aan Nederland opgelegde verboden om van hun vliegvelden gebruik te maken.

De na 7 mei onder inwoners van het sultanaat gewekte vrees voor wraak en geweld, die tienduizenden ertoe gebracht had het gebied te verlaten, bleek ongegrond. Er vonden geen gewelddadigheden plaats, er werden geen maatregelen genomen tegen Indonesiërs die met het koloniale gezag samen- 
gewerkt hadden en Nederlanders die Jogja bezochten konden zich zelfs in verre uithoeken van de stad vertonen zonder dat hun iets overkwam. Dit bleek ook aan de Nederlandse delegatie, die op 16 en 17 juli een bezoek aan Jogja bracht. Van Roijen voerde bij deze gelegenheid gesprekken onder vier ogen met Soekarno, Hatta, de sultan van Jogja, Agoes Salim en Simatoepang.

\section{Akkoord tussen de Republiek en de federalisten}

Gedurende het hele jaar 1949 hebben de Indonesische federalisten een belangrijke politieke rol gespeeld. Daarbij sloten zij begin augustus een veelomvattend akkoord met de Republiek. Terwille van een goed begrip daarvan volgt hier eerst een terugblik op de manier waarop die rol van de federalisten zich heeft ontwikkeld.

Sinds 1946 ging het dekolonisatiebeleid van de Nederlandse regering ervan uit dat een onafhankelijk Indonesië alleen maar goed zou kunnen functioneren als het een federatie vormde. Hoe dit uitgangspunt te rijmen viel met het feit dat Nederland zelf de kolonie Nederlands-Indië altijd unitaristisch bestuurd had legde de regering niet uit. De door haar voorgestane federale opbouw van het toekomstige Indonesië kreeg steun van een in Malino bijeengeroepen conferentie van Indonesische vertegenwoordigers uit gebieden buiten Java en Sumatra. Van Mook pleitte daar voor de vorming van vier grote deelstaten, Java, Sumatra, Borneo en Oost-Indonesië. In het akkoord van Linggadjati van november 1946 aanvaardde ook de Republiek dat Indonesië een federatie worden zou; volgens dit akkoord zou die uit drie deelstaten bestaan, OostIndonesië, Borneo en de Republiek (die Java en Sumatra zou omvatten). Eind 1946 richtte Van Mook de deelstaat Oost-Indonesië op. De oprichting van een deelstaat Borneo werd uitgesteld omdat een deel van de bevolking van dat eiland sterk Republikeinsgezind was; wel werden daar enige autonome gebieden gevormd. Na het Nederlandse offensief van juli 1947 zorgde Van Mook ervoor dat (in strijd met het akkoord van Linggadjati) ook in de op de Republiek veroverde gebieden nieuwe deelstaten gevormd werden: Madoera, Oost-Java, Pasoendan (West-Java), Zuid-Sumatra en Oost-Sumatra. Zijn vroegere gedachte dat de Indonesische federatie alleen uit enkele grote eenheden zou moeten bestaan had hij laten varen.

In de loop van 1948 begon de doelstelling van het Nederlandse federaliseringsbeleid te veranderen. Overal waar Nederland nu de macht in handen had, zowel in het Malinogebied als op Java en Sumatra, had het Indonesiërs gevonden die bereid waren tot samenwerking met het Nederlandse gezag. Terwijl men de stichting van deelstaten en autonome gebieden oorspronkelijk bevorderd had om tegenwichten tegen de Republiek te vormen, dacht men nu aan de mogelijkheid hiermee een alternatief voor de Republiek op te bouwen. 
Men trof voorbereidingen voor de stichting van een Indonesische federatie zonder de Republiek. Meer en meer deed men het voorkomen alsof het bij de dekolonisatie van Indonesië niet ging om een conflict tussen Nederland en de Republiek, maar om een interne tegenstelling in Indonesië tussen de voorstanders van twee verschillende staatkundige concepties, die van de bondsstaat tegenover die van de eenheidsstaat, kortom een tegenstelling tussen federalisten en unitaristen. Daarbij behandelde men de Republiek als kampioen van de unitaire conceptie; weliswaar had zij de federale conceptie herhaaldelijk formeel onderschreven, maar zij weigerde haar eigen status tot die van een deelstaat te verlagen. Tot de echte federalisten rekende men daarentegen de leidende figuren uit de door het Nederlands-Indische gouvernement opgerichte deelstaten en autonome gebieden (de 'federale' gebieden).

De meeste van deze figuren gaven inderdaad voorkeur aan een federale opbouw van het toekomstige Indonesië, maar onderling verschilden ze sterk in hun opstelling tegenover de Republiek. Sommigen waren haar bijzonder vijandig gezind, terwijl anderen met haar sympathiseerden. Verscheidenen betreurden het dat Nederland de keuze tussen een unitair of federaal stelsel tot een keuze voor of tegen de Republiek gemaakt had. Zij wilden niet als schaakstukken gebruikt worden in een door Nederland gevoerde verdeel-enheerspolitiek. Dit onbehagen droeg medio 1948 bij tot de oprichting van een eigen overlegorgaan, de BFO, waarin de federalisten nauw gingen samenwerken als derde politieke factor naast Nederland en de Republiek.

In eerste aanleg verwelkomde de Nederlandse regering de wens van de federalisten een eigen rol te spelen. In september-oktober raadpleegde zij niet de Republiek maar wel de leiders van de $\mathrm{BFO}$ bij de opstelling van de regeling Bewind Indonesië in Overgangstijd (BIO). Daarentegen bekoelde de verstandhouding in november-december, omdat Nederland toen op ministersniveau overleg met de Republiek voerde maar niet bereid bleek de BFO bij dit overleg te betrekken noch haar over de resultaten ervan in te lichten. De kort daarna door Nederland tegen de Republiek ondernomen militaire actie wekte onder de federalisten verdeelde reacties. De regeringen van de twee belangrijkste deelstaten traden af. Nederland wilde nu op basis van het BIO-besluit een Indonesische interimregering instellen, maar de BFO besloot eerst met prominente Republikeinen te gaan praten voordat men aan de vorming van zo' $n$ regering zou meewerken. Hiermee introduceerde zij een nieuw overlegkader over de toekomst van Indonesië, namelijk onderling overleg tussen de federalisten en de leiders van de Republiek.

Een en ander betekende dat de federalisten bij het politieke vervolg op de militaire actie een sleutelrol toebedeeld kregen, omdat Nederland van hun medewerking afhankelijk was om de beoogde interimregering te kunnen instellen. In deze periode verloor Nederland bij de federalisten snel aan gezag, onder meer als gevolg van de door de regering in januari 1949 aan 
de dag gelegde verwarring en besluiteloosheid. Ook de reacties binnen de Verenigde Naties droegen tot dit gezagsverlies bij; Nederland bleek internationaal alleen te staan terwijl de Republiek op internationale steun kon blijven rekenen. Het in februari door de Nederlandse regering gelanceerde aanbod tot vervroegde soevereiniteitsoverdracht maakte bovendien duidelijk dat de dekolonisatie van Indonesië nu werkelijk voor de deur stond. Na het vertrek van de Nederlanders zouden de federalisten met de Republikeinen verder moeten; daarom hadden zij nu bovenal belang bij een goede verstandhouding met de Republiek.

Anak Agoeng, premier van Oost-Indonesië en vice-voorzitter van de BFO, was zich bij uitstek van deze politieke feiten bewust en had bovendien de vindingrijkheid om op grond daarvan initiatieven te nemen. Het was op zijn voorstel dat de BFO in januari besloot tot overleg met de Republikeinse leiders. Het was eveneens aan hem te danken dat de BFO zich begin maart achter de voorwaarden van Soekarno en Hatta stelde voor Republikeinse deelname aan de Rondetafelconferentie (RTC) in Den Haag. Na de totstandkoming van het akkoord tussen Roem en Van Roijen in mei honoreerde de Republiek de rol van de BFO door ermee in te stemmen dat zij ging deelnemen aan het overleg tot uitwerking van dit akkoord. In dat kader werd op 22 juni bekendgemaakt dat de BFO-delegatie instemde met de tussen de delegaties van Nederland en de Republiek getroffen regeling over het staken van de vijandelijkheden en dat de drie delegaties het onderling eens waren geworden over de voorbereiding van de RTC.

Hierna nam Anak Agoeng een nieuw initiatief: hij stelde voor dat na het herstel van de Republikeinse regering in Jogja de BFO en de Republiek onderling overleg zouden plegen om te komen tot een gezamenlijke opstelling in de RTC. De hiertoe door hem voorgestelde Inter-Indonesische Conferentie kwam in twee zittingen bijeen, van 19 tot 23 juli in Jogja en van 31 juli tot 2 augustus in Batavia. De conferentie stond sterk in het teken van verbroedering tussen de federalisten en de Republikeinen. De ruim zestig federale afgevaardigden werden tijdens hun verblijf in Jogja met veel egards behandeld. Sommigen van hen waren verbaasd omdat hun nieuwe ervaringen sterk afweken van het overwegend negatieve beeld dat zij zich op grond van de gangbare berichtgeving over de Republiek gevormd hadden.

In de conferentie kwam een groot aantal staatkundige, militaire, financiele, economische en culturele onderwerpen aan de orde. Men kwam overeen dat de naam van de toekomstige Indonesische federatie zou luiden Republik Indonesia Serikat (RIS, Republiek der Verenigde Staten van Indonesië). Dit was van aanzienlijke symbolische betekenis, evenals de aanvaarding door de conferentie van het Indonesia Raya als nationaal volkslied en van de rood-witte vlag (die toen nog verboden was in al het door Nederland bestuurde gebied) als nationale vlag. Het overleg werd in Batavia voortgezet in het voormalige 
Volksraadgebouw. Deze tweede zitting leidde over de hele linie tot overeenstemming. Dit betrof in de eerste plaats de hoofdlijnen van de grondwet voor de toekomstige federatie en de organisatie van haar regering.

De opstelling van de Republiek hield één belangrijke concessie in, die al in de opzet van de conferentie besloten lag: naast de buiten Java, Madoera en Sumatra gevormde deelstaten en autonome gebieden aanvaardde zij als deelgenoten in de toekomstige Republiek der Verenigde Staten van Indonesië (RVI) ook alle deelstaten en autonome gebieden die in strijd met het akkoord van Linggadjati tussen het eerste en het tweede Nederlandse offensief gevormd waren op door Nederland veroverd Republikeins gebied. Als deelstaat binnen de RVI zou de Republiek alleen het gebied omvatten dat op grond van het Renville-akkoord onder Republikeins bestuur gebleven was. Verder kwam de Republiek de federalisten tegemoet op het punt van de samenstelling en de bevoegdheden van de Volksvertegenwoordiging en de Senaat. Eén derde van de leden van de Volksvertegenwoordiging zou afkomstig zijn uit de Jogjase Republiek, twee derde uit de federale gebieden.

Daarentegen sloten de meeste resultaten van de conferentie nauw bij de Republikeinse opvattingen aan. Tot die resultaten behoorde ook, dat aan de RVI niet alleen de Nederlandse soevereiniteit over Indonesië zou worden overgedragen maar ook de soevereiniteit van de Republiek (op basis van de onafhankelijkheidsverklaring van 17 augustus 1945). Dit laatste betekende dat de RVI zelf een voortzetting van de oorspronkelijke Republiek zou worden, terwijl de tot deelstaat verlaagde Jogjase Republiek zich tot het Renvillegebied zou beperken. Belangrijk waren bovendien de besluiten van de conferentie op militair gebied; ze voldeden volledig aan de 'Zes Punten' van Soedirman uit maart 1948 (zie p. 570). De strijdkrachten van de Republiek zouden de kern vormen van de krijgsmacht van de RVI, terwijl men Indonesische leden van het KNIL op nader te bepalen voorwaarden in die krijgsmacht zou kunnen opnemen. De defensie van Indonesië zou uitsluitend een zaak van de federale regering zijn; de deelstaten zouden geen eigen krijgsmacht onderhouden. Een en ander was precies het omgekeerde van wat in de Nederlandse plannen voorzien was, waarbij de TNI zou verdwijnen en het KNIL de kern van de federale krijgsmacht zou worden, met de mogelijkheid ex-leden van de TNI op individuele basis toe te laten, terwijl daarnaast de afzonderlijke deelstaten over eigen veiligheidsbataljons zouden beschikken. Vergeefs had de BFO in de conferentie voorgesteld dat de RVI zowel de TNI als het KNIL en de veiligheidsbataljons volledig zou overnemen. Verder voorzag de conferentie wel in de mogelijkheid Nederland te vragen tijdelijk marine-eenheden ter beschikking van de RVI te stellen, maar zij besloot dat de Nederlandse landstrijdkrachten de RVI volledig moesten verlaten. Dit was wel ver verwijderd van de Nederlandse plannen uit 1947 die ervan uitgingen dat Nederland in het kader van de Unie nog tenminste vijftien jaar lang eigen 
land-, lucht- en zeestrijdkrachten in Indonesië zou stationeren.

Tussen de twee zittingen van de Inter-Indonesische Conferentie vond in Makassar een plechtigheid plaats die de nieuwe verstandhouding tussen federalisten en Republikeinen onderstreepte. Kort daarvoor was Ratoelangie overleden, een nestor van de nationale beweging. In Nederland had hij al in 1914 de vereniging van Indonesische studenten voorgezeten en al in 1918 Jonkman en Van Mook leren kennen. Na terugkeer in Indonesië was hij leider van de Minahasa-bond en lid van de Volksraad geweest en had hij een nationalistisch tijdschrift uitgegeven. In augustus 1945 behoorde hij tot de oprichters van de Republiek Indonesië, die hem vervolgens tot gouverneur van Celebes benoemde. In april 1946 had het Nederlands bestuur hem in Makassar gevangen genomen; daarna was hij in Nieuw-Guinea geïnterneerd. Pas na het Renville-akkoord had hij zijn vrijheid teruggekregen; hij was toen naar Jogja gegaan waar hij adviseur werd van de Republikeinse onderhandelingsdelegatie. Na zijn overlijden bracht men zijn stoffelijk overschot op 25 juli naar Makassar over. Vergezeld door ministers uit zijn kabinet sprak Anak Agoeng daar een herdenkingsrede uit, staande naast de met rood-wit getooide baar.

\section{Het derde bestand tussen Nederland en de Republiek}

Van de drie in het akkoord tussen Roem en Van Roijen behandelde kwesties die de delegaties in de voorbereidende conferentie nader moesten uitwerken, namelijk de terugkeer van de Republikeinse regering naar Jogja, het programma voor de Rondetafelconferentie en de beëindiging van de vijandelijkheden, bleek de laatste kwestie verreweg de moeilijkste. Het zou na 7 mei nog meer dan drie maanden duren voordat het staakt-het-vuren eindelijk van kracht werd. Eén van de moeilijkheden bij de voorbereiding van het bestand was dat er sinds het decemberoffensief geen frontlijn tussen de Nederlandse en de Republikeinse troepen meer bestond: in de meeste delen van Java en Sumatra bevonden de TNI-eenheden zich tussen de Nederlandse troepeneenheden in. Een andere moeilijkheid was dat sommige invloedrijke Nederlandse militairen en politici er nog van bleven uitgaan dat Nederland sinds het decemberoffensief verantwoordelijk was voor de handhaving van de interne veiligheid op heel Java en Sumatra en daarom niet wilden aanvaarden dat die verantwoordelijkheid ook in gebieden buiten Jogja bij de TNI zou komen te liggen. Een derde moeilijkheid was dat de Republikeinse legerleiding niet aan de totstandkoming van een bestandsregeling wilde meewerken zo lang de Republikeinse regering niet in Jogja teruggekeerd was.

Hoewel de voorbereidende conferentie daarom niet kon beschikken over militair advies van Republikeinse kant, wist zij toch een veelomvattende regeling te ontwerpen voor de beëindiging van de vijandelijkheden en het herstel 
van de vrede. Hierbij stuitte Van Roijen enige malen op ernstige bezwaren, eerst bij de legerleiding in Batavia en later bij de regering in Den Haag. In zijn verschil van mening met Den Haag kreeg hij uiteindelijk steun van Lovink, de nieuwe HVK, en van Buurman van Vreeden, de nieuwe legercommandant, en tenslotte ook van minister Van Maarseveen, die medio juni een bezoek aan Indonesië bracht. Pas daarna gaf de regering toestemming de ontworpen regeling aan te gaan. Vervolgens maakten de delegaties op 22 juni bekend dat ze het over de bestandsregeling eens geworden waren (dit gebeurde in dezelfde vergadering waarin Van Roijen de terugkeer van de Republikeinse regering naar Jogja aankondigde). De inhoud van die regeling werd echter nog niet bekendgemaakt, omdat de Republikeinse legerleiding eerst gelegenheid moest krijgen daar haar oordeel over te geven.

De tussen de delegaties overeengekomen regeling vormde het derde bestand tussen Nederland en de Republiek. Het eerste bestand was op 14 oktober 1946 op Britse aandrang gesloten en vormde toen de opmaat naar het akkoord van Linggadjati; Nederland verbrak het op 20 juli 1947 door het lanceren van de eerste 'politionele actie'. Het tweede bestand was op 17 januari 1948 aan boord van de 'Renville' gesloten en legitimeerde in feite de Nederlandse veroveringen als gevolg van die actie; Nederland verbrak het op 19 december 1948 door het lanceren van de tweede 'politionele actie'.

De nieuwe bestandsovereenkomst bestond uit vier delen. Het eerste deel bevatte de tekst van de door de Nederlandse regering en de Republikeinse regering uit te vaardigen orders tot staking van de vijandelijkheden. Het tweede deel bevatte een door de beide regeringen gezamenlijk af te kondigen proclamatie. Daarin stond onder meer, dat iedereen zich moest onthouden van daden van vergelding of wraak, dat niemand vervolgd zou worden omdat hij in het geschil tussen Nederland en de Republiek partij gekozen had, dat politieke gevangenen in vrijheid gesteld zouden worden en dat zij die vervolgd of veroordeeld waren voor misdaden die duidelijk een uitvloeisel van het politieke conflict waren zouden worden ontslagen van verdere vervolging of worden ontheven van hun straf. Het belangrijkste bestanddeel van de overeenkomst was het derde deel, dat richtlijnen bevatte voor de uitvoering van het staken der vijandelijkheden. Het bepaalde dat de partijen in onderling overleg een afbakening en toewijzing tot stand zouden brengen van patrouillegebieden voor de handhaving van rust en orde. Die patrouillegebieden zouden overeen moeten komen met de bestuurlijke indeling. De strijdkrachten van de partijen zouden hun patrouillegebieden niet mogen uitbreiden, noch op andere manier mogen proberen hun militaire positie ten koste van de andere partij te verbeteren. De uitvoering van deze richtlijnen zou worden gedirigeerd door een centrale gemengde commissie, bestaande uit vertegenwoordigers van de UNCI, Nederland, de Republiek en de BFO; zij zou ook plaatselijke gemengde commissies kunnen instellen. Het vierde deel 
van de overeenkomst was een handboek met aanvullende bepalingen over de uitvoering van het staakt-het-vuren, de proclamatie en de richtlijnen; de tekst hiervan was op 22 juni nog niet gereed.

Na 22 juni moesten verdere stappen tot uitvoering van het bestand wachten op instemming van de Republikeinse legerleiding met de opgestelde documenten. Een week na het herstel van de Republikeinse regering in Jogja werd die instemming op alle hoofdpunten verkregen tijdens een gezamenlijke vergadering van de militaire en de politieke top van de Republiek in het ziekenhuis waar generaal Soedirman verpleegd werd. In aansluiting op die bespreking kwamen de delegaties van Nederland en de Republiek nog enige ondergeschikte wijzigingen overeen en stelden zij de tekst vast van het handboek met aanvullende bepalingen. Daarna formaliseerden ze de bestandsovereenkomst op 1 augustus in een slotvergadering van de voorbereidende conferentie. Twee dagen later vaardigden de beide regeringen hun orders tot staking van de vijandelijkheden en hun gezamenlijke proclamatie uit. Het staakt-het-vuren zou op Java op 11 augustus en op Sumatra op 15 augustus ingaan.

Hoe gewenst het was dat er een eind kwam aan het oorlogsgeweld tussen Nederland en de Republiek werd onderstreept door een incident dat juist in deze dagen plaatsvond en dat bekend geworden is als de 'bloedbruiloft van Tjilatjap'. In de avond van 1 augustus begaf een Nederlandse patrouille zich nabij Tjilatjap op weg om TNI-militairen op te sporen die zich volgens verkregen inlichtingen in een bepaald huis zouden bevinden. Bij het huis aangekomen troffen zij een menigte van enkele honderden mannen, vrouwen en kinderen aan die daar een bruiloftsfeest vierden en naar een wajangvoorstelling met gamelanmuziek keken. Bij vergissing openden enkele Nederlandse militairen het vuur op deze menigte, onder meer met een machinegeweer. Daarbij kwamen zesentwintig personen om het leven en werden drieëndertig gewond.

Bij de afkondiging van het bestand hield zowel Lovink als Soekarno een radiorede. Lovink vroeg de Nederlandse militairen te begrijpen dat ook de TNI-militairen het in de afgelopen periode niet gemakkelijk hadden gehad, dat zij vaak onder moeilijke omstandigheden en met slechte wapens en uitrusting hadden moeten vechten, maar dat zij als geheel trouw waren gebleven aan de roeping van hun vaderland zoals zij die verstonden. Ook generaal Buurman van Vreeden richtte zich tot zijn soldaten en riep hen op voortaan niet tegen maar met de TNI te strijden.

Daar men mocht aannemen dat de toewijzing van de patrouillegebieden zou plaatsvinden op grond van de situatie bij het ingaan van het staakt-hetvuren, was het niet verrassend dat beide partijen in de daaraan voorafgaande dagen hier en daar probeerden hun posities te verbeteren. Op 7 augustus ondernam de TNI zelfs een poging de stad Solo te veroveren; het Nederlandse garnizoen moest luchtsteun inroepen om de aanval af te slaan. Formeel was 
deze TNI-actie niet ongeoorloofd; het nieuwe bestand gold immers nog niet en aan het vorige bestand was niet door de Republiek maar door Nederland een eind gemaakt. Niettemin was Lovink over deze aanval en enkele andere incidenten zo verontwaardigd, dat hij besloot sommige stappen die hij in samenhang met het bestand had willen nemen enige weken uit te stellen. Hiertoe behoorden de teruggave aan de Republiek van het pand Pegangsaän Oost 56 (dat voor de Republikeinen als nationaal heiligdom gold), de opheffing van het verbod op de rood-witte vlag en het toestaan van openbare herdenking van de uitroeping van de onafhankelijkheid. Het niet toestaan van zulke herdenkingen had het door Lovink niet beoogde gevolg dat op 17 augustus ongeveer vifftigduizend personen in Batavia samendrongen rondom het kantoor van de Republikeinse delegatie aan het Koningsplein, waar een viering in besloten kring zou plaatsvinden. Het vlagverbod werd op 23 augustus opgeheven; drie dagen later vond de teruggave van Pegangsaän Oost 56 plaats.

De in de gezamenlijke proclamatie van 3 augustus vervatte oproep om zich te onthouden van daden van wraak of vergelding was vooral op Nederlandse aandrang opgenomen, ter bescherming van Indonesiërs die nauw met het Nederlandse gezag samengewerkt hadden, maar deze oproep gold uiteraard voor beide partijen. Op dit punt gaf Lovink's gouvernement zelf een slecht voorbeeld. In een gevangenis op Java bevond zich ten tijde van het staakthet-vuren Wolter Monginsidi, de jonge Menadonees die in 1946 het antiNederlandse verzet in Makassar geleid had (zie p. 516-9). Hij was sindsdien gevangen genomen, berecht en ter dood veroordeeld. Ondanks de proclamatie werd dit vonnis op 5 september alsnog voltrokken, tot bittere teleurstelling en verontwaardiging aan Republikeinse kant. De begrafenis van zijn stoffelijk overschot in Makassar groeide uit tot een massademonstratie.

Bij de uitvoering van de bestandsovereenkomst viel een belangrijke rol toe aan de Haagse ambtenaar H.L. s'Jacob. Hij was in Nederland secretarisgeneraal van het departement van financiën, maar had al in 1947-1948 enige tijd deelgenomen aan het overleg met de Republiek en was in april 1949 aan Van Roijen toegevoegd om die te assisteren bij zijn onderhandelingen met Roem. Onder meer had hij het overleg met de sultan van Jogja gevoerd over de terugkeer van Soekarno en Hatta naar de Republikeinse hoofdstad. Nadat Van Roijen begin augustus naar Nederland was vertrokken om deel te nemen aan de Rondetafelconferentie, volgde s'Jacob hem op als leider van de Nederlandse onderhandelingsdelegatie in Batavia.

In het kader van de uitvoering van de bestandsovereenkomst stelde de gemengde commissie eind augustus ook subcommissies over bepaalde onderwerpen in, onder meer over de bevoorrading van de patrouillegebieden van de TNI en over de vrijlating van gevangenen. Intussen kwam de afbakening en toewijzing van patrouillegebieden slechts moeizaam op gang, onder meer omdat de plaatselijke TNI-commandanten nog niet over de daarvoor opge- 
stelde richtlijnen beschikten. Wel vertoonden Republikeinse militairen zich nu op tal van plaatsen die naar Nederlandse mening ten tijde van het staakthet-vuren in Nederlandse handen geweest waren. Van Nederlandse kant beschouwde men dit als ongeoorloofde pogingen tot gebiedsuitbreiding, maar van Republikeinse kant stelde men telkens dat die militairen daar ongezien al voor die tijd aanwezig geweest waren. Deze controverses bemoeilijkten de toewijzing van patrouillegebieden des te meer, omdat toewijzing aan de TNI meestal ook meebracht dat die gebieden onder Republikeins bestuur kwamen te staan. Een en ander leidde tot aanzienlijke spanningen, vooral omdat veel Nederlandse officieren en ambtenaren het nog steeds als een ernstig verlies beschouwden om gebieden 'aan de vijand prijs te geven'.

Geleidelijk drong echter het besef door dat men zich van het verleden los moest maken. Omdat Nederland over enkele maanden de soevereiniteit zou overdragen had het er zelf belang bij, dat die overdracht zou geschieden aan een gezag dat over een betrouwbaar machtsapparaat beschikte. Zou dit niet het geval zijn, dan viel onder meer te vrezen dat Indonesië toch nog in de greep van het communisme zou raken. Omdat de TNI nu eenmaal de ruggegraat van het machtsapparaat van de RVI zou vormen, had Nederland dus belang bij een sterke positie van de TNI. Om chaos bij de soevereiniteitsoverdracht te voorkomen was het bovendien belangrijk dat de machts- en bestuursovergang zich niet abrupt zou voltrekken. Deze inzichten leidden tot een veranderende Nederlandse opstelling bij de uitvoering van de bestandsovereenkomst. In het bijzonder s'Jacob was zich bij uitstek bewust van het Nederlandse belang bij een solide positie van de Republiek.

De bestandsovereenkomst ging weliswaar uit van de status quo, maar verplichtte niet tot strikte handhaving daarvan, zoals al bleek uit de richtlijn om bij de afbakening de bestuurlijke indeling te volgen. De overeenkomst liet ruimte om in onderling overleg patrouillegebieden te ruilen of samen te voegen en ook om afspraken over gezamenlijke patrouillering te maken. De Nederlandse legerleiding had haar plaatselijke commandanten al gemachtigd afgelegen posten op te heffen om beter beheersbare gebieden te vormen. Intussen moest die legerleiding er ook rekening mee houden dat zij over steeds minder soldaten beschikte omdat de repatriëring van de uit Nederland uitgezonden militairen nu in volle gang was. Onder meer was de 7 December-divisie na augustus niet meer voor militaire taken beschikbaar omdat zij zich op haar verscheping naar Nederland voorbereidde. Verkleining van het door Nederlandse troepen bezette gebied was dringend gewenst. Men ging de uitvoering van de bestandsovereenkomst dan ook benutten om delen van de tijdens het decemberoffensief bezette gebieden op een onopvallende manier aan de Republiek terug te geven. In plaats van de veroveringen te legitimeren had het nieuwe bestand de mogelijkheid geopend die veroveringen ongedaan te maken.

Op Java begonnen de Nederlandse troepen in oktober zich terug te trekken 
uit de in december 1948 bezette gebieden, niet alleen uit de landelijke gebieden maar ook uit de steden. Begin november ontruimden ze Solo en Madioen, die na Jogja de twee grootste steden van de Republiek waren. Na de sluiting van de RTC ging de legerleiding over tot een nog veel verder gaande terugtrekking en concentratie van de Nederlandse strijdkrachten op Java en Sumatra, vooruitlopend op hun vertrek na de soevereiniteitsoverdracht.

De uitvoering van de bestandsovereenkomst betrof ook samenwerking op andere terreinen dan de verdeling van patrouillegebieden. Zo bepaalde de overeenkomst dat het Nederlands-Indische gouvernement desgevraagd hulp zou bieden bij de bevoorrading van de bevolking in de aan de TNI toegewezen gebieden, onder meer met voedsel, textiel en medicijnen. In aansluiting hierop kwam men overeen van Nederlandse kant ook bij te dragen aan de bevoorrading en de bezoldiging van de Republikeinse militairen zelf. Sinds het decemberoffensief waren deze militairen gedwongen geweest zich door de plaatselijke bevolking te laten onderhouden, wat zowel voor die bevolking als voor de militairen overlast en gebrek meebracht. De verantwoordelijkheid voor deze toestand lag bij Nederland, omdat het Nederlandse offensief het de Republikeinse regering en legerleiding onmogelijk gemaakt had de eigen militairen te blijven bevoorraden en bezoldigen. Om de TNI-eenheden in staat te stellen aan hun soldaten soldij te betalen ging het gouvernement er in oktober toe over hiervoor geldmiddelen te verschaffen op de voet van drie gulden per soldaat per dag. Ook stelde men van Nederlandse kant voedsel, kleding, verbindingsmiddelen en vervoermiddelen ter beschikking van de TNI. Men deed dit niet alleen om de druk op de bevolking te verlichten, maar ook om de Republikeinse militairen beter in staat te stellen zich te kwijten van de taken die nu en in de naaste toekomst op hen rustten. In dat verband hechtte Lovink's gouvernement er bijvoorbeeld belang aan, deze militairen op ruime schaal van nieuwe uniformen te voorzien. Na de sluiting van de RTC breidde men de Nederlandse bevoorrading van de Republikeinse strijdkrachten en politie verder uit, onder meer met vrachtauto's en motorfietsen en soms ook met wapens.

Deze in september-december 1949 van Nederlandse kant gedane verstrekkingen in geld en goederen konden een bevoordeling van de Republiek ten koste van Nederland lijken, maar waren het in feite niet. Al deze verstrekkingen belastten immers het budget van het Nederlands-Indische gouvernement, dat na de soevereiniteitsoverdracht het budget van de RVI worden zou.

Een heel ander onderwerp van overleg in het kader van de beëindiging van de vijandelijkheden was de vrijlating van gevangenen. Van Nederlandse kant werden in de periode september-december ongeveer dertienduizend krijgsgevangenen en politieke gevangenen in vrijheid gesteld. De vrijlatingen aan Republikeinse kant waren minder omvangrijk; het ging hierbij vooral om Indonesiërs die in de loop van het jaar ontvoerd waren. 


\section{De Rondetafelconferentie in Den Haag}

Nadat de BFO in juni 1949 gelegenheid gekregen had deel te nemen aan de voorbereidende conferentie die onder leiding van de UNCI in Batavia plaatsvond, werden de delegaties van Nederland, de Republiek en de BFO het al spoedig eens over de tijd en de voorwaarden van de in Den Haag te houden Rondetafelconferentie (RTC). Deze overeenkomst werd geformaliseerd in de vergadering van 22 juni, waarbij Van Roijen bekend maakte dat zijn regering ermee instemde.

De overeenkomst omschreef het doel van de RTC als het verkrijgen van overeenstemming over overdracht van de werkelijke, volledige en onvoorwaardelijke soevereiniteit aan de Verenigde Staten van Indonesië (VSI) in overeenstemming met de Renvillebeginselen. $\mathrm{Zij}$ bevatte enige procedureregels voor de conferentie en noemde een aantal kwesties die men in Den Haag zou moeten bespreken. Wat die kwesties betreft bevatte de overeenkomst nu al verschillende inhoudelijke bepalingen, onder meer over de constitutie van de VSI en over de Nederlands-Indonesische Unie. Zo bepaalde zij dat het hoogste gezag over de buitenlandse betrekkingen van de VSI en over de federale strijdkrachten uitsluitend bij de regering van de VSI zou berusten. De Unie zou geen superstaat zijn en zou over geen andere rechten beschikken dan die de deelgenoten haar vrijwillig zouden overdragen. Verder bepaalde de overeenkomst dat de UNCI aan de RTC zou deelnemen in overeenstemming met haar door de Veiligheidsraad vastgestelde mandaat en dat zij vervolgens in Indonesië zou toezien op de nakoming van de op de conferentie bereikte overeenkomsten.

Door met deze in Batavia tot stand gekomen overeenkomst in te stemmen had minister Van Maarseveen impliciet al een streep gehaald door sommige aan Nederlandse kant levende denkbeelden over de toekomstige verhouding met Indonesië. Zo was Romme, de leider van de Katholieke Volkspartij (KVP), er steeds op uit geweest van de Unie een superstaat te maken die in verschillende opzichten de rol van het Koninkrijk zou overnemen. Ook Jonkman, lid van de Partij van de Arbeid (PvdA) en van 1946 tot 1948 minister van overzeese gebiedsdelen, had de Unie als een staatsverband gezien waarbinnen bijvoorbeeld eenheid van buitenlands beleid zou moeten bestaan. Verder waren de Nederlandse beleidsmakers er lange tijd van uitgegaan dat Nederland na de soevereiniteitsoverdracht nog tenminste vijftien jaar in het kader van de Unie voor de externe verdediging van Indonesië zou zorgen. Tenslotte volgde uit de nu overeengekomen bepalingen over de UNCI dat Nederland zich niet meer verzette tegen de uitgebreide bevoegdheden die de Veiligheidsraad aan die commissie verleend had.

Wat het tijdschema voor de RTC betreft was men in Batavia overeengekomen ernaar te streven dat de conferentie tegen 1 augustus zou beginnen en tegen 1 oktober zou eindigen. Daarna zouden Nederland, de Republiek en de 
$\mathrm{BFO}$ de resultaten van de conferentie binnen zes weken moeten bekrachtigen; de soevereiniteit zou voor eind 1949 moeten worden overgedragen. Omdat er echter veel tijd verstreek voor de afkondiging van het staakt-het-vuren, bleek enig uitstel onvermijdelijk. Na die afkondiging op 3 augustus konden de delegaties eindelijk naar Den Haag vertrekken. Eveneens op 3 augustus zond Van Maarseveen een nota aan het parlement over de resultaten van de voorbereidende conferentie in Batavia. Op 16 en 17 augustus vond daarover een debat in de Tweede Kamer plaats. Vervolgens werd de RTC op 23 augustus geopend; men ging ervan uit dat die ruim twee maanden zou duren.

Het was een omvangrijke conferentie. De delegaties van Nederland, de Republiek, de BFO en de UNCI telden samen ongeveer honderdvijftig leden, nog afgezien van hun talrijke stafleden en adviseurs. Van Maarseveen leidde de Nederlandse delegatie, met Stikker en Van Roijen als plaatsvervangers. Met het oog op het verkrijgen van zo breed mogelijke politieke steun voor het resultaat van de RTC waren aan deze delegatie negen parlementsleden toegevoegd, onder wie zowel Jonkman, Logemann en Romme als vertegenwoordigers van partijen ter rechterzijde van PvdA en KVP. De Republikeinse delegatie stond onder leiding van Hatta, met Roem als plaatsvervanger. Verder behoorden tot deze delegatie onder meer Leimena, Ali Sastroamidjojo, Simatoepang, Soekiman en Soepomo, maar ook Abikoesno en Yamin, twee politici die zich in het verleden tegen het diplomasi-beleid van Hatta en Soekarno gekeerd hadden. De BFO-delegatie was de grootste van allemaal en had sultan Hamid als voorzitter en Anak Agoeng als eerste ondervoorzitter. Voorzitter van de RTC zelf was Drees, terwijl Van Maarseveen, Hatta en sultan Hamid als vicevoorzitters ervan optraden.

Overigens kwam de conferentie alleen bij de opening en de sluiting plenair bijeen; alle belangrijke onderhandelingen speelden zich in commissies, subcommissies en werkgroepen af. Men besprak een groot aantal staatkundige, juridische, militaire, financiële en economische onderwerpen. De UNCI spande zich keer op keer in om de tijdens de conferentie rijzende tegenstellingen te overbruggen. De RTC duurde langer dan voorzien, maar uiteindelijk werden de delegaties het over bijna alle kwesties eens; men legde dit vast in een reeks afzonderlijke overeenkomsten en briefwisselingen, samen ongeveer honderd pagina's. Alle teksten werden zowel in het Nederlands als in het Indonesisch gesteld, terwijl daarnaast een officiële Engelse vertaling gemaakt werd die in geval van verschil de doorslag zou geven.

De delegaties van de Republiek en van de BFO traden vaak gezamenlijk op. Dit gold onder meer voor de voorlopige grondwet van de RVI. De overeenkomst van 22 juni bevatte daar enkele bepalingen over, maar verder was dit geen zaak meer voor onderhandelingen met Nederland. De delegaties van de Republiek en de BFO stelden tijdens hun verblijf in Den Haag in onderling overleg de tekst van de grondwet vast en deelden die op 31 oktober aan 
Nederland en de UNCI mee; deze tekst werd als bijlage bij de RTC-akkoorden gevoegd.

Terwijl de Nederlandse delegatie niet betrokken was bij het overleg over de grondwet van de RVI, onderhandelde zij wel met de Indonesische delegaties over de formulering van de soevereiniteitsoverdracht en over het statuut van de Nederlands-Indonesische Unie. Volgens de overeenkomst van Linggadjati zouden Nederland en Indonesië (de deelgenoten) die Unie vormen ter behartiging van hun gemeenschappelijke belangen, waaronder samenwerking inzake buitenlandse betrekkingen en defensie; daartoe zou de Unie over eigen organen beschikken. De Nederlandse delegatie stelde als belangrijkste organen voor: een Unieraad, een Interparlementaire commissie en een Uniegerechtshof. De Indonesische delegaties verzetten zich hier krachtig tegen omdat dit toch te veel op een superstaat zou lijken. Het eindresultaat was een constructie die de vrijheid van de deelgenoten weinig beperkte. Als hoofdorgaan zou een tweemaal per jaar bijeenkomende ministersconferentie optreden. Hierin zouden telkens enkele ministers van de deelgenoten bijeenkomen; deze ministersconferenties zouden alleen met eenparigheid van stemmen besluiten mogen nemen; als zo'n besluit het uitvaardigen van een gemeenschappelijke regeling betrof zou daarvoor goedkeuring van de beide parlementen nodig zijn. Er kwam geen interparlementaire commissie; wel zouden de deelgenoten voor een goed contact en een geregelde samenwerking tussen hun parlementen zorgen. Verder zou de Unie over een permanent secretariaat en over een hof van arbitrage beschikken. Zoals al in Linggadjati overeengekomen was zou de Nederlandse koningin aan het hoofd van de Unie staan en zouden de deelgenoten zich over en weer niet door ambassadeurs maar door hoge commissarissen laten vertegenwoordigen. Ook zouden de deelgenoten ernaar streven hun buitenlands beleid zoveel mogelijk te coördineren.

Tot de op de RTC behandelde juridische kwesties behoorden de toescheiding van staatsburgers en de rechtspositie van de burgerlijke overheidsdienaren. Men kwam onder meer overeen dat in Indonesië geboren personen die volgens de Nederlandse wetgeving Nederlanders waren (voor het overgrote deel waren dit 'Indische Nederlanders', dus personen van gemengde Europees-Aziatische afkomst) nog gedurende twee jaar voor de Indonesische nationaliteit zouden kunnen kiezen

Wat de militaire onderwerpen betreft stelden de op de RTC getroffen overeenkomsten voorop, dat de verantwoordelijkheid voor de in- en uitwendige veiligheid van Indonesië, met inbegrip van de beveiliging ter zee en in de lucht, uitsluitend bij de regering van de RVI zou berusten. De uit Nederland uitgezonden land- en luchtstrijdkrachten zouden zo mogelijk binnen zes maanden gerepatrieerd worden; in afwachting van hun vertrek zouden ze in rayons worden verzameld. Ook de KNIL-militairen zouden voorlopig in die rayons bijeengebracht worden; later zouden ze deels in dienst kunnen 
treden bij de RVI, deels in Nederlandse dienst kunnen overgaan en deels moeten afvloeien. Het KNIL zelf zou midden 1950 ophouden te bestaan. De Nederlandse marine zou binnen een jaar uit Indonesië teruggetrokken worden, maar zou gedurende die tijd op verzoek van de RVI nog een aantal taken blijven verrichten. Ook zou Nederland aan de RVI een aantal marineschepen overdragen en zou het een marineofficier beschikbaar stellen als beheerder van de marinebasis Soerabaja. Verder zou na de soevereiniteitsoverdracht een Nederlandse militaire missie in Indonesië behulpzaam zijn bij de opbouw en opleiding van de strijdkrachten van de RVI.

Terwijl de Nederlandse delegatie veel concessies deed bij de staatkundige en militaire kwesties, kwamen de Indonesische delegaties bij de economische en financiële kwesties in aanzienlijke mate aan de Nederlandse wensen tegemoet. De op de RTC opgestelde overeenkomsten over de handelspolitieke en financiële betrekkingen en over de erkenning van rechten en vergunningen schiepen dan ook gunstige voorwaarden voor de voortzetting van de Nederlandse economische activiteiten in Indonesië. Hatta had trouwens al in zijn rede op de openingszitting van de RTC verwezen naar het in november 1945 door de Republiek gepubliceerde Politiek Manifest (zie p. 423) waarin zij verklaard had de rechten van de ondernemingen te zullen eerbiedigen. Wel rees er grote onenigheid over de overneming door de RVI van de schulden van het Nederlands-Indische gouvernement, die in totaal op 6,3 miljard gulden geschat werden. De Republikeinse delegatie wilde hier niet aan meewerken voorzover dit uitgaven betrof (geschat op 2 miljard gulden) ter financiering van de gewapende strijd tegen de Republiek. Dank zij bemiddeling van Cochran aanvaardde de Nederlandse delegatie uiteindelijk dat de RVI de schulden zou overnemen onder aftrek van het bedrag van 2 miljard.

Niettemin leek de RTC eind oktober alsnog schipbreuk te zullen lijden wegens twee kwesties die geen zakelijke belangen betroffen maar aan Nederlandse kant hevige emoties losmaakten: het externe zelfbeschikkingsrecht voor minderheden en de toekomst van Nieuw-Guinea (zie de volgende paragrafen). Op de valreep bereikten de delegaties over beide kwesties een compromis, met veel hulp van de UNCI. Daarna kon op 2 november eindelijk de formele slotzitting van de RTC plaatsvinden. De drie delegaties en de UNCI ondertekenden daarin een 'mantelresolutie' waaraan alle op de conferentie bereikte akkoorden als bijlagen gehecht waren en waarin bepaald werd dat de soevereiniteitsoverdracht uiterlijk op 30 december zou plaatsvinden.

\section{Het externe zelfbeschikkingsrecht voor Indonesische minderheden}

De kwestie van het externe zelfbeschikkingsrecht betrof in hoofdzaak twee minderheden, de Ambonezen en de Menadonezen. Hun stamlanden waren de 
zuidelijke Molukken en de Minahasa, twee gebieden waar de Verenigde OostIndische Compagnie zich al in de zeventiende eeuw stevig gevestigd had (zie pp. 27 en 41). Ambon, het belangrijkste eiland van de zuidelijke Molukken, was in 1605 het eerste steunpunt van de VOC in de Indonesische archipel geworden nadat zij daar op aandrang van de inheemse hoofden de Portugezen had verdreven. Die hoofden hadden zich toen bij verdrag tot eeuwige trouw aan Nederland verbonden en een flink deel van de bevolking was tot het christendom overgegaan. Een halve eeuw later had de VOC een steunpunt gekregen in Menado op Celebes nadat ook daar haar hulp ingeroepen was, in dit geval niet tegen de Portugezen maar tegen de Spanjaarden. Menado was de hoofdplaats van de Minahasa, het meest noordoostelijke deel van Celebes, en alle bewoners van dat gebied werden Menadonezen genoemd. In de negentiende eeuw waren zij bijna volledig tot het christendom overgegaan en sindsdien was de Minahasa het meest Nederlands-georiënteerde deel van Indonesië geworden. Omdat Nederland toen elf provincies telde werd het onder Menadonezen populair de Minahasa als Nederlands 'twaalfde provincie' te betitelen.

Al sinds de begintijd van de VOC waren mannen uit de Zuid-Molukken als soldaten in Nederlandse dienst getreden; later werd ook de Minahasa een belangrijke recruteringsbasis voor het koloniale leger. Verder werd op Ambon en in de Minahasa op ruimere schaal westers onderwijs gegeven dan in de rest van Nederlands-Indië. Een en ander droeg ertoe bij dat velen uit deze gebieden naar andere delen van de kolonie trokken, vaak in dienst van het koloniale gezag, niet alleen als militairen maar ook als ambtenaren en onderwijzers. Bij het einde van de Tweede Wereldoorlog bevonden tienduizenden Ambonezen en Menadonezen zich buiten de Molukken en de Minahasa. Tijdens het daarop uitbrekende grote conflict schaarde een deel van hen zich achter Nederland, terwijl een ander deel de kant van de Republiek koos. Met steun uit de hoek van het KNIL en van de Nederlandse marine kwam vervolgens binnen beide minderheden een separatistische organisatie tot stand die voor het eigen stamland ging streven naar een aparte status buiten de VSI maar met een nauwe band met Nederland. Eén van degenen die zich hiervoor inspanden was admiraal Helfrich, de bevelhebber van de Nederlandse zeestrijdkrachten. Hij gaf daartoe opdrachten aan admiraal Pinke, de marinecommandant in Indonesië.

De beide separatistische organisaties hadden hun aanhang vooral onder KNIL-militairen. De Ambonese organisatie heette Persatoean Timoer Besar (PTB, Vereniging Grote Oost); zij was op Java opgericht en streefde naar de afscheiding van een gebied dat alle Molukse eilanden en het Nederlandse deel van het eiland Timor zou omvatten. De PTB maakte er aanspraak op namens de hele bevolking van dat gebied op te treden, maar dit was zwaar overdreven. Alleen op de Zuid-Molukken had zij enige invloed, al steunde de ZuidMolukken-Raad het separatistische streven destijds niet. De bevolking van de 
Noord-Molukken was sterk Republikeinsgezind en ook op Timor genoot de PTB geen enkele steun. De Menadonese organisatie heette Twapro (afgeleid van Twaalfde Provincie); zij wilde van de Minahasa niet alleen figuurlijk maar ook formeel een Nederlandse provincie maken, met het 'Wilhelmus' als volkslied en het rood-wit-blauw als vlag. In de Minahasa-Raad bezette zij vijf van de vijfentwintig zetels.

Zowel het Nederlands-Indische gouvernement als de Nederlandse regering bejegende deze beide organisaties vriendelijk, maar moedigde hun streven niet aan. Men beschouwde hun doelstellingen als weinig reëel. Bovendien zou verwezenlijking ervan de positie van de federalisten binnen de RVI verzwakken. Dat deze weinig representatieve organisaties niettemin het welslagen van de Rondetafelconferentie hebben kunnen bedreigen, lag niet aan hun eigen kracht maar aan die van de Nederlandse oppositie tegen de dekolonisatie van Indonesië.

Die oppositie, aangevoerd door het Nationaal Comité Handhaving Rijkseenheid (zie p. 510), had sinds de Nederlandse verkiezingen van 1948 weinig meer van zich laten horen. Weliswaar waren daarbij twee van haar aanvoerders, Gerbrandy en Welter, tot lid van de Tweede Kamer gekozen, maar het starre verzet tegen de dekolonisatie had geen breed draagvlak meer onder het publiek. Toen in de zomer van 1949 de Rondetafelconferentie voor de deur stond leed het dan ook geen twijfel meer, dat het streven van het Nationaal Comité om Indonesië binnen het Koninkrijk te houden mislukt was. Niettemin besloot het Comité de strijd nog niet op te geven. Een deputatie, bestaande uit Gerbrandy, Meijer Ranneft, Welter en Winkelman, bracht begin augustus een bezoek aan koningin Juliana om er bij haar op aan te dringen niet aan de soevereiniteitsoverdracht mee te werken; zij probeerden haar te bewegen het kabinet-Drees naar huis te sturen en een nieuwe regering te vormen. Vervolgens belegde het Comité in augustus en september grote protestbijeenkomsten tegen het Indonesië-beleid van de regering. Bijna al haar kopstukken, zoals Feuilletau de Bruyn, Gerbrandy, Gerretson, Helfrich, Meijer Ranneft en Welter, voerden daar het woord.

$\mathrm{Nu}$ het Comité de scheiding tussen het Koninkrijk en Indonesië op zichzelf niet meer kon tegenhouden, spande het zich in om toch nog het meest oostelijke deel van de archipel binnen het Rijk te houden. Als gevolg daarvan deed zich het paradoxale fenomeen voor, dat juist zij die steeds betoogd hadden dat de Indonesiërs niet rijp waren om zichzelf te besturen zich nu opwierpen als kampioenen van het zelfbeschikkingsrecht voor Indonesische minderheden.

Intussen waren vertegenwoordigers van verschillende minderheidsgroepen uit Indonesië in Nederland aangekomen om hun belangen tijdens de Rondetafelconferentie te bepleiten. Daartoe behoorden ook enkele vertegenwoordigers van de PTB en de Twapro. Op de RTC was men bereid hen door een subcommissie te laten horen, maar PTB en Twapro wezen dit af en eisten 
toelating tot de conferentie als volwaardige deelnemers. De twee organisaties richtten een rekest aan de RTC waarin ze verklaarden dat de volken van de Minahasa, de Molukken en Timor buiten de RVI wensten te blijven, omdat de bijzondere banden die hen sedert drieënhalve eeuw met Nederland verbonden in geen geval verbroken mochten worden. Het Comité Handhaving Rijkseenheid liet de vertegenwoordigers van de beide organisaties het woord voeren op zijn protestvergaderingen. De rechtse pers gaf veel publiciteit aan hun verklaringen en deed het voorkomen alsof ze door de RTC werden geboycot.

Deze stelselmatige agitatie maakte diepe indruk op een deel van het Nederlandse publiek. In die kring twijfelde men er niet aan dat deze woordvoerders namens de hele bevolking van de Minahasa, de Molukken en Timor spraken. Men voelde zich schuldig tegenover deze inheemse volken die, naar men dacht, het slachtoffer van hun trouw aan Nederland dreigden te worden. Daarom zag men het als een morele plicht hun stamgebieden in staat te stellen buiten de toekomstige Indonesische staat te blijven nu die gedomineerd zou worden door de Republiek. Men wist in deze kring gewoonlijk niet dat de Ambonese en Menadonese minderheden ook talrijke leden telden die juist de kant van de Republiek gekozen hadden en dat verscheidene van hen daarin zelfs leidende posities innamen.

Artikel 3 van de overeenkomst van Linggadjati had voor Indonesische gebiedsdelen de mogelijkheid geopend om voor een eigen status buiten de VSI te kiezen; het voorzag dus in een extern zelfbeschikkingsrecht. De aan de RTC voorafgaande overeenkomst van 22 juni had bepaald dat de grondwet van de VSI de verwezenlijking van het recht op zelfbeschikking van de volkeren van Indonesië zou moeten garanderen, maar had niet aangegeven of dit ook een extern zelfbeschikkingsrecht zou moeten omvatten. Toen eind oktober eindelijk de tekst bekend werd van de door de Republiek en de BFO opgestelde grondwet bleek die alleen in een intern zelfbeschikkingsrecht te voorzien. Men had trouwens moeilijk anders kunnen verwachten. Niettemin bracht het ontbreken van een voorziening voor een extern zelfbeschikkingsrecht de Nederlandse parlementaire goedkeuring van de RTC-akkoorden in gevaar. Op de laatste conferentiedag aanvaardden de delegaties daarom een door de UNCI voorgestelde compromisformule, geldend voor de periode voordat de voorlopige grondwet plaats zou maken voor een definitieve. In theorie voorzag die formule in de mogelijkheid dat een Indonesisch gebied de definitieve grondwet zou afwijzen en dan zou mogen onderhandelen over een speciale verhouding tot de RVI en Nederland. In de praktijk zou dit niet echt tot afscheiding kunnen leiden, omdat de term 'onderhandelen' meebracht dat daartoe instemming van de RVI zelf nodig zou zijn.

Onmiddellijk na de sluiting van de RTC richtten de Twapro en de PTB een bezwaarschrift tot premier Drees waarin verklaard werd dat de volken van de 
Minahasa, de Molukken en Timor het overeengekomene volledig verwierpen en dat ze zich met alle beschikbare middelen zouden blijven verzetten tegen de schending van hun recht op zelfbeschikking. Eind november begon het Comité Handhaving Rijkseenheid onder de kop 'Redt de volken van Ambon, Timor en de Minahassa' een handtekeningenactie voor een verzoek aan het parlement om aan de eisen van deze drie volken te voldoen. Op 17 december, twee dagen voordat de Eerste Kamer de openbare behandeling van de RTCakkoorden begon, werd het verzoek met bijna 240.000 handtekeningen bij het parlement afgeleverd. Dit was de laatste grote actie van het Nationaal Comité; in februari 1950 hief het zich op.

\section{De kwestie Nieuw-Guinea}

Artikel 3 van de overeenkomst van Linggadjati had in een extern zelfbeschikkingsrecht voorzien in die zin dat, als de bevolking van een Indonesisch gebiedsdeel langs democratische weg te kennen zou geven niet tot de VSI te willen toetreden, men voor dat gebiedsdeel een bijzondere verhouding tot de VSI en tot Nederland in het leven zou kunnen roepen. Daarnaast voorzag artikel 4 van die overeenkomst in een intern zelfbeschikkingsrecht binnen de VSI. Maar toen het ontwerp van de overeenkomst in december 1946 in het Nederlandse parlement besproken werd, verklaarde de regering te wensen dat Nieuw-Guinea 'in de geest van de artikelen 3 en 4 ' een eigen status ten opzichte van Nederland en de VSI zou moeten kunnen krijgen ook zonder uitspraak daarover van de bevolking van het gebied (zie p. 508). De regering vond dit nodig, zo verklaarde minister Jonkman toen, om daar de mogelijkheid open te houden van volksplantingen van Indische Nederlanders die onder een eigen bestel zouden willen leven.

Ondanks de door de regering gebruikte woorden 'in de geest van de artikelen 3 en 4' hield deze verklaring geen interpretatie van het akkoord in, maar een afwijking ervan; anders gezegd: het was geen aankleding maar uitkleding van Linggadjati. Het ging ook helemaal niet over zelfbeschikking. Integendeel, de verklaring ging er juist van uit dat Nederland bevoegd bleef over de westelijke helft van Nieuw-Guinea te beschikken zonder de inheemse bevolking daarbij te raadplegen.

De aanleiding voor de verklaring van de regering was een optreden van Indische Nederlanders geweest tijdens een in oktober 1946 door Van Mook in Pangkalpinang belegde conferentie met vertegenwoordigers van minderheidsgroepen (zie p. 479). Zij hadden ervoor gepleit voor hun bevolkingsgroep op ruime schaal vestiging in Nieuw-Guinea mogelijk te maken en met het oog daarop aan dat gebied een van Indonesië afgescheiden eigen status binnen het Koninkrijk te geven. Deze pleidooien sloten aan bij een al voor de oorlog 
ontstane beweging voor transmigratie van Indo-Europeanen naar NieuwGuinea.

In december 1946 had het nieuwe standpunt van de regering meteen consequenties voor de toen door Van Mook in Denpasar belegde conferentie tot oprichting van de deelstaat Oost-Indonesië (zie pp. 512-4). Deze conferentie vormde een vervolg op de in juli 1946 in Malino gehouden conferentie over de federale opbouw van het toekomstige Indonesië (zie pp. 466-7). Maar terwijl aan die conferentie nog een vertegenwoordiging van Nieuw-Guinea deelgenomen had, nodigde het gouvernement op instructie van Den Haag voor Denpasar geen vertegenwoordigers van dat gebied uit en legde het aan deze conferentie een ontwerp-constitutie voor die Nieuw-Guinea van het grondgebied van Oost-Indonesië uitzonderde. Tegen die uitzondering werd in Denpasar ernstig bezwaar gemaakt, onder meer door de Balinese afgevaardigde Anak Agoeng. Het gouvernement bleef echter onverzettelijk: als de conferentie dit niet wilde aanvaarden zou de oprichting van de deelstaat niet doorgaan. Uiteindelijk zwichtte men voor deze druk, nadat Van Mook onder meer gezegd had dat de uitzondering slechts een voorlopig karakter had en dat het bepaald niet de bedoeling van de regering was om Nieuw-Guinea buiten Indonesië te sluiten.

De Nederlandse regering wenste echter wel degelijk de mogelijkheid open te houden om Nederlands-Nieuw-Guinea van Indonesië af te scheiden. Dit kon verbazing wekken omdat Nederland dat gebied altijd als een deel van Nederlands-Indië behandeld had. In de bestuurlijke indeling van de kolonie had Nieuw-Guinea tot voor kort zelfs geen apart gebied gevormd, maar had het deel uitgemaakt van het bestuursdistrict ('residentie') Molukken, waarvan het hoofd op Ambon zetelde. Voor de Tweede Wereldoorlog had Nederland zich weinig met het gebied beziggehouden, al had het er wel gebruik van gemaakt om politieke dissidenten in Boven-Digoel te interneren (zie pp. 2023). Pas tijdens die oorlog was het gebied meer in de belangstelling gekomen toen het zuiden met de kustplaats Merauke het enige deel van Indonesië was dat niet door de Japanners bezet werd en toen Amerikaanse strijdkrachten het noorden veroverden en daar militaire bases inrichtten. In 1946 was NieuwGuinea een afzonderlijke residentie geworden met Hollandia als hoofdplaats, maar het was blijven behoren tot het bestuursgewest 'Grote Oost' dat nu in de deelstaat Oost-Indonesië getransformeerd werd; bovendien was het grootste deel ervan formeel nog steeds onderhorig aan een Molukse vorst, de sultan van Tidore.

In 1947 en 1948 stelde Nederland het onderwerp Nieuw-Guinea niet aan de orde bij het overleg met de Republiek over de uitvoering van het akkoord van Linggadjati en over de uitvoering van het Renville-akkoord. Intussen bleven particuliere organisaties actie voeren voor het ontwikkelen van Nieuw-Guinea tot vestigingsgebied voor Nederlanders, zowel uit Indonesië als uit Nederland 
zelf. Van de belangrijkste van die organisaties werd de Nederlandse afdeling voorgezeten door Feuilletau de Bruyn. Ook twee andere leden van het Nationaal Comité Handhaving Rijkseenheid, Meijer Ranneft en Welter, waren actieve voorvechters van bestendiging van de Nederlandse band met NieuwGuinea. De verschillende actiegroepen stichtten een samenwerkingsverband dat in september 1948 een petitie tot regering en parlement richtte voor de verlening van een eigen status aan Nieuw-Guinea op basis van de Nederlandse soevereiniteit. Een maand later hield Welter zelf in het parlement een vurig betoog over de politieke en economische betekenis van Nieuw-Guinea voor de toekomst van het Nederlandse volk. Hij kreeg onder meer bijval van Tilanus, de leider van de CHU.

De regering wilde zich lange tijd niet ten aanzien van de toekomstige status van Nieuw-Guinea vastleggen. Het initiatief om dit gebied niet over te dragen ging binnen de regering uit van premier Drees en minister Van Maarseveen. In maart 1949 stelde Drees in de ministerraad dat Nieuw-Guinea geen onderdeel van Indonesië was. In aansluiting daarop noemde Van Maarseveen het wenselijk dit gebied buiten de soevereiniteitsoverdracht te houden. Begin juni gaf hij in de raad een nadere argumentatie hiervoor. Daarbij noemde hij vijf redenen - dat Indonesië geen moreel recht op het gebied had, dat Nederland beter in staat was het gebied te ontwikkelen, dat het voor Nederland van betekenis was in Azië een pied-à-terre te behouden voor Nederlandsgezinde personen uit Indonesië, dat de Nederlandse scheepvaart belang bij de havens van Nieuw-Guinea had en dat het gebied zou kunnen bijdragen tot vermindering van de overbevolking in Nederland.

Het behartigen van de belangen van de inheemse bevolking van NieuwGuinea, de Papoea's, werd door Van Maarseveen niet als reden genoemd, evenmin als Jonkman gedaan had in zijn verklaring van december 1946. Ook sprak hij niet over de noodzaak van het verkrijgen van voldoende parlementaire steun voor de soevereiniteitsoverdracht als argument om Nieuw-Guinea daarvan uit te zonderen. Toch mag men aannemen dat dit laatste het eigenlijke motief was.

Dit parlementair-rekenkundige motief hield verband met twee zeer verschillende zaken: de in 1948 ingevoerde wijziging van de Nederlandse grondwet (zie pp. 581-2) en de in hetzelfde jaar op Java uitgebroken Madioenopstand (zie pp. 596-7). De gewijzigde grondwet opende de mogelijkheid Indonesië van het Koninkrijk af te scheiden, maar bepaalde dat daartoe in het parlement een meerderheid van twee derde nodig zou zijn. De PvdA en de KVP hadden daar samen wel een gewone maar geen tweederde meerderheid. Daarentegen beschikten ze samen met de communistische partij CPN wel over meer dan tweederde van de zetels, zowel in de Tweede als in de Eerste Kamer. De communisten hadden zich altijd voor Indonesische onafhankelijkheid uitgesproken en in december 1946 was de CPN de enige partij geweest 
die samen met PvdA en KVP voor de ondertekening van het akkoord van Linggadjati gestemd had. Maar sinds de onderdrukking van de communistische Madioenopstand was de CPN de Republiek vijandig gezind geworden; zij stelde Soekarno en Hatta voor als handlangers van het Amerikaanse imperialisme. Men moest er nu dus rekening mee houden dat de CPN tegen de soevereiniteitsoverdracht zou stemmen. Dit maakte het veel meer dan vroeger nodig voor die overdracht steun te zoeken bij de VVD en de CHU. Drees en Van Maarseveen voorzagen dat de regering voor het bereiken van een akkoord met de Republiek tal van concessies zou moeten doen waartegen binnen die partijen bezwaren zouden bestaan. Vasthouden aan Nieuw-Guinea leek nu het beste middel om die bezwaren te overwinnen.

Op instructie van Den Haag verbrak het Nederlands-Indische gouvernement de formele band tussen Nieuw-Guinea en het sultanaat Tidore. De delegatie die in Batavia onderhandelde over de uitvoering van het akkoord tussen Roem en Van Roijen kreeg opdracht Nieuw-Guinea op de agenda van de Rondetafelconferentie te plaatsen. De delegaties van de Republiek en de BFO maakten hier bezwaar tegen. Uiteindelijk werd dit twistpunt aldus opgelost dat men op 22 juni bij de vaststelling van het programma voor de RTC wel Nieuw-Guinea als agendapunt opnam, maar dat de Indonesische delegaties daarbij verklaarden hier alleen mee in te stemmen op voorwaarde dat men zich bewust was van hun standpunt dat dit gebied deel van de VSI zou moeten vormen.

Toen Van Maarseveen in de tweede helft van juni zelf in Batavia was liet hij zich door ambtenaren van het Nederlands-Indische gouvernement over de ontwikkelingsmogelijkheden van Nieuw-Guinea voorlichten. De door hem geraadpleegde departementshoofden uitten zich daar uitermate sceptisch over. Vasthouden van dit gebied zou volgens hen aan Nederland enorme sommen gaan kosten en zou de politieke verhouding met het Indonesische volk ernstig schaden. Van Maarseveen liet zich echter niet van zijn koers afbrengen. Kort daarna werd Van Mook door het departement van buitenlandse zaken over de kwestie Nieuw-Guinea geraadpleegd. Hij reageerde met een uitvoerig betoog waarin hij op grond van zowel praktische als principiële argumenten ontraadde dit gebied bij Nederland te houden. Onder meer merkte hij op dat Nederland riskeerde een belangrijk deel van de laatste resten goodwill in Indonesië kwijt te raken voor een object met alleen sentimentswaarde. Zijn advies werd niet onder de leden van het kabinet verspreid.

Het feit dat de Nederlandse regering Nieuw-Guinea op de agenda van de RTC geplaatst wilde zien wekte ongerustheid aan Indonesische kant. Soekarno sprak Van Roijen hierover aan toen deze hem midden juli in Jogja bezocht; hij waarschuwde dat de kwestie een gevaarlijk struikelblok op de conferentie zou kunnen worden. Toen Van Roijen opmerkte dat Hatta weinig persoonlijke belangstelling voor Nieuw-Guinea aan de dag legde zei Soekarno 
over zichzelf: 'Ik ben een Nieuw-Guinea-fanaticus'.

In de nota die Van Maarseveen begin augustus aan het parlement stuurde over de resultaten van de voorbereidende conferentie stond over NieuwGuinea, dat de regering vasthield aan het in december 1946 ingenomen standpunt dat dit gebied een eigen status ten opzichte van Nederland en de VSI zou moeten kunnen krijgen. In deze zelfde tijd kwam een grote actie op gang van de organisaties die van Nieuw-Guinea een vestigingsgebied voor Nederlanders wilden maken; zij zorgden voor een stortvloed van brieven, petities en telegrammen aan regering en parlement. Toen op 16 en 17 augustus het parlementaire debat over de komende RTC plaatsvond, verklaarden de sprekers uit de rechtse oppositie zich, zoals te verwachten, voor handhaving van de Nederlandse soevereiniteit over Nieuw-Guinea. Een nieuwe ontwikkeling was dat van de regeringspartijen nu niet alleen de CHU maar ook de VVD zich hierbij aansloot. Als spreker voor de PvdA liet Schermerhorn een tegengeluid horen: hij betoogde dat het belang van Nederland bij de samenwerking met de RVI lag en dat men er beter aan deed dit niet in de waagschaal te stellen terwille van het behoud van Nieuw-Guinea. Ook de leider van de KVP, Romme, voerde het woord in dit debat, maar over Nieuw-Guinea sprak hij niet.

Volgens de voorstellen die Nederland aan de RTC voorlegde zou NieuwGuinea buiten de soevereiniteitsoverdracht moeten blijven. Voor de Republiek en de BFO was dit volstrekt onaanvaardbaar. Afgezien van de persoonlijke meningen van de afgevaardigden hadden ook zij met een probleem van parlementaire rekenkunde te maken. Als de delegaties van de Republiek en de BFO de Indonesische aanspraken op Nieuw-Guinea opgaven, zoals de Nederlandse delegatie verlangde, werd niet alleen de kans klein dat het KNIP de resultaten van de RTC zou goedkeuren, maar werd het bovendien volstrekt zeker dat het parlement van Oost-Indonesië die resultaten zou verwerpen. Bij hun bestrijding van de Nederlandse eis beriepen de Indonesische delegaties zich onder meer op Van Mook's uitspraak uit december 1946 in Denpasar, op de tekst van het akkoord van Linggadjati en van het Renville-akkoord en op het recente gebruik van de term 'volledige soevereiniteit' in de verklaring van Van Roijen van 7 mei en in de tripartiete overeenkomst van 22 juni. Aan Indonesische kant nam Anak Agoeng de leiding bij de onderhandelingen over deze kwestie. Hij deed onder meer een tussenvoorstel: Nieuw-Guinea zou deel van de RVI uitmaken, maar de beide Uniepartners zouden een overeenkomst kunnen sluiten over sociale, culturele en economische aspecten ervan, met inbegrip van de mogelijkheid van volksplantingen. De Nederlandse delegatie wees dit af; zij was wel bereid tot bepaalde afspraken met de RVI over de toekomst van Nieuw-Guinea, maar de soevereiniteit zou bij Nederland moeten blijven.

Het gouvernement in Batavia was eenstemmig van oordeel dat NieuwGuinea aan Indonesië overgedragen moest worden en liet dit ook aan Van Maarseveen weten. Ook Van Roijen vond dat Nederland niet tot iedere prijs 
aan Nieuw-Guinea moest vasthouden. In de Nederlandse ministerraad vond echter nooit een discussie plaats over de vraag of men de RTC op de kwestie Nieuw-Guinea moest laten stranden. Voordat men aan die vraag toekwam stelde de UNCI als noodoplossing voor, de kwestie een jaar uit te stellen. Op deze basis bereikten de drie delegaties eind oktober een compromis. Men sprak af in het Charter van Soevereiniteitsoverdracht op te nemen dat de status quo van de residentie Nieuw-Guinea gehandhaafd zou worden, maar dat de staatkundige status ervan binnen een jaar bepaald zou worden door onderhandelingen tussen de RVI en Nederland. In een hierbij horende briefwisseling legden de drie delegaties vast dat handhaving van de status quo in deze bepaling voortzetting van het Nederlandse gezag betekende.

Dit was het begin van het geschil over Nieuw-Guinea, dat noodlottig zou blijken voor het voortbestaan van een nauwe band tussen Nederland en Indonesië. Het vasthouden van Nieuw-Guinea vond zijn oorsprong in een wens die destijds in hoofdzaak bij de rechtse partijen leefde. Hun argumentatie voor het behoud van Nieuw-Guinea verschoof overigens van het openstellen van het gebied voor de vestiging van Nederlanders naar het beschermen en bijstaan van de Papoeabevolking. Het eerste argument was in feite strijdig met het tweede. Aan de andere kant was dit nieuwe argument weinig geloofwaardig omdat Nederland die bevolking tot voor kort volstrekt verwaarloosd had. De werkelijke motieven voor het vasthouden van Nieuw-Guinea lagen elders en waren van psychologische aard. Terwijl het in 1945 voor de meeste Nederlanders nog vanzelf sprak dat Indonesië bij Nederland hoorde, waren zij in 1949 wel gaan inzien dat de dekolonisatie ervan onvermijdelijk was, maar deze overgang was erg snel gegaan en betekende voor velen een traumatische ervaring. Dit gold vooral binnen het protestantse deel van de bevolking, waar men algemeen gewend was de band met 'Indië' als een bestanddeel van de nationale identiteit te zien. Het vasthouden van Nieuw-Guinea zou dan enigszins als pleister op de wonde kunnen dienen. Men stelde zich voor dat dit vrijwel ongerepte gebied nog een arbeidsveld voor Nederlandse ondernemingsgeest en Nederlandse roepingsdrang kon worden en dat Nederland door het behoud van een presentie in Azië toch nog een zekere rol op het wereldtoneel zou kunnen spelen.

Aan Indonesische kant lagen de motieven om Nieuw-Guinea in de RVI op te nemen eveneens vooral in het psychologische vlak. Men had weinig zakelijk belang bij het gebied en de meeste Indonesiërs voelden zich met de Papoea's niet verwant. Maar Nieuw-Guinea maakte deel van NederlandsIndië uit zoals de Indonesiërs het in hun schooljaren op de kaart hadden leren kennen. De nationale beweging had haar doel omschreven als onafhankelijkheid 'van Sabang tot Merauke'. Bovendien had die beweging een bijzondere band met het gebied omdat Nederland daar voor de oorlog honderden nationalisten geïnterneerd had (onder wie Hatta en Sjahrir). De door Nederland 
gewenste uitzondering voor Nieuw-Guinea deed dan ook ernstig afbreuk aan de erkenning van de Indonesische onafhankelijkheid. Voor Anak Agoeng was het bovendien een persoonlijk affront. Hoewel hij zich steeds tegen de afscheiding van Nieuw-Guinea gekeerd had, was hij van 1946 af één van de belangrijkste steunpilaren van het Nederlandse federaliseringsbeleid geweest. Dat Nederland nu Nieuw-Guinea toch van Indonesië afscheidde ondermijnde zijn positie in de deelstaat Oost-Indonesië.

\section{De tekst van het Charter van Soevereiniteitsoverdracht}

De op de Rondetafelconferentie overeengekomen tekst van het Charter van Soevereiniteitsoverdracht luidde als volgt:

\section{Artikel 1}

1. Het Koninkrijk der Nederlanden draagt de volledige souvereiniteit over Indonesië onvoorwaardelijk en onherroepelijk over aan de Republiek der Verenigde Staten van Indonesië en erkent deze mitsdien als een onafhankelijke en souvereine Staat.

2. De Republiek der Verenigde Staten van Indonesië aanvaardt deze souvereiniteit op de voet van de bepalingen van haar Constitutie, welke in ontwerp ter kennis is gebracht van het Koninkrijk der Nederlanden.

3. De overdracht van de souvereiniteit zal plaats hebben uiterlijk 30 December 1949.

\section{Artikel 2}

Ten aanzien van de residentie Nieuw-Guinea is overeengekomen:

a. gezien het feit, dat het nog niet mogelijk is gebleken de standpunten van partijen nopens Nieuw-Guinea overeen te brengen, waardoor deze in geschil blijven,

b. gezien de wenselijkheid om de Rondetafelconferentie met goed resultaat te beëindigen op 2 November 1949,

c. gezien de belangrijke factoren, die in ogenschouw moeten worden genomen bij de oplossing van het vraagstuk Nieuw-Guinea,

d. gezien het beperkte onderzoek, dat kon worden ingesteld en voltooid ten aanzien van de problemen, die samenhangen met het vraagstuk Nieuw-Guinea,

e. gezien de moeilijke taak, waarvoor de deelgenoten in de Unie zich al dadelijk zullen zien gesteld, en,

f. gezien de beslotenheid van partijen tot handhaving van het beginsel om door vredelievende en redelijke middelen alle geschillen op te lossen, die later mochten blijken te bestaan of te rijzen,

dat de status quo van de residentie Nieuw-Guinea zal worden gehandhaafd met de bepaling, dat binnen een jaar na de datum van overdracht van de souvereiniteit aan de Republiek der Verenigde Staten van Indonesië het vraagstuk van de staatkundige status van Nieuw-Guinea zal worden bepaald door onderhandelingen tussen de Republiek der Verenigde Staten van Indonesië en het Koninkrijk der Nederlanden. 
Hierbij behoorde een briefwisseling tussen de voorzitter van de Nederlandse delegatie enerzijds en de voorzitters van de delegaties van de Republiek en de $\mathrm{BFO}$ anderzijds waarin werd gesteld:

De zinsnede in artikel 2 van het ontwerp-Charter van Souvereiniteitsoverdracht, luidende: 'de status quo van de residentie Nieuw-Guinea zal worden gehandhaafd' betekent: 'met voortzetting van het gezag van de Regering van het Koninkrijk der Nederlanden over de residentie Nieuw-Guinea'.

Artikel 1 van het Charter bevatte noch expliciet noch impliciet een verwijzing naar artikel 2. Dit maakt het twijfelachtig of dat tweede artikel de strekking van het eerste wel kon beperken. Bovendien hield artikel 1 ook in dat de RVI de soevereiniteit op basis van haar Constitutie aanvaardde, terwijl die Constitutie uitdrukkelijk stelde dat de RVI het gehele grondgebied van Indonesië omvatte. Verder kwam in artikel 2 het woord 'soevereiniteit' in het geheel niet voor, evenmin als in de bijbehorende briefwisseling. Men kan hieruit concluderen dat de overdracht van 'de volledige souvereiniteit over Indonesië' volgens het Charter ook op Nieuw-Guinea betrekking had en dat het in artikel 2 neergelegde voorbehoud over 'de staatkundige status van Nieuw-Guinea' wel allerlei aspecten van die status kon betreffen, maar niet de soevereiniteit.

De in de briefwisseling neergelegde uitleg, dat handhaving van de status quo moest worden verstaan als voortzetting van het Nederlandse gezag, bracht hier geen verandering in. Uitoefening van gezag en bezit van soevereiniteit hoeven niet samen te vallen. Dat tijdens de Tweede Wereldoorlog het grondgebied van Nederland onder Duits gezag en dat van Indonesië onder Japans gezag stond werd niet als aantasting van de Nederlandse soevereiniteit gezien. Hetzelfde gold voor de onderschikking van het Nederlandse gezag in Indonesië aan het Britse gezag in 1945-1946. Verder had de Nederlandse regering in het akkoord van Linggadjati zelf de regering van de Republiek erkend als de facto het gezag uitoefenend over Java, Madoera en Sumatra, zonder dat zij daarmee afstand deed van de Nederlandse soevereiniteit over die gebieden.

De betekenis van de op de RTC overeengekomen formules kan ook worden toegelicht door vergelijking met de oorspronkelijk door de Nederlandse delegatie voorgestelde teksten. In die voorstellen had de aanhef van artikel 1 geluid: 'Het Koninkrijk der Nederlanden draagt met inachtneming van het bepaalde in dit Charter de souvereiniteit over Indonesië bij deze over aan de Verenigde Staten van Indonesië'. Door de woorden 'met inachtneming van het bepaalde in dit Charter' bevatte die tekst dus wél een uitdrukkelijke verwijzing naar de overige bepalingen. Vervolgens stond in ontwerp-artikel 2 dat Nieuw-Guinea niet was begrepen 'onder de overdracht van souvereiniteit over Indonesië'. Het is duidelijk waarom deze formuleringen in het overleg met de Indonesische delegaties niet in stand gebleven zijn. 
Ondanks de uiteindelijk in overeenstemming met de Indonesische zienswijze tot stand gekomen formulering van de soevereiniteitsoverdracht heeft Nederland zich op het standpunt gesteld dat de soevereiniteit over NieuwGuinea daarbij niet aan de RVI overgedragen werd.

\section{De soevereiniteitsoverdrachten}

Na de sluiting van de RTC op 2 november 1949 was nog anderhalve maand beschikbaar voor de goedkeuring van de bereikte akkoorden door de parlementaire organen van Nederland, de Republiek en de bij de BFO aangesloten deelstaten en autonome gebieden. In de meeste in de BFO samenwerkende gebieden verliep de goedkeuringsprocedure zonder problemen. Moeilijker ging het in het parlement van Oost-Indonesië, dat zowel voor als tijdens de RTC verklaard had dat Nieuw-Guinea bij Indonesië moest blijven. Premier Anak Agoeng moest zich dan ook in Makassar verdedigen tegen het verwijt dat hij van zijn mandaat afgeweken was. Uiteindelijk wist hij zijn parlement ervan te overtuigen dat hij onmogelijk de verantwoordelijkheid op zich had kunnen nemen de hele RTC op dit ene punt te laten mislukken.

In de Republiek werden de RTC-akkoorden ter goedkeuring voorgelegd aan de voorlopige volksvertegenwoordiging, het KNIP. Dat die goedkeuring zou worden verkregen stond eind november al vast toen de akkoorden ruime steun kregen in het Werkcomité van het KNIP. Intussen was bijeenroeping van het plenaire KNIP niet eenvoudig, want het had niet meer vergaderd sinds het in maart 1947 het ontwerp-akkoord van Linggadjati besprak (zie p. 524). Sindsdien had Nederland in twee grote militaire acties bijna het hele grondgebied van de Republiek bezet en had de Republiek intern het hoofd moeten bieden aan de Madioenopstand. Van de 535 leden van het KNIP waren velen verspreid geraakt en hadden sommigen het leven verloren, hetzij in de strijd met Nederland hetzij in onderlinge conflicten. De nieuwe zitting begon in Jogja op 6 december en werd door 319 leden bijgewoond. Het debat duurde een week; de kritiek richtte zich vooral op de voor Nederland bijzonder gunstige economische regelingen en op de uitzondering van Nieuw-Guinea. Hatta beet fel van zich af; uiteindelijk keurde het KNIP op 14 december de RTC-akkoorden goed met 226 voorstemmen naast 62 tegenstemmen en 31 onthoudingen. De twee grootste partijen, de Masjoemi en de PNI, stemden voor; de tegenstemmen kwamen vooral van de linkse oppositie wier standpunten strookten met die van de nieuwe PP (Pembela Proklamasi); de onthoudingen kwamen onder meer van de socialistische partij van Sjahrir.

In Nederland begon de openbare behandeling van het voorstel tot goedkeuring van de overeenkomsten eveneens op 6 december in de Tweede Kamer. Het hele kabinet woonde het debat bij; het zou aftreden als de vereiste 
tweederde meerderheid niet bereikt werd. Alle honderd leden van de Kamer waren aanwezig. Op 9 december werd het voorstel aangenomen met 71 tegen 29 stemmen. Naast de fracties van PvdA (27) en KVP (32) had de hele VVDfractie (8) voorgestemd, terwijl van de CHU-fractie 4 leden voor- en 5 tegengestemd hadden; de verdere tegenstemmen kwamen van ARP (13), SGP (2), Welter (1) en CPN (8). In de Eerste Kamer werd het voorstel op 21 december aangenomen met 34 stemmen voor en 15 tegen. De fracties van PvdA (14), KVP (17) en VVD (3) stemden voor; de hele CHU-fractie (5) stemde tegen, samen met ARP (6) en CPN (4); één ARP-lid was wegens ziekte afwezig. Het was een krappe overwinning: had één VVD-lid tegengestemd en was de ARPfractie voltallig geweest, dan zou de vereiste meerderheid niet gehaald zijn.

De behandeling in de Eerste Kamer was met spanning tegemoetgezien, omdat de uitslag tot het laatst onzeker was. De regering in Den Haag had daarom alles willen vermijden dat de indruk kon wekken dat men de Kamer voor voldongen feiten plaatste. Het gouvernement in Batavia had zulke feiten echter moeilijk geheel kunnen vermijden. Voor een enigszins ordelijke overgang van het oude naar het nieuwe regiem moesten nu eenmaal voorbereidingen worden getroffen die men niet tot eind december kon uitstellen. Dit betrof onder meer de terugtrekking en concentratie van de Nederlandse strijdkrachten. Vrijwel dagelijks droegen Nederlandse troepenonderdelen op Java en Sumatra de verantwoordelijkheid voor bepaalde gebieden aan Republikeinse strijdkrachten over. Dit gebeurde niet alleen in het gebied dat in het Nederlandse offensief van december 1948 bezet was, maar ook in delen van het al in juli 1947 bezette gebied. Om te verzekeren dat de TNI en de Republikeinse politie bij de soevereiniteitsoverdracht de zorg voor de openbare veiligheid geruisloos konden overnemen was het bovendien nodig tijdig ook contingenten ervan te legeren in de gebieden die al voor juli 1947 in Nederlandse handen waren, met inbegrip van steden als Soerabaja, Bandoeng en Batavia. De regering in Den Haag schrok echter toen in de Nederlandse pers bekend werd dat op 10 december in Batavia al de eerste TNI-eenheden aangekomen waren; zij haastte zich te verklaren dat het alleen om kwartiermakers ging. Overigens werd de orde in Batavia vanaf medio december gehandhaafd door gemengde patrouilles van gemeentepolitie en Republikeinse politie.

De noodzaak van samenwerking tussen de Nederlandse en de Republikeinse autoriteiten ter vermijding van een gezagsvacuum betrof niet alleen de zorg voor de openbare veiligheid maar ook de civiele regeringstaken. Al op 3 november nodigde het gouvernement daarom de Republiek en de BFO uit om vertrouwensmannen aan te wijzen die zich op de verschillende departementen op de hoogte zouden kunnen stellen van de bestaande organisatie en van de daar behandelde problemen. Ook sprak het de hoop uit spoedig met vertegenwoordigers van de RVI overleg te kunnen plegen over kwesties van algemeen beleid. Met het eerste punt stemde men van Indonesische kant al 
spoedig in; aan het tweede punt kwam men enige weken later tegemoet. Op 26 november richtten de Republiek en de BFO namelijk een bijzonder orgaan op voor het begeleiden van de gezagsovergang, de Panitia Persiapan Nasional (PPN, Nationale Voorbereidingscommissie). De naam herinnerde aan die van de commissie die in 1945 de onafhankelijkheid voorbereid had, de Panitia Persiapan Kemerdekaan Indonesia (zie pp. 341-3 en 359-60). De hoofdtaken van de PPN betroffen de totstandkoming van de noodzakelijke organen van de RVI en de voorbereiding van het overnemen van de overheidstaak door de RVI-regering van het Nederlands-Indische gouvernement.

De PPN bestond uit eenendertig leden, van wie vijftien door de Republiek en zestien door de BFO aangewezen waren. Voorzitter was Roem, vicevoorzitter Anak Agoeng. De PPN vormde subcommissies voor de behandeling van bepaalde onderwerpen; het geheel stond onder leiding van een stuurgroep van acht leden. Van Nederlandse kant richtte men voor de geregelde samenwerking met de PPN een eveneens uit acht personen bestaande contactgroep van hoog niveau op onder leiding van H.L. s'Jacob. Deze groep kon zowel namens het gouvernement als namens de Nederlandse regering optreden. Ook de stafchefs van de Nederlandse landstrijdkrachten en marine maakten er deel van uit.

In de laatste weken die aan de overdracht van de Nederlandse soevereiniteit voorafgingen leek Indonesië niet meer door het Nederlands-Indische gouvernement maar door de PPN geregeerd te worden. Zij droeg de verantwoordelijkheid voor de handhaving van orde en rust in heel Indonesië op aan de sultan van Jogja, Hamengkoe Boewono IX. Zij ontving de rapporten van de vertrouwensmannen die zich op de departementen in Batavia georienteerd hadden en nam die departementen daarna over. Ze vaardigde tal van voorschriften uit, bijvoorbeeld over de onderscheidingstekens van de verschillende soorten politie en over het gebruik van de nationale vlag en van andere vlaggen. Verder hield ze zich actief met voorlichting bezig. Elke dag op dezelfde tijd werden haar communiqués over alle radiozenders uitgezonden in het Indonesisch, het Nederlands en het Engels. Zij liet een voorlichtingsfilm maken die in de bioscopen vertoond werd. In Batavia schakelde zij studenten en scholieren in om ervoor te zorgen dat haar bekendmakingen ook in alle volkswijken verspreid werden.

Omdat het Nederlandse parlement de RTC-akkoorden nog niet goedgekeurd had bemantelde men diplomatiek dat de PPN in de praktijk gezag uitoefende. Een deel van haar voorschriften droeg de naam 'adviezen' en de sultan heette slechts 'coördinator', hoewel hij in feite de supervisie had over zowel de TNI als de Nederlandse strijdkrachten, de veiligheidsbataljons en de politie.

Intussen wijdde de PPN zich ook aan haar andere hoofdtaak, de voorbereiding van het formele staatsapparaat van de RVI. Op 14 december kwamen 
gemachtigden van de Republiek en de BFO-gebieden in Batavia bijeen in het historische pand aan Pegangsaän Oost 56 en ondertekenden daar de voorlopige RVI-constitutie. Op 16 december kwamen de gemachtigden in Jogja bijeen en kozen daar Soekarno en Hatta tot eerste president en vicepresident van de nieuwe staat. De volgende dag werden deze twee beëdigd; daarna legde Soekarno een krans op het graf van de eerste organisator van het Republikeinse leger, Oerip Soemohardjo, die in november 1948 gestorven was. Soekarno wees vier kabinetsformateurs aan om een nationaal kabinet te vormen, Hatta, Anak Agoeng, sultan Hamengkoe Boewono IX en sultan Hamid II. Dank zij de voorbereidingen van de PPN slaagden die in uiterst korte tijd in de vorming van een kabinet; op 20 december werd het door Soekarno geïnstalleerd. Dit eerste kabinet van de RVI bestond uit zestien ministers; Hatta werd premier en minister van buitenlandse zaken, Anak Agoeng minister van binnenlandse zaken en de sultan van Jogja minister van defensie; Roem en sultan Hamid werden minister zonder portefeuille. Overigens werd Roem kort daarna tot Hoge Commissaris van de RVI in Nederland benoemd. De PPN bereikte ook overeenstemming over de samenstelling van het voorlopige parlement van de RVI, waarvan een derde deel uit de Republiek en twee derde uit de overige deelstaten zou komen.

Verder pleegde de PPN overleg met Nederland over de organisatie van de plechtigheden waarbij de Nederlandse soevereiniteit en het Nederlandse bestuur over Indonesië aan de RVI zouden worden overgedragen. Ook trof ze voorbereidingen voor de overdracht in Jogja van de op de onafhankelijkheidsverklaring van 1945 gebaseerde soevereiniteit van de Republiek. Als datum kwam men 27 december overeen.

De in december ondernomen stappen met het oog op de toekomstige situatie betroffen ook het interinsulaire bedrijf van de Nederlandse luchtvaartmaatschappij KLM. Dit bedrijf, dat het luchtverkeer binnen de Indonesische archipel verzorgde, was voor de helft eigendom van de KLM en voor de helft van het gouvernement. Op 21 december sloot de KLM een overeenkomst met de regering van de RVI waarbij het bedrijf in een Indonesische luchtvaartmaatschappij werd omgezet, Garuda Indonesian Airways.

Anders dan veel Nederlanders in de afgelopen maanden gevreesd hadden was de sfeer aan de vooravond van de soevereiniteitsoverdracht vreedzaam en ontspannen. Nederlandse en Republikeinse militairen bleken gemoedelijk met elkaar te kunnen omgaan. Op 25 december werd in Batavia een vriendschappelijke voetbalwedstrijd gespeeld tussen een elftal van het Nederlandse garnizoen en een elftal van de Siliwangidivisie, in aanwezigheid van de sultan van Jogja en verscheidene hoge Nederlandse en Republikeinse officieren.

De overdrachten van de Nederlandse soevereiniteit en het Nederlandse bestuur over Indonesië en van de soevereiniteit van de Republiek vonden op 27 december 1949 plaats in drie plechtigheden die elkaar gedeeltelijk overlapten. 
Eén ceremonie begon 's ochtends om tien uur in het koninklijk paleis in Amsterdam, niet ver van het vroegere hoofdkwartier van de Verenigde Oost-Indische Compagnie. Koningin Juliana en de volledige Nederlandse regering namen hieraan deel, terwijl de RVI vertegenwoordigd werd door een delegatie onder leiding van Hatta waar verder onder meer sultan Hamid toe behoorde. Drees en Hatta ondertekenden een aantal documenten, waaronder het Charter van Soevereiniteitsoverdracht en het Uniestatuut. Daarna ondertekende koningin Juliana een aparte acte die inhield dat de soevereiniteitsoverdracht in overeenstemming met het Charter rechtskracht had verkregen, dat de Nederlands-Indonesische Unie tot stand gekomen was en dat alle bij de mantelresolutie van de RTC horende akkoorden in werking waren getreden. Nadat deze acte door alle Nederlandse ministers medeondertekend was, hield de koningin een korte toespraak.

Gelijktijdig met de plechtigheid in Amsterdam begon in Batavia/Djakarta, waar het toen vijf uur 's middags was, de ceremonie voor de bestuursoverdracht in het vroegere paleis van de gouverneur-generaal. De RVI werd hier vertegenwoordigd door een delegatie onder leiding van de sultan van Jogja; verder behoorden hiertoe onder meer Anak Agoeng en Roem. Van Nederlandse kant nam Lovink, de Hoge Vertegenwoordiger van de Kroon, aan de plechtigheid deel, in gezelschap van de leden van zijn gouvernement en een groot aantal gasten, onder wie ook de zo juist aangekomen Hoge Commissaris van Nederland bij de RVI, H.M. Hirschfeld. Buiten het paleis had zich een grote menigte verzameld. Lovink en de sultan ondertekenden een proces-verbaal van bestuursoverdracht en hielden beiden een toespraak. Daarna luisterde men naar een radiouitzending van dat deel van de plechtigheid in Amsterdam waarin koningin Juliana haar rede uitsprak. Na afloop hiervan gingen allen naar de voorkant van het paleis voor de vlaggenwisseling. Terwijl het Nederlandse volkslied gespeeld werd daalde de rood-witblauwe vlag op het dak van het paleis langzaam omlaag. Er klonk even gefluit en gejoel uit de menigte, maar daarna werd het doodstil. Voor alle aanwezige Nederlanders en ook voor veel Indonesiërs was dit het meest aangrijpende onderdeel van de plechtigheden. Vervolgens ging de rood-witte vlag boven het paleis omhoog onder de klanken van het 'Indonesia Raya', dat door uitbundig gejuich overstemd werd. Meteen hierna stapte Lovink in de auto die hem naar het vliegveld bracht voor zijn terugkeer naar Nederland.

Omstreeks dezelfde tijd vond in het presidentieel paleis in Jogja de plechtigheid plaats tot overdracht van de soevereiniteit van de oude Republiek, de RI, aan de nieuwe Republiek, de RVI. Dit gebeurde in de vorm van een bijzondere zitting van het Werkcomité van het KNIP. Wegens zijn benoeming tot president van de RVI legde Soekarno zijn presidentschap van de RI tijdelijk neer; de voorzitter van het KNIP, Assaat, werd nu tot 'drager van de presidentiële functie' van de RI benoemd. Men luisterde eerst naar de radiouitzendin- 
gen van de ceremonies in Amsterdam en in Djakarta. Daarna droeg Assaat de soevereiniteit van de Republiek over aan de RVI, vertegenwoordigd door haar president Soekarno. Het hoogtepunt van de plechtigheid was dat Assaat aan Soekarno een houten kistje overhandigde met daarin de vlag die op 17 augustus 1945 bij de uitroeping van de onafhankelijkheid voor het huis Pegangsaän Oost 56 gehesen was.

De volgende ochtend, 28 december, vlogen Soekarno en zijn gevolg in twee vliegtuigen van de nationale luchtvaartmaatschappij Garuda naar Djakarta. Soekarno had een gevolg meegenomen waarin niet alleen verschillende geledingen van de Indonesische samenleving vertegenwoordigd waren maar ook verschillende fasen van de nationale vrijheidsstrijd. Onder meer behoorden daartoe Ki Hadjar Dewantoro en Soetardjo Kartohadikoesoemo. Al in 1912 was Dewantoro (die toen nog Soewardi Soerjaningrat heette) één van de leiders van de Indische Partij geweest, de eerste politieke partij die naar onafhankelijkheid voor Indonesië streefde (zie pp. 161-3). In 1932 had hij het verzet tegen de 'wilde-scholen-ordonnantie' geleid, de enige vooroorlogse actie waarin de nationale beweging een overwinning op het gouvernement behaald had (zie p. 220-1). Soetardjo was de indiener geweest van de in 1936 door de Volksraad aangenomen petitie waarin gevraagd werd aan Nederlands-Indië langs de weg van geleidelijke hervorming zelfstandigheid toe te kennen binnen het Koninkrijk der Nederlanden; de Nederlandse regering had deze petitie afgewezen met steun van een grote meerderheid van het parlement (zie pp. 234-9). Na de aankomst in Djakarta hield Soekarno bovenaan de vliegtuigtrap allereerst het kistje met de historische vlag omhoog; dit werd daarna met een speciaal motorescorte naar het paleis gebracht.

Intussen waren honderdduizenden in Djakarta de straat opgegaan om de intocht van de president mee te maken. Volgens het oorspronkelijke plan zou Soekarno eerst naar het huis aan Pegangsaän Oost 56 gaan dat hij in de nacht van 3 op 4 januari 1946 verlaten had (zie p. 436) en pas daarna naar het paleis. Maar omdat men niet over voldoende politie beschikte om op een zo lang traject de orde te handhaven koos men voor de kortste route van het vliegveld naar het paleis. Staande in een open auto kwam Soekarno in de mensenzee maar langzaam vooruit. Toen hij het paleis eindelijk bereikt had doorbrak de menigte alle cordons, stroomde de paleistuin binnen en drong de paleistrappen op. Het was de bedoeling van de PPN geweest Soekarno ceremonieel te ontvangen op een podium dat daartoe aan de voorkant opgericht was, maar het bleek niet meer mogelijk dit podium te bereiken. Op het bordes van het paleis stelde men haastig enige microfoons op, Anak Agoeng sprak een kort welkomstwoord uit en daarna richtte Soekarno zich tot de menigte met een redevoering waarin hij alle registers van zijn volksmennerskunst opentrok. Hij eindigde met een fanatieke oproep de strijd voort te zetten opdat NieuwGuinea voor eind 1950 met Indonesië herenigd zou worden. 
Hoe opwindend Soekarno's rede ook was, zijn gehoor werd er niet agressief door, maar ging ordelijk en tevreden uiteen. Er deed zich op deze dag en de volgende dagen in Djakarta geen enkel incident voor. Tenslotte hield Soekarno op de avond van 29 december een grote ontvangst die bezocht werd door ruim vijfduizend gasten, voor het grootste deel Nederlanders. Nooit was er in de koloniale tijd in dit paleis een zo druk bezochte receptie geweest.

\section{Terugblik}

De Rondetafelconferentie had het mogelijk gemaakt de koloniale verhouding tussen Nederland en Indonesië voorgoed te veranderen in een verhouding tussen twee soevereine staten. Het resultaat van de RTC paste in het kader van het akkoord van Linggadjati. Indonesië werd een bondsstaat waarin de Republiek de positie van een deelstaat innam, terwijl Indonesië en Nederland samen een Unie vormden onder de Nederlandse koningin. Op staatkundig en militair gebied had Nederland veel van zijn oorspronkelijke plannen laten varen, maar op economisch gebied had het gunstige voorwaarden verkregen voor de voortzetting van zijn activiteiten in Indonesië. Er zijn geen aanwijzingen dat de Republiek in juli 1947 of in december 1948 niet bereid geweest zou zijn Nederland even ver tegemoet te komen als nu gebeurd was. Toch had de Nederlandse regering toen gemeend dat Nederland geen andere keus had dan een militaire aanval op de Republiek. Anders gezegd: in 1947 en 1948 had aan Nederlandse kant de bereidheid ontbroken tot een politieke oplossing als uiteindelijk in 1949 tot stand gekomen is.

Twee factoren speelden daarbij een rol. Ten eerste konden de meeste Nederlanders de eerste jaren nog niet aan de gedachte wennen dat Indonesië werkelijk onafhankelijk zou worden. Daarom bleven de Nederlandse beleidsmakers ook na het akkoord van Linggadjati streven naar staatsrechtelijke en militaire waarborgen om Nederland nog lange tijd een tastbare invloed op de gang van zaken binnen Indonesië te geven. Ten tweede beschikte Nederland daar in 1947 en 1948 over een grote strijdmacht (waarvan de aanwezigheid op zichzelf had bijgedragen tot de tegemoetkomingen van de Republiek in Linggadjati). Dit werkte de gedachte in de hand dat Nederland zijn militairtechnische overwicht kon benutten om de nagestreefde waarborgen te verkrijgen. Het Nederlandse offensief van december 1948 had de definitieve 'proef op de som' gevormd; de mislukking ervan had de weg geopend naar een politieke oplossing zonder militaire drukmiddelen.

Door een en ander was de dekolonisatie van Indonesië anders verlopen dan die van de meeste andere Aziatische koloniën. India, Pakistan, Birma, Ceylon, Cambodja, Laos en de Filipijnen waren in deze zelfde periode onafhankelijk geworden zonder een militaire krachtmeting met hun vroegere kolonisatoren. 
In al deze gevallen woog echter de psychologische betekenis van deze gebieden voor de bevolking van het koloniale 'moederland' veel minder zwaar dan die van 'Nederlands-Indië' voor de bevolking van Nederland. Verder waren deze vreedzame dekolonisaties soms gevolgd door hevige interne conflicten; in het geval van India en Pakistan hadden die zelfs een half miljoen mensenlevens gekost. Naast Indonesië was Vietnam het enige andere Aziatische land waar een koloniale macht in oorlog was geraakt met een onafhankelijkheidsbeweging, maar de politieke situatie verschilde hier aanzienlijk. De Vietnamese republiek maakte deel uit van de wereldwijde communistische beweging, terwijl de Indonesische republiek juist een communistische machtsgreep onderdrukt had toen Nederland haar ten tweede male aanviel.

Het gewapende conflict tussen de Indonesische onafhankelijkheidsbeweging en het vroegere koloniale heersersland had bijna vier jaar geduurd en aan beide zijden schade en leed berokkend. Hoewel Nederland verarmd uit de Tweede Wereldoorlog gekomen was, had het grote financiële offers gebracht om een strijdmacht in Indonesië op te bouwen. Ondanks een dringende behoefte aan arbeidskrachten voor de wederopbouw in eigen land had het ruim honderdtwintigduizend jonge mannen aan het Nederlandse arbeidspotentieel onttrokken en als militairen in Indonesië ingezet. Daartoe waren die mannen gedurende enige jaren uit hun gezin, hun werk en hun vertrouwde omgeving weggehaald. Aan Indonesische kant waren de schadelijke gevolgen van het conflict nog ingrijpender. Terwijl de economie van Indonesië door de Japanse bezetting al ernstig ontredderd was, belette het conflict in grote delen van Java en Sumatra niet alleen het herstel, maar veroorzaakte het ook verdere achteruitgang. Dit was onder meer te wijten aan de Nederlandse blokkade van Republikeins gebied en aan de Republikeinse vernielingen in het kader van de 'verschroeide-aarde'-strategie. Bovendien was het Indonesische arbeidspotentieel aangetast door de deelname van honderdduizenden aan de gewapende strijd, deels in het reguliere Republikeinse leger, deels in autonome strijdgroepen. Daarbij hadden veel van die strijders grote ontberingen geleden en waren zij voor hun levensonderhoud afhankelijk geraakt van steun uit de plaatselijke bevolking.

Op het punt van verliezen aan mensenlevens liepen de gevolgen van het conflict voor de twee partijen ver uiteen. Tussen het begin van de vijandelijkheden in najaar 1945 en de wapenstilstand van augustus 1949 waren aan Nederlandse kant ruim vijfentwintighonderd militairen gesneuveld. Daarentegen had het Nederlandse militaire optreden aan Indonesische kant een veel groter aantal dodelijke slachtoffers gemaakt, zowel onder de strijders als onder de burgerbevolking. Volgens Nederlandse militaire schattingen gaat het om een getal in de orde van grootte van honderdduizend. Overigens had het geweld in Indonesië gedurende de eerste vier jaar na de Tweede Wereldoorlog aan nog veel meer Indonesiërs het leven gekost. Daartoe behoorden slachtof- 
fers van de bersiapterreur in 1945-1946, slachtoffers van onderlinge conflicten zoals die van de Republikeinse regering met de Daroel Islam en met Moeso en diens aanhang, en tenslotte velen die in het kader van de guerrilla-strijd gedood waren wegens medewerking met het Nederlandse gezag. Wat de laatste categorie betreft vormde het aantal aldus door guerrillastrijders uit de weg geruimde Indonesiërs waarschijnlijk een veelvoud van de door Indonesiërs gedode Nederlandse militairen.

Gelet op het leed dat de militaire krachtmeting tussen Nederland en de Indonesische vrijheidsbeweging had aangericht, is het opmerkelijk dat het conflict niet had geleid tot bittere haatgevoelens van volk tegen volk. Hierbij valt te bedenken dat de Nederlandse militairen zichzelf nooit als vijanden maar juist als beschermers van de Indonesische bevolking hadden beschouwd. Bovendien hadden zowel die militairen als de Nederlanders in Europa gedurende de laatste jaren steeds meer begrip gekregen voor het Indonesische verlangen om baas in eigen huis te zijn. Daarentegen was het vooral verrassend dat de houding van de meeste Indonesiërs tegenover het Nederlandse volk eind 1949 niet door gevoelens van verbittering en wrok beheerst werd. Ten dele valt dit te verklaren uit het feit dat zij zichzelf konden zien als overwinnaars in de strijd tegen de vroegere koloniale heersers. Die overwinning gaf bovendien zin aan de gebrachte offers en droeg bij tot de Indonesische natievorming. Het besef dat de nationale onafhankelijkheid niet geschonken maar veroverd was versterkte het zelfvertrouwen en het gevoel van eigenwaarde van de Indonesische bevolking. Aan de andere kant waren onder die bevolking nog niet alle wonden geheeld die daar in de afgelopen jaren door onderlinge verdeeldheid waren veroorzaakt. Zowel binnen Nederland als binnen de Republiek Indonesië had sinds het najaar van 1945 een hevige richtingenstrijd gewoed over de aanpak van het conflict. In beide gevallen ging het om de keuze tussen wapengeweld of het doen van concessies. Zowel bij de Nederlanders als bij de Indonesiërs leek zich in die jaren meer vijandigheid te hebben gericht op de interne tegenstanders dan op de externe tegenpartij.

\section{Aantekeningen bij hoofdstuk VIII}

\section{Literatuuroverzicht}

De in dit hoofdstuk beschreven gebeurtenissen hebben zich afgespeeld in het jaar 1949. Voor de literatuur hierover valt in de eerste plaats te verwijzen naar een aantal al eerder genoemde boeken, namelijk Kahin 1952, Smit 1952 en 1962, Taylor 1960, Nasution 1979, Bank 1983, L. de Jong 1988 en Van den Doel 2000. Enige werken die meer specifiek op deze periode betrekking hebben zijn Het laatste jaar van de Indonesische vrijheidsstrijd 1948-1949 door T.B. Simatupang (1985), 'Renville' als keerpunt in de Nederlands-Indonesische onderhandelingen door Ide Anak Agung Gde Agung (1980), Minister Stikker en de soevereiniteitsoverdracht aan Indonesië door L.G.M. Jaquet (1982), 
Het laatste jaar van Nederlands-Indie door J.G. de Beus (1987) en Het einde in zicht door P.J. Drooglever en M.J.B. Schouten (1999). Wat interne documenten betreft wordt de periode bestreken door de delen XVI tot en met XX van de bronnenpublicatie NIB (1992-1996). Sommige van de in dit hoofdstuk vervatte gegevens zijn ontleend aan dagbladen uit de beschreven periode. Verder heb ik bij het schrijven van dit hoofdstuk gebruik gemaakt van eigen herinneringen en aantekeningen uit 1949-1950 toen ik zelf in Batavia/Djakarta woonde.

De militaire situatie na het tweede Nederlandse offensief

Zie Groen 1991:171-236, vooral 231-6, en Simatupang 1985, vooral 59-63. Voor Princen's eigen relaas over zijn desertie zie Princen 1995:83-109. Over Spoor's verwachting dat de guerrilla spoedig zou uitdoven zie Groen 1991:112-3, 145, 178 en Gase 1986:2845. Over de successen van de guerrilla zie ook NIB XVIII:127-8, Van Doorn en Hendrix 1993:193-200 en L. de Jong 1988:962-7. Over de Daroel Islam zie Van Dijk 1981:90-2, Groen 1991:204 en Simatupang 1985:108-9. Over Tan Malaka zie L. de Jong 1988:961-2, Groen 1991:202 en Poeze 2007:1401-94. Over de Republikeinse aanval op Jogja zie L. de Jong 1998:967-8 en NIB XVIII:1-2.

\section{De politieke situatie na het tweede Nederlandse offensief}

Over het verzuim van de Nederlandse regering om een duidelijk politiek doel voor het tweede offensief vast te stellen zie Jaquet 1982:157-8 en Groen 1991:168, 174. Over het motief van Drees zie Drees 1962:239-41. Over de uiteenlopende opvattingen binnen de Nederlandse regering zie onder meer Smit 1962:144, Jaquet 1982:161 en Bank 1983:399. Voor de tekst van de Amerikaanse waarschuwing zie NIB XVI:56-8; voor de voorspelling van Sassen NIB XVI:66.

Nederlands aanbod tot vervroegde overdracht van de soevereiniteit

Over het meningsverschil tussen Drees en Beel over de benadering van de Republikeinse leiders zie NIB XVII:216-7. Voor de brief van Beel aan Soekarno zie BZ 1950:100.

Voor de resolutie van de VN-Veiligheidsraad van 28 januari zie NIB XVII:709-11; voor een Nederlandse vertaling hiervan zie BZ 1949b:509-12. Over de ontvangst van Soekarno op Bangka zie L. de Jong 1988:970-1. Over de BFO-contactcommissie zie Anak Agung 1980:252. Over het bezoek van de UNCI zie NIB XVII:592-3.

Voor de oorspronkelijke opzet van het plan-Beel zie NIB XVII:257-8. Voor het gewijzigde plan NIB XVII:612 (de voornaamste wijziging staat daar in een bijzin tussen haakjes). Over de onenigheid in februari tussen de Nederlandse ministers onderling en tussen de regering en Beel zie Jaquet 1982:197-223 en Bank 1983:411-22.

Over het bezoek van Koets aan Bangka zie NIB XVIII:13-4 en BZ 1950:109. Over het bezoek van de BFO-delegatie aan Bangka zie Anak Agung 1980:265-6. Over het besluit van de BFO-vergadering van 3-4 maart en Beel's reactie daarop zie Anak Agung 1980:268-71 en NIB XVIII:28-9. Voor de tekst van het antwoord van Soekarno aan Beel zie NIB XVIII:37-8 en BZ 1950:107-8.

Akkoord tussen Roem en Van Roijen

Over de bereidheid van de Nederlandse regering tot een compromis over de terugkeer naar Jogja zie NIB XVIII:86-8. Voor de raadpleging van parlementsleden NIB 
XVIII:62-6. Voor de berichtgeving van Beel NIB XVIII:247-8; zie ook De Beus 1987:117. Voor Spoor's mening over de 'Soekarno-kliek' zie NIB XVIII:273-4, voor zijn mening over de laatste fase van de contra-guerrilla NIB XVIII:367. Zie over de toekomstvisie van Spoor ook De Moor 1999:405-6. Over uitstel van de troepenvermindering tot 1951 zie Groen 1991:219. Voor het regeringsbesluit over de repatriëring van de oorlogsvrijwilligers en de 7 December-divisie zie NIB XVIII:263. Over de veranderde opstelling van de ondernemers zie Bank 1983:353 en L. de Jong 1988:973.

Voor de procedurele richtlijn van de Veiligheidsraad van 23 maart zie NIB XVIII:228. Voor het antwoord van Roem aan de UNCI zie NIB XVIII:323. Voor het oordeel van Van Roijen over Spoor NIB XVIII:450. Voor de verklaringen van Roem en Van Roijen van 7 mei NIB XVIII:596-7; voor de Nederlandse vertaling hiervan zie BZ 1950:392-3. Voor het verzet van Spoor en Beel zie NIB XVIII:575-7, 586-8. Voor de machtiging van de Nederlandse regering aan Van Roijen NIB XVIII:594-5. Over de reacties in Nederland zie L. de Jong 1988:986. Voor de officiële reactie van Sjafroeddin zie NIB XVIII:646. Over de vergaderingen van de voorbereidende conferentie van 22 juni en 1 augustus zie NIB XIX:128-42, 420-1.

\section{Terugkeer van Soekarno en Hatta in Jogjakarta}

Over de uittocht uit Jogja zie NIB XVIII:650, 750, NIB XIX:214 en Simatupang 1985:156. Over de terugkeer van Hatta en Soekarno zie Simatupang 1985:158-61; over de terugkeer van Soedirman zie Simatupang 1985:182-4; over de kabinetszitting van 13 juli zie Simatupang 1985:185-6. Voor de gewijzigde samenstelling van het kabinet zie Hatta 1981:308. Over de veiligheid in Jogja zie NIB XIX:326, 349. Over het bezoek van Van Roijen aan Jogja NIB XIX:317-9.

\section{Akkoord tussen de Republiek en de federalisten}

Over de Inter-Indonesische Conferentie zie Anak Agung 1980:298-303. Voor de besluiten ervan zie NIB XIX:357-9, 432-41. De benaming Republiek der Verenigde Staten van Indonesië voor de toekomstige soevereine federatie was intern ook al vermeld in de eerste versie van het plan-Beel, maar in het openbaar was Nederland de benaming Verenigde Staten van Indonesië (VSI) blijven gebruiken. Over het eerbetoon voor wijlen Ratoelangie zie NIB XIX:406.

\section{Het derde bestand tussen Nederland en de Republiek}

Over de aanvankelijke bezwaren van de Nederlandse legerleiding en de Nederlandse regering tegen de ontworpen bestandsregeling zie onder meer NIB XVIII:709-10 en NIB XIX:8, 41, 113. Voor de op 22 juni voorlopig overeengekomen bestandsregeling NIB XIX:133-9. Over de vergadering van de militaire en politieke top van de Republiek zie Simatupang 1985:187. Over de slotvergadering van de voorbereidende conferentie zie NIB XIX:420-1. Voor de definitieve tekst van de bestandsregeling zie BZ 1950:17588; voor de Nederlandse vertaling BZ 1950:394-405.

Over de 'bloedbruiloft van Tjilatjap' zie Excessennota 1995:116-8; vergelijk NIB XX:830. Voor de reactie van Lovink wegens de aanval op Solo zie NIB XIX:512. Over de executie van Monginsidi NIB XIX:661, 750-1, 770.

Over de instelling van subcommissies van de gemengde bestandscommissie zie NIB XIX:656-8, 751. Over de afbakening van patrouillegebieden NIB XIX:389-90, 397-8 en NIB XX:94. Over de aan Nederlandse kant gerezen spanningen zie onder meer 
NIB XIX:502, 590; vergelijk Van den Doel 2000:311, 313-4 en De Beus 1987:134-141. Volgens De Beus zouden de Nederlandse troepencommandanten in een vergadering met Lovink zelfs hebben gepleit voor een derde politionele actie (De Beus 1987:144-6). Ik kan dit moeilijk geloven. In de NIB-serie is geen verslag van zo'n vergadering te vinden. Wel bevat NIB XX:121-4 een memorandum van kolonel Mollinger van 1 oktober 1949 waarin gerept wordt van 'uitschakeling van Djocja'; naar mijn mening is dit echter geen serieus pleidooi voor een derde politionele actie, maar een in dramatische vorm gegoten betoog dat het voor de Nederlandse troepen de hoogste tijd was om gebied te gaan ontruimen. Ook Bouman hecht geen geloof aan het verhaal van De Beus (zie Bouman 1995:316, noot 367).

Zie over het Nederlandse belang bij een solide positie van de Republiek onder meer NIB XIX:545, 657, 717 en NIB XX:7. Zie over de ontruiming van door Nederland bezette gebieden ook Kawilarang 1993:141-8. Over de Nederlandse bevoorrading en financiering van de TNI zie NIB XIX:656 en NIB XX:162, 238-40, 338-9, 554, 573. Over de vrijlating van gevangenen zie NIB XIX:751 en NIB XX:687.

\section{De Rondetafelconferentie in Den Haag}

Voor het akkoord van 22 juni over de RTC zie NIB XIX:139-42; voor de Nederlandse vertaling hiervan zie BZ 1950:406-8. Voor een overzicht van de deelnemers aan de RTC zie NIB XIX:778-9. Voor de Nederlandse voorstellen over de Unie NIB XIX::6417. Over het verloop van de onderhandelingen zie Meijer 1994:42-51. Voor de definitieve tekst van de Mantelresolutie, het Uniestatuut en de Overgangsovereenkomst zie NIB XX:859-61. Voor de volledige Engelse tekst van de RTC-overeenkomsten zie BZ 1950:293-388. Voor de volledige tekst in drie talen zie Staatsblad 1949 J 570. De Engelse tekst van de VSI-grondwet is ook afgedrukt in A.B. Nasution 1992:450-86.

\section{Het externe zelfbeschikkingsrecht voor Indonesische minderheden}

Voor de instructies van Helfrich aan Pinke zie NIB VIII:71 en NIB X:180. Voor de houding van het gouvernement en de regering tegenover de PTB en de Twapro zie NIB VIII:491-4, NIB IX:364, NIB XIII:292-4, NIB XVIII:313, NIB XIX:9, 104, 347. Over de representativiteit van deze organisaties zie NIB XVIII:21, 219, 311, 548-9 en NIB XIX:109. Over het Nationaal Comité Handhaving Rijkseenheid zie Hekman 1981:64-5. Over het streven om het meest oostelijke deel van de archipel binnen het Koninkrijk te houden vergelijk Van Kaam 1977:104-5 en Bosscher en Waaldijk 1985:31-6. Over de wens van de PTB en de Twapro tot volwaardige deelname aan de RTC zie NIB XX:366, 469. Over de behandeling van het zelfbeschikkingsrecht in de RTC zie Anak Agung 1980:320-5. Voor de door de UNCI voorgestelde compromisformule zie NIB XX: 869 (Overgangsovereenkomst, artikel 2, lid 2). Zie ook Chauvel 1990:282-90, 296-8.

\section{De kwestie Nieuw-Guinea}

Er is veel literatuur over dit onderwerp, waaronder Nieuw-Guinea als schakel tussen Nederland en Indonesië door F.J.F.M. Duynstee (1961), The trauma of decolonization door A. Lijphart (1966), De kwestie Nieuw-Guinea door P.B.R. de Geus (1984), Misleiding of zelfbedrog door R. Gase (1984), The New Guinea debacle door C.L.M. Penders (2002) en Een daad van vrije keuze door P.J. Drooglever (2005).

Voor de verklaring van Van Mook in Denpasar zie Van Goudoever 1947:46; zie ook NIB VI:634. Voor de verklaring van Drees in de ministerraad in maart 1949 zie NIB 
XVIII:198. Voor de verklaring van Van Maarseveen in de ministerraad in juni 1949 zie NIB XIX:26; zie ook De Geus (1984):47-8. Over het parlementair-rekenkundig motief zie NIB XX:140. Voor het gesprek van Van Maarseveen met departementshoofden in Batavia zie NIB XIX:172-5. Voor het betoog van Van Mook van 14 juli 1949 zie Nieuwe Rotterdamse Courant van 16 juni 1962:7. Voor het gesprek van Van Roijen met Soekarno zie NIB XIX:318.

Over de opstelling van het parlement van Oost-Indonesië zie NIB XX:447. Over de behandeling van de kwestie Nieuw-Guinea in de RTC NIB XX:185-8, 351-2, 385, 398-9, 467-9, 476-7, 486-90. Voor het eenstemmig oordeel van het gouvernement in Batavia NIB XX:96-7, 159-60. Voor de mening van Van Roijen zie NIB XIX:539. Zie ook Anak Agung 1980:314-7 en Drooglever 2005:159-65, 170-4.

Over de psychologische achtergronden van de kwestie Nieuw-Guinea zie NIB XIX:503, Lijphart 1966:286-8 en L. de Jong 1988:1078.

\section{De tekst van het Charter van Soevereiniteitsoverdracht}

Voor het Nederlandse ontwerp voor het Charter zie NIB XIX:639-40.

De Nederlandse regering maakte de tekst van dit ontwerp al in november 1949 openbaar in de memorie van toelichting bij het wetsontwerp tot goedkeuring van de soevereiniteitsoverdracht (Handelingen II, 1949-50, 1478, nr. 6, p. 6).

Ik heb in deze paragraaf geschreven dat men uit de tekst van het Charter kan concluderen dat de soevereiniteitsoverdracht ook op Nieuw-Guinea betrekking had. Mijn persoonlijke mening is dat men dit niet alleen kan maar ook moet concluderen. Dit meen ik al sinds ik eind 1949 voor het eerst de tekst van het Charter las, terwijl ik toen nog geen kennis droeg van de oorspronkelijk door Nederland tijdens de RTC voorgestelde teksten die in de slotfase van de conferentie plaats gemaakt hadden voor formuleringen in overeenstemming met de Indonesische zienswijze.

In Nederland hebben enige conservatieve parlementsleden de formuleringen van het Charter ernstig bekritiseerd tijdens de parlementaire behandeling van de RTCakkoorden in december 1949. Er waren toen al berichten verschenen over uitlatingen van Hatta en van Anak Agoeng die er op duidden, dat de soevereiniteitsoverdracht volgens hen ook Nieuw-Guinea zou insluiten en dat alleen het beheer van het gebied voorlopig bij Nederland zou blijven. Minister Van Maarseveen sprak die berichten tegen en hield vast aan zijn standpunt, dat de toen geldende status quo nu eenmaal inhield dat Nieuw-Guinea onder Nederlandse soevereiniteit viel en dat artikel 2 van het Charter daarom betekende dat die soevereiniteit bij Nederland bleef berusten. In de Tweede Kamer noemde het CHU-lid F.H. van de Wetering de stelling van de regering dat artikel 2 een uitzondering op artikel 1 inhield 'uiterst aanvechtbaar'. Oud-minister Welter was evenmin overtuigd door de redenering van de regering en vreesde dat, als het Internationale Gerechtshof hierover zou moeten oordelen, Nederland de zaak zou kunnen verliezen. In de Eerste Kamer kwam het CHU-lid G. Kolff uitvoerig op de kwestie terug. Naar zijn mening verschaften de formuleringen van de RTC aan Indonesië een stevige rechtsgrond voor de stelling dat het krachtens het Charter de volle soevereiniteit over Nieuw-Guinea verwierf. Kolff knoopte aan zijn betoog een voorspelling vast: hij waarschuwde dat de verschillende uitleg van het Charter ten aanzien van Nieuw-Guinea zou leiden tot een conflict tussen Nederland en Indonesië dat de stemming grondig zou bederven, zodat het doel van de RTCovereenkomst, het bereiken van een verhouding van vrede en rust tussen de beide 
landen, niet zou worden bereikt. Minister Van Maarseveen reageerde geprikkeld op de kritiek en zei niet in te zien welk Nederlands belang ermee gemoeid was om zo hardnekkig twijfel te willen wekken omtrent het standpunt van de regering.

Buiten het parlement leverde ook prof. F.C. Gerretson kritiek op de formulering van het Charter door aan zijn studenten te verkondigen dat de regering daarmee Nieuw-Guinea had verspeeld. (Dit vernam ik van de oud-politicus Willem Aantjes die tot die studenten had behoord.)

$\mathrm{Na}$ de soevereiniteitsoverdracht is men er in het parlement algemeen van uitgegaan dat de Nederlandse soevereiniteit over Nieuw-Guinea in stand gebleven was. De enige mij bekende juridische uitleg van het Charter die met mijn opvatting overeenstemt is te vinden in een artikel van dr. J.W.H. Leslie Miller in het maandblad Socialisme en Democratie van oktober 1956. Daarentegen heeft geen enkele gezaghebbende Nederlandse jurist ooit uitdrukkelijk het standpunt ingenomen dat Nederland na 1949 niet langer de soevereiniteit over Nieuw-Guinea bezat. Wel heeft prof. Röling de officiële Nederlandse interpretatie aanvechtbaar genoemd (zie Röling 1958:18-25, 28-34, 83-5) en heeft prof. Duynstee gesteld dat het Charter opzettelijk zo geredigeerd was dat er ruimte bleef voor twee tegenstrijdige interpretaties (zie Duynstee 1961:1736). Ik blijf van mening dat de op de RTC overeengekomen formules géén ruimte lieten voor de officiële Nederlandse interpretatie.

Die officiële interpretatie wordt onder meer gelogenstraft door de wijzigingen die op de RTC zijn aangebracht in de oorspronkelijk door de Nederlandse delegatie voorgestelde teksten. Ik zie hier een parallel met de manier waarop Nederland artikel 15 van de overeenkomst van Linggadjati uitgelegd heeft (zie pp. 521-2). De in 1946 oorspronkelijk door de Nederlandse delegatie voorgestelde formulering van dat artikel had een erkenning ingehouden van de staats- en volkenrechtenlijk positie van het Koninkrijk der Nederlanden, maar op wens van de Republikeinse delegatie was men een andere tekst overeengekomen waar die erkenning niet meer in voorkwam. Niettemin heeft Nederland zich zowel bij de uitleg van Linggadjati als bij die van de soevereiniteitsoverdracht steeds gedragen alsof de oorspronkelijk van Nederlandse kant voorgestelde formuleringen gehandhaafd waren gebleven.

Bij mijn (in Nederland vrijwel niet gedeelde) opvatting over de juridische betekenis van de soevereiniteitsoverdracht moet ik wel enkele kanttekeningen maken.

Ten eerste hebben officiële vertegenwoordigers van Indonesië soms zelf uitspraken gedaan die niet met die opvatting strookten. Zij verlangden bijvoorbeeld dat Nederland alsnog de soevereiniteit over Nieuw-Guinea aan Indonesië zou overdragen, in plaats van te verlangen dat Nederland alsnog zijn soevereiniteitsaanspraak ten aanzien van Nieuw-Guinea zou laten varen. Ten tweede heeft Indonesië zich nooit bereid getoond de juridische kwestie van de soevereiniteit over Nieuw-Guinea ter beslechting voor te leggen aan een onpartijdig rechterlijk orgaan zoals het Internationaal Gerechtshof. Het voerde dan aan dat het geschil met Nederland over NieuwGuinea niet een juridische maar een politieke kwestie was.

Daar staat tegenover dat de regering en het parlement van Nederland zelf zich in 1962 volstrekt inconsequent hebben opgesteld door toen geen formele daad nodig te achten voor het overdragen van de vermeende Nederlandse soevereiniteit over Nieuw-Guinea aan Indonesië (zie pp. 754 en 759-60). 
De soevereiniteitsoverdrachten

Over de behandeling van de RTC-akkoorden in het parlement van Oost-Indonesië zie Anak Agung 1980:342-3. Over de behandeling in het KNIP zie Poeze 2007:1601-6. Over de behandeling in het Nederlandse parlement zie Stempels 1950:225-45. Over het voorstel van het gouvernement in Batavia van 3 november zie NIB XX:543-4. Over de PPN zie Anak Agung 1980:344 en NIB XX:684, 711-3. Over de Nederlandse contactgroep NIB XX:686, 698, 712. Voor de samenstelling van het kabinet van de RVI NIB XX:834-5.

Terwijl verscheidene historische werken melding maken van het in augustus 1949 door de Inter-Indonesische Conferentie genomen besluit, dat de RVI haar soevereiniteit ook van de in 1945 opgerichte Republiek zou ontvangen, blijkt de ceremonie op 27 december in Jogja waarin deze soevereiniteitsoverdracht plaats vond vrijwel volledig in het vergeetboek te zijn geraakt (afgezien van een summiere vermelding in Feith 1962:57). Zelfs het grote geschiedwerk Sejarah nasional Indonesia, waarvan deel VI onder redactie van Nugroho Notosusanto deze periode bestrijkt, rept er niet over. Hetzelfde geldt voor deel 11 van het geschiedwerk Sekitar perang kemerdekaan Indonesia van Nasution. L. de Jong 1988 schrijft op pg. 984 wel over een overdracht in Jogja, maar stelt die op één lijn met de bestuursoverdracht in Batavia. Dit is een misverstand. Wat in Jogja plaats vond was géén bestuursoverdracht; het bestuur over het Republikeinse grondgebied binnen de grenzen van 19 december 1948 bleef in handen van de 'oude Republiek', die juist door deze soevereiniteitsoverdracht haar eigen status veranderde in die van een deelstaat binnen de VSI.

Ook het omvangrijke en veelzijdige ere-escorte dat Soekarno bij zijn terugkeer vergezelde wordt in de mij bekende literatuur nergens vermeld.

\section{Terugblik}

Zie over een vergelijking van de concessiebereidheid van de Republiek in 1947 en 1948 met het eindresultaat van de RTC ook L. de Jong 1988:1067.

Volgens door de Nederlandse regering aan het parlement overgelegde verliescijfers zijn tussen najaar 1945 en de wapenstilstand van augustus 1949 in Indonesië 2526 Nederlandse militairen gesneuveld, van wie 1602 behoorden tot de uit Nederland uitgezonden landstrijdkrachten, 202 tot de Nederlandse marine en 722 tot het KNIL. Van die 2526 gesneuvelden vielen er 1162 in de zeven maanden na het tweede Nederlandse offensief. Nederlandse veteranenorganisaties hanteren aanzienlijk hogere getallen voor de Nederlandse verliezen in Indonesië, onder meer door daarin ook alle militairen op te nemen die als gevolg van ziekte of ongelukken overleden zijn. 



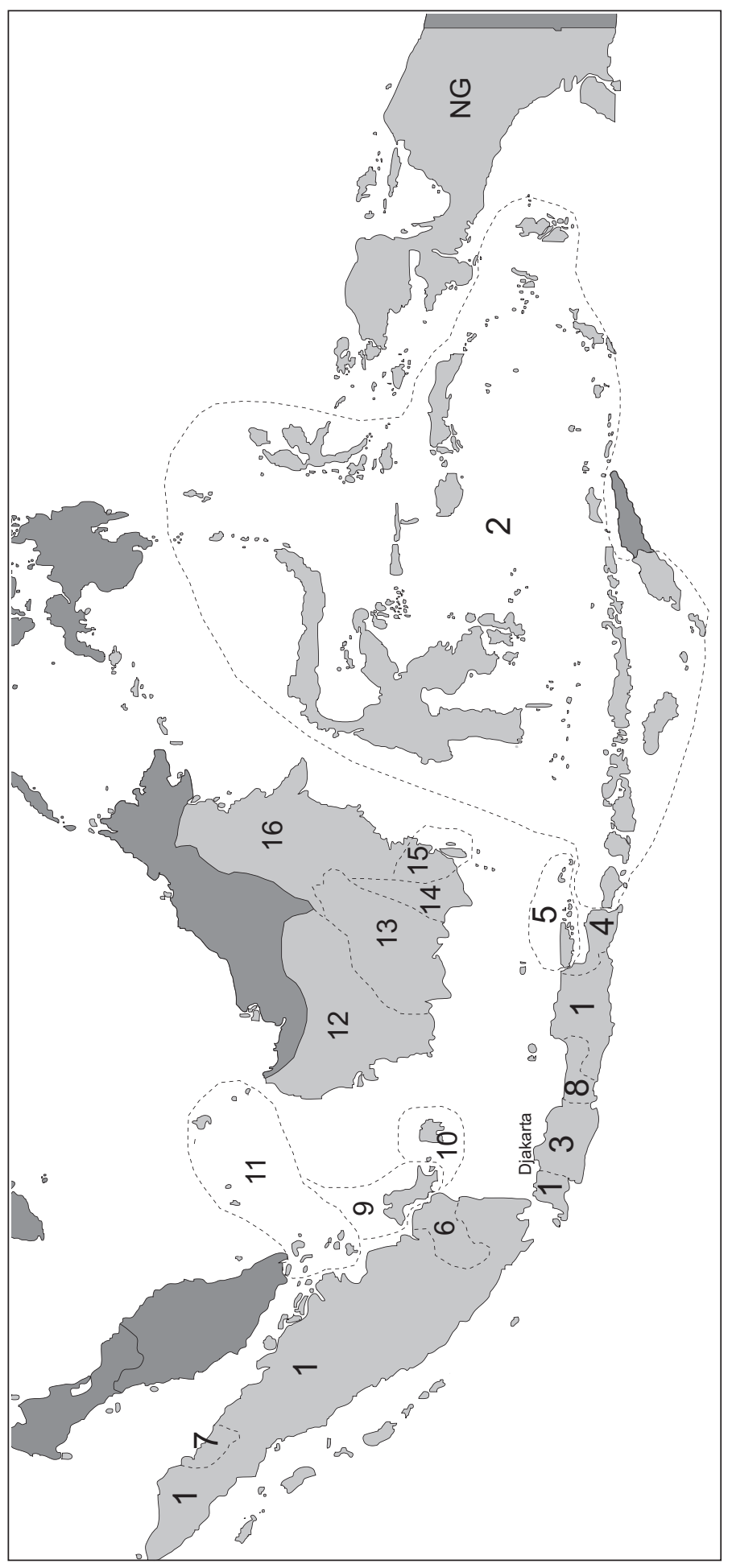

कิ?

䒕

䒕

苟

¿

है

苟芯

त

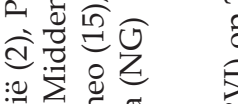

:

泀

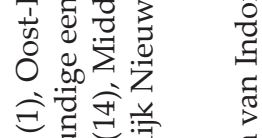

:

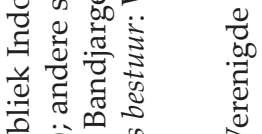

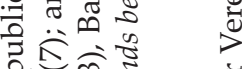

त्ञ

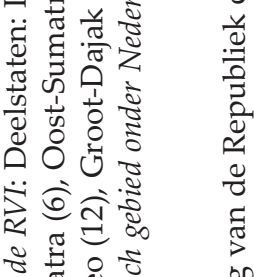

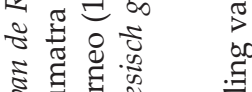

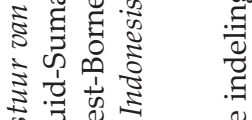

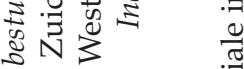

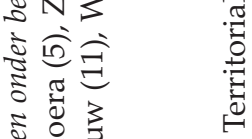

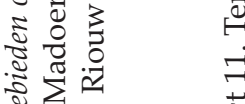

₹声氙 䒕

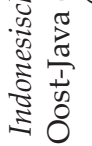


HOOFDSTUK IX

\title{
Het conflict tussen Nederland en de Republiek Indonesië
}

\author{
Laatste fase \\ Het geschil over Nieuw-Guinea
}

\section{Inleiding en overzicht}

Toen het Koninkrijk der Nederlanden zijn soevereiniteit over het voormalige Nederlands-Indië op 27 december 1949 overdroeg aan de Republiek der Verenigde Staten van Indonesië, leek er een waardig einde gekomen te zijn aan het drama dat begonnen was met de Indonesische onafhankelijkheidsproclamatie van 17 augustus 1945. In Amsterdam liet het carillon van het paleis op de Dam het Indonesia Raja horen. In Indonesië voltrok de bestuursoverdracht zich overal ordelijk. Tussen de soldaten van het Republikeinse leger en de Nederlandse militairen bleek weinig vijandigheid te bestaan. Ondanks de strijd van de afgelopen jaren beschikte Nederland nog over veel goodwill in zijn vroegere kolonie. Binnen Nederland zelf stond het merendeel van de bevolking welwillend tegenover het onafhankelijke Indonesië. Men kon dus denken 'eind goed, al goed'.

Maar het was het einde van het drama nog niet en het ging niet goed. Er volgde nog een laatste bedrijf, waarin de verstandhouding tussen Indonesië en Nederland volledig verstoord werd. Dat laatste bedrijf duurde bijna driemaal zo lang als alle bedrijven tussen 1945 en 1949 bij elkaar.

$\mathrm{Al}$ in de loop van het eerste jaar leed het vertrouwen in de wederpartij zowel aan Nederlandse als aan Indonesische kant ernstige schade. Aan Nederlandse kant was dat allereerst een reactie op de Indonesische acties tot ontmanteling van de federale staatsstructuur, die op 17 augustus 1950 uitmondden in vervanging van de Verenigde Staten van Indonesië door een unitaire Republiek Indonesië. De in 1949 op de Rondetafelconferentie overeengekomen federale structuur had voor veel Nederlanders de kern gevormd van het compromis 
tussen Nederland enerzijds en Soekarno's Republiek anderzijds. Daarom zagen zij de opheffing van die structuur als een flagrante contractbreuk. Het leek zelfs alsof alle Nederlandse inspanningen en offers in de strijd tegen Jogja voor niets geweest waren.

Intussen hadden opstandige Indonesiërs op Ambon een Republiek der Zuid-Molukken (RMS) uitgeroepen, die in september-november 1950 door de Indonesische strijdkrachten gewelddadig onderdrukt werd. Ook deze onderdrukking deed ernstige afbreuk aan het vertrouwen in het nieuwe Indonesië bij een deel van het Nederlandse publiek. Veel Nederlanders geloofden dat Ambon zich nauw met Nederland verbonden voelde en daarom buiten de nieuwe Indonesische staat wilde blijven. Sympathie voor de underdog vermengde zich bij hen met gevoelens van schuld jegens het Ambonese volk dat, naar zij meenden, door Nederland in de steek gelaten was.

Omgekeerd leidde de Nederlandse sympathie voor de RMS aan Indonesische kant juist tot ondermijning van het vertrouwen in Nederland. Veel Indonesiërs legden verband tussen de uitroeping van de RMS en enkele andere in 1950 tegen het centrale gezag ondernomen acties, in het bijzonder een mislukte aanslag op Bandung en een mislukte muiterij in Makassar. Men zag hierin vooral machinaties van koloniaalgezinde Nederlanders die het onafhankelijke Indonesië probeerden te ontwrichten.

Veel groter schade aan het Indonesische vertrouwen in Nederland werd eind 1950 aangericht door de Nederlandse weigering tot overdracht van westelijk Nieuw-Guinea. Het ging nu immers niet om de houding van individuele Nederlanders maar om de opstelling van de Nederlandse regering en het Nederlandse parlement. De op de Rondetafelconferentie voor de duur van een jaar gemaakte uitzondering voor Nieuw-Guinea was in Indonesië algemeen opgevat als een tijdelijke kunstgreep, die nodig geweest was om in het Nederlandse parlement de vereiste twee derde meerderheid voor de soevereiniteitsoverdracht te verkrijgen. Dat Nederland nu ondanks het verstrijken van die termijn Nieuw-Guinea bleef vasthouden ervoer men als een flagrante schending van het gegeven woord.

Indonesiërs konden zich volstrekt niet vinden in de Nederlandse redenering dat Nieuw-Guinea eigenlijk niet bij Indonesië hoorde. Met het kaartbeeld van de kolonie Nederlands-Indië waren zij allen vertrouwd. De Nederlandse weigering om Nieuw-Guinea over te dragen betekende een forse verminking van dat kaartbeeld. Weliswaar hadden de contacten tussen dat eiland en de rest van de kolonie zich vroeger meestal tot de Molukken beperkt, maar het koloniale regime had toen politieke tegenstanders uit de hele archipel binnen Nieuw-Guinea geïnterneerd. Ook had de nationale vrijheidsbeweging het Indonesië waarvoor zij onafhankelijkheid verlangde steeds omschreven als 'van Sabang tot Merauke'.

Men kon de Indonesische motieven voor het opeisen van Nieuw-Guinea 
wel afdoen als meer van psychologische dan van zakelijke aard, maar hetzelfde gold in veel sterkere mate voor de Nederlandse motieven om NieuwGuinea vast te houden. Die motieven waren vooral een reactie op de snelle dekolonisatie van Nederlands-Indië. Daarbij valt te bedenken dat de psychologische betekenis van Indonesië voor Nederland veel groter geweest was dan die van bijvoorbeeld India voor Groot-Brittannië of van Indochina voor Frankrijk. Terwijl het in 1945 voor de meeste Nederlanders nog vanzelf sprak dat Indonesië bij Nederland hoorde, had de dekolonisatie zich daarna in enkele jaren voltrokken. Die abrupte verandering had voor veel Nederlanders een traumatische ervaring betekend, vooral voor hen die gewend waren de band met 'Indië' als een bestanddeel van hun nationale identiteit te zien. In die kring kon het vasthouden van Nieuw-Guinea enigszins als pleister op de wonde dienen. Men stelde zich dan voor dat dit vrijwel ongerepte gebied nog een arbeidsveld voor Nederlandse ondernemingsgeest en Nederlands roepingsbesef kon worden en dat Nederland door het behoud van een presentie in Azië toch nog een zekere rol op het wereldtoneel zou kunnen spelen.

De wens om Nieuw-Guinea van de overdracht aan Indonesië uit te zonderen bestond in 1949 alleen bij een minderheid van de Nederlandse politici, al was deze minderheid sterk genoeg om een twee derde meerderheid voor een ongeclausuleerde soevereiniteitsoverdracht te kunnen blokkeren. Enkele jaren later ontwikkelde deze wens zich echter tot een meerderheidspositie in de Nederlandse binnenlandse politiek. In 1954 waren bijna alle partijen het er over eens, dat de soevereiniteit over westelijk Nieuw-Guinea bij Nederland berustte en moest blijven berusten totdat de bevolking van het gebied in staat zou zijn zelf over haar staatkundig lot te beschikken, dat er geen sprake kon zijn van onderhandelingen met Indonesië over de toekomstige status van het gebied en dat Nederland geen enkele vorm van gemengd bestuur of gedeelde verantwoordelijkheid voor het gebied zou mogen aanvaarden.

De officiële vertegenwoordigers van Nederland in Djakarta waarschuwden herhaaldelijk dat alle Nederlandse invloed in Indonesië verloren dreigde te gaan als Nederland op het punt van Nieuw-Guinea onbuigzaam bleef. In de loop der jaren werd in Nederland ook herhaaldelijk van niet-politieke kant aangedrongen op wijziging van het Nieuw-Guineabeleid, onder meer uit kerkelijke kring en uit de hoek van de Nederlandse ondernemers. Het mocht allemaal niet baten. Onder de Nederlandse politici overheerste de mening dat, als men moest kiezen tussen het behoud van Nieuw-Guinea en het behoud van goede betrekkingen met Indonesië, de keus op Nieuw-Guinea moest vallen.

De goede betrekkingen van Nederland met Indonesië bleven dan ook niet in stand. De samenwerking in het kader van de Indonesisch-Nederlandse Unie kwam niet van de grond. De Nederlandse taal raakte binnen enkele jaren buiten gebruik. In 1956 zegde Indonesië de Unie eenzijdig op. Eind 1957 begon in Indonesië een intimidatiecampagne tegen Nederlandse ingezetenen 
die ertoe leidde dat de grote meerderheid van hen het land verliet. In diezelfde periode stelde de Indonesische regering de Nederlandse bedrijven onder beheer; eind 1958 volgde de nationalisatie ervan. In mei 1960 drongen demonstranten in Djakarta het gebouw van de Nederlandse vertegenwoordiging binnen, waar ze de inventaris vernielden en de Nederlandse vlag verbrandden. Enige maanden later verbrak Indonesië de diplomatieke betrekkingen met Nederland. In het kader van de dekolonisatie na de Tweede Wereldoorlog is het nergens ter wereld tot zo'n volledige breuk tussen een voormalige kolonie en het voormalige moederland gekomen als tussen Indonesië en Nederland. Pas jaren later, toen het geschil over Nieuw-Guinea tot het verleden behoorde, bleek tussen de beide landen toch een verstandhouding zonder vijandschap mogelijk.

Bij de langdurige Nederlandse onwil om Indonesië op het punt van NieuwGuinea tegemoet te komen vallen twee kanttekeningen te maken.

Ten eerste was de Indonesische eis tot overdracht van westelijk NieuwGuinea van begin af aan in vormen gegoten die in Nederland averechts werkten. Onafgebroken stelde Soekarno het voor alsof zijn land met geen groter probleem te kampen had dan de voortgezette Nederlandse aanwezigheid in dat gebied. Al sinds 1950 dreigden Indonesische politici met represailles tegen Nederlanders en tegen Nederlandse ondernemingen als Nederland aan Nieuw-Guinea bleef vasthouden. Die dreigementen werden in de volgende jaren veelvuldig herhaald en tenslotte in 1957 en 1958 in daden omgezet. Dit maakte het voor Nederland steeds moeilijker om Indonesië ter wille te zijn, omdat niemand graag de indruk wekt voor chantage te wijken.

Ten tweede maakte Indonesië sinds 1950 een binnenlands-politieke ontwikkeling door die het Nederlandse vertrouwen in de leiding van dat land sterk verminderde. Daartoe behoorde ook de berechting van enige Nederlanders op basis van evident valse beschuldigingen. Intussen ontwikkelde de communistische partij zich tot de best georganiseerde politieke beweging van het land en keerde Soekarno zich tegen de op westerse normen gebaseerde democratie. In die situatie leek het moeilijk met de Nederlandse verantwoordelijkheid te rijmen om de bevolking van Nieuw-Guinea aan dit onberekenbare regime over te dragen.

Uiteindelijk ging Nederland daar in 1962 toch toe over, zij het via een korte tussenfase onder bestuur van de Verenigde Naties. Indonesië had inmiddels een grote strijdmacht opgebouwd die het voor de bevrijding van NieuwGuinea dreigde in te zetten. Nederland zou het gebied niet hebben kunnen verdedigen. Het was aan de Amerikaanse regering te danken dat Nederland in staat werd gesteld om nog met enig gezichtsbehoud het gebied los te laten. 


\section{De politieke situatie na de soevereiniteitsoverdracht}

Nederland had op 27 december 1949 zijn soevereiniteit over Indonesië overgedragen aan de Republiek der Verenigde Staten van Indonesië (RVI). In de eerste weken van 1950 heerste hier in het algemeen een vreedzame en ontspannen sfeer. Bijna iedereen was opgelucht dat de oorlog voorbij was. Aan de Indonesische bevolking gaf het grote voldoening dat Nederland zijn koloniaal gezag had opgegeven en de onafhankelijkheid van Indonesië had erkend. De tijdens en na de Rondetafelconferentie (RTC) gepleegde nauwe samenwerking tussen de Republiek en de BFO wettigde de hoop dat de tegenstelling tussen unitarisme en federalisme in de RVI geen bron van grote conflicten hoefde te zijn. De Nederlandse Hoge Commissaris, H.M. Hirschfeld, onderhield uitstekende betrekkingen met de regering van de RVI. De Nederlandse ondernemers (de 'planters') verwachtten hun werk op de ondernemingen grotendeels op de oude voet te kunnen voortzetten of hervatten op basis van de in de RTC overeengekomen garanties. Van de Nederlandse ambtenaren, die nu door de RTC-akkoorden RVI-ambtenaren geworden waren, hoopten velen dat de nieuwe heersers nog een tijd lang van hun deskundigheid gebruik zouden willen maken. De in de afgelopen jaren uit Nederland naar Indonesië overgebrachte militairen waren blij naar huis te kunnen terugkeren. Overigens bleek tussen deze militairen en de soldaten van de oude Republiek verrassend weinig vijandigheid te bestaan.

De soevereiniteitsoverdracht bevatte weliswaar één manco: de voorlopige handhaving van het Nederlandse bestuur over Nieuw-Guinea, maar daarover maakte men zich geen ernstige zorgen. Men wist dat deze uitzondering nodig geweest was om in het Nederlandse parlement de vereiste twee derde meerderheid te verkrijgen, maar ook dat was afgesproken de kwestie nog in 1950 op te lossen. De verwachting was wijdverbreid, ook onder Nederlanders in Indonesië, dat Nieuw-Guinea dan alsnog overgedragen zou worden.

Het hierboven geschetste beeld van vredigheid en ontspanning was niet in alle opzichten maatgevend. Zo bestonden er aan Indonesische kant nog zowel ultra-linkse als islamitische strijdgroepen die niet bereid waren zich aan het gezag van Soekarno en Hatta te onderwerpen. De 'Indische Nederlanders' (personen van gemengd Europees-Aziatische afstamming die onder het koloniale bestel de status van 'Europeanen' genoten hadden) zagen hun eigen toekomst met zorg tegemoet. Zij verloren hun bevoorrechte positie, maar kregen nog twee jaar de tijd om voor het Nederlandse dan wel het Indonesische staatsburgerschap te opteren; deden zij het eerste dan zouden ze vreemdelingen in eigen land worden. Zij maakten zich bovendien zorgen over hun persoonlijke veiligheid in het licht van het geweld waaraan hun bevolkingsgroep tijdens de bersiap-periode had blootgestaan. Wat de blanke Nederlanders betreft waren er twee groepen wier bestaan zo nauw met het koloniale bestel verweven was 
dat de soevereiniteitsoverdracht hen eigenlijk van hun bestaansgrond beroofde: de bestuursambtenaren en de KNIL-officieren. Een deel van hen koesterde nog steeds kolonialistische denkbeelden. Deze koloniaal-conservatieven vonden dat de inheemse bevolking van Indonesië onvoldoende capabel was om een moderne samenleving te laten functioneren en daarom Nederlandse leiding nodig had. Zij hadden weinig begrip voor het Indonesisch nationalisme en schreven alle inheemse steun voor de Republiek toe aan misleiding, intimidatie en terreur. Zij meenden dat Nederland in december 1948 een klinkende overwinning op de Republiek behaald had en vonden het daarom absurd dat de regering binnen een jaar Indonesië alsnog had prijsgegeven aan Soekarno. In de loop van 1950 vertrokken ongeveer vijftigduizend Nederlandse burgers uit Indonesië naar Nederland; een flink deel hiervan behoorde tot de hier genoemde groepen.

Van de Nederlandse bestuursambtenaren maakten velen op grond van hun opleiding en ervaring nog wel kans op een nieuwe werkkring in Nederland zelf. Voor de Nederlandse KNIL-officieren stond de mogelijkheid open naar de Nederlandse landmacht over te gaan. Hetzelfde gold in beginsel voor de Nederlandse onderofficieren in het KNIL (onder wie vooral Indische Nederlanders). Daarentegen waren de Indonesische KNIL-militairen in een moeilijke positie beland nu in de RTC was overeengekomen het KNIL medio 1950 op te heffen. Op grond van de in Den Haag genomen besluiten konden deze militairen nog slechts kiezen tussen twee mogelijkheden: hetzij overgaan naar de strijdkrachten van de RVI, hetzij de dienst verlaten en een andere broodwinning zoeken.

Het besluit tot opheffing van het KNIL had deze militairen ernstig geschokt. $\mathrm{Zij}$ waren er in de voorgaande jaren steeds van uitgegaan dat het KNIL de kern zou vormen van het leger van het toekomstige onafhankelijke Indonesië. Dat vertegenwoordigers van de deelstaten al in juli-augustus 1949 hadden ingestemd met de wens van de Republiek, dat niet het KNIL maar de TNI de kern van dat leger zou vormen (zie p. 646), was de meesten ontgaan. Vervolgens had het overleg over militaire onderwerpen in de RTC in Den Haag zich in volstrekte geheimhouding voltrokken. Pas na de RTC werd bekend dat het KNIL zou verdwijnen. Overigens was ook ten tijde van de soevereiniteitsoverdracht nog niet geregeld onder welke voorwaarden KNIL-militairen zouden kunnen overstappen naar de nieuwe strijdmacht, de Angkatan Perang Republik Indonesia Serikat (APRIS, Strijdkrachten van de Republiek der Verenigde Staten van Indonesië). Voor veel Indonesische KNIL-militairen was het psychologisch moeilijk om naar de APRIS over te gaan, omdat die nu eenmaal in meerderheid uit hun vroegere vijanden bestond. Bovendien was het onzeker of zij als voormalige dienaren van het koloniaal gezag binnen de APRIS wel welkom zouden zijn.

Voor geen groep gold dit alles in sterkere mate dan voor de Molukse KNIL- 
militairen, meestal 'Ambonezen' genoemd. Vooral veel christelijke Ambonezen voelden zich sterk met het Nederlandse gezag, de Nederlandse vlag en het Nederlandse koningshuis verbonden. Al generaties lang hadden velen van hen voor een loopbaan in het koloniale leger gekozen. In dat leger waren zij dikwijls juist voor de gevaarlijkste opdrachten ingezet. Eind 1948 hadden Ambonezen bijvoorbeeld nog een belangrijk aandeel gehad in de spectaculaire verovering van Jogja. Door het geheel buiten hen om genomen besluit van de Nederlandse regering tot ontbinding van het KNIL voelden de Ambonese KNIL-militairen zich dan ook bij uitstek in de steek gelaten.

\section{De APRA-affaire}

De vredige sfeer na de soevereiniteitsoverdracht werd op maandagochtend 23 januari 1950 ruw verstoord. Uit de westelijk van Bandung gelegen garnizoensplaats Tjimahi trokken toen ruim driehonderd geüniformeerde strijders de stad binnen, schoten op alle TNI-militairen die ze zagen en bezetten enige gebouwen, waaronder het hoofdkwartier van de Siliwangidivisie. Deze strijders, in meerderheid Ambonezen, bleken volgelingen te zijn van de voormalige KNIL-officier Westerling. De verovering van het hoofdkwartier had hun weinig moeite gekost omdat daar in hoofdzaak administratief personeel aanwezig was; de elite-eenheden van de Siliwangidivisie bevonden zich niet in Bandung maar in Djakarta.

Als kapitein van het KNIL had Westerling eind 1946 met een speciale eenheid een meedogenloze terreurcampagne in Zuid-Celebes gevoerd ter onderdrukking van het anti-koloniale verzet (zie pp. 517-8). Zijn eenheid was later uitgebreid tot een Korps Speciale Troepen (KST) van ruim achthonderd man. Onder de leden van dat korps was Westerling uitzonderlijk populair, maar in november 1948 had de legerleiding hem van het commando daarover ontheven. Daarna had hij het KNIL verlaten en was hij directeur geworden van een particulier transportbedrijf in West-Java. In 1949 reisde hij hier veel rond en onderhield hij allerlei contacten, onder meer met vroegere KST-collega's, met hooggeplaatste KNIL-officieren en ook met Indonesische politici. Nadat in mei het akkoord tussen Rum en Van Roijen de weg had vrijgemaakt voor terugkeer van de leiders van de Republiek naar Jogja, begon Westerling plannen te smeden voor de vorming van een strijdgroep die overheersing van Indonesië door Soekarno en Hatta zou moeten voorkomen. Hij noemde die strijdgroep Angkatan Perang Ratu Adil (APRA, Strijdkrachten van de Rechtvaardige Vorst), aanknopend bij de oude Djojobojo-legende die voorspelde dat op Java na allerlei rampspoed een rechtvaardige vorst zou komen die vrede en voorspoed brengen zou (zie pp. 56-7). Eind 1949 gingen steeds meer geruchten over deze APRA de ronde doen. Haar aanhang zou vooral 
uit ontevreden KNIL-militairen bestaan. De leiding van de Republiek maakte zich hier zorgen over, vooral voor het geval zo'n anti-Republikeins leger zou gaan samenwerken met de Darul Islam die al sommige delen van West-Java beheerste en zich uiterst vijandig tegenover de Republiek opstelde. Haar leider, Kartosuwirjo, had in augustus definitief met de Republiek gebroken door een Negara Islam Indonesia (Islamitische Indonesische Staat) uit te roepen. De situatie in West-Java werd nog verder gecompliceerd door het optreden van een strijdgroep van volgelingen van Tan Malaka onder leiding van Chaerul Saleh die de RTC-akkoorden afwees.

Op 5 januari 1950 richtte Westerling een ultimatum tot de regering van de RVI en de regering van de deelstaat Pasundan, waarin hij eiste dat de APRA als het eigen leger van Pasundan erkend zou worden tenzij de RVI binnen een week maatregelen tegen de TNI zou nemen. Namens de Nederlandse regering nam Hirschfeld scherp afstand van dit ultimatum. De Nederlandse legerleiding maakte bekend dat desertie van onder Nederlands bevel staande soldaten streng zou worden bestraft. Het ultimatum verstreek overigens zonder dat er iets gebeurde.

Toen APRA-aanhangers op 23 januari een overval op Bandung pleegden, vreesden velen dat Westerling alsnog een burgeroorlog in West-Java zou ontketenen. Hatta pleegde onmiddellijk overleg met Hirschfeld; de Nederlandse regering liet weten dat zij bereid was de RVI-regering militair bij te staan. De overvallers bestonden voornamelijk uit KST-militairen en uit voormalige KNIL-soldaten die al naar de APRIS overgegaan waren. Al spoedig bleek echter dat hun actie weinig om het lijf had. Zij wisten niet wat ze verder moesten doen en lieten zich nog dezelfde middag door hoge KNIL-officieren overhalen om hun avontuur te beëindigen en de bezette gebouwen te verlaten. De gedeserteerde militairen keerden grotendeels naar hun kampementen terug, waar ze werden ontwapend en in hechtenis genomen. Intussen brachten Nederlandse militaire vliegtuigen soldaten van de Siliwangidivisie naar Bandung over. Het APRA-avontuur had het leven gekost aan drieënnegentig TNI-militairen en zes burgers.

Westerling zelf had in het voorafgaande weekeinde wel aan de voorbereiding van de overval deelgenomen, maar was zondagavond naar Djakarta vertrokken. Het was zijn bedoeling geweest ook daar een machtsgreep te ondernemen en de RVI-regering uit te schakelen, maar van dit plan kwam niets terecht, onder meer omdat de samenzweerders geen beschikking kregen over de wapens waarop ze gerekend hadden. Na de mislukte machtsgreep in Bandung bleef Westerling wekenlang onvindbaar, maar eind februari dook hij plotseling in Singapore op. Het bleek dat hij Indonesië met hulp van Nederlandse officieren had kunnen verlaten.

De KNIL-militairen die aan de aanslag op Bandung deelgenomen hadden kwamen er minder goed af. Midden 1950 veroordeelde de Nederlandse krijgs- 
raad honderdvierentwintig van hen wegens desertie tot gevangenisstraffen van maximaal een jaar, waartoe ze naar Nieuw-Guinea werden overgebracht.

Hoewel de Nederlandse regering zich in de APRA-affaire duidelijk achter de regering van de RVI gesteld had, werd de Indonesisch-Nederlandse verstandhouding door de aanslag op Bandung en de nasleep ervan ernstig geschaad. De affaire bevestigde het vermoeden, dat een deel van de Nederlanders in Indonesië de soevereiniteitsoverdracht afkeurde en ongelukkig was over de overheersende positie van de Republikeinse leiders binnen de RVI. Onder die Nederlanders had Westerling kennelijk aanmoediging en steun gekregen voor zijn subversieve activiteiten. Het wekte extra ergernis dat Nederlandse officieren ook na de mislukte aanslag op Bandung geholpen hadden om hem het land uit te werken en aan de Indonesische justitie te onttrekken. Blijkbaar was men aan Nederlandse kant diep bezorgd over de onthullingen die Westerling zou kunnen doen als hij in Indonesië terecht moest staan. Een andere grond voor Indonesische ergernis en teleurstelling was het leedvermaak waarmee een deel van het Nederlandse publiek op de affaire reageerde. Veel Nederlanders vonden het prachtig dat de APRA in Bandung de TNI vernederd had en bewonderden als een heldendaad wat in feite een even brute als klungelige actie geweest was.

Tot de nasleep van de affaire behoorde ook dat de Indonesische politie een groot aantal personen arresteerde die van medeplichtigheid aan de activiteiten van Westerling verdacht werden. De meeste Nederlanders onder de gearresteerden kwamen weer spoedig vrij, maar sommigen bleven tot 1953 in hechtenis.

\section{Ontmanteling van de federale staatsstructuur}

Het was een onderdeel van de RTC-overeenkomst dat de nieuwe Republiek, waaraan Nederland zijn soevereiniteit over Indonesië overdroeg en waarvan het de onafhankelijkheid erkende, een federale staat zou zijn. De samenstellende delen van die federatie werden in de voorlopige constitutie van de RVI opgesomd. Het waren er zestien in totaal, zeven deelstaten en negen autonome gebieden. Deze federale structuur was zowel onevenwichtig als gecompliceerd: onevenwichtig wegens enorme onderlinge verschillen in bevolkingsomvang en grondgebied, gecompliceerd wegens diverse onderlinge verschillen in bevoegdheden en organisatie.

De Nederlandse regering had in haar conflict met de oorspronkelijke Republiek van 1946 af het standpunt ingenomen, dat een onafhankelijk Indonesië alleen maar goed zou kunnen functioneren als het een federatie vormde. Hoe dit uitgangspunt te rijmen viel met het feit dat Nederland zelf de kolonie Nederlands-Indië altijd unitaristisch bestuurd had legde de regering 
niet uit. Wat de vorm van die federatie betreft had Van Mook oorspronkelijk gepleit voor een verdeling in vier grote deelstaten, Java, Sumatra, Borneo en Oost-Indonesië. In het akkoord van Linggadjati van eind november 1946 had ook de Republiek aanvaard dat Indonesië een federatie zou worden, en wel in de vorm van drie deelstaten, de Republiek zelf (die Java en Sumatra zou omvatten), Borneo en Oost-Indonesië. Maar naast de Republiek en OostIndonesië stichtte het Nederlands-Indische gouvernement in 1948-1949 nog veertien andere deelstaten en autonome gebieden, waarvan zes op grondgebied dat volgens het akkoord van Linggadjati onder de Republiek zou vallen. Meer en meer deed men het van Nederlandse kant voorkomen alsof het bij de dekolonisatie van Indonesië niet ging om een conflict tussen Nederland en de Republiek, maar om een interne tegenstelling binnen Indonesië tussen unitaristen en federalisten.

De federale conceptie was op zichzelf niet onverenigbaar met het Indonesische onafhankelijkheidsstreven. In de jaren twintig hadden verscheidene nationalisten, onder wie ook Hatta en Soekarno, een federaal Indonesië voorgestaan. Pas tijdens de Japanse bezetting ontwikkelde zich een duidelijke voorkeur voor de unitaire staatsvorm (zie p. 342). Daarna was de federale staatsvorm nog veel sterker in diskrediet geraakt toen Nederland de keuze tussen eenheidsstaat en bondsstaat tot een keuze voor of tegen de Republiek maakte.

Na de soevereiniteitsoverdracht openbaarde zich in Indonesië een wijdverbreide weerzin tegen handhaving van de federale staatsstructuur. Velen zagen de lappendeken van deelstaten en autonome gebieden vooral als een product van Nederlandse verdeel-en-heers-politiek. Het verzet hiertegen werd onder meer uitgedragen door Republikeinse militairen die uit de guerrillagebieden terugkeerden. $\mathrm{Al}$ in januari kwamen in verscheidene steden comités tot stand die opriepen tot herstel van de eenheidsstaat.

Begin januari had Westerling te kennen gegeven dat hij met zijn APRA de deelstaat Pasundan wilde beschermen tegen overheersing door de Republiek van Jogja. Het resultaat van de aanslag op Bandung was precies het omgekeerde. Al twee dagen daarna werden twee ministers van deze deelstaat gearresteerd op verdenking van samenspanning met de aanslagplegers. Op 27 januari zei het parlement van Pasundan zijn vertrouwen in het deelstaatkabinet op en sprak het zich uit voor overdracht van het bestuur aan de centrale regering. De president van Pasundan, Wiranatakusuma, legde kort daarna zijn functie neer; ook hij bleek met Westerling gesproken te hebben.

Van februari tot april groeide de agitatie voor herstel van de eenheidsstaat uit tot een politieke storm. In bijna alle federale gebieden vonden massabetogingen plaats die de vertegenwoordigende lichamen van deze gebieden onder druk zetten om hun autonome status op te heffen. De heftigheid van die agitatie riep herinneringen aan de bersiap-tijd op (zie pp. 399-403). Zo 
moesten leden van vertegenwoordigende lichamen zich soms een weg banen door een tierende menigte demonstranten voordat ze de vergadering konden bereiken waarin de kwestie aan de orde zou komen. De minister van binnenlandse zaken van de centrale regering, Anak Agung, die voor de soevereiniteitsoverdracht premier van Oost-Indonesië en vice-voorzitter van de BFO geweest was, wilde zich niet inspannen voor behoud van de federale structuur voorzover die niet levensvatbaar was. Op 8 maart kondigde de regering een noodwet af die voor federale gebieden de mogelijkheid opende zich bij andere federale gebieden aan te sluiten. Op basis hiervan sloot het merendeel van die gebieden zich in de volgende weken aan bij de deelstaat Republiek Indonesië (de Jogjase Republiek). Deze aansluitingen werden telkens door het parlement van de RVI bekrachtigd. Begin april bestonden er naast de Jogjase Republiek nog maar drie andere federale gebieden, Oost-Indonesië, Oost-Sumatra en West-Borneo.

Op 5 april werd bekendgemaakt dat het hoofd van West-Borneo, sultan Hamid II van Pontianak, gearresteerd was wegens samenspanning met Westerling. Hamid, die voorzitter van de BFO geweest was en in het KNIL de rang van generaal-majoor bekleedde, had verwacht in de RVI minister van defensie te worden of een andere belangrijke functie te krijgen. Tot zijn teleurstelling was hij alleen minister zonder portefeuille geworden, terwijl Anak Agung wel een belangrijke plaats in de centrale regering kreeg. Volgens na zijn arrestatie in de pers verschenen berichten zou Hamid met Westerling hebben afgesproken dat deze het kabinet-Hatta gewapenderhand zou uitschakelen, waarna er een nieuwe centrale regering zou moeten komen waarin Hamid wel een zware functie zou vervullen en overheersing van Indonesië door de TNI zou tegenhouden. Het bericht over de arrestatie van Hamid leidde in West-Borneo tot versterkte agitatie voor aansluiting bij de Jogjase Republiek. Op 15 april werd ook deze aansluiting door het RVI-parlement bekrachtigd.

\section{Mislukte muiterij in Makassar}

Van alle door het Nederlands-Indische gouvernement opgerichte deelstaten leek de eind 1946 gevormde staat Oost-Indonesië het meest stevig gevestigd. In tegenstelling tot de andere federale gebieden was de vorming ervan uitdrukkelijk in het akkoord van Linggadjati voorzien; het was dan ook de enige deelstaat die door de Republiek formeel erkend was. Ook zijn territoriale omvang was uitzonderlijk: Celebes plus de Kleine Sunda-eilanden plus de Molukken. Hiertoe behoorden onder meer de twee Indonesische gebieden die het meest Nederlands-georiënteerd waren: Ambon en de Minahasa (waarvan de bevolking Menadonezen genoemd werd). Daar stond tegenover dat Oost-Indonesië ook een lange geschiedenis van verzet tegen de Nederlandse overheersing 
kende en dat sommige delen ervan pas na 1900 volledig onder Nederlands gezag gebracht waren: Zuid-Celebes, Midden-Celebes en de eilanden Bali, Ceram, Sumbawa en Flores (zie pp. 125-8). Bovendien waren niet alleen veel KNIL-militairen maar ook verscheidene prominente Republikeinse politici van Ambonese of Menadonese afkomst.

Sommige leidende Oost-Indonesische politici wilden de deelstaat graag handhaven. Dit gold onder meer voor de president van Oost-Indonesië, de Balinese aristocraat Sukawati, en ook voor zijn schoonzoon Anak Agung, die tot eind 1949 premier van Oost-Indonesië geweest was en nu in de centrale RVI-regering minister van binnenlandse zaken was. Een bijzonder felle antiRepublikein was de Ambonees Chris Soumokil; in de deelstaat Oost-Indonesië was hij procureur-generaal, minister van justitie en waarnemend premier geweest, maar sinds de laatste kabinetsformatie maakte hij geen deel meer van de regering uit. Hij zag nog liever dat Oost-Indonesië uit de RVI zou treden dan dat het in de Jogjase Republiek zou opgaan. Daarentegen telde het OostIndonesische parlement een aanzienlijk aantal leden die geen bezwaar hadden tegen een unitaire staatstructuur voor Indonesië.

Een belangrijk verschil van de situatie in Oost-Indonesië met die in de meeste andere federale gebieden was dat zich hier geen militairen bevonden van de TNI, het Republikeinse leger, maar wel een groot aantal militairen uit het KNIL, het koloniale leger. Intussen kwam in de eerste maanden van 1950 de overgang van KNIL-militairen naar de nieuwe federale strijdmacht, de APRIS, geleidelijk op gang. Eind januari werd bekend gemaakt dat het KNIL op 26 juli ontbonden zou worden. De meeste KNIL-militairen in OostIndonesië waren wel bereid naar de APRIS over te gaan, mits ze in dit gebied gelegerd zouden blijven. Zo ging eind maart in Makassar een KNIL-compagnie naar het federale leger over die geleid werd door kapitein Andi Abdul Aziz. Hij was op Celebes geboren maar in Nederland opgegroeid en had daar tijdens de Duitse bezetting aan het verzet deelgenomen.

Evenals in de hoofdplaatsen van andere federale gebieden werd in maart in Makassar gedemonstreerd voor aansluiting bij de Republiek. Daar stond tegenover dat hier ook demonstraties voor handhaving van de deelstaat plaatsvonden. De spanning in de stad steeg, onder meer door de komst van enige officieren uit Java die een territoriaal APRIS-commando voor Oost-Indonesië moesten opzetten. De Oost-Indonesische regering had eind december met de regering van de RVI afgesproken dat geen APRIS-eenheden zonder haar instemming in Oost-Indonesië gelegerd zouden worden. Niettemin werd begin april bekend dat een uit voormalige TNI-soldaten bestaand APRIS-bataljon in twee schepen onderweg was naar Makassar. Onder de voorstanders van handhaving van de deelstaat wekte dit grote ongerustheid, omdat TNI-eenheden in andere federale gebieden hun positie gebruikt hadden om kracht bij te zetten aan de beweging voor de eenheidsstaat. Soumokil, die kort daarvoor weer tot 
procureur-generaal van Oost-Indonesië benoemd was, besloot zich hiertegen te verzetten en kreeg hierbij steun van Sukawati en Aziz.

Op 5 april 1950 bezette Aziz met zijn compagnie en met steun van een paar honderd KNIL-militairen verschillende strategische punten in Makassar en het kantoor van de uit Java overgekomen APRIS-officieren, terwijl Soumokil een aantal voorstanders van aansluiting bij de Republiek liet arresteren. Aziz verklaarde dat het hem er alleen om te doen was ontscheping van het bataljon voormalige TNI-soldaten te beletten. Op het eerste gezicht leek zijn actie het gevaar in te houden dat Oost-Indonesië zich los zou maken van de RVI. Maar wat de RVI-regering vreesde en wat Aziz hoopte gebeurde niet: de Oost-Indonesische regering stelde zich niet achter zijn actie, zijn voorbeeld leidde niet tot muiterijen elders in Oost-Indonesië en ook in Makassar zelf steunde de meerderheid van de KNIL-militairen hem niet. Op 11 april riep de RVI-regering Aziz op binnen twee dagen naar Djakarta te komen om zich te verantwoorden; zij zond daartoe een vliegtuig naar Makassar en beloofde hem een vrijgeleide.

Toen Aziz hier niet op inging hield president Soekarno op 13 april een dreigend getoonzette radiorede; daarin noemde hij hem nooit bij naam maar sprak hij telkens over 'die jonge officier wiens naam ik niet zal uitspreken'. Zijn rede eindigde met een bevel aan de strijdkrachten om aan de opstand een eind te maken. De volgende dag vloog Aziz op aandrang van Sukawati alsnog naar Djakarta; hij dacht dat zijn vrijgeleide verlengd was, maar werd bij aankomst meteen gevangen genomen. Het APRIS-bataljon ging bij Makassar aan land; de volgelingen van Aziz gaven zich binnen enkele dagen over. Dit bataljon bestond overigens geheel uit soldaten van Oost-Indonesische afkomst. Soumokil had Makassar intussen verlaten. Op 25 april zei het parlement van Oost-Indonesië op voorstel van een Ambonees parlementslid het vertrouwen in de Oost-Indonesische regering op. Er werd een nieuwe regering gevormd onder een pro-Republikeinse premier. Evenals Westerling in januari had Aziz met zijn actie het omgekeerde bewerkstelligd van wat hij beoogd had.

\section{Uitroeping van de Republiek der Zuid-Molukken}

Het eiland Ambon in de Zuid-Molukken was het eerste gebied in Indonesië geweest waar de Nederlanders zich vestigden, nadat zij daar in 1605 op aandrang van inheemse hoofden de Portugezen hadden verdreven (zie p. 27). Die hoofden hadden zich toen bij verdrag tot eeuwige trouw aan Nederland verbonden en een flink deel van de bevolking was tot het christendom overgegaan. Eeuwenlang waren mannen uit Ambon als soldaten in Nederlandse dienst getreden. Men placht niet alleen de bevolking van Ambon zelf maar ook die van de naburige Zuid-Molukse eilanden als 'Ambonezen' te betitelen. 
Sinds de negentiende eeuw waren veel Ambonezen naar andere delen van Indonesië getrokken, niet alleen als militairen maar onder meer ook als ambtenaren en onderwijzers. Ten tijde van de soevereiniteitsoverdracht bevonden tienduizenden Ambonezen zich buiten de Zuid-Molukken; een aanzienlijk deel van hen was niet in de Molukken geboren en opgegroeid.

Traditioneel plachten veel Ambonezen zich te zien als steunpilaren van het Nederlandse gezag. Dit gold in het bijzonder voor de Ambonese KNILmilitairen. Na 1945 was op Java in Ambonese kring maar met steun van Nederlandse officieren een anti-Republikeinse organisatie opgericht, de Persatoean Timoer Besar (PTB, Vereniging Grote Oost), die ernaar streefde de Molukken af te scheiden van de rest van Indonesië onder behoud van een nauwe band met Nederland (zie pp. 657-8). Daarentegen steunden veel Ambonese intellectuelen de Indonesische vrijheidsbeweging en speelden sommige Ambonezen een belangrijke rol in de Republiek, zoals Johannes Leimena, leider van de protestants-christelijke partij Parkindo en minister van volksgezondheid in de RVI-regering. Er bestond zelfs een Ambonees legeronderdeel binnen de TNI: het Pattimura-bataljon, genoemd naar een ZuidMolukse opstandeling uit het begin van de negentiende eeuw (zie pp. 78-9).

In de eerste maanden van 1950 heerste op het eiland Ambon geen eensgezindheid over de toekomst van de Zuid-Molukken. De PTB had er enige aanhang, maar ook een Republikeinsgezinde partij was er actief en de meeste leden van de Zuid-Molukkenraad steunden het separatistische streven niet. Eén van de meest anti-Republikeinse leden van die Raad was J.A. Manusama, een uit Java afkomstige Ambonees die in 1947 hoofd van een middelbare school op Ambon geworden was. De separatistische gelederen werden begin 1950 versterkt doordat het KNIL een aantal Molukse militairen in afwachting van hun demobilisatie naar Ambon overbracht. Daardoor bevonden zich nu ruim tweeduizend KNIL-militairen op het eiland, waaronder een bewapende KST-compagnie.

In april raakte de politieke ontwikkeling op Ambon in een stroomversnelling als gevolg van de muiterij in Makassar. Op 18 april leidde Manusama een massabetoging waarin hij zich fel keerde tegen het streven naar een Indonesische eenheidsstaat. Hij deed een beroep op de regering van Oost-Indonesië om zich tegen de vorming daarvan te verzetten en zo nodig een onafhankelijke staat Oost-Indonesië te stichten. Intussen bevond zich op Ambon ook Soumokil; hij had Makassar na de mislukking van de muiterij tijdig kunnen verlaten. Het werd al spoedig duidelijk dat de Oost-Indonesische regering niet van plan was zich tegen de RVI te keren. Met steun van KST-militairen wisten Manusama en Soumokil nu de voorzitter van de Zuid-Molukkenraad, J.H. Manuhutu, te bewegen tot het proclameren van een onafhankelijke Republik Maluku Selatan (RMS, Republiek der Zuid-Molukken). De proclamatie vond op 24 april plaats en kreeg een geestdriftig onthaal bij een deel van de Ambonese 
bevolking. Er werd een regering gevormd met Manuhutu als president en Soumokil als minister van buitenlandse zaken.

De RVI-regering probeerde in eerste aanleg langs vreedzame weg aan de Ambonse rebellie een eind te maken. $\mathrm{Zij}$ zond eind april per schip een verzoeningsmissie naar Ambon onder leiding van minister Leimena. KST-militairen verhinderden echter contact tussen deze missie en de leiders van de RMS. Wel konden enige honderden Nederlanders midden mei Ambon per schip verlaten, samen met bijna tweehonderd KNIL-militairen die niet aan de rebellie mee wilden doen. De andere Molukse KNIL-militairen hadden intussen hun Nederlandse officieren ontwapend en formeel hun dienstverband met het KNIL opgezegd.

\section{Opheffing van het KNIL}

Volgens de militaire bepalingen van de Rondetafelconferentie (zie p. 655) zouden de uit Nederland naar Indonesië gezonden landstrijdkrachten zo mogelijk binnen zes maanden gerepatrieerd worden. De Nederlandse KNIL-militairen zouden deels kunnen overgaan naar de Nederlandse landmacht (officieel Koninklijke Landmacht geheten, afgekort KL) en deels de dienst moeten verlaten. De Indonesische KNIL-militairen zouden deels kunnen overgaan naar de strijdkrachten van de RVI (de APRIS) en deels eveneens de dienst moeten verlaten. Zes maanden na bekendmaking van de voorwaarden voor overgang naar de APRIS zou het KNIL ophouden te bestaan. De wapens, uitrusting, gebouwen en terreinen van het KNIL zouden aan de RVI worden overgedragen. De Nederlandse marine zou binnen een jaar uit Indonesië worden teruggetrokken, maar zou in die tijd nog taken voor de RVI blijven verrichten; ook zou Nederland een aantal marineschepen aan de RVI overdragen. Verder zou een Nederlandse militaire missie in Indonesië behulpzaak zijn bij de opbouw en opleiding van de strijdkrachten van de RVI.

In de jaren 1945-1949 had Nederland ruim honderdtwintigduizend KL-militairen naar Indonesië overgebracht. Ten tijde van de soevereiniteitsoverdracht waren hiervan de oorlogsvrijwilligers en het grootste deel van de 7 December-divisie al gerepatrieerd en bevonden zich nog ruim zeventigduizend KL-militairen in Indonesië. Nederland beschikte niet over voldoende eigen scheepsruimte om dit aantal binnen zes maanden af te voeren en moest daarom buitenlandse scheepsruimte huren; hierdoor konden bijna al deze militairen nog voor september 1950 Indonesië verlaten.

Op 26 januari 1950 maakte de RVI-regering de voorwaarden voor overgang naar de APRIS bekend. Dit bracht mee dat de Nederlandse regering het KNIL per 26 juli 1950 moest opheffen.

Het KNIL omvatte ten tijde van de soevereiniteitsoverdracht ongeveer 65.000 
man, van wie 15.000 de Nederlandse nationaliteit en 50.000 de Indonesische nationaliteit bezaten. Bijna 8000 van de Nederlandse KNIL-militairen gingen over naar de KL en vertrokken naar Nederland (waar velen van hen nog nooit geweest waren; dit betrof vooral Indo-Europeanen). Van de 50.000 Indonesische KNIL-militairen bestond de meerderheid uit Javanen en ongeveer een vijfde deel uit Ambonezen en Menadonezen. Uiteindelijk zijn ongeveer 26.000 van hen naar de APRIS overgegaan, maar voor een deel gebeurde dat pas na de opheffing van het KNIL. De KNIL-militairen die de dienst verlieten hadden op grond van een vooroorlogse regeling er recht op te worden gedemobiliseerd op een plaats van hun keuze binnen Indonesië. De belangrijkste KNIL-militair die naar de APRIS overging was de Ambonese luitenant-kolonel Julius Tahija. Hij had in de Tweede Wereldoorlog aan de strijd tegen Japan deelgenomen, had de Nederlandse delegatie geadviseerd in de conferentie op de Hoge Veluwe, was adjudant van generaal Spoor geweest en had als lid van de BFO-delegatie de Rondetafelconferentie bijgewoond. Hij wist veel KNIL-militairen ertoe over te halen de overstap naar de APRIS te wagen en het was vooral aan zijn invloed te danken dat de meeste Ambonese militairen in Makassar zich in april afzijdig hielden van de muiterij van kapitein Aziz.

Toen in juli 1950 de datum naderde waarop het KNIL opgeheven zou worden, stond echter voor een deel van de Indonesische KNIL-militairen nog niet vast of ze de militaire dienst zouden verlaten dan wel naar de APRIS zouden overgaan. In een aantal gevallen hadden zij zelf nog niet definitief gekozen, in andere gevallen hadden zij wel gekozen maar had de Indonesische overheid daar nog geen beslissing op genomen. Zoals eerder vermeld vonden vooral veel Ambonese militairen het moeilijk om naar de APRIS over te gaan. De problemen werden nog veel groter na de proclamatie van de Republiek der Zuid-Molukken. Een deel van die militairen verlangde nu op Ambon gedemobiliseerd te worden.

Omdat het onmogelijk was deze problemen voor de opheffingsdatum op te lossen kwamen de Nederlandse en de Indonesische regering overeen, dat de nog niet overgegane of gedemobiliseerde KNIL-militairen met ingang van 24 juli 1950 tijdelijk de status van KL-militair zouden krijgen. Deze militairen en hun gezinnen werden in doorgangskampen op Java ondergebracht. Enige honderden Nederlandse KL-militairen zouden nog tot uiterlijk eind december in Indonesië kunnen blijven om die kampen te beveiligen.

\section{Herstel van de Indonesische eenheidsstaat}

Van de vijftien federale gebieden die de RVI ten tijde van de soevereiniteitsoverdracht telde naast de Jogjase Republiek sloten dertien zich voor het eind van april bij die Republiek aan (zie p. 695). De twee toen resterende gebieden 
waren Oost-Indonesië en Oost-Sumatra. De president van Oost-Indonesië, Sukawati, voelde er niet voor zijn deelstaat in de Jogjase Republiek te laten opgaan, maar na de onderdrukking van de muiterij in Makassar verklaarde hij wel te willen meewerken aan de vestiging van een Indonesische eenheidsstaat, mits zijn deelstaat daarbij op dezelfde voet zou worden behandeld als die Republiek. De president van Oost-Sumatra, Mansur, die zich in 1948 en 1949 scherp tegenover de Republiek opgesteld had, sloot zich hierbij aan. Begin mei kwamen Sukawati en Mansur met Hatta overeen, dat hun deelstaten samen met de Jogjase Republiek de nieuwe eenheidsstaat zouden stichten; zij machtigden Hatta om hun deelstaten te vertegenwoordigen bij het daartoe met Jogja te voeren overleg.

Ter voorbereiding van de eenheidsstaat werd een commissie ingesteld die in de eerste plaats een nieuwe grondwet moest ontwerpen. Voorzitter werd de RVI-minister van justitie, Supomo, die ook een belangrijk aandeel had gehad in de opstelling van zowel de Republikeinse grondwet van 1945 als de federale grondwet van 1949. Men had het zich nu eenvoudig kunnen maken door uit die laatste grondwet alleen die bepalingen te schrappen die op de federale staatstructuur betrekking hadden, maar zo eenvoudig ging het niet. De commissie verdiepte zich ook uitvoerig in allerlei andere aspecten van het nieuwe staatsbestel. Na ruim twee maanden bereikte ze overeenstemming over een ontwerp dat gedeeltelijk aan de grondwetten van 1945 en 1949 ontleend was en gedeeltelijk nieuw geformuleerd was. Zo keerde het recht op onderwijs, dat in de eerste grondwet uitdrukkelijk erkend was maar in de RVI-grondwet niet meer voorkwam, weer in de oude formulering terug. De nieuwe eenheidsstaat zou 'Republiek Indonesië' heten, precies zoals de in augustus 1945 gevormde staat. Evenals de grondwetten van 1945 en 1949 zou de nieuwe grondwet slechts een voorlopig karakter dragen, maar de grondwet van 1950 onderstreepte dit door zich uitdrukkelijk 'Voorlopige grondwet' te noemen. Bovendien bepaalde ze dat de definitieve grondwet zou worden vastgesteld door een 'Konstituante' waarvan de leden door de Indonesische onderdanen in algemene, vrije en geheime verkiezingen zouden worden gekozen.

De commissie behandelde verder ook enige andere kwesties, zoals de samenstelling van het nieuwe parlement en de verdeling van het grondgebied van de eenheidsstaat in provincies. In de tweede week van augustus werd de nieuwe staatsinrichting met ruime meerderheden goedgekeurd door het parlement van de RVI en door het Werkcomité van het KNIP (het voorlopige parlement van de Jogjase Republiek). Op 17 augustus 1950, de vijfde verjaardag van de onafhankelijkheidsproclamatie, maakte Soekarno bekend dat de RVI plaats had gemaakt voor een nieuwe unitaire Republiek Indonesië. Soekarno en Hatta bleven president en vicepresident, maar Hatta zou zijn functie van minister-president neerleggen. De voorzitter van de Masjumi, Mohammad Natsir, kreeg opdracht een nieuw kabinet te vormen. 
De transformatie van de RVI in de nieuwe Republiek Indonesië had voor de Indonesiërs een betekenis die verder reikte dan de vraag of hun staat beter in provincies dan in deelstaten verdeeld kon worden. Dat laatste was een kwestie waar men verschillend over kon denken, maar het stond buiten twijfel dat de federale structuur van de RVI een Nederlandse schepping geweest was. De Nederlandse soevereiniteitsoverdracht aan die RVI had het onafhankelijke Indonesië daardoor met een koloniale erfenis belast. Ook Indonesiërs die geen vurige voorstanders van een unitaire staatsstructuur waren konden daarom in de opheffing van deze federale structuur een voltooiing zien van de Indonesische vrijheidsstrijd.

In Nederland viel de transformatie van de RVI in een nieuwe unitaire Republiek daarentegen buitengewoon slecht. Men kon wel betogen, zoals Hirschfeld deed, dat dit een interne kwestie van het soevereine Indonesië was die men eenvoudig had te accepteren, maar de meeste Nederlanders zagen het anders. Voor hen was de federale staatsvorm geen zaak waar Indonesië vrij over kon beslissen, maar een centraal bestanddeel van het akkoord tussen Nederland en de oude Republiek dat ten grondslag lag aan de RTCovereenkomst. Dat akkoord had zware Nederlandse concessies ingehouden: aanvaarding dat Indonesië onafhankelijk zou worden met Soekarno als president en met de Jogjase republiek als machtigste bestanddeel. Daar hadden (afgezien van de kwestie-Nieuw-Guinea) twee belangrijke Republikeinse concessies tegenover gestaan: aanvaarding dat het onafhankelijke Indonesië een federale staat zou zijn en aanvaarding dat Indonesië en Nederland samen een Unie zouden vormen onder de Nederlandse koningin. Die twee zaken waren trouwens al in 1946 in het akkoord van Linggadjati neergelegd en Nederland had ze bovendien in 1948 in zijn eigen grondwet verankerd (zie p. 582). Omdat de federale structuur een basiselement van de RTC-overeenkomst vormde, zagen veel Nederlanders in de opheffing van die structuur een flagrante contractbreuk. Sommigen verdachten de leiders van de Republiek ervan tijdens de RTC vals spel gespeeld te hebben en slechts in schijn met de federale structuur te hebben ingestemd om er na de soevereiniteitsoverdracht zo gauw mogelijk van af te komen. Men kon moeilijk geloven dat het herstel van de eenheidsstaat een onontkoombare tegemoetkoming aan een spontane volksbeweging geweest was; er waren aanwijzingen dat de agitatie in de eerste maanden van 1950 van bovenaf gedirigeerd was en dat actievoerders soms intimiderend waren opgetreden.

Hoewel het niet vreemd is dat het herstel van de Indonesische eenheidsstaat door velen in Nederland als een contractbreuk beschouwd werd, kan men de intensiteit van de daar gevoelde verontwaardiging en frustratie moeilijk begrijpen als men alleen naar de zaak kijkt waar het formeel om ging, namelijk de vraag of Indonesië beter in deelstaten dan in provincies verdeeld kon worden. Dit was immers een kwestie waar Nederland geen enkel zakelijk 
belang bij had. In de Nederlandse politiek had deze kwestie echter een betekenis gekregen die daar ver bovenuit ging.

Tijdens het conflict met de Republiek had Nederland in alle delen van Indonesië die weer onder Nederlands gezag kwamen te staan Indonesiërs gevonden die bereid waren dit gezag te erkennen en op die basis met Nederland samen te werken. Samen met zulke coöperatieve Indonesiërs had Nederland een reeks autonome gebieden en deelstaten opgericht, eerst buiten Java en Sumatra en later ook binnen die eilanden zelf. Uiteindelijk had het de Republiek zelf niet kunnen uitschakelen, maar het had zich gericht op het bereiken van een compromis waardoor er in het onafhankelijke Indonesië niet alleen voor Republikeinse nationalisten een rol weggelegd zou zijn maar ook voor Indonesiërs die het Nederlandse gezag hadden willen erkennen. De in de RTC bevestigde federale staatsstructuur had hier de belangrijkste waarborg voor moeten vormen. Daarom leek dit compromis door de staatkundige metamorfose van 17 augustus 1950 kapot te zijn gemaakt. De federalisten waren uitgeschakeld en Nederland zag zich net als in 1945 weer geplaatst tegenover een unitaire Republiek Indonesië onder Soekarno en Hatta. Het leek wel alsof alle inspanningen en offers die Nederland zich sindsdien getroost had vruchteloos geweest waren.

\section{Herovering van Ambon}

De uitroeping op Ambon van een Republiek der Zuid-Molukken (RMS) op 24 april 1950 had in Nederland terstond positieve reacties gewekt. Daarbij deed zich opnieuw het merkwaardige fenomeen voor dat juist die Nederlanders die bij hoog en bij laag het recht van het Indonesische volk ontkend hadden om zich van Nederland af te scheiden en over zijn eigen lot te beschikken zich nu vurige pleitbezorgers toonden van het recht van het Ambonese volk op afscheiding en zelfbeschikking. Oud-premier Gerbrandy, nu lid van het parlement, vergeleek de opstand van Ambon tegen Djakarta zelfs met de strijd van de Nederlanders tegen Spanje in de zestiende eeuw.

In dit verband is het nuttig er aan te herinneren dat in 1946 onder leiding van Gerbrandy een Nationaal Comité Handhaving Rijkseenheid was opgericht dat ernaar streefde Indonesië binnen het Koninkrijk der Nederlanden te houden (zie p. 510). Toen het medio 1949 duidelijk werd dat de afscheiding van Indonesië niet viel tegen te houden, had dit Comité zich ingespannen om toch nog het meest oostelijke deel van de archipel daarvan uit te zonderen en in een bijzonder verband met Nederland onder te brengen (zie p. 658). Daartoe voerde het onder meer een grote propaganda-actie waarin vertegenwoordigers van separatistische organisaties zoals de PTB verklaarden dat de volken van de Minahasa, de Molukken en Timor buiten de nieuwe Indonesische staat wil- 
den blijven. Op een deel van het Nederlandse publiek had die actie zo'n diepe indruk gemaakt dat bijna een kwart miljoen Nederlanders een petitie ondertekende waarin gevraagd werd aan de eisen van de drie volken te voldoen. Uiteindelijk slaagde de actie niet en werden op grond van de RTC-overeenkomst ook deze gebieden deel van de RVI, terwijl alleen Nieuw-Guinea voorlopig bij Nederland bleef. In februari 1950 hief het Comité zich op, maar al in diezelfde tijd werd een nieuwe particuliere organisatie voorbereid die zich ten doel stelde de verwezenlijking te bevorderen van 'het zelfbeschikkingsrecht van de volken van Ambon, Timor en de Minahasa'. Deze organisatie kwam eind april formeel tot stand in de vorm van een stichting Door De Eeuwen Trouw. De naam verwees naar het verdrag van 1605 waarin inlandse hoofden op Ambon eeuwige trouw aan Nederland beloofd hadden. De Stichting stelde zich volledig achter de Ambonse rebellie.

De Indonesische regering probeerde die rebellie in de eerste plaats op te lossen door overleg met bemiddeling van nationalistische Ambonezen, maar dit mislukte. De regering was echter niet in staat op korte termijn gewapenderhand tegen de RMS op te treden, omdat daar een grootschalige amfibische operatie voor nodig was. De Republikeinse militairen hadden op dat gebied geen enkele ervaring en de voorbereiding van de beoogde operatie vergde veel tijd. Intussen stelde de Indonesische marine een blokkade van Ambon in om de bevolking onder druk te zetten. Als eerste fase van de militaire operatie bezetten regeringstroepen in juli delen van de naburige eilanden Buru en Ceram.

Er waren overigens in deze maanden heel andere zaken die in Djakarta de aandacht opeisten, waaronder allereerst de voorbereiding van de eenheidsstaat en vervolgens de vorming van een nieuwe centrale regering. De daartoe aangewezen kabinetsformateur Natsir presenteerde op 6 september het nieuwe kabinet. Rum werd minister van buitenlandse zaken en legde dus zijn functie neer als Indonesisch Hoge Commissaris in Nederland. Intussen had Hirschfeld, de eerste Nederlandse Hoge Commissaris in Indonesië, zijn taak eveneens beëindigd; hij werd eind september opgevolgd door de diplomaat A.Th. Lamping.

Op 28 september begon eindelijk de grote aanval op Ambon, die werd ingeleid met een luchtbombardement, terwijl de regeringstroepen op het noordelijk deel van het eiland landden. Deze poging om snel een eind aan de RMS te maken werd een fiasco. Zowel het weerstandsvermogen van de RMSstrijders als de steun die ze bij de bevolking genoten was in Djakarta volledig onderschat. De regeringstroepen kwamen vast te zitten en konden niet doordringen tot het zuidelijk deel van het eiland met de hoofdstad. Nadat uit Java versterkingen waren aangevoerd volgde op 3 november een nieuw offensief, waarbij regeringstroepen ook dicht bij de hoofdstad aan land gingen. Nu werd het verzet op Ambon in enkele dagen gebroken, maar de hoofstad was groten- 
deels verwoest. Manusama, Soumokil en andere RMS-leiders weken met een aantal strijders uit naar het binnenland van het eiland Ceram.

De Indonesische regering stelde zich tegenover de Ambonese bevolking verzoenend op. Gevangen genomen RMS-strijders werden niet als rebellen berecht, maar mochten alsnog toetreden tot het Indonesische leger. Ambtenaren die de kant van de RMS gekozen hadden konden hun functies meestal spoedig weer uitoefenen.

In Nederland was de strijd op Ambon met spanning gevolgd. Bij een deel van het publiek vermengde spontane sympathie voor de underdog zich met gevoelens van schuld tegenover het dappere Ambonese volk dat immers, naar men meende, door Nederland lelijk in de steek gelaten was. Het dagblad Trouw drong zelfs aan op inzet van de Nederlandse marine en luchtmacht om Ambon te hulp te komen. De Nederlandse regering wilde het conflict tussen Djakarta en de RMS liefst als een interne zaak zien waarmee ze geen bemoeienis had, maar de bombardementen van eind september wekten zoveel verontwaardiging dat premier Drees zich op 4 oktober genoodzaakt voelde een gebaar te maken. Dit gebaar had de vorm van een openbaar telegram aan premier Natsir, waarin Drees verklaarde dat de militaire actie niet alleen de regering maar het hele Nederlandse volk diep geschokt had en waarin hij er op aandrong de strijd te staken en naar een vreedzame oplossing te streven. Het telegram wekte woedende reacties in de Indonesische pers en het Indonesische parlement.

De stichting Door De Eeuwen Trouw was de spil van de solidariteit met Ambon. Onder meer zamelde ze geld in voor hulp aan de RMS, organiseerde ze protestvergaderingen en gaf ze een eigen orgaan uit met de titel De Stem van Ambon. Ook bevorderde ze een voor Nederland nieuwe strijdmethode, het forceren van politieke besluiten door juridische procedures. Zo spande een met de stichting verbonden advocaat in oktober namens de RMS een proces aan tegen de KPM, de Nederlandse scheepvaartonderneming die het vervoer in de Indonesische archipel verzorgde. Daarin werd geëist dat de KPM geen schepen meer beschikbaar zou stellen voor het vervoer van Indonesische troepen naar Ambon. In eerste instantie won de RMS het proces; enige maanden later werd deze uitspraak in hoger beroep ongedaan gemaakt.

\section{Impasse over Nieuw-Guinea}

Volgens het Charter van Souvereiniteitsoverdracht zou de staatkundige status van Nieuw-Guinea binnen een jaar na de soevereiniteitsoverdracht bepaald moeten worden door onderhandelingen tussen Indonesië en Nederland (zie p. 666). De eerste gelegenheid hiertoe deed zich voor toen in maart 1950 de eerste ministersconferentie in het kader van de Indonesisch-Nederlandse Unie 
plaatsvond. Op voorstel van minister Van Maarseveen besloot deze conferentie echter de onderhandelingen tot het najaar uit te stellen. Men hoopte dat na een half jaar rust het politieke klimaat gunstiger zou zijn voor het vinden van overeenstemming.

Deze verwachting kwam niet uit: een half jaar later was het politieke klimaat juist ernstig verslechterd. Onder indruk van de opheffing van de deelstaten en de strijd om Ambon stelde het Nederlandse publiek zich tegenover het nieuwe Indonesië veel minder welwillend op dan in het begin van het jaar. Daar droeg ook toe bij dat van de ongeveer vijftigduizend Nederlandse burgers die in de loop van het jaar uit Indonesië naar Nederland gemigreerd waren velen bitter gestemd waren jegens Soekarno en de zijnen. Hetzelfde gold voor het merendeel van de uit Indonesië gerepatrieerde Nederlandse militairen.

Overigens had de Nederlandse regering zelf sinds de soevereiniteitsoverdracht met medewerking van het parlement een aantal maatregelen ten aanzien van Nieuw-Guinea genomen die moeilijk te rijmen vielen met het voorlopige karakter van de in artikel 2 van het Charter overeengekomen regeling. Terwijl toen was afgesproken dat 'de status quo van de residentie' een jaar lang zou worden gehandhaafd, veranderde de regering de bestuursorganisatie van het gebied, verhoogde zij de staatsrechtelijke status ervan van een residentie tot een gouvernement, benoemde zij daarover een gouverneur en richtte zij nieuwe bestuurlijke diensten op. Verder voerde zij onder meer een afzonderlijke geldsoort in (met een afbeelding van koningin Juliana) en diende zij bij het parlement een driejarenbegroting voor Nieuw-Guinea in. Men kan stellen dat Nederland daarmee de eerste was om het Unieverdrag te schenden, zo al niet naar de letter dan toch naar de geest.

Intussen was het politieke klimaat ook aan Indonesische kant niet gunstiger geworden. De RMS-affaire leidde daar tot ongerustheid dat Nieuw-Guinea, als het in Nederlandse handen bleef, een uitvalsbasis kon worden voor tegen Djakarta gerichte acties in Oost-Indonesië. Maar ook los hiervan was de toekomst van Nieuw-Guinea in de loop van het jaar een steeds belangrijker prestigekwestie geworden. In al zijn toespraken hamerde Soekarno er op dat de revolutie nog niet voltooid was zolang Nieuw-Guinea niet met Indonesië herenigd was. Het Indonesische parlement stuurde in oktober een missie naar Nederland om het Indonesische standpunt toe te lichten, met als woordvoerder de radicale nationalist Muhammad Yamin (die al jarenlang betoogde dat Indonesië eigenlijk ook het grondgebied van Malakka, Singapore, Brits Borneo en Portugees Timor moest omvatten). Bij aankomst in Nederland zei hij dat het moeilijk zou worden de Nederlandse belangen in Indonesië veilig te stellen als de Nieuw-Guinea-kwestie niet voor 27 december geregeld zou zijn,. Kort daarna werd uit Indonesië vernomen dat Sutomo ('Bung Tomo'), een onder veel Nederlanders beruchte volksmenner uit de bersiap-tijd, met 
een economische boycot dreigde als Nederland zou weigeren het gebied over te dragen.

De speciale conferentie over Nieuw-Guinea begon in Den Haag op 4 december 1950. Rum leidde de Indonesische en Van Maarseveen de Nederlandse delegatie. Om te bereiken dat Nederland Nieuw-Guinea zou overdragen bood de regering-Natsir in deze conferentie vergaande tegemoetkomingen aan, waaronder erkenning van Nederlandse economische en financiële rechten, voorkeursbehandeling van Nederland bij nieuwe concessies en investeringen, toelating van Nederlandse werkkrachten en immigranten, garanties voor missie en zending en tenslotte autonomie voor de bevolking van het gebied. De regering-Drees meende echter zich volstrekt niet te kunnen veroorloven Nieuw-Guinea los te laten. Pas bij het naderen van de einddatum bood ze een concessie aan, namelijk dat Nederland de soevereiniteit over het gebied zou kunnen overdragen aan de Nederlands-Indonesische Unie, echter onder volledige handhaving van het Nederlandse bestuur en met uitzicht op zelfbeschikking voor de bevolking. Voor de Indonesische delegatie was dit onaanvaardbaar, zodat de conferentie op 27 december in een mislukking eindigde. Rum verklaarde dat, nu het in de RTC overeengekomen jaar van handhaving van de status quo in Nieuw-Guinea voorbij was, de voortzetting van die status quo niet meer de instemming van Indonesië had.

De mislukte conferentie had nog een belangrijk gevolg voor de langere termijn. De Nederlandse regering ging ervan uit dat voor verandering van de status van Nieuw-Guinea nog steeds een twee derde meerderheid in het parlement nodig was. Begin 1951 bleek dat ruim een derde deel van het parlement volstrekt wilde vasthouden aan de Nederlandse soevereiniteit over Nieuw-Guinea en zich ook verzette tegen eventuele overdracht van de soevereiniteit aan de Nederlands-Indonesische Unie. Bovendien bleek dat de minister van buitenlandse zaken, Stikker (die persoonlijk voor overdracht van Nieuw-Guinea aan Indonesië geweest was, maar daarin binnen de regering alleen had gestaan) niet langer het vertrouwen genoot van zijn eigen partij, de VVD. Stikker trad daarom af. Hierop volgde een kabinetscrisis van anderhalve maand. Midden maart trad een nieuw kabinet-Drees op, waarin ook Stikker weer terugkeerde. In zijn regeringsprogram verklaarde dit kabinet dat, omdat enerzijds voor geen enkele verandering van de status van Nieuw-Guinea een twee derde meerderheid in het Nederlandse parlement te vinden was en anderzijds de Republiek Indonesië niets minder wilde aanvaarden dan de volledige soevereiniteit over het gebied, de regering geen andere keus had dan de kwestie voorlopig te laten rusten. Zoals men het destijds placht aan te duiden, zette Nederland de kwestie voor onbepaalde tijd 'in de ijskast'. 


\section{Overbrenging van Ambonese ex-KNIL militairen naar Nederland}

Toen het KNIL op 26 juli 1950 ophield te bestaan, stond voor een deel van de Indonesische KNIL-militairen nog niet vast of zij de militaire dienst zouden verlaten dan wel naar het Indonesische leger zouden overgaan (zie p. 700). Als noodoplossing kregen deze militairen toen een tijdelijke KL-status. Vervolgens gingen ongeveer tienduizend van hen alsnog over naar de APRI (de nieuwe naam van het Indonesische leger na het herstel van de eenheidsstaat), terwijl ongeveer tienduizend zich op verschillende plaatsen binnen Indonesië lieten demobiliseren. Er bleef een groep van ongeveer vierduizend Ambonese militairen over die de kant van de RMS gekozen hadden en verlangden op Ambon gedemobiliseerd te worden. De Indonesische regering wilde dit niet toestaan zolang Ambon in opstand was. Intussen bevonden deze militairen en hun gezinnen zich in doorgangskampen op Java die tijdelijk beveiligd werden door Nederlandse soldaten.

Nadat de Indonesische regering in november haar gezag over Ambon hersteld had verklaarde zij geen bezwaar meer te hebben tegen demobilisatie van deze ex-KNIL-militairen op dit eiland. Maar nu wezen dezen dit zelf af, omdat zij daar represailles verwachtten wegens hun steun aan de RMS. Als alternatief stelden zij voor, hun groep hetzij naar Nieuw-Guinea over te brengen hetzij naar gebied in de Molukken dat nog in RMS-handen was. Ook hier kon noch de Nederlandse regering noch de Indonesische regering mee instemmen.

De Nederlandse regering spande zich in om deze ex-KNIL-militairen ertoe te bewegen zich toch te laten demobiliseren op Ambon of op ander gebied onder gezag van de Indonesische regering. Onder meer bood zij daartoe financiële tegemoetkomingen aan. Intussen hadden deze Ambonezen als hun vertegenwoordiger in Nederland de RMS-minister F.A. Aponno aangewezen, die zich sinds juni in dit land bevond en nauw contact onderhield met de stichting Door De Eeuwen Trouw. Toen de Ambonezen op Java zich eind november bijna lieten overhalen om binnen Indonesië de dienst te verlaten, gaf Aponno hun het dringende advies hiervan af te zien. Hij spande een proces aan tegen de Nederlandse staat met behulp van dezelfde Nederlandse advocaat die het proces tegen de KPM begonnen was. Van de rechter werd gevraagd de Nederlandse staat te verbieden om de Ambonese militairen tegen hun zin te demobiliseren in door de Indonesische regering beheerst gebied.

Op 21 december wees de Nederlandse rechter deze eis toe. De staat ging in beroep, maar verloor een maand later de zaak in hoger beroep. Demobilisatie in gebied onder Indonesisch gezag was daardoor uitgesloten. Demobilisatie op Nieuw-Guinea, zoals door Aponno verlangd, kwam evenmin in aanmerking. In deze situatie meende de Nederlandse regering geen andere keus te hebben dan de vierduizend Ambonese militairen samen met hun ruim achtduizend gezinsleden naar Nederland zelf over te brengen. Met de Indonesische rege- 
ring was intussen afgesproken dat de beveiliging door Nederlandse militairen van de kampen op Java nog enkele maanden voortgezet kon worden. Tussen februari en juni 1951 bracht men de twaalfduizend Ambonese mannen, vrouwen en kinderen in twaalf schepen naar Nederland over. De meesten werden daar gehuisvest in voormalige gevangenkampen die de Duitse bezettingsmacht er tijdens de Tweede Wereldoorlog had laten bouwen. Men ging er in Nederland van uit dat de overbrenging van deze gezinnen naar Europa slechts een tijdelijke noodsprong was in afwachting van een definitieve oplossing.

Intussen had de Nederlandse regering besloten de Ambonese militairen bij aankomst in Nederland uit militaire dienst te ontslaan. Tijdens het transport was dit hun niet bekend; er was tot dan toe alleen gesproken over wachtgeld of pensioen. Het volstrekt onverwachte ontslag uit de dienst betekende voor deze beroepsmilitairen een zware schok, omdat zij de status verloren waar zij hun zelfrespect aan ontleenden.

\section{Mislukking van de Indonesisch-Nederlandse Unie}

De Nederlandse weigering van eind december 1950 om West-Nieuw-Guinea over te dragen kwam in Indonesië hard aan. In de loop van het jaar had de Indonesische verstandhouding met Nederland al enige schade opgelopen door de APRA-aanslag op Bandung, de muiterij in Makassar en de opstand op Ambon. Die schade was vooral veroorzaakt door de sympathie voor deze affaires bij een deel van het Nederlandse publiek, maar daar stond telkens tegenover dat de Nederlandse regering zich er zorgvuldig van gedistantieerd had. Nu was het echter deze regering zelf die Nieuw-Guinea vasthield ondanks het verstrijken van de op de Rondetafelconferentie overeengekomen termijn. In Indonesië werd dit ervaren als een flagrante schending van het gegeven woord; het vertrouwen in Nederland was diep geschokt.

Begin januari 1951 bleek het hele Indonesische parlement geporteerd te zijn voor opheffing van de Indonesisch-Nederlandse Unie en wijziging van de andere RTC-akkoorden. Algemeen beschouwden Indonesische politici die Unie als een constructie die een restant van de koloniale verhouding belichaamde, waardoor er nog steeds geen volledige gelijkheid en gelijkwaardigheid tussen Indonesië en Nederland bestond.

Deze Indonesische visie strookte met wat aan Nederlandse kant oorspronkelijk met de Unie beoogd was. Die constructie dankte haar ontstaan aan de 'commissie-generaal', de in september 1946 door de Nederlandse regering naar Indonesië gezonden delegatie onder oud-premier Schermerhorn die moest proberen een akkoord met de Republiek te sluiten (zie pp. 471-3 en 4814). Het onderhandelingsmandaat van deze delegatie had geen ruimte gelaten voor een oplossing waarbij Indonesië geen deel meer zou uitmaken van het 
Koninkrijk der Nederlanden. Daarentegen wilde de Republiek voor de toekomstige verhouding tussen Indonesië en Nederland niet verder gaan dan een volkenrechtelijk bondgenootschap tussen twee onafhankelijke staten. Op voorstel van Van Mook had de commissie-generaal toen (zonder overleg met de regering in Den Haag) aan de Republiek een constructie voorgesteld tussen die beide posities in: het toekomstige Indonesië zou zelf geen deel van het Koninkrijk uitmaken, maar zou wel met dit Koninkrijk een bijzondere band aangaan in de vorm van een Unie met aan het hoofd de Nederlandse koningin. Vooral tegen dit laatste had de Republikeinse delegatie groot bezwaar, maar tijdens de besprekingen stond de Republiek onder zware druk omdat in deze zelfde periode schip na schip met Nederlandse militairen in Indonesië aankwam. Nadat de commissie-generaal verklaard had de besprekingen te zullen beëindigen als haar voorstel over de Unie niet aanvaard werd, zette de Republikeinse delegatie zich over haar bezwaren heen. Daarop kwam in november 1946 het akkoord van Linggadjati tot stand. Hoewel de commissiegeneraal de grenzen van haar onderhandelingsmandaat overschreden had, schaarde de Nederlandse regering zich achter dit akkoord.

Tijdens de onderhandelingen had Schermerhorn verklaard dat de Unie alleen als een samenwerkingsverband bedoeld was en geen 'superstaat' zou worden. Maar toen het er om ging in Nederland politieke steun voor het akkoord van Linggadjati te verkrijgen, stelde de Nederlandse regering de daarin voorziene Unie voor als een soort voortzetting van het Koninkrijk in andere vorm. Zij noemde de Unie een 'staatsverband' en ging er onder meer van uit dat er binnen de Unie eenheid van buitenlands beleid zou bestaan en dat de defensie van Indonesië onder de verantwoordelijkheid van de Unie zou vallen. In de loop van 1947 en 1948 pleitten invloedrijke Nederlandse politici voor de vorming van een 'zware' Unie met belangrijke eigen organen en bevoegdheden. Op de Rondetafelconferentie van 1949 verzetten de Indonesische delegaties zich echter krachtig tegen voorstellen in die geest. Het eindresultaat was toen overeenstemming over een 'lichte' Unie die de vrijheid van de twee staten weinig beperkte (zie p. 655). Wel bevatte het Uniestatuut de bepaling dat aan het hoofd van de Unie de koningin van Nederland stond (en bij opvolging haar wettige opvolgers in de Kroon der Nederlanden). Verder hoorden bij dit Statuut afzonderlijke overeenkomsten over financiële en economische kwesties en over samenwerking op het gebied van de buitenlandse betrekkingen, de handelsbetrekkingen, de culturele betrekkingen en de defensie. De overeenkomsten over samenwerking bevatten weinig concrete afspraken, maar omschreven vooral verschillende mogelijkheden daartoe.

De meeste Indonesische politici hadden geen principieel bezwaar tegen samenwerking tussen Indonesië en Nederland, mits die op voet van gelijkheid plaatsvond. Hun bezwaren betroffen vooral de regel dat het Nederlandse staatshoofd aan het hoofd van de Unie stond, want dit leek duidelijk afbreuk 
te doen aan de soevereiniteit en onafhankelijkheid van Indonesië. Niettemin bleek ook de samenwerking in Uniekader niet te beantwoorden aan de Nederlandse verwachtingen.

Op het terrein van de buitenlandse betrekkingen beperkte die samenwerking zich voornamelijk tot de behartiging van Indonesische belangen door Nederlandse ambassades in landen waar Indonesië nog niet over een eigen diplomatieke vertegenwoordiging beschikte. Dit duurde niet lang, want de Indonesische regering droeg zulke belangenbehartiging liever op aan haar eigen ambassades in naburige landen. Verder verzorgde Nederland in de begintijd de opleiding van een aantal Indonesische diplomaten. De in het RTC-akkoord neergelegde afspraak dat Indonesië en Nederland zouden streven naar coördinatie van hun buitenlands beleid bleef daarentegen volledig dode letter. Daarbij valt te bedenken dat de Koude Oorlog tussen het Oostelijk en het Westelijk blok in 1950 zijn koudste fase inging als gevolg van de oorlog in Korea. Nederland koos voor een actieve rol in het Westelijk blok en nam aan de zijde van de Verenigde Staten aan die oorlog deel, terwijl Indonesië koos voor een onafhankelijke rol tussen de blokken.

Ook de in het RTC-akkoord voorziene gemeenschappelijke handelspolitiek van Nederland en Indonesië tegenover derde landen kwam niet van de grond. Wel bleef het leeuwendeel van het Indonesische handelsverkeer met Europa via Nederlandse havens lopen en maakten de RTC-bepalingen het voor Nederlandse ondernemingen mogelijk hun economische activiteiten in Indonesië onder redelijke voorwaarden te hervatten of voort te zetten. Juist hiertegen groeide echter in Indonesië steeds meer verzet. Daarbij werd betoogd dat het kolonialisme in economisch opzicht was blijven bestaan en dat Indonesië pas waarlijk vrij zou worden wanneer aan de Nederlandse dominantie op economisch gebied een eind was gemaakt.

Bijzonder teleurstellend voor Nederland waren de ontwikkelingen op cultureel gebied. Velen hadden juist op dit terrein blijvende banden verwacht, vooral omdat Nederland beschikte over een gedurende eeuwen opgebouwde schat van kennis omtrent land en volk van Indonesië en omdat in Nederland nog steeds een levendige belangstelling voor dit land bestond. In dat kader leek het vanzelfsprekend dat ontwikkelde Indonesiërs nog gedurende generaties vertrouwd zouden blijven met de Nederlandse taal. De feitelijke gang van zaken was echter volstrekt anders. Van de verschillende vormen van samenwerking die in de culturele RTC-overeenkomst waren voorzien kwam niets op gang. Al in 1950 werd in het Indonesische parlement aangedrongen op snelle verwijdering van de Nederlandse culturele elementen uit de samenleving. Ook Soekarno liet weten dat hij niet langer van het 'Nederlandse culturele kolonialisme' gediend was. Binnen enkele jaren verdween de Nederlandse taal op de scholen als voertaal en als leervak. Nederlandse leraren moesten voortaan in het Indonesisch onderwijs geven; de meesten van hen vertrokken al 
spoedig naar Nederland. Aan de universiteiten konden hoogleraren nog enige jaren in het Nederlands college geven, maar de Indonesische regering spande zich niet in voor het aantrekken van nieuwe hoogleraren uit Nederland. Ook bevorderde zij niet langer dat Indonesiërs in Nederland studeerden. In april 1954 gaf zij de ongeveer achttienhonderd nog in Nederland verblijvende Indonesische studenten zelfs opdracht hun studie in een ander land voort te zetten.

Aldus verdween in het onafhankelijke Indonesië binnen korte tijd de kennis van de taal van de vroegere koloniale overheersers. Deze gang van zaken week sterk af van die in andere voormalige koloniën van Europese landen. Men kan deze snelle verdwijning van het Nederlands echter niet los zien van het voorheen door de Nederlanders zelf gevoerde taalbeleid, zowel in negatieve als in positieve zin (zie pp. 140-2). Terwijl de Portugezen, de Spanjaarden, de Britten en de Fransen hun eigen taal in hun koloniën hadden ingevoerd als verkeerstaal voor alle bevolkingsgroepen, hadden de Nederlanders dit in Indonesië juist niet bevorderd. Ook toen in de twintigste eeuw onder de Indonesiërs zelf een groeiende vraag naar voren kwam naar onderricht in de Nederlandse taal, was het koloniale gouvernement daar slechts in beperkte mate aan tegemoetgekomen. Aan de andere kant had dit gouvernement al sinds de negentiende eeuw stelselmatig bijgedragen tot de ontwikkeling van één der inheemse talen, het Maleis, tot algemene verkeerstaal. Dit gemoderniseerde Maleis was in 1928 door de nationale beweging onder de naam Bahasa Indonesia tot nationale taal uitgeroepen (zie p. 207). Dank zij deze voorgeschiedenis had die taal in 1942-1945 de rol van het Nederlands kunnen overnemen toen die door de Japanse bezetters verboden werd. Het daarop in 1945-1949 gevolgde conflict tussen Nederland en de Republiek had ertoe bijgedragen, dat veel nationalisten de Nederlandse taal nu sterk met het kolonialisme associeerden.

Het enige terrein waarop de samenwerking in Unieverband wel van de grond kwam was merkwaardigerwijs dat van de defensie. Aan Indonesische kant bestond grote behoefte aan steun bij de professionalisering van het eigen leger en de opbouw van de eigen marine. Zoals afgesproken op de RTC werd daartoe in 1950 een Nederlandse Militaire Missie opgericht, die uit ongeveer duizend Nederlandse militairen kwam te bestaan. De NMM verstrekte militair-technische adviezen en verzorgde zowel officiersopleidingen als opleidingen op lager niveau. Deze militaire samenwerking breidde zich in 1951 steeds verder uit, maar in nationalistische kringen rees hiertegen verzet. Eind 1952 drong het Indonesische parlement aan op opheffing van de NMM. In april 1953 kwamen de regeringen van Indonesië en Nederland overeen de NMM per 1 januari 1954 te ontbinden. Daarmee kwam een eind aan de laatste vorm van samenwerking in het kader van de Indonesisch-Nederlandse Unie.

In 1947-1949 had de beoogde Unie tussen Indonesië en Nederland een 
onmisbaar argument gevormd om bij een meerderheid van het Nederlandse publiek steun te vinden voor de dekolonisatie van Indonesië. Tegen die achtergrond is het verrassend hoe snel men zich er in Nederland bij neerlegde dat die Unie niet levensvatbaar bleek. Al begin 1951 had de Indonesische regering in overeenstemming met de wens van het Indonesische parlement verklaard, dat zij streefde naar opheffing van de Unie en wijziging van de andere RTCakkoorden. In Nederland bleken vervolgens ook politici die vroeger voor een 'zware' Unie gepleit hadden nu te vinden, dat handhaving van de Unie weinig zin had als Indonesië er zelf geen prijs op stelde. Wel hechtte men belang aan behoud van sommige andere delen van de RTC-akkoorden, vooral die van belang waren voor Nederlandse ondernemingen. In juni 1951 maakte de Nederlandse regering bekend dat zij bereid was met Indonesië besprekingen te voeren over herziening van de betrekkingen. Een probleem was dat de Indonesische regering dit onderwerp alleen samen met de kwestie-NieuwGuinea wilde bespreken, wat de Nederlandse regering afwees. Niettemin vond er sindsdien herhaaldelijk Indonesisch-Nederlands overleg plaats over vervanging van de Unie, maar telkens deden zich incidenten voor die leidden tot afbreken van het overleg.

In 1954 leek een nieuwe overlegronde tot resultaat te leiden. De Indonesische regering wilde toen zo snel mogelijk van de Unie af en was bereid daarbij Nederland op financieel en economisch gebied tegemoet te komen. Op 10 augustus 1954 ondertekenden de beide regeringen een protocol dat voorzag in opheffing van de Unie onder handhaving van de voor Nederland belangrijkste financiële en economische bepalingen van het RTC-akkoord. Dit laatste leidde echter in Indonesië tot een storm van protest. Men verweet de regering dat zij een knieval voor het Nederlandse kolonialisme gemaakt had. Het bleek onmogelijk parlementaire goedkeuring voor het protocol te verkrijgen, zodat de in feite al overleden Unie op papier nog bleef voortbestaan.

$\mathrm{Na}$ een regeringswisseling in Indonesië begonnen eind 1955 in Genève nieuwe besprekingen met Nederland over opheffing van de Unie. Ondanks de weerstanden die het protocol van 1954 had opgeroepen was de nieuwe Indonesische regering tot vrijwel hetzelfde bereid, met uitzondering van een daarbij behorende internationale arbitrageregeling voor geschillen over de financieel-economische bepalingen. De Nederlandse regering wilde de beslechting van zulke geschillen echter niet uitsluitend overlaten aan de Indonesische rechterlijke macht, die juist in die tijd een slechte reputatie verworven had (zie pp. 726-9). Nadat de onderhandelingen op dit punt waren vastgelopen, besloot de Indonesische regering in februari 1956 de Unie en de RTC-akkoorden eenzijdig op te zeggen. Het formele einde kwam op 12 mei, nadat de eenzijdige opzegging ook door het Indonesische parlement goedgekeurd was. 


\section{De eerste jaren parlementaire democratie in Indonesië}

Volgens de voorlopige grondwet van augustus 1950 zouden de parlementsleden van de nieuwe Republiek Indonesië te zijner tijd in algemene verkiezingen gekozen worden, maar zou in afwachting daarvan het parlement worden samengesteld uit de leden van de beide kamers van het RVI-parlement plus de leden van het Werkcomité van het KNIP en de leden van de Hoge Adviesraad van de Jogjase Republiek. Het aldus samengestelde parlement telde in totaal 232 leden; zij behoorden tot zeventien politieke partijen. Hoewel deze leden niet gekozen maar benoemd waren, ging men er toch van uit (op grond van een bij de voorbereiding van de grondwet gemaakte afspraak) dat de regering afhankelijk was van steun door een meerderheid in dit parlement. Eenvoudig was dat niet. Evenals in Nederland beschikte geen enkele partij zelf over een parlementaire meerderheid; ieder kabinet had daarom steun van twee of meer partijen nodig en daartoe waren verschillende combinaties mogelijk. Een kabinetscrisis leidde dan ook meestal tot langdurige onderhandelingen over een alternatieve combinatie. Herhaaldelijk bleef een regering die niet meer over een parlementaire meerderheid beschikte toch nog enige maanden in functie voordat ze door een nieuwe ministersploeg werd afgelost. Overigens machtigde de grondwet de regering om op eigen gezag noodwetten uit te vaardigen die van kracht bleven zolang ze niet door het parlement werden ingetrokken.

Anders dan in Nederland was het destijds onbekend in hoever de partijverdeling binnen het parlement overeenkwam met de werkelijke aanhang van de verschillende partijen onder de bevolking. De grootste fractie in het parlement was die van de islamitische Masjumi; ze telde 49 leden. De tweede fractie was die van de nationalistische PNI (vaak als 'Soekarno's eigen partij' beschouwd) met 36 leden. De fractie van de PSI, de door Sjahrir geleide socialistische partij, telde 17 leden. De communistische PKI had een fractie van 13 leden. (Het kan verbazing wekken dat de PKI zitting in het parlement had terwijl de communisten twee jaar eerder onder leiding van Moeso tegen de Republikeinse regering in opstand waren gekomen. Die regering had toen echter wel de opstand neergeslagen, maar de partij zelf niet verboden.) Enige andere in het parlement vertegenwoordigde partijen die al vroeger een rol gespeeld hadden waren de katholieke partij met 9 leden, de protestants-christelijke partij met 5 leden en de door wijlen Tan Malaka gestichte Partai Murba met 4 leden in het parlement. Overigens telde het parlement ook 26 leden die geen lid van een politieke partij waren. Voorzitter van het parlement was het PNI-lid Sartono, die ook het VSI-parlement gepresideerd had. Hij was een veteraan van de nationale beweging, had in de jaren twintig samen met Hatta in het bestuur van de Perhimpoenan Indonesia gezeten en was in 1930 als verdediger opgetreden in het proces tegen Soekarno.

Naast de indeling van Indonesische politici naar de partijen waartoe zij 
behoorden kan men ook een ruwe tweedeling hanteren naar hun persoonlijke opstelling tegenover het politieke werk. Aan de ene kant waren er de zakelijk ingestelde 'bestuurders' die zich vooral richtten op het oplossen van actuele problemen, aan de andere kant waren er de meer populistisch en ideologisch ingestelde 'volksleiders' die hun aanhangers geestdriftig wilden maken voor een toekomstvisioen. De eersten waren geneigd tot geleidelijkheid en overleg; de tweede tot radicale stappen en confrontatie. Deze tweedeling correspondeert min of meer met de tegenstelling tussen de voorstanders van 'diplomatie' en die van 'strijd' in de jaren 1946-1949. De PSI was een typische bestuurderspartij, met veel invloed in de hogere kringen van het bestuursapparaat en de strijdkrachten, maar weinig aanhang onder het grote publiek. De PKI was een ideologische partij die vooral invloed probeerde te krijgen via de vakbeweging. Daarentegen speelden in sommige andere partijen, zoals de Masjumi en de PNI, zowel 'bestuurders' als 'volksleiders' een belangrijke rol. De Masjumi was overigens de enige grote partij die ook buiten de steden en buiten Java veel aanhang had. De nationalistische PNI had geen duidelijke eigen doelstelling meer, nu de Indonesische onafhankelijkheid bereikt en de federale staatsstructuur opgeheven was.

Begin september 1950 trad het eerste kabinet van de nieuwe eenheidsstaat aan. Het werd geleid door Mohammad Natsir, die behoorde tot de bestuurlijk ingestelde jongere garde van de Masjumi, evenals Mohammad Rum en Sjafruddin Prawiranegara, die de ministersposten van buitenlandse zaken en financiën bezetten. Het meest opvallende aan dit kabinet was dat het geen enkele minister uit de PNI bevatte. Daarentegen telde het wel twee ministers uit Sjahrir's PSI en bovendien verscheidene partijloze ministers die daar politiek dicht bij stonden, zoals Hamengku Buwono IX (de sultan van Jogja), die vice-premier werd, en Assaat, die Anak Agung opvolgde als minister van binnenlandse zaken. Het kabinet had een goede verstandhouding met de leiding van de strijdkrachten, maar beschikte nauwelijks over een basis in het parlement. Het nam verschillende maatregelen voor verbetering van de economie en rationalisering van de strijdkrachten en probeerde in december Nederland met grote concessies te bewegen tot overdracht van Nieuw-Guinea. De mislukking van deze poging droeg bij tot verdere verzwakking van zijn binnenlands-politieke positie.

In maart 1951 diende het kabinet-Natsir zijn ontslag in, nadat het met een meerderheid van het parlement in conflict was geraakt over een regeling voor plaatselijke en regionale verkiezingen die in het voordeel van de Masjumi bleek te zijn. Eind april trad een nieuw kabinet aan met als kern zowel leden van de PNI als van de Masjumi, naast leden van enige kleinere partijen. Premier was Sukiman Wirjosandjojo, een oudere Masjumileider die al in 1927 als voorman van de Sarekat Islam met Soekarno samengewerkt had. Het kabinet-Sukiman had een stevige parlementaire basis maar geen goede verstandhouding met 
de legerleiding. Een merkwaardige bijzonderheid was dat twee van de nieuwe ministers in 1946-1948 in de Republiek gevangen hadden gezeten wegens hun rol in een mislukte staatsgreep tegen de regering-Sjahrir (zie pp. 461-2, 572 en 595). Dit waren de minister van buitenlandse zaken Achmad Subardjo en de minister van justitie Muhammad Yamin. Overigens was Subardjo ook in 1945 al minister van buitenlandse zaken geweest in de eerste regering van de Republiek.

Het kabinet-Sukiman was minder bestuurlijk ingesteld dan zijn voorganger. Zowel de premier als sommige andere ministers namen belangrijke initiatieven zonder overleg met hun collega's. Zo liet Yamin in juni 1951 bijna duizend personen vrij die door het leger gearresteerd waren wegens (al of niet vermeende) subversieve activiteiten. Eén van hen was de in maart 1950 gevangen genomen Chaerul Saleh, die tot zijn politieke vrienden behoorde. De legerleiding nam bijna alle vrijgelatenen, onder wie Saleh, opnieuw gevangen en Yamin trad af.

In augustus 1951 liet Sukiman onverwacht op Java en Sumatra ongeveer vijftienduizend personen arresteren die volgens hem de staatsveiligheid bedreigden, voornamelijk communisten en Chinezen. (Sinds het vasteland van China in 1949 als 'Chinese Volksrepubliek' deel van het communistische blok geworden was, werden ook Chinezen in Indonesië ervan verdacht daar diensten aan te bewijzen.) Ook deze golf van arrestaties gebeurde zonder overleg met de legerleiding. Op buitenlands-politiek gebied sloeg Sukiman samen met Subardjo een pro-Amerikaanse koers in. Beiden stonden zij in nauw contact met de Amerikaanse ambassadeur die toen niemand minder was dan Merle Cochran, de man die zich in 1948-1949 als lid van de VN-commissie voor Indonesië bijzonder had ingespannen voor een vergelijk tussen Nederland en de Republiek. Subardjo ondertekende het door de Amerikaanse regering opgestelde vredesverdrag met Japan, dat door China en de Sovjet-Unie afgewezen werd. In januari 1952 sloot hij met Cochran een akkoord in het kader van de Amerikaanse Mutual Security Act, waardoor Indonesië van de Verenigde Staten zowel economische als militaire hulp zou kunnen ontvangen. Toen dit bekend werd rees hier echter zoveel verzet tegen dat het kabinetSukiman zich in februari gedwongen zag af te treden. In Indonesië bleek een brede voorkeur te bestaan voor een buitenlands beleid van onafhankelijkheid tussen de grote blokken.

Begin april 1952 trad een nieuw kabinet aan onder Wilopo, een vertegenwoordiger van de meer bestuurlijk ingestelde jongere garde van de PNI. Dit kabinet leek in zover op zijn voorganger dat hier wederom zowel de PNI als de Masjumi aan deelnamen, maar het was in politieke opstelling meer verwant aan het kabinet-Natsir. Zo keerden Hamengku Buwono en Mohammad Rum in de regering terug, de eerste als minister van defensie, de tweede als minister van binnenlandse zaken, terwijl het kabinet ook twee leden uit Sjahrir's PSI 
telde. Deze regering ontsloeg overigens Chaerul Saleh opnieuw uit gevangenschap en stuurde hem voor een langdurige studiereis naar Europa.

Het kabinet-Wilopo is ruim een jaar in functie gebleven. In die periode deden zich belangrijke veranderingen voor in het binnenlands-politieke landschap van Indonesië. Eén daarvan was een scheuring in de Masjumi. Deze partij had haar basis voornamelijk in twee nog uit de koloniale tijd stammende islamitische massa-organisaties, de modernistische Muhammadiah en de traditionalistische Nahdatul Ulama. De leider van laatstgenoemde organisatie, Wachid Hasjim, was minister van godsdienstzaken geweest in de kabinetten van Hatta, Natsir en Sukiman, maar verder bekleedden leden van zijn organisatie geen belangrijke functies in het Indonesische staatsbestel. Midden 1952 bracht een conflict tussen de beide massa-organisaties de Nahdatul Ulama ertoe uit de Masjumi te treden en een eigen politiek verbond op te richten onder leiding van Wachid Hasjim.

De andere verandering was de wederopstanding van de PKI als belangrijke speler op het politieke toneel. Sinds de Madiun-opstand van 1948 had zij het stigma gedragen van verraad aan de nationale zaak; bovendien had zij in die opstand een deel van haar leiders verloren. In 1951 werd zij verder verzwakt door de anticommunistische acties van premier Sukiman. Maar in datzelfde jaar kreeg zij een nieuwe leider, D.N. Aidit, die haar tot een ingrijpende koerswijziging bracht. Voorheen had de PKI de politiek in klassentermen geïnterpreteerd; zij beschouwde het Indonesisch nationalisme toen als een 'burgerlijke' ideologie en keerde zich tegen Hatta en Soekarno als 'burgerlijke' politici en tegen de PNI als 'burgerlijke' partij. Onder Aidit verdween de marxistische analyse naar de achtergrond. De PKI ging nu de nationalistische toer op en zocht toenadering tot de PNI. Terwijl zij Soekarno vroeger gehekeld had wegens zijn collaboratie met Japan, vereerde zij hem nu als de grote leider van de natie. Ook werd de PKI oppermachtig in de grootste vakcentrale, de SOBSI.

Het kabinet-Wilopo probeerde de belangrijkste interne problemen aan te pakken waar Indonesië destijds mee te kampen had. Naast de zwakke financiële en economische situatie was dit ook de grote omvang van de strijdkrachten: als erfenis van de vrijheidsstrijd waren die nog tweehonderdduizend man sterk. Generaal-majoor Simatupang, staf-chef van de strijdkrachten, en kolonel Nasution, staf-chef van het landleger, wilden hiervan tachtigduizend man demobiliseren als stap naar de vorming van een kleinere maar meer professionele strijdmacht. Naar hun mening had Indonesië nu niet een volksleger maar een beroepsleger nodig. Deze reorganisatie had de instemming van minister Hamengku Buwono, maar stuitte op hevig verzet binnen de strijdkrachten zelf, zowel onder hoge officieren die hun militaire loopbaan onder Japanse leiding begonnen waren als onder soldaten die vreesden het leger te moeten verlaten. Dit verzet kreeg steun van president Soekarno, van de radicale vleu- 
gel van de PNI en verder onder meer van de PKI en de Nahdatul Ulama.

Er ontstond een situatie die enigzins leek op die van september 1948, toen een controverse over sanering van het Republikeinse leger tot conflicten leidde die uitmondden in de Madiunopstand. Nu werd de kwestie van legersanering maandenlang besproken in het parlement, waarbij zowel het ministerie van defensie als de legerleiding een stortvloed van kritiek te verduren kreeg. Nasution ergerde zich hieraan; hij vond de meeste parlementariërs incompetent en onverantwoordelijk. Een aantal met hem gelijkgezinde officieren maakten plannen voor uitschakeling van het parlement. Op 16 oktober nam dit parlement een motie aan die zinspeelde op vervanging van de leiding van de strijdkrachten en van het ministerie van defensie. De volgende ochtend brachten legervoertuigen duizenden demonstranten naar het centrum van Djakarta, waar zij zich voor het presidentspaleis verzamelden en ontbinding van het parlement eisten. Staande op het bordes van het paleis hield Soekarno een toespraak waarin hij uitlegde niet aan deze eis te kunnen voldoen omdat dit dictatuur zou betekenen. De menigte juichte hem geestdriftig toe en ging uiteen. Intussen waren ook tanks en pantserwagens verschenen, met hun geschut dreigend op het paleis gericht. Soekarno kreeg bezoek van een deputatie van officieren die eveneens ontbinding van het parlement verlangde, maar ook hier gaf hij niet aan toe. Uiteindelijk staakten de rebellerende officieren hun acties.

De mislukte machtsgreep van 17 oktober 1952 leidde tot langdurige tweespalt binnen de strijdkrachten tussen 'pro-17-oktober'-officieren en 'anti-17oktober'-officieren. De regering schorste Nasution als stafchef van het leger. Er kwam geen radicale legerhervorming. Het parlement drong aan op opheffing van de Nederlandse Militaire Missie. Begin 1953 trad Hamengku Buwono af als minister van defensie. Binnen de PNI was de positie van premier Wilopo ernstig verzwakt, maar het duurde nog tot juni 1953 voordat ook hij zich gedwongen zag af te treden.

De afwisseling tussen bestuurlijk ingestelde en populistisch ingestelde kabinetten zette zich nog enige jaren voort. Van juli 1953 tot juli 1955 stond de regering onder leiding van Ali Sastroamidjojo, die tot de oude garde van de PNI behoorde en in 1928 samen met Hatta in Den Haag terechtgestaan had. In dit kabinet zaten voor het eerst geen ministers uit de Masjumi; daarentegen wel drie ministers uit de Nahdatul Ulama. Naast Ali Sastroamidjojo bevatte het kabinet nog een andere veteraan uit de nationale beweging, namelijk Iwa Kusuma Sumantri, die in de jaren dertig samen met Hatta en Sjahrir op Banda geïnterneerd had gezeten en in 1945 deel had uitgemaakt van het eerste kabinet van de Republiek; hij werd nu minister van defensie. Ook keerde Muhammad Yamin in de regering terug, nu als minister van onderwijs. De regering-Ali voerde een uitgesproken populistisch en nationalistisch beleid, ook omdat de PNI de nieuwe radicaal-nationale koers van de PKI probeerde te overtroeven. Zij zette generaal Simatupang aan de kant door diens functie 
van stafchef van de strijdkrachten af te schaffen. Zij gaf de Indonesische studenten in Nederland opdracht hun studie elders voort te zetten. Tijdens haar regeerperiode begonnen opzienbarende processen tegen enige Nederlanders op beschuldiging van grootscheepse subversieve activiteiten. Verder wilde de regering-Ali zo snel mogelijk een eind maken aan de Indonesisch-Nederlandse Unie onder de Nederlandse koningin. Zij sloot daartoe in augustus 1954 een akkoord met de Nederlandse regering, maar, zoals al in de vorige paragraaf vermeld, werd dit door het thuisfront verworpen.

Ali Sastroamidjojo's grootste succes was de organisatie in april 1955 van een conferentie van Aziatische en Afrikaanse staten in Bandung, waar Soekarno als belangrijk wereldleider kon optreden naast onder meer de Indiase premier Nehru en de Egyptische president Nasser. Intussen had binnen de krijgsmacht een verzoening plaatsgevonden tussen de 'pro-17-oktober'-officieren en de 'anti-17-oktober'-officieren. Beide groepen verzetten zich tegen een reeks ingrepen van minister Iwa in de defensieorganisatie. Dit verzet leidde in juli 1955 tot de val van Ali's kabinet.

De volgende regering werd weer geleid door een vertegenwoordiger van de jonge garde van de Masjumi, Burhanuddin Harahap, en was opnieuw vooral een kabinet van 'bestuurders'. In tegenstelling tot het door de PNI gedomineerde kabinet-Ali bevatte dit nieuwe kabinet geen enkele minister uit de PNI. Anak Agung, die in 1950 minister van binnenlandse zaken geweest was in de regering van de RVI, keerde nu terug als minister van buitenlandse zaken. Het kabinet-Harahap duurde van augustus 1955 tot maart 1956. Tijdens die kabinetsperiode vonden in september 1955 eindelijk de lang verwachte parlementsverkiezingen plaats; het kabinet functioneerde daarom als een soort interim-regering in afwachting van de bijeenkomst van het nieuwe parlement. Het stelde Nasution, die intussen weer op goede voet met Soekarno was komen te staan, opnieuw aan als stafchef van het leger, nu met de rang van generaal-majoor. Verder vonden onder het kabinet-Harahap voor het laatst besprekingen met Nederland plaats over ontbinding van de Indonesische-Nederlandse Unie en wijziging van de RTC-akkoorden. Zoals in de vorige paragraaf vermeld mislukten die onderhandelingen, waarna het kabinet in februari 1956 besloot de Unie en de RTC-akkoorden eenzijdig op te zeggen. Het kabinet-Harahap bleef in functie totdat in maart 1956 het gekozen parlement bijeenkwam en een tweede kabinet-Ali aantrad.

\section{Verscherping van het geschil over Nieuw-Guinea}

In maart 1951 had de Nederlandse regering de kwestie van de toekomst van Nieuw-Guinea voor onbepaalde tijd 'in de ijskast' gezet. Daarentegen was die kwestie voor Indonesië zelf een steeds dringender prestigezaak geworden. 
Dat Nieuw-Guinea nog niet met Indonesië herenigd was werd door Soekarno voorgesteld als het grootste probleem van zijn land. De heftigheid waarmee hij en zijn radicaal-nationalistische aanhang overdracht van dat gebied eisten werkte echter in Nederland averechts. Zo hadden de dreigende verklaringen van Muhammad Yamin en Bung Tomo in oktober-november 1950 het voor de Nederlandse regering alleen maar moeilijker gemaakt om Indonesië op dit punt tegemoet te komen, want niemand wil graag de indruk wekken dat hij voor dreigementen zwicht.

Overigens was de Nederlandse opstelling in deze kwestie niet minder emotioneel dan de Indonesische. Het leek wel alsof alle frustratie in Nederland over het verlies van 'Indië' nu een uitlaat zocht in het vasthouden van NieuwGuinea. Wat de juridische kant van het geschil betreft ging men er zonder meer van uit dat de soevereiniteit over het gebied bij Nederland was blijven berusten. Invloedrijke Nederlandse politici zoals Romme legden zich hardnekkig vast op het standpunt, dat Nederland het gebied moest blijven besturen zolang de bevolking zich niet zelf over haar toekomst kon uitspreken. Als Nederland moest kiezen tussen Nieuw-Guinea en het behoud van de Indonesisch-Nederlandse Unie, dan zou de keuze volgens die politici op Nieuw-Guinea moeten vallen.

Nadat het kabinet-Natsir in december 1950 vergeefs geprobeerd had Nederland langs de weg van overleg tot overdracht van Nieuw-Guinea te bewegen, ondernam het kabinet-Sukiman eind 1951 een nieuwe poging. Het zond een delegatie naar Nederland onder leiding van oud-minister Supomo, met machtiging om zowel over opheffing van de Indonesisch-Nederlandse Unie als over Nieuw-Guinea besprekingen te voeren. De Indonesische delegatie, waar ook Yamin deel van uitmaakte, nam daarbij het standpunt in dat de soevereiniteit over Nieuw-Guinea al bij Indonesië berustte. Een Nederlands voorstel om het juridische geschil over de status van Nieuw-Guinea aan een onafhankelijke rechterlijke instantie voor te leggen werd door Supomo afgewezen met het argument dat het niet om een juridisch maar om een politiek geschil ging. In januari 1952 stelde hij voor dat men in afwachting van de in juni in Nederland te houden parlementsverkiezingen alvast een gemengd Indonesisch-Nederlands bestuur zou instellen onder een Indonesische gouverneur, waarna de beide regeringen dan na de verkiezingen onderhandelingen zouden voeren over de definitieve bestuursoverdracht. Dit voorstel was volstrekt kansloos. Niet lang daarna moest Supomo de besprekingen afbreken wegens de val van het kabinet-Sukiman.

In het voorjaar van 1952 deed Soekarno zelf een compromisvoorstel in een gesprek met Paul Rijkens, president-directeur van Unilever (één van de grootste Nederlandse concerns). Ook dit voorstel voorzag in gezamenlijk beheer van het gebied, waarbij Nederland de positie van een 'senior partner' zou krijgen met grote bestuursbevoegdheden en speciale voordelen op economisch 
terrein. Drees wilde dit voorstel echter niet in behandeling te nemen wegens de naderende parlementsverkiezingen.

Na de Nederlandse verkiezingen van juni 1952 trad in september een nieuw kabinet-Drees aan, nu met ministers uit de PvdA, de KVP, de CHU en de ARP. De toetreding van de ARP betekende dat een partij die het Nederlandse Indonesiëbeleid in de afgelopen jaren steeds te toegeeflijk gevonden had nu verantwoordelijkheid voor het regeringsbeleid ging dragen. De uittreding van de VVD betekende onder meer het vertrek van Stikker, die persoonlijk voor overdracht van Nieuw-Guinea aan Indonesië geweest was maar zich had neergelegd bij het standpunt van zijn partij en van het kabinet. Als minister van buitenlandse zaken werd hij in het nieuwe kabinet opgevolgd door twee ministers, van wie de één zich zou bezighouden met Europese zaken en de ander met niet-Europese zaken. Op voorstel van Romme werd deze laatste rol toebedeeld aan J.M.A.H. Luns, een katholieke diplomaat die hem al dikwijls van advies had gediend over internationale kwesties. Luns was een markante figuur die vond dat Nederland zijn invloed aan de andere kant van de aardbol zoveel mogelijk moest behouden; daarom moest Nederland volgens hem een sterke marine handhaven en het westelijk deel van Nieuw-Guinea even lang vasthouden als Australië het oostelijk deel. (In 1956 kwam het departement van buitenlandse zaken weer onder eenhoofdige leiding. Luns bleef tot 1971 minister van buitenlandse zaken en kon dus nog vele jaren zijn stempel op het Nederlandse Indonesiëbeleid drukken.)

Kort na de verkiezingen had Lamping, de Nederlandse Hoge Commissaris in Djakarta, de regering gewaarschuwd dat alle Nederlandse invloed in Indonesië verloren dreigde te gaan als Nederland op het punt van NieuwGuinea onbuigzaam bleef. Soortgelijke waarschuwingen waren in Den Haag geuit door ambtenaren van het departement van buitenlandse zaken die de relatie met Indonesië behandelden. Het mocht niet baten; de Nederlandse opstelling werd steeds harder.

Zo deed zich eind 1952 ook een opmerkelijke verharding voor in de opstelling van de Partij van de Arbeid. Twee invloedrijke leden van de PvdAfractie in de Tweede Kamer die in 1945-1949 vurige pleitbezorgers voor het Indonesische vrijheidsstreven geweest waren, Frans Goedhart en Jacques de Kadt, vonden overdracht van Nieuw-Guinea nu niet langer verantwoord. Hun politieke denken werd destijds overheerst door de Koude Oorlog en zij waren zeer beducht dat Indonesië naar het communistische kamp zou kunnen overgaan. Goedhart had in najaar 1952 op uitnodiging van de Indonesische regering enige maanden door Indonesië gereisd, maar had zich toen bijzonder geërgerd aan Soekarno's monomane retoriek over Nieuw-Guinea onder verwaarlozing van Indonesië's reële problemen.

Soekarno was bij uitstek een volksleider en geen bestuurder. Tot 1950 had hij al zijn politieke inspanningen op één doel gericht: onafhankelijkheid voor 
Indonesië, maar hij had nooit veel belangstelling getoond voor de vraag wat er gebeuren moest wanneer dat doel eenmaal bereikt was. Intussen wekte de nu bereikte onafhankelijkheid onder de Indonesische bevolking niet alleen voldoening maar ook teleurstelling. Velen hadden daarvan louter vooruitgang en voorspoed verwacht, maar het tegendeel was eerder het geval. Vooral op Java was er sprake van een voortschrijdende economische en sociale ontreddering, die onder meer veroorzaakt werd door de naweeën van de Japanse bezetting en het conflict met Nederland en door een nijpend tekort aan geschoolde krachten. Dat Soekarno in zijn toespraken steeds hamerde op het onvoltooid zijn van de Indonesische revolutie zolang Nieuw-Guinea nog in Nederlandse handen bleef, kwam ten dele voort uit zijn verlangen iets van het elan, de opofferingsgezindheid en de saamhorigheid terug te roepen waarmee de vrijheidsstrijd gepaard was gegaan. Dit betekent niet dat hij deze onvoltooidheid het liefst zag voortduren, want hij wenste wel degelijk de rood-witte vlag over Nieuw-Guinea te zien waaien. Door het mobiliseren van nationale volkswoede hoopte hij de druk op Nederland te vergroten. Overigens was hij niet altijd tegen concessies om het Nederland gemakkelijker te maken de soevereiniteitsaanspraak op Nieuw-Guinea te laten varen. Dit was nog in het voorjaar van 1952 in zijn gesprek met Paul Rijkens gebleken.

In Indonesië deed het in april 1952 aangetreden kabinet-Wilopo geen pogingen meer om de kwestie Nieuw-Guinea met Nederland te bespreken. Vervolgens stelde het in juli 1953 gevormde kabinet-Ali Sastroamidjojo zich in deze kwestie aanzienlijk militanter op. Het liet al spoedig weten dat, als Nederland overeenstemming over Nieuw-Guinea bleef uitsluiten, Indonesië voorbereidingen zou treffen om het gebied met andere middelen dan onderhandelingen terug te krijgen. In 1954 stelde deze regering een West-Irian Bureau in dat de bevolking moest doordringen van de noodzaak van terugkeer van Nieuw-Guinea in het Indonesische staatsverband. Toch opende deze zelfde regering ook besprekingen met Nederland, niet omdat zij verwachtte daarmee ten aanzien van Nieuw-Guinea een stap verder te komen, maar omdat zij definitief een eind wilde maken aan de Indonesisch-Nederlandse Unie. Inderdaad weigerde Nederland over Nieuw-Guinea te spreken, maar wel ondertekenden de beide regeringen in augustus 1954 een protocol over opheffing van de Unie. Zoals al eerder vermeld werd dit protocol in Indonesië zeer negatief ontvangen zodat het niet in werking kon treden.

Bij haar weigering om over Nieuw-Guinea te spreken kon de Nederlandse regering in 1954 rekenen op massieve steun in het parlement. Met uitzondering van de communistische partij waren alle partijen het erover eens, dat de soevereiniteit over het gebied bij Nederland berustte en moest blijven berusten totdat de bevolking ervan in staat zou zijn zelf over haar staatkundig lot te beslissen, dat er geen sprake kon zijn van nieuwe onderhandelingen met Indonesië over de toekomstige status van het gebied en dat Nederland geen 
enkele vorm van gemengd bestuur of gedeelde verantwoordelijkheid voor het gebied zou mogen aanvaarden.

De regering-Ali besloot nu een andere weg in te slaan. Op 17 augustus 1954 kondigde Soekarno aan dat Indonesië zich over deze kwestie tot de Verenigde Naties zou wenden. In september zette de Algemene Vergadering der Verenigde Naties (AVVN) de kwestie inderdaad op de agenda van haar najaarszitting en ook in enige latere zittingen hield zij zich met dit onderwerp bezig. De pogingen van Indonesië om langs deze weg Nederland onder druk te zetten werden echter een uitermate frustrerende exercitie.

Omdat Indonesië de kwestie voorstelde als een probleem dat de vrede in gevaar zou kunnen brengen, kon de AVVN hier alleen met een meerderheid van twee derde besluiten over nemen. De door Indonesië gewenste ontwerpresoluties behaalden echter telkens wel een gewone maar geen twee derde meerderheid. Er bestond destijds in de Verenigde Naties nog niet zo'n overwicht van niet-westers georiënteerde staten als later ontstaan is, vooral na de toetreding van tientallen voormalige Franse en Britse koloniën. Verder kreeg Nederland in zijn verzet tegen die ontwerp-resoluties niet alleen steun van de Europese niet-communistische landen maar ook van veel Latijns-Amerikaanse landen. De Verenigde Staten onthielden zich van stemming.

In 1954 ging de stemming over een ontwerp-resolutie die alleen maar de hoop uitsprak dat de regeringen van Indonesië en Nederland zouden blijven streven naar een oplossing van hun geschil over Nieuw-Guinea en die hun verzocht daarover verslag uit te brengen aan de AVVN. Desondanks verzette Nederland zich hier krachtig tegen. De ontwerp-resolutie kreeg uiteindelijk 34 voorstemmen en 23 tegenstemmen.

In 1955 voelde Indonesië zich gesterkt omdat de Afro-Aziatische conferentie in Bandung in april met algemene stemmen een resolutie aangenomen had die het Nederlandse Nieuw-Guineabeleid verwierp als een vorm van kolonialisme. Niettemin zag de regering-Harahap er eind 1955 van af om weer in de AVVN te laten stemmen over een Nederland onwelgevallige tekst, omdat zij toen zelf nieuw bilateraal overleg met Nederland aanging. De tussen de beide regeringen overeengekomen agenda voor dat overleg betrof in de eerste plaats de beëindiging van de Indonesisch-Nederlandse Unie, maar bevatte ook een agendapunt luidende: 'Bespreking van bepaalde vraagstukken betreffende Nieuw-Guinea, met dien verstande dat ten aanzien van de soevereiniteit iedere partij haar eigen standpunt handhaaft'. Kennelijk was het eerste deel van deze formule voor het Indonesische publiek bestemd en het tweede deel voor het Nederlandse publiek. Het overleg vond in Genève plaats. Daarbij werd de Indonesische delegatie geleid door minister Anak Agung en de Nederlandse delegatie door minister Luns. De bespreking van kwesties met betrekking tot Nieuw-Guinea leidde echter tot niets, terwijl zoals al in vorige paragrafen vermeld ook het overleg over de beëindiging van de Unie op een mislukking 
uitliep. Begin 1956 is dit voor Indonesië aanleiding geweest is om de Unie eenzijdig op te zeggen.

In het voorjaar van 1956 maakte het kabinet-Harahap plaats voor het tweede kabinet onder Ali Sastroamidjojo. In het najaar kwam in de AVVN een nieuwe ontwerp-resolutie over Nieuw-Guinea in stemming. Naar het voorbeeld van de VN-bemoeienis uit 1947-1948 met het conflict tussen Nederland en de Republiek voorzag dit ontwerp in de benoeming van een VN-Commissie van Goede Diensten die een rechtvaardige en vreedzame oplossing van de NieuwGuinea-kwestie zou moeten bevorderen. Deze resolutie kreeg 40 voorstemmen en 25 tegenstemmen en haalde dus wederom niet de vereiste twee derde meerderheid. In najaar 1957 legde de Indonesische regering de kwestie voor de derde maal aan de AVVN voor, waarbij zij uitdrukkelijk liet weten dat dit de laatste maal zou zijn.

De frustratie in Indonesië over de mislukking van de initiatieven in de Verenigde Naties was des te groter, omdat de bevolking in deze zelfde periode bewerkt werd met een steeds heftiger propagandacampagne tegen de Nederlandse aanwezigheid in Nieuw-Guinea. Hierbij werd de regeringAli krachtig gesteund door de PNI, de PKI en ook de Nahdatul Ulama. Er vonden talloze anti-Nederlandse demonstraties plaats en er werd dikwijls gevraagd om stappen tegen de Nederlandse belangen in Indonesië. Ook trokken Indonesische strijders soms Nieuw-Guinea zelf binnen. In oktober 1954 ontvoerde een Indonesische infiltratiegroep onder Papoealeiding daar een Nederlandse politieagent. De internationale publiciteit hierover was de Indonesische regering welkom, opdat men ook binnen de Verenigde Naties zou gaan beseffen dat het conflict over Nieuw-Guinea zich tot een gevaarlijke situatie ontwikkelde. De Nederlandse agent bleef een jaar lang in Indonesische gevangenschap. Daarna liet de regering-Harahap hem vrij omdat zij het bilaterale overleg met Nederland wilde hervatten. Na de mislukking van dat overleg en het aantreden van de tweede regering-Ali Sastroamidjojo nam de anti-Nederlandse campagne nog in hevigheid toe.

\section{Anti-Nederlandse processen in Djakarta}

Hoewel er in 1949 een eind gekomen was aan het grote militaire conflict tussen de Republiek Indonesië en Nederland, betekende dit niet dat er daarna binnen Indonesië geen gewapende strijd meer gevoerd werd. Al ten tijde van de Nederlandse soevereiniteitsoverdracht bestonden hier verschillende Indonesische strijdgroepen die niet bereid waren zich aan het gezag van Soekarno en Hatta te onderwerpen. Verreweg de belangrijkste daarvan was de Darul Islam die sommige delen van West-Java beheerste en wier leider, Kartosuwirjo, een Islamitische Indonesische Staat uitgeroepen had. Midden 
1950 ontstond er ook een breuk tussen de centrale regering en een grote guerrilla-organisatie in Zuid-Celebes die bezwaar had tegen de voorwaarden waaronder zij tot het leger kon toetreden. Deze opstandige beweging onder leiding van Kahar Muzakkar, een streng-orthodoxe moslim, sloot zich in 1952 bij de Darul Islam aan. In 1953 vond in Indonesië een verdere scheuring plaats in de vorm van een opstand in Atjeh onder leiding van Daud Beureuh, een Masjumi-politicus die voor 1950 de belangrijkste Republikeinse bestuurder in Atjeh geweest was. Verder waren de Indonesische strijdkrachten, ondanks de herovering van Ambon eind 1950, er nooit in geslaagd volledig een eind te maken de opstandige beweging die zich Republiek der Zuid-Molukken (RMS) noemde; onder meer op het eiland Ceram voerden RMS-aanhangers nog steeds een guerrilla tegen de centrale regering.

Voor een groot deel van het Indonesische publiek was het onbegrijpelijk dat de eigen strijdkrachten er niet in slaagden deze opstandige bewegingen uit te schakelen. De veronderstelling lag daarom voor de hand dat die bewegingen buitenlandse steun kregen. Daarbij richtten de verdenkingen zich in de eerste plaats op Nederland. De Nederlandse avonturier Westerling had immers begin 1950 zelf beweerd over een eigen leger te beschikken, de APRA. Daarna was zijn aanslag op Bandung weliswaar mislukt en was hij zelf uit Indonesië gevlucht, maar men kon zich afvragen waar het gros van zijn leger gebleven was. Bovendien genoot hij in Nederland alle vrijheid om tegen de Indonesische eenheidsstaat te ageren en werd in hetzelfde Nederland openlijk geld ingezameld voor steun aan de RMS. Tegen die achtergrond deden al jarenlang geruchten de ronde dat Nederlandse oud-officieren actief meestreden met de Darul Islam.

In 1953 zaten nog twaalf Nederlanders in hechtenis die in 1950 gearresteerd waren op verdenking van medeplichtigheid aan de activiteiten van Westerling. In augustus en november werden zij nu eindelijk vrijgelaten, maar dit leidde tot felle kritiek op de regering-Ali Sastroamidjojo. Zowel van militaire als van links-politieke kant stelde men dat deze verdachten terecht hadden moeten staan.

$\mathrm{Na}$ deze omstreden vrijlatingen volgde tot veler verrassing een nieuwe arrestatiegolf, niet door de gewone politie of door het leger maar door een onder de premier staande veiligheidsdienst, de Dinas Pengawas Keselamatan Negara (DPKN, Dienst voor Toezicht op het Welzijn van de Staat). Deze veiligheidsdienst nam op Java tussen half december 1953 en eind januari 1954 meer dan dertig Nederlanders gevangen. Al in januari berichtten Indonesische kranten dat een grote ondergrondse organisatie opgerold was, die NederlandsIndische Guerrilla Organisatie (NIGO) zou heten en zou samenwerken met de Darul Islam. Al deze berichten berustten niet op eigen journalistiek onderzoek maar op anonieme mededelingen van hogerhand. De zogenaamde NIGO bestond in werkelijkheid niet en had nooit bestaan. 
Hoewel de DPKN ruim dertig Nederlanders gearresteerd had, richtte zij zich in hoofdzaak op de voorbereiding van processen tegen slechts twee van hen, L. Jungschläger en H. Schmidt. Jungschläger had voor de Tweede Wereldoorlog gewerkt bij het interinsulaire scheepvaartbedrijf KPM. Tijdens de oorlog had hij bij de Nederlandse marine gediend; eind 1944 was hij in Australië bij de Nederlandse inlichtingendienst NEFIS gekomen en van april tot november 1947 was hij daar hoofd van geweest. Daarna was hij gedemobiliseerd en teruggekeerd bij de KPM. Schmidt was een voormalige KNILofficier die de oorlog in Japanse gevangenschap doorgebracht had. Na de opheffing van het KNIL in 1950 had hij eerst bij Garuda Indonesian Airways in Djakarta gewerkt en was hij vervolgens in dienst getreden bij een makelaarskantoor in Bandung.

De DPKN wilde deze twee Nederlandse oud-officieren presenteren als leiders van een grote subversieve organisatie. De overige arrestanten zouden bewijs tegen hen moeten leveren door verklaringen af te leggen die hun door de DPKN werden opgegeven. Om hen tot die verklaringen te dwingen werden veel arrestanten mishandeld, onder meer met afranselingen en met onderdompeling in water. Het lukte enkelen van hen om briefjes uit de gevangenis te smokkelen waarin zij om hulp vroegen. $\mathrm{Al}$ in februari bereikten zulke noodkreten het Nederlandse Hoge Commissariaat. Omdat het ministerie van justitie liet weten geen zeggenschap over de DPKN-gevangenen te hebben wendde de Nederlandse Hoge Commissaris zich tot premier Ali zelf, maar die deed de berichten over mishandeling af als verzinsels.

Pas eind juni, toen de regering-Ali onderhandelingen met Nederland opende over ontbinding van de Indonesisch-Nederlandse Unie, kregen medewerkers van het Hoge Commissariaat toestemming om de Nederlandse arrestanten te bezoeken, maar zonder mogelijkheid hen onder vier ogen te spreken. Op 9 september 1954 begon onder grote publieke belangstelling het proces tegen Schmidt. Sommige dagbladen verlangden al bij voorbaat de doodstraf tegen 'deze vijand van het volk'. Volgens de openbare aanklager was Schmidt opgetreden als leider van de NIGO en was dit een organisatie die ten doel had de wettige Indonesische regering omver te werpen; daarbij zou hij onder meer de Darul Islam van wapens en levensmiddelen hebben voorzien en gewapende aanvallen hebben geleid op leger- en politie-eenheden. Het Hoge Commissariaat had er intussen voor gezorgd dat Schmidt verdedigd werd door twee advocaten, de Nederlander H. Bouman en de Indonesische mevrouw Razak. Er volgden nog vele zittingen. Het proces was openbaar en werd ook door Nederlandse journalisten bijgewoond.

In Nederland trok deze rechtzaak uiteraard bijzondere aandacht, die nog toenam toen daar in oktober onthullingen in de pers verschenen over de mishandeling van arrestanten. De Nederlandse regering had zelf nog geen bekendheid aan die mishandelingen gegeven, omdat zij hoopte de 
Indonesische regering onder druk te kunnen zetten door met publiciteit te dreigen.

Tot de door de openbare aanklager in het proces opgevoerde getuigen behoorden, naast Nederlanders die in het begin van het jaar gearresteerd waren, ook verscheidene Indonesiërs. Vooral hun verklaringen waren vaak bijzonder vreemd. Zo zei een getuige dat Kartosuwirjo (de belangrijkste opstandelingenleider van Indonesië) meermalen in Djakarta de Nederlandse Hoge Commissaris persoonlijk had bezocht. Ook zou Kartosuwirjo in de eetzaal van een groot hotel in Djakarta een geheime bespreking met Schmidt hebben gevoerd. Verder zou Schmidt aan de zuidkust van Java zijn gezien terwijl daar een duikboot opdook waaruit drie grote motorboten gelost werden. Overigens noemden de getuigen zoveel dagen waarop ze Schmidt in de bergen van West-Java gezien hadden, dat hij nauwelijks tijd gehad zou hebben om op zijn kantoor in Bandung te werken. De meeste Indonesische kranten gaven de aantijgingen tegen de zogenaamde NIGO uitgebreid weer, zonder aandacht voor deze ongerijmdheden.

Schmidt en zijn advocaten toonden de ongeloofwaardigheid van veel zulke getuigenissen aan. Kennelijk was de rechter zelf ook niet van die getuigenissen onder de indruk, naar bleek uit zijn kritische vragen aan de getuigen. In november werd het proces echter plotseling geschorst; kort daarna trok de rechter zich om gezondheidsredenen terug. Pas in maart 1955 werd het proces hervat, nu onder een andere rechter die zich minder kritisch opstelde dan zijn voorganger.

In februari 1955 begon eindelijk ook het proces tegen Jungschläger, onder nog een andere rechter. Volgens de openbare aanklager was Jungschläger het eigenlijke brein achter de complotten. Hij zou de leiding gehad hebben van verschillende ondergrondse bewegingen, waaronder de APRA en de NIGO, die er op uit waren de regering van Indonesië omver te werpen en het Nederlandse gezag te herstellen.

Ook in het proces-Jungschläger traden Bouman en mevrouw Razak als verdedigers op, maar de aanklager spande zich nu in om hen uit te schakelen door henzelf van strafbare feiten te beschuldigen. Al in februari onderwierp hij Bouman aan een langdurig verhoor; in april werd ook mevrouw Razak beschuldigd en verhoord. Bouman trok zich als verdediger terug; hij kreeg een uitreisverbod maar wist begin mei via Singapore naar Nederland te vluchten. Kort daarop trok ook mevrouw Razak zich uit de verdediging terug. Intussen had de Nederlandse regering een Britse advocaat bereid gevonden om Schmidt en Jungschläger te verdedigen, maar de Indonesische regering weigerde hem toe te laten.

Er kwam nu een nieuwe wending die de belangstelling in Nederland voor de processen bijzonder stimuleerde: Bouman's vrouw, die zelf geen juriste was maar de twee processen nauwkeurig gevolgd had, nam de verdediging van 
Schmidt en Jungschläger over. Zij bleek over een uitstekend geheugen, een helder inzicht en grote persoonlijke moed te beschikken. Verder publiceerde de Nederlandse regering in juni een witboek in verschillende talen over de politieke processen in Indonesië en de daarmee verbonden mishandeling van arrestanten. Overigens kwam het nu ook in die processen zelf voor dat getuigen in de rechtzaal openlijk verklaarden te zijn mishandeld.

In augustus 1955 maakte het kabinet-Ali plaats voor het kabinet-Harahap, maar tot teleurstelling van Nederland bleven de processen zich voortslepen. Bovendien werd de sfeer steeds dreigender. Op de zittingsdagen werd het gerechtsgebouw omringd door demonstranten die riepen om de doodstraf tegen Jungschläger en Schmidt. Soms werd ook mevrouw Bouman bedreigd. In februari 1956 eiste de aanklager de doodstraf tegen Jungschläger. In maart kreeg Jungschläger voor het laatst het woord. De uitspraak zou eind april volgen, maar zover kwam het niet. Op 19 april stierf hij aan een hersenbloeding.

Intussen was Ali Sastroamidjojo eind maart teruggekeerd als ministerpresident. De rechter die het proces tegen Jungschläger voorgezeten had werd minister van justitie in het nieuwe kabinet-Ali. Verder kwam er een eind aan de Indonesisch-Nederlandse Unie, zodat Nederland nu niet meer door een Hoge Commissaris vertegenwoordigd werd. Het proces tegen Schmidt ging nog een half jaar door.

In augustus 1956 eiste de aanklager tegen Schmidt een gevangenisstraf van vijftien jaar. Op 17 september hield deze zijn laatste verdedigingsrede. Heel Djakarta hing vol leuzen die de doodstraf tegen hem verlangden. Mevrouw Bouman werd na de zitting door demonstranten aangevallen; met hulp van Nederlandse journalisten kon zij zich binnen het gerechtsgebouw verbergen en later wegvluchten over een muur. Omdat zij haar leven niet meer zeker was vertrok zij kort daarna naar Nederland. De rechter veroordeelde Schmidt in oktober overeenkomstig de eis tot vijftien jaar gevangenisstraf.

Een deel van de in 1954 gearresteerde Nederlanders was intussen vrijgelaten. In de loop van 1957 kregen alle nog in voorarrest vastzittende arrestanten hun vrijheid terug. Schmidt zelf bleef gevangen tot maart 1959.

Niets heeft de verhouding tussen Indonesië en Nederland ooit meer kwaad gedaan dan de schijnprocessen tegen Schmidt en Jungschläger. Voor sommige Indonesische gezagsdragers kwamen die processen goed van pas, omdat ze de aandacht afleidden van hun eigen falen in de oplossing van de binnenlandse problemen en in de beëindiging van de opstandige bewegingen. Vooral op Java heerste er onder de bevolking teleurstelling over de economische en sociale achteruitgang sinds het bereiken van de onafhankelijkheid. De berichten over de zogenaamde NIGO brachten daar een bevredigende verklaring voor: die achteruitgang was het gevolg van Nederlandse sabotage. Tussen de eerste berichten hierover in januari 1954 en de veroordeling van Schmidt in oktober 1956 verstreek ruim tweëenhalf jaar. Al die tijd werd het Indonesische 
publiek tegen Nederland opgehitst met de verzinsels van de DPKN. Niemand durfde daar tegen in te gaan. De processen kregen een haast rituele betekenis. Schmidt en Jungschläger waren zondebokken geworden die moesten boeten voor alles wat Indonesië aan Nederland verweet.

De tijd waarin deze schijnprocessen het Nederlandse publiek in beroering brachten duurde niet veel korter: ruim twee jaar van september 1954 tot oktober 1956. Via pers en radio volgde men deze vertoning met spanning, verbijstering en afschuw. Na het overlijden van Jungschläger liet de Nederlandse regering zijn stoffelijk overschot per vliegtuig naar Nederland overbrengen; duizenden woonden daar zijn begrafenis bij. Een half jaar later werd mevrouw Bouman bij haar aankomst in Nederland door duizenden op het vliegveld verwelkomd. Zij was toen de meest bewonderde vrouw van Nederland en werd kort daarna door koningin Juliana ontvangen. De processen droegen in Nederland bij tot grote weerzin tegen het Indonesië van Soekarno. De bereidheid om Nieuw-Guinea daaraan over te dragen werd onder het Nederlandse publiek kleiner dan ooit. Slechts weinigen trokken een tegenovergestelde conclusie, namelijk dat men juist aan Indonesië tegemoet zou moeten komen om de Indonesische bevolking uit haar anti-Nederlandse psychose te verlossen.

\section{De eerste Indonesische parlementsverkiezingen en het laatste parlementaire kabinet}

Toen tijdens de laatste maanden van 1945 in de eerste Republiek Indonesië politieke partijen opgericht werden, verwachtte men algemeen dat in 1946 verkiezingen voor het Indonesische parlement zouden plaatsvinden. Niemand vermoedde toen dat de parlementsverkiezingen nog bijna tien jaar op zich zouden laten wachten.

De voorlopige grondwet van de nieuwe Republiek Indonesië van 1950 bepaalde dat de parlementsleden in algemene verkiezingen gekozen zouden worden volgens een bij wet te bepalen regeling. In afwachting van die verkiezingen kreeg de Republiek een uit benoemde leden bestaand voorlopig parlement. Het duurde tot 1953 voordat dit parlement eindelijk een kieswet vaststelde; daarna verstreken nog twee jaren voordat de uitvoering ervan geregeld was. Die vertraging was voor een belangrijk deel te wijten aan de vrees van veel parlementsleden niet in het gekozen parlement te zullen terugkeren. Dit gold onder meer voor veel parlementariërs uit de voormalige federale gebieden. Als late erfenis van het door Van Mook opgezette federale stelsel waren zowel de niet-Javaanse gebieden als de aristocratische families in het voorlopige parlement oververtegenwoordigd. Daarnaast verwachtten verscheidene politieke partijen er bij verkiezingen op achteruit te zullen gaan. Zo vreesde men in de nationalistische PNI dat het overwicht van de islamitische Masjumi dan nog flink zou toenemen omdat zij de enige partij was met veel aanhang 
buiten de steden. Die vrees werd weliswaar minder toen de traditionalistische Nahdatul Ulama (NU) zich van de meer modernistische Masjumi afsplitste, maar daar stond tegenover dat de positie van de PNI nu steeds meer bedreigd werd door de communistische PKI, de enige partij met een strak geleide partijorganisatie.

Volgens de grondwet moest naast het parlement ook een Konstituante worden gekozen die de definitieve grondwet zou moeten ontwerpen. In april 1955 werd afgesproken dat de verkiezingen voor het parlement gehouden zouden worden op 29 september en die voor de Konstituante op 15 december. De parlementsverkiezingen vonden zonder ernstige incidenten plaats. De opkomst was zeer hoog: ongeveer 90\%. De uitslagen weken sterk af van de partijverhoudingen in het voorlopige parlement. Er bleken nog maar vier grote partijen te bestaan. De PNI was de grootste met $22 \%$ van de stemmen; de Masjumi werd tweede met 21\%; daarna volgden de NU met $18 \%$ en de PKI met $16 \%$. Alle andere partijen behaalden hooguit enkele procenten. Zo kreeg Sjahrir's PSI, die lange tijd een belangrijke politieke rol gespeeld had, nu nog maar $2 \%$ van de stemmen. De in december gehouden verkiezingen voor de Konstituante leverden een overeenkomstige uitslag op. Het nieuwe parlement kwam op 26 maart 1956 voor het eerst bijeen.

Sommigen hadden gehoopt dat de vervanging van het benoemde parlement door het gekozen parlement een heilzame invloed zou uitoefenen op het slecht functionerende parlementair-democratische stelsel. Het tegendeel bleek het geval: de verkiezingen hadden de opmaat gevormd naar de ondergang van dit stelsel.

Het nieuwe parlement beschikte over minder politieke ervaring dan zijn voorganger; slechts een kwart van zijn leden had ook deel uitgemaakt van het voorlopige parlement. De langdurige verkiezingsstrijd had de politieke verdeeldheid verscherpt. Ook beklemtoonde de uitslag de verschillen tussen de Javanen en de niet-Javanen (met inbegrip van de Soendanezen). De overgrote meerderheid van de aanhang van PNI, NU en PKI bevond zich op Java en vooral in Midden- en Oost-Java; daarentegen was de Masjumi zowel in de rest van Indonesië als in West-Java de sterkste partij.

In maart 1956 vormde Ali Sastroamidjojo een nieuw kabinet. De leden daarvan kwamen in hoofdzaak uit de PNI, de Masjumi en de NU. Tijdens de formatie hadden deze drie partijen zich verzet tegen aandrang van president Soekarno om ook leden van de PKI in de regering op te nemen. Wel waren nog vijf kleine partijen in het kabinet vertegenwoordigd. Er heerste echter binnen dit kabinet zoveel verschil van mening dat het onvoldoende in staat bleek de grote problemen van het land aan te pakken.

Steeds meer Indonesiërs raakten ontevreden over het partijpolitieke stelsel, dat naar hun mening de verdeeldheid van de natie bevorderde en doelmatig bestuur in de weg stond. Zulke gedachten leefden sterk onder de militairen, 
maar ook bij anderen. Soekarno zelf maakte zich tolk van die gedachten door bij de opening van het parlement te verklaren, dat een echte Indonesische democratie op broederschap moest berusten en niet op westers individualisme.

Er was hier een samenhang met de in deze zelfde tijd gevoerde anti-Nederlandse agitatie. Voor de Tweede Wereldoorlog hadden de meeste Indonesische nationalisten het Nederlandse parlementaire stelsel als politieke norm gehanteerd. In 1938 had dit geleid tot de grote campagne 'Indonesië parlementair', die het verzet tegen het koloniale bestel gekleed had in de eis dat Indonesië een uit en door de bevolking gekozen parlement zou moeten krijgen met een daaraan verantwoordelijke regering (zie pp. 241-2). In oktober-november 1945 had dezelfde norm geleid tot een ingrijpende hervorming van het Republikeinse staatsbestel (zie pp. 421-2). Nu deed zich het omgekeerde voor: het Indonesische parlementaire stelsel kwam juist in een slecht daglicht te staan omdat het met het Nederlandse stelsel overeenkwam.

Wat Soekarno betreft, die had zich nooit kunnen vinden in de rol van een titulair staatshoofd. Weliswaar liet hij het dagelijks bestuur van het land graag aan anderen over, maar hij wilde zelf wel de opperste leider zijn die het laatste woord had. Na de bijeenkomst van het nieuwe parlement bleef hij herhaaldelijk lange tijd uit Indonesië weg. In mei-juli 1956 reisde hij naar de Verenigde Staten en verschillende West-Europese landen, waarbij hij het Amerikaanse parlement mocht toespreken en zowel president Eisenhower als andere staatshoofden mocht ontmoeten. In augustus-oktober 1956 bezocht hij de SovjetUnie en de Chinese Volksrepubliek. Na zijn terugkeer uit China verklaarde hij dat Indonesië in 1945 een ernstige fout gemaakt had door de oprichting van een groot aantal politieke partijen te bevorderen. Indonesië had volgens hem een 'geleide democratie' nodig.

Intussen namen binnen Indonesië de spanningen toe tussen de centrale regering en de gebieden buiten Java. In veel van die gebieden achtte men zich economisch benadeeld ten voordele van het hoofdeiland. Het grootste deel van de Indonesische inkomsten uit export werd door deze gebieden opgebracht, maar die opbrengsten kwamen vooral aan de bevolking van Java ten goede. Daarnaast ergerde men zich aan het centralistische stelsel waardoor men allerlei regionale kwesties niet regionaal kon regelen maar telkens afhankelijk was van besluiten in Djakarta. Tenslotte bestonden er ook psychologische tegenstellingen tussen Javanen en niet-Javanen. De niet-Javanen, met inbegrip van de Soendanezen, vormden $55 \%$ van de bevolking; velen van hen waren beducht voor een samenleving waarin alleen Javanen de dienst zouden uitmaken. Juist als Sumatraan genoot vice-president Hatta veel vertrouwen onder de niet-Javanen.

In de loop van 1956 namen plaatselijke gezagsdragers zowel op Celebes als op Sumatra maatregelen waardoor een groter deel van de export-inkomsten 
aan de exporterende gebieden zelf ten goede kwam. Militaire commandanten en burgerlijke bestuurders werkten hierbij samen. De centrale regering was verdeeld over de vraag hoe men deze regionale insubordinatie moest aanpakken. Vooral binnen de Masjumi bestond begrip voor de regionale wensen.

Op 1 december 1956 trad Hatta af als vice-president. De verschillen van opvatting tussen hem en Soekarno waren te groot geworden. Zijn aftreden gaf een verdere stimulans aan de regionale pogingen om zich aan het gezag van de centrale regering te onttrekken. In de loop van december namen militaire commandanten zowel in Midden-Sumatra als in Noord-Sumatra het bestuur over.

In januari 1957 verlieten de tot de Masjumi behorende ministers het kabinet, waardoor dit zijn meerderheid in het parlement kwijtraakte. Niettemin bleef het afbrokkelende kabinet-Ali nog aan. In februari verklaarde Soekarno dat Indonesië een nieuw regeersysteem nodig had, niet gebaseerd op geïmporteerde westerse normen maar op traditionele Indonesische waarden. Tot die westerse normen rekende hij zowel partijstrijd als besluitvorming bij meerderheid van stemmen, tot de Indonesische tradities behoorden volgens hem zowel wederzijds hulpbetoon als het streven naar overeenstemming door voortgezet overleg. In aansluiting hierop zette hij zijn eigen denkbeelden (zijn konsepsi) over het wenselijke staatsbestel uiteen, waaronder de instelling van een Nationale Raad ter vertegenwoordiging van groepen die onvoldoende in de politieke partijen tot hun recht kwamen.

Begin maart kwam er een nieuwe breuk in de eenheid van Indonesië. De territoriale commandant van Oost-Indonesië, luitenant-kolonel Ventje Sumual, trok de macht over de hele provincie aan zich. Tegelijk publiceerde hij onder de titel Piagam Perdjuangan Semesta Alam (Handvest van de Universele Strijd) een samenvatting van de wensen van de regio's tegenover de centrale regering; zijn opstandige beweging werd daarom wel de Permesta-beweging genoemd. Kort daarna maakte ook de militaire commandant van Zuid-Sumatra zich los van het centrale gezag.

De positie van het kabinet-Ali was onhoudbaar geworden. Op 14 maart 1957 trad het af. Soekarno nam nu in overeenstemming met zijn konsepsi de afbraak van het parlementaire stelsel ter hand. Nog op dezelfde dag kondigde hij voor heel Indonesië de staat van beleg af, wat onder meer inhield dat het burgerlijke bestuur op plaatselijk niveau ondergeschikt werd aan het militaire gezag. Op 8 april vormde hij zelf een extra-parlementair kabinet. Premier hiervan werd de partijloze maar algemeen gerespecteerde oud-minister Djuanda Kartawidjaja. Het kabinet bestond voornamelijk uit leden van de PNI en de NU naast negen partijloze deskundigen; Chaerul Saleh maakte er deel van uit als minister van veteranenzaken. Vervolgens installeerde Soekarno in juli de door hem al aangekondige Nationale Raad. De Raad telde 42 leden, onder wie de chefs van de strijdkrachten en de politie naast vertegenwoordigers 
van groepen zoals arbeiders, boeren, ondernemers, journalisten, kunstenaars, vrouwen, jongeren, veteranen en de 'generatie van 1945'. Soekarno werd zelf voorzitter van deze Raad; Ruslan Abdulgani werd secretaris-generaal.

\section{Volledige breuk van Indonesië met Nederland}

Na de opzegging van de Indonesisch-Nederlandse Unie in het voorjaar van 1956 raakten Indonesië en Nederland steeds verder uit elkaar. Met uitzondering van de communisten hielden vrijwel alle Nederlandse politici vast aan het standpunt, dat de soevereiniteit over westelijk Nieuw-Guinea bij Nederland berustte en moest blijven berusten totdat de inwoners van het gebied in staat zouden zijn over eigen lot te beslissen. Terwijl in juni verkiezingen voor de Tweede Kamer plaatsvonden, speelde de verhouding met Indonesië in de daaraan voorafgaande verkiezingsstrijd geen rol. De daarop gevolgde kabinetsformatie duurde nog veel langer dan destijds in Indonesië gebruikelijk was. Pas in oktober 1956 trad een nieuw kabinet-Drees aan, overigens van dezelfde politieke samenstelling als het vorige en met Luns als minister van buitenlandse zaken. In zijn regeringsverklaring liet dit nieuwe kabinet weten dat het geen initiatieven over Nieuw-Guinea zou nemen.

Een tegengeluid kwam in juli 1956 uit niet-politieke hoek. Een grote protestants-christelijke kerkelijke organisatie, de Generale Synode der Nederlands Hervormde Kerk, publiceerde toen een 'Oproep tot bezinning' waarin zij verklaarde dat Nederland bereid moest zijn af te zien van zijn aanspraken om Nieuw-Guinea alleen op eigen gezag te besturen. Daarbij merkte zij ook op dat Nederland door de handhaving van zijn bestuur de bewoners van dit gebied afsneed van de naburige gebieden in Oost-Indonesië waarmee zij door historische banden verbonden waren. De oproep van de Synode was verrassend omdat juist de protestants-christelijke partijen al sinds 1945 de felste voorstanders waren van een harde lijn in het Indonesië-beleid. De oproep kreeg echter weinig steun. Bij een opiniepeiling verklaarden slechts $10 \%$ van de ondervraagde Nederlanders zich voor een nieuwe poging tot bijleggen van het conflict met Indonesië. Zo kort na de dramatische dood van Jungschläger kon men ook moeilijk anders verwachten.

Zoals vaker werden de verkiezingen gevolgd door een grondwetswijziging (omdat wijzigingen van de Nederlandse grondwet pas van kracht kunnen worden wanneer ze na verkiezingen opnieuw in het parlement behandeld zijn). Sinds 1948 luidde artikel 1 van de grondwet: 'Het Koninkrijk der Nederlanden omvat het grondgebied van Nederland, Indonesië, Suriname en de Nederlandse Antillen'. Bij de grondwetswijziging van 1956 verdween de vermelding van Indonesië uit dit artikel, maar werd tegelijk Nederlands Nieuw-Guinea erin opgenomen. Naar Nederlandse opvatting was dit niets 
meer dan een aanpassing van de tekst aan de nieuwe situatie sinds de soevereiniteitsoverdracht van december 1949. Daarentegen zag men in Indonesië deze grondwetswijziging als een onrechtmatige en vijandige daad.

Intussen was in Indonesië de tweede regering-Ali aangetreden en was de anti-Nederlandse campagne daar nog in hevigheid toegenomen. In massavergaderingen en in persartikelen werd onder meer gepleit voor nationalisatie van de Nederlandse ondernemingen als Nederland bleef weigeren NieuwGuinea over te dragen. In augustus 1956 zette de Indonesische regering zelf een nieuwe stap na de opzegging van de Unie: zij verklaarde de nog bestaande financiële schulden van Indonesië aan Nederland niet langer te erkennen. Een en ander gaf de meeste Nederlandse politici geen aanleiding tot nadenken over de consequenties van het Nieuw-Guineabeleid. In het algemeen dachten deze politici niet dat dit beleid op een ramp in de verhouding met Indonesië afstevende; bovendien meenden ze dat iedere Nederlandse tegemoetkoming het Indonesische radicalisme alleen maar zou versterken. Ook het merendeel van de Nederlandse pers vond dat men niet moest wijken voor Indonesische chantage.

Daarentegen gaven de in Indonesië werkende Nederlandse ondernemers herhaaldelijk uiting aan hun diepe zorgen over de gevolgen van de starre Nederlandse houding. Hun pleidooien voor verandering maakten echter weinig indruk op de Nederlandse politici. Wel werden hun zorgen in Nederland gedeeld door enige leidende figuren van zeer grote ondernemingen. Op initiatief van Paul Rijkens, president-directeur van Unilever, waarschuwden deze figuren in informele contacten met Nederlandse beleidsmakers voor de rampzalige consequenties van het Nieuw-Guineabeleid. De niet-openbare waarschuwingen van deze 'groep-Rijkens' leidden evenmin tot politiek resultaat.

Een openbaar tegengeluid tegen het immobilisme van de Nederlandse politici kwam eind 1956 wederom uit niet-politieke hoek. Een groep van honderdzestien Nederlandse hoogleraren en andere intellectuelen vroeg toen aan de besturen van de zes grote partijen opnieuw om heroverweging van het Nieuw-Guineabeleid. Daarbij wezen zij de opvatting af dat het Nederlands bestuur over Nieuw-Guinea zijn rechtvaardiging vond in een zedelijke roeping. Ook dit verzoek vond geen weerklank.

Intussen nam de verontrusting ernstig toe op de Nederlandse vertegenwoordiging in Djakarta (die sinds de opzegging van de Unie geen Hoge Commissariaat meer was). De staf van die vertegenwoordiging redigeerde een kritisch stuk waarin het bestaande Indonesiëbeleid als legalistisch, passief en inconsequent werd bestempeld en waarin gepleit werd voor het zoeken van een oplossing in bilateraal overleg met Indonesië; daartoe zou herziening van het Nieuw-Guineabeleid noodzakelijk zijn. De staf zond dit stuk in januari 1957 aan minister Luns, met kopieën aan premier Drees en aan de voorzitters van de beide kamers van het parlement. Luns verwierp het stuk 'categorisch'; 
hij bleef bij zijn standpunt dat Nederland ten aanzien van Indonesië geen enkel initiatief moest nemen.

Eveneens in januari 1957 richtten ruim vierhonderd in Indonesië werkende Nederlanders, onder wie achttien hoogleraren, een petitie aan het Nederlandse parlement waarin zij erop aandrongen dat Nederland opnieuw met Indonesië over de status van Nieuw-Guinea zou praten. De petitie was georganiseerd door Willem Oltmans, een Nederlandse journalist die medio 1956 met Soekarno kennis gemaakt had tijdens diens bezoek aan WestEuropa. Oltmans was zich sindsdien gaan inzetten voor doorbreking van de tussen Nederland en Indonesië heersende impasse en kreeg daarbij financiële steun uit de groep-Rijkens. De petitie bleef zonder gevolg.

Op het politieke toneel in Indonesië zelf ging de aandacht in de eerste maanden van 1957 vooral uit naar de tweedracht tussen de centrale regering en enige militaire commandanten in Sumatra en Celebes, die leidde tot het aftreden van het kabinet-Ali, de afkondiging van de staat van beleg en Soekarno's stappen ter verwezenlijking van zijn eigen staatkundige konsepsi. De in april aangetreden regering-Djuanda polste de Nederlandse vertegenwoordiger in Djakarta over de mogelijkheid van toenadering tussen de beide landen, maar de onverzoenlijke standpunten over Nieuw-Guinea lieten hier geen ruimte voor.

In de tweede helft van 1957 ondernam de Indonesische regering een laatste poging om een voor Indonesië gunstige resolutie aangenomen te krijgen in de Algemene Vergadering van de VN. Die zeer korte en gematigde maar door Nederland fel bestreden ontwerp-resolutie hield een uitnodiging aan beide partijen in om hun pogingen tot het vinden van een oplossing van de Nieuw-Guinea-kwestie voort te zetten met bijstand van de Secretaris-Generaal van de VN. In nauwe samenhang met de Indonesische actie in de VN werd in Indonesië zelf de agitatie voor de terugkeer van West-Irian (westelijk NieuwGuinea) sterk opgevoerd. Vooral de politieke partijen PNI en PKI en de daarmee verbonden vakbonden ontplooiden in dit kader allerlei activiteiten. De door Soekarno voorgezeten Nationale Raad stelde voor een grote campagne te organiseren. De regering droeg de coördinatie daarvan op aan een nieuw Comité voor de Bevrijding van West-Irian. De campagne zou drie fasen tellen en telkens een stap verder gaan. Ook de in Indonesië wonende Nederlanders zouden daarbij het doelwit van acties worden.

Op 28 oktober begon de eerste fase met een grote demonstratie voor het gebouw van de Nederlandse vertegenwoordiging, waarbij een pop verbrand werd die het Nederlandse kolonialisme voorstelde. In de daarop volgende dagen werden Nederlandse kantoren en woningen met leuzen beklad en soms geplunderd. Op 10 november begon de tweede fase van de campagne met de bezetting van de twee belangrijkste Nederlandse clubgebouwen in Djakarta. De intimidatie van Nederlanders werd verhevigd; onder meer werden zij niet 
meer geholpen in winkels en markten en niet meer toegelaten tot restaurants en het openbaar vervoer.

Op 29 november vond in New York de stemming over de resolutie plaats. De uitslag was: 41 stemmen voor en 29 stemmen tegen, dus wederom wel een meerderheid maar geen twee derde meerderheid zodat de resolutie niet aangenomen was. De volgende dag steeg de spanning in Indonesië nog verder omdat in Djakarta een aanslag met handgranaten op Soekarno plaatsvond, waarbij hijzelf ongedeerd bleef maar elf anderen om het leven kwamen.

Op 3 december begon de derde fase van de Iriancampagne met een staking van vierentwintig uur in de Nederlandse bedrijven, een landingsverbod voor de Nederlandse luchtvaartmaatschappij KLM en beslag op de vloot van de Nederlandse scheepvaartmaatschappij KPM. Overigens hadden de meeste KPM-schepen de Indonesische wateren al tijdig verlaten; wel bezetten demonstranten het hoofdkantoor van de KPM in Djakarta. Eén dag later verbood de regering alle Nederlandstalige publicaties. Op 5 december verklaarde de minister van justitie (die voordien als rechter het proces tegen Jungschläger had voorgezeten) dat alle Nederlanders Indonesië zouden moeten verlaten. De fatale datum van deze verklaring kreeg onder de Nederlanders als spoedig de naam van 'Zwarte Sinterklaas'. Overigens werd de verklaring later afgezwakt in die zin dat alleen Nederlanders zonder werk zouden worden uitgewezen. Verder werden in deze derde fase steeds meer Nederlandse kantoren en bedrijven door demonstranten bezet; vaak gebeurde dit door vakbondsleden die daar dan rode vlaggen hesen.

De campagne kreeg een radicaler karakter dan de regering had voorzien. In het bijzonder de plotselinge overname van de talrijke grote landbouwbedrijven (de plantages) was de regering niet welkom. Op 9 december verklaarde Soekarno dat acties alleen toegestaan waren als ze door de centrale autoriteiten bevolen waren. Premier Djuanda onttrok de leiding van de Iriancampagne aan het Comité voor de Bevrijding van West-Irian. Generaal Nasution stelde alle plantages onder militair beheer. De rode vlaggen maakten plaats voor het nationale rood-wit. Ook werd er een eind gemaakt aan de anti-Nederlandse boycot. Wel kwamen nu alle Nederlandse bedrijven onder Indonesisch toezicht te staan, met uitzondering van bedrijven waar veel buitenlands kapitaal in geïnvesteerd was zoals Shell en Unilever.

Hoewel de regering de oorspronkelijk aangekondigde uitwijzing van de Nederlanders niet handhaafde, leidde die aankondiging samen met de van bovenaf ontketende intimidatie- en boycotcampagne wel degelijk tot verdrijving van de Nederlandse bevolkingsgroep uit Indonesië. Begin december 1957 telde Indonesië nog bijna vijftigduizend ingezetenen van Nederlandse nationaliteit (minder dan een kwart van het aantal Nederlandse ingezetenen van Indonesië in 1950). De overgrote meerderheid hiervan was in Indonesië geboren; de meesten waren van gemengd Europees-Aziatische afkomst; velen 
waren de bersiap-terreur van 1945 nog niet vergeten. Er kwam nu een grote uittocht op gang. Alleen al in december 1957 vertrokken er negenduizend. Passagiersschepen en vliegtuigen onderhielden een pendeldienst op Singapore; daar werden de evacués in geïmproviseerde kampen ondergebracht om vervolgens naar Nederland door te reizen. Binnen een half jaar trokken vierendertigduizend Nederlanders uit Indonesië weg. Van de resterende Nederlanders was een deel in dienst van zending of missie of van internationale oliebedrijven, terwijl een ander deel bestond uit onbemiddelde Indische Nederlanders zonder reële banden met Nederland.

Eind december 1957 besprak de Nederlandse regering de in Indonesië genomen anti-Nederlandse maatregelen met de Tweede Kamer. Zij kreeg brede instemming met haar mening dat die maatregelen geen uitvloeisel waren van het conflict over Nieuw-Guinea, maar dat dit conflict daartoe slechts tot voorwendsel gediend had. Ook de Nederlandse pers zag in het algemeen in die maatregelen geen gevolgen van de Nederlandse houding over Nieuw-Guinea, maar meende dat het de Indonesische leiders er alleen om ging zich op onwettige manier meester te maken van de Nederlandse ondernemingen. Daarentegen liet de fractie van de PvdA in de Eerste Kamer (waar oud-premier Schermerhorn deel van uitmaakte) begin 1958 een afwijkend geluid horen. Onder meer vond zij het onjuist dat Nederland zich in de VN tegen de resolutie gekeerd had die op overleg over Nieuw-Guinea aandrong.

Overigens betekenden de Indonesische maatregelen tot onderbeheerstelling van de Nederlandse bedrijven nog niet dat ze nu door Indonesië genationaliseerd werden, hoe vaak daar ook in het kader van de anti-Nederlandse agitatie op was aangedrongen. Nog lange tijd hoopte de Indonesische regering ze als onderpand te kunnen gebruiken om Nederland alsnog tot overdracht van Nieuw-Guinea te bewegen. Pas toen in het najaar duidelijk was dat hier geen enkele kans op bestond, besloot zij tot nationalisatie over te gaan. Daarbij verklaarde Soekarno dat de betaling van schadeloosstelling zou worden opgeschort zolang het geschil over Nieuw-Guinea bleef voortbestaan. De voor nationalisatie nodige wetgeving werd eind december 1958 door het parlement aangenomen. De waarde van de door Indonesië genationaliseerde bedrijven wordt op vier à vijf miljard gulden geschat.

Ook ging Indonesië in 1958 nog niet over tot verbreking van de diplomatieke betrekkingen met Nederland. Dit deed het pas op 17 augustus 1960, vijftien jaar na de proclamatie van de Indonesische onafhankelijkheid (zie p. 745).

\section{Ondergang van de democratie in Indonesië}

Op korte termijn bezorgden de anti-Nederlandse acties van december 1957 meer nadeel aan Indonesië dan aan Nederland. De plotselinge uitschake- 
ling van de Nederlandse banken en handelsondernemingen ontwrichtte de Indonesische economie. Het beslag op de KPM, die drie kwart van het interinsulaire scheepvaartverkeer in Indonesië verzorgd had, leidde zowel op Java als elders tot acute voedseltekorten. Hatta en verscheidene andere politici, onder meer van de Masjumi, uitten kritiek op de acties. Zo waarschuwde oud-minister Sjafruddin Prawiranegara, nu president van de Bank Indonesia, dat de Indonesische staat het merendeel van zijn belastinginkomsten uit Nederlandse ondernemingen betrok. De actievoerders keerden zich fel tegen hun critici. Omstreeks de jaarwisseling weken Sjafruddin, Natsir en Harahap naar Sumatra uit omdat zij zich op Java bedreigd voelden. Daar voerden ze in Padang overleg met enige dissidente militaire commandanten.

Het overleg leidde tot een ultimatum van deze groep aan het kabinetDjuanda waarin zij eiste dat dit kabinet zou aftreden, dat er een nieuwe regering zou komen onder Hatta en de sultan van Jogja, en dat Soekarno zich zou beperken tot zijn rol van constitutioneel staatshoofd. Het kabinet verwierp het ultimatum en ontsloeg de betrokken officieren. Daarna riep de Padangse groep op 15 februari 1958 een tegenregering uit die zich aandiende als Pemerintah Revolusioner Republik Indonesia (PRRI, Revolutionaire Regering van de Republiek Indonesië). Sjafruddin trad op als premier. Twee dagen later sloot de Permesta-beweging op Celebes zich bij de PRRI aan.

Ondanks het prestige van Sjafruddin, die in 1948-1949 de Republikeinse noodregering op Sumatra geleid had toen Soekarno en Hatta in Nederlandse gevangenschap verkeerden, genoot deze tegenregering weinig gezag. De rebellen hadden uiteenlopende belangen en motieven en kregen weinig steun van de bevolking. De rebellie was zowel militair als politiek slecht voorbereid. In feite beheerste de PRRI alleen Midden-Sumatra, een deel van NoordSumatra en het noorden van Celebes. In de andere gebieden buiten Java hielden de machthebbers zich afzijdig of bleven zij trouw aan Djakarta. Voorzover de rebellen sympathie verwacht mochten hebben van staf-chef Nasution als Sumatraan kwam die verwachting niet uit. Met vaste hand leidde hij de onderdrukking van de opstand. In maart 1958 gingen de eerste regeringstroepen op Sumatra aan land; begin mei waren daar alle belangrijke steden in hun handen. Daarna landden regeringstroepen in juni op Celebes, waar zij ook al spoedig alle steden beheersten. De leiders van de opstand weken met een deel van hun aanhangers naar de binnenlanden van Sumatra en Celebes uit.

De PRRI was aanvankelijk clandestien gesteund door de Amerikaanse geheime dienst, vooral via Taiwan en de Filipijnen. Naast de levering van wapens omvatte die steun onder meer de uitvoering van luchtaanvallen op Ambon dat een belangrijke basis voor de regeringstroepen vormde. Midden mei werd daar één van de aanvallende vliegtuigen neergeschoten, waarbij de piloot levend in Indonesische handen viel. Hij bleek een Amerikaan te zijn. Voor de Verenigde Staten was dit een ernstige blamage, al ontkende de 
Amerikaanse regering uiteraard iedere betrokkenheid.

De geslaagde onderdrukking van de opstand versterkte Nasution's positie als machtigste man van het land naast Soekarno. Hierbij valt te bedenken dat het leger er al sinds 1945 aanspraak op maakte niet onder maar naast de regering te staan. Na 1950 had het zelfs al tweemaal een minister gearresteerd op beschuldiging van corruptie. De in maart 1957 afgekondigde staat van beleg had aan de militairen bovendien uitdrukkelijke bevoegdheden gegeven om in te grijpen in het burgerlijk bestuur. In december 1957 had Nasution zijn macht verder uitgebreid door de bezette Nederlandse bedrijven onder militair toezicht te stellen. Zijn overwinning op de dissidente officieren op Sumatra en Celebes in 1958 vergrootte nu ook zijn gezag tegenover de territoriale commandanten. Hij benutte de nieuwe situatie om de rationalisatie van de strijdkrachten te hervatten. Veel officieren die hij in dat kader uit de actieve dienst verwijderde kregen nieuwe functies als toezichthouders van onder beheer gestelde bedrijven.

Het mislukte PRRI-avontuur had de positie van de Masjumi ernstig verzwakt. Enige van haar meest prominente leden hadden daar leiding aan gegeven; zelf had zij geweigerd de rebellie te veroordelen; zij zat niet in de regering en gaf geen steun aan Soekarno's staatkundige konsepsi. Daarentegen had de communistische PKI de strijd tegen de rebellie krachtig gesteund en was haar positie nu sterker dan ooit. Bij provinciale verkiezingen in 1957 was al gebleken dat zij kon rekenen op een grotere aanhang dan enige andere partij. Niet alleen beschikte zij over een gedisciplineerde partijorganisatie, maar ook voerde zij de regie over een reeks met haar verbonden arbeiders-, boeren-, vrouwen- en jeugdbonden die miljoenen leden telden. De leiding van de PKI wist echter dat het leger haar vijandig gezind was en zocht daartegen bescherming door zich nauw bij Soekarno aan te sluiten. Zo had zij grote demonstraties georganiseerd tot steun aan Soekarno's konsepsi. Ook was zij de motor geweest van de in december 1957 uitgevoerde bezetting van Nederlandse bedrijven. Soekarno van zijn kant gebruikte de steun van de PKI om niet uitsluitend van het leger afhankelijk te zijn.

Naast de in 1957 in het kader van Soekarno's konsepsi ingestelde Nationale Raad functioneerde intussen nog steeds het in 1955 gekozen parlement. Volgens de grondwet moest na vier jaar, dus in 1959, een nieuw parlement gekozen worden, maar de regering-Djuanda besloot in september 1958 de parlementsverkiezingen uit te stellen. Dit uitstel hield verband met het feit dat de aanhang van de PKI sinds 1955 enorm was toegenomen, waardoor de andere partijen vreesden bij verkiezingen een deel van hun zetels te zullen verliezen. Omgekeerd wilde de PKI de verkiezingen laten doorgaan nu zij mocht verwachten in het nieuwe parlement de grootste partij te worden. Verder bestond naast het parlement ook nog de eveneens in 1955 gekozen Konstituante, die in Bandung vergaderde en het ontwerp voor de definitieve 
grondwet moest opstellen. Weliswaar was in deze Konstituante veel gediscussieerd over het meest wenselijke staatsbestel, maar die discussies waren vastgelopen op de wens van de orthodox-islamitische leden om in de grondwet vast te leggen dat de Indonesische staat op de islam gebaseerd moest zijn. De Konstituante kon deze kwestie niet oplossen omdat zij alleen met een twee derde meerderheid besluiten mocht nemen, terwijl noch de voorstanders noch de tegenstanders van die wens over zo'n meerderheid beschikten.

In deze vastgelopen situatie lanceerde Nasution medio 1958 een nieuw denkbeeld, namelijk helemaal geen nieuwe grondwet opstellen, maar de grondwet van 1950 afschaffen en eenvoudig terugkeren tot de oorspronkelijke grondwet uit augustus 1945. Die grondwet (zie p. 343) voorzag in een tamelijk autoritair staatsbestel en sprak niet over een door verkiezingen samen te stellen parlement. Na veel overleg stemden begin 1959 zowel Soekarno als de PNI, de PKI en de NU met het denkbeeld in. Het leger organiseerde nu een grote propagandacampagne voor 'terugkeer naar 1945' en dreigde met maatregelen tegen persorganen die zich aan 'tendentieuze berichtgeving' schuldig zouden maken.

De voorstanders van herstel van de grondwet van 1945 zagen het liefst dat de Konstituante daar zelf mee zou instemmen. Een probleem daarbij was echter dat die grondwet geen speciale positie aan de islam toekende. De regering-Djuanda meende aan de orthodoxe islamieten tegemoet te kunnen komen door in het besluit tot herstel van de oude grondwet te verwijzen naar een in juli 1945 opgestelde ontwerp-preambule (het zogenaamde Handvest van Djakarta) die wel aan de islam een bijzondere plaats gegeven had maar die uiteindelijk in augustus 1945 niet in de definitieve tekst opgenomen was. In deze vorm werd het voorstel tot terugkeer naar 1945 aan de Konstituante voorgelegd. De manoeuvre mislukte echter, omdat een aantal orthodox-islamitische leden die verwijzing onvoldoende vond. Dank zij hun verzet kreeg het voorstel tot herstel van de grondwet van 1945 bij de uiteindelijke stemming op 2 juni 1959 geen twee derde meerderheid

Terwijl de Konstituante hierover beraadslaagde was Soekarno weer bezig met een wereldreis. Na de fatale laatste stemming kondigde Nasution een tijdelijk verbod op politieke activiteiten af. Eind juni keerde Soekarno in Indonesië terug. Op voorstel van Nasution ontbond hij op 5 juli 1959 de Konstituante en voerde hij bij decreet de grondwet van 1945 weer in. Kort daarna vormde hij een nieuwe regering, nu met hemzelf als minister-president en met Nasution als minister van nationale veiligheid, terwijl Djuanda met de dagelijkse leiding van de regering belast bleef.

Het parlement keurde op 22 juli het herstel van de oude grondwet goed en beroofde zich daarmee van zijn constitutionele basis. De twee jaar eerder ingestelde Nationale Raad werd weer opgeheven, want die moest nu plaats maken voor de in de oude grondwet voorziene Hoge Adviesraad. Eveneens 
in juli werd het aan hoge ambtenaren en aan bestuurders van staatsbedrijven verboden om lid van een politieke partij te zijn.

Deze in juli 1959 in nauw overleg tussen Soekarno en Nasution genomen maatregelen voerden een autoritair staatsbestel in zonder dat duidelijk was bij wie de oppermacht berustte. Nasution had de militaire macht in handen, maar Soekarno bezat het charisma van leider van de onafhankelijkheidsstrijd. Omdat hij niet over een eigen organisatie beschikte gebruikte hij de PKI als tegenwicht tegen de macht van de militairen. Soekarno wilde echter niet alleen macht, maar verlangde ook erkenning als denker en als ideologisch leider van de natie.

Op 17 augustus 1959 gebruikte hij zijn toespraak ter herdenking van de onafhankelijkheidsproclamatie voor een betoog over de ideologische basis van de 'geleide democratie'. Het betoog bevatte een bloemlezing van zijn geliefkoosde thema's, waaronder samenwerking tussen alle revolutionaire krachten, centrale leiding van de politiek en de economie en verwerping van de compromissen van Linggadjati, Renville en de RTC. Deze toespraak vormde het startsein voor een propagandacampagne waarin zijn betoog werd aangeprezen als een politiek manifest (aangeduid met het acroniem Manipol) dat richtlijn moest zijn voor de nationale politiek. Voortaan gold instemming met Manipol als toetssteen voor politieke betrouwbaarheid.

Het gekozen parlement bleef nog tot maart 1960 bestaan en werd toen vervangen door een benoemd parlement, gedeeltelijk bestaand uit vertegenwoordigers van 'functionele groepen', maar zonder leden van de Masjumi of van Sjahrir's PSI. Op grond van de grondwet van 1945 werd bovendien een 'Congres voor Volksoverleg' ingesteld dat ruim zeshonderd leden zou tellen, onder wie alle parlementsleden plus bijna honderd regionale vertegenwoordigers en nog eens ruim tweehonderd vertegenwoordigers van functionele groepen. Tot de verdere in 1960 genomen stappen ter invoering van de 'geleide democratie' behoorden afschaffing van verkiezingen voor regionale en plaatselijke raden en afschaffing van de verantwoordingsplicht van bestuurders tegenover zulke raden.

Tegen deze liquidatie van de democratie rees in Indonesië weinig verzet. Enige politici uit de kring van de Masjumi, de PSI en de christelijke partijen richtten in juni 1960 een Democratische Liga op om zich tegen de 'geleide democratie' te weren, maar deze Liga werd al in juli verboden. In augustus volgde een verbod op de Masjumi en de PSI zelf. De persvrijheid werd steeds verder beknot. In 1961 kwam een perswet tot stand die bepaalde dat de pers de ideologie van de staat moest onderschrijven.

Intussen kwam er geleidelijk een eind aan het in sommige delen van Indonesië gevoerde gewapende verzet tegen de centrale regering. De in maart 1958 op Sumatra uitgeroepen tegenregering, de PRRI, was niet in staat gebleken tot daadwerkelijk tegenspel tegen het door Soekarno en Nasution ingevoerde 
autoritaire stelsel. Haar leiders raakten in een uitzichtloze situatie. Dank zij gunstige capitulatievoorwaarden lieten de meesten van hen zich in de loop van 1961 overhalen tot het staken van de strijd. De capitulerende PRRI-leiders, onder wie de politici Sjafruddin, Natsir en Harahap en de kolonels Kawilarang en Sumual, werden als teruggekeerde verloren zonen verwelkomd. In oktober 1961 volgde zelfs een algemene amnestie voor allen die aan de PRRI-rebellie deelgenomen hadden. Verder leidde een verzoeningsgezinde opstelling van Djakarta medio 1962 ook tot beëindiging van de opstand in Atjeh onder Daud Beureuh. In hetzelfde jaar slaagde het leger er eindelijk in de Darul Islam in West-Java uit te schakelen; haar leider Kartosuwirjo werd gevangen genomen en terechtgesteld. Een jaar later eindigde de guerrillastrijd van de RMS op Ceram met de gevangenneming van haar leider Soumokil. Tenslotte staakte de Darul Islam in Zuid-Celebes de strijd in 1965 nadat haar leider Kahar Muzakkar gesneuveld was.

In januari 1962 werd Soekarno opnieuw het doelwit van een mislukte aanslag. Op beschuldiging van betrokkenheid bij die aanslag werden daarna verscheidene zeer prominente politici gearresteerd, onder wie Sjahrir, Rum, Anak Agung, sultan Hamid, Sjafruddin, Natsir en Harahap. De beschuldigingen berustten op een bizarre complottheorie. De gearresteerden waren in feite zuiver politieke gevangenen; hun gevangenneming bezegelde de ondergang van de democratie in Indonesië.

\section{Militaire confrontatie over Nieuw-Guinea}

De in najaar 1957 in Indonesië ontketende campagne voor de 'bevrijding van West-Irian', die was uitgelopen op de verdrijving van de Nederlandse bevolking en de inbeslagneming van de Nederlandse ondernemingen, had geen verandering gebracht in de opstelling van de Nederlandse regering in de kwestie-Nieuw-Guinea. De Indonesische machthebbers richtten zich sindsdien vooral op versterking van de Indonesische strijdkrachten om Nederland ertoe te brengen het gebied los te laten. De snelle onderdrukking van de opstand op Sumatra en Celebes in het voorjaar van 1958 liet zien dat die strijdkrachten al in staat waren tot omvangrijke operaties, maar voor verovering van West-Nieuw-Guinea zou een veel groter militair potentieel nodig zijn.

$\mathrm{Al}$ sinds 1954 werkte Indonesië stelselmatig aan de versterking van zijn militaire uitrusting. Onder meer bestelde het toen marineschepen en ander oorlogsmaterieel in Italië, Groot-Brittannië en West-Duitsland. Ook wilde het graag Amerikaanse wapens aankopen, maar de Verenigde Staten leverden die slechts op kleine schaal. Daarentegen bood de Sovjet-Unie sinds 1956 grote leningen aan voor de aanschaf van militair materieel. De leveringen op basis hiervan kwamen in 1958 goed op gang. Daarbij kreeg Indonesië onder 
meer de beschikking over Russische bommenwerpers en straaljagers. Ook deed het militaire aankopen in andere communistische landen zoals Polen en Tsjechoslowakije. Naast de spectaculaire versterking van de Indonesische luchtmacht leidden de Oost-Europese leveringen tot versterking van de landmacht met onder meer tanks, helikopters, kanonnen en handwapens en tot uitbreiding van de marine met tientallen oorlogsschepen waaronder ook onderzeeboten.

De Verenigde Staten leverden tot 1958 slechts weinig militair materieel aan de Indonesische strijdkrachten. Het Amerikaanse Aziëbeleid richtte zich bovenal op het voorkomen van een verdere uitbreiding van het communisme, dat het vasteland van China en het noorden van Korea en Vietnam al beheerste. De sterke opkomst van de communistische beweging in Indonesië en de welwillende opstelling van Soekarno tegenover die beweging leidden dan ook tot grote ongerustheid in Washington. Daarom gaf de Amerikaanse geheime dienst in de eerste helft van 1958 militaire steun aan de opstand van de PRRI op Sumatra en Celebes. De snelle onderdrukking van die opstand door het Indonesische regeringsleger bewees echter dat deze dienst op het verkeerde paard gewed had. De mislukking van dit avontuur was voor Washington extra pijnlijk door de gevangenneming van de Amerikaanse piloot op Ambon. In de zomer van 1958 besloot de Amerikaanse regering tot een radicale koerswijziging. Om te voorkomen dat Indonesië naar het communistische kamp zou overgaan vestigde zij nu al haar hoop op het regeringsleger onder Nasution. Daarom besloot zij over te gaan tot zowel economische als militaire steun aan Indonesië. Het in dat kader door de VS geleverde militaire materieel was voornamelijk voor de Indonesische landmacht bestemd en omvatte geen zware wapens.

De Amerikaanse steun betekende niet dat Indonesië nu naar het westelijke kamp overging. Indonesië trok profijt van de 'koude oorlog' tussen het oostelijk en het westelijk blok. De Russische regeringsleider Chroesjtsjov bracht in februari-maart 1960 een uitvoerig staatsbezoek aan Indonesië. In aansluiting daarop voerde Nasution enige malen overleg in Moskou over militaire leveranties. De Sovjet-Unie bleef Indonesië steunen met grote militaire kredieten, die vooral de versterking van de Indonesische marine en luchtmacht ten goede kwamen. Zowel Amerikaanse als Russische instructeurs trainden nu Indonesische militairen in het gebruik van het door hun regeringen geleverde materieel.

In Nederland maakte men zich tot het eind van de jaren vijftig weinig zorgen over het vooruitzicht van een militaire krachtmeting om Nieuw-Guinea. De meeste politici beseften wel dat Nederland het gebied niet tegen een grootscheepse aanval zou kunnen verdedigen, maar ze dachten dat de Verenigde Staten het nooit zo ver zouden laten komen. Vooral minister Luns was hiervan overtuigd. Overigens kwam er in deze periode een belangrijke wijziging in de samenstelling van de Nederlandse regering. Conflicten tussen de PvdA en de 
KVP leidden in december 1958 tot het aftreden van Drees en de andere PvdAministers. Er kwam nu een eind aan de coalitie van PvdA en KVP die sinds 1946 de basis van de Nederlandse regering gevormd had. In maart 1959 vonden parlementsverkiezingen plaats waarbij de PvdA twee zetels verloor en de VVD zes zetels won. In mei trad een kabinet aan van de confessionele partijen KVP, ARP en CHU samen met de VVD. Het nieuwe kabinet werd geleid door de KVP-politicus J.E. de Quay; Luns bleef minister van buitenlandse zaken.

Begin 1960 besloot het kabinet-De Quay de Nederlandse strijdmacht in Nieuw-Guinea, die ruim tweeduizend man telde, sterk uit te breiden en ook tientallen straaljagers en andere vliegtuigen naar het gebied over te brengen. Bovendien besloot men het grootste schip van de Nederlandse marine, het vliegkampschip 'Karel Doorman', in mei samen met twee torpedobootjagers op een wereldreis te sturen waarbij het Nieuw-Guinea zou bezoeken en daar tegelijk een deel van de nieuwe vliegtuigen zou afleveren. Daarna zou het eskader onder meer Japan bezoeken ter viering van het 350-jarig bestaan van Japans-Nederlandse betrekkingen. Deze wereldreis voor 'vlagvertoon' werd al eind maart aangekondigd.

In Indonesië wekte het reisplan woedende reacties. De Indonesische regering veroordeelde het zenden van het eskader als een bedreiging van de Indonesische veiligheid; de pers noemde het een oorlogsdaad. Er vonden antiNederlandse demonstraties plaats en op 6 mei 1960 bestormden honderden demonstranten het gebouw van de Nederlandse diplomatieke vertegenwoordiging in Djakarta. Weliswaar lieten ze daar het personeel ongemoeid, maar ze sloegen de inventaris stuk, vernielden het portret van koningin Juliana en verbrandden de Nederlandse vlag. De Nederlandse regering reageerde verontwaardigd, maar zag niet van het reisplan af. De 'Karel Doorman' vertrok op 31 mei. Als represaille sloot Indonesië zijn territoriale wateren voor alle schepen onder Nederlandse vlag. Overigens betaalde de Indonesische regering wel een vergoeding aan Nederland voor de in het gebouw van de vertegenwoordiging aangerichte schade.

De vlagvertoonreis van de 'Karel Doorman' liet zien in welk een internationaal-politiek isolement Nederland door zijn conflict met Indonesië beland was. Egypte had al vroeg duidelijk gemaakt dat de schepen niet door het Suezkanaal zouden mogen varen; de reis ging dan ook om Afrika heen. De regering van Madagascar gaf echter geen toestemming voor een bezoek aan dat eiland. Bij aankomst in Australië werd het eskader door de Australische havenarbeiders geboycot. Nadat het eskader gedurende augustus NieuwGuinea bezocht had zette het koers naar Japan, maar de Japanse regering trok nu haar toestemming in voor het afgesproken feestelijke bezoek zodat de schepen rechtsomkeert moesten maken. Bovendien gaf de Filipijnse regering geen toestemming voor doorvaart door haar gebied. Uiteindelijk keerde het eskader via Australië, Nieuw-Zeeland en Zuid-Amerika naar Nederland terug. 
De vlagvertoonreis had nog een ander gevolg. In zijn rede op 17 augustus 1960 hekelde Soekarno de houding die Nederland die aan de dag had gelegd door de 'Karel Doorman' naar West-Irian te sturen en maakte hij bekend dat Indonesië daarom de diplomatieke betrekkingen met Nederland verbrak.

\section{Ontdooiing van het Nederlandse standpunt over Nieuw-Guinea}

In 1951 had de Nederlandse regering de kwestie van de toekomst van NieuwGuinea voor onbepaalde tijd 'in de ijskast' gezet. Van niet-politieke kant werd in Nederland vooral sinds 1956 meer dan eens gepleit voor herziening van het Nieuw-Guineabeleid. Niettemin hielden de meeste Nederlandse politici nog lang vast aan het standpunt dat de soevereiniteit over het gebied bij Nederland berustte en moest blijven berusten totdat de bevolking ervan in staat zou zijn zelf over haar staatkundige lot te beslissen, dat er geen sprake kon zijn van onderhandelingen met Indonesië over de toekomstige status van het gebied en dat Nederland geen enkele vorm van gemengd bestuur of gedeelde verantwoordelijkheid voor het gebied zou mogen aanvaarden. Het duurde tot 1958 voordat er enige beweging in dit standpunt kwam.

Het in 1950 door Nederland met grote verwachtingen begonnen afzonderlijke bestuur over westelijk Nieuw-Guinea had toen acht jaar geduurd. De redenen die destijds voor het vasthouden van dit gebied waren aangevoerd hadden hun overtuigingskracht grotendeels verloren. Het gebied had zich niet geleend voor volksplantingen van Indische Nederlanders (de reden die minister Jonkman in december 1946 had aangevoerd om de mogelijkheid open te laten voor afscheiding van Nieuw-Guinea van de rest van Indonesië). De voorspellingen over lucratieve exploitatie van bodemschatten waren niet uitgekomen. De gedachte dat Nederland met Nieuw-Guinea als basis voor zijn marine een invloedrijke rol in de Pacific zou kunnen spelen (een vooral door Luns gekoesterde gedachte) was een hersenschim gebleken. Zo hadden de Verenigde Staten in 1951 een defensieverdrag met Australië en NieuwZeeland gesloten, het ANZUS-pact, maar Nederland was hier niet bij betrokken. Vervolgens was in 1954 op Amerikaans initiatief een bondgenootschap tot stand gekomen onder de naam Southeast Asian Treaty Organization (SEATO), met als leden de Verenigde Staten, Groot-Brittannië, Frankrijk, Australië, Nieuw-Zeeland, de Filipijnen, Thailand en Pakistan, maar ook hier werd Nederland buiten gehouden.

Het enige overgebleven motief voor de voortzetting van het Nederlandse gezag over Nieuw-Guinea was het begeleiden van de Papoeabevolking op de weg naar zelfbeschikking, een door Nederland zelf bedachte taak die het geen andere baten dan morele bevrediging opleverde. De gedachte dat Nederland zich nog decennia lang van deze belangeloze taak zou moeten kwijten begon 
sommige politici te benauwen, ook omdat Nederland het hierin zonder hulp van anderen moest stellen. Dit laatste had al eerder geleid tot nadenken over mogelijkheden van samenwerking met andere landen bij de vervulling van die taak. De eerste vorm van 'internationalisering' die in aanmerking leek te komen was samenwerking met Australië, dat immers de oostelijke helft van Nieuw-Guinea bestuurde. Wat de toekomst van dat gebied betreft dacht men in Australië wel eens aan een zelfstandig samengaan van Oost- en West-Guinea, bij voorkeur samen met een aantal ten oosten daarvan gelegen eilanden in een onafhankelijke 'Melanesische federatie'. Ook in Nederland bestond belangstelling voor die gedachte. Op 6 november 1957 maakten de Australische en de Nederlandse regering bekend dat zij hun bestuur over Oost- en West-Guinea zouden gaan coördineren met het oog op de verwezenlijking van het zelfbeschikkingsrecht voor de bevolking van de beide gebieden. De bekendmaking geschiedde net voordat in Indonesië de tweede fase begon van de nationale campagne voor de 'bevrijding van West-Irian'. Deze Australisch-Nederlandse samenwerking wekte daar verontrusting omdat het denkbeeld van een Melanesische federatie waar heel Nieuw-Guinea deel van zou uitmaken wel eens een gunstig onthaal zou kunnen krijgen binnen de Verenigde Naties.

De eind 1957 in het kader van de Indonesische campagne voor de 'bevrijding van West-Irian' ondernomen anti-Nederlandse acties lieten het denken in Nederland niet geheel onberoerd. Wel hadden velen zich in eerste aanleg aangesloten bij de opvatting van de regering dat die acties geen uitvloeisel van het conflict over Nieuw-Guinea waren maar dat dit conflict daartoe slechts tot voorwendsel gediend had. Niettemin begonnen sommigen zich af te vragen of het werkelijk nodig geweest was in Indonesië het lot van vijftigduizend Nederlanders plus Nederlandse investeringen ter waarde van vier à vijf miljard gulden op te offeren voor het heilige doel van het behoud van Nieuw-Guinea. Vooral binnen de PvdA groeide ontevredenheid over de onwrikbaarheid van het regeringsstandpunt. Haar fractie in de Eerste Kamer liet al in januari 1958 blijken geen bezwaar te hebben tegen overleg met Indonesië over Nieuw-Guinea. De PvdA-fractie in de Tweede Kamer vroeg in september aan de regering de mogelijkheid te onderzoeken om Nieuw-Guinea tot een trustschapgebied van de Verenigde Naties te maken. Ook maakte zij bezwaar tegen gedwongen uitzending van dienstplichtige militairen naar het gebied.

De val van het kabinet-Drees in december 1958 en het aantreden van het kabinet-De Quay in mei 1959 maakten het gemakkelijker de kwestie NieuwGuinea 'uit de ijskast' te halen. Nu de PvdA in de oppositie was hoefde zij zich niet meer gebonden te voelen tot steun aan het officiële standpunt om de regeringscoalitie niet in gevaar te brengen. Verder was het vooral Drees geweest die halsstarrig aan dat standpunt had vastgehouden, terwijl de nieuwe premier, De Quay, persoonlijk meer voor internationalisering voelde. 
Ook enige andere ministers uit zijn kabinet twijfelden aan de houdbaarheid van het officiële standpunt. Niettemin verklaarde de nieuwe regering het Nieuw-Guineabeleid van het vorige kabinet te zullen voortzetten. Bovendien besloot zij de ontwikkeling van de bevolking in de richting van zelfbeschikking aanzienlijk te versnellen. Onder meer bereidde zij daartoe de instelling voor van een vertegenwoordigend lichaam dat in meerderheid uit Papoea's zou bestaan, de Nieuw-Guinea Raad. Ook richtte zij een Papoea Vrijwilligers Korps op. In april 1960 presenteerde zij een tienjarenplan voor de ontwikkeling van Nieuw-Guinea, dat ook instemming van de PvdA kreeg.

Voor het overige werden de discussies in Nederland over Nieuw-Guinea in 1960 sterk beïnvloed door de voortgaande versterking van het Indonesische militaire potentieel, de toenemende Indonesische infiltraties op het eiland en de ongelukkig verlopen reis van de 'Karel Doorman'. Nadat Soekarno op 17 augustus bekendgemaakt had dat zijn land de diplomatieke betrekkingen met Nederland verbrak, hield hij eind september een bijzonder dreigende toespraak tot de AVVN in New York. Hij noemde daarin de Nederlandse bezetting van westelijk Nieuw-Guinea een koloniaal zwaard dat op het hart van Indonesië gericht was en de wereldvrede bedreigde. In Nederland gingen nu steeds meer stemmen op ten gunste van internationalisering van Nieuw-Guinea in die zin dat de verantwoordelijkheid niet meer uitsluitend op Nederland zou rusten. Ook het kabinet-De Quay besloot deze weg in te slaan. In het najaar deed minister Luns al een kleine stap in die richting door in de AVVN te verklaren dat Nederland bereid was zijn beleid in Nieuw-Guinea te onderwerpen aan onderzoek en beoordeling door de VN.

De meeste Nederlandse politici, met inbegrip van die van de PvdA, waardeerden het dat er beweging zat in de opstelling van de Nederlandse regering. Maar 'internationalisering' kon nog van alles betekenen. Voor Luns was het slechts een middel om Indonesië buiten Nieuw-Guinea te houden. Streven naar internationalisering in die zin kon echter het acute gevaar van oorlog over Nieuw-Guinea niet bezweren. Tegen die achtergrond ondernamen andere Nederlanders dan politici in 1961 diverse activiteiten ten gunste van een vreedzame oplossing van het conflict. Zulke activiteiten werden ook bevorderd door verklaringen van prominente Indonesiërs dat hun land weliswaar in staat was Nederland met geweld uit Nieuw-Guinea te verdrijven, maar dat zij een oorlog liever zouden willen vermijden. Zo zei de Indonesische minister van buitenlandse zaken, Subandrio, in februari 1961 dat zijn land zich niet zou verzetten tegen deelname van de $\mathrm{VN}$ aan het zoeken van een oplossing mits van tevoren zou vaststaan dat Nieuw-Guinea na verloop van één of twee jaar bij Indonesië zou terugkeren.

Tot de hier bedoelde activiteiten van Nederlandse niet-politici behoorde een in april 1961 verschenen manifest tegen het Nieuw-Guineabeleid van de regering, ondertekend door een honderdtal intellectuelen en kunstenaars. 
Het manifest wees er onder meer op dat dit beleid de Papoea's opvoedde in vijandschap tegen Indonesië terwijl zij daar in de toekomst toch mee zouden moeten samenleven. Buiten de openbaarheid voerden leden van de groepRijkens in het eerste halfjaar van 1961 herhaaldelijk overleg met Indonesische vertegenwoordigers. Deze groep van Nederlandse 'captains of industry' (zie p. 734) onderhield zowel contact met president Soekarno als met premier De Quay en beschikte bovendien over relaties met de Amerikaanse regering. Ook in de kringen van kerk en zending zocht men naar mogelijkheden om een oor$\log$ met Indonesië te voorkomen. Verder spande professor F.J.F.M. Duynstee, een conservatieve katholiek, zich bijzonder voor een vreedzame oplossing in. Generaal Nasution sprak medio 1961 tijdens een bezoek aan Europa zowel met Duynstee als met Nederlanders uit kerkelijke kringen. In diezelfde tijd berichtte de journalist Oltmans in het weekblad Vrij Nederland uitvoerig over de activiteiten van de groep-Rijkens.

In de loop van het jaar stelden ook enige belangrijke Nederlandse kranten zich steeds kritischer op tegenover het officiële Nieuw-Guineabeleid. Het meest gezaghebbende dagblad, de Nieuwe Rotterdamse Courant, sprak zich in augustus zelfs uitdrukkelijk uit voor aansluiting van Nieuw-Guinea bij Indonesië.

Intussen ging de Nederlandse regering door met haar programma van versnelde ontwikkeling van de Papoeabevolking naar zelfstandigheid. Op 5 april 1961 werd de Nieuw-Guinea Raad geïnstalleerd, bestaande uit dertien benoemde en zestien gekozen leden. Later in het jaar kreeg het gebied zelfs een eigen vlag en een eigen volkslied. In Indonesië zag men een en ander als de voorbereiding van een pseudo-onafhankelijke Papoeastaat. De hierbij door Nederland gevolgde methodiek kwam sterk overeen met die waarmee het in 1947-1949 een aantal deelstaten in Indonesië opgericht had.

Na overleg met Washington (zie p. 750) besloot de regering bovendien bij de Verenigde Naties een eigen voorstel tot internationalisering in te dienen. Luns zette dit voorstel in september 1961 in de AVVN uiteen; journalisten noemden het sindsdien het 'plan-Luns'. De ontvangst van dit plan door de Nederlandse politici liet zien dat hun opstelling ten aanzien van NieuwGuinea in het algemeen achterbleef bij de veranderende opvattingen in niet-politieke kring. Het plan kreeg brede steun in het parlement, ook van de PvdA. Een verrassende uitzondering hierop deed zich voor bij de ARP die altijd een harde lijn tegenover Indonesië had voorgestaan. Onder invloed van de protestants-christelijke zending pleitte zij nu voor een open gesprek met Indonesië over Nieuw-Guinea en keerde zij zich tegen het Nederlandse internationaliseringsvoorstel.

Dit voorstel stelde voorop dat Nederland bereid was zijn bestuur over Nederlands Nieuw-Guinea over te dragen aan een door de VN op te richten internationaal orgaan, mits het recht van zelfbeschikking van de bevolking 
gewaarborgd zou zijn. Met het oog daarop zou de AV eerst een commissie moeten instellen die naar het gebied zou gaan om daar onder meer de mogelijkheid te onderzoeken van een onder VN-toezicht te houden volksstemming over de wensen van de inwoners. Vervolgens zou die commissie de mogelijkheid van een interim-bestuur onder gezag van de VN moeten bezien. Als zo'n interim-bestuur er zou komen, zou Nederland zijn soevereiniteit over het gebied aan de bevolking afstaan.

Het voorstel werd in najaar 1961 in de AVVN gesteund door Australië en Nieuw-Zeeland maar kreeg verder vrijwel geen bijval, terwijl het wel scherpe kritiek uitlokte. De Amerikaanse delegatie leek het voorstel te steunen, maar gaf er een andere strekking aan door ervan uit te gaan, dat Indonesië gedurende het tijdelijke VN-bestuur volop gelegenheid zou krijgen om te streven naar de integratie van West-Nieuw-Guinea en dat het onder dat bestuur toegang zou hebben tot het gebied. Minister Subandrio waardeerde de Nederlandse bereidheid om de aanspraak op soevereiniteit over West-Irian op te geven, maar verzette zich tegen de plannen tot stichting van een Papoeastaat. Hij zei dat Indonesië de stichting van zo'n staat evenmin zou dulden als het de stichting van de RMS op Ambon geduld had. Zou Nederland zijn plannen tot afscheiding van West-Irian doorzetten, dan betekende dat oorlog. Aan de andere kant verklaarde hij ook dat Indonesië bereid was tot een oplossing met een overgangsperiode waarin de $\mathrm{VN}$ een rol zou spelen.

De Nederlandse delegatie zag er van af het plan-Luns in stemming te brengen. Wel stemde zij voor een voorstel van een aantal Afrikaanse landen waarin Indonesië en Nederland werden aangespoord om met elkaar over de toekomst van Nieuw-Guinea te onderhandelen zonder afbreuk te doen aan de zelfbeschikking van de bevolking. Dit voorstel haalde echter geen twee derde meerderheid.

De mislukking van het Nederlandse initiatief in de AVVN versterkte binnen Nederland de gedachte dat een radicale wijziging van het NieuwGuineabeleid nodig was. In december 1961 riepen zowel de rooms-katholieke bisschoppen als het bestuur van de Nederlands Hervormde Kerk op tot rechtstreeks overleg met Indonesië.

\section{Beëindiging van het conflict en overdracht van Nieuw-Guinea}

De hoofddoelstelling van het beleid van de Verenigde Staten met betrekking tot Azië was het voorkomen van een verdere uitbreiding van het communisme, dat het vasteland van China en het noorden van Korea en Vietnam al beheerste. De mogelijkheid dat Indonesië naar het communistische kamp zou overgaan was dan ook een bron van grote zorg in Washington. Om zo'n ontwikkeling tegen te gaan vestigde de Amerikaanse regering sinds medio 
1958 haar hoop op het Indonesische leger onder generaal Nasution en gaf zij Indonesië zowel militaire en economische steun. Het tussen Indonesië en Nederland bestaande conflict over Nieuw-Guinea was in dat verband een storende factor. Er was de Amerikaanse regering dus veel aan gelegen dit conflict de wereld uit te helpen, maar onder president Eisenhower ondernam zij geen actieve pogingen hiertoe. Dit werd anders toen John F. Kennedy in januari 1961 als president aantrad.

Kennedy beschouwde Nieuw-Guinea als een gevaarlijke crisishaard. De situatie was in 1960 ook steeds ernstiger geworden door de voortgaande opbouw van de Indonesische strijdkrachten, door de verbreking van de diplomatieke betrekkingen van Indonesië met Nederland en door de steeds radicaler anti-westerse opstelling van Soekarno. Kennedy vreesde dat de Nederlandse Nieuw-Guineapolitiek Indonesië in de armen van Moskou dreef. Zou er over Nieuw-Guinea werkelijk oorlog uitbreken dan zou Indonesië niet alleen door landen als India en Pakistan en de Arabische landen gesteund worden, maar dan zou de Sovjet-Unie zich zeker actief aan de kant van Indonesië scharen, en dat tegen Nederland dat in de NAVO met de Verenigde Staten verbonden was. Het was een nachtmerriescenario dat zelfs tot een wereldoorlog zou kunnen leiden. Om dit gevaar af te wenden zou men een procedure moeten vinden om Nederland ertoe te brengen Nieuw-Guinea los te laten zodat het gebied met Indonesië verenigd kon worden.

Eén van de eerste dingen die Kennedy ondernam was het scheppen van een persoonlijke band met zijn Indonesische collega. Op zijn uitnodiging bracht Soekarno in april 1961 een bezoek aan Amerika, waarbij Kennedy zijn gast met veel egards behandelde. Kort daarvoor sprak hij uitvoerig met Luns over Nieuw-Guinea. Luns zei dat Nederland openstond voor iedere vorm van trustschap, maar het zelfbeschikkingsrecht vooropstelde. Kennedy beval hem aan over de mogelijkheden van internationalisering overleg te plegen met het State Department. In de volgende maanden sprak de Nederlandse ambassade in Washington hier inderdaad herhaaldelijk over met het State Department. Het vervolgens in september 1961 door Nederland gelanceerde internationaliseringsvoorstel week echter af van de aan Amerikaanse kant levende gedachten. Het plan-Luns leek in de eerste plaats bedoeld om de weg te bereiden voor een onafhankelijke Papoeastaat. Daarentegen dachten de Amerikaanse beleidsmakers aan een scenario dat juist zou moeten leiden tot hereniging van Nieuw-Guinea met Indonesië, via een tussenfase waarin het Nederlandse bestuur plaats zou maken voor een interim-bestuur van de VN maar met volle toegang van Indonesie tot het gebied voordat de bevolking gelegenheid zou krijgen tot een keuze over haar staatkundige toekomst.

Nadat in november 1961 in de AVVN gebleken was dat Nederland met zijn plan vrijwel alleen stond, vond de Amerikaanse regering dat het tijd was om rechtstreeks overleg tussen de Nederlandse en de Indonesische regering 
tot stand te brengen. Begin december vroeg zij aan de beide regeringen hoe zij behulpzaam kon zijn bij het vinden van een oplossing. Luns wilde erkenning van het recht op zelfbeschikking van de Papoea's als prealabele voorwaarde stellen voor een gesprek met Indonesië, maar het kabinet besloot hiervan af te zien. Eind december deelde de Nederlandse regering aan Washington mee dat zij bereid was tot een open gesprek met Indonesië, bij voorkeur in aanwezigheid van een derde partij, en dat het zelfbeschikkingsrecht daarbij voor Nederland 'uitgangspunt' zou zijn.

De Amerikaanse vraag aan Indonesië was vergezeld gegaan van een persoonlijke brief van Kennedy waarin hij Soekarno dringend vroeg om af te zien van het gebruik van geweld. Het conflict over Nieuw-Guinea was inderdaad een gevaarlijker stadium ingegaan. In Indonesië was aangekondigd dat Soekarno op 19 december 1961 zijn 'laatste bevel' voor de bevrijding van WestIrian zou geven. Op die dag hield hij een rede waarin hij een algemene mobilisatie aankondigde en zijn volk opdroeg de vorming van een marionettenstaat in West-Irian te verhinderen en ervoor te zorgen dat de Indonesische vlag boven West-Irian zou worden gehesen. Ook stelde hij een speciaal commando in voor de bevrijding van het gebied. In de afgelopen jaren was het Indonesische militaire potentieel wel sterk uitgebreid, vooral met schepen en vliegtuigen, maar pas nu bouwde men daaruit een geïntegreerde aanvalsmacht op. Het commando kwam onder leiding te staan van kolonel Suharto, die tot generaal-majoor bevorderd werd en zijn hoofdkwartier vestigde in Udjung Pandang (het vroegere Makassar).

Op de dag waarop Soekarno zijn rede uitsprak zond de secretaris-generaal der Verenigde Naties, U Thant, telegrammen aan de Indonesische en de Nederlandse regering waarin hij zijn grote zorg over de gevaarlijke situatie uitsprak en er bij beide partijen op aandrong samen naar een vreedzame oplossing te zoeken.

De initiatieven van de Amerikaanse regering en de secretaris-generaal der VN leidden tot een waaier van verkennende gesprekken in Washington, New York, Djakarta en Den Haag. Onder andere bezocht Robert Kennedy, een broer van de president, zowel Soekarno als de Nederlandse regering. Uiteindelijk werd men het er over eens dat Indonesië en Nederland onder auspiciën van de VN en zonder prealabele voorwaarden geheim overleg zouden voeren in Amerika onder leiding van een Amerikaan die zou optreden als vertegenwoordiger van U Thant. Dit overleg begon op 20 maart 1962 in een landhuis in de buurt van Washington onder leiding van Ellsworth Bunker, een gepensioneerde Amerikaanse diplomaat. De Nederlandse delegatie werd geleid door de ambassadeur in Washington, J.H. van Roijen; de Indonesische delegatie door Adam Malik, die toen ambassadeur in Moskou was. Nadat Van Roijen in 1949 voor een goede afwikkeling had mogen zorgen na de mislukking van de Nederlandse politiek tegenover de Republiek, viel hem nu dus een 
soortgelijke taak toe na het volledige bankroet van het Nederlandse NieuwGuineabeleid.

Het op 20 maart geopende overleg tussen Indonesië en Nederland leidde pas op 15 augustus tot een akkoord. Daarmee duurde dit overleg onnodig lang, want in feite ging het om een eenvoudige zaak: Nederland moest westelijk Nieuw-Guinea loslaten zodat het gebied met Indonesië verenigd kon worden. Dat bracht enige praktische problemen mee, maar die kwamen in het overleg pas laat aan de orde. Daarentegen werd het overleg van begin af aan door prestigekwesties overheerst. De Amerikaanse regering had in de door haar voorgestane oplossing twee elementen opgenomen om de vernedering voor Nederland te verzachten: ten eerste geen rechtstreekse overdracht van het bestuur door Nederland aan Indonesië maar indirecte overdracht via een tijdelijk VN-bestuur, en ten tweede een gelegenheid voor de bevolking van het gebied tot vrije keuze over haar staatkundige toekomst na een aantal jaren Indonesisch bestuur. Het eerste element hield geen rekening met de belangen van die bevolking, want die zouden met rechtstreekse overdracht door Nederlandse aan Indonesische functionarissen meer gebaat zijn dan met een tussenbewind door tijdelijk personeel in VN-dienst dat noch Nederlands noch Indonesisch kende. Ook het tweede element was pure symboliek ten behoeve van Nederlands gezichtbehoud, want het was politiek ondenkbaar dat de Indonesische machthebbers de bevolking van West-Irian werkelijk zouden toestaan zich van Indonesië af te scheiden. Een andere belangrijke prestigekwestie die het overleg bemoeilijkte was de Indonesische wens dat de roodwitte vlag nog voor het eind van het jaar in West-Irian zou worden gehesen.

Het was zowel aan Luns als aan Soekarno te wijten dat tussen de opening van het overleg en de sluiting van het akkoord veel tijd verstreek. Luns wilde lange tijd niet inzien dat zijn Nieuw-Guineabeleid mislukt was en belemmerde daardoor een vlotte afwikkeling. Soekarno wilde lange tijd niet definitief kiezen tussen diplomatie en strijd als methode om West-Irian met Indonesië te herenigen. Hij voerde de militaire confrontatie voortdurend op. Al in januari had dit er onder meer toe geleid dat een Indonesische motortorpedoboot voor de kust van Nieuw-Guinea door de Nederlandse marine tot zinken gebracht werd. Om de druk op Nederland te verhogen werden Indonesische militairen niet alleen per boot op Nieuw-Guinea en de bijbehorende eilanden aan land gezet, maar werden daar van april tot augustus ook honderden parachutisten neergelaten. Intussen ging de opbouw van de eigenlijke aanvalsmacht onverminderd voort.

Het op 20 maart geopende overleg werd al na drie dagen afgebroken omdat Adam Malik in Indonesië nadere instructies wilde halen. In afwachting van de hervatting van het overleg stelde ambassadeur Bunker een schets voor een akkoord op die hij begin april aan beide partijen voorlegde. Deze schets, die bekend is geworden als het 'plan-Bunker', hield het volgende in. Nederland 
zou het bestuur over westelijk Nieuw-Guinea overdragen aan een tijdelijk gezagsorgaan onder de secretaris-generaal van de $\mathrm{VN}$, dat het gebied minimaal een jaar en maximaal twee jaar zou besturen. Tijdens die periode zouden eerst de Nederlandse functionarissen worden vervangen door personeel in VN-dienst en zou vervolgens dit personeel worden vervangen door Indonesische functionarissen, zodat het bestuur bij het eind van de periode volledig bij Indonesië zou berusten. Verder zou Indonesië samen met de VN regelingen treffen om de bevolking van het gebied na een nog nader te bepalen aantal jaren gelegenheid te geven voor een vrije keuze. Het woord 'soevereiniteit' kwam in het hele stuk niet voor. President Kennedy beval dit plan-Bunker in persoonlijke brieven aan de beide regeringen aan.

In Nederland was intussen de PvdA overstag gegaan en had zij zich uitgesproken voor overdracht van Nieuw-Guinea aan Indonesië. Dit leidde er echter toe dat de regering en de meerderheid in het parlement zich nog steviger vastbeten in het zelfbeschikkingsrecht van de Papoea's. Pas op 26 mei verklaarde de regering zich bereid het plan-Bunker te aanvaarden als een basis voor verdere onderhandelingen. De Indonesische regering had zich al eerder in die zin geuit, overigens zonder in te stemmen met de in het plan aangegeven termijnen. $\mathrm{Na}$ de Nederlandse bereidverklaring hield Soekarno de heropening van het overleg echter nog anderhalve maand op. Pas op 13 juli konden Van Roijen en Adam Malik hun gesprek hervatten. In deze tweede ronde van het overleg nam soms ook minister Subandrio er aan deel.

De nieuwe overlegronde voltrok zich in een zeer gespannen sfeer. De Indonesische aanvalsmacht werd in Oost-Indonesië in gereedheid gebracht. Deze strijdmacht telde ongeveer dertigduizend man en beschikte over dertig oorlogsschepen, honderdtwintig transportschepen en honderden vliegtuigen. Het grootste marineschip was een moderne Russische kruiser die de naam 'Irian' kreeg. Intussen had Nederland nog enige versterkingen naar Nieuw-Guinea overgebracht, zodat de Nederlandse verdediging daar nu ongeveer tienduizend man telde. De onderhandelaars raakten in tijdnood, want men moest rekening houden met oorlog als geen akkoord bereikt zou zijn voor 17 augustus, de dag waarop in Indonesië de onafhankelijkheidsproclamatie van 1945 herdacht werd. In afwijking van het plan-Bunker wilde de Indonesische delegatie de fase van het VN-tussenbestuur nu eenvoudig overslaan en het bestuur rechtstreeks van Nederland op Indonesië laten overgaan. In tweede aanleg wilde zij het VN-intermezzo zo kort laten duren dat Indonesië in elk geval nog in 1962 zelf het bestuur zou overnemen. Deze voorstellen hielden kennelijk verband met de herhaalde publieke uitspraken van Soekarno, dat West-Irian nog voor het eind van het jaar met Indonesië herenigd zou worden.

Dank zij door zowel secretaris-generaal U Thant als president Kennedy ondernomen stappen kon de Indonesische delegatie tot een meer coöperatieve 
houding worden gebracht. Daardoor wisten de twee delegaties eind juli toch overeenstemming te bereiken over alle belangrijke punten. Die overeenstemming hield in dat het interim-bestuur van de $\mathrm{VN}$ zou duren van 1 oktober 1962 tot 1 mei 1963, dat de eerste fase al op 31 december 1962 zou eindigen en dat de bevolking uiterlijk in 1969 zou mogen kiezen of zij wel of niet met Indonesië verbonden wilde blijven. De manier waarop zij die keuzevrijheid zou kunnen uitoefenen zou te zijner tijd nader worden bepaald in overleg met vertegenwoordigende lichamen.

Overigens sprak men tijdens deze tweede ronde ook over een reeks praktische kwesties, waartoe de beide delegaties werden uitgebreid met onder meer militaire en financiële deskundigen. Hierbij rezen geen ernstige moeilijkheden. Het overleg vond nu niet meer in een afgelegen landhuis plaats maar deels in Washington deels in New York. De delegatieleiders bespraken het ontwerpakkoord (waar het woord 'soevereiniteit' niet in voorkwam) begin augustus met hun regeringen. Met $U$ Thant werd onder meer nog een regeling getroffen over het voeren van de nationale vlaggen tijdens het $\mathrm{VN}$-tussenbestuur: naast de VN-vlag zou van 1 oktober tot 31 december de Nederlandse vlag waaien en van 1 januari 1963 tot 1 mei de Indonesische vlag.

Terwijl in de tweede week van augustus in New York met behulp van het $\mathrm{VN}$-secretariaat alle voorbereidingen werden getroffen om tot ondertekening van het akkoord over te gaan, begon in het oosten van Indonesie de aanvalsmacht toch in actie te komen en maakte Soekarno plotseling bezwaar tegen de vlaggenregeling. Uiteindelijk ging hij ermee akkoord mits de Indonesische vlag al in de avond van 31 december gehesen zou worden. Met één dag vertraging vond op 15 augustus 1962 de ondertekening van het akkoord plaats namens de beide regeringen. Tegelijk kwamen die regeringen overeen hun diplomatieke betrekkingen te zullen hervatten. Op 17 augustus kon Soekarno in zijn rede op Onafhankelijkheidsdag triomfantelijk bekendmaken dat Nederland gecapituleerd had. Daarbij verklaarde hij lijnrecht in strijd met de in New York ondertekende tekst dat de daarin overeengekomen keuzevrijheid geen extern zelfbeschikkingsrecht maar alleen een intern zelfbeschikkingsrecht inhield.

$\mathrm{Na}$ de ondertekening wikkelden verschillende organen in recordtempo de procedures af die nodig waren om de overeenkomst van New York in werking te stellen. De Nederlandse regering legde de overeenkomst op 25 augustus voor aan het parlement. Bij de parlementaire behandeling nam zij het standpunt in dat geen formele handeling nodig was om de Nederlandse soevereiniteit over westelijk Nieuw-Guinea te beëindigen. Zowel de Tweede als de Eerste Kamer keurde de overeenkomst met overweldigende meerderheid goed. Op 20 september werd de overeenkomst in New York namens de Indonesische en de Nederlandse regering bekrachtigd. De volgende dag nam de AVVN een door deze beide regeringen ingediende resolutie aan waarin de secretaris-generaal gemachtigd werd om de taken uit te voeren die hem bij de 
overeenkomst waren toevertrouwd. Dat betrof in de eerste plaats de instelling van de United Nations Temporary Executive Authority (UNTEA), het VN-bestuursorgaan dat westelijk Nieuw-Guinea tot 1 mei 1963 zou besturen.

Het VN-secretariaat had intussen voorbereidend werk gedaan. De Indiase generaal Rikhye, militair adviseur van U Thant, was al in augustus naar WestIrian en Indonesië vertrokken voor overleg met de plaatselijke autoriteiten en voor toezicht op het militaire bestand dat sinds 18 augustus van kracht was. De regering van Pakistan stelde aan de VN een korps van vijftienhonderd militairen ter beschikking dat begin oktober aankwam om de Nederlandse militairen af te lossen. Hoofd van de UNTEA werd een Perzische diplomaat, Djalal Abdoh. Maar toen de UNTEA op 1 oktober het bestuur formeel van Nederland overnam, had zij voor de uitoefening van dat bestuur pas ruim veertig niet-Indonesische en niet-Nederlandse functionarissen in dienst. De meeste Nederlandse ambtenaren vertrokken spoedig en tegelijk stroomden Indonesische ambtenaren en vrijwilligers binnen. Al in november stemde de UNTEA ermee in dat Indonesische officieren de leiding van de politie overnamen. Ook verschenen er steeds meer Indonesische militairen. Op 31 december hielden Indonesische troepen een parade door de straten van Hollandia ter gelegenheid van het hijsen van de rood-witte vlag. Hoewel het bestuur over West-Irian formeel nog vier maanden bij de VN bleef berusten, oefende de UNTEA haar bestuur in die periode al voornamelijk met Indonesische functionarissen uit.

Op 1 mei 1963 droeg de VN het bestuur formeel aan Indonesië over. Eliëzer Bonay, een voormalig Papoealid van de Nieuw-Guinea Raad, werd de door Djakarta benoemde gouverneur van de provincie Irian Barat. Op 4 mei heette hij Soekarno welkom die aan boord van de kruiser 'Irian' in het voormalige Hollandia aankwam. De president sprak als gebruikelijk een volksmenigte toe en liet zijn gehoor vele malen 'merdeka' roepen. Ook legde hij een krans bij een monument voor de gesneuvelde parachutisten. Eindelijk mocht Soekarno de nationale vrijheidsstrijd als voltooid beschouwen, nu het Indonesische gezag zich uitstrekte over het hele gebied dat hij altijd had omschreven als 'van Sabang tot Merauke'.

\section{Aantekeningen bij hoofdstuk IX}

\section{Literatuuroverzicht}

De politieke ontwikkelingen in Indonesië gedurende de jaren 1950-1962 worden globaal beschreven in diverse algemene geschiedwerken over dit land zoals $A$ history of modern Indonesia door M.C. Ricklefs (1991). Meer gedetailleerde studies zijn The decline of constitutional democracy in Indonesia door H. Feith (1962) over de periode 1950-1957 en The transition to guided democracy; Indonesian politics 1957-1959 door D.S. Lev (1964). Ook het derde deel van Verguisd en vergeten; Tan Malaka, de linkse beweging 
en de Indonesische Revolutie, 1945-1949 door H.A. Poeze (2007) bevat veel bijzonderheden over dit tijdvak. Een veelomvattend maar beknopter overzicht is te vinden in Indonesië; kolonialisme, onafhankelijkheid, neo-kolonialisme door J. Pluvier (1978).

De Nederlandse kant van de relatie tussen Indonesië en Nederland gedurende dit tijdvak is grondig beschreven in Den Haag-Djakarta; De Nederlands-Indonesische betrekkingen 1950-1962 door H. Meijer (1994).

Een afzonderlijk aspect van die relatie was het geschil over westelijk Nieuw-Guinea. Dit heeft aanleiding gegeven tot een overvloed van geschriften, deels van polemische, deels van historische en deels van journalistieke aard. Op de grens van de eerste en de tweede categorie bevinden zich twee publikaties van Nederlandse hoogleraren in het publiekrecht, namelijk Nieuw Guinea als wereldprobleem door B.V.A. Röling (1958) en Nieuw Guinea als schakel tussen Nederland en Indonesië door F.J.F.M. Duynstee (1961). De belangrijkste geschiedkundige studies zijn The trauma of decolonization; The Dutch and West New Guinea door A. Lijphart (1966), De kwestie Nieuw Guinea; Aspecten van buitenlands beleid en militaire macht door P.B.R. de Geus (1984), Misleiding of zelfbedrog; Een analyse van het Nederlandse Nieuw Guinea-beleid aan de hand van gesprekken met betrokken politici en diplomaten door R. Gase (1984), Ons laatste oorlogje: de Pax Neerlandica, de diplomatieke kruistocht en de vervlogen droom van een Papoea-natie door J. Jansen van Galen (1984), The West New Guinea debacle; Dutch decolonization and Indonesia 1945-1962 door C.L.M. Penders (2002) en Een daad van vrije keuze; De Papoea's van westelijk NieuwGuinea en de grenzen van het zelfbeschikkingsrecht door P.J. Drooglever (2005).

\section{De politieke situatie na de soevereiniteitsoverdracht}

Deze kenschets van de sfeer in begin 1950 berust allereerst op mijn persoonlijke herinnering. Over Hirschfeld zie Meijer 1994. Over de ontbinding van het KNIL zie Den Hoed 1990, over de Molukse KNIL-militairen zie Manuhutu 1990.

Op 29 januari 1950 stierf Panglima Besar Sudirman, de leider van de Republikeinse strijdkrachten tijdens de vrijheidsstrijd. Hoewel de term Panglima Besar op zichzelf niets anders dan 'opperbevelhebber' betekent, was die titel zo nauw met Sudirman's persoon verbonden geraakt dat dezelfde titel nooit meer aan latere opperbevelhebbers toegekend is.

\section{De APRA-affaire}

Zie onder meer NIB XX:757-62, 786, 840-2, 854-5, Meijer 1994:100-22 en De Moor 1990 en 1999. De achtergrond van deze affaire is altijd onduidelijk gebleven. Ik vermoed dat het APRA-plan in eerste aanleg niet van Westerling zelf afkomstig was, maar van personen binnen de Nederlandse militaire inlichtingendienst. Voor de uitroeping van de Negara Islam Indonesia door Kartosuwirjo zie Van Dijk 1981:92. De eveneens tegen de RVI strijdende Chaerul Saleh werd in maart 1950 door de TNI gevangen genomen. Sultan Hamid is in april 1953 veroordeeld tot tien jaar gevangenisstraf met aftrek van voorarrest; hij is in 1956 vrijgelaten.

\section{Ontmanteling van de federale structuur}

Zie Kahin 1952:446-52, Feith 1962:58-77 en Meijer 1994:155-7.

Het parlement van de RVI kwam op 20 februari 1950 voor het eerst bijeen. Bij die gelegenheid werd ook een voorlopige versie getoond van het staatswapen van het nieuwe Indonesië, met onder meer de mythische vogel Garuda, de spreuk ‘Bhinekka 
tunggal ika' (Eenheid in verscheidenheid) en een schild met symbolen voor de vijf onderdelen van de Pantja Sila. Verder is als verwijzing naar de datum van de Indonesische onafhankelijkheidsverklaring (17 augustus 1945) de Garuda getooid met 17 veren aan elke vleugel, 8 staartveren en 45 borstveren.

Mislukte muiterij in Makassar

Zie Van Kaam 1977:105-12, Van der Meulen 1981:11-25, Chauvel 1990:331-46, Kawilarang 1993:162-3 en Bouman 1995:335-40.

Andi Abdul Aziz is in april 1953 veroordeeld tot veertien jaar gevangenisstraf met aftrek van voorarrest; een half jaar later is die straf verminderd tot acht jaar; hij is in 1956 vrijgelaten.

Uitroeping van de Republiek der Zuid-Molukken

Zie Van Kaam 1977:113-30, Van der Meulen 1981:27-32, 45-56, Chauvel 1990:347-63 en Kawilarang 1993:181-2.

Opheffing van het KNIL

Zie Den Hoed 1990, Manuhutu 1990:35-8 en Meijer 1994:197-200. Over J. Tahija zie Van Kaam 1977:96, 106-7.

Herstel van de Indonesische eenheidsstaat

Zie Kahin 1952:460-7 en Feith 1962:68-9, 92-9. Over de zienswijze van Hirschfeld zie Meijer 1994:157. Voor een Engelse vertaling van de Indonesische grondwet van 1950 zie A.B. Nasution 1992:487-510.

Herovering van Ambon

Zie Van Kaam 1977:131-52, Van der Meulen 1981:141-6, Bosscher en Waaldijk 1985:10755, Chauvel 1990:387-91 en Kawilarang 1993:182-96.

\section{Impasse over Nieuw-Guinea}

Zie Feith 1962:155-65, Lijphart 1966:163-77, Anak Agung 1973:79-89, De Geus 1984:608, Meijer 1994:255-9, 287-90 en Drooglever 2005:186-203.

De Nederlandse regering nam de hier genoemde maatregelen op basis van een op 21 december 1949 door het Nederlandse parlement aangenomen 'Machtigingswet Nieuw-Guinea' (zie ook NIB XX:652, noten 12 en 13). De uitspraak dat Nederland met die maatregelen als eerste het Unieverdrag heeft geschonden is ontleend aan oudminister De Geus (zie De Geus:1984:52).

Van Maarseveen werd in maart 1951 minister van binnenlandse zaken in het nieuwe kabinet; hij stierf echter in november van dat jaar.

Overbrenging naar Nederland van Ambonese ex-KNIL-militairen

Zie Bosscher en Waaldijk 1985:53-60, Manuhutu 1990:39-42 en Meijer 1994:239.

Mislukking van de Indonesisch-Nederlandse Unie

Zie Meijer 1994:271-87, 299-307, 341-4, 386-96, 440-5, 491-518 en Groeneboer 1993:4603. 
De eerste jaren parlementaire democratie in Indonesië

Voor een uitvoerig overzicht van de binnenlands-politieke ontwikkelingen in Indonesië in 1950-57 zie Feith 1962. Voor meer beknopte overzichten zie Pluvier 1978:112-95 en Ricklefs 1991:237-56. Voor de samenstelling van het parlement zie Feith 1962:93-5, 128. Voor een overzicht van de politieke partijen zie Feith 1962:122-45.

De grondwet van de RVI van 1949 had in artikel 122 uitdrukkelijk bepaald dat het parlement in zijn voorlopige samenstelling noch het kabinet noch individuele ministers tot aftreden kon dwingen. Een overeenkomstige bepaling was welbewust niet opgenomen in de voorlopige grondwet van 1950. Daardoor kon het stelsel voldoen aan de politieke norm van de in 1939 door de vrijheidsbeweging gelanceerde campagne 'Indonesië parlementair'(zie pp. 241-2).

Het onderscheid tussen 'bestuurders' en 'volksleiders' heb ik ontleend aan de onderscheiding tussen 'administrators' en 'solidarity makers' in Feith 1962:33-4, 113-22.

Verscherping van het conflict over Nieuw-Guinea

Zie Duynstee 1961:203-19, Lijphart 1966:177-91, Anak Agung 1973:95-177, Meijer 1994:296-9, 342-5, 373-7, 397-8, 404-5, 425-6, 457-73 en Drooglever 2005:208-37, 3089. Over de reis van Frans Goedhart zie Goedhart 1953. Over de behandeling van de kwestie Nieuw-Guinea in de AVVN in 1954-1957 zie BZ 1955, BZ 1956, BZ 1957, BZ 1958.

\section{Anti-Nederlandse processen in Djakarta}

Zie Goedhart 1953:111-3, Beynon 1956, Schmidt 1961, Meijer 1994:431-8, 459-62, 46776, 541-2, 554-5 en Penders 2002:226-36. Over de islamitische opstandige bewegingen in West-Java, Zuid-Celebes en Atjeh zie Van Dijk 1981:97-108, 166-95, 300-20. Voor een Nederlands pleidooi om aan Indonesië tegemoet te komen zie Beynon 1956:190-201.

Schmidt werd in maart 1959 in het geheim aan Nederland overgedragen nadat de Nederlandse regering smeergeld betaald had en nadat een Indonesisch hof van beroep zijn gevangenisstraf verlaagd had tot de tijd die hij al in gevangenschap doorgebracht had. Toen dit bekend werd volgden in Indonesië woedende reacties. De regering-Djuanda ontsloeg de procureur-generaal die de zaak behandeld had en verklaarde tegen gerechtshoven te zullen optreden als hun vonnissen de nationale veiligheid in gevaar brachten. Zie Feith 1962:331 en Meijer 1994:571.

De eerste Indonesische parlementsverkiezingen en het laatste parlementaire kabinet Zie Feith 1962:424-40, 462-555, Lev 1964:1-42, Pluvier 1978:158-68 en Ricklefs 1991:2509. Zie over Soekarno's buitenlandse reizen in 1956 ook Giebels 2001:122-39. Over Chaerul Saleh zie Poeze 2007:1702-4, 1724-5, 1787-90.

Tot de gekozen parlementsleden behoorde de voormalige Nederlander Poncke Princen die kandidaat gesteld was door een bond van oud-militairen, de Ikatan Pendukung Kemerdekaan Indonesia (IPKI, Bond van Ondersteuners van de Indonesische Onafhankelijkheid). Overigens zat hij van medio 1958 tot eind 1959 gevangen wegens kritiek op de strijdkrachten en raakte hij toen in gevangenschap bevriend met Schmidt (zie Schmidt 1961:221-2 en Princen 1995:161-2). 
Meijer 1994:545-64, 575-94 en Drooglever 2005:308-11. Zie over de behandeling van de kwestie-Nieuw-Guinea in de AVVN in 1957 ook Röling 1958:45-78 en BZ 1958.

\section{Ondergang van de democratie in Indonesie}

Zie Feith 1962:578-608, Lev 1964, Pluvier 1978:179-82, 189-213 en Ricklefs 1991:262-70. Voor de discussie in de Konstituante zie A.B. Nasution 1992. Over de beëindiging van de opstandige bewegingen zie Van Dijk 1981:124-6, 215-7, 334-9.

De eind 1957 begonnen aanstelling van beroepsofficieren tot toezichthouders over de onder beheer gestelde Nederlandse bedrijven heeft de opmaat gevormd naar de vervlechting van het Indonesische officierscorps met de nationale economie die kenmerkend zou worden voor de later onder president Soeharto ingevoerde 'Nieuwe Orde'.

\section{Militaire confrontatie over Nieuw-Guinea}

Zie Duynstee 1961:271-2, 279, 298-302, 310-1, De Geus 1984:95-6, 104-10, 115-27, Meijer 1984:606-8, Van Holst Pellekaan, De Regt en Bastiaans 1989 en Drooglever 2005:35271. Het vliegkampschip 'Karel Doorman' was genoemd naar de commandant van een geallieerd marine-eskader die in februari 1942 gesneuveld was in de zeeslag met de Japanse invasievloot in de Javazee (zie p. 263).

\section{Ontdooiing van het Nederlandse Nieuw-Guinea-beleid}

Zie Duynstee 1961:278-98, 329-40, Lijphart 1966:223-76, De Geus 1984:111-3, 130-2, 139-41, 147-153, Drooglever 2005:379-416 en de Nieuwe Rotterdamse Courant van 23 augustus 1961. Voor de behandeling van het plan-Luns in de AVVN in 1961 zie BZ 1962 en Van Gorkom 2009:56-63, 67-72.

De uitspraak dat het lot van vijftigduizend Nederlanders en investeringen ter waarde van vier à vijf miljard gulden zijn opgeofferd voor het heilige doel van het behoud van Nieuw-Guinea is afkomstig van oud-minister De Geus (De Geus 1984:93).

Het opzienbarende pleidooi van de Nieuwe Rotterdamse Courant stond in de editie van 23 augustus 1961. De ommezwaai van de ARP in 1961 was des te opmerkelijker omdat die in het parlement werd bekendgemaakt door de fractievoorzitter Bruins Slot (tevens hoofdredacteur van het dagblad Trouw), een politicus die in 1946-48 een fervent pleitbezorger was geweest van militair optreden tegen de Republiek.

Een heldere en evenwichtige analyse van zowel de Nederlandse als de Indonesische motieven ten aanzien van Nieuw-Guinea is in december 1957 geschreven door de volkenrechtsgeleerde B.V.A. Röling, nadat hij als lid van de Nederlandse delegatie in de AVVN de behandeling van het onderwerp had bijgewoond (Röling 1958). Zijn conclusie was dat Nederland er goed aan zou doen Nieuw-Guinea snel aan Indonesië over te dragen. Röling, die hoogleraar in Groningen was, trad in 1958 ook als spreker over dit onderwerp op. Wegens zijn stellingname werd hij voor landverrader uitgemaakt en had hij herhaaldelijk politiebescherming nodig. Zijn stellingname had nog een ingrijpender gevolg. In 1959 kwam de leerstoel volkenrecht vrij aan de Rijksuniversiteit in Leiden, de meest prestigieuze Nederlandse leerstoel op dit vakgebied. De juridische faculteit in Leiden had Röling hiervoor unaniem voorgedragen. De Nederlandse regering besloot echter een jurist van mindere statuur (die zelfs nog niet gepromoveerd was) op deze leerstoel te benoemen. 
Beëindiging van het conflict en overdracht van Nieuw-Guinea

Zie BZ 1963, Lijphart 1966:277-84, De Geus 1984:154-92, Penders 2002:332-75 en Drooglever 2005:417-91, 571-99. Over de rol van Luns zie Huydecoper van Nigtevegt 1990. Over de rol van Kennedy zie Koster 1991. Over de militaire confrontatie zie Van Holst Pellekaan, De Regt en Bastiaans 1989.

Wat betreft het achterwege laten van een formele beëindiging van de soevereiniteit over westelijk Nieuw-Guinea verklaarde de Nederlandse regering op 12 september 1962 onder meer: 'Wanneer Nederland krachtens de overeenkomst op 1 oktober de uitoefening van zijn soevereine bevoegdheden staakt, komt daarmee de facto en de jure een einde aan de Nederlandse soevereiniteit' (BZ 1963:134). Ik vind dit een absurde redenering. Op grond van de sinds eind 1949 door alle Nederlandse regeringen gehuldigde (maar door mij niet gedeelde) theorie dat de Nederlandse soevereiniteit over het gebied gehandhaafd was gebleven, zou Nederland die soevereiniteit volgens mij wel degelijk met een formele daad hebben moeten beëindigen. Dit had bijvoorbeeld de vorm kunnen krijgen van een door koningin Juliana te ondertekenen, door het kabinet te contrasigneren en in het Staatsblad te publiceren verklaring, dat het Koninkrijk met ingang van 1 oktober 1962 afstand deed van de soevereiniteit over het gebied. 


\section{Afkortingen}

ABDA

AFNEI

AMACAB

AMS

API

APRA

APRI

APRIS

ARP

AVVN

BB

BFO

$\mathrm{BIO}$

BKR

BPM

BPOPKI

BSO

CGD

$\mathrm{CHU}$

CPN

DPKN

EIC

ELS

FDR

FIR

Gapi

Gerindo

GPP

HBS

$\mathrm{HC}$

HCS
American-British-Dutch-Australian Command

Allied Forces in the Netherlands East Indies

Allied Military Administration Civil Affairs Branch

Algemene Middelbare School

Angkatan Pemoeda Indonesia

Angkatan Perang Ratu Adil

Angkatan Perang Republik Indonesia

Angkatan Perang Republik Indonesia Serikat

Anti-Revolutionaire Partij

Algemene Vergadering der Verenigde Naties

Binnenlands Bestuur

Bijeenkomst voor Federaal Overleg

Bewind Indonesië in Overgangstijd

Badan Keamanan Rakjat

Bataafsche Petroleum Maatschappij

Badan Penjelidik Oesaha-oesaha Persiapan Kemerdekaan Indonesia

Bevelhebber Strijdkrachten Oosten

Commissie van Goede Diensten

Christelijk-Historische Unie

Communistische Partij Nederland

Dinas Pengawas Keselamatan Negara

East India Company

Europese Lagere School

Front Demokrasi Rakjat

Federale Interim-Regering

Gaboengan Politik Indonesia

Gerakan Rakjat Indonesia

Gaboengan Pembela Proklamasi

Hogere Burger School

Hoge Commissaris

Hollands-Chinese School 
HIS

HVK

IEV

IPKI

ILS

ISDP

ISDV

IV

IVS

KL

KLM

KM

KNI

KNIL

KNIP

Komintern

KPM

KRIS

KVP

Masjoemi

MIAI

MRI

MULO

NAVO

NEFIS

NEI

NICA

NIGO

NIP

NMM

NSB

NU

OSVIA

Pari

Parindra

Parkindo

Partindo

PBI

Pesindo

Peta

PI

PID
Hollands-Inlandse School

Hoge Vertegenwoordiger van de Kroon

Indo-Europees Verbond

Ikatan Pendukung Kemerdekaan Indonesia

Inlandse Lagere School

Indische Sociaal-Democratische Partij

Indische Sociaal-Democratische Vereeniging

Indische Vereeniging

Indonesisch Verbond van Studeerenden

Koninklijke Landmacht

Koninklijke Luchtvaart Maatschappij

Koninklijke Marine

Komite Nasional Indonesia

Koninklijk Nederlandsch-Indisch Leger

Komite Nasional Indonesia Poesat

Communistische Internationale

Koninklijke Paketvaart Maatschappij

Kebaktian Rakjat Indonesia Soelawesi

Katholieke Volkspartij

Madjelis Sjoero Moeslimin Indonesia

Madjlisoel Islamil A'laa Indonesia

Madjelis Rakjat Indonesia

Meer Uitgebreid Lager Onderwijs

Noord-Atlantische Verdragsorganisatie

Netherlands Forces Intelligence Service

Netherlands East Indies

Netherlands-Indies Civil Administration

Nederlands-Indische Guerrilla Organisatie

Nationaal-Indische Partij

Nederlandse Militaire Missie

Nationaal-Socialistische Beweging

Nahdatul Ulama

Opleidingsschool voor Inlandse Ambtenaren

Partai Republik Indonesia

Partai Indonesia Raja

Partai Kristen Indonesia

Partai Indonesia

Persatoean Bangsa Indonesia

Pemoeda Sosialis Indonesia

Barisan Soekarela Pembela Tanah Air

Perhimpoenan Indonesia

Politieke Inlichtingen Dienst 
PKI

PKI

PNI

PNI

PNI

Poetera

POPDA

PP

PP

PPBB

PPKI

PPN

PPPI

PPPKI

PRI

PRRI

PS

PSI

PTB

PvdA

PvdV

RAPWI

RI

RIS

RMS

RTC

RVI

SEAC

SEATO

SDAP

SDP

SGP

$\mathrm{SH}$

SI

SOBSI

SR

STOVIA

SWPA

TKR

TNI
Perserikatan Kommunist di India

Partai Komunis Indonesia

Perserikatan Nasional Indonesia

Partai Nasional Indonesia

Pendidikan Nasional Indonesia (meestal aangeduid als 'PNI Baroe')

Poesat Tenaga Rakjat

Panitia Oeroesan Pengangkoetan Djepang dan APWI

Persatoean Perdjoeangan

Pembela Proklamasi

Perhimpoenan Pegawai Bestuur Boemipoetra

Panitia Persiapan Kemerdekaan Indonesia

Panitia Persiapan Nasional

Perhimpoenan Peladjar-Peladjar Indonesia

Permoefakatan Perhimpoenan-Perhimpoenan

Kebangsaan Indonesia

Pemoeda Republik Indonesia

Pemerintah Revolusioner Republik Indonesia

Partai Sosialis

Partai Sosialis Indonesia

Persatoean Timoer Besar

Partij van de Arbeid

Partij van de Vrijheid

Recovery of Allied Prisoners of War and Internees

Republik Indonesia

Republik Indonesia Serikat

Republik Maluku Selatan

Rondetafelconferentie

Republiek der Verenigde Staten van Indonesië

South-East Asia Command

Southeast Asian Treaty Organization

Sociaal-Democratische Arbeiders Partij

Sociaal-Democratische Partij

Staatkundig Gereformeerde Partij

Sarekat Hindia

Sarekat Islam

Sentral Organisasi Buruh Seluruh Indonesia

Sarekat Rakjat

School Tot Opleiding Van Inlandse Artsen

South-West Pacific Area

Tentara Keamanan Rakjat

Tentara Nasional Indonesia 
TRI

Twapro

UNCI

UNTEA

$\mathrm{VC}$

VFR

$\mathrm{VN}$

VNI

VOC

VR

VSI

VSTP

VVD
Tentara Republik Indonesia

Twaalfde Provincie

United Nations Commission for Indonesia

United Nations Temporary Executive Authority

Vaderlandsche Club

Voorlopige Federale Regering

Verenigde Naties

Vereniging Nederland-Indonesië

Verenigde Oost-Indische Compagnie

Veiligheidsraad

Verenigde Staten van Indonesië

Vereeniging van Spoor- en Tramweg Personeel

Volkspartij voor Vrijheid en Democratie 


\section{Bibliografie}

Abeyasekere, Susan

1973 'The Soetardjo petition', Indonesia 15:81-107.

1976 One hand clapping; Indonesian nationalists and the Dutch 1939-1942. Clayton: Centre of Southeast Asian Studies Monash University.

Adams, Cindy

1965

Sukarno; An autobiography as told to Cindy Adams. Indianapolis: BobbsMerrill.

Alers, Henri J.H.

1956 Om een rode of groene Merdeka; 10 jaren binnenlandse politiek Indonesië 1943-1953. Eindhoven: Vulkaan.

Anak Agung Gde Agung, Ide

1973

Twenty years Indonesian foreign policy 1945-1965. The Hague/Paris: Mouton.

1980 'Renville' als keerpunt in de Nederlands-Indonesische onderhandelingen. Alphen aan den Rijn: Sijthoff.

Anderson, Benedict R. O'G.

1972 Java in a time of revolution; Occupation and resistance, 1944-1946. Ithaca, NY: Cornell University Press.

Aziz, M.A.

1955 Japan's colonialism and Indonesia. 's-Gravenhage: Nijhoff.

Baars, A. en H. Sneevliet

1991 Het proces Sneevliet. Ingeleid en bewerkt door Emile Schwidder en Fritjof Tichelman. Leiden: KITLV Uitgeverij.

Ballintijn, G.

1944 Rumphius, de blinde ziener van Ambon. Utrecht: De Haan.

Bals, K. en M. Gerritsen

1989 De Indonesië-weigeraars. Amsterdam: Antimilitaristische Uitgeverij.

Bank, Jan

$1983 \quad$ Katholieken en de Indonesische revolutie. Baarn: Amboboeken.

Barents, J. et al.

1947 Linggadjati-Militaire actie - Wat nu? Amsterdam: Arbeiderspers.

Bastian, Adolf

1884-94 Indonesien oder die Inseln des malayischen Archipels. Berlijn: Dümmler.

Vijf delen. 
Baudet, H. en I.J. Brugmans (red.)

1984 Balans van beleid; Terugblik op de laatste halve eeuw van Nederlands-Indië. Assen: Van Gorcum. [Oorspronkelijk uitgegeven 1961].

Benda, H.J.

1985

The crescent and the rising sun; Indonesian Islam under the Japanese occupation 1942-1945. The Hague/Bandung: Van Hoeve.

Benda, H.J., James K. Irikura en K. Kishi (red.)

1965 Japanese military administration in Indonesia; Selected documents. New Haven, Conn.: Southeast Asia Studies, Yale University.

Beus, J.G. de

1987

Het laatste jaar van Nederlands-Indië; Van de zwaardhouw der tweede politionele actie tot de handtekening onder de soevereiniteitsoverdracht. Rotterdam: Donker.

Beynon, H.C.

1956

Nederland staat terecht in Indonesië; Achtergronden bij de processeen tegen de Nederlanders Jungschläger, Schmidt en anderen in Djakarta. Utrecht: Bruna. 1995 Verboden voor honden en inlanders; Indonesiërs vertellen over hun leven in de koloniale tijd. Amsterdam: Mets.

Blauw, Seerp de en Lodewijk Severein

1980 De Vereniging Nederland-Indonesië; Vooruitstrevend Nederland: dekolonisatieopvattingen en de houding in het konflikt met Indonesië. Doctoraalscriptie, Universiteit van Amsterdam.

Blom, J.C.H.

1975 De muiterij op de 'Zeven Provinciën'; Reacties en gevolgen in Nederland. Bussum: Fibula-Van Dishoeck.

Blumberger, J.Th. Petrus zie Petrus Blumberger, J.Th.

Blussé, Leonard

1986 Strange company; Chinese settlers, mestizo women and the Dutch in VOC Batavia. Dordrecht: Foris. [KITLV, Verhandelingen 122.]

Bootsma, N.A.

1986 Buren in de koloniale tijd; De Philippijnen onder Amerikaans bewind en de Nederlandse, Indische en Indonesische reacties daarop, 1898-1943. Dordrecht: Foris. [KITLV, Verhandelingen 119.]

1995

'The discovery of Indonesia; Western (non-Dutch) historiography on the decolonization of Indonesia', Bijdragen tot de Taal-, Land-en Volkenkunde 151:1-22.

Bosscher, Doeko en Berteke Waaldijk

1985

Ambon eer en schuld; Politiek en pressie rond de Republiek Zuid-Molukken. Weesp: Van Holkema en Warendorf.

Bossenbroek, Martin

1994 'Wetenschappelijke exploraties', in Weerzien met Indië 16.

1995a 'Zending en missie', in Weerzien met Indië 34.

1995b 'Indië in de Nederlandse wetenschap', in Weerzien met Indië 37.

1995c 'Ons Indië als nationaal symbool', in Weerzien met Indië 39.

$1996 \quad$ Holland op zijn breedst; Indië en Zuid-Afrika in de Nederlandse cultuur omstreeks 1900. Amsterdam: Bert Bakker. 
Bouman, B.

1995

Van driekleur tot rood-wit; De Indonesische officieren uit het KNIL 19001950. Den Haag: Sectie Militaire Geschiedenis Landmachtstaf.

$2006 \quad$ Ieder voor zich en de Republiek voor ons allen; De logistiek achter de Indonesische revolutie 1945-1950. Amsterdam: Boom.

Bouwer, J.

1988

Het vermoorde land. Franeker: Van Wijnen.

Boxer, C.R.

1965

The Dutch seaborne empire. Londen: Hutchinson.

Breman, Jan

1987

Koelies, planters en koloniale politiek; Het arbeidsregime op de grootlandbouwondernemingen aan Sumatra's Oostkust in het begin van de twintigste eeuw. Dordrecht: Foris. [KITLV, Verhandelingen 123.]

Brooshooft, $\mathrm{P}$.

1901 De ethische koers in de koloniale politiek. Amsterdam: De Bussy.

Brouwer, B.J.

1958 De houding van Idenburg en Colijn tegenover de Indonesische beweging. Kampen: Kok.

Brug, P.H. van der

1994

Malaria en malaise; De VOC in Batavia in de achttiende eeuw. Amsterdam:

De Bataafsche Leeuw.

Brugmans, I.J.

1938 Geschiedenis van het onderwijs in Nederlandsch-Indië. Groningen/Batavia: Wolters.

Brugmans, I.J., H.J. de Graaf, A.H. Joustra en A.G. Vromans (red.)

$1960 \quad$ Nederlandsch-Indië onder Japanse bezetting; Gegevens en documenten over de jaren 1942-1945. Franeker: Wever.

Bruin, Rodney de

1982 Indonesië; De laatste etappe naar de vrijheid 1942-1945. Proefschrift, Universiteit van Amsterdam.

Buijze, W.

2006 Leven en werk van Georg Everhard Rumphius. Den Haag: eigen uitgave.

Burgers, J.H.

1998 'What sovereignty was transferred to the Republic of Indonesia?', in:

M. Castermans-Holleman e.a. (red.), The role of the nation-state in the

21st century; Essays in honour of Peter Baehr, pp. 367-84. The Hague/ Boston/London: Kluwer Law International.

2008 'Linggadjati en de erkenning van de Nederlandse soevereiniteit over Indonesië', Pro Memorie; Bijdragen tot de rechtsgeschiedenis der Nederlanden 10:222-33.

Bussemaker, H.Th.

2005 Bersiap! Opstand in het paradijs; De Bersiap-periode op Java en Sumatra 1945-1946. Zutphen: Walburg Pers.

Bywater, Hector C.

1925 The great Pacific war; A history of the American-Japanese campaign of 19311933. Boston: Houghton Mifflin. 
BZ

$1948 \mathrm{a}$

$1948 b$

$1948 c$

1949a

$1949 b$

1950

1955

1956

1957

1958

1961

1963

Carey, Peter

2007

Cats, B.C.

1961
Indonesië in de Veiligheidsraad van de Verenigde Naties (Januari 1946-September 1947). 's-Gravenhage: Staatsdrukkerij. [Uitgave 5 van het Ministerie van Buitenlandse Zaken.]

Indonesië in de Veiligheidsraad van de Verenigde Naties (October-November 1947). 's-Gravenhage: Staatsdrukkerij. [Uitgave 8 van het Ministerie van Buitenlandse Zaken.]

Indonesië in de Veiligheidsraad van de Verenigde Naties (December 1947-Februari 1948). 's-Gravenhage: Staatsdrukkerij. [Uitgave 9 van het Ministerie van Buitenlandse Zaken.]

Indonesie in de Veiligheidsraad van de Verenigde Naties (Maart-October 1948). 's-Gravenhage: Staatsdrukkerij. [Uitgave 14 van het Ministerie van Buitenlandse Zaken.]

Indonesië in de Derde Algemene Vergadering van de Verenigde Naties (AprilMei 1949). 's-Gravenhage: Staatsdrukkerij. [Uitgave 18 van het Ministerie van Buitenlandse Zaken.]

Indonesië in de Veiligheidsraad van de Verenigde Naties (November 1948-Januari 1949). 's-Gravenhage: Staatsdrukkerij. [Uitgave 19 van het Ministerie van Buitenlandse Zaken.]

Indonesië in de Veiligheidsraad van de Verenigde Naties (Februari-December 1949). 's-Gravenhage: Staatsdrukkerij. [Uitgave 21 van het Ministerie van Buitenlandse Zaken.]

Nederlands Nieuw Guinea in de Negende Algemene Vergadering van de Verenigde Naties (September-December 1954). 's-Gravenhage: Staatsdrukkerij. [Uitgave 37 van het Ministerie van Buitenlandse Zaken.]

Nederlands Nieuw Guinea in de Tiende Algemene Vergadering van de Verenigde Naties (september-december 1955). 's-Gravenhage: Staatsdrukkerij. [Uitgave 42 van het Ministerie van Buitenlandse Zaken.]

Nederlands Nieuw Guinea in de Elfde Algemene Vergadering van de Verenigde Naties (november 1956-maart 1957). 's-Gravenhage: Staatsdrukkerij. [Uitgave 49 van het Ministerie van Buitenlandse Zaken.]

Nederlands Nieuw Guinea in de Twaalfde Algemene Vergadering van de Verenigde Naties (september-december 1957). 's-Gravenhage: Staatsdrukkerij. [Uitgave 53 van het Ministerie van Buitenlandse Zaken.]

Nederlands Nieuw Guinea in de Zestiende Algemene Vergadering van de Verenigde Naties (september-december 1961). 's-Gravenhage: Staatsdrukkerij. [Uitgave 73 van het Ministerie van Buitenlandse Zaken.]

Nederlands Nieuw-Guinea en de Verenigde Naties (januari-oktober 1962). 's-Gravenhage: Staatsdrukkerij. [Uitgave 76 van het Ministerie van Buitenlandse Zaken.]

The power of prophecy; Prince Dipanegara and the end of an old order in Java, 1785-1855. Leiden: KITLV. [Verhandelingen 249.]

L.I.B.'s in de tropen; Een overzicht van het verblijf van onze oorlogsvrijwilligers bij de lichte infanteriebataljons in het voormalige Nederlands-Indie 1945-1949. Maastricht: Departement van Defensie. 
Chauvel, Richard

$1990 \quad$ Nationalists, soldiers and separatists; The Ambonese islands from colonialism to revolt 1880-1950. Leiden: KITLV Press. [Verhandelingen 143.]

Cheong, Yong Mun zie Yong Mun Cheong.

Chijs, J.A. van der

1886 De vestiging van het Nederlandsche gezag over de Banda-eilanden (15991621). 's-Gravenhage: Nijhoff.

Colenbrander, H.T.

1925-26 Koloniale geschiedenis. 's-Gravenhage: Nijhoff. Drie delen.

Colijn, H.

1907

(1834-1898). Batavia: Landsdrukkerij.

1918 Staatkundige hervormingen in Nederlandsch-Indië. Kampen: Kok.

1928 Koloniale vraagstukken van heden en morgen. Amsterdam: De Standaard.

Cribb, Robert

1986 'Administrative competition in the Indonesian revolution; The dual government of Jakarta, 1945-1947', in: J. van Goor (red.), The Indonesian revolution; Papers of the conference held in Utrecht 17-20 June 1986, pp. 129-46. Utrecht: Instituut voor Geschiedenis.

1991 Gangsters and revolutionaries; The Jakarta People's Militia and the Indonesian revolution 1945-1949. Sydney: Allen and Unwin.

1994 (red.) The late colonial state in Indonesia; Political and economic foundations of the Netherlands Indies 1880-1942. Leiden: KITLV Press. [Verhandelingen 163.]

Daalder, Hans

$2004 \quad$ Vier jaar nachtmerrie; Willem Drees 1886-1998; De Indonesische kwestie 1945-1949. Amsterdam: Balans.

Dahm, Bernhard

$1964 \quad$ Soekarno en de strijd om Indonesië's onafhankelijkheid. Meppel: Boom.

Dam, Pieter van

1927-54 Beschryvinge van de Oostindische Compagnie. 's-Gravenhage: Nijhoff. [Oorspronkelijk voltooid in 1701, gepubliceerd tussen 1927 en 1954 in zeven delen onder redactie van F.W. Stapel et al.]

Delden, Mary Catharina van

2007 De republikeinse kampen in Nederlands-Indië, oktober 1945-mei 1947; Orde in de chaos? Wageningen: Ponsen en Looijen.

Deventer, C.Th. van,

1899 'Een eereschuld', De Gids, 1899:215-28, 249-52. [Gedeeltelijk herdrukt in Fasseur 1980, deel I:186-99; volledig herdrukt in R. Aerts en Th. Duquesnoy (red.), Een ereschuld; Essays uit De Gids over ons koloniaal verleden, Amsterdam: Meulenhoff 1993.]

Dillo, I.G.

1992 De nadagen van de Verenigde Oost-Indische Compagnie 1783-1795; Schepen en zeevarenden. Amsterdam: De Bataafsche Leeuw.

Dimyati, Muhammad

1951

Sedjarah perdjuangan Indonesia. Djakarta: Widjaya. 
Djajadiningrat, I.N.

$1958 \quad$ The beginnings of the Indonesian-Dutch negotiations and the Hoge Veluwe talks. Ithaca, NY: Modern Indonesia Project, Cornell University.

Djojoadisuryo, Ahmad Subardjo zie Subarjo Djojoadisuryo, Ahmad

Djojopoespito, Soewarsih

1940 Buiten het gareel. Utrecht: De Haan. [In 1946 herdrukt, Amsterdam: Vrij Nederland.]

Doel, H.W. van den

1994 De stille macht; Het Europese binnenlands bestuur op Java en Madoera 18081942. Amsterdam: Bert Bakker.

1996 Het rijk van Insulinde; Opkomst en ondergang van een Nederlandse kolonie. Amsterdam: Prometheus.

$2000 \quad$ Afscheid van Indië; De val van het Nederlandse imperium in Azië. Amsterdam: Prometheus.

Dolk, Liesbeth

1993

Twee zielen, twee gedachten; Tijdschriften en intellectuelen op Java (19001957). Leiden: KITLV. [Verhandelingen 159.]

Doorn, J.A.A. van en W.J. Hendrix

$1970 \quad$ Ontsporing van geweld; Over het Nederlands/Indisch/Indonesisch conflict. Rotterdam: Universitaire Pers.

1983 Het Nederlands/Indonesisch conflict; Ontsporing van geweld. Dieren: De Bataafsche Leeuw. [Aangevulde herdruk van vorige titel.]

Drees, W.

1962 Zestig jaar levenservaring. Amsterdam: De Arbeiderspers.

Drooglever, P.J.

1980 De Vaderlandse Club 1929-1942; Totoks en de Indische politiek. Franker: Wever.

1986 'De post-Renvillebesprekingen', in: J. van Goor (red.), The Indonesian revolution; Papers of the conference held in Utrecht 17-20 June 1986, pp. 223-45. Utrecht: Instituut voor Geschiedenis.

1987 'Mars in beweging; Denkbeelden over legerhervorming in het tijdvak van de dekolonisatie', in: G. Teitler en P.M.H. Groen (red.), De politionele acties, pp. 73-90. Amsterdam: De Bataafsche Leeuw.

1988 'From coordination to confrontation; The Netherlands and the United States of America in the period between the two "police actions" in Indonesia', in: C.S. van Minnen (red.), The decolonization of Indonesia; International perspectives, pp. 39-54. Middelburg: Roosevelt Study Center.

1996

Sultan in oorlogstijd; Hamengkubuwono IX en de bezetting van Yogyakarta in 1948/49. Nijmegen: Katholieke Universiteit.

2005 Een daad van vrije keuze; De Papoea's van westelijk Nieuw-Guinea en de grenzen van het zelfbeschikkingsrecht. Amsterdam: Boom.

Drooglever, P.J. en M.J.B. Schouten

1996 (red.) De leeuw en de banteng; Bijdragen aan het congres over de NederlandsIndonesische betrekkingen 1945-1950, gehouden in Den Haag van 27-29 maart 1996. Den Haag: Instituut voor Nederlandse Geschiedenis. 
Het einde in zicht; Stemmen uit het laatste jaar van Nederlands-Indië. Den Haag: SDU.

Duynstee, F.J.F.M.

$1961 \quad$ Nieuw Guinea als schakel tussen Nederland en Indonesië. Amsterdam: De Bezige Bij.

Dijk, C. van

1981

Rebellion under the banner of Islam; The Darul Islam in Indonesia. 's-Gravenhage: Nijhoff. [KITLV, Verhandelingen 94.]

2007 The Netherlands Indies and the Great War, 1914-1918. Leiden: KITLV. [Verhandelingen 254.]

Encyclopaedie

1917-39 Encyclopaedie van Nederlandsch-Indie.. 's-Gravenhage en Leiden: Nijhoff Engelbrecht, W.A. en Brill. Vier delen en vier supplementen.

1938

De Nederlandsch-Indische Wetboeken benevens de Grondwet voor het Koninkrijk der Nederlanden, en de belangrijkste in Nederlandsch-Indië geldende algemeene verordeningen en besluiten, bewerkt door E.M.L. Engelbrecht. Leiden: Sijthoff. [De laatste editie van een verzameling van in Nederlands-Indië geldende wetgeving waarvan de eerste editie in 1890 te Semarang was uitgegeven door A. Bisschop.]

Ensiklopedi

1988-91 Ensiklopedi Nasional Indonesia. Jakarta: Cipta Adi Pustaka. Achttien delen, plus supplement uit 1994.

Excessennota 1995

De Excessennota; Nota betreffende het archiefonderzoek naar de gegevens omtrent excessen in Indonesië begaan door Nederlandse militairen in de periode 1945-1950. Ingeleid door Jan Bank. Den Haag: SDU. [Heruitgave van een door de Nederlandse regering op 3 juni 1969 aan het parlement aangeboden nota, Kamerstuk 1968-1969, 10008.]

Fabricius, Johan

1947 Hoe ik Indië terugvond. 's-Gravenhage: Leopold.

Fasseur, C.

$1975 \quad$ Kultuurstelsel en koloniale baten; De Nederlandse exploitatie van Java 18401860. Leiden: Universitaire Pers.

1980 (red.) Geld en geweten; Een bundel opstellen over anderhalve eeuw Nederlands bestuur in de Indonesische archipel, I. De negentiende eeuw, II. Het tijdvak tussen 1900 en 1942. Den Haag: Nijhoff. Twee delen.

1993

De Indologen; Ambtenaren voor de Oost 1825-1950. Amsterdam: Bert Bakker.

1995 De weg naar het paradijs en andere Indische geschiedenissen. Amsterdam: Bert Bakker.

Feith, Herbert

1962

The decline of constitutional democracy in Indonesia. Ithaca, NY: Cornell University Press.

Frederick, W.H.

1989

Visions and heat; The making of the Indonesian revolution. Athens, Ohio: Ohio University Press. 
Friend, Theodore

1988

The blue-eyed enemy; Japan against the West in Java and Luzon. Princeton: Princeton University Press.

Gaastra, Femme S.

1991 De geschiedenis van de VOC. Zutphen: Walburg Press. [Eerste druk 1982.]

Gase, Ronald

$1984 \quad$ Misleiding of zelfbedrog; Een analyse van het Nederlandse Nieuw-Guineabeleid aan de hand van gesprekken met betrokken politici en diplomaten. Baarn: In den Toren.

1986 Beel in Batavia; Van contact tot conflict; Verwikkelingen rond de Indonesische kwestie in 1948. Baarn: In den Toren.

Geus, P.B.R. de

1984 De kwestie Nieuw-Guinea; Aspecten van buitenlands beleid en militaire macht. Leiden: Nijhoff.

Giebels, Lambert

1999 Soekarno Nederlandsch onderdaan; Een biografie 1901-1950. Amsterdam: Bert Bakker.

2001 Soekarno president; Een biografie 1950-1970. Amsterdam: Bert Bakker.

Glissenaar, Frans

1999 D.D.; Het leven van E.F.E. Douwes Dekker. Hilversum: Verloren.

Goedhart, F.J.

1953

Een revolutie op drift; Indonesisch reisverhaal. Amsterdam: Van Oorschot. Gonggrijp, G.F.E. et al. (red.)

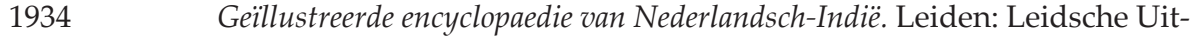
geversmaatschappij. [In 1991 herdrukt, Wijk en Aalburg: Picture Publishers.]

Goor, J. van

1986

(red.) Imperialisme in de marge; De afronding van Nederlands-Indië. Utrecht: HES.

1994 De Nederlandse koloniën; Geschiedenis van de Nederlandse expansie 16001975. Den Haag: SDU.

Gorkom, Lodewijk van

2009 Door Europa en de wereld; Een trektocht in de Buitenlandse Dienst. Amsterdam: Boom.

Goudoever, W.A. van

1946 Malino maakt historie; Een overzichtelijke bewerking van notulen en tekstueele redevoeringen ter conferentie van Malino 15-25 juli 1946. Batavia: RVD.

1947 Denpasar bouwt een huis; Een overzichtelijke bewerking van notulen en tekstueele redevoeringen ter conferentie van Denpasar 7-14 december 1946. Batavia: RVD.

Gouka, N.B.G.

2001

De petitie-Soetardjo; Een Hollandse misser in Indië? (1930-1938). Amsterdam: Rozenberg.

Graaf, H.J. de

1949 Geschiedenis van Indonesië. 's-Gravenhage/Bandung: Van Hoeve. 
Groen, P.M.H.

1985

"'Patience and bluff"; De bevrijding van de Nederlandse burgergeïnterneerden op Midden-Java (augustus- december 1945)', Mededelingen van de Sectie Militaire Geschiedenis Landmachtstaf 8:91-154.

1991 Marsroutes en dwaalsporen; Het Nederlands militair-strategisch beleid in Indonesië 1945-1950. Amsterdam: De Bataafsche Leeuw.

Groen, P.H.M. en G. Teitler (red.)

1986 De politionele acties. Amsterdam: De Bataafsche Leeuw.

Groen, Petra en Elly Touwen-Bouwsma (red.)

1992 Nederlands-Indië 1942; Illusie en ontgoocheling. Den Haag: SDU.

Groeneboer, Kees

1993 Weg tot het Westen; Het Nederlands voor Indie 1600-1650. Leiden: KITLV Uitgeverij. [Verhandelingen 158.]

Groot, Hans

2007

Van Batavia naar Weltevreden; Het Bataviaasch Genootschap van Kunsten en Wetenschappen, 1778-1867. Leiden: KITLV Uitgeverij. [Verhandelingen 243.]

Haan, F. de

1922 Oud Batavia; Gedenkboek uitgegeven door het Bataviaasch Genootschap van Kunsten en Wetenschappen naar aanleiding van het driehonderdjarig bestaan der stad in 1919. Deel 1. Batavia: Kolff.

Han Bing Siong

1996 'The secret of major Kido; The battle of Semarang, 15-19 October 1945', Bijdragen tot de Taal-, Land-en Volkenkunde 152:382-428.

1998 'The Japanese occupation of Indonesia and the administration of justice today; Myths and realities', Bijdragen tot de Taal-, Land-en Volkenkunde 154:416-56.

2000 'Sukarno-Hatta versus the Pemuda in the first months after the surrender of Japan (August-November 1945)', Bijdragen tot de Taal-, Land- en Volkenkunde 156:233-73.

2001 'The Indonesian need of arms after the proclamation of independence', Bijdragen tot de Taal-, Land-en Volkenkunde 157:799-830.

Hanifah, Abu

1972 Tales of a revolution; A leader of the Indonesian revolution looks back. Sydney: Angus and Robertson.

Hatta, Mohammad

1928 Indonesië vrij; Onuitgesproken aan de rechtbank overgelegde rede. 's-Gravenhage: Perhimpoenan Indonesia.

1952 Verspreide geschriften. Djakarta/Amsterdam/Surabaja: Van der Peet.

1979 Bung Hatta antwoordt; Vraaggesprek met Z. Yasni. Hengelo: Smit.

1981 Mohammad Hatta; Indonesian patriot; Memoirs edited by C.L.M. Penders. Singapore: Gunung Agung.

Heekeren, C. van

1983 Batavia seint Berlijn; De geschiedenis van de Indische Duitsers in Nederlandse gevangenschap. 's-Gravenhage: Nijgh en Van Ditmar. 
Heeres, J.R. en F.W. Stapel (red.)

1907-55 Corpus diplomaticum Neerlando-Indicum; Verzameling van politieke contracten en verdere verdragen door Nederlanders in het Oosten gesloten, van privilegebrieven aan hen verleend, enz. 's-Gravenhage: Nijhoff. [Zes delen, betreffende 1596-1799.]

Hekman, J.

1981

Nationaal Comité handhaving Rijkseenheid. Doctoraalscriptie, Universiteit van Amsterdam.

Helsdingen, W.H. van (red.)

1941 Daar wèrd wat groots verricht...; Nederlandsch-Indië in de XXste eeuw. Amsterdam: Elsevier.

Henssen, E

1983

Gerretson en Indië. Groningen: Wolters-Noordhoff.

Hering, Bob

1997

M.H. Thamrin and his quest for Indonesian nationhood 1917-1941. Stein: Yayasan Kabar Seberang.

2002 Soekarno; Founding father of Indonesia 1901-1945. Leiden: KITLV Press. [Verhandelingen 192.]

Heijboer, Pierre

1979

De politionele acties; De strijd om Indië 1945/1949. Haarlem: Fibula-Van Dishoeck.

Hoed, A. den 1990

'Het KNIL in de knel'; De ontbinding van het KNIL en het lot van de militairen', in: G. Teitler en J. Hoffenaar (red.), De politionele acties; Afwikkeling en verwerking, pp. 21-34. Amsterdam: De Bataafsche Leeuw.

Holst Pellekaan, R.E. van, I.C. de Regt en J.F. Bastiaans

1989-1990 Patrouilleren voor de Papoea's; De Koninklijke Marine in Nederlands Nieuw-

Guinea. Amsterdam: De Bataafsche Leeuw. Twee delen.

Holst Pellekaan, R.E. van en I.C. de Regt

$2003 \quad$ Operaties in de Oost; De Koninklijke Marine in de Indische archipel (19451951). Amsterdam: De Bataafsche Leeuw.

Huydecoper van Nigtevegt, J.L.R.

1990 Nieuw-Guinea; Het einde van een koloniaal beleid. 's-Gravenhage: SDU.

Idenburg, P.J.A.

1984 'Het Nederlandse antwoord op het Indonesisch nationalisme', in: H.

Baudet en I.J. Brugmans (red.), Balans van beleid, pp. 121-51. Assen: Van Gorcum.

Idris, I. et al.

2000

Herinneringen aan 17 augustus 1945; Oud-leerlingen van de Koning Willem III School (Batavia) aan het woord. Jakarta: Djambatan.

Indonesian heritage

1996-98 Indonesian heritage. Jakarta/Singapore: Archipelago Press. [Tiendelig overzichtswerk over cultuur, natuur en geschiedenis van Indonesië, onder redactie van Timothy Auger et al.] 
Ingleson, John

1975 Perhimpunan Indonesia and the Indonesian nationalist movement 19231928. Clayton: Centre of Southeast Asian Studies Monash University.

1979 Road to exile; The Indonesian nationalist movement 1927-1934. Singapore: Heinemann.

1986 In search of justice; Workers and unions in colonial Java, 1908-1926. Singapore: Oxford University Press.

Jansen, L.F. 1988

In deze halve gevangenis; Dagboek van mr dr L.F. Jansen, Batavia/Djakarta 1942-1945. Bezorgd en geannoteerd door dr G.J. Knaap. Franeker: Van Wijnen.

Jansen van Galen, John

1984

Ons laatste oorlogje; Nieuw-Guinea: de Pax Neerlandica, de diplomatieke kruistocht en de vervlogen droom van een Papoea-natie. Weesp: Van Holkema en Wa-rendorf.

Jaquet, L.G.M.

1978

Aflossing van de wacht; Bestuurlijke en politieke ervaringen in de nadagen van Nederlandsch-Indië. Rotterdam: Donker.

1982

Minister Stikker en de soevereiniteitsoverdracht aan Indonesië: Nederland op de tweesprong tussen Azië en het Westen. 's-Gravenhage: Nijhoff.

Jong, Janny de

$1989 \quad$ Van batig slot naar ereschuld; De discussie over de financiële verhouding tussen Nederland en Indië en de hervorming van de Nederlandse koloniale politiek 1860-1900. Den Haag: SDU.

Jong, J.J.P. de

1988

Diplomatie of strijd; Het Nederlands beleid tegenover de Indonesische revolutie 1945-1947. Amsterdam/Meppel: Boom.

1998 De waaier van het fortuin; Van handelscompagnie tot koloniaal imperium; De Nederlanders in Azië en de Indonesische archipel 1595-1950. Den Haag: SDU.

Jong, L. de 1984

Het Koninkrijk der Nederlanden in de Tweede Wereldoorlog, Deel 11a, Nederlands-Indië I. 's-Gravenhage: Staatsuitgeverij.

1985 Het Koninkrijk der Nederlanden in de Tweede Wereldoorlog, Deel 11b, Nederlands-Indië II. 's-Gravenhage: Staatsuitgeverij.

1986 Het Koninkrijk der Nederlanden in de Tweede Wereldoorlog, Deel 11c, Nederlands-Indië III. 's-Gravenhage: Staatsuitgeverij.

1988 Het Koninkrijk der Nederlanden in de Tweede Wereldoorlog, Deel 12, Epiloog. 's-Gravenhage: SDU.

Jonge, J.K.J. de en M.L. van Deventer (red.)

1862-1909 De opkomst van het Nederlandsch gezag in Oost-Indië; Verzameling van onuitgegeven stukken uit het Oud-Koloniaal Archief. 's-Gravenhage: Nijhoff. [Tien delen, betreffende 1595-1811.]

Jongmans, P.H.C.

1921 De exorbitante rechten van den gouverneur-generaal in de praktijk. Amsterdam: De Bussy. 
Jonkman, J.A.

Memoires; Het oude Nederlands-Indie. Assen: Van Gorcum.

1977

Memoires; Nederland en Indonesië beide vrij, gezien vanuit het Nederlands parlement. Assen: Van Gorcum.

Junghuhn, F.

1849-53 Java; deszelfs gedaante, bekleeding en inwendige structuur. Amsterdam: Van Kampen. Vier delen.

Kaam, Ben van

1977 Ambon door de eeuwen. Baarn: In den Toren.

Kadt, J. de

1948

De Indonesische tragedie; Het treurspel der gemiste kansen. Amsterdam: Van Oorschot.

Kahin, Audrey R. (red.)

1985 Regional dynamics of the Indonesian social revolution; Unity from diversity. Honolulu: University of Hawaii Press.

Kahin, George McTurnan

1952 Nationalism and revolution in Indonesia. Ithaca, NY: Cornell University Press.

Kan, J. van

1942

De rechtstitels der Compagnie. Amsterdam: Noordhollandsche Uitgevers Maatschappij.

Kanahele, George Sanford

1967 The Japanese occupation of Indonesia; Prelude to independence. PhD thesis, Cornell University.]

Karels, René

2010 Mijn aardse leven vol moeite en strijd; Raden Mas Noto Soeroto, Javaan, dichter, politicus, 1888-1951. Leiden: KITLV Uitgeverij.

Kartini, Raden Adjeng

1911

Door duisternis tot licht; Gedachten over en voor het Javaansche Volk. 's-Gravenhage: Luctor et Emergo.

Kartodirdjo, Sartono zie Sartono Kartodirdjo

Kawilarang, A.E.

1992

Officier in dienst van de Republiek Indonesië (ervaringen 1942-1961). Breda: Warung Bambu.

Kertapati, Sidik

1957 Sekitar proklamasi 17 Agustus 1945. Djakarta: Pembaruan.

Kleintjes, $\mathrm{Ph}$.

$1903 \quad$ Het staatsrecht wan Nederlandsch-Indië; Beginselen en beschouwingen. Amsterdam: De Bussy.

1938 Herstel van inheemsche rijken in Nederlandsch-Indië. Amsterdam: De Bussy.

Klinken, Gerry van 
Klooster, H.A.J.

$1985 \quad$ Indonesiërs schrijven hun geschiedenis; De ontwikkeling van de Indonesische geschiedbeoefening in theorie en praktijk. Dordrecht: Foris. [KITLV, Verhandelingen 113.]

1997 Bibliography of the Indonesian revolution; Publications from 1942 to 1994. Leiden: KITLV Press. [Bibliographical Series 21.]

Knaap, G.J.

1987

Kruidnagelen en christenen; De Verenigde Oost-Indische Compagnie en de bevolking van Ambon 1656-1696. Dordrecht: Foris. [KITLV, Verhandelingen 212.]

Knaap, G.J. en G. Teitler (red.)

2001 De Verenigde Oost-Indische Compagnie tussen oorlog en diplomatie. Leiden: KITLV Uitgeverij. [Verhandelingen 197.]

Koch, D.M.G.

1950 Om de vrijheid; De nationalistische beweging in Indonesië. Djakarta: Pembangunan.

1956 Verantwoording; Een halve eeuw in Indonesië. 's-Gravenhage/Bandung: Van Hoeve.

Kohlbrugge, J.H.F.

1927 De inlandsche beweging en de onrust in Indië; Voordrachten gehouden in October 1927 bij de opening der lessen voor de Indologische Faculteit der Rijksuniversiteit te Utrecht. Utrecht: Oosthoek.

Kok, A.S. (red.)

1903 Multatuliana; Verspreide en onuitgegeven stukken. Baarn: Hollandia.

Korver, A.P.E.

1982 Sarekat Islam 1912-1916; Opkomst, bloei en structuur van Indonesië's eerste massabeweging. Amsterdam: Historisch Seminarium.

Koster, Ben

$1991 \quad$ Een verloren land; De regering Kennedy en de Nieuw-Guinea kwestie 19611962. Baarn: Anthos.

Kuitenbrouwer, Maarten

$1985 \quad$ Nederland en de opkomst van het moderne imperialisme; Koloniën en buitenlandse politiek 1870-1914. Amsterdam/Dieren: De Bataafsche Leeuw.

2001 Tussen oriëntalisme en wetenschap; Het Koninklijk Instituut voor Taal-, Land- en Volkenkunde in historisch verband. Leiden: KITLV Uitgeverij.

Kusuma Sumantri, Iwa

1966-69 Sedjarah revolusi Indonesia. Djakarta: Grafica. [Drie delen: I. Masa perdjuangan sebagai perintis revolusi, II. Masa revolusi bersendjata, III. Masa mempertahankan keutuhan negara.]

2002 Sang pejuang dalam gejolak sejarah. Bandung: Satya Historika. [Posthuum uitgegeven autobiografie.]

Kwantes, R.C. (red.)

1975-82 De ontwikkeling van de nationalistische beweging in Nederlandsch-Indië. Groningen: Tjeenk Willink (1975), Wolters-Noordhoff (1978, 1981, 1982). [Vier delen, betreffende 1917-42.] 
Lapian, A.B. (red.)

1988 Di bawah pendudukan Jepang; Kenangan empat puluh dua orang yang mengalaminya. Jakarta: Arsip Nasional.

Legge, J.D.

$1972 \quad$ Sukarno; A political biography. Sydney: Allen and Unwin.

Lelyveld, J.E.A.M.

1992 'Waarlijk geen overdaad, doch een dringende eisch'; Koloniaal onderwijs en onderwijsbeleid in Nederlandsch-Indië 1893-1942. Proefschrift, Rijksuniversiteit Utrecht.

Leslie-Miller, J.W.H.

1956 'Het politieke aspect van het Nieuw-Guinea-vraagstuk', Socialisme en democratie; Maandblad van de Partij van de Arbeid 13:478-89.

Liempt, Ad van

1994 Een mooi woord voor oorlog; Ruzie, roddel en achterdocht op weg naar de Indonesië-oorlog. Den Haag: SDU.

1997 De lijkentrein; Waarom 46 gevangenen de reis naar Surabaya niet overleefden. Den Haag: SDU.

Locher-Scholten, E.B.

$1981 \quad$ Ethiek in fragmenten; Vijf studies over koloniaal denken en doen van Nederlanders in de Indonesische archipel 1877-1942. Utrecht: HES.

Lockwood, Rupert

1970 'The Indonesian exiles in Australia, 1942-47', Indonesia 10:37-56.

Logemann, J.H.A.

$1962 \quad$ Nieuwe gegevens over het ontstaan van de Indonesische grondwet. Amsterdam: Noord-Hollandsche Uitgevers Maatschappij.

Lijphart, Arend

1966 The trauma of decolonization; The Dutch and West New Guinea. New Haven, Conn.: Yale University Press.

Maas, P.F. en J.E.C.M. van Oerle

1986 'Het leger te gelde', in G. Teitler en P.M.H. Groen (red.), De politionele acties, pp. 11-28. Amsterdam: De Bataafsche Leeuw.

Maier, H.M.J. en A. Teeuw (red.)

$1976 \quad H o n d e r d$ jaar studie van Indonesië 1850-1950; Levensbeschrijvingen van twaalf Nederlandse onderzoekers. Den Haag: Smits.

Maier, Henk, Don van Minde en Harry Poeze (red.)

1995 Wisseling van de wacht; Indonesiërs over de Japanse bezetting 1942-1945.

Leiden: KITLV Uitgeverij.

Malaka, Tan zie Tan Malaka

Malik, Adam

$1948 \quad$ Riwajat dan perdjuangan sekitar proklamasi kemerdekaan 17 Agustus 1945.

Surakarta: Wakaf Republik.

1980 In the service of the Republic. Singapore: Gunung Agung.

Manuhutu, W.

1990

'De Molukse KNIL-militairen; Tussen wal en schip', in: G. Teitler en J. Hoffenaar (red.), De politionele acties; Afwikkeling en verwerking, pp. 35-44. Amsterdam: De Bataafsche Leeuw. 
Maters, Mirjam

$1998 \quad$ Van zachte wenk tot harde hand; Persurijheid en persbreidel in NederlandsIndie 1906-1942. Hilversum: Verloren.

McVey, Ruth

1965

The rise of Indonesian communism. Ithaca, NY: Cornell University Press.

Memoar

1993 Memoar; Senarai kiprah sejarah diangkat dari majalah Tempo. Jakarta:

Pustaka Utama Grafiti. Drie delen. [Herdruk van herinneringen van achtentwintig bekende Indonesiërs, tussen 1989 en 1992 gepubliceerd in het tijdschrift Tempo.]

Meulen, Daniël van der

$1977 \quad$ Hoort gij de donder niet? Begin van het einde der Nederlandse gezagvoering in Indië; Een persoonlijke terugblik. Franeker: Wever.

Meulen, E.I. van der (red.)

1981 Dossier Ambon 1950; De houding van Nederland ten opzichte van Ambon en de RMS. 's-Gravenhage: Staatsuitgeverij.

Meij, Jan M.

2004

Geen daden maar woorden; Koloniale uitingsvrijheidsprocessen en de naweeën hiervan. Amsterdam: Otto Cramwinckel.

Meijer, Hans

1994 Den Haag-Djakarta; De Nederlands-Indonesische betrekkingen 1950-1962.

Utrecht: Het Spectrum.

Miert, Hans van

1995 Een koel hoofd en een warm hart; Nationalisme, javanisme en jeugdbeweging in Nederlands-Indië 1918-1930. Amsterdam: De Bataafsche Leeuw.

Miksic, John en Anthony Reid (red.)

1997 Geschiedenis van Indonesië; Land, volk en cultuur. Abcoude: Uniepers.

[Vertaling van de delen 'Ancient history' en 'Early modern history' uit

het in Jakarta en Singapore gepubliceerde overzichtswerk Indonesian heritage.]

Mook, H.J. van

1949 Indonesië, Nederland en de wereld. Amsterdam: De Bezige Bij.

Moor, J.A. de

1990

'Kapitein Westerling en de APRA-coup. Het eind van een mythe', in: G. Teitler en J. Hoffenaar (red.), De politionele acties; Afwikkeling en verwerking, pp. 45-60. Amsterdam: De Bataafsche Leeuw.

1995a 'Oorlogen in de archipel 1817-1870', in: Weerzien met Indië 25.

1995b 'De Atjeh-oorlog', in: Weerzien met Indië 35.

1997 'Generaal Spoor en het ontbrekende dossier', in: P.J. Drooglever en M.J.B. Schouten (red.), De leeuw en de banteng; Bijdragen aan het congres over de Nederlands-Indonesische betrekkingen 1945-1950, gehouden in Den Haag van 27-29 maart 1996, pp. 220-34. Den Haag: Instituut voor Nederlandse Geschiedenis.

1999 Westerling's oorlog; Indonesië 1945-1950; De geschiedenis van de commando's en parachutisten in Nederlands-Indië 1945-1950. Amsterdam: Balans.

2011 Generaal Spoor; Triomf en tragedie van een legercommandant. Amsterdam: Boom. 
Morriën, Joop 1985

Indonesië los van Holland; De CPN en de PKI in hun strijd tegen het Nederlandse kolonialisme. Amsterdam: Pegasus.

Mrázek, Rudolf

1994 Sjahrir; Politics and exile in Indonesia. Ithaca, NY: Southeast Asia Program, Cornell University.

Multatuli (pseudoniem van E. Douwes Dekker)

1860 Max Havelaar, of de koffyveilingen der Nederlandsche Handel-Maatschappij. Amsterdam: J. de Ruyter. [Vele malen herdrukt.]

Mijer, P.

$1848 \quad$ Verzameling van instructien, ordonnanciën en reglementen voor de regering van Nederlandsch-Indië, vastgesteld in de jaren 1609, 1617, 1632, 1650, 1807, 1815, 1818, 1827, 1830 en 1836, met de ontwerpen der Staats-commissie van 1803. Batavia: Landsdrukkerij.

Nagazumi, Akira

1972 The dawn of Indonesian nationalism; The early years of Budi Utomo 19081919. Tokyo: Institute of Developing Economies.

Nagtegaal, Luc

$1996 \quad$ Riding the Dutch tiger; The Dutch East Indies Company and the northern coast of Java 1680-1743. Leiden: KITLV. [Verhandelingen 171.]

Nasution, Adnan Buyung

1992 The aspiration for constitutional government in Indonesia; A social-legal study of the Indonesian Konstituante 1956-1959. Jakarta: Pustaka Sinar Harapan.

Nasution, A.H.

$1965 \quad$ Fundamentals of guerrilla warfare. London: Pall Mall Press.

1977-79 Sekitar perang kemerdekaan Indonesia. Bandung, Angkasa. Elf delen.

Nederburgh, I.A.

1929 'Nederlandsch recht op en in Indië', Politiek Economisch Weekblad; Orgaan ter versterking van de Rijkseenheid Nederland-Indië 1-1.

NIB

1971-96 S.L. van der Wal, P.J. Drooglever en M.J.B. Schouten (red.), Officiële bescheiden betreffende de Nederlands-Indonesische betrekkingen 19451950. 's-Gravenhage: Nijhoff (1971-88), Instituut voor Nederlandse Geschiedenis (1989-96). [Twintig delen, betreffende 1945-49.]

Noer, Deliar

2002

Mohammad Hatta; Hati nurani bangsa/Conscience of a nation, 1902-1980. Jakarta Djambatan/Perwakilan KITLV.

Notosusanto, Nugroho

1970 The battle of Surabaya. Jakarta: Centre for Armed Forces History.

1977 The PETA army during the Japanese occupation of Indonesia. Jakarta: Universitas Indonesia.

Oranje, D.J.P.

$1936 \quad$ Het beleid der commissie-generaal; De uitwerking der beginselen van 1815 in het regeeringsreglement van 1818. Utrecht: Oosthoek. 
Overdijkink, G.W.

$1946 \quad$ Het Indonesische probleem; De feiten. 's-Gravenhage: Nijhoff.

$1948 \quad$ Het Indonesische probleem; Nieuwe feiten. Amsterdam: Keizerskroon.

Penders, C.L.M.

1980 The life and times of Sukarno. London: Sidgwick and Jackson.

2002 The West New Guinea debacle; Dutch decolonization and Indonesia 19451962. Leiden: KITLV Press.

Petrus Blumberger, J.Th.

1931 De nationalistische beweging in Nederlandsch-Indië. Haarlem: Tjeenk Willink. [In 1987 heruitgegeven met inleiding door Harry A. Poeze. Dordrecht: Foris.]

1935 De communistische beweging in Nederlandsch-Indië. Haarlem: Tjeenk Willink.

1939 De Indo-Europeesche beweging in Nederlandsch-Indië. Haarlem: Tjeenk Willink.

Platteel, P.J.

1936

De grondslagen der constitutie van Nederlandsch-Indië; De wording van het regeeringsreglement van 1815 . Utrecht: Oosthoek.

Pluvier, J.M.

$1953 \quad$ Overzicht van de ontwikkeling der nationalistische beweging in Indonesie in de jaren 1930 tot 1942. 's-Gravenhage/Bandung: Van Hoeve.

1978 Indonesië; kolonialisme, onafhankelijkheid, neo-kolonialisme. Nijmegen: Socialistiese Uitgeverij.

Poeze, Harry A.

1976 Tan Malaka, strijder voor Indonesië's vrijheid; Levensloop van 1897 tot 1945. 's-Gravenhage: Nijhoff. [KITLV, Verhandelingen 78.]

1980 'De PvdA en Indonesië', in: Verstrikt in verbondenheid, pp. 12-22. Amsterdam: Evert Vermeer Stichting.

1986 In het land van de overheerser; Indonesiërs in Nederland 1600-1950. Dordrecht: Foris. KITLV, Verhandelingen 100.]

1994 'Political intelligence in the Netherlands Indies', in: Robert Cribb (ed.), The late colonial state in Indonesia; Political and economic foundations of the Netherlands-Indies 1880-1942, pp. 229-45. Leiden: KITLVPress. [Verhandelingen 163.]

$2007 \quad$ Verguisd en vergeten; Tan Malaka, de linkse beweging en de Indonesische Revolutie, 1945-1949. Leiden: KITLV. [Verhandelingen 250.]

Poeze, Harry en Henk Schulte Nordholt (red.)

1995 De roep om Merdeka; Indonesische vrijheidlievende teksten uit de twintigste eeuw. Amsterdam: Mets.

Post, Peter en Elly Touwen-Bouwsma (red.)

1996 'Japan, Indonesia and the war; Myths and realities', Bijdragen tot de Taal-, Land-en Volkenkunde 152.

PPO

1982-94 Harry A. Poeze (red.) Politiek-Politioneele overzichten van NederlandschIndië. 's-Gravenhage: Nijhoff (1982), Dordrecht: Foris (1983, 1988), Leiden: KITLV Uitgeverij (1994). [Vier delen, betreffende 1927-41.] 
Princen, Poncke

$1995 \quad$ Een kwestie van kiezen; Zijn levensverhaal opgetekend door Joyce van Fenema. 's-Gravenhage: BZZTôH.

Pringgodigdo, Abdul Karim

1949 Sedjarah pergerakan rakjat Indonesia. Djakarta: Pustaka Rakjat.

Raben, Remco (red.)

1999 Beelden van de Japanse bezetting van Indonesië; Persoonlijke getuigenissen en publieke beeldvorming in Indonesië, Japan en Nederland. Zwolle: Waanders.

Raffles, Thomas Stamford

1817 The history of Java. London: Murray. Twee delen. [Meermalen herdrukt.] Raliby, Osman (red.)

1953 Documenta historica; Sedjarah dokumenter dari pertumbuhan dan perdjuanReid, Anthony gan Republik Indonesia. Djakarta: Bulan-Bintang.

1974 The Indonesian national revolution 1945-1950. Hawthorn: Longman.

1979 The blood of the people; Revolution and the end of traditional rule in northern Sumatra. Kuala Lumpur: Oxford University Press.

Reid, Anthony en Akira Oki (red.)

1986 The Japanese experience in Indonesia; Selected memoirs of 1942-1945. Athens,

Ohio: Center for International Studies Ohio University.

Reinsma, Riemer

1955 Het verval van het cultuurstelsel. 's-Gravenhage: Van Keulen.

Remmelink, Willem

1994 The Chinese war and the collapse of the Javanese state 1725-1743. Leiden: KITLV Press. [Verhandelingen 162.]

Ricklefs, M.C.

1991

A history of modern Indonesia since c. 1300. London: Macmillan. [Herziening van eerste uitgave uit 1981.]

Röling, B.V.A.

$1958 \quad$ Nieuw Guinea als wereldprobleem. Assen: Van Gorcum.

Roem, Mohamad

1972 Bunga rampai dari sedjarah. Djakarta: Bulan Bintang.

Rose, Mavis

1987

Indonesia free; A political biography of Mohammad Hatta. Ithaca, NY: Modern Indonesia Project, Cornell University.

Rumphius, G.E.

1910 'De Ambonsche historie, behelsende een kort verhaal der gedenkwaardigste geschiedenissen zo in vreede als oorlog voorgevallen', Bijdragen

Said, Salim

1991 tot de Taal-, Land- en Volkenkunde 64.

Salim, I.F.M.

1973

Genesis of power; General Soedirman and the Indonesian military in politics 1945-1949. Singapore/Jakarta: Institute of Southeast Asian Studies.

Vijftien jaar Boven-Digoel; Concentratiekamp in Nieuw-Guinea; Bakermat van de Indonesische onafhankelijkheid. Amsterdam: Contact. 
Sartono Kartodirdjo

1989 Pengantar sejarah baru; Sejarah pergerakan nasional; Dari kolonialisme sampai nationalisme. Jakarta: Gramedia Pustaka Utama.

Sartono Kartodirdjo et al. (red.)

1975-77 Sejarah nasional Indonesia. Jakarta: Departemen Pendidikan dan Kebudayaan. Zes delen.

Sastroamijoyo, Ali

1979 Milestones on my journey; The memoirs of Ali Sastroamijoyo, Indonesian patriot and political leader, edited by C.L.M. Penders. St. Lucia: University of Queensland.

Scagliola, S.I.

2002

Last van de oorlog; De Nederlandse oorlogsmisdaden in Indonesie en hun verwerking. Amsterdam: Balans.

Schermerhorn, W.

$1970 \quad$ Het dagboek van Schermerhorn; Geheim verslag van prof.dr.ir. W. Schermerhorn als voorzitter der commissie-generaal voor Nederlands-Indië 20 september 1946-7 oktober 1947, uitgegeven door mr.dr. C. Smit. Groningen: Wolters-Noordhoff.

Schmidt, H.

1961 In de greep van Soekarno. Leiden: Sijthoff.

Scholtens, H.H.

2007 Rawahgedeh, 9 december 1947. Een nieuwe Nederlandse versie? Doctoraalscriptie, Rijksuniversiteit Groningen.

Schulte, J.W.M.

1987 'Soldaten, legerleiding en thuisfront; Een belangengemeenschap onder een ongelukkig gesternte', in: G. Teitler en P.M.H. Groen (red.), De poli-

Schulten, C.M. (red.)

tionele acties, pp. 29-43. Amsterdam: De Bataafsche Leeuw.

19861 Divisie '7 December'. Amsterdam: De Bataafsche Leeuw.

Schutte, G.J.

1974 De Nederlandse Patriotten en de koloniën; Een onderzoek naar hun denkbeelden en optreden. Groningen: Wolters.

Shiraishi, Takashi

1990 An age in motion; Popular radicalism in Java 1912-1916. Ithaca, NY: Cornell University Press.

Simatupang, T.B.

1985

Het laatste jaar van de Indonesische vrijheidsstrijd 1948-1949; Een authentiek verslag door de voormalige chef-staf van de Indonesische strijdkrachten. Kampen: Kok.

Siong, Han Bing zie Han Bing Siong

Sitorus, L.M.

1947 Sedjarah pergerakan kebangsaan Indonesia. Djakarta: Pustaka Rakjat.

Sjahrazad (pseudoniem voor Soetan Sjahrir)

1945 Indonesische overpeinzingen. Amsterdam: De Bezige Bij.

Sjahrir, Soetan

1945 Perdjoeangan kita. Djakarta: Pertjetakan Repoeblik Indonesia.

1946 Onze strijd. Amsterdam: Vrij Nederland. [Vertaling van vorige titel.] 

Smail, John R.W. aanvulling over belevenissen in 1941-42.]

$1964 \quad$ Bandung in the early revolution 1945-1946; A study in the social history of the Indonesian revolution. Ithaca, NY: Modern Indonesia Project, Cornell University.

Smit, C.

1952 De Indonesische quaestie; De wordingsgeschiedenis der soevereiniteitsoverdracht. Leiden: Brill.

1959 Het akkoord van Linggadjati; Uit het dagboek van prof.dr.ir. W. Schermerhorn. Amsterdam: Elsevier.

1962 De liquidatie van een imperium; Nederland en Indonesië 1945-1962. Amsterdam: De Arbeiderspers.

Snouck Hurgronje. C.

1923 'Vergeten jubilés', De Gids 1923:328-30. [Herdrukt in Fasseur 1980, deel II:61-77.]

Soedjatmoko

1988

'Choices and circumstances; The Indonesian revolution 45 years on; Some personal reflections', in: C.A. van Minnen (red.), The decolonization of Indonesia; International perspectives, pp. 9-22. Middelburg: Roosevelt Study Center.

Soekarno

1931

Indonesië klaagt aan! Pleitrede voor den landraad te Bandoeng op 2 december 1930 gehouden. Amsterdam: De Arbeiderspers.

Somer, J.M.

1934 De korte verklaring. Breda: KMA.

Somers, Jan A.

2001 De VOC als volkenrechtelijke actor. Gouda: Quint.

Stapel, F.W.

1930

Geschiedenis van Nederlandsch-Indië. Amsterdam: Meulenhoff.

1938-40 (red.) Geschiedenis van Nederlandsch-Indië; Deel 1: A. Praehistorie, B. De Hindoe-Javaansche tijd, C. De verbreiding van den Islam; Deel 2: A. Javaansche geschiedschrijving, B. Portugeezen en Spanjaarden, C. Franschen en Engelschen, D. De Nederlandse voorcompagnieën; Deel 3: De oprichting der Vereenigde Oostindische Compagnie, B. De Nederlandsche Oostindische Compagnie in de zeventiende eeuw; Deel 4: De Nederlandsche Oostindische Compagnie in de achttiende eeuw; Deel 5: A. De Bataafsche Republiek en de Fransche tijd; B. Het Engelsch tussenbestuur; C. Het Koninkrijk der Nederlanden. Amsterdam: Joost van den Vondel.

Stempels, A.

1950

De parlementaire geschiedenis van het Indonesische vraagstuk. Amsterdam:

De Arbeiderspers.

Steur, Jacob Johan

1984

Herstel of ondergang; De voorstellen tot redres van de Verenigde OostIndische Compagnie, 1740-1795. Utrecht: HES. 
Subardjo Djojoadisuryo, Ahmad

$1978 \quad$ Kesadaran nasional; Otobiografi. Jakarta: Gunung Agung.

Sumantri, Iwa Kusuma zie Kusuma Sumantri, Iwa

Swift, Ann

1989 The road to Madiun: The Indonesian communist uprising of 1948. Ithaca, NY: Modern Indonesia Project, Cornell University.

Tan Malaka

1948-50 Dari pendjara ke pendjara. Drie delen.

1991 From jail to jail. Athens Ohio: Center for International Studies Ohio University. Drie delen.

Tantri, K'tut (pseud. van Muriel Pearson)

1960 Revolt in paradise. London: Heinemann.

Taselaar, Arjen

1998 De Nederlandse koloniale lobby; Ondernemers en de Indische politiek. Leiden: CNWS.

Taylor, Alastair M.

$1960 \quad$ Indonesian independence and the United Nations. London: Stevens.

Tichelman, F. (red.)

1985 Socialisme in Indonesië; De Indische Sociaal-Democratische Vereeniging 1897-1917. Dordrecht: Foris.

Tirtoprodjo, Susanto

1962a Sedjarah pergerakan nasional Indonesia. Djakarta: Pembangunan.

1962b Sedjarah revolusi nasional Indonesia: Tahapan revolusi bersendjata 19451950. Djakarta: Pembangunan.

Tollenaere, Herman Arij Oscar de

1996 The politics of divine wisdom; Theosophy and labour, national, and women's movements in Indonesia and South Asia, 1875-1947. Proefschrift Katholieke Universiteit Nijmegen.

Touwen-Bouwsma, Elly

1992 'De Indonesische nationalisten en de oorlog met Japan; Houding en reacties', in: P. Groen en E. Touwen-Bouwsma (red.), Nederlands-Indië 1942; Illusie en ontgoocheling, pp. 57-74. Den Haag: SDU.

1996

'De opvang van de burgergeïnterneerden op Java en Sumatra (15 augustus 1945-15 april 1946)', in: Elly Touwen-Bouwsma en Petra Groen (red.), Tussen banzai en bersiap, pp. 25-42. Den Haag: SDU.

Touwen-Bouwsma, Elly en Petra Groen

1996 (red.) Tussen Banzai en Bersiap; De afwikkeling van de Tweede Wereldoorlog in Nederlands-Indië. Den Haag: SDU.

Treub, M.W.F.

$1923 \quad$ Nederland in de oost. Haarlem: Tjeenk Willink.

1927 Het gist in Indië; Een analyse der hedendaagsche inlandsche beweging. Haarlem: Tjeenk Willink.

Trimurti, S.K.

1993

'Dari politik ke kebatinan', in: Memoar, tweede deel, pp. 201-38. Jakarta: Pustaka Utama Grafiti.

Tsuchiya, Kenji

1987 Democracy and leadership; The rise of the Taman Siswa movement in Indonesia. Honolulu: University of Hawaii Press. 
Valentijn, François

1724-26 Oud en nieuw Oost-Indiën, vervattende een naaukeurige en uitvoerige verhandelinge van Nederlands mogentheyd in die gewesten. Dordrecht. Vijf delen. [In 2002 heruitgegeven te Franeker: Van Wijnen.]

Van der Post, Laurens

1996 The Admiral's baby. London: Murray.

Van Niel, Robert

1960 The emergence of the modern Indonesian elite. 's-Gravenhage/Bandung: Van Hoeve.

Vanvugt, Ewald

$1985 \quad$ Wettig opium; 350 jaar Nederlandse opiumhandel in de Indische archipel. Haarlem: In de Knipscheer.

1996 Nestbevuilers; 400 jaar Nederlandse critici van het koloniale bewind in de Oost en de West. Amsterdam: Babylon-De Geus.

VARA

1969

Nederlandsch Indië 1945; Indonesië 1949; Achter het Nieuws 1969. Hilversum: VARA. [Volledige tekst van drie uitzendingen van de televisierubriek 'Achter het Nieuws' over gebeurtenissen tijdens de politionele acties in Nederlands-Indië.]

Veer, Paul van 't

1958 Geen blad voor de mond; Vijf radicalen uit de negentiende eeuw. Amsterdam: De Arbeiderspers.

1969 De Atjeh-oorlog. Amsterdam: De Arbeiderspers.

Velden, D. van

1963 De Japanse interneringskampen voor burgers gedurende de Tweede Wereldoorlog. Groningen: Wolters.

Verhoog, A.

1982

Onze laatste oorlog; De voorgeschiedenis van en de strijd om de onafhankelijkheid van Indonesie. Utrecht/Antwerpen: Het Spectrum.

Vermeulen, Johannes Theodorus

1938 De Chineezen te Batavia en de troebelen van 1740. Leiden: IJdo.

Verwijnen, J.J.

1902

'Eene bladzijde uit de geschiedenis der vestiging van het Nederlandsch gezag in de Ambonsche kwartieren', in: M. Greshoff (red.), Rumphius gedenkboek 1702-1902. Haarlem: Koloniaal Museum.

Veur, Paul W. van der

1987 (red.) Toward a glorious Indonesia; Reminiscences and observations of Dr. Soetomo. Athens, Ohio: Center for International Studies Ohio University.

2006 The lion and the gadfly; Dutch colonialism and the spirit of E.F.E. Douwes Dekker. Leiden: KITLV Press. [Verhandelingen 228.]

Vlekke, Bernhard H.M.

1947 Geschiedenis van den Indischen archipel, van het begin der beschaving tot het doorbreken der nationale revolutie. Roermond-Maaseik: Romen.

Vredenburch, H.F.L.K. van

1985 Den Haag antwoordt niet. Leiden: Nijhoff. 
Vught, Nell van

1982 De dekolonisatie van Nederlandsch-Indië resp. de Indonesische onafhankelijkheidsstrijd in de Westerse historiografie. Doctoraalscriptie, Katholieke Universiteit Nijmegen.

Wal, S.L. van der (red.)

1964-65 De Volksraad en de staatkundige ontwikkeling van Nederlands-Indië. Groningen: Wolters. [Twee delen, betreffende 1891-1942.]

1967 De opkomst van de nationalistische beweging in Nederlands-Indië. Groningen: Wolters.

1968 Herinneringen van jhr.mr. B.C. de Jonge. Groningen: Wolters.

Wallace, Alfred Russel

1869 The Malay archipelago; The land of the orang-utan and the bird of paradise. London: Macmillan. Twee delen.

Weerzien met Indie

1994-6 Weerzien met Indië. Zwolle: Waanders. [Verzamelwerk over de historie, cultuur en natuur van Nederlands-Indië en Indonesië, in 52 afleverin-

Wehl, David

$1948 \quad$ The birth of Indonesia. London: Allen and Unwin.

Wekker (pseudoniem)

$1907 \quad H o e$ beschaafd Nederland in de twintigste eeuw vrede en orde schept op Atjeh.

's-Gravenhage: Avondpostdrukkerij.

Wiselius, J.A.B.

1872 'Djajabaja, zijn leven en profetie', Bijdragen tot de Taal-, Land-en Volkenkunde 19:172-217.

Wolf, Charles Jr.

$1948 \quad$ The Indonesian story; The birth, growth and structure of the Indonesian republic. New York: John Day.

Yamin, Muhammad (red.)

1959 Naskah persiapan Undang-undang dasar 1945. Deel I. Djakarta: Prapantja.

Yong Mun Cheong

1982 H.J. van Mook and Indonesian independence; A study of his role in DutchIndonesian relations 1945-48. The Hague: Nijhoff.

IJzereef, Willem

1984 De Zuid-Celebes affaire; Kapitein Westerling en de standrechtelijke executies.

Dieren: De Bataafsche Leeuw.

Zorab, A.A.

1954 De Japanse bezetting van Indonesië en haar volkenrechtelijke zijde. Leiden: Universitaire Pers.

Zwaan, Jacob

1980

Nederlands-Indië 1940-1946; Deel I: Gouvernementeel intermezzo 19401942. Den Haag: Omniboek.

$1981 \quad$ Nederlands-Indië 1940-1946; Deel II: Japans intermezzo 9 maart 1942-15 augustus 1945. Den Haag: Omniboek. 
1985

Nederlands-Indië 1940-1946; Deel III: Geallieerd intermezzo 15 augustus 1945-30 november 1946. Amsterdam/Dieren: De Bataafsche Leeuw.

Zwart, Henny

1995

Er waren er die niet gingen; Vijftien eeuwen straf voor Indonesië-weigeraars. Amsterdam: Solidariteit. 


\section{Register van personen}

Voorzover Indonesiërs na de in 1948/1949 ingevoerde spellingswijziging de oe-klank in hun naam met de letter -u- zijn gaan weergeven, is in dit register in het algemeen de eerdere spelling aangehouden. Namen van Japanners zijn in dit register in Engelse transcriptie weergegeven, onder toevoeging van een Nederlandse transcriptie waar daartoe aanleiding is.

Abdoelgani zie Roeslan Abdoelgani Abdoelkadir Widjojoatmodjo (1904-1992) 299, 323, 385-6, 392, 408, 431, 540, 559, $563,583,599,630$

Abdoh, Djalal 755

Abendanon, J.H. (1852-1925) 155, 157, 164,174

Abikoesno Tjokrosoejoso (1897-1968) 231, 240, 253, 259, 281, 284, 291, 298, $314,326,376,426,446,595,654$

Ageng, sultan (1631-1692) 42-3

Agoeng, sultan (1591-1645) 32-3, 41-2

Aidit, D.N. (1923-1965) 717

Albuquerque, Alfonso d' (1453-1515) 15-6

Ali Sastroamidjojo (1903-1976) 268, 272, $578,606,640,654,718,722,724-5,728$, 730

Alimin Prawirodirdjo (1889-1964) 198-9, 201, 594, 596

Alkadrie zie Hamid II

Amir Sjarifoeddin (1907-1948) 206, 219, 225, 230, 233, 240, 264, 272, 291, 305, $323,327,375-7,409,416,422,425-6$, $428,435,444,458,461-2,469,477,481$, $498,520,522,547,550-2,560,562,569-$ 72, 594-7, 605

Anak Agoeng Gde Agoeng, Ide (1921-
2002) 513, 576, 583-4, 602, 610, 631, 633, 635, 641, 645, 647, 646, 661, 664, $666,668,670-3,695-6,715,719,723$, 742

Aponno, F.A. (1907-1983) 708

Aroeng Palaka (1634-1696) 41-2

Asbeck, F.M. van (1889-1968) 212

Assaat (1904-1976) 606, 672, 715

Attlee, C. (1883-1967) 389, 434, 527

Aung San (1915-1947) 278, 373, 390, 405, 526, 577

Aziz, Andi Abdul 696-7, 700, 757

Bagoes Hadikoesoemo (1890-1954) 310, 345

Barentsz, Willem (1555-1597) 23

Bastian, A. (1826-1905) 105

Baud, J.C. (1789-1859) 85-6, 89-90, 92, 107, 148

Beel, L.J.M. (1902-1977) xix, 357, 394, 434, 463-4, 471-2, 477, 507, 529, 535$41,547-8,552,554-5,558,564,573$, $581,585-7,598-603,609,629-31,633-6$, 638-9

Beerling, R.F. (1905-1979) 563

Beureuh, Daud (1906-1987) 725, 742

Bevin, E. (1881-1951) 434, 440

Boeng Tomo zie Soetomo 
Boer, F. de (1892-1976) 471, 473, 509, 524

Bonay, E. 755

Bosch, J. van den (1780-1844) 84-7, 91

Bosscha, K.A.R. (1865-1928) 143, 171

Both, Pieter $( \pm 1550-1615)$ 26, 65

Bouman, H.A. (1909-1968) 726-7

Bouman-van den Berg, M.S. (Mieke) (1907-1966) 727-9

Brooke, James (1803-1868) 89

Brooshooft, P. (1845-1921) 116

Bruins Slot, J.A.H.J.S. (1906-1972) 549, 759

Bunker, E. (1894-1984) 751-3

Burhanuddin zie Harahap

Buskes, J.J. (1899-1980) 441

Buurman van Vreeden, D.C. (1902-1964) 266, 437-8, 456, 481, 518, 520, 640, 648-9

Bywater, Hector (1884-1940) 213

Camphuys, J. (1634-1695) 52, 104

Capellen, G.A.G.Ph. van der (1778-1848) 74-6, 81

Carpentier Alting, J.H. (1864-1929) 1734, 186, 190, 208, 241, 244, 407, 410

Chairoel Saleh (Chaerul Saleh) (19161968) 307, 333-4, 348-9, 359, 377, 381, $446,692,716-7,732,756$

Chasteleyn, Cornelis (1657-1714) 52

Christison, Ph. (1893-1993) 389-91, 393, 397-8, 400, 402, 405, 409, 412, 416-7, $429,435-7,447$

Chroesjtsjov, N.S. (1894-1971) 743

Churchill, W. (1874-1965) 256, 261, 301, 326, 370, 389

Clark Kerr, A.J. (1882-1951) 439, 449, 451-2, 459

Cochran, H.M. (1892-1973) 593-4, 599$601,603,625,638,656,716$

Coen, Jan Pieterszoon (1587-1629) 31-6, 43,65

Colijn, H. (1869-1944) 178-9, 193, 208-9, 211, 223-4, 236-7, 259, 367, 442, 453

Cramer, Ch.G. (1879-1976) 171-2, 236-7, 395

Critchley, T.K. (1916) 578, 580-1, 583, 593-4

Daalen, G.C.E. van (1863-1930) 119-20
Daendels, H.W. (1762-1818) 62, 71-7, 81

Darsono (1897-1971) 167, 186, 188, 199

Darwin, Charles (1809-1882) 105, 107

Dening, M. (1897-1977) 407, 423

Deventer, C.Th. van (1857-1915) 115-6

Dewantoro, Ki Hadjar zie Soewardi Soerjaningrat

Diah, B.M. (1917-1996) 333-4, 349, 377, 382

Diponegoro, prins (1785-1855) 80-3, 89, 193

Djajadiningrat, Achmad (1877-1943) 190, 208

Djajadiningrat, Hilman 574

Djajadiningrat, Hoesein (1886-1960) 174, 239, 243, 246, 298, 309, 314, 330, 409,

Djajadiningrat, Loekman (1891-1944) 243, 266, 299

Djojobojo, koning (regeerde van 1135 tot 1160) 9, 56

Djuanda Kartawidjaja, R.H. (1911-1963) 732, 735-6, 738-40, 758

Doel, H.W. van den (1962) xxii

Doorman, Karel W.F.M. (1889-1942) 2623, 759

Douwes Dekker, E. (Multatuli) (18201887) 93-5, 113-4, 159

Douwes Dekker, E.F.E. (Setiaboedi) (1879-1950) 159-61, 163, 165, 180-1, 184-5, 197-8, 253, 259, 270, 478

Drees, W. (1886-1988) 368, 391, 395, 452, 454, 464, 547, 551, 558, 564, 584-5, 587, $592,598,600,602-3,606-7,629,631$, 633, 654, 658-9, 662-3, 672, 705, 707, 721, 733-4, 744, 746

DuBois, C. (1881-1960) 578, 580-1, 584, 593-4

Dubois, E. (1858-1940) 107

Duynstee, F.J.F.M. (1914-1981) 681, 748

Effendi, Roestam zie Roestam Effendi

Eisenhower, D.D. (1890-1969) 338, 731, 750

Erlangga (Airlangga), koning (regeerde van 1019 tot 1049) 7

Fatmawati (1923-1980) 306

Feuilletau de Bruyn, W.K.H. (1886-1972) 
$442,510,584-5,658,662$

Fock, D. (1858-1941) 177, 179, 183, 185, 203, 208

Gadjah Mada († 1364) 9

Gama, Vasco da (1469-1524) 15

Gandhi, Mohandas K. (Mahatma) (18691948) 182-3, 216, 219-21, 232, 364, 373, 526

Gani, A.K. (1905-1968) 230, 378, 478, 481, 511, 524, 550-2, 556

Gerbrandy, P.S. (1885-1961) 259, 299, 301, 336, 367-8, 510, 536, 549, 584, 658, 703

Gerretson, F.C. (1884-1958) 179, 192-3, 218, 441-2, 658, 681

Goedhart, F.J. (1904-1990) 721

Goes van Naters, M. van der (1900-2005) 509, 602

Graeff, A.C.D. de (1872-1957) 203-4, 207, 209, 212, 215-6, 218

Graham, F.P. (1886-1972) 561, 566, 578, 593

Groot, Hugo de (1583-1645) 28

Hadikoesoemo, Bagoes zie Bagoes Hadikoesoemo

Hagen, Steven van der (1563-1624) 26-7, 35

Hajam Woeroek, koning (1334-1389) 9

Hamengkoe Boewono IX, sultan (19121988) 428, 436, 478, 570, 641, 670-1, 715-8

Hamid II Alkadrie, sultan (1913-1978) 454, 466, 534, 583-4, 602, 609-10, 635, $641,654,671-2,695,742,756$

Harada, K. (1888-1947) 299, 309, 312, $323,326,328,332$

Harahap, Burhanuddin (1917-1987) 719, 723-4, 728, 738, 742

Hasanoedin, sultan († 1670) 40-1

Hasjim, Wahid zie Wahid Hasjim

Hassan, T.M. 378, 397

Hatta, Mohammad (1902-1980)

- afkomst en opleiding 194

Hazeu, G.A.J. (1870-1929) 155, 177, 190, 198

Heemskerk, Jacob van (1567-1607) 23,
26,35

Helfrich, C.E.L. (1886-1962) 262-4, 321, 405-6, 419-21, 437, 509-10, 657-8

Helsdingen, W.H. van (1888-1985) 234

Herremans, R. 578, 580

Heutsz, J.B. van (1851-1924) 118-21, 124, 131, 144, 157, 169, 178, 194

Heuven Goedhart, G.J. van (1901-1965) 441, 474, 549, 555

Heijden, K. van der (1826-1900) 99

Hinloopen Labberton, D. van (18741961) 159, 169, 171

Hirohito, keizer (1901-1989) 310

Hirschfeld, H.M. (1899-1961) 672, 689, 692, 702, 704

Ho Chi Minh ( \pm 1890-1969) 373, 450-1, 525-6, 595

Hoëvell, W.R. van (1812-1879) 92-3, 103, 114-5, 148

Hogendorp, Dirk van (1761-1822) 69-70, 147

Houtman, Cornelis de (1550-1599) 23-4

Houtman, Frederik de (1554-1627) 24-5, 27,50

Idenburg, A.W.F. (1861-1935) 157, 161, 164, 170, 268

Idenburg, P.J.A. (1896-1976) 409, 431, $546,557,563$

Imam Bondjol zie Peto Sarif

Imamura, H. (Imamoera) (1886-1968) 265, 267-8, 286, 294-5, 297, 299

Imhoff, G.W. van (1705-1750) 57-8

Iskandar Dinata, Oto (1897-1945) 216, $235,305,326,345,374,376,402$

Iskandar Moeda, sultan (1590-1636) 40

Iwa Koesoema Soemantri (1899-1971) 239, 274, 359, 376, 384, 426, 461-2, 490, $572,595,718-9$

s'Jacob, H.L. (1906-1967) 650-1, 670

Jager, Herbert de (1636-1694) 50, 52

Jinnah, M.A. (1876-1948) 526

Jong, J.J.P. de (1941) xxii

Jong, L. de (1914-2005) xxi-i

Jonge, B.C. de (1875-1958) 218, 220-1, 224, 236

Jonkman, J.A. (1891-1976) xvi, 176, 203, 
208, 211-2, 234, 240, 244, 255, 295, 4645, 467, 482-4, 508, 514, 521, 524, 535, 538-41, 551, 564, 585, 587, 599, 615, $647,653-4,660,662$

Josselin de Jong, J.P.B. de (1886-1964) 441

Juliana, koningin (1909-2004) 223, 582, $658,672,706,729,744$

Junghuhn, F.W. (1809-1864) 105

Jungschläger, L.N.H. (1904-1956) 726-9, 733, 736

Kadt, J. de (1897-1988) 395, 422, 441, 489, 563, 604, 721

Kahin, G.M. (1918-2000) xx

Kartini (1879-1904) 157

Kartosoewirjo, S.M. (1905-1962) 231, 273, 572, 627, 692, 724, 727, 742

Kasimo, I.J. (1900-1986) 229, 235, 250, $305,375,425,570,605$

Kawilarang, A.E. (1920-2000) 742

Ken Angrok, koning (13e eeuw) 9

Kennedy, J.F. (1917-1963) 750-1, 753

Kennedy, R.F. (1925-1968) 751

Kern, J.H.C. (1833-1917) 107

Ketoet Poedja 378, 466

Kiai Modjo zie Modjo, kiai

Killearn, M.W.L. (1880-1964) 474, 478-81, 484

Kirby, R.C. (1904-2000) 561, 578

Kleffens, E.N. van (1894-1983) 245, 3401, 391, 440, 507, 555, 558, 602

Koch, D.M.G. (1881-1960) 240, 244

Kock, H.M. de (1779-1845) 82, 83

Koesoema Soemantri, Iwa zie Iwa Koesoema Soemantri

Koesoemo Joedo, prins (1882-1955) 131, 171, 208

Koesoemo Oetojo (1871-1953) 216, 2345, 309

Koets, P.J. (1901-1995) 212, 244, 466, 479, 546, 635

Koiso, K. (1880-1950) 325-7, 331-2

Kol, H.H. van (1852-1925) 115-7

Kruls, H.J. (1902-1975) 509

Kuyper, A. (1837-1920) 112, 115-6, 178

Lamping, A.Th. (1893-1970) 704, 721
Latuharhary, J. (1900-1959) 345, 378

Lawson, J.J. 389-90, 393, 398

Lieftinck, P. (1902-1989) 434, 465, 482

Leimena, J. (1905-1977) 425, 446, 551, $570,592,640,654,698-9$

Limburg Stirum, J.P. van (1873-1948) $170-3,177,179,203,270$

Linschoten, Jan Huyghen van (15631611) 21,23

Lodewijk Napoleon, koning (1778-1846) 71

Logan, J.R. († 1869) 105

Logemann, J.H.A. (1892-1969) 212, 338, 368-9, 390, 392-4, 403, 407-9, 430, 4334, 439, 442-3, 449, 452, 454-6, 464, 654

Lovink, A.H.J. (1902-1999) 264, 266, 639, 648-50, 672

Luns, J.M.A.H. (1911-2002) 721, 723, 733-4, 743-5, 747-50, 752

Maarseveen, J.H. van (1894-1951) 634, 640, 648, 653-4, 662-4, 680, 706-7, 757

MacArthur, D. (1880-1964) 233, 261, 278, $321-3,337,339-40,370,525,542$

Maeda, T. (1898-1977) 289, 327, 333, 3479, 397

Magelhaes, Fernando de (1480-1521) 16

Malik, Adam (1917-1984) 333-4, 377, 381, 383, 427, 462, 751-3

Mallaby, A.W.S. (1899-1945) 415-6

Mangoenkoesoemo, Tjipto zie Tjipto Mangoenkoesoemo

Mansoer, kiai (1896-1946) 280, 297-8, 305, 308, 310, 316

Mansoer, Tengkoe (1897-1955) 574, 583, 701

Manuhutu, J.H. 698-9

Manusama, J.A. (1910-1995) 698, 705

Mao Tse-Tung (1893-1976) 595

Maramis, A.A. (1897-1977) 376

Matoelesia, Thomas (1783-1817) 78, 698

Maurits, prins (1567-1625) 25

Meyer Ranneft, J.W. (1887-1968) 208, 242, 442, 510, 658, 662

Miyoshi, S. (Mijosji) 289

Modjo, kiai ( $\pm 1792-1849)$ 82-3

Moeis, Abdoel (1890-1959) 164, 169, 171, $180,186-9$ 
Moelia, T.S.G. (1896-1966) 229, 240, 244, 251-2, 291, 298, 426

Moeso (1897-1948) 198-9, 201-2, 594-7, 676, 714

Monginsidi, W. (1925-1949) 516-7, 519, 650

Mook, H.J. van (1894-1965)

- afkomst en opleiding 271

Mountbatten, L. (1900-1979) 321-2, 340, 370-2, 379, 386, 389-91, 397-8, 405-6, 408, 410, 412, 416, 418, 430, 447, 450, 458-9

Multatuli zie E. Douwes Dekker

Mussert, A.A. (1894-1946) 366, 409, 510

Muzakkar, Kahar (1919-1965) 725, 742

Nadjamoeddin Daeng Malewa 466-7, 512-3, 576

Nagano, J. 332, 361, 380-4, 386

Napoleon, keizer (1769-1821) 71-3

Nasoetion, A.H. (1918-2000) 469, 570, $590,605,625,630,717-9,736,738-41$, 743, 748-9

Nasser, G.A. (1918-1970) 719

Natsir, M. (1908-1993) 444, 446, 478, 570, 592, 701, 704-5, 707, 715-7, 720, 738, 742

Neck, Jacob van (1564-1638) 24, 26

Nederburgh, S.C. (1762-1811) 61, 69

Neher, L. (1889-1967) 538, 564, 587, 602

Nehru, Jawaharlal (1889-1964) 195, 373, 430, 474, 526-7, 534, 556, 606-7, 719

Nishijima, S. (Nisjidjima) 289, 327, 348-9

Noor, Tadjoeddin zie Tadjoeddin Noor

Noort, Olivier van (1558-1627) 24

Noto Soeroto (1888-1951) 175, 194

Oerip Soemohardjo (1893-1948) 404, 520, 570, 671

Oldenbarnevelt, Johan van (1547-1619) 21,25

Oltmans, W. (1925-2004) 735, 748

Oyen, L.H. van (1889-1953) 321, 419-21, 437

Palar, L.N. (1900-1981) 497, 555, 562, 605

Pamontjak, M.N. 272, 497

Pati Oenoes, prins († 1521) 15
Patterson, W.R. (1893-1954) 384-6, 405

Pattimoera zie Matoelesia

Peekema, W.G. (1899-1967) 303

Peto Sarif (Imam Bondjol) (1772-1864) 89

Pinke, A.S. (1894-1966) 437, 519-20, 558, 561,657

Plas, Ch.O. van der (1891-1977) 212, 244, 264, 266, 299, 321, 324, 326, 337, 339, 344, 367-8, 372, 384-6, 389-94, 405, 407, $409,431,437,494,574$

Poedja zie Ketoet Poedja

Poeradiredja, Adil 575, 583-4

Poetiray, E. (1918) 441

Poll, M.J.M. van (1881-1948) 443, 454-5, $471,481,508,524,532,543,546,552$, 555,558

Polo, Marco (1254-1323) 14

Poorten, H. ter (1887-1968) 262-3, 266-7, 276-7

Pordenone, Oderico de (1286-1331) 14

Post, L. van der zie Van der Post, L.

Prawiradirdjo (Sentot) (1808-1854) 82-3, 89,93

Prawiranegara, Sjafroeddin zie Sjafroeddin Prawiranegara

Princen, J.C. (Poncke) (1925-2002) 625, 758

Pringgodigdo, A.K. (1906-1961) 452, 454, 606

Quay, J.E. de (1901-1985) 744, 746-8

Quezon, M.L. (1878-1944) 233-4, 525

Quisling, V. (1887-1945) 366

Radjiman Wedioningrat (1879-1952) 331, 341, 344-5

Raffles, Thomas Stamford (1781-1826) 72-7, 80-1, 103-4

Randwijk, H. van (1909-1966) 441, 474, 554

Ratoelangie, G.S.S.J. (1890-1949) xvi, xx, 175-6, 229, 235, 240-1, 244, 253, 271, $305,310,345,378,457,466,512,514$, $516,578,604,647$

Razak, N. 726-7

Reael, Laurens (1583-1637) 31, 35-6

Reinwardt, C.G.C. (1773-1854) 105 
Resink, G.J. (1911-1997) 563

Rikhye, I.J. (1920-2007) 755

Ringers, J.A. (1885-1965) 482, 538

Rivai, Abdoel (1871-1933) 154, 159, 171, 198, 270

Rizal, José (1861-1896) 158

Roem, Mohammad (1908-1983) xix, 231, $478,481,484,511,524,578,580-1,606$, 622, 636, 638-42, 645, 647, 650, 654, 663, 670-2, 691, 704, 707, 715-6, 742

Roeslan Abdoelgani (1914-2005) 334, 733

Roestam Effendi (1905-1979) 223, 409, 497

Romme, C.P.M. (1896-1980) 453, 463-5, 508-9, 529, 537, 599, 602, 636, 653-4, $664,720-1$

Roorda van Eysinga, S.E.W. (1825-1887) 93, 135

Roosevelt, F.D. (1882-1945) 256, 261, 245, 278, 301-2, 321, 326

Roijen, J.H. van (1905-1991) xix, 391, $434,452,605-7,622,631,636,638-43$, $645,647-8,650,653-4,663-4,691,751$, 753

Rumphius, G. (1628-1702) 50, 52

Rijkens, P.C. (1888-1965) 720, 722, 734-5, 748

Saleh, Chairoel zie Chairoel Saleh

Salim, Agoes (1884-1954) xvi, xx, 180, 186-8, 198, 206, 216, 231, 236, 305, 377, 409-10, 446, 477, 534, 548, 550-1, 556, $570,592,606,610,631,643$

Sanders, P. (1912) 555

Sartono (1900-1968) xx, 204, 207, 215, $217,219,230,236,297,326,426,714$

Sassen, E.M.J.A. (1911-1995) 585, 592-3, 598-2, 609-10, 628-9, 634

Sastroamidjojo, Ali zie Ali Sastroamidjojo

Schermerhorn, W. (1894-1977) 356-8, 368-70, 388, 391-4, 407, 410, 419, 434, 442-3, 452-6, 460, 463-5, 471, 476, 4789, 481, 483-4, 521-4, 532, 535, 537, 541, $543,546,551-2,555,558,562,664,709-$ 10,737

Schilling, W. (1890-1958) 266, 397, 401,
420, 431, 437, 455

Schmidt, H.C.J.G. 726-9, 758

Schmutzer, J.I.J.M. (1882-1946) 338

Semaoen (1899-1971) 166-7, 172, 186-8, 195, 198-9, 271

Senopati († 1601) 11, 42

Sentot zie Prawiradirdjo

Setiaboedi zie E.F.E. Douwes Dekker

Setiadjit (1907-1948) 368, 441, 454, 478, 497, 550-1, 569

Siliwangi, koning (14e eeuw) 9, 469

Simatoepang, T.B. (1920-1990) 630, 643, 654, 717-8

Sjafroeddin Prawiranegara (1911-1989) $x x, 446,478,570,604,630,636,640$, $642,715,738,742$

Sjahrir (1909-1966) xix, xx, 195, 217, 219, 227, 239, 250, 261, 272, 297, 306, 327, 329, 333-4, 344-5, 347, 356-7, 375, 377, $384,395,421-30,432-6,439,441-6,449-$ 51, 453, 458-62, 469-70, 473-4, 477-81, 483-4, 500, 522-4, 532-5, 539, 545, 549$50,554,556-7,572,606,665,668,714$, $716,718,742$

Sjarifoeddin, Amir zie Amir Sjarifoeddin

Slotemaker de Bruïne, G.H. (1899-1976) 441

Smit, C. (1899-1991) xx

Sneevliet, H.J.F.M. (1888-1942) 165-7, 181, 186, 215, 223

Snouck Hurgronje, C. (1857-1936) 107, $117-9,121-2,131,174,190,192$

Soebandrio (1914-2004) 747, 749, 753

Soebardjo, Achmad (1896-1978) 280, $289,327,333,345,348,359,376,384$, $409,426,461-2,572,595,716$

Soedarsono (generaal-majoor) 461-2, 572,595

Soedarsono (minister) (1911-1976) 452

Soedirman (1912-1950) 428, 445, 461-2, 470, 480-1, 520-1, 523-4, 570, 603, 605, $628,630,636,640,642,646,649,756$

Soeharto (1921-2008) 628, 751, 759

Soejono (1886-1943) 243, 252, 266, 299, 301-3

Soekarni (1916-1971) 273, 307, 333-4, 348-9, 359, 381, 383, 427, 446, 595

Soekarno (1901-1970) 
- afkomst en opleiding 198

Soekawati, T.G.R. (1899-1979) 216, 237, 251, 466, 512-3, 576, 696-7, 701

Soekiman Wirjosandjojo (1898-1974) xx, 206, 231, 305, 425, 569, 605, 630, 654, $715-7,720$

Soepomo (1903-1958) 252, 289, 298, 309, 326, 330, 341-2, 376, 607, 654, 701, 720

Soepratman, W.R. (1903-1938) 207

Soeriadarma, S. (1912-1975) 606

Soeripno (1920-1948) 580, 595, 605

Soeropati (1660-1706) 55

Soetardjo Kartohadikoesoemo (18901976) 216, 234-9, 241, 251, 255-6, 305, $309,345,375,673$

Soetomo (dokter) (1888-1938) 159, 176, 197, 203, 206, 216-7, 219-20, 229-30, 239, 253, 270, 384

Soetomo (Boeng Tomo) (1920-1981) 417, 470, 511, 706, 720

Soewandi (1899-1964) 452-3

Soewardi Soerjaningrat (Ki Hadjar Dewantoro) (1889-1959) xvi, xx, 159, 161-4, 175-6, 181, 183-5, 217, 220-1, 244-5, 270, 273, 280, 297-8, 305, 308, $326,359,376,426,604,673$

Soumokil, C. (1905-1966) 696-8, 705, 742

Speelman, Cornelis (1628-1684) 41-3

Spit, H.J. (1886-1967) 294, 380-1, 399

Spoor, S.H. (1902-1949) xix, 266, 325, 393, 421, 437-8, 454-5, 513, 518, 523, 529-30, 537, 539, 541-2, 551-3, 555, 558, $564-5,570,587-8,599,601,603,612$, $626,629-30,636-40,700$

Stikker, D.U. (1897-1979) 585, 594, 599, 601-2, 610, 628, 654, 707, 721

Sumual, H.N. Ventje (1923) 732, 742

Tabrani, Mohammad (1904-1984) 207

Tadjoeddin Noor 311, 512-4, 516, 518, 575

Tagore, Rabindranath (1861-1941) 157, 182, 185

Tahija, J.W. (1916-2002) 454, 513, 700

Tan Malaka, Ibrahim (1897-1949) 184-5, 188, 195, 198-202, 329, 333, 342, 383-4, 427, 444-6, 458, 461-2, 572, 595-7, 627, $640,692,714$
Tantri, K'tut (pseudoniem van Muriel Pearson) (1899-1997) 418

Tasman, Abel (1602-1659) 50

Terauchi, H. (Teraoetsji) (1879-1946) 297, 310, 344-5, 372

Teukoe Oemar (1854-1899) 117-8, 403

Thamrin, M.H. (1894-1941) 153, 203, 216-20, 225, 228-9, 233, 235, 240-1, 2445, 251-3, 272, 384

Tjarda van Starkenborgh Stachouwer, A.W.L. (1888-1978) 236, 238, 245, 250, 253, 255-9, 261, 263-4, 266-7, 292, 3934, 407, 409

Tjipto Mangoenkoesoemo (1886-1943) 159, 161, 163, 166, 171, 180-3, 198, 203, 205, 213, 225, 236, 239, 245, 250, 270, 274, 384

Tjoet Nja Din (1850-1908) 119-20

Tjokroaminoto, Oemar Said (1882-1934) 163-5, 171-2, 180, 186-8, 197-8, 203, 205-6, 228, 231, 236

Tojo, H. (Toodjo) (1884-1948) 308-10, 312, 325

Treub, M.W.F. (1858-1931) 179, 190, 192, 211

Trimoerti (1912-2009) 273

Trip, L.J.A. (1876-1947) 208-9

Troenodjojo, prins (1640-1680) 42

Truman, H.S. (1884-1972) 370

U Thant (1909-1974) 751, 753-5

Uyl, J.M. den (1919-1987) 555, 563

Van der Post, L. (1906-1996) 276, 380-1, 385-6, 389

Van Zeeland, P. (1893-1973) 561, 578

Verdoorn, J.A. (1903-1991) 441

Veth, P.J. (1814-1895) 105

Victoria, koningin (1819-1901) 110

Visman, F.H. 252

Vlekke, B.H.M. (1899-1970) xix

Vollenhoven, C. van (1874-1933) 107, 190

Vredenburch, H.F.L.K. van (1905-1981) 563,581

Wahid Hasjim, kiai (1914-1953) 314, 330, 345 
Wallace, A.R. (1823-1913) 105, 107

Wavell, A. (1883-1950) 262-3

Wehl, D. $x x$

Welles, S. (1892-1961) 301

Welter, Ch.J.I.M. (1880-1972) 208, 237-9, 242, 245, 254, 259, 442-3, 464-5, 510, $537,584-5,658,662,669,680$

Westerling, R.P.P. (1919-1987) 517-8, 691-5, 697, 725, 756

Wikana (1914-1965) 273, 327, 333-4, 3478, 359, 381, 444, 446, 596

Wilhelmina, koningin (1880-1962) 112, 114, 169, 171, 238-9, 244-5, 255, 299, 302-3, 364, 366, 368-9, 388, 410, 466, $473,475,509,557,582,617$

Willem I, koning (1772-1843) 74, 76, 84, 86-7

Willem III, koning (1817-1890) 93, 112
Willem IV, prins (1711-1751) 59

Willem V, prins (1748-1806) 62, 74

Willem van Oranje (de Zwijger), prins (1533-1584) 21, 25

Wilopo (1908-1981) 716-8, 722

Winkelman, H.G. (1876-1952) 510, 658

Wiranatakoesoema (1888-1965) 216, 221, 229, 234, 359, 375-6, 459, 575, 694

Wiwoho Poerbohadidjojo 250-2

Wongsonegoro (1897-1978) 384

Yamamoto, M. (Jamamoto) 360, 380, 384 Yamin, Muhammad (1903-1962) xx, 2067, 219, 230, 233, 245, 297, 309, 326, 333, $341,377,446,462,572,595,654,706$, $716,718,720$

Zeeland, P. Van zie Van Zeeland, P. 


\section{Register van zaken}

aardolie 101, 246, 262, 317, 319, 431, 530 ABDA Command 261-3

AMACAB 407, 457-8, 489

Ambarawa 379, 411-3, 428

Ambon 2, 13-4, 16-7, 19, 24, 26-8, 31, 33, 35-8, 47-8, 50-2, 78-9, 83, 93, 108, 140, 143, 202, 262, 277, 293, 378, 542, 657, 660, 686, 695, 697-700, 703-6, 708-9, $725,738,743,749$

Ambonezen 17, 27-8, 89, 378, 388, 397, 400, 402, 411, 413, 415, 423, 435-6, 468, $515,517,656-7,659,686,691,696-8$, 700, 703-5, 708-9

Angkatan Pemoeda Indonesia (API) 381, 444

Angkatan Perang Republik Indonesia (APRI) 708

Angkatan Perang Republik Indonesia Serikat (APRIS) 690, 692, 696-7, 699700

Anti-Revolutionaire Partij (ARP) 178, 190, 208, 223, 367, 442, 463, 510, 529, 536, 582, 584-5, 602, 669, 721, 744, 748

APRA-affaire zie Westerling-affaire

Arabië 14, 19, 26, 42, 45, 53, 58, 410, 606 Arabieren 129, 131, 133, 138, 170, 191, 211, 220, 254, 291, 295, 315, 342, 479

Asrama Angkatan Baroe 307, 327, 333, 382

Asrama Indonesia Merdeka 327, 333, 348

assistent-resident 77

Atjeh 9, 11, 17, 24-5, 40, 43, 61, 80, 87, 89, $91,97,100,277,402,437,604,630,635$, 725,742
- Atjeh-oorlog 97-9, 103, 111-3, 117-20, 123-5, 158, 178

Atlantisch Handvest 256, 313

Australië xx, 50, 202-3, 232, 248-9, 260-2, 264, 266, 276-8, 291, 297, 299, 301, 304, $321-5,335,337-41,344,356-7,369,371-$ 2, 380, 386-8, 396-7, 399, 418-9, 431, 437, 456-7, 515-6, 532, 534, 540, 554-5, 560-1, 576, 578, 605-8, 721, 726, 744-6, 749

Badan Keamanan Rakjat (BKR) 374, 377, 404-5, 411, 413-4

Balai Poestaka 142

Balambangan 10-1, 59

Bali 6-7, 9-10, 23, 36, 59, 87, 90, 109, 124, $128,237,263-4,277,312-3,332,378$, $418,447,457,512,519$

Banda-eilanden 14, 16, 24, 28, 35-6, 48, 204-5, 213, 239, 261, 359, 718

Bandjermasin 59, 61-2, 90, 125, 378

Bandoeng 102, 133, 143, 161, 164-5, 185, 197-8, 204, 206, 215, 219, 245, 248, 263, 265-7, 292, 294, 307, 324, 327, 334, 359, 379-80, 396-7, 401-2, 406, 411, 435, 4468, 469-71, 534, 546, 574-5, 583-4, 593, $669,686,691-4,709,719,723,725-7$, 739

Bangka 59, 79, 101, 447, 467, 542, 606-7, 622, 631, 635-8, 642

Banjoewangi 471, 553

Bantam (gebied en stad) 4, 9, 11, 17, 234, 27, 31-2, 43, 109, 174, 190, 198, 201, 265-6, 553, 603

Bantam (sultanaat) 2, 11, 17, 20, 23-4, 31- 


\section{2, 41-3, 47-8, 71-2}

Barisan Pelopor 327-8, 334, 347, 382, 399, 448

Batakgebieden 125

Batavia

- stichting 31-3

- betekenis van de naam 32,65

Bataviaasch Genootschap voor Kunsten en Wetenschappen xix, 58, 73, 92, 108

batig slot $68,84-6,89,95-7,116$

Bekasi 402, 470

Benkoelen 43, 80, 87, 239, 253, 297, 306

Benteng Repoeblik 511-2, 569, 572

benteng-stelsel 82-3

bersiap-terreur 400-3, 448, 459-60, 504, $531,574,689,694,706,737$

bestand tussen Nederland en de Republiek Indonesië

- eerste bestand (1946) 478-81, 519-20, $532,552-3,556,587,648$

- tweede bestand (1948) 562-6, 590, $601,603,626,648$

- derde bestand (1949) 647-51

Biliton 59, 74, 80, 101, 104, 397

Binnenlands Bestuur (BB) 489, 515, 527-8, 534, 558-9, 574, 626

- inrichting 76-8, 131, 138, 189, 234, 237

- opleiding bestuursambtenaren 78, 107, 131-2, 143, 145

Birma (dekolonisatie van) 232-4, 308, 310, 331, 370-1, 373, 388-90, 396, 474, 526, 577, 604, 606, 674

Blitar 330-1, 404, 428

Brits-Indië 131-2, 146, 232-3, 243, 302, 364, 388

Boeginezen 40, 42, 46, 61, 73, 89

Boedi Oetomo 151-2, 158-60, 169-70, 172, 176-7, 183-4, 190, 197-8, 205-6, $216,220,229,233,331$

bondgenootschappelijke rijken 48-9, $110,121-2$

Bondowoso 563

Boni 40-1, 79, 90, 125

Boven-Digoel 202-3, 225, 227, 230, 239, 250, 261, 278, 322, 387, 661

Buitenzorg (Bogor) 58, 78, 105, 138, 143, 189, 243, 265-6, 396-7, 401, 406, 435, $447,470,488,520,532,534$ burgergeïnterneerden

- onder de Japanse bezetting 293-6

- na de Japanse bezetting 355-6, 371, 379-81, 384-5, 390-1, 396, 400-1, 406, 409-13, 415-7, 436, 459, 471, 474, 478-9, 540

Bijeenkomst voor Federaal Overleg (BFO) 583-4, 600, 602, 610, 622-3, 631, 633-6, 641, 644-6, 648, 653-4, 659, 663$4,667-71,689,695,700$

Ceram 13, 36, 38, 91, 128, 696, 704-5, 725,742

Ceylon 7, 13, 25, 33, 39, 41, 43, 45-6, 48, $50,52,54,57,61,67,69,73,108,264$, $321,372,381,384,389,430,527,606$

Charter van Soevereiniteitsoverdracht 665-7, 672, 680-1, 705-6

China 1, 3-7, 9-11, 14, 23, 26, 34, 42, 45, $58,62,110,123,157,188,199,202,230$, 240, 246, 249, 258, 278-9, 283, 310, 370, $383,450,560,595,716,731,743,749$

Chinezen xxi, 4, 33, 46, 49, 53-5, 58, 79, $84,92,103,129-31,133,138,142,151$, $158,164,170,174-6,184,191,201,211$, 220, 254, 25?, 280, 291, 295-6, 309, 315, $318,332,342,364,387,401,423,446$, $459-60,479,560,716$

chinezenmoord (1740) 53-4

Christelijk-Historische Unie (CHU) 463, 510, 536, 581-2, 585, 599, 602, 662-4, $669,680,721,744$

Comité Boemi Poetra 161-4

Commissie-Carpentier Alting 173-4, 186, 190, 208, 241, 244, 407, 410

Commissie-Generaal (1793-1799) 61-2

Commissie-Generaal (1815-1818) 74-6

Commissie-Generaal (1946-1948) 471-5, 478-85, 500, 507-9, 513, 520-2, 524, 529, 532-5, 539-41, 546, 549, 551, 555, 563, 709-10

Commissie van Goede Diensten (CGD, in 1947 ingesteld door de VNVeiligheidsraad) 560-2, 564-9, 578, 580-1, 583, 586-7, 590, 592-3, 599-601, $605,607-8,631$

Commissie-Nederburgh 69-70

Commissie-Visman 252-4, 289, 341 
Communistische Partij Nederland (CPN) 166, 188, 201, 223, 237, 365, 409, 455, $463,475-6,509,582,585,662-3,669$ controleur 53, 77, 131 coöperatoren zie non-coöperatiepolitiek Cultuurstelsel 67, 84-7, 95-6, 100

Daroel Islam/Darul Islam 572-3, 590, 627, 676, 692, 724-6, 742

Deli 91, 100-2, 120, 277, 402

Denpasar (conferentie van) 512-4, 517, 661, 664

Depok 52, 401, 403

De Zeven Provinciën (schip) zie muiterij dienstplichtigen (Nederlandse) 358, 419, 453, 460, 468, 470, 475-7, 504, 509, 523, $529,536,543,587-8,597$

dienstweigeraars (Nederlandse) 476

Djakarta

- verovering door de VOC 31-2

- herstel van de naam 205, 242, 299

Djambi 40, 91, 125, 262, 604

Djawa Hokokai 315-7, 334, 344, 376

Djojobojo-legende 56, 82, 213, 249, 280, 691

'dodentrein' zie Bondowoso

Door de Eeuwen Trouw 704-5, 708

Door duisternis tot licht 157

Duitse bezetting van Nederland (19401945) 244-6, 337-8, 365-6, 391, 395, 478

Duitsers 45, 104-5, 129, 245, 258-61, 296

dwangarbeid 103-4, 133

East India Company (EIC) 28, 37, 43, 612, 72, 80, 104, 110, 157

Eed van de Jeugd 207

eerste Nederlands offensief (1947)

- aanloop 547-552

- verloop 552-5

- reactie Verenigde Naties 555-8

Empat Serangkai 299, 304, 308, 315-6

ethische politiek $68,114-7,123,141-2$, 146, 157, 164, 168, 170, 176, 211, 243

Europeanen (rechtsbegrip) 132-4, 142-3, 145-6, 155, 158, 243, 254, 288, 295, 304, 363

Excessennota 491, 618

exorbitante rechten xvi, 134-6, 163,
166,188, 201, 215, 225

Expeditionaire Macht 336, 338-9, 418-20

federalisering van Indonesië

- opvattingen voor de Tweede Wereldoorlog 178-9, 199, 215, 224

- bespreking bij voorbereiding Indonesische onafhankelijkheid 342

- Nederlandse keuze voor federalisering 431-4

- Indonesische aanvaarding in Linggadjati (1946) 483-4

- Nederlandse stappen tot federalisering (1947-1949) 466-7, 504, 506, 5124, 543-4, 564, 573-8, 583, 598-600, 622, $629,639,643$

- Indonesische beëindiging van de federalisering (1950) 700-3

Filippijnen 2-3, 16, 25, 34, 37, 42-3, 123, 146, 153, 158, 171-2, 199, 207, 232-5, 246, 248, 258, 261-2, 265, 276, 278-9, 283, 294, 302, 304, 308, 310, 331, 340, $342,364-5,383,408,474,525-6,542$, 577,595

Flores 13, 17, 59, 109, 123, 128, 225, 239, 696

Frankrijk 61-2, 67, 69, 72, 85, 110, 112-3, 115, 246-7, 362, 390, 450-1, 525-6, 560, 687,745

Front Demokrasi Rakjat (FDR) 572, 594-6

Gaboengan Politik Indonesia (Gapi) 239-42, 250, 253-6, 258-9, 281

Garoeda 6, 756

geconcentreerde linie $99,117-8$

geleide democratie 731,741

Gerakan Rakjat Indonesia (Gerindo) 230-1, 236, 240, 242, 258, 264, 327, 378, 425,478

Goa 15, 17, 21

gouverneur-generaal 19, 26, 31, 33, 36, $43,47,49,52,57,62,70-2,74,77,84$, 120-2, 124, 131-2, 134-9, 144, 157, 161, 164, 169-70, 172-3, 179, 185, 191, 203-4, 207-8, 212, 215-6, 218, 220-2, 224, 227$8,236,239,245,247,250,253,255-7$, 259, 261, 263, 266-7, 286, 292-4, 297, $393,398,407$ 
Gowa 40-1, 43, 125

grondwet (Indonesië)

- eerste grondwet Republiek Indonesië (1945) 342-3, 354, 360-1, 374-5, 421-2, $426,432,740$

- grondwet RVI (1949) 653-5, 659, 666$7,671,693$

- voorlopige grondwet nieuwe Republiek Indonesië (1950) 701, 714, 730, 739-40

- terugkeer naar grondwet van 1945 740-1

grondwet (Nederland)

- eerste grondwet Koninkrijk der Nederlanden (1815) 74

- grondwet van 1848 91, 134

- grondwet van 1922 174, 29-10, 235, $239,245,251,367,441,475,479$

- grondwet van 1948 581-2, 584, 662

- grondwet van 1956 733-4

Groot-Brittannië 73-4, 85, 110, 112-3, $128,153,212,232,241,247-8,257-8$, 261-3, 335, 338-40, 357, 362, 364-5, 3703, 383-6, 388-91, 393-5, 397-9, 404-7, 410-20, 430, 434-7, 439-40, 443, 445-50, 452-3, 458-60, 471, 474, 478-81, 488-9, 519-20, 526-7, 548, 554, 559, 576-7, 595, $687,742,745$

- conflicten met VOC 20, 28, 32, 61

- overname Kaapkolonie, Ceylon en VOC-vestigingen in India 62, 67, 69 $70,73,80$

- bestuur over Java 72-3

- verdrag van 1824 met Nederland 80

- verdrag van 1871 met Nederland 97-8

- tijdelijk gezag over Indonesië (19451946) $355,370-2,458,469,488$

Grote Oost zie Oost-Indonesië

Grote Postweg 71

guerrilla 470, 474, 558, 588-90, 605, 621, $625-6,638,640,676$

haatzaai-artikelen xvi, 136-7, 166, 215

Handvest van Djakarta 342, 740

Heiho 294-5, 313-4, 349, 363, 376, 383-4, 401, 406-7

Hindoe-Indonesische culturen 5-7, 107
Hitoe 13, 26-7, 38

Hizboellah 328, 382, 572

Hoge Adviesraad 343, 360, 459, 575, 714, 740

Hoge Regering 47, 49, 54, 70

Hoge Veluwe conferentie 452-6, 459, $461,466,478$

hongi-tochten $38,59,76,78$

Ikada-terrein 382, 494

imperialisme 109-10, 212

India 1, 4-7, 15, 19, 31-2, 39-43, 45-6, 48, $50,58,61,67,73-4,80,110,113,131$, 168

- nationale beweging 157, 182-3, 366, 375

- dekolonisatie 153, 157, 172-3, 179, 190, 232-5, 301, 364-5, 373, 388-9, 430, 474, 526-7, 558, 674-5

- steun aan Republiek Indonesië 459, 532, 534, 554-5, 606

Indian Mutiny 110, 168

Indië Weerbaar-campagne 168-70, 175, 186,254

indigo 45, 84-5, 95

Indische Partij 161-4, 166, 175, 180-2, 184,359

Indische Sociaal-Democratische Vereeniging (ISDV) 165-7, 169, 181, 186-7, 198

Indo-Europeanen xxi, 102, 129-30, 133, 146, 151, 160-1, 166, 175, 180-1, 211, $218,245,260,286-7,291,296,315-6$, $318,342,363,400,402,423,435,446$, $459,531,661,700$

Indo-Europeesch Verbond (IEV) 180-1, 184, 208-9, 235

Indonesië

- betekenis van de term 2

- oorsprong van de term 105, 175-6

Indonesië Parlementair (campagne) 239$42,251,359$

Indonesisch Jeugdcongres (1928) 206-7 Indonesisch-Nederlandse Unie 482-4, 486, 503-4, 508, 511, 522-3, 532, 537, $540-1,544,568,578,582-3,607,612$, $615,624,633,646,653,655,672,674$, 702, 705, 707, 709-13, 719-20, 722-4, 
$728,733-4$

Indonesisch Verbond van Studeerenden 176,244

Inlanders (rechtsbegrip) 132-4, 138, 155, 221-2, 243, 304

islam 2, 9-11, 13-4, 17, 40, 83, 89, 97, 107, 151, 163-5, 184, 187, 189, 197, 206, 231, $244,313,328,332,341-3,360,399,572$, 740

Itinerario 23

Japan 14, 19, 24, 26, 31, 34, 45-6, 48, 58, $62,123,133,153,168,199,212-3,219$, 230, 233, 238, 240-1, 246-7, 249, 716, 744

- voorbeeld voor Indonesische nationalisten 157-8, 230

- in oorlog met Nederland 257-9, 2617, 276-8

- bezetter van Indonesië 281-99, 30420, 325-8, 361, 382

- wegbereider voor Indonesische onafhankelijkheid 325-7, 330-2, 341-5, 356, 360, 368-9, 372, 394

Japanners 133, 158, 257-60, 285-6

Java-oorlog 80-3

Javazee (zeeslag op de ) 263-4

Jogjakarta

- verplaatsing regeringszetel Republiek naar 436

- bezetting door Nederlandse troepen 603

- terugkeer Republikeinse regering in 607-8, 641-2

Jong-Sumatranen Bond 194, 207

Kaapkolonie 43, 48, 50, 52, 73

kabinetten in Indonesië

- presidentieel kabinet (1945) 376

- kabinetten Sjahrir (1945-1947) 426, 446, 477-8

- kabinet Amir Sjarifoeddin (1947-48) 550

- kabinetten Hatta (1948-1950) 569, 671

- kabinet Natsir (1950-1951) 704

- kabinet Sukiman (1951-1952) 715-6

- kabinet Wilopo (1952-1953) 716-7

- eerste kabinet Ali Sastroamidjojo
(1953-1955) 718-9

- kabinet Burhanuddin Harahap (19551956) 719

- tweede kabinet Ali Sastroamidjojo (1956-1957) 724

- kabinet Djuanda (1957-1959) 732-3

- tweede presidentieel kabinet (1959) 740

kabinetten in Nederland

- kabinetten Colijn (1933-1939) 223, 237

- kabinet Gerbrandy (1940-1945) 249

- kabinet Schermerhorn (1945-1946) 368-9

- eerste kabinet Beel (1946-1948) 463-5

- kabinetten Drees (1948-1958) 585, 707, 721, 733

- kabinet De Quay (1959-1963) 744

Kalidjati 265-7

Kandy 39, 48

Kantoor voor Volkslectuur zie Balai Poestaka

Karel Doorman (schip) 744-5

Katholieke Volkspartij (KVP) 443, 454, 463-5, 473, 505, 507-9, 529, 537-8, 547, 581, 584-6, 602, 634, 653-4, 662, 664, $669,721,744$

Kempeitai 287-9, 295, 305, 310, 323-4, 328-30, 348, 361, 414

Kerintji-vallei 125

kerstboodschap 564

kina 101-2, 105

KNIP zie Komite Nasional Indonesia Poesat

Koetaradja 98-9, 117-9, 222, 277

koffie 19-20, 45, 53, 59, 70, 73, 75, 84, 96, 101-2, 317, 530, 553

Koloniaal Instituut 114

koloniaal leger 68, 82-3, 89-91, 93, 99, $102,112,115,118-20,123-5,128,168-$ 9, 178, 199, 221, 224, 247-8, 275, 404, 471, 514, 528, 657, 691, 696, zie ook Koninklijk Nederlands-Indisch Leger koloniaal onderwijsbestel 142-7

koloniaal taalbeleid 140-2

koloniale troika 527, 530, 637

Komite Nasional Indonesia Poesat (KNIP) 375-6, 421-2, 426-7, 445-6, 477$8,511,522,524,552,570,606,642,664$, 
$668,672,701,714$

Koningsplein 71, 75, 78, 108, 285, 349, 382, 494

Koninklijk Instituut voor Taal-, Land- en Volkenkunde (KITLV) 107

Koninklijk Nederlands-Indisch Leger (KNIL) 224, 228, 247-8, 258, 262-6, 276-7, 279-80, 292, 321-2, 324-5, 335, 337-9, 387-8, 396-7, 401, 404-6, 419-20, 435-8, 447-8, 454, 456-7, 466, 468-9, $480,505,513,515-7,527-9,534,579$, $587,626,629,646,655,657,690-2,695-$ 700, 708, 726

Koninklijke Paketvaart Maatschappij (KPM) 100, 118, 260, 387-8, 398-9, 705, 708, 726, 736, 738

konsepsi 732, 735, 739

Konstituante (1956-1959) 701, 730, 73940

Korte Verklaring 121-2

kruidnagelmonopolie 37-8, 75-6

krijgsgevangenen (van Japan) 275, 285, 292-3, 296, 371, 379-81, 384-5, 390-1

Ksatrian Instituut 185, 198

landrente $67,73,77,84-6,116$

Lampong-gebied 43, 91, 93

leenroerige rijken 48-9, 110, 121

Linggadjati (akkoord van)

- totstandkoming 482-4

- aankleding 507-9

- Indonesisch verzet tegen akkoord 510-2

- Nederlands verzet tegen akkoord 509-10

- ondertekening 524

- interpretatie 504, 521-3, 533-5, 537, 541-4

Lombok 6, 10, 59, 109, 112-3, 124, 178, $332,371,396,403$

Madjelis Rakjat Indonesia (MRI) 256-7, 259, 281

Madioen 243, 572, 596, 605, 652

Madioenopstand 596-7, 599, 605, 626-7, $662-3,668,718$

Madoera 11, 23, 48, 56-7, 59, 282, 286-7, $299,471,534,556,563-4,573-4$
Magelang 82-3, 411-3, 428, 542

Makassar xix, 17, 37, 40-1, 48, 59, 62, 83, $125,287,311,362,378,458,466,512-8$, $647,650,668,695-8,700-1,709,751$

Malakka (sultanaat) 10-1, 15

Malino (conferentie van) 357, 466-7, 512, $514,516,523,533,541,544,643,661$

Manipol zie Politiek Manifest

marineblokkade van de Republiek 51920, 538, 546

Masjoemi/Masjumi 313-6, 328, 330, 334, 344, 425, 444-6, 477-8, 511, 524, 545, 562, 569-71, 573, 595, 605, 640, 668, 701, 714-9, 725, 729-30, 732, 738-9, 741

Mataram 2, 11, 20, 32-3, 40-3, 46, 48, 546,81

Max Havelaar 93

Medan xviii, 102, 277, 362, 378, 380, 390, 396-7, 553

Menado 41, 59, 109, 262, 457, 657

Menadonezen 109, 118, 360, 397, 411, $415,423,468,656-7,695,700$

Menteng 31382

Merauke 128, 278, 661, 665, 686, 755

MIAI 232, 242, 253-4, 256, 259, 309, 314

Midden-Java (strijd in oktober-november 1945) 401, 411-4, 417, 420, 426, 428, 435, 446

Minahasa 109, 143, 175, 623, 656-60, 695, 703-4

Minahasa-bond 229, 240, 446, 514, 647

Minangkabau 40, 79, 87, 89, 100, 164, 184, 186, 194-5, 198-9, 201, 206, 235, 277, 378

missie (rooms-katholieke) 108-9, 707

Modjopahit xvi, 1, 7, 9-10, 14, 41-2, 154, 165

Moehammadiah/Muhammadiah 184, 206, 231, 280, 310, 314, 717

Molukken 2, 9, 13-4, 16-7, 19-20, 23-8, $31-2,35,37-9,41,45,50,59,67,70,72$, 74-5, 78-9, 96, 109, 374, 378, 392, 454, 467, 524, 623, 656-61, 686, 695, 697-8, $700,703,708,725$

muilkorfcirculaire 136-7, 224

muiterij op De Zeven Provinciën 221-4, 237

muiterij in Makassar (1950) 696-8, 700 
Nahdatoel Oelama/Nahdatul Ulama (NU) 206, 231, 314, 717-8, 724, 730

Nationaal Comité Handhaving Rijkseenheid 510, 536, 549, 584, 623, 658-60, 662, 703-4

nationale comités 220, 236, 242, 280, 284, 359, 374-7, 401, 404, 427

Nationale Fractie 216, 218, 228-9, 235, 254

Nederlands-Indonesische Unie zie Indonesisch-Nederlandse Unie

Nederlandsche Handel-Maatschappij 76, 85-6, 93, 101

Nederlandse Militaire Missie (NMM) $656,699,712,718$

Negara Indonesia Timoer (NIT) zie Oost-Indonesië

Netherlands Forces Intelligence Service (NEFIS) 323-5, 393, 398, 421, 437, 726

Netherlands-Indies Civil Administration (NICA) 321-3, 336-40, 370-2, 385, 390, 396-9, 406-7, 431, 457, 489, 515-6

Nieuw-Guinea

- Nederlandse aanspraak op 87, 111-2, 123,128

- in conferentie van Denpasar 513

- in RTC 660-6

- in 'ijskast' 707, 719, 745-6

- in AVVN 723-4, 735-6, 747-50

- militaire confrontatie 742-5, 751-3

- beëindiging conflict 751-4

non-coöperatiepolitiek 152, 182-3, 193, $198,203,206,216,219,228-31$

november-beloften 172-3, 177, 179, 183

Ondernemersraad voor NederlandschIndië 179, 192, 209, 237

onderwijs zie koloniaal onderwijsbestel en 'wilde scholen'

onthoudingsbeleid 87,89

ontvoering van Hatta en Soekarno 347-8 ontvoering van Sjahrir 461-2

Onze strijd 423-6, 429, 444

oorlogsmisdaden 36, 119-20, 278-9, 448, $491,517-8,563,589$

oorlogsvrijwilligers (Nederlandse) 3389, 356-7, 368, 397, 410, 419, 447-8, 468, $529,536,587$
Oost-Indonesië (deelstaat) 467, 512-4, 517-8, 533, 544, 556, 575-6, 579, 583, $609,643,645,661,664,666,668,694-8$, 701

Oost-Java (deelstaat) 539, 573-4, 643

Oost-Sumatra (deelstaat) 573-4, 583, 609, $643,695,701$

opium 45-6, 57, 70, 73, 79, 84, 138, 160

Opleidings School Voor Inlandse Ambtenaren (OSVIA) 145, 163

ordonnanties 132, 191, 228, 251, 322, 398

pacificatie 122,419

Padang 40, 59, 61, 80, 87, 297, 378, 380, 390, 396-7, 738

Padjadjaran 9, 11

Padri-oorlog 79, 87-9

Palembang 7, 10, 40, 59, 62, 72, 79-80, 87, 91, 100, 262, 378, 380, 382, 396-7, 553

Pangkalpinang (conferentie van) 479, 660

Pantja Sila $341-3$

Papoea's 3, 109, 202-3, 335, 665, 747-8, 750

parlementsverkiezingen in Indonesië (1955) 426, 714, 729-30, 739-40

parlementsverkiezingen in Nederland

- (1933) 223

- (1937) 237, 418, 443

- (1946) 452, 460, 463

- (1948) 581-2, 588, 592, 658

- (1952) 720-1

- (1956) 733

- (1959) 744

Partai Boeroeh/Partai Buruh 511, 569, 572

Partai Indonesia (Partindo) 217-9, 224-5, 227-31, 233, 426

Partai Indonesia Raja (Parindra) 229-30, 236, 240, 242, 250, 290, 307

Partai Katolik Repoeblik Indonesia 425

Partai Keristen Indonesia (Parkindo) 425, 477, 698

Partai Komunis Indonesia (PKI) 140, 167, 181, 187-9, 195, 197-201, 204, 215 , 425, 445, 511, 580, 594-6, 714-5, 717-8, 724, 730, 735, 739-41

Partai Murba 597, 714 
Partai Nasional Indonesia, opgericht in 1927 (PNI) 204-7, 213-9, 280

Partai Nasional Indonesia, opgericht in 1946 (PNI) 425-6, 445-6, 477-8, 511, $524,545,569-71,578,640,668,714-9$, 724, 729-30, 732, 735, 740

Partai Republik Indonesia (Pari) 202

Partai Sosialis (PS) 425, 444, 477, 511, 569, 572, 594

Partai Sosialis Indonesia (PSI) 572, 7146, 730, 741

Partij van de Arbeid (PvdA) 443, 453, 455, 463-5, 473, 475, 505, 507, 509, 537$8,547,552,554,562,581,585-6,598$, 602, 604, 633, 653-4, 662, 664, 669, 721, 737, 743, 746-8, 753

Partij van de Vrijheid (PvdV) 463, 536, 581

Pasoendan (deelstaat) 573-4, 583, 609-10, 627, 643, 692, 694

Pasoendan (vereniging) 159, 205, 216, 220, 233, 240

Pasoendan-affaire 543

Panitia Persiapan Kemerdekaan Indonesia (PPKI) 345, 347-9, 359-60, 374-5, 377, 381

Panitia Persiapan Nasional (PPN) 670-1, 673

Pantja Sila 341, 343

Pegangsaän Oost 56 349,354, 358, 436, $481,500,552,556,577,590-1,600,650$, 671,673

Pembela Proklamasi (PP) 597, 627-8, 668

Pemerintah Revolusioner Republik Indonesia (PRRI) 738-9, 741-3

Pemoeda Sosialis Indonesia (Pesindo) 444-7, 462, 511, 572

Pendidikan Nasional Indonesia (PNI Baroe) 217-9, 225, 227-8, 230, 329, 425

Perhimpoenan Indonesia (PI) 193-8, 204-6, 210, 212, 215, 219, 223, 229, 237, $239,280,327,359,368,370,395,409$, 441,714

Perhimpoenan Peladjar-Peladjar Indonesia (PPPI) 206-7

Permesta-beweging 732, 738

Persatoean Bangsa Indonesia (PBI) 217, 219,229
Persatoean Perdjoeangan (PP) 445-6, 461, 511, 572

Persatoean Timur Besar (PTB) 657-9, 698,703

Perzië 1, 5, 14, 26, 34, 42-3, 45, 48, 50, 58

Peta 311-3, 315, 328, 330-1, 334, 347-8, $361,374,381-2,399,404-5,411,427-8$, 469

petitie-Soetardjo 234-9, 251, 359, 365, 514,673

PID zie Politieke Inlichtingen Dienst

plan-Beel 631, 633

plan-Cochran 593-4, 600-1

plan-Luns 748-50

Plantentuin 105

plopper 448

poenale sanctie 103-4, 192

poepoetan 124, 126

Poetera 304-6, 308-9, 314-6, 324, 359

Politiek Manifest (1945) 423, 426, 530, 656

Politiek Manifest (1959, Manipol) 741

Politieke Inlichtingen Dienst (PID) 167, 204, 227-9, 288-9

politionele acties zie eerste Nederlands offensief, tweede Nederlands offensief

Pontianak 59, 61, 90, 378, 454, 466, 534, 539

POPDA 459, 540

Portugal

- machtsuitbreiding in Azië 2, 14-7

- conflicten met de VOC 21, 25-7, 37, 39

Preanger-stelsel 53, 84, 96

presidentieel besluit X (1945) 422

proclamatie van de onafhankelijkheid van België 85

proclamatie van de onafhankelijkheid van Indonesië

- opstelling 349

- voorlezing 358

Progressieve Concentratie 562, 564

Raad van Indië 26, 47, 58, 70-1, 74, 77, 91-2, 132, 135, 172-3, 208-9, 228, 234, 240, 243-4, 252, 264, 294, 299, 309, 380, $385,398-9,407,437,442,575$

raciale (wettelijk vastgelegde) discrimi- 
natie xvi, 132-5, 138, 155, 221, 243, 288, 302, 304, 392, 407, 429

Radicale Concentratie (1918) 172, 190, 241

RAPWI 379-81, 384-6, 401, 411-5, 447

Ratoe Adil zie Djojobojo-legende

Rawagede (razzia in) 563

rechtstreeks bestuurd gebied 47-50, 72, $77,79,84,89,96,110,120-2,124-5$, $128,131,237$

recomba 559,574

Regeeringsreglement 74-5, 77, 92, 96, $132,134-5,138-9,173,191$

regent $76-7$

Rengasdengklok 348

Renville-akkoorden 506, 560-74, 576-9, $583,587,589,592,594-6,604,627,640$, 646-8, 661, 664, 741

Republiek Indonesië (RI)

- oprichting in 1945 358-60

- herstel in 1950 700-3

Republiek der Verenigde Staten van Indonesië (RVI) 646, 651-2, 654-6, 658-9, 664, 667-72, 689, 692-3, 695-702

Republiek der Zuid-Molukken/Republik Maluku Selatan (RMS) 686, 698-9, 703-6, 708, 725, 742, 749

resident, residentie $76-7$

Riouw 61, 91, 458, 467

Roem-Van Roijen-akkoord 622-3, 636-43, 645, 647-50, 653, 664, 691

romusha's 319-20, 328

Rondetafelconferentie (RTC) 622-4, 634$6,638-9,645,652-72,689-90,693,702-$ 4, 707, 709, 711-3, 719, 741

rubber $101-2,317,431,519-20,530$

Sabang 100, 128, 396, 542, 665, 686, 755

Sajap Kiri 511, 569, 572

Saparoea 78-9

Sarekat Islam (SI) 151-2, 163-6, 169-70, $172,175,177,180,184,186-90,194$, 197-8, 204-6, 217, 225, 231, 240, 250, 259, 273, 281, 410, 425, 572, 715

schepenboycot in Australië (1945-1949) 387-8, 399, 532, 540, 554, 576, 606

School Tot Opleiding Van Inlandse Artsen (STOVIA) 146, 158-9, 164, 270, 333
Semarang 42, 55, 81, 100-1, 160, 165-6, $169,181-2,184,186,201,379,385-6$, 396-7, 406, 411-3, 415, 448, 470, 489, 554

Siak 91, 97-8, 102

Siliwangi-divisie 469, 570, 572, 596, 605

Singapore 80, 89, 199, 202, 207, 248, 2578, 261-3, 278, 282, 295, 310, 344, 370-1, $374,379,384,389-91,393,396-7,405-6$, 408, 430, 447, 474, 519, 692, 706, 727, 737

slavernij 33-4, 36, 47, 52, 69, 73, 96, 103, 123

SOBSI 572,717

Sociaal-Democratische Arbeiders Partij (SDAP) 115, 163, 166, 175, 195, 215, 221, 223, 236-7, 242, 303, 365, 368, 395, $408,441,443,465,537$

Soekamiskin (gevangenis in) 133, 215, 225, 292, 295

Soerabaja $11,32,42,55,163-5,197-8$, 201, 209, 217, 221-2, 239, 248, 262-4, 266, 287, 314, 334, 372, 385, 390, 396-7, 401, 411-2, 444, 448, 470-1, 489, 521, $563,596,656,669$

- (strijd in oktober-november 1945) 413-20, 426-7, 435, 446

Soerakarta (Solo) 55-6, 71-2, 81-3, 445-6, $458,461-2,542,596,605,649-50,652$

soevereiniteit 47-9, 69, 90, 110, 125, 149, $303,322,340,371,399,449,460,505$, $521-2,525,527,533,540,544,548,550$, 565-6, 580, 594, 607-8, 622-3, 630-4, $639,646,653-6,664,666-8,671-3,680-$ $2,687,707,711,720,722-3,733,745$, $749,753-4,759-60$

soevereiniteitsoverdracht in Amsterdam $672-3,685$

soevereiniteitsoverdracht in Jogjakarta 672-3

Solo zie Soerakarta

Spanje 16, 20-1, 25, 33, 37, 39, 123, 158, 240

specerijen $1,13-5,19,21,24,34-8,40-1$, $45,59,70,75,78,84$

Speciale Troepen 517, 691-2

speerpuntenstrategie 603, 621

Sriwidjaja xvi, 1, 7, 10, 154 
Staatkundig Gereformeerde Partij (SGP) $463,536,582,585,669$

Staatsblad-Europeanen 133, 186

Staten-Generaal (regering van de Republiek der Verenigde Nederlanden) 21, 25-6, 28, 33, 39, 47, 59,61

Staten-Generaal (parlement van het Koninkrijk der Nederlanden) 74, 91, 443,472

strafexpedities 111,125

studieclubs 197-8, 203-6, 217, 244

Stuw-groep 211-2, 215, 240, 244, 259, $338,367-8,392,442,464$

Suezkanaal 98, 100

suiker $45,52-4,84-5,96,100,160,193$, $209,280,317,519-20,530,553$

suzereiniteit 48

tabak 85, 96, 101-2, 317, 431, 519, 530

Taman Siswa 185, 217, 245, 280

Tangerang 459, 470

Tentara Keamanan Rakjat (TKR) 404-5, 412-3, 415-7, 427-8, 435-6, 444

Tentara Nasional Indonesia (TNI) 548, $553,559,570,579-80,589-90,595-6$, 603-5, 625-30, 635, 642, 646-7, 649-52, 669-70, 691-3, 695-8

Tentara Republik Indonesia (TRI) 444, 447, 459, 469-71, 478-9, 481, 548

Ternate 13, 16-7, 24, 27, 37-9, 41, 43, 48$9,62,79,122,125$

thee $19,45,59,85,100,102,143,317$, 530,553

theosofische beweging 159, 197

Tidore 13, 16-7, 27, 37-9, 48, 79, 111, 661, 663

Tiga A Beweging 289-1, 298, 306-7, 314

Timor 17, 43, 59, 62, 109-10, 123, 188, $207,263,277,335,340,342,467,623$, 657, 659-60, 703-4, 706

tin $40,101,103,397,431,530$

Tjilatjap ('bloedbruiloft' van) 649

Tjirebon (Cheribon) 11, 42-3, 48, 72, 483, 520

Tonarigumi-stelsel 316, 319, 329

Twapro 658-9

tweede Nederlands offensief (1948)
- aanloop 597-603

- verloop 603-5

- reactie Verenigde Naties 605-8

- reactie Indonesische federalisten 609-10

ultimatieve voorstellen van Nederland (mei 1947) 538-43, 546-8

United Nations Commission for Indonesia (UNCI) 608, 622-3, 628, 631, 634-5, 637-9, 648, 653-6, 659, 665

United Nations Temporary Executive Authority (UNTEA) 754-5

Vaderlandsche Club (VC) 209-10, 212, 228, 247-8, 253, 442, 471

Van Imhoff (KPM-schip) 260-1

Van Mook-lijn 559, 562-4, 566, 572, 589

verbanning 50, 83, 89, 119, 134-5, 163, $166,175,195,199,202-3,205,227,230$, $239,250,297,359,383,429$

verbreking diplomatieke betrekkingen Indonesië-Nederland 737, 745, 747, 750

Vereeniging Insulinde 161, 166, 169, 172, $175,181,198$

Vereeniging van Spoor- en Tramweg Personeel (VSTP) 160, 165-6, 188

Verenigde Naties (VN)

- bemoeienis Algemene Vergadering (AV) met kwestie Nieuw-Guinea 723-4, 735-6, 747-50

- eerste bemoeienis Veiligheidsraad (VR) met kwestie Indonesië (februari 1946) 440

- reactie VR op eerste Nederlands offensief (juli-augustus 1947) 555-8, 560-1

- reactie VR op tweede Nederlands offensief (december 1948) 605-8

Verenigde Oostindische Compagnie (VOC)

- oprichting 25-6

- handelsrijk 34, 39, 43-7, 58

- bestuursstelsel 47-50

- machtsuitbreiding 31-3, 35-43

- einde 59-62

Verenigde Staten van Amerika (VS) 
- bemoeienis met conflict tussen Nederland en Republiek Indonesië (1947-1949) 507, 534, 548, 550, 557-8, 561-5, 571, 578, 580, 586, 592-4, 597, 599-602, 605-8, 625, 629, 634

- bemoeienis met conflict over NieuwGuinea (1961-1962) 688, 723, 743, 749-54

Vereniging Nederland-Indonesië (VNI) 369-70, 441-2, 473, 475-6, 509-10, 543

Vietnam 373, 405, 450-1, 525-6, 595, 675, 743, 749

Volkspartij voor Vrijheid en Democratie (VVD) 581-2, 585, 599, 602, 663-4, 669, $707,721,744$

Volksraad

- instelling 151-2, 170-1

- uitbreiding bevoegdheden 172-3, 191-2

- 'inlandse meerderheid' 207-9

voorlichting Nederlandse militairen 529

Vreemde Oosterlingen (rechtsbegrip) 133

Werkcomité van het KNIP 422-3, 425-7, $445,477,552,642,668,672-3,701,714$
West-Borneo (federaal 'bijzonder gebied') 534, 539, 556, 583, 609, 695

Westerling-affaire 691-5

'wilde scholen' 147, 184-6, 220, 227, 240

wilde-scholenordonnantie 220-1, 359, 673

zelfbeschikkingsrecht

- van Indonesië 240, 256, 302-3, 357, 394, 438-9, 455, 473-4

- van Indonesische minderheden 65660, 703

- van Papoea's 660, 745, 747-50

zelfbestuursgebieden 48, 110, 121-3, 125, 128,432

zending (protestantse) 108-9, 116, 441, 473, 707, 737, 748

Zes Punten van Soedirman 570, 646

Zeven Provinciën zie muiterij

Zuid-Celebes 40-1, 61, 73, 79, 82, 90, 125, $128,237,277,324,378,457,466-7,514-$ $9,725,742$

Zuid-Celebesaffaire 517-9

Zuid-Molukkenraad 657, 698

Zwarte Sinterklaas 736-7 
